\title{
Urbanismo y arquitectura medieval en La Pobla de Vallbona (Valencia)
}

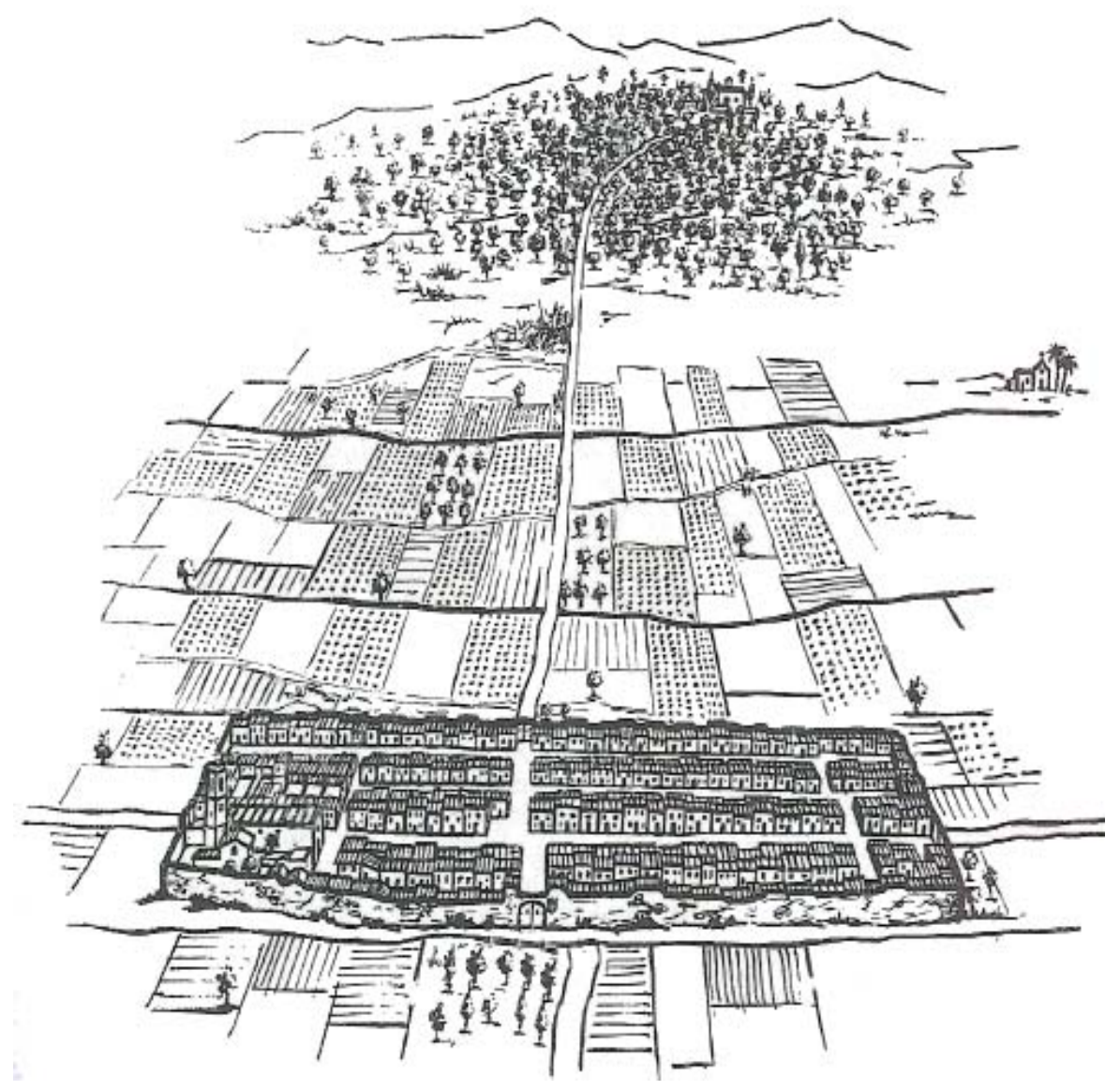

Autora: Ana Isabel Contelles Llopis 

Para Francis 
Portada: Dibujo recreando la Pobla de Vallbona durante el periodo medieval. Dibujado por Jose Luis Navarro (1981) Historia de la Villa y Baronía de la Pobla de Vallbona. Modificado por Ana Isabel Contelles Llopis 


\begin{abstract}
Y... cuando mi hija me pregunte ¿Por qué el pueblo del papa tiene castillo y el tuyo no? Simplemente responderé, sí que lo tuvimos, era el castillo de la Pobla de Benaguazir.....y seguidamente le contaré una historia...
\end{abstract}




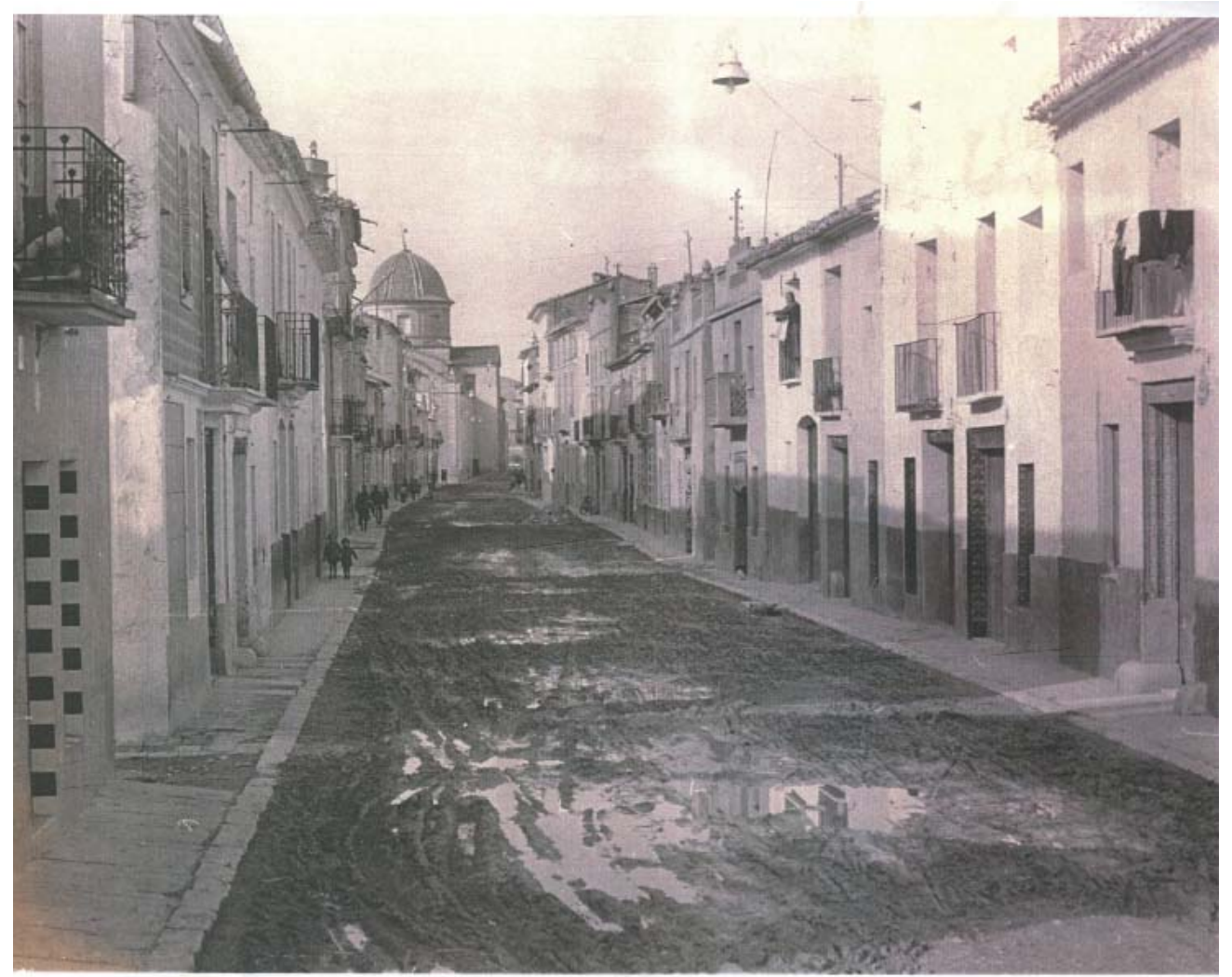

Fig. 001. El carrer Major de la vila de La Pobla de Vallbona durante los años 50 antes de que se procediera a su asfaltado. 


\section{RESUMEN | CASTELLANO}

Diferentes investigaciones han demostrado cómo a finales del $\mathrm{S}$. XII, en Jaca, en el interior del Camino de Santiago y gracias a unos fueros se creó una ciudad regular que luego se transmitió a lo largo de la ruta jacobea, al resto de Aragón y de la Corona Aragonesa.

En el presente estudio se verá como ese urbanismo regular medieval también llego a nuestro territorio y se materializó en las pueblas de colonización Valencianas. No solo se comprobará que estas villas siguieron unas pautas en su planificación, unos patrones comunes que reflejaron un modelo de construcción medieval tipificado en un trazado regular y ortogonal, sino que además se evidenciarán similitudes tanto en su patrimonio material como inmaterial.

Con el fin de conseguir el resultado anteriormente indicado se prestará especial atención a las trazas, las dimensiones y los elementos arquitectónicos de municipios similares fechados con origen en el siglo XIII en la Comunidad Valenciana, para posteriormente, realizar un análisis gráfico y comparativo entre ellos que nos ayudará a enmarcar, documentar y analizar el origen y creación de la villa de La Pobla de Vallbona.

Al finalizar el presente trabajo se habrá demostrado el origen medieval del municipio centro de este estudio, sus coincidencias con el resto de pueblas de colonización valencianas, además de documentar todos sus bienes muebles e inmuebles del bajo medievo que se conocen en la actualidad.

La importancia del presente plan de investigación radica en conocer el origen y modulación de la Pobla de Vallbona para poder poner en valor un patrimonio urbanístico y arquitectónico el cual se ha conservado hasta la actualidad y todavía se puede observar en su centro histórico.

PALABRAS CLAVE: Vila medieval, urbanismo, arquitectura, la Pobla de Vallbona 


\section{RESUM | VALENCIÀ}

Diferents recerques han demostrat com a la fi del S. XII, a Jaca, a l'interior del Camí de Santiago i gràcies a uns furs es va crear una ciutat regular que després es va transmetre al llarg de la ruta jacobea, a la resta d'Aragó i de la Corona Aragonesa.

En el present estudi es veurà com aquest urbanisme regular medieval també va arribar al nostre territori i es va materialitzar en els pobles de colonització valencians. No solament es comprovarà que aquestes viles van seguir unes pautes a l'hora de planificar-les, uns patrons comuns que van reflectir un model de construcció medieval tipificat en un traçat regular i ortogonal, sinó que a més s'evidenciaran similituds tant en el seu patrimoni material com immaterial.

Amb la finalitat d'aconseguir el resultat anteriorment indicat es prestarà especial atenció a les traces, les dimensions i els elements arquitectònics de municipis similars datats amb origen al segle XIII a la Comunitat Valenciana, per a posteriorment, realitzar una anàlisi gràfic i comparatiu que ens ajudarà a emmarcar, documentar i analitzar l'origen i creació de la vila de la Pobla de Vallbona.

En finalitzar el següent treball s'haurà demostrat l'origen medieval del municipi centre d'aquest estudi, les coincidències amb la resta de pobles de colonització valencians, a més de documentar tots els seus béns mobles i immobles de la baixa edat mitjana que es coneixen a l'actualitat.

La importància del present pla de recerca es conéixer l'origen i modulació de la Pobla de Vallbona per a poder posar en valor un patrimoni urbanístic i arquitectònic, que s'ha conservat fins a l'actualitat i on encara es pot observar al seu centre històric.

PARAULES CLAU: Vila medieval, urbanisme, arquitectura, la Pobla de Vallbona 


\section{SUMMARY |ENGLISH}

Different studies have demonstrated how at the end of the 12th century, in Jaca - in Camino de Santiago (thanks to a few jurisdictions) a regular city was created, which was then passed along the Santiago route to the rest of Aragon and the Aragonese Crown.

In this study, it can be seen that the regular medieval urbanism has also influenced our area and objectified in the colonised Valencian towns. Not only it is verified that these villas followed some guidelines in its planning, common patterns that reflected a model of medieval construction typified in a regular and orthogonal layout, but the similarities are also shown both in their material patrimony as intangible.

In order to achieve the above result, special attention was given to traces, dimensions and architectural elements of similar municipalities, dated within the origin of 13th century in the region of Valencia. Later on, a graphic and comparative analysis also helped us frame, document and analyze the origin and the creation of La Pobla de Vallbona village.

At the end of this paper the medieval origin of the municipality centre will have demonstrated its similarities with the rest of colonised Valencian towns, in addition to documenting all its real and personal estate of the early part of the middle ages as it is known today.

The importance of this research lies in knowing the origin and modulation of la Pobla de Vallbona, in putting value in its urban and architectural heritage, which is preserved until this day and can be still seen in its historic centre.

KEY WORDS: Medieval vila, urbanism, architecture, la Pobla de Vallbona. 
6 de 536

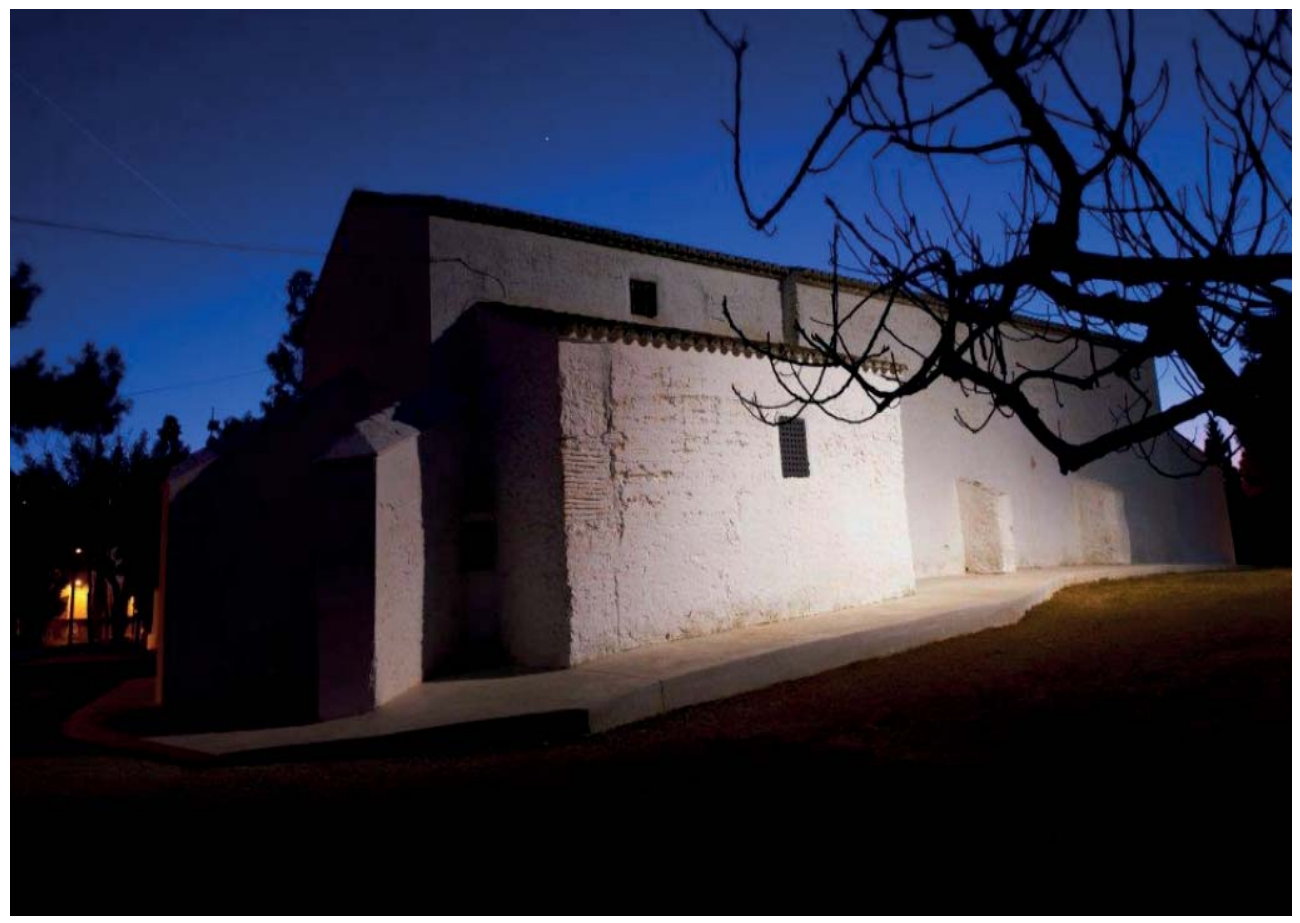

Fig. 002. Imagen noc-

turna de la fachada

trasera de la ermita

gótica de San Sebas-

tián del municipio de

La Pobla de Vallbona. 
NDICE

RESUMEN | CASTELLANO

RESUMEN | VALENCIANO

RESUMEN | INGLES

1) OBJETO DEL TRABAJO, METOdOLOGÍA, FASES Y RECURSOS 013

1.1| Objeto del trabajo 013

1.2| Metodología y Fases 014

1.3| Recursos 016

2| ANTECEDENTES, MOTIVACIÓN Y JUSTIFICACIÓN 019

2.1| Antecedentes $\quad 019$

2.2| Motivación $\quad 020$

2.3| Justificación $\quad 021$

3| EL ORIGEN DEL URBANISMO REGULAR EN LOS REINOS DE ARAGÓN

3.1 Introducción 025

3.2| La ciudad ortogonal planificada y los poderes fuertes 025

3.3| El camino de Santiago y su influencia 028

3.4| El fuero de Jaca y su influencia en la traza regular 033

3.5 Las villas de fundación: las cartas de población y los fueros 036

3.6| La ciudad aragonesa en el sur del Reino: aparición de la $\begin{array}{ll}\text { plaza y la muralla } & 040\end{array}$ 
4.1| Antecedentes históricos: La Reconquista de Valencia

4.2 El proceso de fundación de una villa nueva o pobla en la Valencia del siglo XIII 052

4.3| El urbanismo 054

4.4| Las poblaciones de nueva planta y trazado regular: Las Pueblas 057 4.5| El Parcelario 063

4.5.1 El concepto de edificación en los Fueros valencianos $\quad 066$

4.6| Comparativa entre pueblas de la Comunidad Valenciana 068
4.6.1| Metodología
072
4.6.2 Situación y fundación 078
4.6.3| Las trazas urbanas $\quad 081$
4.6.4| El urbanista 104
4.6.5| Elementos arquitectónicos 109
4.6.6| Toponimia 132

5| LA POBLA DE VALLBONA; LA POBLA DE BENAGUAZIR 137

5.1| Antecedentes

5.2| Acontecimientos históricos anteriores a la fundación del municipio

5.3| La fundación de la Pobla de Benaguazir. Situación y fundación

5.3.1| La organización social: La Carta Pobla 1382 y otros documentos inéditos

5.3.2 Dependencia religiosa: La cartuja de Porta-celi 169

5.4| La parcelación de la tierra 171

5.4.1| El regadío histórico $\quad 175$

5.4.2 Las tierras de secano 188

5.5|Las trazas urbanas de la Pobla de Benaguazir. 193

5.5.1 Cartografía, planimetría y fotografías históricas 193

5.5.2 Tamaño de la vila 216

5.5.3| Viales 219

5.5.4|Ordenación urbanística 224

5.6| Elementos arquitectónicos 236

$\begin{array}{ll}\text { 5.6.1| La muralla } & 237\end{array}$

5.6.2 El fossar medieval 248

5.6.3| La Plaza mayor y su entorno 252

5.6.4| La galerías subterráneas 262

5.6.5 Conventos o edificaciones civiles de órdenes religiosas $\quad 266$

5.6.6| Arquitectura religiosa $\quad 279$

5.7| Toponimia $\quad 321$ 
6| EL URBANISMO POSTERIOR

6.1| Francesc Eiximeniç

6.2 Semejanzas y diferencias entre el urbanismo valenciano y mallorquín medieval

7| DISCUSIÓN GENERAL DE LOS RESULTADOS

CONCLUSIONES

ANEXOS| Documentación

A.1 Ampliaciones notas a pie de página

Documentos inéditos del Sindicato de Riegos

La Carta Pobla

Listado de posesiones del Monasterio de Porta-celi en la Vila de la Pobla de Vallbona a lo largo de la historia Protocolos Notariales 1700-1702. Archivo del Seminario del Corpus Christi de Valencia Protocolos, 21.981. Notari Jaume Llorens.

A.2| Restauración de las pinturas murales góticas de la Iglesia Santiago Apóstol

A.3| Restauración de la ermita de San Sebastián

A.4| Inventario del año 1873 perteneciente al Ayuntamiento de La Pobla de Vallbona señalando los documentos existentes en el archivo del municipio

Documento del año 1945 que deja constancia la quema del archivo municipal durante la Guerra Civil Española

A.5I Fichas de los municipios con los resultados

Datos históricos, mediciones y bienes inmuebles

Tablas comparativas

CRÉDITOS FOTOGRÁFICOS

FUENTES Y BIBLIOGRAFÍA

F.1| Fondos de archivos consultados

F.2| Páginas web consultadas

F.3| Bibliografía 

TESIS DOCTORAL

Programa de Doctorado en Arquitectura, Urbanismo y Paisaje

\section{Urbanismo y arquitec tura medieval en La Pobla de Vallbona (Valencia)}


$\mathbf{1 2}$ de 536

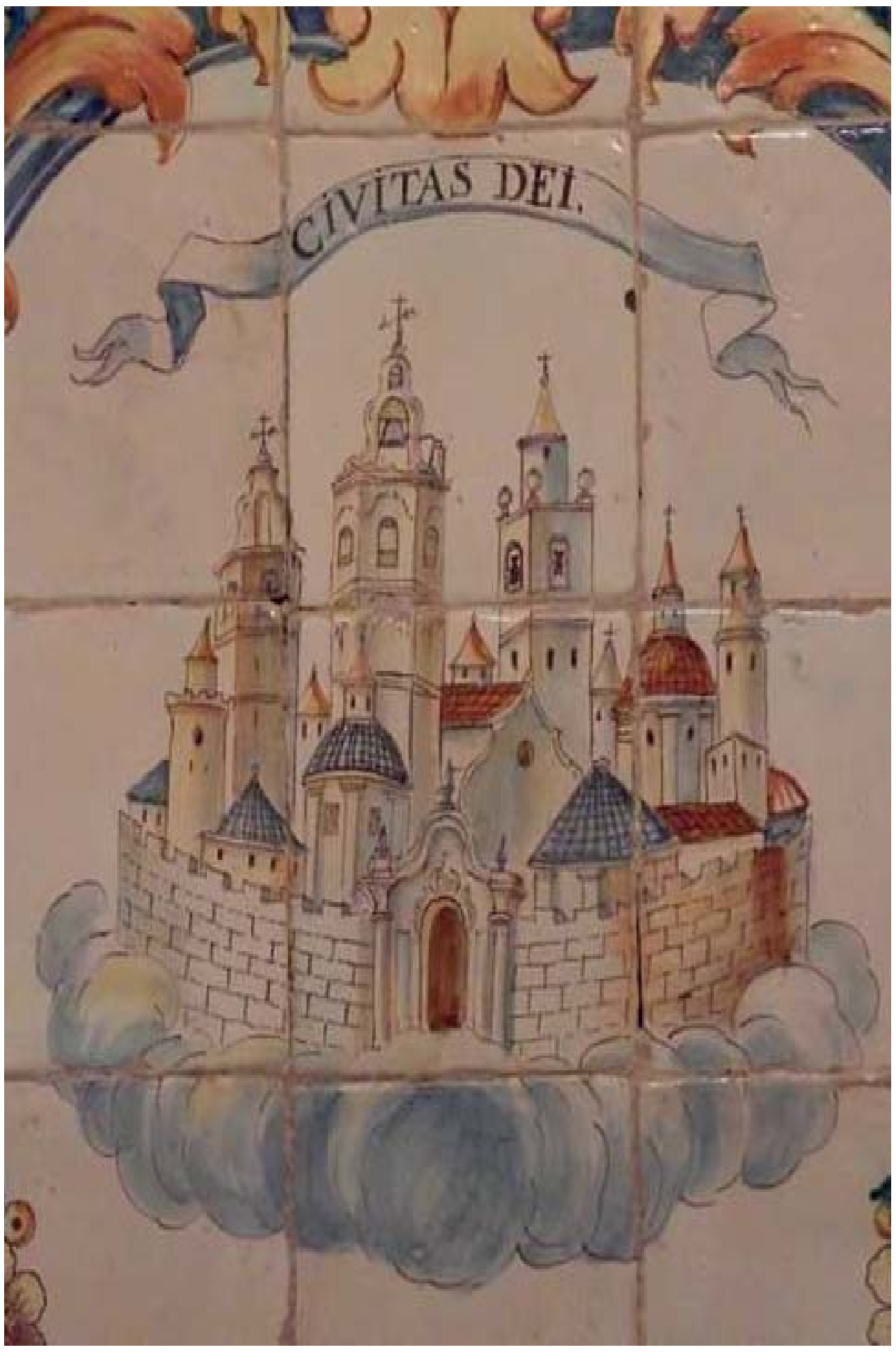


Fig. 003. Grabado en cerámica de Valencia amurallada. Zócalo del Cambril de la Mare de Deu de la Consolació. Parroquia de San Bernabé de Corcolilla. Alpuente.

\section{APítulO I|}

\section{OBj EIO DEL TRABAJ O, MEIODOLOGÍA, FASESY RECURSOS}

\section{1| Objeto del trabajo}

El presente trabajo tiene como objetivo principal el análisis del origen y urbanismo medieval concerniente a la villa de La Pobla de Vallbona, alias de Benaguazir, mediante la documentación y descripción de cómo se formaron y originaron las poblaciones de nueva planta durante la conquista de Valencia a partir del s. XIII.

A tal efecto, mi experiencia laboral como profesional de la Arquitectura Técnica durante diecisiete años y los estudios de Ingeniero de la Edificación y de Master en Conservación del Patrimonio Arquitectónico me han llevado a interesarme por el urbanismo medieval tanto de nuestro entorno más cercano, como de las villas que se originaron en el mismo periodo, y a plantearnos la hipótesis de que, quizás, estas poblaciones de nueva planta pudieran haber contado con pautas y patrones comunes que reflejaran un modelo de construcción medieval en el antiguo Reino de Valencia o incluso estar influenciadas por los modelos de ciudades regulares expandidas por la Corona de Aragón. 
Este trabajo se enmarca perfectamente dentro de la temática del Doctorado de Arquitectura, Urbanismo y Paisaje. Para ello se ha contado con el apoyo, orientación y refuerzo del profesor Dr. Vicente García Ros, director del Departamento de Composición Arquitectónica

\section{2 | Metodología y Fases}

Con el fin de conseguir el resultado anteriormente indicado se prestarán especial atención a las trazas, las dimensiones y los elementos arquitectónicos que han Ilegado hasta la actualidad de municipios similares y la misma fecha fundacional, para posteriormente realizar un análisis gráfico y comparativo entre ellos que nos ayudará a enmarcar, documentar y analizar el origen y creación de la villa de La Pobla de Vallbona.

Para desarrollar la presente tesis doctoral se plantearán varios objetivos operativos y se distribuirán a lo largo del periodo previsto para su realización.

- Objetivo 1: Búsqueda de los municipios similares tanto en trazas y de la misma fecha fundacional (Listado de municipios e indagación histórica de cada uno de ellos).

- Objetivo 2: Análisis gráfico y comparación de las trazas urbanas de los municipios elegidos. Equiparándolas entre ellas y con el modelo regular de Aragón nacido a partir del fuero de Jaca.

- Objetivo 3: Documentación histórica y gráfica del municipio de La Pobla de Vallbona.

El procedimiento utilizado constará de dos fases claramente identificadas, una primera, centrada en la labor de búsqueda de documentación histórica, identificando los núcleos históricos de interés y la toma de datos, y una segunda basada en un trabajo de análisis de gráfico.

En líneas generales cabe destacar que ha resultado ser una recopilación muy exhaustiva ya que se ha tenido que analizar fuentes documentales referidas a la trama histórica de cada una de las poblaciones. Con este objetivo se revisaron los fondos municipales de cada una de estas villas, solicitando esta delimitación en las oficinas técnicas municipales. En los casos en los que ya existían estudios realizados sobre estas zonas se tomó éstos como referencia de delimitación. 
Seguidamente se visitó los cascos antiguos de las villas y se obtuvo a través del Colegio Oficial de Arquitectos de la Comunidad Valenciana la planimetría catastral y los correspondientes planes generales.

Toda esta documentación fue utilizada para comparar cada una de las tramas urbanas, teniendo en cuenta, además, el patrimonio edificado que da forma a los centros históricos en la actualidad.

Documentados los datos, se comenzó a realizar el análisis gráfico de la planta que formaban inicialmente estas poblaciones. Se realizó todos los levantamientos gráficos de los municipios elegidos pasando a comparar no sólo la historia de cada uno de ellos sino las trazas urbanísticas y los elementos arquitectónicos medievales. En cada uno de los centros históricos se procedió a analizar, observar y/o medir:

- Los restos de las murallas, número de portales, tipología constructiva, anchura y altura.

- La longitud y la anchura del casco histórico.

- La anchura de cada una de las calles.

- Las dimensiones de la plaza central.

- La longitud y anchura de cada manzana.

- Los frentes de fachada y profundidad máxima de cada parcela.

- La ubicación de los edificios en el interior de las murallas (iglesia, casa consistorial, pozo, lavaderos, etc.). Documentando la existencia de edificios de arcos de diafragma, bóvedas de crucería y cruces de término.

Una vez obtenidos y analizados los datos, se pusieron en común con la información referente al municipio principal objeto de este estudio, La Pobla de Vallbona, con el fin de buscar coincidencias tanto en las trazas urbanas como en los bienes inmuebles.

Al finalizar este estudio se contará con la delimitación de las tramas urbanas de las villas analizadas, con indicación de los límites del espacio intramuros, el trazado de los viales y la distribución aproximada de las manzanas, además de la identificación de los elementos arquitectónicos de valor patrimonial destacado, que servirá posteriormente para ver todas las coincidencias entre ellas y con la villa de la Pobla de Vallbona. 
Para terminar no podía faltar una referencia a la figura de Francesc Eiximenis. Aunque su urbanismo es posterior a la creación de las poblaciones analizadas, no se puede dejar de tratar en este plan de investigación debido a sus publicaciones en este campo.

\section{3| Recursos}

Para el estudio de las fases antes citadas se requirió y aportó, según los casos, material documental que fue facilitado a través de distintas entidades y personas físicas:

a) Archivo de la Corona de Aragón.

b) Archivo del Reino de Valencia.

c) Archivo de la Diputación Provincial de Valencia.

Presupuestos municipales de La Pobla de Vallbona. Años 1842-1889.

Inventario del archivo municipal año 1873.

d) Archivo Municipal de Valencia.

e) Archivo de la Biblioteca Valenciana, Nicolau Primitiu.

f) Archivo de Protocolos del Colegio del Patriarca de Valencia.

Protocolos Notariales 21.981. Notari Jaume Llorenç

Protocolos Notariales, 21.983. Notari Jaume Llorenç

g) Archivo digital de la archidiócesis de Valencia.

h) Archivo Parroquial de la Iglesia Santiago Apóstol.

Libros de fábrica 1700

Libros de fábrica 1800

Libros de fábrica 1900

i) Archivo del Sindicato de Riegos de La Pobla de Vallbona.

Pergamino 1. 1370

Pergamino 2. 1376

Pergamino 3. 1384

Pergamino 4. 1390

Pergamino 5. 1402

Pergamino 6. 1405

Pergamino 7. 1591

Pergamino 8. 1426

Pergamino 9

Pergamino 10. 1389

j) Archivo del Colegio Oficial de Arquitectos de la Comunidad Valenciana.

k) Archivo del Colegio Oficial de Arquitectos Técnicos de Valencia.

I) Oficinas técnicas municipales de todos los municipios estudiados. 
m) Oficina virtual del catastro del Gobierno de España.

n) Fotografías y datos tomados in situ.

o) Resultado de pruebas de laboratorio.

p) Archivo fotográfico del Arquitecto Francisco Cervera Arias.

q) Archivo fotográfico del Ayuntamiento de La Pobla de Vallbona.

r) Archivo fotográfico Biblioteca Valenciana Nicolau Primitiu.

s) Archivo fotográfico Pilar Comes Bañó, vecina de La Pobla de Vallbona.

t) Archivo fotográfico Joan Alepuz, secretario del Gremi de Campaners de la Comunidad Valenciana.

u) Archivo fotográfico Javier Ruiz, periodista de la Red Comarcal .

v) Archivo fotográfico Maribel Garcia Corbin, Técnico de Cultura del Ayuntamiento de Castellón.

w) Archivo fotográfico varios particulares. 


\section{c}

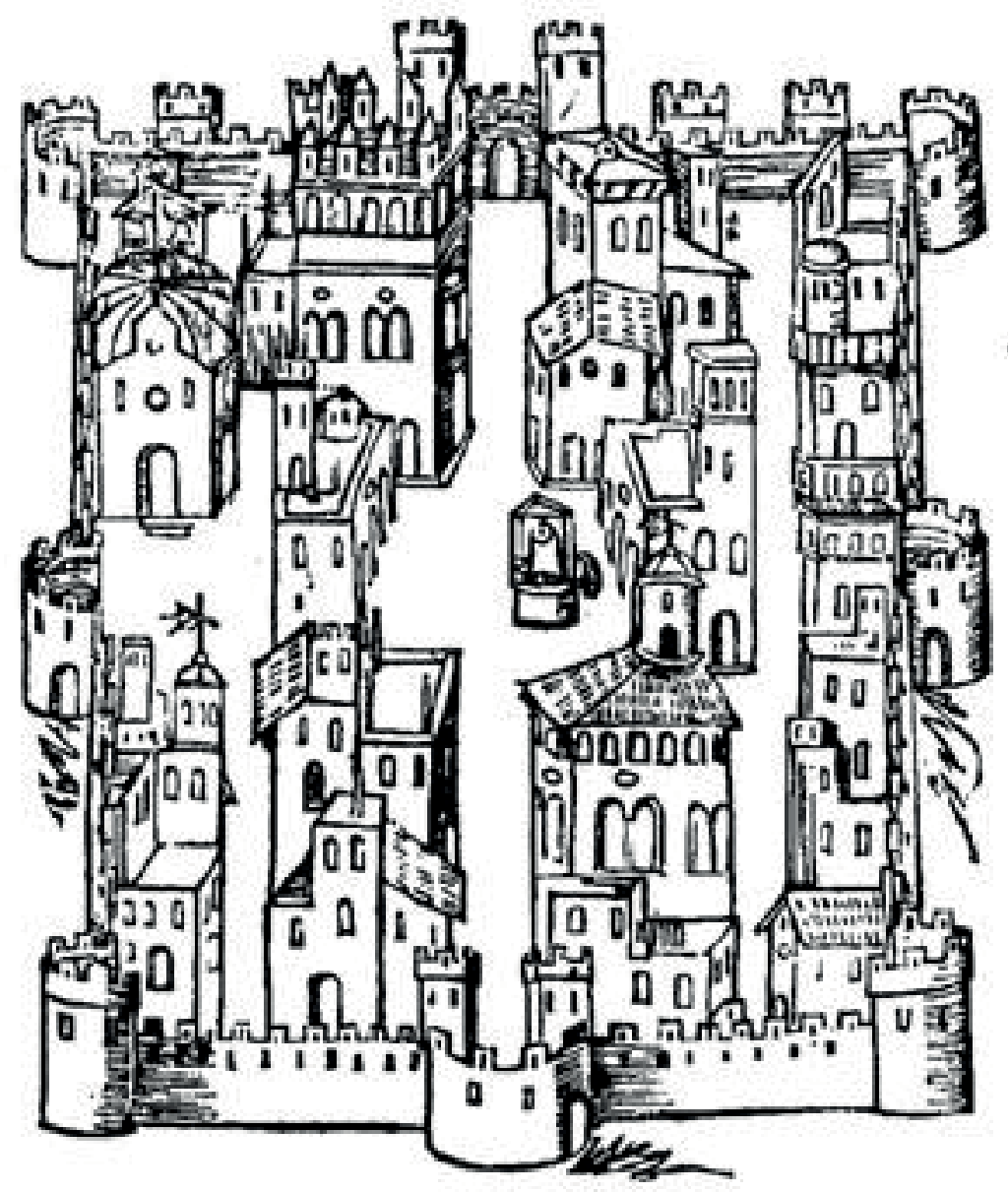


Fig. 004. Vila-real. Grabado de la Tercera Parte de la crónica de la ínclita y coronada Ciudad de Valencia y su reino. Martín de Viciana. 1566.

\section{APítulo II|}

\section{ANTECEDENTES, MOTIVACIÓN Y J USIIFCACIÓN}

\section{1| Antecedentes}

Cuando se estudiaba cómo ha ido evolucionando el urbanismo en los distintos periodos de la historia, a grandes rasgos se solía decir que la ciudad ortogonal o cuadrangular correspondía a unos cánones clásicos frente a la ciudad espontánea que se identificaba en períodos medievales. De esto se exceptuaba la bastida, desde que en el s. XIX Viollet-le-Duc y otros investigadores franceses la describieron como un núcleo ordenado en escuadra construido en pleno siglo XIII.

Investigadores aragoneses como Vicente Bielza de Ory demostraron cómo a finales del siglo XII, en Jaca, en el interior del Camino de Santiago y gracias a unos fueros, se creó una ciudad regular que luego se transmitió a lo largo de la ruta jacobea, al resto de Aragón y a resto de la Corona aragonesa.

En el presente plan de Investigación se ha realizado una pequeña introducción de este trabajo para comprobar que este sistema fue el que se llevó a cabo en la conquista de Valencia, y que los nuevos pobladores lo que hicieron fue crear nuevas poblaciones siguiendo unos criterios que llevaban ya años implantado en la corona de Aragón. 


\section{2| Motivación}

A la hora de elegir el contenido del presente estudio, no sólo nos motivó el interés profesional por estudiar el urbanismo medieval de estos núcleos históricos, sino el interés personal, el afán por conocer y ahondar concretamente en nuestras propias raíces, es decir, conocer la villa o pueblo del que forma parte de la familia en la que crecí.

Todo tiene un punto de partida y este se gestó durante la realización del Master en Conservación del Patrimonio Arquitectónico en la Universidad Politécnica de Valencia. Durante el curso me pareció interesante elegir como optativa la asignatura de "Arquitectura gótica valenciana", lo que fue una verdadera inspiración. Esta materia contribuyó a abrirme los ojos a un mundo conocido superficialmente hasta ese momento, y que arrojó luz a una época en la cuál se formó fundamentalmente el territorio que habitamos.

Al estudiar las diferentes tipologías constructivas y su historia me percaté de que mi municipio contaba con varios edificios medievales desconocidos para la mayoría de la población. Además, al profundizar en las tipologías de los municipios de nueva creación de aquella época, observé claramente que la Pobla de Vallbona era un municipio medieval y que, a pesar de que en algunos estudios era mencionada, nunca se habían analizado sus trazas ni puesto en valor, tal y como lo habían sido poblaciones como Vila-real, Nules o Almenara.

Todo ello hizo que naciera en mi una inquietud por saber cómo y cuándo se había formado el municipio en el que había estado presente a lo largo de mi vida, y sobre todo identificar los elementos arquitectónicos medievales que lo conformaban y que, hasta el momento, habían pasado desapercibidos y olvidados.

Empecé a preguntarme si habría pautas, si todas las villas que se formaron en aquel mismo momento seguían un patrón en las trazas urbanas, si su regularidad y ortogonalidad eran debidos a alguna causa específica, si la ubicación de los edificios era aleatoria o realmente venía determinada por algún tipo de ordenación.

Estos pensamientos tomaron mas fuerza cuando en el año 2009 actuamos en la recuperación de la cubierta y del pavimento de 
una vieja ermita sita en la población. La sorpresa fue enorme cuando, al retirar el cañizo, aparecieron los arcos de diafragma, los muros de tapial y todos los elementos que la definían como una ermita gótica, posiblemente, el primer edificio de culto cristiano de la zona.

\section{3| Justificación}

En los últimos años mis funciones en el ámbito laboral como profesional en la Administración municipal se centraron en tareas de gestión del Patrimonio local, desarrollando y coordinando los trabajos de investigación, de conservación y de difusión en este campo. Si se observa, desde el punto de vista de la construcción social, el patrimonio de un cabildo no tiene porqué presentar diferencias sustantivas respecto a otros ámbitos de construcción patrimonial.

En este sentido, podríamos decir que el patrimonio local está compuesto por todos aquellos objetos, lugares y manifestaciones que, en cada caso, guardan una relación con la externalidad cultural, aunque precisamente el factor escala introduzca variaciones significativas.

La puesta en valor de los referentes patrimoniales por parte de la población sigue de alguna manera, de forma implícita, los mismos principios de legitimación que ésta ha adquirido en su proceso de aprendizaje cultural, aunque debemos tener en cuenta que existe otro principio que adquiere un valor aun más relevante: el significado.

Es ese significado el que hace que para cada una de las personas que reside en ese lugar, cada bien patrimonial adquiere una connotación especial, puesto que ha formado parte de su historia y ha estado presente a lo largo de su existencia.

Conocer el origen y modelación de la Pobla de Vallbona y compararlos con varios municipios ordenados en plena Edad Media y sus impactos en otros modelos regulares posteriores aplicados en otros territorios, sirve para recuperar un patrimonio urbanístico el cual se ha podido conservar en la actualidad, y que todavía se puede observar en buena parte de los centros históricos de los municipios. 
22 de 536

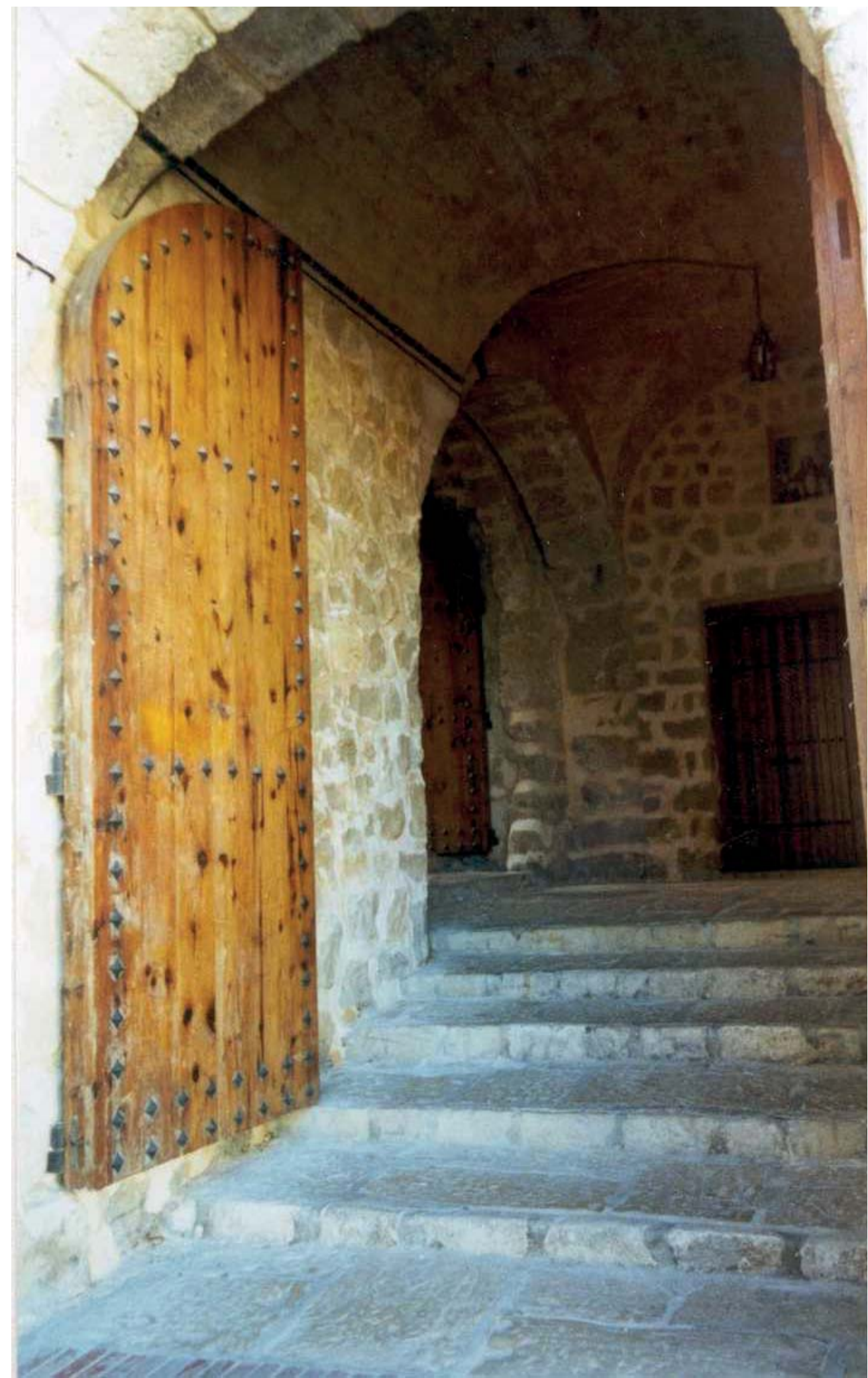


El hecho de conocer cómo y porqué se concibieron contribuye a su correcta preservación. El saber de dónde se procede, el conocer nuestra propia historia debe ser parte fundamental de la esencia del ser humano y está en nuestras manos poder transmitirla a nuestros descendientes, cuidarla, mimarla y protegerla. Se trata de nuestro legado.

$Y$ ese respeto por el patrimonio es una de las disciplinas más importantes adquiridas durante estos años, además de aprender a escucharlo con paciencia y saber interpretar sus signos, para poder tomar la decisión correcta con un equipo pluridisciplinar puesto que, de este modo, se puede contar con el mayor número de señales e interpretaciones posibles.

Este criterio es el que se ha intentado seguir a lo largo de toda esta investigación, analizando la historia, observando los diferentes modelos urbanísticos y tomando las opiniones y perspectivas tanto de historiadores, como de arquitectos, arqueólogos, medievalistas u otros oficios, con el fin de contar con sus conocimientos para que, como si de un prisma se tratara, pudiéramos observar las distintas caras de un mismo objeto para conocerlo en toda su amplitud.

Por todo lo expuesto cabe señalar que la realización y redacción del siguiente trabajo de investigación ha supuesto un esfuerzo significativo que ha merecido sobradamente la pena por todo lo aprendido en el camino, sobre todo por las lecciones recibidas durante los últimos años a medida que ejercía la profesión.

Para concluir indicar que sin la ayuda y orientación de mi director de tesis (y de los profesores y profesionales que respondieron a un sinfín de preguntas), no podría haberlo llevado a cabo. Su labor me ha enriquecido y dotado de un criterio más firme que nada tiene que ver con las dudas que albergaba al comenzar.
Fig. 005. Penáguila. Imagen de una de las puertas de la muralla del municipio de Penáguila en la actualidad, denominada el Portalet. 


\section{4 de 536}

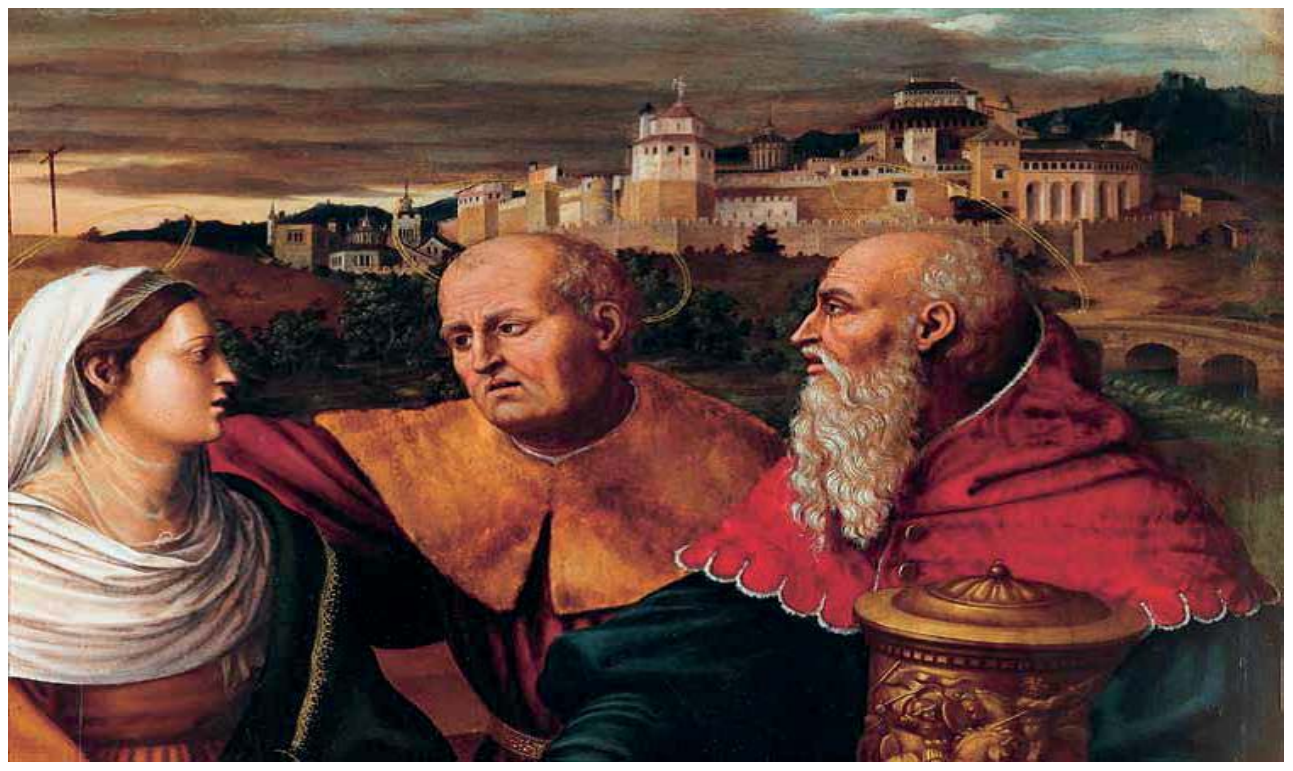

Fig. 006. Vista de la ciudad de Jerusalén recreando de forma ideal la ciudad de Segorbe y su alcázar llegando desde el camino de Valencia, en la tabla Llanto por Cristo muerto de Vicente Macip (c. 15251531). 


\title{
Capítulo III
}

\section{ELORIGEN DEL URBANISMO REGULAR EN ARAGÓN}

\section{1| Introducción}

\begin{abstract}
El trazado regular en la planificación de las ciudades o municipios desde su teorización con Eiximenis enel siglo XIV se adelantó a la recuperación renacentista de Vitruvio, de modo que desde Aragón y una vez unida esta Corona a la de Castilla, a través de las Leyes de Indias, debió tener también su influencia en el urbanismo regular hispanoamericano
\end{abstract}

Vicente Bielza de Ory, 2000

\subsection{La ciudad ortogonal planificada y los poderes fuertes}

A lo largo de la historia de la humanidad la ciudad geométricamente diseñada, frente a la nacida espontáneamente, responde a poderes fuertes capaces de organizar una sociedad y un territorio. Lo normal es que se trace el plano ortogonalmente, con manzanas cuadradas o rectangulares, cuyas calles se cortan perpendicularmente. Se trata de la forma más sencilla y equitativa de repartir el espacio tal y como señala Le Corbusier ${ }^{1}$. 
${ }^{2}$ Navarro Segura, M. I.(2006): "Las fundaciones de ciudades y el pensamiento urbanístico" Revista electrónica de Geografía y ciencias sociales. Universidad de Barcelona, vol. X, núm. 218.

${ }^{3}$ 2Sa 5,9: La Biblia. Antiguo Testamento En los primeros capítulos del Génesis y sobre todo en los libros de los profetas mayores y menores se describe esa ciudad -sociedad ideal en un amplio sentido utópico.

${ }^{4}$ Ap 5,12; 21,2 : La Biblia. Nuevo Testamento. La palabra nueva Jerusalén se encuentra dos veces en el Nuevo testamento $y$ se indica las dimensiones que tendrá la ciudad y la dimensión y espesor de su muralla.
Sin embargo no siempre la ciudad planificada se traza a escuadra: hay soluciones radio-céntricas, lineales, en arabescos, etc; pero la geometría cuadricular ha sido la más utilizada a lo largo de la historia y muchas veces sin solución de continuidad en el tiempo y en el espacio, aunque sí con matices y remodelaciones, teorizaciones y sacralizaciones.

Torres Balbás distingue, en cuanto a procedimientos de trazado desarrollados en la época medieval durante el proceso repoblador peninsular, diversas modalidades de núcleos o ciudades de trazado regular. Esta tradición clásica procedería de Hipodamo de Mileto quien, como geómetra, propuso una fórmula gráfica y elemental de distribución del territorio según una idea regular, y con capacidad de serialidad ilimitada. Tal procedimiento tuvo múltiples aplicaciones en núcleos trazados con finalidad militar y constituyó una estrategia conocida desde época romana, que en España se consolidó a partir de Alfonso X, como expresión de una práctica militar de la que deriva el juego del ajedrez. Durante el episodio de la Reconquista, junto a las fronteras en las que se luchaba, de manera similar a las bastides francesas, los cristianos construían sus campamentos siguiendo probablemente noticias romanas y con una forma regular característica, que Alfonso $X$ el Sabio especifica al precisar los procedimientos y formas de asentamiento. Se refiere a ellos comparándolos con la Puebla de la Villa, y como éstas deben adoptarse a la configuración del terreno, de lo que se derivan tres formas de trazado: rectangular, cuadrada o circular².

La ciudad regular que nace en Aragón a finales del siglo XI proviene de una voluntad firme, la de Sancho Ramírez, con la idea de prevalecer sobre los poderes señoriales concede unos fueros con el fin de atraer hombres libres a los que reparte parcelas iguales. Pero en la trama perpendicular del municipio de Jaca y otros núcleos urbanos creados a posteriori (además de la equitas, que también se buscaba en las colonias romanas como en Cesaraugusta), los "urbanistas ramirenses" se dejaron influir por el ejemplo próximo de la admirada Saraqusta.

Siguiendo un orden de ideas también se debe apuntar la contribución de los textos de la Biblia en la fundación cristiana de Jaca y otros núcleos de población originados en el camino jacobeo, ya que en ella se alude tanto en el Antiguo testamento ${ }^{3}$, pero sobre todo, en el Nuevo, a la ciudad utópica como una ciudad ortogonal. Así, la Jerusalén celestial del Apocalipsis de San $J^{J u a n}{ }^{4}$ es una ciudad cúbica, con cerca defensiva, perfectamente perpendicular, armónica y concebida desde el peso de las 


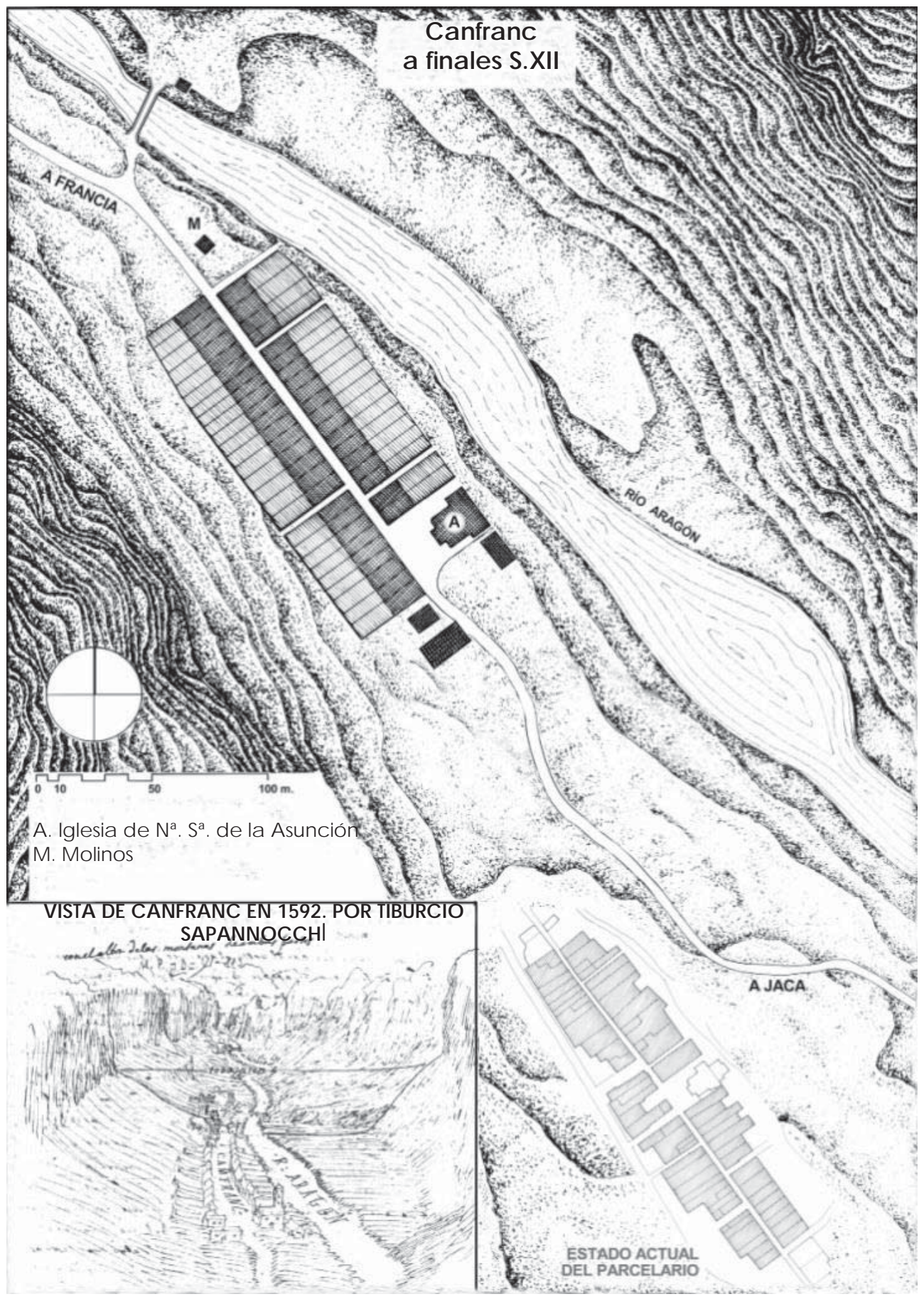

Fig. 007. La Población de Cafranc en el siglo XII. Se observa su planta en formación de línea. 
sagradas escrituras y del modelo hipodámico que se podía percibir desde la isla griega de Patmos. Hecha la consideración anterior cabe añadir la visión que se tiene en el Antiguo Testamento sobre la ciudad judaica, la concepción de un pueblo nómada que tomó de Egipto y de Mesopotamia el modelo ortogonal y lo sacralizó.

Para concluir señalar que este modelo urbanístico está presente en la mayoría de las vilas situadas a lo largo de las rutas jacobeas, por lo que resulta evidente que su difusión se llevó a cabo por estos caminos de peregrinación durante el Medievo, y que los transmisores de este conocimiento fueron las órdenes religiosas de Cluny y sobre todo, del Císter, los monjes de ambas congregaciones a través de su red de monasterios y conventos dispuestos en las diversas vías del camino, consolidaron la unidad del territorio independientemente de las rupturas de los diferentes estados ${ }^{5}$.

\section{3 | El camino de Santiago y su influencia}

El Camino de Santiago desde tiempos inmemorables contó con dos aspectos fundamentales, el primero dedicado a fomentar el fervor hacia el Apóstol patrón de Galicia y el segundo destinado a la circulación e intercambio de personas, artículos y conocimientos. Estas vías formaron el primer eje cultural europeo y jugó un papel urbanizador en el interior del continente y especialmente al norte de la Península Ibérica. Asimismo fue continuador del camino iniciado en Venecia en el siglo $X$ y en las demás repúblicas portuarias italianas -Génova, Pisa- desde comienzos del siglo XI, en la llamada etá comunale y transmitido por el Ródano y Rhin a otras ciudades-puerto de los Países Bajos o costa gala.

El auge del comercio y el renacer de las ciudades del mediterráneo en los siglos XI y XII concurren con la formación de los núcleos urbanos del norte de la península ibérica. Los reyes Sancho Ramírez de Aragón y Navarra y Alfonso VI de Castilla y León conocedores de la importancia económica de las vías mejoraron

${ }^{5}$ Bielza de Ory, V. (2000): "La ciudad ortogonal aragonesa del Camino de Santiago y su influencia en el urbanismo regular posterior". Aragón en la Edad Media, XVI, Univ. Zaragoza, Zaragoza, pág. 27. el camino francés entre los años de Cluny y del Císter desde territorio galo.

De las cuatro rutas que, según el Codex Calixtinus, en el s. XII aportaba los caminantes por Francia, tres de ellos convergían hacia Roncesvalles y un cuarto accedía por el Somport, para discurrir por Canfranc-Campus francus-, Jaca, Canal de Berdún, 


\section{Formaciones en Espina de pez}
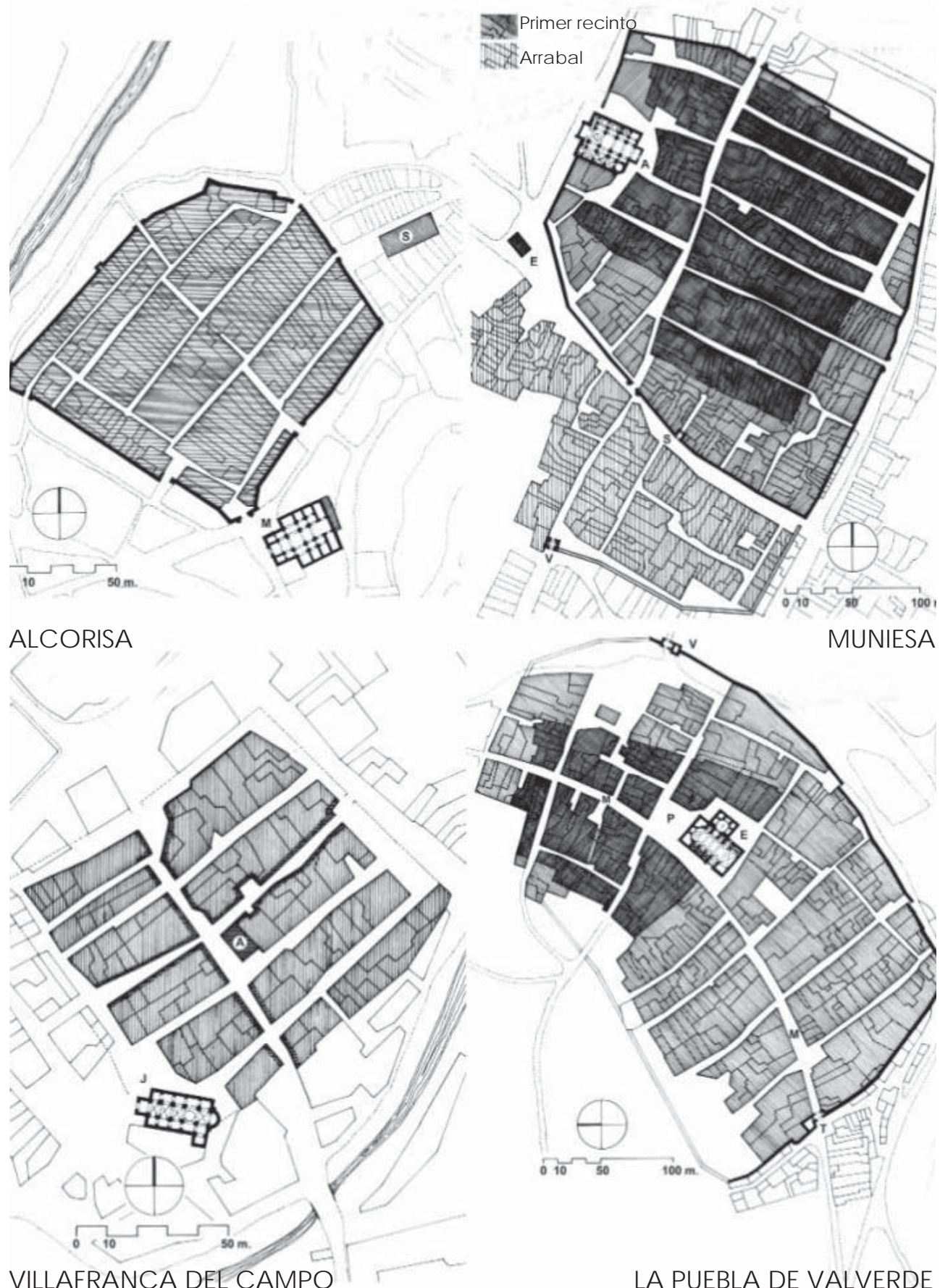

LA PUEBLA DE VALVERDE

Fig. 008. Planos de diversos municipios de la comunidad de Aragón donde se observa en su planta la tipología de espina de pez. 
Fig.009. La Población de Jaca fundada con arreglo a su fuero en el año 1.706, queda reflejado el trazado ortogonal en su urbanismo y su evolución.

${ }^{6}$ Bielza de Ory, V. (2000): "La ciudad ortogonal aragonesa del Camino de Santiago y su influencia en el urbanismo regular posterior". Aragón en la Edad Media, XVI, Univ. Zaragoza, Zaragoza, pp. 28-29.

${ }^{7}$ Caniggia,G.(1973): "La casa-corte: Definizione, diffusione, origine ed accezione comense", en AA.VV. XVIII Congreso Internazionale di Storia dell Architetturam Studi e note, Firenze, Alinea, 1985, pp. 1362.

8Beltrán Abadía, R. (2005): "Planeamiento y geometría en la ciudad aragonesa". Colegio de Arquitectos de Zaragoza. Arqueología y Territorio medieval. Revista de Arqueología del Área de Historia Medieval. Universidad de Jaén. Tomo 12.2, pág. 87.
Sangüesa hasta unirse al camino navarro en Puente la Reina. Este a su vez se unía con Estella, para salir enseguida a Logroño, Santo Domingo y continuar por tierras castellanas hasta Santiago.

De acuerdo con los razonamientos que se han venido realizando la fundación de las ciudades europeas transcurrió junto con la actividad comercial, de una burguesía dedicada a estos menesteres potenciada por el intercambio marítimo y fluvial. Sancho Ramírez, conocedor de la sociedad del momento, sabía que en Aragón no se hallaba este grupo social, debía de crearlo, atraerlo a través del Camino jacobeo, y esto lo consiguió además de mejorando las rutas de acceso con la concesión de privilegios $y$ fueros.

Las medidas adoptadas en las diferentes vías a finales del siglo $\mathrm{XI}$ originaron, un efecto urbanizador, que se concretó en la construcción de villas-etapa donde descansaba el peregrino, el cual acudía normalmente a hospitales. El Codex Calixtiunus del siglo XII describe donde se emplazaban los citados inmuebles, las hospederías e iglesias, espacios que se convertían en centros de vida y de intercambio de experiencias. La actividad religiosa y de circulación por estas vilas hacía crecer las relaciones comerciales e intercambiar conocimientos en las diferentes técnicas artesanales, lo cual iba asentado la vila, cuyos inmuebles se situaban unos junto a otros en la vía principal: la rúa de los francos, la rúa de Santiago (según las poblaciones) 6 .

Como consecuencia se formó una villa-calle, similar a la de Canfrac originaria del siglo XI, delimitada por el angosto abierto por el río Aragón en el relieve pirenaico o en Estella. La tendencia urbanística del camino resultaba evidente, los inmuebles se estaban situando a ambos lados del camino en forma axial.

Caniggia ${ }^{7}$ propuso una serie de constantes en la formación de cualquier agregado urbano espontáneo, evidentes en las poblaciones medievales, que se podrían hacer extensivas a los núcleos planificados más simples de los siglos XI y XII, de tipo lineal ${ }^{8}$ :

a) Todo asentamiento se produce sobre un recorrido previo que lo genera: las parcelas residenciales se van sucediendo a los lados de un camino territorial existente.

b) En el tejido parcelario-edificatorio que se apoya en el recorrido aparecen siempre unas características precisas como: 


\section{Evolución urbana de Jaca en la Edad Media}
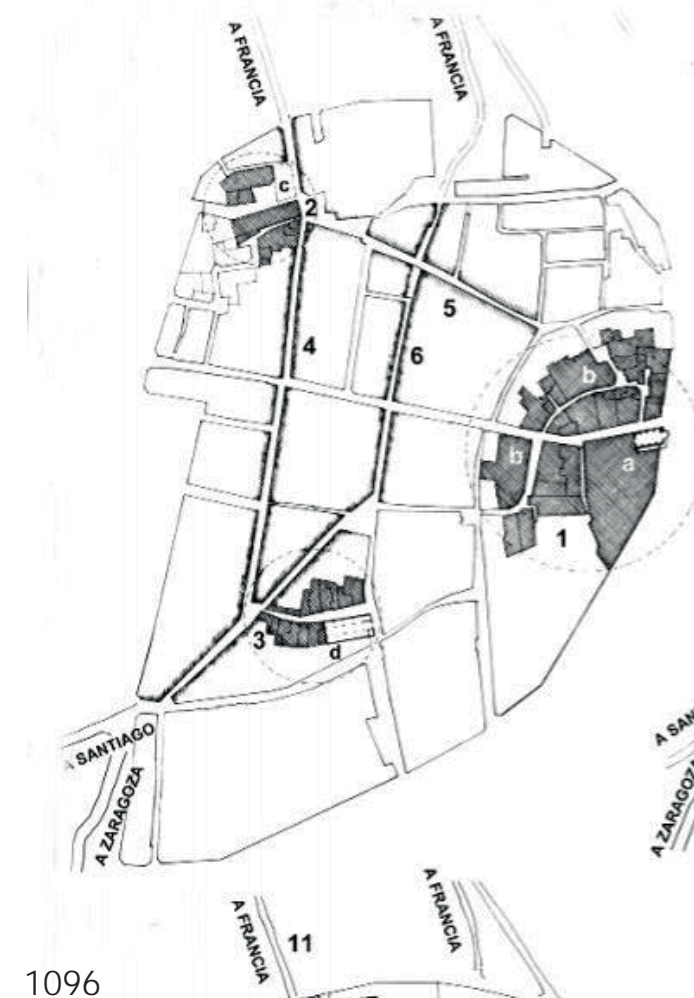

\section{LEYENDA}

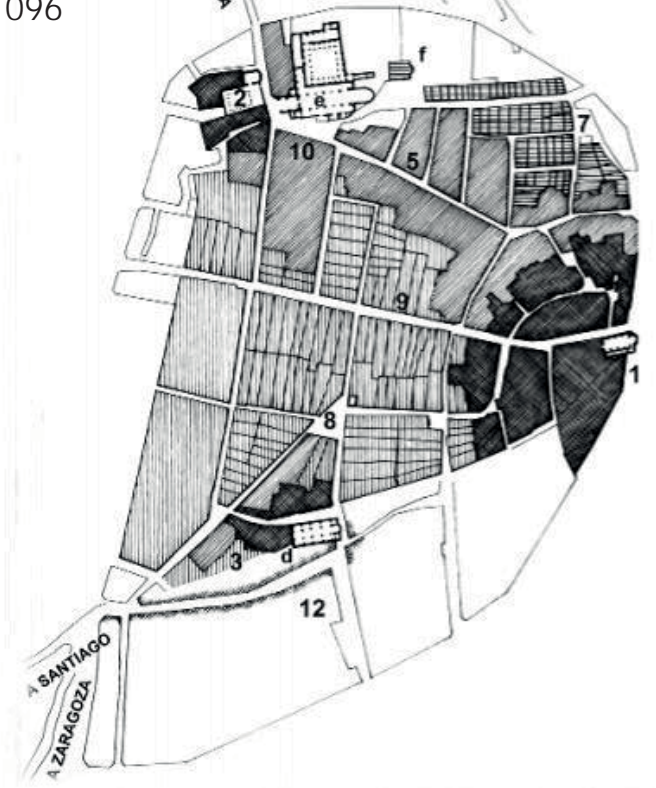

1- Castro
a) Castillo
b) Vila
i. Iglesia de San Ginés (S. XIII) y cripta de San Salvador

2- Bamio Ec lesiástico

3- Burto de Santiago

4- Camino de Francia a Compostela (Camino real de Sab Marcos)

5- Camino del Castro al Monasterio

6- Camino de Francia a Compostela (Ramal de la Bola)

7- Burgo de San Nicolas (Iglesia y fosar)

8- Ensanche principal de la ciudad

9- Calle Mayor

10- Plaza del Mercado

11. Burgo Novo

12- J udería

13. Muralla 
${ }^{9}$ Beltrán Abadía, R. (2.005):"Planeamiento y geometría en la ciudad aragonesa". Colegio de Arquitectos de Zaragoza. Arqueología y Territorio medieval. Revista de Arqueología del Área de Historia Medieval. Universidad de Jaén. Tomo 12.2, pág. 88.
- La modulación del ancho del frente de fachada. La citada dimensión solía coincidir con la longitud usual de una viga de madera o de ésta más el ancho de la escalera longitudinal (4'50-6 metros); si los inmuebles se construían con medianeras comunes, como era habitual en la época, esta longitud de fachada equivalía a la anchura de la parcela. Asimismo era común que entre cada casa y la contigua se dejara un callizo, herencia del ambitus romano, que correspondía a un corredor de cinco pies que mediaba entre parcelas contiguas para evitar riesgos de propagación de incendios y para favorecer el desagüe; esta solución suponía una mayor autonomía individual de los pobladores y una menor presencia del sentido de lo colectivo.

- La ortogonalidad de las parcelas con respecto al vial donde tienen situado el acceso.

- La similitud de las profundidades de las parcelas en la zona edificada, que comprende tanto los inmuebles como los espacios libres adosados, destinado como corral y patio de luces. Las profundidades de estos terrenos en el citado período presentan un intervalo desde 15 a 25 metros, incluidas la profundidad de la casa y la de la zona, generalmente trasera, sin edificar.

Todas estas singularidades configuran un uso modular de un tipo residencial, el inmueble estrecho y profundo con dos frentes en los lados cortos. En el caso de que la población necesitara mayor superficie, el camino original podía abastecerse con nuevos viales paralelos. Ante la situación planteada, se formaban manzanas longitudinales construidas por dobles filas de parcelas estrechas y profundas lindantes por sus frentes traseros y con sus fachadas dirigidas a viales rectos y paralelos donde se situaba el acceso principal; de éstas, una -el camino matriz- ostentaba el nivel jerárquico superior.

También era habitual que surgieran trazados urbanos en forma de espina de pez, estas tramas implicaban una mayor complejidad y conseguían que todos los inmuebles contaran con mayor semejanza, puesto que, a diferencia del ejemplo anteriormente descrito, se diferenciaban dos tipos de calles esencialmente distintos:

- La calle dorsal, coincidente con el recorrido matriz, sólo servía para la circulación general, dando acceso a las calles costales pero no a viviendas;

- Las calles costales, que partían de la dorsal y a cuyos lados se alineaban, perpendicularmente, las parcelas, con acceso 
desde ellas; la circulación de estas calles estaba más restringida, ya que se limitaba, en general, a la que iba y venía del recorrido matriz a sus parcelas ${ }^{9}$.

Por las consideraciones anteriores se podría pensar que la separación de los viales secundarios estuviera también modulada, pero no era así, estos viales contaban con mayor flexibilidad que los ejes principales, ya que el potencial de agregación transversal de las parcelas estaba limitado al doble de su profundidad, pero la capacidad de agrupación longitudinal era indefinido, pudiendo ser muy variable la longitud resultante de las manzanas, que no dependía ya del tipo edificatorio sino de la distancia razonable entre conexiones de calles primarias y secundarias, de acuerdo con las necesidades de la circulación urbana y de la evacuación pluvial ${ }^{10}$.

Para concluir cabe agregar un breve apunte, en los núcleos surgidos con mayor espontaneidad, las rúas secundarias cortaban a los ejes principales de manera independiente en cada espacio, con lo que la alineación en todo el conjunto correspondía a las calles por donde se situaba el acceso del inmueble, pero no en las de conexión.

\section{4 | El fuero de Jaca y su influencia en la traza regular}

La tendencia áxil, descrita en el apartado anterior, aparece consolidada y rebasada por la ortogonal, intensificada por el fuero de Jaca. Según se ha visto los reyes de Aragón y Navarra, con el fin de asegurar el territorio y consolidar su poder sobre los señores de los castros, toman la decisión de atraer población burguesa para ello activan en la zona un tráfico mercantil y de servicios suficiente que permita la consolidación de núcleos poblacionales. Con este propósito tuvieron que aprovechar la posible riqueza generada en el tráfico del camino y tentar a ciudadanos de más allá de los Pirineos para que acudieran a residir en una nueva población "franca" libre de las ataduras vasallísticas.

Sancho Ramírez contaba para ello con dos alicientes, por un lado la posición estratégica de Jaca en el cruce de caminos del Somport hacia Saraqusta y del Canal hacia Castilla y Santiago y por otro la concesión de derechos y libertades a partir de la concesión del fuero de Jaca. Otorgado entre los años 1076 o 1077, concedía a los nuevos colonos que se instalaran en el

${ }^{10}$ Ibídem, pág. 89. 
suelo de propiedad regia una serie de franquicias y privilegios excepcionales entonces en Europa, tales como:

- Libertad de circulación.

- Exenciones fiscales.

- Rebaja de las cargas militares en la hueste regia ${ }^{11}$.

El éxito del modelo promulgado no se hizo esperar llegando rápidamente pobladores al abrigo del nuevo régimen jurídico. No solo se asentaron nuevos vecinos en la citada población sino que se extendieron inmediatamente en otros puntos próximos de las rutas de peregrinación. Para ilustrar lo anteriormente indicado tres años después, en 1080, Centulo IV, promulga el For d'Oloron (la más antigua carta de municipalidad de Francia). Al mismo tiempo, y como sucede en Jaca, la vieja Illuro se convierte en sede episcopal. Ante los buenos resultados el mismo Sancho Ramírez repitió la experiencia concediendo el fuero al burgo nacido a los pies de la fortaleza de Lizarra, según Martín Duque entre 1007 y 1084.

Después de todo lo expuesto se puede asegurar que el nacimiento del urbanismo regular en el territorio pirenaico-aragonés durante los últimos decenios del siglo XI no fue por pura casualidad sino que se produjo al unirse una serie de circunstancias que no se habían dado hasta entonces en otros territorios.

Ante la situación histórica del momento el emergente reino aragonés tenía la obligación de fomentar una labor repobladora. Para que los colonos valoraran irse del lugar donde residían para asentarse en nuevos territorios totalmente desconocidos, resulta evidente pensar que se le tuvo que convencer o recompensar a partir de una serie de ventajas que hacia viable el arriesgarse a emprender rumbo a lo desconocido. Los reyes cristianos lo consiguieron a través de fueros o privilegios, ya que pudieron contar con una gran cantidad de suelo urbanizable para planificar de una vez, y bajo el espíritu romanizante introducido a través de

11 Bielza de Ory, V. (2000): "La ciudad ortogonal aragonesa del Camino de Santiago y su influencia en el urbanismo regular posterior". Aragón en la Edad Media, XVI, Univ. Zaragoza, Zaragoza, pág. 30.

\footnotetext{
${ }^{12}$ Ibídem, pág. 31.

${ }^{13}$ I bídem, pág. 31-32.
} la Ruta Jacobea por la red de monasterios (que tenía aquí una tierra de cruzada, especialmente apta para su realización).

Los nuevos colonos no se hicieron esperar seducidos por los fueros de Jaca y Estella, "los burgueses", eran francos, llegados de distintas regiones francesas; y cuyas actividades laborales pertenecían normalmente al sector comercial desarrollado en el camino, pero interesados en poder tener una parcela destinada a la explotación agraria y si la parcela correspondía a tierras de regadío las expectativas se cumplían con creces. 
La trama urbana de cada una de las vilas se formó a partir del reparto de suelo, llevado a cabo con un único criterio: parcelas iguales para hombres iguales, sobre un territorio que era cedido para su explotación pero seguía siendo propiedad del rey. La parcela, que era la unidad fiscal, primaba en la ordenación, sobre lo que eran los espacios públicos, con excepción de la rúa de peregrinación, donde se alineaban los hospitales, las tiendas y los servicios en general. Podría decirse que el Camino de Santiago fue el eje ordenador del plano, de las parcelas y de las viviendas.

Sin embargo aunque la trama medieval seguía unas pautas eran tenidas en cuenta las condiciones del emplazamiento y el castro preexistente puesto que se adaptaban a él. Así, mientras Jaca podía crecer su ensanche al oeste del plano en aureolas concéntricas del castrum primitivo, de forma ortogonal según una cruz, en Estella el fuero se aplicó inicialmente a un burgo alargado en la orilla derecha del Ega. Esta población se dispuso en torno a una calle, que sólo se ensanchaba en la pequeña plaza de San Martín de los Francos abierta al puente sobre el río, que daría paso en la otra ribera a nuevos burgos y que más tarde podrán expandirse ortogonalmente con una cierta mayor planitud $^{12}$.

A la hora de realizar el replanteo de los espacios privados el suelo se distribuía en manzanas iguales y éstas a su vez se dividían en parcelas iguales, donde el nuevo colono constituía su vivienda entre medianeras con una fachada de ancho que permitía la viga de madera de $4,5 \mathrm{~m}$ o de ésta más el ancho de la escalera llegando hasta $6 \mathrm{~m}$. En la parte posterior de la vivienda se encontraba el corral y patio de luces hasta alcanzar una profundidad de $25 \mathrm{~m}$. Hasta hace poco tiempo en la calle Mayor de Jaca o en la rúa de las tiendas de Estella era fácil descubrir el efecto de aquel reparto medieval en las estrechas fachadas de las viviendas.

El fuero de Jaca se aplicó en Aragón fuera del Camino en el avance reconquistador hacia el sur por necesidades de repoblación, contribuyendo dentro de la época románica a configurar unos burgos y un modelo urbanístico aragonés que se perfeccionaría en época gótica ${ }^{13}$.

A manera de resumen final queda demostrado que en el siglo $\mathrm{XI}$, mientras Europa experimentaba un gran auge económico, el nuevo reino de Aragón, apenas sin población y con escasos recursos naturales, no reunía las condiciones necesarias para 
que el comercio fluyera de un modo espontáneo y natural; sin embargo los Reyes cristianos con una buena amplitud de miras supieron ver las ventajas de su territorio, etapa obligada en las vías del camino de Santiago, para fundar un conjunto de burgos de mercado que se acompañaron con los más remotos trazados regulares del urbanismo feudal aragonés ${ }^{14}$.

Con el fin de atraer pobladores los reyes ramirenses promovieron la construcción de nuevas poblaciones en tierras de su patrimonio personal, obteniendo en contra partida varios beneficios en concepto de tasas e impuestos a cambio de los privilegios que se les otorgaba, el provecho era mutuo. Pero el destino de estas fundaciones no se agotaba en ellas mismas; antes bien, su fin primordial era el impulso de la producción agraria en las tierras próximas sobre los niveles de subsistencia, propiciando la superproducción para el mercado y el consiguiente incremento de la renta de la que se beneficiaban, además del propio rey, los monasterios cluniacenses y los señores laicos beneficiarios de concesiones territoriales en el entorno de las grandes rutas de comunicación, (entre las que en ese momento el camino de Santiago ostentaba la supremacía) ${ }^{15}$.

\section{5 | Las villas de fundación: las cartas de población y los fueros}

${ }^{14}$ Beltrán Abadía, R. (2005): "Planeamiento y geometría en la ciudad aragonesa". Colegio de Arquitectos de Zaragoza. Arqueología y Territorio medieval. Revista de Arqueología del Área de Historia Medieval. Universidad de Jaén. Tomo 12.2, pág. 90.

${ }^{15}$ Ibídem.

${ }^{16}$ Beltrán Abadía, R. (2005): "Planeamiento y geometría en la ciudad aragonesa". Colegio de Arquitectos de Zaragoza. Arqueología y Territorio medieval. Revista de Arqueología del Área de Historia Medieval. Universidad de Jaén. Tomo 12.2, pág. 85 .
La función de las villas para crear nuevas redes de poder centralizado explica el papel que en su implantación tuvo la geometría, tanto en la escala urbana como en la territorial. El territorio debía ser controlado mediante villas uniformemente espaciadas y sujetas a una jerarquía. En el orden interno, la geometría permitía disponer de un modo ordenado y calculado el establecimiento del burgo, repitiendo un modelo urbano que resultaba ser eficaz y, más adelante, ejercer el poder mediante recursos urbanísticos que superaban las exigencias impuestas a las aldeas campesinas formadas por impulso de sus propios pobladores. El contenido simbólico del poder implícito en las geometrías rígidas se enfatizó con la consolidación de los nuevos estados centralizados, desde las últimas décadas del siglo XII, para producir ejemplares muy acabados a lo largo del siglo $\mathrm{XIII}^{16}$.

Desde el último cuarto del siglo $\mathrm{XI}$, el proceso de repoblación y reestructuración demográfica, económica y jurídico-política del territorio se atuvo a una planificación general y a instrumentos jurídicos más elaborados, como las cartas de población y los fueros, cuyo contenido era diferente según el tipo de habitantes 
y funciones que los dueños de la tierra querían implantar en la población naciente, ampliada o refundada. Las nuevas poblaciones no sólo se beneficiaron del perfeccionamiento de las herramientas jurídicas, sino también del instrumental urbanístico que, a finales del siglo $\mathrm{XI}$, materializó trazados regulares y sistematizados. Estas tramas urbanas fueron posibles gracias a que las fundaciones se producían en suelos pertenecientes a un señor. A él le correspondía realizar la ordenación en todos sus aspectos antes de entregar las parcelas a los pobladores en régimen de tenencia para que se instalaran y ejercieran sus actividades ${ }^{17}$.

El procedimiento era el siguiente: El rey o el señor que quería ubicar un nuevo núcleo de población en terrenos de su pertenencia promulgaba un fuero ${ }^{18}$ o una carta puebla que contenía privilegios ${ }^{19}$ para atraer colonos, a la medida del tipo de ciudadanos pretendido. Además de las citadas anteriormente, libertad de circular, reducciones fiscales y exenciones militares para atraer burgueses, también se encontraban:

- La obligación de tener siempre un hombre armado en casa.

- La participación obligatoria en cabalgadas y huestes con derecho a parte del botín, u otorgamiento de parcelas mayores para quienes tuvieran caballo para atraer guerreros. - El derecho de escaliar (apropiación de la tierra yerma que cada cual cultive) para atraer agricultores dispuestos a poner en cultivo extensos términos incultivos ${ }^{20}$.

Las nuevas vilas medievales requerían una planificación parcelaria que, por medio de la geometría, impusiera un orden en la división del suelo y de este modo facilitara su incorporación al proceso productivo y fiscal; la parcela destinada a albergar la casa de una familia nuclear -padre, madre e hijos solterosera a la vez unidad fiscal y unidad compositiva de la nueva villa. En estas poblaciones el plano parcelario era el punto de arranque de la vida urbana, el elemento originario a partir del cual entran a generarse todos los órdenes. Pasado un tiempo también se utilizó, como mecanismo para asignar las rentas urbanas y rústicas en la vila, el parcelario seguiría siendo un elemento económico y social fundamental.

Este modelo regular no solo se utilizó para fundar nuevas poblaciones, también se utilizó en las ciudades y barrios para trazar nuevos ensanches ordenados que buscaban la máxima eficacia funcional, la división en espacios adecuados para
${ }^{17}$ Ibídem, pág. 86 .

${ }^{18}$ Son Leyes hechas en Cortes.

${ }^{19}$ Son resoluciones decretos de los reyes por su propia autoridad y de marcado carácter ejecutivo.

${ }^{20}$ Beltrán Abadía, R. (2005): "Planeamiento y geometría en la ciudad aragonesa". Colegio de Arquitectos de Zaragoza. Arqueología y Territorio medieval.. Revista de Arqueología del Área de Historia Medieval. Universidad de Jaén. Tomo 12.2, pág. 87. 
la parcelación pretendida y, a partir de cierto momento, un determinado diseño y gusto estético buscando el ideal tardío medieval de la ciudad como forma bella.

En las villas planificadas, los ejes de las callejas de conexión que atravesaban manzanas paralelas tendían a coincidir, aproximando el trazado viario a una retícula desigual, con calles más frecuentes, más anchas y con accesos en una dirección, y calles más raras, estrechas y sin accesos en la perpendicular (como sucede en el barrio de San Pablo de Zaragozá) ${ }^{21}$.

Con el paso del tiempo los trazados también se van modificando, la longitud de las manzanas, al principio muy larga, tiende a disminuir, reduciéndose al doble o el triple de la anchura, y en los ejemplos más avanzados, ya del siglo XIII en adelante, a una dimensión igual a la anchura, produciendo manzanas cuadradas y calles equidistantes en las dos direcciones.

En esta época, los inmuebles cuentan con un solo acceso, siempre hacia el vial mas importante, incluso cuando las islas fueran cuadradas y los viales parecieran iguales en las dos direcciones.

En las villas de los siglos XI y XII, a la homogeneidad del parcelario se añadió la inexistencia de algo comparable a un centro urbano, con exclusión de plazas y edificios privilegiados que, aunque inmediatos, solían quedar fuera del caserío. Antes del siglo XIV, las plazas del mercado eran más bien amplios yermos situados a la entrada a la villa, normalmente junto a la iglesia. Incluso muchas de las iglesias que hoy en día ocupan el centro del parcelario, como la parroquia de la Asunción de Canfranc, estuvieron inicialmente en un extremo, que en los núcleos itinerantes solía ser el de la entrada; en poblaciones con dos parroquias era muy frecuente que se emplazara una en cada extremo, y en las más complejas, con tres o más parroquias, se mantenía la tendencia a emplazarlas junto a puertas de la cerca ${ }^{22}$.

${ }^{21}$ Beltrán Abadía, R.(2005) : "Planeamiento y geometría en la ciudad aragonesa". Colegio de Arquitectos de Zaragoza. Arqueología y Territorio medieval. Revista de Arqueología del Área de Historia Medieval. Universidad de Jaén. Tomo 12.2, pág. 89.

${ }^{22}$ Ibídem,
Con estos principios básicos, se trazaron las nuevas poblaciones en los siglos XI y XII según criterios sólo dirigidos a lograr la igualdad del parcelario y una lógica elemental en el trazado de las calles; más que la regularidad en sí misma se buscó la semejanza y la repetición. Como ya se ha mencionado para el señor la prioridad no era el espacio urbano sino la parcela, unidad tributaria a partir de la que se generaba el pago de rentas. La regularidad de las villas de fundación, como casi todo lo inherente a las trazas urbanísticas en la mayoría de todas las ciudades, no se debía a un capricho estético: la ciudad no pertenecía a la 
categoría de lo artístico. Detrás del replanteo de las parcelas existía unas detalladas intenciones políticas y económicas. De ahí que cuando el relieve del terreno $u$ otras circunstancias lo recomendaron, el plano se deformó cuanto hizo falta para preservar la urbanización regular y la funcionalidad del viario, como lo que ocurrió en Aínsa, Berdún o Cordes.

El mecanismo para la fundación de las nuevas villas y de los burgos mercantiles -también artificiales- que se adosaron a otras ya existentes, fue la concesión de franquicias y privilegios a los pobladores, mediante un fuero o una carta de población. Dichos privilegios quedaban referidos a zonas urbanas acotadas aquellos burgos y villas que habitaban los burgueses ${ }^{23}$.

El objeto del fuero era crear y preservar una trama urbana lo mas similar posible con el fin de albergar un estrato social burgués en la que todos los nuevos colonos cristianos fueran jurídicamente iguales entre sí y ante el rey, fuera cual fuera su anterior condición, es decir, ya se tratara de caballeros, labradores o burgueses, lo que fue un importante logro para estos dos últimos grupos. Para ejemplificar tal decisión constatar que entre los siglos XI y XIII todas las redacciones del fuero de Jaca coincidían en excluir de la posibilidad de posesión de tierras a los nobles y los clérigos ${ }^{24}$.

Una vez el colono llegaba a su nuevo destino se le concedía gratuitamente una heredad urbana (partem, plaçam o plaztam) igual a todas las demás, lo que requería una ordenación urbanística previa por parte de los merinos del rey. Quienes vinieran una vez poblada la vila deberían adquirir el suelo a título oneroso a los pobladores que quisieran venderlo. Los nuevos vecinos no eran propietarios del suelo, sino que, permaneciendo éste siempre bajo el dominio del rey, lo utilizaban libremente en régimen de honor; en consecuencia, no podían vender ni comprar un suelo que no era suyo, y que el rey les había concedido libre de cargas y gratuitamente por el hecho de acudir a poblar el lugar; pero sí eran de su propiedad las construcciones que sobre estas parcelas edificaban y, por ello, se les reconocía el derecho a enajenarlas y transmitirlas a sus descendientes indefinidamente, si bien con ciertas limitaciones consustanciales a los intereses que habían inspirado la fundación de esas poblaciones ${ }^{25}$.

Una vez adjudicadas las parcelas los nuevos pobladores tenían la obligación de edificar y cercar la parcela que le fuera asignada por sus propios medios.

${ }^{23}$ Ibídem, pág. 91.

${ }^{24}$ Ibídem, pág. 91.

${ }^{25}$ Ibídem, pág. 92. 


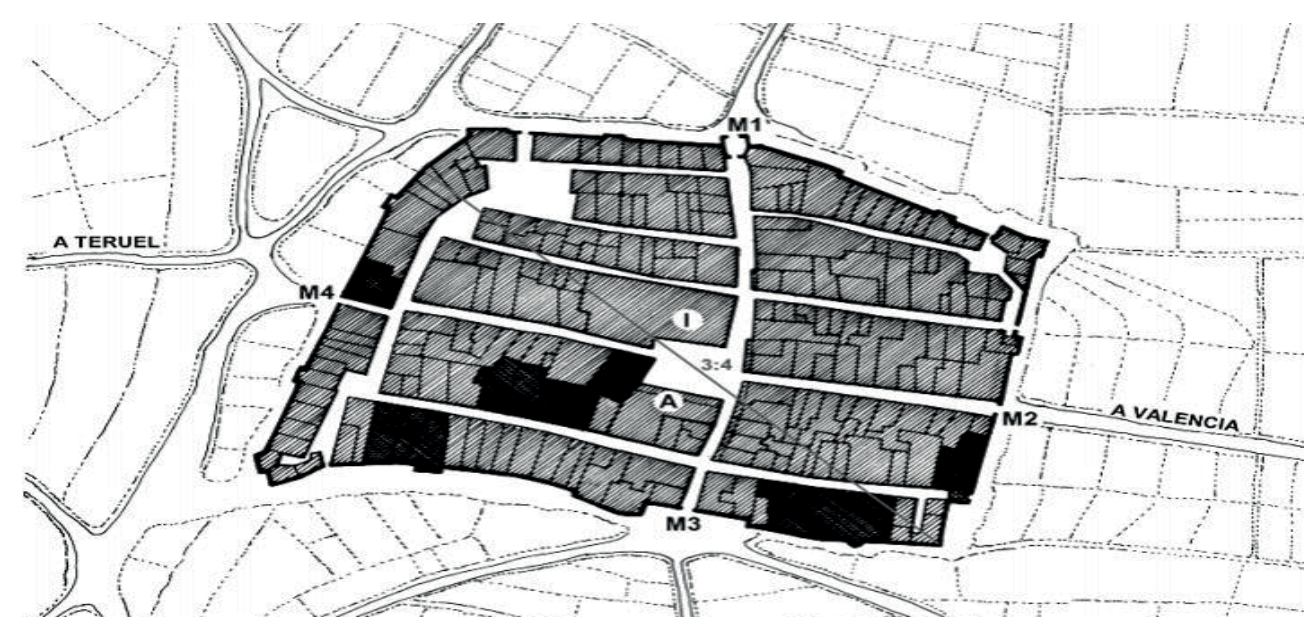

Fig. 010. Plano de la vila de Mosqueruela, fundada en 1.263. La plaza central está situada en el cruce de los dos viales principales.

\footnotetext{
${ }^{26}$ Beltrán Abadía, R.(2005): "Planeamiento y geometría en la ciudad aragonesa" ,Colegio de Arquitectos de Zaragoza, Arqueología y Territorio medieval. Revista de Arqueología del Área de Historia Medieval. Universidad de Jaén, Tomo 12.2, pág. 113.
}

Tanto en las villas nuevas como en las operaciones de ampliación y reforma de las ciudades existentes fue fundamental desde el siglo XIII la recuperación de la antigua herencia de los romanos, conocida a través de manuscritos y de la práctica arquitectónica monástica, y perfilada por una nueva ciencia topográfica basada en el uso de la cuerda, el compás, la brújula y otros instrumentos ópticos.

Para concluir el apartado un dato significativo, ante un urbanismo que florecía rápidamente y siguiendo la geometría más rigurosa y compleja fue de vital importancia la adquisición de nuevos conocimientos que Occidente absorbió del Islam mediante las traducciones acometidas sistemáticamente en Toledo, Sicilia y Bizancio durante los siglos XII y XIII y que dieron a conocer a los tratadistas griegos y musulmanes, junto a materias totalmente ajenas, como la geometría o el álgebra ${ }^{26}$.

\section{6 | La ciudad aragonesa en el sur del Reino: aparición de la plaza y la muralla}

Desde el punto de vista actual se puede llegar a imaginar que tanto la plaza como la cerca defensiva fueron elementos arquitectónicos presentes en las vilas desde su origen, pero ambos bienes no se incorporaron al trazado hasta el siglo XII y fue debido a dos razones, por la defensa y el paso del mercado al burgo foral de traza ortogonal, ya consolidado en Aragón.

En el siglo XIII, se aplicará en el Sur del Reino de Aragón con dichos elementos debidamente integrados y jerarquizados, de acuerdo con la nueva mentalidad gótica. 


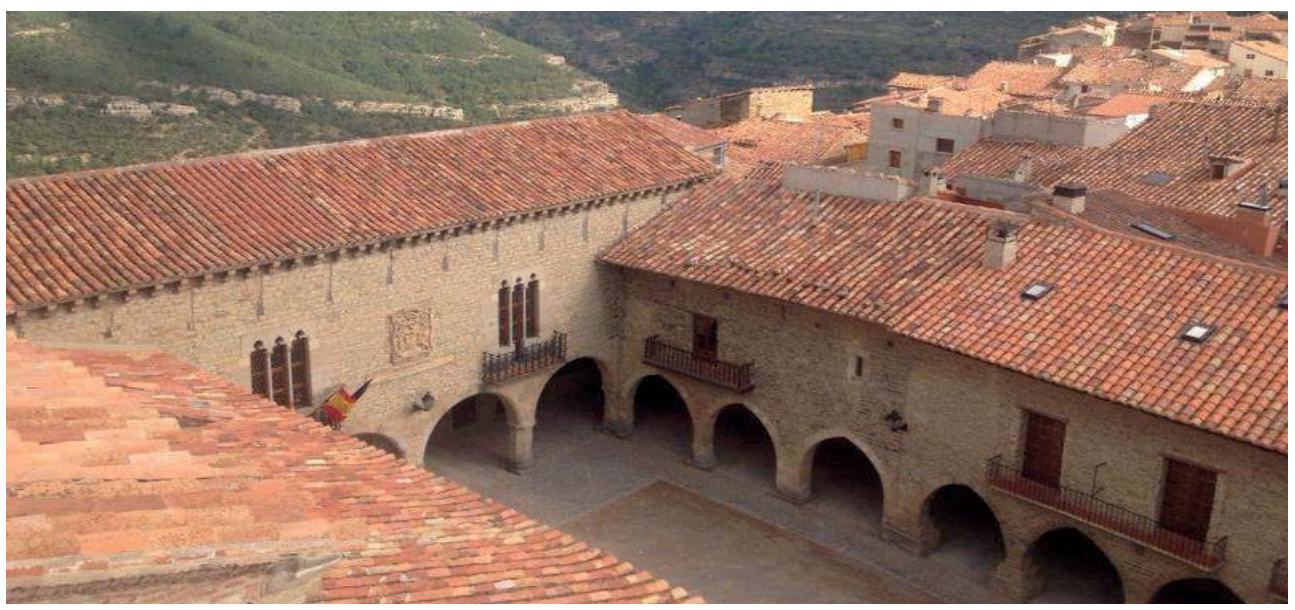

El núcleo fundacional surgido por el fuero de Jaca nace en un camino seguro, defendido en su conjunto por los reyes Sancho Ramírez de Aragón y Pamplona y Alfonso VI de Castilla, es decir, no necesitaba defensa amurallada y solo una cerca que limite el espacio jurídico privilegiado frente a la población servil del castrum o simplemente respecto del exterior campesino. Tampoco se organiza en torno a una plaza mercantil y social como en la época gótica, porque inicialmente los burgueses traficaban sobre el camino de Santiago y, dentro del recinto urbano, en la rúa. Es por ello que la muralla y la plaza irán apareciendo posteriormente por distintos motivos.

El recinto amurallado surgió como necesidad defensiva ante la inseguridad bélica. Las primeras correspondieron a Alquezar y Aínsa, que en 1114 y 1127 recibieron el fuero de Jaca y empezaron a necesitar murallas frente a las invasiones del Norte y del Este ${ }^{27}$.

La plaza como centro urbano se añade a la regularidad del trazado urbano en las villas burguesas del románico aragonés. Los espacios destinados a ubicar el mercado, antes del siglo XIV eran más bien amplios yermos situados junto a la entrada de la villa, normalmente junto a la iglesia.

Las dos funciones generadoras de nuevas directrices del plano son las que desarrollan y consolidan el carácter urbano de muchos de los nuevos burgos en cuanto a los servicios defensivos y comerciales se refiere. Las comarcas, forjadas en torno a éstos, serán las que convierten a los burgos en pequeñas ciudades de servicios, aún después de coagulada la vena circulatoria jacobea. A todo esto cabría añadir la ordenación en función de una cruz orientada a los cuatro puntos cardinales.
Fig. 011. Plaza mayor de Cantavieja. Se observan los soportales en la planta baja de la casa consistorial donde se realizaba el mercado y las diferentes reuniones.
${ }^{27}$ Bielza de Ory, V (2000).: "La ciudad ortogonal aragonesa del Camino de Santiago y su influencia en el urbanismo regular posterior". Aragón en la Edad Media, s. XVI, Univ. Zaragoza, Zaragoza, pág. 33. 
${ }^{28}$ Bielza de Ory, V (2000).: "La ciudad ortogonal aragonesa del Camino de Santiago y su influencia en el urbanismo regular posterior". Aragón en la Edad Media, s. XVI, Univ. Zaragoza, Zaragoza, pág. 36

${ }^{29}$ Aquino de, S. Tomás (1266): Del Gobierno de los príncipes, opúsculo no 11, libro prim., Buenos Aires, Losada, 1964, pág. 5.
En Aragón del Valle Medio del Ebro en el s. XII ya encontramos espacios urbanos previos a la conquista; en cambio en el sur de Aragón, en las tierras turolenses que hubo que organizar casi partiendo de cero, sí fue posible crear nuevas poblaciones regulares con arreglo al modelo nacido en el norte, pero incorporando desde el principio plaza y muralla bajo una nueva mentalidad. También hizo falta nuevas poblaciones en otros territorios más allá del Reino de Aragón, como en Castellón, Valencia, Alicante y Mallorca ${ }^{28}$.

La división del trabajo al crecer y evolucionar las sociedades burguesas de unas villas y ciudades que fueron generando servicios y oficios se tradujo en una jerarquía social que tendría su expresión en una concepción del espacio bajomedieval, configurando la ciudad prerrenacentista, en la que la parcelación ya no será homogénea. De la exigencia socioeconómica de la heterogeneidad pronto se harán eco los filósofos. Así Santo Tomás de Aquino, enuncia:

\section{Si se comienzan las obras de fundación de una ciudad, es preciso prever cuál será el lugar sagrado, cuál será el de administrar justicia, cuál el de los diversos gremios ${ }^{29}[\ldots]$}

Es a partir de este momento cuando se sustituye el modo de replantear la trama urbana, la plaza como centro y la muralla como límite ya no serán añadidos a una vila parcelada regularmente sino elementos fundamentales que organizarán la jerarquía de los viales y la trama urbana. El concepto se modifica puesto que el replanteo de la vila no se iniciará desde la parcela sino desde los espacios públicos, el primero de los cuales la plaza, la cual será bordeada por edificos públicos más relevantes (la iglesia principal, el palacio civil...) y en la que se celebrará el mercado semanal, la feria anual o semestral y los acontecimientos más relevantes de la vida social.

Normalmente la plaza se encontraba en la intersección ortogonal de los ejes principales, que abrían en la muralla las cuatro puertas por las que, prolongándose dichas vías, se ordenaban reticularmente los espacios agrarios circundantes, como lo hicieran antaño las centurias romanas. Se trataba de una forma de facilitar el acceso al mercado de los productos agropecuarios de la comarca que aprovisionaban las necesidades de la villa y que eran transformados por sus artesanos, quienes se distribuían en gremios organizados en las calles adyacentes a la plaza. Como señala Gilles Bernard en L'Adventure des bastides: 


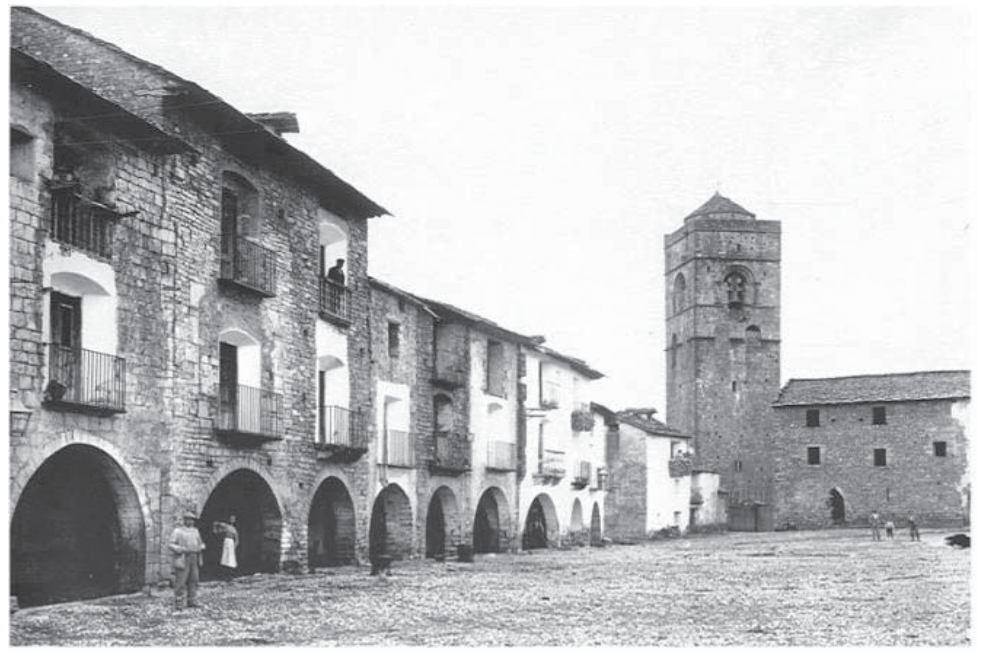

La regularidad de los planos ha dado lugar a numerosas interpretaciones, pero la clave se encuentra en la mentalidad gótica que descubre las relaciones entre lo elemental y lo complejo. Es a través de ello como se puede analizar la importancia, del mercado, el lugar secundario de la iglesia y la ordenación del parcelario fuera del espacio construido ${ }^{30}[\ldots]$

La plaza fue el elemento que caracterizó al urbanismo del período que se inicia hacia 1250 , y que muchas veces arquitectónicamente fue bordeado con soportales. Los mercado medievales de Cataluña y Aragón solían rodearse por amplios soportales abiertos por arcos de piedra; en la mayor parte de los casos se formaron por adición de edificios desiguales, cada uno con uno o más arcos de distinto tipo, pero lograron la unidad por la continuidad espacial del espacio porticado. Todas estas plazas solían tener accesos por las esquinas y la planta rectangular o trapezoida ${ }^{31}$.

Además de ser utilizado como centro comercial, la plaza del mercado era el lugar público más importante de la ciudad, y pronto fue su centro representativo. La escasez de espacios públicos intramuros hizo de ella un lugar plurifuncional muy apto para funciones colectivas, espectáculos o juegos; la condición cívica de que estaba impregnada la hizo atractiva para las instituciones comunitarias de la ciudad a la hora de elegir su emplazamiento. Las nuevas casas consistoriales, las cárceles y otros edificios representativos fueron edificándose en torno a estas plazas de mercado que ya podían llamarse
Fig. 012. Plaza mayor del municipio aragonés de Aínsa. Imagen que detalla los restos patrimoniales de los soportales y la torre gótica a principios de siglo XX.

\footnotetext{
${ }^{30}$ Bernard, G. (1993): L'Advenutre des bastides, Ed.Privat, Tolouse, Ed. 2003, pág. 63.

${ }^{31}$ Beltrán Abadía, R. (2005):“Planeamiento y geometría en la ciudad aragonesa". Colegio de Arquitectos de Zaragoza. Arqueología y Territorio medieval. Revista de Arqueología del Área de Historia Medieval. Universidad de Jaén. Tomo 12.2, pág. 112.
} 
Fig. 013. Puente gótico de la zona de Cantavieja en Teruel. Imagen actual.

\footnotetext{
${ }^{32}$ Beltrán Abadía, R. (2005):"Planeamiento y geometría en la ciudad aragonesa". Colegio de Arquitectos de Zaragoza. Arqueología y Territorio medieval. Revista de Arqueología del Área de Historia Medieval, Universidad de Jaén, tomo 12.2, pág. 112.

33 Ibídem, pág. 113.
}

con propiedad plazas mayores. Este proceso se siguió, entre los siglos XIII y XVI, en Aínsa, Graus, Ejea, Calatayud, etc. En las ciudades de nueva fundación de Levante y la provincia de Teruel, las plazas de mercado constituían desde un principio el centro urbano $^{32}$.

En Aragón y en las zonas mediterráneas -Cataluña, Valencia, Baleares, la Península Itálica-, las plazas mercantiles quedaron normalmente descubiertas, con la única protección de los pórticos adintelados o arcados con que a veces se rodearon al final del medievo. En muchas poblaciones de la Corona de Aragón las plazas se completaron con pequeñas lonjas, edificios públicos cubiertos pero abiertos en su frente, destinados a usos mercantiles, contratación de mercancías, operaciones bancarias, etc. Este tipo emparentaba con logias ${ }^{33}$.

Fueron utilizados también como lonjas los porches de la planta baja de las casas consistoriales construidas entre los siglos XV y XVII; como se pueden contemplar en los municipios de Bielsa, Cantavieja, Beceite, Calaceite, Valderrobres y tantos otros municipios aragoneses. En algunas vilas, las lonjas fueron estructuras independientes anexas a los edificios consistoriales, abiertas por sus frentes como porches exentos; como quedan documentados en las vilas de Alcañiz y Sos.

A manera de resumen final se puede enunciar que el parcelario ortogonal y homogéneo, a finales del siglo XI dio lugar a una trama urbana que incorporó dos elementos fundamentales la muralla y la plaza- ante la creación de nuevas vilas. Desde finales del siglo XII y primera mitad del XIII la regularidad deja de ser toda semejante para jerarquizarse desde la plaza central hacia los viales, distinguiendo el espacio público al trazado de la manzana y parcela de las viviendas y quedando la iglesia y la Sala del Consell en lugar secundario respecto a la plaza del mercado. 
45 de 536

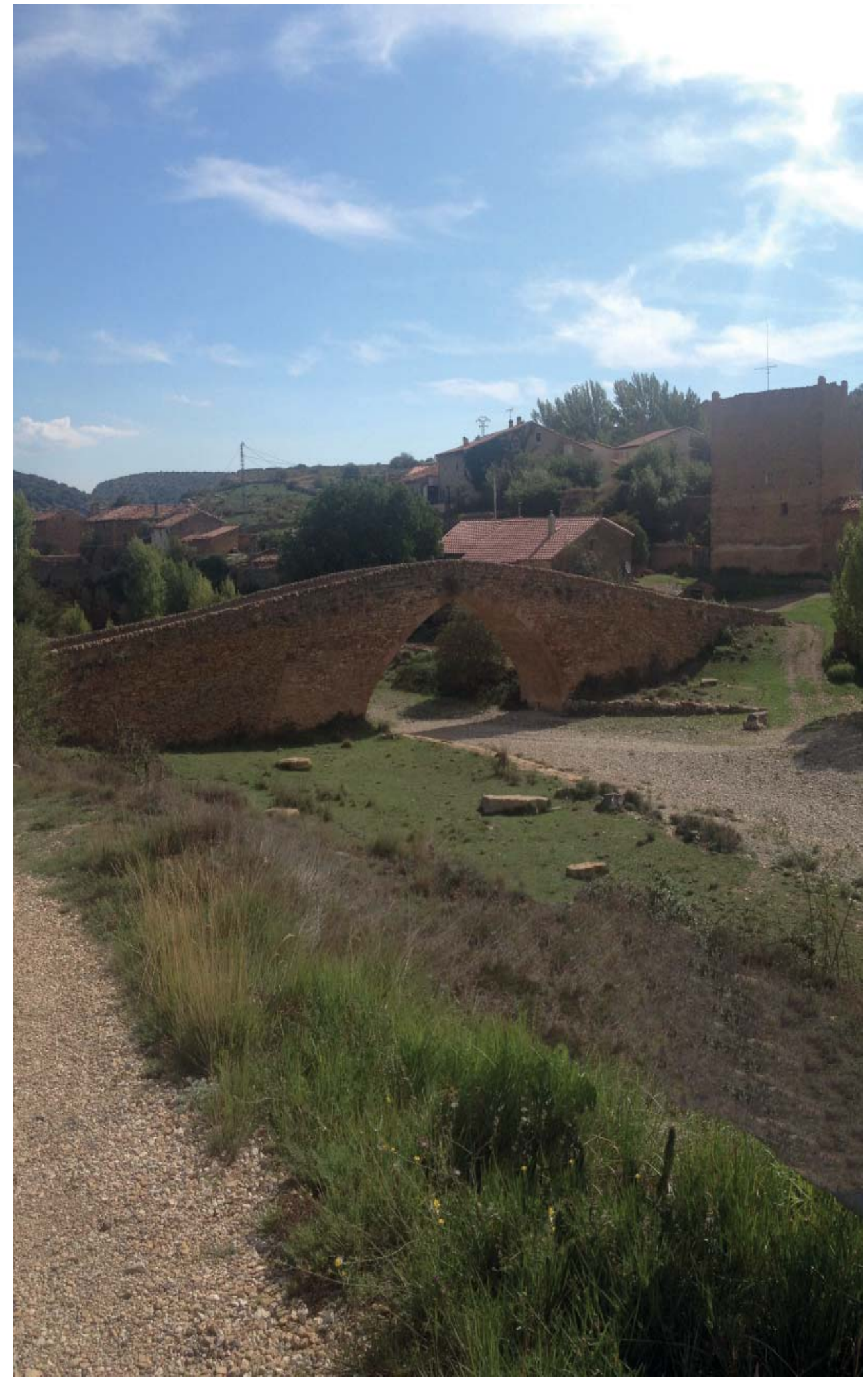

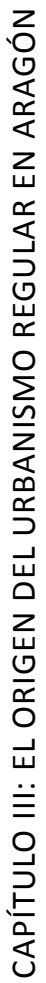


$\mathbf{4 6}$ de 536

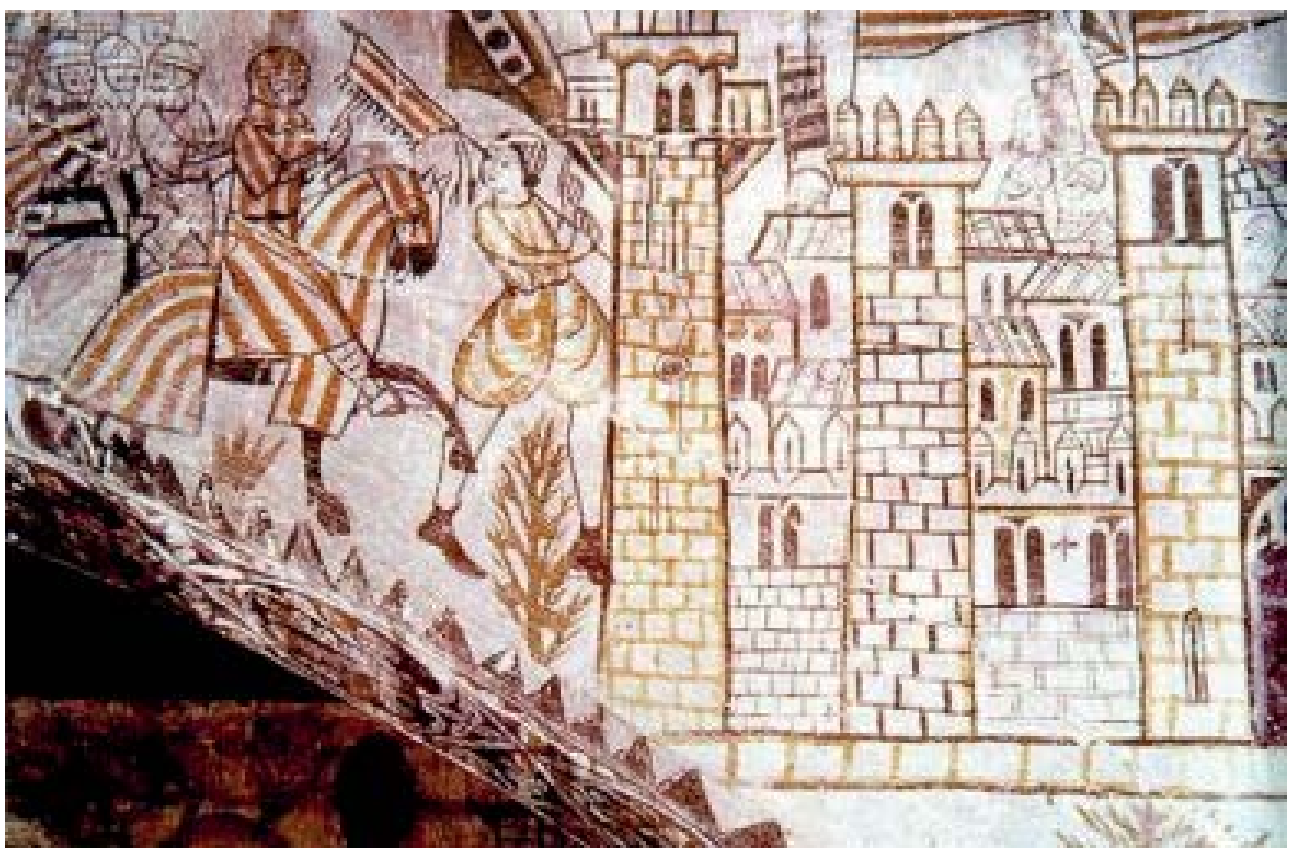


Fig. 014. Pinturas murales del castillo de Alcañiz (Teruel). Siglo XIII. Representa la entrada de Jaime I en Valencia durante la reconquista.

\section{APÍtulO IV|}

\section{URBANISMO VALENCIANO EN LA BAJ A EDAD MEDIA}

\section{1| Antecedentes históricos: La reconquista de Valencia}

El poder andalusí se hundió durante el siglo XIII frente a las fuerzas feudales en buena parte de la Península Ibérica, de manera que el denominado Sharq Al-Andalus, un territorio que de forma aproximada comprendía los posteriores reinos medievales de Valencia y Murcia, no tuvo mejor suerte.

Las tropas cristianas comandadas por el rey Jaime I ocuparon todo la región valenciana hasta la población de Biar en unos pocos años, entre el asedio de Borriana en el año 1233 y la conquista del espacio situado al sur del río Xúquer en 1245, sin encontrar prácticamente una resistencia militar digna de mención.

Tal y como ha destacado la historiografía se trató de un proceso de expansión general en toda Europa, de forma especial en el Este de la Península Ibérica, que supuso en esta última área la desaparición de todos los reinos musulmanes salvo el de Granada ${ }^{34}$.

A mediados 1237, el ejército cristiano se encontraba ya acampado al Puig de Cebolla, donde el rey había resuelto

34 Bordes García, J. y otros: La Pobla de Vallbona, historia, geografía y arte. Universidad de Valencia. Cap. Historia Medieval, pág 37. 
Fig.015.Expansión del modelo social de las pueblas de colonización desde la corona de Aragón hacia Valencia, Murcia y Baleares.

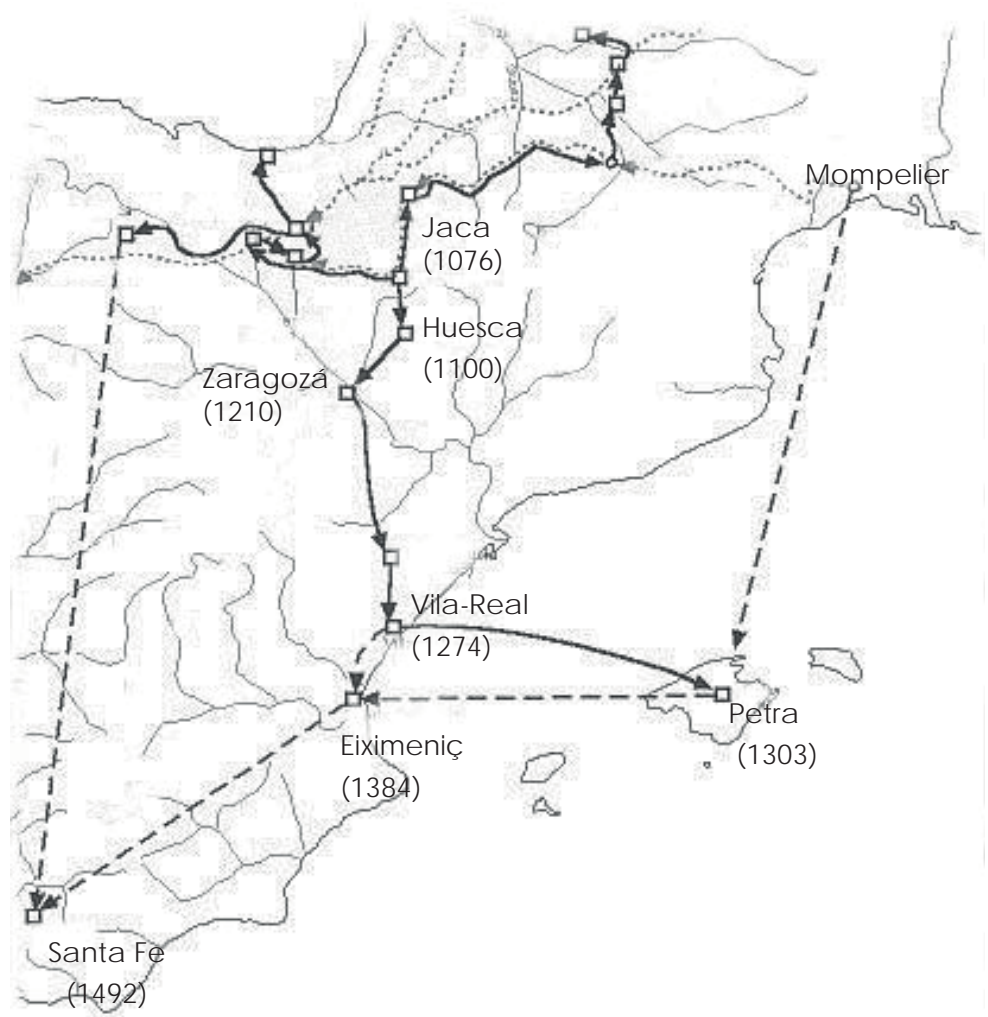

establecer su cuartel general. A partir del día 9 de julio comienza a redactar un registro notarial en el cual iba escribiendo las donaciones de castillos, villas y alquerías que el rey concedía a sus compañeros con el fin que siguieran a su lado ${ }^{35}$.

Estas donaciones hacen referencias a bienes que estaban aún por conquistar, dentro de la ciudad de Valencia y su huerta, y se refieren, a veces, a una superficie de tierras sin fijar un lugar $y$ otras veces a alquerías, castillos o villas bien especificadas. Esta ubicación suponía un conocimiento admirablemente perfecto de la topografía de un territorio que aún estaba en poder del enemigo.

La creación del Reino de Valencia por el rey Jaime l en 1239 supone la paulatina disgregación del mundo islámico. Su intención era crear un reino ex novo, al que dotó de una ordenación política y administrativa propia, Les Costumnes que fueron revisadas en 1251 y estructuradas en libros y furs o capítulos.

${ }^{35}$ Nicolau i Bauza, J. (1990): Págines de la Història de Benaguasil. Edición Ayuntamiento de Benaguacil, cap.1, pág. 19.
El rey Jaime I, para atraer nuevos colonos, basándose en la experiencia de siglos antes en Aragón a partir del fuero de 
Jaca, procede a redactar unos derechos o privilegios que se les concederá a cada uno de ellos, conforme al municipio que acudan, a partir de las cartas de población.

Se trataba de un derecho particular del nuevo reino que, por una parte afirmaba la supremacía del monarca frente a la nobleza y, por otra, favorecía el desarrollo de los estratos medios urbanos y de los municipios. Así, para este nuevo reino, que depende directamente del monarca, se creó una estructura social nueva y totalmente revolucionaria en la época que concede el dominio a los estratos medios urbanos -la burguesía ciudadana y al estado popular- frente a la nobleza y el clero.

La conquista de los reinos de Valencia y de Mallorca por los aragoneses y las consiguientes repoblaciones mediante fueros, derivados de los de Aragón, facilitaron la expansión y mejora del modelo gótico aragonés.

Este nuevo orden influyó, sin duda alguna, en el progresivo auge que experimentaron las ciudades en aquel momento gracias al concepto de organización social basada en la ciudad, más acorde con el progresivo auge de las ciudades en la Europa occidental. Jaime I facilitó la instalación no sólo de pequeños propietarios agrícolas independientes, sino también de artesanos, comerciantes y otros profesionales que pronto se convirtieron en una homogénea base de hombres independientes con una nueva forma de vida. No obstante, cuando los primeros colonos llegaron a tierras valencianas se encontraron con una amplia y numerosa población musulmana que estaba poco dispuesta a colaborar con los nuevos propietarios de las tierras y las ciudades.

La conquista cristiana dirigida por el rey Jaime I tuvo lugar entre los años 1233 y 1244 y fue la monarquía la que tuvo la potestad de repartir el territorio, cosa que llevó a cabo a través del Llibre de Repartiment de la ciudad y Reino de Valencia como a través de un largo y fragmentario proceso de donaciones.

En este entorno de villas reales, los colonos emigrantes reunieron no solo campesinos sino también grupos de artesanos, mercaderes y gentes de otros niveles sociales. Por su parte, en el ámbito de la amplia nómina de señoríos nobiliarios otorgados por la corona, se produjo un proceso paralelo de asentamiento como colonos y vasallos de grupos fundamentalmente campesinos. 
Fig.016. Imagen de Llibre del Repartiment. En este libro Jaime I anotó como se iban adjudicando las tierras entre aquellos que le habían ayudado durante la Reconquista.

${ }^{36}$ La Vila sería un poblado más extensivo que el castrum y la alquería, que resulta difícil sujetar a un patrón único: podía tener alcazaba o ciudadela, al entorno de la cual se construían caprichosamente las casas.

${ }^{37}$ El castrum o castells de los que también habla el Llibre del Repartiment, comprendía una extensión considerable. Parece ser que el espacio de los más pequeños no iría por debajo de dos o tres mil metros cuadrados, mientras que los más extensos podían llegar a tener unas cuantas hectáreas. La función primordial del castillo valenciano, según parece, sería la de constituir un refugio para los habitantes del término en caso de peligro inminente.

${ }^{38}$ La palabra alquería del árabe "al-qarya (poble xicotet), no tenía entonces el significado actual de una residencia - de algunas casas dedicadas al cultivo de los campos vecinos, sino que venía a ser la unidad socio-geográfica del paisaje humano. Un conjunto de casas, entre diez o cincuenta posiblemente, los habitantes de los cuales explotaban un determinado territorio alrededor de un poblado.

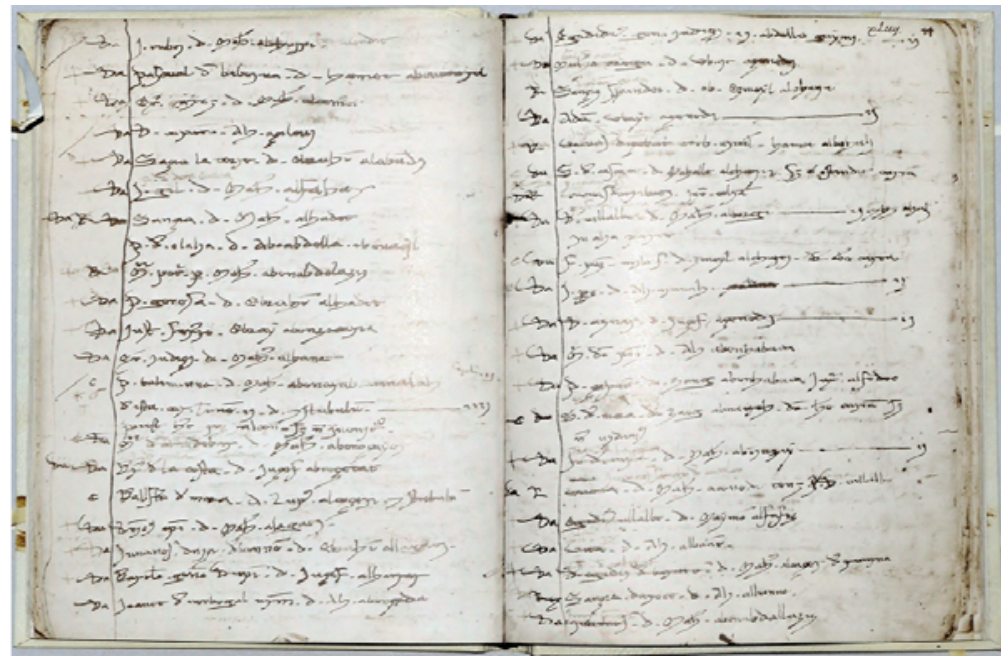

La mayor parte de las villas ${ }^{36}$, castillos $^{37}$ y alquerías ${ }^{38}$ fueron dados a señores que conservaron la antigua población musulmana para el mantenimiento y cultivo de las tierras.

Las condiciones de permanencia de la población musulmana del Reino de Valencia no fueron homogéneas. De un modo simplificado podemos distinguir, en primer lugar, las aljamas que pudieron conservar sus tierras, bajo la protección del rey o de otros aristócratas que ejercían el señorío sobre ellas, sin padecer intrusiones colonizadoras importantes. Se trataría de una situación similar a la del valle murciano de Ricote, pero que en Valencia tenía una expresión territorial mucho más amplia.

La segunda gran particularidad de la Reconquista parece hallarse en contradicción con la señalada anteriormente. En este caso se trata de la rapidez con la que se produce la inmigración cristiana y el notable volumen que, consecuentemente, adquiere este cuerpo social en breve plazo (60.000 individuos hacia 1270, más de 100.000 al comenzar el nuevo siglo). La permanencia de una buena parte de la población indígena - quizá en torno a la mitad, o algo menos, de la existente antes de la conquistano representó ningún obstáculo al flujo de colonos catalanes y aragoneses, que acudieron con una velocidad mucho mayor a la registrada coetáneamente en Mallorca, donde las comunidades musulmanas habían sido desmanteladas por completo de forma inmediata.

Los colonos cristianos se establecieron en distritos donde la población nativa fue totalmente expulsada 0 , cuando menos, disminuida de un modo importante. Todo esto se produjo en el 
cuarto más septentrional del reino (área montañosa y ganadera del Maestrazgo, poco habitada antes de la conquista a causa de su posición fronteriza) y en los corredores del interior que garantizaban las comunicaciones con Aragón (valle del Palancia y corredor de Sarrión) la Mancha (valles del Cànyoles y de Albaida) y Murcia (hoyas de Alcoy y de Castalla). Pero donde la colonización tuvo el mayor impacto demográfico fue, sin duda, en las llanuras aluviales de los principales ríos del reino (Júcar, Turia, Millars, Palancia, Serpis), es decir, las zonas de mayor productividad agraria, ceñidas por los macizos montañosos en cuyos estrechos valles se mantuvieron, por lo general, las aljamas musulmanas ${ }^{39}$.

En todo caso, tanto en unámbito como en el otro el mecanismo de asentamiento general fueros las cartas de población entendidas como vehículo jurídico por el poder feudal para establecer las tierras, fijar la renta feudal y reconocer en su caso algún tipo de franquezas y derechos comunales a la nueva población, lo que conlleva que el asentamiento, urbano o rural, siempre fue un proceso dirigido y ordenado por el poder feuda $\left.\right|^{40}$.

Por su parte y desde el punto de vista espacial, el asentamiento físico de los colonos cristianos en sus lugares de residencia implicó bien la ocupación de una localidad musulmana ya existente de la cual se había expulsado a sus anteriores moradores andalusíes o bien la fundación de un nuevo núcleo residencial que fue diseñado y construido por los pobladores.

En la práctica en muchos lugares se produjo la fundación de una nueva villa cristiana (una Pobla) sobre una sola de las pequeñas alquerías de un término o distrito, elegida por el nuevo poder feudal como punto de poblamiento concentrado para los colonos cristianos, lo que comportó además el abandono y desaparición de los restantes asentamientos andalusíes de dicho término ${ }^{41}$.

Durante el siglo XII se desarrolló un proceso histórico de colonización en el marco de la expansión feudal de la Corona de Aragón que implicó:

- Un reparto jerarquizado del territorio del Sharq al-Andalus entre rey y nobleza.

- La expulsión de muchos lugares de sus vecinos musulmanes.

- La inmigración de pobladores cristianos, campesinos en su mayoría.

- Y la fundación de casi dos centenares de nuevas localidades
${ }^{39}$ Torró, J.(2001): La conquista del reino de Valencia. Un proceso de colonización medieval desde la arqueología del territorio.

${ }^{40}$ Guinot, E. y Martí, J.(2006) : "Las villas nuevas medievales valencianas(siglo XIIIXIV)" Boletín Arkeolan 14, Universidad de Valencia. Pág. 183216.

${ }^{41}$ Guichard, P(2001): "Al-Andalús frente a la conquista cristiana". Madrid: Biblioteca Nueva. Universidad de Valencia. Pág. 237-256. 
como puntos de poblamiento concentrados a lo largo y ancho del nuevo Reino de Valencia, unas veces sobre zonas bastantes despobladas y otras eliminando de forma paralela el poblamiento disperso en alquerías andalusíes ${ }^{42}$.

Dos grandes cuestiones deben presidir el estudio del proceso colonizador: la construcción de los asentamientos (entendidos aquí en el sentido estricto de áreas de residencia y actividad doméstica 0 , si se prefiere, espacios urbanos) y la creación y modificación de espacios agrarios ${ }^{43}$. El presente plan de investigación se centrará en la primera.

\subsection{El proceso de fundación de una villa nueva o Pobla en la Valencia del siglo XIII}

En muchos lugares se mantuvo a la población musulmana indígena pero en otros muchos se la expulsó y se repobló la región con colonos cristianos. Es pues en el marco de dicho asentamiento, dirigido por el poder feudal -bien fuera por el rey o más bien por oficiales reales, bien fuera el noble titular del señorío- en el que se elegía el emplazamiento para situar el núcleo residencial concentrado de dichos colonos.

La elección del punto donde se iba a erigir la nueva villa dependía de elegir un emplazamiento aparentemente nuevo o uno preexistente, en este caso normalmente una alquería andalusí. En una mayoría de los casos se constata que se partió de dicha pequeña alquería andalusí, tal como refleja la continuidad de la toponimia árabe.

Así por ejemplo, en el caso de Castellón de la Plana, la primera carta puebla del año 1.239, otorgada por el Conde Nunyo Sans, conde de Rosellón, asentaba inicialmente a los pobladores

42 Guinot, E. y Martí, J.(2006) : "Las villas nuevas medievales valencianas (siglo XIII-XIV)" Boletín Arkeolan 14, Universidad de Valencia. Pág. 183-216.

43 Torró, J.(2001): La conquista del reino de Valencia. Un proceso de colonización medieval desde la arqueología del territorio. Universidad de Valencia. en el pequeño castillo conocido como de la Magdalena, pero al mismo tiempo les otorgaba permiso para trasladarse a una de las alquerías situadas en el territorio de lo que después se conoció como Acequia Mayor de Castellón:

Item, volumus et mandamus quod vos positis insimuí popular et villam construere in villa vek alcharia pernominata in quocumque loco vobis in ipsa vel terminis suis magis visum fuerit expederi et quod possitis ibi fortiam el tomos construere et 
de dicat fortia et villa sitis nobis et nostris fideles el legales in ómnibus et per omnis, domos itaque habeatis in dicat villa franchas et sine aliquo censu $^{44}[\ldots]$

Por otra parte, es necesario plantearse una cuestión ¿quien sería la figura responsable de elegir el lugar de emplazamiento de la nueva puebla?. Para obtener la respuesta, primero se debería dirigir la mirada al poder feudal respectivo, representado por el agente repartidor, delegado o Batlle real o señorial, hecho que debió de ser más claro en el caso de las pueblas más planificadas, ortogonales y de diseño más elaborado. Sin embargo, en el caso de pequeñas comunidades rurales, no se debería descartar al menos algún tipo de participación de los primeros colonos en el proceso de concreción espacial de las nuevas pueblas. Es decir, quizás no existió siempre necesariamente una planificación previa del espacio donde asentarse por parte de los agentes reales o señoriales, y luego la llegada de los colonos a un territorio ya edificado, sino que pudo darse también un proceso de negociación durante un tiempo entre ambas partes, en el marco del cual se debieron concretar no solo cuestiones como el reparto y la delimitación de las tierras de cultivo, sino también la fijación del lugar de residencia ${ }^{45}$.

Un tercer aspecto, el cual resulta más difícil de documentar por ahora, es la existencia de una planificación respecto a las dimensiones del espacio urbano que se debía crear, esto es, un cálculo basado en el número de residentes que se pretendía establecer. Existen cartas de población del siglo XIII que fijan un número ideal o máximo de pobladores para los asentamientos, fueran estos 20, 50 o 200, los cuales, al menos en los casos más numerosos, no estaban presentes desde el primer momento, sino que se trataba de una cifra que tenía que alcanzarse. Por ejemplo, la carta de población de Benicarló del 14 de junio de 1236 indicaba que debía ser ocupada por 30 pobladores, en Ninarzóns año 1241 la cifra sube a 50 pobladores y en Bocairent hace referencia a 300.

Estas previsiones habrían de implicar algún tipo de cálculo del número de solares que eran necesarios, de las dimensiones de éstos, así como del número y ancho de las calles requeridas, - la ubicación y espacio que debía ocuparse por los edificios públicos (como es el caso de la parroquia). Parece lógico pensar que sólo con estas previsiones era como podía decidirse el trazado concreto de las murallas a construir.

\footnotetext{
${ }^{44}$ Guinot, E. (1991): "Cartes de Poblament medievals valencianes". Generalitat Valenciana. Traducción en anexo.

${ }^{45}$ Guinot, E. y Martí, J. (2006): "Las villas nuevas medievales valencianas (siglo XIIIXIV)" Boletín Arkeolan 14, Universidad de Valencia. pp. 183216.
} 
Cierto es que muchas cartas de población indican de forma explícita que no sólo se han medido sogueado las tierras, sino también las casas ${ }^{46}$.

En otros casos, el lugar elegido para el emplazamiento de la puebla era una pequeña alquería musulmana tal y como hemos mencionado anteriormente. Este caso implicaba que existían ya unas casas construidas que simplemente eran repartidas entre los colonos cristianos. Sin embargo a veces no se repartían con la frecuencia adecuada y la asignación resultaba insuficiente para todos ellos, así que se hacía necesaria la asignación de solares por parte de la señoría feudal.

\section{3| El urbanismo}

En el imaginario colectivo valenciano existe la idea de que toda construcción antigua, o de época imprecisa, así como las tramas urbanas más añejas de sus poblaciones son, empleando la expresión popular, del temps del moros, es decir, de época musulmana. Sin embargo esta creencia no se atiene generalmente a la realidad. Ciertamente muchas poblaciones valencianas eran ya importantes: Alcira, Xátiva, Orihuela o Denia tenían una larga historia urbana y una acreditada fama como ciudades con anterioridad a la conquista cristiana. No obstante el nuevo orden originó una estructura diferente del asentamiento de la población en el territorio y la renovación de sus núcleos urbanos. La creación de una nueva red de poblaciones y la transformación de las existentes fue un proceso largo, consciente y eficaz. Al final de la Edad Media la herencia urbana musulmana era prácticamente irreconocible.

Evidentemente, los asentamientos cristianos no se constituyeron sobre un completo vacío arquitectónico sino que debió de tenerse muy en cuenta las preexistencias andalusíes. De hecho, las madîna/s principales - una vez evacuados sus antiguos moradores- eran siempre ocupadas por colonos, manteniendo o incrementando el tamaño original, como sucedió en Onda, Morvedre, Llíria, Alcira, Xàtiva y, por supuesto, en la propia ciudad de Valencia. Otras veces, las menos, se produjo un

${ }^{46}$ Guinot, E. y Martí, J.(2006) : "Las villas nuevas medievales valencianas(siglo XIII-XIV)",Boletín Areola 14, Universidad de Valencia, pág. 188. retroceso, como en el caso de Orihuela o, más claramente, el de Denia, donde un puñado de pobladores se instaló en lo que había sido una importante madîna portuaria, que sobrepasaba con mucho las necesidades de éstos, y que a punto estuvo de quedar abandonada por un nuevo emplazamiento más discreto. 
Durante el período de la colonización, el control del territorio y la roturación de nuevas tierras fueron los ejes de la repoblación. El modelo musulmán de organización territorial se transformó. Éste se basaba en una gran abundancia de poblamiento disperso alrededor de un castillo o medina. El hecho de que los cristianos privilegiaran algunas de las antiguas alquerías o fundaran nuevas poblaciones condujo al declive progresivo de muchos otras. Matéu Bellés ${ }^{47}$, Catedrático de Geográfica Física de la Universidad de Valencia, ha indicado que la estrategia de la repoblación siguió varias tácticas:

La primera consistió en asegurarse la impermeabilidad de la franja costera, evitando el contacto entre los corsarios berberiscos y moriscos. Gracias a ello, en las zonas del litoral se favoreció un poblamiento concentrado, protegido por murallas donde vivían los cristianos.

La segunda de las tácticas de la colonización consistió en llenar los vacíos demográficos. Las dos "Extremaduras" del final de la época musulmana estaban situadas al norte y al sur del reino. Eran éstas las tierras septentrionales, aproximadamente hasta el río Mijares, y las meridionales alrededor de la línea BiarBussot.

La tercera zona de poblamiento privilegiado buscó situarse controlando las vías de comunicación y correspondió al eje Borriol-Tortosa que coincidía con un vacío demográfico, vio surgir numerosas poblaciones. Los corredores con Aragón es decir, el valle del Palencia, els Ports de Morella y el camino Llíria-Serranos, vieron controlados los lugares estratégicos. Un hecho similar sucedió con la Costera que es el corredor natural que une Valencia con Castilla. Por último la población mudéjar vio transformada su articulación en el territorio. En las ciudades se construyeron morerías en los arrabales y en el campo y se sometieron a un señor territorial.

Lo que hicieron los colonos cristianos con las estructuras físicas heredadas en centros de población menores, como madîna/s pequeñas, husûn anteriormente habitados $y$, sobre todo, alquerías, parece ofrecer una amplia variedad. A grandes rasgos podríamos distinguir tres posibilidades: fundaciones nuevas, emplazamientos trasladados y emplazamientos coincidentes.

Es una distinción bastante convencional, de límites borrosos, susceptible de muchos matices, pero útil para percibir la versatilidad de los gestores de la colonización a la hora de
${ }^{47}$ Mateu Bellés, J. (2001): L'empenta del poblament cristiá, Temes d'Etnografía valenciana, Institució Alfons el Magnanim, Valencia, 1983, pág. 68. 
seleccionar los lugares de asentamiento y manejar el espacio construido que se heredó de Al-Andalus ${ }^{48}$.

Arturo Zaragozá describe que partir de los factores urbanos más sobresalientes que nos han llegado, se pueden agrupar en tres capítulos particularmente significativos ${ }^{49}$ :

a) Las poblaciones en ladera de arrimo de un castillo.

b) Las transformaciones urbanas de preexistentes (emplazamientos trasladados o coincidentes).

c) Las poblaciones de nueva planta y trazado regular.

\section{POBLACIONES AL ARRIMO DE UN CASTILLO}

Denominamos así a las frecuentes poblaciones desarrolladas en la Valencia medieval situadas en la falda de una montaña, al arrimo y protección de un castillo. Generalmente el castillo estaba construido en la cima de una montaña inexpugnable por uno de los lados. En la vertiente opuesta se situaba el caserío. Éste se disponía escalonado en calles aproximadamente semicirculares que seguían las curvas de nivel. Otras calles en travesía con gran pendiente escalaban la montaña. La iglesia se erigía, generalmente, en el punto más alto del caserío. A menudo pueden observarse en este tipo de poblaciones diversos recintos defensivos sucesivos. La población valenciana de estas características que mejor conserva el trazado y disposición urbana es Morella.

\section{TRANSFORMACIONES URBANAS}

Las núcleos de población andalusí fueron profundamente modificados. En la segunda mitad del siglo XIV, en la ciudad de Valencia, se llevó a término una notable reforma urbana. La

${ }^{48}$ Torró J. (2001): La conquista del reino de Valencia. Un proceso de colonización medieval desde la arqueología del territorio. Universidad de Valencia.

${ }^{49}$ Zaragozá Catalá, A. (2000): Arquitectura gótica valenciana, capítulo IV Valencia: un laboratorio urbanístico medieval, pp. 106-116.

${ }^{50}$ Ibídem, pág. 115.

${ }^{51}$ Ibídem, pág. 111. voluntad de transformación fue recogida por los abundantes acuerdos del Consell Municipal de abrir azucats o calles sin salida, ensanchar calles y plazas y construir edificios públicos para el embelliment de la ciutat ${ }^{50}$.

La evidencia escrita de estas transformaciones y de la decisión cambio urbanístico fue demostrada por Milagros Cárcel y José Trenchs al publicar la regesta de casi 300 documentos referentes a disposiciones urbanísticas de la ciudad de Valencia en el siglo XIV. Posteriormente, Milagros Cárcel ha ampliado este estudio con otros 300 documentos del mismo tipo del siglo $\mathrm{XV}^{51}$. 
Pero la capital de Túria no fue la única población transformada en época medieval. Los cambios posteriores han enmascarado o eliminado generalmente la imagen original de nuestras poblaciones. Sin embargo, en el Maestrazgo al no contar con un gran avance económico se ha podido conservar hasta nuestros días su aspecto medieval.

\section{4| Las poblaciones de nueva planta y trazado regular: Las Pueblas}

Una de las cuestiones importantes y significativas de este proceso de mutación de los siglos XII y XIII fue, como se ha indicado, la dinámica de colonización y construcción de una nueva sociedad feudal sobre los territorios de Al-andalus que iban siendo ocupados, repartidos y reorganizados espacial y socialmente. La llamada "repoblación" tuvo un componente de donación de señoríos entre la nobleza y de tierras entre los campesinos cristianos ${ }^{52}$.

Un aspecto relevante es el del asentamiento poblacional de los grupos de colonos que participaban del proceso migratorio hacia tierras de Al-Andalus y, por ello, tanto la fundación de nuevas poblaciones como la reorganización espacial de las formas de poblamiento rural andalusí fueron una de las constantes del proceso en el nuevo Reino de Valencia creado por Jaime I el año 1240. Esto es, por toda la mitad sur del Reino de Aragón, los siglos XII y XIII fueron testigos de un amplio proceso de creación de núcleos de población que respondieron tanto a las demandas de poblamiento concentrado de una sociedad con necesidades de centros comerciales y artesanales, como a las exigencias de un asentamiento ordenado y controlable, dirigido por el poder feudal (representado bien por la Corona o por los nobles titulares de los señoríos) $)^{53}$.

El proceso de su creación siempre fue jerárquico, es decir, tanto la corona -o por delaciones reales oficiales-, como los nobles en sus respectivos señoríos, procedieron a dirigir la instalación de los primeros grupos de colonos que llegaban o eran atraídos o dirigidos hacia un lugar concreto. Evidentemente a lo largo de todo el siglo XIII y aún la primera mitad del XIV dichas villas nuevas siguieron recibiendo nuevos emigrantes, pero en todo caso el primer asentamiento ya se había producido.
${ }^{52}$ Zaragozá Catalá, A. (2000): Arquitectura gótica valenciana, capítulo IV Valencia: un laboratorio urbanístico medieval.

53 Guinot, E. y Torró, J. (2006): "Repartiments medievals a la Corona d'Arago". Universidad de Valencia. 
${ }^{54}$ Guinot, E. y Martí, J.(2006) : "Las villas nuevas medievales valencianas (siglo XIIIXIV)" Boletín Areola 14, Universidad de Valencia, pág. 191.

\section{${ }^{55}$ Ibídem.}

${ }^{56}$ Torró, J.(2002): La conquista del reino de Valencia. Un proceso de colonización medieval desde la arqueología del territorio. Universidad de Valencia.
Fruto de esta misma gradación temporal en la migración así como de las diferencias entre el norte, centro y sur del Reino de Valencia en cuanto a la continuidad o expulsión de la población indígena musulmana, es el hecho de la amplitud cronológica de la fundación de las villas nuevas que abarca desde 1234 (las primeras en las tierras más septentrionales del reino) hasta ya entrado el XIV, de forma puntual en diversos lugares y comarcas al calor de nuevas expulsiones locales de aljamas mudéjares o de intentos de conseguir nuevos vasallos ${ }^{54}$.

Asimismo se constata que no existe un único tipo de Villanueva o puebla, ni por sus dimensiones ni tampoco estrictamente por sus funciones. Junto a villas a las que se otorgaba una mayor población inicial y/o funciones de mercadeo y presencia de artesanos (como es el caso por ejemplo de San Matéu, Castelló de la Plana, Vila-real o Alcoy) la mayoría de las fundaciones fueron planteadas para establecer comunidades campesinas. Durante todo el doscientos, al sur de Játiva donde el conflicto era más frecuente, los asentamientos cristianos tuvieron a menudo un carácter más fortificado y con una visión militar en sus primeros tiempos, que poco a poco, ya hacia el 1300, derivaron en villas y lugares más campesinos y artesanales ${ }^{55}$.

En algunos casos éstas fueron dotadas de murallas desde el mismo instante de su creación, mientras que en otras sólo se fortificaron décadas después, e incluso lugares más pequeños nunca llegaron a contar con murallas, pues estaba regulado en los fueros que tan sólo las villas podían tenerlas, excluyendo tal posibilidad en los lugares situados dentro del término de una villa.

Las formas de asentamiento implantadas tras la conquista se caracterizaron por el predominio de núcleos fuertemente agrupados, ordenados con criterios geométricos más o menos rigurosos y, muchas veces, fortificados. Estas agrupaciones urbanas se calificaron normalmente de villas (viles), o lugares (/locs) cuando dependían jurídicamente de las primeras. Frente al matiz institucional de estas denominaciones, parece preferible el término coetáneo de "pueblas» (pobles, sing. Pobla), de uso más genérico y cuyo sentido remite, más bien, a la constitución física de las áreas de residencia ${ }^{56}$.

Entendemos pues por fundaciones nuevas, aquellas agrupaciones urbanas no superpuestas, por lo que sabemos, a ningún asentamiento andalusí preexistente. Se incluyen, no obstante, aquellos casos en los que sí pudo haber estructuras anteriores 
en el mismo ámbito topográfico (sobre todo alquerías), aunque no hubieran dejado incidencias morfológicas perceptibles. Los rasgos más llamativos que las caracterizan son la regularidad del callejero, que puede ser ortogonal o en abanico (cuando la puebla debía adaptarse al terreno).

Las poblaciones fundadas por los cristianos reemplazaron normalmente a formas de agrupaciones menores, más separadas y menos compactas, como eran las alquerías musulmanas, que solían organizarse en redes articuladas por las instalaciones de riego y los caminos, albergando al menos una decena de unidades. En el emplazamiento que se elegía para construir una pobla, las alquerías quedaban desiertas o su número disminuía considerablemente, mientras el antiguo castillo andalusí (hisn), localizado siempre en los lugares mas altos, terminaban sin pobladores o reducido a labores auxiliares (ya que la propia pobla una vez amurallada cumplía los deberes de defensa y sede administrativa que antes le eran propios). Eso sí, aunque el hisn ya no era el referente topográfico del territorio, su nombre es heredado casi siempre por la villa de nueva creación, y así permanece. Por este motivo, y a diferencia de lo que sucedía en otras regiones colonizadas por la cristiandad latina, resultan tan extrañas las invenciones onomásticas - como la de Vilareal- que relacionan expresamente los asentamientos con la sociedad avenida que los crea. Este dato es muy interesante tenerlo en cuenta porque su desconocimiento propició que durante mucho tiempo -cuando se manejaban los textos sin un gran conocimiento de la época y no se realizaba investigación arqueológica - se adquiriera una imagen errónea de continuidad de las poblaciones y de sus propios habitantes.

Las poblas de nueva creación se llamaron, pues, como los antiguos husûn andalusíes, pero no se encuentran ubicadas en su misma situación. Existen casos, sin embargo que lo hicieran en el emplazamiento donde antes se había construido una alquería, aprovechando las ventajas del lugar y de los sistemas hídricos y de conexión con otros territorios (caminos, captaciones de agua) que podía ofrecer, tal y como sucedió en la puebla de Pego, ubicada sobre un pequeño montículo que anteriormente había albergado una de las principales alquerías del castillo homónimo. Pero la alquería de la época andalusí es, normalmente, una entidad de superficie y de edificaciones menor que la pobla; no solía contar con cerca amurallada, y tampoco mostraba una configuración compacta, siendo más bien su delimitación poco precisa. De hecho normalmente no es posibles identificar en una pobla la situación de la alquería más 


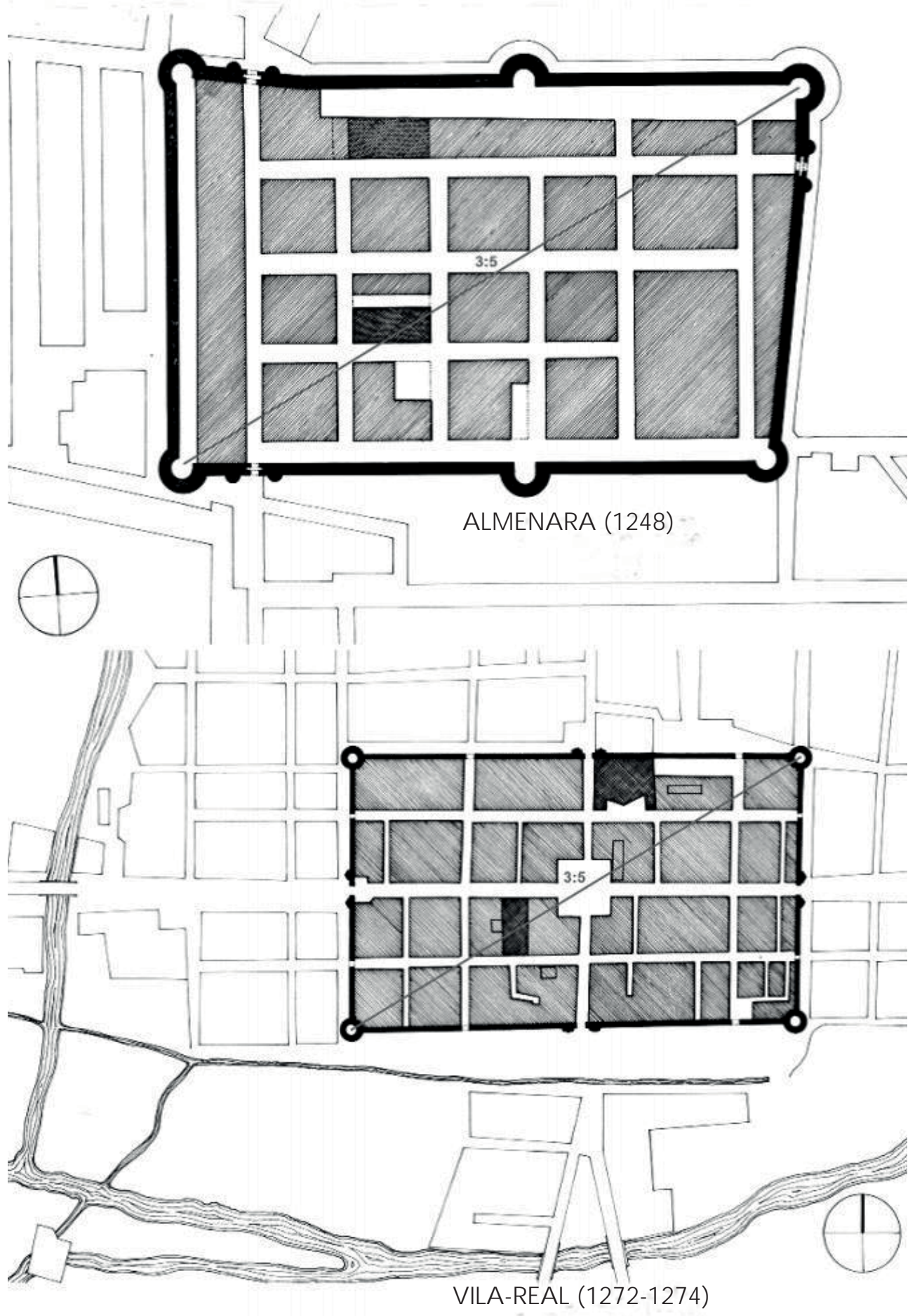


allá de los caminos y sistemas de riego andalusíes. De hecho, aunque no siempre lleguen a alcanzar el rigor geométrico de municipios como Almenara, las poblas suelen caracterizarse por perímetros cuadrangulares y viarios ortogonales y paralelos entre si. Sin necesidad de entrar en detalles en el presente apartado, pueden mencionarse ejemplos, como los de Vinaroz, Nules, Vila-real, Pobla de Vallbona y Puzol, todos ellos en las llanuras litorales del reino. Existen otras poblaciones, no obstante, en los que la implantación urbana no presenta un planta regular ni una trama urbana formado por viales ortogonales, ni siquiera la organización en abanico que ofrecen algunas pueblas del Maestrazgo, emplazadas sobre colinas.

Un segundo grupo de poblas estaría conformado por aquellas cuya implantación tuvo lugar, inicialmente, en el interior de un hisn, pero que al poco tiempo se trasladan a otro emplazamiento cercano, en el mismo distrito, pero en un valle o llanura. Por ejemplificar este dato el caso de Bairén, cuyos pobladores cristianos se instalaron, a partir de 1242 , en el hisn andalusí, pero que en 1249 comenzaron a edificar una pobla amurallada a una distancia de $3 \mathrm{~km}$ hacia el sur, en el mismo lugar en que estaba la alquería de Candia (Gandia), cuyo nombre finalmente se adoptó para la villa nueva (seguramente para distinguirla del castillo, que siguió utilizándose). Similar es lo sucedido en Castellón, cuyos primeros colonos se asentaron en el hisn del mismo apelativo, trasladándose desde 1251 al llano inmediato para crear una pobla en el emplazamiento de una alquería llamada Benimahomet, que aquí sí cambiaron por el nombre del castillo. En ambos casos la mutatio ville implica volver a fundar el asentamiento en emplazamientos cercanos a las principales instalaciones de riego andalusíes y a las tierras irrigadas por éstas. El hecho de que se superpongan a antiguas alquerías, como se ha señalado, no tiene una incidencia decisiva en la regularidad de los planos resultantes, puesto que son desbordados por la nueva trama y por los inmuebles que se ejecutan rápidamente.

Por último, quedaría un tercer grupo, compuesto por las poblas creadas de forma permanente en el ámbito físico de un hisn o una pequeña madîna fortificada y que, por tanto, deben asumir las limitaciones de una trama urbana preexistente compacta, amurallada y de cierta entidad constructiva, más difícil de ignorar que una zona abierta. Aunque existen casos de llanura como los de Borriana o Elx, esta situación también se dio en zonas de montaña. Bocairent, emplazado sobre una elevación rodeada de barrancos, constituye un buen ejemplo.
Fig. 017. Planos del centro histórico de Almenara y Vila-real. Se observa el trazado ortogonal de sus viales. 
Fig. 018. Traslado del centro colonizador del Castillo de Bairén a una zona más llana, la ubicación actual de la vila de Gandía (1249).

\footnotetext{
${ }^{57}$ Torró, J.(2002): La conquista del reino de Valencia. Un proceso de colonización medieval desde la arqueología del territorio.

${ }^{58}$ Torró, J.(1989): “ El problema del hábitat fortificado en el sur del Reino de Valencia después de la segunda revuelta mudéjar (1276-1304), pág. 62.
}

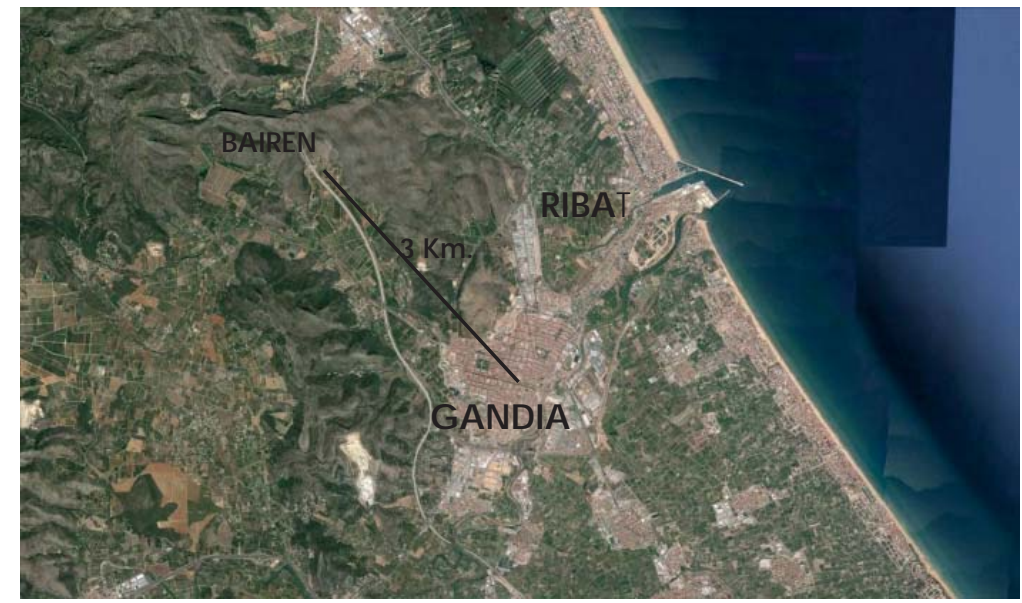

El problema es que, por ahora, no disponemos de informaciones para saber en qué medida sus calles sinuosas mantienen la antigua disposición andalusí, o simplemente responden a las dificultades que encontraron los nuevos pobladores para alterar el relieve. Muy cerca de allí, en Ontinyent, nos hallamos ante una situación similar: un hisn urbanizado de dimensiones parecidas, sobre el mismo tipo de emplazamiento, aunque con callejero algo más geométrico. En este caso, sin embargo, la realización de numerosas intervenciones arqueológicas en el subsuelo ha puesto de manifiesto que las únicas estructuras de época andalusí consistían en silos y otras fosas de las que sólo se conservaban los fondos, ya que fueron cortadas por desmontes de terreno realizados al poco de la conquista. Parece evidente, pues, que aquí lo esencial de la trama urbana anterior fue arrasado para edificar el nuevo asentamiento cristiano ${ }^{57}$.

Dentro de este grupo podría incluirse, también, la villa de Cocentaina, constituida, en principio, sobre lo que había sido la modesta aglomeración de Qusan-tâniya, desarrollada al pie del hisn homónimo. Las numerosas prospecciones y seguimientos llevados a cabo durante las últimas décadas han permitido delimitar con bastante precisión la superficie máxima que llegaron a abarcar las edificaciones, advirtiéndose que el área del asentamiento cristiano (bien delimitada por un recinto amurallado) sólo ocupaba una porción menor de aquella (alrededor de un tercio), concretamente la situada en la parte más baja. Tanto los hallazgos como las referencias de la documentación escrita sugieren que se trataba de una zona de reales (riyâd/s, casas con huertos), con una ocupación menos densa que la de otras partes más altas del área urbana andalusí. 


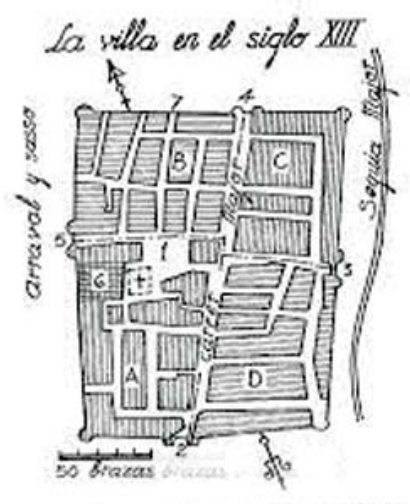

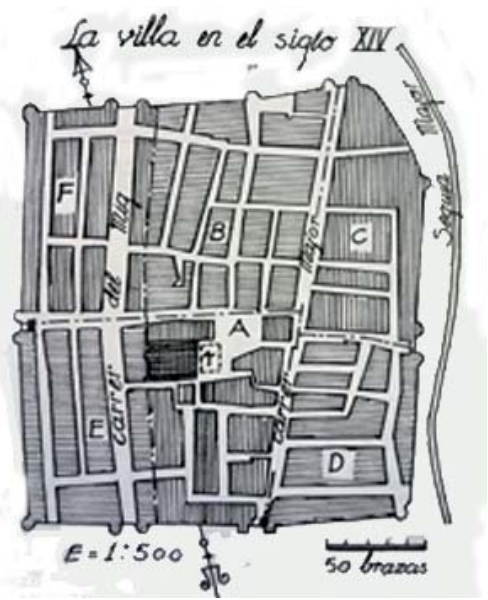

Fig.019.Perímetros urbanos históricos del municipio de Castelló (1251, 1272). Basado en E. Guinot y J. Martí.

Una vez abandonada ésta por completo, hacia 1249 , los colonos seleccionaron el sector que podían modificar con mayor facilidad y levantaron en él una pobla semejante a las de nueva planta.

La alquería o el hábitat "disperso" es una forma de asentamiento reconocida para los colonos cristianos y combatidos con clara determinación por el poder real a partir de 1280 aproximadamente ${ }^{58 .}$

Junto a las disposiciones de tipo político que presionaron a los colonos para que se congregaran en las albacaras o villas, se emprendieron, también, intervenciones de tipo técnico que permitieron materializar el modelo de asentamiento propugnado por la corona.

En primer lugar, las obras de construcción y acondicionamiento de los recintos cástrales se documentan en Guadalest y en las demás fortalezas que han de acoger una villa. En segundo lugar, pero con una importancia muy especial, la localización o parcelación. El solar de la villa nueva implica una modulación regular y una disposición ortogonal

\section{5| El Parcelario}

Como se ha visto en el capítulo dedicado a Aragón las parcelas actuaban como unidades generadoras de la planta urbana. $Y$ tanto la tipología de las parcelas domésticas edificadas por los colonos cristianos como las pautas de agregación que se observan (por medianerías) tienden naturalmente hacia 
${ }^{59}$ Torró, J.(2002): La conquista del reino de Valencia. Un proceso de colonización medieval desde la arqueología del territorio. formas relativamente homogéneas e identificables, de escasa variabilidad.

Estos factores relevantes, son los que marcan verdaderamente la novedad, más allá de la llamativa geometría de algunos planos de fundación. Es decir, no se trata de una cuestión de "hábitos» o de "tradiciones constructivas». Ambos factores derivan directamente de la organización social específica de la cristiandad latina, donde el parentesco desempeñaba un papel marginal, contrariamente a lo que sucedía en el mundo musulmán. Si la tipología parcelaria era coherente con unidades domésticas concebidas para familias elementales, sin ninguna previsión de co-residencia que contemplara la articulación de un grupo doméstico compuesto, no es menos cierto que el orden de las pautas de agregación respondería al carácter «inorgánico» de la comunidad local. Ésta se compondría de unidades familiares individualizadas, unidas por vínculos de vecindad y regidas por una autoridad vecinal. De este modo, y a diferencia de lo que era habitual en Al-Andalus, no pudieron generarse agrupaciones residenciales identificadas con linajes determinados que debían negociar constantemente por la ocupación del suelo edificable. En este contexto, resulta sencillo imponer concentraciones residenciales indiferenciadas a los reyes o a otros poderes señoriales que, con la colaboración de los agentes colonizadores (divisores) - muchas veces convertidos en autoridades vecinales-, darán lugar a las morfologías ordenadas propias de las fundaciones cristianas ${ }^{59}$.

No obstante no debemos entender, sin embargo, que la tipología parcelaría descrita y la agregación de unidades domésticas por medianerías, pese a su indudable eficacia, representara la única solución posible a la hora de concentrar comunidades vecinales formadas por familias elementales. En el ámbito geográfico que nos ocupa hay que tener en cuenta un importante condicionante técnico, como lo es la arquitectura de arcos diafragma. Estos arcos se disponen sucesivamente en dirección transversal a la nave construida, lo que permite colocar los envigados en el sentido longitudinal del espacio, aligerando la carga de los muros laterales y reduciendo los empujes. De este modo se edificaban las parcelas en profundidad y podían alinearse por medianerías. Se trata de una técnica presente en la arquitectura cisterciense desde mediados del siglo XII, que tendrá amplia propagación en las tierras occitanas y catalana-aragonesas.

La parcelación medieval se componía de solares - patis- de forma rectangular y dimensiones regulares. Estos tenían entre 
cuatro y cinco metros de fachada. Esa misma casa ideal tenía entre 10 y 20 metros de profundidad, de los cuales la porción trasera correspondía a un patio donde se situaba el corral o un pequeño huerto familiar. En caso de que el propietario fuera un menestral, en los bajos se situaba el obrador abierto a la calle y que quedaba, a menudo, protegido por soportales sobre los que solía descansar el voladizo de la primera planta. En Morella subsisten aún magníficamente ejemplares de este modelo edificatorio. Si el propietario era agricultor o ganadero la planta baja guardaba los aperos, servía de cuadra a los animales o custodiaba algún ganado. La vivienda se situaba en la planta piso y las cosechas se guardaban bajo la techumbre en les golfes, l'andana o el prexe. La casa del jornalero era mínima, frecuentemente de una sola planta y sin duda cercana a la del musulmán desfavorecido ${ }^{60}$.

Cabe señalar que este tipo de asentamientos son más abundantes de los que se ha venido considerando. Todos ellas tienen unas mismas constantes formales. Estos núcleos urbanos adoptan forma cuadrangular muy bien definida. Las viviendas se subordinan a la viabilidad conformándose como un solar estrecho y alargado: el patt ${ }^{61}$.

Los viales de las poblas de colonización valencianas tienen tendencia a ser rectilíneas y continuas. Esta continuidad únicamente no se cumple cuando la topografía del emplazamiento elegido lo impide o causa de ampliaciones no previstas en su planteamiento inicial. Lo habitual en todas ellas es encontrar calles públicas paralelas unas a otras, incidiendo perpendicularmente sobre otras vías dispuestas de la misma forma. La mayor parte de las poblaciones cuentan, en origen, con una plaza que acoge la mayor de las actividades económicas: el mercado, y donde se sitúan los edificios administrativos como la Sala, la Cort y la Presó -la incorporación a la trama de este elemento urbano fue analizado en el capítulo del urbanismo aragonés - . La plaza acostumbrará a situarse en la intersección de los dos ejes principales a partir de los cuales se replanteará el resto de los viales.

Por último indicar que todos estas poblaciones nacidas en el bajo medievo contaron con cercas y construcciones defensivas que tuvieron trazados e importancias diversas, adaptándose al crecimiento urbano y a las necesidades del momento.
60 Zaragozá Catalá, A. (2000): "Arquitectura gótica valenciana", capítulo IV Valencia: un laboratorio urbanístico medieval, pág. 116.

61 Ibídem, pág 106. 
4.5.1| El concepto de edificación en los Fueros valencianos

La vivienda supuso un preciado bien para aquellas familias Ilegadas desde la inmigración a lo largo de los siglos XIII/XIV, de forma que los Furs concretan, en algunas rúbricas precisas, toda una suerte de disposiciones con la finalidad de promocionar y defender el citado inmueble ${ }^{62}$.

No se trataba de regular el tipo de material de construcción, ni las dimensiones mínimas de estas, pero sí de dejar una serie de normas para asegurar que la sociedad civil siguiera unas pautas ordenadas con el fin de evitar conflictos. Se podrían resumir como una mezcla de Código Civil y normativa urbanística.

De este modo, lo primero que se recoge es que nadie podía edificar una casa junto a torre pretendiendo, desde ella, disfrutar de ventana, terraza o mirador que le permitiera observar al vecino en sus intimidad, de suerte que cualquiera podía libremente obrar su casa junto a otra siempre que respetase las luces de su vecino. Este derecho todavía existe en la actualidad en el código civil español, conocido como servidumbres de luces y vistas:

Tot hom qui façe cases prop l'altre o haje carrera enmig, pusque alçar e fer quals obres se vulle, no constrastan si l'altre li diu que li tot la llum, o si fara obra en la paret on la finestra será, per la qual la lum entra en son alberch. (Furs, III, XVI,1)

En cuanto a las alturas, cualquiera podía construir libremente su vivienda siempre que no perjudicase la casa contigua ${ }^{63}$ :

Si alcu haura aytal servitut en les cases de son vehi, ço es, que aquel vehi no-y-pusque obrar pus alt, $e$ puys hi obrara pus altr, lo jutgee lo deu destrenyer que desface ab ses propies despeses aquella obra nova que haura feyt pus alta. ( Furs, III, XVI, 3)

${ }^{62}$ Roca Traver, F. (2006) : Tierra y propiedad en la Valencia Medieval, Ajuntament de Valencia, Delegación de Cultura, servicio de publicaciones, Valencia, pág. 110.

${ }^{63}$ Ibídem.
En cuanto al vuelo sobre los viales, también quedaba regulado, eso sí, considerando la estrechez de las calles; los municipios solamente permitían que la vivienda pudiera sacar un saliente que tuviere $1 / 3$ sobre la vertical de la edificación y únicamente con la finalidad de que pudieran verter fuera las aguas pluviales: 
...solamente qu'el vehi qui obrara o hedificara, ab les seues despeses façe l'aygua correr e caer en la carrera si aquella aygua pora exiir, ni caern en la carrera e sino hi, pora exiir, do loch o l'ayga pe lo qual pusque exir e decorrer sens dan del vehí. (Furs, III, XVI, 28)

Por lo general la vivienda rural contaba con una relativa amplitud y todas debían permitir fácil acceso a los carros agrícolas que portaban las cosechas. La pared medianera entre dos casas era considerada un bien común, de forma que ninguno de los dos vecinos podía deshacerlas, reconstruirlas a su albedrío en su propio provecho o cargar en ellas jácenas o cabirones ${ }^{64}$. Este concepto tan medieval sigue vigente con ligeras modificaciones en la normativa civil presente.

En cambio, todo propietario de una vivienda era libre de abrir en su frontera o fachada el conveniente portal y, en caso de menestrales, amplio ventanal en su obrador, de forma que los viandantes pudieran ver el trabajo que se hacía en su interior. Muchos de los trabajos ya terminados eran expuestos en el portal o colgados en paredes exteriores.

Ya por último destacar que los Furs concedían un plazo de diez años para exigir la reparación de un derecho lesionado, de suerte que, transcurrido aquel plazo, la servidumbre quedará por siempre en pleno vigor, mientras que el actual código civil es más exigente al pedir 20 años para afianzar una servidumbre de luces o vistas. 


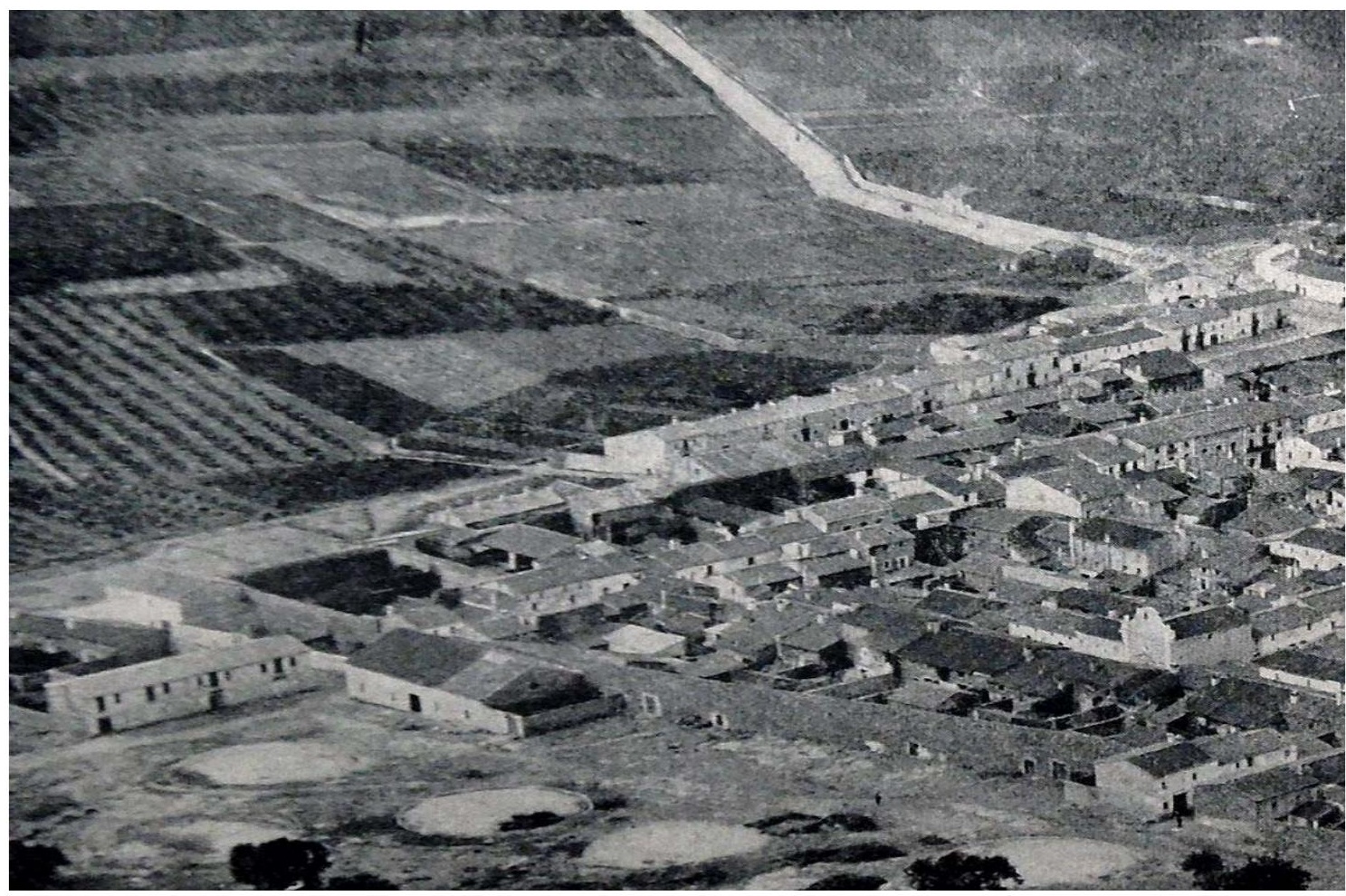

\section{6| Comparativa entre pueblas de la Comunidad Valenciana}

Se pueden considerar de nueva creación, en la Comunidad Valenciana, 200 villas y lugares por ser pueblas de cristianos, con carta de población y concesión de fuero, más allá de que según el emplazamiento elegido se tratase claramente de una fundación ex novo sobre un lugar yermo o de la creación de una puebla sobre la situación de una antigua alquería andalusí, la cual en todo caso era desbordada inmediatamente por las dimensiones y planta de la nueva población cristiana.

Con el fin de facilitar la compresión y la clasificación para referirse a estas nuevas villas, se considera oportuno presentar una breve clasificación ${ }^{65}$ :

${ }^{65}$ Guinot, E. y Martí, J. (2006): "Las villas nuevas medievales Valencianas (siglos XIII-XIV)", Boletín Arkeolan, 14, pág. 192.

a) Pueblas con muralla y planta rectangular. Sin duda las más representativas, unas 80 , si bien su planta puede variar desde los modelos prácticamente ortogonales hasta los casos de calles ordenadas con trazado curvo para adaptarse al nivel de una montaña. 


\section{Las Poblas de colonización valencianas ( S.XIII -S.XIV)}

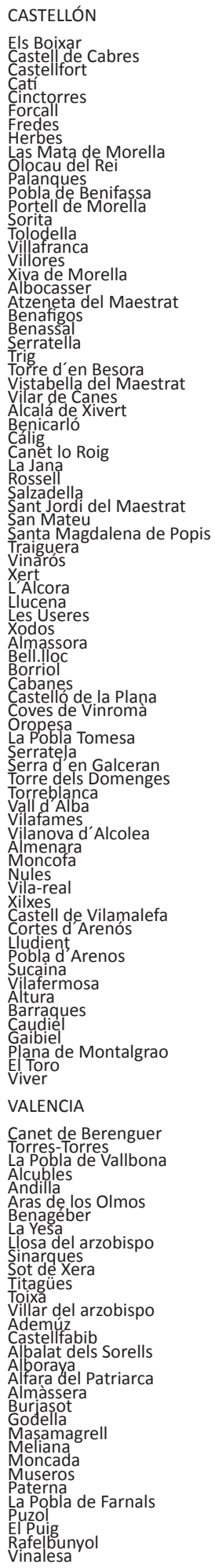

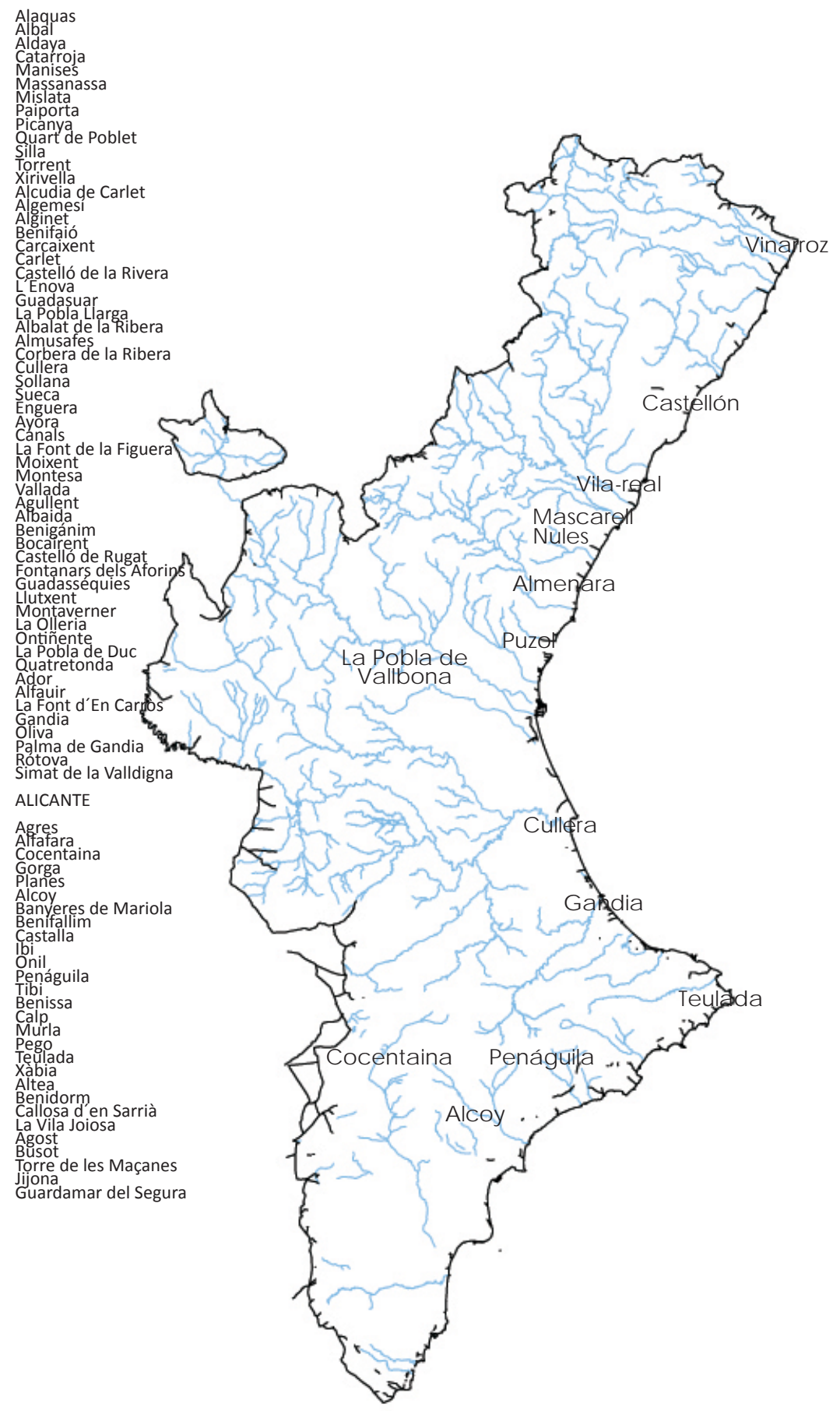


planificar se tuvieron muchos aspectos en común o en cambio no fueron tantos. Se verá que se trata de villas perfectamente proyectadas, normalmente delimitadas por murallas o cercas, respondiendo a las iniciativas de ordenación y dominio espacial de los poderes regionales y de las monarquías, y que cuentan con documentos fundacionales que establecen el régimen jurídico de su vecindario, los fueros y cartas pobla.

Para ello, se seleccionaron trece municipios cuyo origen es posterior a la conquista de Valencia, estudiado cada uno de ellos y comprobado sus similitudes y contradicciones. Los municipios de la Comunidad Valenciana, considerados, de norte a sur fueron:

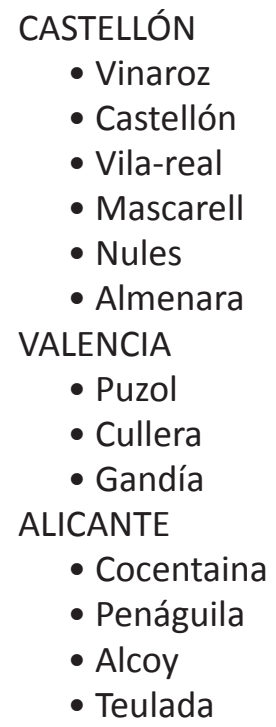

Los bloques desarrollados han sido:

- Situación y fundación

- Las trazas urbanas

o Tamaño de la vila

o Viales

o Ordenación urbanística

- Arquitectura

o La muralla

- La plaza y la Sala del Consell

o Arquitectura religiosa

Ermitas con arcos de diafragma

Iglesias con bóvedas de crucería

Peirons o cruces de término

- Toponimia
Fig. 021. Listado general de las poblas valencianas nacidas después de la Reconquista de Valencia según E. Guinot y J. Martí. Se sitúan en el plano las catorce pueblas analizadas en el presente plan de investigación. 


\subsection{1| Metodología}

El procedimiento utilizado consta de dos fases claramente identificadas, una primera labor histórica seguida de un trabajo de análisis de campo.

La primera tarea, crear una ficha con una serie de datos que debían completarse con el fin de recopilar los mismos detalles de cada municipio. Los apuntes recogidos, según las fichas elaboradas, fueron los que se observan en la ficha tipo 1 y la ficha tipo 2.

De manera semejante se trataron los restos medievales de cada municipio, se documentó qué tipo de edificaciones ha llegado a nuestros días de cada uno de ellos y sus ubicaciones (véase ficha tipo 3 página siguiente).

Fue una recopilación muy exhaustiva, que se caracterizó por la búsqueda de fuentes documentales referidas a la trama histórica de cada una de las poblaciones. Con este objetivo se revisó los fondos municipales de cada una de estas villas a través de la delimitación solicitada en las oficinas técnicas municipales. En los casos en los que había estudios realizados sobre estas zonas, se tomó éstos como referencia de delimitación.

Seguidamente se visitó los cascos antiguos de las villas y se obtuvo, a través del Colegio Oficial de Arquitectos de la Comunidad Valenciana, la planimetría catastral y los correspondientes planes generales.

Toda esta documentación fue utilizada para comparar cada una de las tramas urbanas, teniendo en cuenta, además, el patrimonio edificado que daba forma a los centros históricos en la actualidad.

${ }^{66}$ Torró, J. (1989): El problema del hábitat fortificado en el sur del Reino de Valencia después de la segunda revuelta mudéjar ( 1276-1304), pág. 60.

${ }^{67}$ Datos obtenidos de la medición sobre el plano de la oficina virtual del catastro. 2014.

Una vez archivadas cada una de los referencias, se comenzó a realizar el análisis gráfico de la planta que formaban inicialmente estas poblaciones.

En primer lugar se realizó un levantamiento del centro histórico, identificando sobre todo el entorno de la muralla, sus torres, puertas, materiales y espesor (en los casos que quedaran restos). Se prosiguió con la operación de medición del perímetro y los lados del recinto delimitado por la muralla. Seguidamente se identificó la plaza central de aquellos municipios que contaban 


\section{DATOS DE LA POBLACIÓN}

\begin{tabular}{l|l|l|l|}
\hline NOMBRE ACTUAL & & NOMBRE ORIG INAL & \\
\hline Hisn o castillo cerca del cual se construye & \multicolumn{2}{l|}{} \\
\hline FUNDACIÓN & & \\
\hline $\begin{array}{l}\text { AÑO CARTA PUEBLA O PRIVILEGIO DE } \\
\text { FUNDACIÓN }\end{array}$ & & OTORGANTE & \\
\hline FUERO & & & \\
\hline VILA O LOC & Casasen 1560 & \\
\hline Casasen 1490 & & \\
\hline NOTAS &
\end{tabular}

Ficha tipo 1: Utilizado para tomas los datos históricos de cada uno de los municipios estudiados

\begin{tabular}{|c|c|c|c|c|}
\hline \multicolumn{5}{|l|}{ URBANISMO } \\
\hline \multicolumn{5}{|l|}{$\begin{array}{l}\text { RAZÓN DEL PERÍMEIRO CON LOS } \\
\text { LADOS }\end{array}$} \\
\hline LONGITUD & $---\mathrm{ml}$ & & AMPUTUD 66 & $---\mathrm{ml}$ \\
\hline \multicolumn{5}{|l|}{ SITUACIÓN DE LA POBLA } \\
\hline \multirow[t]{3}{*}{ ANCHO DECAШE } & \multicolumn{2}{|c|}{ Decumanus (Este- Oeste ml) } & \multicolumn{2}{|c|}{ Cardus ( Norte-Sur ml) } \\
\hline & \multirow{2}{*}{\multicolumn{2}{|c|}{ 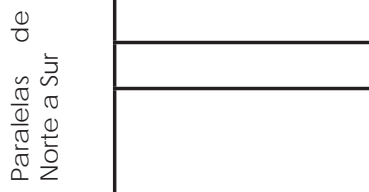 }} & \multirow{2}{*}{ 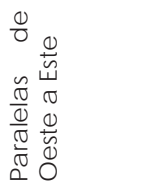 } & \\
\hline & & & & \\
\hline COMPARATIVA & \multicolumn{2}{|c|}{ Aragón S.XIJaca } & \multicolumn{2}{|c|}{ Urbanismo en CV S. XIII ${ }^{68}$} \\
\hline MANZANAS & \multicolumn{2}{|c|}{ Iguales } & & \\
\hline LONG ITUD MANZANAS & \multicolumn{2}{|c|}{ Doble o triple ancho de calle } & & \\
\hline PARCELAS & \multicolumn{2}{|c|}{ Iguales } & & \\
\hline FRENTE DE FACHADA & \multicolumn{2}{|c|}{$4-5 \circ 6 \mathrm{~m}$} & & \\
\hline PROFUNDIDAD & \multicolumn{2}{|c|}{ Hasta $25 \mathrm{~m}$} & & \\
\hline TIP. VIVIENDAS & \multicolumn{2}{|c|}{ Entre medianeras } & & \\
\hline MURAШA & \multicolumn{2}{|l|}{ No } & & \\
\hline PLAZA CENTRAL & \multicolumn{2}{|c|}{ No, situada a la entrada } & & \\
\hline \multicolumn{3}{|l|}{ NOTAS: } & & \\
\hline
\end{tabular}

Ficha tipo 2: Utilizada para tomar los datos sobre los viales y perímetro de los centros históricos estudiados 
${ }^{68}$ Las viviendas están orientadas en su gran mayoría en esta dirección y cuentan con el acceso principal de la fachada recayente a estas calles, por esta razón se toman como referencia para este estudio.

${ }^{69}$ Se toma como profundidad de la parcela la media aproximada de las parcelas existentes en la manzana. Se toma como referencia aquellas edificaciones que solo tienen acceso por un solo vial o las que tienen acceso por dos viales.

${ }^{70}$ Las manzanas se enumeran desde el centro el centro de intramuros hacia la muralla. De dentro a fuera, las últimas manzanas son siempre las perimetrales.

${ }^{71}$ Zaragozá Catalán, A. (2008): Arquitectura any zero (1.208 - 2008). Generalitat Valenciana. Valencia. Any Jaume I Generalitat Valenciana, pág. 5. con ella y se realizó su correspondiente toma de datos. A continuación se reseñaron los viales y las agrupaciones de edificaciones que quedaban en intramuros.

Las manzanas - espacio de terreno con casas o sin ellas, pero circunscrito por calles por sus cuatro lados - ubicadas en el núcleo histórico, fueron enumeradas todas ellas, siguiendo siempre el mismo orden, de norte a sur, y de izquierda a derecha. Una vez registradas se procedió a comprobar sus dimensiones (a lo largo y ancho) documentando también la profundidad de las parcelas en cada bloque (véase ficha tipo 4).

Al mismo tiempo fueron dimensionados los viales, tomando su anchura e ubicación. Primero se identificaba las calles principales, el eje longitudinal y el eje transversal, su orientación y anchura. A continuación las vías secundarias, reseñando cuántas eran paralelas a cada uno de los ejes primordiales. De cada una de ellas quedó referenciado el ancho de la calle y la existencia o no de fachadas principales recayentes a cada vial. En las calles que si contaban con accesos a viviendas, se midió la fachada menor.

Con todas las dimensiones anotadas, había que proceder a comprobar la dirección del parcelario, para identificar qué sentido seguían los solares en cada una de las calles, poniendo en común la manzana con la calle hacia donde se dirigían las fachadas.

A continuación fueron puestas en común la tipología de manzanas existentes en estas villas. Tomando como referencia el único municipio que mantiene intacta la cerca, Mascarell, se determinó la formación de distintos tipos de agrupaciones de viviendas y, por medio de un levantamiento gráfico, hubo que localizar en las distintas villas los mismos patrones.

Estudiados todos los centros históricos y tomadas sus dimensiones procedía hallar su equivalencia con varas valencianas. Josep Vicent del Olmo, Cocharán y muchos otros autores señalan que la vara de medir valenciana es igual a la de la antigua Roma, y el pie igual al del antiguo pie romano ${ }^{71}$, por lo que esta ha sido la referencia tomada.

Una vez encontrado el paralelismo emanaba realizar el cálculo, pero cabe señalar que para poder obtener resultados exactos, habría que realizar un levantamiento topográfico de cada uno de los centros históricos. El hecho es que si se realizan las mediciones sobre planos catastrales y planimetría del plan 


\section{ARQUTTECTURA}

\begin{tabular}{|c|c|c|}
\hline $\begin{array}{l}\text { MURAШA O CERCA } \\
\text { Muraria }\end{array}$ & & \\
\hline \multicolumn{3}{|l|}{ Materiales } \\
\hline Altura & Espesor & \\
\hline № de puertas & № de torres & \\
\hline \multicolumn{3}{|c|}{$\begin{array}{l}\text { Construida al mismo tiempo o posterior a la } \\
\text { fundación de la puebla }\end{array}$} \\
\hline $\begin{array}{l}\text { CISTERNA O POZO } \\
\text { CENTRAL }\end{array}$ & $\begin{array}{l}\text { ERMITA ARCOS } \\
\text { DIAFRAGMA }\end{array}$ & \\
\hline $\begin{array}{l}\text { IGLESIA BÓVEDASDE } \\
\text { CRUCERÍA }\end{array}$ & $\begin{array}{l}\text { CASTILO EN } \\
\text { INTRAMUROS }\end{array}$ & \\
\hline \multicolumn{3}{|l|}{ CRUCES DE TERMINO } \\
\hline \multicolumn{3}{|l|}{ NOTAS } \\
\hline \multicolumn{3}{|l|}{ Lavadero en --- } \\
\hline $\begin{array}{l}\text { La iglesia se } \\
\text { encuentra en la --- }\end{array}$ & & \\
\hline
\end{tabular}

Ficha tipo 3: Utilizada para tomar los datos de los elementos arquitectónicos medievales que han llegado hasta la actualidad en cada municipio

\begin{tabular}{|c|c|c|c|c|c|c|}
\hline \multicolumn{7}{|c|}{ URBANISMO: Estudio de las manzanas y de las parcelas } \\
\hline \multicolumn{2}{|l|}{ Plaza mayor } & LONGITUD (ML & & \multicolumn{2}{|c|}{ ANCHURA (ML) } & \\
\hline \multicolumn{7}{|c|}{ DECAMANUS ${ }^{68}$} \\
\hline SITUACIÓN & LONG ITUD $^{69}$ & $\begin{array}{c}\text { A N C HURA - } \\
\text { PROFUNDIDAD } \\
\text { (ML) }\end{array}$ & ANCHURA & FACHADA & 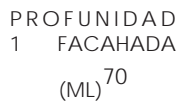 & $\begin{array}{l}\text { PRO FUNDIDAD } \\
2 \quad \text { FACHADAS } \\
\text { (ML) }\end{array}$ \\
\hline \multicolumn{7}{|l|}{ M1 } \\
\hline \multicolumn{7}{|l|}{ M2 } \\
\hline \multicolumn{7}{|l|}{ M3 } \\
\hline \multicolumn{7}{|l|}{ M4 } \\
\hline \multicolumn{7}{|l|}{ M5 } \\
\hline \multicolumn{7}{|l|}{ M6 } \\
\hline \multicolumn{7}{|l|}{ M7 } \\
\hline
\end{tabular}

Ficha tipo 4: Utilizada para tomar los datos de las dimensiones de las manzanas, viales y parcelas de cada uno de los centros históricos 
general, cualquier medida que no precisa llevaría a un cálculo erróneo. Se debe tener entonces en cuenta la problemática del estudio de las trazas y del parcelario de los centros históricos, y el hecho de que estos núcleos han ido evolucionando a lo largo de toda su historia, sería idóneo poder contar con planos medievales (en algunos casos existen bocetos, pero la mayoría de la cartografía pertenece al siglo XIX).

La realidad es que cuando se empezó acometer esta empresa, nos percatamos de que la mayoría del perímetro amurallado típico de estas poblaciones había desaparecido, es decir, se encontraba embebido por las edificaciones posteriores. En el mejor de los casos pudimos encontrar un lienzo conservado debido a que en algún momento de la historia fue de alguna utilidad. Los viales habían modificado sus alineaciones, al igual que las parcelas, las cuales se habían ido segregando o unificándose a lo largo de la historia. Por todo ello, se intentó encontrar las mayores semejanzas posibles, midiendo cada uno de ellos en los distintos núcleos históricos para, posteriormente, unificar los datos en un estudio conjunto de todas ellas las villas, y comprobar cuales eran las medidas más similares en cada uno de los casos.

Al finalizar este estudio se contó con la delimitación de las tramas urbanas de las villas analizadas, con indicación de los límites del espacio de intramuros, el trazado de los viales y la distribución aproximada de las manzanas, además de la identificación de los elementos arquitectónicos de valor patrimonial destacado, que nos sirvió posteriormente para analizar en mayor profundidad el caso específico de la villa de La Pobla de Vallbona

Esta línea de investigación se aplicó a los 14 cascos históricos descritos con resultados homogéneos en todos ellos. Las fichas con todos los datos se detallan en el apartado de anexos. 
77 de 536

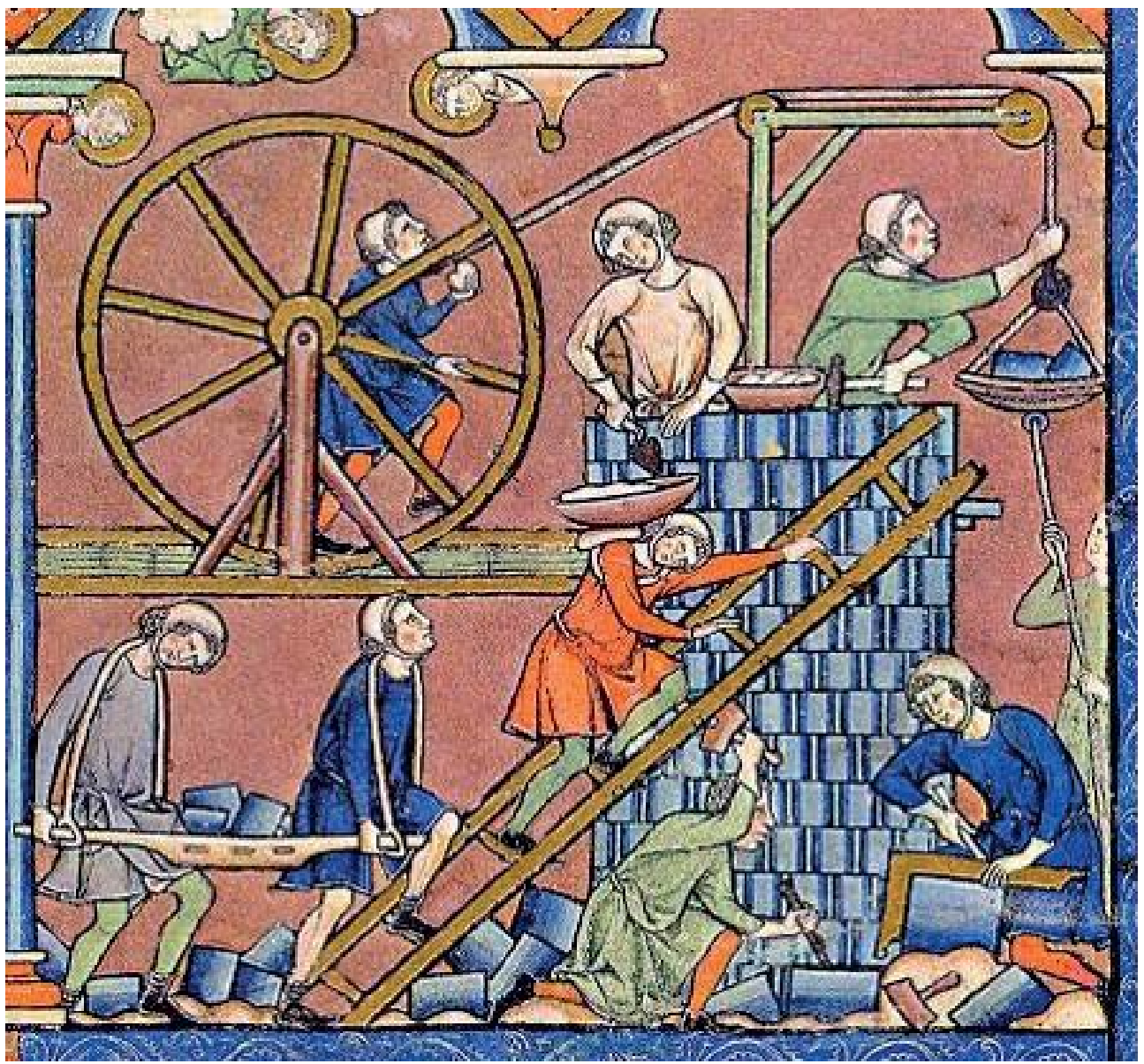

Fig. 022. Imagen medieval de albañiles trabajando en la construcción de la torre de Babel. Pertenece a la Biblia de Maciejowski. llustrada en el año 1250. Lámina no3. 


\begin{tabular}{|c|c|c|c|c|c|c|c|c|}
\hline \multicolumn{7}{|c|}{ AÑO } \\
\hline & 1233 & 1241 & 1242 & 1244 & 1248 & 1250 & 1253 \\
\hline Munic ipio & MASC AREL & VINAROZ & PUZOL & CUШERA & ALMENARA & NULES & GANDÍA \\
\hline \multicolumn{7}{|c|}{ AÑO } \\
\hline
\end{tabular}

Tabla 1: Fecha de fundación según la carta pobla. Se observa que no corresponde el orden de Norte a Sur de la Comunidad Valenciana

\subsection{2| Situación y fundación}

Los primeros datos analizados corresponden a la fecha de fundación de los municipios. Como se ha podido constatar, todos los casos corresponden a núcleos formados después de la reconquista de su región. El citado acontecimiento no viene dado al mismo tiempo que se iban reconquistando el territorio, sino de la necesidad de su ocupación e ir asegurándolo. Encontramos municipios de la provincia de Alicante que fueron fundados antes que algunos de Castellón (véase tabla 1), como es el caso de Cocentaina. Se debe de tener en cuenta la posibilidad de que quizás se erigía el lugar y no era ocupado inmediatamente. También cabe la opción de que en un principio no fueran consideradas como vilas o que la carta pobla que se conoce en la actualidad -como la población al que hace referencia este estudio principalmente - no fuera la primera que se concedió o no fue otorgada inicialmente.

Es evidente entonces que eran núcleos formados para atraer al máximo de nuevos colonos, y siempre situados en una llanura, bajo la protección de un castillo, un hisn, musulmán. El castrum o castell, de los que también habla el Llibre del Repartiment, comprendían una extensión considerable. La superficie de los más pequeños se estimaba entre dos o tres mil metros cuadrados, mientras que los más extensos podían llegar a tener unas cuantas hectáreas. La función primordial del castillo valenciano, según parece, era la de constituir un refugio para los habitantes del término en caso de peligro inminente. En algunas ocasiones equivalía simplemente a una zona rocosa en la ladera de una montaña, mientras que otras veces aquello que los cristianos denominaron castrum o castell se identificaría con un cerramiento defensivo único, el cual podía llegar a estar rodeado por una barbacana. 


\begin{tabular}{|c|c|c|c|}
\hline PROVINCIA & VIШA O ШОC & HISN o castillo del que dependen & Carta Pobla o fuero \\
\hline \multirow{6}{*}{ 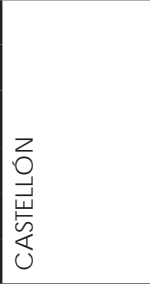 } & Vinaroz & Castillo de Peñíscola & Fuero de Zaragoza \\
\hline & Castellón & Castillo de la Magdalena & Fuero de Valencia \\
\hline & Vila-real & Medina de Bomiana & Fuero de Zaragoza $^{73}$ \\
\hline & Mascarell & Bumiana & Carta pobla. 1276. \\
\hline & Nules & Castillo de Villavieja & Fuero de Valencia \\
\hline & Almenara & Castillo de Almenara & \\
\hline \multirow{4}{*}{ 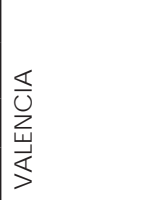 } & Puzol & Castillo del Puig & Fuero de Valencia \\
\hline & La Pobla de Vallbona & Castillo de Benaguacil & Fuero de Valencia $^{74}$ \\
\hline & Cullera & Castillo de Cullera & Fuero de Valencia \\
\hline & Gandía & Castillo de Bayren $^{75}$ & Fuero de Valencia. 1253 \\
\hline \multirow{4}{*}{ 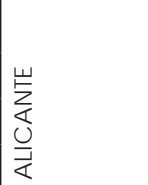 } & Cocentaina & Castillo de Qusantaniya (s. X) ${ }^{76}$ & Fuero de Valencia \\
\hline & Penáguila & Castillo de Penáguila & Carta Pobla. 1278. \\
\hline & Alcoy & Centro fortific a do el castellar & Fuero de Vale \\
\hline & Teulada & Castillo de Calpe & Fuero de Valencia \\
\hline
\end{tabular}

Tabla 2: Castillo y carta de población de los centros históricos investigados

Como se ha indicado cada nueva población venía acompañada por una carta pobla o fuero que acreditaba que sus constituyentes eran hombres libres, profesaban la religión cristiana y se les concedía derechos varios y propiedades.

En todos los casos el mecanismo de asentamiento general se basó en las cartas de población las cuales eran entendidas como el vehículo jurídico usado por el poder feudal para establecer y reconocer los derechos del nuevo núcleo de población. De hecho se ha conservado hasta la época actual un centenar de ellas y, en su contenido, siempre se reflejaba el fuero por el que se tenía que regir la población en caso de conflicto. En algunos pocos casos de asentamientos de los primeros años, se da la circunstancia de que se ha encontrado referencia a la concesión del fuero de Zaragoza o la costumbre de Lérida, pero a medida que se producían nuevas poblaciones, de forma más usual y finalmente generalizada, los nuevos poblados se acogían al nuevo fuero de Valencia ${ }^{72}$.

En el caso de Vinaroz y Vila-real, sus cartas pobla indican que fueron concedidas bajo el fuero de Zaragoza, sin embargo en documentos de años más tardíos se ha podido comprobar que posteriormente se regían por el fuero de Valencia.

En la tabla 2 se observa cómo la mayoría de municipios creados eran villas. La villa correspondería a un poblado más extensivo que el castrum y la alquería (la cual resulta difícil de sujetar a
${ }^{72}$ Guinot, E.(1991): Cartes de Poblaments Medievals Valencianes. Valencia: Generalitat Valenciana.

${ }^{73}$ Adopta los fueros de Valencia en 1330.

${ }^{74}$ La carta Pobla señala el fuero de Aragón, pero en posteriores documentos notariales, después de esta, ya aparece que se encuentran bajo el fuero de Valencia. Jaume I permitió a los señores aragonés que siguieran en sus tierras con sus fueros propios, aunque ya había jurado los fueros de Valencia.

${ }^{75}$ Ayuntamiento de Gandía. Conoce Gandía.

${ }^{76}$ Torró, J y Ivars, J.(1989): “ Villas fortificadas en el sur del País Valenciano: los casos de Concentaína, Alcoy y Penáguila". Actas del III Congreso de Arqueología medieval Española. Universidad de Oviedo. 


\begin{tabular}{|c|c|c|c|c|}
\hline PROVINCIA & Munic ipio & Situa ción en el llano & Villa-lloc & Edific ios en 1490 \\
\hline \multirow{6}{*}{ 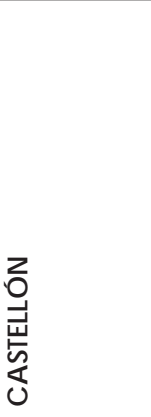 } & Vinaroz & $\begin{array}{l}\text { Sobre una alquería, a orillas del mar, } \\
\text { conocida en el siglo XIII como de los } \\
\text { "Beni-Al-Arus". }\end{array}$ & Villa & 152 \\
\hline & Castellón & $\begin{array}{l}\text { J unto a la acequia mayor, en la parte no } \\
\text { regable. }\end{array}$ & Villa & 484 \\
\hline & Vila-real & $\begin{array}{l}\text { Junto a un acequia nueva, en la cota } \\
\text { inmediatamente superior no regable. }\end{array}$ & Villa real & 350 \\
\hline & Mascarell & J unto a la acequia de Mascarell. & பloc & --- \\
\hline & Nules & $\begin{array}{l}\text { Junto a un acequia nueva, en la cota } \\
\text { inmediatamente superior no regable. }\end{array}$ & பoc/Vila & 248 \\
\hline & Almenara & Terreno llano cerca del mar. & Villa & 108 \\
\hline \multirow{4}{*}{ 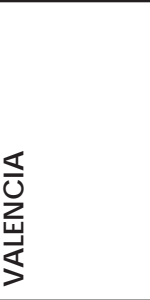 } & Puzol & $\begin{array}{l}\text { J unto la acequia de Moncada, lindando } \\
\text { a norte y a oeste con ella. }\end{array}$ & Villa & 106 \\
\hline & $\begin{array}{l}\text { La Pobla de } \\
\text { Vallbona }\end{array}$ & $\begin{array}{l}\text { Al lado de la acequia primera, en la } \\
\text { cota no regable, zona sur. }\end{array}$ & Uoc/Villa & 168 \\
\hline & Cullera & $\begin{array}{l}\text { Junto al ńo Xúquer. A } 1 \mathrm{~km} \text { de su } \\
\text { desembocadura. }\end{array}$ & Villa & 189 \\
\hline & Gandía & $\begin{array}{l}\text { Se fundó junto a la acequia real de } \\
\text { Moncada y junto al ńo Serpis. }\end{array}$ & Villa & 363 \\
\hline \multirow{4}{*}{ 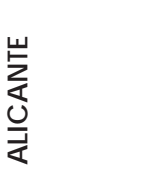 } & Cocentaina & ---- & Villa & 544 \\
\hline & Penáguila & ---- & Villa & 142 \\
\hline & Alcoy & Entre el ńo Xúquer y el ńo Molinar. & Villa & 413 \\
\hline & Teulada & ----- & Villa & 46 \\
\hline
\end{tabular}

Tabla 3: Situación del nuevo enclave, tipología de núcleo e inmuebles en el año 1490

un patrón único: podía tener alcazaba o ciudadela, alrededor de la cual se construían caprichosamente las casas). El nuevo núcleo era denominado como I/oc, cuando dependía de una villa más importante.

Todos los municipios estudiados fueron considerados como villas, a excepción de Mascarelli7, y Nules, que fueron considerados como /locs, y Vila-real que, como su nombre indica, fue construida bajo la protección del rey.

El lugar elegido para establecer estos primeros asentamientos urbanos solía corresponderse con un llano, -donde existía ya una alquería o bien ningún tipo de edificación- y a una distancia próxima del castillo donde sus pobladores debían de resguardarse. Estos castillos distaban un máximo $3 \mathrm{~km}$ del nuevo núcleo cristiano de población, aunque existen excepciones como es el caso del municipio de Teulada cuyo recorrido resultó ser mucho mayor.

Otro condicionante a la hora de elegir el lugar en la llanura era el suministro de agua. Todos los municipios de nueva creación se establecieron en una zona donde se encontraba asegurada la captación 


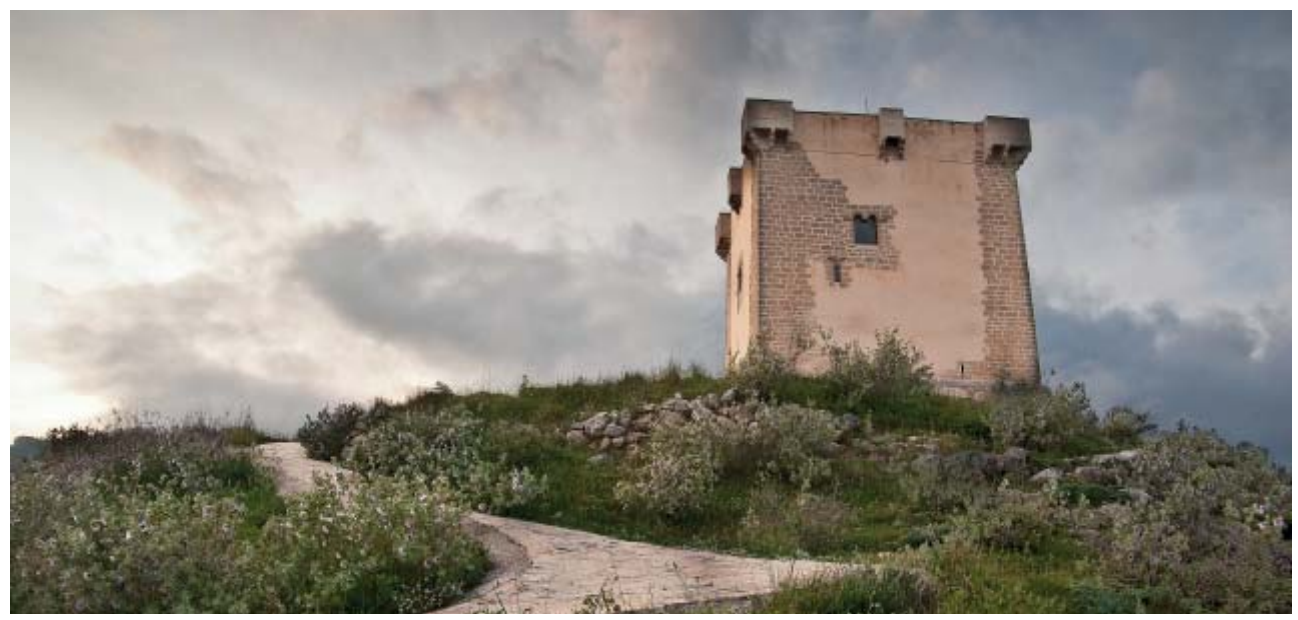

de ésta, ya fuera cerca de una acequia, de un río o del mar, en la cota inmediatamente superior no regable de éstos. Aquellos poblados cuyos límites se correspondían con una acequia no continuaron su expansión ni se ensancharon en esa dirección, puesto que la acequia hacía las veces de límite natural.

\subsection{3| Las trazas urbanas}

Sobre la base de las consideraciones anteriores procede observar las trazas urbanas de los municipios elegidos. Comenzando por las altas tierras de Teruel y, descendiendo a la Plana, los núcleos históricos de las villas de Almenara (1248), Castellón (1251) y sobre todo Vila-real (1272), se desarrollan con una regularidad mayor que las poblaciones turolenses, condicionados por un medio más montañoso. La citada vila recibió los fueros de Aragón en 1274 , y se construyó en torno a una plaza central cuadrada, en el cruce ortogonal de los dos ejes principales que abrían cuatro puertas en el perfecto rectángulo amurallado.

La planificación urbana aragonesa sigue ya en el siglo XIII métodos sistemáticos, produciendo resultados cada vez más generalizables y más lejanos de una simple parcelación del suelo urbano, es decir, la ciudad se adentra en la categoría del fenómeno estético ${ }^{78}$.

En efecto, en la Plana de Castellón los maños fundaron en el siglo XIII, mediante fueros derivados de los de Zaragoza, Daroca o Aragón, un grupo de ciudades que se cuentan entre los más altos ejemplos de la planificación medieval europea. Las
Fig. 023. Castillo de Concentaina. Al abrigo de este castillo en el valle, se planificó y construyó la vila de Cocentaina.
${ }^{77}$ Mascarell, se ha tomado como referencia para este estudio, por ser el único municipio de la comunidad valenciana, que conserva intacta su muralla, estando toda la población aun concentrada en su interior. El topónimo significa campamento en árabe y se ha supuesto que la población perpetúa el campamento levantado por Jaime I para asediar Burriana.

${ }^{78}$ Beltrán Abadía, R.(2005) "Planeamiento y geometría en la ciudad aragonesa". Colegio de Arquitectos de Zaragoza. Arqueología y Territorio medieval. Revista de Arqueología del Área de Historia Medieval. Universidad de Jaén. Tomo 12.2, pág. 115-116. 
82 de 536
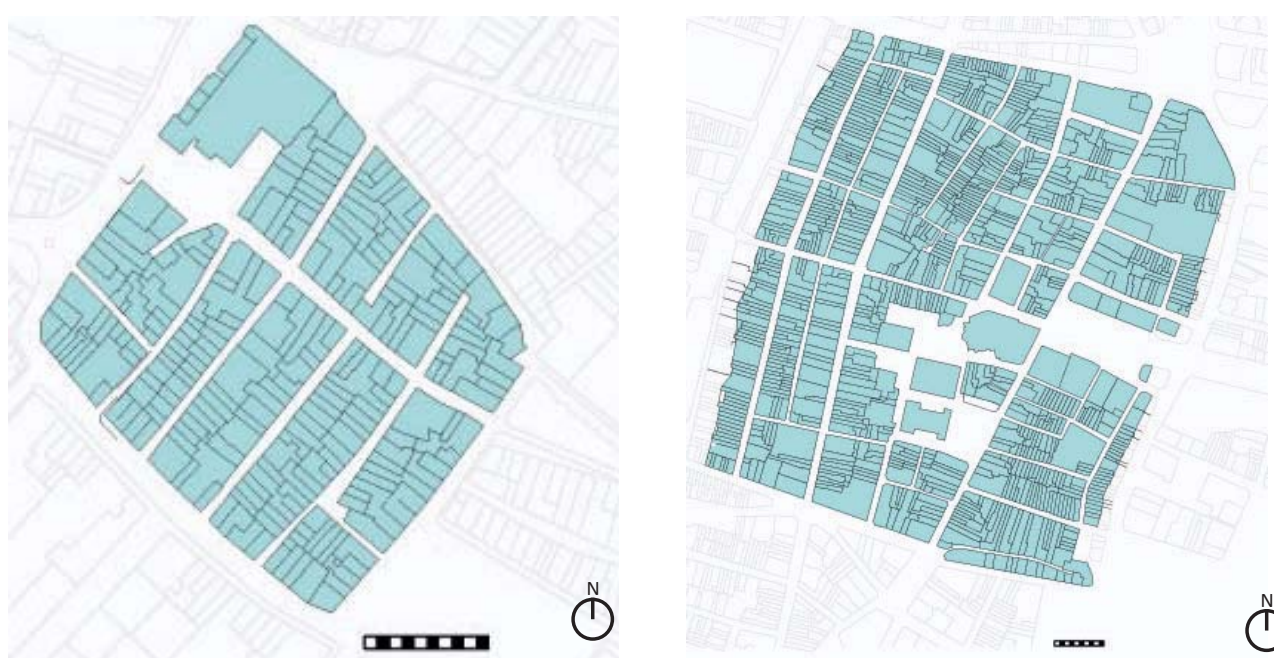

(ั)
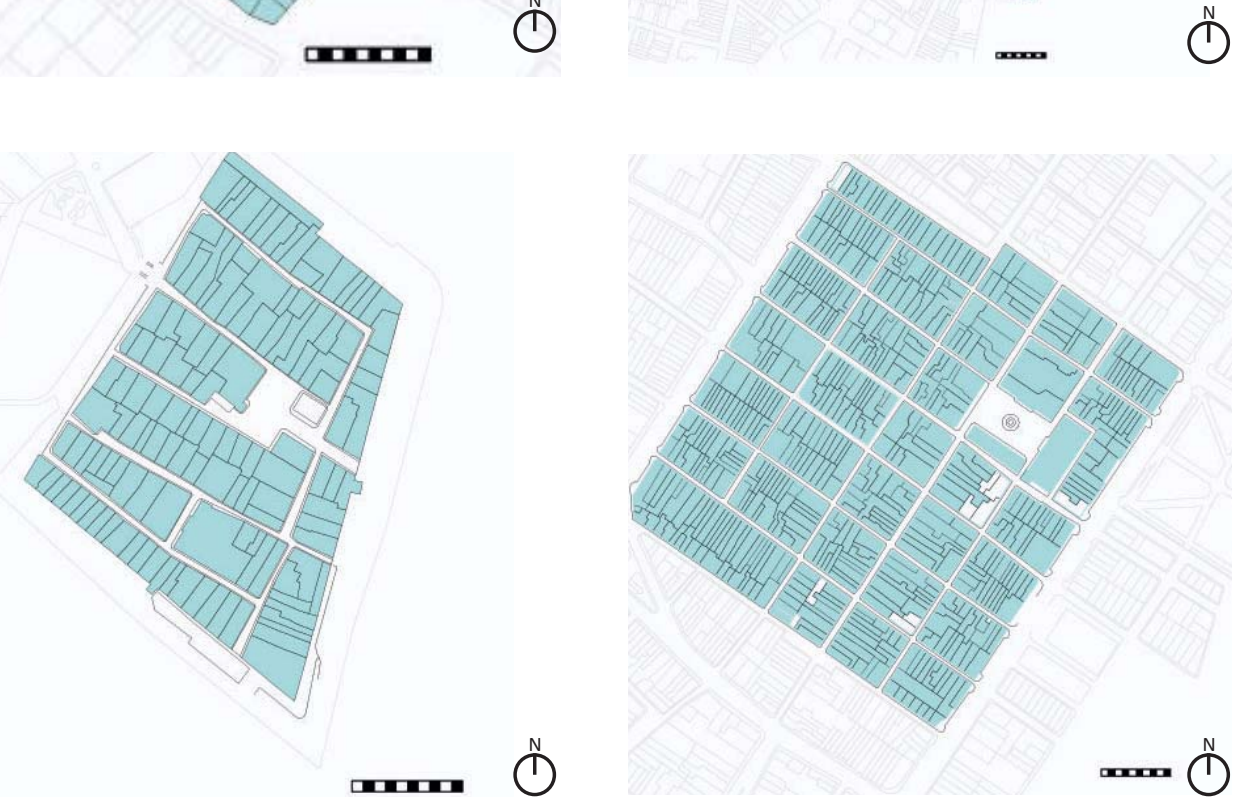

\section{Delimitación de los centros históricos analizados}

Fig. 024. Ámbitos de los centros históricos analizados, basados en diferentes historiadores. De izquierda a derecha y de arriba abajo. Página izquierda: Vinaroz y Castellón por E. Guinot y J. Martí, Mascarell, Nules y Puzol Rossello Verguer y Contelles Llopis. Página derecha: Cullera y Gandía según Vicenç M. Rossello Verguer, Cocentaina, según Torró-Ivars, Penáguila por J. Ivars, J. Torró y E. Cortell, Alcoy medieval, por J. Torró y Teulada por J. Ivars.

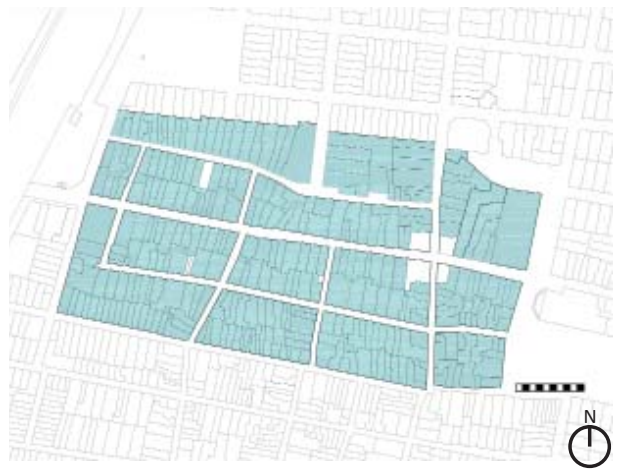


83 de 536
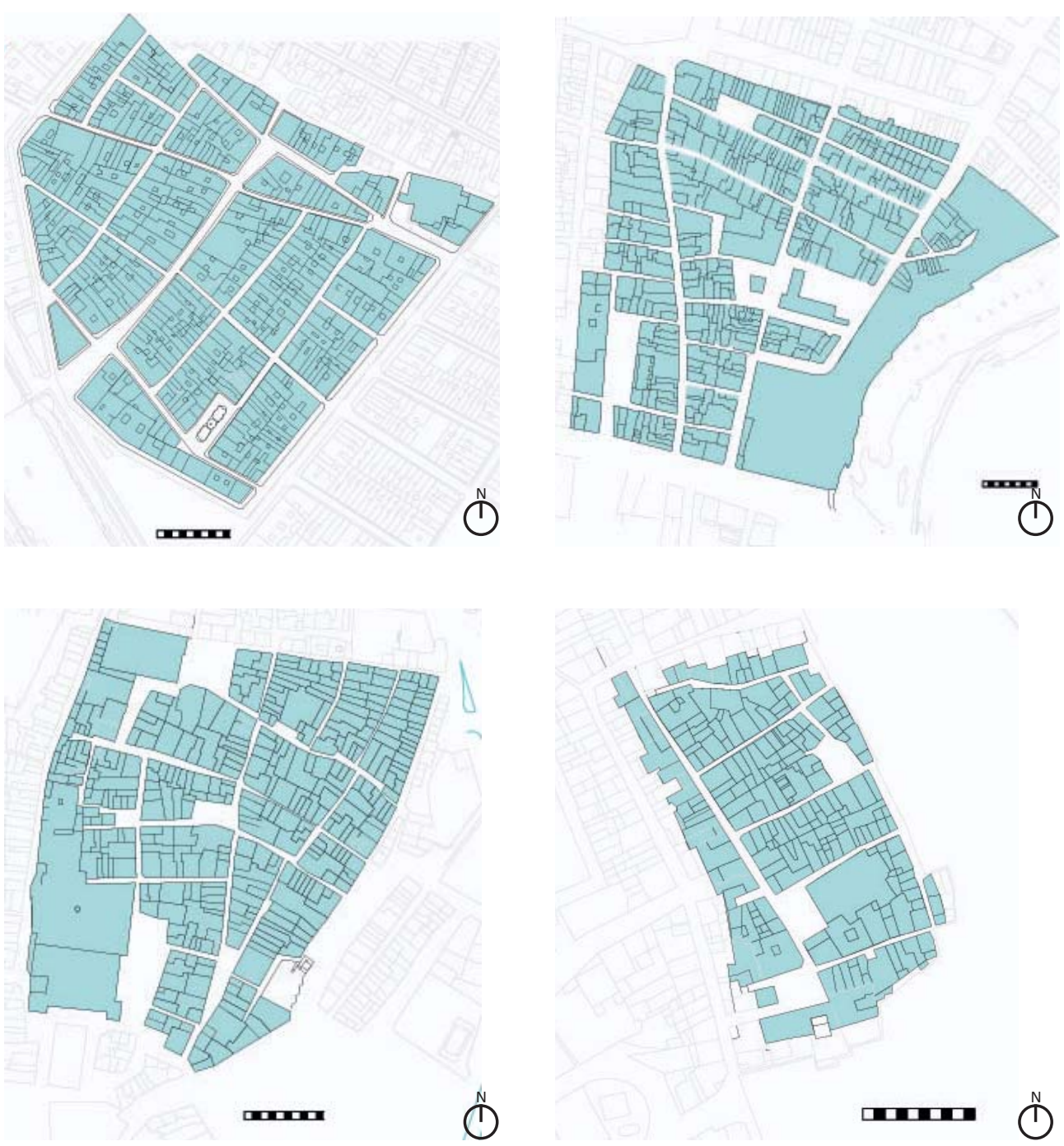

(1)

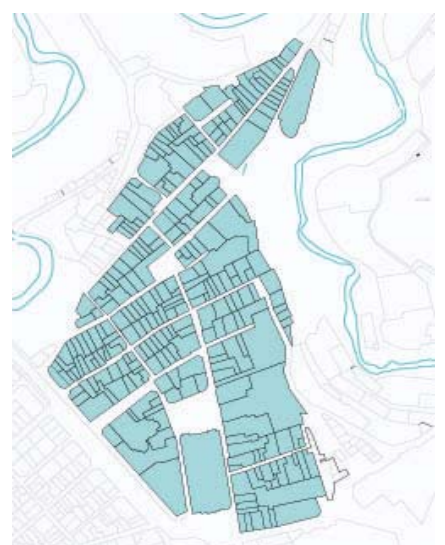

$\$$

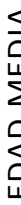

प्रत्व
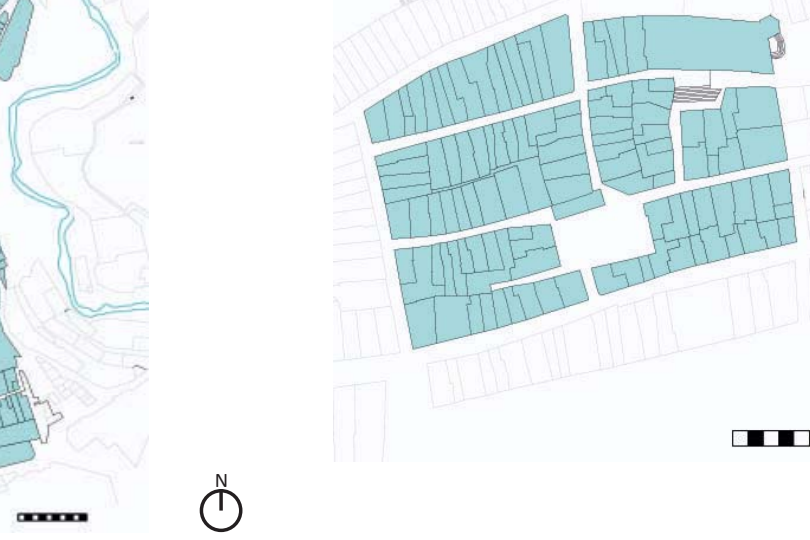

○ 
${ }^{78}$ Beltrán Abadía, R.(2005) "Planeamiento y geometría en la ciudad aragonesa". Colegio de Arquitectos de Zaragoza. Arqueología y Territorio medieval. Revista de Arqueología del Área de Historia Medieval. Universidad de Jaén. Tomo 12.2, pág. 116.

${ }^{79}$ Ibídem.

${ }^{80}$ Ibídem.

${ }^{81}$ Urteaga, M. (2014): "Trama urbana en villas medievales del País Vasco. Las Villas nuevas medievales de Castilla. León. Universidad de Valladolid. Junta de Castilla León. E.T.S. de Arquitectura de Valladolid. plantas de Almenara, Castellón, Vila-real o Nules muestran una clara continuidad en los métodos planificadores que se habían ido formando en Aragón desde el siglo XI y que habían alcanzado resultados similares en las fundaciones realizadas en el siglo XIII al sur de la provincia de Teruel, con ordenamientos jurídicos muy parecidos $^{78}$.

Entre todas estas fundaciones castellonenses destaca Vila-real, comenzada a edificar en 1272 y dotada con los fueros de Aragón en 1274. Su planta se realiza con una mayor precisión geométrica que la del modelo que se había ejecutado en Mosqueruela, ante la que resulta ya inevitable recordar el trazado de la ciudad colonial romana, con su cardo y su decumanus máximos, y el foro porticado en la intersección de los dos ejes. Se trata de un rectángulo perfecto, de proporción 3:5 entre sus lados, delimitado por una muralla con cubos cilíndricos en los ángulos y una puerta en el centro de cada uno de los cuatro paños, unidas entre sí por dos calles principales en cruz, en cuyo centro se forma la plaza, cuadrada y con las esquinas cerradas, como en los modelos piamonteses y venecianos realizados desde finales del siglo XII; a cada lado de las calles principales corre de extremo a extremo otra secundaria, delimitando manzanas perfectamente rectangulares ${ }^{79}$.

Todo ello obedece a la misma proporción que los perímetros amurallados de Almenara y Nules, también en Castellón, o que las francesas Aigues-Mortes (1246) y Monpazier (1284). La frecuencia con que perímetros urbanos, plazas y manzanas de fundaciones de este período se atienen a proporciones elementales como 3:5, 3:4 o 1:1 acredita el manejo de sistemas geométricos carentes de contenido funcional e inspirados por una voluntad estética ${ }^{80}$.

De los anteriores planteamientos se deduce que las nuevas villas medievales se manifiestan como núcleos de población concentrada en un espacio rodeado de un perímetro amurallado; con intramuros que reparten los solares y los edificios, más o menos ordenados entre las calles y la plaza; que en el recinto impera un corpus legal diferenciado del entorno rural que garantiza ciertos privilegios, y habría que añadir que estas villas medievales tienen, además, un marcado carácter comercial y artesano ${ }^{81}$.

Asimismo, tradicionalmente se considera que el plano urbano actual de los núcleos herederos de la fundación del villazgo se correspondería con la planificación fundacional. La extensión del 


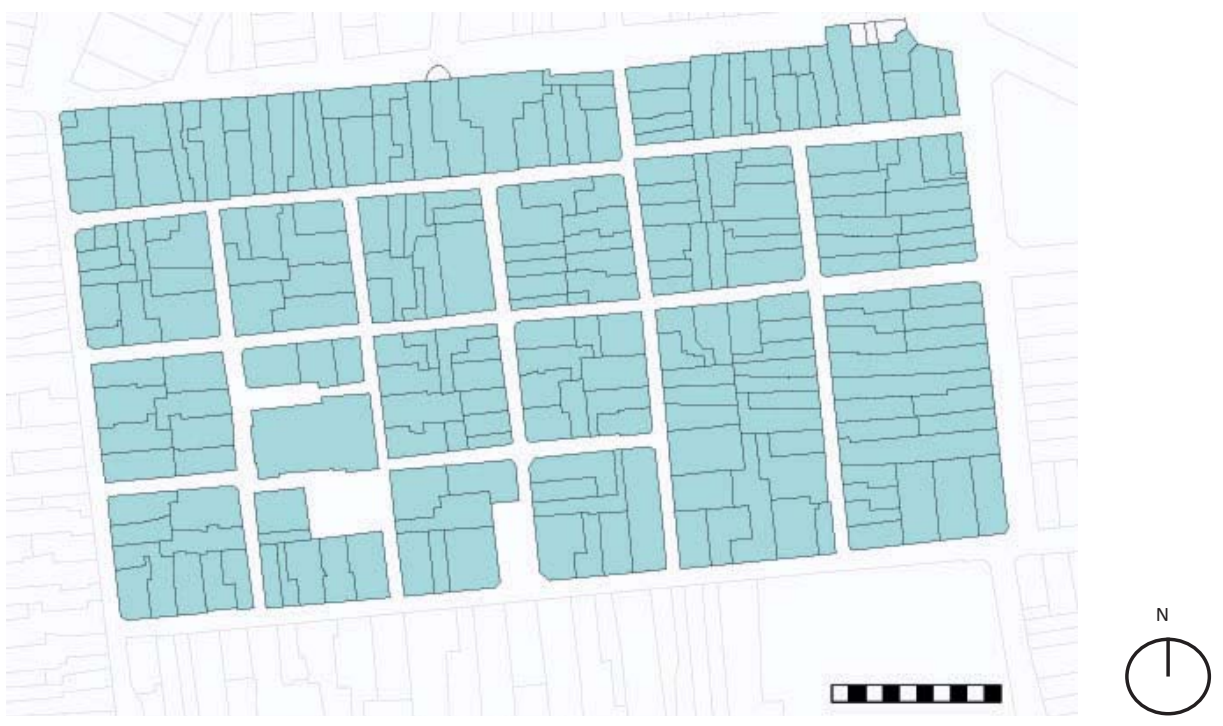

área y la distribución actual del caserío, en manzanas, calles y plazas, nos serviría por lo general de pauta a la hora de establecer el punto de partida del proceso de formación de las villas. Sin embargo, como se ha indicado en capítulos anteriores, esta vía de análisis no resulta del todo satisfactoria puesto que las villas se han ido modificando a lo largo de la historia. Así que para poder garantizar que el casco medieval analizado pertenece a la zona de intramuros, deberemos servirnos de otros cauces, entre las cuales consta el estudio etnológico de las fiestas poblacionales, y comprobación del recorrido de la procesión de los santos patrones del municipio.

En relación con esto último, en un principio la idea puede sorprender, pero si se ahonda en la historia se comprueba que estas vilas estaban pobladas por cristianos viejos, y en sus cartas poblas, se prohibía la residencia de personas de otras religiones, por lo que sus tradiciones, usos y fiestas en muchos lugares se conservan en el presente como antaño. Aquellos pueblos en los cuales se realizan todavía hoy procesiones cuyo recorrido se ciñe al original, se ha comprobado que el trayecto por el que desfila la comitiva recorre todas las calles que se encontraban en el interior de la muralla. Almenara es uno de estos ejemplos.

De acuerdo con los razonamientos que se han venido planteando los resultados obtenidos permiten ver una serie de líneas maestras en la aproximación a la trama fundacional. Todos ellos confluyen en un mismo aspecto: sólo el acercamiento al parcelario del plano fundacional, con sus manzanas, solares,
Fig. 025. Centro histórico de Almenara, según Vicenc Rossello Verguer. Detalla sus trazas ortogonales $y$ la plaza central. 


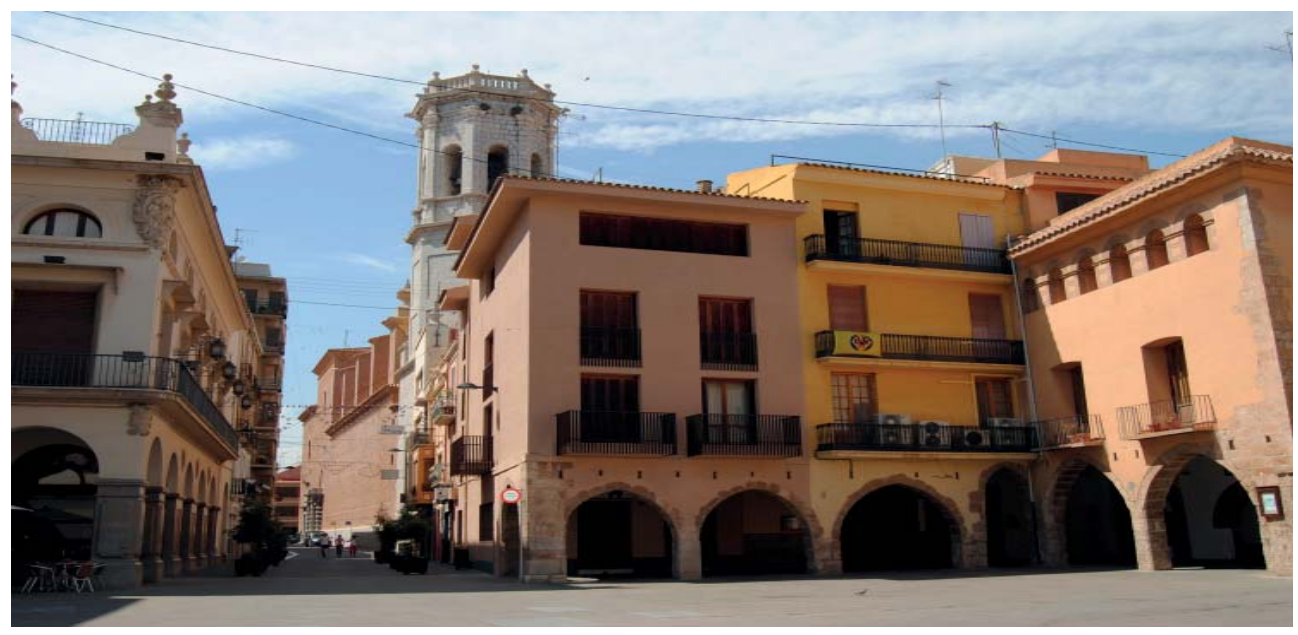

Fig. 026. Plaza mayor de Vila-real. Las fachadas aún conservan los arcos apuntados formando un porche típico de la época medieval. viales, espacios públicos y fortificaciones puede garantizar el conocimiento del programa urbanístico con el que se levantaron las villas. Sin ese instrumento de acercamiento, es el perímetro amurallado el que puede considerarse indicador del espacio en el que se desarrolló la fundación; en combinación con el trazado de los viales, la línea de muralla ofrece, además, las pautas para plantear la distribución de las manzanas, y es esto último lo que se tuvo en consideración en cada uno de los centros históricos analizados.

En cualquier caso la lectura del plano urbano actual no puede valorarse más allá de una realidad correspondiente al presente, si bien heredera, en su identidad urbanística, de una planificación histórica determinada. Lo que procede, en este caso, es determinar el grado de relación entre ambas fases históricas - la fundacional y la actual- y para ello resulta obligado recurrir a los estudios históricos de dichas poblaciones.

\subsubsection{1| Tamaño de la vila y de su plaza}

Se observa claramente que las poblaciones analizadas cuentan en su mayor parte con una planta de trazado cuadrangular, ya sea cuadrada o rectangular. Únicamente se encuentra un centro histórico que presenta una forma irregular, Alcoy, y dos municipios cuyo diseño es pentagonal, Cullera y Teulada.

Comparativamente al evaluar cada uno de los centros históricos conforme la delimitación facilitada por las oficinas técnicas municipales o por estudios ya realizados sobre ellos, se encuentra 
que no existe un tamaño estándar, puesto que coexisten diferentes tamaños de villa:

- Las dimensiones más reducidas las mostraría Teulada con unas medidas aproximadas de $130 \times 115 \mathrm{~m}$, seguido de Penáguila con $148 \times 89 \mathrm{~m}$.

- Para continuar con los 3 centros históricos de mayor superficie Castellón, Gandía y Vila-real, llegando la primera a contar con las dimensiones 500 × 450 m.

Hecha la observación anterior se puede indicar que no se ha encontrado relación entre ellas respecto a su tamaño, puesto que cada una presenta unas dimensiones lineales y superficiales diferentes. El tamaño dependía de la importancia de la villa, cuando más importante es el núcleo de nueva creación, mayor superficie tendrá y mayor número de nuevos pobladores quiere atraer.

Después de lo anterior expuesto era evidente que se debía de proceder a relacionar los datos hallados con el fin de encontrar alguna constante. En primer lugar se pusieron en común las magnitudes de los lados de cada una de ellas. Los resultados fueron diversos, pero todos comprendidos en un mismo un intervalo:

- La menor relación es 1:1,1 y se encuentra en los municipios de Nules, Cullera y Castellón.

- La relación mas considerable se halla en 1:2 y los muestran Concentaina, Vila-real y Puzol.

\begin{tabular}{|l|c|c|}
\hline & \multicolumn{2}{|c|}{ Relación entre sus lados } \\
\hline MUNICIPIO & 1 lado & 2 lado \\
\hline Nules & 1,00 & 1,10 \\
\hline Castellón & 1,00 & 1,10 \\
\hline Vinaroz & 1,00 & 1,30 \\
\hline Gandia & 1,00 & 1,30 \\
\hline Mascarell & 1,00 & 1,50 \\
\hline Penáguila & 1,00 & 1,70 \\
\hline La Pobla & 1,00 & 1,70 \\
\hline Almenara & 1,00 & 1,80 \\
\hline Alcoy & 1,00 & 1,80 \\
\hline Concentaina & 1,00 & 2,00 \\
\hline Villa Real & 1,00 & 2,00 \\
\hline Puzol & 1,00 & 2,00 \\
\hline
\end{tabular}

Tabla 4: Relación entre los lados de cada planta de los núcleos históric os estudiados 
88 de 536

Núcleo histórico de la vila de Alcoy

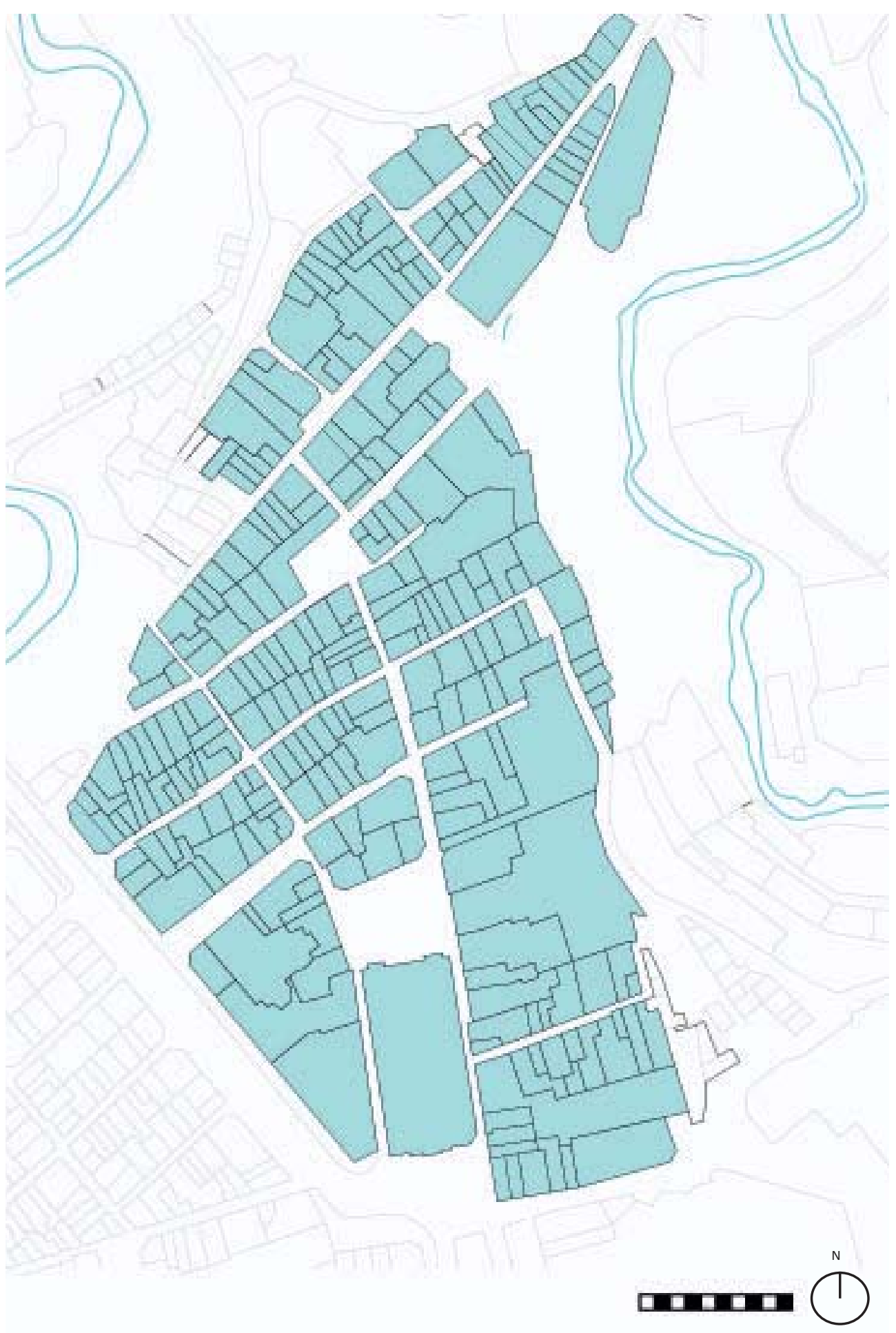


Seguidamente se buscó la siguiente correlación entre ellos. Tomando únicamente los datos de los 12 municipios ${ }^{82}$ que presentaban planta rectangular, se intentó asociar el perímetro de cada centro amurallado con cada uno sus lados. Como resultado no podía ser mejor, la proporción en todos los núcleos históricos es aproximadamente de 3:583. Es evidente entonces que las villas no eran trazadas al libre albedrío sino que seguían unas pautas.

Sobre la base de las consideraciones anteriores se analizó la distribución interna. Todos los municipios se encuentran divididos por dos ejes principales que actúan como arterias para la distribución de las calles del municipio. Todas ellas, en la intersección de ambos o ejes, cuentan con una plaza central denominada plaza de la vila o plaza mayor.

La magnitud del citado espacio público varía de unas a otras, pueden ser prácticamente cuadradas, como la de Puzol 14 x $15 \mathrm{~m}$, o rectangulares, como Alcoy y Cocentaina que son idénticas $23 \times 13 \mathrm{~m}$. La de Vila-real es de las mayores $31 \times 26$ $\mathrm{m}$ exceptuando a la de Castellón, que mide $58 \times 21 \mathrm{~m}$. De acuerdo con los razonamientos que se han venido realizando se podría llegar a pensar que hubiera una relación entre la forma de la planta del municipio - planta villa cuadradas plaza mayor cuadrada o planta rectangular plaza rectangular- pero no es así. No guardan ningún tipo de relación entre ambas, es decir, aunque la plaza sea cuadrada todo el territorio ocupado puede ser rectangular o viceversa.

Hecha la observación anterior, procedía comparar el tamaño de cada vila con la dimensión de su propia plaza. En este caso se cumple que a mayor superficie de villa mayor plaza. De todo esto se desprende que las tres villas más grandes en extensión, Castellón, Gandía y Vila-real, tienen las plazas de mayores dimensiones.

Como apunte final indicar que las urbes con mayor extensión no fueron aquellas que crecieron más rápidamente en número de inmuebles. Si se observa la tabla 3 (pág. 80), queda reflejado que en el año 1490, los municipios anteriormente citados, contaban con un número considerable de inmuebles, pero tenían mayor número los municipios de Cocentaina y Alcoy que cuentan con menor superficie.
Fig. 027. Plano del centro histórico de Alcoy. Identificadas sus trazas ortogonales y la plaza central.

\footnotetext{
${ }^{82}$ En este estudio se ha eliminado Cullera y Teulada por tener forma hexagonal.

${ }^{83}$ Se toma como referencia el número entero que salde de la operación. . La relación es el resultado de cada uno de sus lados divididos por el perímetro. $a / a+a+b+b: b /$ $a+a+b+b$.
} 
$\mathbf{9 0}$ de 536

\section{Núcleo histónico de Vila-real con sus topónimos medievales}

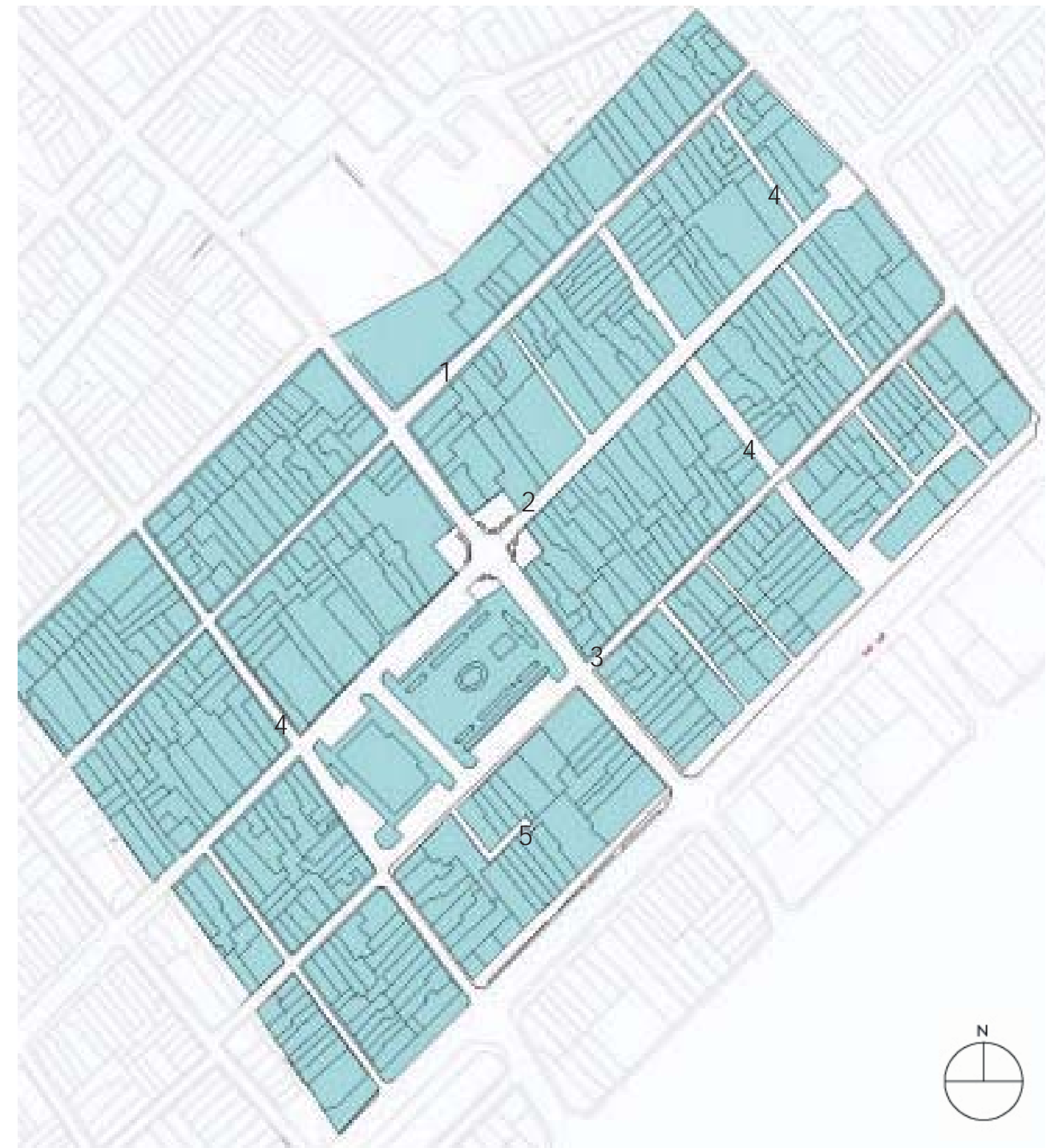

\section{LEYENDA}

1- Carrer de Dalt o d'Amunt

2-Carrer Major

3- Carrer de Baix o d’avall

4- Travesera

5- Carreró 


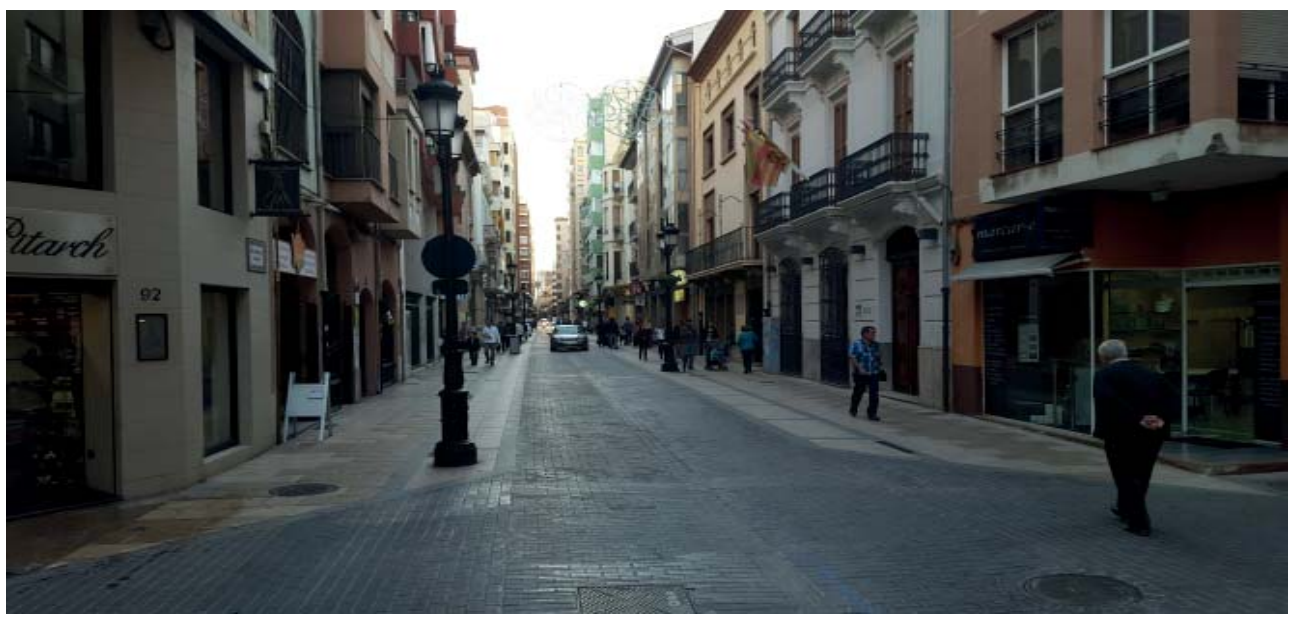

\subsubsection{2| Viales}

En lo que se refiere a la trama urbana, todos ellos cuentan con dos ejes principales que dividen el centro histórico, el cardus y el decumanus. La primera a la que se hace referencia es la calle orientada de norte a sur y la segunda la que va en dirección este a oeste. Torres Balbás señala en sus estudios que la calle mayor siempre era su eje longitudinal, y que, paralelas a este vial, surgen otras calles simétricas, normalmente tres, guardando el mismo orden, pero más estrechas.

En los casos analizados se cumple que el carrer Major es el eje longitudinal en planta. Además, coincide que ese vial es el que cuenta con mayor anchura del núcleo histórico, seguido de la calle que la corta perpendicularmente.

Por tanto, lo primero que se observa del trazado en los municipios es la calle mayor y el vial que la atraviesa ortogonalmente, ambos ejes primordiales del parcelario, y las calles principales de la población.

En el marco anteriormente descrito aparecen paralelamente a uno de los dos ejes principales - contrario a lo indicado por Torres Balbás - , un número de vías, denominadas secundarias, que dependiendo de su ubicación, van denominándose con distintos nombres, el carrer del mig o mitja, el carrer de dalt $i$ el de baix. Estas calles cuentan con menor importancia, tienen menos anchura, pero se les denomina calles puesto que recaen fachadas de viviendas a ellas.
Fig. 028. Plano del centro histórico de $\mathrm{Vi}$ la-real donde son detalladas las calles, principales, secundarias, travesseres i carrerons.

Fig. 029. El carrer Major de Castellón en la actualidad. 


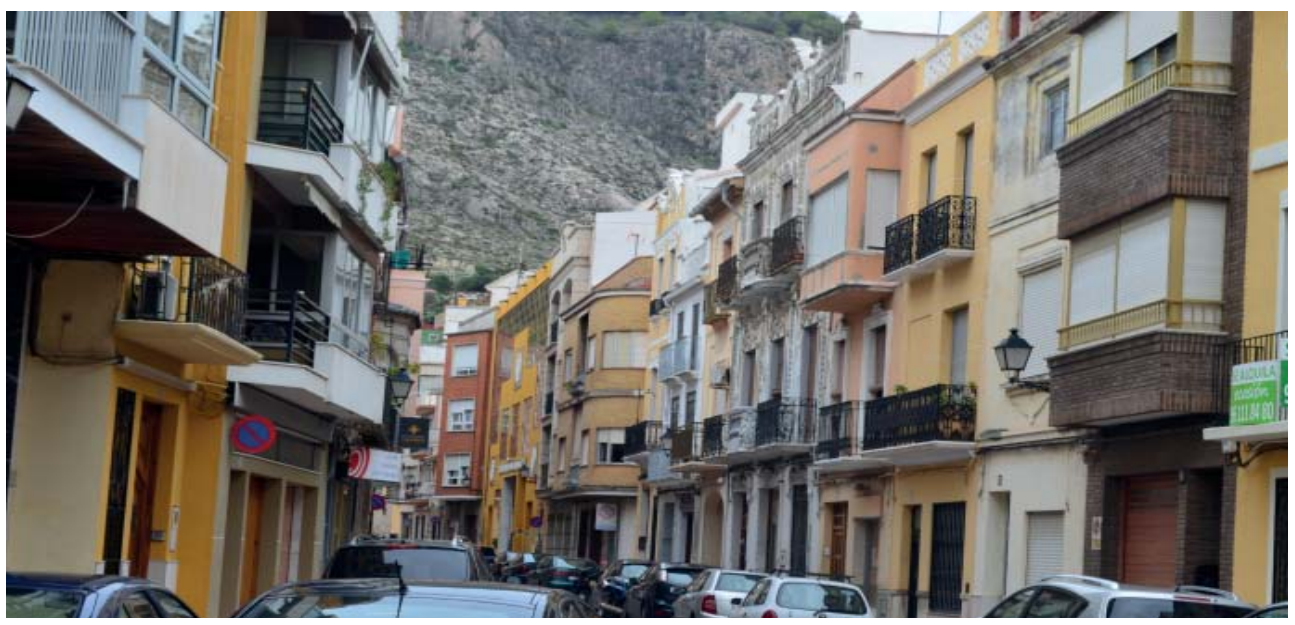

Fig. 030. Carrer Major de Cullera actual calle del Riu. En las fachadas no se observa ningún resto que recuerde a las antiguas edificaciones medievales.

Fig. 031. Carrer Mitjà situado en el centro histórico de la vila de Castellón.

\footnotetext{
${ }^{84}$ Felip, V. (2008): “La Vila de Nules com a expemple 'urbanisme de nova planta en I'epoca de Jaume I". Arquitectura any zero, pág. 88 .

${ }^{85}$ Gil Vicent, V.(2008): "El Paisatge de VilaReal al temps de Jaume I". Arquitectura any zero, Generalitat Valenciana, pág. 106.
}

Seguidamente se encuentra otro grupo de calles que dependiendo del autor, reciben un nombre u otro. Suelen corresponderse con travesías auxiliares que sirven para acceder de una calle a otra. En lo que se refiere a frontis principales de edificaciones, estas vías, no suelen contar con ellas, solo se suelen encontrar en los paramentos verticales huecos destinados a la iluminación y ventilación de los inmuebles, hecho que denota su carácter funcional. Hay historiadores que las llaman travesseres; en Nules se conocen así a aquellas calzadas a las que no se abría ninguna puerta de fachada principal y por lo tanto no tenían la consideración de calle como tal ${ }^{84}$. También queda documentada la existencia de carrerons, espacios que sólo llevaban a un lugar perteneciente a un único propietario y que solía conocerse con el nombre del lugar o del dueño ${ }^{85}$.

Por las consideraciones anteriores es evidente que el estudio en cada vila acontecía primero identificar las vías principales, para seguir con sus paralelas y secundarias finalizando con las travesseres y los carrerons.

Una vez identificados cada uno de los viales se procedió a comprobar si la orientación geográfica condicionaba ser la denominada calle major. El resultado indicó claramente que no influía en nada, puesto que se ha documentado viales denominados carrer major tanto siendo el cardus como el decumanus. Como puede apreciarse se encuentra que el decumanus coincide como eje longitudinal principal en las vilas de Teulada, Mascarell, Puzol, Almenara, Vinaroz, La Pobla de Vallbona, Vila-real y Cullera. En las demás poblaciones, el cardus lleva el nombre de calle mayor: Penáguila, Cocentaina, Alcoy, Nules, Gandía y Castellón. 
93 de 536

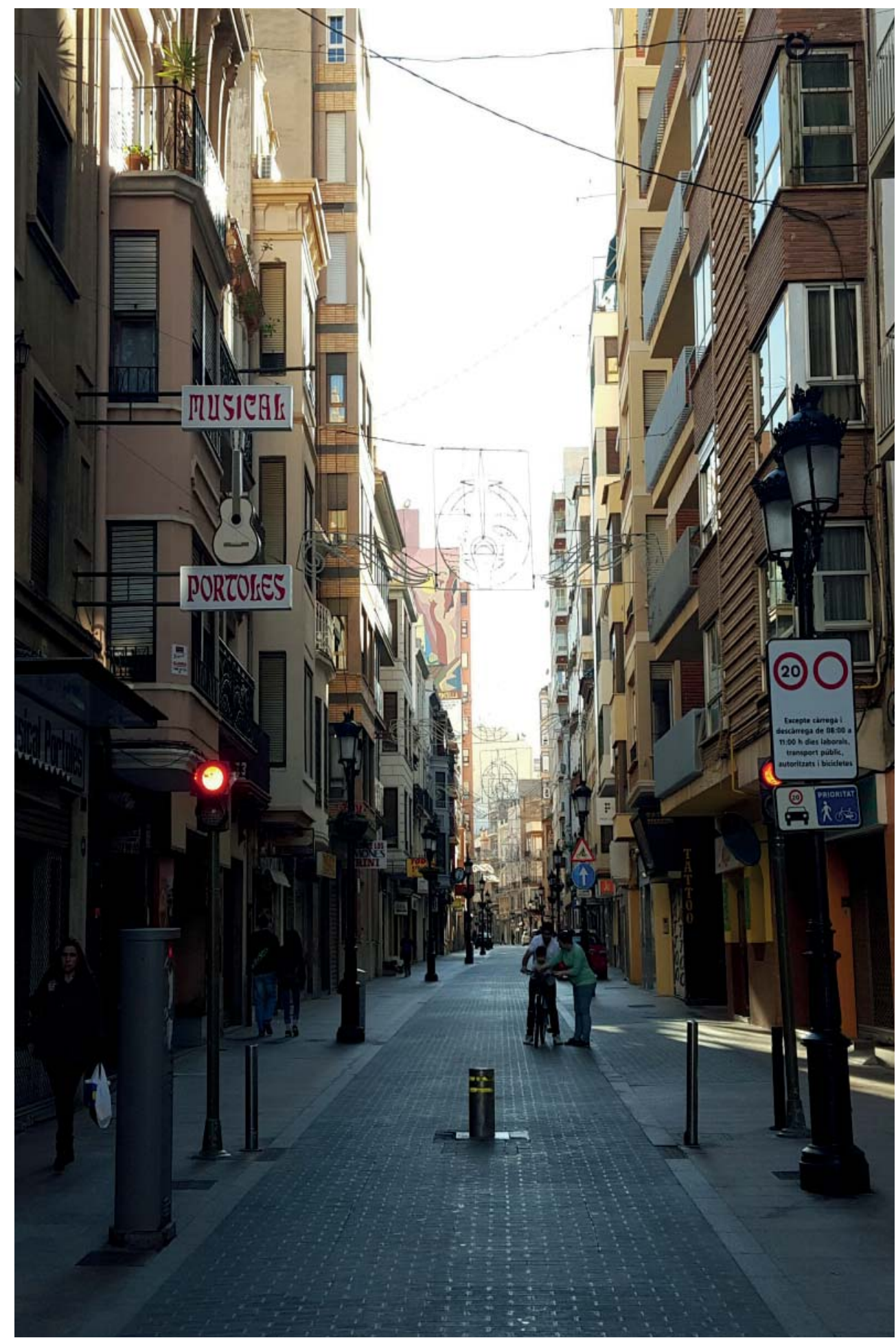

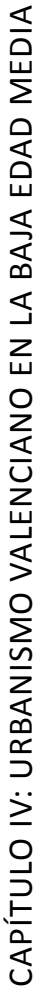




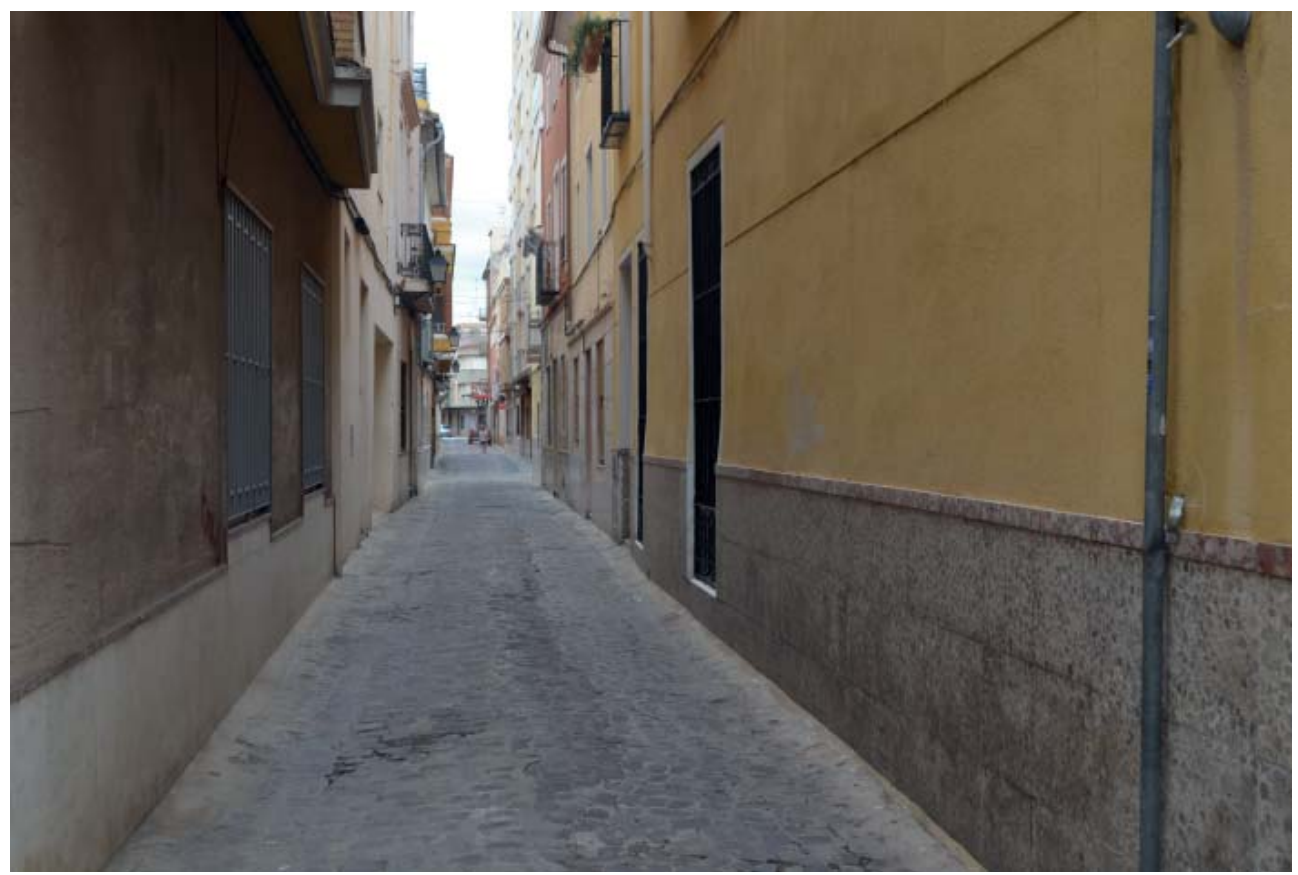

Fig. 032. Una de las calles conocidas como "travessera" en el núcleo medieval de $\mathrm{Cu}$ llera.
Sobre la base de la consideración anterior, se procedió a analizar las dimensiones transversales de estas rúas. El resultado, de dichas mediciones varían de una población a otra, es decir, no se encuentra una constante uniforme. Es evidente que los viales han ido modificando su alineación con el paso del tiempo. Ante la situación planteada lo que puede observarse claramente es que la calle mayor y su perpendicular corresponden a las vías de mayor anchura, aunque la calle mayor siempre lo es más.

Con este propósito se tomaron medidas de los ejes principales de las catorce pueblas elegidas. Los resultados en la calle mayor - eje longitudinal - oscilan en un intervalo que alberga desde los 3,30 m hasta 7,00 m. En este caso la franja mayor de casos se encuentran entre 5,00 y $6,00 \mathrm{~m}$ con lo que la media aritmética se sitúa en un ancho de 5,79 m. En lo que respecta al eje transversal se documentan anchos desde 3,10 m hasta $10,00 \mathrm{~m}$, siendo el intervalo que más se repite el de dimensiones situadas entre $3,50 \mathrm{~m}$ a 5,50 m, correspondiendo una media 5,18 m.

Siguiendo el orden anteriormente dispuesto se procedió a estudiar las calles paralelas al eje longitudinal o transversal, las denominadas calles secundarias. Al norte se encuentran dos viales en la mayor parte de los casos, el primero, el de mayor proximidad-denominado carrer mitjà- suele contar en varios municipios con el mismo ancho que el eje transversal 
y si tiene una dimensión menor apenas se trata de un metro de diferencia. La media aritmética hallada para este vial se ha establecido en 4,95 m. El segundo vial -denominado carrer de dalt- suele tener una dimensión mucho menor pero muy parecido a la calle paralela situada al sur del eje principal conocido como carrer de baix - han obtenido respectivamente unos promedios de $4,12 \mathrm{~m}$ y 3,69 m.

Del mismo modo se procedió a estudiar los viales paralelos al eje que no se había tomado como referencia para formar las calles, las travesías. Como ya se ha indicado se trata de espacios entre manzanas, simplemente funcionales, para acceder de una calle a otra, las que anteriormente se ha denominado como travesseres y cantons o carrerons. Tal y como se ha observado son viales donde no es habitual encontrar frentes principales de inmuebles, están destinadas a facilitar el acceso de una manzana a otra, por esta razón, suelen contar con las menores dimensiones de todo el parcelario. La distancia entre sus alineaciones presentan unos anchos muy similares, presentando espacios que discurren desde el $2,50 \mathrm{~m}$ a 2,80 $\mathrm{m}$. Se puede constatar lo indicado en Villa-real en la calle Insa, cuya dimensión es $2,64 \mathrm{~m}$ o la calle Trinquet Vell, del mismo municipio que presenta un ancho de $2,82 \mathrm{~m}$.

De los anteriores planteamientos se deduce que se mantiene una completa jerarquización en la mayoría de los casos, lo que resulta casi evidente en una sociedad tan jerarquizada como la medieval.

Para concluir este apartado se presenta las medias aritméticas de la anchura de los viales en la actualidad pero convertidas a la medida de la época en el territorio, - la vara valencianateniendo en cuenta su correspondiente factor de tolerancia:

\begin{tabular}{|l|c|c|}
\hline Ejes Principales & Ancho en metros & Ancho en varas val. \\
\hline Carrer Major & $5,79 \mathrm{~m}$ & 7 varas \\
\hline Carrer Perpendicular & $5,18 \mathrm{~m}$ & 6 varas \\
\hline Viales paralelos & \multicolumn{2}{|l|}{} \\
\hline Carrer Mitja & $4,95 \mathrm{~m}$ & 6 varas \\
\hline Carre de Dalt & $4,12 \mathrm{~m}$ & 5 varas \\
\hline Carre de Baix & $3,69 \mathrm{~m}$ & 4 varas \\
\hline Travesseresi Cantons & $2,50 \mathrm{~m}$ oo & 3 varas \\
\hline
\end{tabular}

Tabla 5: Dimensión ancho de calles relacionado con la unidad de medida medieval 
96 de 536

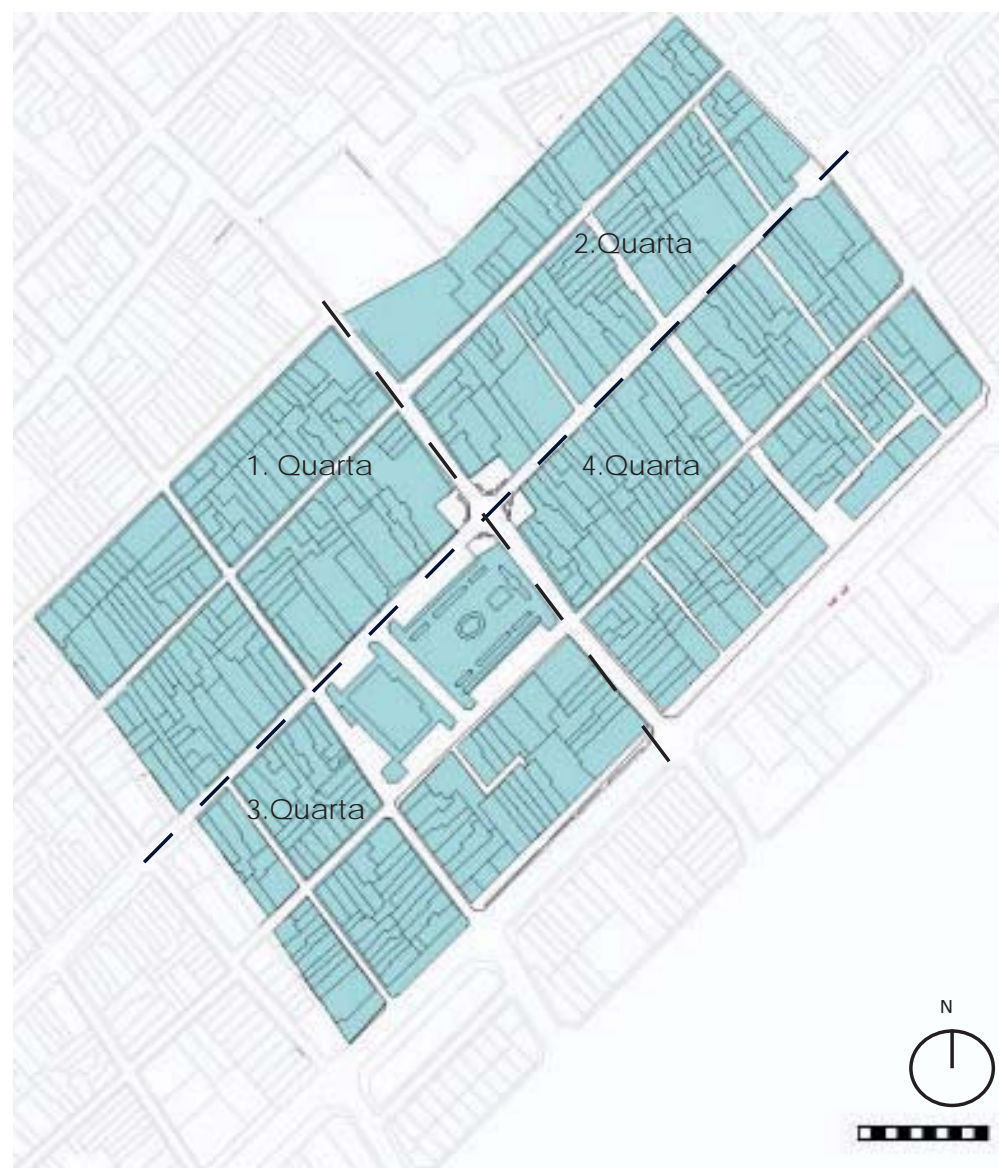

Fig. 033. Plano del centro histórico de Vila-real donde se observan la división administrativa en quarters.

Fig. 034. Situación de la vila medieval de La Pobla de Vallbona detallando la organización administrati$v a$ en quarters.

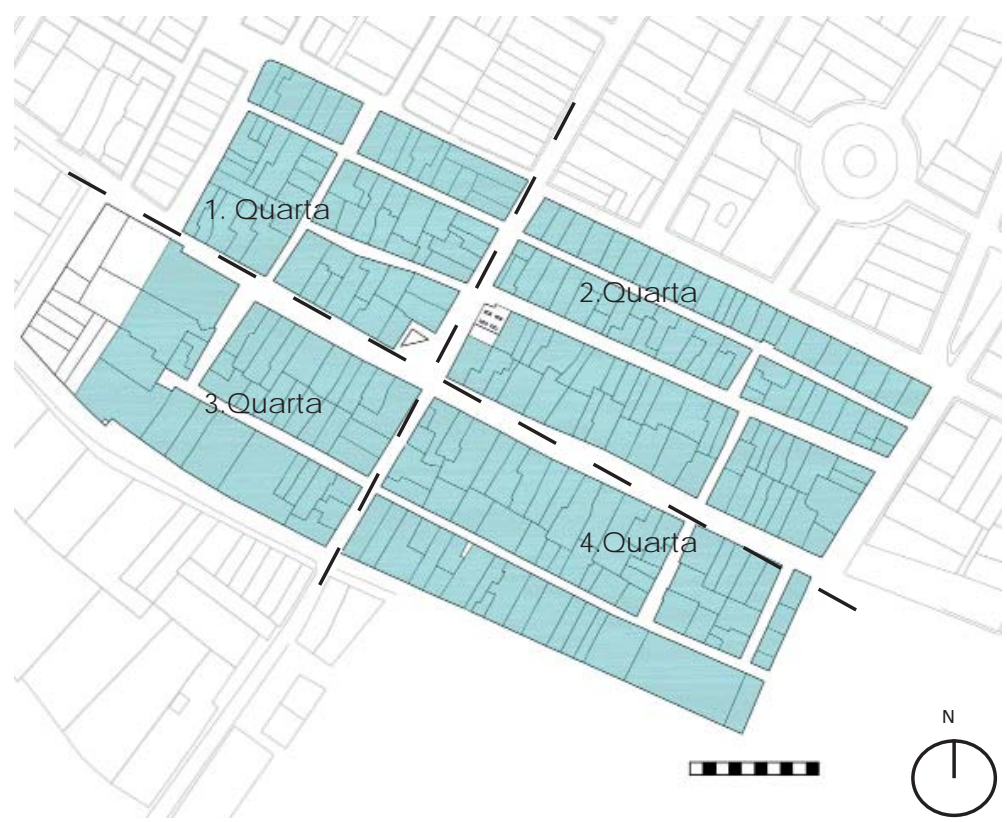




\subsubsection{3| Ordenación urbanística}

Desde el punto de vista administrativo la planta de estas poblaciones quedaba dividida en quarta o quartes ${ }^{86}$ a partir de la partición realizada por los dos ejes principales que forman la calle mayor y su perpendicular.

Se denominaba como quarta o quartes a la estructura formal de carácter comunitario que marcaba las jurisdicciones para la elección de los jurados y de la justicia. Para ilustrar lo indicado únicamente hace falta contemplar el parcelario de poblaciones como Vila-real o Puzol donde estas divisiones se observan claramente.

Desde el punto de vista urbanístico, a las vías principales se unen las secundarias y sus perpendiculares, que dan lugar a la cuadrícula de calles o vías, a través de las cuales se distribuyen las islas de casas o manzanas. Estos espacios son ocupados en su totalidad por los bienes inmuebles allí construidos, formando una tipología propia de viviendas unifamiliares entre medianeras y construidas hasta la alineación de vial.

Tomando como referencia el único municipio amurallado que queda en la actualidad en la Comunidad Valenciana, Mascarell, se pueden identificar 2 clases de espacios delimitados por sus viales existentes en su centro histórico:

\begin{tabular}{|l|l|l|l|}
\hline \multicolumn{3}{|c|}{ CLASES DE MANZANAS } \\
\hline \multirow{2}{*}{$\begin{array}{l}\text { Lindan con la } \\
\text { muralla }\end{array}$} & Y con 1 único vial & No lindan con & Islas \\
\cline { 2 - 3 } & Y con 2 o 3 viales & mura lla & \\
\hline
\end{tabular}

Tabla 6: Tipologías de manzanas en los munic ipios amurallados a partir de sus lindes

En todos los centros históricos analizados se pueden encontrar estos dos modos de bloques de edificaciones, con sus diferentes variantes.

El primer tipo está constituido por manzanas que lindan con el perímetro amurallado. Suelen ser superficies rectangulares, de mayor longitud que el resto de bloques del núcleo poblacional. Se ha llegado a comprobar en uno de los municipios que la superficie destinada a este grupo de viviendas es diez veces más larga que ancha. Comparativamente lo habitual ha sido hallar superficies que sean cuatro, cinco, seis y ocho veces más

${ }^{86}$ Gil Vicent, V.(2008): "El Paisatge de Vilareal al temps de Jaume I". Arquitectura any zero, Generalitat Valenciana, pág 106. 
Fig. 035. Plano de la vila de Mascarell, único municipio que queda amurallado en Castellón. Se detalla los dos tipos de manzanas, las perimetrales pegadas al muro y la tipo isla, rodeadas de viales, en la zona central.

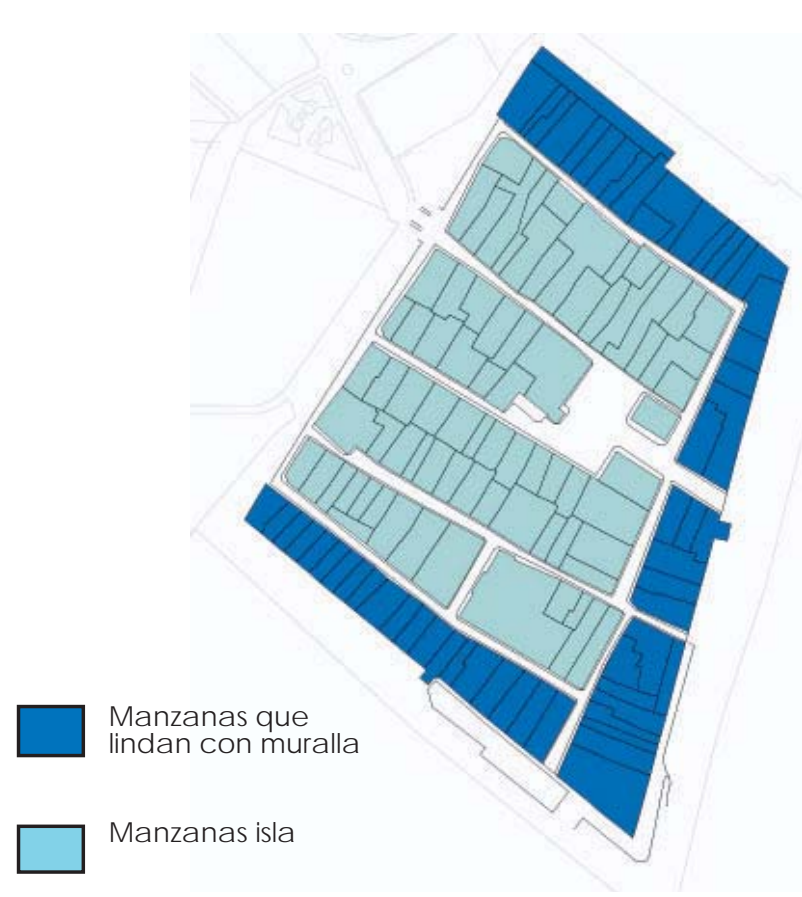

largas que anchas. Un ejemplo de esto se halla en el municipio de Cullera en las manzanas m-1, m-6 y m-11.

Esta primera tipología en la mayor parte de su longitud suele encontrarse delimitada por el paramento vertical de la muralla en su parte trasera y el vial al que recae el frente del edificio. Solamente los inmuebles situados en sus extremos suelen lindar con dos o tres calles. Debido a esto suelen tener un único inmueble cuya fachada principal se sitúa en el vial de acceso, normalmente una calle secundaria.

La única diferencia en estos espacios se encuentra en la orientación de las edificaciones situadas en los extremos de las manzanas cuando están delimitados por dos o incluso tres rúas. En estos casos las parcelas se orientan hacia el vial que tienen enfrente y, al llegar a la esquina a la zona de intersección con otro eje, si ese vial es más importante, la vivienda cambia su dirección y se dirige hacia él. Si la calle carece de mayor interés o pertenece al mismo rango, no se modificará la dirección.

Por su parte las edificaciones ubicadas en estas manzanas cuentan con la misma profundidad de esta. La mayoría de las superficies analizadas no sobrepasan los $25 \mathrm{~m}$ de profundidad, siendo lo más habitual no llegar a los $20 \mathrm{~m}$. 


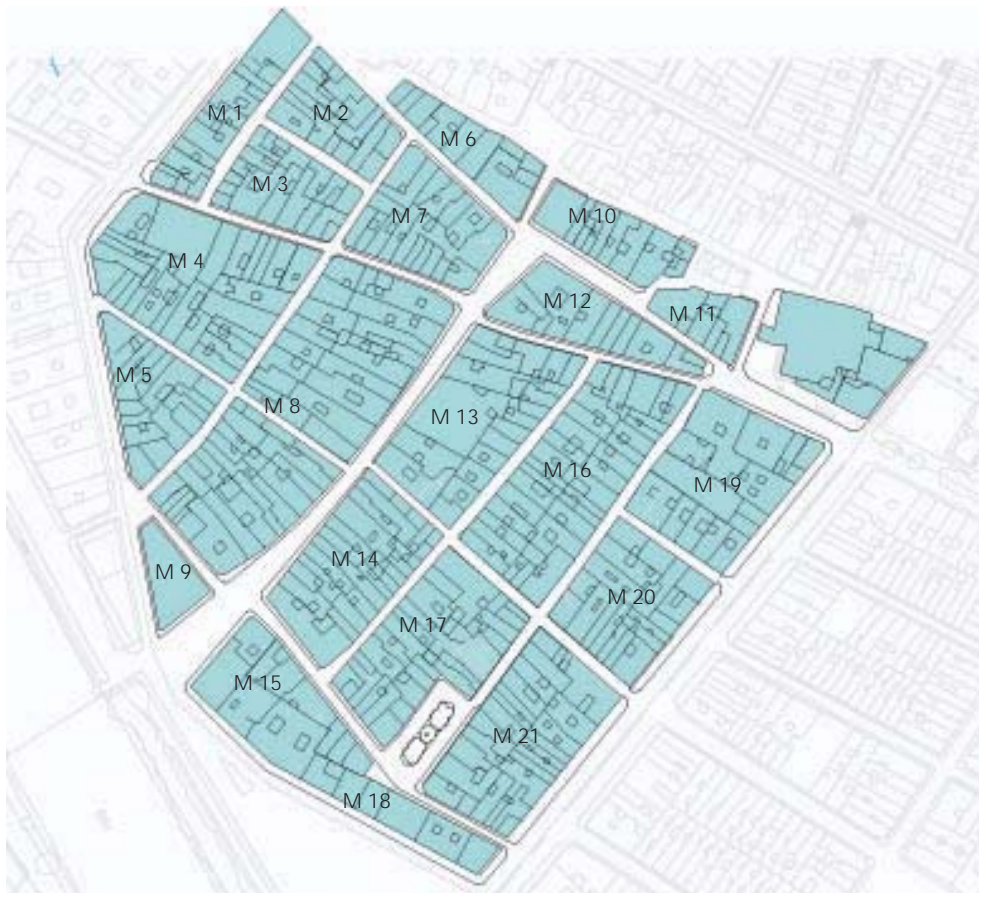

Para ejemplificar tales consideraciones tres de los municipios examinados. Estas villas cuentan con espacios lindantes con muralla y vial excesivamente cortos de profundidad $y$, en dos casos, si se toma la dimensión desde el paramento vertical del inmueble defensivo hasta el frente del bloque mas cercano ambos cuentan con la misma longitud de 11,35 $\mathrm{m}$. Estas manzanas son muy estrechas respecto a todas las demás, por lo que podría haber sido un terreno libre situado entre el último bloque de viviendas y la muralla, que se ha ocupado y transformado en solar con el paso del tiempo. Hecha la observación anterior se procede a enumerar los casos encontrados:

a) La Pobla de Vallbona con la manzana m-16.

b) Vila-real, concretamente el denominado m-22 .

c) Penáguila, las superficies llamadas $m-8, m-9, m-10$ y m-11.

Se expone a continuación las características del segundo tipo de manzanas, las que se encuentran en el interior del municipio. Suelen ser espacios delimitados por cuatro viales, como una especie de isla. En lo tocante a la forma geométrica de estos espacios suelen haber dos clases, cuadradas o rectangulares. En las citadas en segundo lugar su longitud es el doble o el triple que el ancho que ocupan.
Fig. 036. Plano de Cullera. Las manzanas situadas en el carrer Major, cuentan con más profundidad que sus parcelas opuestas. 

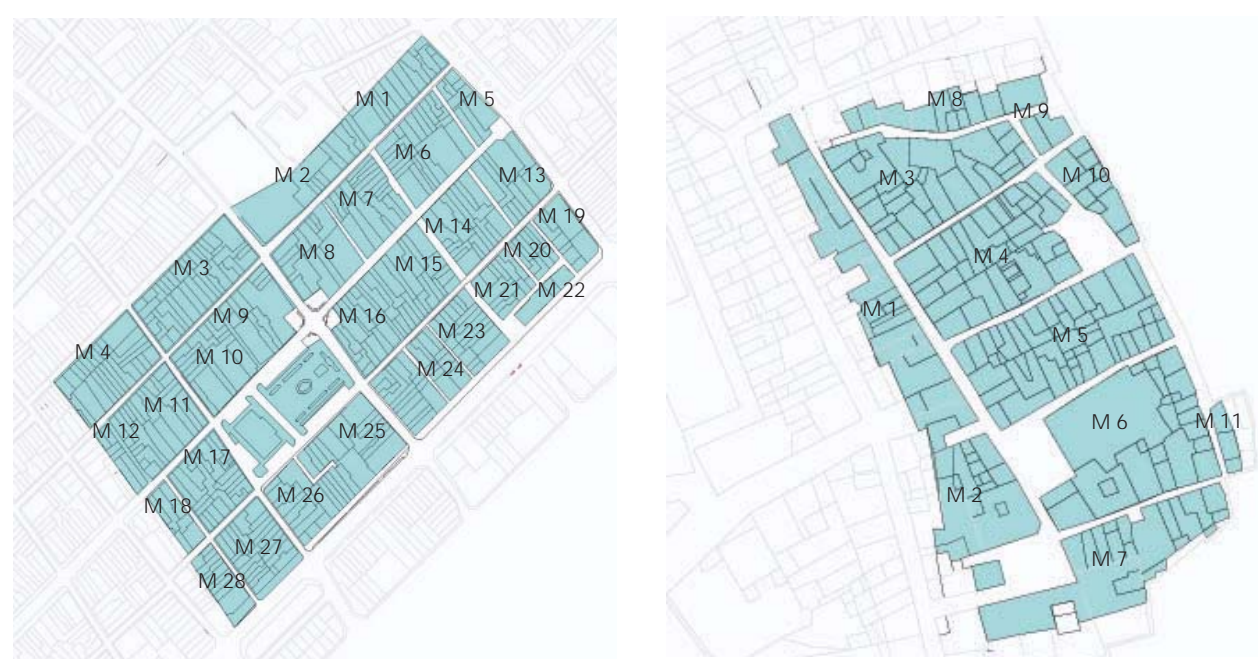

Fig. 037. Planos donde se identifican las manzanas con menos profundidad de lo habitual. Municipios de Vila-real, $m-22$ y de Penáguila, $m-8, m-9$, $m-10$ y $m-11$.
Para continuar procede detallar la disposición de las edificaciones en estas superficies. Lo más habitual es hallar dos inmuebles enfrentadas por su fachada posterior: una tiene el acceso por una calle y la segunda por otra paralela. Las bloques siempre se encuentran construidos perpendiculares a la calle mayor y a las secundarias. Los inmuebles donde una de las alineaciones de sus paramentos verticales viene delimitado por una de los viales denominado como travesseres, el inmueble no cambia su dirección ni siquiera aunque tenga mayor longitud de fachada - toda su profundidad - al tener este espacio la consideración de travesía sólo se abren en los cerramientos de los inmuebles huecos de ventana, nunca accesos al edificio.

En cuanto a los anchos de los espacios estudiados la gran mayoría no alcanza los $40 \mathrm{~m}$, pero en algunas poblaciones se ha hallado vestigios de viviendas de $50 \mathrm{~m}$ de profundidad. Este último dato podría, como se verá continuación, no ser representativo. En lo que concierne a las manzanas de los trece municipios comparados, que suman un total de 267, tras evaluarlas, únicamente 13 manzanas sobrepasan los $50 \mathrm{~m}$ de profundidad. Se encuentran en las siguientes villas:

a) Castellón m-16, m-25, m-18, m-31 y m-32.

b) Alcoy, se sitúan 5 manzanas que los superan, $m-1, m-5$, $\mathrm{m}-8, \mathrm{~m}-14$ y $\mathrm{m}-16$.

c) Cocentaina, las denominadas m-3, m-14 y m-19.

Aunque únicamente son unos pocos metros mayores que las demás este dato debe ser relativizado pensando que únicamente son 13 manzanas respecto a 255, no llegando a alcanzar ni siquiera el $5 \%$ de las manzanas analizadas. 


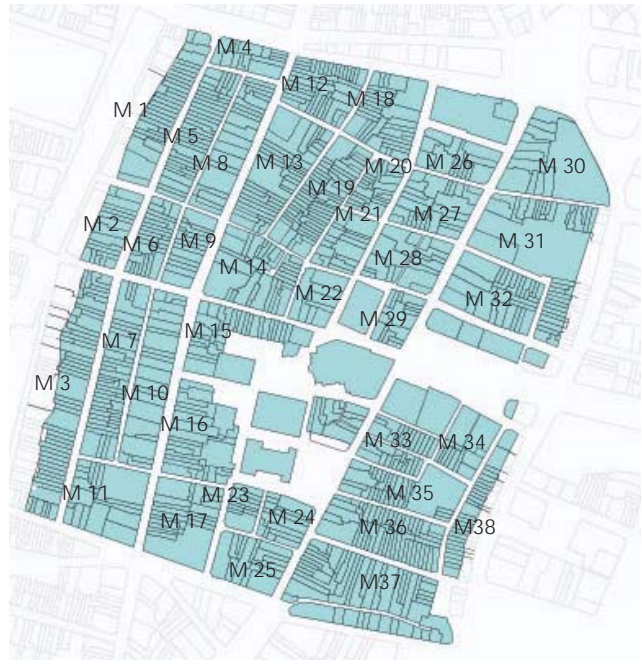

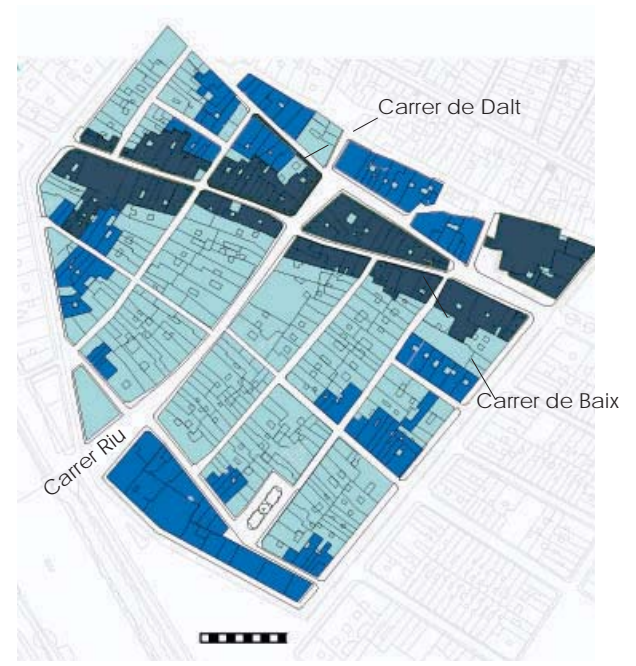

Sobre la base de lo expuesto es el momento de ver como se repartían los inmuebles estos espacios. Como se ha indicado en el párrafo anterior enfrentados por su parte trasera, dejando el acceso principal a una de las alineaciones y siempre paralelas sus medianeras con el ancho de la manzana. Cabria pensar que este ancho, que formará la profundidad de la parcela, sería al 50 $\%$ siguiendo el lema aragonés que dio origen a este urbanismo, parcelas iguales para hombres iguales, pero la realidad no fue así. En una sociedad tan jerarquizada como la medieval donde, las clases sociales presentaban grandes diferencias y los ciudadanos estaban delimitados por los estamentos sociales, es evidente entonces que el replanteo de las parcelas no iba a ser ecuánime sino un reflejo de su modo de entender la vida.

Resulta oportuno recordar las consideraciones anteriores sobre las dimensiones de los viales. Las calles de los núcleos históricos se encuentran clasificadas por su anchura, a mayor dimensión, mayor rango. En este mismo sentido las edificaciones no podían ser menos. Los inmuebles situados en una manzana tipo isla cuyo frente de fachada recae a la calle Mayor tendrá mayor profundidad que el edificio opuesto. El ancho de esta manzana no se reparte al 50\% entre los dos edificios, sino que se cumple que será mayor el delantero en decrecimiento del inmuebles cuya fachada recae a un vial de menor importancia. Esta característica se encuentra únicamente en las islas que uno de los viales resulta ser el eje longitudinal principal, los demás espacios delimitados que albergan dos inmuebles uno por cada vial y no lindan con esta calle se encuentran divididas por la mitad y son iguales de longitud ambas parcelas.
Fig. 038. Las manzanas de Castellón como se han tenido en cuenta para analizar el centro histórico de dicho municipio.

Fig. 039. Orientación de las parcelas del municipio de Cullera. Los inmuebles se sitúan perpendiculares a los ejes principales.

${ }^{83}$ Felip, V.(2008): "La Vila de Nules com a expemple d'urbanisme de nova planta en l'epoca de Jaume I". Arquitectura any zero, Any 2008, pág 88. 


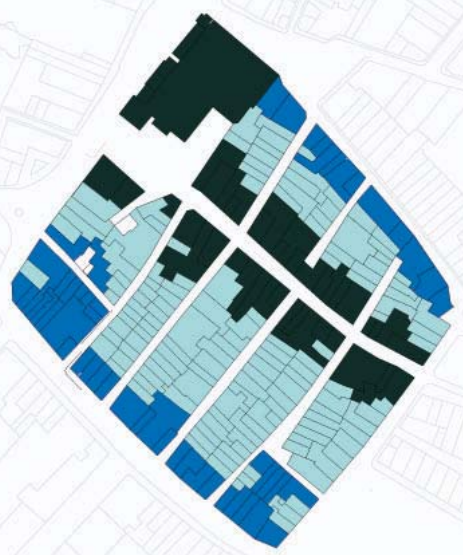

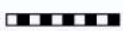
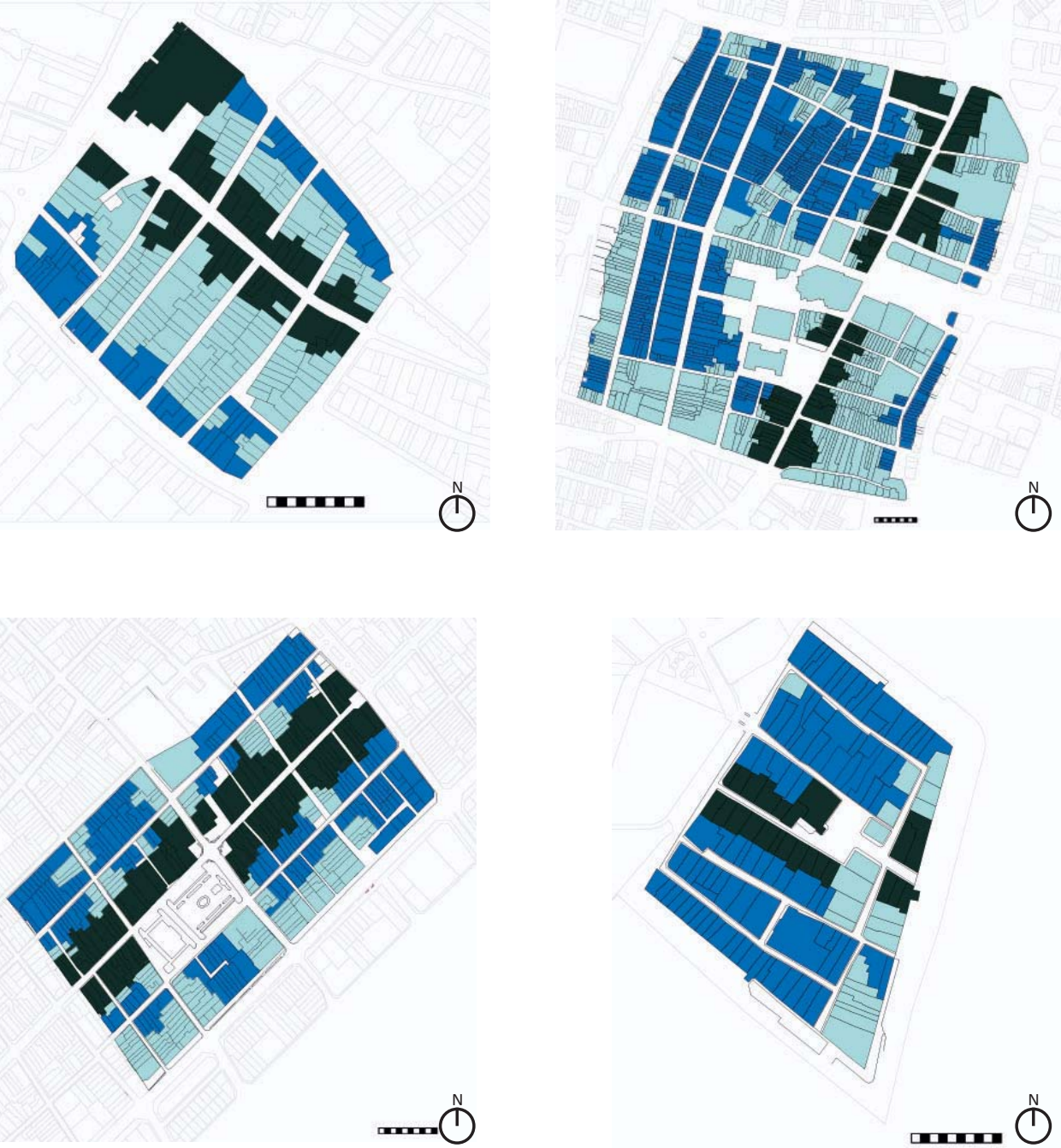

$\stackrel{N}{0}$

\section{Orientac ión de las inmuebles en las differentes vilas medievales}

Parcelas perpendicularesa la calle Mayor situa das en esta misma calle

Parcelascon la misma orientación perpendiculara la calle Mayorpero en otros viales

Parcelas con la orienta ción paralela a la calle Mayor

Fig. 040. Ámbitos de los centros históricos analizados, marcando la orientación de sus parcelas. Se encuentra en todos casos las viviendas perpendiculares al carrer Major y su eje transversal. El resto ortogonales a los viales secundarios. De izquierda a derecha y de arriba abajo. Página Izquierda, Vinaroz, Castellón, Vila-real, Mascarell y Nules. Página derecha: Almenara, Gandía, Cocentaina, Penáguila, Alcoy y Teulada.

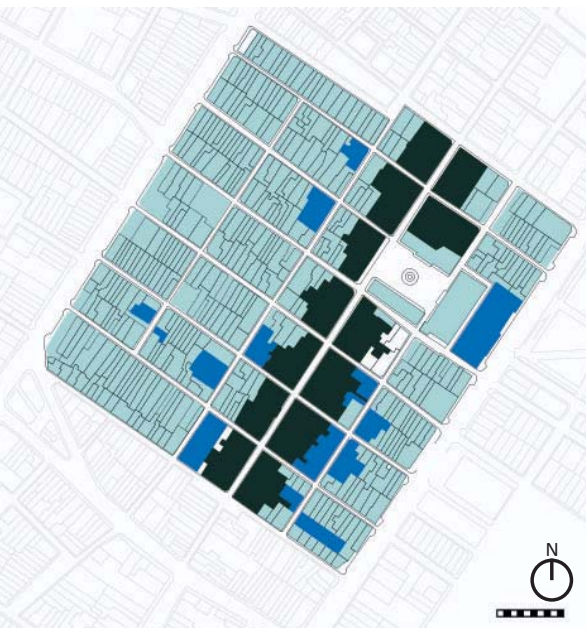


103 de 536

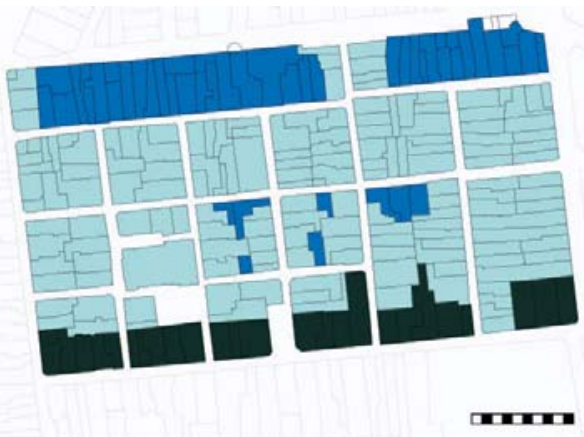

(1)
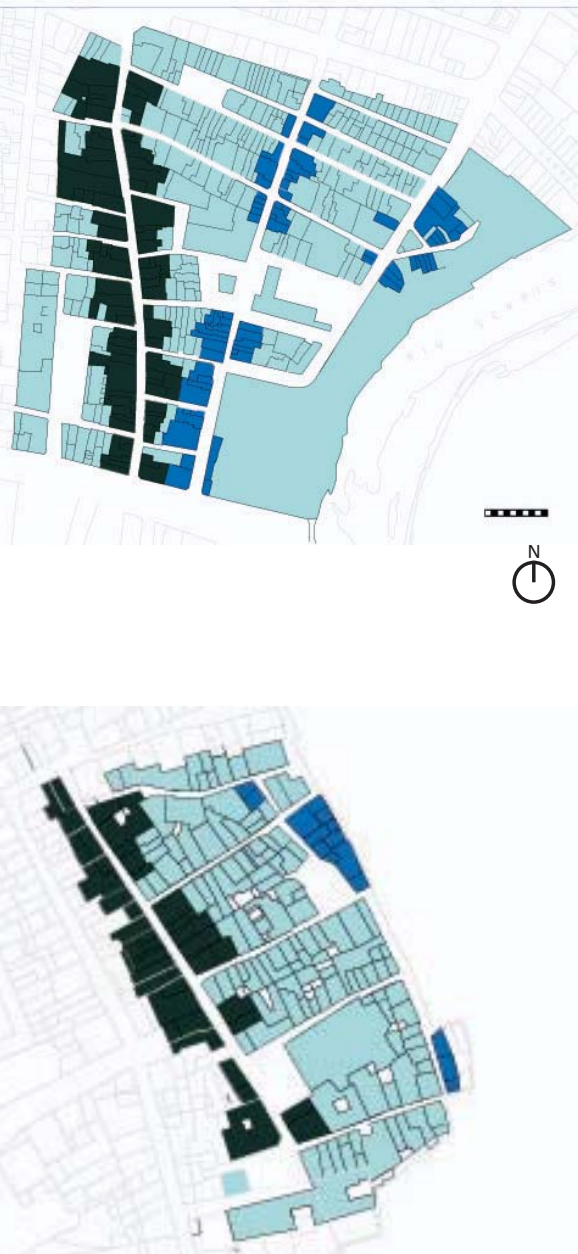

(1)

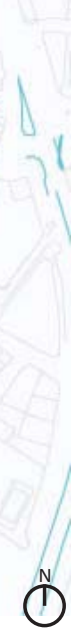

O

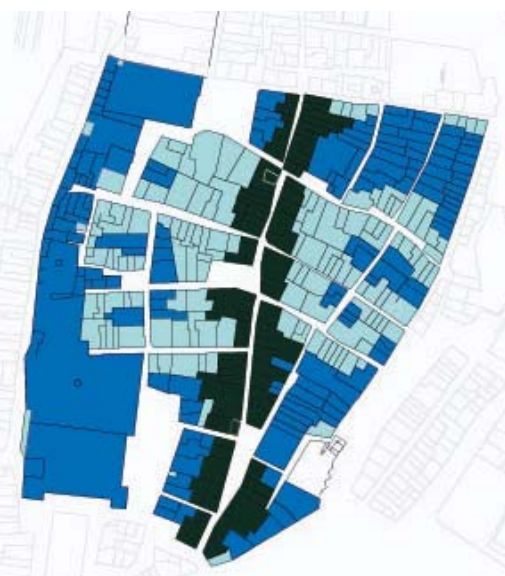

무무료

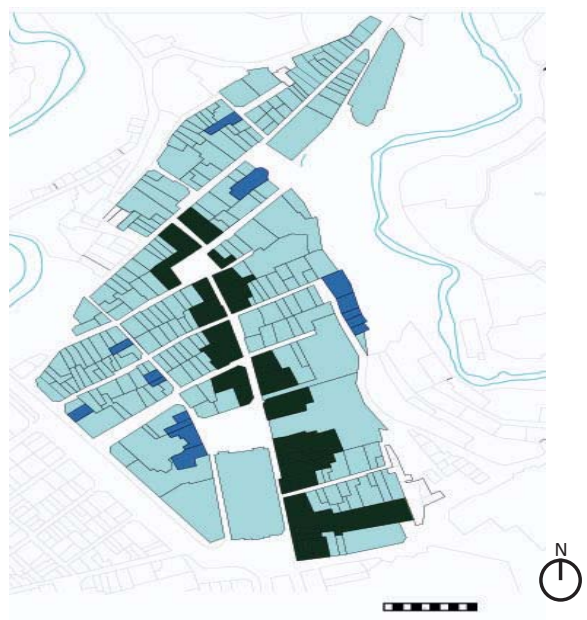

ก

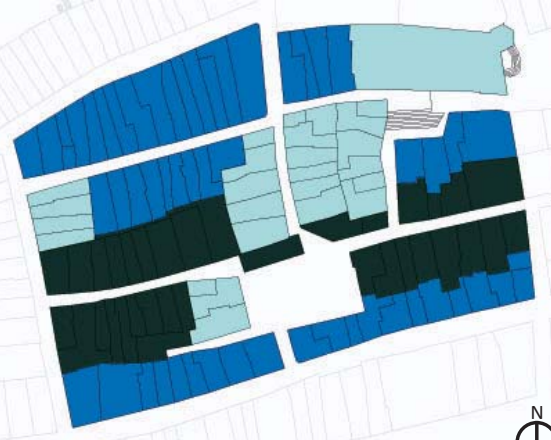

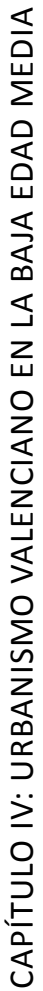




\footnotetext{
87 Felip, V.(2008):

"La Vila de Nules com a expemple d'urbanisme de nova planta en l'epoca de Jaume I". Arquitectura any zero, año 2008, pág. 88.

88 Ibídem.
}

Es evidente entonces que la profundidad de la parcela depende de la calle en la que recae, es decir, siempre tiene mayor profundidad el inmueble que recayente a un vial más importante y suele abarcar más de la mitad de la manzana, siendo siempre menos profundos los inmuebles que se encuentran opuestos.

Hecha la observación anterior constatar que en todos los municipios analizados ha llegado hasta nuestros días un ejemplo donde se cumple esta orden en la parcelación.

El siguiente parámetro urbanístico a tener en cuenta es la longitud de las fachadas de los inmuebles. El ancho de las casas pudo estar condicionado por la medida común de las vigas de madera de la época ${ }^{87}$. Es necesario remarcar que este dato es muy complicado de obtener puesto que los frentes han ido modificándose a lo largo de la historia, pero era importante documentarlas en este plan de investigación, por ello después de analizar todas las fachadas del vial, se ha tenido en consideración aquellas que presentan una menor dimensión en cada vial.

Ante la situación planteada -estudiar cada una de las fachadas mínimas de cada calle- queda documentado que las edificaciones recayentes a los ejes principales contaban con mayor frente en comparación con los viales secundarios, en las que era mucho menor. En las calles mas importantes se encuentran en su gran mayoría inmuebles que oscilan entre los 4,00 y $8,00 \mathrm{~m}$, situándose la media aritmética en $5,32 \mathrm{~m}$. En cambio en las vías secundarias se encuentran edificios de 3,50 m de fachada, aunque se debe reconocer que son más numerosos los que se encuentran en el intervalo de 4,00 o 5,00 m.

En Nules, las casas con más fachada y mayor profundidad se hallan en la Plaza Mayor y sus proximidades, y corresponden a edificios comunales o de familias nobles, aunque también a hospederías y talleres ${ }^{88}$.

Por lo tanto queda comprobado que existe un grado de jerarquización en la ubicación de los inmuebles, que conforme a su importancia estarán situados en una calle de más anchura, tendrá más frente de fachada y su profundidad será mayor.

Y por último procede analizar la orientación de las parcelas. Las 13 villas estudiadas se ubican en su gran mayoría en orientación noroeste, únicamente Puzol y Gandía, cuentan con orientación noreste, aunque no existe una regla común. 


\section{Orientación de las inmuebles en la vila de Puzol}

\section{LEYENDA}

Parcelas

perpendiculares a la calle Mayor situa das en esta misma calle

Parcelascon

la misma

orientación

perpendiculara

la calle Mayor

pero en otros

viales

Parcelascon

la orientación

paralela a la

calle Mayor

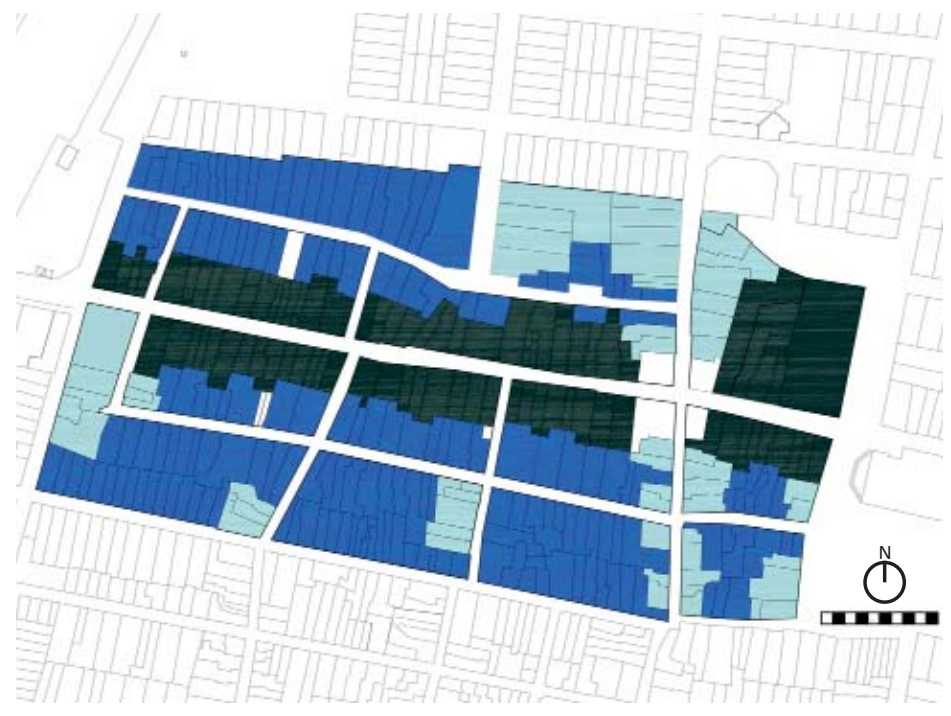

Varios de los autores consultados llegan a la misma conclusión, esta característica dependía de la climatología del lugar, ubicando los municipios en la dirección más saludable. En el caso de Cocentaina y de Alcoy se podría aventurar, que sería por adaptarse al medio. Si bien es cierto que a lo hora de replantear las parcelas se encuentra dos reglas:

- Las edificaciones se construyen en todos los casos perpendiculares a la calle mayor y a su calle transversal, a los dos ejes principales.

- Replanteados los ejes principales se obtienen las vías secundarias, independientemente de que sean paralelas a uno de los dos ejes siempre, las fachadas se colocaran perpendiculares a estas calles.

A partir de esta premisa, se identifican municipios donde las vías secundarias son paralelas al carrer Major. En este caso el 90\% de los inmuebles son paralelos entre sí a excepción de los recayentes al eje transversal. Los municipios que se encuentran en esta situación son Castellón, Vila-real, Teulada, Puzol y La Pobla de Vallbona. Para concluir las villas donde la gran mayoría de las edificaciones Ilevan una dirección opuesta a lo situados en el eje principal como es el caso de, Vinaroz, Almenara, Gandia, Nules, Cocentaina, Penáguila y Alcoy.

Fig. 041. Plano de la orientación de las parcelas de Puzol. En la mayoría de las manzanas las parcelas se sitúan en la misma dirección, perpendiculares al carrer Major. 
Fig. 042. Escena de agrimensura representada en la Siençia de destrar y la Siençia d'atermenar de Bertrand Boysset. Carpentras. Biblioteca Ingibertina.
89 Jaume I (1238): "Llibre del Repartiment del Regne de València", Ed. Garcia Edo, archivo digital Jaume I.

90 Zaragozá Catalan, A (2008): " Arquitectura any zero (1.2082008). Generalitat Valenciana, 2008, pág. 5.

91 Bielza de Ory, V (2000): La ciudad ortogonal aragonesa del Camino de Santiago y su influencia en el urbanismo regular posterior. Aragón en la Edad Media, XVI, Univ. Zaragoza, Zaragoza, 2000, pág.38.

92 Guinot, E. y Martí, J.(2006): Las villas nuevas medievales valencianas (siglo XIII-XIV) Boletín Arkeolan 14, Universidad de Valencia. Pp.189.

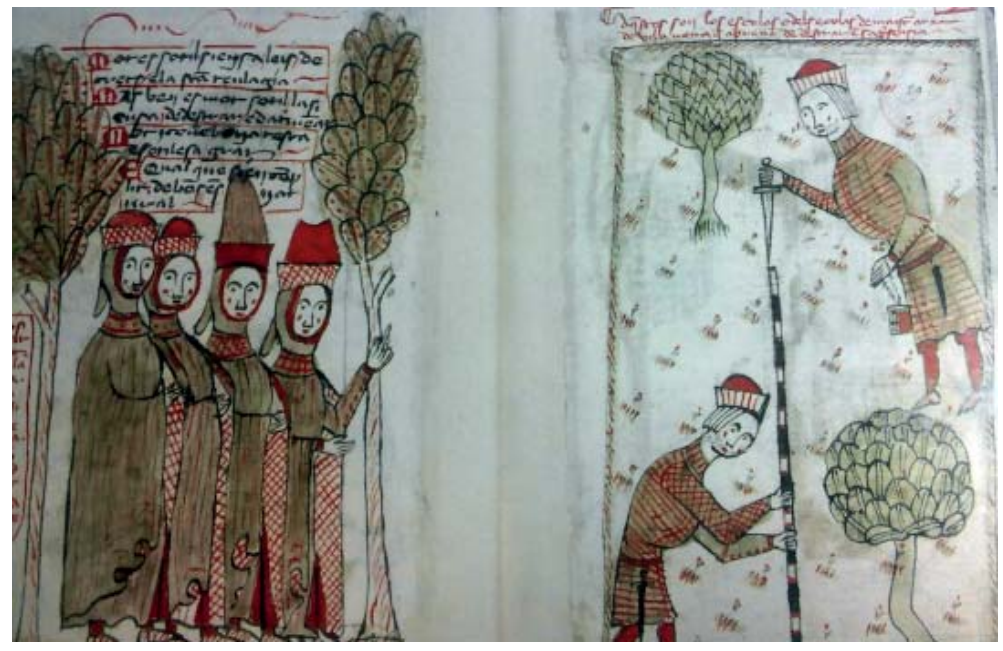

\subsection{4| El urbanista}

Pero, ¿quién se encargaba de está planificación?. Después de haber analizado las trece vilas de la Comunidad Valenciana se puede afirmar que siguen las mismas pautas a la hora de dimensionar sus viales, sus solares, y sobre todo al elegir su ubicación. Es evidente que existía un grupo de personas encargadas de planificar el territorio, de dibujar el plano del conjunto que permitía a la comunidad vivir y prosperar. Sin duda, la planificación urbana era obra de un colectivo determinado.

Se sabe por la crónica real que Jaume I iba acompañado por ingenieros ${ }^{89}$. En una época en la que la ingeniería militar y civil no estaban separadas, los ingenieros militares del rey podían diseñar igualmente una máquina de guerra para un combate o una construcción de nueva planta ${ }^{90}$.

En Aragón eran llamados los quiñoneros, cuyo nombramiento de 1262 para Mosqueruela, Camarena, Valdelinares y otras fundaciones turolenses ordenaba que se eligieran para el emplazamiento de los pueblos aquellos lugares

\section{do a vos fueres mellor visto e más conveniente ${ }^{91}$}

Enric Guinot y Joan Martí dejan claro en sus estudios sobre las nuevas villas Valencianas ${ }^{92}$ la existencia de uno o varios agentes repartidores locales que iban regulando la ocupación progresiva del espacio. La documentación valenciana del siglo XIII nos habla en diversas ocasiones de partidors, otras de soguejadors, 
porque medían el terreno con cuerdas sogues, pero no parece haber duda que tanto ellos como los batlles, los primeros oficiales reales locales encargados del control y gestión del patrimonio real y su fiscalidad, debieron ser también los encargados de dirigir el diseño del espacio urbano, de asignar solares y de llevar a cabo las ampliaciones de nuevos barrios cuando se hacía necesario por la elevada inmigración.

En este contexto resultaba sencillo a los reyes o a los otros poderes señoriales imponer concentraciones residenciales indiferenciadas que, con la colaboración de los agentes colonizadores (divisores), muchas veces convertidos en autoridades vecinales, dieron lugar a las morfologías ordenadas propias de las fundaciones cristianas ${ }^{93}$.

En Alcoy, el Procurador General del Reino, Eiximén Pérez de Arenós, nombró en 1256 como repartidores a Joan Garcés, Bernat Savall, Bernat Colom y Guillem d'Hortoneda para que distribuyesen casas y heredades, y posteriormente, a final de dicho año, el propio rey Jaime I ratificó en un privilegio los establecimientos hechos por éstos ${ }^{94}$.

Otro nombre que se encuentra es la figura del agente asentista en tanto que responsable de la división y distribución de los solares urbanos.

La supervisión general la desempeñaba, en todo el Reino de Valencia, y desde el 9 de febrero de 1286, Guillem de Torres, a quien el rey Alfons el Liberal nombró procurador super ordinandis, meliorandis et con dirigendis de la población de las villas de Vila-real, Pego, Penáguila, Altea, Calp, Biar, Castalia, Serra de Finestrat y de ómnibus alus populación ibus Nostris $n o[v]$ is regni Valencie ${ }^{95}$. Sus funciones incluían el reconocer las nuevas poblaciones que se estaban construyendo y disponer todo lo que fuera de utilidad, sobre todo al rey.

El nombramiento facultaba también a Guillem de Torres para embargar las casas y heredades abandonadas por los pobladores absentistas o poseídas por quienes no cumplían las condiciones bajo las cuales habían sido entregadas, así como reasignarlas a otros colonos. También le sería asignada la autoridad para disponer en Biar y Castalla (1287), posiblemente debido a las dificultades que entraba la concentración de estas villas en los emplazamientos designados; el procurador del rey en Valencia, Pere Ferrández, debía proporcionarle auxilio, consejo y ayuda en estos conflictivos asentamientos ${ }^{96}$.
${ }^{93}$ Torró, J.(2006): La conquista del reino de Valencia. Un proceso de colonización medieval desde la arqueología del territorio.

${ }^{94}$ Guinot, E. y Martí, J.(2006): Las villas nuevas medievales valencianas (siglo XIIIXIV) Boletín Arkeolan 14, Universidad de Valencia. Pp.189.

${ }^{95}$ Traducción: Y de todas las poblaciones del Reino de Valencia.

${ }^{96}$ Torró, J(1989): “El problema del hábitat fortificado en el sur del Reino de Valencia después de la segunda revuelta mudéjar (1276-1304), pág. 66. 


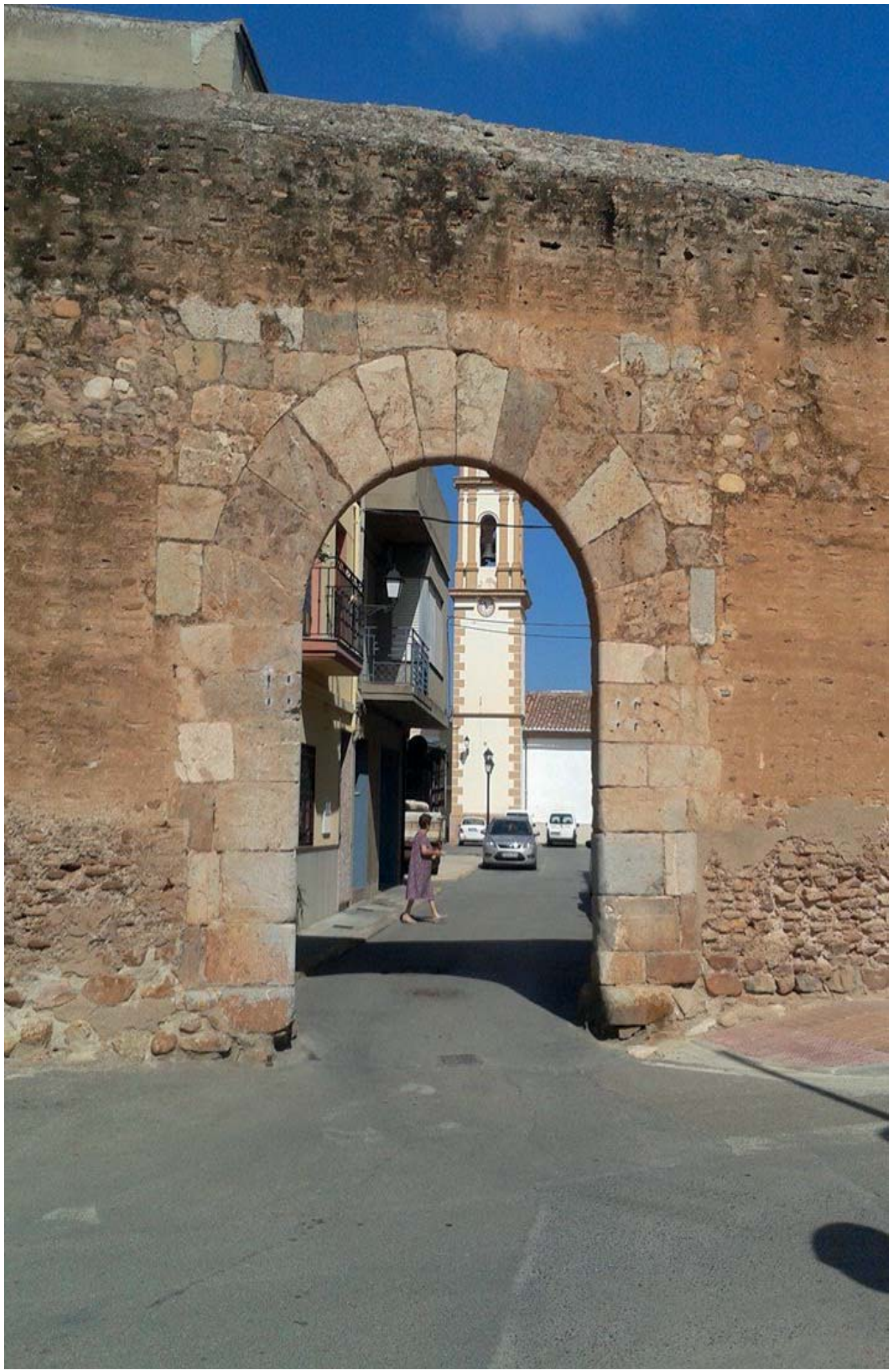


En Mallorca, aplicar las ordenaciones era competencia dels ordenadors, estos agentes, en primer lugar, habían de decidir la ubicación de la pobla para posteriormente proceder a fijar sus límites y valorarlos. En palabras de Josep Francesc López Bonet, eran los agentes encargados de la construcción de las nuevas villas y de la ejecución de lo dispuesto en las ordenaciones ${ }^{97}$. De los documentos donde se concretaba la aplicación de las ordenaciones de cada población planificada, solo se conservan dos en Mallorca: el de Felanitx y el de Petra ${ }^{98}$.

Hechas las consideraciones anteriores y ante toda esta diversidad de soluciones se demuestra, no obstante, que los agentes responsables de la construcción de los asentamientos tenían criterios homogéneos que adaptaban con mayor o menor pericia a las características de cada medio local tratando de rentabilizar al máximo las infraestructuras viarias e hidráulicas heredadas.

\subsection{5| Elementos arquitectónicos}

Una vez analizadas las tramas urbanas se procedió a comprobar el uso de los bienes inmuebles existentes en todas ellas, limitados por el conocimiento de los edificios que habían llegado hasta nuestros días, o por aquellos que, aún no existiendo (porque se habían derribado o reformado) sí se podía encontrar documentación escrita que acreditara su existencia.

Como curiosidad, a veces obvia, es necesario constatar un punto en común respecto a un edificio que nunca fue construido en el interior de ninguno de estos núcleos urbanos. Estos municipios compartían la característica de haberse construido en llano y estar al abrigo de un castillo a poca distancia, con lo cual, intramuros, nunca se erigirá un castillo: se compondrán de casas nobles, conventos y palacios, pero siempre se echará en falta la existencia del edificio medieval por excelencia, el castillo.
Fig. 043. Uno de los portales y parte del paramento vertical de la cerca de Mascarell en la actualidad.

\footnotetext{
${ }^{97}$ Mas i Fornes, A. (2003): “L'antiga vila de Manacor i les ordenacions de Jaume II". Pág 18-20. III Jornades d'Estudis Locals de Manacor. 2003.

98 Ibídem.
} 
Fig. 044. Croquis de Vila-real medieval, con su recinto amurallado y sus cuatro portales coincidentes con sus viales principales.
${ }^{99}$ Perez Santiago (2012): "Almenara 2 Patrimonio artístico". Bloc para el curso de antropología Cultural de nuestro entorno, Universidad Jaime I, Alicante.

${ }^{100}$ Calve, O.(2015): “ Un siglo y medio del derribo de la muralla medieval". Las Provincias. Valencia.

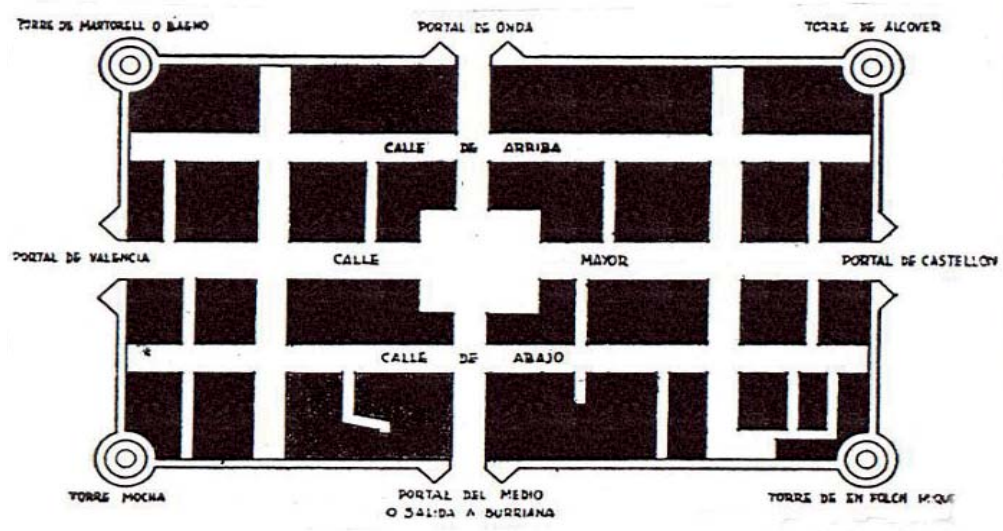

4.6.5.1| La Muralla

La muralla puede considerarse como el indicador principal para conocer la línea que marcaba el espacio urbano de las villas medievales, antes sistema defensivo y ahora patrimonio que debe conservarse ${ }^{99}$.

Es necesario señalar que la mayoría de las cercas defensivas de los municipios de la provincia de Valencia fueron derruidas por el mismo tiempo que las de Valencia. El 20 de febrero de 1865 en la ciudad de Valencia, lejos de cualquier prejuicio conservador las autoridades promovieron un multitudinario acto anunciando a bombo y platillo que debía celebrarse en los alrededores de la Puerta del Real, ubicada frente al puente homónimo. Y ante una muchedumbre entusiasmada, el propio gobernador civil Cirilo Amorós y Pastor asestaba el golpe simbólico que daba inicio al derribo de las murallas, tras un breve y emocionado discurso. Quizá hoy se considere una aberración patrimonial, pero es preciso ponerse en la piel de aquellos hombres que tuvieron varios factores para impulsar la demolición.

Entre los más evidentes puede resaltarse la pérdida del valor funcional de la muralla tanto en Valencia como en otras ciudades. Los avances armamentísticos en artillería pesada y explosivos de largo alcance no sólo mostraban el carácter obsoleto de la fortificación, sino que también obligaban a tomar medidas que oprimían aun más el recinto urbano. La muralla constreñía el natural desarrollo urbano, generando un anillo sin edificaciones por fuera del recinto, lo que agravaba las diferencias entre el casco urbano y las poblaciones periféricas ${ }^{100}$. Valencia, como capital, 


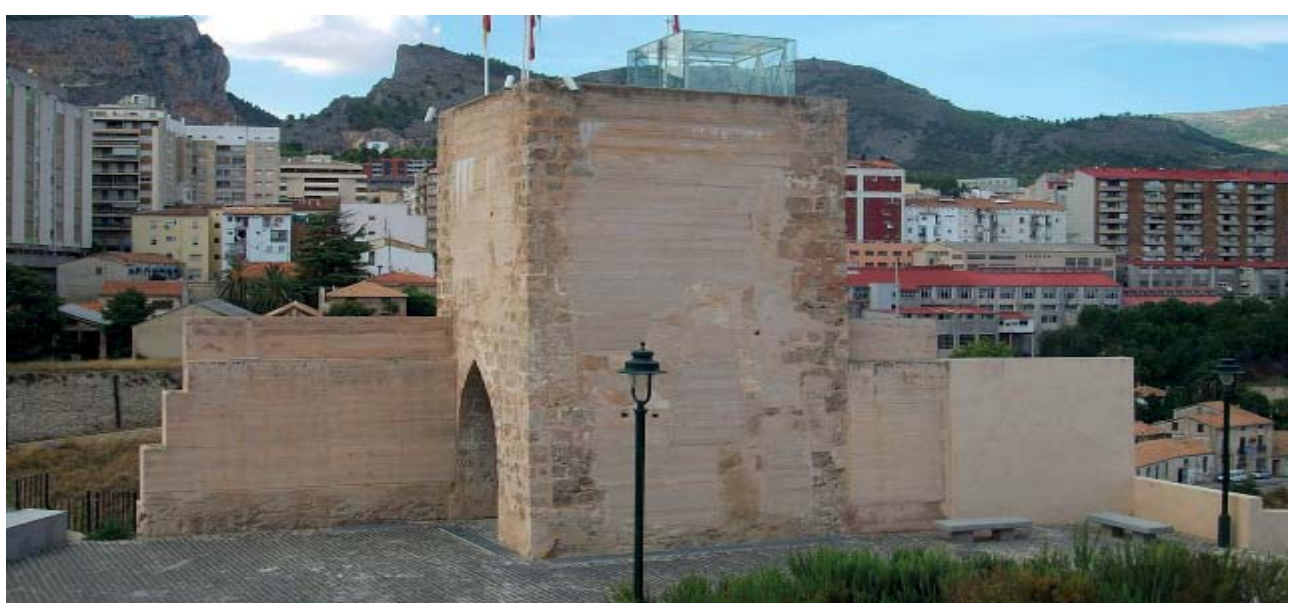

derruyó las suyas e inmediatamente le siguieron los municipios de la provincia.

En origen estas murallas podían corresponderse con simples estacadas de madera, puesto que, como se ha visto, normalmente se construían posteriormente a la redacción de la carta pobla. Entonces se construía un muro grueso, exento, torreado y con portales para controlar los accesos. Además los portales venían marcados por los dos ejes de los viales principales de la villa.

La existencia de cercas puede rastrearse por medios de documentación escrita, pero en muchos casos quedan testimonios - restos arqueológicos - incluso paños completos, que bordean los cascos históricos, aunque en su gran mayoría han desaparecido tanto los adarves como las almenas.

Como puede apreciarse en los restos de las estructuras murarias de los municipios de Vila-real o Mascarell, muestran paramentos verticales realizados con tapial reforzando los puntos singulares con mampostería. Las oquedades destinadas a albergar las puertas de acceso a la villa se realizaban a base de sillar o sillarejo y venían flanqueadas por dos torres para resaltar su especial importancia.

Sobre la base de las consideraciones anteriores se procede a describir como eran las cercas murarias de las poblas seleccionadas para el presente estudio comenzando por la única población, de la provincia de Valencia, de estas características que conserva la cerca, Mascarell. La muralla dispone de cuatro torres cuadradas situadas en el centro de los muros y posee
Fig. 045. La Torre Na Valora de Alcoy posteriormente a su restauración. 
Fig.046. Resto del paramento vertical de la torre Motxa de Vila-real, uno de los pocos restos que existen en la actualidad.

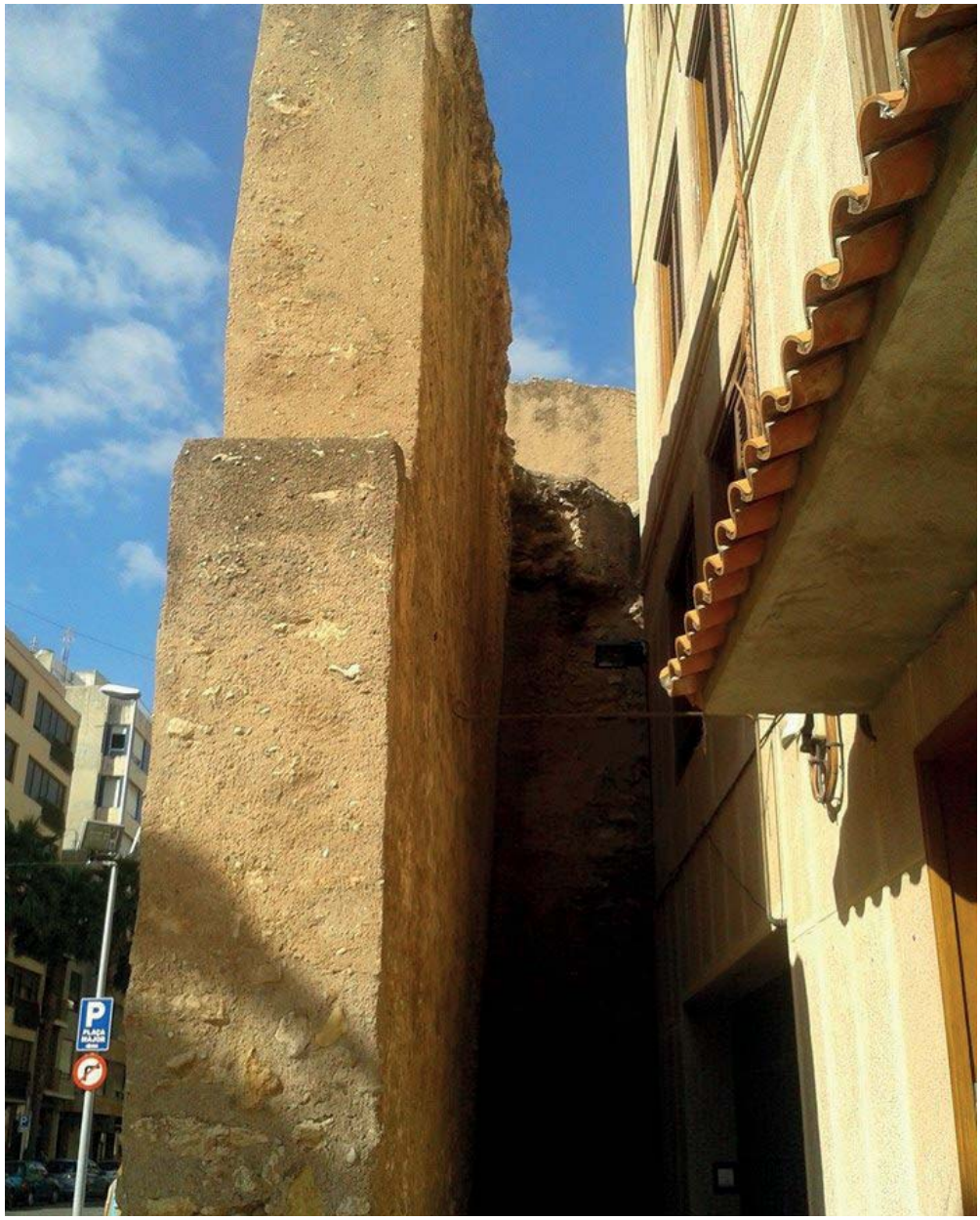

únicamente dos accesos, situados en muros opuestos: la primera puerta recae al camino de Burriana a Nules y el segundo acceso se encuentra dirigido hacia Valencia.

La puerta de entrada principal cuenta con una luz de 2,50 m para el paso y el acceso secundario tiene un ancho menor contando con 2,25 m. Este elemento defensivo se encuentra construido con tapial mixto, contando con un espesor de 1,25 m. La muralla estaba rodeada por un foso que en la actualidad ha sido convertido en acequia de riego. Recientemente Mercedes Gómez-Ferrer y Juan Jesús Gavara han dado a conocer el contrato de la construcción de las murallas de Mascarell, lo que data éstas a mediados del siglo XVI.

Otro ejemplo se puede encontrar en el municipio de Almenara donde las murallas fueron construidas posteriormente a la implantación del núcleo urbano y, como era habitual en la 


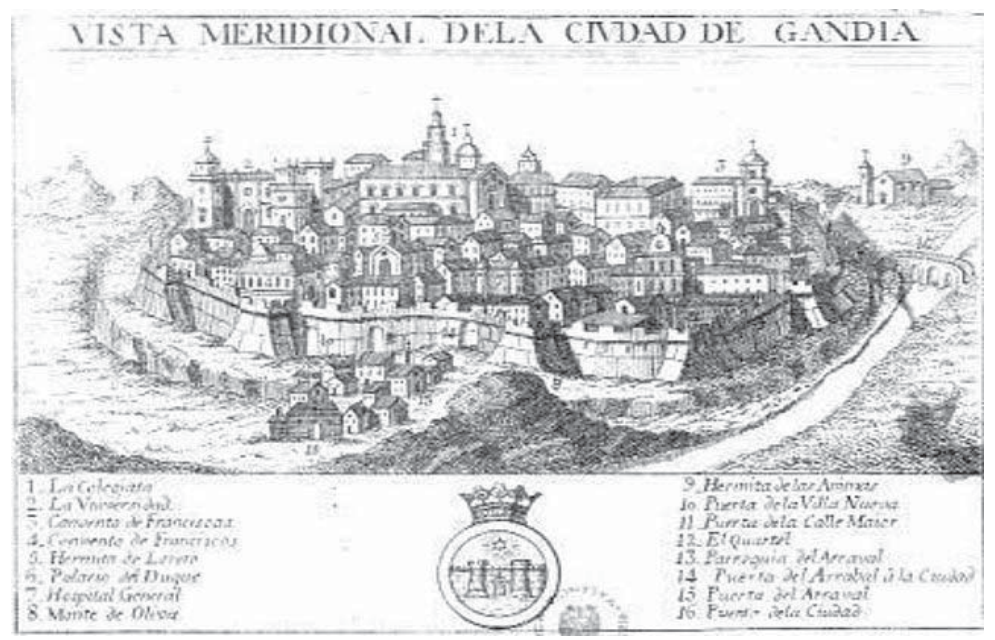

mayoría de estas villas, fueron levantadas en la segunda mitad del S. XVI, entre 1543 y 1553, por el arquitecto Mosén Miquel de Santander mientras estaba al frente de las obras Pedro Montoya. Contaban con 6 palmos de espesor y 25 de elevación. Se salía al campo por las tres puertas: la de Valencia, la de Nules y la de la Vall.

En Nules la muralla dispone de cuatro torres cuadradas situadas en el centro de los muros y cuenta únicamente con dos puertas, ubicadas en paramentos opuestos: la que da al camino de Burriana a Nules y la de Valencia, la cual recae a la acequia de Mascarell que transcurre paralela la muralla. Teodoro Llorente ${ }^{101}$, describiría Nules con románticos trazos:

Nules ofrece un golpe de vista pintoresco es la única población de la Plana que conserva sus antiguas murallas. Esas tapias bermejas, que forman un recinto cuadrado, están defendidas por veintidós torreones; sobre ellas surgen el caserío y las cúpulas de las iglesias que resplandecen al sol con el brillo turquesa; fuera de los muros extiéndase los arrabales dominados también por las cúpulas de los arruinados conventos todos fueron derribadas hace pocos años [...]

También quedan documentadas las murallas de Castellón, que como elementos de flanqueo, contaban con las estructuras arquitectónicas que albergaban las puertas de ingreso; con las torres de flanqueo propiamente dichas, situadas generalmente en el punto medio entre dos puertas, y las torres cantoneras ${ }^{102}$.
Fig. 047. Grabado de la ciudad de Gandía en el año 1786. La villa aún contaba con su perímetro amurallado y sus portales.
${ }^{101}$ Llorente Olivares, T (1887): Valencia, volumen 1, Ed. Nabu Press, 2010, pág 256.

${ }^{102}$ Sánchez Adell, J. y Traver Tomás, S: Castelló, el Plano. La muralla. . Intercentres.. Sociales, Generalitat Valenciana. 
También existieron varias puertas en la cerca muraria del municipio de Vila-real. En origen queda constancia de las 4 puertas básicas (portal de Castelló, de Onda, de Valencia y del $\mathrm{Mig}$ ), opuestas dos a dos como extremos de las dos calles principales que se cruzaban en la Plaza mayor. En el siglo XV, se construyeron 4 portales más, pero de todos ellos sólo ha llegado a la actualidad la Torre Motxa; al igual que en Puzol de cuya muralla sólo queda la torreta o Torre Talaia.

En situación semejante se encuentra La torresa del Pi uno de los últimos testigos de la antigua muralla medieval de Gandía. Fue el duque Francisco de Borja quien mandó su construcción en el año 1543. Se trata de una torre con forma circular cuya función era principalmente defensiva. El torreón se encuentra en la calle San Rafael, desde donde es posible apreciar el enorme monumento fortificado.

En Alcoy el recinto fortificado ocupaba 5 ha. Todavía se puede contemplar la Torre Na Valora compuesta de tapial en los paramentos verticales y sillarejos en las esquinas. De 4 $\mathrm{m}$ de altura, espesor variable de 0,92 a 1,12 m, 5 soportales y 14 torres, como en los municipios anteriores, también fue construida después de la concesión de su Carta pobla. Las obras de construcción se iniciaron en el año 1264 y no fueron finalizadas hasta acontecer el año el 1290.

En Cocentaina la distribución de las torres tenía el siguiente orden: al este, norte y oeste había seis torres; al sur tan sólo había tres y se repartían cuatro en cada esquina. Las puertas principales de entrada a la villa se situaban, al norte la puerta de l'Àngel, al este la puerta de Travadell', y, al sur el Portal Fosc.

En Penáguila la muralla cerca una superficie de 1,3 ha. También fue construida posteriormente a la fundación del núcleo urbano, a principios del S. XIV. Estaba construida con tapial con un núcleo interno mejorado con cal, grava y algunos mampuestos, contando con un espesor de 7 palmos (150 o 160 $\mathrm{cm})$. Constaba de dos torres de ingreso y setenta y seis torres de flanqueo.

Esta muralla presenta similitudes con las de Alcoy y Cocentaina. El conjunto fortificado es de planta rectangular y orienta el eje principal de norte a sur. La muralla no era igual en la vertiente de levante que en la de poniente. En la de levante (calle del Mar) aprovecharon el corte del barranco del Anadrac y solo levantaron lienzo de muro y al nordeste la torre renombrada 


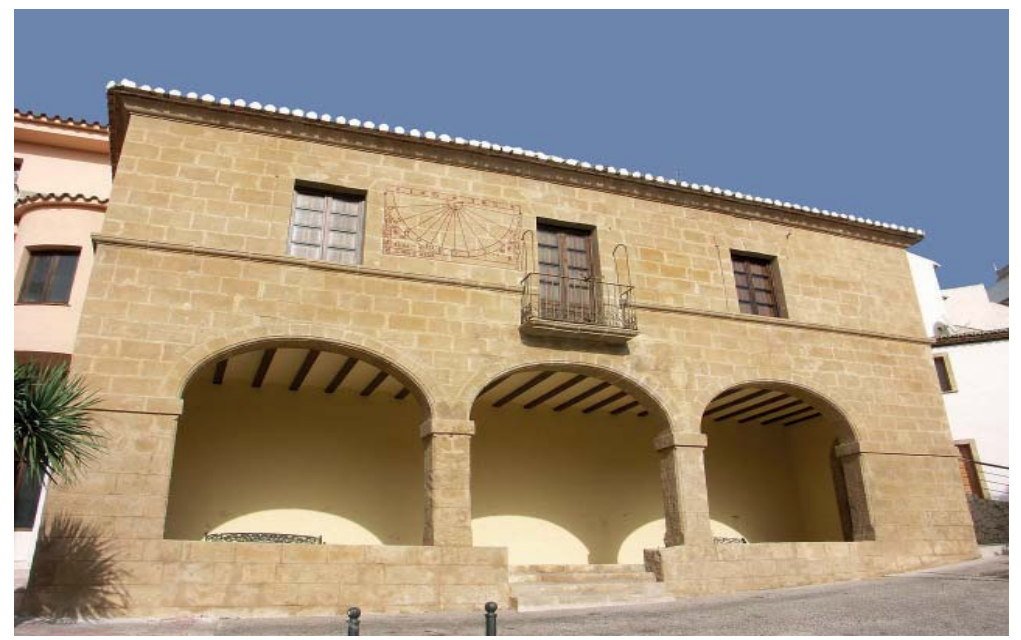

Vernet. En la vertiente de poniente (calle de la Virgen del Patrocinio) la muralla era imponente: alternaba lienzos y torres de planta cuadrada, aunque todo ha quedado desdibujado y absorbido por las casas, por dentro de las cuales se encuentran restos de los paramentos verticales de la cerca muraria (visibles desde la calle). El principal acceso al pueblo, era cubierto por una puerta denominada el Portalet, por donde sigue accediéndose al corralón medieval en la actualidad. Es un curioso acceso medieval que impide entrar en la villa en línea recta, y obliga a hacer un doble ángulo de 90 grados al caminante, lo que evidentemente, aumentaba la seguridad y el control sobre los que accedían. De la torre Vernet, situada al noroeste de la muralla, solo queda un fragmento, si el visitante se dirige desde ella hacia el mercado se encontrará con un imponente lienzo de muralla medieval engastado en las casas de la calle ${ }^{103}$.

Como resultado de todo lo anteriormente descrito, sintetizar cuatro ideas, primero que las pueblas construían las cercas con fecha posterior a su fundación, eran obras que se prolongaban con el tiempo, solían ser de tapial aunque los puntos singulares se reforzaban con sillares o sillarejos y todas contaban con varias torres, las que flanqueaban las puertas de acceso que correspondían con los ejes principales y las que reforzaban los paramentos verticales.

\subsubsection{2| Plaza Mayor y Sala del Consell}

La mayor parte de las villas analizadas cuentan con una plaza que acoge la mayor de las actividades económicas: el mercado
Fig. 048. Arquitectura civil gótica, sala de los Jurados Teulada.
103 Ayuntamiento de Penáguila. El municipio. Restos de la muralla, el Portalet y la torre Vernet. 
$\mathbf{1 1 6}$ de 536

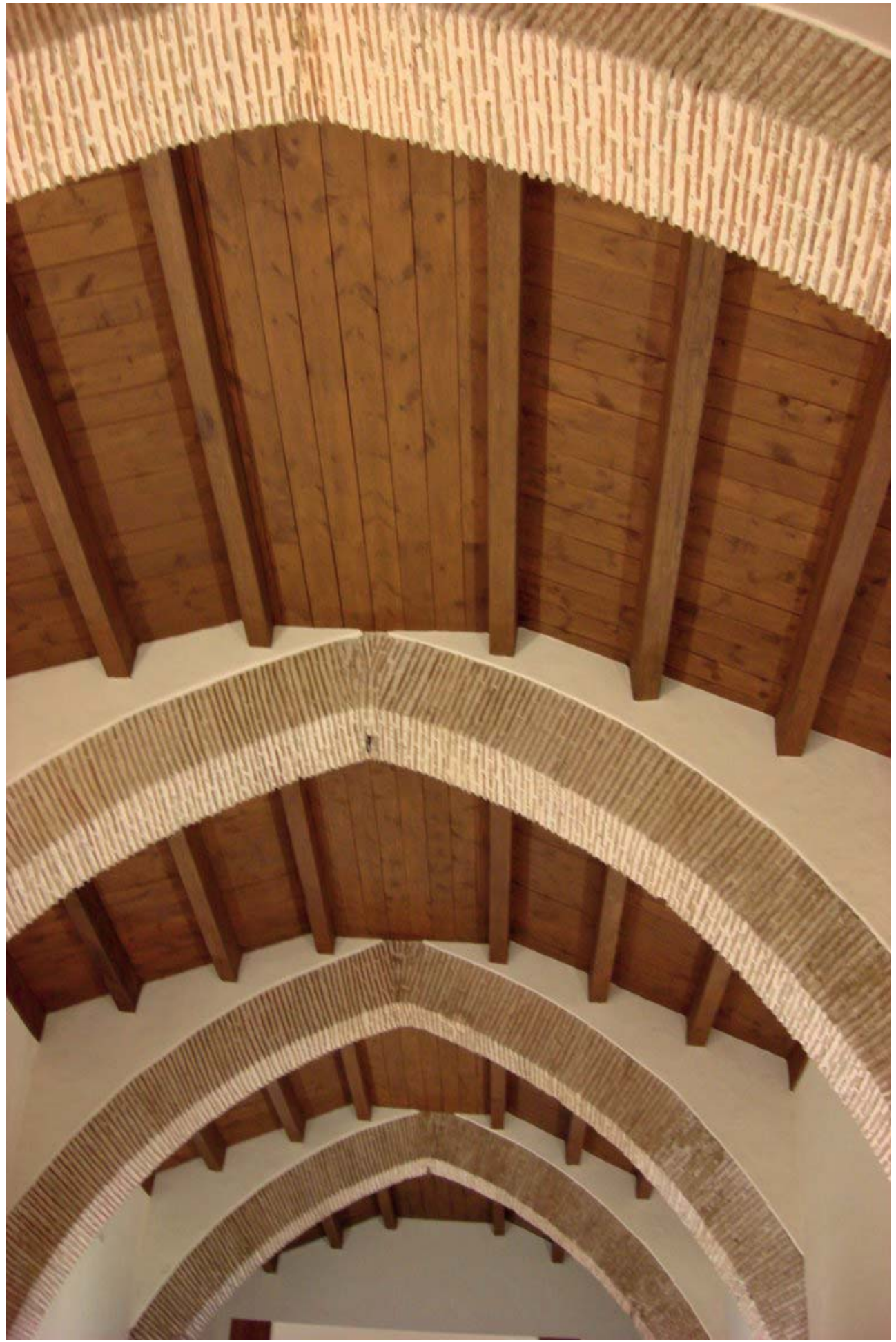


y donde se sitúan los edificios administrativos: la Sala, La Cort y la Presó. La plaza acostumbraba a situarse en el eje de la calle principal, que era generalmente el camino a partir del cual se fundaba la población, y también solía tener incidencia en el eje perpendicular.

Tanto la plaza central como las dos calles principales contaron con soportales; a la plaza se abría la casa consistorial pero no la iglesia que, como en otros muchos modelos peninsulares, se construyó junto a una de las puertas de la muralla, reforzándola y dignificándola ${ }^{104}$.

Cabe agregar que no han llegado muchos testimonios de plazas aporticadas hasta la actualidad, pero quedan como testigos la de Teulada y Vila-real. La plaza del citado municipio se encuentra en la confluencia de las calles Major y Comte Albay. Ésta es de planta cuadrada y en sus frentes lleva porches formados por arcos apuntados de piedra. En la plaza se ubicaba la casa de la villa, los hostales, el Almudín y en ella se celebraba la feria. La plaza de la Vila se encuentra declarada Bien de Interés Cultural y es uno de los escasos ejemplos de plazas porticadas que se conservan, junto con la plaza del Almudín o Font de dins situada en el centro histórico del municipio de Onda.

Para concluir el municipio de Gandía, quien presenta en la zona de intramuros, además de los edificios comunes a las otras vilas, el Palacio ducal, la universidad y el convento de Santa Clara $(1429)^{105}$.

\subsubsection{3| Arquitectura religiosa}

Con la creación del nuevo Reino de Valencia, se fue construyendo una red de parroquias por todo el territorio. Los minaretes de las antiguas mezquitas fueron sustituidos por torres campanario. Los templos islámicos, que no sólo eran centros espirituales, sino que vertebraban la vida económica de la comunidad islámica, fueron reemplazados por iglesias, que pasaron a cumplir el mismo papel, hecho que ayudó a estructurar administrativamente el territorio ${ }^{106}$.

No es de extrañar que la mayor parte del patrimonio arquitectónico que ha llegado hasta la actualidad sea el destinado a la arquitectura religiosa. En la mayoría de los pueblos objetos de este estudio se ha podido constatar la presencia de
Fig. 049. Detalle de los arcos de diafragma de Hospital de San Marcos en Gandía.
104 Beltrán Abadía,R.'( 2005): "Planeamiento y geometría en la ciudad aragonesa". Colegio de Arquitectos de Zaragoza. Arqueología y Territorio medieval. Revista de Arqueología del Área de Historia Medieval. Universidad de Jaén. Tomo 12.2, pág.163

105 Rossello Verguer, M.(1987) "Anales de Geografía de la Universidad Complutense, núm. 7. Ed. Univ. Complutense.

${ }^{106}$ Gómez i Sahuquilo, M.(2010): " La Torre i Ermita de Sant Miquel de Corbera". Castillos de España. Generalitat Valenciana. 
Fig. 050. Ermita de San Antonio situado extramuro del municpio de Alcoy.

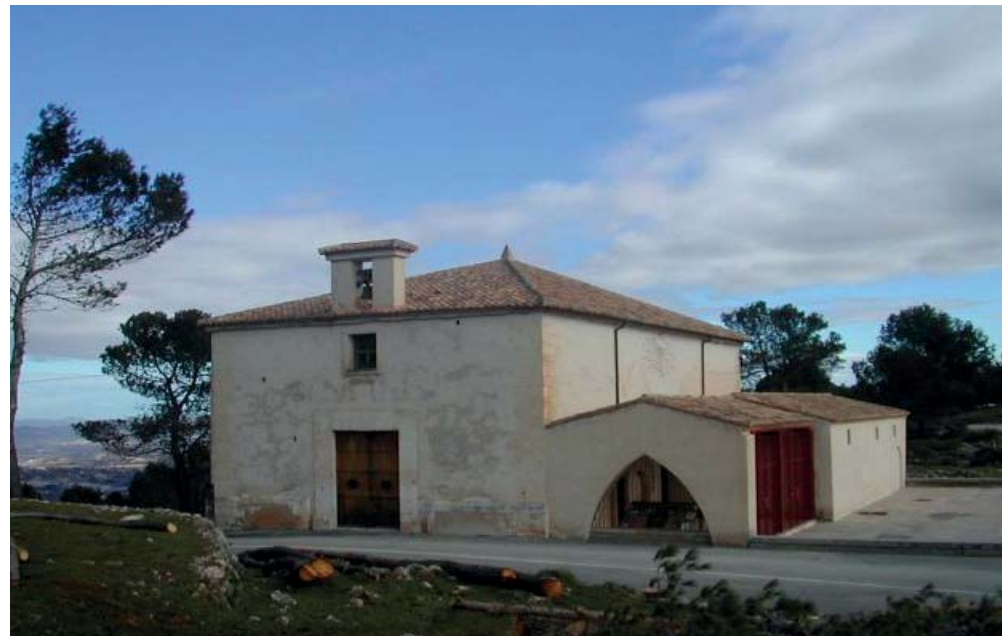

una ermita construida con arcos de diafragma, una iglesia erigida con bóvedas de crucería y una cruz de término o peiró.

En extramuros, situada por una zona elevada del término municipal, se suele encontrar una pequeña ermita de nave rectangular y un peiró. En todos los términos municipales existía una cruz de término, muchas de ellas restauradas o sustituidas a lo largo de su historia, pero con documentación escrita que acredita su origen en época medieval.

En intramuros, se encontraban las iglesias levantadas con bóvedas de crucería. Estos edificios no solían ubicarse en la plaza central sino que pasaban a situarse, en su gran mayoría, a la entrada del municipio junto a una puerta, siendo uno de sus paramentos verticales parte de la muralla del núcleo histórico. La situación de estos inmuebles coincide con las iglesias de los municipios de Aragón descritos en los primeros capítulos.

Hechas las consideraciones anteriores procede realizar una breve descripción de cada uno de estos edificios de carácter religioso:

\section{a) Ermitas con arcos de diafragma}

En el año 1223 Burriana es reconquistada, y Alicante lo fue en 1248 , lo que da a entender la rapidez de la reconquista cristiana del Reino de Valencia. A partir de este momento la región se llena de repobladores llegados de diferentes lugares de España, lo que da lugar a la mezcla de diferentes estilos arquitectónicos a lo largo de todo el territorio valenciano. 


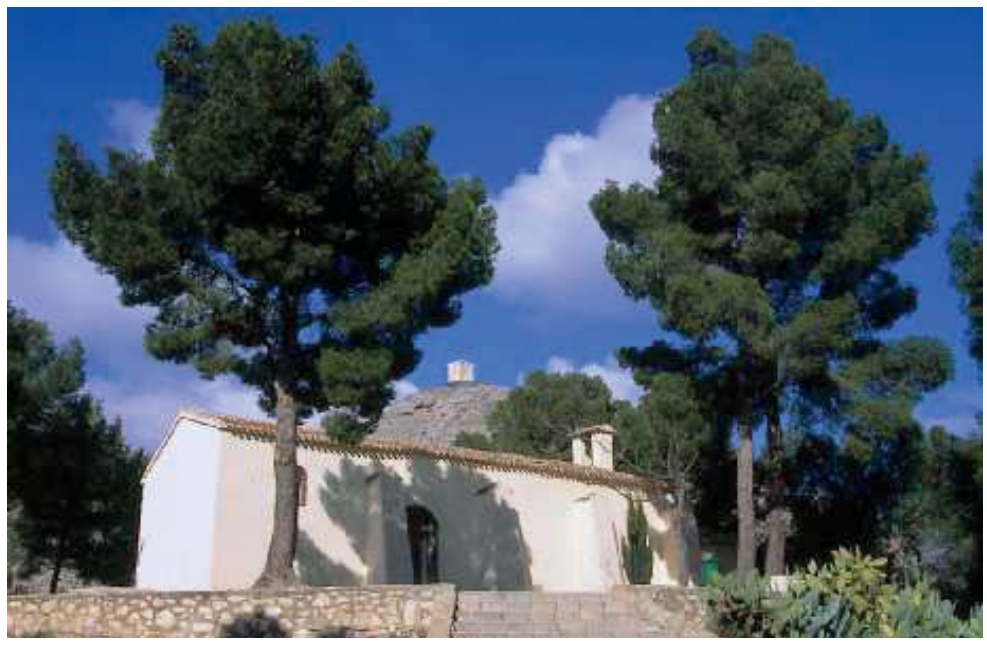

Las primeras construcciones fueron las religiosas (iglesias), ya que los cristianos lo consideraban como una forma de asegurar la presencia del cambio de cultura, costumbres y política en el lugar. La red parroquial representaba el frente de batalla social y religioso y por ello había que implantarlo aunque fuese en forma rudimentaria incluso antes que el propio gobierno municipal107.

La nueva iglesia era un elemento cohesionador y unificador de las diversas alquerías dispersas por toda el área de influencia del castillo, e impregnaba a todos sus habitantes al igual que la parroquia. Ésta era el centro social y religioso de la comunidad cristiana que residía en el territorio del castillo. Era en este templo donde se elegían los representantes de la comunidad.

En un primer momento aprovecharon las antiguas mezquitas para establecerse, pero muy pronto surgió la idea generalizada de sustituirlas por algún tipo de construcción más apropiada y de estilo cristiano. La urgencia de construir y la adaptación al entorno obtuvo rápidamente sus resultados. Estos tipos de iglesias fueron construidas de un modo veloz y simple, ya que lo que se pretendía era crear un entramado de parroquias, de forma inmediata, que permitiera una apresurada cristianización de las tierras Valencianas, ser un elemento unificador y ayudar a la administración pública además de tener su función religiosa ${ }^{108}$.

Todas ellas muestran la misma tipología constructiva, nacidas de la necesidad de levantar un pequeño templo sin muchos problemas constructivos. Son edificios sencillos de planta rectangular, de una nave, cabecera plana, estructura de arcos de
Fig. 051. Ermita de Santa Bárbara situada en un pequeño montículo del término municipal de la vila de Cocentaina.

107 Torres Balbás, L. (1952): La Arquitectura gótica: Valencia y Murcia. Volumen 4. Madrid.

108 Gómez i Sahuquilo, M.(2010): "La Torre i Ermita de Sant Miquel de Corbera". Castillos de España. Generalitat Valenciana. 
diafragma y cubierta de armadura de madera a dos vertientes.

Este sistema constructivo está formado por una serie de arcos de fábrica dispuestos transversalmente al eje longitudinal de la nave que se pretende cubrir. Los arcos tienen la función de soportar la cubierta del edificio. De hecho esta tipología puede entenderse, igualmente, como el que estaba formado por muros perforados por arcos paralelos entre si y colocados transversalmente a la nave que cubren. Además este sistema es el que menos coste requiere para su construcción. Esto es así porque, a diferencia de las construcciones de cubiertas con roscas de fabrica, no requiere las tradicionales y costosas cimbras de madera que eran necesarias para montarla.

Esta tipología fue empleada con frecuencia en los lugares recientemente reconquistados a partir del segundo tercio del siglo XIII, gracias a su facilidad y economía de construcción. Este sistema constructivo conformó el grupo más abundante de los inmuebles más significativas de la época: las iglesias y ermitas.

Las parroquias de la repoblación cristiana, constituirán un tipo definido. Las diversas conformaciones que adoptan relativas a su implantación y riqueza no suponen variantes relativas a su situación. Según afirma Arturo Zaragozá:

Se da el caso que en estos términos municipales, se encuentra en un punto elevado del Término municipal, pero fuera de las murallas, ermitas construidas con arcos de diafragma. Además de estar en un punto elevado, y tener similares características constructivas, todas ellas forman parte de la historia del municipio, están datadas desde tiempos medievales y están dedicadas al patrón del municipio ${ }^{109}[\ldots .$.$] .$

109 Zaragozá Catalan, A. y "otros" (2008) Arquitectura any zero (1.208-2008). Generalitat Valenciana. Valencia. Any Jaume I Generalitat Valenciana. 276p.

110 Moncho, V (sacristán de S. Roque 2012): "Un poco de historia, breve historia de la parroquia de San Roque y San Sebastián". Blog de la Comisión de Fiestas de la parroquia de San Roque y San Sebastián de Alcoy.
Para ilustrar las consideraciones anteriores procede revisar cada una de las pueblas de colonización elegidas para buscar pautas similares. El primer municipio, Vinaroz, donde quedan documentadas las ermitas dedicadas a sus patrones a menos $6 \mathrm{~km}$ del casco urbano, estas se denominan la ermita de San Sebastián y de la Virgen de la Misericordia. De manera semejante en La Pobla de Vallbona a menos de $2 \mathrm{~km}$ del núcleo histórico también se encuentra la ermita de San Sebastián. 
En Castellón se encuentra la Basílica del Lledó, en origen de arcos de diafragma. En Vila-real, situada a $2 \mathrm{~km}$ de la población, y en un promontorio a orillas del río Mijares, el ermitorio de Nuestra Señora de Gracia, y en Alcoy la ermita de san Antonio Abad.

Desde el punto de vista arquitectónico se ha clasificado la ermita de Santa Bárbara de Cocentaina como una iglesia de reconquista, al estar caracterizada por una cubierta leñosa de doble vertiente apoyada sobre arcos apuntados.

En Almenara existía en lo alto de un montículo detrás del calvario, la ermita de los Santos Juanes, aunque fue destruida durante las guerras carlistas y reconstruida en el año 1738 .

Del mismo modo en Alcoy queda documentada que la primera ermita fue destruida totalmente en la Guerra de Sucesión (1705-1714). Se encontraba situada en lo que hoy es el interior de la calle Onofre Jordá, en el Paseo de Cervantes, que luego se convirtió en la Plaça de Bous Vella. Mejor y más capaz, situada a espaldas de lo que sería el Cuartel de Infantería, se ubicaba sobre un gran rellano frente a la cruz de término del Camino de Madrid $^{110}$.

Los últimos casos se encuentran en Penáguila y en Teulada. El primer municipio cuenta con dos de estos inmuebles, la de San Roque y la ermita del Calvario, ambas construidas durante esta época y con el mismo sistema constructivo. En Teulada queda documentada con esta misma tipología el oratorio de Font Santa. 


\section{b) Iglesias con bóvedas de crucería}

Gran parte de las parroquias que entre mediados del siglo XIV y principios del siglo XV se construyeron en la ciudad de Valencia y alrededores presentan: una sola nave, con capillas entre contrafuertes, presbiterio poligonal -algunas cuentan con el testero plano semejante al modelo de Llíria - y cubierta de bóvedas de crucería sencilla o simple (San Juan del Mercado, San Martín, San Esteban, San Nicolás, etc.).

La gran anchura que presenta la nave central obliga a emplear un sistema de abovedamiento por tramos relativamente estrecho y rectangular que apoya en los contrafuertes. Estos no se perciben en el exterior, pues se ocultan por muros de cerramiento, y entre ellos se sitúan las capillas laterales sin comunicación entre ellas. El interior de estas iglesias góticas era relativamente sombrío, debido a la escasez y al pequeño tamaño de las aberturas al exterior que perforan el muro por encima de las capillas laterales. En su origen estas estrechas ventanas se cubrían con láminas de alabastro, en lugar de las coloristas y luminosas vidrieras del gótico europeo, material que permitía controlar la entrada excesiva de luz a los interiores.

Este espacio interior unitario, de gran sobriedad volumétrica, presenta un fuerte carácter funcional. Al tener una sola nave se permite reunir a un elevado número de fieles, proporcionando una buena y completa visibilidad del altar mayor, de modo que los feligreses puedan asistir sin obstáculos visuales a la celebración cristiana. En las primitivas iglesias góticas valencianas los púlpitos se situaban a ambos lados del presbiterio que se elevaba, además, sobre gradas para mejorar la visibilidad pero sobre todo la acústica. Por otro lado la existencia de capillas laterales permitía la celebración simultánea de diferentes actos litúrgicos, siendo estos lugares costeadas por agrupaciones gremiales, nobles y burgueses que se encargaban de mantenerlas y a menudo se enterraban en ellas.

Esta concepción espacial unitaria producía en el exterior una volumetría de características similares. Las templos góticos situados en el territorio de levante, como es habitual por otra parte en los edificios del gótico mediterráneo, presentarán volúmenes exteriores cúbicos, macizos, simples y compactos, sin la verticalidad del gótico francés. 
123 de 536

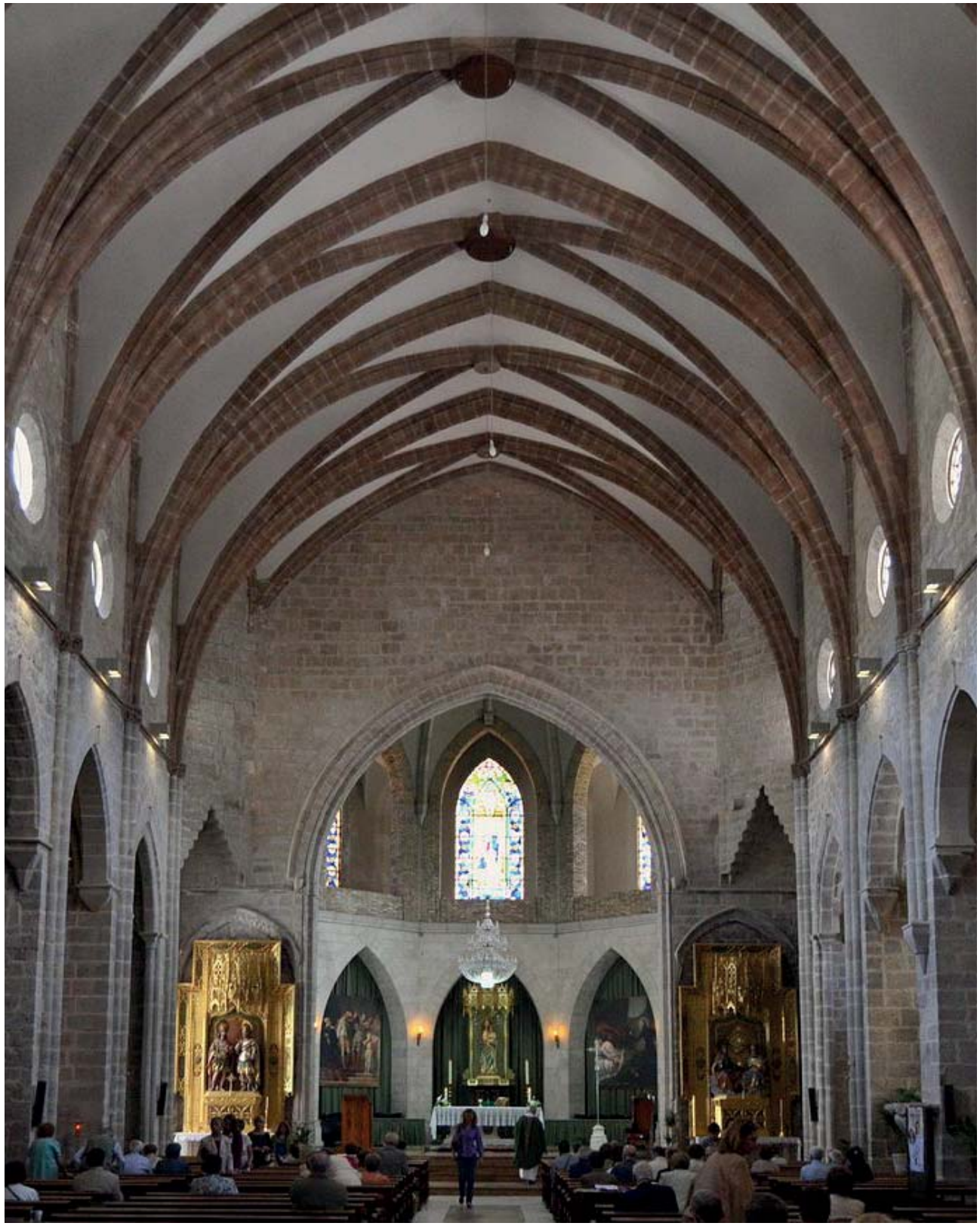

Fig. 052. La Seu de Gandía, Colegiata de Santa Maria. Se observa el sistema de cubrición construida con bóvedas de crucería. 
Fig. 053. Resto de los nervios de las bóvedas de crucería de la iglesia parroquial de Almenara.

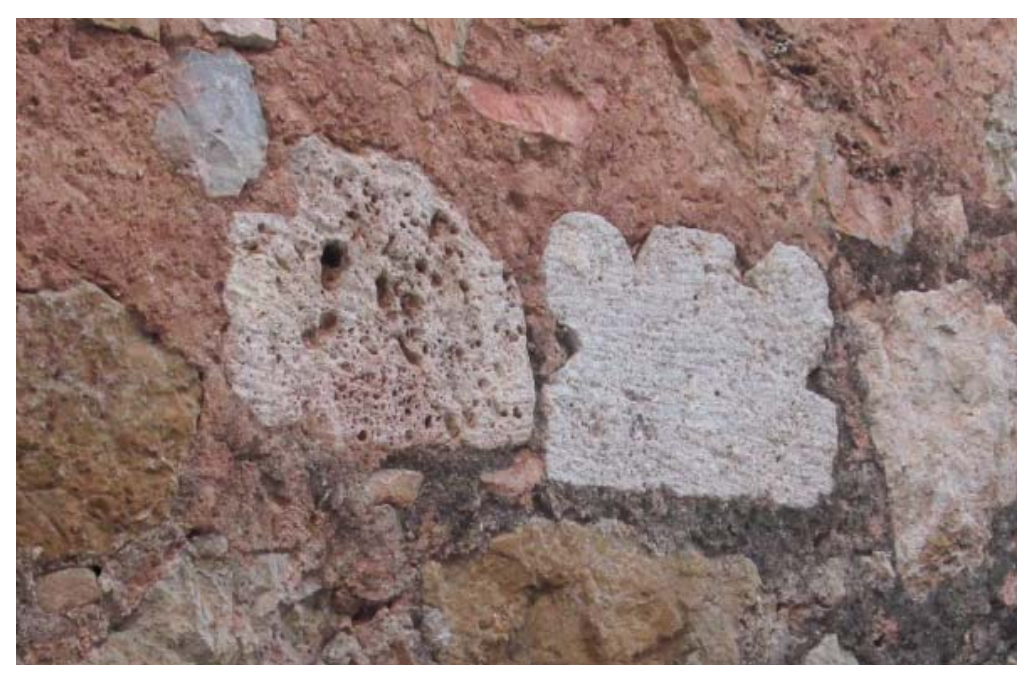

La mayor parte de estas edificaciones han llegado a la actualidad, ocultas por la ornamentación barroca, aunque queda documentado su origen medieval.

Para ilustrar las observaciones anteriores procede documentar este tipo de edificaciones en los municipios del Reino de Valencia elegidos para obtener similitudes en el presente plan de investigación. Para empezar la villa de Castellón, donde se encuentra la Catedral de Santa María, en Gandía la Colegiata de Santa María, en La Pobla de Vallbona, la iglesia de Santiago Apóstol, en Alcoy la Iglesia parroquial de Santa María ${ }^{111}$ al igual que en Cocentaina la iglesia parroquial homónima.

Para continuar la actual iglesia y convento de los franciscanos de Cocentaina ocupa el espacio de una antigua ermita del siglo XIV dedicada a San Sebastián mártir. De la antigua iglesia cristiana fundada en la segunda mitad del siglo XIII apenas quedan testimonios, a excepción de los restos arqueológicos aparecidos cerca de la fachada principal y del antiguo cementerio, localizado en el exterior de la fachada lateral. Debido a esto no se ha podido documentar si este inmueble estaba construido con el sistema estudiado en este apartado.

En Almenara, la antigua iglesia parroquial construida en el año 1530 contaba con bóvedas de crucería, como indican los restos hallados en sus paramentos verticales, aunque la iglesia fue reformada al gusto barroco. Penáguila, también albergaba uno de estos edificios construidos en el siglo XIV, el cual fue destruido para levantar el nuevo edificio para el culto cristiano en el siglo XVIII.
111 En la actualidad solo quedan restos de la clave del las bóvedas de crucería del siglo $\mathrm{XV}$, decorada con el escudete de las armas reales en losange, bastante bien conservada. 

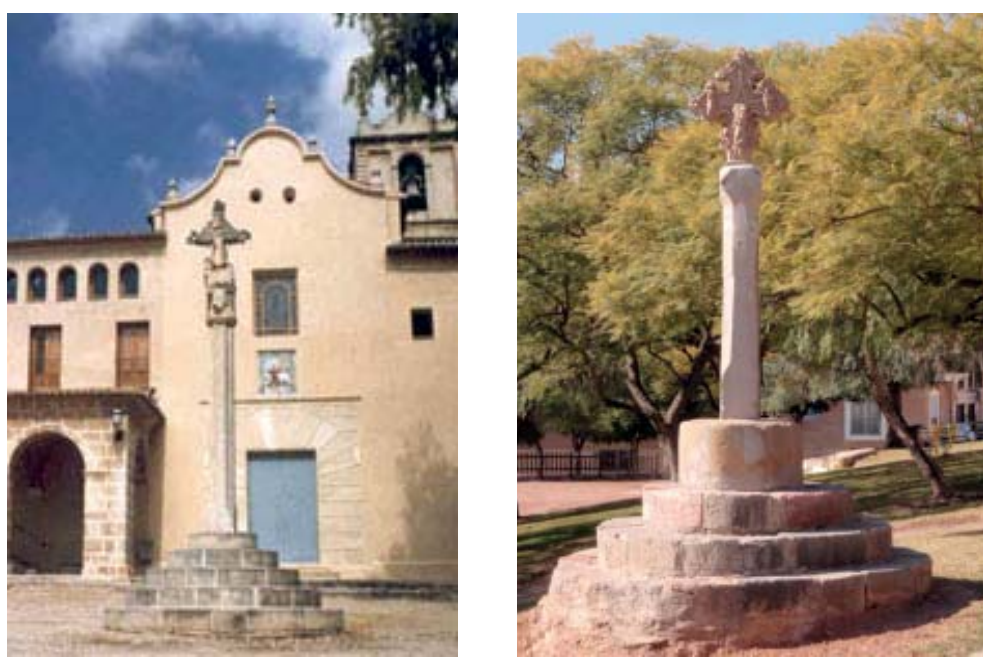

Para finalizar este apartado el templo de Teulada, iglesia de Santa Caterina, la cual se puede datar el inicio de su construcción a principios del último tercio del siglo $\mathrm{XVI}$, sobre una primitiva iglesia gótica que había sido construida entre finales del siglo XIV y principios del $X^{112}$. Se encuentra ubicada en una esquina del parcelario.

\section{c) Peirons o cruces góticas}

Los peirons son monumentales cruces de piedra levantadas con profusión en la Baja Edad Media en las tierras de la Corona de Aragón. Habituales también en el paisaje valenciano, se encuentran construidas en piedra caliza, y generalmente a la entrada de las poblaciones o de los santuarios, aunque también los había junto a alejados caminos y en lugares aislados ${ }^{113}$.

De igual manera se les conoce como cruces de término pero no fue esta su única función. En ocasiones conmemoraban un hecho histórico o un suceso extraordinario, otras eran producto de algún feligrés de la comunidad. En la mayoría de los casos los promotores fueron los propios consejos municipales, si bien aparecen también documentados con financiaciones de peirons diversos particulares, generalmente de holgada posición económica. En cualquier caso eran una señal indicativa del dominio sobre el territorio. Un paisaje cultural que la nueva sociedad cristiana se afanaba en construir y en marcar, dejando huella que ya era un territorio cristianizado.
Fig. 054. Peiró de Almenara. Quedan detallados sus tres elementos, la zona escalonada, la cruz y el capitel.

Fig. 055. Peiró de Cocentaina en la actualidad.
${ }^{112}$ Llopis Bertomeu, V., 1972: "Las murallas y Fortines de Teulada y su costa». Revista de Fiestas. Teulada.

${ }^{113}$ Zaragozá Catalan, A.(2000): Arquitectura gótica valenciana, Generalitat Valenciana. Conselleria de Cultura iducació, Direcció General de Promoció Cultural i Patrimoni Artístic. Valencia, pág 198-199. 
En el Medievo la construcción de un peiróno se consideraba una obra menor. Generalmente se encargaba su construcción a los mejores maestros. Prueba de ello es que en las cruces de piedra de la ciudad de Valencia intervinieron maestros de la talla de Antoni Dalmau, Francesc Baldomar o Pere Compte ${ }^{114}$.

El mayor número de estos bienes patrimoniales se esculpen en el siglo XV, época de bienestar social y económico en el antiguo reino. Las diferentes poblaciones compiten entre sí por la financiación de estas devotas estructuras, reflejo de su espiritualidad y de la aceptación en sus tierras de la fe cristiana, afirmación no exenta de sentido en una región con un elevado porcentaje de población morisca. Esto es, sin lugar a dudas, lo que ha determinado que las ubicaciones más habituales de los peirons sean la entrada y salida de los pueblos.

Junto a este deseo colectivo de afirmación religiosa hubo otras razones que justificaron otras tantas ubicaciones de las cruces:

- Delimitar el término de un pueblo.

- Marcar el espacio sacro de un santuario

- Conmemorar alguna fecha de interés local o alguna visita importante.

- Una desgracia natural, como podía ser inundaciones o epidemias.

Con respecto a los elementos que lo conforman, si se analiza este bien cultural como patrimonio arquitectónico, se encuentra integrado por los siguientes:

- Una gradería de dos o tres escalones circulares, cuadrados o poligonales;

- Una basa, cuya sección suele corresponder con la gradería;

- La caña o fuste, habitualmente circular u octogonal, a veces ecorada con estrías, y recorrida en su interior hasta hundirse en la gradería por un eje de cobre llamado "ánima", cuya función consistía en entrelazar los diferentes

${ }^{114}$ Zaragozá Catalan, elementos de la cruz;

A. (2000) : Arquitectura gótica valenciana, Generalitat Valenciana. Conselleria de Cultura $i$ educació, Direcció General de Promoció Cultural i Patrimoni Artístic. Valencia, pág. 198199.

- La macolla, mançana o capitel, de varias formas, decorado o no con ornamentación escultórica;

- Y finalmente la cruz propiamente dicha, donde se concentra la decoración y que evoluciona desde la tracería gótica hasta formas más depuradas. 


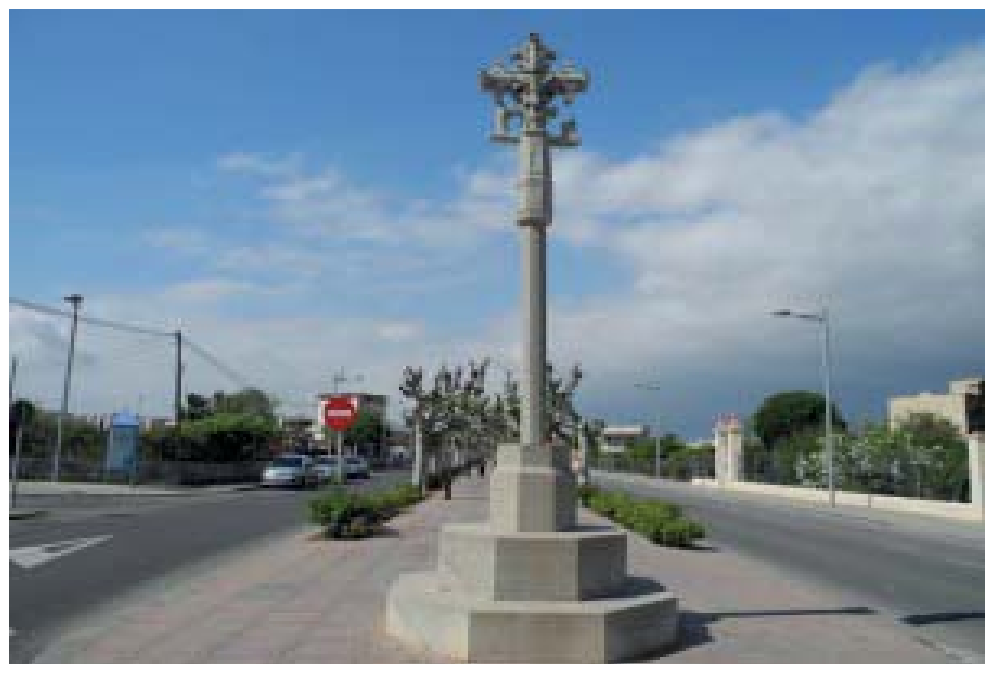

La decoración escultórica, de reducidas dimensiones debido al limitado espacio que otorga el soporte, se caracteriza por la tosquedad de sus formas y la reiteración de sus elementos iconográficos, concentrados exclusivamente en la cruz. En consecuencia estas piezas se elaboraban en una piedra que permitiera una labra fina y posteriormente se policromaban o se esmaltaban. Así, por ejemplo, en un contrato para la construcción de una cruz en Vila-real, en 1494, se dice:

\section{E toda la dita creu e esmatges e armes daurades e colos, segons tals obres requiren e han de menester ${ }^{115 .}$}

Muchas veces los peirons se cubrían, para protegerlos, con un edículo o porche. Estos se construyeron en un principio con una cubierta de madera chapada con plomo, con cuatro postes como pilares; en el siglo XV la cubierta se levantaba en unas ocasiones sobre bóveda y en otras sobre un entramado de madera, quedando sostenida, casi siempre, sobre cuatro pilares de piedra o de mampostería. Raras veces (cosa que ocurre la cruz cubierta de Alcira) eran de ladrillo. Lo más selecto de los peirons es el equilibrio de sus proporciones, la ecuación que relaciona unas partes con otras, haciendo que el conjunto ofrezca una visión armónica, claramente identificada con la distancia.

La fácil lectura y sencilla realización de la simbología de estas cruces sorprende en ocasiones con elementos iconográficos de la más pura tradición medieval. Sus elementos parlantes son de gran simpleza, debido con toda seguridad a estar
Fig. 056. Peiró del Lledó situado en la vila de Castellón delante de la ermita del mismo nombre. 
Fig.057. Ermita de San Roc en Alcoy en el año 1.916. La imagen deja constancia de la existencia de un peiró delante del inmueble.

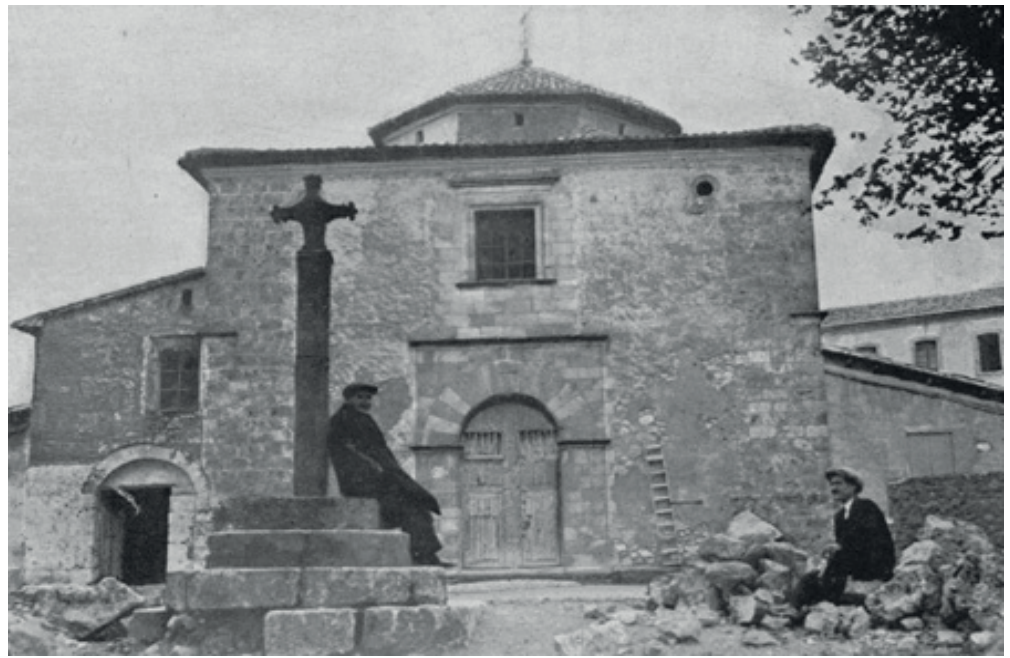

destinada su lectura a un público que asimilara el mensaje gracias a la claridad y reiteración de sus elementos.

La última guerra civil se ensañó especialmente con estas construcciones, siendo rara la que le sobrevivió intacta ${ }^{116}$. De los numerosos peirons que hubo siglos atrás, aparte de los restaurados o custodiados en museos, pueden encontrarse únicamente, dispersos por los campos, restos de graderías, basamentos y cañas.

Sin embargo existe un abundante material fotográfico que revela el aspecto primitivo de las cruces - Archivo Más, fotografías de Sarthou y fotografías de particulares, anteriores todas a la Guerra Civil-, con documentos de archivo que las describen y, lo que es más importante, con restos originales todavía

116 Zaragozá Catalan, Arturo (2000): Arquitectura gótica valenciana, Generalitat Valenciana Conselleria de Cultura Educació,Direcció General de Promoció Cultural i Patrimoni Artístic. Valencia, pág. 198-199.

117 Decreto 571/63 del 14 de Marzo B.O.E. del 30/3/63.

118 Diputació de Castelló (2015) : La Diputación pone en valor Els Peirons del norte de la provincia como símbolo cultural y art'sitico, Blog Castellón, 17-03-2015. significativos. Esta amplísima memoria gráfica, junto a los restos que quedan, asombra por la riqueza artística de estas piezas. En la actualidad se encuentran protegidos por ley desde $1963^{117}$.

En el marco de las consideraciones anteriores es necesario reseñar que en la provincia de Castellón de la Plana, sus poblaciones -Ares, Atseneta del Maestrat, Bensasal, Castellfort, Catí, Cinctorres, Forcall, Herbés, La Mata, Morella, Olocau del Rey, Ortells, Palanques, Portell, Tolodella, Vilafranca y Zorita ${ }^{118}$ contaron en su momento con numerosos peirons, y hasta principios del siglo XX han formado parte del paisaje rural $\mathrm{y}$ urbano; aunque en la actualidad los restos de aquella rica herencia son muy escasos. 


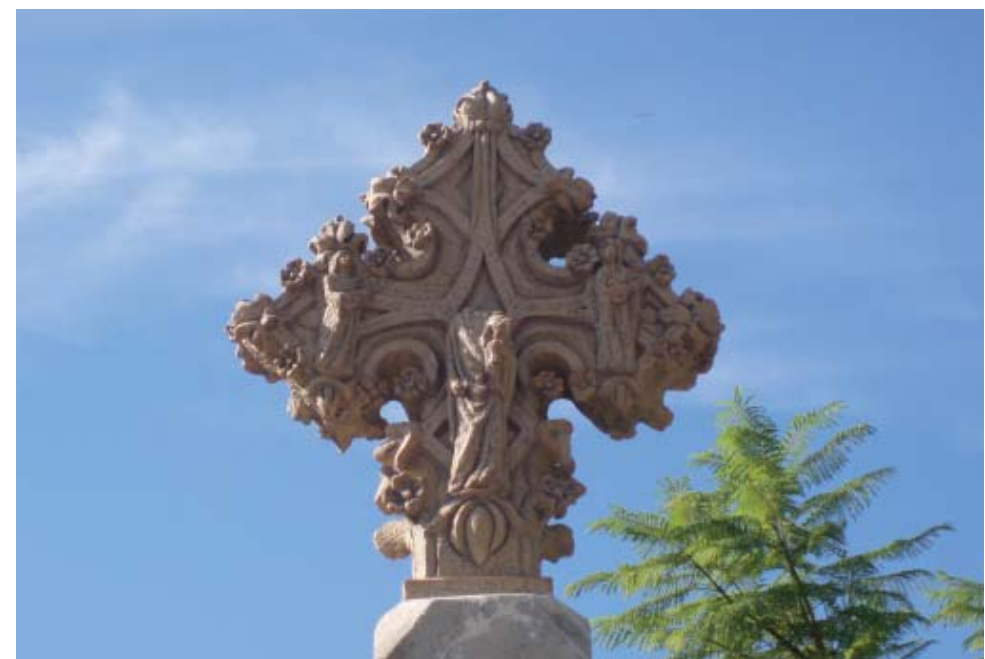

Para ejemplificar tales consideraciones se procede a enumerar la existencia de estos bienes entre los municipios estudiados. El primero de estos monumentos se encuentra en Almenara en dirección a Castellón (hoy la antigua N-340), al lado de una era, ahora integrada en la zona ajardinada del recinto del centro de la tercera edad en la Plaza de la Constitución. Denominado popularmente como la Creueta de Almenara, no se conoce el nombre de su escultor al no existir de documentos de contratación.

Su base está compuesta por cuatro hiladas de piedras. Sobre tres gradas circulares asienta la voluminosa base también circular de la que arranca la octogonal caña. La primera grada está formada por 17 piezas, la segunda por 11 y la tercera por 8 , todas ellas de piedras calcárea. La columna octogonal se encuentra compuesta de tres tramos. Asimismo la cruz cuenta con unas dimensiones lineales de $75 \mathrm{~cm}$ de alto por $60 \mathrm{~cm}$ de ancho. Para finalizar esta descripción, el capitel, su forma es de poliedro hexagonal.

De igual manera que las anteriores fue destruida en el año 1936, pero levantada y reconstruida al final del 1936, sin la cruz original y la falta de un tramo aproximadamente de $35 \mathrm{~cm}$. Fue en ese momento cuando se insertó una cruz de hierro forjada. La reconstrucción del soporte se realizó en gres artístico de alta cocción, a mano y decorada con colores naturales ${ }^{119}$.

La siguiente se halla en el municipio de Vila-real, la cruz de Aliaga se remonta a comienzos del siglo XV, cuando debía de estar confeccionada en madera, pero la erección definitiva en
Fig. 058. Detalle de la cruz del peiró de Almenara. Zona del capitel. 


\begin{tabular}{|c|c|c|c|c|}
\hline & Municipio & Emita arcos diafragma & Iglesias de Bóvedas de & Peiró \\
\hline \multirow{6}{*}{ 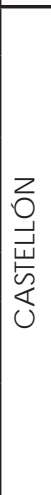 } & Vinaroz & Virgen de la Miseric ordia & Virgen de la Asunción & $\begin{array}{ll}--- \\
---\end{array}$ \\
\hline & Castellón & $\begin{array}{c}\text { Basilica del Lledo en } \\
\text { origen }\end{array}$ & Catedral de Santa María & $\mathrm{Si}$ \\
\hline & Vila-real & $\begin{array}{c}1383 \text { doc.,entrada. S.XVI } \\
\text { la actual emita Virgen } \\
\text { de gracia }\end{array}$ & $\begin{array}{c}\text { Nuestra Señora de } \\
\text { Gracia }\end{array}$ & $\mathrm{Si}$ \\
\hline & Mascarell & Font Santa & Santa Catarina & $\begin{array}{c}--- \\
\end{array}$ \\
\hline & Nules & Ermita de San Miguel & $\begin{array}{c}\text { San Bartolome y San } \\
\text { Jaime }\end{array}$ & $\begin{array}{c}--- \\
-\cdots\end{array}$ \\
\hline & Almenara & $\begin{array}{c}\text { San J uan, destruido } \\
\text { durante las guerras } \\
\text { carlistas }\end{array}$ & \begin{tabular}{|c|} 
Los santos J uanes en \\
origen, reconstruida 1738
\end{tabular} & $\mathrm{Si}$ \\
\hline \multirow{4}{*}{$\frac{\Xi}{U}$} & Puzol & $\begin{array}{l}\text { Virgen al pie de la cruz. } \\
\text { Reconstruida }\end{array}$ & Derribada en 1607 & $\mathrm{Si}$ \\
\hline & $\begin{array}{l}\text { La Pobla de } \\
\text { Vallbona }\end{array}$ & San Sebastián & Santiago Apóstol & --- \\
\hline & Cullera & Demumbada en 1614 & SantosJ uanes & --- \\
\hline & Gandía & Santa Ana & Santa Mańa & $\begin{array}{c}\mathrm{Si}, \\
\text { desaparecida }\end{array}$ \\
\hline \multirow{4}{*}{ 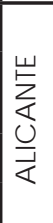 } & Cocentaina & Santa Bárbara & Santa Maŕa & 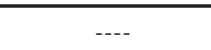 \\
\hline & Penáguila & $\begin{array}{c}\text { San Roque y la del } \\
\text { Calvario }\end{array}$ & Reconstruida en el S.XVIII & $\begin{array}{c}--- \\
\end{array}$ \\
\hline & Alcoy & San Antonio Abad & Santa Mańa & $\mathrm{Si}$ \\
\hline & Teulada & Font Santa & Santa Catarina & $\begin{array}{ll}--- \\
-\cdots\end{array}$ \\
\hline
\end{tabular}

Tabla 7: Arquitectura religiosa medieval documentada en cada uno de los municipios estudiados de la Comunidad Valenciana 
piedra data de los años 1441-1456. Otras cruces de término, de Vila-real, fueron la existente en el camino de la ermita, renovada repetidamente desde la primitiva de madera, rehecha en piedra en 1583, hasta la diseñada en bronce por el escultor Pere Gil que se muestra en la actualidad; o la del convento del Roser, ya mencionada de 1421, y obra del pedrapiquer de Alcañiz Agustín Ciruelo, bellamente decorada en estilo gótico con las figuras de Sant Jaume, Santa Bàrbara, Sant Miquely Sant Pere y cuatro ángeles con escudos en las manos con las armas reales, desgraciadamente desaparecida durante la guerra civil ${ }^{120}$.

Puzol también cuenta con una de estos simbólicos bienes. Fue erigida en un primer momento a las afueras de la población, más concretamente en la parte norte del barrio Hostalets, emplazada a la entrada de un camino que conducía al convento de La Vall de Chesus, sitio al pie del Monte Picaio. Se la reconocía con el nombre de "La Cruz de Piedra" y parece ser que data de los siglos XV-XVI. La memoria popular recuerda que era muy venerada y que existía la costumbre de visitarla en vísperas del 6 de enero, llevando cascabelearías, con la intención de pedir a los reyes; hasta que finalmente en época de adversidad fue destrozada. Una persona de quien sólo se conoce la inicial de su nombre grabó un escrito que fue difundido por Radio Nacional. Este escrito fue impreso en 1941 y posteriormente repartido en la cabalgata de los festeros de ese mismo año, lo que instó a las autoridades a iniciar la reconstrucción de la cruz en 1947, pero con la diferencia, de que ahora se emplazaría en el camino del cementerio.

También queda documentado un peiró en el municipio de Gandía, aunque hoy está desaparecido. Si se conoce la imagen del capitel que tenía los escudos del Consejo de la ciudad y de Juan II, antes de ser éste rey de Aragón, siendo príncipe de Viana y duque de Gandía ${ }^{121}$. Una vez hubo desaparecido el soporte la pieza superior fue recogida del suelo a trozos el año 1912 y conservada durante un tiempo en el Museo del Palacio Ducal. Cabe señalar que se conserva una reproducción en la Guía del P. León.

Finalmente, Alcoy, que cuenta con su cruz de término delante de la ermita de San Roc al igual que el municipio de Castellón la tiene delante del oratorio del Lledó. Como único testimonio de la antigua ermita de Cocentaina se expone en la capilla la cruz gótica tallada en piedra del siglo XV, así como una réplica en la plaza del convento. La original se encuentra ubicada en la actualidad en el cementerio municipal.
${ }^{120}$ Garcia Maiques, R:
"El concepto icónico
de san Francisco de
Borja elaborado por
los jesuitas a partir
de la adquisición del
palacio ducal de Gan-
día". Universidad de
Valencia.
121 Ibídem. 
A manera de resumen final se puede dictar que todas ellas presentan formas y tamaños diferentes pero coinciden en su ubicación extramuros y delante de las ermitas anteriormente expuestas. Muchos peirons fueron reconstruidas de un modo diferente al original después de la guerra de la Independencia o la guerra civil, otros se encuentran documentadas pero nunca se volvieron a construir, y seguro que hubo otros de las que nunca se sabrá de su existencia.

\subsection{6| Toponimia}

El diccionario de la Real Academia Española define como toponimia:

Estudio del origen y significación de los nombres propios de lugar.

La Enciclopedia de los topónimos españoles completa la anterior definición:
Es una disciplina de la onomástica que consiste en el estudio etimológico de los nombres propios de un lugar. El término "toponimia» deriva etimológicamente del griego tóros (tópos, «lugar»)

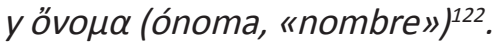

Desde el punto de vista etnológico, el estudio toponímico resulta de vital importancia para poder recuperar los nombres originales de un determinado lugar. Pero desde el punto de vista urbanístico es necesario para ubicar correctamente la situación de las distintas calles de los municipios vista la gran cantidad de coincidencias encontradas. De todo esto se desprende la trascendencia del presente apartado.

En primer lugar se debe analizar la denominación de cada uno de los municipios. Como se vio al principio de este capítulo los núcleos de población fundados por los cristianos después de la reconquista sustituyen normalmente a formas de poblamiento menores, más dispersas y menos densas, como lo son las alquerías. Allí donde se crea una pobla, las alquerías desaparecen

122 Albaiges Olibart, J.M.(1998): Enciclopedia de los topónimos españoles, Barcelona, Planeta, pág 5. o su número disminuye de forma ostensible, mientras el antiguo castillo andalusí (hisn), localizado invariablemente en lugares elevados, queda abandonado o reducido a funciones subalternas, ya que la propia puebla fortificada cumple los cometidos de 

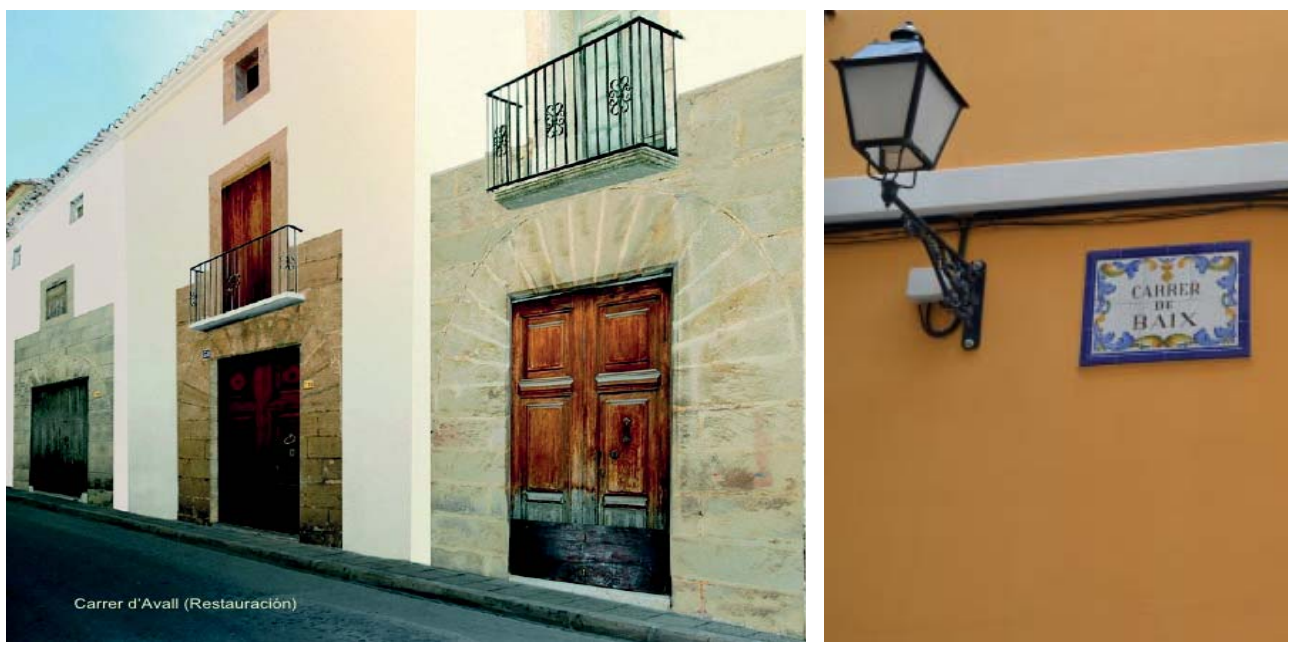

defensa y sede administrativa que antes le eran propios. Eso sí, aunque el hisn deje de constituir el referente topográfico del territorio local, su nombre es heredado casi siempre por la villa suplantadora, y así permanece.

Por este motivo son tan extrañas las invenciones onomásticas, como la de Vila-real, que relacionan expresamente los asentamientos con la sociedad avenida que los crea sin hacer referencia al castillo del que depende. La novedad viene subrayada por el propio topónimo, acuñado para la ocasión, aunque no se trata, en absoluto, de una práctica frecuente. Lo normal es que las fundaciones nuevas mantengan el nombre del hisn en cuyo territorio se implantan. Las villas, en efecto, no se conciben únicamente en su calidad de núcleos urbanos (poblas), sino también como unidades territoriales delimitadas con precisión, al igual que los castra (castillos con término). Si Vila-real adopta un nombre inédito es porque su término se constituye como una segregación del distrito original de Borriana, no tanto para resaltar lo novedoso de su planificación urbana. Cabe destacar que en los primeros documentos fechados en el año 1269 la villa aparece denominada como la Pobla de Vila-real ${ }^{123}$, dejando constancia de que su origen como pobla valenciana, aunque sin hacer referencia al castillo del que depende.

Ante la situación planteada se puede afirmar que las poblas de nueva planta se llaman, pues, como los antiguos husûn andalusíes, pero no se ubican en su emplazamiento. La Pobla de Pego, La Pobla de Nules o La Pobla de Pusso/24. Actualmente la gran mayoría de estos pueblos han cambiado el nombre
Fig. 059. Calle denominda d'Avall situada en Teulada.

Fig. 060. La rúa de Baix del municipio de Cullera. El topónimo se mantiene en el presente.

${ }^{123} \mathrm{Gil}$ Vicent, V. (2008) : "El Paisatge de Vila-Real al temps de Jaume I". Arquitectura any zero,, Museu de Belles Arts de Castelló, Generalitat Valenciana, pág 100.

${ }^{124}$ Torro, J.(2012): "La conquista del reino de Valencia. Un proceso de colonización medieval desde la arqueología del territorio". Centro de estudios Medievales. Murcia, pág. 16. 
Fig. 061. Calle de Dalt del municipio de Teulada. En este vial aún se conserva el topónimo medieval.

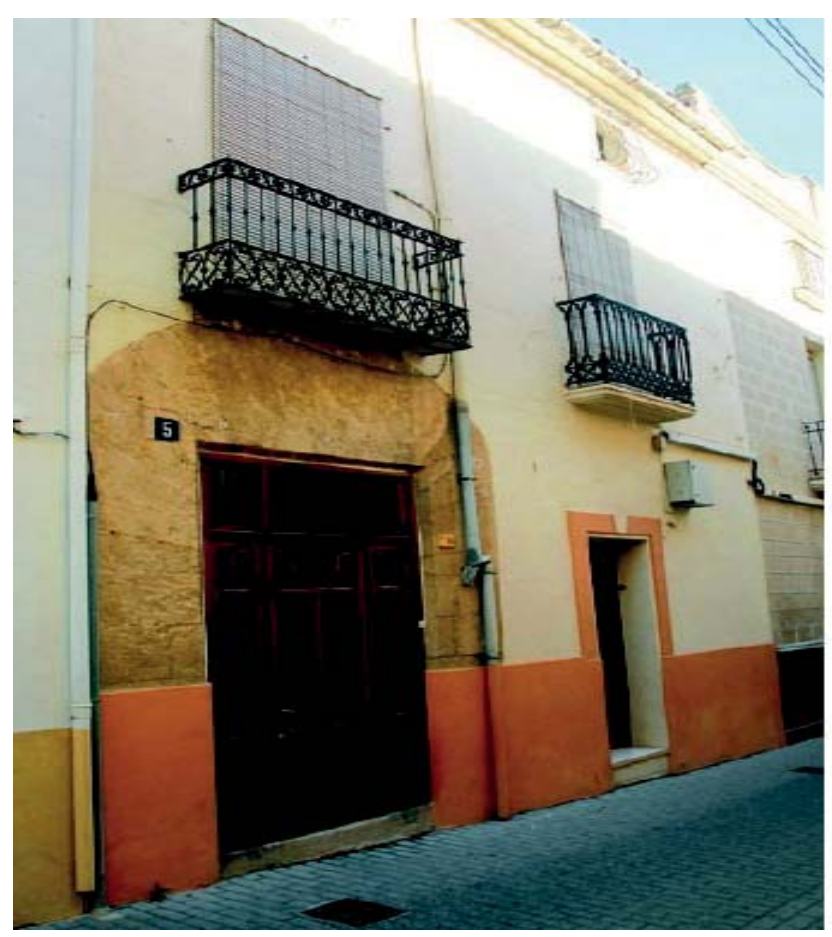

del hisn que hacía referencia o han eliminado la referencia a la pobla.

Es evidente que siguiendo un orden decreciente, una vez analizado el nombre del lugar al que hace referencia procede analizar el callejero de cada uno de estos municipios. En primer lugar, siguiendo el esquema marcado en el apartado dedicado a los viales, los ejes principales. Queda demostrado que la calle de mayor ancho y el eje longitudinal de la población siempre era denominado como el carrer Major, en cambio no se encuentra para el eje transversal una toponimia similar en las diferentes villas. Paralelas a uno de los ejes principales aparece un grupo de rúas secundarias que toman el nombre según su situación con referencia al carrer Major. De este modo se encuentra al norte de este, el carrer d'Enimg o carrer Mitjà, el primer topónimo hace referencia a que se encuentra en el medio del carrer Major y del carrer de Dalt. En este caso, la segunda denominación puede llevarnos a pensar que es la calle que cuenta con el ancho intermedio con referencia a todas las demás. Al norte del carrer Mitjà, se encuentra, en las villas estudiadas, el carrer de Dalt o d'Amunt y por último el vial paralelo al carrer Major pero situado al sur de este, el carrer d'Avall. En algunos casos estos nombres no son los que están en vigor en la actualidad, pero se mantienen en el imaginario colectivo, coloquialmente, por sus 
moradores. Por citar algunos ejemplos se pueden hallar todavía en Cullera, Vila-real, Castellón, Almenara y Teulada.

A continuación procede analizar las denominaciones de las calles perpendiculares al carrer Major, las paralelas al eje transversal. Estas travesías son las de menor importancia, reciben el nombre en su gran mayoría de santos. Es conveniente precisar que estas poblaciones valencianas, cristianas y dependientes de una economía básicamente agraria, el culto mariano se entremezclaba con la devoción a los santos patrones de la agricultura. Una de las devociones medievales más antiguas es la otorgada a los Santos de la Piedra, San Abdón y San Sénen y de forma colateral a San Gil Abad, como defensores de las tormentas veraniegas, de la lluvia y el granizo que podían perjudicar las cosechas y con ello el trabajo de todo un año. Los animales estaban protegidos por San Antonio Abad, venerado en tierras Valencianas como Sant Antoni del Porquet por ser patrón de las bestias ${ }^{125}$.

Después de lo anterior expuesto es comprensible que les dieran a las calles los seudónimos de aquellas figuras que para ellos eran de vital importancia. Así se repite la misma denominación de una travesía en los municipios de Cullera, Vinaroz, Gandia, Mascarell y Penáguila, la calle San Roc. También se encuentra en las villas de Mascarell y Nules, la calle San Antonio y la calle San Sebastián en el parcelario de Cullera y la Pobla de Vallbona. La calle San Juan se puede ubicar en los núcleos de Puzol, Vinaroz y Gandia, y para finalizar la calle Sant Pere que se sitúa en Puzol, Vila-real y Almenara.

Para concluir ese apartado, el último apelativo, el cual hace referencia a una zona del patrimonio arquitectónico defensivo, el foso. Aquellos municipios donde alrededor de la cerca contaban con la citada excavación, lo solían denominar como el Vall o Valladar. En los municipios analizados ya no se observa esta concavidad, pero todos ellos cuentan con un espacio ya fuera de extramuros que se conoce popularmente por este alias. Para ejemplificar este dato, se puede hallar este topónimo en el municipio de Castellón, incluso en Vila-real a una de las calles le han puesto este nombre.
${ }^{125}$ Alba Pagab, Éster
y otros (2011): La
Pobla de Vallbona,
Historia, Geografía y
Arte, Universidad de
Valencia, Facultada
de Geografía i
Historia. La Pobla de
Vallbona, pág. 347. 
$\mathbf{1 3 6}$ de 536

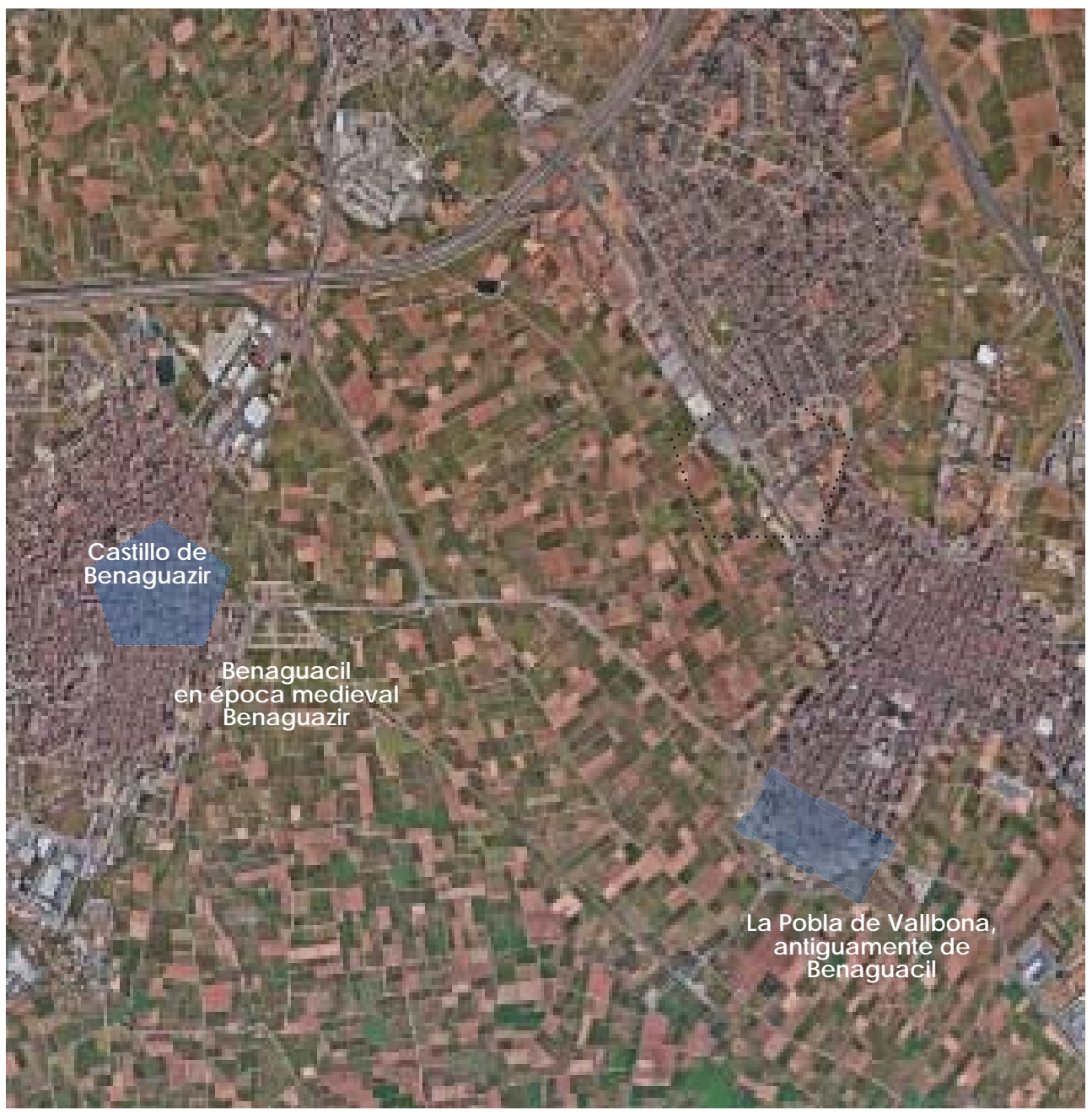

Núcleos histónicos 
Fig. 062. Fotografía aérea de los términos de La Pobla de Vallbona y de Benaguacil. Se ubica el castillo de Benaguazir y la distancia a la que se formó el nuevo de población cristiano, en un valle a apenas dos $\mathrm{km}$ de distancia del castillo del que dependía.

\section{APITLO V|}

\section{LA POBLA DE VAUBONA; LA POBLA DE BENAGUAZR}

\section{1| Antecedentes}

Una vez analizadas las características de varias poblas medievales de la Comunidad Valenciana, se procede a estudiar una de ellas con mayor profundidad, La Pobla de Vallbona, en la edad media conocida como La Pobla de Benaguazir, puesto que la nueva población tomó el nombre del hisn al que pertenecía el castillo que les daba protección, Beneguazir ${ }^{126}$.

Durante la exposición se pretende demostrar que se enmarca completamente en el grupo de poblaciones que acabamos de analizar y cómo cumple cada una de las condiciones descritas anteriormente para sus coetáneas, documentando también los restos arquitectónicos que han Ilegado hasta nuestros días.

El esquema que se propone seguir se enmarca en la misma organización presentada en el capítulo anterior para analizar las pueblas de colonización aunque, a priori, se ha creído necesaria la documentación de los hechos históricos acontecidos en la zona para situar en el contexto la creación del municipio. El guión planteado se muestra a continuación.

\footnotetext{
${ }^{126}$ Se ha encontrado a lo largo de este estudio diferentes modos de denominar al municipio de Benaguacil, desde Benaguazir, Beneguazir, Benalgacir, Benagucil, Benagacil, Algacil. A partir de este apartado aparecerá siempre con el nombre que lleva en la actualidad Benaguacil, a no ser que se esté citando una cita histórica.
} 


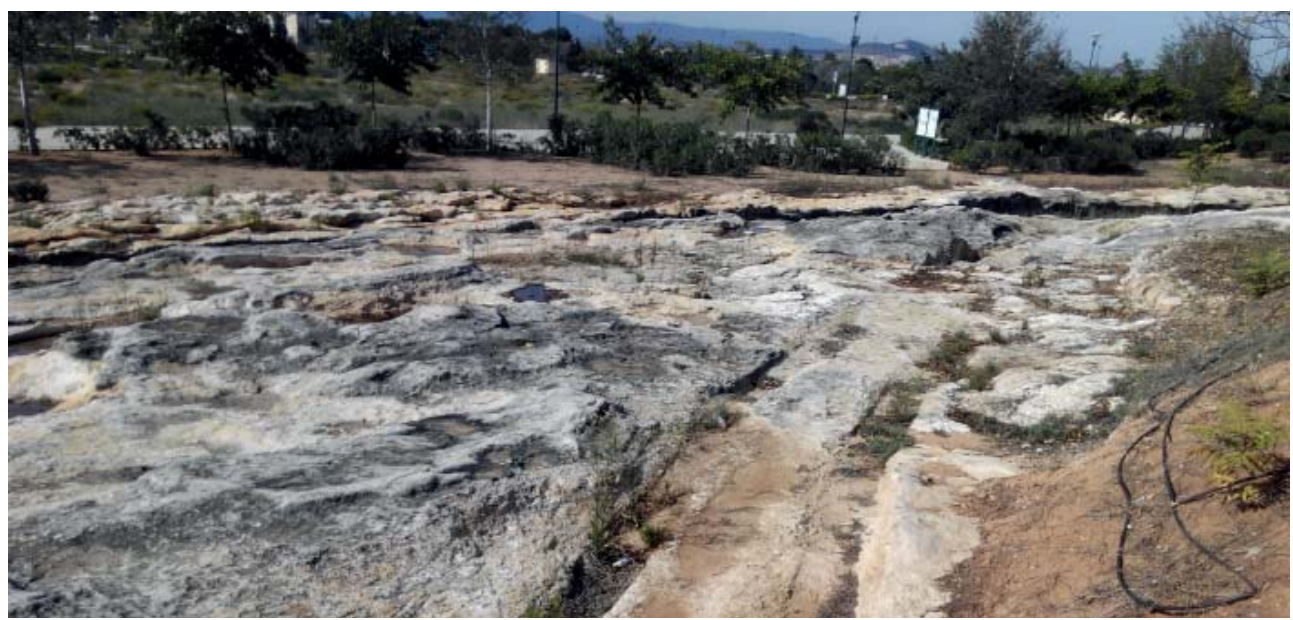

Fig. 063. Huellas de las carriladas del camino ibero existente en el término municipal de la Pobla de Vallbona.
-Acontecimientos históricos anteriores a la fundación del municipio

- Situación y fundación

o La organización social

o Dependencia religiosa, el monasterio de Porta-celi

- La parcelación de la tierra

o El regadío histórico

o Las tierras de secano

- Las trazas urbanas

o Cartografía

o Tamaño de la vila

o Viales

o Ordenación urbanística

- Elementos arquitectónicos

o La muralla

o E/ fossar medieval

o La plaza y su entorno

- Las galerías subterráneas

o Conventos o edificaciones civiles de órdenes religiosas

o Arquitectura religiosa

Ermita con arcos de diafragma

Iglesia con bóvedas de crucería

Peiró o cruz gótica

- Toponimia 


\section{2| Acontecimientos históricos anteriores a la fundación del municipio}

Los primeros asentamientos de los que se tiene noticia en el término municipal de La Pobla de Vallbona datan de la época romana, aunque existe de época de los iberos un yacimiento arqueológico que deja patente la ocupación de este territorio.

\section{Camino ibero de la Covatella}

La necesidad de comunicación entre los diferentes asentamientos humanos establecidos en un territorio crea las redes viarias. Los caminos organizan las sociedades dentro de un espacio, y su trazado a lo largo de la historia está condicionado por el medio físico, el marco políticoadministrativo, las necesidades del comercio y una economía favorable para realizar su construcción.

Durante la conquista romana las principales vías existentes ampliaron su recorrido y mejoraron su infraestructura, dando lugar a la Vía Augusta, camino que desde Roma llegaba hasta Cádiz, utilizada para el desplazamiento de militares, civiles y mercancías a lo largo del imperio. Algunos de estos viejos caminos perpetuaron su trazado a través del tiempo y fueron utilizados para el tránsito de pasajeros, el comercio o el paso de ganado. La cartografía histórica recoge el trazado del Camí de Llíria y la Vereda de Llíria a Valencia, que, a su paso por La Pobla de Vallbona, coincidiría con el antiguo camino ibérico que se encontraba en el conjunto arqueológico de la Covatella.

La vía Edeta-Valentia sale hacia Valencia desde la ladera de San Miguel, en donde estaba situada la antigua Edeta. A unos 300 $m$ de Llíria en dirección a Villamarxant aparece el Camino viejo de Valencia, llamado también 3, utilizado hoy en día para ir a Benaguacil, uniéndose, una vez pasado Benisanó, al camino que procedería de La Pobla de Vallbona. Ya en el término de esta última población, a unos $20 \mathrm{~m}$ de la carretera CV-35, poco antes de llegar al centro comercial, se observan unas carriladas, que tras las últimas excavaciones se han datado de época ibera puesto que el canal de La Covatella que cruza dicho camino corta estas carriladas. 
Fig. 064. Acueducto islámico de la Cova Tella. Aunque inicialmente se creía romano los arqueólogos no encontraron restos que lo acreditaran.

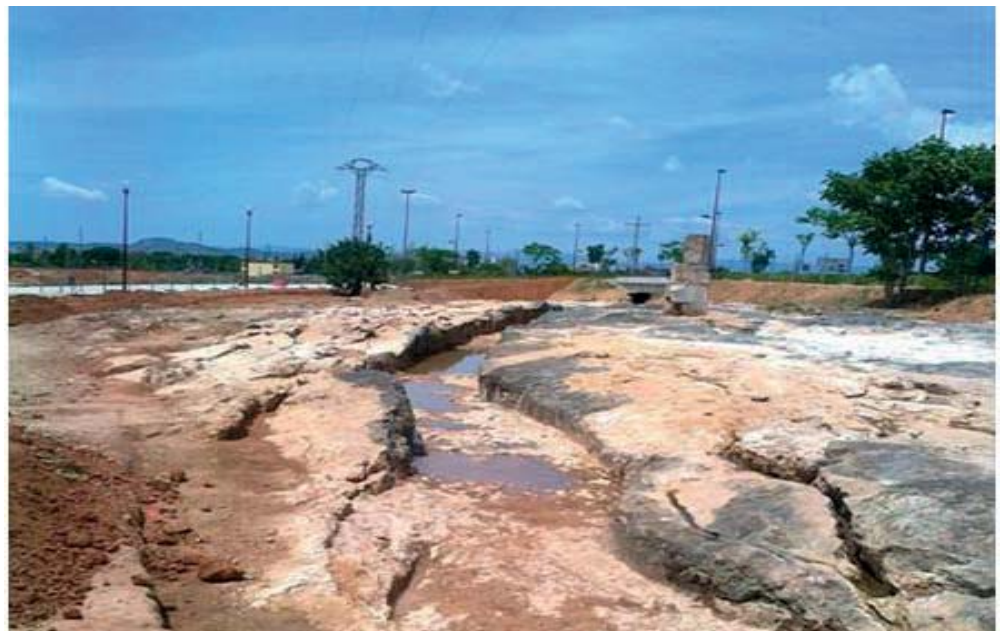

Pasando el centro comercial, el camino sigue paralelo y a veces coincidente con la anterior carretera, para llegar a San Antonio de Benagéber ${ }^{127}$.

El camino de La Covatella se conserva en un tramo de $68 \mathrm{~m}$, con un ancho de vía entre 1,90 y $2,00 \mathrm{~m}$, excavado en la roca natural. La intervención arqueológica realizada ha sacado a la luz numerosos vestigios que han proporcionado una valiosa información para el conocimiento de los usos y costumbres empleados en el transporte de esta época. Únicamente a través de la iconografía ibera se conocía el aspecto y la tipología de los vehículos utilizados en esta época aunque hasta hoy se echa en falta un análisis de estos elementos en función de las huellas de uso marcadas en los caminos. A través del estudio de este tramo de camino se han obtenido numerosos datos referidos a los usos habituales de esta vía de comunicación ${ }^{128}$.

\footnotetext{
${ }^{127}$ Pérez Minguez, R. (2006): "Aspectos del Aspectos del mundo rural romano en el territorio comprendido entre los ríos Turia y $\mathrm{Pa}$ lancia "Servicio de investigación prehistórica. Diputación de Valencia. Tesis doctoral, pág. 44.

${ }^{128}$ Martínez García, R. y otros (2011): "Tríptico conjunto arqueológico La Cova Tella". Ayuntamiento de La Pobla de Vallbona. Concejalía de Patrimonio.
}

Estudiando su recorrido se ha podido establecer que la circulación vendría dada para un sólo vehículo, contando con un arrimadero para facilitar el cruce en el caso de encontrarse más de un carruaje en su tránsito. La fuerte pendiente del camino en un punto de este tramo, $42 \%$, ha ocasionado en su firme profundos surcos dejados por las ruedas de los carruajes en las carriladas, además de diversas hendiduras en la base del camino, coincidentes donde las rodaduras eran más profundas, debido al ímpetu de los vehículos al alcanzar este punto. También para salvar esta accidentada cuesta se empleó trancas encastradas en sendos orificios localizados a ambos lados del camino. Asimismo, otros vestigios visibles en la roca que constituyen los márgenes del camino son los producidos por el roce de los ejes de la ruedas a su paso. Todas estas improntas sobre la roca han permitido, 
mediante el estudio detallado que proporciona la metodología arqueológica, obtener numerosos datos respecto a los vehículos que habitualmente frecuentaban este camino, como son las dimensiones de los carros, el diámetro de las ruedas, además de la existencia de un servicio de mantenimiento del camino a fin de evitar el deterioro producido por su constante circulación. Con el paso del tiempo el camino entró en desuso a causa de los cambios sociales determinados por los nuevos ciclos históricos. No obstante, este devenir determinó que su traza se recuperara, siendo coincidente con la Vereda de Llíria a Valencia, a su paso por la Pobla de Vallbona, según aparece en el plano catastral de 1928.

\section{Canal de riego: El Canal de la Covatella}

Tradicionalmente se ha estimado que el origen de este canal pudiera ser de construcción romana, sin embargo un estudio pormenorizado del elemento y los datos arqueológicos obtenidos han determinado su adscripción cronológica a otro período histórico, pudiéndose encuadrar su construcción, presumiblemente, en época islámica. Cabe señalar que se conserva un tramo de $92 \mathrm{~m}$, con una anchura de cajero de 1,95 $\mathrm{m}$ y $0,57 \mathrm{~m}$ de profundidad media, con una pendiente inversa en su parte final, donde también el cajero adquiere mayor anchura. Esta particularidad permite que el agua se amanse y se pierda lentamente a fin de evitar la erosión sobre el campo al que iba a desaguar. Las características del tramo de canal localizado en la Covatella no permiten establecer que éste fuera empleado para el abastecimiento de un núcleo urbano, ya que su cajero, de poco calado, y su terminal difuso, indican que correspondería al tramo final de un sistema hidráulico empleado para el riego. La Covatella está situada en la partida denominada Seca de Blanes, donde previo a la transformación agrícola a favor del cultivo de cítricos prevalecían los cultivos de secano. Además la partida al oeste se denomina Cap de l'Horta, por donde pasan las acequias del Alguacily del Campés, que sí son de regadío ${ }^{129}$.

En el plano catastral de 1928 aparece en este lugar una casa en ruinas y un pozo, vestigios de lo que pudo ser un molino, por donde pasaba una acequia. El extremo que aquí se localiza permitiría derivar el agua antes de llegar al molino, evitando así su afección ante una gran avenida. 
Fig. 065. Fachada de una posible villa romana conocida como el Más de Tous según estudios comarcales relacionados con aspectos del mundo rural romano en el territorio.

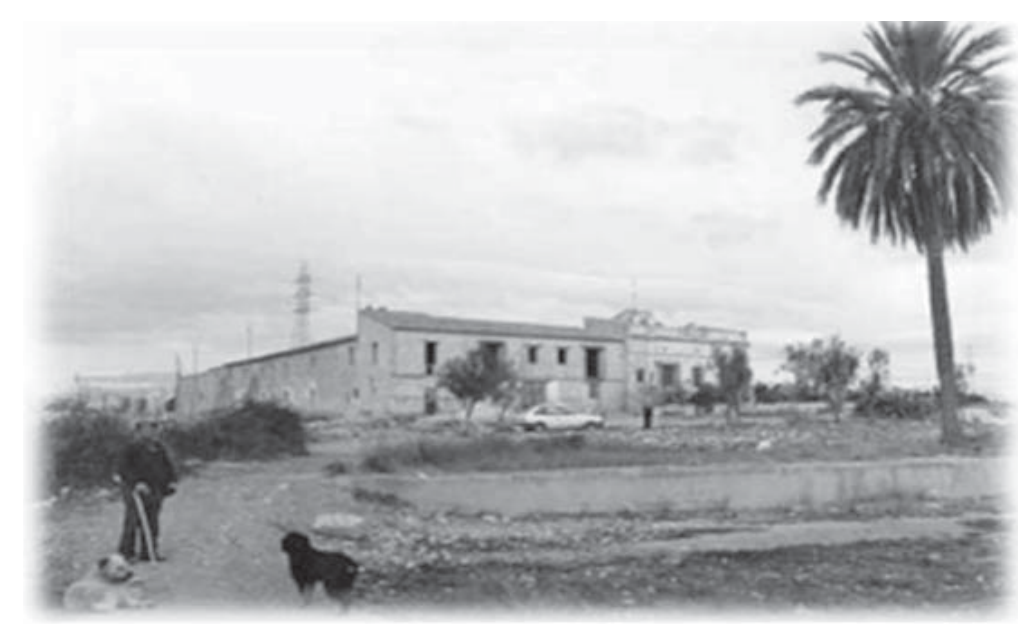

La Diputación de Valencia publicó en el año 2006 una serie de trabajos de investigación, entre ellos el realizado por el servicio de investigación del Museu Valencià de Prehistoria, donde recoge información sobre las villas romanas existentes en el municipio que se está analizando.

Estos 4 asentamientos romanos comunicaban a lo largo de la vía Valentia-Edeta con Llíria (la antigua Edeta) y ellas son: El Camp del Castellet, el Más de Tous-Villa Flora, la Casilla de los peones camineros y la Rascaña. Las conclusiones indican que podían ser villas romanas dispersas. Las características de cada una de ellas se describen a continuación.

\section{Camp del castellet}

a) Situación: en el ángulo que forma la vereda que procede del Más de Tous con la vía de ferrocarril de vía estrecha, ValenciaLlíria; a unos $800 \mathrm{~m}$ antes de llegar a la estación. Está situada a unos 90 m.s.n.m ${ }^{130}$ y en zona de cultivo. Coordenadas: 39 ㅇ $34^{\prime} 40^{\prime \prime}$ Lat. N y 0 o 33'10".

b) Material encontrado: Cerámica común romana y teguale.

${ }^{130}$ Metros situados sobre el nivel del mar.

${ }^{131}$ Pérez Minguez, R. (2006): "Aspectos del Aspectos del mundo rural romano en el territorio comprendido entre los ríos Turia y Palancia "Servicio de investigación prehistórica. Diputación de Valencia. Tesis doctoral. Pág. 73. Señales evidentes de una balsa y posibles conducciones de agua o secciones de acueducto. Cronología: siglos I-II dC.

c) Conclusiones: Villa completamente arrasada por los trabajos agrícolas. En la actualidad, es imposible saber si se trataba de un único asentamiento o de varios establecimientos menores ya que aparece transformado y el material muy escaso ${ }^{131}$. 


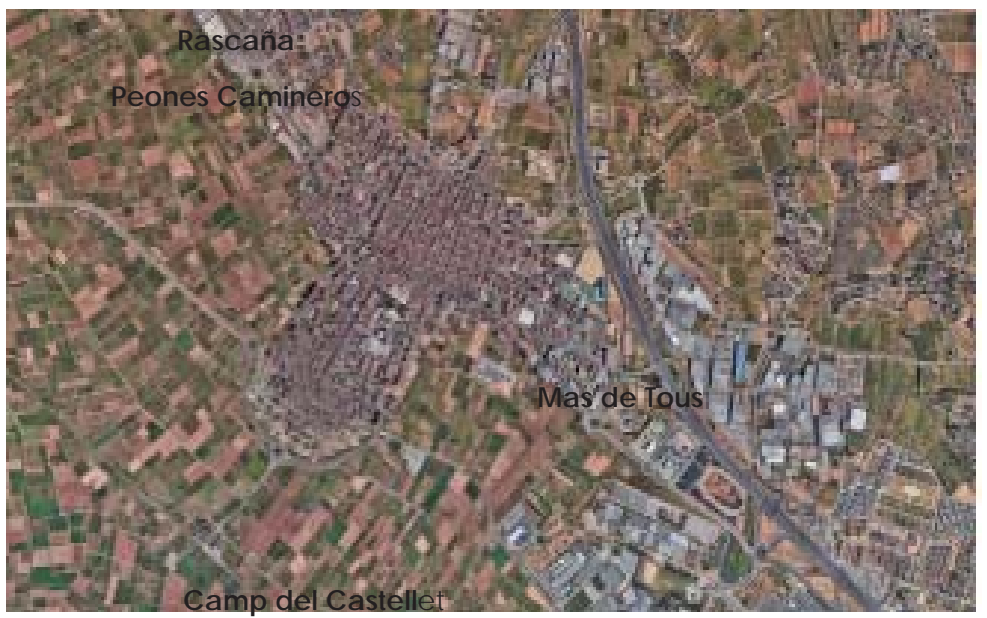

Más de Tous- Villa Flora

a) Situación: Junto al Barranquet de Pepetón. A unos 90

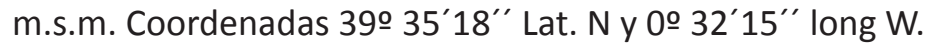

b) Material encontrado: canal-acueducto; en su fondo se hallaron dos ánforas Dressel, una de ellas con restos anforiscos. Muchos restos cerámicos y líticos: sillares, muelas, terra sigillata, tegulae y dolia ${ }^{132}$.

c) Cronología: siglos I-II d.C.

Casilla de los Peones Camineros

a) Situación: En la partida de Rascanya junto al Km.. 21,300 de la carretera Valencia-Ademúz, a espaldas de la casilla de peones camineros. Rodeado de naranjos, a una altura de unos 110 m.s.n.m y hoy convertido en una urbanización de viviendas unifamiliares aisladas.

b) Material encontrado: Restos de construcción y muros semienterrados. Existió un viejo pozo. Fragmento de terra sigillata. Restos de construcciones y muros. Ímbrices, lateres y canal hidráulico.

c) Cronología: siglos I-IV dC ${ }^{133}$.

\section{Rascanya}

a) Situación: Junto a la carretera de Valencia a Ademúz en el Km.. 20, en el límite del término de Benisanó. Está a unos 140 m.s.n.m.

b) Material: Fragmentos de terra sigillata hispánica de un vaso de forma 29; fragmentos de vasos también hispánicos, cerámica común romana, pondus, un ladrillo romboide.
Fig. 066. Vista aérea del municipio de La Pobla de Vallbona en la actualidad situando las villas romanas de las que se tiene conocimiento.
${ }^{132}$ Traducción del latín al castellano: Tierra de sílice, azulejos y barricas.

${ }^{133}$ Pérez Minguez, R. (2006): "Aspectos del Aspectos del mundo rural romano en el territorio comprendido entre los ríos Turia y Palancia "Servicio de investigación prehistórica. Diputación de Valencia. Tesis doctoral, pág. 73. 


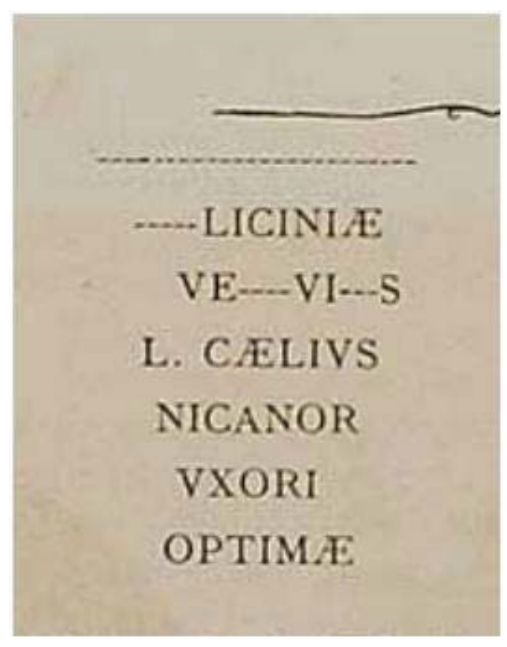

1) 3

(iR.ITTIAE C FILLE

CRININAE N XXIX

( A ECILIA ARTEMIS

FILIA PIISSIMAE ET

( (iRATTIO POLYNICO

ANNOR XX MARITO

() PTIMO ET SIBI
Fig.067. Lápida romana encontrado en La Pobla por Escolano. Década primera de la Historia de la Insigne Coronada Ciudad y Reyno de Valencia.

Fig.068.Inscripción de una piedra romana existente en el término municipal de la Pobla de Benaguazir, según Carlos Sarthou y no reproducido por Escolano.
Restos de paredes de antiguas construcciones. Una piedra troncocónica de basalto, con pilón central de otro tipo de piedra. Podría ser parte de un molino o lagar.

c) Cronología: Siglos I-II dC $\mathrm{C}^{134}$.

Todos estos yacimientos arqueológicos vienen a apoyar los datos facilitados en sus escritos por Gaspar Escolano, en su primer libro sobre la Historia de la Insigne y Coronada Ciudad y Reyno de Valencia, publicado en el año 1610. En este libro, se describe que en uno de sus viajes de Valencia a Edeta, paró a pernoctar en una pequeña villa denominada la Puebla de Benaguazir, y cuenta la siguiente historia ${ }^{135}$ :

En efte viage, luego al defalojarle Pompeio de fobre Xucar, dize Saluftio, que tuuo manera de faquear el real de Sertorio, que fe lo dexo defguarnecido de gente; porque viendo que Pompeio y Metello fe encaminaban a Laurona, el a paffo largo fe fue a meter a Valencia, receloso por ventura, que no le dieffen faco los enemigos, más ellos dexandolos a Mano Derecha, doblaron a la izquierda y hizieron alto en un pueblo, diftando una legua de Llíria, que agora Ilamanos la Puebla de Benaguazir. De cuy avenida de tegtimonio, fegun Beuter, una piedra grande que efta en aquel campo, que habla de Metello. Sertorio que tuuo lengua dellos, camino en fu demanda, y llegadoa darles vifta, les prefento la batalla, Ribera [...]. 
Escolano hace una mayor referencia al municipio de la Pobla de Vallbona y a la existencia de villas romanas en este término municipal, en el libro segundo donde en su capítulo XX habla del Monasterio de Porta-celi, indicando lo siguiente:

Después de Bétera, cargando hacia el río Turia de Valencia, muy acostados a su ribera, viene la Puebla de Benaguacil, Benaguacil y Benisanó. La Puebla, sabe á tiempo de romanos, por las piedras. De una de ellas hicimos mención en dicho libro; y ágora la hacemos de otra, que todavía permanece, aunque quebrada y comida muchas letras, en la forma siguiente:

Lucio Celio Nicanor, hizo esta estatua ó sepultura, a su buena mujer Licinia. Otros en el último renglón no leen Optima, sino Ortiniane, y venia ase sobrenombre de la Licinia: más va poco en ello.

También hace referencia a su población:

Las casas de este pueblo llegan á ciento y cincuenta de cristianos viejos ${ }^{125}$.

La referencia a la citada piedra se vuelve a documentar siglos después por Carlos Sarthou ${ }^{137}$ :

Beuter y Escolano hablan de una piedra grande, hallada en la Pobla de Benaguazir y mencionan a Metello; pero entre ambos se les pasó por alto copiar la inscripción. Escolano cita que una de ellas es romana hallada en esta población, pero que ya no pudo encontrar el príncipe Pío. En cambio vio la que cita Masdeu en su tomo XIX y es la que sigue:

Diis Manibus: Gratiae Caii filiae Crispiniae annorum vigintiet octo Gaecilia Artemis filiae pissimae et Caio Grattio Polymico annorum septuaguntu marito optimo el sibi138.

Fue copiada en la fachada y puerta del antiguo castillo feudal.
${ }^{136}$ Escolano, G. (1610)

r: Década primera de la Historia de la Insigne Coronada Ciudad y Reyno de Valencia. Valencia.

${ }^{137}$ Sarthou, C.(1922) : Geografía General del Reino de Valencia, Tomo II, Casa Editorial Alberto Martín, Barcelona.

138 Traducción: Por otra parte, Grace C. vigintiet hija de ocho años de edad, Crispiniae Cecilio Artemisa, hija de riña y Caio Grattio Polymico mejor marido, tenía setenta años. 


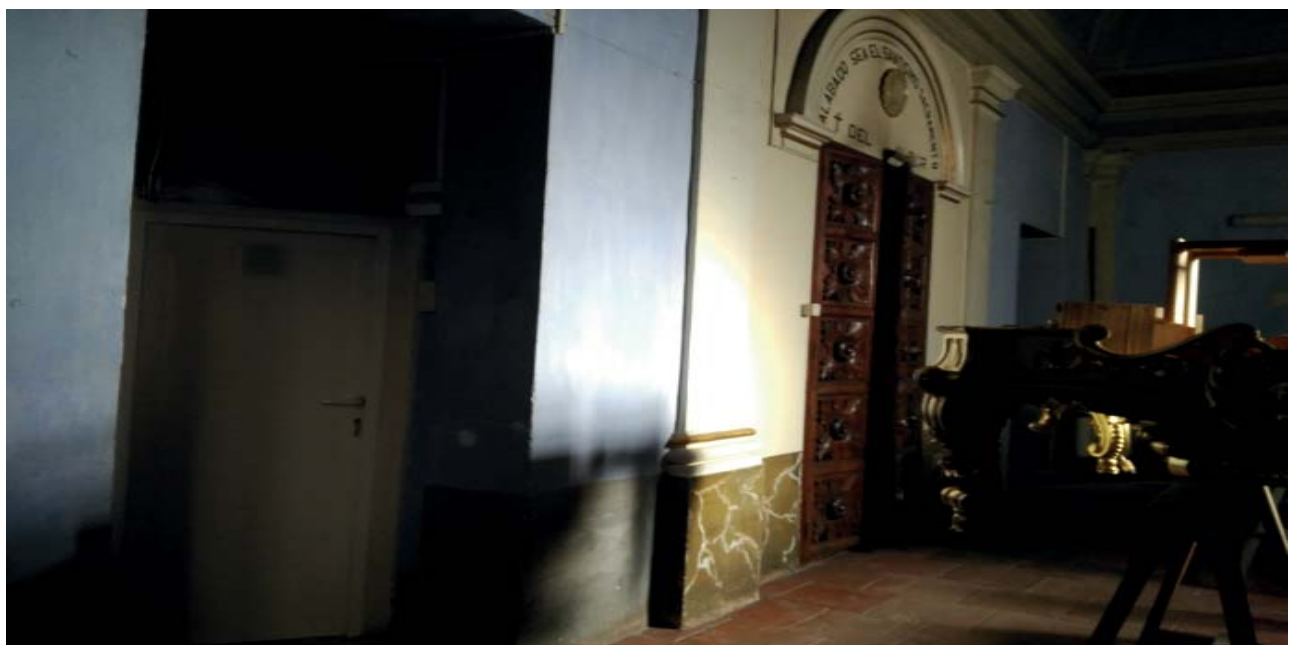

Fig. 069. Imagen en la actualidad de detrás del altar de la iglesia de San Jaime donde Pedro Sucías Aparicio indica que estaba ubicada la lápida romana en el año 1911.
139 Sucías Aparicio, P. (1911): Notas útiles del Reino de Valencia, Distritos de Onteniente y Liria, Tomo 7, Valencia, pág. 155.
La ubicación de la primera lápida romana a la que hace referencia a la sepultura de Licina se ubica según el canónigo Pedro Sucías Aparicio en la Iglesia de Santiago Apóstol, justo detrás del altar mayor:

Por dos lápidas del tiempo de los romanos encontradas en este pueblos que seguidamente copiamos se justifica la antigüedad del mismo... (Solo aparece copiada la primera)

\section{La traducción es "lucio Celio Niano hizo esta estatua o sepultura a su buena mujer Licina". Está lapida está en la iglesia detrás del altar mayor ${ }^{127}$.}

Después de lo anterior expuesto había que comprobar si actualmente en la zona descrita por Sucías Aparicio se encontraba depositada la citada piedra. Se acudió a la iglesia y se revisó toda la zona trasera del altar mayor del citado edificio con el fin de hallar la lápida indicada. Según se ha podido verificar este resto arqueológico de la edad romana no se encuentra detrás del altar de la Iglesia de San Jaime, siendo su ubicación totalmente desconocida.

Hechas las consideraciones anteriores, con estos datos, es evidente que hubo asentamientos, alquerías o villas desperdigadas por el actual término municipal de La Pobla de Vallbona (véase fig. 066), aunque el municipio como tal no se formó hasta la conquista de Valencia. Señalar que si se observa el plano de situación de las villas romanas conocidas en la actualidad y se compara con la situación del casco histórico, 


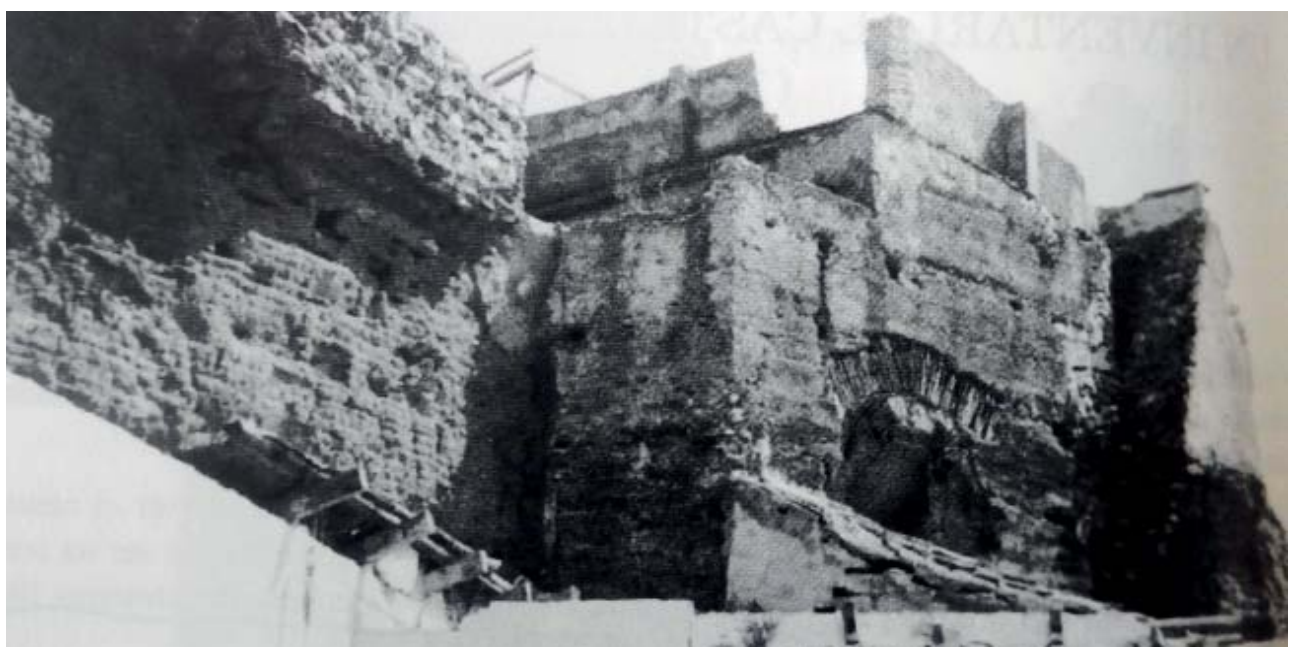

queda patente que ninguna de las villas coincide en ubicación con la situación del casco histórico medieval

\section{3| La fundación de la Pobla de Benaguazir. Situación y fundación}

La creación, organización y evolución política de la Pobla de Vallbona a lo largo de la baja Edad Media sólo puede entenderse en un contexto de profundas transformaciones.

El nacimiento de la Pobla de Vallbona tiene su origen en la ocupación de las tierras Valencianas por parte de las tropas cristianas. No obstante, la documentación generada por los feudales y que hace referencia a la conquista de las poblaciones de la comarca del Camp de Turia en la década de 1230 no menciona a la localidad objeto de este estudio. Gracias a la información que proporciona el Llibre del Repartiment, un registro documental que recoge las donaciones de bienes inmuebles realizadas por el monarca antes y poco después de la conquista efectiva de parte del territorio valenciano, se sabe que otras poblaciones y pequeñas unidades de población muy cercanas -Benaguacil, Benissanó, Llíria, entre las villas, y numerosas alquerías dispersas por el territorio- estaban habitadas por hispanomusulmanes.

La Pobla se ubicó en una zona del término de Benaguacil. Este municipio en tiempo de la reconquista, era ya un núcleo de población. Así aparece ya su nombre en el Llibre del
Fig. 070. Fachada del castillo islámico de Benaguacil antes de su derribo. 
Fig. 071. Plano de la comarca del Camp de Turia, donde se encuentra delimitado el territorio que estaba bajo el castiIlo de Benaguacil, en época medieval.
140 Jaume I: Llibre del Repartiment de Valencia. Universidad Jaume I - Arxiu virtual Jaume I. Traducción del latín al castellano en el anexo pág 360.

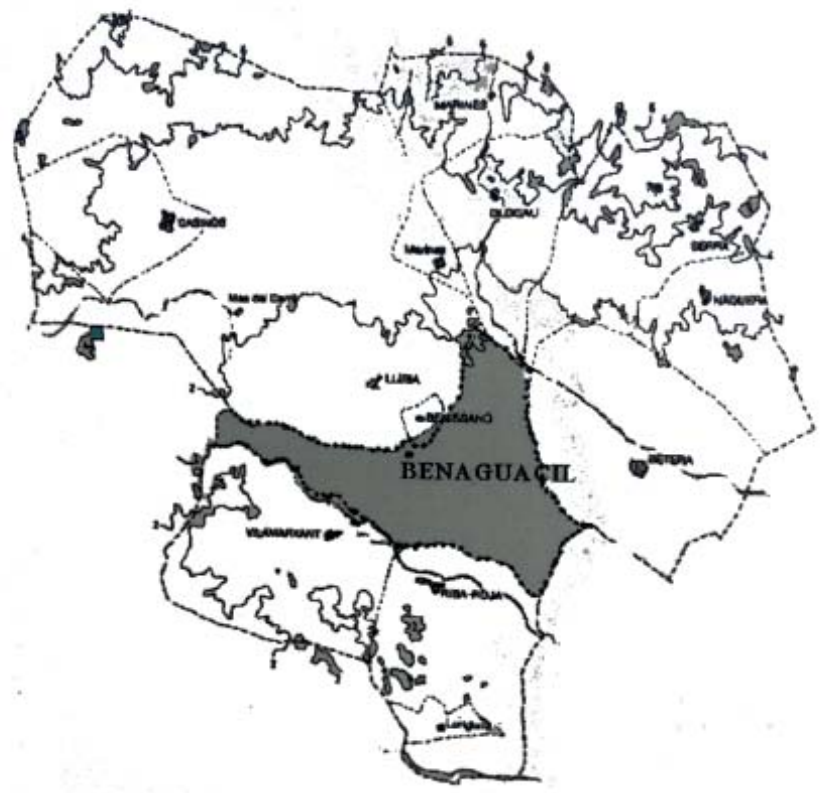

Repartiment, aunque con muchas variantes. Indistintamente se la llama: Benalguasil, Benalgasir, Benagazir, Beneguazir, Venalguazil y Venalizari.

Sin entrar en el estudio de como sería el territorio, pero transcribiendo las partidas que en el Llibre del Repartiment tienen relación con el citado municipio y su comarca, se observa que habla de la existencia de la villa de Benaguacil, su castillo y las masías de su término, l'alquería de Félix, la de l'Aldaya, la del Felx, l'aldea de Beniaro, junto a sus hornos y molino. Estas partidas de rústica aún existen en la actualidad y no coinciden ninguna con la partida donde se originó la Pobla de Vallbona.

[106] F. Deiç, castrum et villam de Venaliaçir. VIII kalendas januarii.

[121] Dominge Lupi de Ricla, alqueriam de Feilx que est inter Villam Merxant et Venalgaçir. II kalendas februarii. Miles.

[1227] Aceyt aboceyt, alqueriam de Addaya, iuxta Venalguasir, cum furnis et molendinis.

[2206] Ferradus Didaci, villam de Benalguazir et alqueriam de Felx, cum alde de Abenduf el locum de Beniaro ${ }^{140 .}$ 


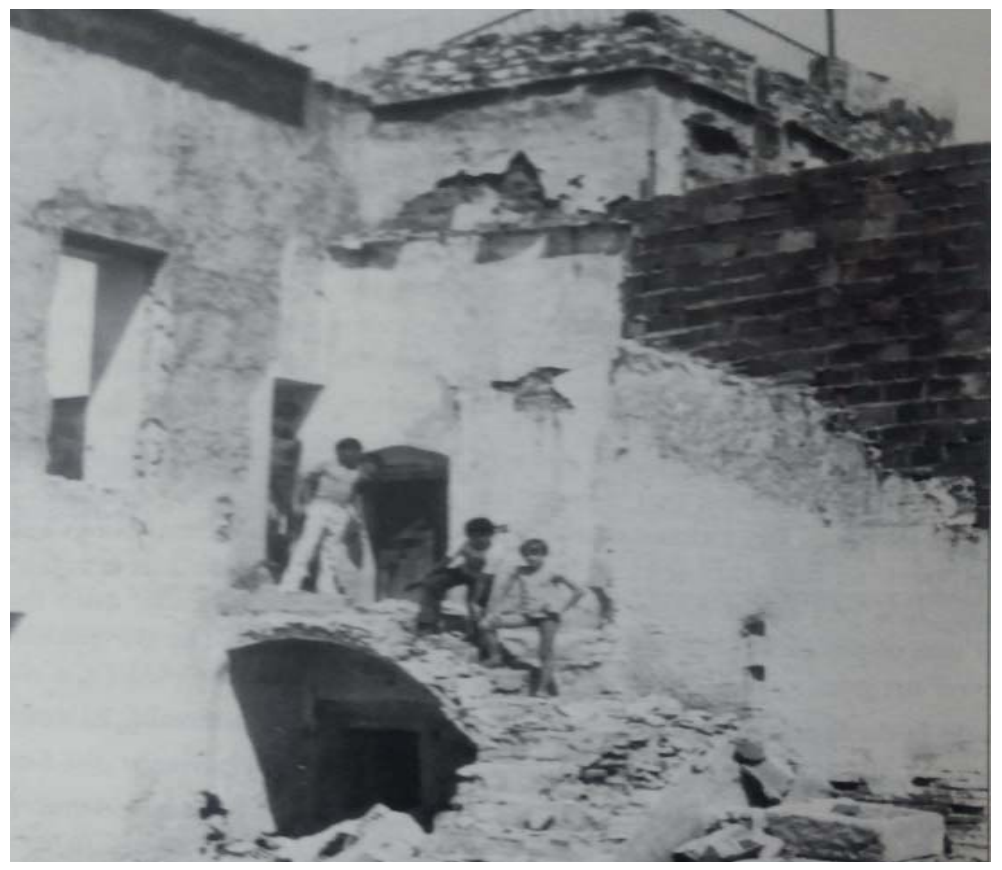

D. Francisco Fuster Serra ${ }^{141}$ investigador y escritor de la Cartuja de Porta-celi, Historia, vida, arquitectura y arte, durante una conferencia, afirmó que cuando estaba investigando en los archivos del monasterio en una de las reseñas especificaba que la Pobla se formó donde antiguamente había una pequeña alquería. Esta alquería no debió de tener mucha importancia puesto que no aparece nombrada en el Llibre del Repartiment, o simplemente sería un grupo muy reducido de edificaciones inferiores a un número de diez.

Según afirma Josep Torró142 las aglomeraciones fundadas por los cristianos sustituyeron normalmente a formas de poblamiento menores, más dispersas y menos densas, como son las alquerías. Se encuentra aquí la primera coincidencia puesto que los monjes reflejan en sus archivos la existencia de esta alquería en el llano donde se ubicó La Pobla de Benaguazir.

Antes de la conquista efectiva de la capital, el rey Jaume I comenzó a recompensar a diversos personajes, nobles y eclesiásticos en su mayoría, que le habían ayudado en la toma de la ciudad de Valencia, con tierras y rentas de diferente importancia según la categoría social, la relación que mantenían con la monarquía y la ayuda efectiva que habían ofrecido en la campaña militar valenciana. Es en este contexto cuando se produjo el reparto de parte de las poblaciones y tierras que rodeaban lo que después
Fig. 072. Interior del castillo de Benaguacil antes de su derribo. 
Fig. 073. La acequia primera a su salida del centro histórico de la Pobla de Vallbona. Junto a ella se fundó el lloc La Pobla de Benaguazir.

\footnotetext{
143 Bordes García, J. y otro (2011): La Pobla de Vallbona, historia, geografía y arte. Universidad de Valencia. Cap. Historia Medieval. Ayuntamiento de La Pobla de Vallbona, pág 42.
}

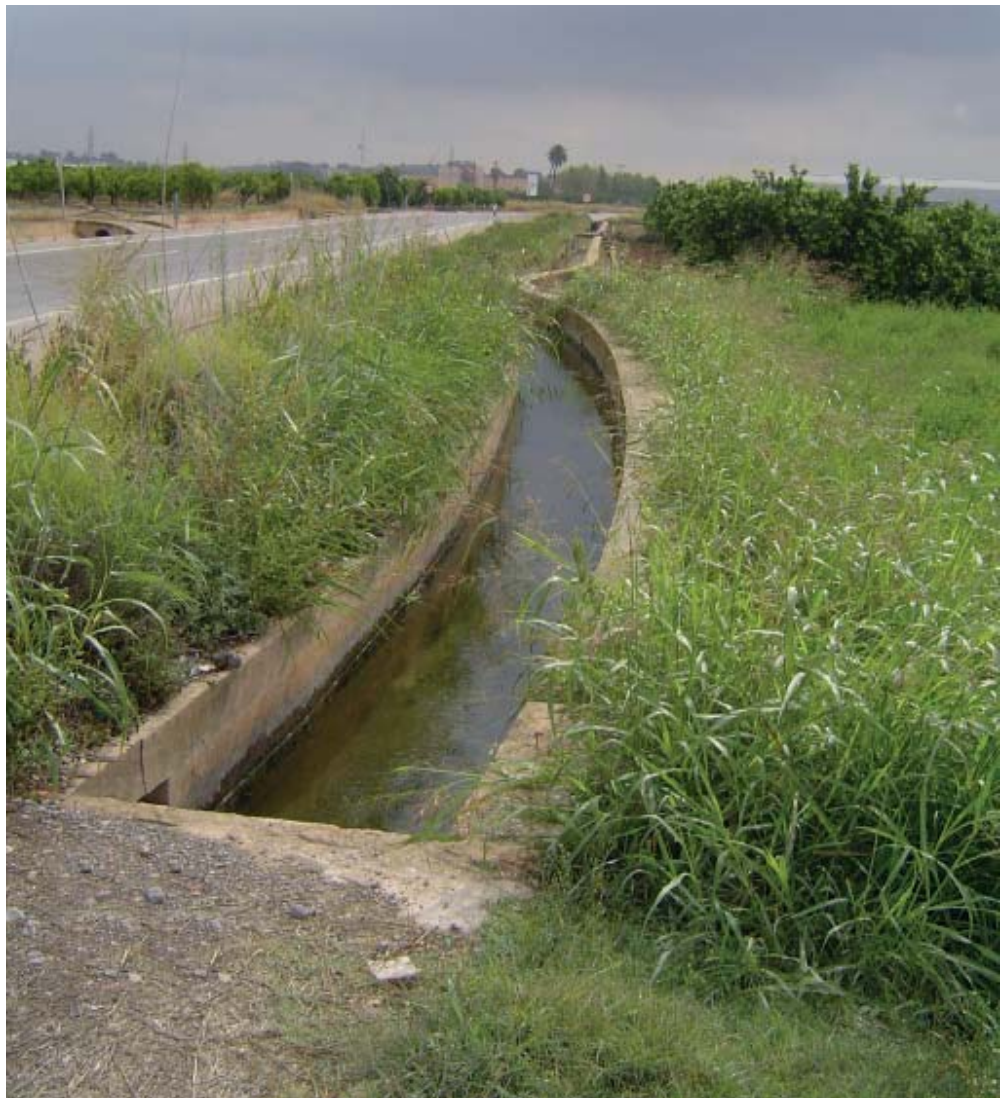

se transformó en el término de la Pobla. Así, el castillo y la villa de Benaguacil fue entregada el 26 de septiembre de 1237 al noble aragonés Ferrán Díaz (o Díeç), un caballero que había participado directamente en las campañas militaras que condujeron a la conquista de Morella. A partir de esa donación se repartieron entre miembros de la pequeña nobleza aragonesa y de linajes musulmanes que habían colaborado con los conquistadores, algunas de las alquerías que rodeaban Benaguasil ${ }^{143}$.

Se sabe que Rodrigo Díaz sucedió a Ferrán a mediados del doscientos y que se mantuvo como cabeza de la familia hasta los años 1268-1270. Desde aquel momento la historia de los señores de Benaguacil y, después, de La Pobla de Vallbona, comenzó a cruzarse con la de algunos miembros de la familia real catalanoaragonesa y del poderoso linaje de los Luna. Como aparece reflejado en la documentación oficial de la década de 1280, la hija de Rodrigo Díaz, Sancha, se casó con Jaume Pérez, hijo natural del rey Pedro el Grande. Tras la muerte de Jaume, su hija Constanza Pérez contrajo matrimonio con Rodrigo Luna, entrando el señorío de Benaguacil como parte integrante de los 
territorios de los Luna, familia que poseía un importantísimo patrimonio territorial.

Es necesario comenzar señalando que la llegada de nuevos pobladores cristianos no fue un proceso sencillo y fácil. Como tampoco lo fueron las relaciones con los habitantes hispanomusulmanes que no pudieron 0 no quisieron emprender el camino de la emigración.

Por lo que respecta a la élite socioeconómica, laica y eclesiástica, algunas de las donaciones territoriales, como ya se ha señalado, no fueron ocupadas de manera efectiva por sus señores sino que fueron intercambiadas en los años posteriores a la conquista. Así, mientras algunos caballeros no tomaron posesión de las tierras, otros realizaron diferentes estrategias -permutas, compraventas, alianzas matrimoniales, etc- con el objetivo de agrupar parte de su patrimonio en el reino y obtener la mayor rentabilidad y control posible de los hombres, tanto musulmanes como cristianos. Casi con seguridad eso es lo acontecido con las tierras y pequeñas alquerías que rodeaban Benaguacil. Unos pocos años después de la conquista, pese a que en el Llibre del Repartiment aparecen donaciones a diferentes caballeros, un solo señor, de procedencia aragonesa, aparecía a la cabeza de un pequeño territorio que tenía a Benaguacil como el centro del mismo. No obstante, la presencia cristiana en esos lugares debía ser mínima, seguramente compuesta por los miembros de la guarnición que se había establecido en el castillo de la villa.

La consecuencia de la decisión señorial fue la fundación de un nuevo núcleo con población exclusivamente cristiana y compuesta en su mayor parte por inmigrantes aragoneses y catalanes.

El nuevo núcleo se llamó en origen, como su antiguo husûn andalusí, La Pobla de Benaguazir, pero no se ubicó en su emplazamiento sino a unos $2 \mathrm{~km}$ aproximadamente, en el valle, cerca de un camino y al lado de una acequia, la conocida actualmente como acequia primera. De este modo se aseguraba la captación del agua y prevenía de futuras inundaciones puesto que el nuevo núcleo de población se situaba en la cota inmediatamente superior no regable. 


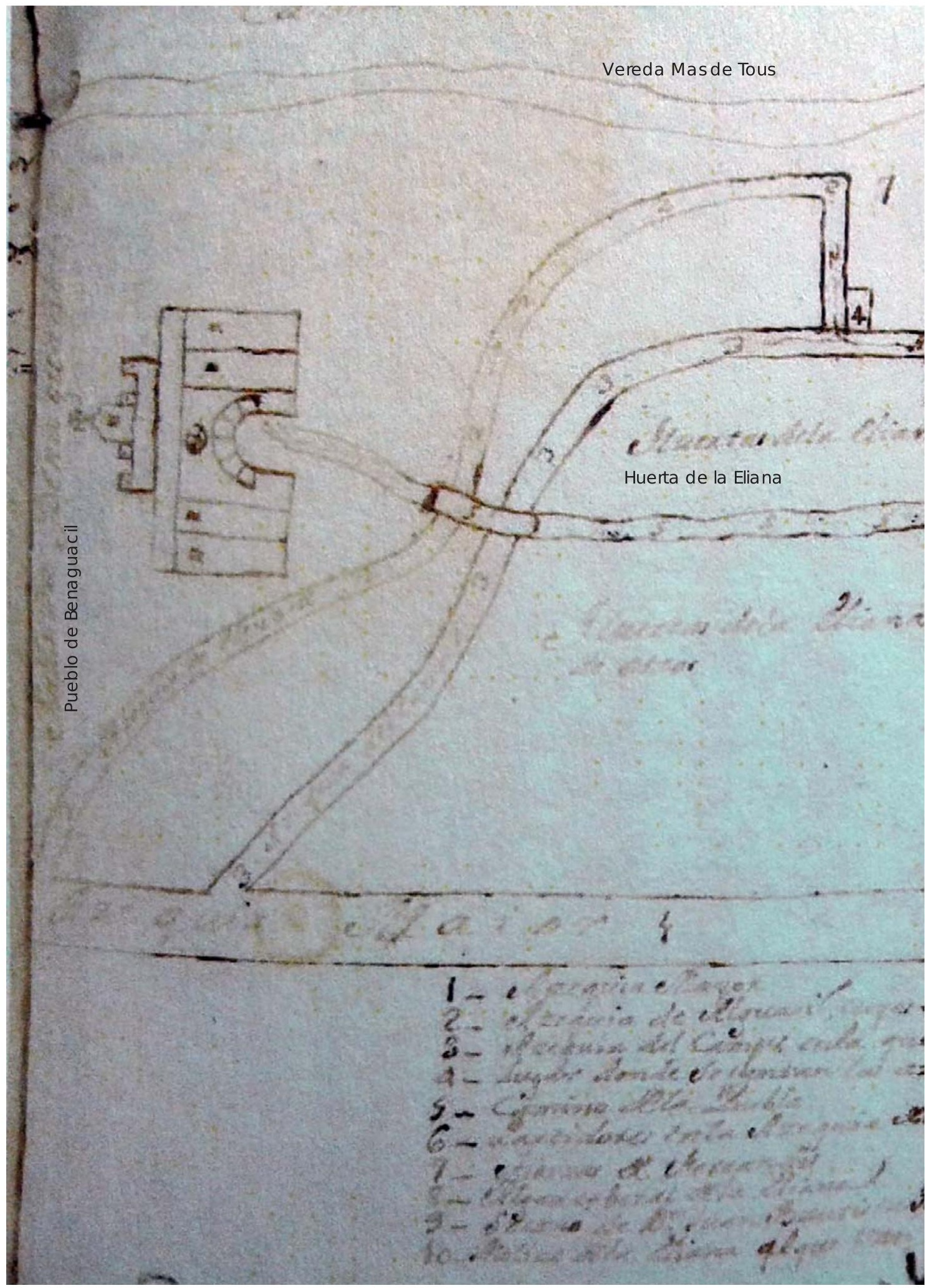




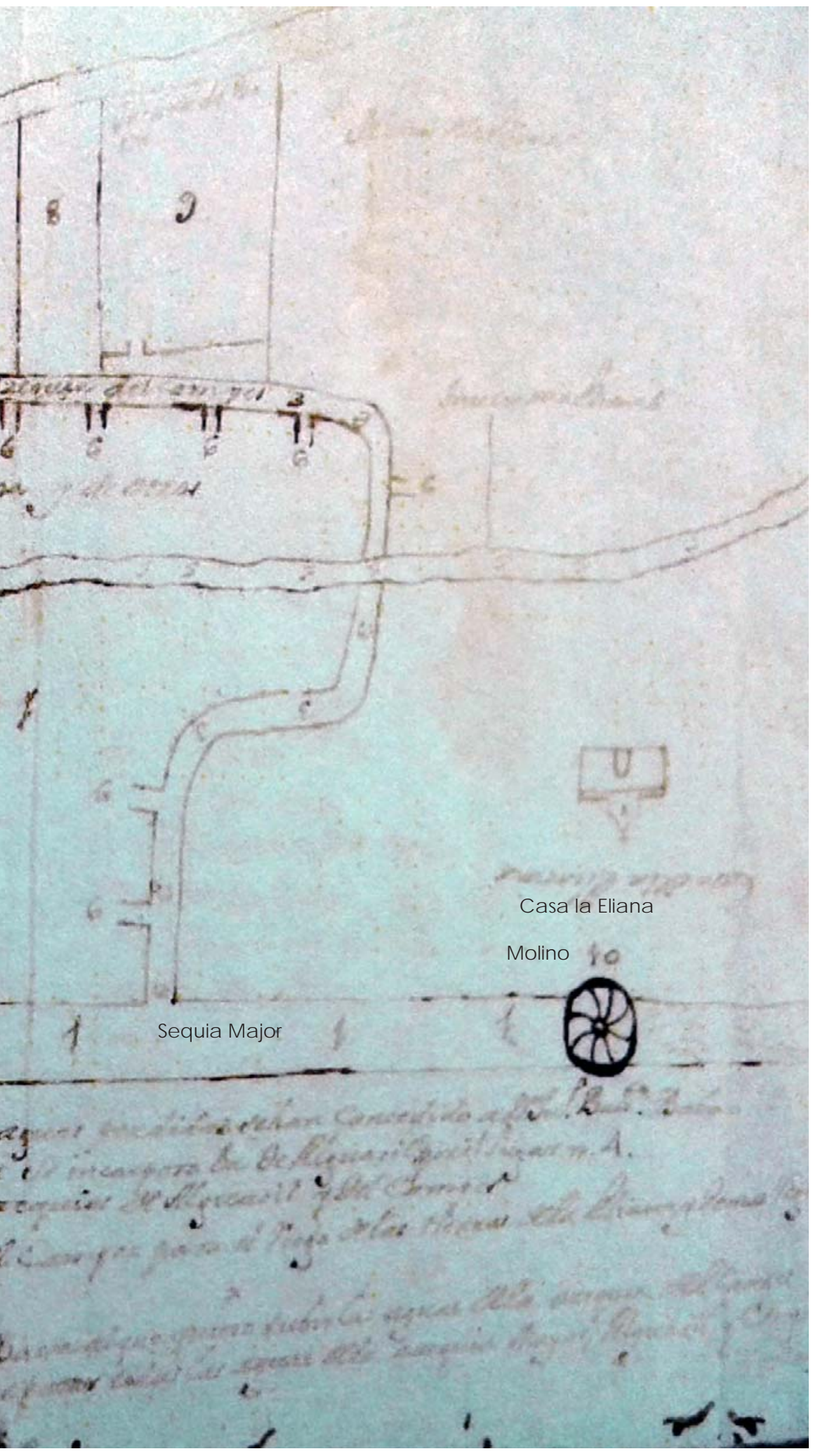

Fig. 074. El presente croquis refleja el sistema de riego (acequias) existentes desde Benaguacil hasta La Eliana, parte del Término Municipal de La Pobla hasta que se segregó en el año 1958. . Como curiosidad indicar que la villa de La Pobla que debería aparecer en el centro, no se encuentra indicada, pero si el Castillo de Benaguacil y la ubicación del molino de L'Eliana. Documento existente en el pleito del Convento del Carmen por el agua de Riego contra D. Juan Baba. Año 1743. 


\footnotetext{
144 Bordes García, J y otro (2011): La Pobla de Vallbona, historia, geografía y arte. Universidad de Valencia. Cap. Historia Medieval. Ayuntamiento de La Pobla de Vallbona, pág 44.

145 Ibídem.
}

En cuanto a la fecha de fundación, algunas referencias documentales permiten inferir que se produjo entre finales de la década de 1270 y comienzos de 1280 . Con toda probabilidad una de las principales razones debemos buscarla en la revuelta musulmana de los años 1276-1277 en la que participó la aljama de Benaguacil. Y aunque el rey Pere el Gran les otorgó un perdón en septiembre de 1277 y una autorización para poder seguir viviendo en la población, los señores pudieron pensar que una nueva villa repoblada totalmente con cristianos permitiría controlar mejor el territorio y al mismo tiempo facilitar la instalación de nuevos pobladores cristianos. En ese contexto histórico, la existencia de la Pobla de Vallbona se encuentra documentada por primera vez a comienzos de 1282 cuando en un registro del 27 de abril de ese año la monarquía ordenaba que se desviara el camino real que discurría entre la ciudad de Valencia y Llíria haciéndolo pasar por la Pobla, propiedad en aquellos momentos de Jaume Pérez ${ }^{144}$.

Queda documentada en este momento no solo su ubicación, junto a una zona con agua, sino también junto a un camino real, por lo que se trata de un espacio agrario idóneo y cercano a una vía de comunicación, perfecto para asegurar un asentamiento.

A partir de 1280, desde el mismo momento de su fundación, la Pobla de Vallbona comenzó a adquirir una entidad política propia. Al mismo tiempo que llegaban nuevos pobladores, en un número que por el momento es imposible de cuantificar, se formaron las primeras estructuras políticas que permitieron el funcionamiento de la villa. Es más que probable que el señor otorgara una carta de población o, al menos, algún tipo de privilegio para los inmigrantes cristianos que delimitase las relaciones jurídicas y económicas entre el grupo campesino y el titular del señorío, y que autorizara a la comunidad local para establecer una organización política propia. Al menos eso es lo que sucedió en otras partes del reino ${ }^{145}$.

El éxito de la fundación de la Pobla también se puede creer por la importancia demográfica que comenzaba a adquirir la villa a comienzos del siglo XIV. En el año 1304 se produjo la solicitud del traslado de la parroquia desde Benaguacil a la Pobla de Vallbona, comprometiéndose los señores a ofrecer al sacerdote titular una casa y tierras suficientes para su mantenimiento. Hasta este año los cristianos de la Pobla dependían de la parroquia de Benaguacil: 
la parroquia de Benaguacil fue puesta desde el principio y erigido en el citado lugar de Benaguacil, por razón de que, en el tiempo de su erección, dentro de los límites de la misma Parroquia no había ningún otro lugar poblado sino el predicho Benaguacil. Más ahora, por la gracia de Dios, dentro de dichos límites hay una nueva puebla llamada Vallbona, en la que habitan más de doscientos cristianos, mientras que en el predicho lugar de Benaguacil, aunque moran más de quinientos sarracenos, sin embargo cristianos habitadores no hay más de cinco o seis, exceptuando al Señor de dicho lugar, quien en ocasiones con su familia allí suele residir ${ }^{146}[. .$.$] .$

Tal y como narra el documento anterior, la petición elevada al arzobispo de la Diócesis de Valencia, Raimundo Despont, fue realizada por el señor de Benaguacil, Jaime de Pedro, y su mujer Sancha Ferrandis, así como por el rector de la iglesia parroquial de Benaguacil, Guillermo Ginebrelo y los cristianos de la Pobla que se veían obligados a trasladarse hasta la vecina Benaguacil para asistir a los oficios. De esa manera, el arzobispo Raimundo Despont decidió finalmente:

que es mucho mejor y más útil que la Parroquial Iglesia esté allí donde hay mayor número de cristianos, como sea penoso al Rector desplazarse al dicho lugar de Vallbona y a los hombres de Vallbona trasladarse al citado lugar de Benaguacil, a causa de la distancia entre ambos lugares, a recibir los Eclesiásticos Sacramentos, con el asentimiento del Capítulo Valentino, transferimos y mudamos la Parroquial Iglesia desde el citado lugar de Benaguacil al lugar predicho de Vallbona ${ }^{147}[. .$.

Es a partir de ese momento cuando se ha de situar la construcción de la primitiva iglesia parroquial de San Jaime de la Pobla de Vallbona, que por mandato expreso del arzobispo había de contar con su propio cementerio para dar sepultura a los feligreses de la Pobla y que sus cuerpos no hubiesen de ser trasladados a Benaguacil, como hasta entonces. La erección de la iglesia de la Pobla supuso además la traslación de la parroquialidad, pues desde ese momento se estableció que:

\footnotetext{
${ }^{146}$ Despont, R(1695): Manaments i Empares, no, 27, f.48.

147 Ibídem.
} 


\footnotetext{
148 Manaments i Empars(1695): volumen 3, Universitat Jaume I - Arxiu virtual Jaume I. Texto completo del documento y traducción del latín al castellano en el apartado de anexos pág. 356.

149 Transcripción de los textos originales de los diez pergaminos originales y la regesta de cada uno de ellos en el apartado de anexos pág. 359.
}

en el lugar de Benaguacil no haya Iglesia parroquial; pero que la iglesia que alli hay y fue hasta ahora Parroquial de Benaguacil, quede a modo de Capilla; sin embargo pueden en el Cementerio de Benaguacil ser sepultados los cadáveres de los difuntos de dicho lugar si esto prefieren [...]

Del mismo modo, a partir de ese momento el rector de la parroquia de Benaguacil había de trasladarse a la Pobla, donde residiría de forma permanente en las casas y huertos proporcionados por los señores del lugar, Jaime de Pedro y Sancha Ferrandis. Igualmente se le liberaba de celebrar los oficios en Benaguacil

sino tres veces en la semana por los días de fiesta y en estos días en que celebre misa en dicha Capilla de Benaguacil o haga celebrarla, no esté obligado a decirla en la misma parroquial Iglesia de Vallbona, ni esté constreñido el mismo Rector a tener otro presbítero mientras él personalmente esté en disposición de celebrar el sumo oficio [...]

Este documento escrito se encuentra fechado el 16 de marzo de 1305 en Valencia. En él, el Obispo de Valencia traslada la iglesia de Benaguacil habitada mayoritariamente por musulmanes al lugar de la Pobla de Vallbona también Ilamado de Benaguacil situado en el mismo término municipal y habitado únicamente por cristianos. Se observa por tanto el peso de los cristianos y su influencia en el traslado de la parroquia, al tiempo que se deja constancia de que aún pertenecen ambos lugares al mismo término municipal ${ }^{148}$ :

Si ea que a principio sunt rationabiliter ordinata, tempore procedente ex iustis super venientibus causis mutari posunt in melius mutentur, non est absonum nec debet reprehensibile judicari [...].

En estos momentos La Pobla de Vallbona, alias de Benaguazir, no contaba con la consideración de una villa, sino que era un I/oc puesto que todavía no tenía término propio, dependiendo del municipio de Benaguazir.

Sobre la base de las consideraciones anteriores se procede a detallar los siguientes datos históricos. Los aportan una serie de diez pergaminos ${ }^{149}$ inéditos custodiados por el Sindicato de 
157 de 536

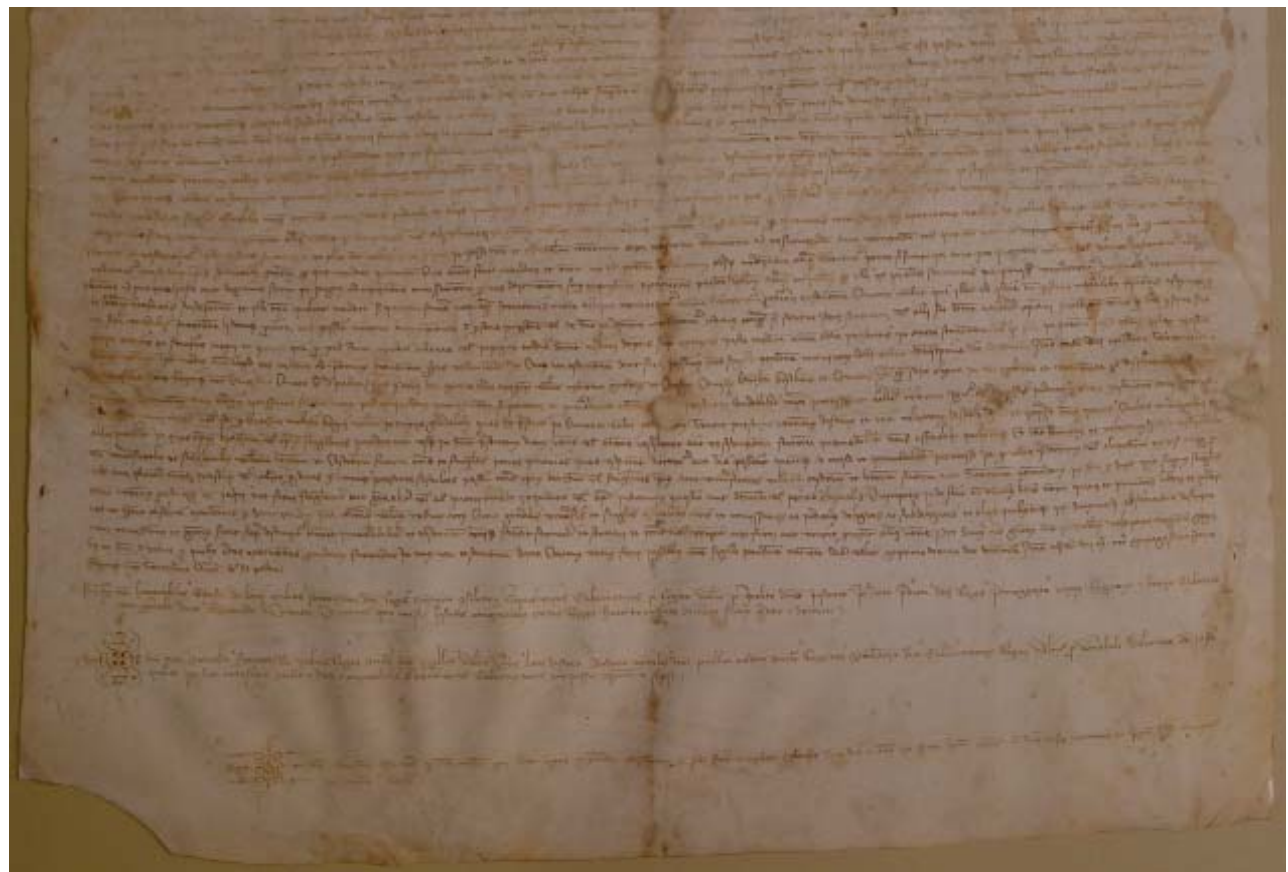

Fig. 075. En el presente documento se habla de llocs o castells, en ningún momento se nombra al municipio o indica que sea una Vila. 12 de enero de 1.370. Pergamino 1. 
Fig.076. En el presente pergamino fechado el 12 de enero de 1376 se detallan los mismos topónimos de partidas de rústica que aún existen en la actualidad y se menciona la acequia primera, al lado de la cual se fundó el municipio. Pergamino 2.
Riegos de La Pobla de Vallbona. Esta agrupación es una de las más antiguas del municipio. La figura del cequier, persona encargada de la distribución de las aguas de riego, ya aparece en la carta de poblament de la vila. El Sindicato cuenta con el mayor archivo histórico del municipio, más del 90 \% inédito, y el único que se salvó de ser quemado en la plaza mayor durante la Guerra Civil Española ${ }^{150}$.

De su archivo se han utilizado para este plan de investigación los citados pergaminos, los cuales han sido restaurados y traducidos en colaboración con la Concejalía de Patrimonio de La Pobla de Vallbona en enero 2015. Aunque los documentos hacen referencia en su gran mayoría a obligaciones, derechos de pagos, escrituras de ventas y censos de propiedades, de su lectura se pueden extrapolar datos que reflejan el modo de vida de este municipio, su toponimia y las costumbres de su sociedad.

El primer documento se encuentra fechado en el año 1370, el 12 de enero y está firmado por el caballero y representante real en Valencia Gacá de Loríc, por Arnau Ferrer de la Palma, notario real de Valencia y Guillermo Serra, notario público de Valencia. Se trata de un acuerdo entre un representante de la monarquía y las autoridades locales de La Pobla de Vallbona, avisando que si toman parte en la guerra que se está llevando a cabo con el rey Pere de Castella, puede haber represalias sobre el municipio. En este documento se habla de llocs o castells, pero en ningún momento se nombra al municipio o se indica que sea una Vila.

El segundo pergamino se documenta el 7 de octubre de 1376 y trata sobre las propiedades que tiene un vecino de la Pobla, Pere Gilabert, y su esposa. En él queda reflejado que ambos están cediendo posesiones a favor de un tercero, algunas de las cuales se sitúan en el municipio. Los datos más importantes que se evidencian en este documento para el presente estudio son:

a) Los nombres de las partidas de rústica, con nombres idénticos a los de la actualidad.

150 Véase en los anexos apartado A.4, Inventario del año 1873 perteneciente al Ayuntamiento de La Pobla de Vallbona señalando los documentos existentes en el archivo del municipio. Archivo documental de la Diputación de Valencia, pág 446. b) La aparición como lindero de la acequia primera, al lado de la cual se fundó el municipio.

c) El municipio se denomina en varios párrafos como, La Pobla de Benaguazir y queda documentado que para cualquier desavenencia se está bajo el fuero de Valencia.

d) Se repite varias veces, al describir las propiedades una a una, que siempre se acuña el termino de "franco y libre", es decir libres de cargas señoriales. 


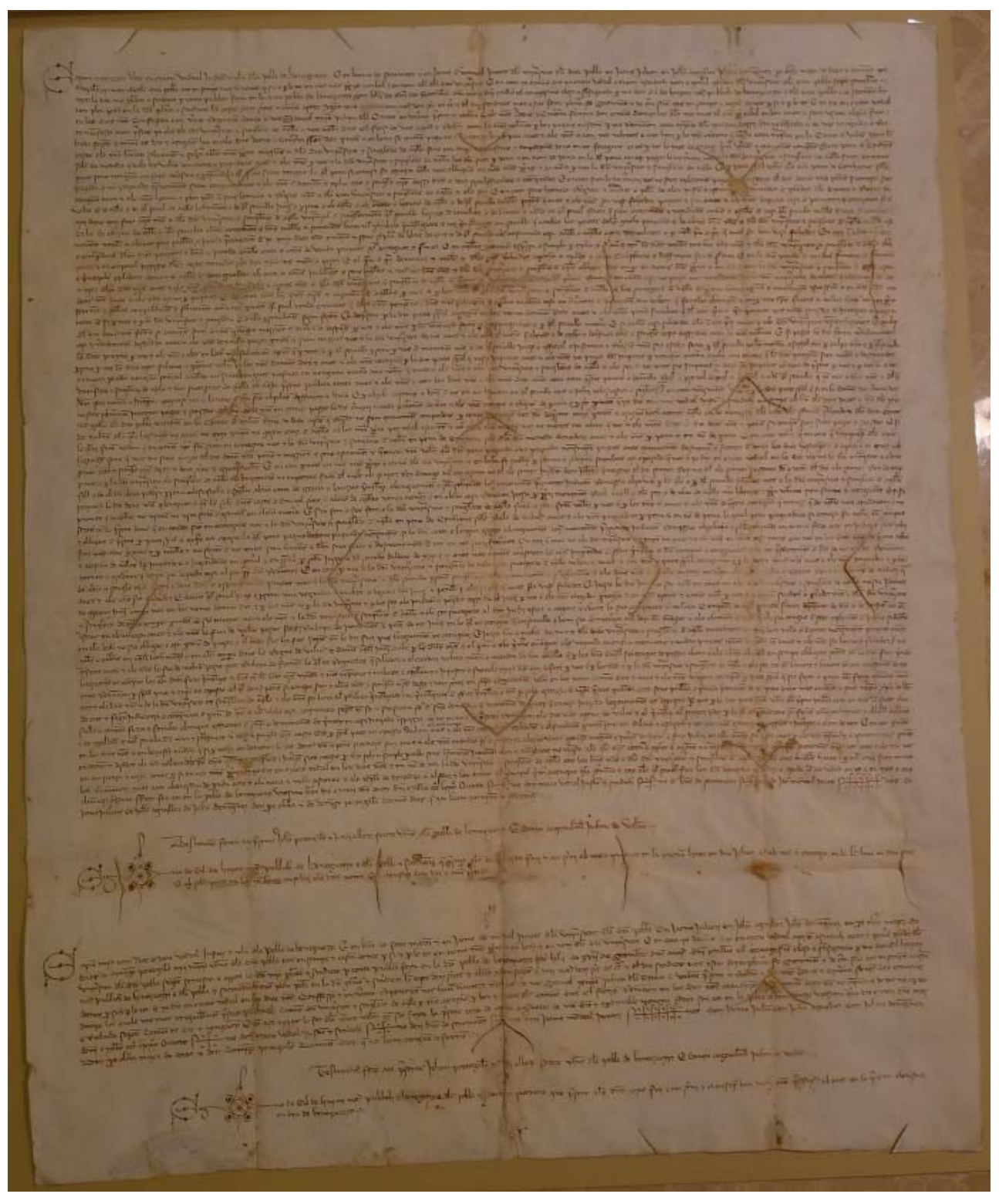


Fig.077. Carta de Población de la Pobla de Vallbona sita en el Archivo del Reino, transcrita en el año 1626.

\footnotetext{
${ }^{151}$ Manaments i Empars, 1626. Libro 5, mà 39 , fol. $38 \mathrm{v}-48 \mathrm{v}$ mà 40 , fol 39-44. Transcripción en el apartado de anexos pág 400.
}

5.3.1 La organización social: La Carta Pobla 1382 y otros documentos inéditos

La Carta Pobla llega en el año 1382; en la mayor parte de los casos las cartas puebla fueron otorgadas en los años inmediatamente posteriores a la conquista, pero en el caso de la Pobla de Vallbona no existe constancia de un documento fundacional de ese tipo y la única que se ha conservado corresponde a finales del siglo XIV, en el año antes mencionado. El pergamino original está perdido pero existe una copia realizada por el escribano de la Curia de Justicia civil de Valencia en el año 1626 que describe esta carta pobla ${ }^{151}$.

El núcleo ya estaba consolidado, puesto que se había pedido la parroquialidad. En el inicio, los otorgantes indican que aunque la población existe, no se tiene constancia de carta o fueros anteriores a los concedidos en ese momento:
Primerament, que per l'alt senyor Infant don Martí, e per la egrègia la senyora Comtessa de Luna, sia reconegut al lloch de la dita Pobla com no era privilegiada e volen que d'asi en avant hajen tots los vehins y habitants de la dita Pobla totes les seues posessions franques et lliures, e puixen aquelles vendre, alienar e transportar [...].

También indica que se concede bajo el fuero de Aragón, pero en documentos posteriores se podrá comprobar, como siempre señalan, que se acoge al fuero de Valencia. Esto también se encuentra en los municipios de Vinaroz y Vila-real.

\section{Fol. 39ro..] e fer de aquelles a totes les seues pròpies voluntats en vida o en mort, a fur de Aragó [...].}

En ese año el infante Martí y su mujer María de Luna, condes de Jérica y de Luna, antes de subir al trono otorgaron diferentes derechos a los cristianos de la Pobla.

En primer lugar, se señala que los vecinos de la Pobla de Vallbona podrán poseer todos sus bienes con carácter franco, es decir, sin cargas señoriales; asimismo que también podrán usar las unidades de medida y peso utilizadas en la ciudad de Valencia. 


$$
\begin{aligned}
& \text { incondistis }
\end{aligned}
$$

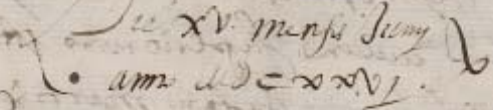

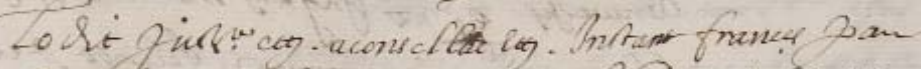

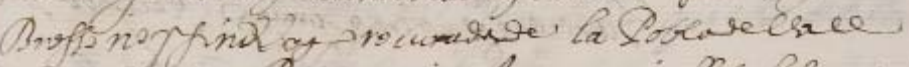

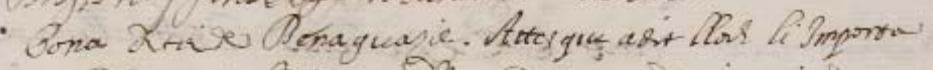

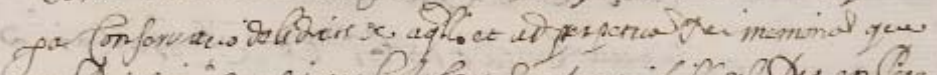

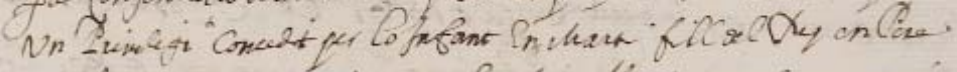

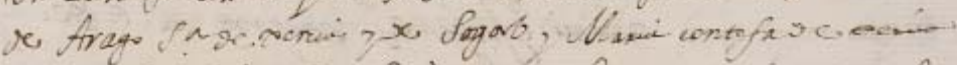

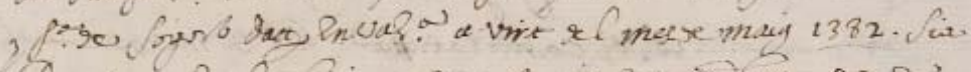

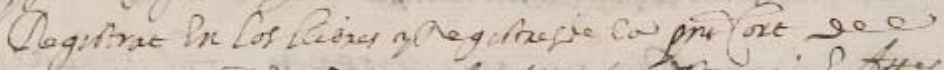

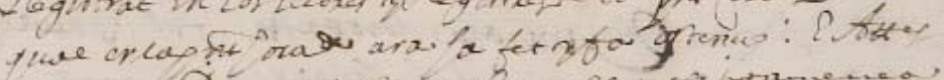

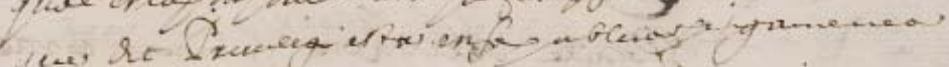

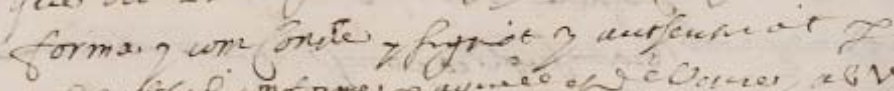

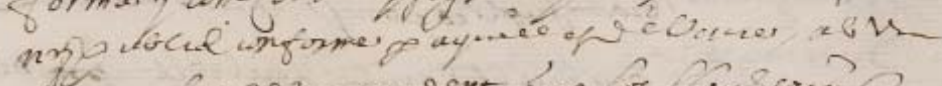

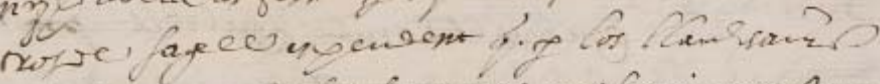

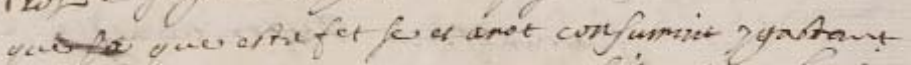

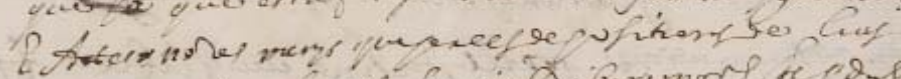

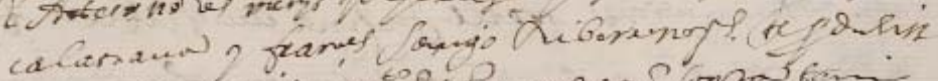

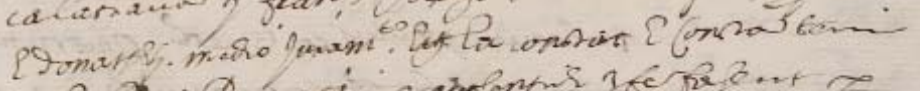

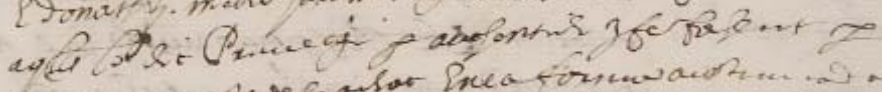

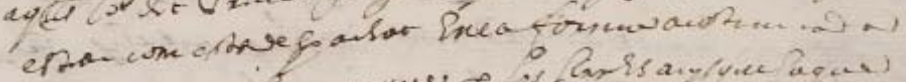

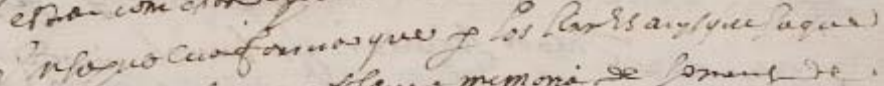

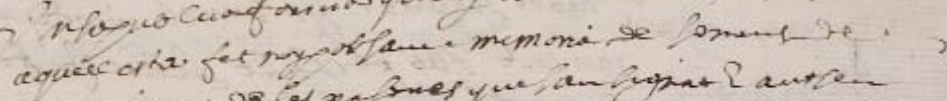

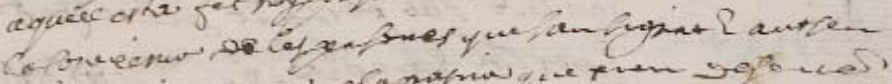

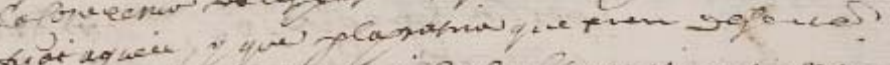

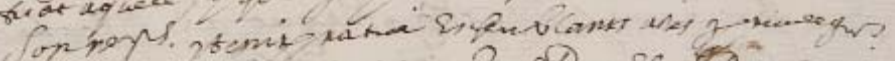

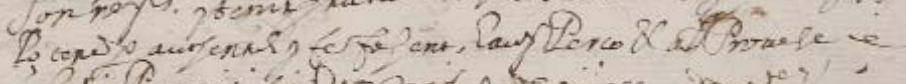

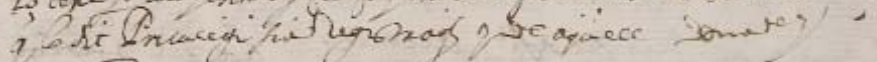
27 
${ }^{152}$ Alba Pagab, E. y otros (2011): La Pobla de Vallbona, Historia, Geografía y Arte, Universidad de Valencia, Facultad de Geografía i Historia. La Pobla de Vallbona. Pág. 47.

${ }^{153}$ Torres Balbás, L.(1952): La Arquitectura gótica: Valencia y Murcia. Volumen 4. Madrid. de así avant hajen tots los vehins y habitants de la dita Pobla totes les seues posesiones franques et lliures, e puixen vendre, alienar e transportar e fer de aquelles a totes les seues pròpies voluntats en vida o mort [...]

Respecto a la organización municipal, los señores autorizaban al conjunto de vecinos de la población la elección de sus representantes durante la fiesta de Navidad: aquellos relacionados con la justicia, los jurados y el mostasaf, una especie de policía del mercado. En este caso la vía administrativa copia las instituciones tomadas de Aragón, teniendo estos cargos que ser detentados por ciudadanos y no por caballeros o clérigos ${ }^{152}$.

que la universitat de la dita Pobla puixa per cascun any elegir los seus oficials, Justícia, Jurats et Mostasaf en la festa de la Nativitat de Nostre Senyor, en lo mes de desembre; que aquells juran en lo seu comensament de l'any, de bé e lealment usar de son oficial [...]

Estos agentes municipales, junto al resto de habitantes del pueblo, estaban capacitados para establecer normas de aprovechamiento de la tierra o del riego ${ }^{153}$.

que el Consell e Universitat de la dita Pobla, ço és, Justícia e Jurats e altres vehins e habitants en aquella, puixen ordenar per cascun any tots aquells establiments e ordinacions [...].

Y nombrar oficiales del riego -con la denominación de sequiers-, guardianes de la huerta y corredores,

ítem, que lo dit loch [...] puixen posar de ací avant en e per tots temps en per cascuns anys, cequiers, guardians, corredors, axí d'orella com altre qualsevol en totes aquelles maneres et condicions que a ells serà vist fahedor [...].

Otro cargo administrativo era el baile local, el encargado de controlar los derechos reales en la Vila; este cargo no era elegido por el Consell Municipal sino que era concedido por el propio rey. En el archivo del Reino de Valencia, en los documentos de la Real Cancillería del Consejo Supremo de Aragón, aparece el nombramiento vitalicio otorgado por Alfonso $V$ a Jaume Ferrer 
como alcaide del castillo y baile local de Benaguacil desde el año 1416 hasta el año $1458^{154}$.

En la carta puebla también se regulaban las relaciones con Benaguacil y el exclusivo poblamiento cristiano de la Pobla de Vallbona. Una cláusula especifica la prohibición de residir en la localidad a personas de otras religiones:

ítem, que de assí en avant lo lloch de la damunt dita Pobla no puixa ser poblat de sarraïns, sinó de christians; e tota vegada de así en avant, al damunt dit fur de Aragó et no a altre fur o costum o usatje. Plau al senyor Infant que havent-hi compliment de pobladors christians, moros no y puixen ser poblats dins lo dit lloch de la Pobla [...].

Además, la carta puebla de 1382 añadiría que los cristianos de Benaguacil (la cual sí que era una localidad de carácter mixto aunque con una presencia mayoritaria de mudéjares) debían acudir a la Pobla en caso de cualquier pleito porque la justicia de esta villa ejercía al mismo tiempo su autoridad sobre los cristianos de aquella.

que'ls christians de Benaguazir sien tenguts de venir a la damunt dita Pobla a juhí per determinar totes e qualsevols qüestions, pleyts e contrasts que entre aquells seran o hauran ab altres persones. $E$ lo Justícia de la Pobla que ara és o per temps serà, sie Justícia e jutge ordinari de aquells dits christians de Benaguazir et no altre algú [...].

Es necesario dejar constancia de que en toda la documentación existente referente al período medieval, ya fuera de carácter privado (como los numerosos protocolos notariales conservados) o ya fuera de carácter oficial (como los registros señoriales) no ha aparecido nunca una referencia en la Pobla de habitantes musulmanes o judíos ${ }^{155}$.

La Carta Puebla del año 1382, indica entre otros:

1- Que los vecinos de la Pobla poseen todos sus bienes sin cargas señoriales.

2- Que Los vecinos pueden elegir a sus representantes.

3- Cómo se producen las relaciones con Benaguacil.

4- El permiso de contar con un término propio.
${ }^{154}$ Real Cancillería (1416-1458): Archivo del Reino de Valencia. Consejo Supremo de Aragón, Oficiales 1416-1620.

${ }^{155}$ Alba Pagab, E. $y$ otros (2011): La Pobla de Vallbona, Historia, Geografía y Arte, Universidad de Valencia, Facultad de Geografía i Historia. La Pobla de Vallbona. Pág. 46. 
El documento presenta una extensa serie de cláusulas que, entre otras cuestiones, delimitaban la organización interna de la población y las rentas que debían pagarse a los señores.

También describe las obligaciones que debía cumplir el conjunto de la villa, entre ellas la obligación de pagar una peita de 4.000 sueldos, el tercio-diezmo y el morabatín.

que'ls de la dita vila de la Pobla han acostumat e són tenguts de pagar peyta ordinària per cascún any Quatre milia sous, que aquells sien pagats segons és acostumat, e ters denme e morabatí [...].

Además, en el escrito centro de este apartado, se daba autorización para tener un término municipal propio del que podía disfrutar el conjunto de vecinos -la segregación de la villa de Benaguacil- con tierras comunales, destinado una parte de ellas de forma específica al pasto del ganado.

Desafortunadamente la carta no describe como debían de ser las parcelas ni las calles, datos que sí se recogen en otras cartas de población, seguramente debido a que el municipio ya se encontraba construido desde hacía una centuria, aunque sí que queda claro el derecho que tenían los habitantes de dicho lugar a edificar ${ }^{156}$ :

que dits vehins e habitadors en la dita Pobla puixen en les montanyes e terme de la dita Pobla bastir et fer cases, corrals, colmenars, mallades, a obs dels bestiars e altres qualsevols edificis que fer-ne volran, et en qualsevulla lloch o llochs del damunt dit terme, açò sens que no sien tenguts de demanar llicència a senyor $o$ altres persones, e açò francament e lliure, sens alguna inquietació o impediment. Emperò, que per aquelles cases, mássos, corrals, colmenars que edificaran e obraran sien tenguts de peytar per aquells ab los altres vehins de la dita Pobla, segons que els altres pagaran. Plau al senyor Infant, sens perjudici seu e de les sues regalies [...].

156 Martí L'Huma, Infant (1382): La Carta de Poblament de la Pobla de Vallbona. Archivo del Reino. Manaments i Empars, 1626. Libro 5 , mà 39 , fol. $38 v-48 v$ mà 40 , fol 39-44.
Cabe destacar que desde el punto de vista arquitectónico y urbanístico, la parte que más llama la atención es la que indica claramente la no existencia de murallas ni cercas en el municipio, puesto que en caso de guerra los cristianos de la Pobla debían de 
guarecerse en Benaguacil y tenían los mismos derechos que los que sí residían allí:

ítem, que si ve per cars el lloch de la Pobla o los habitants d'aquell, per voluntat dels senyors que hara són o per temps seran, per fet de guerra o de altres necessitats se havien de recollir en lo lloch de Benaguazil, que en lo dit lloch de Benaguazil los christians de la dita Pobla puixen tenir tenda o tendes de qualsevol mersés o coses que tenir ne volrran, e taverna o tavernes, així de sos propis vins com de altres, si menester serà, açò sen rehemsó alcuna o contrast alcú que no és puixa ésser feyt, com com així ho hajen acostumat en tots los temps passats.

Al mismo tiempo señalar a los señores de la villa la responsabilidad de poner a disposición de los pobladores molinos o instalaciones para hacer harina:

ítem, que'ls senyors Infant e Comtesa e los seus succesors, presents et avenidors, sien tenguts de donar a la universitat de la dita Pobla e habitants de aquella bastament de molins, bons e aparellats de moldre, e fer bastament farina;

Se expone la idea de que tiene que haber un horno:

del forn de la dita Pobla, sien tenguts de fer forn e forns, tants com seran menester per obs de coure pà, estants als vehins e habitants de la dita Pobla així que per culpa o falta de forn no puixen perdre alguns pans.

Y se describe el derecho de poseer una taberna y tiendas donde abastecerse:

ítem, que tots los vehins e habitants de la dita Pobla de assíavant com per tots temps puixen tenir en la dita Pobla taverna o tavernes, tenda o tendes de totes e qualsevols coses o mercés que volrran tenir o vendre en les seus cases o en altres parts, sens que no sien tenguts de donar al damunt dit senyor $o$ als seus servici [...]. 


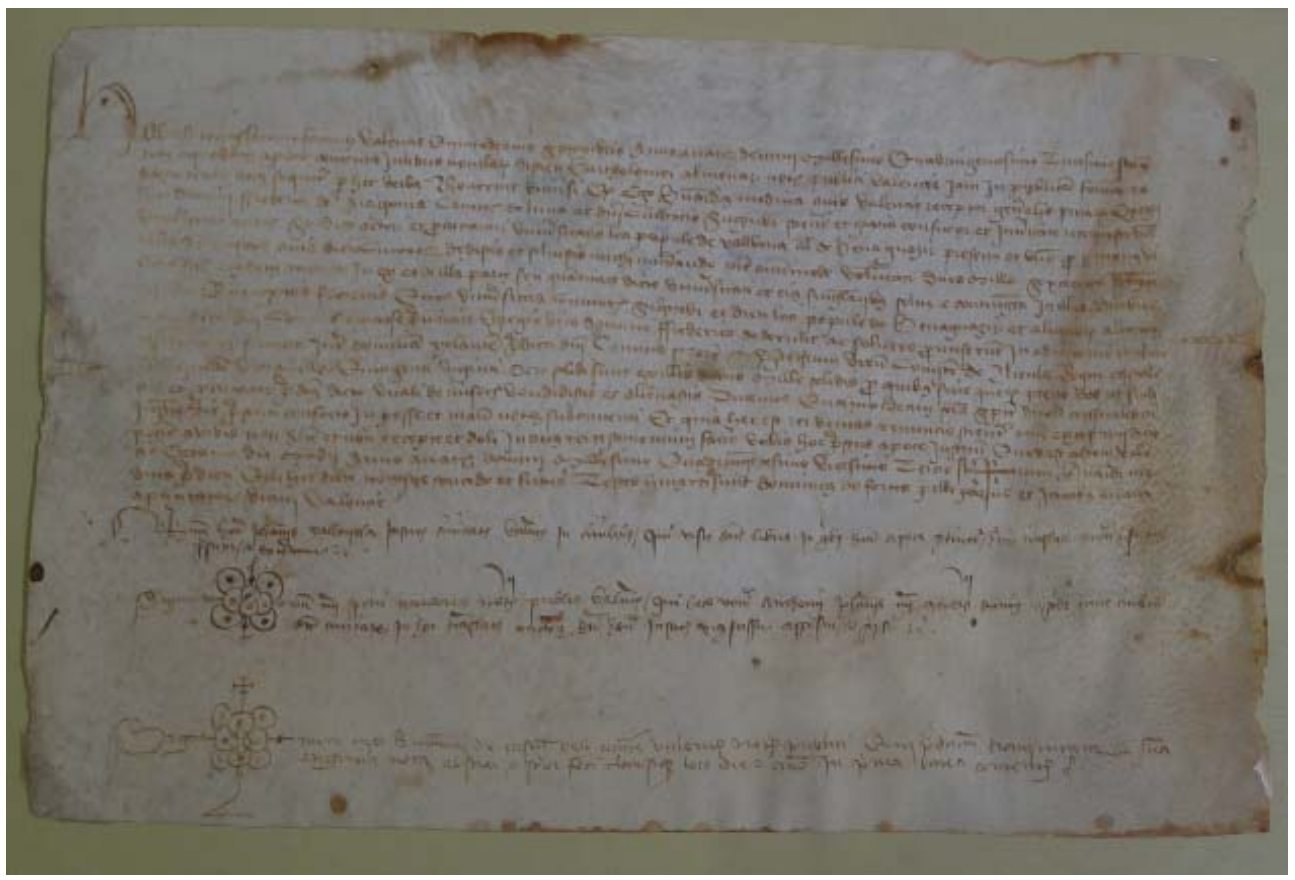

Fig. 078. En el documento de la imagen superior aparece denominado el municipio como la Pobla de Vallbona, alias de Benaguazir con fecha 15 de septiembre de 1420. Pergamino 8.
Con la carta pobla queda, pues, definido el nacimiento de La Pobla de Vallbona como municipio, con derecho a tener término propio, aunque el asentamiento tuviera su origen en el año 1282, un siglo antes.

Conviene subrayar que el documento original se encuentra desaparecido y la carta pobla a la que se hace referencia en este estudio es la que se encuentra transcrita en el Archivo del Reino de Valencia en el año 1626, datándola del año 1382 y concedida por María de Luna y Martín l'Humà. Este dato es importante porque Pedro Sucías Aparicio ${ }^{157}$ en su libro denominado Notas útiles del Reino de Valencia afirma:

En vista de que la población que nos ocupa era de tiempos de $D$. Pedro IV de corto vecindario se autorizó carta puebla en 20 de mayo de 1.383 la cual se halla en el timo 30 de manaments e impares np.2.781 y dice así:

Carta puebla. La mandó poblar D. Pedro de Aragón y su esposa y lleva 26 capítulos de obligaciones sin sombrar a nadie de los nuevos pobladores que eran moros de Benaguacil y cristianos viejos
157 Sucías Aparicio, P. (1911): Notas útiles del Reino de Valencia, Distritos de Onteniente y Liria, Tomo 7, Valencia, pp. 154-155. 


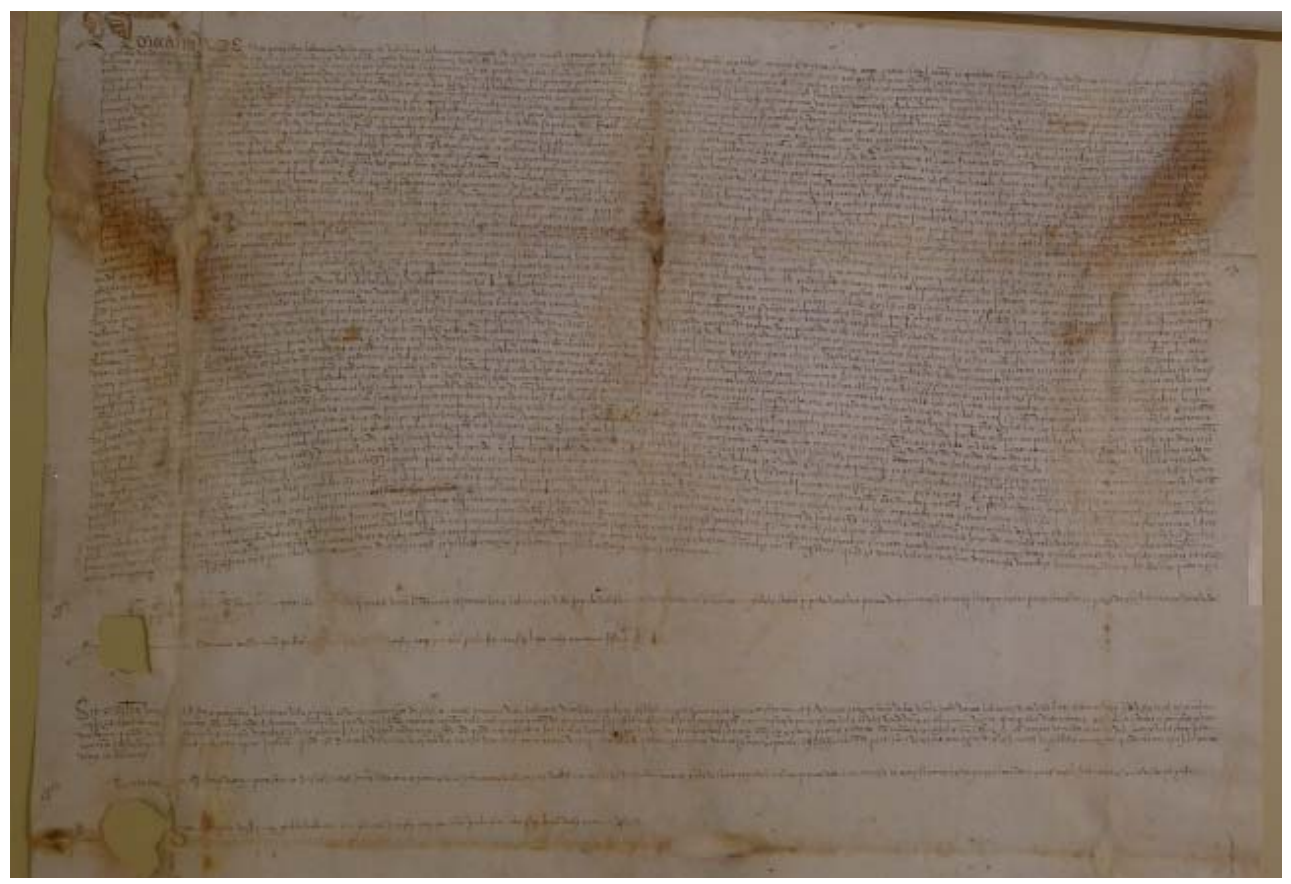

La referencia dada tan claramente por el canónigo corresponde a una numeración antigua de ordenación del Archivo del Reino. En la actualidad no ha sido posible encontrar el citado archivo. Se ha podido comprobar la existencia de la transcripción fechada en el año 1382 pero no se ha podido constatar la carta pobla del año 1383. Podría tratarse por lo tanto de una errata del sacerdote o tal vez la confirmación real de la carta pobla otorgada por el Infante Martín, esta vez por su padre Pedro de Aragón, aunque este acto no era estrictamente necesario.

Después de lo anterior expuesto procede, cronológicamente, describir otros dos documentos medievales, propiedad del Sindicato de Riegos de La Pobla de Vallbona. Los citados, detallan datos interesantes que a continuación se detallan:

En primer lugar el pergamino 8, el cual está fechado el 15 de septiembre de 1420 , trata sobre un pago que la Pobla y otros lugares deben abonar a Frederic de Aragón con motivo de su matrimonio. En este texto ya se nombra por primera vez la Pobla como Vallbona, puesto que dice textualmente

la Pobla de Vallbona, alias de Beneguazir.

A lo largo de todo el documento, igual que los pergaminos de fechas anteriores, al lado del nombre del municipio se añade
Fig. 79. En pergamino de la imagen superior ya no aparece nombrado el municipio como un lloc sino referenciado como una vila. Años posiblemente 1449-1488. Pergamino 9. 
como aclaración el nombre de $/ / o c^{158}$. Es evidente entonces que la nueva pobla en esta época no ha adquirido todavía la suficiente importancia para ser denominado vila.

El cambio de $/ l o c$, a vila, al lado del nombre del municipio, aparece en el siguiente documento medieval, el número 9. A diferencia de los demás no se encuentra fechado, sí consta el nombre del notario que lo escribe, Bernat Dassio. Perteneciente a una familia de Notarios, el padre, trabajó en la Pobla durante 39 años, durante el periodo comprendido entre los años 1449 al 1488; Bernat Dassio, hijo, conocido en la Pobla como júnior, comenzó a trabajar junto a su padre como notario en el año 1462, aunque su labor se desarrolló más en Valencia capital. En el escrito no se desprende quien de los dos actúa de fedatario pero queda claro, que es un documento del siglo XV. En él se reconoce la venta de unas parcelas, pero el detalle que más Ilama la atención es la palabra que se sitúa delante del nombre de la Pobla, aparece como una coletilla la denominación de vil.la, en vez de $/ / o c^{159}$.

Habitants de la vil.la de la Pobla de Vallbona, Vicent e Isabel [...]

Después de las consideraciones anteriores se puede afirmar que la Pobla de Vallbona alias de Benaguazir nació como un Iloc del municipio de Benaguacil. Con la concesión de la carta-pobla tuvo derecho a un término propio y con el paso del tiempo fue creciendo y ganando en importancia obteniendo el derecho de ser denominada vil.la.

\footnotetext{
${ }^{158}$ Archivo Sindicato de Riegos de La Pobla de Vallbona. Pergamino 8.

${ }^{159}$ Archivo Sindicato de Riegos de La Pobla de Vallbona. Pergamino 9.
} 


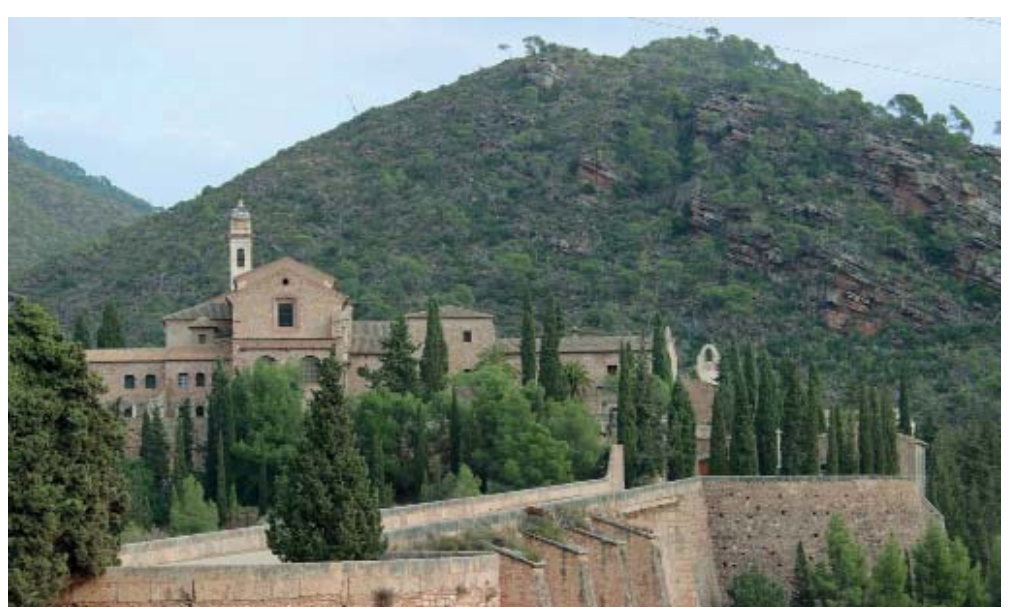

5.3.2 Dependencia religiosa: El monasterio de Porta-celi

La conquista del Reino de Valencia por el rey Jaime I de Aragón constituyó una cruzada de liberación de los territorios ocupados por el imperio almohade ${ }^{160}$. Hay que tener en cuenta, sin embargo, que la mayor parte de la población era musulmana y conservaba su infraestructura en el nuevo reino cristiano, sus tribunales y sus consejos de gobierno; todo esto no podía ser cambiado con la única presencia de varios miles de soldados y las enseñanzas del rey conquistador. Para ello era necesario que la gente del norte quisiera tomar posesión de las nuevas tierras.

En los últimos años de Jaime I este proceso de asentamiento todavía no era suficientemente importante para asegurar su tranquilidad. La Iglesia tuvo entonces una influencia directa en este proceso de consolidación del cambio social y político, pues :

"actuaba directamente con poderes fronterizos, como señor seglar, como empresario, como guarnición, como proveedor de casi toda la asistencia pública o de la seguridad social disponible en aquella época ${ }^{161 "}$."

Dentro de la Iglesia las órdenes religiosas representaban un elemento característico en el proceso de la conquista y consolidación, puesto que cada una de ellas había sido fundada para satisfacer alguna necesidad en la comunidad cristiana. A todas se les concedió posesiones por adelantado que luego tuvieron que consolidar con su conquista, acumulando una gran cantidad de privilegios, posesiones y propiedades.
Fig. 080. Vista del Monasterio de Porta-celi del que dependía la Pobla religiosamente desde la edad media.
${ }^{160}$ Fuster Serra, F. (2003): Cartuja de Porta-celi, Historia, vida, arquitectura y arte. Capítulo II, Pág. 89. Colección "Estudis" 5, Ajuntament de Valencia, pág. 15.

${ }^{161}$ Ibídem, pág. 91. 
Fig. 081. Plano de las posesiones del monasterio de Porta-celi en la comarca del Camp de Turia en la edad media.
162 Fuster Serra, F. (2003): Cartuja de Porta-celi, Historia, vida, arquitectura y arte. Capítulo III, Pág. 151. Colección “Estudis" 5, Ajuntament de Valencia.

163 Manifiesto y puntual relación de los individuos, rentas y obtenciones de la Real Cartuja de Porta-celi, deducciones de gastos de fábrica, comunicado al arzobispado, año 1776 . Cargos reales de bienes impuestos por testadores y donantes, legajo 417 caja 1135.

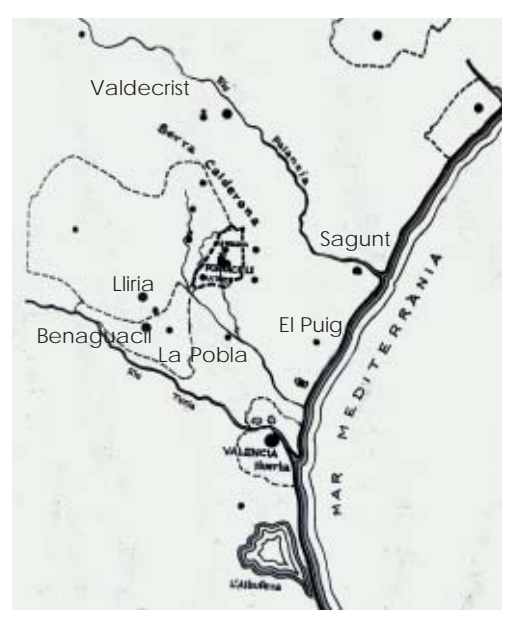

Es en este contexto donde se enmarca la fundación de la cartuja de Porta-celi en el año 1272. La iniciativa correspondió al dominico Andreu Albalat quien realizó una gran actividad en la disputa de los diezmos y primicias, era confidente del rey Jaime y desarrolló una extraordinaria labor política. Durante su obispado se sustituyeron las mezquitas-parroquias por nuevas estructuras cristianas.

La relación directa de esta cartuja con la Pobla no llegará hasta el año 1401 cuando el Papa Benedicto, por bula dada en Aviñón el 11 de diciembre de 1401, cede a la cartuja de Porta-celi la rectoría de Benaguacil con todos los frutos y pertenencias que correspondían a la Iglesia. La cartuja, por su calidad de rector de dicha parroquia, se encargará a partir de entonces de la provisión del vicario y de su sustento ${ }^{162}$. Los cargos reales hacen mención al sueldo del vicario de la iglesia de Santiago Apóstol:

\section{Al vicario perpetuo de la Puebla de Benaguacil de dicha villa 60 libras $^{163}$.}

Mientras que Benaguacil se convierte en un lugar de señorío morisco, los cristianos viejos viven en La Pobla de Vallbona y es aquí donde reside el rector de la iglesia parroquial por decreto episcopal del año 1304. Dicho rector tenía a su cargo, por tanto, las dos poblaciones y sus términos. A partir de este momento la influencia de la cartuja en la historia de la población, a través de sus innumerables posesiones, durará hasta la actualidad. 
Porta-celi es rector de las iglesias parroquiales de Llíria y Benaguacil. Por ello tiene derecho a percibir las primicias de todos los frutos de la agricultura y ganadería de los términos de Llíria, Benissanó, Olocau, Benaguacil y La Pobla. La primicia de Benaguacil y la Puebla es a todos los frutos sin excepción ${ }^{164}$.

\section{4| La Parcelación de la tierra}

Jaime I tenía un gran interés por favorecer el asentamiento del mayor número de familias en el nuevo reino, no solo para controlar y asegurar las fronteras y el territorio sino para alcanzar prontamente la rentabilidad de unas tierras que fueron abandonadas por los musulmanes y, ahora, deberán sustentar la permanente y cotidiana llegada de masas de familias cristianas, que podían y debían redundar en beneficio del siempre exhausto real patrimonio ${ }^{165}$.

Por consiguiente, considerando el legislador que la razón fundamental para promocionar la llegada de nuevas familias cristianas y alcanzar su asentamiento en el nuevo reino era favorecer la propiedad, Jaime I establece que cualquier persona podría adquirir la propiedad de tierras -yermas o ya labradas-, así como casa u otras posesiones, rentas y censos, de cualquier persona, ya fuere caballero, clérigo o ciudadano libre.

Cascun pot vendre e alienar caes, estatges, heretats e totes altres possessions, les quals ha per franch alou e liure, en forar a cavallers e sants, si que nos, ni'ls nostres, en nenguna cosa, no siam demanats $^{166}$

En los primeros momentos de ocupación cristiana fue la tierra la base de la economía de aquella sociedad, por lo que era normal que fuera parte fundamental de las posesiones. La tierra era el bien más apetecido por la familia medieval, y la adquisición de una parcela, si era regable, colmaba sus ilusiones. La propiedad de la tierra era cuidada por los Consells, que vigilaban los campos, atendían el estado de los caminos y acequias de riego, habilitaban puentes, incluso arbitraban los nivells para ampliar los regadíos.

La propiedad fue siempre protegida con rigor, y una determinada concesión venía sujeta a unas rígidas normas vigiladas con celo

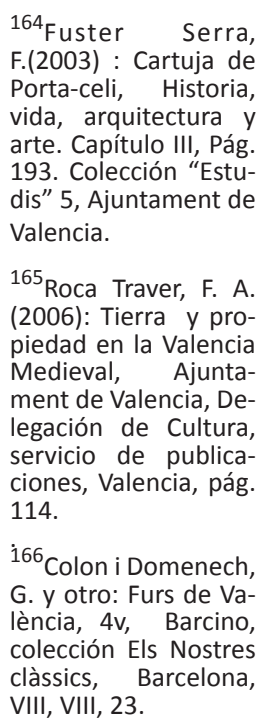

${ }^{165}$ Roca Traver, F. A. (2006): Tierra y propiedad en la Valencia Medieval, Ajuntament de Valencia, Delegación de Cultura, servicio de publicaciones, Valencia, pág. 114.

${ }^{166}$ Colon i Domenech, G. y otro: Furs de València, 4v, Barcino, colección Els Nostres clàssics, Barcelona, VIII, VIII, 23. 
${ }^{167}$ Roca Traver, F.A. (2006): Tierra y propiedad en la Valencia medieval, Ajuntament de Valencia, Delegación de Cultura, servicio de publicaciones, Valencia, pág. 79.

168 Ibídem, pág. 98. por los Consells. Por consiguiente, toda clase de servidumbre en el campo era concedida con suma prudencia, se vigilaba celosamente cualquier tolerancia, y en todo caso era siempre asumida por la tierra y no por el propietario.

Stablir una terra era el acto jurídico por el cual un consell asignaba una determinada parcela a un labrador, bien por cesión a instancia de parte, o bien por compara, que era la forma más corriente. Este sistema-stabliment, que producía un asentament, fue seguido con mucha frecuencia en todas las tierras del nuevo reino valenciano como consecuencia de la constante movilidad de la población inmigrante ${ }^{167}$.

Como se ha indicado en varios estudios sobre la sociedad del bajo medievo, muchas de las familias de colonos que llegan a tierras valencianas tras la conquista, posteriormente se fueron trasladando, con relativa frecuencia, de unas comarcas a otras, hasta acomodarse en un definitivo asentamiento y siempre considerando tanto las facilidades como los beneficios que los Consells les concedían. Porque si el municipio era muy exigente con el pago de impuestos, era natural que los posibles vecinos se asentaran en otros lugares, precisamente allí donde encontraren mayores beneficios y mejor acomodo.

Francisco Roca, en su estudio sobre la tierra y propiedad en la Valencia medieva ${ }^{68}$, separa el tipo de terreno que se ofrecía a los nuevos colonos, como secano, regadío, marjal y bosque.

Las tierras de regadío fueron las más apetecidas por aquella masa de población que llegaba a estas comarcas, dejando atrás, en algún caso, familia y modesta hacienda con el afán de labrarse una situación estable.

Las parcelas de regadío es donde se encuentra la mayor plantación y variedad de árboles. Los musulmanes habían realizado una gran red de acequias y redes de riego que estaban en funcionamiento y facilitaban el seguir trabajando la tierra sin ningún tipo de problemas que los inherentes al campo. Allí donde había parcelas que corría el agua, el labrador aprovechaba tal circunstancia para ubicar un molino. Los molinos tuvieron en tiempos medievales una gran importancia en el desarrollo de la economía valenciana.

Conocedor Jaume I de la relevancia que tenía el sistema hídrico para los nuevos pobladores, deja dispuesto en els Furs que 
otorga, francas y libres, todas las acequias de la ciudad y del reino, mayores y menores, con todas sus aguas, excepto la acequia real que va a Puzol. El monarca además deja claramente establecida la función del cequier a tenor de unas rúbricas, tal vez extremadamente pormenorizadas, pero siempre indicando que debe seguir en cultivo y riego. Los jurats de los Consells nombraban al cequier, con el que suscribían un contrato estipulando sus obligaciones, al tiempo que le autorizaban a cobrar a los propietarios el cequiatge por su trabajo, a tenor de la tierra cultivada y regada.

El volumen de agua era controlado por els açuts, canales de riego o partidors, cuya misión era la de repartir, proporcionalmente, el agua de cada acequia, entre los brazos en los que el canal se dividía. Así se encuentra una acequia principal-çequia mareque daba origen a un brazo mayor o braçal, del cual partían, según su tamaño, la fila y la fillola, y finalmente la cequiola. Para atender toda esa distribución y conducción del agua se clonaba con el roll-abertura o conducto para verter el agua de la acequia principal a canales secundarios- y la boquera portillo para llevarla al propio campo del labrador.

El secano ocupaba la zona más extensa del Reino de Valencia. Esas tierras las aprovechaba trabajosamente el campesino para cultivar cereales, viña, el algarrobo y el olivo, y solamente un constante abancalament de tierras lo hacían posible.

El abancalament forma parte de la arquitectura de piedra seca que trabajó el campesino desde su llegada al reino para acotar las parcelas de sus tierras y conducir sus ganados ${ }^{169}$. Esta arquitectura tiene en cuenta tanto los accesos a la parcela como sus límites, els margens, como la forma de resguardarse los ganaderos con pequeñas casetas, els catxirulos, y la forma de recoger agua de lluvia, en los aljubs.

En los marcos de las observaciones anteriores se puede indicar que todos estos conceptos se pueden observar en el territorio de La Pobla de Vallbona. En lo que se refiere a la división de las parcelas, toda la zona sur está íntegramente formada por propiedades con cultivos de regadío (denominado regadío histórico). En oposición la zona norte del término municipal donde se encuentran los bancales de la zona de secano, aunque desde el siglo XIX, gracias al aprovechamiento de aguas subterráneas, se han construido pozos que han convertido la tierra en regadío. 
Plano término municipal de La Pobla de Vallbona en la actualidad

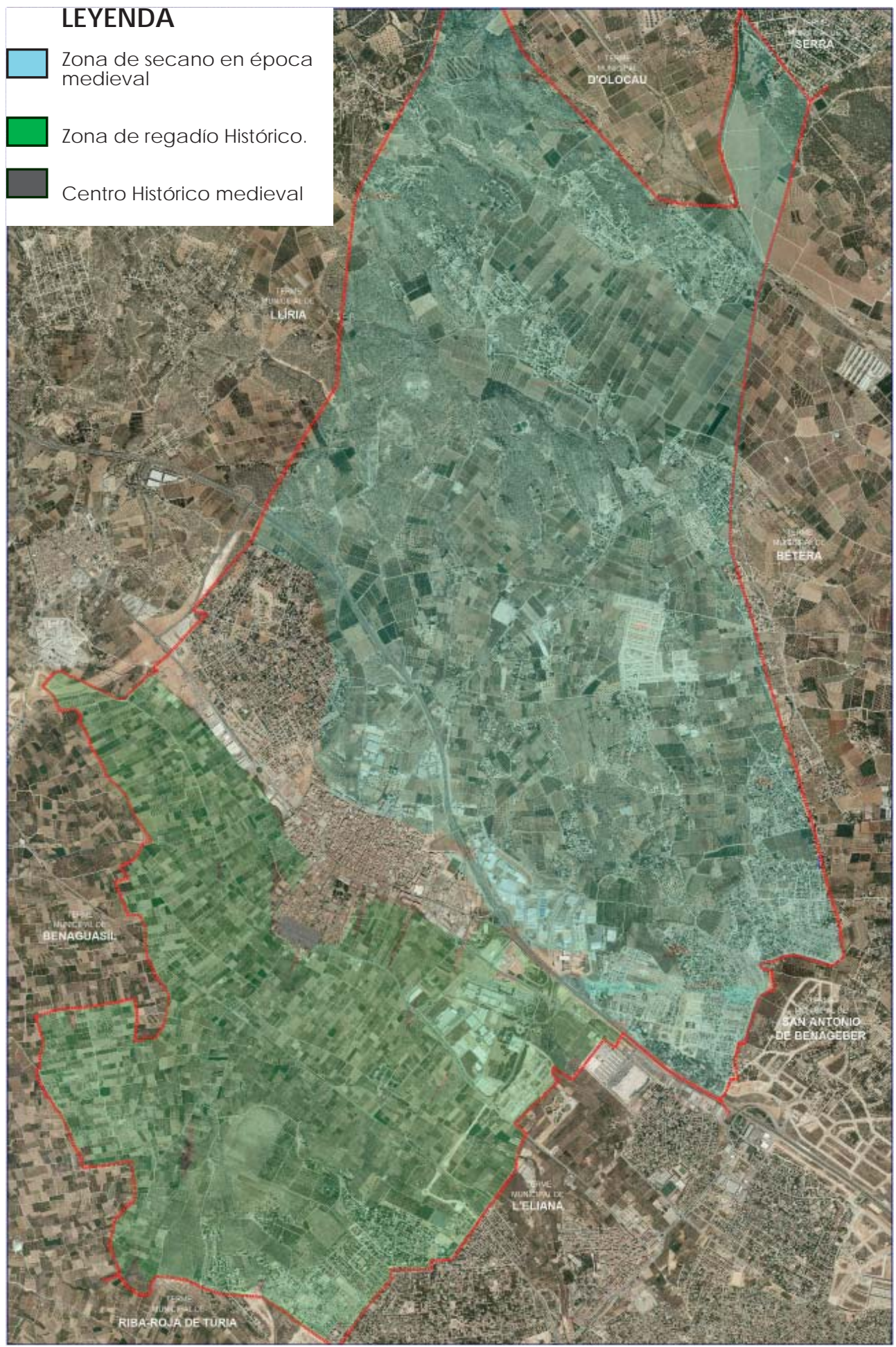




\subsection{1| El regadío histórico}

Las ingeniosas técnicas hidráulicas andalusíes permitieron derivar hacia las huertas de Benaguacil y La Pobla de Benaguzir los limitados recursos hídricos disponibles. Se construyó un açud para poder recoger el agua del río Turia, un sistema para captar agua en una cota fija e iniciar su distribución regular. La combinación del açud, partidores y acequias tejió una red sutil que garantizó el riego por gravedad de cultivos extensos.

La acequia madre o mayor es el eje vertebrador de todo este sistema, sucesivamente ramificado en brazales, hila e hijuelas. El agua sobrante es recogida por los azarbes. Esta red de acequias permitió, en La Pobla del siglo XV, transformar los aguazales y las lagunas litorales en espléndidos arrozales. La herencia de aquel universo cultural ha pervivido hasta hoy.

Tanto por sus condiciones topográficas como por sus antecedentes históricos y la diversidad de su régimen, las tierras que riegan el río Turia o Guadalaviar, desde su entrada en el reino de Valencia, pueden considerarse divididas en cuatro secciones perfectamente caracterizadas, a saber:

\section{1- La Vega de Valencia}

2- Moncada

3- Els pobles Castells

4- Los pueblos altos

La Pobla de Vallbona pertenece desde el bajo medievo a los denominados Pobles Castells. Conforme la división del río hecha por el extinguido Sindicato General del Turia en 1853, "Els Pobles Castells" eran seis ${ }^{170}$ :

- Benaguasil

- La Pobla de Vallbona

- Riba-roja

- Villamarxant

- Pedralba

- Bugarra

La primera documentación escrita haciendo referencia a este grupo de municipios se haya en el privilegio del rey Jaime II del 5 de julio de 1321, en el reparto de las aguas del río Guadalaviar.En este escrito hace referencia als Pobles Castells: Benaguacil, Riba-
Fig. 082 Término municipal de La Pobla de Vallbona en la actualidad. Aparecen coloreadas dos zonas, las parcelas de regadío y de secano.
${ }^{170}$ Contelles Llopis, A. y otros (2008): El sistema de riego a La Pobla de Vallbona: Pozos y acequias, Ayuntamiento de La Pobla de Vallbona, Concejalía de Patrimonio, autoedición, La Pobla de Vallbona pág. 13. 
176 de 536

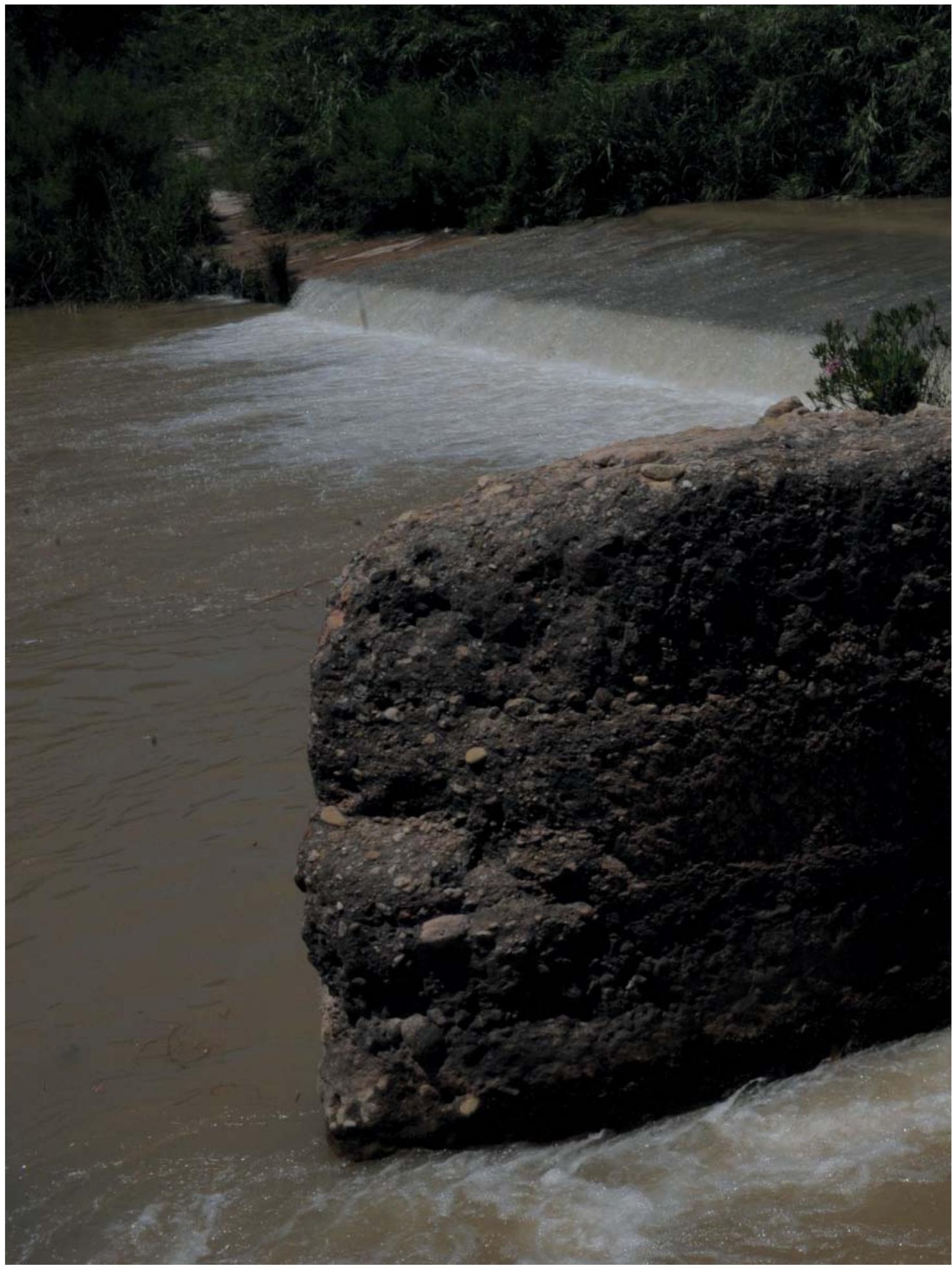

Fig. 083. Imagen del açud de La Pobla de Vallbona y Benaguacil sobre el río Túria. También se observa la compuerta la Real. En el paramento vertical se observan sillares de la compuerta original. 


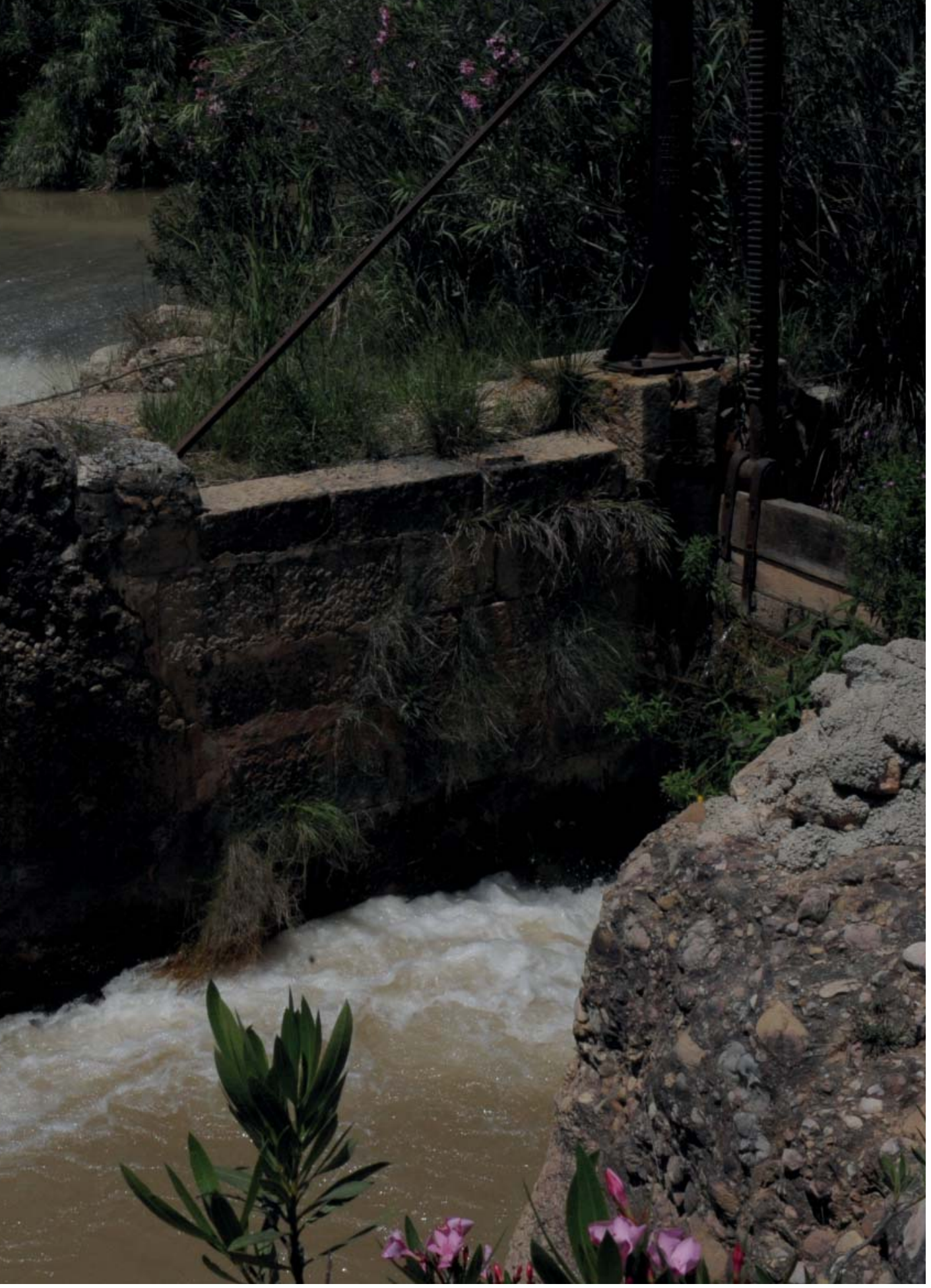


roja, Pedralba y Villamarxant quedando la Pobla incluida por el mismo señorío de Benaguacil. La Pobla de Benaguacil aparece documentálmente, deslindada de Benaguacil, como otro Poble Castell en un documento del año 1413, al describir la sequía en la ciudad de Valencia ${ }^{171}$.

\section{LAS INSTALACIONES DE RIEGO}

Desde el punto de vista topográfico, el modelo adoptado parece ser el sistema de fondo valle, constituido en un llanura sin bosque y acondicionado para el riego mediante una sola acequia principal que riega directamente mediante partidores las acequias secundarias regularmente distribuidas, incluso para admitir molinos si el caudal lo permite.

La acequia presenta un cauce único hasta la partida del Molí de Dalt, ramificándose a partir de este punto en acequias secundarias. La zona de regadío de La Pobla de Vallbona, en esta zona, son 850 hectáreas. Como principales características de este sistema de riego:
A) El açud ( azud o assud)
B) La acequia madre o mare
C) Red de distribución: acequias

\section{A) El açud}

Situación: Polígono 21 Parcela 274 del término municipal de Benaguacil. La presa se encuentra en la partida de la Pea a unos $7 \mathrm{~km}$ al oeste de Benaguacil río arriba del Turia.

Altitud: 115 m.s.n.m.

Cronología: Se basa en factores documentales. El açud actual fue construido en 1640 .

Estado de Conservación: Bueno, por lo que sigue manteniendo su función operativa.

Dimensiones: $50 \mathrm{~m}$ de largo, $8 \mathrm{~m}$ de ancho y $4 \mathrm{~m}$ de altura.

Materiales: La estructura es de un núcleo de mampostería revestido por paramentos de sillería o gruesas losas de diferentes medidas. El recubrimiento pétreo está bien encajado y trabado

${ }^{171}$ Contelles Llopis, A. y otros (2008): El sistema de riego a La Pobla de Vallbona: Pozos y acequias, Ayuntamiento de La Pobla de Vallbona, Concejalía de Patrimonio, autoedición, La Pobla de Vallbona pág 15. formando un conjunto compacto de gran resistencia, y donde la superficie de todo el conjunto presenta una superficie pulida y lisa por la continua acción del agua.

Descripción: Estructura hidráulica destinada a derivar las aguas del río Turia hacia una acequia de distribución, es decir, un açud o presa para toma de agua hacia la acequia Mare o Mayor de 
Benaguacil situada al margen izquierdo del cauce. Se puede decir que el açud es el primer elemento de la infraestructura del sistema de irrigación para campos de cultivo de regadío.

El açud está situado casi transversalmente al cauce del río, permitiendo retener y elevar el nivel del agua hacia la boca principal o Almenara real, pero destaca su situación al final de un meandro para que el propio impulso del agua la conduzca hacia ese lado. Dispone de dos grandes golas, la primera conduce el agua derivada en la acequia y la segunda devuelve al río el excedente de agua.

La estructura ha sido instalada río arriba de las ramblas, por lo que minimiza el riesgo de avenidas procedentes de las mismas, pero debe atender a las subidas del nivel del propio río Turia.

La estructura principal que deriva el agua del río Turia es el açud. Riega un total de $2.100 \mathrm{Ha}$ con un caudal concedido de unos 2,8 $\mathrm{m}^{3} / \mathrm{seg}$ y cuyas aguas movían 11 molinos, bajo la supervisión de las dos comunidades de regantes (Benaguacil y la Pobla) ${ }^{154}$.

En la actualidad mantiene una serie de elementos:

- El açudo presa transversal al río.

-La compuerta perteneciente a la acequia Mayor de Benaguacil y La Pobla

-Compuerta La Real

-La Casa del Açud ( que contiene los elementos de control y protección)

\section{La Compuerta La Real}

Cronología: La estructura actual procede de la segunda mitad del siglo XIX y las compuertas de inicios del mismo siglo.

Estado de Conservación: Es de destacar su buen estado de conservación, aunque ya no se utiliza desde que se construyó el nuevo cauce de la acequia.

Dimensiones: La compuerta cuenta con las siguientes dimensiones $(300 \times 160 \times 20 \mathrm{~cm})$, las cuales, a su vez, describen las dimensiones del cajero de la canal.

Elementos: El canal de entrada, la compuerta y la canal de desagüe o derramador

Materiales: La compuerta está a continuación de la presa a través del canal de entrada, construido mediante una fuerte estructura de grandes sillares de piedra caliza con una base de mampostería. (Posiblemente esta base tosca de mampostería 
haya sido reutilizada como cimiento de los sillares, es decir, la base debía ser el primitivo muro de la canal de entrada anterior a 1640).

El conjunto del tablero está reforzado por elementos férreos y encajados perpendicularmente en las paredes de la canal en dos cremalleras simétricas del mismo material. En los elementos férreos subsiste la siguiente inscripción:

Se hizo en el año 1894 Siendo presidente de la Junta de las Aguas de La Puebla D. José Iranzo Presencia.

\section{La Casa del Açud}

Cronología: Parece ser de la primera mitad del siglo XIX, al ser su mecanismo similar al visto en la Almenara del Jabalí.

Estado de Conservación: Bastante aceptable, aunque como la Real, está en desuso.

Dimensiones: Las esclusas gemelas cuentan con una anchura de 1,20 m, siendo el resto de las medidas muy similares a la Real. El edificio es de planta rectangular $(5,90 \times 5,70 \mathrm{~m})$ de paredes de $90 \mathrm{~cm}$ de espesor y una altura de 4,00-3,50 m. La entrada cuenta con una abertura de $(2,10 \times 0,85 \mathrm{~m})$ y la ventana $(0,65 \mathrm{x}$ $0,40 \mathrm{~m}$ ). El banco cuenta con un largo de $2,10 \mathrm{~m}$ por $0,80 \mathrm{~m}$ de anchura

Elementos: Dispone de las antiguas compuertas del antiguo cauce de la acequia Mare. Situada a pocos metros de la anterior, dispone de dos esclusas gemelas, aunque las compuertas son elevadas por un mecanismo de tornillo o torno situados en eje centro de las mismas facilitado por las guías presentes en las paredes de la canal.

Materiales: Muros de carga de mampostería, con cubierta a dos aguas con techo de tejas. La puerta de entrada es metálica. El banco corrido es de mampostería que debía ser utilizado como lecho para los vigilantes. En el lado inferior de la casa se encuentra la bóveda de grandes sillares por donde recorría el antiguo cauce de la acequia con sus dos ramales, divididos por un muro de $1 \mathrm{~m}$ de espesor, que se vuelven a unir una vez que

${ }^{173}$ Contelles Llopis, A. y otros (2008): El sistema de riego a La Pobla de Vallbona: Pozos y acequias, Ayuntamiento de La Pobla de Vallbona, Concejalía de Patrimonio, autoedición, La Pobla de Vallbona, pág 32. han sobrepasado las compuertas ${ }^{173}$.

\section{B) La acequia Mare}

Estado de Conservación: Aceptable, sigue en uso.

Dimensiones: 2,15 $\mathrm{m}$ de anchura por 1,60 $\mathrm{m}$ de altura; los túneles que cruzan tienen una altitud de 2,50 m. 
Elementos: Acequias cubiertas, descubiertas y zona entubada Trazado: Desde el açud hasta la rambla Primera o de Llíria, la acequia aparece cubierta con una rosca de ladrillo cerámico, entre esta Rambla y la Masía del Riu, no presenta ningún tipo de cubrición, para volverse a techar de nuevo en la carretera de Villamarxant a Llíria ( C-3322). El cubrimiento de la acequia en este primer tramo es consecuencia de las frecuentes avenidas de las ramblas Castellerda y Primera o del mismo río Turia. En este sector de la acequia se encuentra:

- El motor de la partida de la Nahora (o l'Anahora) que sube agua por la acequia general para regar esta partida.

- El rol/del Jabalí, por el margen derecha de la acequia Madre, que permite el riego de parte de la Nahora y de la Vilanova de Benaguacil y el Jabalí, Noguera y l'Horteta al término de Villamarxant, por medio de pequeños rollos que desembocan al río (Sanxis, Cabilos y Bebedor). Aparece de nuevo la acequia Madre a la altura de la partida del Molinet.

El trazado de La acequia Mare transcurre entubado por la carretera que une la C-3322 y la población de Benaguacil hasta la antigua fábrica de papel el Molinet. En este tramo hay otro motor, el dels Cremats, que riega las partidas del Pla del la Barca, els Cremats y parte de Vilanova. A partir del Molinet el sistema de riego adquiere una cierta complejidad. La acequia Mare se desdobla en dos ramales:

a) La acequia de I'Alguacil

b) La acequia Major

Nota curiosa: La acequia constituye una de la arteria de riego derivada del Turia más importante a causa de:

a) La longitud de la acequia Mare, mas de $12 \mathrm{~km}$ (sin contar la prolongación a través de las acequias del Campes y del Alguacil, al término de la Pobla).

b) La superficie regada, cerca de 2.100 hectáreas.

c) El número de términos municipales afectados, tres (Benaguacil, La Pobla de Vallbona y L'Eliana).

d) Las dos comunidades de regantes creadas, Benaguacil y La Pobla ${ }^{174}$. 
182 de 536

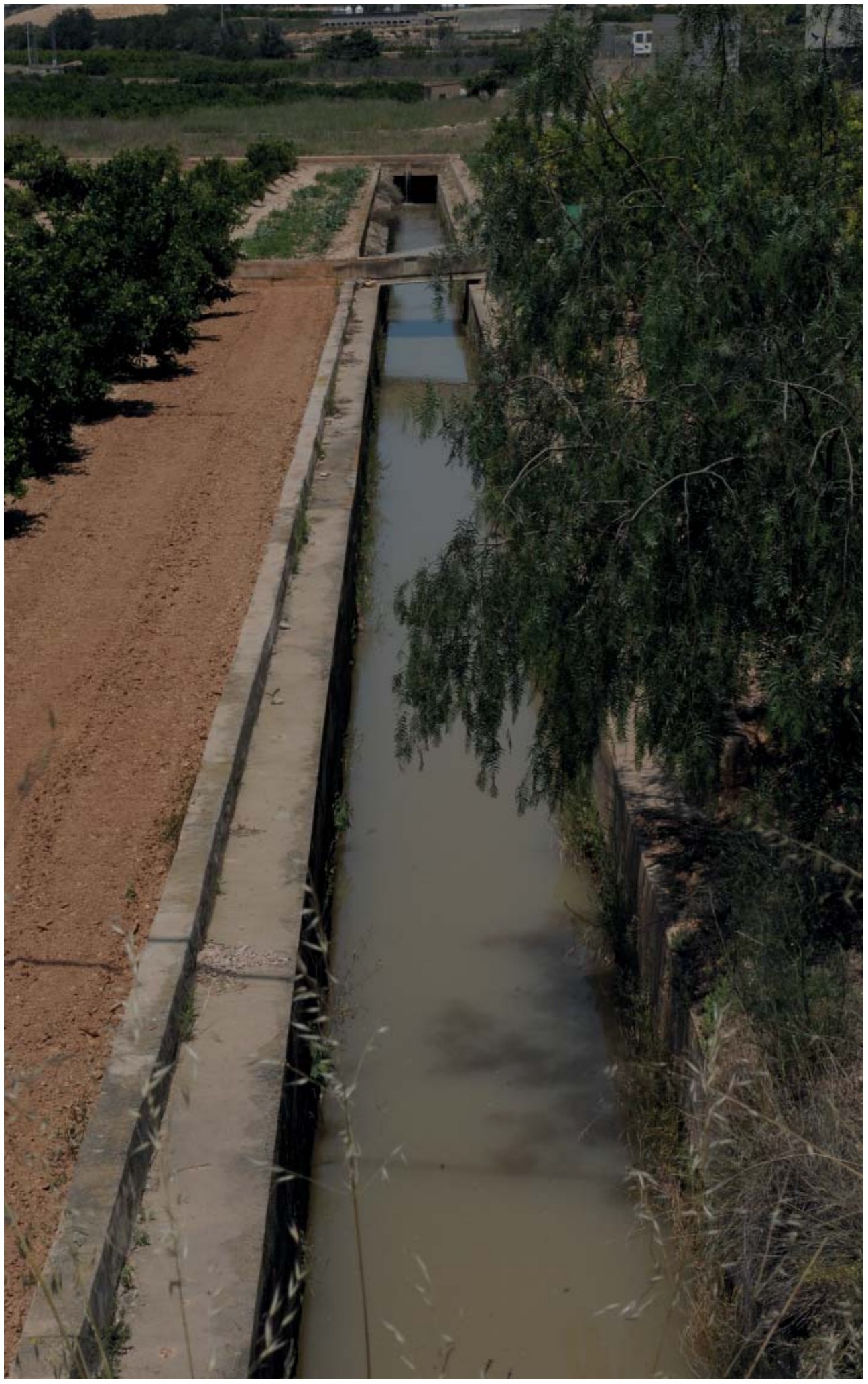




\section{C) Red de distribución}

Las principales redes de distribución de acequias utilizadas por el Sindicato de Riego de La Pobla de Vallbona por orden son ${ }^{175}$ :
a) La Acequia del Alguacil
b) El Roll del Gallipont
c) La Acequia del Campes
d) La Acequia Mayor o Major
e) La Acequia de Ginet
f) La Acequia Primera

Resulta oportuno señalar que hasta el año 1957 el material con el que estaban construidos los paramentos verticales de todo este sistema de riego era la tierra. Con las lluvias de ese año - se inundó entre otros municipios la ciudad de Valencia- las acequias se desbordaron completamente dejando toda la zona sur navegable. A consecuencia de esta situación al año siguiente todos los ramales destinados a riego del Término Municipal se forraron con mortero de cemento u hormigón.

\section{a) La Acequia del Alguacil}

Estado de Conservación: Bueno, sigue en uso.

Dimensiones: En su inicio, 0,90 m de alto por 2,00 m de anchura. En la Pobla su cauce se ensancha con objeto de recibir las aguas de arrastre de las lluvias.

Materiales: En el término de la Pobla, se halla revestida de cemento.

Partidas de Riego: Riega las partidas de I'Alguasil, el Mas de Tous y el Barranquet.

Recoge agua: De la Acequia Madre y las aguas sobrantes de las acequias procedentes de la fuente de San Vicente de Llíria.

Trazado: Nace frente a la Fábrica de Papel o Molino de Ferrándiz en el término de Benaguacil.

Cruza la partida del Rajolarpor la derecha. Después de atravesar el núcleo urbano de Benaguacil discurre por las partidas de la Pila y de los Francs.

Penetra en La Pobla cerca del mojón no 3, camino de la Reya. Cruza por la calle Colón, entre los números 135 y 92 por medio de sifón.

Desemboca: Se une con la acequia del Campes, en la partida del Barranquet ${ }^{176}$.
Fig. 084. La acequia Mare a su entrada en La Pobla de Vallbona desde el Término de Benaguacil.

\footnotetext{
${ }^{175}$ Contelles Llopis, A. y otros (2008): EI sistema de riego a La Pobla de Vallbona: Pozos y acequias, Ayuntamiento de La Pobla de Vallbona, Concejalía de Patrimonio, autoedición, La Pobla de Vallbona, pág. 33.

176 Ibídem, pág 34.
} 
b) El Rol/ del Gallipont

Estado de Conservación: Bueno

Dimensiones: En su origen 1,15 m de ancho por 1,15 m de alto. Materiales: Desde su nacimiento hasta el final está revestido de hormigón.

Recoge agua: Primero recoge las aguas arriba del Molí de Quelo. Posteriormente recibe aguas del Roll de la Caiguda.

Partidas de Riego: El Mas Nou, el Mas de Santa Bárbara, el Mas de Lloca y el Mas de Canonge.

Trazado: Nace directamente de la acequia Madre, entre el Molino de Ferrándiz y la partida de La Máquina. Puede considerarse como el eje más importante y el de mayor longitud de todos.

Bordea el término de Benaguacil, marca un ángulo de 900 , acordona la partida de Aldaya y, lindando con el término de Riba-roja, penetra en La Pobla, no pasando muy lejos del Mas Nou y describiendo una circunferencia; dobla en dirección este, pasando la carretera entre la Masía de la Trinidad y a pocos metros de la de Santa Bárbara.

A partir de aquí recorre todo el Gallipont, se dirige a la partida - Masía de la Lloca, donde por la derecha origina un ramal que transcurre por esta misma dirección hacia la Masía de Canonje. Desemboca: en el barranco del Mandor, por la partida de Canonje.

\section{Notas curiosas:}

1- Presenta el trazado más largo.

2- La acequia Granotera nunca fue una acequia utilizada para riego, sino únicamente un desagüe del término municipal. Según comentan los lugareños, su nombre se debe a que se podía observar sólo en $1 \mathrm{~m}^{2}$ entre 30 y 40 ranas.

c) La Acequia del Campés

Estado de Conservación: Bueno, sigue en uso

Dimensiones: En su origen tiene 1,20 m de ancho por $1 \mathrm{~m}$ de altura.

Materiales: Revestida de hormigón.

${ }^{177}$ Contelles Llopis,

A. y otros (2008): El sistema de riego a La Pobla de Vallbona: Pozos y acequias, Ayuntamiento de La Pobla de Vallbona, Concejalía de Patrimonio, autoedición, La Pobla de Vallbona, pág 34.
Partidas de Riego: Riega la partida de este nombre (Campés Alto y Campés Bajo) a través de una serie de acequias pequeñas (L'Alqueria, Canyaretes) y la partida Cap de l'Horta. A L'Eliana riega la partida de $L$ 'Almassereta.

Recoge agua: de la acequia del Alguacil en el Barranquet.

Trazado: Nace de la misma acequia madre, en la partida de la 
"maquina". Discurre por la izquierda de la acequia Major. Pasa junto al Molino de Pallardó. Corre después en línea recta hacia Benaguacil por la calle Padre José Ma. Esta acequia penetra en el término de La Pobla cruzando el camino de la Ralla, que delimita los lindes de Benaguacil, Llíria y La Pobla. Tras cruzar la partida del mismo nombre, penetra en el casco urbano, atraviesa la calle Colón entre los números 57 y 40 de la misma y es a partir de aquí cuando la acequia invade la partida del Campés bajo. Tras abandonar la población transita junto a la Guardería Municipal de la Pobla para seguir luego siempre dirección este. Circunda el núcleo urbano de I'Eliana, atraviesa el barranco del Mandory discurre bordeándolo hasta el molino de Penyot.

Desemboca: En L'Eliana, en la partida escueta. Suelta un ramal, llamado dels Mallols. Desemboca en la acequia Major.

Nota curiosa: Es la acequia de mayor desnivel.

d) La Acequia Major

Estado de Conservación: Bueno, sigue en uso.

Dimensiones: En su inicio, $1,10 \mathrm{~m}$ de altura por $1,90 \mathrm{~m}$ de anchura.

Materiales: En todo su recorrido son de hormigón.

Partidas de Riego: L'Aldaia, el roll fondo, el Ginet.

Recoge : Las aguas sobrantes de la acequia del Campés

Trazado: Nace directamente de la acequia Madre. Se desliza por debajo del Molino de Pallardó y, algo más adelante, al sureste, en la fileta d'Herraez; rinde sus aguas en el Roll del Mentirós.

Cerca de la población de Benaguacil, la acequia tuerce a su derecha, pasa frente a la estación del ferrocarril eléctrico de Valencia- Llíria, franquea el "Molino de Donís" y se endereza hacia la Pobla, entrando en su término por el "Molino del Mojón".

Transcurre paralela a la acequia del Alguacil por el sur, desde donde nacen numerosos brazos más pequeños. Por la izquierda, a la altura de la partida del Camp Rodat, incoa el recorrido de la acequia del Campes, describiendo un trazado parecido al del Alguacil.

Al abandonar el Molino, la acequia penetra en la partida del Real, cruza el camino de la estación, se introduce en la partida de La Foya, discurre a lo largo de ella hasta la partida La Canal en donde discurre perimetrálmente por "La Canal o Escorredor". Penetra seguidamente en la llamada Barraca de la Xulla y en el paraje titulado Pouet de Pere, cobra las aguas de la acequia Primera, adentrándose en el término de l'Eliana. 
Desemboca: en el barranco del Mandor ${ }^{178}$.

Las ramificaciones de la acequia Major llegan a La Pobla de Vallbona a través de las acequias de:

- L'Alguacil

- Campes

e) La Acequia de Ginet

Estado de Conservación: Bueno, sigue en uso.

Dimensiones: En su inicio mide 0,80 m de altura por 1,00 m de ancho.

Materiales: Desde su entrada en el término de La Pobla hasta el final se halla revestido de hormigón.

Partidas de Riego: El Real, el Campo y la Foia (parte).

Recoge agua: Dos dels Rolls de Forensa y el del "Fondo".

Trazado: Esta acequia se origina en la partida de Ginet, de la conjunción de cuatro rolls: dos de "Forensa" y el del "Fondo" y el del Roll de Ginet (este último nace en la acequia mayor).

Después de cruzar parte del término de Benaguacil penetra en la Pobla entre los mojones 9 y 10. Atraviesa el campo, por medio de sifón, por el camino de la Pobla - Riba-roja, pasando cerca de la estación del tren.

Desemboca: Se junta con la acequia Nueva y ambas desembocan en el Barranco del Mandor.

\section{f) La acequia Primera}

Estado de Conservación: Bueno, sigue en uso.

Dimensiones: En su inicio mide $0,80 \mathrm{~m}$ por $1,00 \mathrm{~m}$ de altura.

Materiales: En todo su trayecto los paramentos verticales se encuentran revestidos de mortero de cemento.

Partidas de Riego: Riega las partidas del Portalet y entre dos céquies.

Recoge agua: Acequia Mayor de Benaguacil y La Pobla de Vallbona.

Trazado: Tiene su principio en el "Molino del Mojón" o Molí de l'Espatarrat, nํ10 y en la acequia Major.

${ }^{179}$ Contelles Llopis, A. y otros (2008): El sistema de riego a La Pobla de Vallbona: Pozos y acequias, Ayuntamiento de La Pobla de Vallbona, Concejalía de Patrimonio, autoedición, La Pobla de Vallbona, pág. 35 . la atraviesa en toda su extensión, teniendo a su derecha la acequia Major y a la izquierda la carretera Benaguasil-La Pobla. Al penetrar en La Pobla lo realiza cruzando por medio de sifón la carretera de La Pobla-Riba-roja, recorre la calle San José y al abandonar la población, deja a mano derecha la parida de entre dos cequies. 


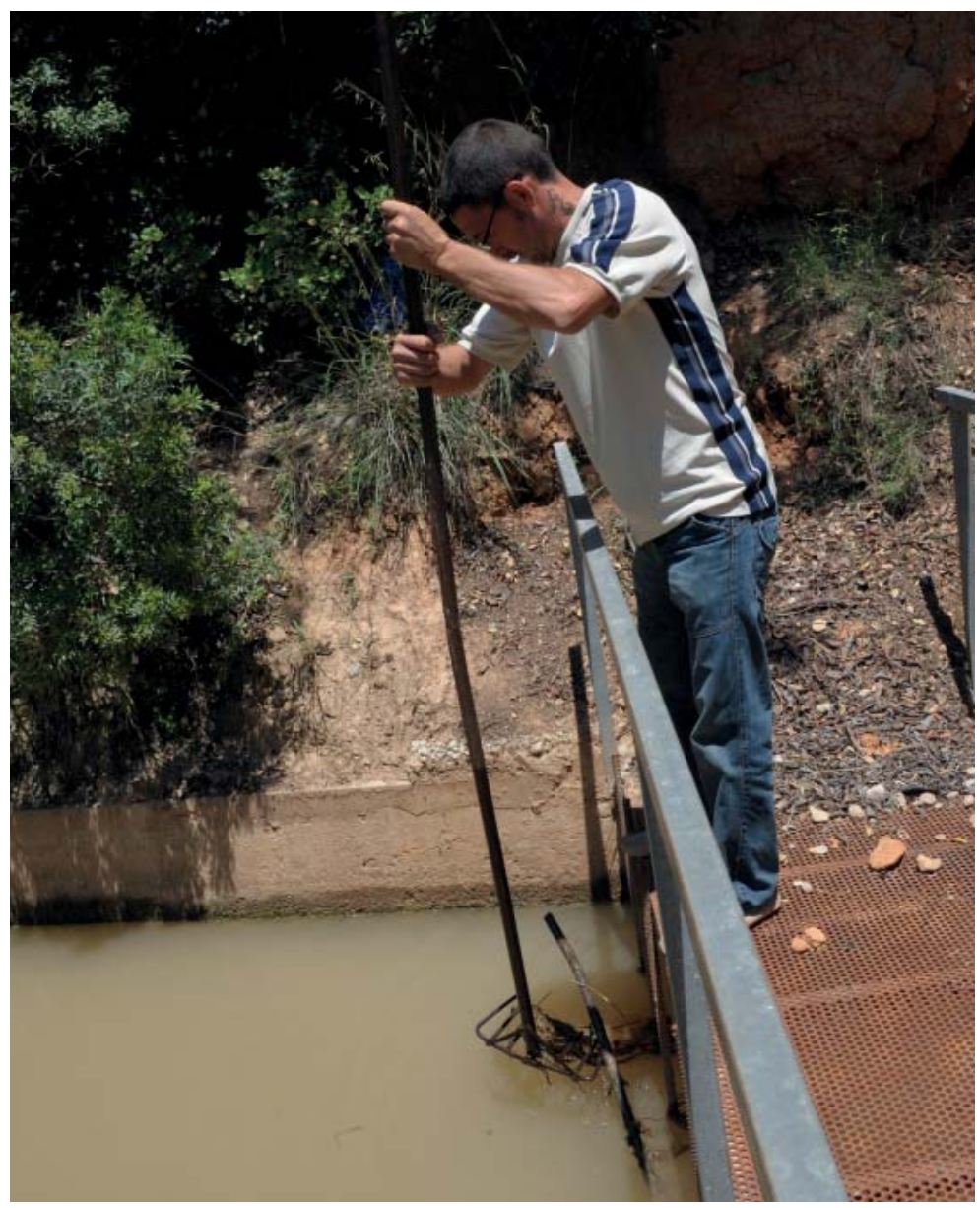

Fig. 085. Uno de los cequiers del Sindicato de Riegos de La Pobla de Vallbona haciendo tareas de mantenimiento $y$ limpieza en una de las compuertas. Cargo medieval que existe en época actual.

Desemboca: En la acequia Major ${ }^{179}$.

Después de todo lo expuesto, cabe plantearse cual es el organismo encargado del mantenimiento de toda esta red de acequias y rolls. El sindicato de riegos de La Pobla, es la agrupación que representa a la comunidad de regantes de esta población y hace en la actualidad el mismo menester que hacia el Consell medieval. Su función es defender a los labradores de la zona de regadío, desde tiempos de Jaime II. Las funciones y secciones de este, vienen regulados en sus Ordenanzas. En este mismo texto se indica que el sindicato es un órgano totalmente independiente del tribunal de las aguas de la Vega (Valencia) por lo que cuenta con su propia jurisdicción.

Son los encargados de gestionar el agua del Turia y de mantener sus acequias, para lo que cuentan con una organización interna y con unas ordenanzas de la Policía de las aguas, de usos y costumbres. Las funciones de velar por estas ordenanzas las desempeña els cequiers o guardes. 


\subsection{2| Las tierras de secano}

La arquitectura de piedra en seco se ha vinculado directamente a los terrenos de secano como se ha visto anteriormente. El municipio objeto de este estudio, La Pobla de Vallbona, no es ajeno a esta tipología de arquitectura popular. En la zona norte de su territorio, parcelas históricamente dedicadas al cultivo de secano, existen una serie de edificaciones dispersas construidas con piedra en seco sin ningún tipo de argamasa.

Esta serie de construcciones y edificaciones, típicas del carácter rural y agrario de la zona, refleja, desde un punto de vista costumbrista, el modo de vida y la forma de hacer las cosas de sus antepasados.

El patrimonio de piedra en seco existente en el municipio se diferencias en tres grupos:

-Los Catxirulos, Aljubs y muros de contención o delimitación de propiedad de piedra en seco, margens.

En primer lugar los catxirulos constituyen pequeñas construcciones cuya funcionalidad es la de servir de refugio ocasional ante las inclemencias del tiempo. También puede ser usado como lugar de descanso parcial durante las tareas agrícolas. Se construye con los materiales del terreno, esto es, piedra caliza para las paredes y losas para tapar la cubierta. La técnica constructiva utilizada para levantar los cucos es la mampostería, sin mortero de unión en las piezas pues se realiza en seco. Para ello se insertan unas piedras con otras, intentando que queden los menores huecos posibles; los espacios entre unas piedras y otras se rellenan con otras más pequeñas denominadas ripios. Suelen contar con unas reducidas dimensiones en torno a los 3,00 metros de diámetro por 1,70 o 2,00 metros de altura y la anchura de los muros suele oscilar entre los 0,40 y los 0,60 $\mathrm{m}$ espesor. Este tipo de obras, por su similitud formal, ha sido puesto en relación con las construcciones megalíticas y con túmulos funerarios de la antigüedad.

También se pueden observar en los mismos polígonos catastrales los aljubs, depósitos para recogida de agua de lluvia realizados con piedra en seco y bóvedas. 
Por último también se pueden contemplar los muros de contención de los bancales con piedra en seco. En la ermita de San Sebastián finalizó en el año 2009 la restauración del muro de piedra en seco que servía como soporte del entorno del inmueble.

Las construcciones de las que se tiene constancia en el actual término municipal son:

\section{Catxirulos}

1- Paretetes; parcela 49.

2- Pla de la cova, parcela 79.

3- Pla de la cova taron.

4- Garroferal clar. Propiedad municipal.

5- Tos Pelat.

6- Maquiva. Parcela 55.

7- Lloma Llarga. Parcelas 65 y 62.

8- Rincons. Parcela 66.

\section{Aljubs}

Aljub grande. Delante de las denominadas Taules de miralles. Pla d'Aljubs.

Aljub pequeño. Casa Blanca.

\section{Margens}

En la ermita de San Sebastián .

En la parcela de la masía de la Casa Blanca.

Después de todo lo expuesto resulta oportuno indicar que el interés por este tipo de patrimonio arquitectónico ha ido creciendo en los últimos años al igual que la concienciación en los poderes políticos de su conservación. En este propósito se introdujo en el año 2013 una modificación puntual al Plan General de Ordenación Urbana directamente en el catálogo de bienes y espacios protegidos, precisando que todas estas edificaciones se deben de conservar y mantener. El texto dice así:

La Ley 5/2007, de 9 de febrero, de la Generalitat, de Modificación de la Ley 4/1998, de 11 de junio, del Patrimonio Cultural Valenciano, en su artículo 1 indica que:

\footnotetext{
${ }^{180}$ Tercer expedietne de modificaciones puntuales del Plan General de Ordenación Urbana, BOP $\mathrm{n}$ 인 de 13 de julio de 2013, art.1..
} 
190 de 536

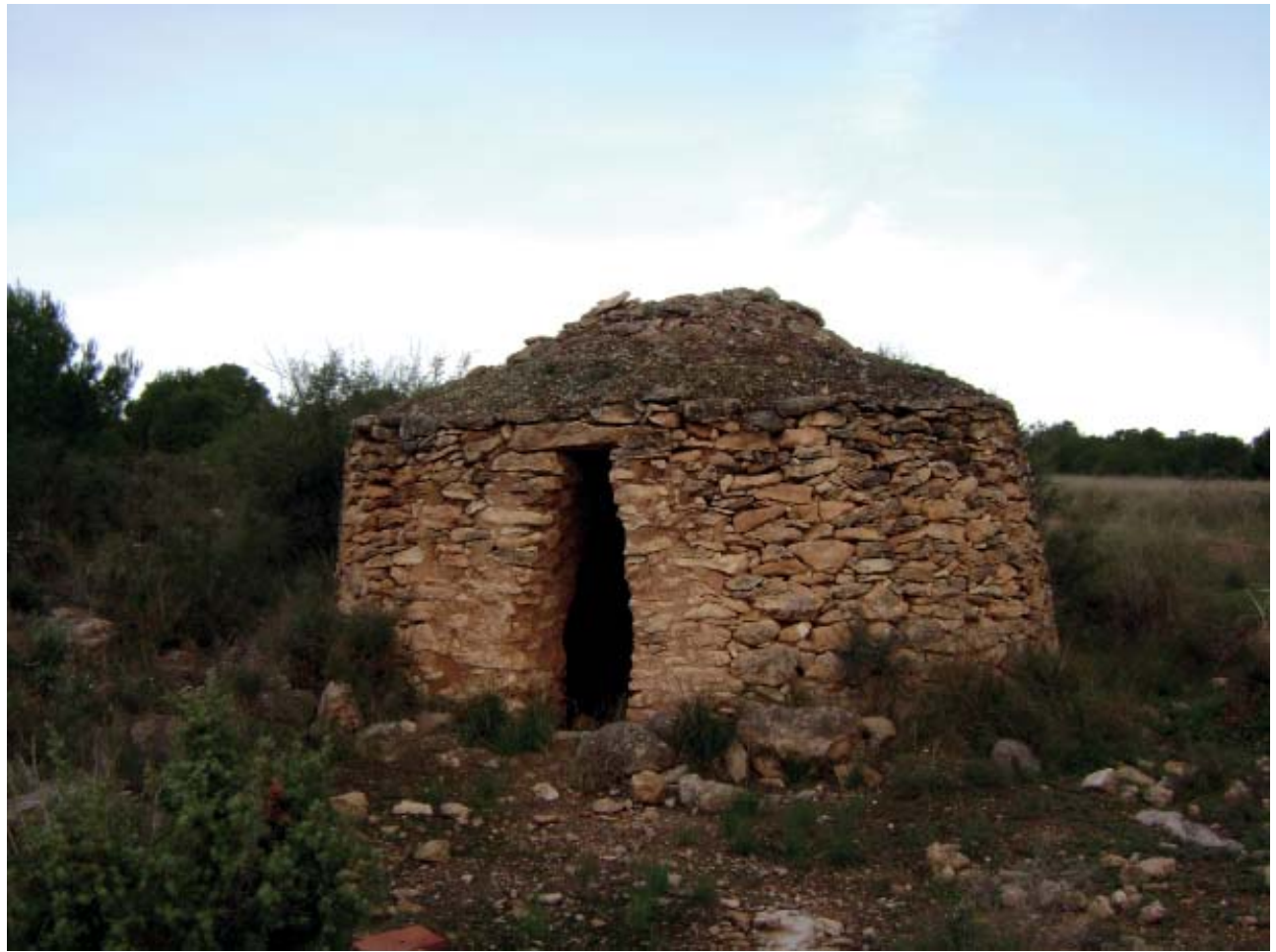

Fig.086. Algunas de construcciones de piedra en seco existentes en la zona de secano del Término Municipal de La Pobla de Vallbona:

1- Catxirulo dels Rincons. Imagen superior 2- Catxirulo del Garroferal Clar. Imagen inferior
3- Aljub davant Taula de Miralles. Imagen superior derecha 4- Muro de contención Ermita de San Sebastián. Inferior derecha

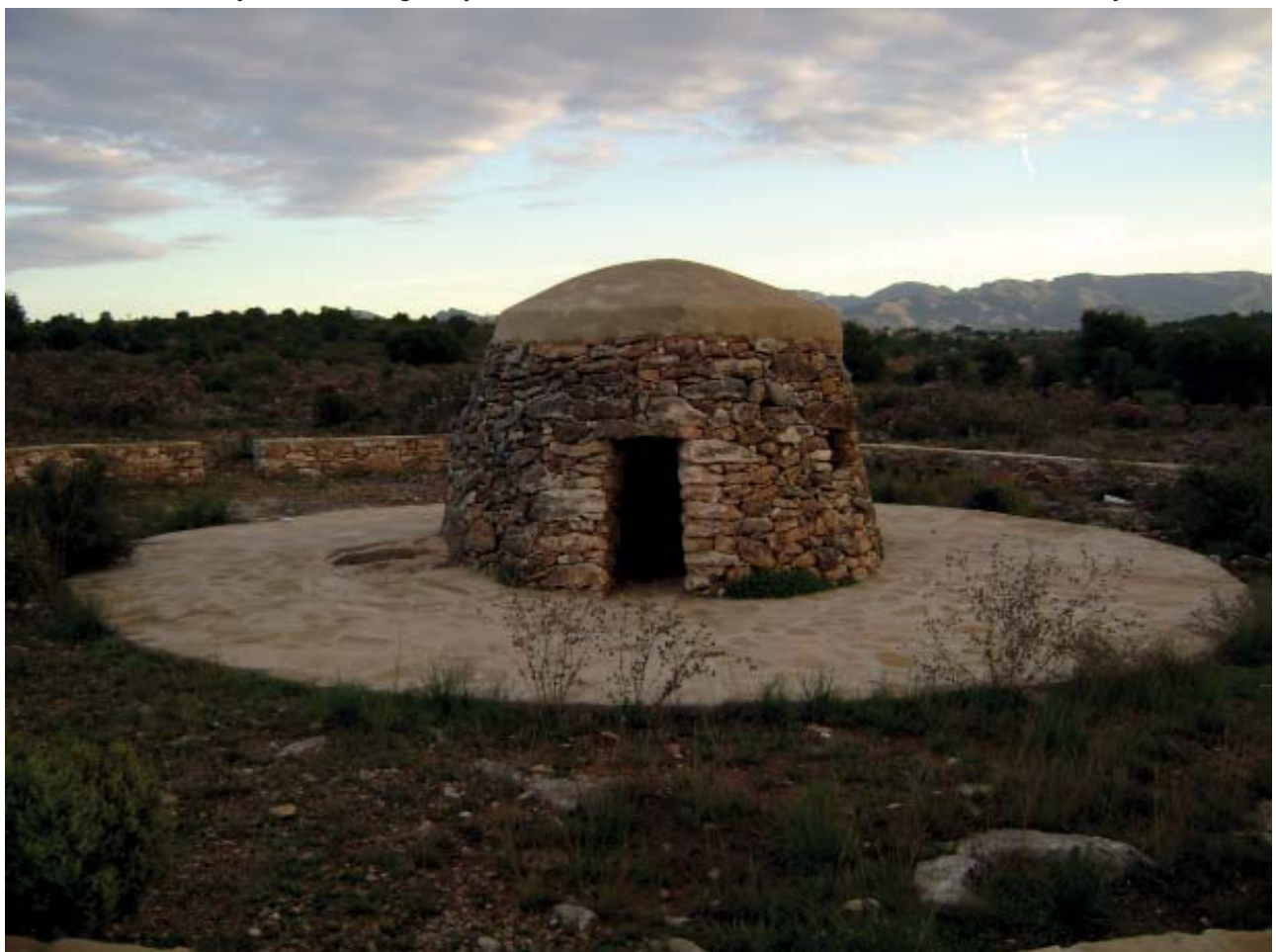


191 de 536
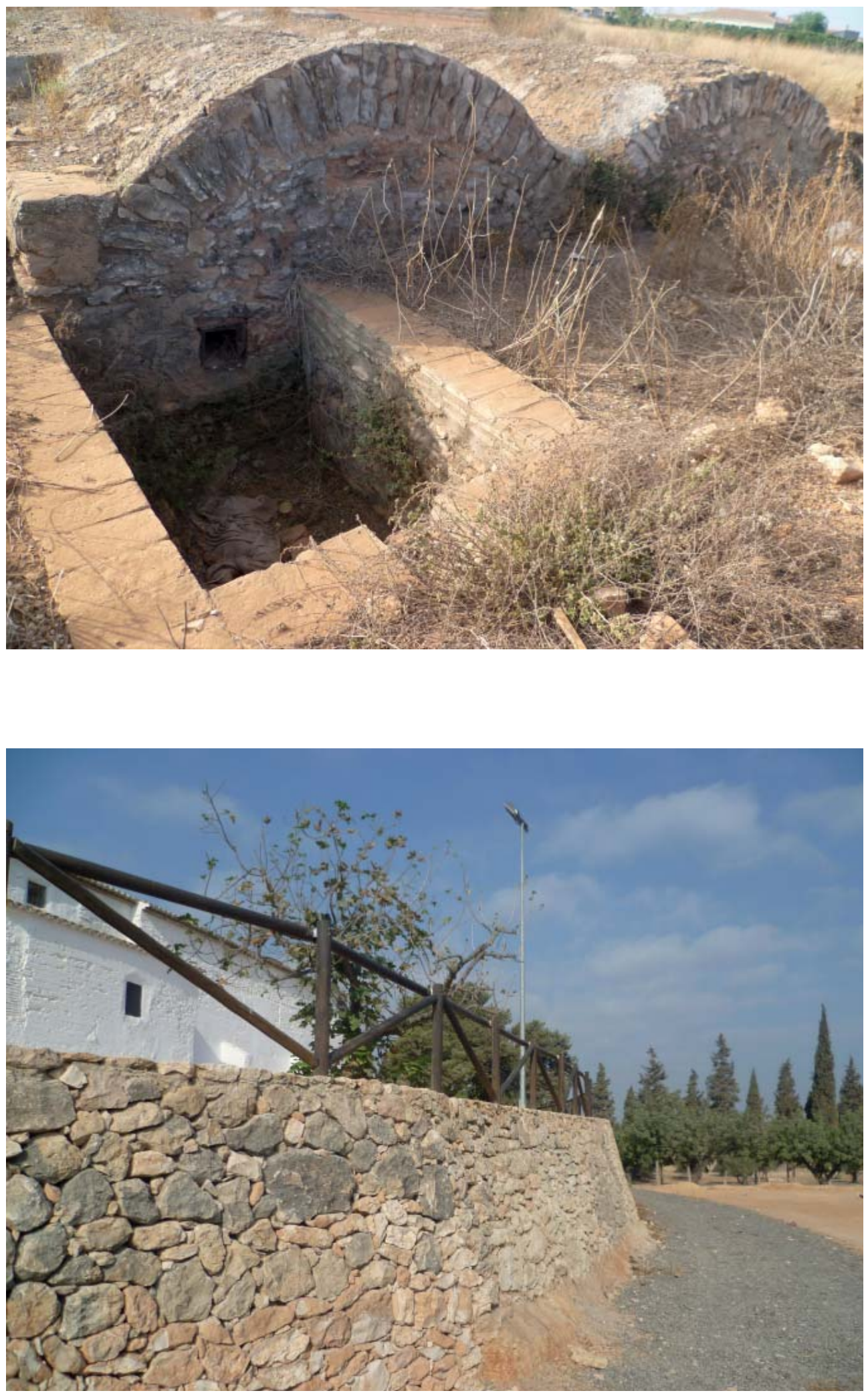
El patrimonio cultural valenciano está constituido por los bienes muebles e inmuebles de valor histórico, artístico, arquitectónico, arqueológico, paleontológico, etnológico, documental, bibliográfico, científico, técnico, o de cualquier otra naturaleza cultural, existentes en el territorio de la Comunidad Valenciana o que, hallándose fuera de él, sean especialmente representativos de la historia y la cultura valenciana.

También la Ley 4/2004, de 30 de junio, de la Generalitat, de Ordenación del Territorio y Protección del Paisaje, en su artículo 2, señala que la política territorial de la Generalitat para el desarrollo sostenible de la Comunidad Valenciana se basará, fundamentalmente, en:

a. Identificación y protección de los hitos geográficos que constituyan referentes del paisaje de este territorio.

b. Conservación y puesta en valor del patrimonio cultural.

En la Pobla de Vallbona, contamos en nuestro territorio con unos bienes inmuebles, de arquitectura popular que forman parte de nuestro patrimonio cultural y etnológico.

Estas construcciones manifiestan claramente la forma de vida de nuestros antepasados y son un hito, presente en las zonas del municipio, donde antaño solo era secano. Estamos hablando de las construcciones de piedra en seco, catxirulos, aljubs y otros. 


\subsection{Las trazas urbanas de la Pobla de Benaguazir}

\subsection{1| Cartografía, planimetría y fotografías históricas}

Al hablar de las trazas de un municipio se refiere al sistema de conectores entre espacios, es decir, al entramado de calles y edificios de una Vila resultado de las distintas fases de crecimiento y del proceso de urbanización. Con el paso del tiempo este entramado va modificándose, ya que los municipios tienen momentos de auge y decadencia que se traducen en variaciones sobre las características locales de la trama.

En los anteriores capítulos se ha analizado el origen de un urbanismo regular en el reino de Aragón, quedando demostrado cómo las trece pueblas de colonización Valencianas estudiadas cumplen con similares características en sus núcleos históricos.

En el presente apartado se pretende identificar estas características en el centro histórico de la Pobla de Vallbona. Este análisis se realizará en la trama urbana conforme ha llegado a nuestros días, pero previamente se tratará de identificar con la mayor exactitud posible los viales y manzanas que pertenecen a la época del bajo medievo. A falta de un estudio arqueológico, que todavía no se ha llevado a cabo en la zona, se ha realizado una búsqueda a través de la cartografía histórica puesto que siempre quedan en el recinto urbano vestigios de lo acontecido en las diferentes etapas de la crónica que permite su identificación. La búsqueda se llevó a cabo tanto en los diferentes fondos documentales existentes en la provincia como en el Ayuntamiento de la citada población.

Asimismo señalar que el mayor problema de este estudio ha sido la inexistencia de archivo histórico municipal. Durante la Guerra Civil Española el consistorio se encontraba emplazado en su ubicación original, en la plaza Major de la Vila (en la actualidad plaça de I'Àntic Ajuntament). En este edificio se encontraban tanto los fondos documentales pertenecientes a todas las etapas del municipio como el archivo histórico del Sindicato de Riegos. Toda la documentación existente en el archivo municipal fue sacada al medio de la plaza por personas afines al ejército republicano, se formó una gran hoguera y fue quemado en su totalidad. El archivo del Sindicato de Riegos fue el único que se salvó. En relación con esto último, puntualizar 
Fig.087. Extracto del plano posterior donde se observa el grabado de la Pobla, sus murallas, un portal y el foso.

Fig.088. Plano del pleito de los arroces naguacil, Riba-roja de Turia y La Pobla de Vallbona 1584. entre las vilas de Be-

con este dato el carácter agrario del municipio y la importancia que tenía este archivo para los vecinos, circunstancia que lo salvó de seguir el mismo camino que el anterior ${ }^{181}$.

En lo que concierne a la planimetría desaparecieron todos los planos de cualquier tipología de suelo, siendo el primer plano catastral de rústica encontrado en esta sede municipal fechado en el año 1928, y el primer plano de urbana de 1980.

A partir de este punto se llevó a cabo una búsqueda por los diferentes archivos provinciales con objeto de encontrar algún grabado, plano o fotografía que mostrara como eran las trazas urbanísticas originales, y cuyo resultado es el que se muestra a continuación.

\section{A- Grabado villa de la Pobla de Vallbona, año 1584.}

El primer mapa forma parte del inventario de fondos digitales que se encuentran en el Archivo del Reino de Valencia, este documento es el no 9 del apartado "mapas y cartografía", y en él se refleja un proceso judicial sobre los arroces que se plantaron entre la Pobla de Vallbona, Benaguacil y Riba-roja del Turia en el año 1584. Debido a esto se grafía todo el sistema de riego de los municipios de la comarca del Camp de Turia mostrando la llegada del agua desde el río Turia hasta la distribución por toda superficie de tierras destinadas en aquella época al cultivo del arroz. Además se representa con unos croquis cada uno de los municipios y he aquí uno de sus principales valores.

La ilustración de la Pobla de Vallbona muestra un municipio amurallado con dos torres en una de sus puertas y el foso existente alrededor de la muralla. Se puede intuir el inmueble que se destina a la iglesia Santiago Apóstol con el óculo de la fachada correspondiente a la zona del altar y la torre gótica.

\footnotetext{
${ }^{181}$ Véase en los anexos apartado A.4, Inventario del año 1873 perteneciente al Ayuntamiento de La Pobla de Vallbona señalando los documentos existentes en el archivo del municipio. Archivo documental de la Diputación de Valencia, pág. 446.
}

Es necesario señalar que los bocetos dejan constancia del material con el que está construida el recinto amurallado. Los paramentos verticales del municipio centro de este estudio son lisos, en cambio los de municipios como Benaguacil o Riba-roja de Turia se representan con sillares. 
195 de 536
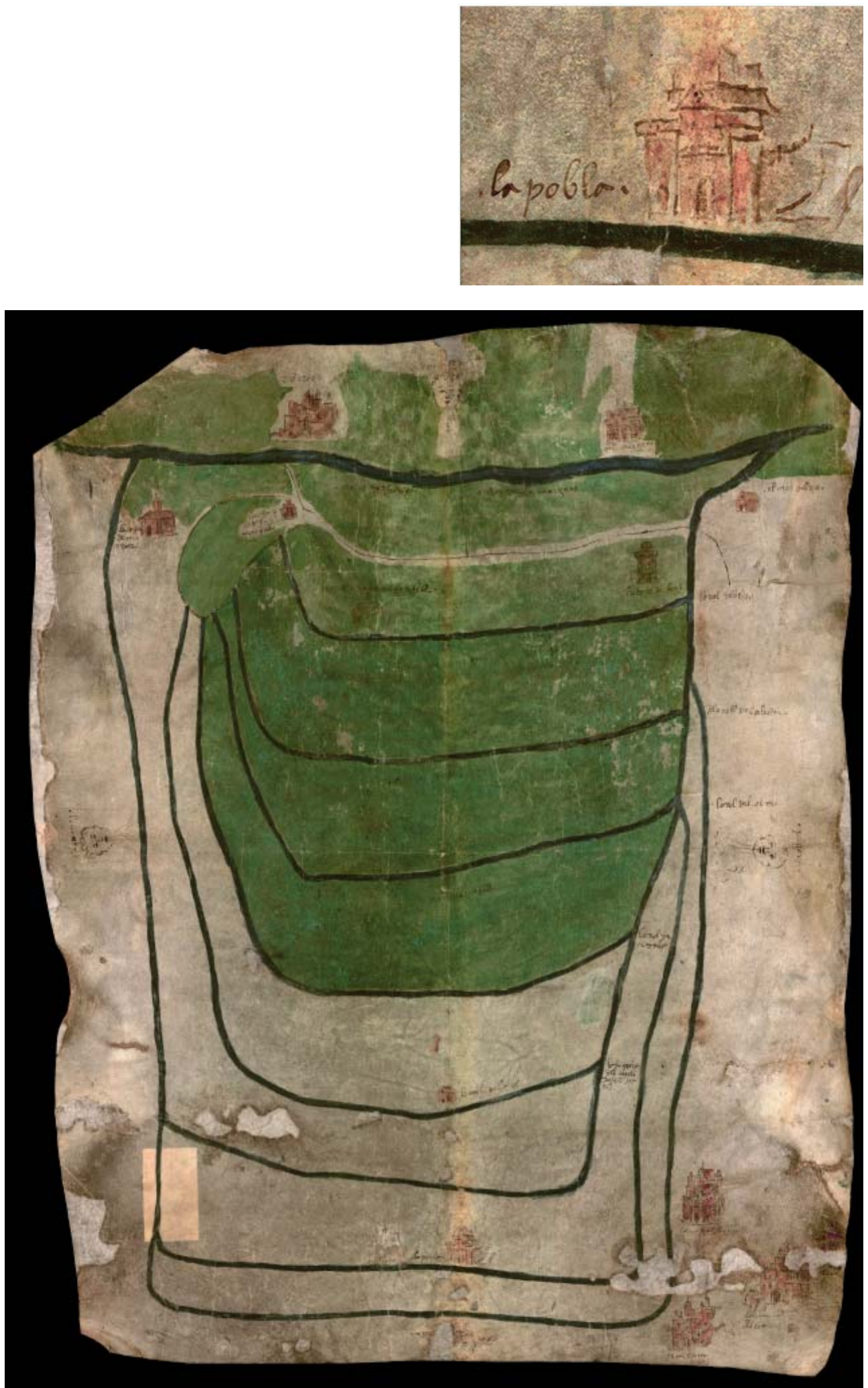

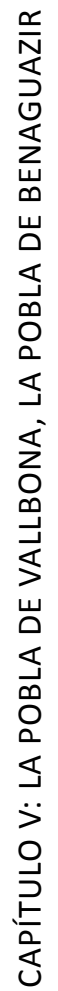




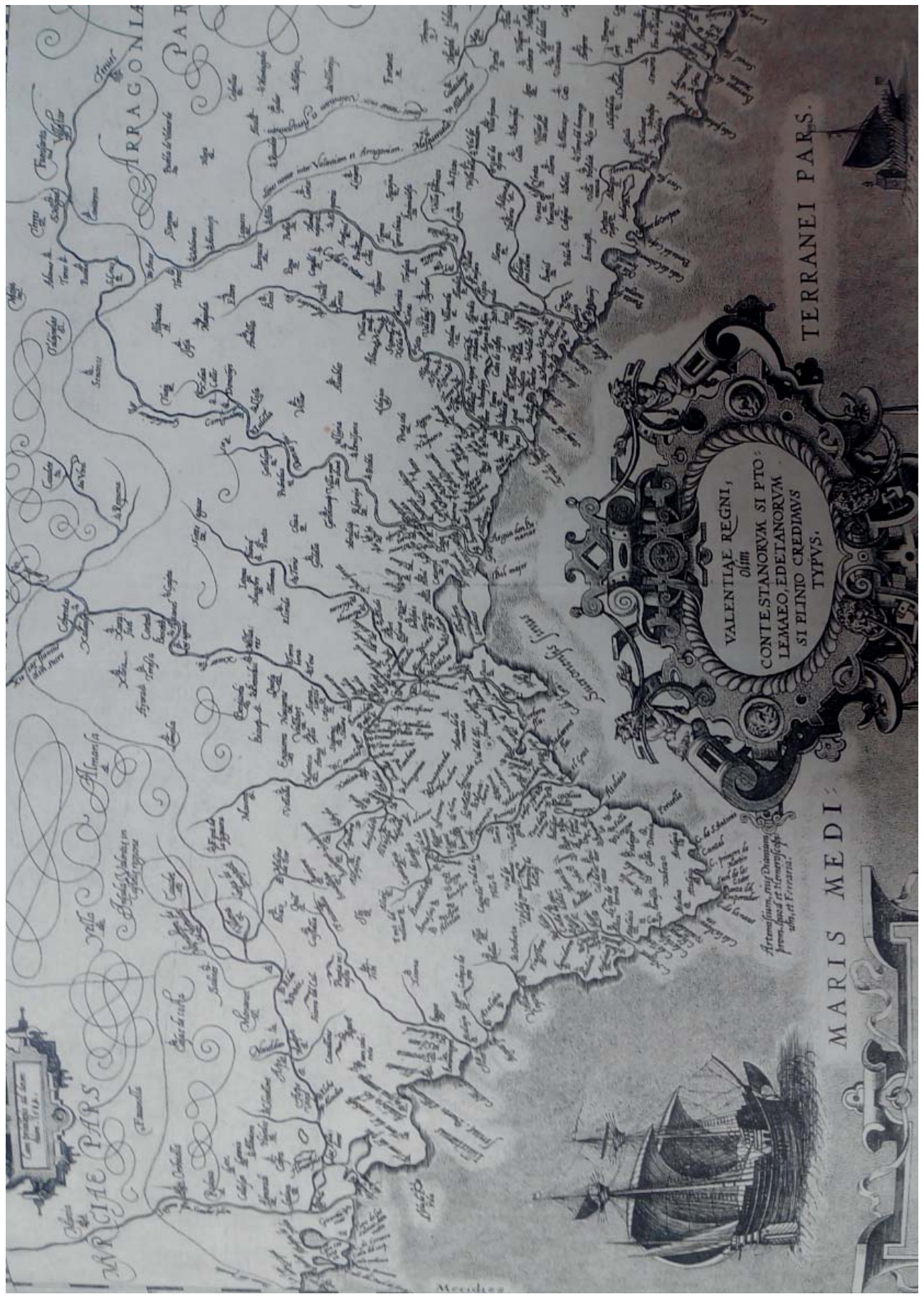




\section{B- Cartografía Valentica Regni Olim. Año 1585}

Recogido dentro del libro Cartografía Valenciana (siglos XVI$X(X)$, editado por el Centro Cultural la Beneficencia, aparecen los primeros planos cartográficos que indican la existencia del municipio de la Pobla de Vallbona.

En efecto se trata de los documentos mas antiguos dedicados de forma exclusiva al Reino de Valencia son, precisamente, hojas impresas enmarcadas en atlas flamencos. Llama poderosamente la atención, y así lo destacan Sanchis Guarner y Roselló y Verguer, la elegancia y la relativa precisión con la que fue elaborado el presente mapa.

El documento que se observa en la imagen número 89 fue realizado por Abraham Ortelius y fue editado en Amberes, procede de la colección denominada "Valencia" perteneciente a Luis Giménez Lorente. El Reino de Valencia está representado a una escala aproximada de 1:640.000 y en formato apaisado.

Aparecen delineados con mucha precisión para aquella época los cursos de los dieciséis ríos, así como nueve lagunas y la albufera. Las poblaciones están localizadas por estimación y hay un signo, pequeño círculo de puntos, que se repite seis veces y que en cinco de ellas coincide con Valls de poblamiento morisco disperso. Se observa claramente a la derecha el río Turia cerca de los municipios de Llíria y Benisano, la vila de La Pobla.

Este autor cuenta con dos planos cartográficos más, uno de año 1603 donde el municipio viene grafiado como una pequeña edificación con una torre ,y otro plano muy similar fechado en el año 1667.

Del artífice(1527-1598) de las trazas, se sabe que fue junto a Gerard Mercator el primer cartógrafo que preparó mapas uniformados específicamente para la formación de atlas. En 1570 publicó el tenido como primer atlas moderno de la historia con el título de Theatrrum Orbis Terrarum. 


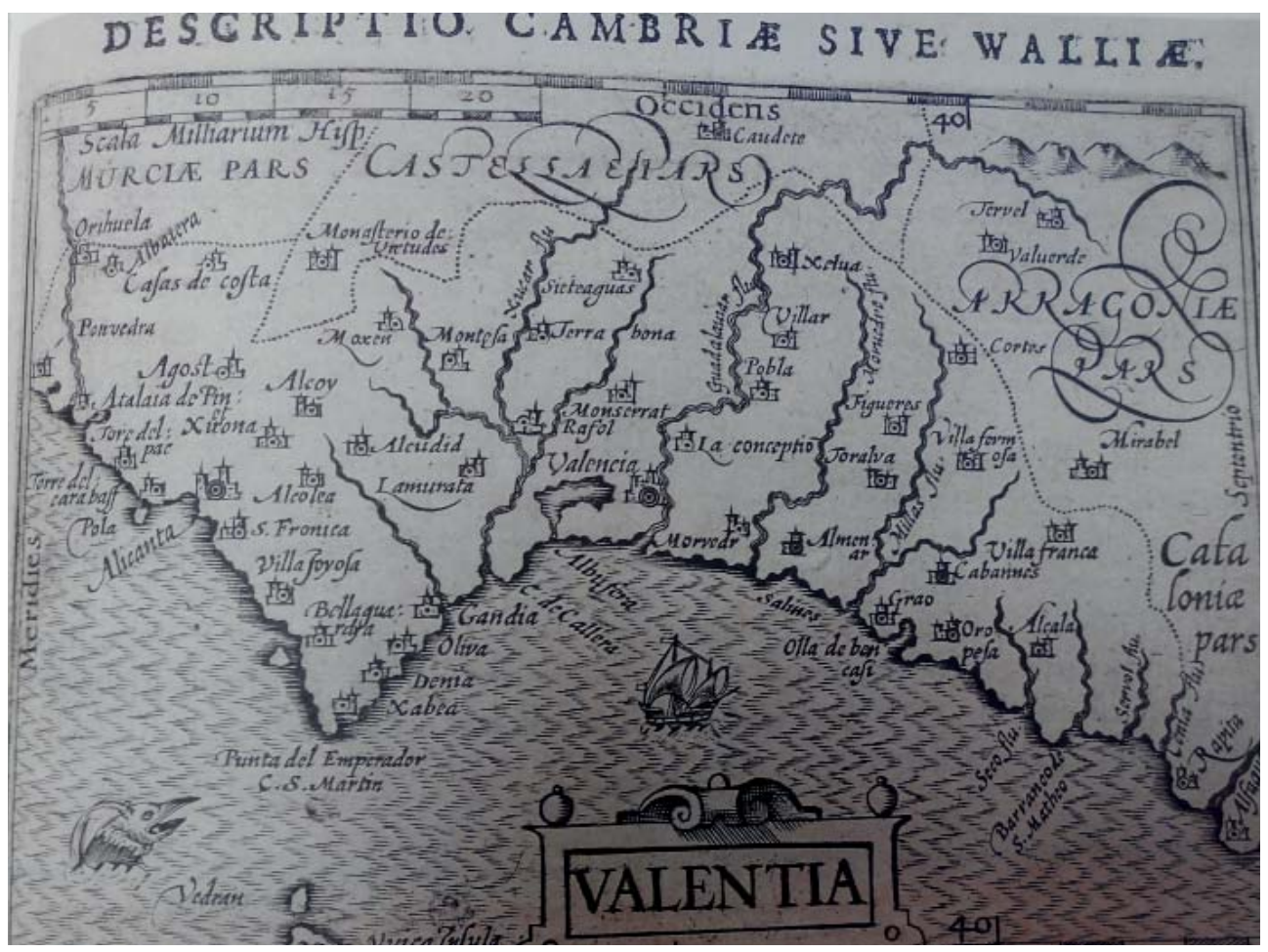

Fig. 090. Cartografía Valentia. Año 1606. Autor Petrus Bertius y Barent Langenes.

\section{C- Cartografía Valentia. Año 1606}

En el mismo libro ${ }^{182}$ que las cartografías anteriores aparece este plano realizado por Petrus Bertius y Barent Langenes en el año 1606, y editado en Ámsterdam. Pertenece a la colección de José Huguet. En este mapa se observa grafíado el río Guadalaviar y la Pobla como un recinto amurallado donde destaca una torre central.

Es importante destacar que en estos planos cartográficos no aparecen grafiados el municipio de Benaguacil ni el de Llíria. Este dato es relevante porque en los planos de la misma categoría de los siglos posteriores (XIX y $\mathrm{XX}$ ) sucede al contrario:

- Es mas habitual que La Pobla no aparezca y se indiquen los municipios anteriormente citados.

Esto podría ser debido a que La Pobla de Vallbona, municipio de cristianos, tiene mas importancia en época medieval que los municipios donde conviven diferentes religiones.

\footnotetext{
${ }^{182}$ Sin autor (1997): Cartografía Valenciana, (siglos XVI - XIX). Centre cultural La Beneficencia. Diputación de Valencia. Colección Imagen, pp. 136-188.
} 


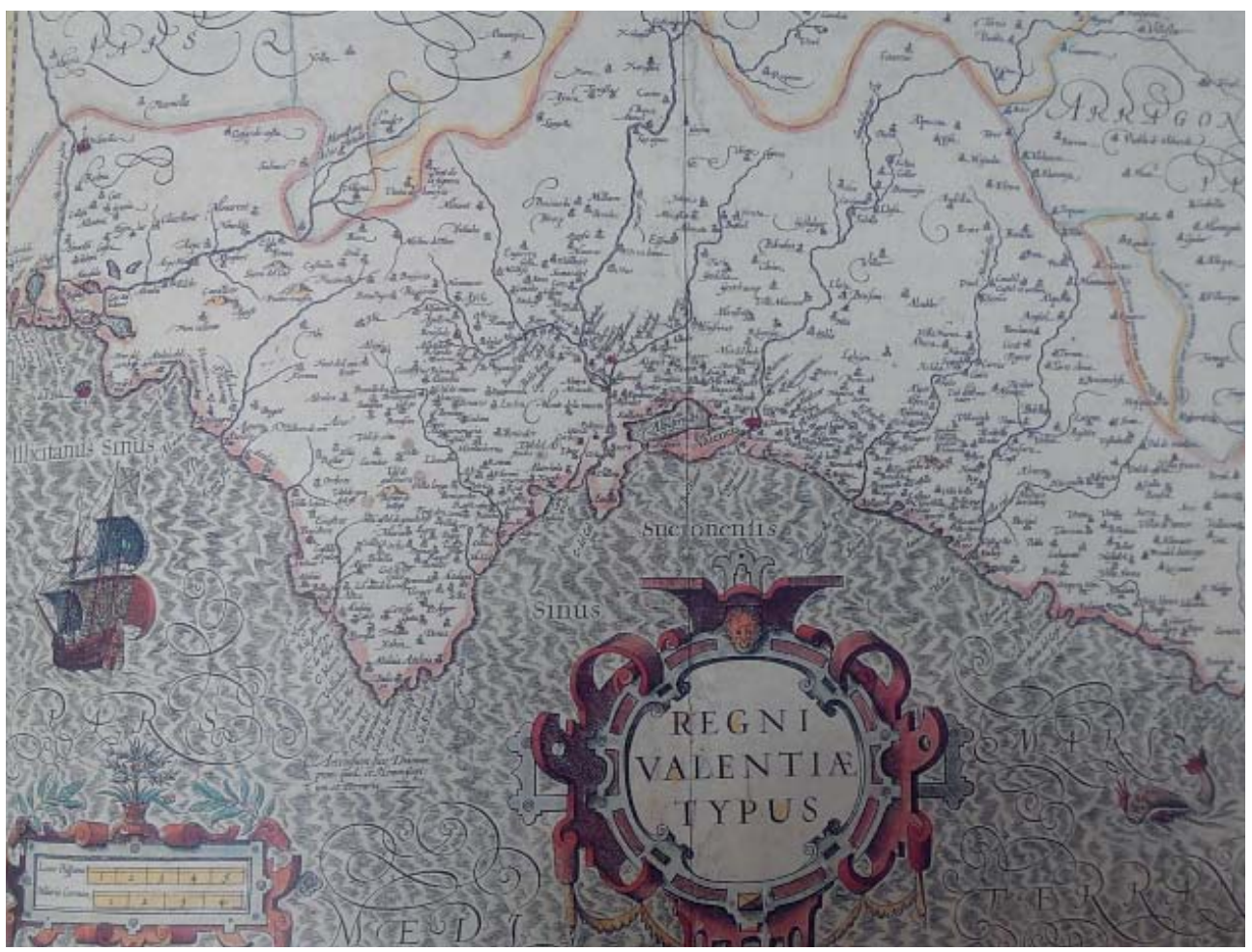

D- Mapa cartográfico. Regni Valentia Typus. Año 1609

Una cartografía más elaborada se encuentra fechada tres años después, en 1609, realizada por Gerard Mercator o Kremer, y editada en Ámsterdam. En este plano procedente de la colección de Luis Giménez Lorente se ubican además los pueblos vecinos de la Pobla, al mismo tiempo que aparecen ilustrados como un recinto amurallado cada uno de ellos.

El mismo autor presenta en la misma recopilación otros planos cartográficos fechados en los años 1607 y 1634, donde vuelve a indicar los mismos municipios. Fue el cartógrafo más influyente del siglo XVI. De él se recuerda sobre todo, la proyección cartográfica cilíndrica que lleva su nombre y que conoció una larga vigencia al permitir la representación rectilínea de las líneas loxodrómicas.
Fig. 091. Cartografía Valentia. Año 1606. Autor Petrus Bertius y Barent Langenes. 


\section{E- Carte du Royaume de Valencia. Año 1760}

En el mismo marco de las observaciones anteriores se llega al siguiente plano cartográfico. En este documento se detalla toda la superficie de la Comunidad Valenciana con sus rios, lagos y delimitaciones. Los pueblos los indica con su nombre y su localización con un punto, por esta razón, no aparece dibujada ninguna silueta al lado del topónimo de la villa que pueda dar una idea de como era el municipio visualmente. En el dibujo de detalle situado a mayor escala a la derecha del plano si que se observa en el municipio de la Pobla un pequeño boceto que detalla la muralla y un edificio alto, lo que podría ser la torrecampanario. El autor es Jean Beaurain y pertenece a la colección "Valencia" de Luis Giménez Lorente

Jean Beaurain (1696-1772), ingeniero y geógrafo real, es conocido sobre todo gracias a la edición de una carta de Edmond Halley dedicada a las corrientes marinas del Canal de la Mancha. Colaboró repetidamente con Nicolás Fer indicando las posiciones de los ejércitos beligerantes durante la guerra de Sucesión de 1702.

A partir de este momento, en los planos cartográficos es mas habitual encontrar la situación de los municipios vecinos que la villa de La Pobla, que pasa a estar omitida en muchos de estos planos. Sucede un cambio: de aparecer la villa de La Pobla y los pueblos de alrededor no estar referenciados, a desaparecer el municipio de la cartografía. Posiblemente este cambio se deba a que, según cuenta Cavanilles, en esta época, debido a las plantaciones de arroz, había una gran mortandad en la zona. Puede ser que La Pobla viera reducida muchísimo su población y por este motivo perdió importancia territorial. Para entender la situación de la población se transcribe unos párrafos de la entrevista que mantiene Cavanilles con el cura de Riba-roja del Turia, D. Julián Trezzi, una persona que le ayudaría a fundamentar datos demográficos contrarios al cultivo del arroz.

El grande aumento de nuestra especie en los quatro pueblos, que acabamos de ver, y haberse verificado en el corto espacio de tiempo de 25 años, prueba que en 1769 hubo alguna feliz mudanza en las causas que influyen en la salud y la prosperidad. Se vió el recinto convertido en pantanos y lagunas, $y$ el suelo firme y fértil en asqueroso cieno. Nacian allí infinitos vegetales é insectos, que con e tiempo eran 


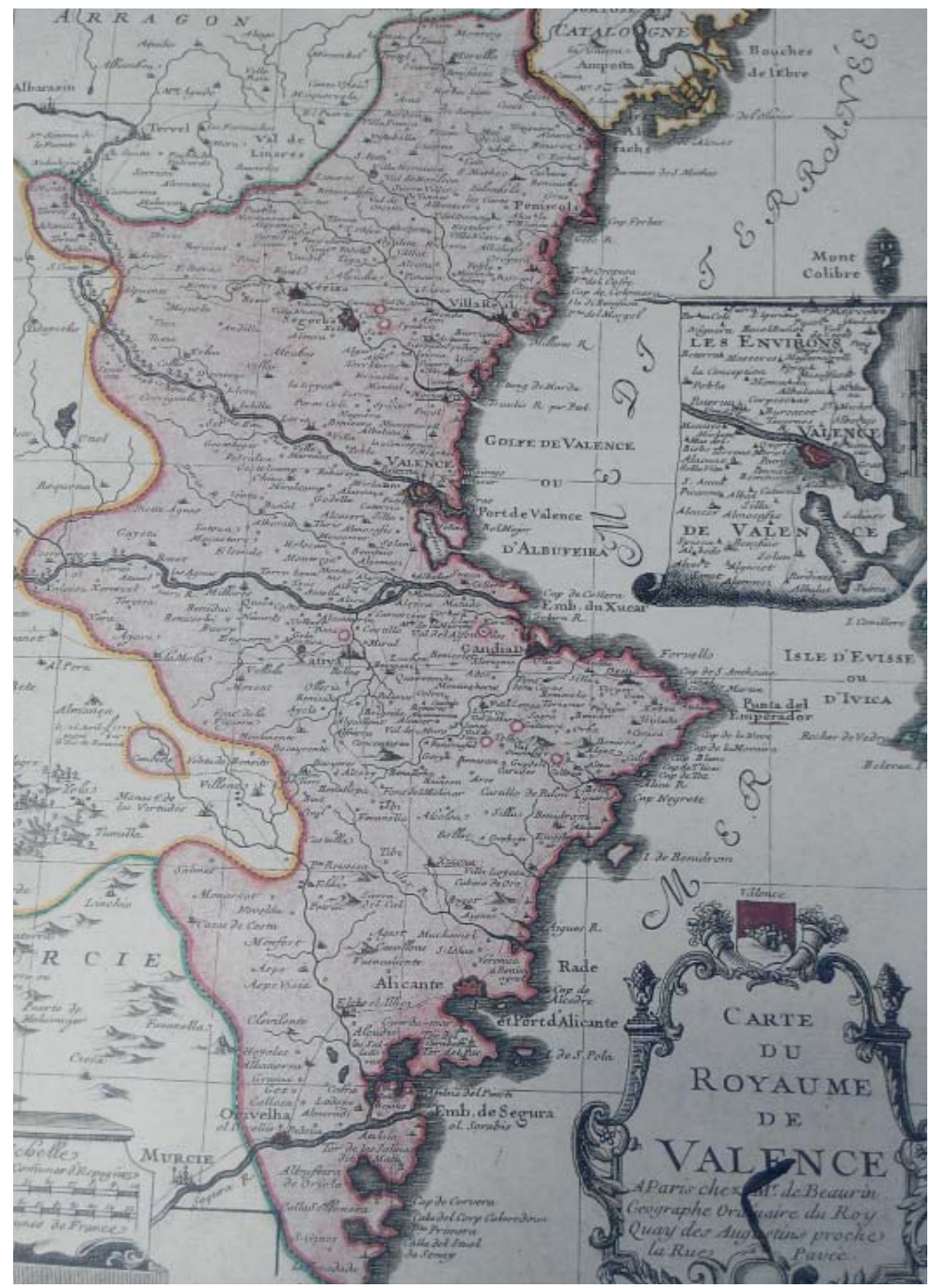

podridas. La atmósfera estaba siempre cargada de humedad, que se oponía á la fecundación de granos e infectaban el aire. Quanto se hallaban en el pestilencial esfera de los aroces ó enfermaba o moria. Los pueblos parecían más bien cementerios, que habitaciones de vivientes. En La Pobla hubo año de 94 muertes y otros de 80. Desaparecían los hombres como humo; faltaban brazos para cultivar las haciendas; y a fuerza de renacer cada día las necesidades, se enajenaban los cultivos $i$ campos, pasaban a manos extrañas y se finalizaba el dominio en una o dos generaciones.

Prevaleció entonces la razón y la justicia, triunfó la humanidad y se prohibieron los arroces.

Fig. 092. Cartografía Valentia. Año 1606. Autor Petrus Bertius y Barent Langenes. 


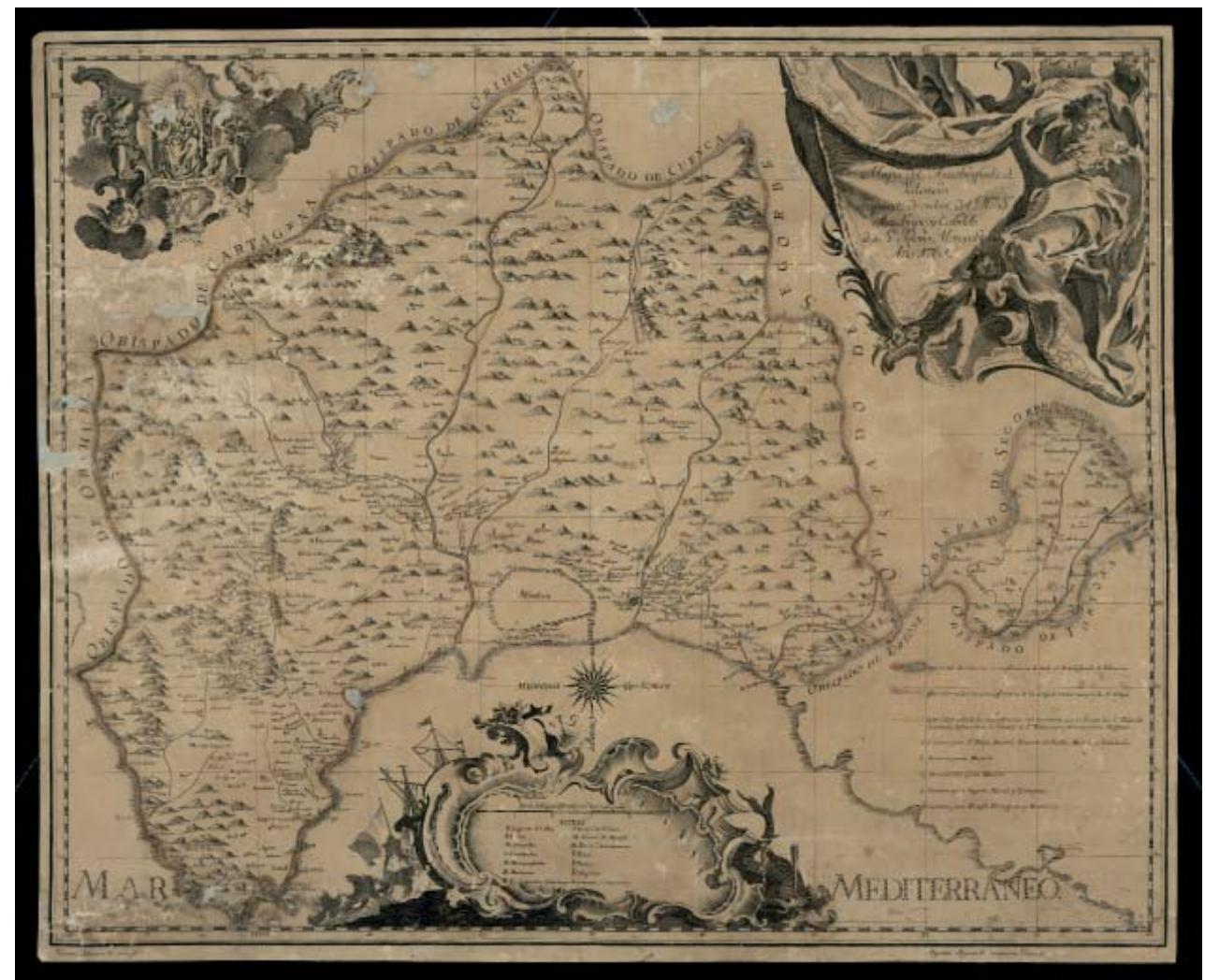

Fig. 093. Mapa del arzobispado de Valencia dispuesto por orden del anterior $y$ del Cabildo a su iglesia en el año 1761.
F- Cartografía provincial del arzobispado de Valencia, año 1761

La próxima referencia se halla en un plano cartográfico existente en los fondos del Archivo del Reino de Valencia y pertenece a un mapa del Arzobispado de Valencia dispuesto por orden de I arzobispo y cabildo a su iglesia en el año 1761. No se indica cual es la persona que lo delineó .

En la leyenda, situada en la esquina derecha inferior, se identifica las vilas que pertenecen al rey, los pueblos, los condados, los ducados, las diferentes encomiendas (Santiago, Montesa, Calatrava...), las ventas existentes en los caminos, pero lo más significativo es que indica los diferentes caminos para llegar a Madrid, Barcelona, Teruel...

En lo que concierne a la Pobla se observa que viene definido como Vila y la señala dentro de un camino "alternativo para ir a Madrid". No ubica la existencia de ninguna venta en el municipio. 


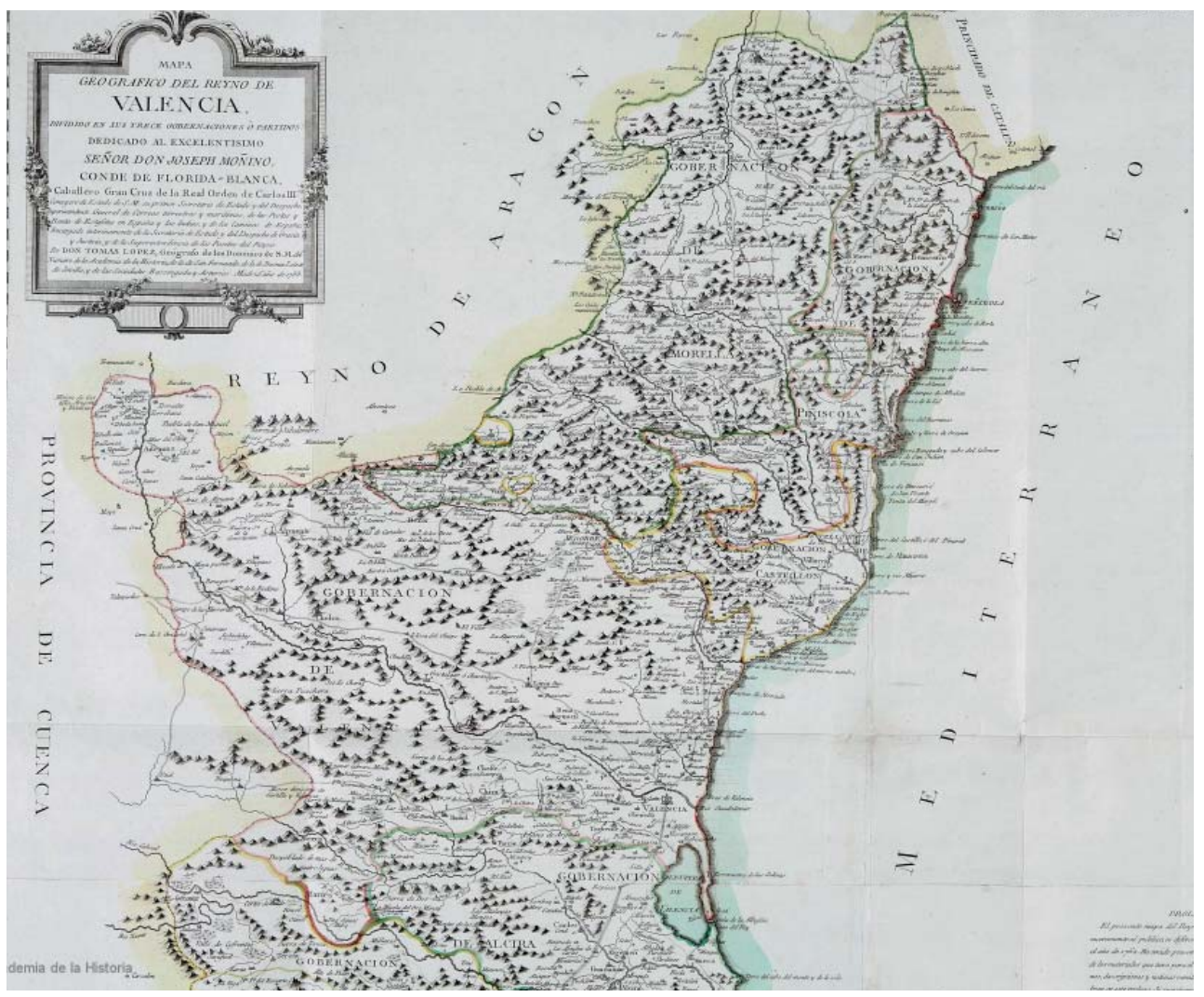

\section{G- Mapa geográfico del Reino de Valencia, año 1788}

Sobre la base de las consideraciones anteriores procede analizar a continuación un mapa cartográfico que se encuentra fechado en el año 1788, realizado por D. Tomás López de Vargas para su estudio Mapas de los reinos y provincias de España en su diccionario geográfico. En este plano se observa la situación de los pueblos y alquerías de la provincia de Valencia conforme a sus trece partidos. En la leyenda situada en el margen izquierdo inferior mediante una iconografía distingue las diferentes ciudades, villas, pueblos o aldeas. La Pobla aparece conforme a la leyenda de Vilas amuralladas mientras que Benaguacil se presenta como villa amurallada con castillo.
Fig. 094. Mapa geográfico del Reyno de Valencia conforme a sus trece partidos por Tomás López de Vargas, 1788. 


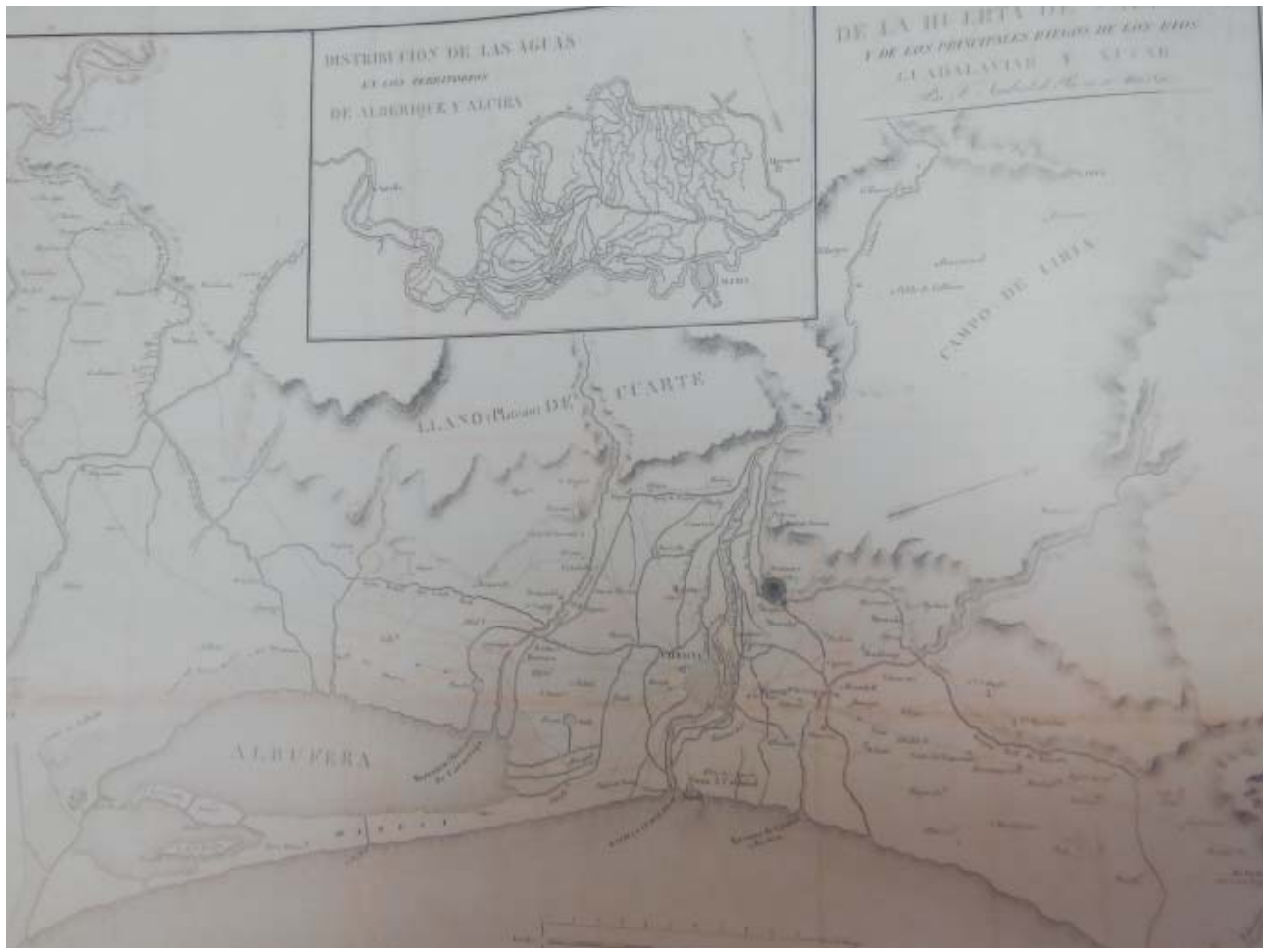

Fig. 095. Mapa de la huerta de Valencia y de los principales riegos de los ríos Guadalaviar y Júcar. Año 1820.
H- Mapa de la huerta de Valencia y de los principales riegos de los ríos Guadalaviar y Júcar. Año 1820

En este mapa realizado por el francés François-Jacques Jaubert de Passa ${ }^{183}$, existente en el fondo de la Diputación provincial de Valencia, con las referencias MP 18, no 17, diapositiva no 8003 , aparece grafiado la ubicación de la Puebla de Vallbona dentro del Término denominado como Campo de Llíria.

\footnotetext{
${ }^{183}$ Sanchis Moreno, F. y otros (2010): Mapas y Planos (16781884), arxiu general i fotogràfic, Diputació de València, Ed. Gráficas Varona, Salamanca, pág. 61.
} 


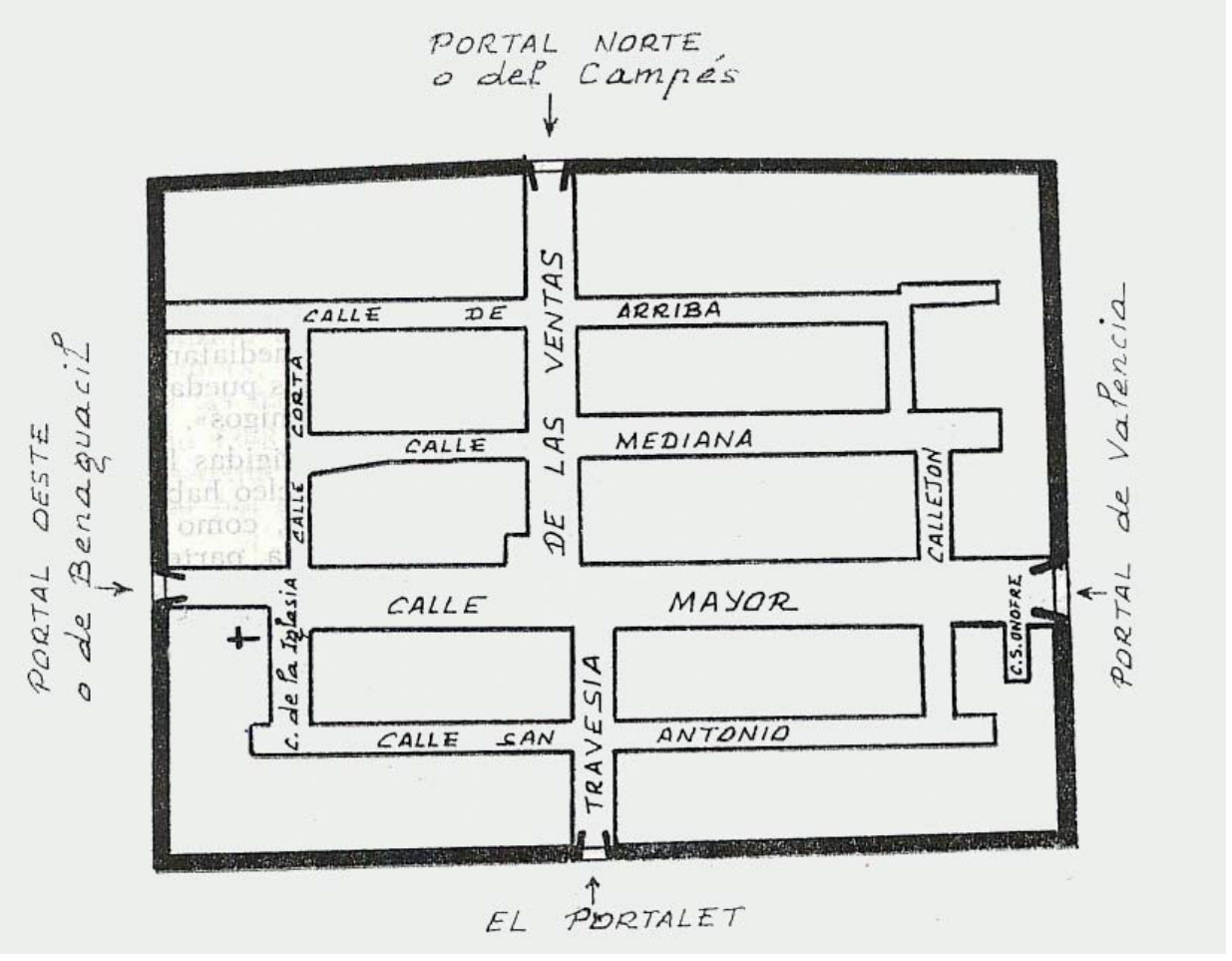

I- Croquis realizado por Pedro Sucías Aparicio, año 1860

Hechas las consideraciones anteriores se procede a analizar con mas detalle el núcleo fundacional de La Pobla de Vallbona. EI plano o croquis que se muestra en la parte superior de este texto es el dibujo mas antiguo del que se tiene constancia que describe gráficamente el casco histórico de la villa. Tal como se observa están diferenciadas por una cerca intramuros y extramuros.

La ilustración representa la muralla, con sus cuatros puertas de acceso y sus viales. Los viales están formados por dos ejes principales y en su cruce se ubica la plaza del municipio. El carrer Major es el eje longitudinal y la calle Travesía de las ventas el eje transversal. Paralelas a la calle mayor describe la calle de arriba, la calle mediana y la calle san Antonio. También dibuja dos calles travesseres y varios callejones. En cuanto a las manzanas, ya aparecen agrupaciones de viviendas pegadas al límite de la muralla y espacios tipo isla en su interior. Aunque proporcionalmente el plano no es exacto sí que lo es, en cuanto a detalle, puesto que aparecen retranqueos en viales que aún existen, y un carreró denominado C.S. Onofre.
Fig. 096. Croquis de las trazas medievales realizado en 1860 por el canónigo Pedro Sucías Aparicio. Llavata, Vicente: Historia de la Villa y Baronía de La Puebla de Vallbona, La Puebla de Vallbona 1981. 
Fig. 097. Croquis de la provincia de Valencia en el que se representan las carreteras que comprende el plan provincial aprobado el 14 de mayo de 1881 y las del plan general del estado de 1880.

Fig. 098. Lindes entre los términos municipales de la Pobla de Vallbona y Riba-roja, propiedad de conde de Revillajijedo en el año 1891.

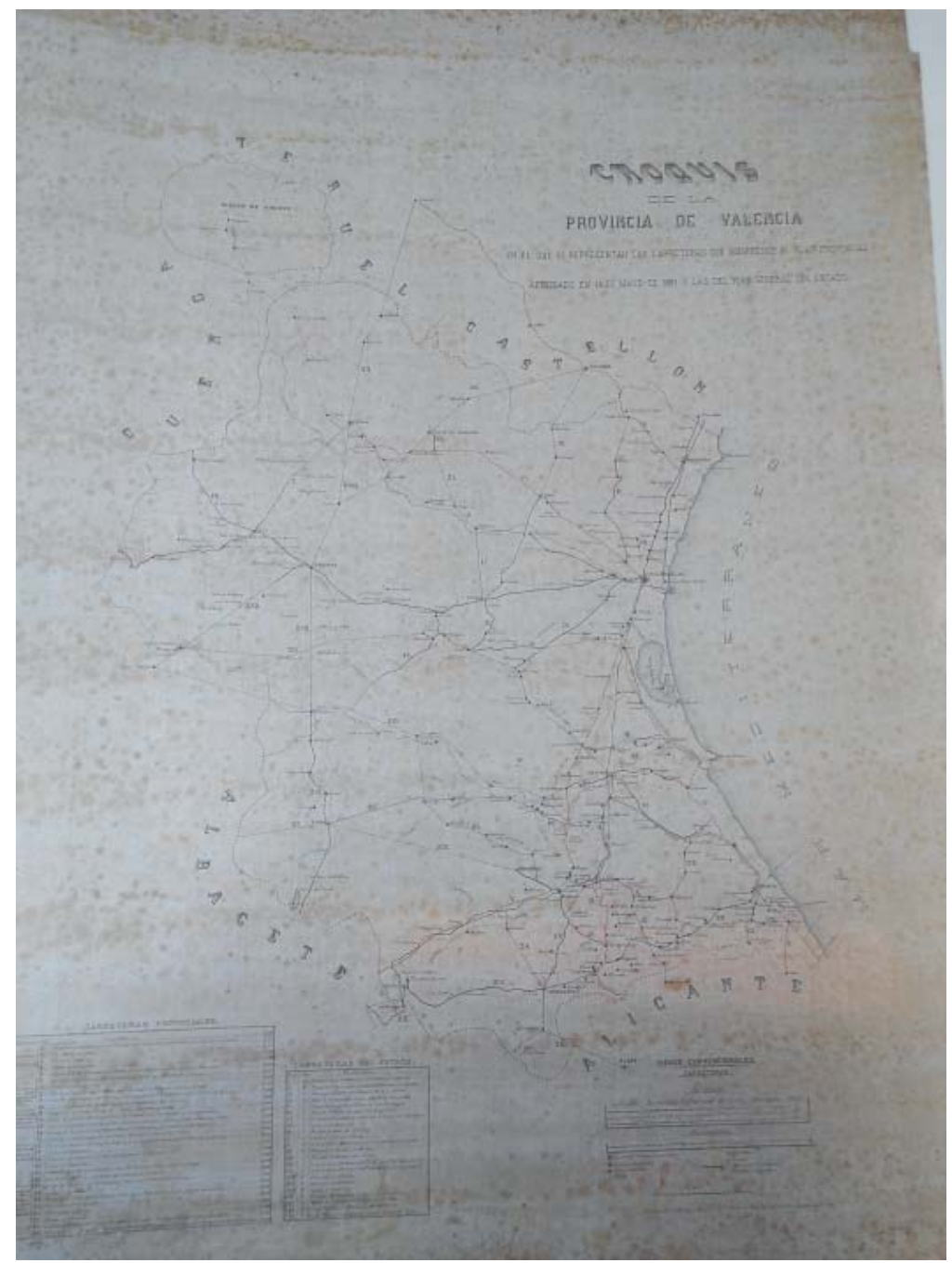

J- Mapa de la provincia de Valencia en el que se representan las carreteras que comprende el plan provincial aprobado el 14 de mayo de 1881 y las del plan general del estado de 1880 .

Delineado en el siguiente plano de procedencia desconocida cuyo autor pudiera ser Fidel Garrido y existente en el Archivo de la Diputación de Valencia, aparece grafiado por primera vez el paso de la carretera provincial por el término de la Pobla, aunque denominado como Ventas de la Puebla. Este topónimo corresponde a la zona de expansión o ensanche de extramuros en la zona norte del centro histórico. El documento se ubica en la misma época que se presume el derribo de las murallas y el desmontaje de las puertas del núcleo histórico. 

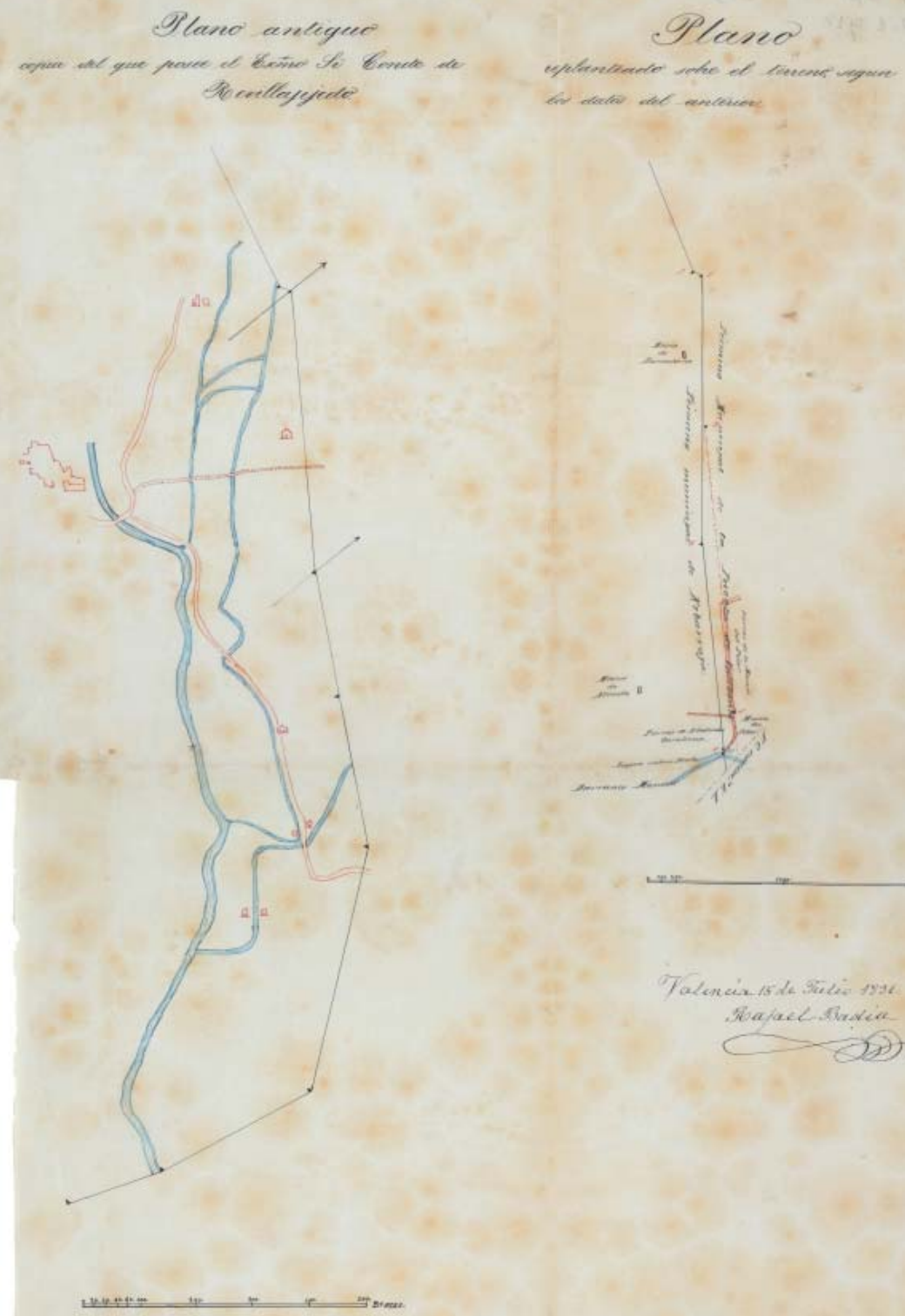


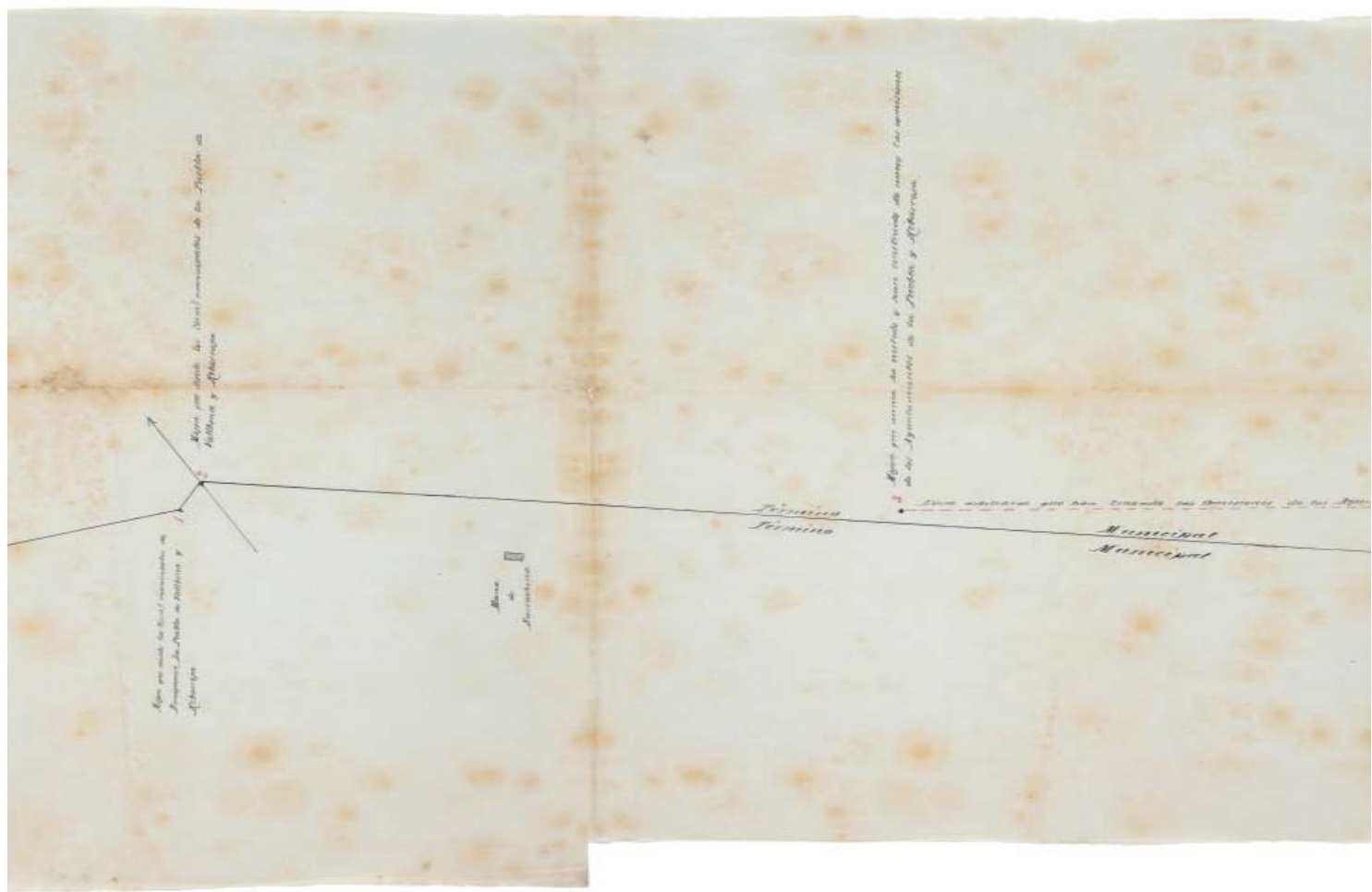

Fig. 099. Plano topográfico de los lindes entre los términos municipales de la Pobla de Vallbona y Riba-roja realizado por el perito Rafael Badia por Año 1891.
K-Plano de los lindes entre los términos municipales de la Pobla de Vallbona y Riba-roja. Año 1891

A continuación se presenta un plano fechado el 15 de julio de 1891 y realizado por el perito Rafael Badía y Aviñó. Se encuentra en el Archivo General y fotográfico de la Diputación Provincial de Valencia en la colección de mapas y planos.

Se trata de un documento de tela de dimensiones aproximadas a $110 \times 38 \mathrm{~cm}$. En él se puede observar los lindes entre los dos municipios citados, sus términos municipales, la masía del Pilar, la línea de ferrocarril Valencia-Llíria y el barranco del Mandor.

Las tierras de la Masía del Pilar pertenecieron a Mariano Mascarós, labrador y vecino de La Pobla de Vallbona, el cual transformó el secano en regadío y construyó una pequeña casa 
de labradores en dichas tierras, según consta en el escrito de fecha 26 de octubre de 1770 según escritura de Concordia de Aguas $^{184}$.

La mayoría de los lindes aquí representados se encuentran en la actualidad en el municipio de L'Eliana. Este territorio perteneció a la Pobla de Vallbona hasta mitad del siglo XX cuando se segregó en 1958. Cabe señalar que el presente plan de investigación se centra únicamente en el territorio que ocupa el actual término municipal de la Pobla de Vallbona. 


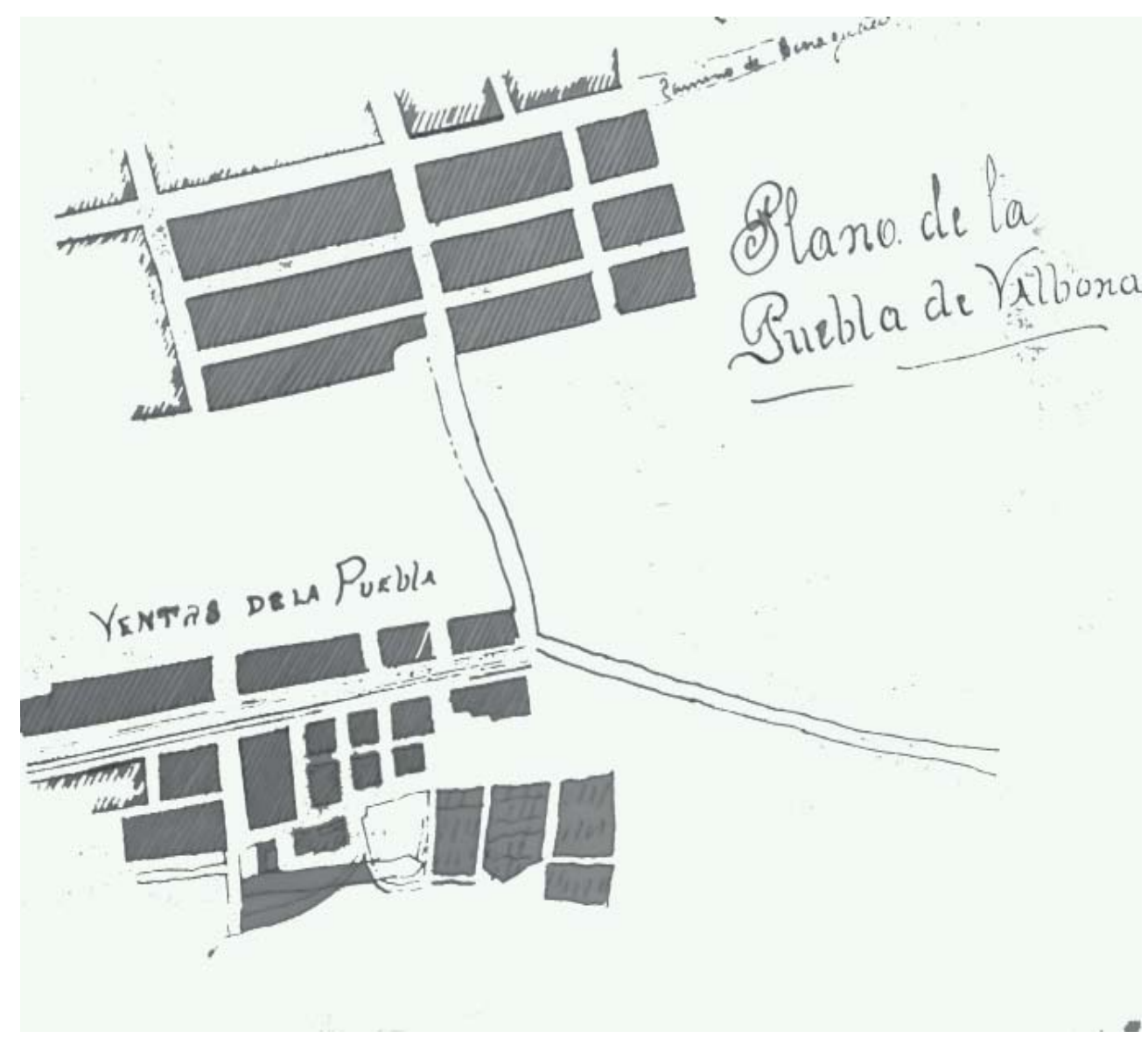

Fig. 100. Croquis de las trazas medievales $y$ del ensanche realizado en 1911 por el canónigo Pedro Sucías Aparicio para sus Notas útiles del Reino de Valencia distritos de Onteniente y Liria.

\section{L- Croquis realizado por Pedro Sucías Aparicio, año 1911}

De la mano del mismo autor citado anteriormente llega el siguiente croquis, pero esta vez realizado ya pasados unos años. El presente croquis se ha extraído del libro denominado Notas útiles del Reino de Valencia distritos de Onteniente y Llíria, redactado por el presbítero en el año 1911.

Lo más relevante de este boceto es que el recinto de la Vila ya no se encuentra amurallado, la Pobla ya ha crecido extramuros formando un barrio denominado las Ventas de la Puebla. 


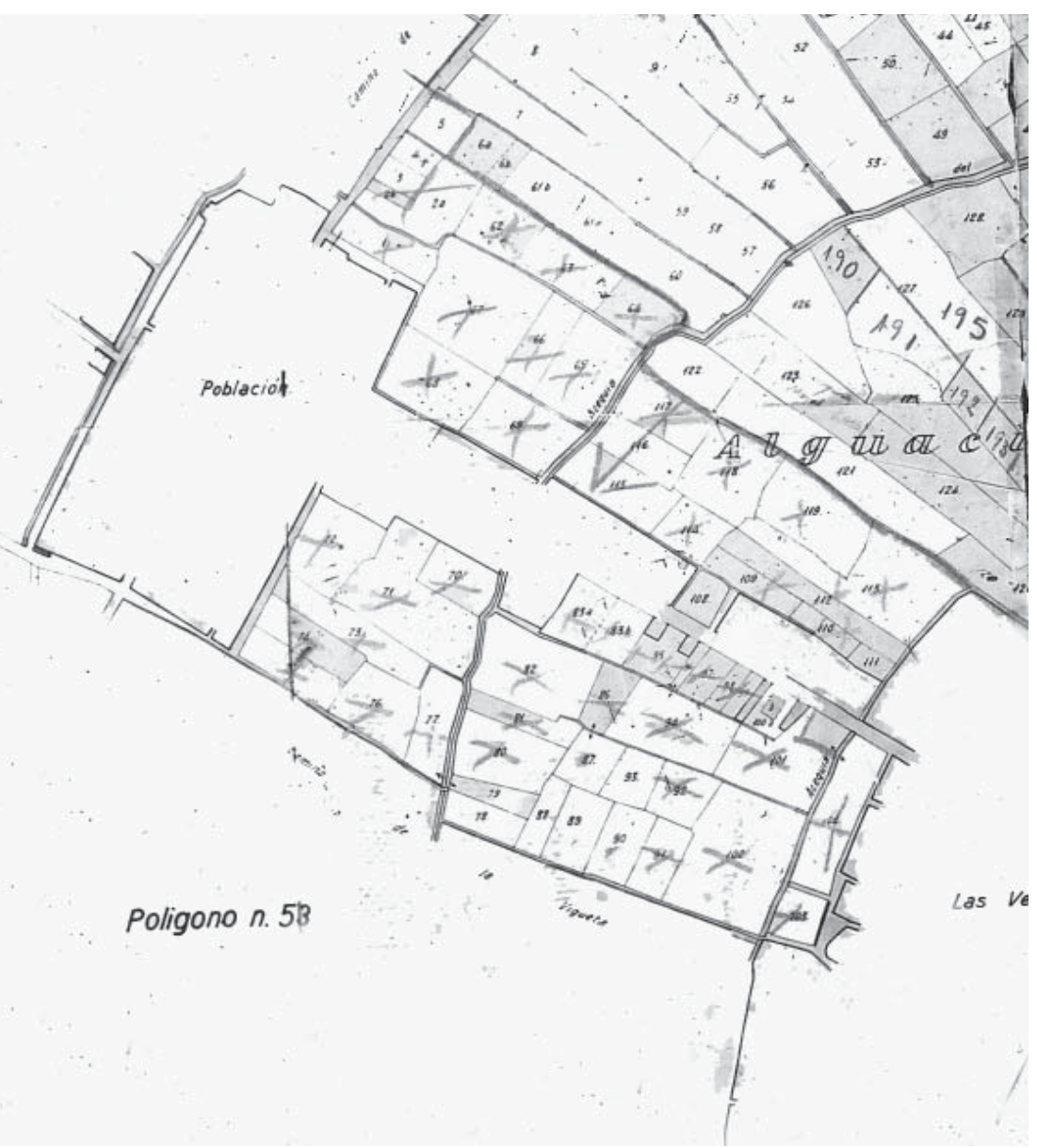

LL- Plano del Instituto Geográfico y catastral realizado por Ingeniero Víctor Gesalvez, año 1928

El siguiente detalle viene dado por la cartografía catastral de rústica del año 1928. El presente plano se realizó para documentar las parcelas de suelo no urbano, por esta razón no viene detallado el suelo urbano del municipio. Sin embargo muestra la envolvente del municipio aportando datos importantes.

En primer lugar la delimitación del casco histórico, en segundo lugar la apertura de algunas calles, puesto que se observa una oquedad donde anteriormente había un muro, la ampliación neoclásica de la iglesia de san Jaime, la ubicación del antiguo lavadero que estaba situado extramuros $y$, sobre todo, un cambio de ubicación: el camino de Riba-roja a La Pobla, en la actualidad perpendicular al portal de Riba-roja, en esta época
Fig. 101. Plano del Instituto Geográfico y catastral realizado por Ingeniero Víctor Gesalvez, año 1928. Se observa el centro la delimitación del centro histórico. 


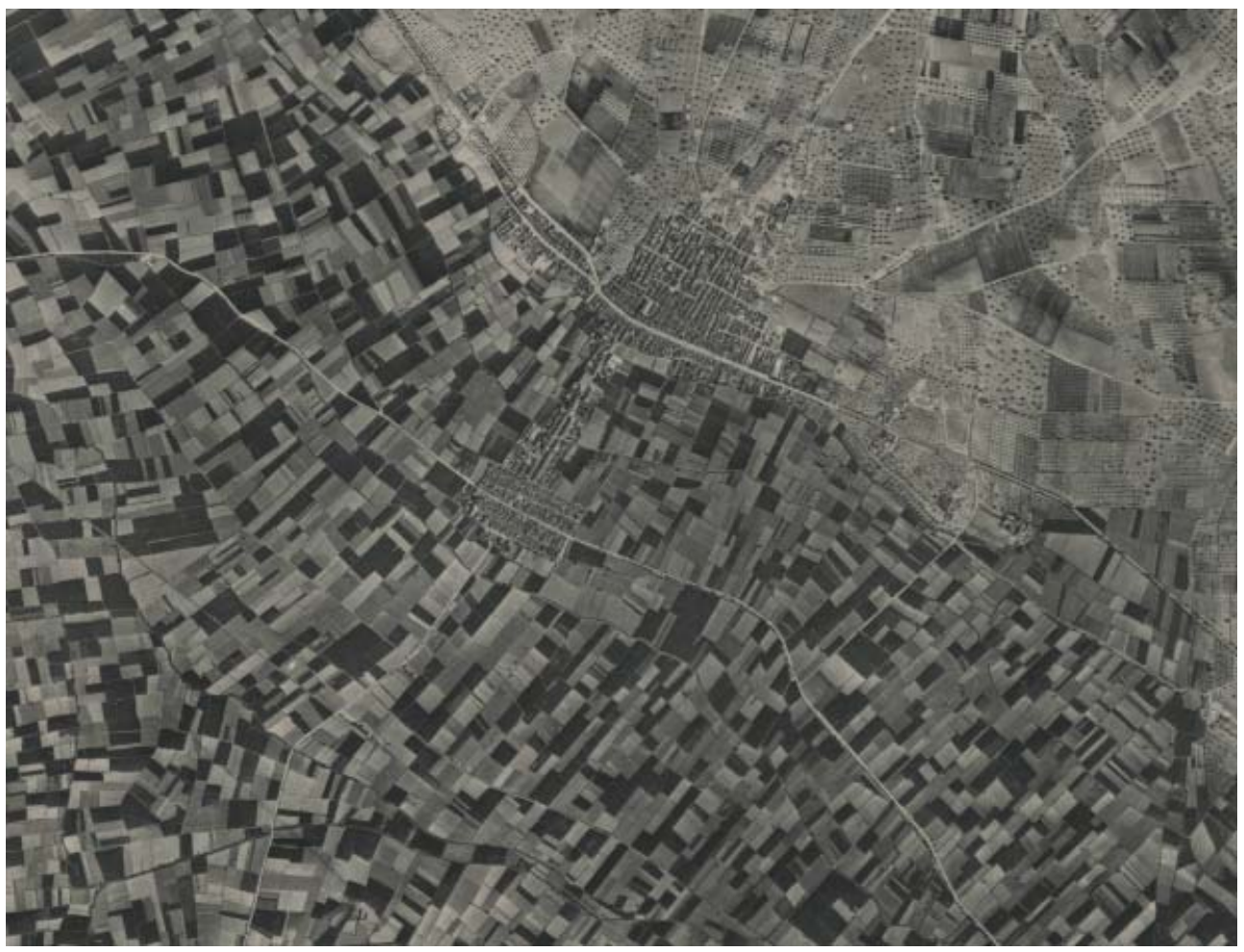

Fig. 102. Vista aérea del vuelo americano del año 1950 donde aún se puede observar el centro histórico de la vila perfectamente. se situaba a 10,00 m de ésta, no llegando directamente al portal sino que se debe hacer un quiebro para llegar al acceso. Este hecho hacía mas difícil el ataque directo a la puerta.

También se observa el trazado de la acequia primera que discurre por extramuros paralelo al centro histórico.

\section{M- Fotografía área, año 1950}

En este vuelo americano del año 1950 aparece gráficamente la delimitación del perímetro de la población, sobre todo es de suma importancia observar la zona noroeste. Se puede apreciar en esta ubicación un sombreado, donde todavía no se había llevado a cabo ninguna ampliación. 


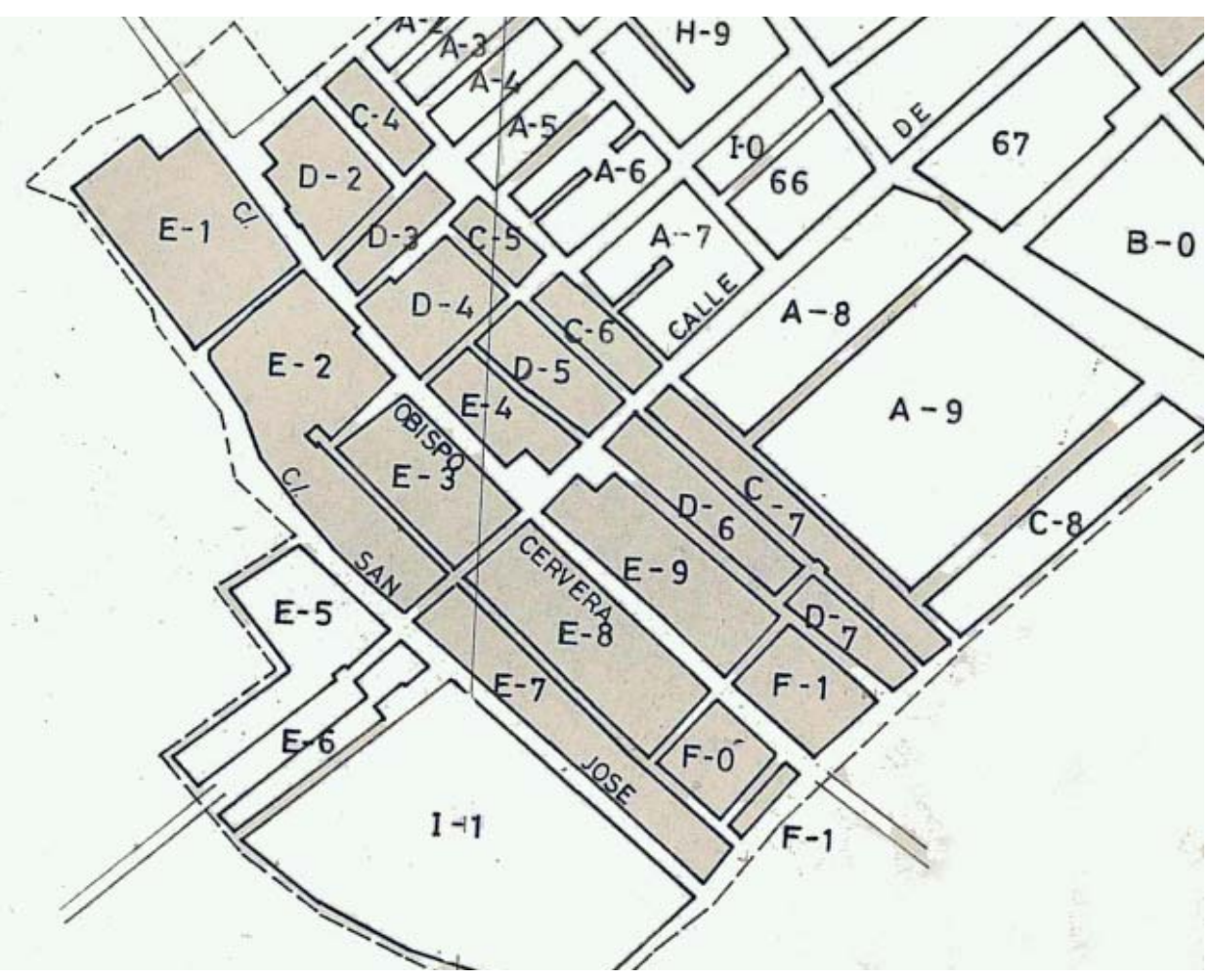

N- Plano del Instituto Geográfico y catastral, año 1980

Fig. 103. Plano de la vila del Instituto Geográfico y catastral, año 1980.

En lo que concierne a planos delimitados de urbana, el primer plano encontrado, destinado a reflejar la trama urbana, es del año 1980, reflejando la actualidad de este tiempo. Se observa que se ha abierto un vial perpendicular al portal de Riba-roja de forma que no hay ningún tipo de quiebro sino que se accede directamente al municipio.

Cabe destacar la existencia de un retranqueo en la manzana D-4 que ya no existe hoy, y en la manzana C-7 el cual se mantiene. Se desconoce el autor que lo dibujó, pero forma parte de la documentación del Instituto geográfico catastral de esta época. 


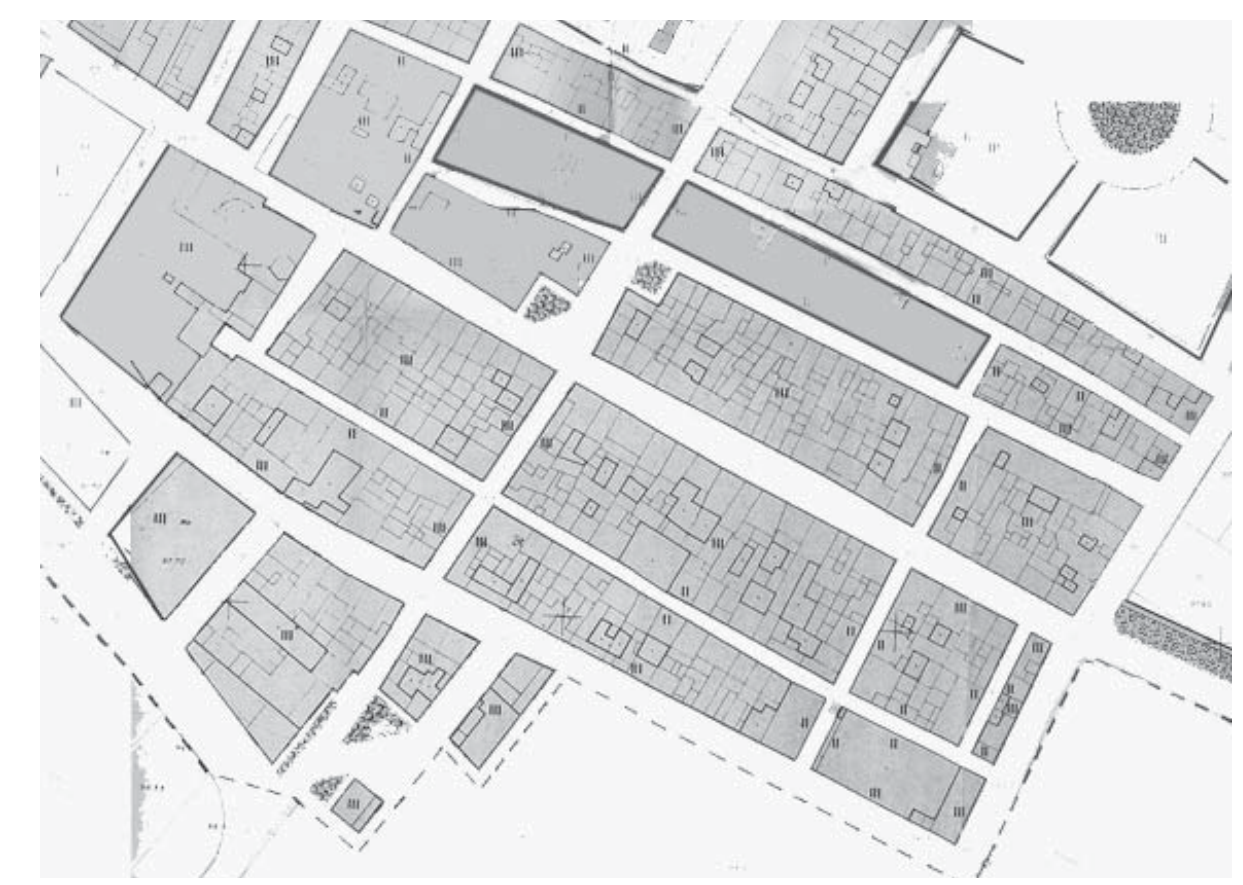

Fig. 104. Delimitación del núcleo medieval en las normas subsidiarias año 1986.

\section{Ñ- Plano Normas Subsidiarias 1986}

En el año 1986 se publican las primeras normas urbanísticas con el fin de regular la actividad urbanística del municipio y sobre todo delimitar el suelo urbano y el no urbanizable.

En este primer plano ya se grafía las alturas y algunos retranqueos, pero no trata de modo diferente el suelo del centro histórico del resto de ensanche de las diferentes épocas de la historia.

\section{O- Planos de Plan General, 1995 y 2004}

Para dar por concluido este apartado, se aportan los dos planos realizados para los Planes Generales, del año 1995 y del año 2004, siendo el redactor el arquitecto José Aragó. Cabe destacar que es en el plano del año 1995 donde ya se delimita la zona del casco histórico y se crea una ordenanza de protección de las fachadas de esta zona. En la ordenación pormenorizada del Plan General se redacta un artículo con las medidas que deben cumplir las frentes de los inmuebles del núcleo fundacional y se les concede un nivel de protección. 


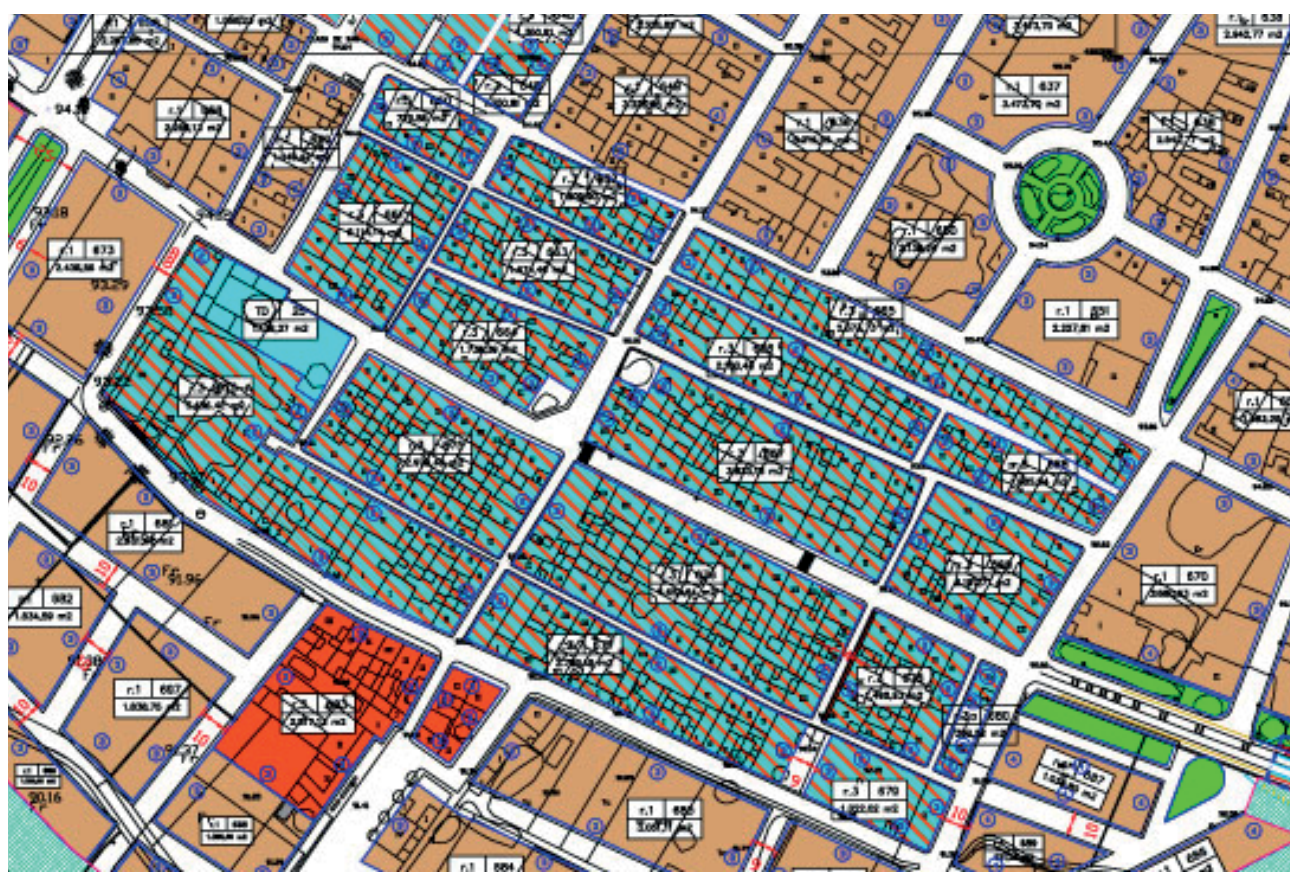

En lo que concierne a la trama urbana se observa cambios de alienaciones y retranqueos respecto a la trama urbana medieval en ambas ordenaciones, al tiempo que un incremento en las alturas y permisibilidad a la hora de construir edificios en bloque.

Fig. 105. Ordenación pormenorizada Plan General del año 2004. Archivo Ayuntamiento de La Pobla de Vallbona.

A modo de resumen final se puede señalar que el casco urbano de La Pobla de Vallbona ha crecido, urbanísticamente hablando, en el último siglo diez veces mas que en toda su historia. El ensanche hacia la zona norte ha sido propiciado por varios factores:

- La tierra es de secano

- Las vía de comunicación Valencia-Lliria

- La acequia primera en la zona sur, que hace de barrera natural.

Sin embargo, aun se está a tiempo, su pasado se puede contemplar en las trazas medievales de sus viales, un patrimonio urbanístico que merece la pena conservar. 


\subsubsection{Tamaño de la Vila y de su plaza}

Para empezar a analizar la trama histórica del núcleo fundacional del municipio objeto de este estudio, se debe, en primer lugar determinar su perímetro conforme a los mapas expuestos en el apartado anterior.

Una vez delimitado el ámbito, queda claro, que el recinto medieval presenta una forma en planta rectangular, muy similar a las trazas urbanas del mismo periodo de los municipios de Vilareal y Puzol. Asimismo comparando las trazas de los centros históricos de estas pueblas de colonización se desprenden muchas semejanzas, aunque si se procede a analizarlas con mayor detalle queda patente que La Pobla de Vallbona es la menor de las tres en superficie. Hecha la observación anterior únicamente hay que examinar sus dimensiones geométricas para su verificación.

\begin{tabular}{|l|c|c|}
\hline Munic ipio & Longitud $(\mathrm{m})$ & Ancho $(\mathrm{m})$ \\
\hline Vila-real & 380,00 & 190,00 \\
\hline Puzol & 302,74 & 279,14 \\
\hline La Pobla & 281,00 & 160,70 \\
\hline
\end{tabular}

Tabla 8: Dimensiones lineales de municipios de planta rectangular

En este orden de ideas se pude citar que no se ha encontrado ningún nexo de unión entre ellas con respecto a sus medidas. Como se ha demostrado en apartados anteriores, la superficie del núcleo medieval dependía de la relevancia de la vila, a mayor importancia mas superficie y mayor número de nuevos pobladores se pretendía atraer. La Pobla de Benaguazir, en su origen era un $/ l o c$, ni siquiera era una vila, por lo que su dimensión corresponde a esta situación, su fundación no ambicionaba atraer un gran número de vecinos.

Siguiendo el esquema del capítulo anterior se procede a comprobar la relación entre sus lados y con su perímetro. El primero, al tratarse de una vila de planta rectangular la relación entre sus lados es 1:1,7. Comparativamente con las demás poblas de colonización, se encuentra dentro del intervalo estudiado.

Se toma como referencia el número entero que salde de la operación. La relación es el resultado de cada uno de sus lados divididos por el perímetro. a/ $a+a+b+b: b / a+a+b+b$.

En cuanto a la correspondencia del perímetro respecto a sus lados se obtiene el mismo resultado que en todos los núcleos históricos analizados,aproximadamente la proporción 3:5 $5^{185}$. 


\section{Centro histónico medieval de La Pobla de Vallbona, alias de Benaguazir}

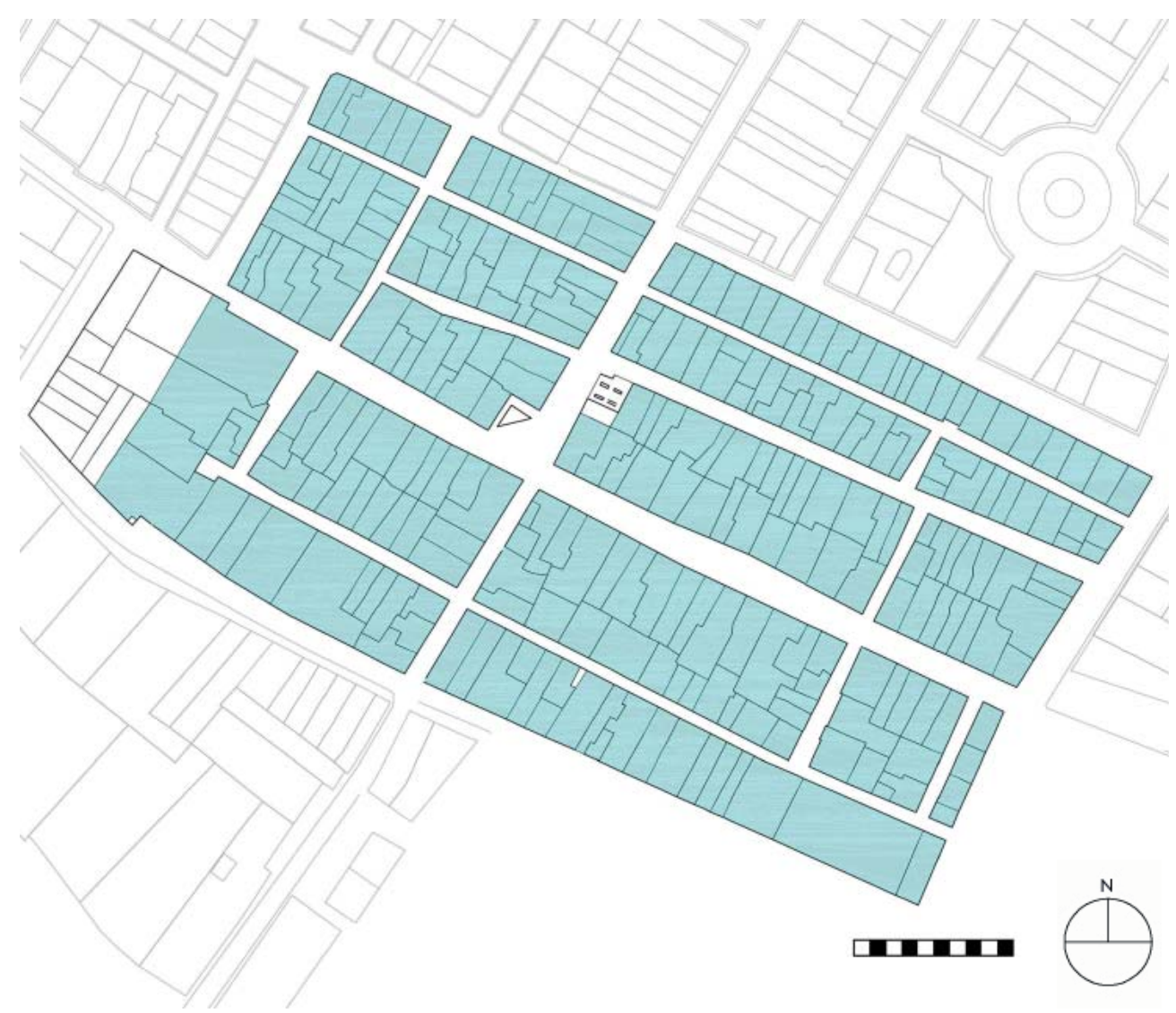

Con respecto a la plaza central situada en la intersección de los dos ejes principales que forman la vila medieval, cuenta con las dimensiones de 14,00 x 15,00 m, comparativamente con la de Puzol es con la que presenta mayor similitud.

En último lugar existe un modo de comprobar el recinto medieval desde un punto de vista etnológico. Al igual que en Almenara, desde hace siglos se mantiene en La Pobla de Vallbona, el mismo recorrido de las procesiones de San Antonio y San Sebastián por el núcleo histórico. El trayecto discurre por todas las calles de intramuros, los ejes principales, los viales secundarios e incluso por les travesseres. Este patrimonio inmaterial del municipio sirve para delimitar perfectamente el perímetro amurallado del núcleo urbano en origen.
Fig. 106. Delimitación del centro histórico de la Pobla de Vallbona, denominado la Vila, según el Plan General de Ordenación urbana en la actualidad. 
$\mathbf{2 1 8}$ de 536

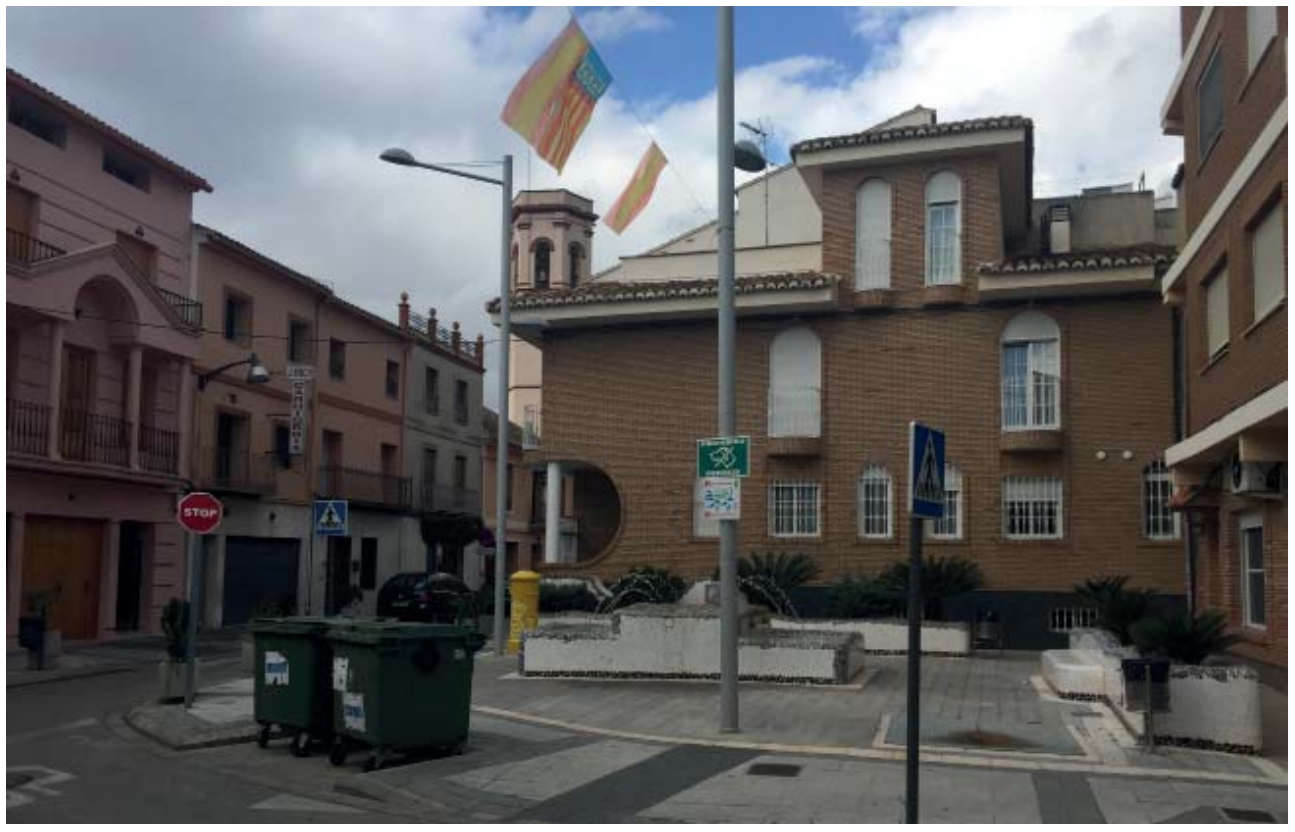

Fig.107. La plaza mayor de la Vila de la Po-

bla de Vallbona, alias de Benaguazir en la actualidad. El edificio situado en el centro ocupa el inmueble donde se ubicaba la Sala del Consell en el bajo medievo. 


\subsection{3| Viales}

En el presente apartado se procederá a estudiar cada uno de los viales existentes en el centro histórico de la vila objeto de esta investigación. Lo que quiere decir analizar las características de las diferentes calles que forman la trama urbana. Para ello se toma como referencia el único plano histórico que señala los viales intramuros, fue realizado por el canónigo Pedro Sucías Aparicio, en el año 1860 (véase fig.096).

Si se examina su planta lo primero que llama la atención -al igual que en los demás casos de pobles valencianas- es que se encuentra dividida por dos ejes principales, el cardus y el decumanus. La primera es la calle que va de este a oeste, conocida popularmente como carrer Major (aunque en la actualidad se denomina calle Obispo Cervera) y la segunda la que toma dirección norte a sur (Avda Colón y Maestro Barona). En la intersección de ambos viales aparece la plaza, la plaça Major, denominándose en la actualidad de / àntic Ajuntament. En este emplazamiento se ubicaba antiguamente el poder civil, como su nombre indica, la Sala del Consell, y el Sindicato de Riegos del municipio, de suma importancia por el carácter agrícola de la población.

El vial que cuenta con mayor anchura es el carrer Major, presentando una medida de $9,00 \mathrm{~m}$. Le sigue el eje transversal principal. Este calle se encuentra con topónimos diferentes para cada tramo que intersecta con la plaza central. Solo uno de los tramos, el conocido como Maestro Barona, parece no haber modificado su alineación original, presentado un ancho de 5,70 $\mathrm{m}$. La diferencia entre ambos es considerable, aproximadamente 3,00 m. Si se compara este dato con las demás calles de la misma tipología del resto municipios, se obtiene que el carrer Major de la Pobla, cuenta con una dimensión superior a todos los casos analizados. Debido a esto se puede asegurar que la vía fue ampliada, modificando su anchura original. Otro dato que se obtiene similar a todas las demás pueblas es que también se cumple que estos dos viales son las que cuentan con la mayor dimensión.

En el marco anteriormente descrito aparecen paralelamente al carrer Major un número de vías secundarias, que dependiendo de su ubicación les corresponderá un determinado nombre. Al norte, la inmediatamente superior, el carrer Mitja, (actualmente 


\section{Plano de situación de los viales del centro histórico}

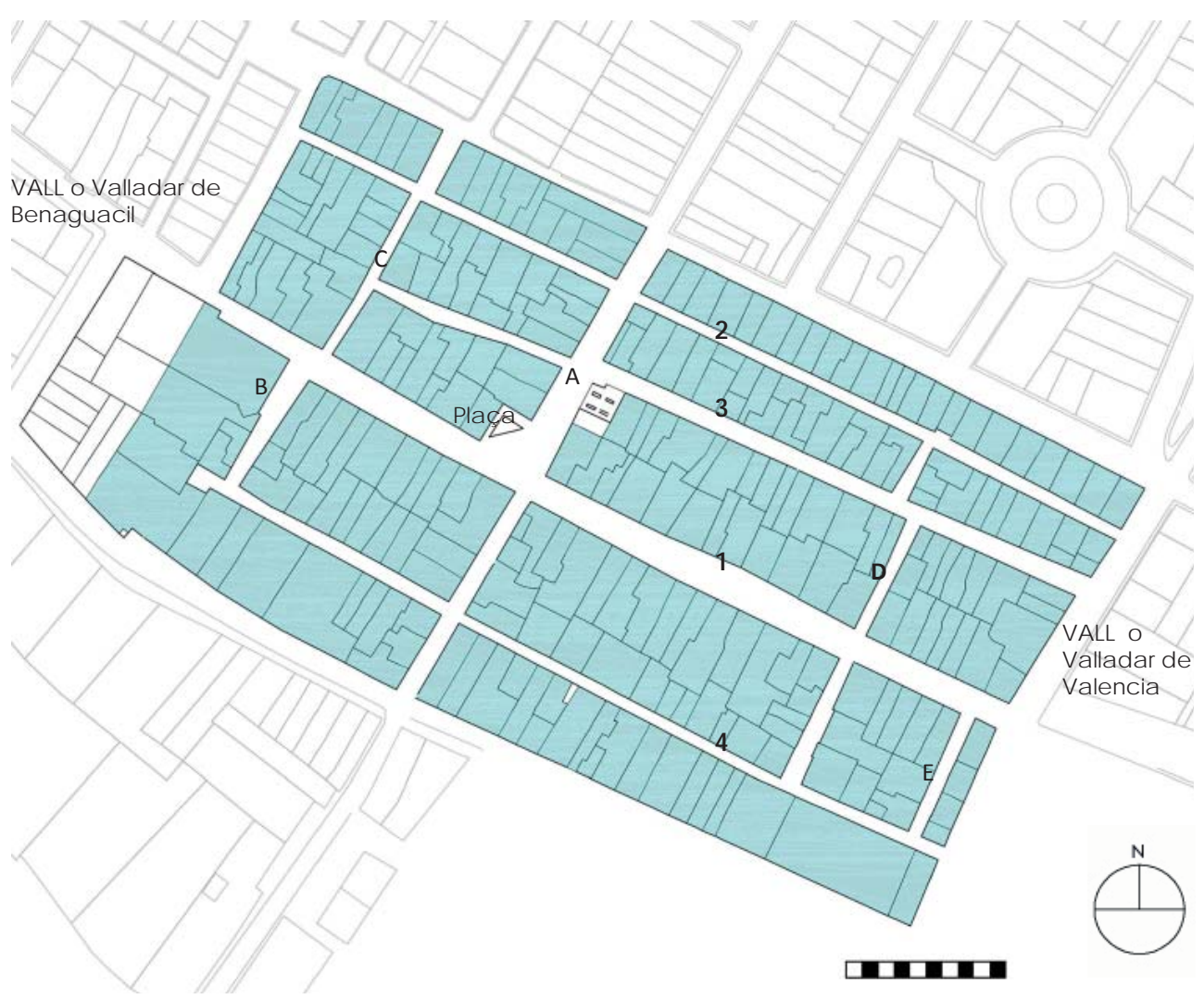

Fig. 108. Plano de viales. El carrer Major, su eje transversal, la calles secundarias paralelas, y les travesseres y carrerons.

\begin{tabular}{|c|c|c|c|c|}
\hline & \multicolumn{2}{|c|}{ EE LONG IUDINAL (este-oeste ml) } & \multicolumn{2}{|c|}{ E E TRANSVERSAL (norte-sur ml) } \\
\hline \multirow{5}{*}{ 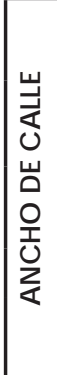 } & $\begin{array}{l}\text { C/Obispo Cervera } \\
\text { (1- CamerMajor) }\end{array}$ & $9,00 \mathrm{~m}$ & $\begin{array}{l}\text { Avda. Colón-Maestro Barona } \\
\text { (A-Travesía de les Ventes) }\end{array}$ & $\begin{array}{l}9,20 \mathrm{~m} \\
5,70 \mathrm{~m}\end{array}$ \\
\hline & $\begin{array}{l}\text { C/ Maestro Giner } \\
\text { (2- Camerde Dalt) }\end{array}$ & $3,50 \mathrm{~m}$ & $\begin{array}{l}\text { C/ Miguel Tańn } \\
\text { (B- Carreró de la iglesia) }\end{array}$ & $4,70 \mathrm{~m}$ \\
\hline & $\begin{array}{l}\text { C/ J esús Pitarch } \\
\text { (3-Camer del Mig o Mitja) }\end{array}$ & $\begin{array}{l}3,50 \mathrm{~m} \\
5,50 \mathrm{~m}\end{array}$ & $\begin{array}{l}\text { C/ Padre J ose Ma } \\
\text { (C-Carrercurt) }\end{array}$ & $3,50 \mathrm{~m}$ \\
\hline & \multirow{2}{*}{$\begin{array}{l}\text { C/ Sant Antoni } \\
\text { (4- Camerde Baix) }\end{array}$} & \multirow[t]{2}{*}{$3,50 \mathrm{~m}$} & C/ Angel del Alcazazar- D & $3,70 \mathrm{~m}$ \\
\hline & & & $\begin{array}{l}\text { C/ Francisco Barella } \\
\text { (E- Cameró C.S.Onofre) }\end{array}$ & $4,30 \mathrm{~m}$ \\
\hline
\end{tabular}




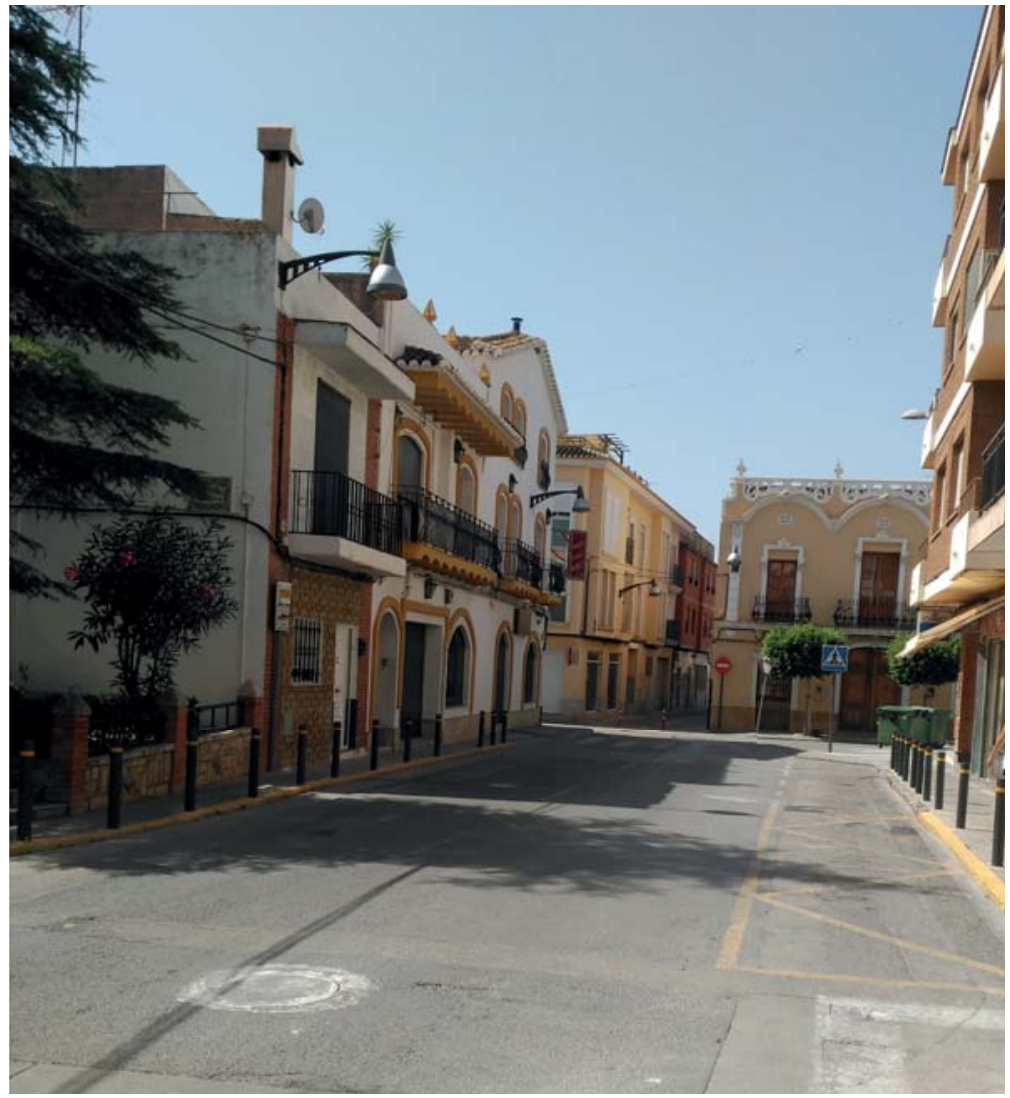

calle Jesús Pitarch), presentando una anchura de $5,50 \mathrm{~m}$ y la calle superior, el carrer de Dalt, (actual Maestro Giner). Al sur del eje longitudinal aparece la rúa denominada carrer de Baix (según catastro San Antonio). Los dos últimos viales mencionados presentan la menor dimensión, 3,50 m respectivamente.

Cabe señalar, que todas las calles secundarias - paralelas a la calle mayor - intersectan con el eje perpendicularmente transversal y con otras vías de carácter funcional.

Con respecto a las calles paralelas al eje transversal, que se han denominado en este estudio como travesseres, de las cinco existentes tres de ellas son similares, no llegando a los 4,00 m. Dos de ellas cuentan con mayor anchura porque se abrieron en siglos posteriores: en época medieval la calle Francisco Barella no se encontraba abierta y la calle Miguel Tarín seguramente era más ancha por recaer la fachada de la iglesia desde el año 1701, lo que indica que seguramente se modificaría la alineación de esa calle.
Fig. 109. Vial principal que corta perpendicularmente al carrer Major. En la actualidad calle maestro Barona y Avda. Colón. El primer tramo cuenta con la antigua alineación. 
Fig. 110. El carrer Major en la actualidad, denominada calle Obispo Cervera. No mantiene la antigua alineación, se ensanchó a lo largo de la historia.
Por último, els carrerons, en el plano actual de la vila no existen pero si se observa el plano de finales del siglo XVIII, se encuentran tres de ellos. Estos viales solían llevar el nombre del inmueble al que daban acceso. Dado que en el plano realizado por Sucías Aparicio detalla los topónimos de las vías se conoce el destino de dos de ellos, el primero daba servicio al convento de San Onofre y el otro a la iglesia.

En resumen se puede indicar que cada vial cuenta con un ancho diferente dependiendo de su ubicación y función en el entramado urbano. Se observa claramente la misma jerarquización que en el resto los municipios valencianos referenciados: las calles principales, las de mayor anchura, seguidas por el carrer Mitjà y sus paralelas y, por último, les traveseres y els carrerons.

Del mismo modo si se comparan los resultados obtenidos con las villas analizadas, únicamente se encuentra coincidencia exacta en dos viales. La calle Maestro Barona -en el ancho del eje transversal principal que no ha modificado su anchura - y la calle del medio o carrer Mitja, ambas con un ancho de 6 varas (usando como medida la propia de aquella época: la vara valenciana).

A mi juicio, las variaciones de las dimensiones suceden como consecuencia de los cambios de alineaciones realizadas por el paso de tiempo. Pero queda latente y demostrado, que se buscaba una jerarquía a la hora de replantear y distribuir los viales. Su ubicación en el parcelario demostraba su importancia, y a mayor relevancia mayor anchura. 
223 de 536

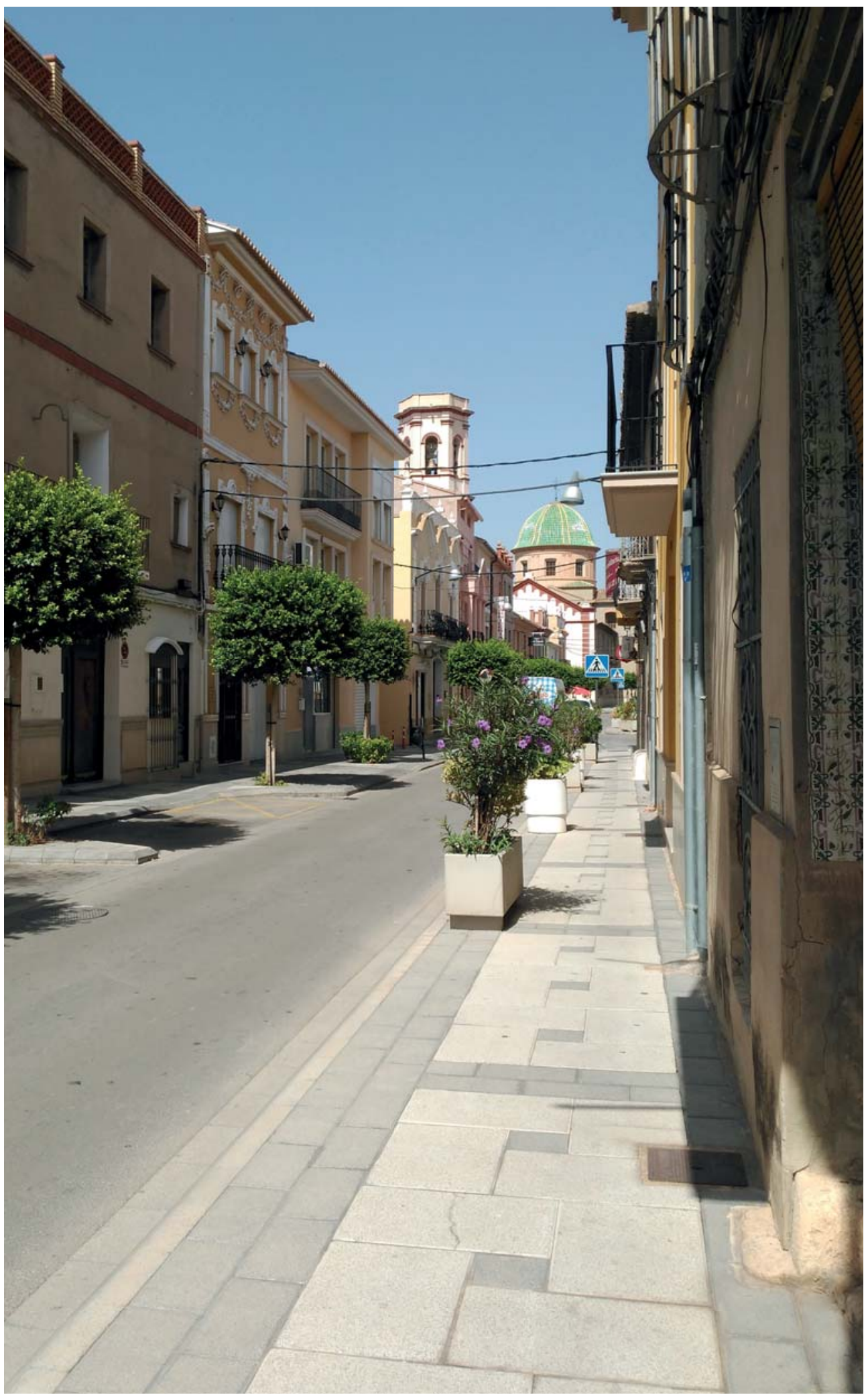

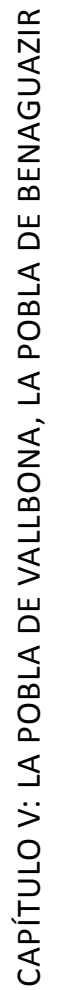



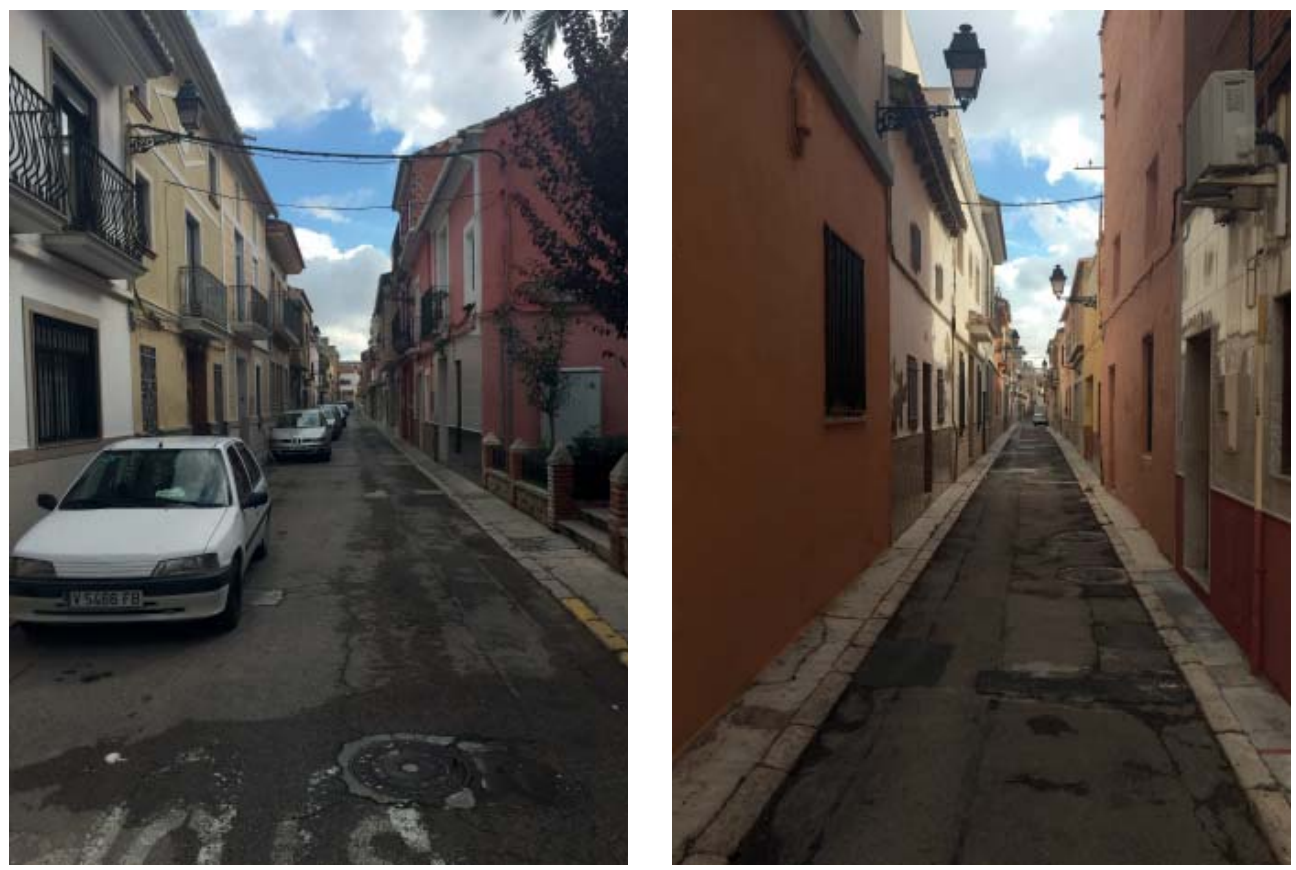

Fig. 111. El carrer Mitjà en la actualidad, conocido por calle Jesús Pitarch. Cuenta con el mismo ancho que la calle Maestro Barona.

Fig. 112. Imagen del carrer de Dalt, en el presente con el apelativo calle Maestro Giner.

\subsection{4| Ordenación Urbanística}

Desde el punto de vista administrativo, la planta de las poblas de colonización quedaban dividida en quarta o quartes ${ }^{186}$ a partir de la partición realizada por los dos ejes principales que forman el carrer Major y su perpendicular. Estas quartes se pueden contemplar en el parcelario de La Pobla de Vallbona, de igual forma que en Vila-real o Puzol.

Desde el punto de vista urbanístico, la zona de núcleo histórico presenta un entramado característico y diferenciado. Este suelo se configura por tres variables urbanísticas que se definen por:

- La integración ordenación por alineación de calle .

- El uso global residencial.

- La tipología edificatoria de manzana compacta.

Se entiende por alineación de vial la línea que delimita los espacios parcelarios respecto a los espacios públicos integrados por calles, plazas, zonas verdes o espacios libres. Este sistema se caracteriza porque las edificaciones se disponen de manera continua a lo largo de las alineaciones de las calles. Las viviendas se sitúan sin guardar ningún retranqueo entre ellas, formando la tipología de viviendas unifamiliares entre medianeras.

\footnotetext{
${ }^{186}$ Gil Vicent, V. y otros (2008): "El Paisatge de Vila-Real al temps de Jaume I". Arquitectura any zero. Generalitat Valenciana. Valencia. Any Jaume I Generalitat Valenciana, pág. 106.
} 


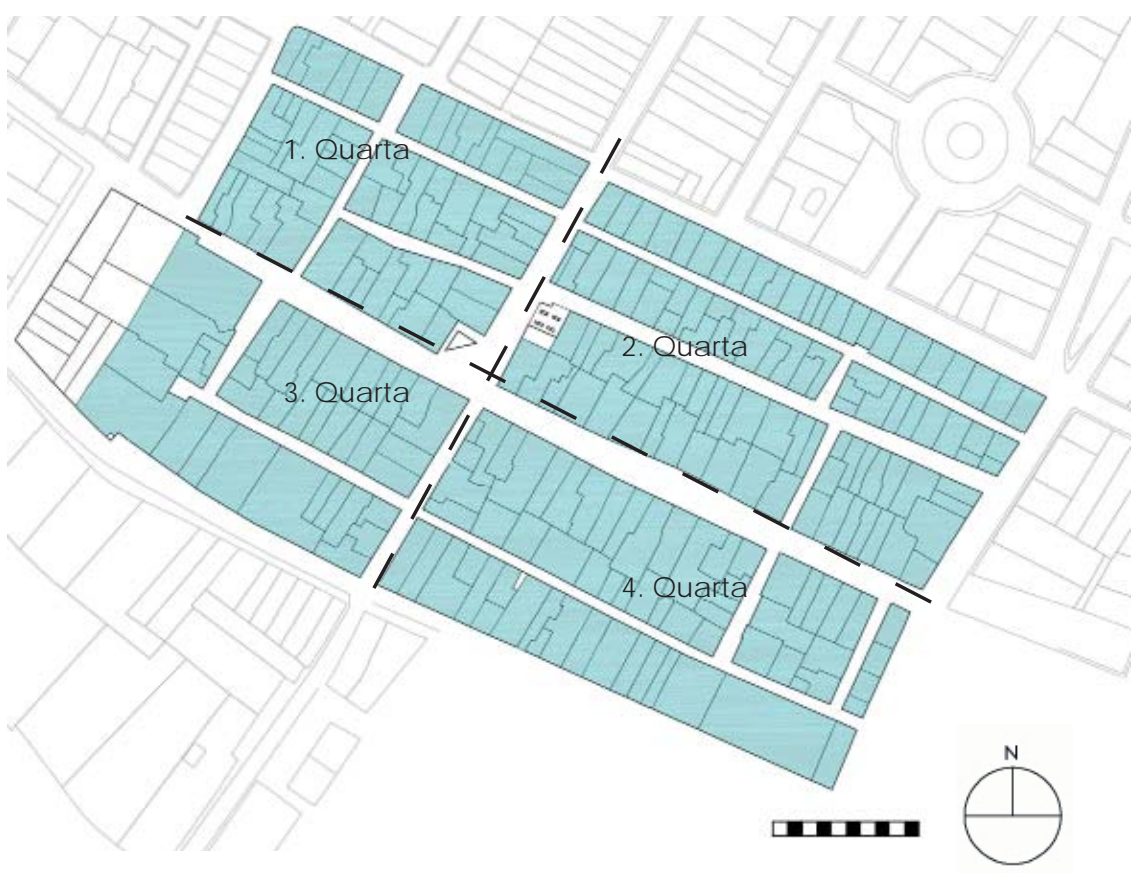

Los parámetros urbanísticos definitorios de este modo de ordenación son la alineación de vial, la altura reguladora y la profundidad edificable. Todos los inmuebles del centro histórico

Fig. 113. Organización administrativa de la Pobla de Vallbona en quarters. de la Pobla de Vallbona presentan sus fachadas alineadas a la calle a la que recaen. En cuanto a la ocupación de parcela se encuentra al $100 \%$.

En cuanto a la tipología edificatoria de manzana completa entendiendo por manzana a la superficie de suelo delimitada por alineaciones de vial contiguas o, en dependiendo del caso, situado entre vial y muralla - al igual que en todos los centros históricos analizados, en La Pobla de Vallbona se identifican 2 clases de agrupaciones acotados por dotaciones públicas existentes en su centro histórico:

1) Manzanas que lindaban con la muralla.
a. $Y$ con 1 solo vial .
b. $Y$ con 2 o 3 viales .

2) Manzanas o islas entre 4 viales .

Del primer grupo se hallan las espacios denominados $m-1$, $\mathrm{m}-2, \mathrm{~m}-3, \mathrm{~m}-7, \mathrm{~m}-8, \mathrm{~m}-12, \mathrm{~m}-13, \mathrm{~m}-14$ y $\mathrm{m}-16$. Como puede observarse las parcelas situadas en estas superficies no sobrepasan los $25,00 \mathrm{~m}$ de profundidad, únicamente cuenta con mayor longitud la agrupación identificada como m-12 cuya longitud asciende a $22,00 \mathrm{~m}$. 


\begin{tabular}{|c|c|c|c|c|c|}
\hline \multicolumn{6}{|c|}{ CLASES DE MANZANAS } \\
\hline TIPO 1 & DENOMINACIÓN & $\begin{array}{c}\text { Relación } \\
\text { Largo/Ancho }\end{array}$ & TIPO 2 & DENOMINACIÓN & $\begin{array}{c}\text { Relación } \\
\text { Largo/Ancho }\end{array}$ \\
\hline \multirow{9}{*}{$\begin{array}{l}\text { Lindan } \\
\text { con la } \\
\text { mura lla }\end{array}$} & $M-1$ & 6 & \multirow{9}{*}{$\begin{array}{l}\text { No lindan } \\
\text { con } \\
\text { murlla } \\
\text { Islas }\end{array}$} & $M-4$ & 2 \\
\hline & $M-2$ & 1 & & $M-5$ & 2 \\
\hline & $M-3$ & 2 & & $M-6$ & 2 \\
\hline & $M-7$ & 3 & & $M-9$ & 5 \\
\hline & M-8 & 11 & & $M-10$ & 3 \\
\hline & $\mathrm{M}-12$ & 7 & & $M-11$ & 3 \\
\hline & $M-13$ & 4 & & \multirow[t]{3}{*}{ M-15 } & \multirow[t]{3}{*}{1} \\
\hline & M-14 & 1 & & & \\
\hline & M-16 & 6 & & & \\
\hline
\end{tabular}

Tabla 10: Tipologías de las manzanas y relación entre el largo y ancho de las agrupaciones existentes en la actualidad en el municipio de La Pobla de Vallbona

En lo que se refiere a la relación entre el ancho y el largo de estas manzanas se obtiene un intervalo cuyo punto de inicio es el encuadre $\mathrm{m}-3$, siendo este el doble de ancho que de largo, hasta llegar a la superficie existente en $\mathrm{m}-8$, la cual alcanza ser once veces más larga que ancha. Estos espacios si se observa su planta suelen ser rectangulares.

Como consecuencia los bienes inmuebles que se ubican en las espacios descritos ocupan la totalidad de la profundidad del terreno, por esta razón, solo suelen albergar un edificio desde el vial hasta la muralla, es decir, no se encuentran en su fachada trasera lindando con otro edificio, solo con la cerca muraria. Al lindar su parte posterior con el paramento vertical del cierre perimetral del municipio, el acceso, habitualmente, se emplaza en una calle secundaria. Sólo cuando estas espacios se encuentran delimitadas por tres viales y una de ellas es el conocido como carrer Major las construcciones cuentan con una entrada a la calle principal, como pueden observase en los bloques identificadas como m-2 y m-14.

El segundo grupo se ubica en el interior del municipio normalmente, delimitados por cuatro calles a modo de isla. Como puede apreciarse, en el plano de la página siguiente, se designan como m-4, m-5, m-6, m-9, m-10, m-11 y m-15. 


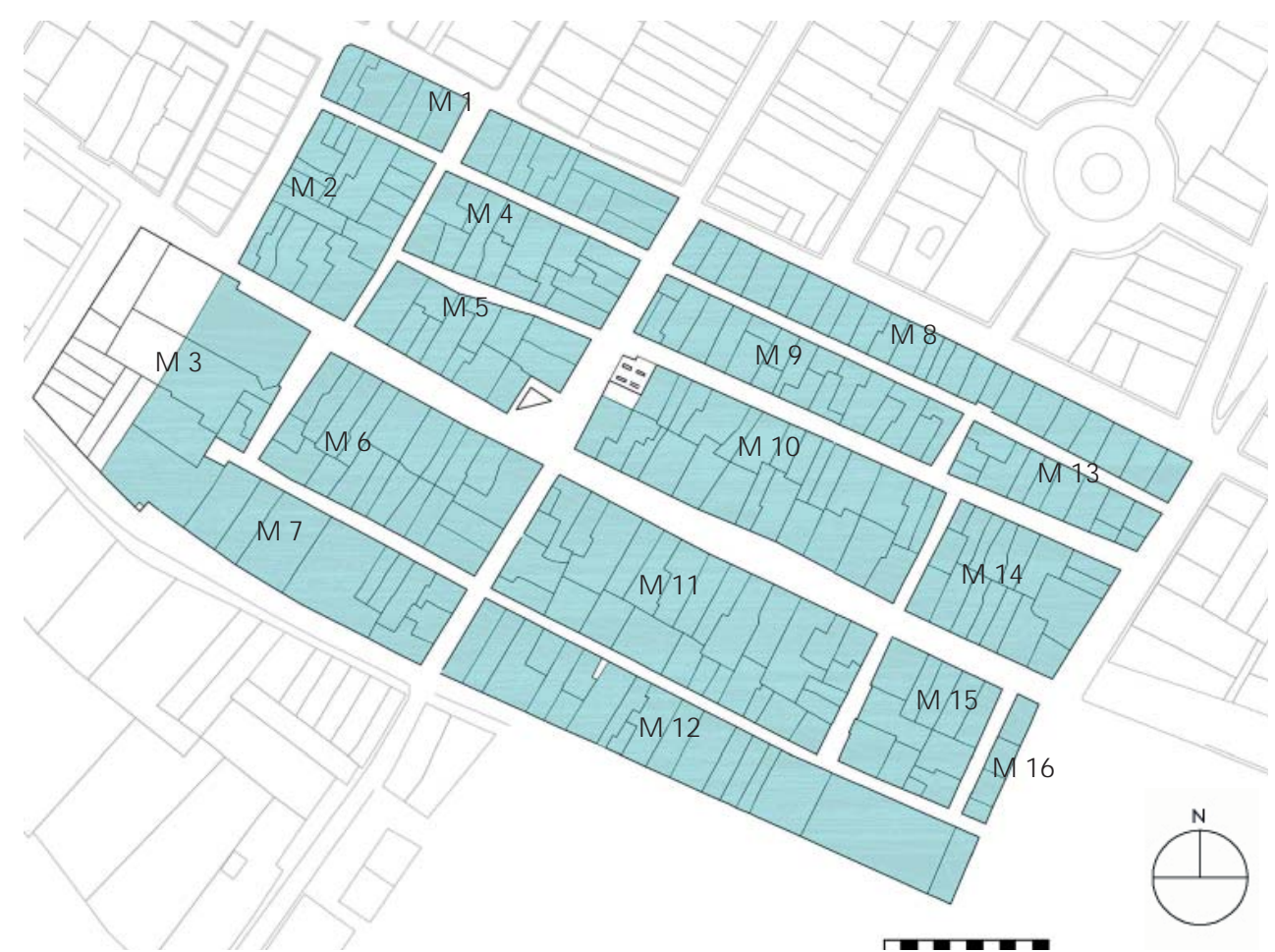

Asimismo, en lo que se refiere a la forma que presentan, la mayoría cuentan con forma rectangular, teniendo todas ellas, una relación del doble o el triple de longitud respecto al ancho. Esta dimensión cuenta con un intervalo desde 28,00 m de longitud a 40,00 m. Ninguno de los casos estudiados cuenta con una anchura superior a la indicada, si bien es cierto, que existen dos manzanas cuya geometría es básicamente cuadrada, las nombradas como $\mathrm{m}-14$ y la $\mathrm{m}-15$. En referencia a esta última, según el plano de Sucias Aparicio, en el siglo XIX, se encontraba unida a la denominada $m-16$. En la actualidad están separadas al convertirse el antiguo carreró de San Onofre en un vial completamente abierto.

Retomando las observaciones anteriores cabría la posibilidad de pensar que la profundidad de las viviendas no sería mayor a 20 $\mathrm{m}$, partiendo las islas por la mitad y siguiendo el principio del fuero de Jaca "parcelas iguales para hombres iguales", pero esta premisa no se cumple siempre en la parcelación. En el municipio objeto de este estudio se encuentran las islas $m-5, m-6, m-10$ y $\mathrm{m}-11$ donde se comprueba que los inmuebles que recaen al carrer Major ocupan una mayor profundidad de parcela, en detrimento de las viviendas que se encuentran enfrentadas a ellas y que recaen a viales secundarios.
Fig. 114. Designación de las manzanas conforme al estudio realizado. 
La profundidad del solar depende de la calle a la que recae, siempre cuenta con mayor profundidad el edificio que tiene el frente en el vial más importante. Para ejemplificar tal consideración se debe examinar las manzanas tipo isla donde una de las alineaciones se ubica en el carrer Major. En estos espacios son más profundas las parcelas que recaen a la rúa con mayor relevancia. Las viviendas también cuentan en este caso con un único acceso, pero nunca ocupan en profundidad la totalidad de la manzana, sino que unas viviendas acceden por una calle y las otras por la otra.

El siguiente parámetro que se deba analizar, la longitud de las fachadas de los inmuebles. Las edificaciones de mas trascendencia se sitúan en la calle que cuenta con mayor anchura, tienen más frente de fachada y cuentan con mayor profundidad, como se puede constatar en las viviendas del carrer Major, cuya dimensión mínima se encuentra en frentes de $6,00 \mathrm{~m}$, en oposición de los inmuebles situados en las vías secundaria donde se encuentran frentes mínimos que apenas llegan a tener 3,50 $\mathrm{m}$ de longitud. Los viales funcionales, les travesseres, actuales calle Ángel del Alcázar y calle Padre José M.ạ, no suelen tener fachadas principales.

Por lo tanto queda demostrado, que al igual que en el resto de les pobles de colonización anteriormente estudiadas, existe un grado de jerarquización en la ubicación de los inmuebles, que conforme a su importancia estarán situados en una calle de más anchura, tendrá más frente de fachada y su profundidad será mayor.

Para concluir se procede a verificar la orientación de los inmuebles. El núcleo histórico se encuentra ubicado hacia el noroeste, variable no vinculante para los municipios, puesto que depende de la climatología del lugar. En cambio, a la hora de replantear las parcelas se encontraba una semejanza en todos ellos:

- Las edificaciones se construyen en todos los casos perpendiculares a la calle mayor y a su calle transversal, a los dos ejes principales.

Como se puede apreciar todos los inmuebles que tienen el frente de fachada por la actual calle Obispo Cervera se disponen perpendicularmente hacia este. Esta característica también se cumple en los viales secundarios - paralelos al carrer Majorlas edificaciones siguen el mismo criterio, situándose siempre 


\section{Orientación de los inmuebles en La Pobla de Vallbona}

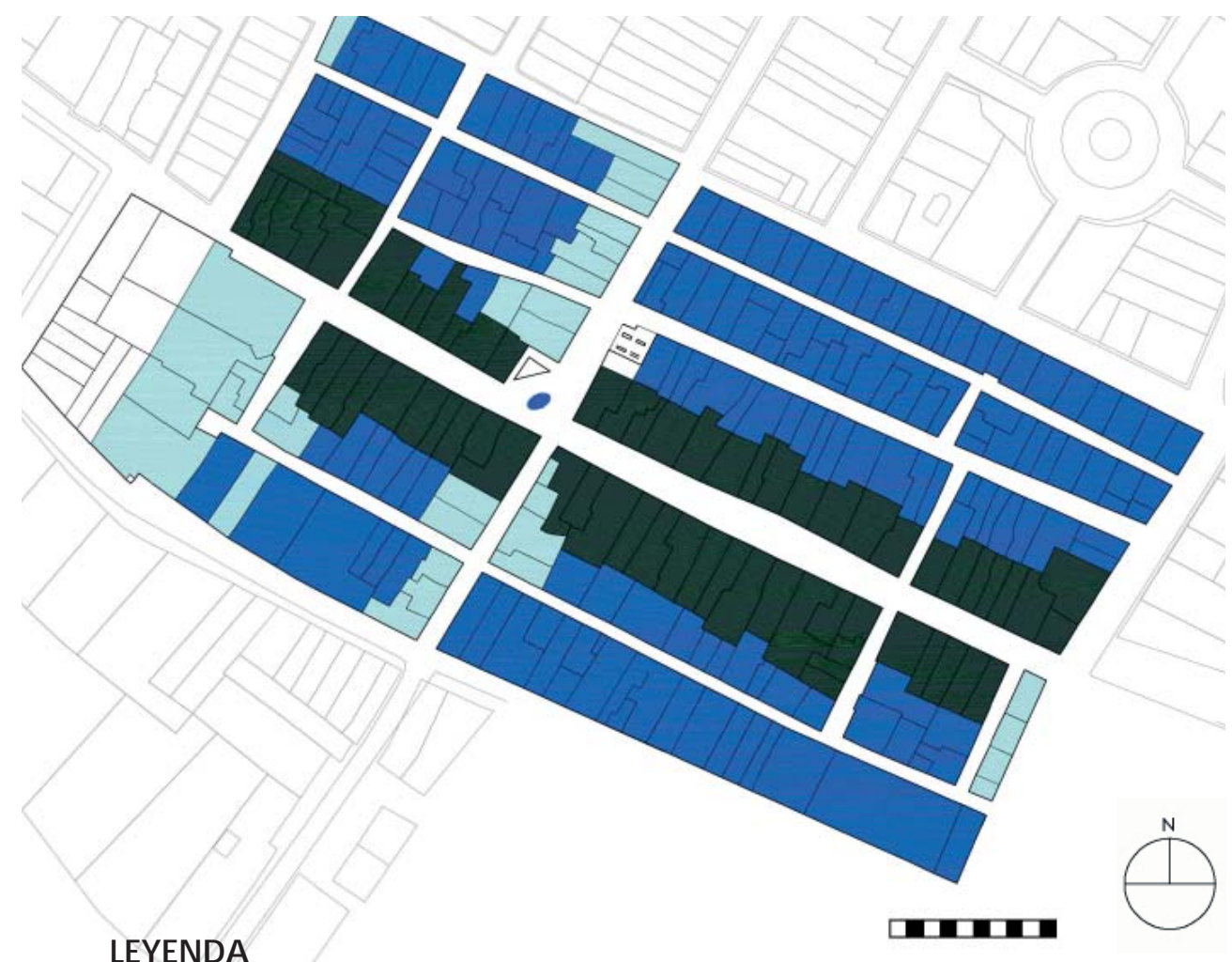

Parcelas perpendicularesa la calle

Mayor situa das en esta misma calle

Parcelas con la misma orientación

perpendiculara la calle Mayor

pero en otros viales

Parcelas con la orientación

paralela a la calle Mayor

perpendiculares al vial, tanto en la calle san Antonio (carrer de Baix), como en la calle Jesús Pitarch (carrer Mitja), como en la calle Maestro Giner (carrer de Dalt). En referencia a la disposición de los inmuebles en la travesía de les Ventes - vial perpendicular al carrer Major- sitúan su frente de fachada perpendicular hacia este, su profundidad de parcela será paralelo al eje longitudinal.

Después de lo anterior expuesto se puede constatar, que en cuanto a ordenación urbanística, el núcleo fundacional de La Pobla de Vallbona guarda todas las similitudes y semejanzas propias de las poblas valencianas originadas en el bajo medievo.

Fig. 115. Plano donde se grafía la orientación de las viviendas en las diferentes bloques de la Pobla de Vallbona. 


\section{Evolución de las trazas urbanas}

Después de lo anterior expuesto conviene precisar que se han observado una serie de características o particularidades que pueden aportar indicios de la evolución de las trazas de la villa, por esta razón, se procede a detallarlas en los párrafos siguientes.

La primera singularidad viene detallada en los espacios $m-4$, $m-9$ y $m-13$. Como se ha demostrado los inmuebles que lindan con la muralla nunca tienen una profundidad superior a 25 $\mathrm{m}$, cuentan con un solo acceso y un edificio. Los bloques de viviendas indicados, presentan profundidades de 20,00 y de $17,00 \mathrm{~m}$ respectivamente, y las fachadas de sus viviendas solo abren hacia la calle más importante, el carrer Mitja. Estas islas cumplen todas las características de una manzana que linda con muralla, pero no es así, al encontrarse en el interior de núcleo histórico, son tipo isla. Además, comparando su profundidad con el bloque m-12, (descontando las ampliaciones posteriores de los patios como se verá posteriormente), el resultado evidencia que prácticamente son iguales. Lo que quiere decir que pudo construirse un primer recinto fundacional, cuando era Iloc y no había murallas. Éste se formaría por un plano completamente simétrico compuesto por el carrer Major, el eje perpendicular principal y dos viales paralelos, las actuales calle San Antonio y calle Jesús Pitarch. Su permanencia en el tiempo se situaría hasta el momento que se construyó la cerca perimetral, instante en que pasó a cerrarse el núcleo histórico.

Según los grabados de la época los bienes inmuebles no se construían junto a la muralla sino que había un espacio entre ellos, dejando una superficie de separación entre las viviendas y el muro defensivo. El primer recinto cerrado estaría constituido por todas las manzanas a excepción de la m-1, m-8 y m-16.

Con el paso del tiempo y ante la necesidad de disponer de nueva superficie para albergar distintas construcciones los espacios dejados entre las viviendas y la muralla serían ocupados utilizando el lienzo de la cerca como parte de los paramentos verticales de las edificaciones, materializándose las manzanas anteriormente excluidas ( $m-1, m-8$ y $m-16)$. Todo esto se desprende de los siguientes datos:

- De los espacios perimetrales, destaca el denominado $\mathrm{m}-16$, lindante con el valladar de Valencia. Su profundidad 


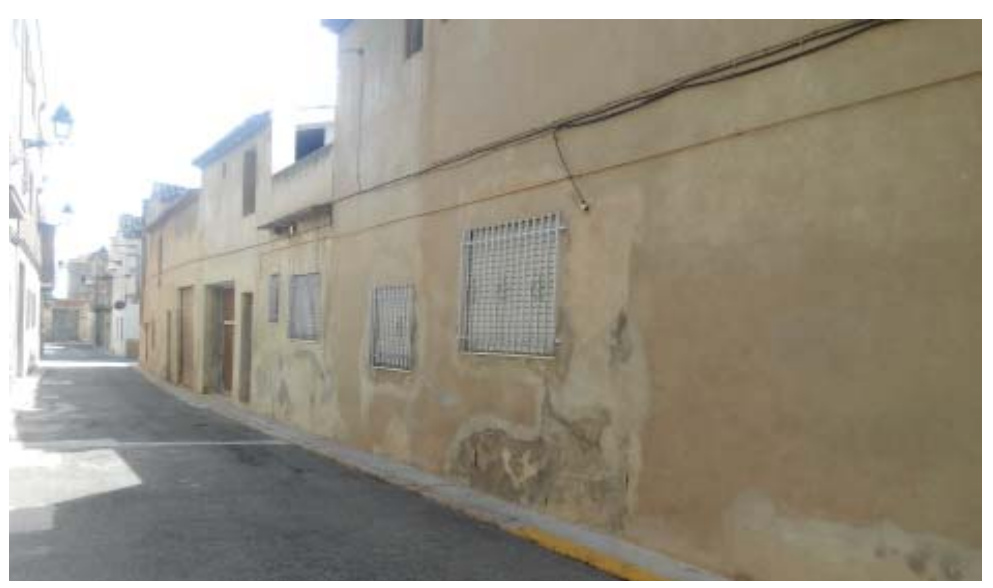

respecto con el resto de manzanas es excesivamente corta, únicamente presenta $8,00 \mathrm{~m}$. Si se toma la distancia existente desde el linde, de lo que se supone, que era la muralla, hasta el frente de fachada opuesta, exactamente la m-15, la separación que presenta es de 11,35 m. Se pueden apreciar casos muy similares en los municipios de Vila-real Penáguila. Es posible que pudiera corresponderse con el camino de Ronda ${ }^{187}$.

- De manera semejante se pueden analizar la superficie de los bloques m-2 y m-4. En este caso no se habría creado un espacio nuevo sino que se habría ampliado su territorio hasta encontrar la cerca defensiva. En los protocolos notariales del año 1701 y 1702 de la reforma de la iglesia gótica a barroca, en uno de los apartados se indica que se amplíe la iglesia, pero que no se llegue a la muralla, por lo que debemos suponer que había un espacio entre ésta y la iglesia gótica.

ítem que se ha de fer lo Sagrari en esta forma hon es la paret de la trada de la lglesia y en la part del Carrer ha de cerrar sens encontrar la muralla de aquella amplaria que sia menester aixi en fer fonament que sia menester y pera esta diligencia se ha de proseguir la pared de la Muralla a la alsada que sia menester y a la tirada y plom de aquella amplaria que mes convinga per a fer lo dit Sagrari [...].

Lo que podría desmentir esta teoría es que la manzana m-2 cuenta con puertas hacia esa calle, que sería la trasera. Sin embargo analizando este espacio se observa que cuenta con un ancho de $38,18 \mathrm{~m}$, lo que no suele corresponder a lo
Fig. 116. Una de les "travesseres", actualmente calle ángel del Alcázar. Se observa que no hay fachadas principales.
187 Pasillo estrecho situado sobre la muralla protegido al exterior por un parapeto, que permitía tanto hacer la ronda como la distribución de defensores en caso de asedio. 
habitual para la profundidad de una manzana que contiene dos viviendas contrapuestas. Si a esta superficie se le resta la distancia de la manzana m-16, separación desde la cerca a la alineación de vial, el resultado es aproximadamente $26 \mathrm{~m}$.

A la referencia anterior hay que añadir que las viviendas actuales, que recaen al vial opuesto, actual Padre José $M$ a, son excesivamente cortas, una profundidad de $11,89 \mathrm{~m}$, por lo que estos inmuebles podrían haberse segregado de otras de mayor profundidad con el paso del tiempo. De manera semejante habría sucedido para la manzana m-14.

Después de las consideraciones anteriores se puede afirmar que en ambos espacios, $\mathrm{m}-3$ y $\mathrm{m}-2$, en su origen, las edificaciones no se encontraban adosadas a la cerca muraria, puesto que después de realizar las comprobaciones se observa que el espacio de separación sería aproximadamente de $11,50 \mathrm{~m}$ y el ancho de la manzana resultante se ajustaría a los existentes en estos centros históricos.

- Para concluir, se detallan las incongruencias existentes en las manzanas m-7 y m-12, lindantes con la acequia primera, en el portal de Riba-roja. Estos espacios se encuentran identificadas en el Plan General del municipio como centro histórico. Para contrastar este hecho se consultó a los vecinos que residen actualmente en la calle San Antonio, confirmando que en la parte trasera todos poseían corrales, y que antiguamente no existían huecos de fachada al exterior. Fue ya en el siglo XX cuando se empezó a edificar en estas zonas. Cabe pensar que las viviendas fueron alargadas, embebiendo el camino de Ronda y que la muralla ha quedado en el límite perimetral de estos edificios. El anterior planteamiento se puede fundamentar en los siguientes datos:

1- La profundidad edificable de ambas zonas, si no se toma como referencia la ampliación, se determina en 20$21 \mathrm{~m}$, medidas semejantes a las que presenta la manzana $\mathrm{m}-9$.

2- Las viviendas existentes en $\mathrm{m}-7$ y $\mathrm{m}-12$, tienen todas la frente de fachada recayente a la calle San Antonio, luego tienen un patio y coincidiendo con una alineación interior todas han construido un pequeño porche, garaje etc. En esta edificación secundaria han abierto un accesos la calle posterior, la calle San José, extramuros. 


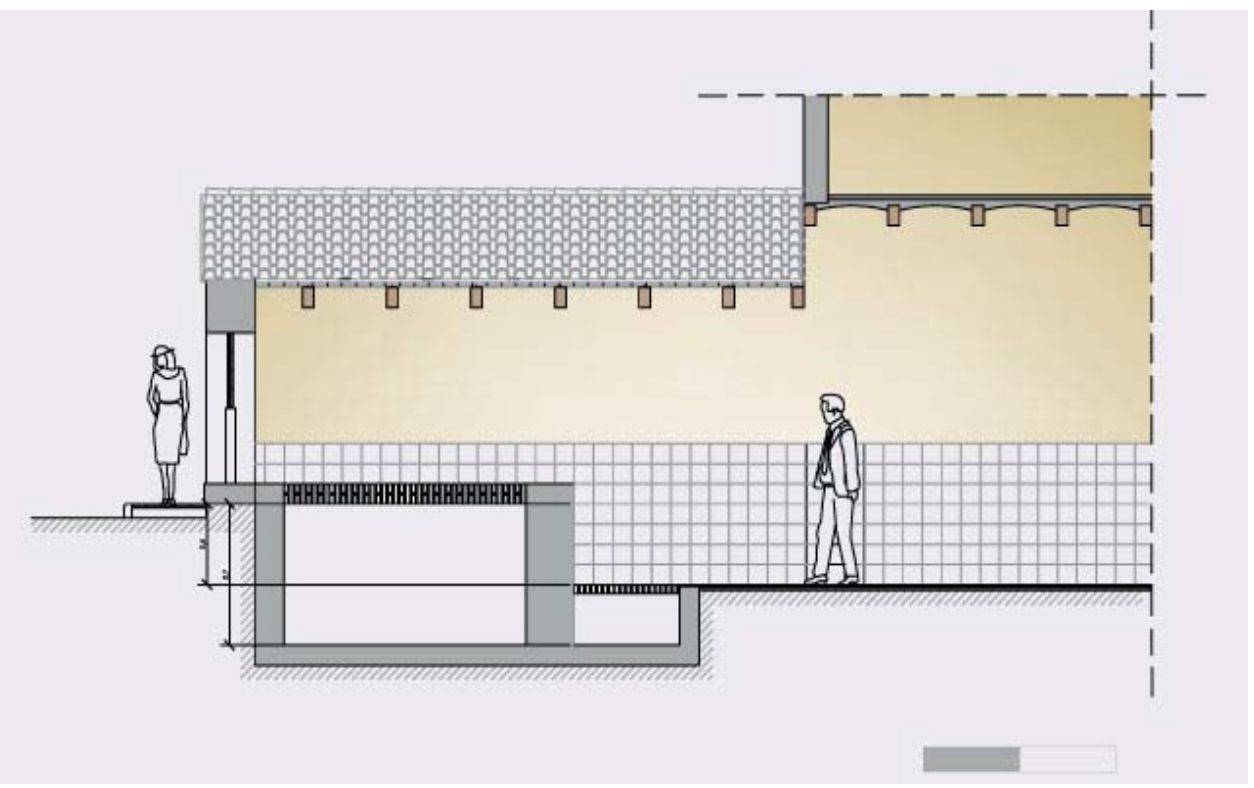

Otra teoría podría ir dirigida a demostrar que los inmuebles situados en m-7 hubieran ampliado sobre el foso de la muralla. Los datos que refrendan esta idea los aportan los dos edificios públicos existentes en ese espacio, el hogar parroquial y la actual casa museo de la población. Ambos inmuebles cuentan en esta zona, la primera unos vestuarios en semisótano y la segunda unos trullos. Estos últimos se encuentran excavados hasta a $1,10 \mathrm{~m}$ por debajo de la cota del edificio. Debido a esta situación cada vez que llueve los elementos indicados se inundan pero sin llegar a sobrepasar la cota de nivel del inmueble. El espesor del muro que linda con la calle san José, no sobrepasa en ambos casos los 50 $\mathrm{cm}$, por lo que puede ser un muro hecho a posterior y que la muralla quedará en el interior del edificio. Puede desmontar esta suposición la ubicación del portal de Riba-roja, que según la memoria popular estaba en la esquina con la calle San José-Maestro Barona, pero no hay ninguna prueba documental ni arqueológica que acredite una cosa u otra.

Contrariamente a lo expresado, una de las teorías más defendidas popularmente, señala que puesto que los inmuebles se encontraban edificados, no se construyó ninguna cerca perimetral, sino que, fueran los propios muros de las viviendas, los que cegaron la población, colocando el perímetro defensivo únicamente donde no existía inmueble y cerrando en esos cuatro puntos de acceso que se formaban por su estructura, el cardus i el decumanus, con los 4 portales.
Fig. 117. Sección de los Trullos de la casa gran, lindante con la muralla o tal vez amplió sobre el foso aprovechando la oquedad del este para construir los trullos. Detalla la diferencia de cotas de la calle al interior de la vivienda. Cuando llueve se llenan de agua pero no sobrepasan el nivel de pavimento. 
234 de 536

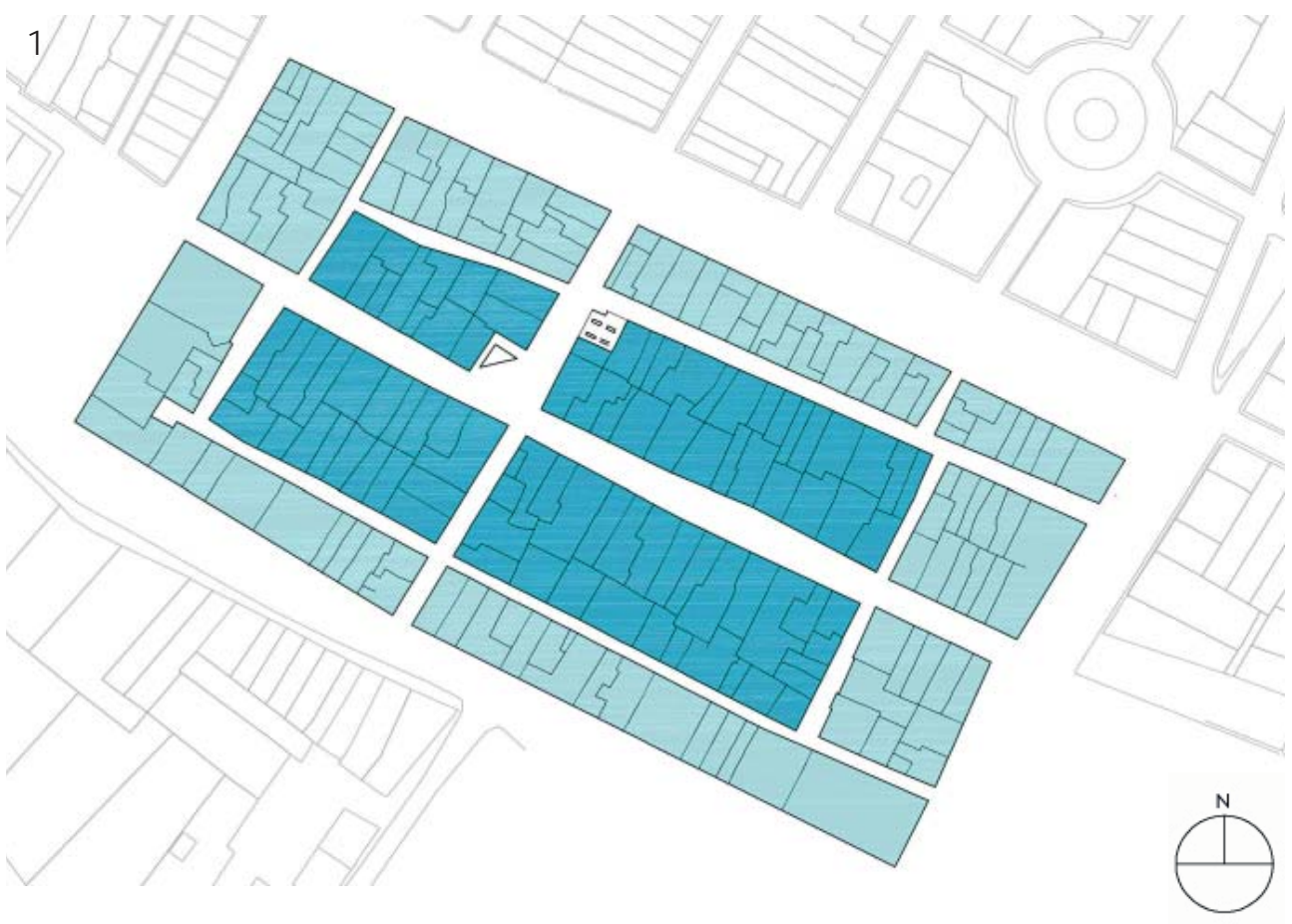

Evolución del centro histónico medieval de La Pobla de Vallbona

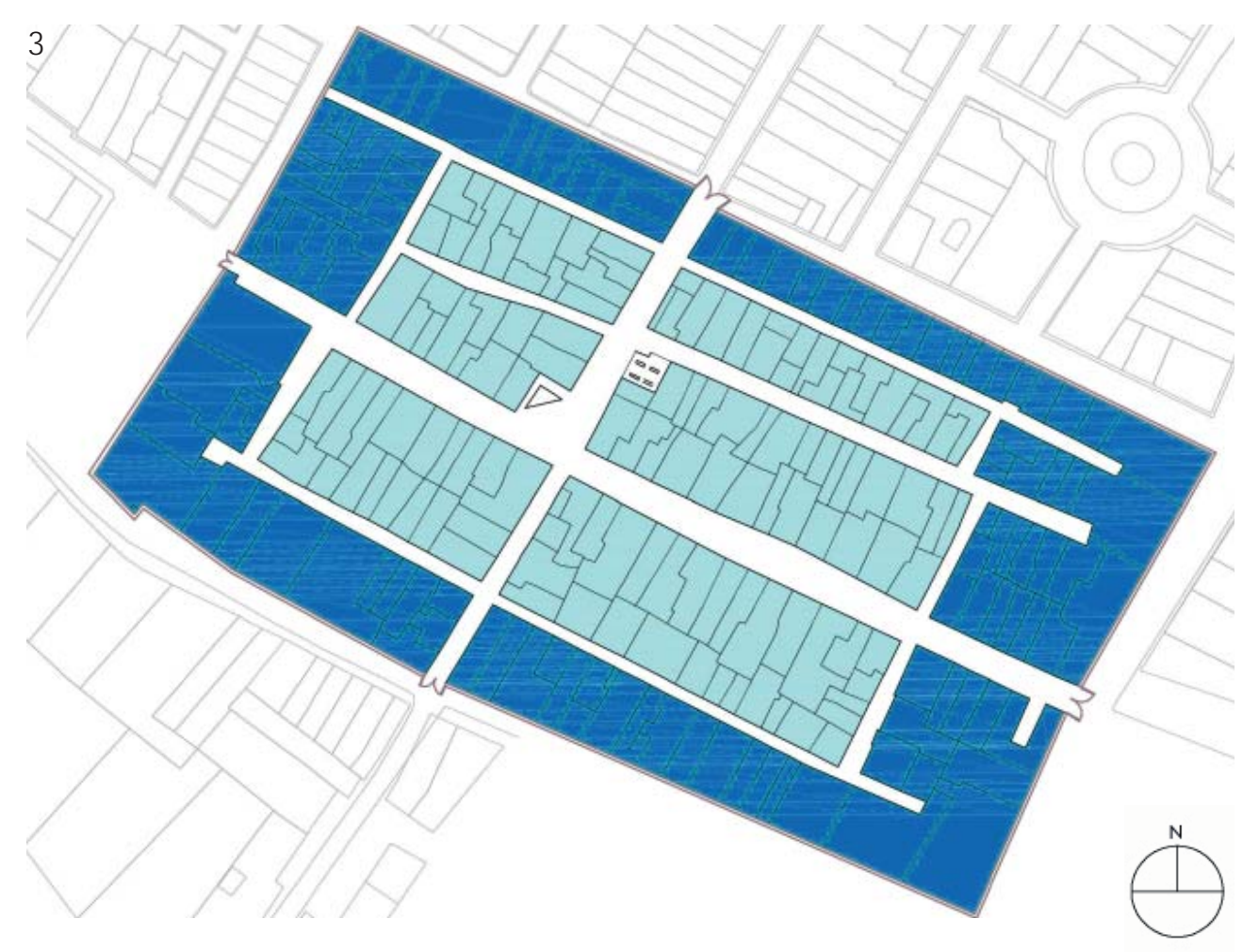




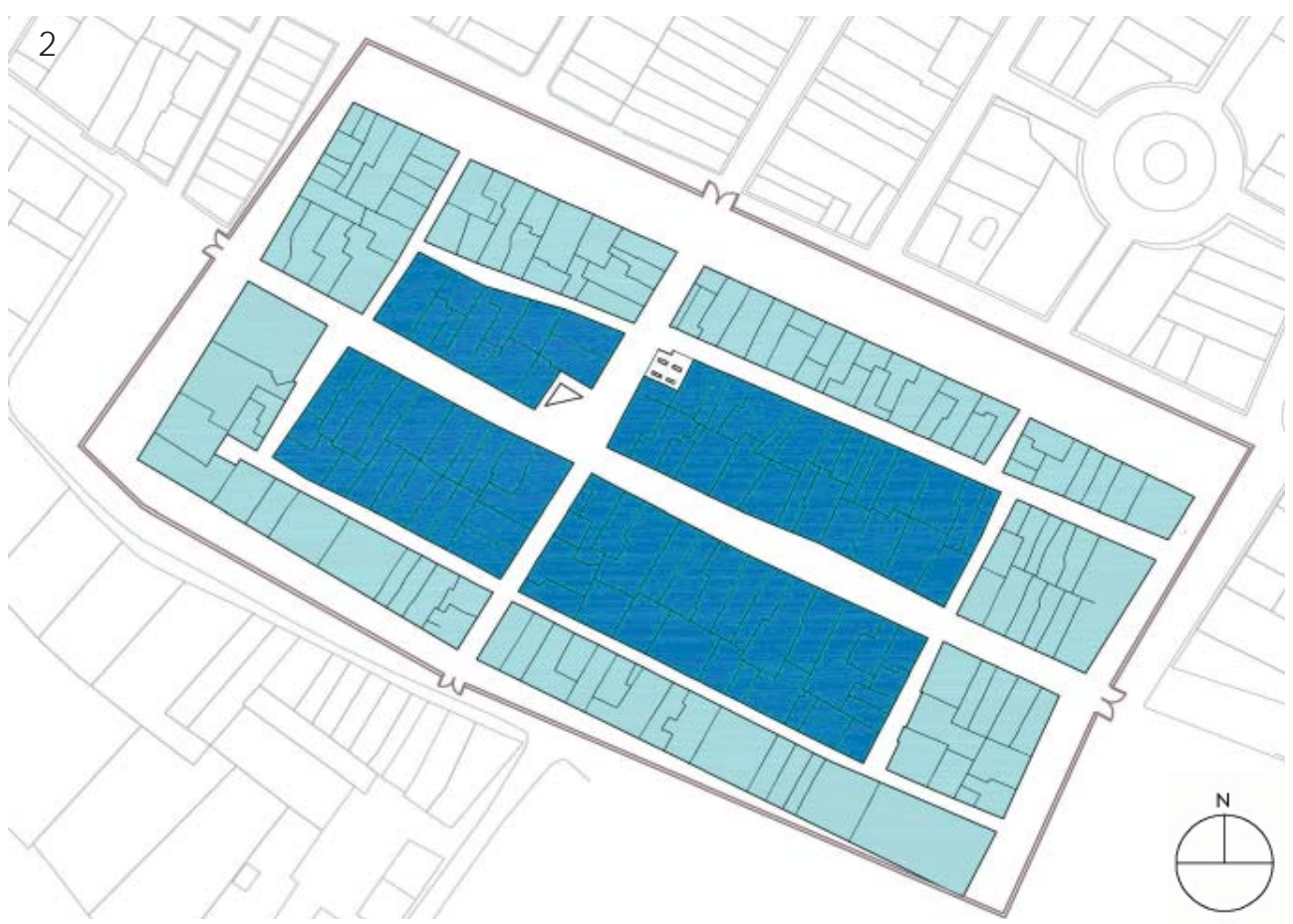

Fig. 118. Hipótesis sobre la evolución de la villa. Primero cuando fue lloc sin amurallar, en la presente página en la zona superior, cuando se amuralla. La tercera imagen muestra como la necesidad de solares va cogiendo el camino de ronda hasta hacerlo desaparecer. La última imagen en centro histórico de la Pobla en la actualidad, sin restos de muralla a la parte inferior de este texto.

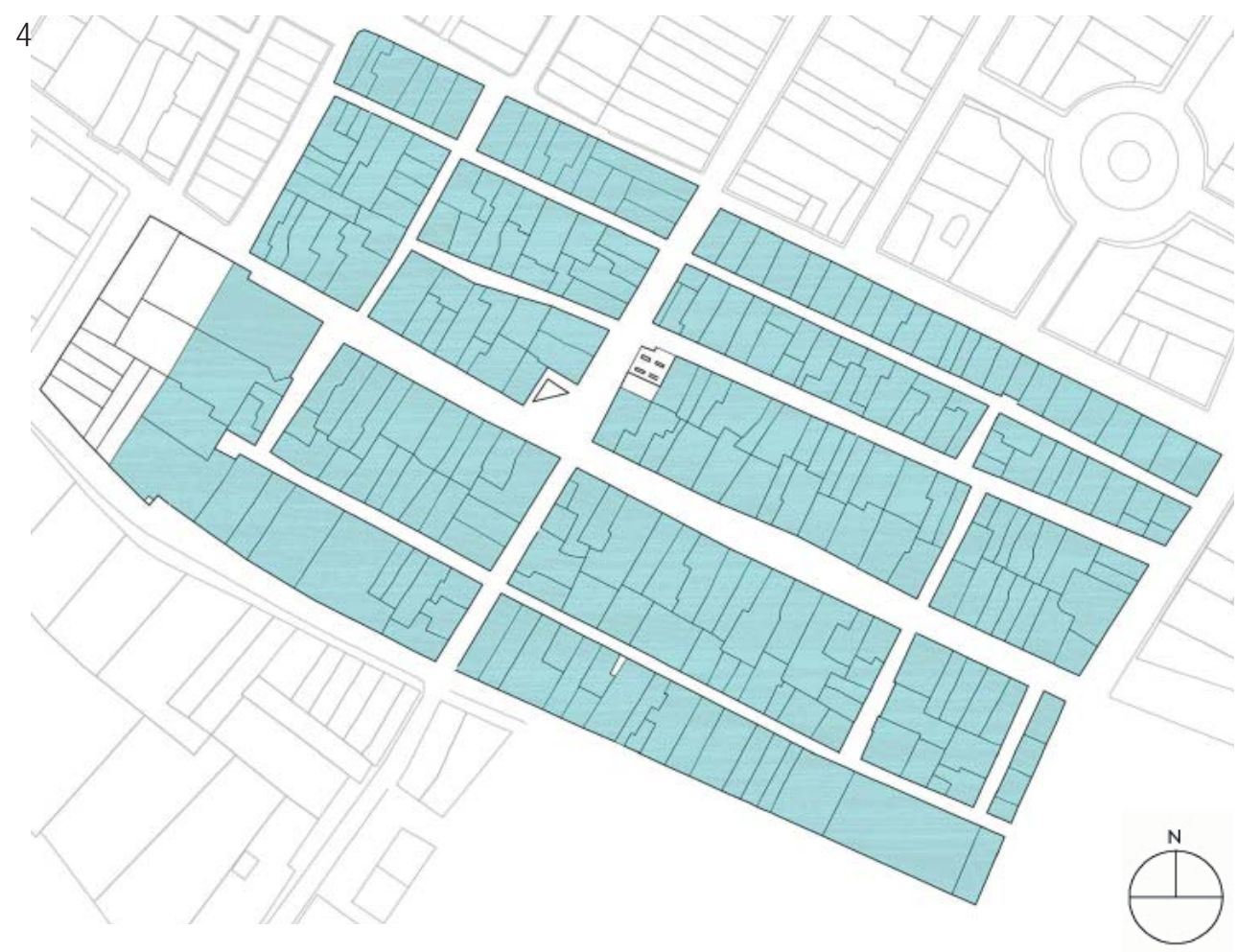


A modo de resumen final y a partir de los razonamientos anteriores se ha grafiado la hipótesis sobre la evolución de la planimetría de la villa, la cual se puede observar en la figura 118

\section{6| Elementos arquitectónicos}

Tal como se ha visto la fisonomía urbana de la Pobla es, quizás, la huella más evidente de su carácter medieval: las trazas urbanas, su esquema ortogonal, son la muestra más representativa del periodo de nacimiento de la vila, pero no el único referente. El patrimonio mas relevante del municipio evoca a un pasado gótico, aunque durante mucho tiempo ha estado enmascarado dificultando su identificación.

En otras palabras si se toma como referencia las propiedades particulares, las huellas dejadas en las fachadas, la red de caminos y de acequias, que guardan una fidelidad sorprendente, las construcciones destacadas - la iglesia, la plaza, la ermitaen el entorno, podemos observar todavía la herencia trasmitida, no sólo en la ortogonalidad, sino en los restos llegados hasta la época actual.

En lo referente al patrimonio arquitectónico civil pocos restos han sobrevivido el paso del tiempo. Los portales de la muralla fueron desmontados y los paramentos verticales visualmente desaparecieron, las viviendas residenciales fueron modificadas según el gusto decimonónico, todo ello al tiempo que se modificó la planta gótica de la iglesia con la ampliación neoclásica. La causa que lo motivó en gran parte, fue el auge económico que tuvo en este periodo el municipio al sustituir el cultivo del arroz por las plantaciones de seda. Este crecimiento hizo que la mayor parte de los edificios cambiaran sus frentes adaptándose a un estilo más clásico acorde con la época, aunque como se verá, todavía quedan algunos restos o vestigios en fachadas y en el interior de las viviendas.

En cuanto a la arquitectura religiosa, la parroquia de San Jaime es una iglesia claramente de estilo gótico, con bóvedas de crucería albergando en su interior un tesoro pictórico del bajo medievo. Pero lo más relevante es que por primera vez quedará documentada la ermita de San Sebastián (construida con tapial y arcos diafragma). 
Por último se demostrará que existen evidencias que acreditan que tiempo atrás, el municipio, contaba con un peiró gótico entre sus bienes inmuebles

\subsection{1| La muralla}

La Pobla sufrió las consecuencias de la guerra de los dos Pedros, Pedro I el Ceremonioso y Pedro el Cruel de Castilla, por lo que hubo de ser repoblada en 1382, momento en que se otorga a la vila una Carta Pobla. Durante los años de la contienda entre el monarca aragonés y el castellano muchas ciudades valencianas se fortificaron ante las frecuentes y brutales incursiones. Así lo demuestra el edicto de la reina Leonor dirigido a la vila de Llíria el 24 de enero de 1358:

\begin{abstract}
Atendiendo a que el ilustrísimo Señor Rey (...) nuevamente ha ordenado que en cualesquiera ciudades, villas y lugares de su Reino, situadas en la frontera del Reino de Castilla, para mayor seguridad de las mismas se construyan murallas y estacas, si no estuviesen ya elegidas ${ }^{187 "}[. .$.$] .$
\end{abstract}

Debido a esta situación debieron plantearse construir las murallas o cercas de la vila de la Pobla de Vallbona, que desde su origen se había establecido en un llano sin defensa, como era habitual, puesto que era un /loc dependiente de Benaguazir.

Construir una muralla suponía el inicio de un proceso largo y muy costoso que obligaba a la corona a renunciar, durante largo tiempo, a importantes partidas tributarias de las vilas con el fin de destinarlas a la construcción de los muros ${ }^{188}$.

Así, en el verano de 1295 Jaume Il amonestaba a los vecinos de Biar que tenían casas extra vila (cosa que sucedía con algunos de ellos) y que no querían construir sus viviendas en el albacar ${ }^{189}$.

Azuzando el miedo a peligros inminentes y favoreciéndolos con una franquicia de cinco años, el monarca ordenó a los que carecían de domicilio en el albacar que las construyeran y, sobre todo, que se cerrara la villa sub-castral con paredes.

A este respecto conviene advertir que, en muchas ocasiones, las pueblas no llegaban a rodearse de una muralla, sino que
${ }^{187}$ Llavata, V.(1981): Historia de la Villa y Baronía de La Puebla de Vallbona, La Puebla de Vallbona . Ayuntamiento de La Pobla de Vallbona, pág. 99.

188 Torro, J.(1989): “EI problema del hábitat fortificado en el sur del Reino de Valencia después de la segunda revuelta mudéjar (1276-1304), pág. 60.

${ }^{189}$ Recinto murado en la parte exterior de una fortaleza con la entrada en la plaza y salida al campo y en la cual se solía guardar ganado vacuno. 
simplemente bloqueaban las bocacalles exteriores colocando portales y haciendo de recinto los muros de las propias casas. Se debe evitar, pues, los malentendidos a que pueden llevar algunos documentos cuando mencionan puertas en bastantes poblaciones no muy importantes ${ }^{190}$.

La Pobla debía presentar durante el siglo XIII y parte del XIV la imagen de un espacio en el que comenzaban a proliferar las casas en torno a un entramado de carácter regular, pero desprovisto de fortificación o cerramiento defensivo y, por tanto, fácilmente expugnable. Se conoce este hecho gracias a distintas evidencias: el primer argumento lo aporta el documento, anteriormente referido, de los infantes Don Martín y Doña María de Luna de 1382 que estipulaba que en caso de conflicto los habitantes de la Pobla tenían que ir a resguardarse al castillo de Benaguazir:

que si ve per cas quels christians de la dita Pobla per fet de guerres o altre necesitats se haguessen a residir en lo dit loch de Benaguazir, quels sarrahins de Benaguazir que ara son altres qualsevols persones cristianes o sarrahins que en dit lloch de Benaguazir habitaran sien tenguts de donar la mitat del lloch de Benaguazir, a una part dels christians de la dita Pobla ${ }^{191}[\ldots .$.$] .$

Estas disposiciones no dejaban lugar a dudas: la Pobla constituía un lugar que no ofrecía posibilidad de defensa, por lo que sus habitantes debían marchar a resguardarse a Benaguacil, un lugar cuya morfología musulmana y su emplazamiento junto a una pequeña loma resultaba más favorable para dicho fin.

190 Torro, J.(1989): “EI problema del hábitat fortificado en el sur del Reino de Valencia después de la segunda revuelta mudéjar ( 1276-1304). Pág. 63.

${ }^{191}$ Llavata, V.(1981): Historia de la Villa y Baronía de La Puebla de Vallbona, La Puebla de Vallbona. Ayuntamiento de la Pobla de Vallbona.

${ }^{192}$ Sindicato de Riegos de La Pobla de Vallbona. Pergamino 3.

En definitiva, la falta de murallas, sumada a la cuestión de su emplazamiento en el llano de un valle, hacía de la Pobla un lugar de fácil accesibilidad. Con la lectura de la carta pobla en 1382 se rebate pues el argumento de la creación de las murallas, como hemos mencionado anteriormente, en la guerra de la Unión. Su puesta en pie tuvo entonces que producirse durante los años posteriores.

En este mismo orden, uno de los pergaminos ${ }^{192}$ recientemente traducidos, del Sindicato de Riegos, y fechado el 24 de marzo de 1384, habla del reconocimiento de una deuda de 290 florines que prestó Samuel Xixá, judío de Valencia, a La Pobla de Benaguacil. En este protocolo notarial se reconoce que el municipio le debe esa cantidad de dinero e indica todo lo que pasaría en el caso de 


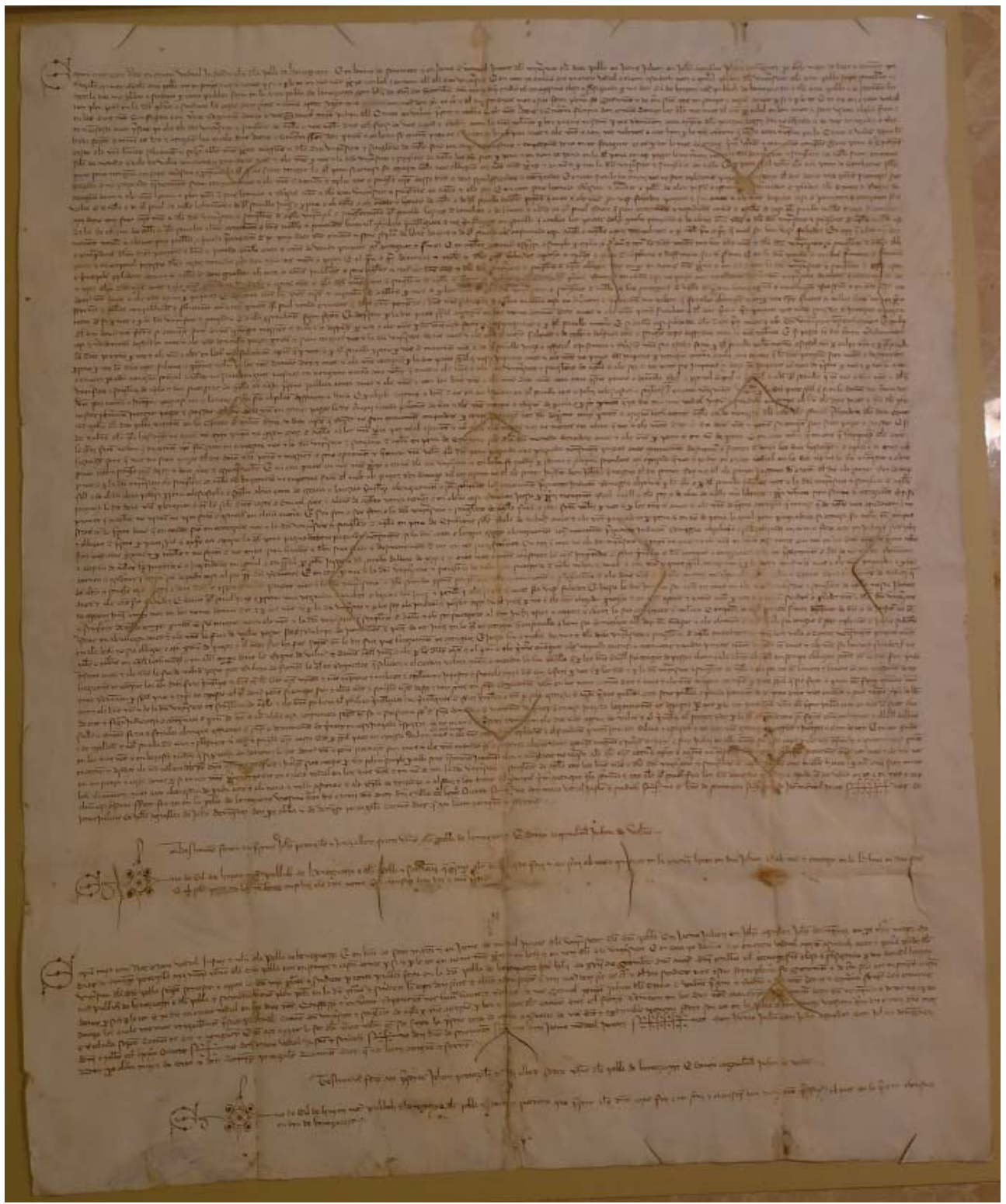

Fig. 119. Protocolo notarial del 24 de marzo de 1384, reconociendo de una deuda de 290 florines que prestó Samuel Xixá judío de Valencia a La Pobla de Benaguazir. 
Fig. 120. En azul claro el núcleo medieval sibles ampliaciones hasta la muralla que se han ido realizando con el paso del tiempo. original con las po-

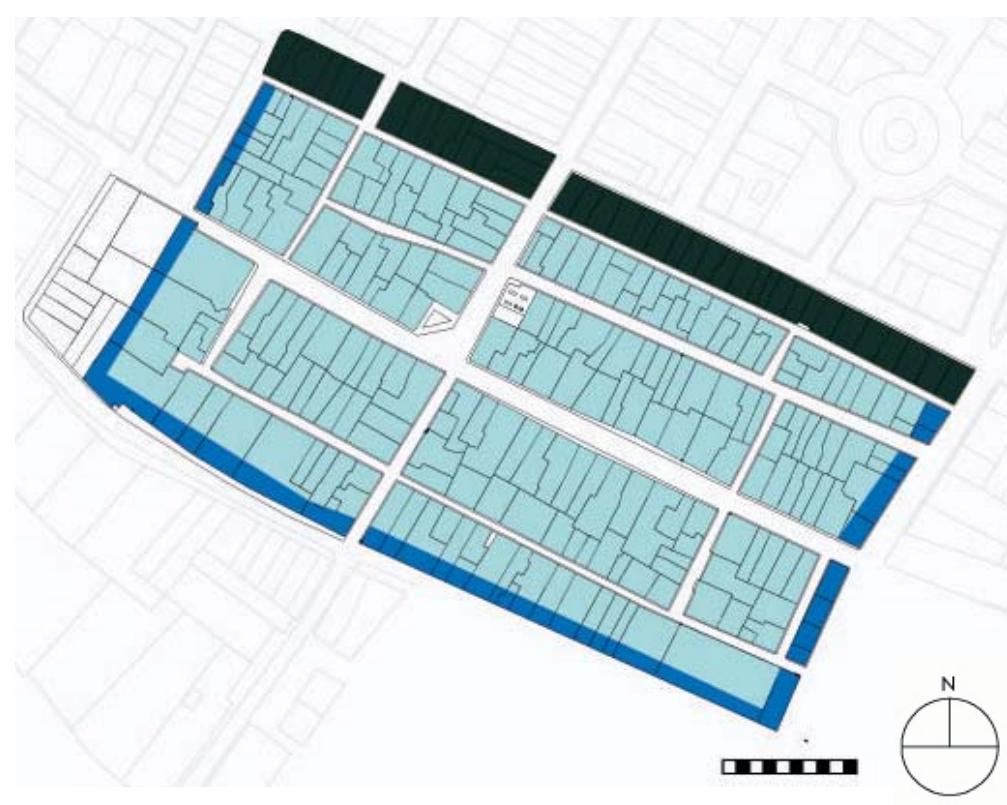

que el municipio no pagara, pero desafortunadamente no nos señala el motivo por el cual se solicitó esa cantidad de dinero, aunque debió de ser algún tipo de obra de interés y de carácter general, puesto que la deuda es del municipio.

Dadas las consideraciones que anteceden es sabido, que el municipio estaba consolidado desde años antes al cierre perimetral, en el caso de la Pobla sería factible pensar que en vez de murallas pudiese haber optado por otro tipo de lienzo defensivo más próximo al carácter de los murs o cercas. Las murallas constituían por regla general un cuantioso dispendio y además tenían un considerable volumen: normalmente costaban de un espesor de tres o cuatro metros. Los murs, de dimensiones menores se realizaban igualmente con la técnica del tapial Valenciano y tenían una función más fiscal que defensiva ${ }^{193}$.

El plano de los arrozales del año 1584, donde se grafían todos los municipios de la comarca del Camp de Turia, documentaba ya la existencia de las murallas y dejaba constancia que al menos el portal de Valencia contaba con dos torres, que la cerca defensiva eran de tapia - en los demás municipios se aprecian los sillaresy que contaba con la existencia de un foso, seguramente el que se representa, el valladar de Valencia.

${ }^{193}$ Archivo del Reino. Manaments y Empares, n. o 1626, Libro 4. Libro 5, mà 39, fol. $38 v-48 v$ mà 40 , fol $39-44$.
El siguiente dato lo aportan los protocolos notariales que describen el contrato de la reforma de la iglesia de San Jaime, del año 1700-1702. En uno de sus apartados se documenta 


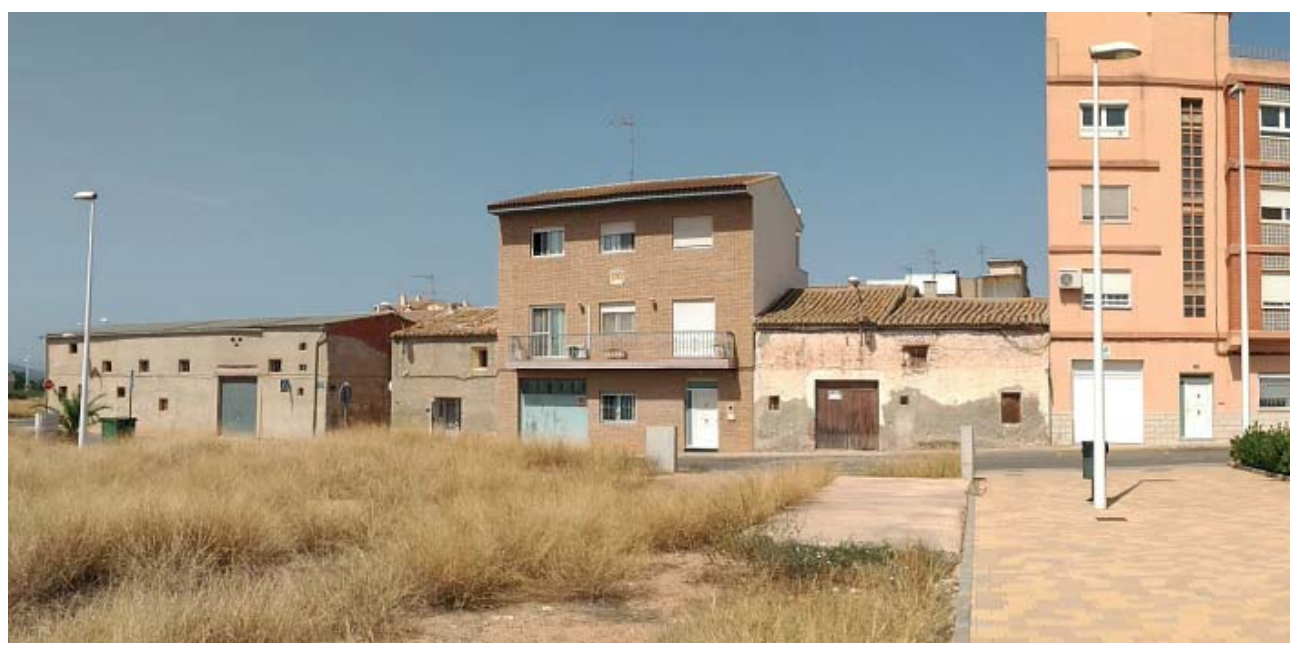

exactamente la existencia de la muralla en la zona oeste, indicando claramente que no se debe construir hasta ella.

La siguiente referencia histórica que acredita la existencia de esa cerca muraria, se halla en la construcción de un convento en el callejón de San Onofre, apuntado por Llavata ${ }^{194}$ :

Antes de la entrada de los franceses en la Vila, en el año 1811 pegado a la muralla[...].

Ante la situación planteada precisar una situación que ha cambiado en este periodo de tiempo. En los protocolos notariales de la reforma barroca de la Iglesia de San Jaume, del año 1700 , se especificaba claramente que no se debía llegar a construir adosado al lienzo defensivo, pero una centuria después esta preocupación ha pasado a un segundo plano.

El único documento gráfico del recinto amurallado aparece fechado en el año 1860, de la mano del presbítero Pedro Sucías Aparicio. Durante uno de sus viajes estuvo en la Pobla de Vallbona y croquizó las trazas de la vila. Un municipio cerrado con una cerca, cuatro portales y con calles paralelas y perpendiculares entre sí, en la intersección de los viales principales, la plaza de la vila.

A finales del siglo XIX, al igual que en la mayoría de los municipios valencianos, se llevó a cabo el derribo de parte de cerca muraria para la apertura de viales y la eliminación de

Fig. 121. El Valladar de Valencia. En la fachada de las casas antiguas se puede intuir una hipotética altura de la muralla medieval.
${ }^{194}$ Llavata, V. (1981): Historia de la Villa y Baronía de La Puebla de Vallbona, La Puebla de Vallbona, pág. 120 
las puertas de acceso a la población, coincidiendo en el tiempo con la construcción de la ampliación neoclásica del crucero de la iglesia - situada extramuros-. En este periodo, la Pobla de Vallbona sufre un cambio y un crecimiento demográfico debido a varias causas:

- El cambio del cultivo del arroz a la seda.

- La liberación de las casas de posta, que hace que se empiece a construir en la zona de las ventas, fuera de las murallas.

Como se puede entender, la economía de La Pobla era floreciente, y se podía permitir la ampliación de la iglesia, debido al crecimiento demográfico. Esta situación contrasta a lo ocurrido en la época barroca cuando fue imposible terminar torre campanario por escasez en la financiación.

Para comprobar las consideraciones anteriores se ha intentado localizar en el Archivo de la Diputación Provincial de Valencia alguna referencia que haga pensar que había una partida presupuestaria destinada al mantenimiento de las puertas o de la muralla. No se ha encontrado ningún tipo de referencia en todos los documentos del ayuntamiento del municipio allí depositados, aunque se ha encontrado un dato importante:

El expediente que hace referencia a los años 1886-1887, informa que siendo Victoriano Segarra alcalde, se encargó el reloj público de la torre-campanario apareciendo por primera vez un gasto para colocar alumbrado público con petróleo. Debido a esta referencia, queda acreditado que a partir de este momento la vila ya estará iluminada por la noche.

En lo tocante a documentos que aporten noticias sobre el tipo de cerca muraria del núcleo medieval son bastante escasos y

\begin{tabular}{|c|c|c|}
\hline Años & Casas & Habitantes \\
\hline 1815 & 340 & 1.500 \\
\hline 1849 & 500 & 2.102 \\
\hline 1875 & 510 & ---- \\
\hline
\end{tabular}

Tabla 11: Datos de evolución demográfica en el siglo XIX en la vila de La Pobla de Vallbona ${ }^{195}$ pág. 449. 
algunos de ellos entran en contradicción. Para ilustrar lo indicado se toma como referencia un documento del archivo parroquial, fechado en el año 1866, de Manuel Adam, rector de la iglesia parroquial de San Jaime desde 1846 a 1876, encontrado tras la cubierta del libro de Visitas del año 1920, se indica que la ampliación neoclásica se produjo alrededor del año 1846.

\begin{abstract}
así mismo en el recinto del Templo hay otro (Calvario), que si bien en tiempos remotos estaba habilitado para el ejercicio piadoso, empero no lo está al presente, desde que en el año 1846 se alteraron las estaciones en cuanto al lugar y forma, por causa de haberse agregado la nueva fábrica del Presbiterio y del Crucero a la pequeña y antigua iglesia ${ }^{196}[\ldots]$.
\end{abstract}

Sin embargo el plano realizado por el canónigo Pedro Sucias Aparicio, según Vicente Llavata, se encuentra fechado en el año 1860, y no aparece dibujado el crucero de la iglesia. Estos datos hacen suponer que uno de los dos datos es erróneo, puesto que el documento lleva fecha del año 1866. Posiblemente ésta sea la fecha correcta, pero no se puede asegurar. Lo único cierto es que esta parte de la muralla lindante a la iglesia desapareció con la reforma neoclásica de la segunda mitad del siglo XIX.

Diversos acontecimientos sociales de la época, tanto a nivel provincial como local, orientan sobre la fecha y las causas de la desaparición de la cerca:

-El derribo de la muralla de Valencia en el año 1.865.

-El documento, referenciado anteriormente, de Manuel Adán fechado en el año 1866.

-El nacimiento de una nueva agrupación de inmuebles extramuros. Documentos del año 1864, indican el barrio o Caserío de las Ventas tenia la necesidad de adquirir un pozo puesto que allí habitan 1.300 almas, siendo alcalde Luis Segarra.

-Un grabado del año 1911 presenta una vila sin muralla frente a una gran zona de expansión en la zona de las ventas (véase fig.100).

Dadas las condiciones que anteceden se puede llegar a la conclusión de que en el siglo XIX las murallas de la vila habían perdido todo su valor defensivo y lo que hacían era frenar su expansión. Es congruente a la vista de los datos encontrados
${ }^{196}$ Llavata Pitarch, V.(1981): Historia de la Villa y Baronía de La Puebla de Vallbona, Ayuntamiento de La Puebla de Vallbona 1981, pág. 207. 


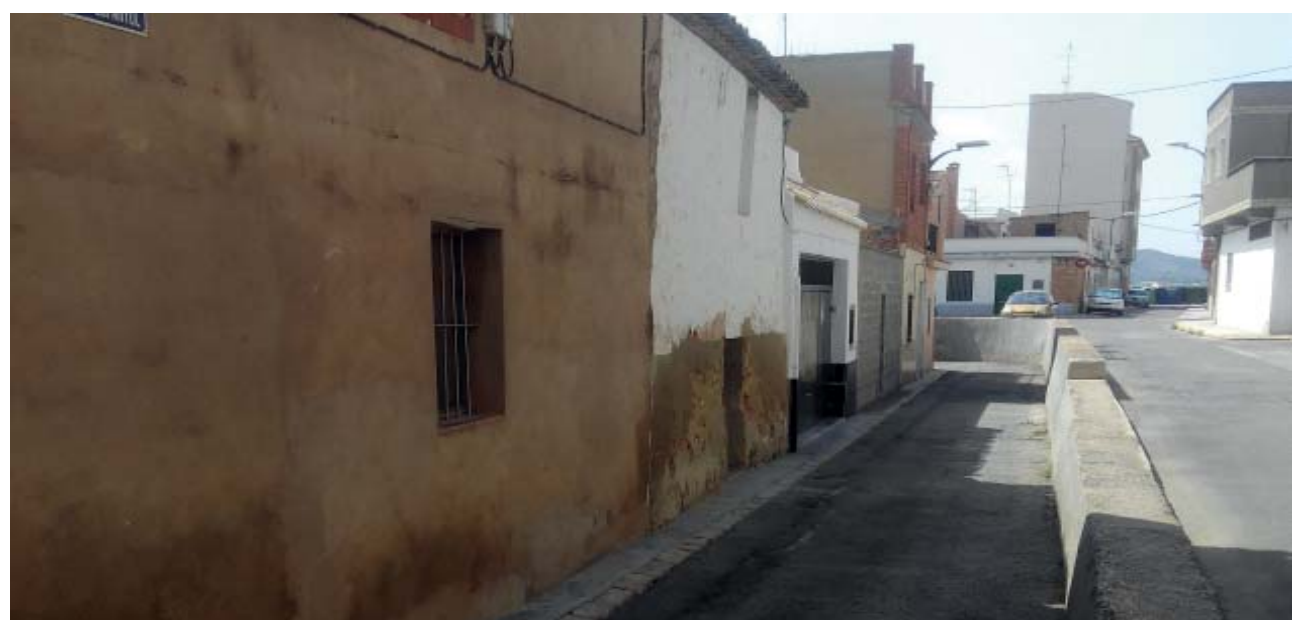

Fig. 122. Vista actual del valladar de Benaguacil. Se observa el desnivel existente entre la zona trasera de la muralla y la nueva zona de expansión. llegar a pensar que el derribo de la muralla o el desmontaje de las puertas se tuvieron que realizar entre los años 1860-1886.

La descripción del recorrido de la muralla y su posible espesor se encuentra de mano de Vicente Llavata en su libro sobre la historia de la Villa y Baronía de la Pobla de Vallbona, editada en el año 1981,que dice así:

Su recorrido era el siguiente: En la parte sur, en lo que actualmente es la calle san José, se hallaba el portal denominado "el portalet". A la izquierda del portal y en su misma pared a unos $3 \mathrm{~m}$ del suelo, se conservaba un escudo heráldico con las barras de Aragón que ostenta la fecha de 1.701 y la leyenda "Salvaguardia Real".

Desde el portalet el muro tendía hacia levante, a lo que hoy denominamos la Eliana y antiguamente el valladar de Valencia. Doblaba en dirección norte, llegando al Portal de Valencia, cuya puerta daba a la calle mayor por el este. Seguía idéntica dirección unos $100 \mathrm{~m}$ dejando a mano izquierda la calle del mitj y la de dalt (las cuales no tenían acceso) y dando la vuelta en dirección oeste recorrían el poblado por su parte noroeste hasta su llegada al Portal Norte o del Campes.

En este punto doblaba unos $3 \mathrm{~m}$, dejando a su izquierda tras el portal, la calle nombrada travesía de las ventas, proseguía en dirección este, rodeado por el llamado valladar de Benaguacil, hasta el portal oeste o de Benaguacil. Confrontando precisamente 


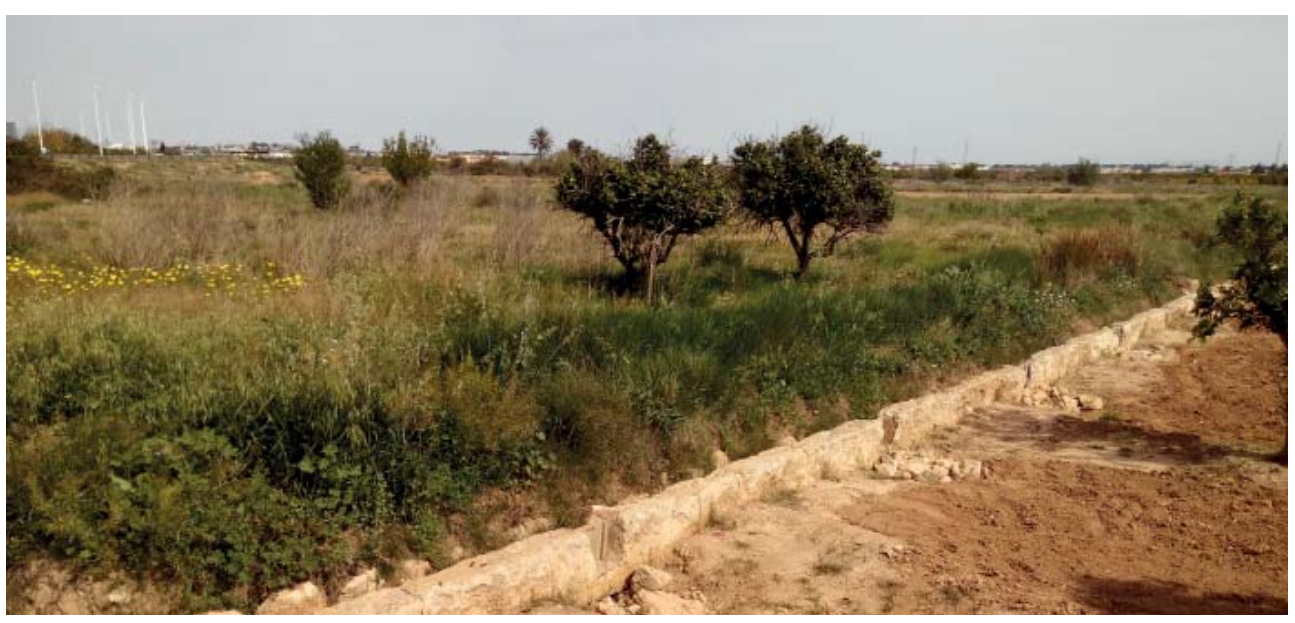

con lo que hoy es el gran crucero de la Iglesia Santiago Apóstoles.

Seguía la muralla por detrás de la iglesia y la casa badía hasta llegar al sitio que ocupaba el antiguo matadero municipal, al oeste de la calle san José, discurriendo a unos metros de la acequia primera, finalizando en "El Portalet", entrada de la calle travesía de las Ventas por el camino que une a Riba-roja y la Puebla.

En la actualidad (año 1981), aun podrían apreciarse algunos vestigios de la vetusta muralla que en algunos sitios alcanzaba un espesor de $1 m^{197}[\ldots]$.

Nada queda, pues a, simple vista del muro muralla de la Pobla de Vallbona en la actualidad. Únicamente el escudo que tuvo que estar en el Portal de Riba-roja, según Carlos Sartouh ${ }^{198}$, podría proceder de la antigua muralla y posiblemente estuviera colocado en el frontis del portal principal.

El escudo cuenta con las mismas medidas originales, está tallado en piedra de sillar y tiene un espesor aproximado de $30 \mathrm{~cm}$. La fecha que resta en él, 1701. Se encuentra situado actualmente en la fachada de una vivienda cercana a su ubicación original, en la calle Maestro Barona, $n$ ㅇ 8. Según explica la propietaria, D. a Amparo Marti, el escudo estaba colocado en la parte superior de su fachada. No tiene conocimiento si el escudo se colocó allí cuando se derribaron las puertas, puesto que su padre, nacido en el año 1916, no se lo contó. Sin embargo esta vecina de la Pobla sí le contó que las puertas estaban ancladas con golfos en el paramento vertical de su inmueble, en cambio
Fig. 123. Acequia realizada con sillares a menos de $100 \mathrm{~m}$ de donde si situaba la muralla medieval junto al portal de Riba-roja.
${ }^{197}$ Llavata Pitarch, V.(1981): Historia de la Villa y Baronía de La Pobla de Vallbona. Ayuntamiento de La Pobla de Vallbona, pág. 100.

${ }^{198}$ Sartouh, C. (1922): Geografía General del Reino de Valencia. Tomo II. Casa Editorial Alberto Martín. Barcelona. 
Fig. 124. Único resto de la muralla del casco antiguo de La Pobla, el escudo del portal de Riba-roja de Turia.

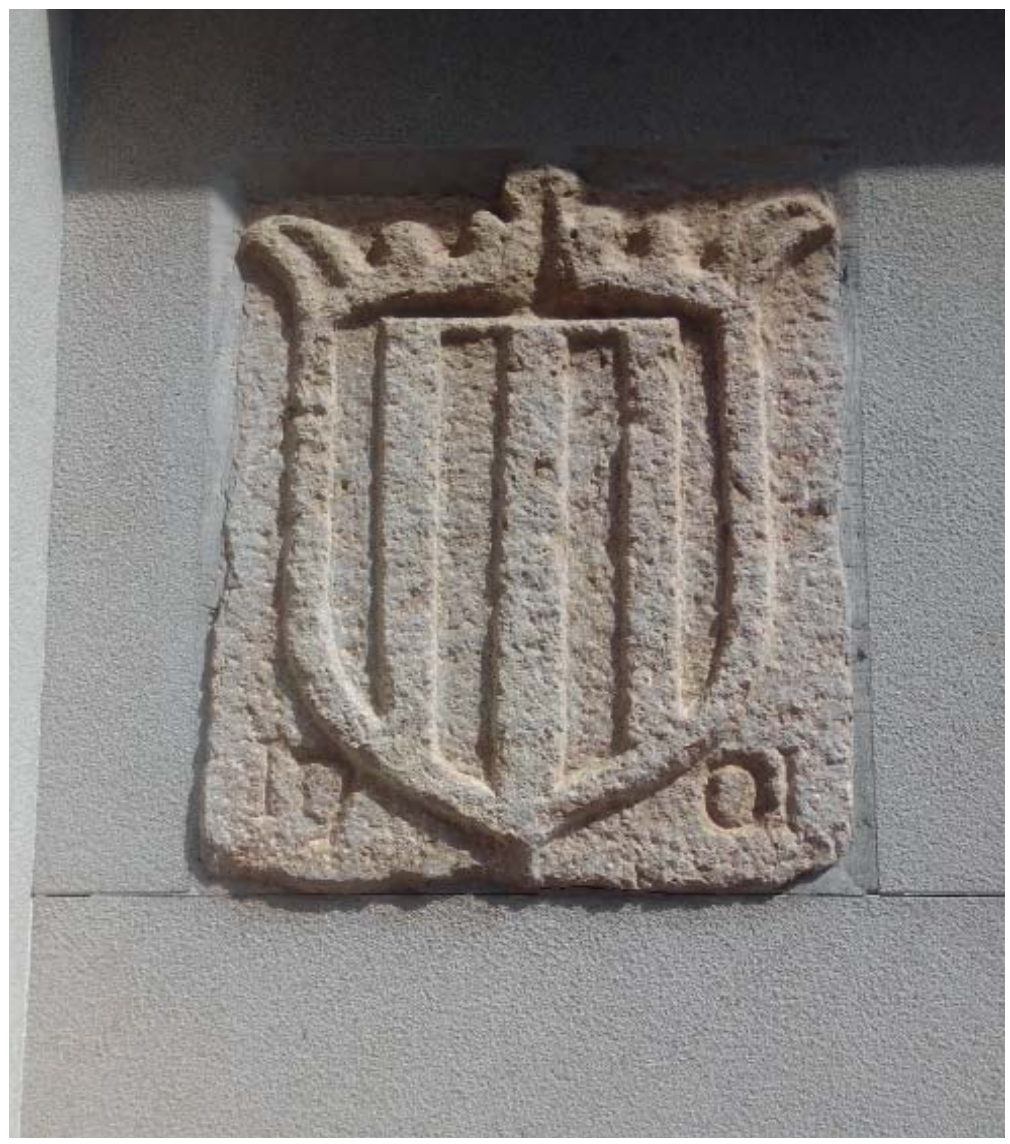

el lado izquierdo se encontraba amarrado a una pilastra. Ambas se encontraban unidas por un arco. Así es como se ha transmitido de generación en generación.

En cuanto al perímetro amurallado de $1,00 \mathrm{~m}$ de espesor, como identifica D. Vicente Llavata, no se encuentran restos a simple vista. Se ha analizado el recinto por donde se supone que iría la muralla, y estudiado desde el exterior todas las edificaciones que cuentan todavía con muro de tapial y que existen en la actualidad. Todas ellas cuentan con una pequeña puerta auxiliar que se ha abierto posteriormente a la apertura de la calle, a lo que vendría a ser el antiguo foso. La mayoría de las edificaciones cuentan con un muro de tapia de espesor aproximado de $50 \mathrm{~cm}$. Sólo en dos casos, parece existir un muro mayor de $75 \mathrm{~cm}$.

Seguidamente procede analizar el foso que circundaba la cerca. En el caso de la Pobla, este espacio se ha convertido en calle, puesto que así se conoce la zona norte del casco antiguo, el vall. Esta superficie se encuentra completamente llana, pero se sitúa 

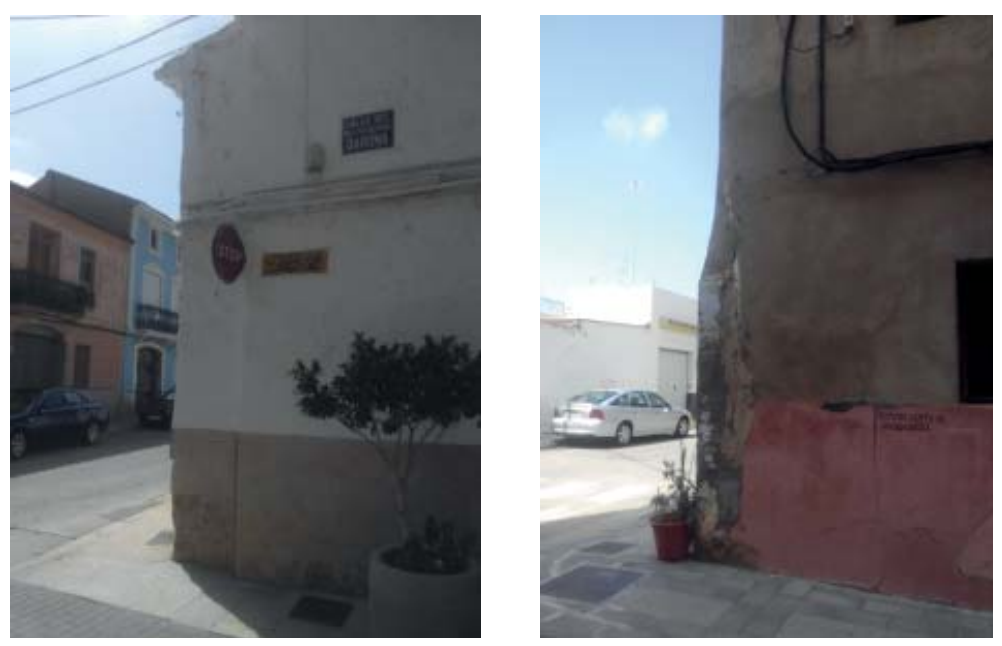

Fig. 125. Imagen actual del las ubicaciones donde hipotéticamente se encontraban el portal de Benaguacil y el Portal de Riba-roja. Se puede observar en uno el rebaje del pilar y en el otro un remate de final de muro.

en descenso hacia el oeste hasta que alcanza una profundidad de 1,50 m. De este modo la vila se queda a una cota inferior que el nuevo ensanche, que se construye en la zona de cota más alta, y entre ambos se sitúa el valladar de Benaguacil.

Para concluir podríamos decir que, sea como fuere, lo cierto es que la Pobla quedó delimitada por un muro una cerca en el que se abrían cuatro puertas o portales: el portal norte, el portal de Valencia, el portalet (dirección Riba-roja del Turia) y el portal de Benaguacil, y así permaneció hasta bien entrado el siglo XIX.

Después de todo lo analizado, queda demostrada la existencia del perímetro amurallado y de sus cuatro puertas. Cabe precisar que las últimas edificaciones que se han derribado en el límite del recinto no han dejando constancia de la presencia de un paramento mayor de $50 \mathrm{~cm}$ de espesor. Por lo tanto aquí queda una duda: las edificaciones cerraban el perímetro y posteriormente se colocaron cuatro puertas, había cerca y edificaciones perimetrales o lo que parece más similar a todas las pueblas analizadas, fue $l / o c$, luego villa, posteriormente se amurallo, se construyó adosado al camino de ronda y una vez perdida su función derruida, parte de la muralla fue derrumbada, parte pasó a ser la trasera de las viviendas y en otros casos un muro interior. Sea como fuere aun falta encontrar esos restos arqueológicos que lo demuestren. 


\subsection{2| El fossar medieval}

La utilización de piedras como elementos de señalización de sepulturas se documenta en nuestra península desde época neolítica, al menos desde el IV o V milenio antes de nuestra era. En las comarcas del Matarraña y Bajo Aragón fueron ya muy habituales en época ibérica, existiendo un variado conjunto de estelas funerarias de piedra a modo de mojones, en los que se suelen representar lanzas, escudos, jinetes, buitres u orlas decorativas $^{199}$.

El uso de estelas discoideas de piedra (Ilamadas así por tener su parte superior en forma de disco o círculo) aparece plenamente documentado desde la Edad media. Las estelas se colocaban en las cabeceras de las tumbas, orientadas generalmente hacia el este, al igual que las cruces actuales. Las estelas más sencillas se limitarían a simples mojones de piedra, mientras que las de tipo discoideo solían estar decoradas por una o ambas caras y tenían una base trapezoidal y lisa que se hincaba en el suelo para su sujeción ${ }^{200}$.

Uno de los pueblos que las mantiene en la actualidad es el municipio aragonés de Fuentespalda, el cual posee uno de los conjuntos más interesantes de época medieval de toda la Provincia de Teruel, sobre las paredes del antiguo cementerio situado junto a la iglesia parroquial ${ }^{201}$.

En fossar vell, situado en la calle Valencia nำ11 de Fuentespalda, se ha recreado recientemente un singular espacio funerario aprovechando un reducido sector de unos $120 \mathrm{~m} 2$ de superficie. Hasta entonces se conservaban encima de la tapia de este cementerio abandonado una veintena de antiguas estelas funerarias discoidales que constituyen uno de los conjuntos más completos de este tipo de señalización funeraria conservados en

${ }^{199}$ Benavente, José A. (2003): "Proyecto de recuperación y puesta en valor del cementerio viejo de Fuentespalda (Teruel)", inédito.

200 Ibídem.

${ }^{201}$ Puch Foncuberta, E. (1990): "Estelas discoideas de Fuentespalda" Gaceta del Matarraña no 19 noviembre pago 4 y 5 . la Comunidad Autónoma Aragonesa.

La mayoría están decoradas por ambas caras, combinando generalmente el motivo de la cruz inscrita en orla circular simple en el anverso, con decoraciones de entrelazados inscritos también en orla circular simple en el reverso. Las cruces son el símbolo cristiano por excelencia y aparecen en formas muy variadas y artísticas; los entrelazados son símbolos de inmortalidad desde tiempos muy remotos, anteriores en varios siglos a la aparición de la fe cristiana, y constítuyen un motivo abundantemente utilizado en el arte hispano-musulmán. 


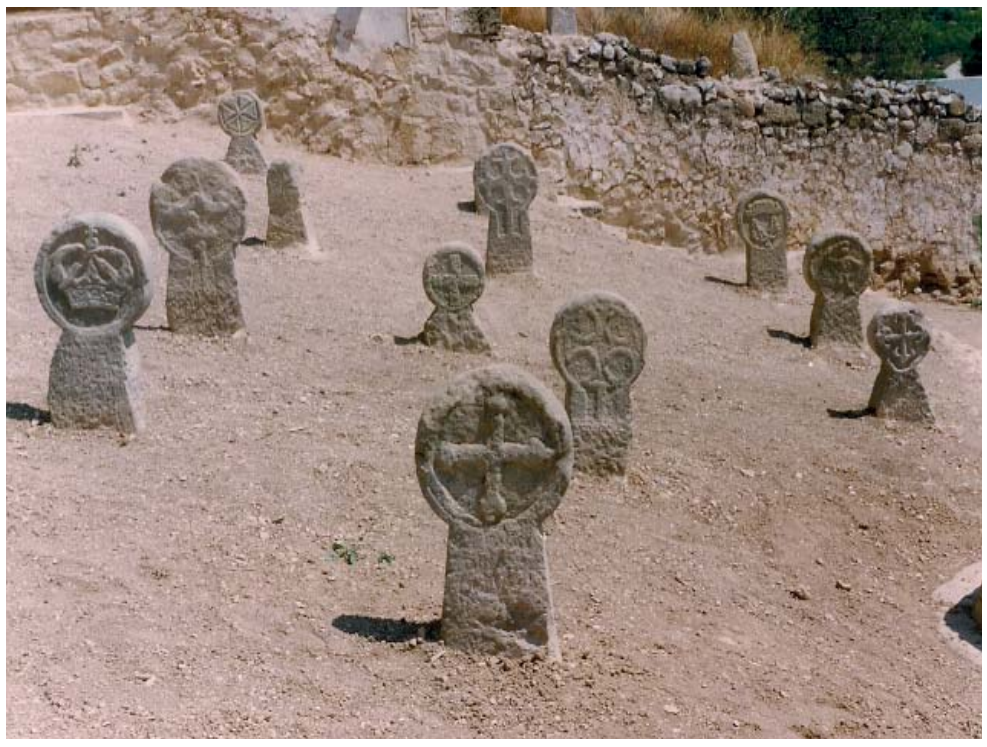

Hay también entre las decoraciones un buen repertorio de tocados: una corona real, dos mitras, un bonete... A excepción del primero todos los demás son de uso común entre los ministros de la iglesia, lo que puede hacer suponer que las estelas que los ostentan corresponderían a sacerdotes de la localidad, aunque tal vez solo sean un motivo decorativo cuando se combina una mitra con útiles de picapedrero.

Solo en dos casos aparecen instrumentos relacionados con la profesión en vida del difunto: en uno hay un arado, indicación probable de que la estela corresponde a un labrador, y en otro hay grabados dos escoplos y un martillo de picar piedra ${ }^{202}$.

La única estela con figura humana tiene representada la muerte con su guadaña. Esta misma es la que posee una inscripción, aunque difícilmente legible por el desgaste.

Este grupo de estelas discoideas corresponde a la época medieval, en el período que abarca aproximadamente desde la fundación de la iglesia parroquial, a mediados del siglo XIII, hasta el siglo XV, en que se generalizó el enterramiento dentro de las iglesias.

En la mayoría de los municipios valencianos estudiados en el presente plan de investigación aparece documentado el antiguo cementerio municipal en un lateral de la iglesia, aunque en la actualidad no se utilice como tal. En La Pobla de Vallbona se identifica y asegura, la ubicación exacta del fossar, nunca certificados, por un registro notarial y por la presencia de restos
Fig. 126. Las estelas discoidales del municipio de Fuentespalda (Aragón) con diferentes grabados. 
Fig. 127. Cementerio medieval situado en el municipio de Fuentespalda (Aragón).

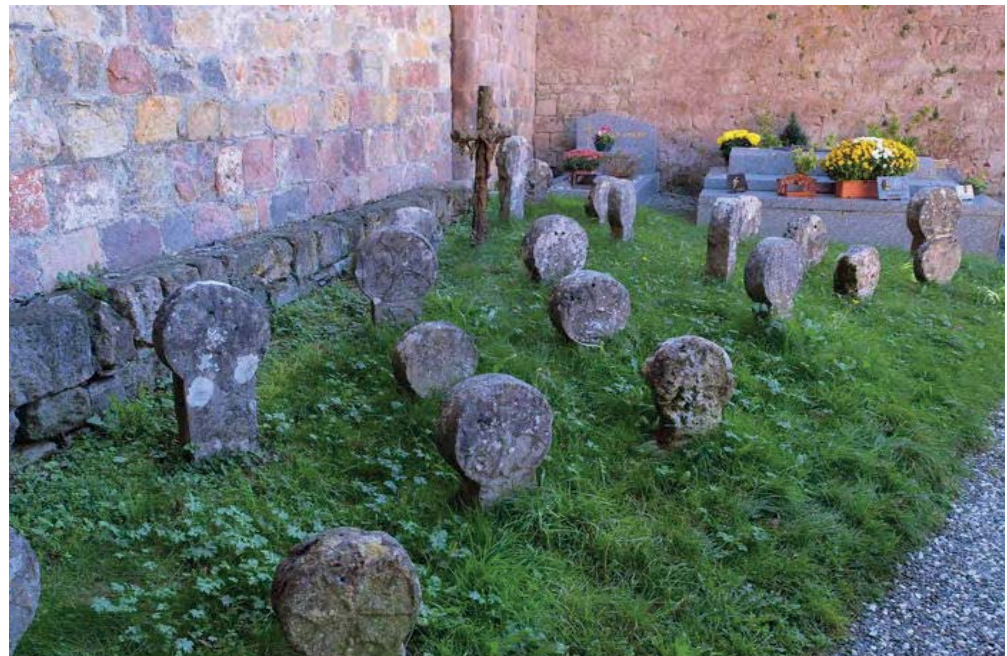

arqueológicos en lo que sería en la actualidad un jardín sito en la calle Reverendo Miguel Tarín no3, en el lateral izquierdo de la iglesia Santiago Apóstol.

En efecto, los protocolos notariales del año 1701, donde se describen las obras a realizar para convertir la iglesia gótica al estilo de la época, el barroco, en su apartado XXXV describen la ubicación de la torre campanario, y al hacerlo acreditan la existencia del fosar medieval:

\begin{abstract}
Ítem que en la paret del Cap de altar en la porta que correspon al Sagrari esta se ha de obrir pera dar entrada al campanar fent a la part del fosar una paret de rachola y micha de amplaria [...].
\end{abstract}

Asimismo en este lateral izquierdo de la iglesia actual nunca se han realizado excavaciones arqueológicas. Según la memoria colectiva el solar perteneció, antes de la Guerra Civil Española, a la Iglesia pasando después a mano de un particular que lo utilizaba como huerto y almacén. En el año 2002 fue adquirido por el Consistorio municipal con la idea de derribar el inmueble que se había construido en su acceso y dejarlo convertido en jardín para que el bloque eclesiástico quedará exento de construcciones.

Las obras de ajardinamiento se llevaron a cabo por la Brigada Municipal de obras en el año 2007. Al realizar los trabajos que convertían ese huerto-solar en un jardín, sin apenas excavar se encontraron dos estelas discoidales de piedra circulares y con 

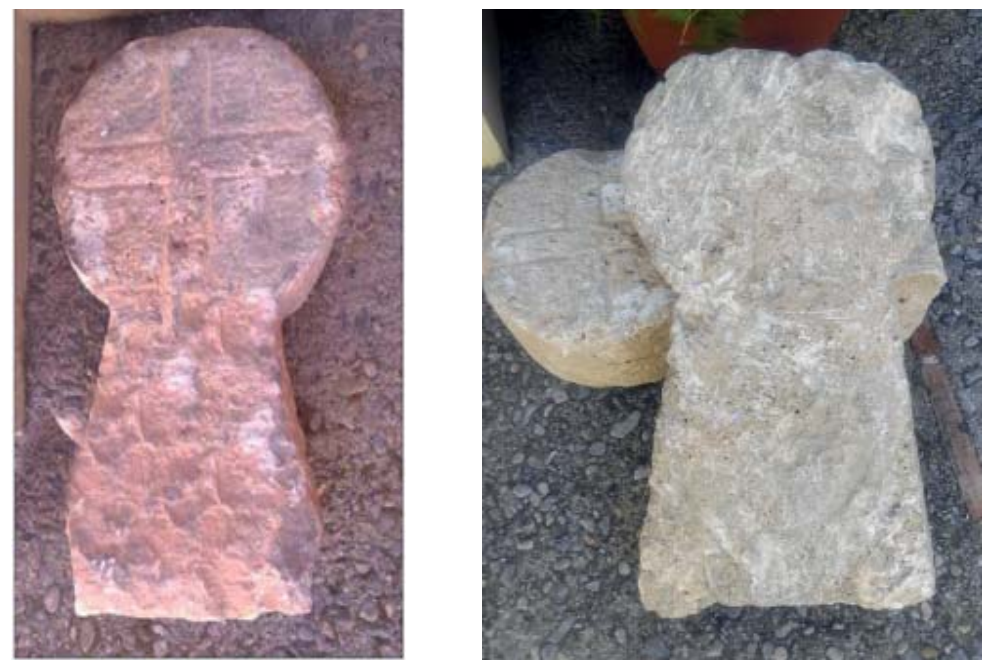

Fig. 128. Las dos estelas discoidales encontrada en el antiguo "fossar" de la iglesia, en la actualidad sitas en el patio del museo etnológico de la población.

final tronco-cónico. Se desconoce cómo estaban colocadas, pues estaban tumbadas en el suelo, pero seguramente orientadas hacia al este. Ambas estelas se encuentran esculpidas en el anverso y el reverso con una cruz que se podría asemejar a la cruz de malta). En ninguna de las dos caras aparece grafiado ningún tipo de texto.

Su ubicación ideal, colocadas orientadas hacia el este en el propio fossar. A la espera de su reubicación, ambas estelas se encuentran actualmente en el museo etnológico de la población. 
Fig.129. Esquina de fachada de una edificación pasando de una calle travessera al carrer de Baix. Se observa la esquina realizada con sillares curvos.

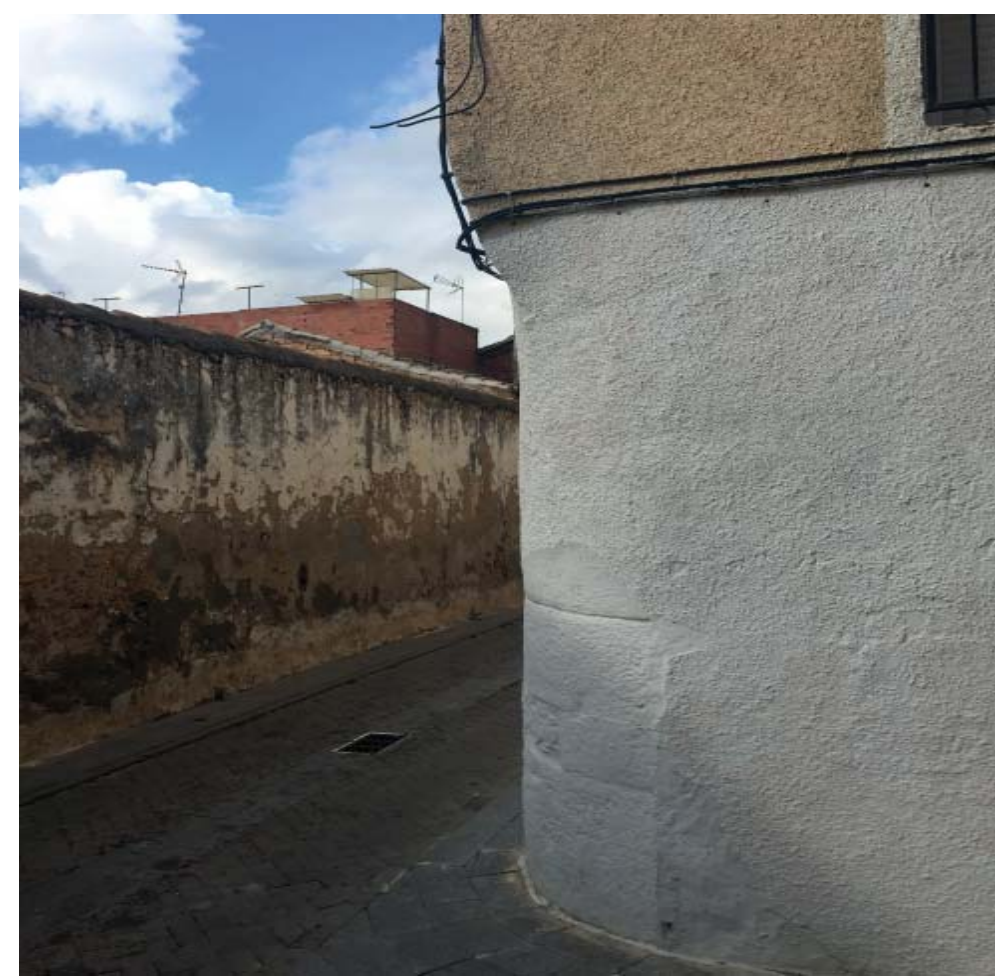

5.6.3| La Plaza mayor y su entorno

En primer lugar cabe decir que en cuanto a edificios civiles, aunque no queda ningún testimonio arqueológico que indique exactamente como eran, si se tienen indicios de cómo podrían haber sido y alguna de sus ubicaciones originales.

Desde el punto de vista arquitectónico la Pobla tuvo que contar con numerosos edificios de carácter nobiliario, dada su naturaleza como pobla de cristianos viejos, así como con otras construcciones de menor entidad donde habitaría la población de menores recursos: labradores y artesanos. Este tipo de edificaciones respondería al modelo de construcción sencilla y de reducidas dimensiones en las que se articulaban casi conjuntamente las distintas estancias de carácter privado y público.

Otro carácter tenían, sin embargo, las casas señoriales de las que, a buen seguro, la Pobla tuvo que contar con sus propios ejemplos, como atestigua la presencia de escudos nobiliarios que todavía perviven en la fachada de algunos de sus inmuebles. Se trataba de edificios que en alzado se componían de planta 


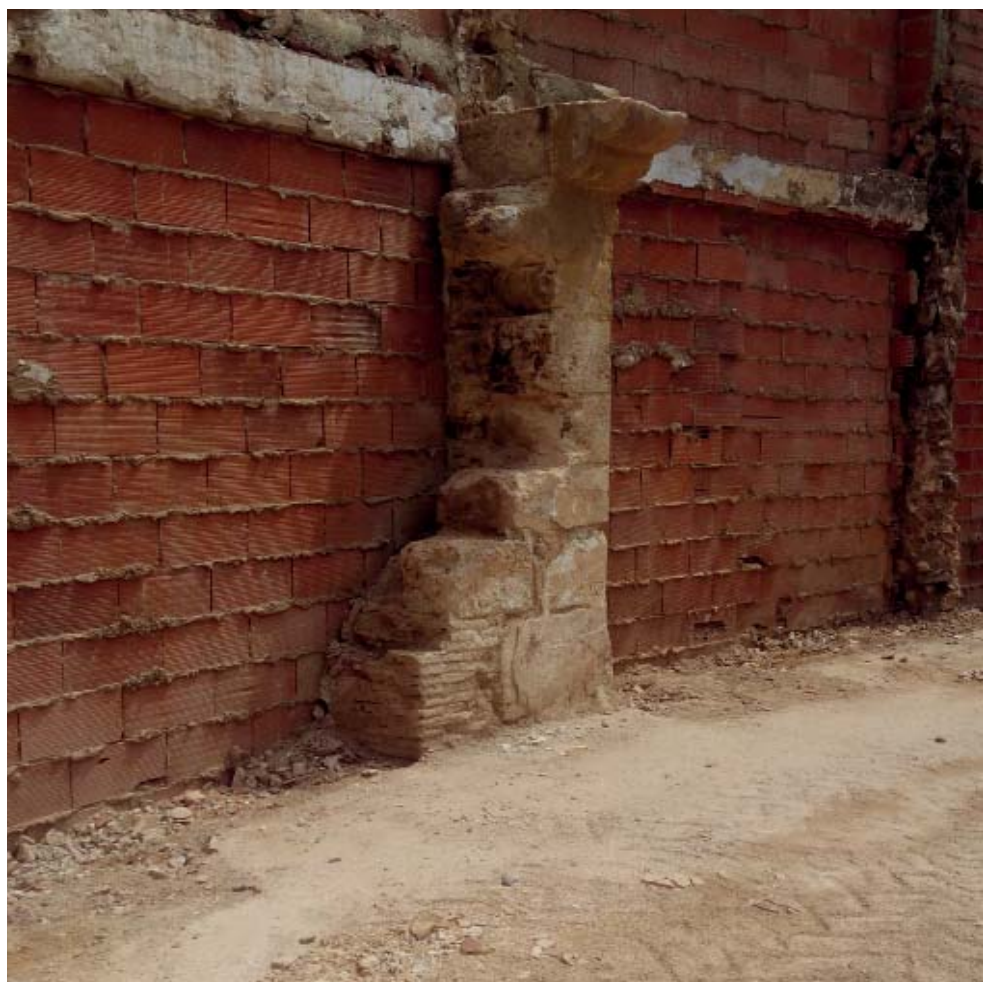

baja con semisótano y entresuelo, planta noble o piso principal y andana simple. La planta baja presentaba un espacio zaguán al que flanqueaban pequeñas dependencias anejas a la entrada que podían servir de despacho del señor. Tras la entrada o zaguán se abría una primera crujía paralela a la puerta que daba paso al patio, en torno al cual se organizaba la distribución de la casa. Este espacio comprendía la cocina y la escalera de acceso a las plantas superiores. Una nueva crujía precedía el huerto-jardín posterior. El piso principal solía disponer de las habitaciones del señor y el comedor principal, mientras que la andana asumía la función de cámara de almacenamiento. Evidentemente, dentro de esta tipología arquitectónica, el uso del lenguaje artístico contribuía a dar entidad y belleza, de manera que las puertas de entrada solían revestirse de arcos de medio punto o adintelados con grandes dovelas, las crujías estaban conformadas por arcos ojivales o carpaneles, según el periodo, mientras que los vanos de la fachada se adornaban con motivos decorativos. Normalmente la fábrica tradicional se realizaba con alfarjes o techumbres planas con envigado de madera y revestimiento de tapial. El tapial valenciano fue igualmente el material preferido para la construcción de los muros de cerramiento del edificio.
Fig. 130. Resto de un pilar construido con sillares encontrados recientemente en el "carrer Mitja". Posiblemente perteneció a un inmueble propiedad del Convento del Carmen. 
Este perfil urbano y arquitectónico fue el que debió poseer la vila de la Pobla durante los siglos venideros. Seguramente algunas casas eran construidas con tapial, siendo las más importantes de sillería. Se tiene constancia de varias fachadas que todavía conservan los sillares, la primera situada en la esquina de la calle San Antonio - carrer de Baix - con la calle Ángel del Alcázar, imagen $n$ ㅇ 129, y la segunda en la esquina del carrer Mitja con el vial que le corta perpendicularmente, actual Avda. Colón, en lo que debió ser un edificio civil importante puesto que su ubicación es inmejorable, delante de la cisterna y controlando dos puertas de acceso del recinto amurallado. Otro ejemplo se puede apreciar en la imagen no 130 se observan restos de una columna de sillarejos encontrados en el interior de un inmueble del denominado carrer Mitja al realizar un derribo.

La mayoría de los edificios medievales no ha llegado hasta nuestros días pero, a partir de esta investigación, se ha podido documentar la ubicación de los siguientes inmuebles ${ }^{203}$ :

A- En la plaça Major

La sala del Consell

El pozo

B- En el carrer Major

La casa abadía

El convento de San Onofre

La casa Primicia del Convento de Porta-celi

Inmueble propiedad de Porta-celi

El horno

La carnicería

C- En el vial transversal principal

La cisterna

Inmueble propiedad del convento del Carmen

D- En otros viales:

El fossar

La iglesia

${ }^{203}$ Los conventos y sus posesiones se describen el apartado 5.6.5.

El fossar en el punto 5.6 .2 y la iglesia, en la arquitectura religiosa 5.6.6.2.
Según se ha visto el núcleo medieval de La Pobla se encuentra dividido por dos ejes principales, en la intersección de ambos se sitúa una plaza central denominada plaza de la Vila o plaza Major. La primera referencia histórica de su existencia se obtiene a través de uno de los pergaminos inéditos del Sindicato de Riegos de La Pobla de Vallbona fechado en el año 1402. Así 


\section{Situación de los edificios medievales}

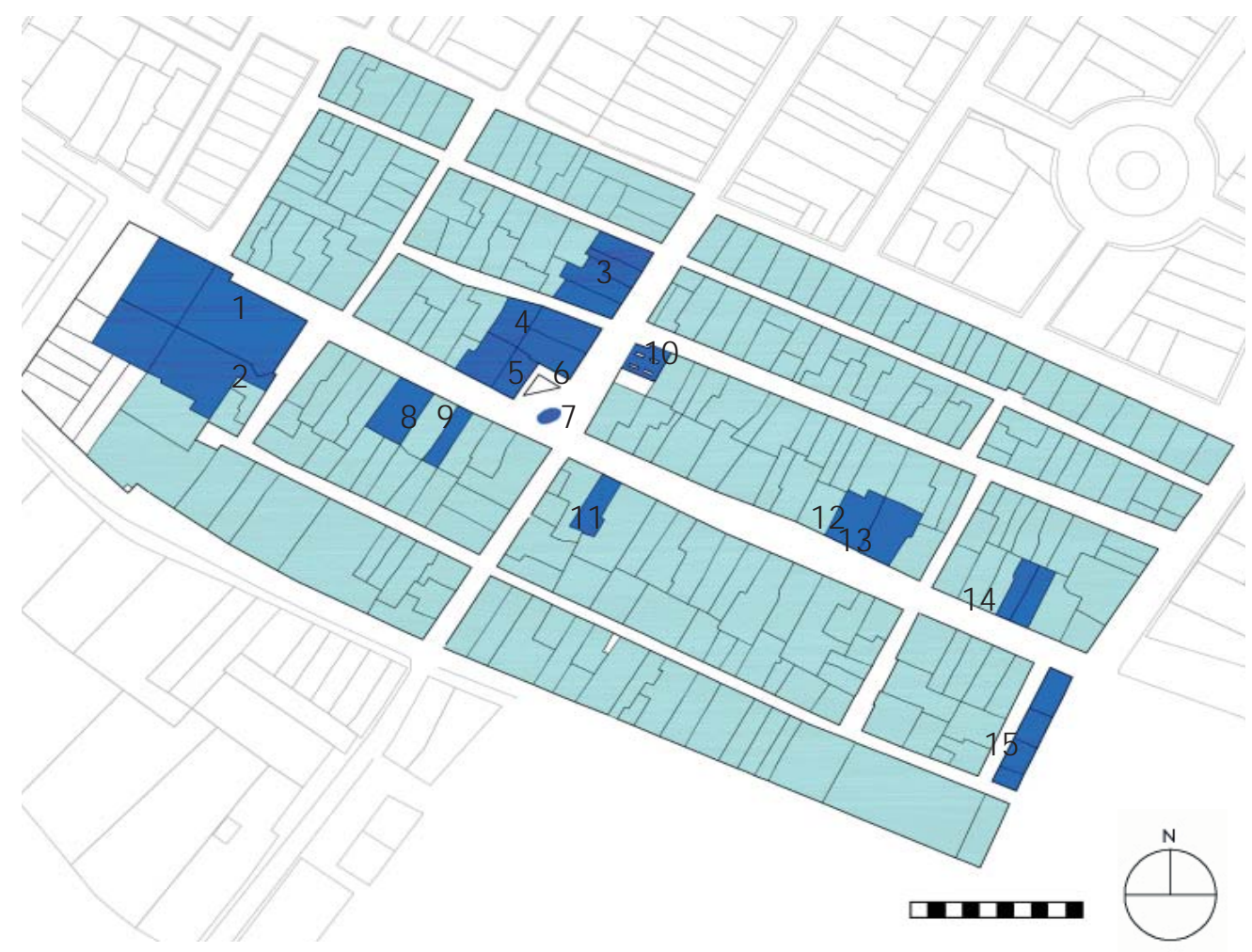

\section{LEYENDA}

1- Iglesia gótica de Santiago Apóstol

2- Fossar. Cementerio medieval

3- Edific io civil de relevancia. Construcción en piedras de sillar

4- Inmueble propiedad del convento del Camen

5- Sala del Consell y Sindic a to de Riegos

6- Plaça Major

7- Pozo central

8- Homo

9- Camiceńa

10- Cistema

11- Casa abadía

12- Casa procura del convento de Porta-coeli

13- Inmueble propiedad de la cartuja de Porta-celi

Fig. 131. Situación de

14- Edific io del convento de San Onofre

los edificios más im-

15- Convento de San Onofre

portantes del bajo medievo en el núcleo de la vila. 
Fig. 132. Pergamino 4 del Sindicato de Riegos fechado en el año 1402 donde indica que los prohombres del municipio se encuentran en esta pla za reunidos.
204 Archivo Sindicato de Riegos de La Pobla de Vallbona, pergamino 6.

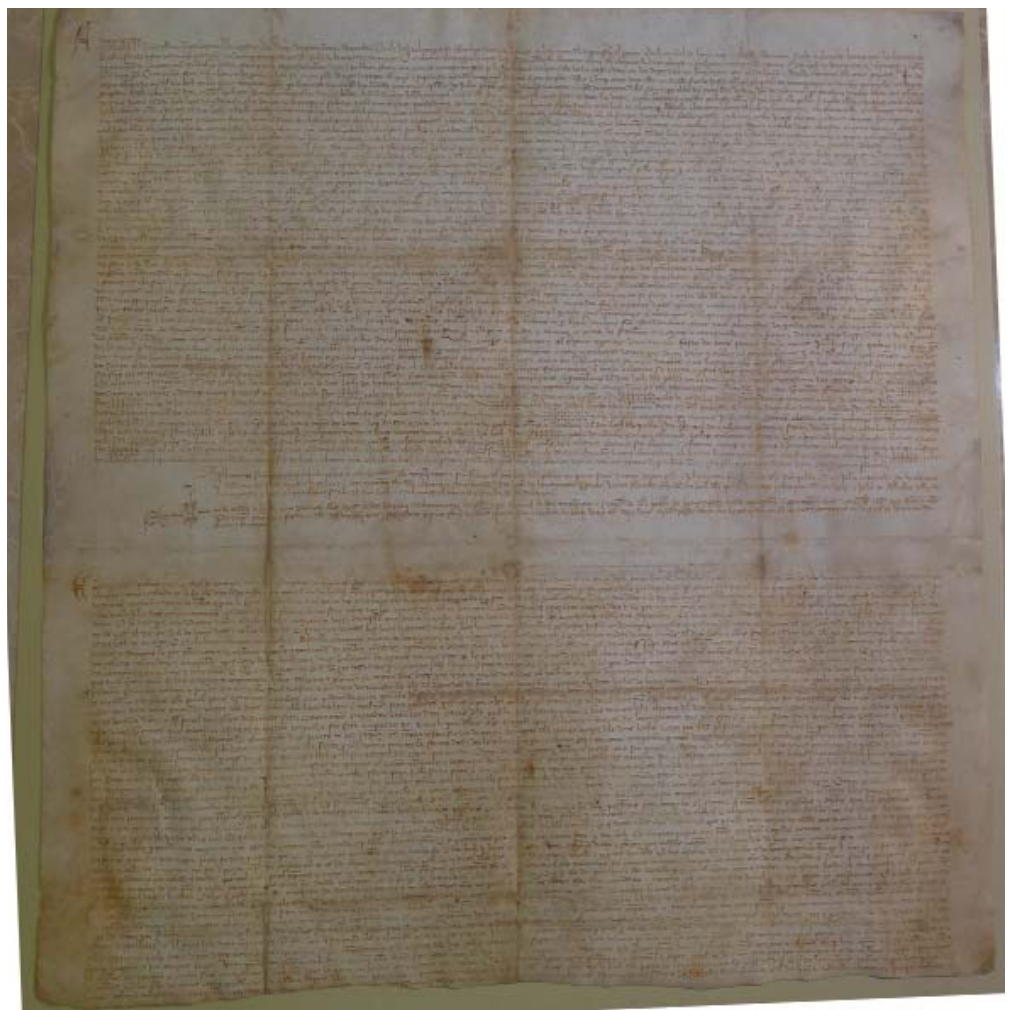

pues, se encuentra el documento número seis que describe el conflicto entre los representantes de la Pobla de Vallbona y Joan Aguilar relacionado sobre el pago de ciertas pensiones cénsales el 22 de mayo de 1402. En este escrito se sigue nombrando a la Pobla, como Iloc, hace referencia al topónimo, la Pobla de Beneguazir, pero sobre todo se señala la existencia de la plaza, pues indica que los prohombres del municipio se encuentran en esta plaza reunidos, y que el consejo es habitual que se reúna allín ${ }^{204}$.

Matheu de Calatayú, e molts altres consellers e pròmens, vehins e habitadors del dit loch dela Pobla, a consell general appellats, specialment per fer les coses deiús scrites.

E convocats ab crida públcia per veu d'en Rodrigo Peralta, satg e públich corredor del dit loch,..ajustats en la plaça dl dit loch, en lo qual loch e segons és acostumat consell general tener e ajustar e celebrar en lo loch dessús, dit [...].

La plaza cuenta con forma rectangular. En la actualidad mide $14,00 \times 13,00 \mathrm{~m}$, siendo muy similar a la plaza mayor de Puzol. De 


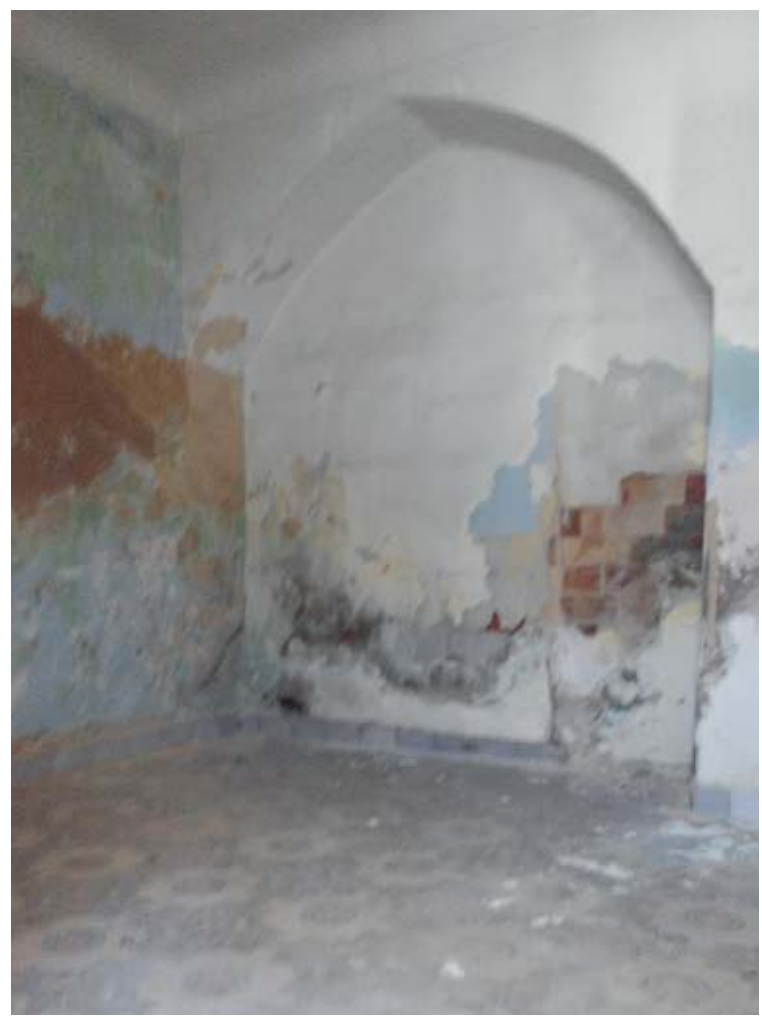

Fig. 133. Arco apuntado en el interior de una casa a 4,00 $\mathrm{m}$ de la alineación actual del carrer Major.

las villas analizadas es la que posee el menor tamaño y del mismo modo acogía la mayor parte de las actividades económicas del municipio: el mercado y los edificios administrativos: la Sala, La Cort y la Presó.

Se conoce perfectamente dónde estaba la Sala del Consell, en el carrer Major esquina Plaça de la Vila - calle Obispo Cervera, n. ㅇ 27 esquina plaza de los Mártires- en la actualidad ocupado por un edificio destinado a uso residencial. En el citado inmueble se encontraba el poder civil y también el Sindicato de Riegos.

De igual manera que el resto de poblas valencianas, los inmuebles recayentes en el carrer Major y el vial que lo corta perpendicularmente estarían formados por edificios porticados de arcos apuntados. La imagen no 133 corresponde a un edificio sito en la calle Obispo Cervera, apenas a 4,00 m de la fachada actual de la vivienda, aunque no se ha podido comprobar si el arranque del arco es de tapial o de sillería.

No menos representativo es el siguiente elemento, el pozo, que encuentra en el centro de lo que fue la antigua plaza mayor. Relacionando los grabados de Viciana de los municipios de 
Fig.134. Brocal del pozo encontrado en el año 2002 en el centro de la plaza mayor. La planta es elíptica, actualmente cegado.

Fig.135. Dibujos realizados por Martín de Viciana de los municipios de Nules y Vila-real medieval, en ambas se observa un pozo en la plaza mayor.

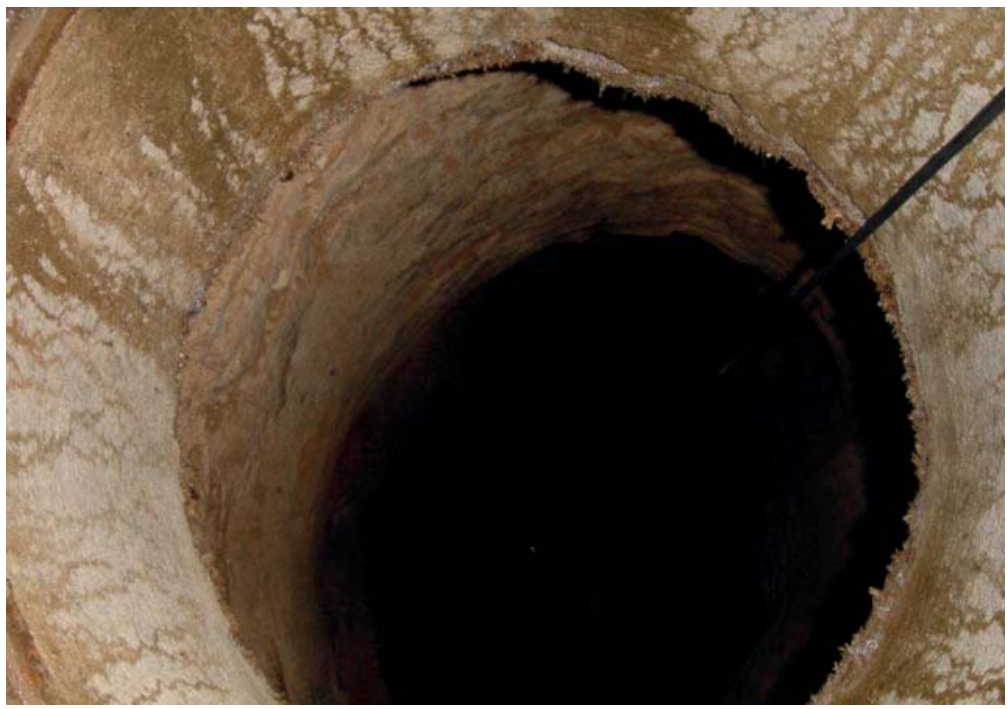

NVLEJ.

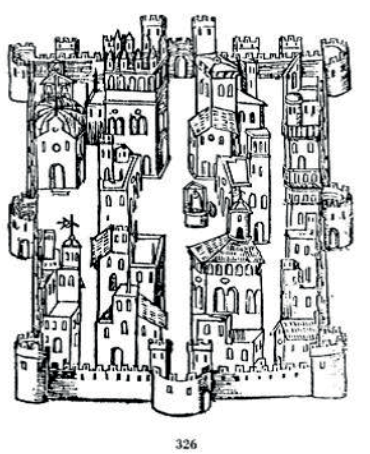

๔ $\Xi$ igueffe el retrato bela willa.

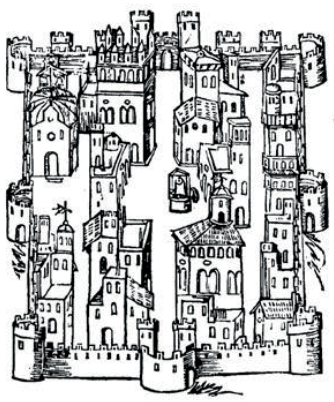

Vila-real y de Nules, aparece detallado en la plaza en ambos municipios un pozo. También queda documentada la existencia de esta bien hídrico en la plaza mayor de Almenara según afirma Luis Cebrián en sus estudios de dicho municipio. Estas oquedades se encuentran ubicados en el mismo lugar donde se sitúa el pozo de la Pobla de Vallbona. Posee planta elíptica y más de $14 \mathrm{~m}$ de profundidad. Sus paramentos verticales son completamente rectilíneos desde la cota superior hasta llegar a unos pocos metros de su base donde se ensancha llegando al fondo adoptando una forma tronco cónica.

Cerca de la plaza Major a escasos metros se encontraba la cisterna, en el cruce del eje perpendicular principal con la calle del Mig o Mitjà. En la actualidad ocupado por un pequeño jardín al que se le denomina plaza de los Mártires. La existencia de la cisterna se ha transmitido de generación en generación. Hasta la fecha no se ha producido ninguna excavación arqueológica 


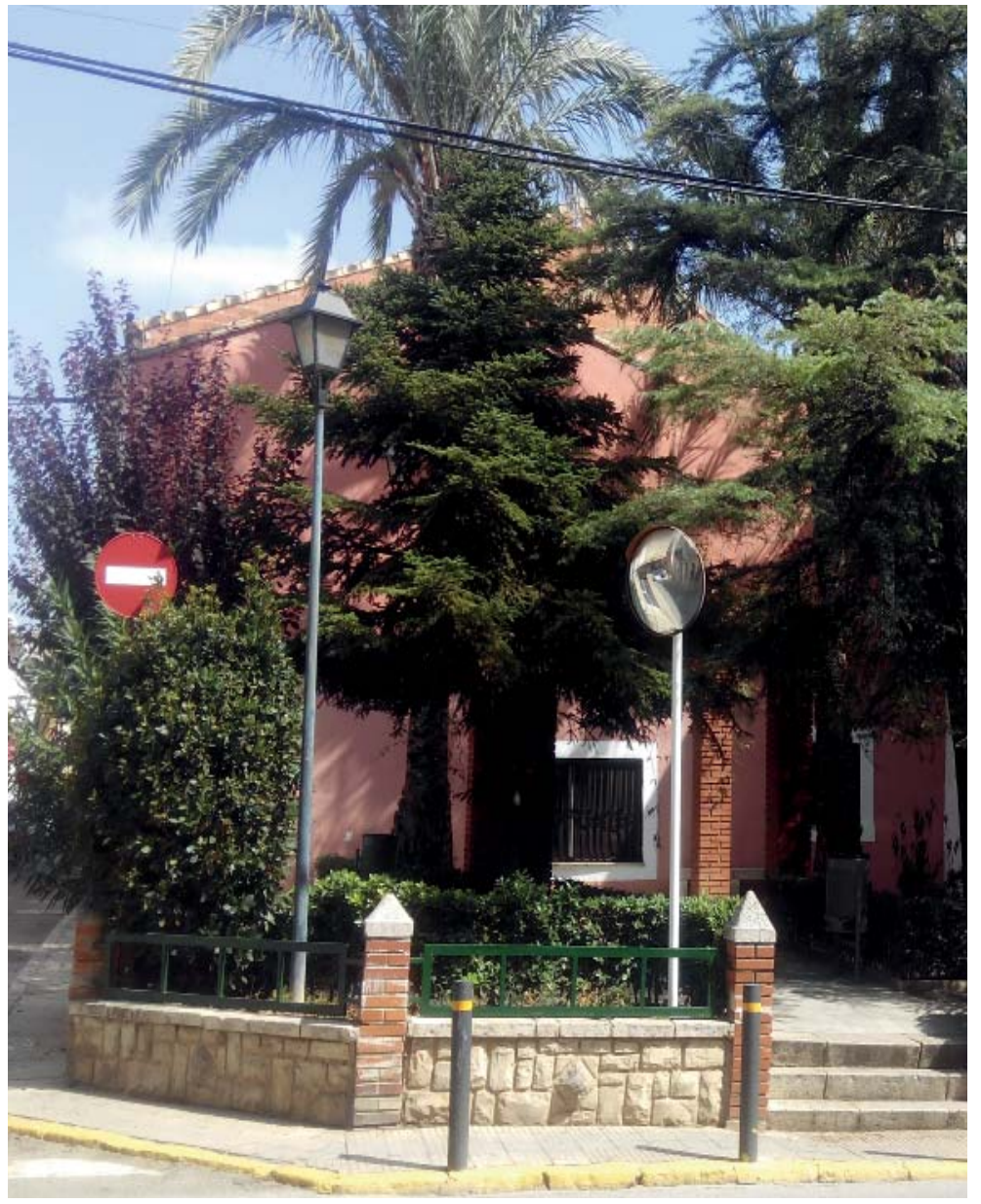

en esta ubicación por lo tanto, no existe documentación de la fecha de su construcción aunque, los mayores de la población indican "que ha estado toda la vida". Escritos del convento del Carmen, como se verá en posteriores capítulos, acreditan que ya se encontraba construida en el año 1655.

Este elemento hídrico era llenado en la luna nueva de enero a través de un canalillo que la unía a la acequia Primera. Esta operación duraba cuatro noches. Antes de proceder a este acto se hacía un bando en el Municipio de Benaguacil para que los vecinos de dicha población se abstuvieran de lavar en el mencionado canal durante esos días a fin de que el agua vertida en la cisterna estuviera totalmente limpia y fuera potable. En 1927 se dejó de utilizar el antedicho canalillo y pasó a utilizarse agua potable procedente del Pou de San Gerardo de Llíria.
Fig. 136. Jardín situado sobre la antigua cisterna. Popularmente se cuenta que cuando se derribo se construyó en su parte superior este jardín, actual plaza de los mártires. 
Durante los años de la contienda española (1936-1939), fue habilitada para refugio natural, teniendo una entrada por la Plaza del Ayuntamiento y la otra en la misma escalera de entrada.

Según fuentes orales a la cisterna se accedía por una escalera emplazada en la calle Jesús Pitarch - carrer Mitjà-, y manualmente se llenaban los cubos. Estaba construida con dos bóvedas de cañón sobre dos arcos realizados con ladrillos cerámicos. Su capacidad aproximada era de unos $800 \mathrm{~m}^{3}$.

En el año 1945 fue completamente restaurada por el Ayuntamiento siendo Alcalde D. Joaquín Aguilar. Esta restauración consistió en realizar una escalinata encima de las bóvedas y en su parte superior una pequeña placita. En este lugar había unos bancos y un pozo manual a través del cual se accedía a través de una pequeña escalinata de hierro al interior para realizar las convenientes reparaciones y comprobar el nivel del agua. Al lado del pozo había una pequeña caseta cuadrada donde se encontraba la bomba manual, en cuyo lateral se encontraba una pila de obra por donde salía el agua a través de una fuente de metal.

Fuentes orales explican que la cisterna fue derruida en el año 1970 y llenada de escombros. Aseguran que únicamente fueron destruidas las bóvedas mientras que los arcos, se encuentran enterrados junto con los restos de las bóvedas.

Siguiendo hacía la calle Major el primer inmueble que se encontraría, el edificio destinado a la residencia del cura párroco. La situación de la casa Abadía está documentada por Llavata ${ }^{205}$, indicando que el edificio que la vila tuvo que ceder al cura párroco de Benaguacil para que trasladara su residencia a La Pobla, se encontraba en la calle Major.

La casa no 24 fue por muchos años la casa abadía de
la Parroquia, hasta el año 1920, en que se erigió una
nueva, pasando la antiguo a ser café púbico, que
desapareció años después [...].

En cuanto a la existencia de comercios, Martí l'Huma y María de Luna conceden a sus habitantes el derecho de albergar en la población un horno o varios, tantos como sea necesario para

${ }^{205}$ Llavata Pitarch, V. (1981): Historia de la Villa y Baronía de La Puebla de Vallbona, Ayuntamiento de La Puebla de Vallbona, pág. 401-404. amasar suficientes panes. En el mismo documento les dispensan el derecho a detentar tantas tiendas como sea necesario para abastecerse. De todos estos comercios, la ubicación inmueble destinado a horno y a carnicería no presenta ninguna duda 
puesto que distintas fuentes orales lo recuerdan con su típico:

Han estat ahí tota la vida.

Ambas edificaciones se situaban en el carrer Major y en la misma quarta administrativa. El horno emplazado en la actual calle obispo Cervera, no 10 y hasta hace unos años aún se podía ver como se cocía en pan a leña. El inmueble destinado a la venta de carne se ubicaba en la actual calle Obispo Cervera, no 16 enfrente del antiguo ayuntamiento. Este uso se trasladó al no 18 a principios de los años 80 .

Después de lo anterior expuesto es importante señalar que la memoria oral es reforzada, en este caso, por dos protocolos notariales existentes en el Archivo del Reino de valencia. Ambos documentos ${ }^{206}$ se encuentran fechados en el mes de abril del 1741. El primero es una carta de pago de Manuel Barrero, a Juan Bautista Bava, vecino de Valencia, por el pago de 8 libras por el alquiler de la carnicería de la Pobla de Vallbona. El segundo es una carta de obligación del Ayuntamiento del municipio para asegurar el abastecimiento de carnes ofrecido por Juan Bautista Baba, vecino de Valencia, por 200 Libras anuales. De estos documentos se desprende que Juan Bautista Baba era el propietario de la carnicería aunque la tenía arrendada.

Para finalizar un breve apunte, en el marco de las observaciones anteriores queda demostrado que todas las edificaciones relevantes para el municipio se situaban en los dos viales principales del municipio, el carrer Majory su eje transversal. 


\subsection{4| La galerías subterráneas}

La existencia de terrenos adecuados ha permitido a lo largo de la historia la excavación de cuevas para viviendas, bodegas o galerías subterráneas. Son numerosos los municipios valencianos que presentan en su casco antiguo este tipo de construcciones, un total de 78 municipios en la Comunidad Valenciana presentan este tipo de construcciones ${ }^{207}$.

Uno de los casos más conocidos se encuentra en la población de Requena. En este concejo son muchas los inmuebles que albergan su propia cueva artificial, que era usada como bodega, despensa, silo e incluso refugio. Los materiales calizos extraídos al perforar la toba y extraer la arcilla del subsuelo fueron usados para edificar las propias casas, sobre todo la arcilla para paredes de tapial. El citado estrato funciona como bóveda en la cueva y el espacio vaciado corresponde, más o menos, al solar de la edificación construida sobre ella.

Las 22 cuevas que se encuentran bajo la Plaza de la Vila son de época musulmana, entre los siglos IX al XIII. En el s. XV se prohibió el tránsito de carros por la vila para que no se hundiera el suelo por la existencia de las cuevas. Tuvieron uso hasta el siglo XVII en que se derribaron las casas privadas y edificios públicos de la plaza quedando semi-colmatadas de los escombros de los derribos. A partir de 1972-1973 fueron vaciadas de escombros y posteriormente se pusieron en valor. Por debajo de las citadas perforaciones, existe una red de túneles por todo el barrio de la Villa que se empezaron a horadar en 1706 hasta épocas cercanas.

Situadas en el mismo emplazamiento que las de Requena se encuentran las galerías en La Pobla de Vallbona, en pleno centro de la vila. De origen desconocido estas perforaciones horizontales se encuentran a unos $7,00 \mathrm{~m}$ de profundidad. El núcleo histórico medieval cuenta en su subsuelo con un estrato

${ }^{207}$ Conejo Martin, Miguel A.(2014): Propuesta metodológica para el sistema de estudios gráficos topográficos aplicados a la representación gráfica de bodegas subterráneas tradicionales, Tesis doctoral, Universidad Politécnica de Madrid, Escuela de Ingenieros agrónomos, Madrid, pág. 60. de roca a poco nivel de la superficie, a una profundidad entre 1,00-2,00 m, donde apoyan la mayoría de las cimentaciones de las edificaciones de la zona. Esta capa además de servir de apoyo a los inmuebles sirve para garantizar la estabilidad a los túneles. Las dimensiones aproximadas 2,00 $\mathrm{m}$ de altura por 4,00 $\mathrm{m}$ de ancho. El número de recorridos resulta incierto, aunque quizá sean cuatro. En este apartado se definirán únicamente dos de ellos, puesto que son los que se ha podido recorrer. 


\section{Situación de las galeńas subtenáneas del núcleo histórico}

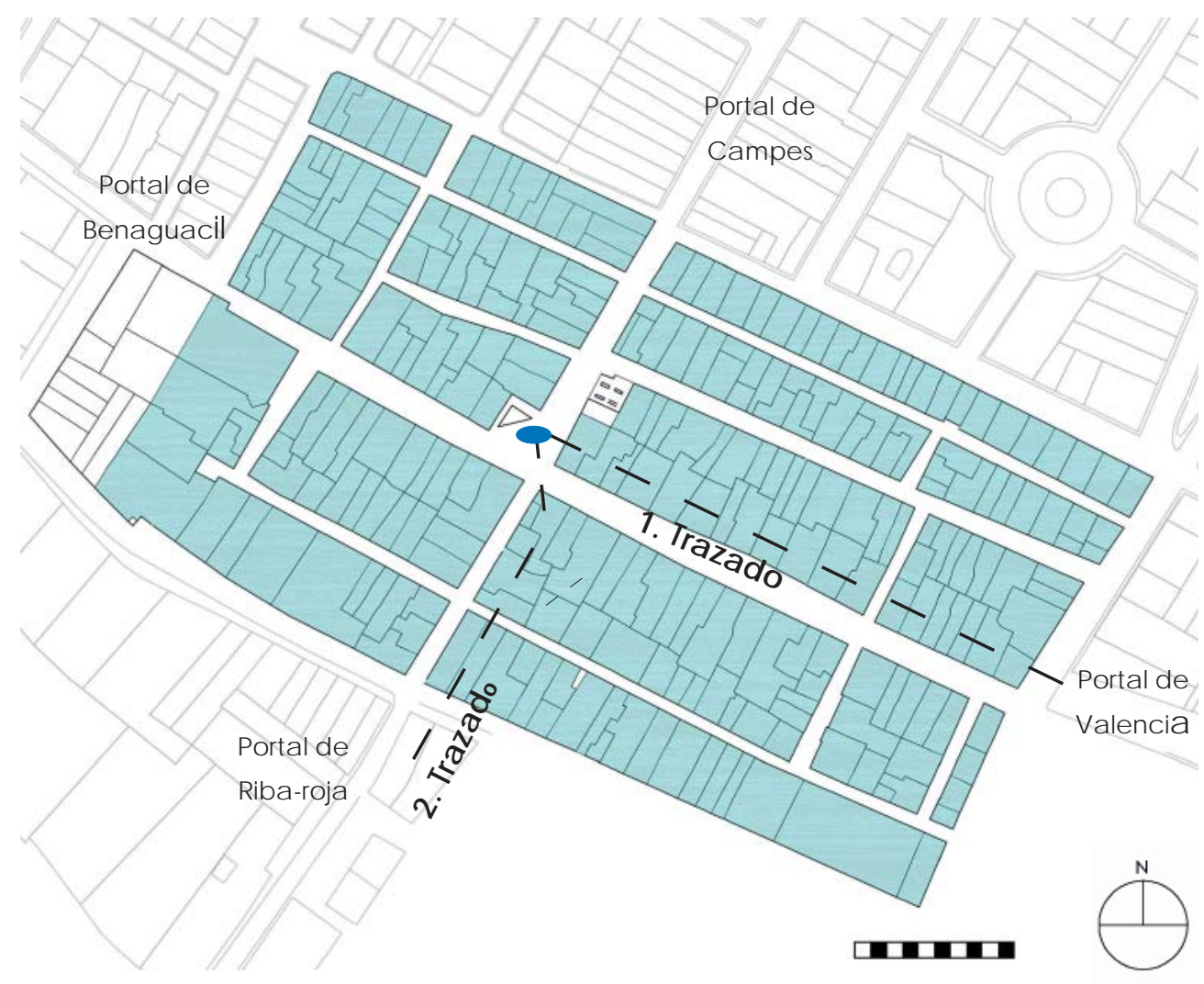

\section{LEYENDA}

Traza dos de las ga leńas subterrá neas comprobadas porgeorradar

Fig. 137. Situación del trazado de las galerías subterráneas por debajo de los inmuebles de los ejes principales. 
Fig. 138. Interior de las galerías que discurren por el subsuelo de la vila, se aprecia un acceso desde los túneles a un inmueble través de una escalera.

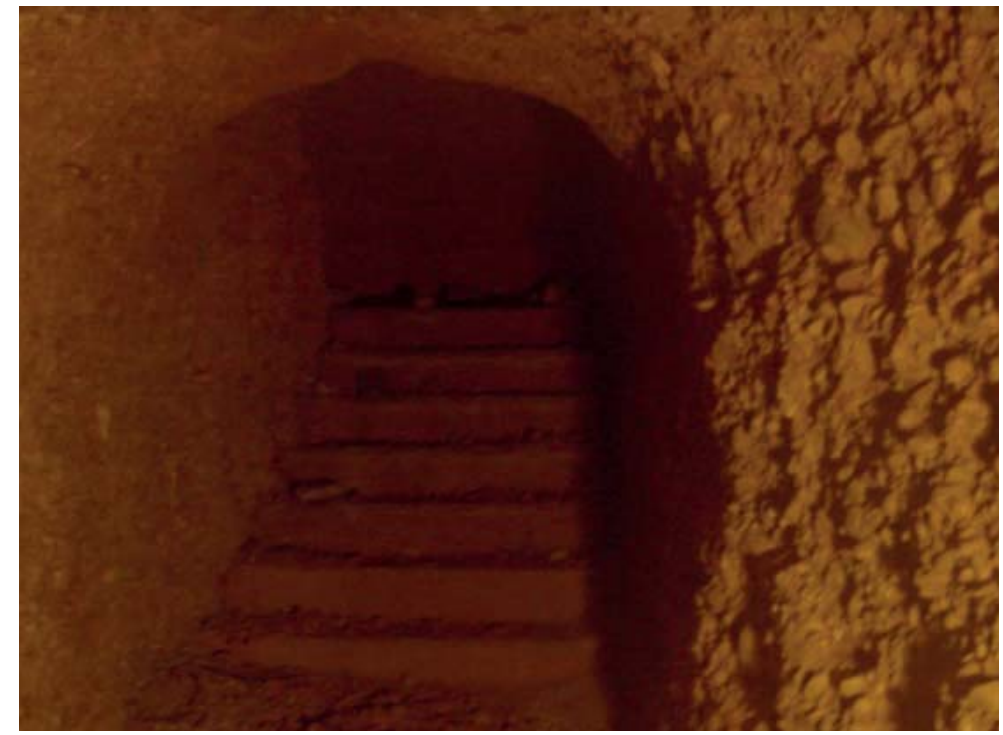

En el año 2009, visto el desconocimiento de la trayectoria de las galerías, la concejalía de Patrimonio del Ayuntamiento de La Pobla de Vallbona localizó un georradar de la Universidad Politécnica de Valencia para que se realizara un análisis del subsuelo del carrer Major, el vial perpendicular a este, actual calle Maestro Barona, por la travessera calle Ángel del Alcázar y en la zona extramuros del valladar de Valencia.

El resultado fue el siguiente: el recorrido de los pasadizos va paralelo al carrer Major, eje longitudinal de la vila, desde el antiguo ayuntamiento a la puerta de la muralla, el Portal de Valencia. Lo lógico sería pensar que discurriera por el centro del vial, pero no es así, su trayecto se sitúa por debajo de las inmuebles. Asimismo se constata que cada una de estas edificaciones contaba con accesos a estas galerías a través de escaleras de peldaño, como escaleras góticas. Al igual que en Requena se accedía a estas desde la parte superior, pero lo que en el citado municipio son cuevas individuales en la Pobla de Vallbona son pasillos comunicados entre sí. En la actualidad solo se conoce una de estas entradas, y aunque el propietario accedió a que se viera y poder constatar que se trata de una escalera de caracol de husillo, no permite dejar constancia de la dirección ni tampoco tomar fotografías.

El segundo tramo, discurre a la misma profundidad, con las mismas dimensiones, pero esta vez en dirección al portal de Riba-roja o el Portalet, por debajo de los edificios que se sitúan en el eje principal transversal. 


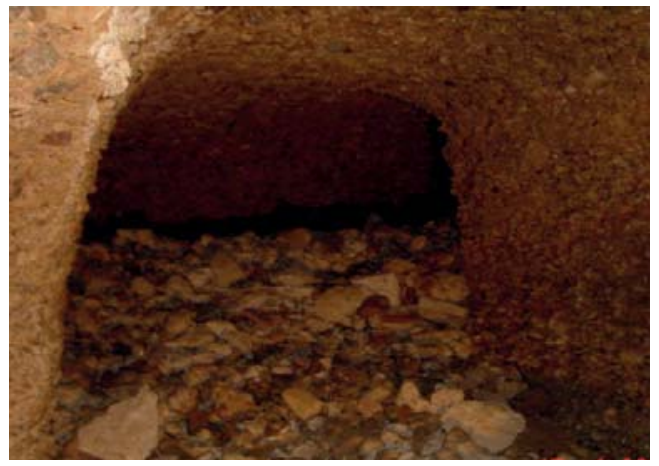

El acceso a estas galerías se puede realizar a través de un hueco encontrado en el paramento vertical del pozo de la plaza Major hallado en el año 2002. En la actualidad no se puede transitar por ellas, el descenso es muy complicado y se necesita un gran despliegue de medios auxiliares. El trayecto tampoco es visitable, por esta razón, no ha sido recorrido completamente puesto que hay tramos llenos de cascotes, al haber sido utilizado por los habitantes del núcleo fundacional, para ir vertiendo los escombros cuando reformaban algún edificio.

Al inspeccionarlas se observa que los túneles están excavados en un estrato formado por roca-grava tanto los paramentos verticales como la bóveda que lo cubre. En su interior aparecen escaleras de acceso reforzadas con materiales más actuales, accesos cegados con ladrillo macizo cegado, cruces entre las diferentes direcciones y elementos metálicos para sujetar candiles. En su gran mayoría, están limpias de insectos u otro tipo de animales.

Para finalizar precisar que los citados túneles no han sido objeto de ningún estudio arqueológico por este motivo no se puede datar su origen, lo que resulta evidente es que era una zona destinada a salvaguardar los bienes de los pobladores de la vila. Su cronología es incierta, podrían datarse de la época que no existían las murallas, pero se dirige hacia sus portales, o pensar que fueran refugios de la Guerra Civil Española, pero entonces no existía la cerca defensiva, ¿que sentido tenía que dirigirse hacia los portales y finalizar extramuros? Las preguntas quedan en el aire hasta que se lleve a cabo las correspondientes excavaciones arqueológicas.
Fig. 139. Vista de los escombros arrojados a las galerías a lo largo de la historia.

Fig. 140. Acceso desde las galerías a un inmueble. En la actualidad se encuentra cegado. 
5.6.5 Conventos o edificaciones de órdenes religiosas

Una característica típica de las poblas de colonización valencianas es la existencia de algún convento de una determinada orden religiosa en la vila.

Como se ha visto en el apartado 5.3.2., el monasterio de Portaceli contaba con primicia sobre la Pobla de Vallbona por derecho de realengo desde el siglo XIII. Es evidente entonces que contara con varios bienes en el citado municipio. Sobre todo fueron terrenos con varias cahizadas que arrendaban a cambio de unos frutos, pero también constan propiedades inmuebles. Los bienes que se han podido referenciar son dos casas en el carrer Major de la vila. Una de estas edificaciones estaría arrendada y la otra era la casa procura del monasterio en la población.

Cabe destacar que tanto los terrenos como los inmuebles pagaban un arriendo además de la realía que tenia que abonar anualmente todo el municipio. Del bajo medievo se encuentran varios documentos que muestran las expensas a favor del convento, aunque no identifican los inmuebles y los terrenos como se conocen en la actualidad. Sin embargo se encuentra coincidencia en la utilización de los topónimos de las partidas de suelo rústico y las acequias pudiendo ubicar de este modo la zona de sus posesiones. En el listado ${ }^{208}$ de propiedades del monasterio de Porta-celi en la vila en cuestión, desde el año 1375 al 1553 se encuentran las siguientes anotaciones:

a) Recepta el Expensa de Porta-celi. Años 1375-1388

Describe los gastos del monasterio pero no indica en que municipio ni en que terreno se ha realizado el gasto o el ingreso

b) Memoria escrita por el prior D. Francesc Maresme ${ }^{209}$, prior de esta casa de Porta-celi en el año 1417 de todas sus posesiones, bienes y rentas

208 En el apartado de anexos se encuentra una relación de los bienes del Monasterio de Porta-celi desde el siglo XIII hasta la época de la desamortización pág. 409.

\section{De Benaguazir e de la Pobla}

Item reeb tota la primicia del loch de Benaguazir e de la Pobla sesua sesus alguna excepcio e cosa reservada per al rector daqui sino la sua pensio tatxada per suma de totes coses acostumades pagar e pendre primicia, la qual primica se acostuma de 


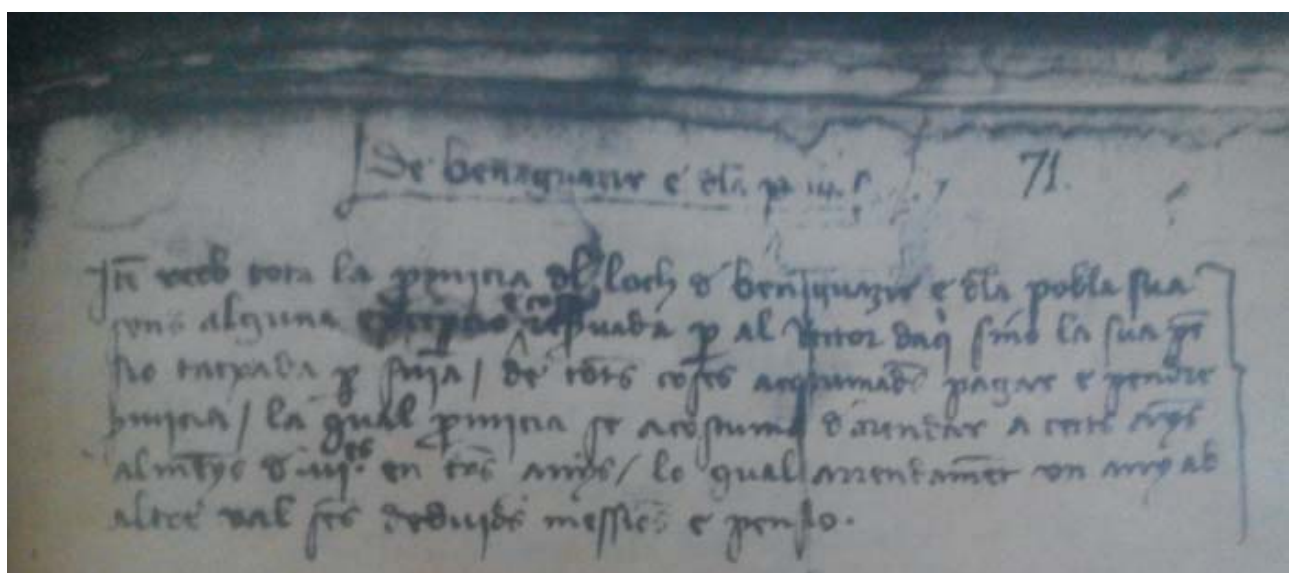

arendar a cent anya al menys de tres en tres anys, lo qual arrendamente un any ab altre val seus deduies messions e pensió [...].

En el citado documento también queda reflejado el pago al cura de la iglesia de la Pobla, siempre realizado durante el mes de noviembre. También indica que el rector debía de dar 3 caffiços de forment a la cartuja.

c) Manifest dels bens de realench de Porta-celi. $1448^{210}$

\section{Rendes de la Pobla e Benaguzir 136.5 Iliures}

d) Pensiones de censos y arriendos de Porta-celi año 1553

En estos escritos se describe los recibos y gastos del año $1553^{211}$ del monasterio. Fue realizado por Joan Castro prior de Portaceli e indica siempre en el recibo la parte del arrendador o aquello que explotan directamente, dejando constancia de la clase de bien de que se trata ya sean tierras o frutos como paja. En este censo no aparece ningún inmueble referenciado en La Pobla de Vallbona.

Las ubicaciones se encuentran mas detalladas en el siglo $\mathrm{XVI}$ donde quedan documentados claramente tanto bienes inmuebles como hanegadas de tierras. Los bienes referenciados son siete casas y cuatro hanegadas de huerta que se encuentran arrendadas $^{212}$. En la zona de la vila, en el centro histórico, identifica dos bienes en el carrer Major, el resto de bienes inmuebles los sitúa extramuros. El texto dice así:
Fig. 141. Memoria escrita por el Prior D. Francesc Maresme, prior de esta casa de Porta-celi en el año 1417 de todas sus posesiones, bienes y rentas.

${ }^{209}$ Archivo histórico nacional. Memoria escrita por el Prior D. Francesc Maresme, prior de esta casa de Porta-celi en el año 1417 de todas sus posesiones, bienes y rentas. Recepta et Expensa de Porta-celi. Códice 529 B, pág. 71.

${ }^{210}$ Manifeste dels bens de realench de Portaceli. Año 1448. Secciones real Cancellería no 493.

${ }^{211}$ Libro de recibos y gastos con sus definiciones desde 1553 hasta 1561. Clero. Libro 329. Fol 1 a $9 \mathrm{v}$.

${ }^{212}$ Propiedades antiguas del reino de Valencia, Inventarios de la cartuja de Porta-celi en el tiempo de las exclaustraciones 181240, legajo 470, pág. 127 


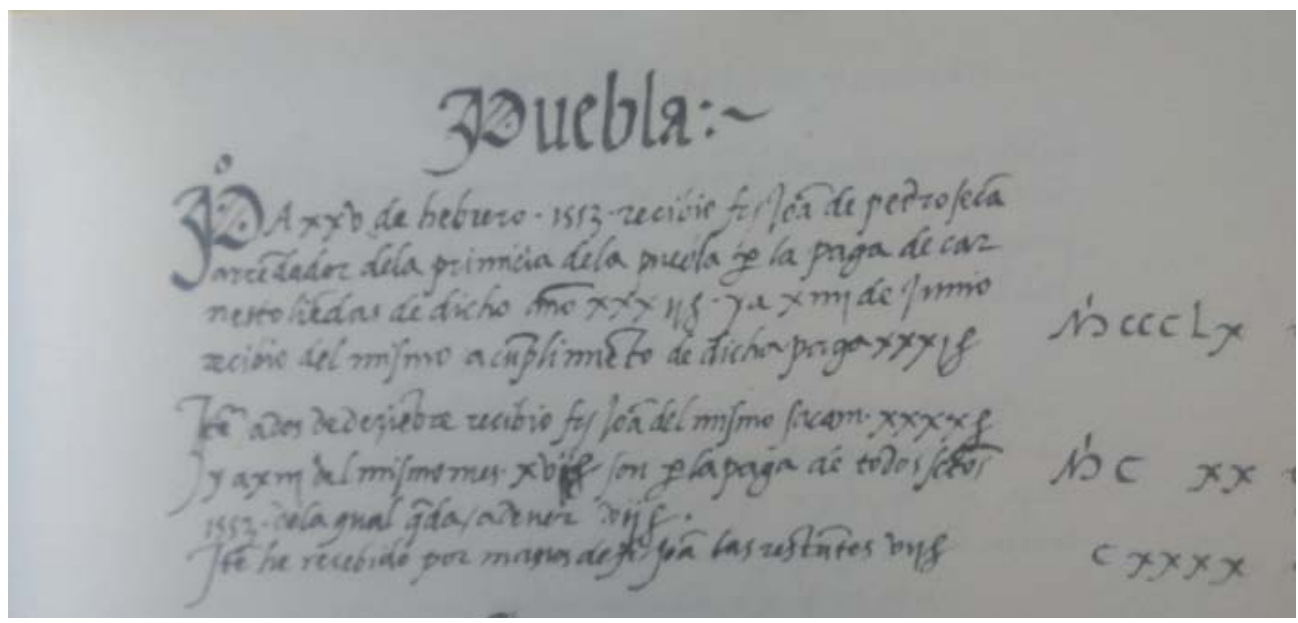

Fig. 142. Documento del año 1553 que describe las posesiones de Porta-celi en la vila de La Pobla.
${ }^{213}$ Llavata Pitarch, V. (1981): Historia de la Villa y Baronía de La Puebla de Vallbona, Ayuntamiento de La Puebla de Vallbona, pág. 401-404.
Una casa grande instaurada para casa procura en la calle mayor de la Puebla que tiene de su cuenta el Monasterio para la recolección de frutos de primicia.

Otra casa en la calle mayor de Puebla junto a la antecedente inquilino Mariano aleixandre paga trenta libras al año, vencen el diecisiete de julio no tiene escritura y debe el presente año.

Estos dos inmuebles están localizados en la actualidad, puesto que la casa procura, se sitúa en lo que hoy se denomina calle Obispo Cervera, no 47, puesto que allí se encontraba ubicado el escudo del Monasterio de Porta-celi. Llavata ${ }^{213}$ lo describe así:

La casa núm. 49 (actual núm. 47), data de los siglos XIV en adelante, teniendo por aquel entonces su oficina recaudadora de diezmos y primicias la cartuja de Porta-celi. En su fachada campeó hasta el año 1973 el escudo de dicha real cartuja. Junto a la casa existía una especie de jardín con un pozo en su mitad, en donde era tradición ir a beber todos los arrieros y transeúntes y abrevaban sus caballerías mientras ellos reponían fuerzas. En la parte dorsal de este jardín y casa existían hasta hace muy pocos años aljibes y bodegas, que fueron demolidos en el año 1960 por no tener objeto ya. Como recuerdo de todo ello sólo permanecía el escudo heráldico de la real cartuja de Porta-celi, y en el año citado, por reforma de la fachada y casa fue derribado. 
Para ubicar el segundo inmueble, el que tenían arrendado, no existe documentación escrita que indique si se situaba a la derecha o a la izquierda del edificio destinado a casa procura. Pero observando el plano catastral, el edificio lindante a la diestra tiene aproximadamente las mismas dimensiones $y$ comparten ubicación de patio de luces, por lo tanto sería la finca emplazado en la C/ Obispo Cervera, nㅇ49.

Ante la situación planteada conviene precisar que la cartuja contaba con propiedades en el término municipal y con sus primicias pero, nunca tuvo ningún convento. Después de las consideraciones anteriores procede enunciar las ordenes que poseían las citadas edificaciones en el territorio del municipio, estas serían:

- El convento de San Luis Beltrán

- El convento Virgen del Carmen

- El convento de San Onofre

Del primero de ellos, el citado convento de San Luis Beltran, la documentación histórica acredita la existencia de este orden de dominicos intramuros, aunque no especifica su ubicación señala que estuvo presente en la vila durante el periodo comprendido entre los años 1550-1619. Dos son los escritos que lo demuestran, el primero procedente del archivo del Ministerio de cultura ${ }^{214}$ y el segundo el registro de dominicos españoles ${ }^{215}$.

Por su parte, las otras dos ordenes eclesiásticas aparecen referenciadas en documentos del monasterio de Porta-celi certificando su ubicación. Según lo indicado el siguiente dato histórico lo aportan los documentos sobre los procesos judiciales ${ }^{216}$ que tiene Porta-celi con otras personas o órdenes eclesiásticas a lo largo de la historia.

La orden llevó causa al tribunal de la Real Audiencia, desde los primeros años de 1600, contra los conventos de Nuestra Señora del Carmen y San Onofre para cobrar de estos la primicia que se le debe del convento sito en l'Eliana término de la Pobla de Vallbona y de la Casa Blanca, en el mismo municipio, de los cuales son señores los citados conventos.

Estos pleitos se sucedieron a lo largo de la historia cada vez que se cambiaba de prior siempre resolviendo a favor de Portaceli. Los procesos civiles de los años 1707-1835 se encuentran
${ }^{214}$ Ministerio de Cultura, Portal de archivos españoles, clero, secular, car. 3192,1718.

${ }^{215}$ Manuel María Pedro (1962): Registro Hispano Dominical. Editorial Sever Cuesta. Valladolid, pág. 113.

${ }^{216}$ Procesos de Portaceli sobre el termino sus lindes y derechos de las rectorías de Liria y Benaguacil. Escribanía de cámara, año 1754. Ep.14, sentencias. Archivo del Reino de Valencia. 
documentados en los expedientes de los años 1754-65. En los citados manuscritos se indica que el convento del Carmen se encuentra situado en la zona conocida como I' Eliana y que la masía denominada Casa Blanca en el término municipal de La Pobla pertenece al convento de San Onofre de Musseros. Cabe precisar que en ese momento de la historia l'Eliana pertenecía al término de la Pobla de Vallbona, por lo que sería uno de los conventos sitos extramuros.

Hecha la observación anterior, señalar que aunque la orden se situara fuera del perímetro amurallado contó con inmuebles en su interior. Del listado de posesiones del Convento del Carmen depositado en el Archivo del Reino de Valencia, se obtiene que poseía una edificación destinada a vivienda situada delante de la cisterna, en la calle denomina carrer Mitjà o Michà y que llega a situarse delante del horno de la vila. El texto lo describe así:

\begin{abstract}
Una casa con corral situada y posada en La Pobla de Vallbona, alias de Benaguacil, en lo carrer michá per lo qual aporta terres, franca: confrontada por una part ab lo forn de dita Vila que era de S. Nofre Assió; carrer...en mig, per altra part ab la casa de ...Pere Folgado... y aba casa de Jaume August, carrer que va al portal de les heres en mig y als patis del carrer del mig que eren de Domingo Ximenez y per part davant de la sisterna, del carrer en mig [...].
\end{abstract}

Con referencia a lo anterior apuntar la existencia un documento redactado por el Notario Jaime Llorens en el año 1702 que describe un inmueble del convento del Carmen situada delante de la cisterna, seguramente hace referencia a la misma edificación que se describe en el listado de posesiones de la orden del año 1655.

En el orden de las ideas anteriores acontece referirse al Convento de San Onofre. Los escritos citados acreditan que, desde el año 1583 hasta el año 1754, Porta-celi se enzarzó en varios pleitos con el convento de san Onofre de Musseros. Esta orden de dominicos, tenía presencia en la Pobla de Vallbona y por esta razón el monasterio le exigía que le pagará su derecho de renta. Los de Musseros tuvieron posesiones intramuros y extramuros como se verá a continuación.

La ubicación de la orden en el núcleo medieval es un dato desconocido, pero posiblemente estaría ocupando la manzana 
sita entre la actual calle l'Eliana y la calle Francisco Barela, adosado a la muralla. Esta hipótesis viene refrendada por tres fuentes diferentes pero todas dirigidas a la misma dirección.

En primer lugar, un fuente oral, el testimonio de Gerardo Contelles Pons - propietario del inmueble que se sitúa actualmente en esa misma dirección - recuerda, que su abuela le narraba que en esta manzana había antiguamente colindante al portal de valencia un convento. La segunda referencia aparece en el plano de Pedro Sucías Aparicio donde marca el nombre de la calle Francisco Barella en la actualidad como un carreró con el nombre C.S. Onofre. Los carrerons solían llevar a un solo edificio y cogían el nombre del bien inmueble al que dirigían. Y por último el dato facilitado por Vicente LLavata ${ }^{217}$, dejando documentados dos crónicas referidos a los inmuebles de esta orden. Primero que este convento tenía dos salas en un edificio sito en la calle mayor.

Las casas núm., 63-65 (actualmente según catastro $59,61)$ fueron hace un par de siglos salas adjuntas de un convento de San Onofre, que tenía residencia en Musseros. Más tarde fue el primer cuartel de la Guardia Civil de la población, pasando finalmente a ser viviendas.

Asimismo indica que, posteriormente se empezó una obra de construcción de un convento mas grande, en la ubicación anteriormente indicada. Al entrar en el año 1811 las tropas napoleónicas la villa, los monjes abandonaron este edificio

Las casa núm. 68 (actual 58). Se encuentra entre el callejón de San Onofre y el Valladar o Portal de Valencia. Pertenecía a la orden del Císter, pero moraban en la casa núm. 17 de la calle Maestro Barona. Hallándose construyendo un pequeño convento en la citada casa núm. 68, cuando las tropas de Napoleón invadieron la Pobla en el año 1811; los religiosos fueron perseguidos, no sabiéndose nada sobre los mismos. El convento quedó inconcluso pasando a ser morada de labradores. Frente a la casa núm. 68 se encontraba el portal de Valencia, puerta principal de entrada a la población, la cual fue derruida a mediados del siglo XIX.
${ }^{217}$ Llavata Pitarch, V. (1981): Historia de la Villa y Baronía de La Puebla de Vallbona, Ayuntamiento de La Puebla de Vallbona, pág. 201-204. 
Fig. 143. Pleito del Monasterio de Portaceli contra el convento de San Onofre, donde indica que la propiedad de la Casa Blanca es de los dominicos de San Onofre.
De los anteriores planteamientos se deduce la ubicación del convento en el denominado carreró de San Onofre. A continuación, siguiendo el orden de ideas marcado, acontece documentar el edificio que poseían extramuros, la Casa Blanca.

El edificio civil de época medieval mas conocido en el término municipal de la Pobla de Vallbona era el denominado como la Masía de la Casa Blanca. El mencionado inmueble se situaba a $1600 \mathrm{~m}$ de distancia del casco urbano, al norte de la misma. El edificio era conocido por el deslumbrante blanco de cal con el se revestían sus paramentos verticales. En un principio la propiedad contaba con un terreno de $2.760 \mathrm{~m}^{2}$ y siempre estuvo rodeada por un muro almenado de tres metros de altura aproximadamente. En relación con la creación y los primeros tiempos se presenta un extracto de un documento presentado en el libro de Vicente Llavata, La Historia de la Villa y Baronía de La Pobla de Vallbona, facilitado por el archivero del monasterio de Porta-celi, Rafael Roca Miguel, que describe así:

No bastando la masía de La Torre, puesta en
explotación a principios de 1400, siendo Prior D.
Bonifacio Ferrer, que llegó a General de la Orden,
para atender a las necesidades del cultivo de las
numerosas tierras que la Cartuja de Porta-Celi
poseía en el término de Llíria, se formó otra masada,
a corta distancia de la Pobla de Vallbona, a la que
se le denominó Casa-Blanca; cuyo terreno formado
en su mayor parte de tierras de secano, de superior
calidad, rendía una abundante cosecha de vino,
algarrobas y aceite. El edificio que se construyó era
menor que la torre, pues ocupaba un área de 2.700
$m^{2}$., estando dotado de todas las dependencias
necesarias para su explotación. [...] Desconociendo
la fecha de la creación de esta importante finca
de labor, nos inclinamos por el tiempo de priorato
de V. P. D. Francisco Gispert $1408-1414$, o el de D.
Francisco Maresme, que también llegó a General de
la Orden, que gobernó Porta-celi diez años, 1414-
1424 [...).

El presente documento, que únicamente aparece en el libro anteriormente señalado, deja constancia de que el inmueble se construyó para abastecer a Porta-celi puesto que la Masía de la Torre no era suficiente para cubrir las necesidades de los monjes. A partir de este momento no vuelve a aparecer ningún 


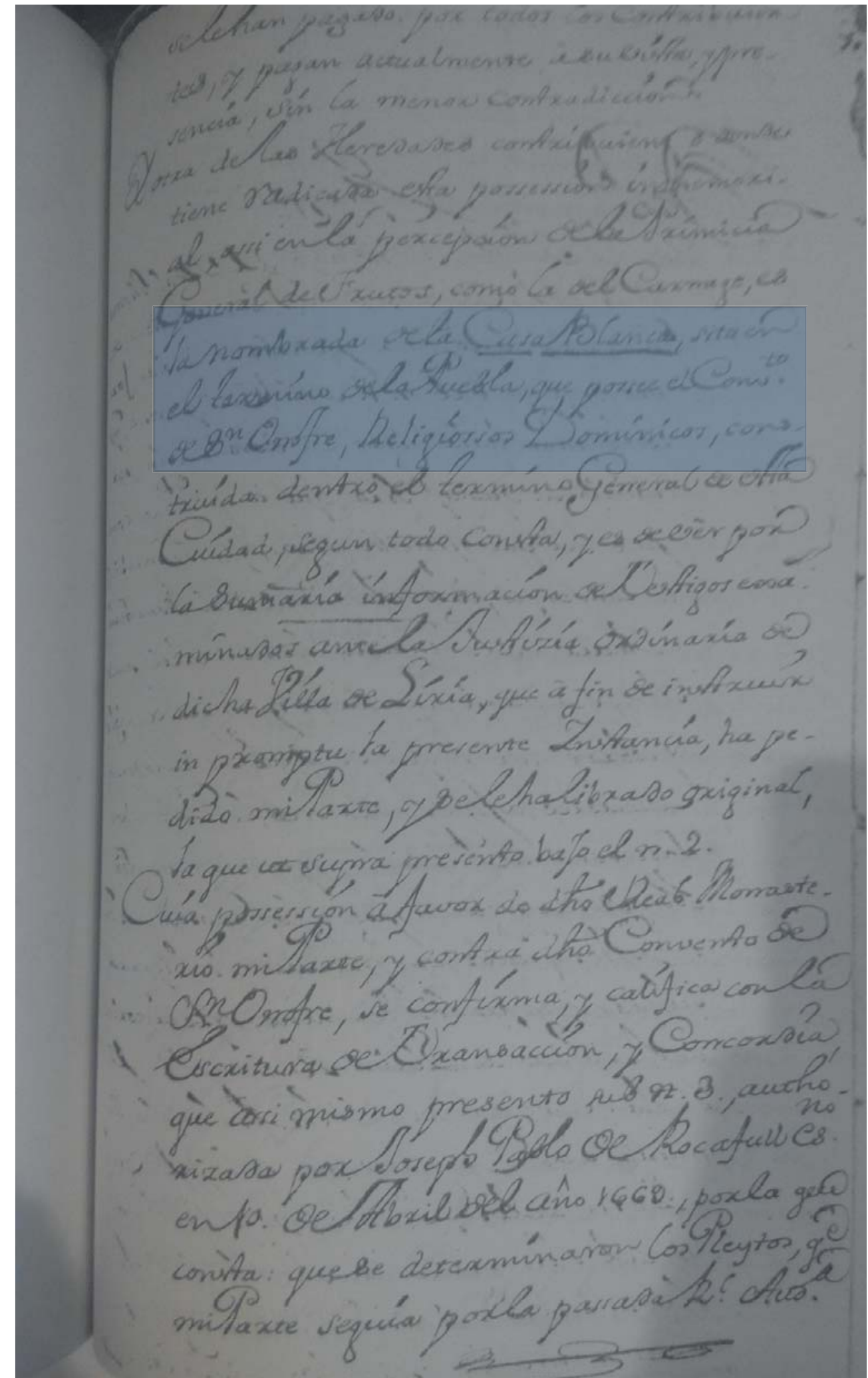


Fig.144. Azulejos de San Onofre situados en la fachada de la calle Salvador Giner, no 1 de Valencia. Se supone semejante al que se ubicaba en la fachada de la Casa Blanca.

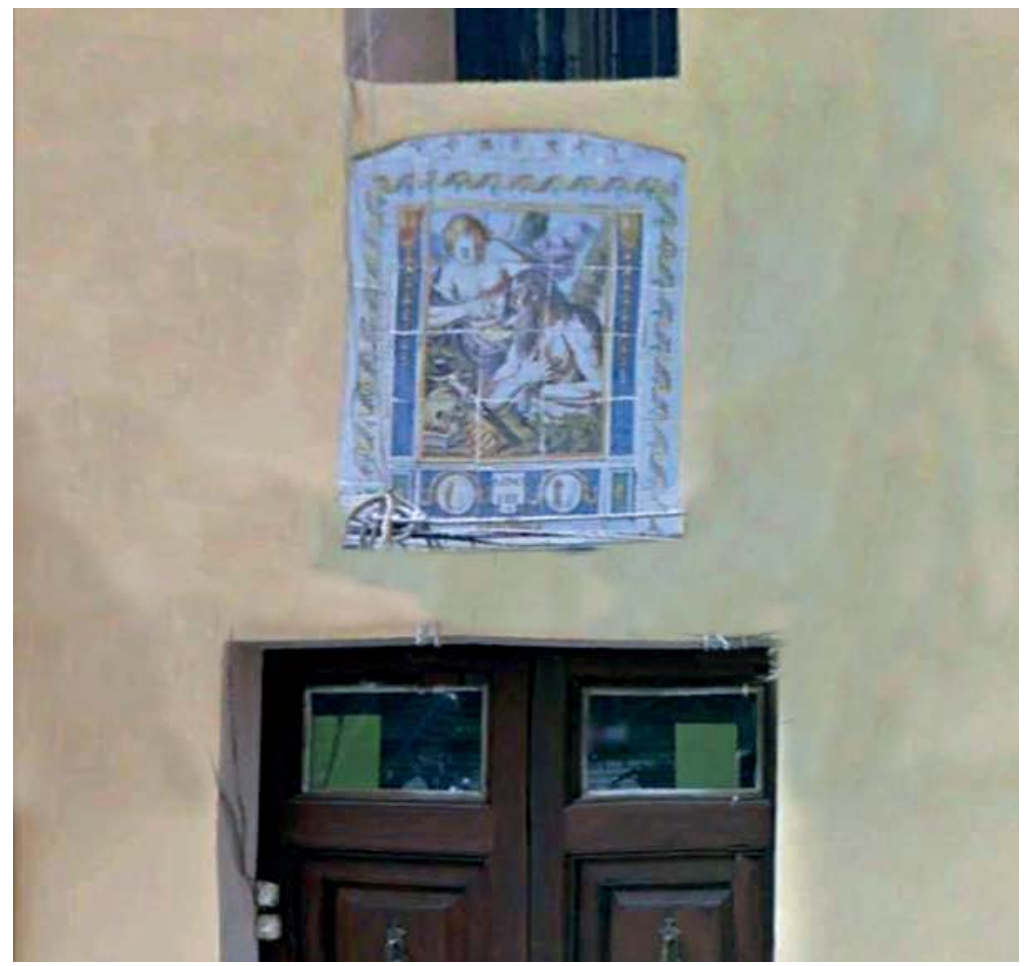

escrito que acredite que la masía sigue perteneciendo a Portaceli. En cambio en los documentos que describen sus pleitos con el convento de San Onofre no dejan lugar a dudas, la Casa Blanca era propiedad de la orden de Musseros desde el siglo XVI. Asimismo a modo de referencia en el frente de la fachada tenía ubicados unos azulejos que hacía referencia a San Onofre, muy semejante al que existe en la calle Salvador Giner, nㅇ1 en Valencia. Es evidente entonces que el convento se situaba intramuros y la masía de la Casa Blanca, extramuros, estaba destinada asegurar su suministro de prevendas.

En los legajos de la subasta de las exclaustraciones comprendidos en los años 1812-74, existe una descripción de como era la masía en aquel momento. En el escrito indica, entre otros datos, que el inmueble de la Casa Blanca, linda con propiedades de la cartuja de Porta-celi. Dice así:

La Masía titulada "casa Blanca". Esta masia sita en la provincia de Valencia, termino de la puebla de Vallbona, partido judicial de Lliria y partida Ilamada de safareig, linda por norte con el monte llamado Tos Pelat, por el este por el camino que conduce de Betera a Llíria y tierras de José Navarro y José 


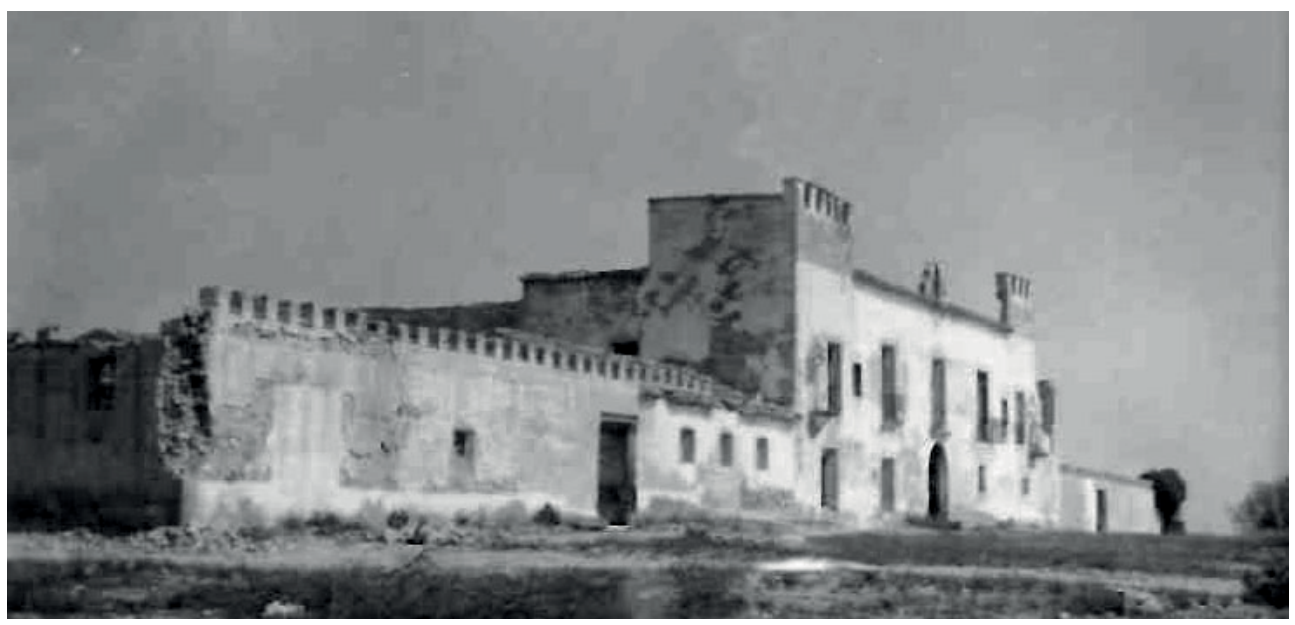

Pelecha, por el Sur por el camino referido de Betera a Llíria y tierras de Jose Pitarch, conde de Trigona y D. Mariano Vila, por oeste con tierra de Jose Condal, José Contreras, José Feranadez, Pascual Cervera, Jose Soriano y Monte Ilamado Tos Pelat. Esta toda cerrada esta heredad de este a oeste por el camino de Porta-celi y de norte a sur por el camino Betera a Llíria. Tiene un perímetro de $11 \mathrm{Km}$. y $84 \mathrm{~m}$ que forma un polígono irregular de -----y cuatro lados. Su cabida es de doscientas diecinueve hectáreas y cinco áreas, cientro setenta y nueva hectáreas y veintiuna áreas de secano, vid, algarrobos y olivos, cuarenta y nueva hectáreas y ochenta y cuatro áreas de monte blanco para pastos y además fuera de lo anterior dos hectáreas y siete áreas de secano en el mismo campos lindantes con tierras que fueron del extinguido convento de Porta-celi....La finca se resuelve a favor de D. Rafael Beltran de lis el en escritura otorgada en valencia el diecisiete de.. de mil ochocientos sesenta y nueve ${ }^{218}$.

La Casa Blanca estuvo por lo tanto en posesión del convento de San Onofre hasta el año 1869, momento en que el ministro Mendizábal propuso su decreto de desamortización de los bienes de las órdenes monásticas, quedando la mayor parte de las tierras en manos de pequeños y medianos propietarios. En un principio la masía fue adjudicada a don Rafael Bertrán de Lis, el cual también adquirió bastantes terrenos y edificios pertenecientes en origen al monasterio de Porta-celi, es posible
Fig. 145. Fachada de la Masía la Casa Blanca a principios de la década de los 80.

\footnotetext{
218 Medición y valoración de las fincas: Porta-celi, Pobleta, La Torre y Casa Blanca (1866). Propiedades antiguas: Legajo 143. Archivo del Reino de Valencia.
} 

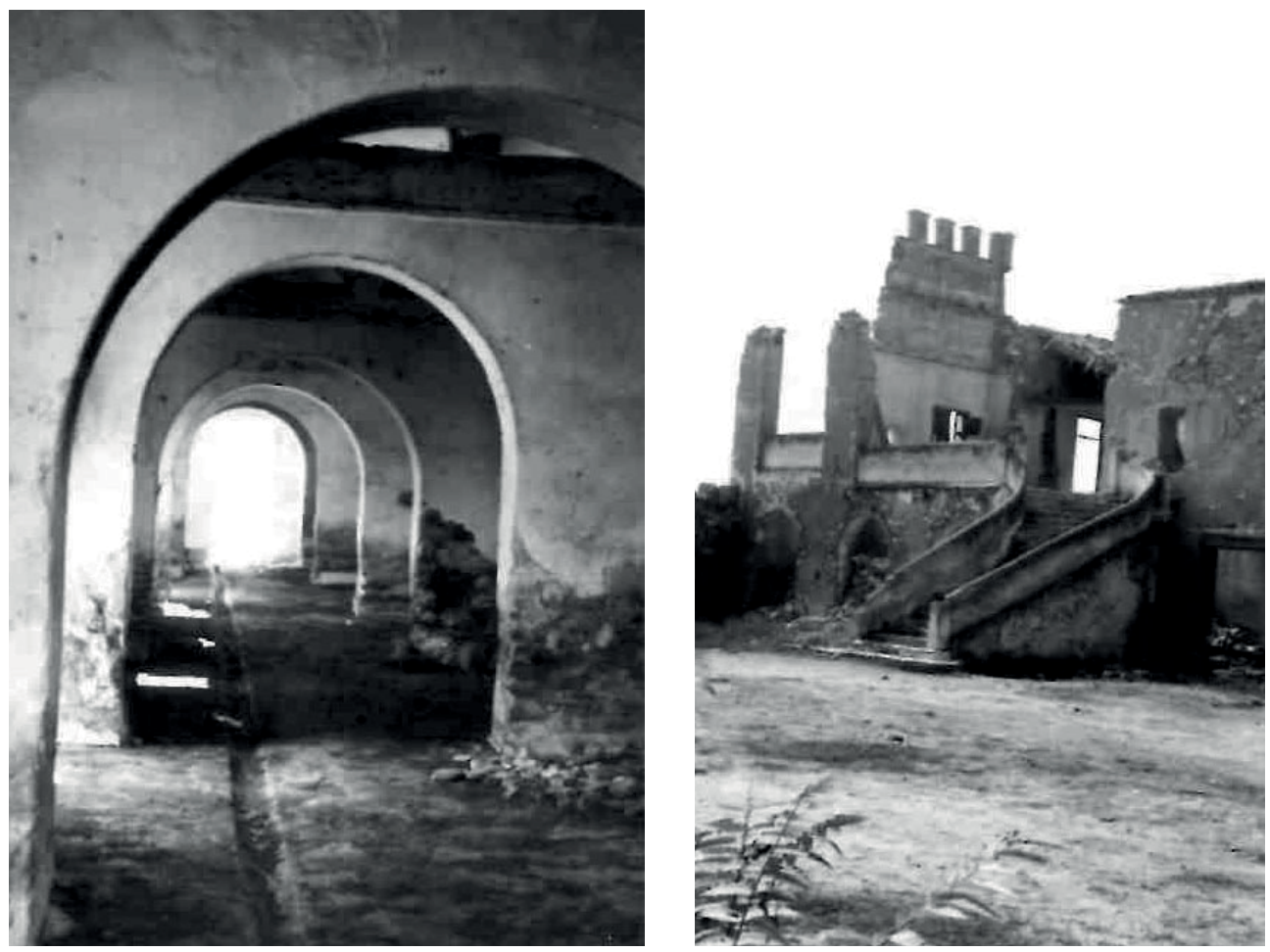

Fig. 146. Muros de carga del interior de la Casa Blanca.

Fig. 147. Restos de la escalera imperial que existía en el interior de la masía. Situación antes de su derribo.

Fig. 148. Plano catastral del polígono donde se situaba la Casa Blanca del año 1928. Se observa en planta la extensión de la propiedad.

Fig. 149. Recorte de noticia del Diario provincial: Las Provincias, página 4, sábado 10 de mayo de 1928, Biblioteca virtual, prensa histórica. Edicto de pública subasta de la masía de la Casa Blanca en el citado año. que sea en este momento donde se arrastre la creencia de que todo pertenecía a la misma propiedad.

Este primer propietario al no poder hacer efectivo el pago de los plazos, la propiedad fue de nuevo incautada por la Hacienda Pública a los pocos años de haber sido subastada en la desamortización. En las décadas siguientes la Masía contó con numerosos dueños hasta que fue adquirida varios años más tarde por don José de Iranzo y Barruchi, militar destacado en la campaña de Filipinas y Coronel del Primer Regimiento de Artillería. Éste estuvo casado con doña Pilar Palavecino, hija de los marqueses de Mirasol y fue también presidente de la Cámara Agrícola de Valencia durante los años 1891 y 1892.

Don José Iranzo y Barruchi dio a la finca un nuevo impulso y la mantuvo en activo durante largos años. Replantó centenares de hanegadas de viñedos y árboles, teniendo a su disposición un gran número de trabajadores de la Pobla y de Benissanó, manteniendo la productividad de la misma y disfrutando de años de esplendor. También se debe a él la colocación de la campana que hay en la pequeña hornacina situada entre las dos torres gemelas y almenadas de la fachada de la masía. 


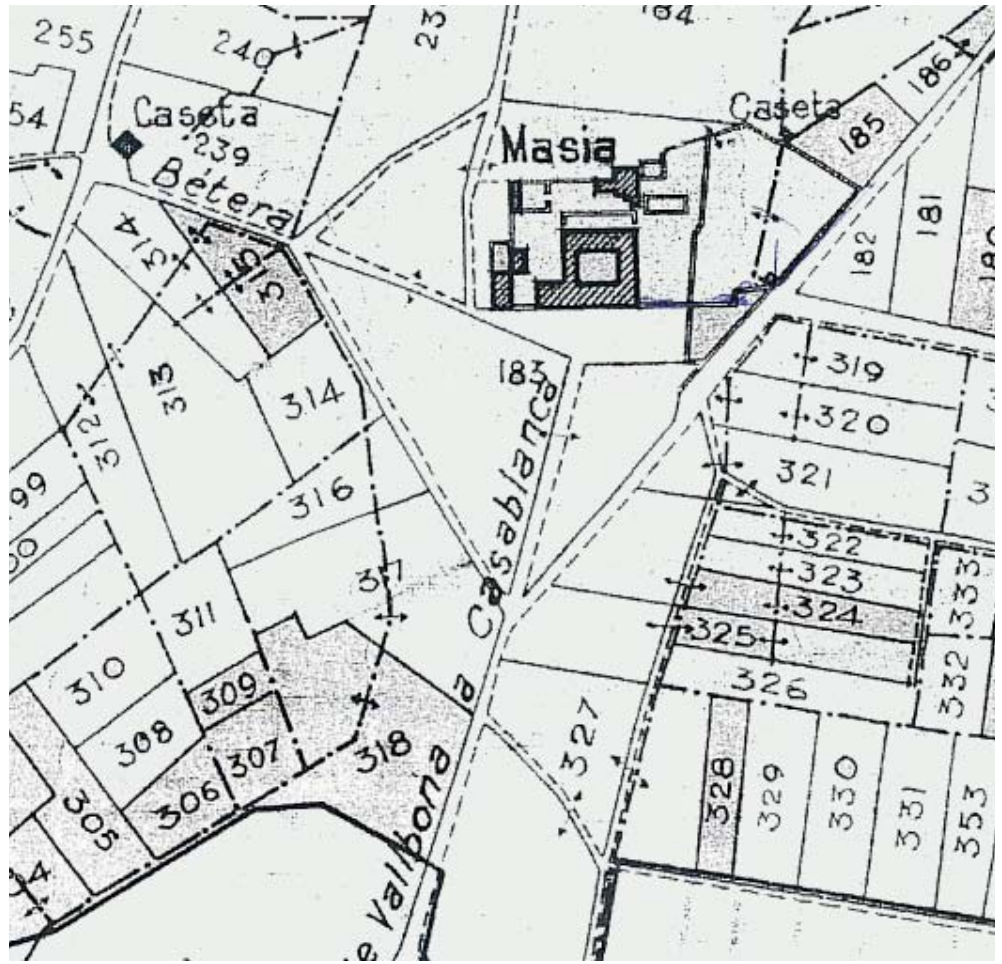

La finca la heredó su hijo D. Vicente Iranzo Palavecino, pero a la muerte de este en los años veinte del siglo XX, su viuda $D$ a. Soledad Ruiz no pudo soportar la hipoteca y la finca vuelve a ser subastada. Es adquirida por un potentado de Madrid apellidado Carriaga (véase fig.148). Éste señor reorganizó la masía y mantuvo su prosperidad hasta 1944, año en que se hizo cargo de la finca el Instituto Nacional de Colonización por medio del Ministerio de Agricultura.

La masía fue finalmente abandonada por el Instituto Nacional de Colonización antes de la década de los sesenta del siglo XX y estuvo en un estado deplorable hasta su derrumbamiento a mediados de la década de los ochenta. Desde 1973, que el Instituto cedió todas las propiedades, pagadas debidamente por los colonos, la masada pasó a ser propiedad mancomunada de la Comunidad de Regantes del Pozo Casa-Blanca.

Para concluir señalar que se encuentra protegida por el Catalogo de Bienes y Espacios Protegidos del Plan General, como Yacimiento Arqueológico.

\section{EDICTO}

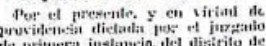

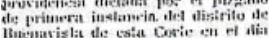

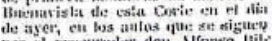
jor al provintuler don Mifontio bil

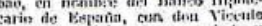

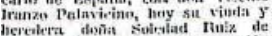

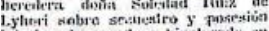

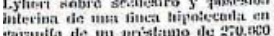
irsiclas te principal inlerteses $y$ cos

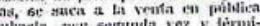

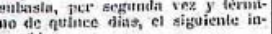

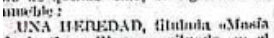

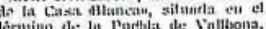

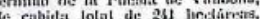

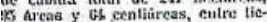
Imes huerta, secaun $y$ inonte, en

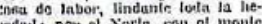
redaut: poe el Norice, con of monle con el tamino que condace de BCIera a Liria, tierras de Jose Nava-

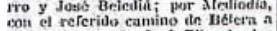
Liria, lierras ó de losé Pilarch, las the! conde de Trizona y I Ius do doña Mfarinan Vila, $y$ por Pouicnte, con

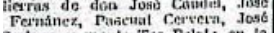
soriano $y$ monte Tos Pelat: en ta parle ecenna cala alravesata de ineli, $y$ de Nerta a sur, por el canino de inetera n Lirin; su perim fo ed de once kilemesires que ror aulos, Dentro de sae yerituclro sto zullu siluato el calificto o cosat da

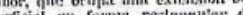
$760)$ un neen, putios y corrulest, elevain tede

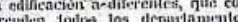
oficintas y atmacents indiepensaliber in relinciùn con las productos des

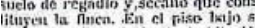
neserentra ef oratorio, la liabitación ara of tubrado:, correctorts, eister nae, almacenee, graneres, almazide luerro para vino y aecile, tre

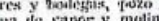
lo viento para ta extracición de

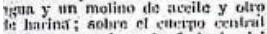

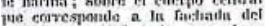

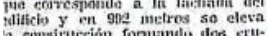
a consirnection fonatamali, thes ertlas, $y$ en clla so hollian las babilta-

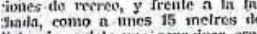
Slancia, estisle una espifciosst eri ot do mampiosturla cubierto de ic nido de 140 melrne, $y$ un pocos usa Naseste, a Jos metros, una cis Lopantaniculos paralelos paira reco-

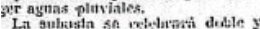
Lit gubsasta SA riblureat dedle or el de L.thi. el diat it dis Mtayo róxliano, a tas noce the sal menñatas, rajo las siguicnles vounlictons:

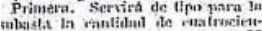
as cimro tuil nesetas, of ses, el t5 iat int ale: frectio pachath on' lat es. sitma de prislamo base de tos nu-

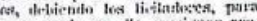

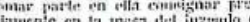
tow

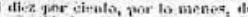

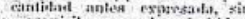

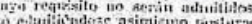

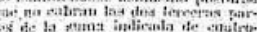
intas cines wiil y Segrata. Si fo hiowen dos per attü colte los ties nenatantice, y

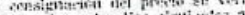

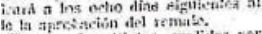

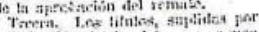
rlitecacitit det Hezistro, AC enetian

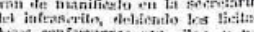

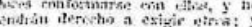

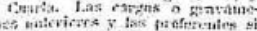

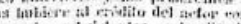

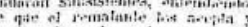

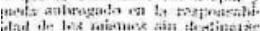
a estit sit of yorio etel roneat.

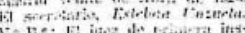
Firla ingito 
$\mathbf{2 7 8}$ de 536

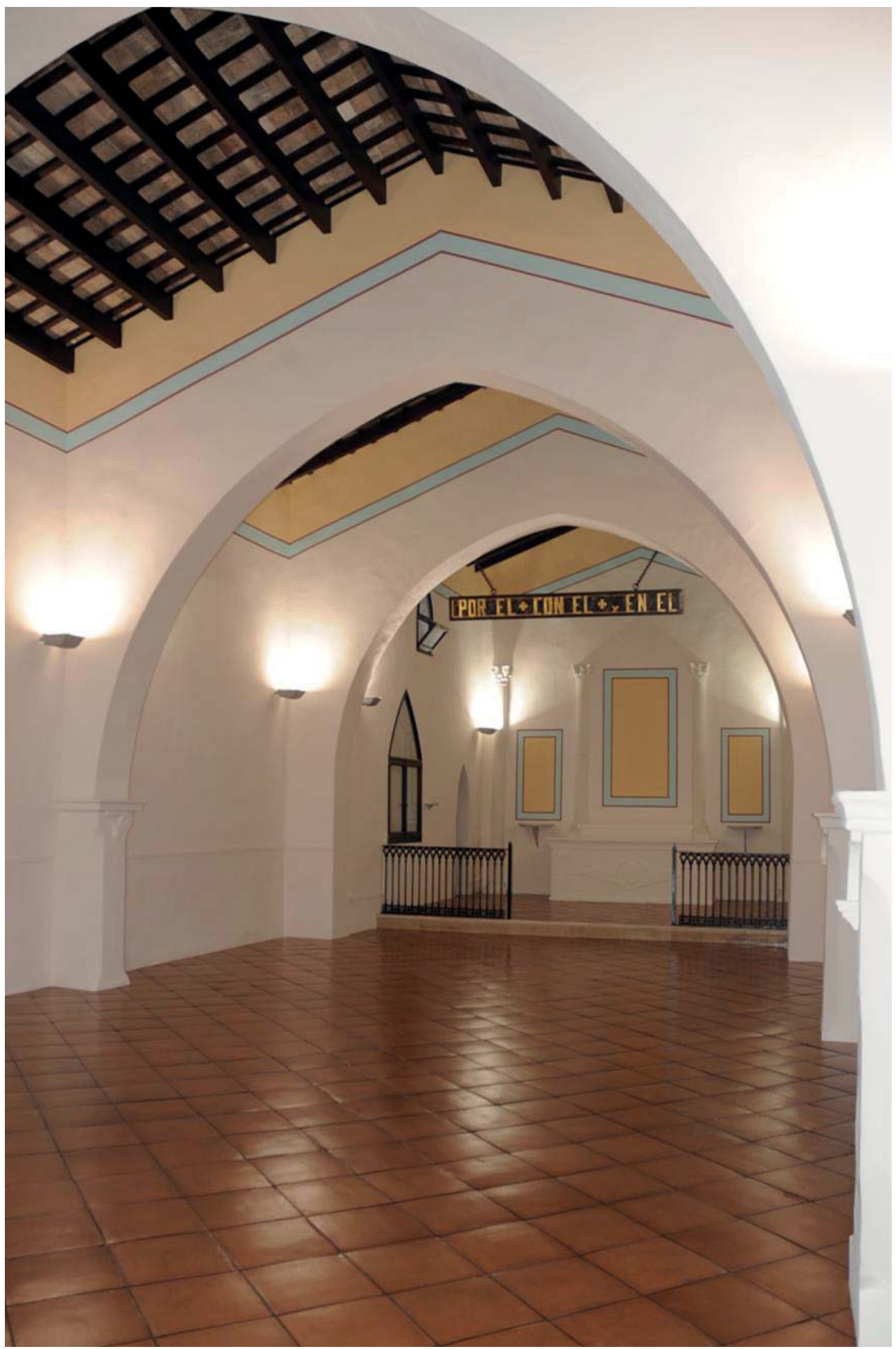




\subsection{6| Arquitectura religiosa}

El mayor número de patrimonio arquitectónico que ha llegado hasta la actualidad, al igual que en otras poblaciones, es el destinado a la arquitectura religiosa. La Pobla de Vallbona presenta una gran riqueza de restos medievales, aunque desconocidos para la gran mayoría de la población.

A lo largo de este capítulo se pondrá en valor los tres edificios del bajo medievo presentes en la población, la ermita de San Sebastián, erigida con muros de tapial y arcos de diafragma, la iglesia Santiago Apóstol, edificio construido con bóvedas de crucería, aunque en la actualidad está enmascarada por la ornamentación barroca, y por último, se enumerarán los indicios que pueden llevar a la hipótesis de la existencia a lo largo de la historia de un peiró de término, aunque actualmente se encuentra desaparecido.

5.6.6.1| Ermita con arcos de diafragma: La Ermita de San Sebastián

\section{Antecedentes históricos}

Extramuros pero en su término municipal, en el punto más alto de todo el llano se erige en un pequeño montículo, que llega alcanzar unos 4,00 m sobre el nivel natural, la ermita de San Sebastián. El inmueble tiene planta rectangular, presenta una orientación este-oeste y tiene adosado al frente de la izquierda la casa del ermitaño. Según fuentes orales la ermita dependía de la Cartuja de Porta-celi, aunque no aparece nunca referenciada en su listado de posesiones.

Las fuentes escritas vienen dadas, en su gran mayoría, por las descripciones que se encuentran en los documentos que detallan las distintas visitas pastorales. El primer escrito encontrado en el archivo parroquial viene fechado en 1525 , y en él se indica:

Desde antaño, se sube a la antigua ermita de sant sebastiá219

La ermita vuelve a mencionarse en la del año 1690, en la que se atestigua la fiesta que desde antiguo y de manera tradicional el
Fig. 150. Interior de la ermita de San Sebastián después de su restauración en el año 2009. 


\section{$\mathbf{2 8 0}$ de 536}

Fig. 151. Sección A-

$A^{\prime}$ de la ermita de San

Sebastián de La Pobla

de Vallbona donde se

observan los arcos de

diafragma. Al fondo

la casa del ermitaño.

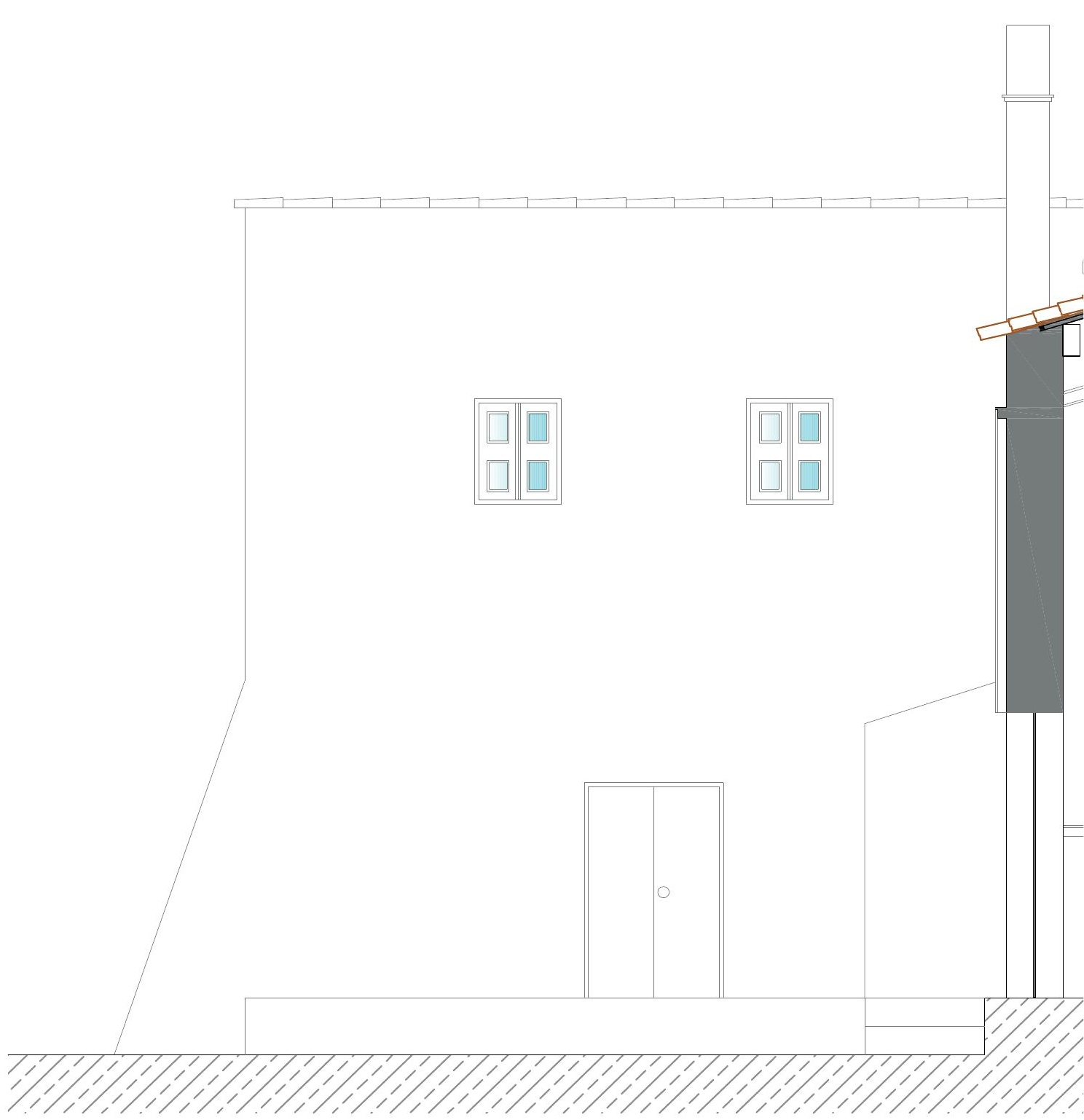



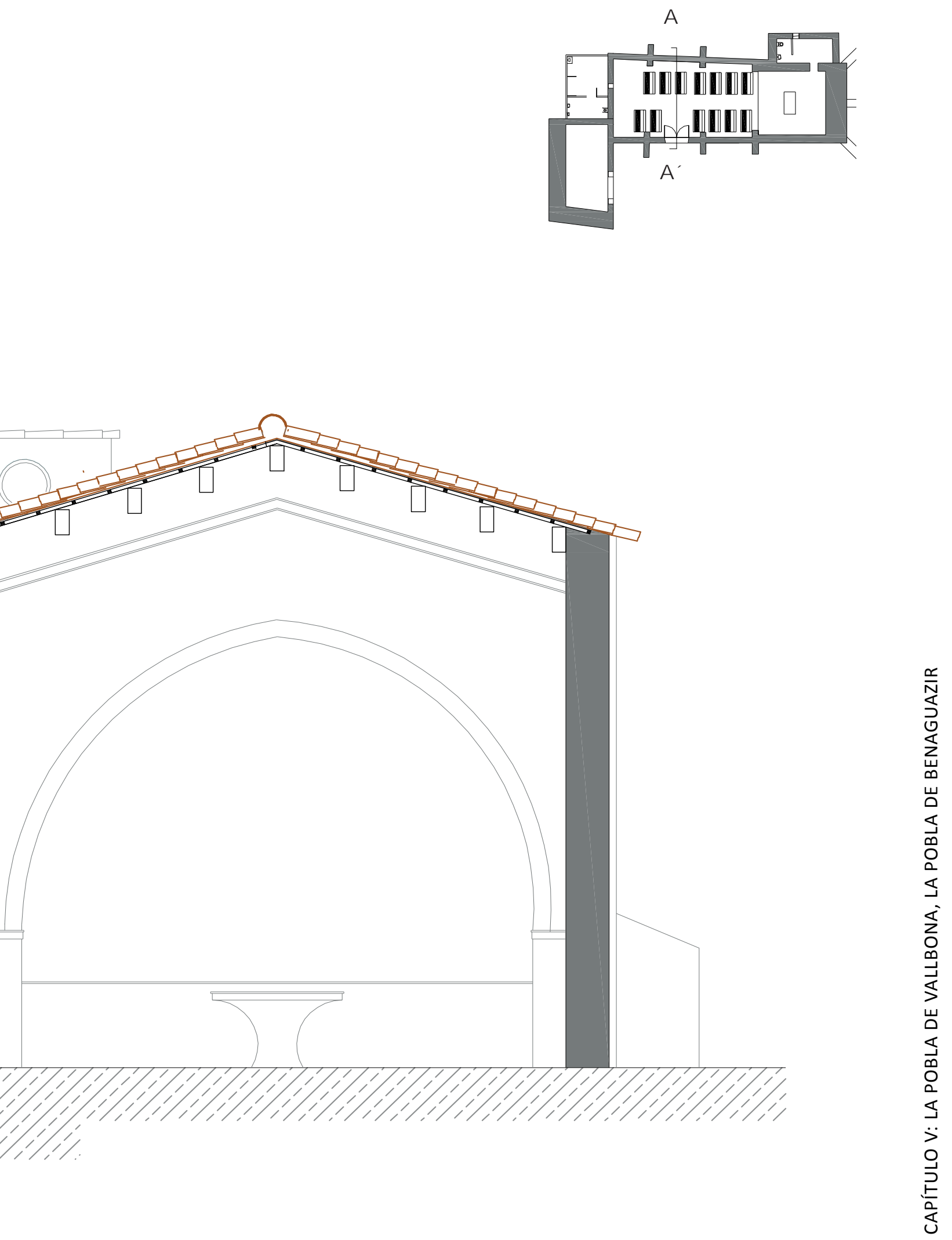
pueblo realizaba en el día del santo el 20 de enero y que consistía en subir al santo hasta la ermita en romería:

hallo su excelencia el Arzobispo mi Señor una Hermita en el termino y territorio de la villa de la Puebla de Vallbona, cuyo titular es San Sebastián Martyr, y el día del Santo suben a la dicha Hermita en procesión, donde se celebra una missa cantada se predica y hay costumbre que el Rector no lleva porcion; pero dos beneficiados sí, como lo proveyó (...) el señor oficial de causas Pías en dos de Agosto del año mil seiscientos noventa

Además, el día de la festividad del mártir al que está dedicado el oratorio se adornaba y por la noche contaba con luminarias, gastos que eran sufragados con las limosnas recogidas en la iglesia parroquial de San Jaime.

tiene un plato y demanda en la iglesia (...) cuyas limosnas sirven para la Luminaria y adorno de dicha Hermita y para la fiesta del día dado de San Sebastián" aunque "no son las dichas limosnas bastantes para dichos gastos los Lumbreros casi siempre gastan de propios ${ }^{220}$.

En la visita de 1731, el visitador general describe la ermita como un edificio simple el cual,

tiene su Altar con Ara, manteles frontal y lámpara de Azofar con bastante decencia para poder celebrar el Santo Sacrificio de la missa, bien que no tiene campana y necesita de algunos reparos para su conservación, lo que se mandó en la visita pasada y se cumple cabalmente en haviendo fondo que se recoge para dicho $\mathrm{fin}^{221}$.

${ }^{220}$ Archivo parroquial de la iglesia de San Jaime Apóstol. Visita pastoral de 1690 .

${ }^{221}$ Archivo parroquial de la iglesia de San Jaime Apóstol. Visita pastoral de 1731.
Al parecer en esos años la renta de la capilla de "trece sueldos y seis dineros" procedente de los bienes de Sor Juliana Jorge, beata de la ermita de San Miguel Arcángel de Llíria - de los que en 1731 respondían sus herederos Juan Caxes y Cecilia Ruiz, sus herederos al haber comprado sus bienes- se dedicaron a la reparación del inmueble, junto al fondo procedente de las limosnas recogidas en la iglesia parroquial y sufragaron los gastos de reparación y construcción de una campana para el inmueble medieval, que en estos momentos estaba en muy mal estado: 
Hay cierta recolecta de 12 libras y 15 sueldos y el Sr. Visitador mandó que los emplearan en hacer una Campanilla para la Hermita, pues parece mal sin ella y era necesaria para tocar a misa el día de la fiesta de este santo. Y que si cualquier devoto la mandase hacer, el dinero recolectado se invirtiese en socorrer el tejado de la Hermita y hacer un tabique en el Coro de la Hermita ya que se estaba cayendo, lo haga lo más pronto que se pueda ${ }^{222}[. .$.$) .$

En la visita de 1784 se registra una cláusula del testamento de Francisco Gomis dado en 1779, en el que deja sus bienes a sus hermanos y familiares con la condición de que las rentas se utilicen en aniversarios perpetuos, para lo que crea una nueva fundación de San Sebastián. El testamento recogía la prohibición de vender y enajenar sus bienes y dejaba copia del testamento bajo la custodia del párroco de la iglesia de San Jaime.

La siguiente referencia data del 2 de octubre de 1810. Este día se produce una intensa batalla entre las tropas napoleónicas, comandadas por el general París, y las tropas españolas al mando de los generales O'Donell y San Juan. En el fragor de la batalla las tropas se atrincheraron en el interior de la ermita que sufrió muchos desperfectos, al punto que tan sólo un año después, el 2 de octubre de 1811 el arzobispo de Valencia autoriza a la iglesia de San Jaime a que sean derribadas las ruinas persistentes del Calvario y de la ermita de San Sebastián. Tan sólo se conservaron los paramentos medievales de tapial, y los arcos de diafragma.

El edificio fue reconstruido, siendo los siguientes datos hallados del año 1887 , donde se vuelve a señalar la necesidad de mantenimiento del edificio. El 19 de agosto de 1887 se documenta el pago de 24 pesetas a Pedro Juan Soriano por "los materiales y dos jornales de albañil" empleados en las almas de la ermita de San Sebastián. Posteriormente, años más tarde, en 1892 se encarga "blanquizar" la iglesia, algo que era habitual y que le confiere ese aspecto peculiar que aún conserva hoy en día.

La zona fue visitada por Carlos Sarthou ${ }^{223}$ en el año 1913 cuando estaba redactando su libro Geografía del reino de Valencia. En el capítulo dedicado a la Pobla de Vallbona describe la visita a un santuario gótico cuyo retablo describía la vida de San Sebastián y un púlpito de la misma época, seguramente procedente de la

${ }^{222}$ Archivo parroquial de la iglesia de San Jaime Apóstol. Visita pastoral de 1731.

${ }^{223}$ Sarthou, C. (1922): Geografía General del Reino de Valencia. Tomo II. Casa Editorial Alberto Martín. Barcelona. 

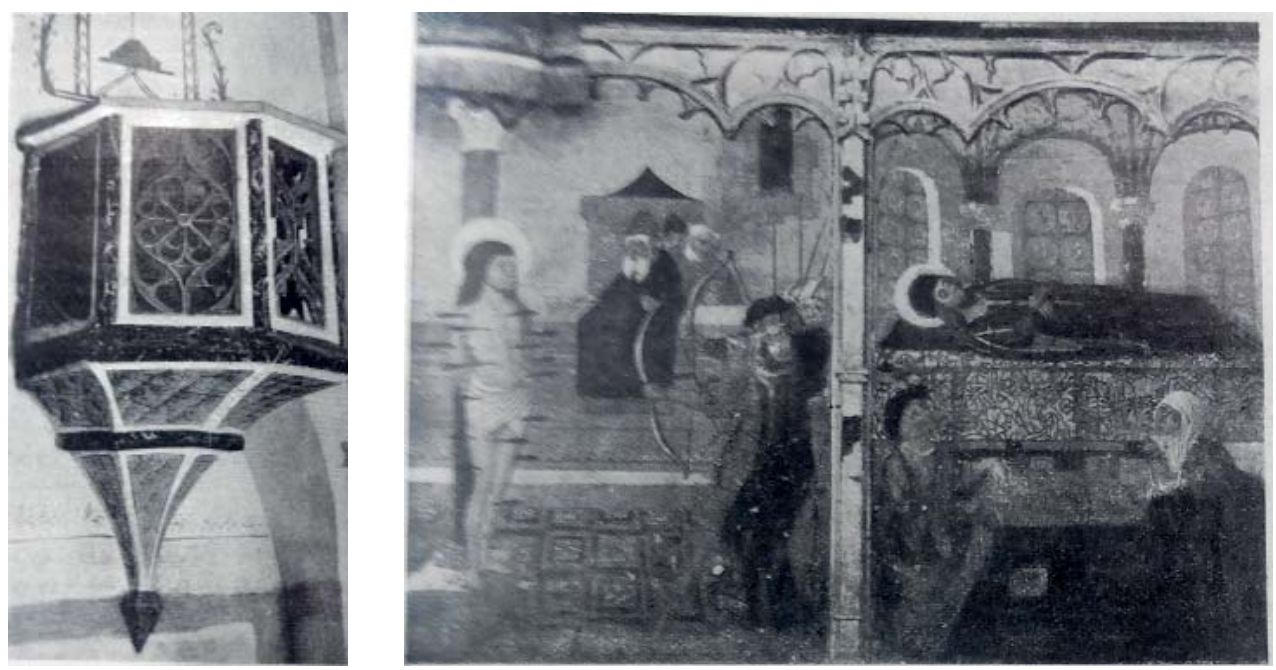

Fig. 152. Púlpito gótico existente en la ermita de San Sebastián antes de la Guerra Civil Española.

Fig. 153. Retablo medieval desaparecido de la ermita de San Sebastián durante el conflicto bélico de 1936.

\footnotetext{
224 Llavata Pitarch, V. (1981): Historia de la Villa y Baronía de La Puebla de Vallbona, Ayuntamiento de La Puebla de Vallbona, pág. 237.
}

antigua iglesia medieval de san Jaime. Estos dos bienes muebles desaparecieron durante la Guerra Civil Española, pero Llavata224, aporta la siguiente descripción:

El primero estaba colocado a los pies de la nave $y$ estaba constituido por una predela con cinco tablas pintadas de origen medieval y en el cuerpo principal aparecían varios lienzos, al parecer de escaso mérito.

El otro retablo gótico estaba situado en el altar mayor de la ermita de San Sebastián y estaba dedicado al titular de la ermita. Este Retablo de San Sebastián estaba conformado por una predela de cinco tablas con escenas del martirio de San Sebastián y en el centro la representación de la Virgen con el Niño entre San Joaquín y Santa Ana. En el cuerpo superior aparecía representado en la tabla central la imagen de San Sebastián asaetado, desnudo y atado a la columna ante el fondo de una ciudad y en las tablas laterales un santo pontífice $y$ una santa, posiblemente Santa Ana o Santa Mónica. En el ático del retablo se representó en su centro el Calvario y en los laterales, dividida, la escena de la anunciación: el arcángel San Gabriel y la Virgen María. La escultura del retablo era de estilo gótico con tracerías doradas, contaba además con sus correspondientes pulseras, en las que ante fondos dorados y entre tracerías caladas aparecían San 


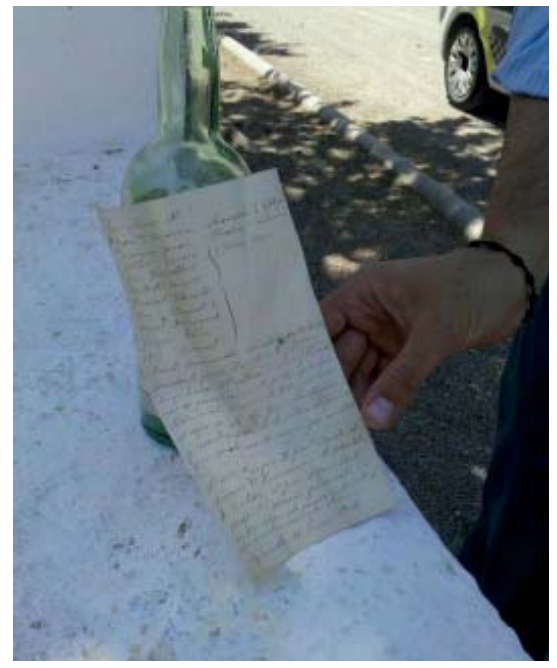

Vicente Ferrer y San Vicente Mártir, San Pedro y San Pablo, y los mártires San Lorenzo y San Esteban, y la Santísima Trinidad en el centro. En las entrecalles del retablo aparecían representaciones de otros santos y se remataban con blasones de la Corona de Aragón.

La obra se databa tradicionalmente como un retablo gótico del siglo XV. Elías Tormo en su estudio sobre las tablas del primitivo arte Valenciano, diferenciaba dos épocas en la confección del retablo. La primera, de hacia 1420, correspondería a un maestro anónimo, mientras que las tablas principales del retablo las atribuía al pintor Valenciano Nicolás Falcó. Este espléndido retablo se perdió durante la Guerra Civil (1936), cuando fue quemado y perdido para siempre junto al retablo medieval situado a los pies de la ermita.

Las penurias en el inmueble siguen hasta el año 1929, cuando sufre una importante remodelación, siendo la imagen que llega hasta la actualidad. El gusto neoclásico de la época hace que introduzcan cambios a la ermita original, cambiando el arco de medio punto de la entrada por un apuntado, y fingiendo los paramentos verticales de la fachada un revestimiento a modo de sillares.

Esta obra, de las que existen imágenes, se documentó en una cápsula del tiempo que se introdujo en el interior del paramento
Fig. 154. Cápsula del tiempo fechada en 1929, encontrada en el interior de un paramento vertical de la fachada principal. Detalla las obras realizadas en el citado año. 
Fig. 155. Fachada de la ermita de arcos de diafragma. Se observa el arco original de la puerta de medio punto. La ermita de San Sebastián 1928.

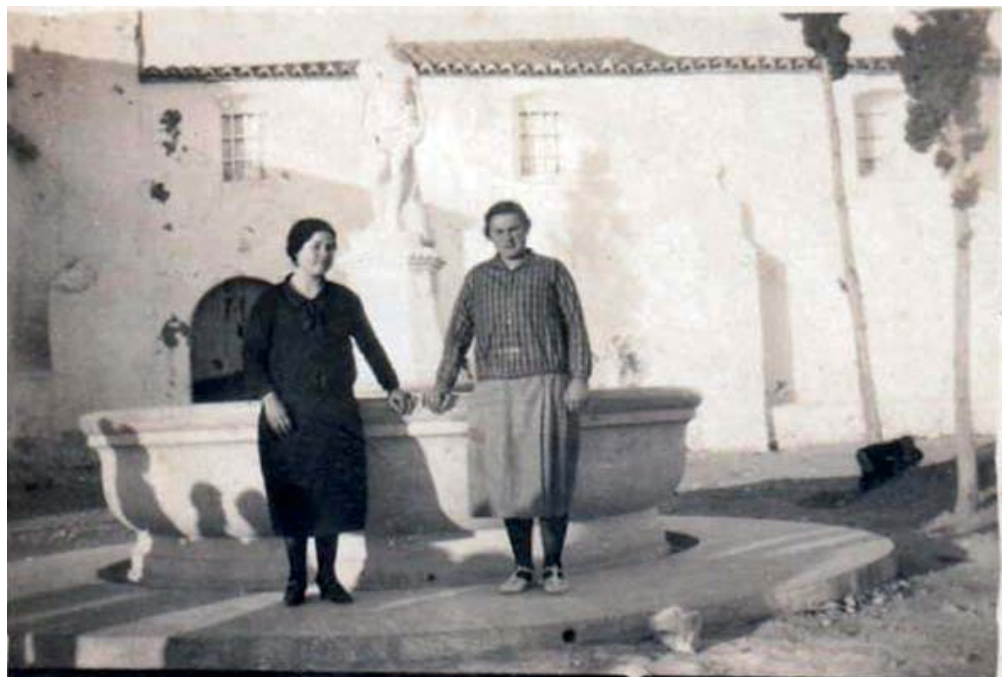

vertical del frente de acceso, siendo descubierta fortuitamente en el año 2012. El mensaje introducido en el interior de una botella de cristal y rodeado por los periódicos de ese día, dice así:

\section{Los señores}

D. Juan Camarena, sacerdote T. Valldigna, D. Enrique García, médico Valencia, D. Julián García, D. José García, D. Bautista Campos, D. Pascual Llavata, D. José Boquet, D. Miguel Domenech, D. Joaquín Esteve, D. José Bernat, D. Vicente Raimundo director y maestro de obras, formaban la junta Proermita y fueron los que hicieron el calvario nuevo y lo crearon de pared, hicieron la pista, plantaron los árboles, hicieron la balsa y subieron el agua que regalo D. Juan Montañana y reconstruyeron toda la ermita, el primero que descubra este escrito ruegue por nosotros.

El cura de la parroquia D. Juan Bosch, el vicario D. Juan Camerena, el alcalde D. Custodio Sabater, el juez Alfonso Martí, adjunto van los diarios provinciales, estos señores saludan a la generación presente y la invitan a que conserven esta obra.

Puebla de Vallbona, 11 de enero de 1929

Durante la contienda española del 36 , el calvario y la ermita sufrieron importantes desperfectos. La zona de las estaciones 


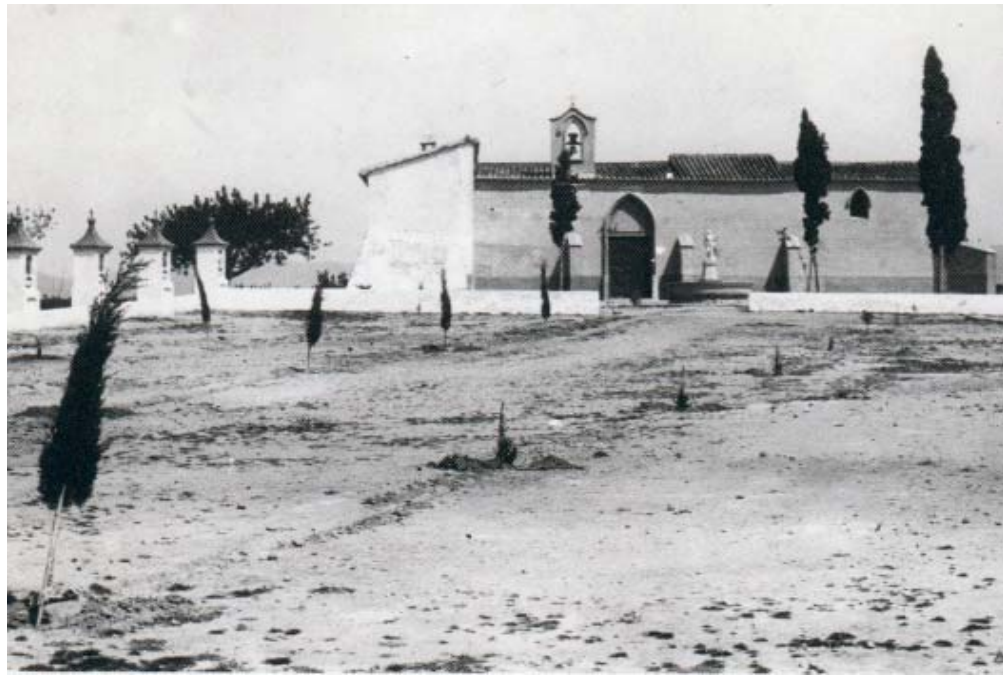

fue prácticamente derruida, los casilícios y la cruz derribados y la estatua de San Sebastián que presidía la fuente fue decapitada, siendo la cabeza recompuesta por el marmolista y escultor local Vicente Faulí Gramuntell.

En 1944 se inaugura el recompuesto ermitorio, gracias a los esfuerzos de Miguel Tarín Calvet, párroco de la iglesia de San Jaime de la Pobla y al sufragio de la Clavaría de San Sebastián. Al año siguiente, en 1945, se colocó en el altar mayor una imagen de San Sebastián, pintura mural representando al santo atado a un árbol y un angelito depositando un ramo de laurel sobre su cabeza. La representación es a formato natural en cuanto a lo ancho y lo alto. Este cuadro fue pintado por el pintor-decorador Benjamín Biot, natural de Meliana.

La última intervención sobre el oratorio se realiza en el año $2007^{225}$. La ermita presentaba un gran deterioro, sobre todo en las cubiertas, por esta razón el ayuntamiento de la Pobla de Vallbona - siendo alcaldesa de la Pobla, D.a Ma Carmen Contelles- , y la parroquia de Santiago Apóstol - con el cura párroco D. Joaquín Aguilar - colaboraron en su restauración con el fin de devolver a el edificio aspecto original. La obra se llevó a cabo desde los años 2007-2009. Se actuó en el entorno, en la casa del ermitaño, se sustituyeron las cubiertas y se recuperó la policromía original de los paramentos verticales interiores. En la actualidad todo el entorno junto al patrimonio arquitectónico se encuentra catalogado como Bien de Relevancia Local.
Fig. 156. Vista desde el calvario, al fondo, la plaza, la ermita, lateral izquierdo la casa del ermitaño y en el perímetro del calvario izquierda, los casilicios de los dolores. 1930.

${ }^{225}$ La descripción de los trabajos realizados durante la restauración se encuentran detallados en el apartado Anexos. A-3. pág. 440. 

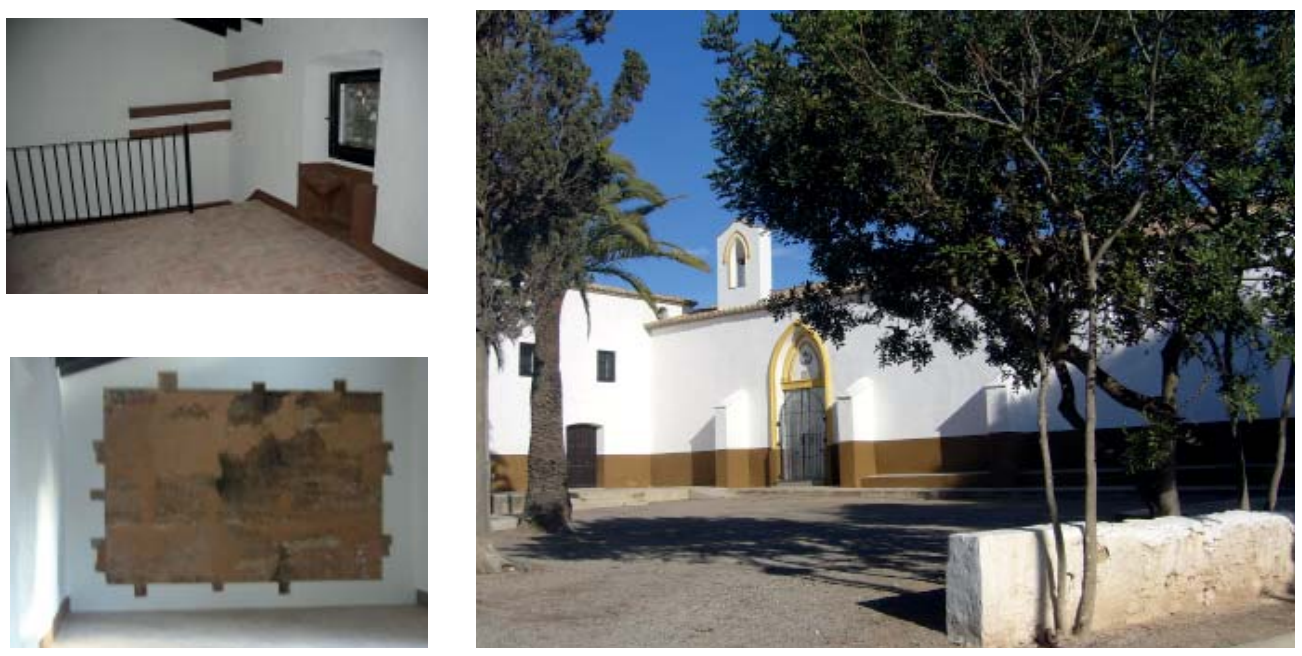

Fig.157. Festejador existente en la planta primera de la casa del ermitaño. Típico de las masías valencianas en el s. XV.

Fig. 158. Ventanas arqueológicas dejadas en el muro de tapial, el paramento vertical del inmueble de uso no religioso.

Fig. 159. Fachada actual de la ermita de arcos de diafragma, el oratorio de San Sebastián.

\section{Descripción del Entorno y de la ermita}

La ermita de San Sebastián es sin duda un edificio de inestimable valor tanto por su antigüedad como por su valor artístico. El interés histórico del oratorio está fuera de toda duda, en especial por la tipología típica de las ermitas con muros de tapial con arcos de diafragma, los cuales han perdurado a lo largo de su historia y sus diversas reconstrucciones.

El inmueble se encuentra en la parte superior de una parcela que cuenta en la actualidad con $8.500 \mathrm{~m}^{2}$ aproximadamente. EI terreno presenta su cota inferior en la zona sur y lleva pendiente ascendiente hacia el norte. En el interior del recinto lo primero que se aprecia es la cruz que preside el entorno. El calvario aparece cerrado perimetrálmente por un pequeño muro de mampostería de unos $40 \mathrm{~cm}$ de altura recubiertos con cal y se encuentra dividido en dos zonas.

La primera, la más antigua, contiene los 14 casilícios de las estaciones distribuidos siete a la derecha y siete a la izquierda. Cada soporte contiene una reducida hornacina donde guarda los pasos del vía crucis sobre unas imágenes de escayola, enmarcadas en arcos apuntados. La segunda zona, construida en 1929, se ubica en la parte superior y corresponde a los casilícios de los dolores. Estas imágenes se encuentran representadas con azulejería de la escuela italiana.

Tanto el calvario, como la zona de la ermita presentan diferente arbolado, pinos y cipreses. En el año 2011 se habilitó una 


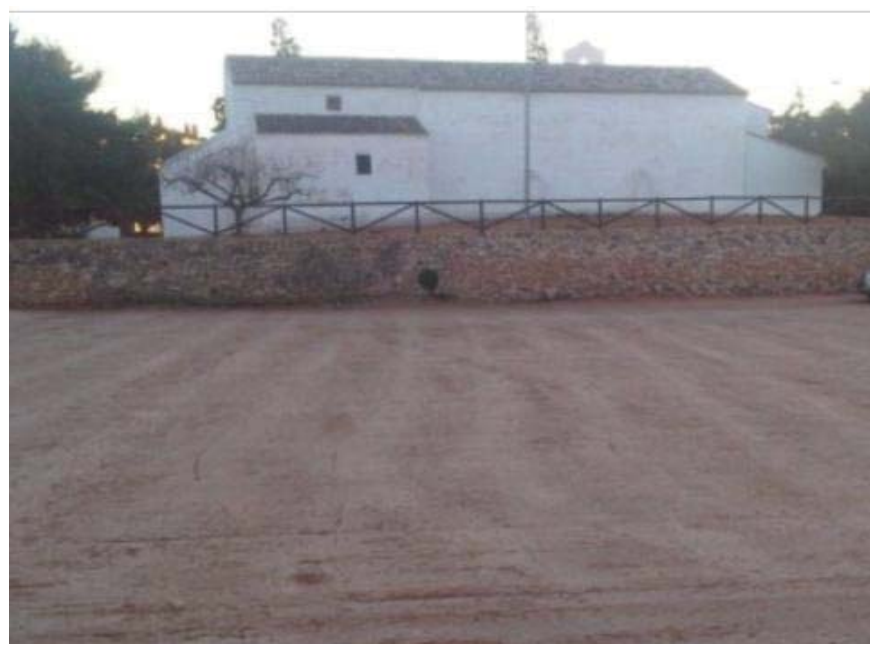

rampa de acceso a la parcela trasera, cuya propiedad es de la corporación local. Toda la parcela se encuentra rodeada por un muro de piedra en seco, que delimita la propiedad de la ermita. En la parte superior se encuentra la plaza a la que recae el santuario y la casa del ermitaño. En el cruce trasero de ambas edificaciones un patio de luces hace de trastero y de servicio higiénico. Este espacio fue ampliado en el siglo XX, puesto que los materiales eran bastante actuales y además se había constatado su inexistencia en el plano del año 1928 del Instituto catastral.

El ermitorio de San Sebastián, es un edificio de planta rectangular de dimensiones $20,68 \times 8,25 \mathrm{~m}$, cuyo ábside se encuentra orientado hacia el este. Esta circunstancia ha sido mantenida hasta la actualidad. Su fachada es plana, y la entrada se encuentra en el lateral. El inmueble nunca fue ampliado, por esta razón la puerta sigue encontrándose en el penúltimo tramo de la nave, en su tercera crujía. Si que se modificó en el año 1929 el arco de medio punto que se encontraba en el acceso, convirtiéndolo en un arco apuntado u ojival, como se ha descrito anteriormente.

En el interior se encuentran los arcos de diafragma. Son de piedra picada y en algunos casos de ladrillo, puesto que se ha intervenido en ella varias veces. Sus arranques, son muy bajos, como corresponde a este tipo de edificaciones. La nave se encuentra divida formando cuatro crujías.

La cubierta, a dos aguas, está realizada con pares de madera, rastreles y ladrillo cerámico. Como peculiaridad cabe indicar
Fig. 160. Vista actual de la parte trasera ermita. Muro de contención de piedra en seco.

Fig. 161. Interior de la capilla donde se observan los arcos de diafragma y el cambio de dirección de los pares de madera. 
que sólo en los dos últimos tramos los pares de madera descansan en los arcos de diafragma. En las dos primeras crujías en la reforma del año 1929 o en la de después de la guerra de la independencia, se colocaron dos vigas principales en la zona de la clave del arco y las vigas van como en una cubierta tradicional. En la restauración acontecida en el año 2009, se dejaron las vigas como se encontraron para dejar testimonio de las obras realizadas en las intervenciones anteriores.

Los paramentos verticales interiores se encuentran policromados con una ligera cenefa de dos colores que recorren la zona inferior de los pares de madera. La misma representación pictórica se encuentra en contorno del óculo ubicado en el testero.

Los muros que se conservan de tapia son los situados a la izquierda del acceso, en la fachada principal, y en la zona trasera de la ermita. Estos muros poseen un espesor considerable.

Adosado al edificio principal, se encuentra la casa del ermitaño, situada perpendicularmente a la ermita, se trata de un edificio de dos plantas, con muros de tapial de grosor descendente. La cubierta, a un agua, está formada por pares de madera y rastreles con tablero cerámico. El forjado con pares de madera y revoltones de ladrillo cerámico. En su interior, en la planta primera, se sitúa un festejador en la ventana trasera, típico de las masías Valencianas del siglo XV, puesto en valor en la última restauración.

Durante la última intervención, al eliminar los revestimientos de los muros interiores, se observó una capa antes de llegar al muro, de hollín, que dejaba constancia del atrincheramiento durante la batalla contra los franceses.

Por último cabe destacar que se ha puesto en valor el muro de tapial mediante la delimitación de dos ventanas arqueológicas que permiten observar la técnica constructiva con la que se encuentra construido el paramento vertical. 


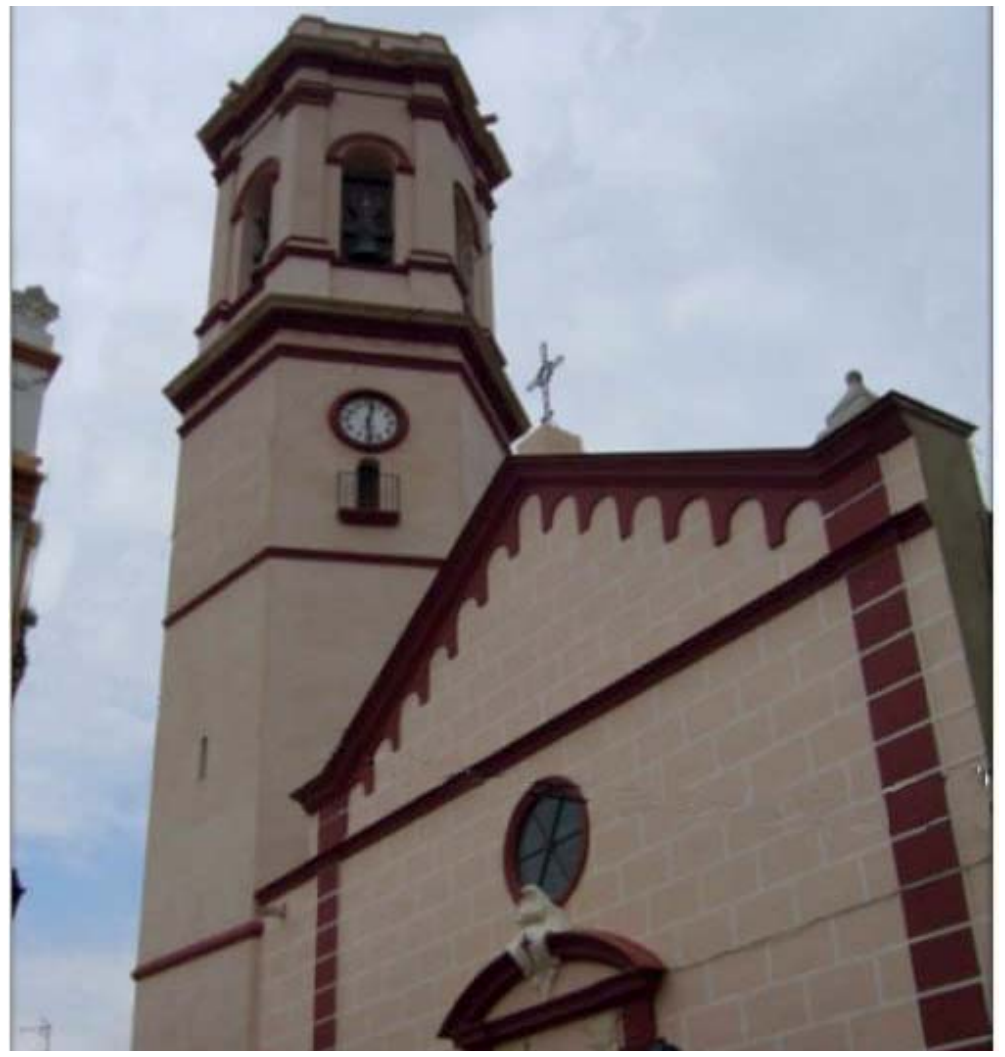

5.6.6.2 Iglesia con bóvedas de crucería: Iglesia Santiago Apóstol

En una esquina de la trama urbana, colindante al Portal de Benaguacil, se encuentra la Iglesia de Santiago Apóstol o de Sant Jaume. Este edificio de origen gótico ha sufrido a lo largo de su historia una reforma barroca y una ampliación neoclásica, pero ello no ha impedido que se pueda observar las trazas del inmueble original en nuestros días.

Esta primera iglesia de estilo medieval contaba con una única nave, de dimensiones 26,41 x 14,07 m, de cuatro tramos cubiertos por bóvedas de crucería apuntadas y de capillas laterales situadas entre contrafuertes. Los paramentos verticales muros de tapial de más de 1,00 m de espesor. El acceso principal se encontraba situado en la penúltima crujía pero con orientación norte.

También se conserva la primitiva decoración del presbiterio, unas bellas pinturas murales que en su origen formaban parte del altar mayor, y que hoy se sitúan a los pies de la iglesia.
Fig. 162. Fachada actual de la Iglesia Santiago Apóstol de la Pobla de Vallbona. En la baja edad media en este paramento no se situaba el acceso principal sino el altar mayor. 
292 de 536

\section{Sección Longitudinal A-A'de la Iglesia Santiago Apóstol}

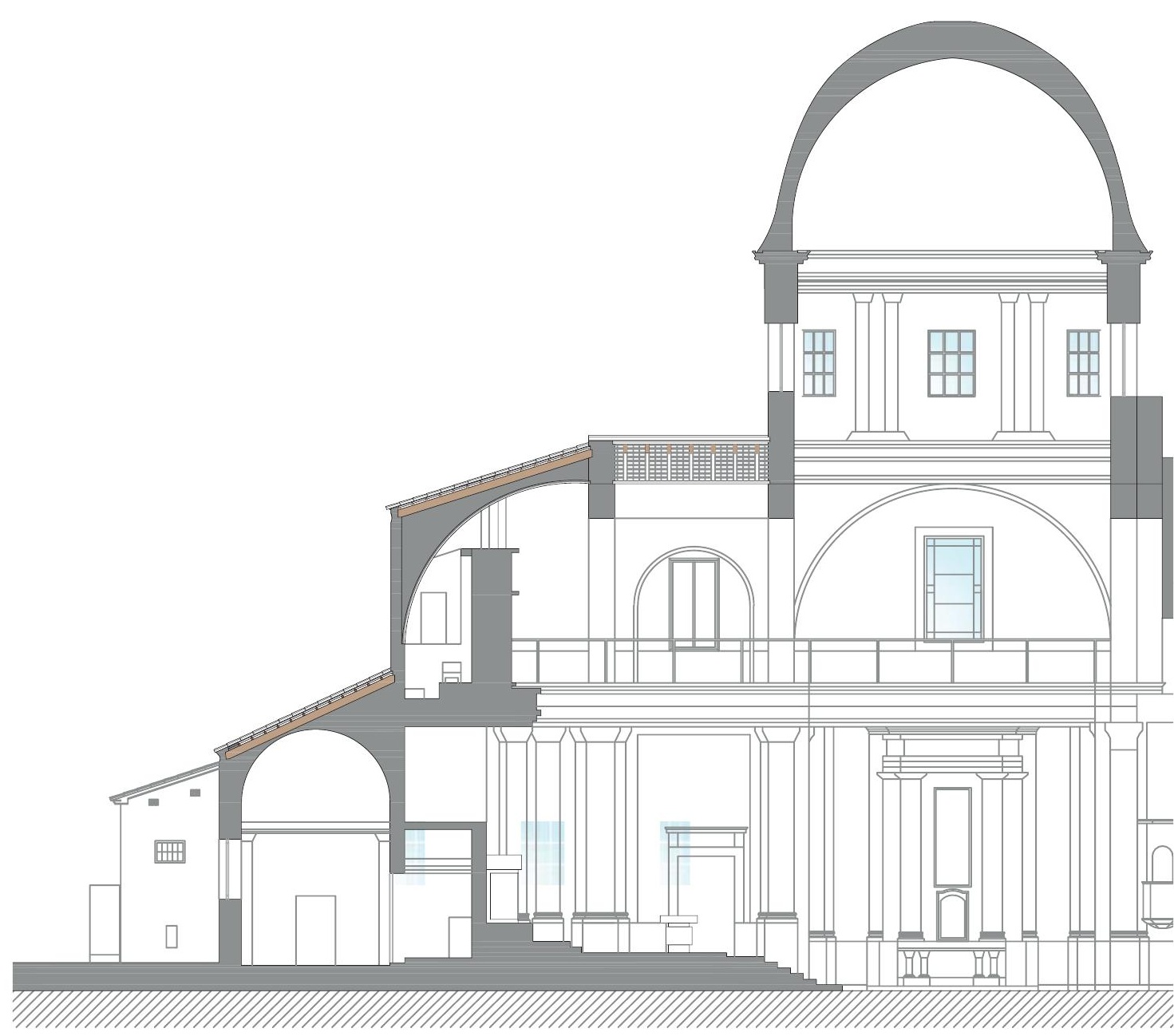

Fig. 163. Sección $A-A^{\prime}$ de la iglesia de Santiago Apóstol. En sombreado la nave gótica. El acceso se situaba el segundo altar por la izquierda y el altar se situaba en la actual entrada, a la derecha. 

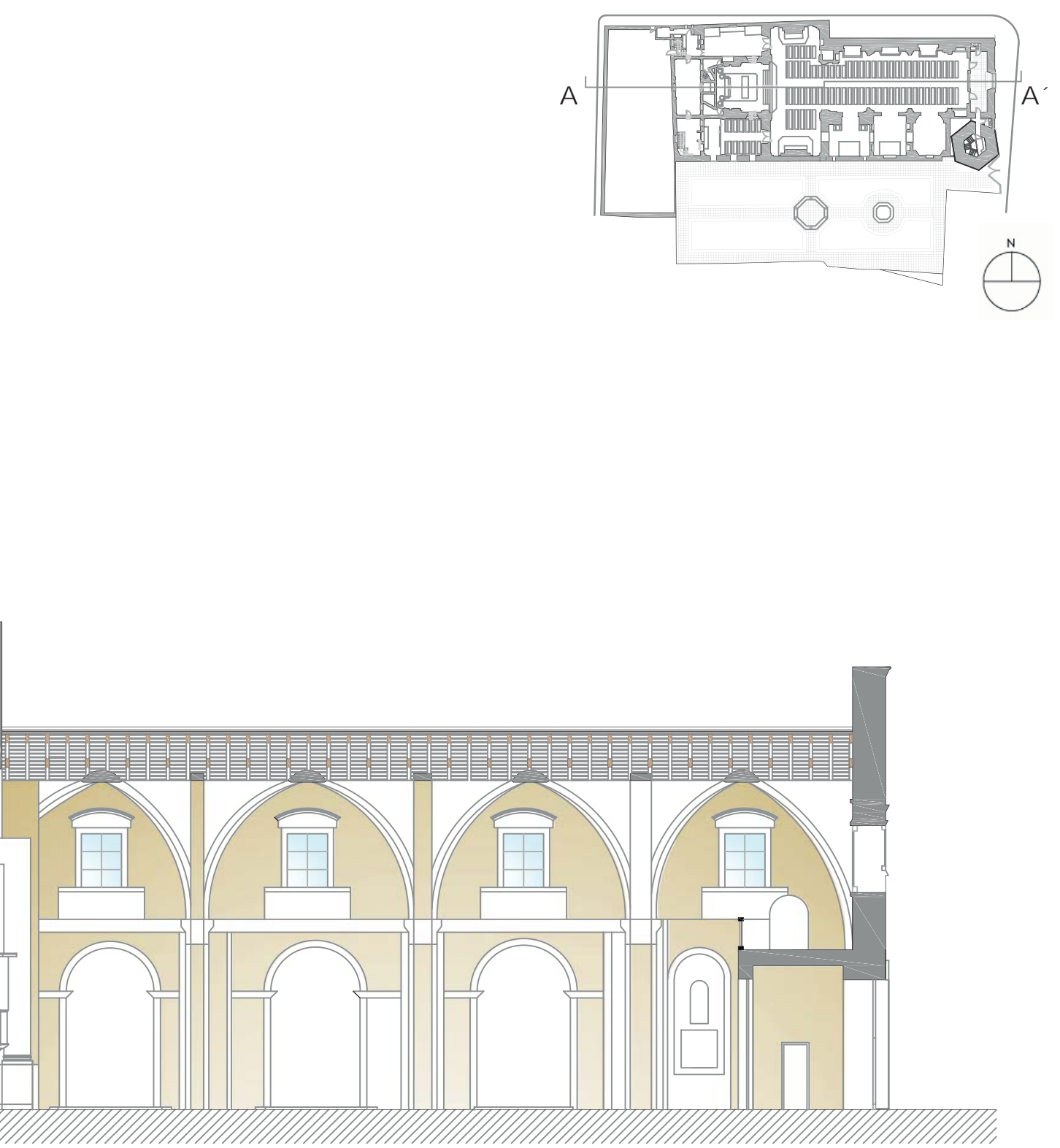

La Zona sombreada es la parte gótica 
La situación del inmueble es coincidente con la ubicación de las edificaciones con el mismo uso en la época de su construcción, dentro del municipio pero no el centro en la plaza mayor, sino junto a una de las puertas de entrada, en una esquina del parcelario.

Hay documentos que atestiguan que en 1304 se hace efectivo el traslado de la parroquia de Benaguacil a la Pobla de Vallbona como sede de los cristianos de ambos municipios. También indican que la situación requería la construcción presurosa de un nuevo templo para ofrecer servicio a la numerosa comunidad de cristianos que vivía en la Pobla. La referencia anterior asegura la existencia de otra iglesia o ermita anterior. Hasta 1304 parece que los cristianos de la Pobla dependían de la parroquia de Benaguacil:

la parroquia de Benaguacil fue puesta desde el
principio y erigido en el citado lugar de Benaguacil,
por razón de que, en el tiempo de su erección,
dentro de los límites de la misma Parroquia no
había ningún otro lugar poblado sino el predicho
Benaguacil. Más ahora, por la gracia de Dios, dentro
de dichos límites hay una nueva puebla llamada
Vallbona, en la que habitan más de doscientos
cristianos, mientras que en el predicho lugar de
Benaguacil, aunque moran más de quinientos
sarracenos, sin embargo cristianos habitadores no
hay más de cinco o seis, exceptuando al Señor de
dicho lugar, quien en ocasiones con su familia allí
suele residir226....).

Tal y como nos narra el documento citado, la petición elevada al arzobispo de la Diócesis de Valencia, Raimundo Despont esta iglesia fue realizada por el señor de Benaguacil, Jaime de Pedro, y su mujer Sancha Ferrandis, así como por el rector de la iglesia parroquial de Benaguacil, Guillermo Ginebrelo y los cristianos de la Pobla que se veían obligados a trasladarse hasta la vecina Benaguacil para asistir a los oficios. De esa manera, el arzobispo Raimundo Despont decidió finalmente:

${ }^{226}$ Despont, Raimun (1695): Manaments i Empares, $\mathrm{n} \div 3, \mathrm{~m}$ 27, f.48 año 1695. que es mucho mejor y más útil que la Parroquial Iglesia esté allí donde hay mayor número de cristianos, como sea penoso al Rector desplazarse al dicho lugar de Vallbona y a los hombres de Vallbona trasladarse al citado lugar de Benaguacil, a causa 
de la distancia entre ambos lugares, a recibir los Eclesiásticos Sacramentos, con el asentimiento del Capítulo Valentino, transferimos y mudamos la Parroquial Iglesia desde el citado lugar de Benaguacil al lugar predicho de Vallbona ${ }^{227}$ [...).

Es a partir de ese momento, 1304, cuando se ha de situar la construcción de la primitiva iglesia parroquial de San Jaime de la Pobla de Vallbona, que por mandato expreso del arzobispo había de contar con su propio cementerio para dar sepultura a los feligreses de la Pobla y que sus cuerpos no hubiesen de ser trasladados a Benaguacil, como hasta entonces. La erección de la iglesia de la Pobla, supuso además la traslación de la parroquialidad, pues desde ese momento se estableció que

en el lugar de Benaguacil no haya Iglesia parroquial; pero que la iglesia que allí hay y fue hasta ahora Parroquial de Benaguacil, quede a modo de Capilla; sin embargo pueden en el Cementerio de Benaguacil ser sepultados los cadáveres de los difuntos de dicho lugar si esto prefieren [...).

Del mismo modo, a partir de ese momento el rector de la parroquia de Benaguacil había de trasladarse a la Pobla, donde residiría de forma permanente en las casas y huertos proporcionados por los señores del lugar, Jaime de Pedro y Sancha Ferrandis. Igualmente, se le liberaba de celebrar los oficios en Benaguacil

sino tres veces en la semana por los días de fiesta y en estos días en que celebre misa en dicha Capilla de Benaguacil o haga celebrarla, no esté obligado a decirla en la misma parroquial Iglesia de Vallbona, ni esté constreñido el mismo Rector a tener otro presbitero mientras él personalmente esté en disposición de celebrar el sumo oficio [...).

Lo habitual es que existiera otra iglesia anterior a ésta, de similares características a la ermita de San Sebastián. Pero no se puede aseguar puesto que no existen restos ni documentación que lo acredite. Lo que se puede afirmar es que, la ermita de San Sebastián, es casi con seguridad anterior a la parte gótica de la iglesia de Santiago Apóstol, como se conoce en la actualidad. 


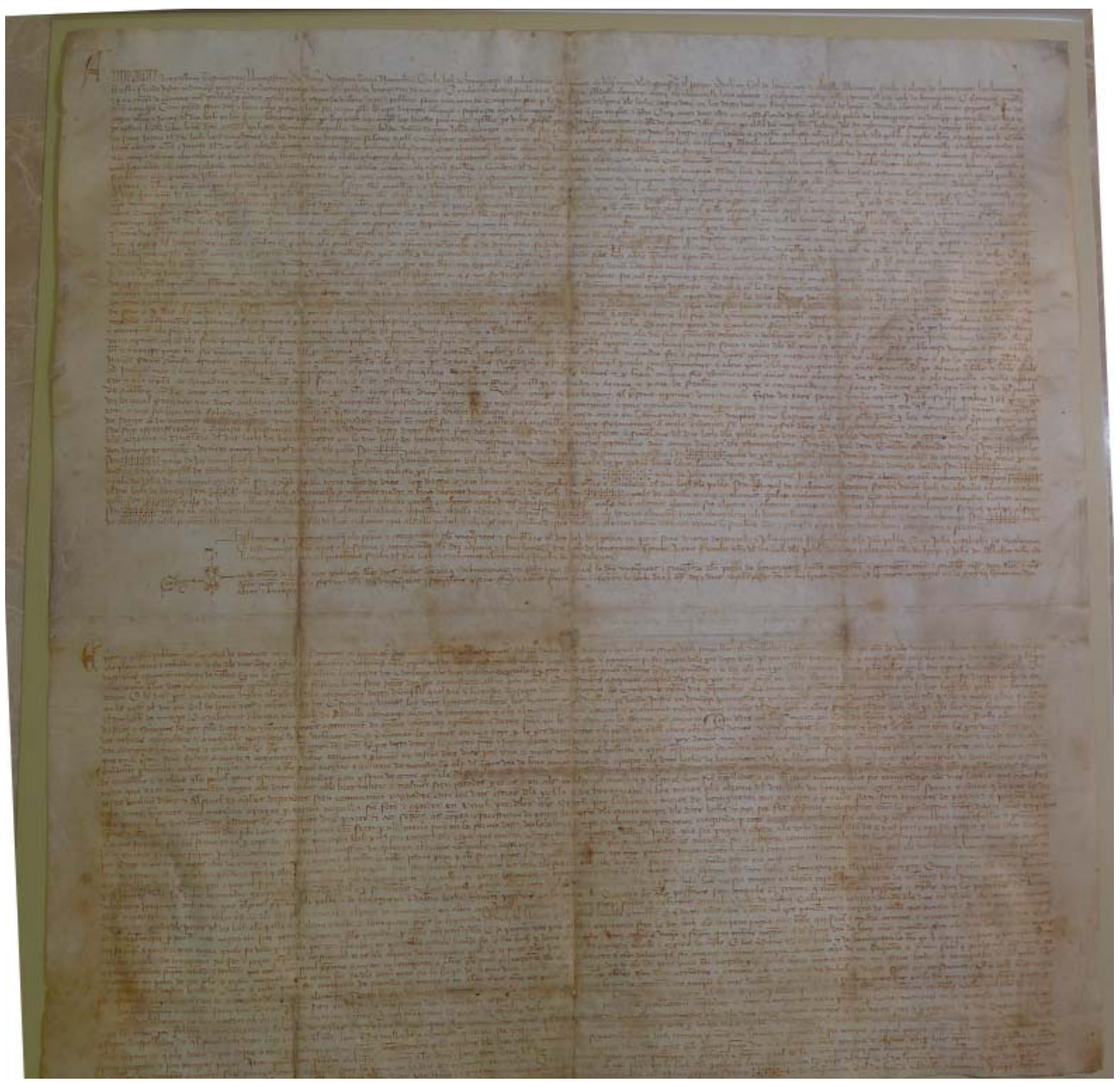

Fig. 164. Pergamino del Sindicato de Riegos fechado en el año 1390 donde indica que los hombres se encuentran reunidos en la iglesia de San Jaime.
Además de su factura gótica y las pinturas de gótico lineal, en lo que fue el altar mayor de la iglesia, uno de los documentos inéditos en el Sindicato de Riegos, nombra la existencia ya de la iglesia de Sant Jaume en el año 1390. En este pergamino, se recoge un acuerdo firmado entre los representantes de La Pobla de Vallbona y la comunidad musulmana de Benaguacil, fechada el 23 de septiembre de 1390 en el que nombra claramente la iglesia de San Jaime, puesto que indica que los prohombres de la pobla se encuentran reunidos en la iglesia de San Jaume de este municipio. Además queda reseñado que, en esta época, se continúa utilizando la denominación de La Pobla de Benaguazir para nombrar al municipio.

Después de las consideraciones anteriores es evidente que la iglesia parroquial de la iglesia de la Pobla de Vallbona debía servir culto no sólo a los habitantes de esta población sino también 
a los escasos cristianos que vivían en la cercana localidad de Benaguacil. Es por ello que su primitiva orientación se ve condicionada por este hecho y presenta su portada principal hacia el norte, recayente la portada lateral a la Calle Mayor. Se desconoce si habría más accesos.

Asimismo se ve condicionada por su ubicación ya que a la izquierda del edificio se encuentra el cementerio o fossary a la derecha, la vía principal de comunicación con Benaguacil. Este dato es fundamental, puesto que como se verá posteriormente, la iglesia nunca podrá ampliarse hacia la derecha convirtiéndose en una iglesia asimétrica.

No será hasta principios del siglo XVIII, entre los años 1700 y 1702, cuando se modifique la orientación de la iglesia parroquial. En esos años se decide reedificar la iglesia per a sa mayor perfecció y en las segundas capitulaciones, vistas las primeras por los expertos arquitectos Gil Torralba y Juan Pérez Castiel llamados a supervisar la obra, se decide cerrar ambas puertas y abrir unas nuevas en lo que era la antigua cabecera o testero de la iglesia ${ }^{228}$ :

\section{el haber de fer la Porta hon estava lo altar mayor de dita Iglesia}

Como consecuencia de estas obras se redactaron unos documentos para asegurar la correcta ejecución de las obras, dejando de este modo constancia para la historia de cómo era la iglesia gótica, $y$, aunque los documentos cuentan qué es lo que se tiene que ejecutar, señalan datos que describen someramente como era la iglesia original.

\section{Descripción de la iglesia gótica}

Una imagen superficial de esta primitiva iglesia medieval la ofrece los capítulos de obra que en 1700 se acuerdan entre los obreros Joseph Piño y Joan Batista Vinyes y la Vila de la Pobla de Vallbona, revisadas por los arquitectos expertos Gil Torralba y Juan Pérez Castiel. Debido a estos protocolos notariales, existentes en el archivo del Seminario del Corpus Christi de Valencia (Protocolos 21.981 - Notario Jaume Llorens ${ }^{229}$ ), es posible conocer cómo era la iglesia gótica y también como se quedó tras la reforma barroca.

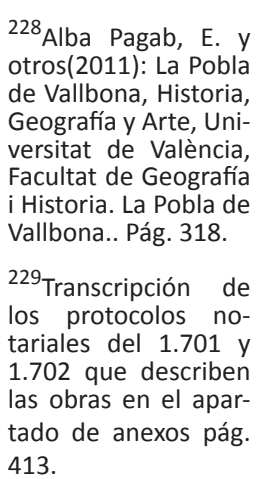

${ }^{228}$ Alba Pagab, E. y otros(2011): La Pobla de Vallbona, Historia, Geografía y Arte, Universitat de València, Facultat de Geografía i Historia. La Pobla de Vallbona.. Pág. 318.

${ }^{229}$ Transcripción de los protocolos notariales del $1.701 \mathrm{y}$ 1.702 que describen las obras en el apar413. 


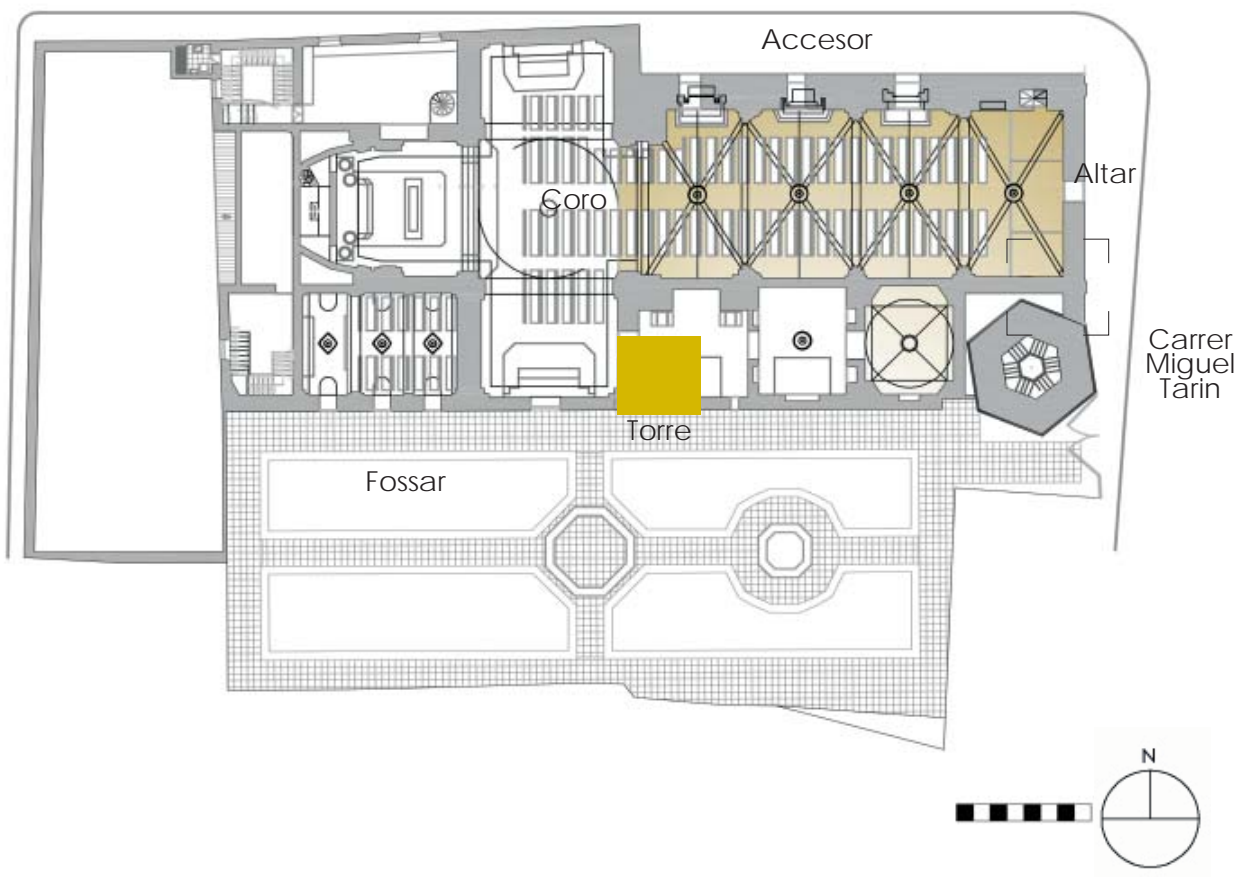

Fig. 165. Planta de la iglesia de Santiago Apóstol. En sombreado la nave gótica. La entrada se situaba en el tercer tramo por la izquierda y el altar se situaba en la actual entrada, a la derecha. El fossar se situaba en lo que actualmente es un jardín municipal.
La Zona sombreada es la parte gótic a 
Cabe decir que por los protocolos y debido al descubrimiento de las pinturas medievales pertenecientes al altar mayor, se tiene claro que el inmueble en época gótica se situaba orientado al contrario que en la actualidad y contaba con las siguientes estancias:

- Sacristía

- Sagrario/ Archivo

- Presbiterio

- Campanario

- Coro

- Altar mayor

- Capilla de Sant Jaime

- Pila Bautismal

- Capilla de san Luis Beltrán

- Capilla de San Andreu

- Capilla de la Virgen del rosario

- Nicho de Santa Bárbara

- Nicho Maria Magdalena

Los escritos redactados para la reforma barroca, constan de dos partes. En el primero de ellos se detalla el nombramiento de los electos y la descripción de las obras que tenían que realizarse $y$, en el segundo, se redactan las explicaciones para ejecutar la obra de aquello que no ha quedado claro.

A continuación se procede a analizar ambos documentos para obtener aquellos datos que servirán para hacer una composición descriptiva de cómo era la iglesia gótica

\section{ALTAR PRESBITERIO}

A consecuencia del descubrimiento de las pinturas góticas, se conoce a ciencia cierta que el altar mayor estaba en lo que actualmente es la zona de entrada de la iglesia. Este hecho queda ratificado por los protocolos notariales de la reforma barroca, cuando se indica que debe de cambiarse la puerta al lugar dónde se encuentra el altar.

\section{PUERTA ENTRADA}

Los protocolos notariales reflejan que la puerta de entrada se situaba en el penúltimo tramo de la iglesia, pero no al sur, como es normal, sino al norte, puesto que daba a la vía de acceso, más cercana al municipio de Benaguacil. Hay que tener en cuenta 
Fig. 166. Conforme lo descrito en los protocolos notariales de la reforma barroca, los pilares de la iglesia gótica eran de piedra redondos. Similares a los existentes en el Castillo de Calatrava la Nueva (Ciudad Real).

Fig. 167. Pilares actuales conforme al la Iglesia Santiago Apóstol. gusto del barroco en
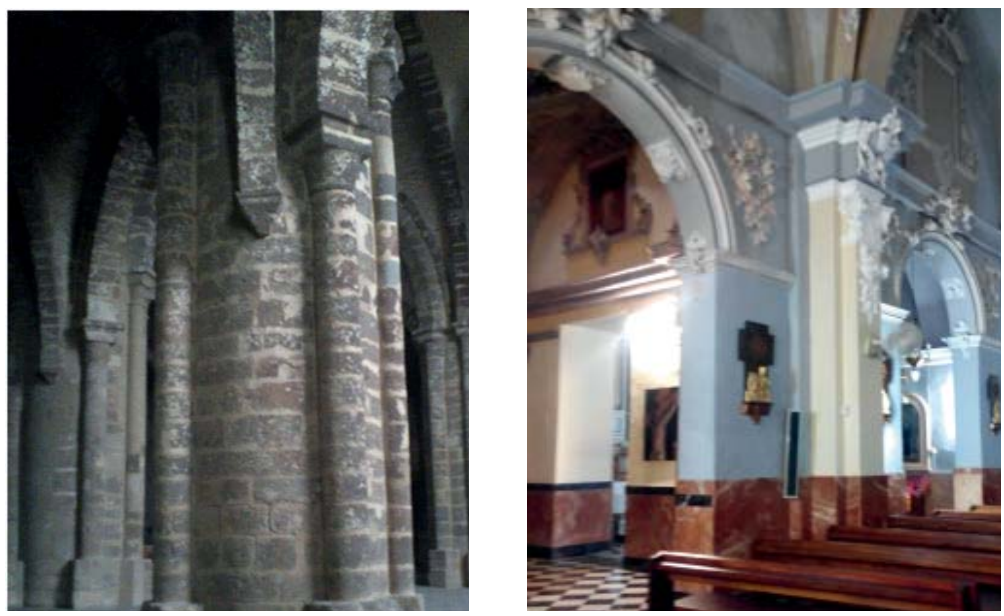

que al citado municipio le habían quitado la parroquiabilidad a favor de La Pobla, y, que sus pocos habitantes cristianos tenían que asistir a los ritos este templo, se obtiene una razón bastante lógica para ubicar la puerta en este lugar. En el párrafo trascrito también se puede extraer el material que formaba la portada, era de piedra.

Item que el dit mestre tinga obligació de retirar la prota principal de dita iglesia que está al carrer machor de la present Vila, lo qual ha de estar retirada a la part y deves del cor...y la dita orta se ha de obrir de la mateixa amplaria y alsada que hui es trova aprofitant les pedres de la Portalada que allí y ha y posantles que faltaran o rompran al temps de desferla en son llindar de pedra.... Item se ha de fortificar y asegurar per a la fortaleza de dita porta $y$ arch de la gruixa...y asegurar lo dit arch sobre dites branques $i$ axi el de pedra 230

Características de la puerta de entrada a la iglesia
y clavades dos ferradures que es troben en les portes velles, guarnintles dites ferradures en dos tarchetes picondes sobre la mateixa llanda per ser tradició del rey Don Jaume y quatre travesseres cada porta per la part de dins (...)

\footnotetext{
${ }^{230}$ Llorenç, J.(1700): Protocolos Notariales 21.981. La Puebla de Vallbona. Archivo de Protocolos del Colegio del Patriarca de Valencia.
}

Esta cita señala claramente que en las puertas de la antigua iglesia había do herraduras y que debían reutilizarse. 

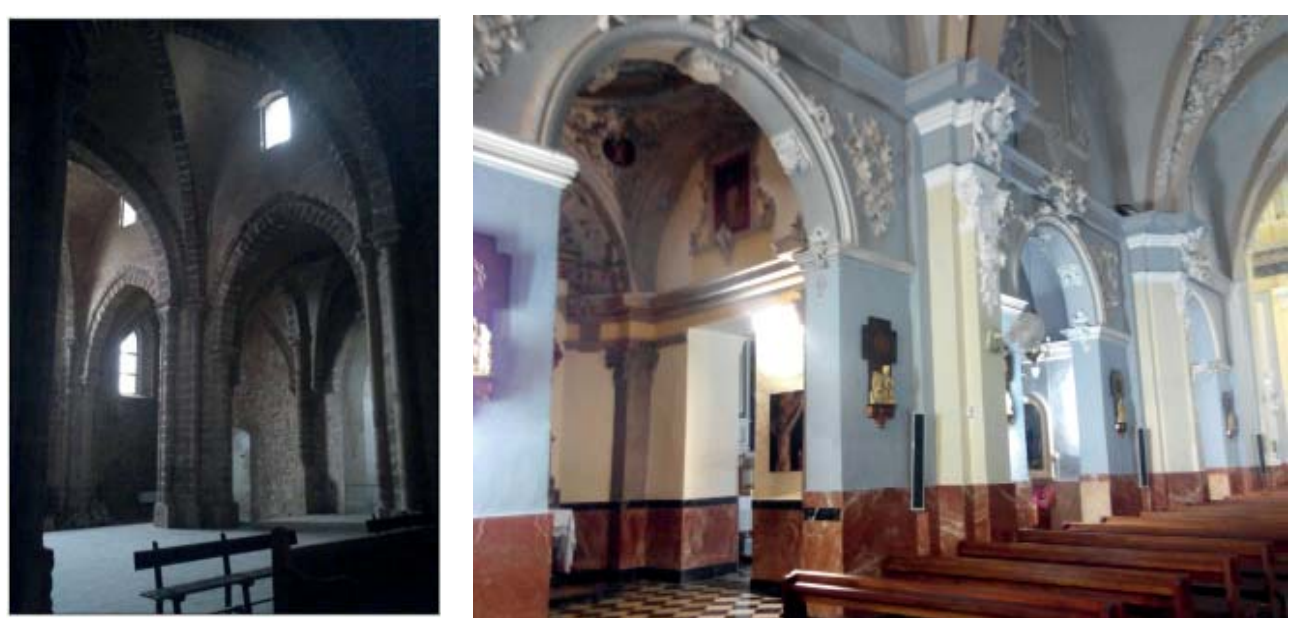

\section{COLUMNAS DE PIEDRA REDONDAS}

En los documentos se describe

obligació de fer fonaments en tots los puestos que carreguen los Archs de la Esglessia que al present son columnes de pedra redones y afondar aquells lo que sera menester y de la amplaria y llargaria que es trobara en lo carregant de dits archs en un pam de rabasa, o escarpa tota la arrededor ademes de la dita amplaria y llargaria de forma que la perpinticular del buelo que tenen tots los archs de pedra vinga a plom de les pilatres, ó pilastrons com en avan [...].

Por lo tanto de este párrafo se deduce que parte de la fábrica de la primitiva iglesia medieval era de piedra, al menos sus elementos estructurales tales como pilares y las mencionadas columnes de pedra redones, mientras que los muros y paredes debían ser de mampostería o tapial.

\section{COLUMNESO TAMBORINES DE PIEDRA}

Si se prosigue leyendo se describen exactamente:

[...] que sobre els fonaments del capitol antecedent se hagen de puchar les pilastres ó pilastrons en tota forma com es del payment de la Esglessia en amunt desta la alsada de quatre o sinch pams de rachola y morter blanch per raho de les humetats y lo restant de alli en amunt de algep y rachola ben

Fig. 168. Conforme lo descrito en los protocolos notariales de la reforma barroca, los pilares de la iglesia gótica eran de piedra redondos. Similares a los existentes en el Castillo de Calatrava la Nueva (Ciudad Real).

Fig. 169. Pilares actuales conforme al gusto del barroco en la Iglesia Santiago Apóstol. 


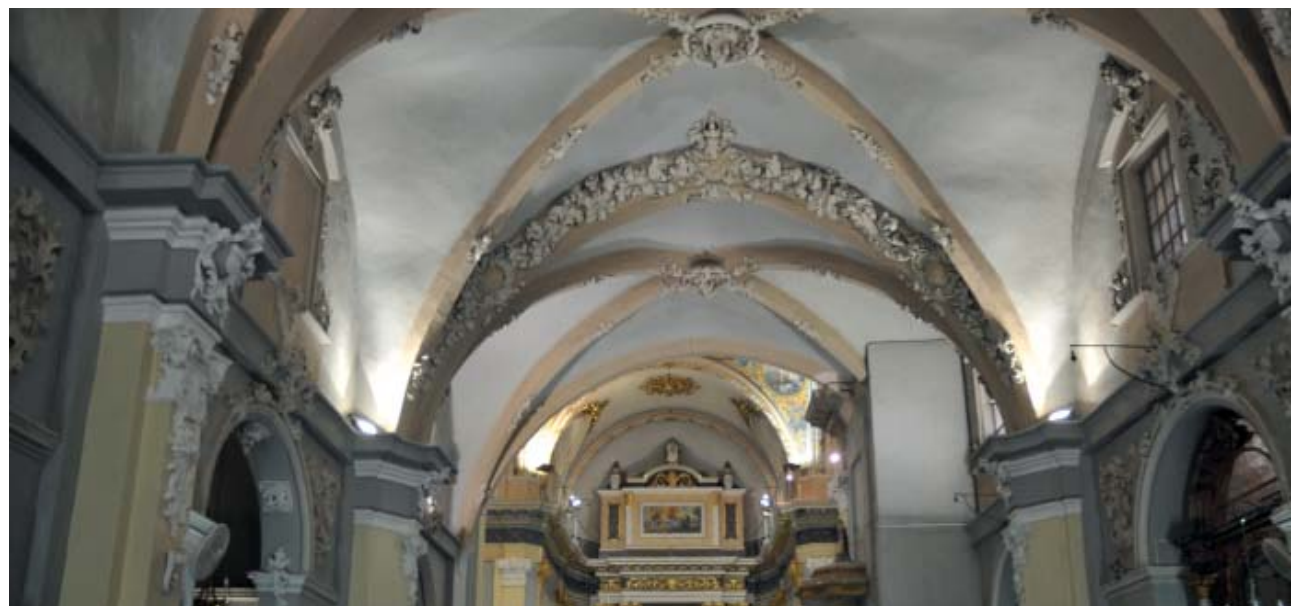

Fig. 170. Bóvedas barrocas tapando los arcos apuntados medievales y las bóvedas de crucería conforme al gusto barroco del a reforma efectuada. trabat fent moles en les dites colunes o tamborinos de pedra pera que quede ben trabada la pedra en la rachola y algeps [...].

No se puede creer que la iglesia contara con columnas exentas - sería uno de los pocos ejemplos en tierras Valencianas- dada la tipología parroquial de su planta, sino que en el documento se hace alusión a los baquetones de piedra y perfil redondo o curvo que se adosan a los pilares que se situaban entre capilla y capilla y sustentaban los arcos formeros, fajones y nervios cruceros de las bóvedas. Así se parece afirmar seguidamente, cuando se explica cómo hay que revestirlos. Asimismo también se mencionan los Columnes o tamborinos, denominación dada a los baquetones medievales.

\section{BÓVEDAS DE CRUCERÍA DE ARCOS APUNTADOS}

Si se continua con el análisis de los escritos notariales se señala que todos los arcos de la iglesia y los formeros son apuntados o del perfil ojival o apuntado de las bóvedas de crucería góticas, puesto que solicita "que se le cambie por otros de punt redo", conforme los dictámenes barrocos y clasicistas. De ello se deduce que el aspecto primigenio de la iglesia medieval era el habitual en las iglesias parroquiales que desde el siglo XIV se alzaron en el territorio Valenciano, de estructura gótica uninave, bóvedas de crucería apuntadas y capillas entre contrafuertes que contarían posiblemente también con pequeños abovedamientos de crucería simple.

en tots los demes archs de la Nau de la Iglesia y forners de aquella el quadrarlos de algeps y rachola 
del millor modo, y forma que es...

fent traves en los archs de pedra y de la amplaria que el planteig de gruixa de ells requirira y el quadrar dits archs ha de ser reduhintlos a punt redo en lo mig de aquells... y la mateixa diligencia se fara en demes voltres suavisant aquelles com ya esta dit en les dos primeres [...].

\section{SITUACIÓN SACRISTIA Y CUBRICIÓN}

Item que el dit mestre tinga obligació de desfer la volta de la Sacristía y la paret que sustenta aquella que es la que esta entrant en dita Sacristía a ma dreta y puchar les tres parets tot lo que dara la teulada y bolta de la Capella de Sent Lluysy teulada de la Sacristía [...].

El párrafo anterior indica que la sacristía lindaba a la derecha, con la capilla de san Luis, y que estaba cubierta por una bóveda, más baja de altura que la del anterior. También nombra la primera advocación que tiene la iglesia a Sant Luis.

\section{REVESTIMIENTOS CERÁMICOS}

El siguiente capítulo expone que en la capilla de san Luis se han de reutilizar todos los alicatados cerámicos existentes, aludiendo claramente a su procedencia de Manises.

Advertint que totes les racholetes de Manises les hacha de guardar y conservar y posar les que faltavan para tornar a chapar tota dita Capella y el sol de aquella la hatja de paymetar de taulells grans a cartabón [...].

\section{MUROS DE TAPIAL}

Tal y como se indica, los muros de los cerramientos de la iglesia eran de tapial. Este hecho queda marcado por el protocolo, pero también por la actualidad: todavía existen dos de estos cerramientos, el muro de la entrada (antiguo altar) y el cerramiento derecho, que puesto que estaba el camino real no se podía ampliar, y por esta razón, supuestamente, nunca se modificó. 
advertint que si paregues a la present vila la tapia fos de bona calitat e la fondar tres pams par el nicho o retable [...].

\section{VENTANAS}

En las segundas capitulaciones se nombra por primera vez la existencia del campanario gótico. Su ubicación se irá perfilando a lo largo de la lectura, pero de momento ya se puede saber que había una ventana en el arco formero del coro que no estaba centrada, pero no indica nada de sus dimensiones. También se señala que han de abrirse ventanas en el resto de los arcos formeros, por lo que podíamos pensar que no había ventanas en los siguientes arcos.

Item que el dit mestre tinga obligació de retirar la finestra que está en el Forner del cor tan arrimada al Campanari com se puga [...].

\section{CAPILLA DE LA VIRGEN DEL ROSARIO}

Conforme indica los archivos del ministerio de Cultura la orden de los dominicos tuvo un convento en intramuros en el municipio que nos atañe desde el año 1550 hasta 1619, denominado Convento de San Luis Beltran. Por lo tanto esta orden eclesiástica estuvo presente en el municipio durante sesenta y nueve años, dato también señalado en el registro hispano domincal ${ }^{231}$. Por esta razón, no extraña que la capilla de la comunión ya existiera en la iglesia gótica, aunque seguramente no la ubicarían hasta finales del siglo indicado. Los protocolos marcan su existencia, indicando que era pequeña, de 6 palmos de ancho y también el lugar de su ubicación.

Item que en la capella de la Mare de Deu del Roser...y en el cas que el arch que está a la part de dins de dita capella te set pams de gruixa no donas Iloch [...].

\section{CORO Y CAPILLAS} cap de altra que es present fer y se adevertís que derrocades aquelles se han de macizar les dos boques de aquella de tota I gruixa [...]. 


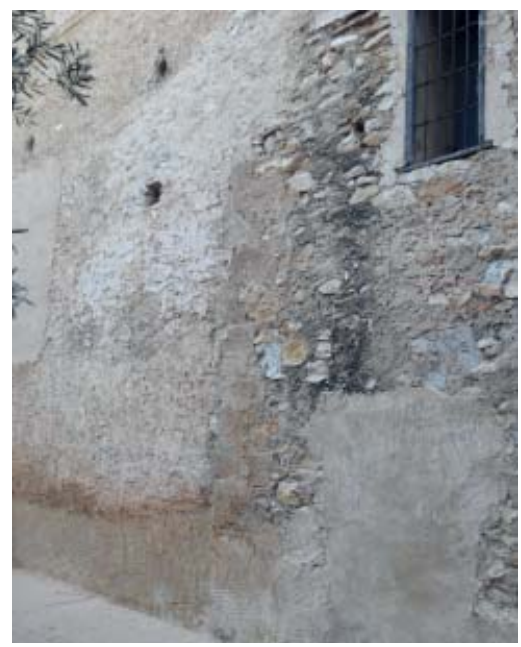

Fig. 171. Posibles restos del paramento vertical de la torre gótica en la fachada medianera situada frente al fossar medieval.

Como se puede observar también se habla claramente de la existencia de dos capillas debajo del coro.

\section{TORRE CAMPANARIO}

Por la descripción encontrada, y puesto que la torre actual es barroca, siempre se supuso que había existido una torre anterior perteneciente a la primera iglesia. Su ubicación parece estar clara, lindando al fossar, separado del coro exento. Aunque no es ámbito de estos protocolos su restauración, si que indican una serie de reparaciones que debían realizarse y es por esta razón se puedes conocer su ubicación:

Item que en la paret del Cap de altar en la porta que correspon al Sagrari esta se ha de obrir pera dar entrada al campanar fent a la part del fosar una paret de rachola y micha de amplaria a la alçada que sia menester co es a cartabó obrint una porta en la paret del Campanar asegurant ambes dos parets en dos Archs de Rachola y micha de Huella y de tota la amplaria de la pared cobrint el dit pasadis en una bolteta del modo que es puga acomodar doblant aquella y encarreronantla be en ses bandes en la teulada paymentada com les restants de dita obra [...].

\section{ADVOCACIONES}

Si se siguen analizando los protocolos, se extraen las antiguas advocaciones, puesto que va nombrando con el nombre del 
santo las diferentes capillas, aunque no describe como eran. Nos encontramos con la capilla de Santa Bárbara,

XXIV Item que el dit mestre tinga obligació de fer un adornato en dos pilatretes y un frontispici en una tarcheta en lo mig de bona talla en lo nicho de la Gloriosa Senta Bárbara en la imposta ala part de fora bases daticurbes, y que el dit adornato sia de ordre composta en son alquitrau, fris y cornisa y tot lo demes que es requereix segons bones regles de architectura posant uns relampaguets de talla en los puestos que mes convinga (...) y moldures ben llavades y florons donats de alabastre [...].

Y la capilla de Santa María Magdalena:

XXV Item que el dit mestre tenga obligació de fer un adornato en los mateixos pactes condicios, circunstancies $y$ ordenanses que el de Senta Barbera en la capella que esta davall lo Cor colateral al caragol que puchen al Cor so advocació de Senta María Magdalena [...].

\section{INSIGNIAS DEL REY JAIME I}

Al ser la Pobla de Vallbona un municipio creado a partir de la reconquista, son innumerables las señales que aparecen dedicadas en los protocolos, indicando la existencia de las insignias de rey Jaime I y del deber de guardarlas.

En la puerta:

Arquitectua y talla que ha de la Sacristía principal con se veu en lo perfil y fer les portes de la Iglesia les que cahuen al carrer de dos cloendes ab son portich apeinasa des la part de dins y en llandades per la part de fora picades les dites llandes en les armes o insignes que voldran los elets y clavades dos ferradures que es troben en les portes velles, guarnintles dites ferradures en dos tarchetes picondes sobre la mateixa llanda per ser tradició del rey Don Jaume y quatre travesseres cada porta per la part de dins [...]. 
En las bóvedas y paramentos:

XVII Item que el dit mestre tinga obligació de picar totes les boltes y parets de la Iglesia ben picades y aixi mateix llevar totes les corfes de algeps que haura quebrantades y cascarrades aixi de les boltes $y$ parets $y$ en tot lo demes que sera menester $y$ después de (...) ben picat se agranara pera que salte be la pols y se arruixara molt en aigua y es llafardara de algeps lo que será menester y lo restant reparat de paleta que quede ben igual posant (...) les insignies de les armes (...) en la forma per ben ser la introducció del rey don Jaume de Aragó.

Después de lo anterior expuesto queda probado y demostrado el origen de la iglesia de Santiago Apóstol de La Pobla de Vallbona.

\section{Descubrimiento de las Pinturas Murales}

En el año 1993, tras unas rutinarias labores de albañilería en la iglesia Santiago Apóstol, el albañil D. Fernando Martínez y las feligresas D. a . Mạ Carmen Llopis Tortajada y D. a . Vicenta Castellano, descubrían, casi accidentalmente que detrás de una desconchado aparecía, la imagen de lo que podía ser una virgen María.

A la semana siguiente $\mathrm{D}$. Joaquín Aguilar, cura párroco de la iglesia Santiago Apóstol, lo comunicó al Arzobispado, quienes decidieron avisar a la Consellería de Cultura de la Generalitat Valenciana.

A partir de este momento se sucedieron una serie de visitas, del Ayuntamiento, del delegado diocesano, del director de restauraciones de la Consellería de Cultura, el director del museo San Pío $V$ y el director del Departamento de Arte del Ayuntamiento de Valencia. Todos coincidieron en que las pinturas eran importantes por la peculiaridad y singularidad de las mismas, señalando la importancia de su restauración ya que muy son pocas o nulas, las manifestaciones de este estilo que existen en la Comunidad Valenciana: gótico de transición del románico al gótico y por las fechas posibles de su realización, 
Sección Transversal B-B'de la Iglesia Santiago Apóstol
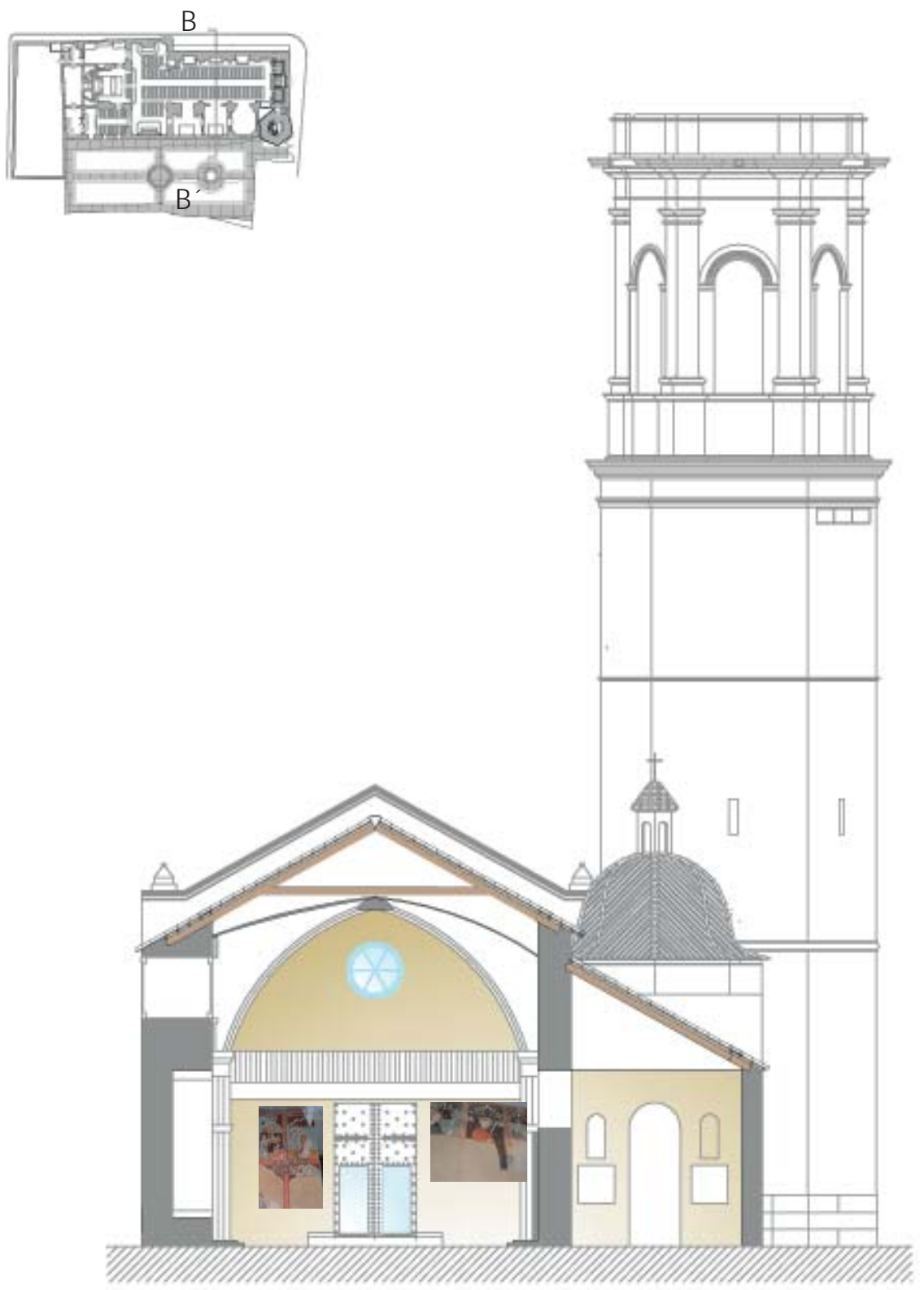

Situac ión de las pinturas mura les gótic as 
finales del siglo XIV, principios del S. XV, finales de los años 1300 , principio de $1400^{232}$.

La Generalitat Valenciana, a través de la Consellería de Cultura, Educación y Ciencia, después de tener la noticia del descubrimiento de las pinturas murales, dispuso, junto con el Arzobispado de Valencia, la restauración de tan importante conjunto.

La Dirección General de Patrimonio Artístico realizó la coordinación y la dirección de los trabajos. La ejecución se basó en los principios del máximo respecto a la historia artística de la original y en la finalidad de dotar adecuadamente al entorno con tal de garantizar unas condiciones de conservación ideales para el futuro ${ }^{233}$.

En la pintura gótica, la ornamentación tiene una función decorativa y narrativa al mismo tiempo. Así como la función decorativa prevalece en los ornamentos estilizados, el intento narrativo inspira, en cambio, la distribución del espacio, subdividiéndolo en compartimentos que contiene cada escena. Al artista gótico, no le interesa la profundidad espacial, que daría más realidad a la pintura, sino expresar una atmósfera mística y divina del episodio religioso. Los rostros de los personajes son dulces, serenos, agraciados y ligeramente estilizados, según el modelo ideal. El mundo figurativo de la pintura gótica es un universo de gracia, belleza, quietud, equilibrio, donde se borran el pecado, el dolor y la vulgaridad cotidiana ${ }^{234}$.
Fig. 172. Sección transversal $B-B^{\prime}$ de la iglesia donde se observa la ubicación de las pinturas medievales, altar mayor de la iglesia gótica.

${ }^{232}$ Aguilar Claramunt, J. (1997) "Crónica del Hallazgo de las Pinturas murales góticas en el atrio del templo parroquial de Santiago Apóstol".

${ }^{233}$ Los trabajos de recuperación de las pinturas que se realziaron en el año 1997 se detallan en el apartado Anexos A.2, pág. 432.

234 Blanco Gómez, P. y "otros" (1997):" Restauración. La Pobla de Vallbona, Pintures murals gótiques. Església Sant Jaume. Conservació i Resturació del Patrimoni Históric Valencià" en el Tríptico de la Conselleria de Cultura, Educació i Ciencia, Direccio General de Patrimoni Artístic. Valencia. 
$\mathbf{3 1 0}$ de 536

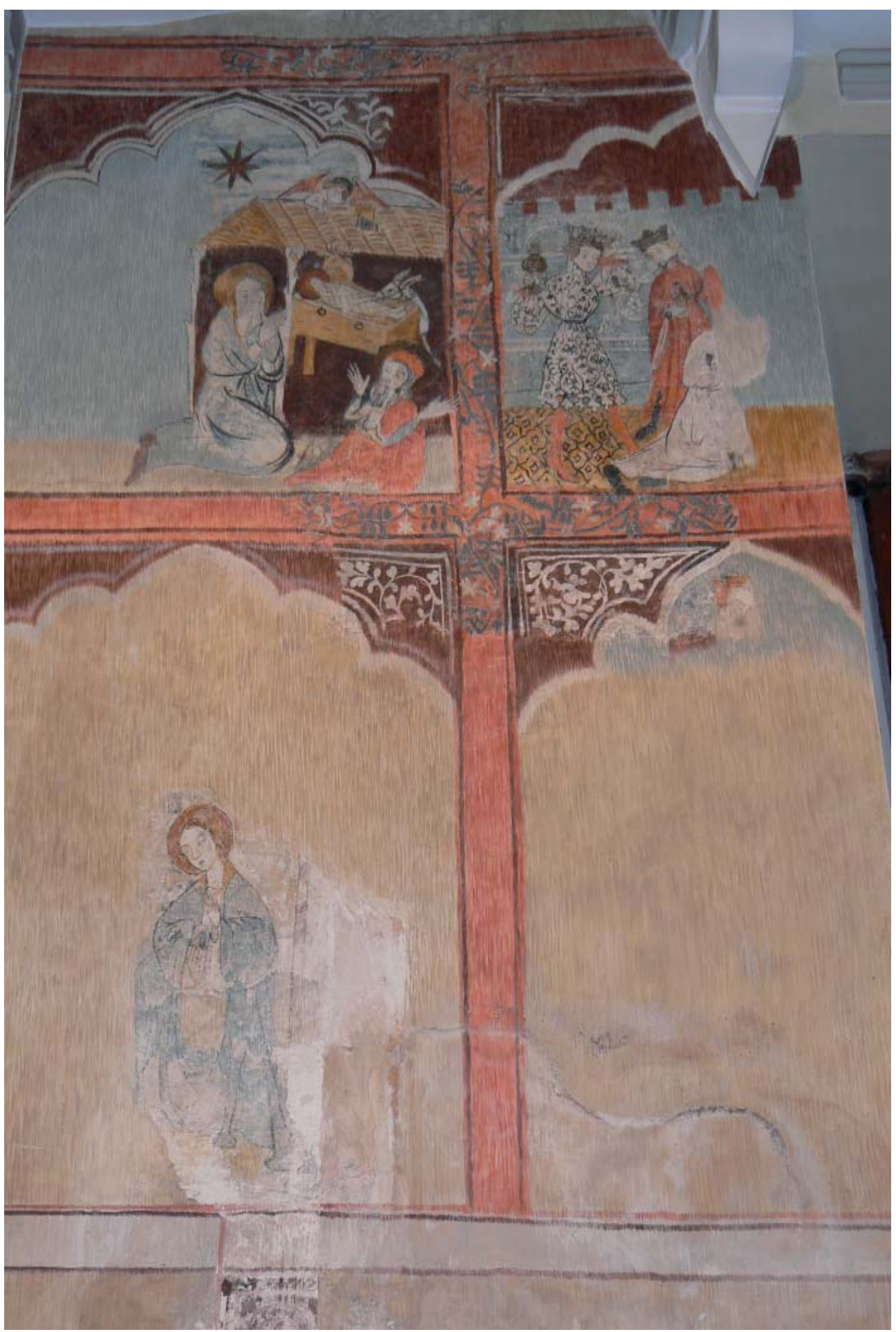


DESCRIPCIÓN DE LAS PINTURAS

Varios son los artículos y textos que Esther Alba ha dedicado a describir de manera detallada y precisa el arte pictórico del altar medieval de la iglesia de Santiago Apóstol ${ }^{235}$. Dichos escritos enumeran la riqueza ornamental que albergó esta zona del inmueble, siendo de vital importancia para entender la composición estética del edificio en la citada época.

Como se ha visto en el apartado anterior en el año 1701 la vila de La Pobla de Vallbona comenzó la transformación del inmueble gótico al gusto del periodo, el barroco. Entre otros muchos cambios, el más importante fue la modificación de la orientación de la iglesia, pasando a convertirse el altar mayor en el acceso principal del inmueble. En la zona central del paramento se abrió una oquedad para colocar la puerta de acceso, como consecuencia desaparecieron las pinturas existentes en este tramo y el muro de tapial al que recaía el antiguo altar quedó dividido en dos tramos.

Como consecuencia de la citada obra se puede contemplar en la actualidad a la izquierda de la entrada, los santos de la piedra, San Abdón y San Sénen, junto a San Gil, patrón de la Iluvia. Junto a estas escenas se observa, además, una escena de la Crucifixión. En el otro extremo del paramento vertical en la zona derecha, se puede admirar en la zona más baja la imagen de la figura de la Virgen María arrodillada rezando. En la parte superior las escenas se enmarcan en los recuadros creados por el fingimiento arquitectónico polilobulado: la Natividad y la Adoración de los Reyes.

Una primera impresión evoca de manera inmediata a las pinturas murales de la Sangre de Llíria ${ }^{236}$ y concederles una edad no muy menor a las pinturas del gótico lineal. Sin embargo un examen detallado de las pinturas, de su composición y detalles indica que debieron de ser realizadas antes de 1390, una fecha muy tardía para la realización de pinturas murales, pues hacia la segunda mitad del siglo XIV en Valencia comienza a generalizarse el uso del retablo para la decoración de altares mayores y capillas. Es por ello que se podría estar ante un ejemplo tardío de la utilización de la decoración mural en una iglesia de finales del siglo $\mathrm{XIV}^{237}$.
Fig. 173. Pinturas murales góticas del altar situada a la izquierda del acceso actual.

Fig. 174. Restos pictóricos medievales situados a la derecha de la entrada en la página siguiente.
${ }^{235}$ Alba Pagab, E. y
otros(2011): La Pobla
de Vallbona, Historia,
Geografía y Arte, Uni-
versidad de Valencia,
Facultad de Geografía
i Historia, La Pobla de
Vallbona, pág. 319
${ }^{236}$ Iglesia medieval
construida con arcos
de diafragma en la
misma época en el
municipio vecino de
Liria.

${ }^{237}$ Ibídem 235, 
312 de 536

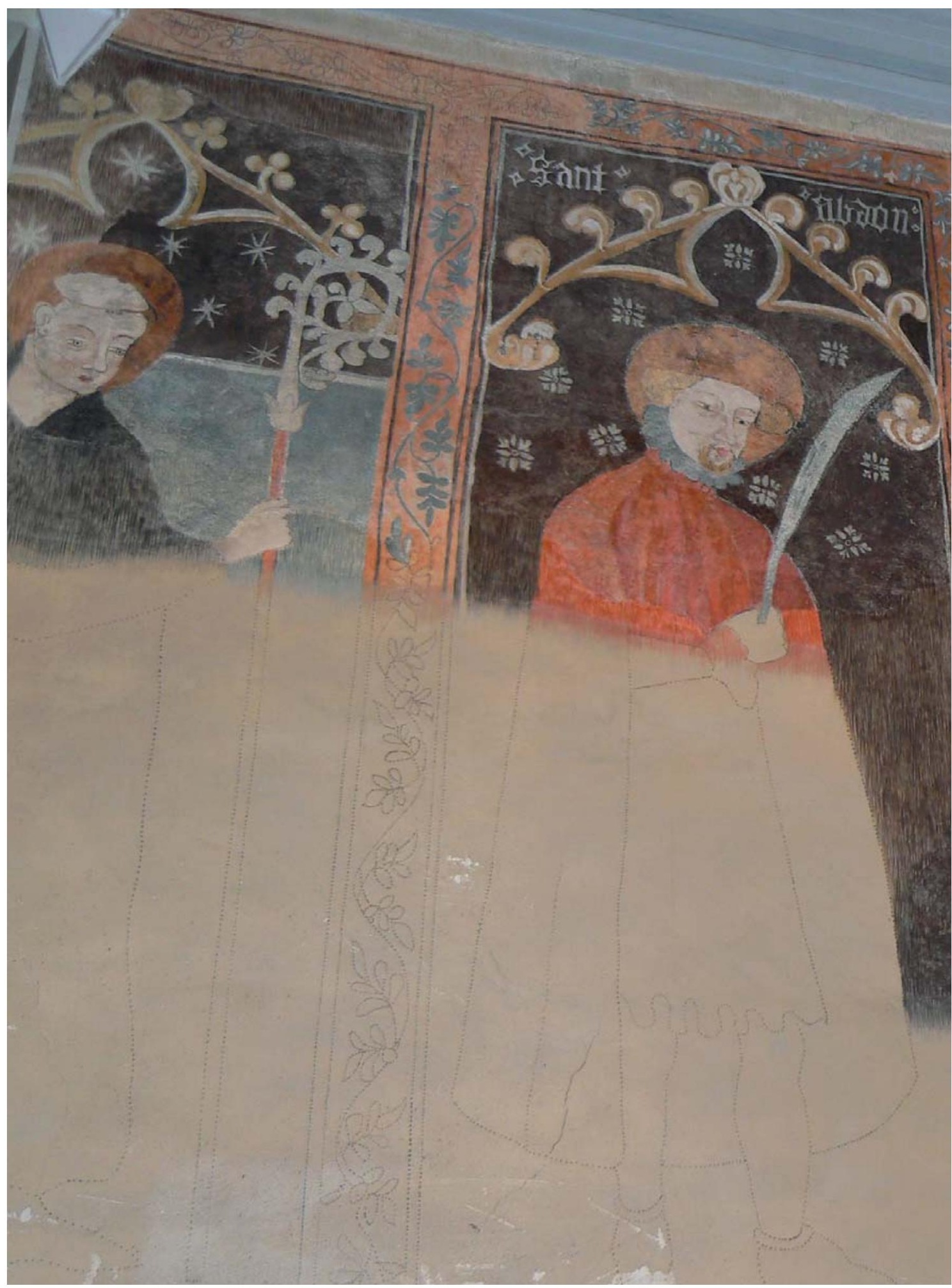




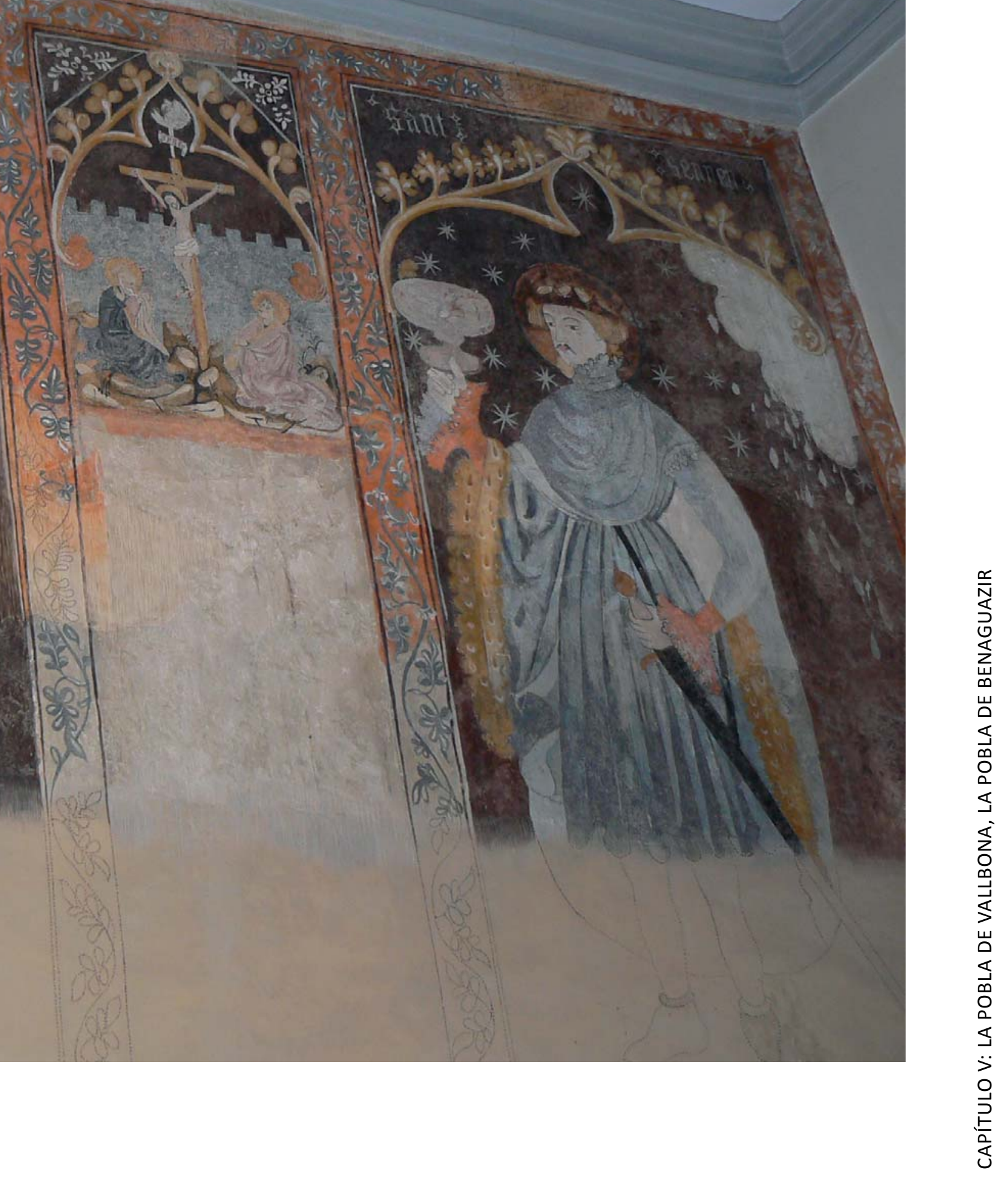


Tanto en Llíria como en Játiva existe cierta predilección por los colores planos, terrosos, ocres y siena. Sin embargo, en el caso de la Pobla se contempla la introducción de colores vivos y expresivos que pretenden emular el cromatismo de las tablas de los retablos góticos del momento. Igualmente sorprende la peculiar manera de encuadrar las escenas mediante recuadros fingidos que imitan la madera de los retablos y que incluso recogen la preciosa decoración vegetal que presenta en ocasiones la arquitectura retablística ${ }^{238}$.

En primer lugar procede describir las imágenes situadas a la izquierda de acceso actual. Este conjunto se divide en cuatro registros diferenciados, siendo el primero de ellos San Sénen, ricamente vestido sostiene una copa y con la otra mano sujeta su espada. Destaca la grandeza del personaje y la sutileza del dibujo, así como la búsqueda de la naturalidad al ubicar como detalles del personaje al que representan la nube, la nieve, el pedrisco y la lluvia.

Este mismo carácter de distinción también se observa en las figuras de San Abdón, que muestra la espada desenvainada, y San Gil con hábito monacal benedictino y báculo abacial. Una iconografía muy similar se observa en la tabla de San Jaime realizado por Joan Reixach y conservado en la misma iglesia pero fechado en el siglo de oro valenciano. El citado retablo puede contemplarse en el interior de la capilla lateral derecha.

El trabajo realizado tan detallado y pulcro, muestra un artista culto, conocedor de las corrientes europeas del momento. Por otro lado, los lujosos vestidos de moda, con cuellos abullonados y mangas con ricos encajes, las joyas y accesorios elegantes que revisten los santos, junto a la expresión serena, solemne, pero amable de los rostros de las figuras sagradas, son los medios que utiliza para comunicarse con los fieles y hacerles llegar el mensaje religioso además de darles a conocer los diferentes acontecimientos de la historia del cristianismo.

La devoción a San Abdón y San Sénen, los santos de la piedra o santos mártires como son conocidos entre los valencianos,

${ }^{238}$ Alba Pagab, E . y otros (2011): La Pobla de Vallbona, Historia, Geografía y Arte, Universidad de Valencia, Facultad de Geografía i Historia. La Pobla de Vallbona, pág. 321. se sitúa en el primer periodo histórico de la Pobla de Vallbona, fervor comprensible puesto que se trataba de una sociedad dependiente de la agricultura. 
Siguiendo las pautas marcadas, emana describir, la escena de la crucifixión. Cristo aparece clavado en la cruz con tres clavos según la iconografía tradicional, no es un Cristo triunfante, sino que está muerto, con la cabeza con la corona de espinas caída sobre el hombro derecho. La iconografía planteada está muy próxima a la de la tabla central del conocido retablo de Bonifacio Ferrer o Retablo de los Sacramentos (1396-1398), conservado en el Museo de Bellas Artes de Valencia, procedente de la Cartuja de Porta-celi, de la que dependía canónicamente la vicaría de la Pobla de Vallbona. En ambos retablos la sangre manada de las heridas de Cristo, especialmente de su costado, adquiere un importante protagonismo en la representación. Su intención es subrayar el valor de los sacramentos y especialmente el de la eucaristía ${ }^{239}$.

A continuación procede contemplar las representaciones pictóricas que se hayan a la derecha del acceso. La primera, la Epifanía o Adoración de los Reyes Magos: tan sólo se observan dos de las figuras de los reyes, la tercera arrodillada en actitud de adoración casi ha desaparecido, como el resto de la secuencia.

Aunque la escena de la Adoración de los pastores apenas deja intuir el aspecto original de la composición, la distribución espacial y el emplazamiento de las figuras guarda cierta similitud con la tabla anónima de la Adoración de los pastores del Retablo de los Gozos de la Virgen de Pobla Llarga, hoy en el Museo de Bellas Artes de Valencia, y con la Adoración de los pastores perteneciente al Retablo de la Virgen de la Esperanza, de Antonio Peris, en la parroquia de Pego. En las tres escenas se recurre a un cobertizo similar, paralelo al plano de la pintura, mostrando una estructura de planos entrecruzados de la techumbre a dos aguas y de manera idéntica se representa al niño Jesús cobijado en su cuna ${ }^{240}$.

En la zona inferior de las dos escenas descritas aparece una virgen María completamente sola, puesto que se ha perdido toda la representación original, recuerda a la imagen bíblica de la anunciación del Ángel Gabriel.

Para finalizar indicar que poco se puede decir de estas tres pinturas, puesto que cuentan con mayor simplicidad que las descritas en el otro tramo del muro, sin embargo es importante reseñar el carácter narrativo y elegante de la escena, mostrando un cierto expresionismo elemental pero fácilmente comprensible por el pueblo llano.

${ }^{239}$ Ibídem, pág. 322.

${ }^{240}$ Ibídem pág. 325. 
En estas mismas escenas se vuelve a comprobar la predilección por ricos vestuarios, especialmente el tejido con el que se adorna el primer personaje, confeccionado con un rico brocado decorado con aves y motivos geométricos, el mismo que muestran algunos personajes de los retablos de Gonçal Peris Sarriá (+ 1451), como el San Martín del Retablo de San Martín, Santa Úrsula y San Antonio Abad, conservado en el Museo de Bellas Artes de Valencia -y procedente de la Cartuja de Porta-celi - , y que se repiten en las telas o alfombras de las tablas laterales. Curiosamente ese mismo tejido aparece en la pintura mural de la Pobla de Vallbona, cuya vicaría como ya se ha indicado anteriormente era dependiente de la Cartuja de Porta-celi. Sea como fuese lo cierto es que de nuevo hay un dato que indica la cronología de la pintura, entre la última década del siglo XIV y la primera del siglo XV²4. 


\subsubsection{3| Peiró o cruz gótica}

Como se ha indicado anteriormente los peirons o cruces de término son monumentales cruces de piedra, levantadas con profusión en la baja edad media en las tierras de la corona de Aragón y en el Reino de Valencia, siendo habitual encontrarlos en municipios de origen cristiano y sobre todo en regiones con un elevado porcentaje de población morisca.

La Pobla de Benaguazir, era una villa de nueva creación cristiana, situada en un territorio ocupado en su gran mayoría por población islámica y dependiente, en origen, del municipio de Benaguacil donde residían un gran número de población musulmana. Por todo lo descrito no sería de extrañar la existencia de uno o varios peirons dispersos en su territorio.

Sin lugar a dudas las ubicaciones más habituales de estos bienes patrimoniales eran la entrada y salida de los pueblos o frente un espacio sacro de un santuario, delante de los calvarios o las ermitas. Tales consideraciones se cumplen en los municipios de Castellón, Vila-real, Almenara, Puzol, Gandia y Alcoy.

Por lo que respecta a los diferentes elementos que los componían, resaltar los siguientes: una gradería de dos o tres escalones circulares, cuadrados o poligonales; una basa, cuya sección suele corresponder con la gradería; la caña o fuste, habitualmente circular u octogonal, a veces decorada con estrías, y recorrida en su interior hasta hundirse en la gradería por un eje de cobre llamado "ánima", cuya función consistía en entrelazar los diferentes elementos de la cruz; la macolla o capitel, de varias formas, decorado o no con ornamentación escultórica; y finalmente la cruz propiamente dicha, donde se concentraba la decoración.

En La Pobla de Vallbona delante de la ermita de San Sebastián se conservaba un calvario con sus correspondientes pasos del vía crucis. Se desconoce su antigüedad, pero en un documento de solicitud realizada por el párroco Manuel Adam para la bendición arzobispal del lugar se menciona que el calvario existía desde antiguo: 
Fig. 175. Inauguración de la cruz del calvario en el año 1930 en sustitución de la destruida durante la Guerra de la Independencia.

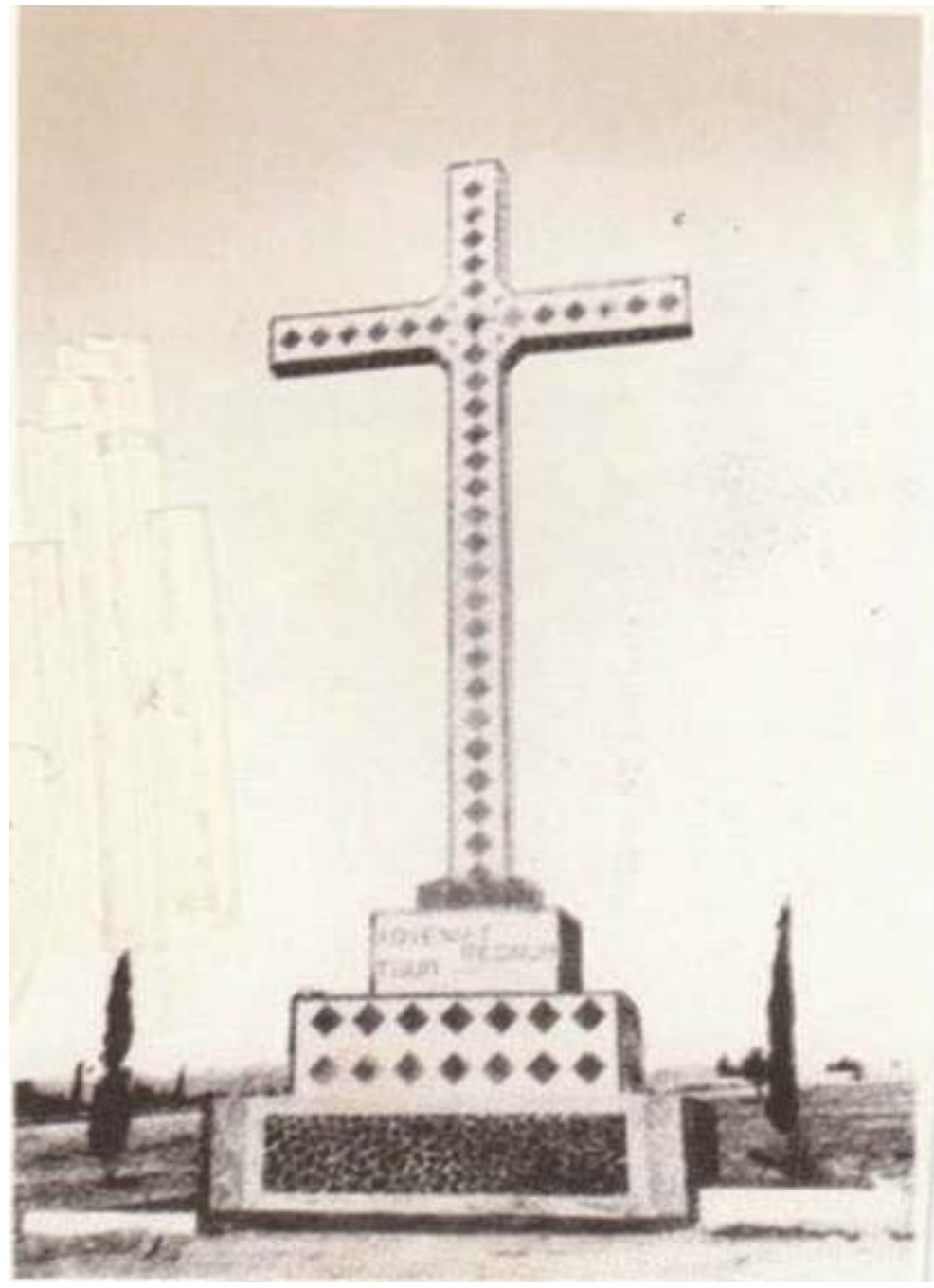

Que de tiempo inmemorial existe un Vía Crucis sito en la pendiente de la montaña de San Sebastián, término de dicha villa, cuyas casillas por razón de deterioro han sido restauradas ${ }^{242}$ [...).

El recinto del calvario se cierra con pequeños muros, y presenta una orientación de Sur a Norte, colocadas las estaciones, siete a cada lado, junto a los muros de cerramiento.

El acceso al recinto se encuentra presidido por una gran cruz. La antedicha se encuentra situada sobre una base escalonada, $y$, según fuentes orales, ha sido reconstruida dos veces. No se tiene constancia de documentos escritos que acrediten la
${ }^{242}$ Llavata Pitarch, V.(1981): Historia de la Villa y Baronía de La Pobla de Vallbona. Ayuntamiento de La Pobla de Vallbona, pág. 237. 


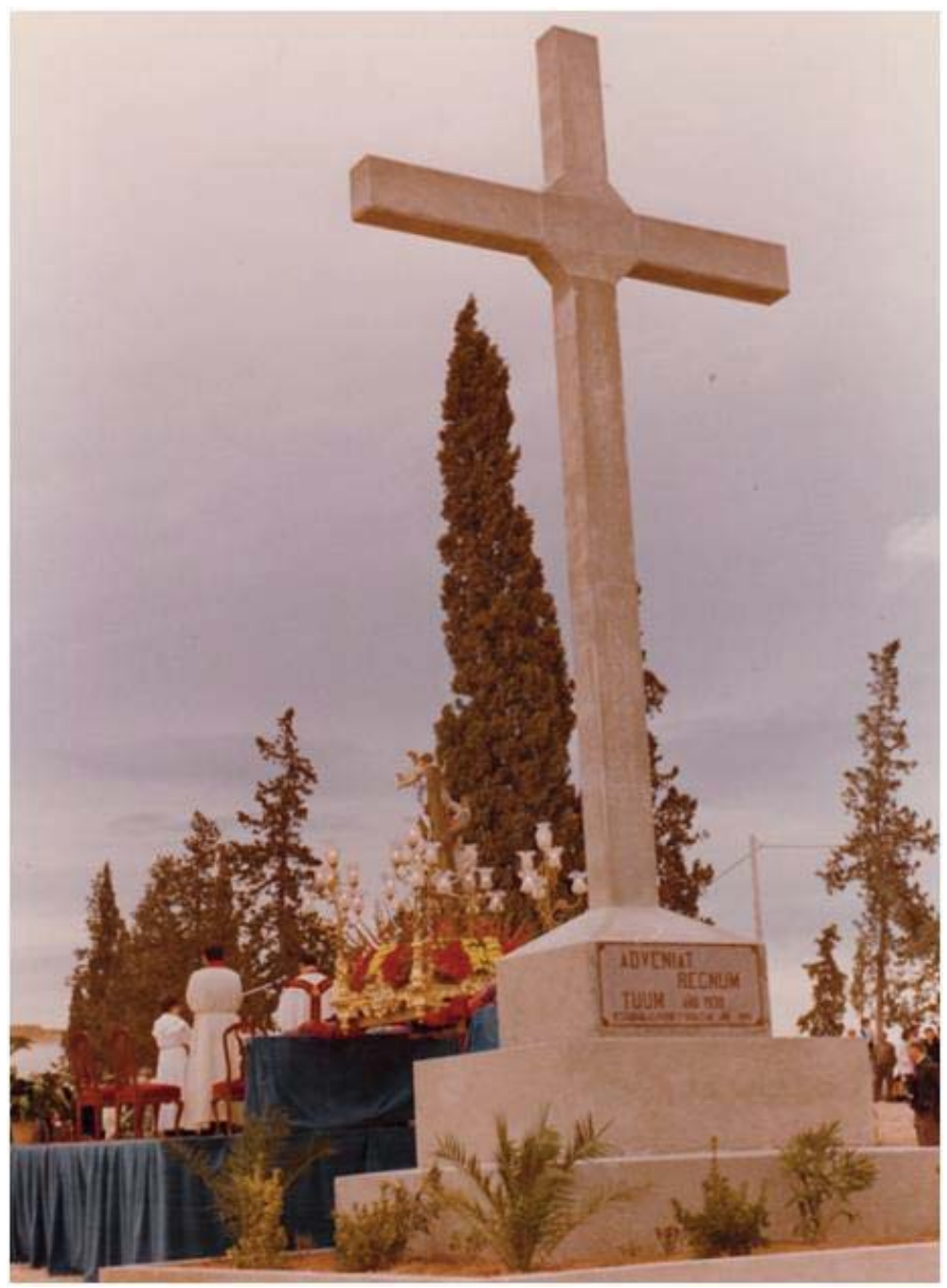

existencia de un peiró en el municipio objeto de este estudio, pero si lo hubo, todas las consideraciones anteriores apuntan que se ubicaría en esta zona, delante del calvario que da acceso a la ermita de San Sebastián y sustituyendo la actual.

Este bien patrimonial, tal como se conoce, se encuentra construida con hormigón armado, situado encima de un graderío de cuatro escalones de planta cuadrada. Fue bendecida el 20 de enero de $1985^{243}$ en sustitución de la que fue destruida durante la Guerra Civil Española.

Sin embargo precisar, que la cruz que se destruyó durante el conflicto bélico del 39 se colocó e inauguró el día 3 de mayo de 1930, en sustitución de otra que fue destruida durante la guerra
Fig. 176. Cruz actual, colocada en sustitución de la destruida durante la Guerra Civil Española. 
Fig. 177. Mapa de la batalla acontecida cerca de la ermita de San Sebastián durante la guerra de la Independencia el 2 de octubre de 1811.

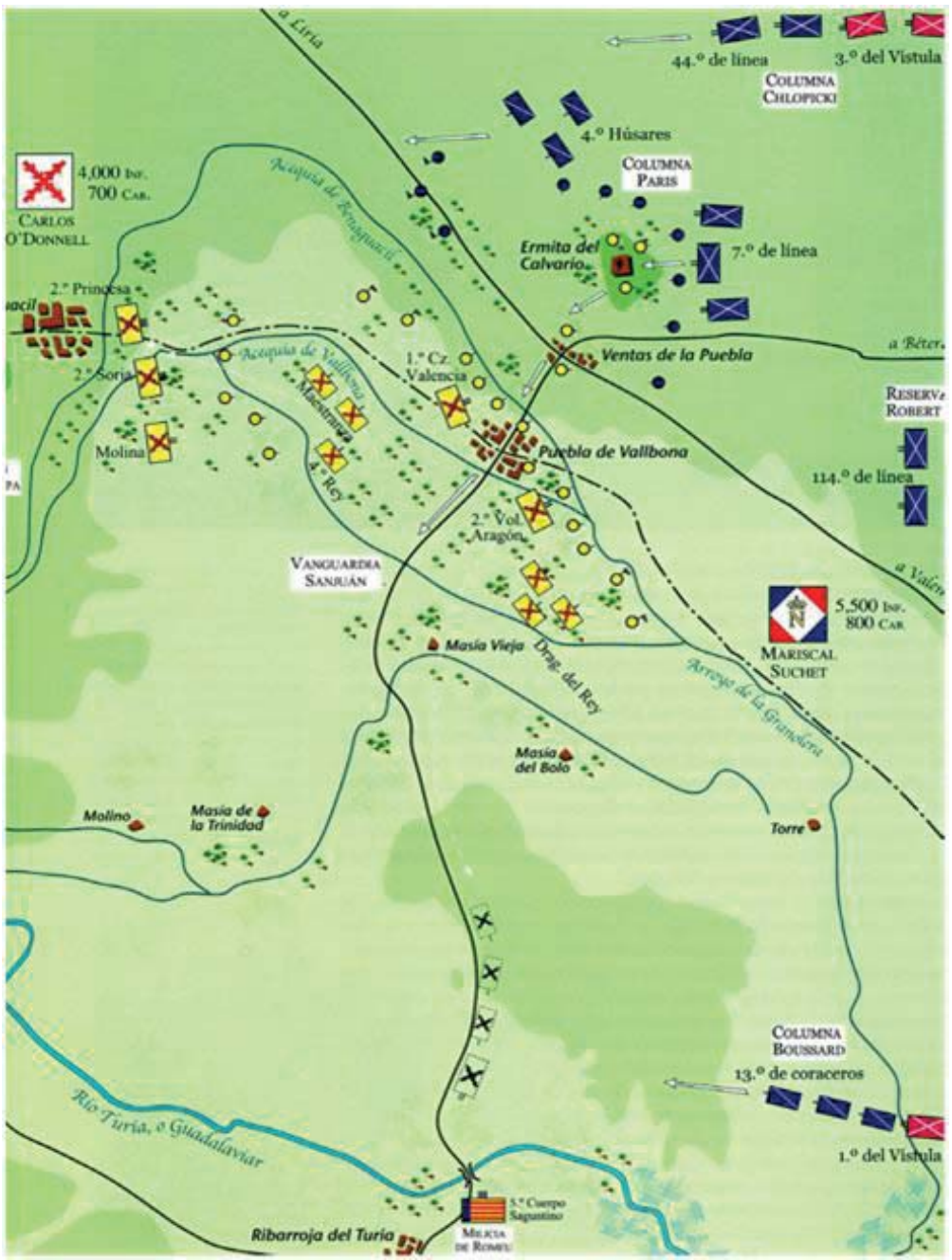

de la Independencia, en el fulgor de una batalla que acontecida en las espaldas del inmueble dedicado al patrón del municipio.

Dentro de las operaciones preparatorias de la llamada batalla de Sagunto, que condujo al sitio de la ciudad de Valencia, el 2 de octubre de 1811 tuvo lugar en su territorio un feroz enfrentamiento entre las fuerzas francesas del mariscal Suche y las españolas dirigidas por Carlos O'Donnel ${ }^{244}$. Los españoles se atrincheraron en la ermita de San Sebastián - situada en la parte superior del recinto-y, la cruz fue destruida. La nueva se realizó con ladrillo cerámico, tal y como muestra la imagen fig. 175 , respetando únicamente de su forma anterior el graderío escalonado. Pobla de Vallbona, Historia, Geografía y Arte, Universidad de Valencia, Facultad de Geografía i Historia. La Pobla de Vallbona, Pág.139. 
No se ha encontrado referencia escrita que describa la apariencia del símbolo anterior, pero de acuerdo con los razonamientos que se han venido realizando: población creada a partir de la reconquista, nuevo núcleo cristiano situado en una zona de moriscos, delante de un calvario y una ermita de arcos de diafragma y los únicos restos un graderío poligonal escalonado de piedra, es lógico pensar que originalmente este espacio albergó un peiró de época medieval.

\section{7| Toponimia}

El estudio de la toponimia a través de la documentación histórica existente o a partir de fuentes orales, permite en ocasiones identificar zonas de un centro histórico. Para ilustrar tal consideración, la existencia en la memoria colectiva de un carrer del Mig supone que había una calle arriba y otra abajo o si la denominación era Mitjà, la referencia es clara a su dimensión, se refiere ni al de mayor anchura ni al mas estrecho de los viales.

En el municipio objeto de este estudio donde toda la documentación escrita de la Corporación Municipal se destruyó durante la guerra civil española, es de vital importancia mantener aquella información y testimonios que han pasado de generación en generación. En ocasiones excepcionales se dispone de planos antiguos que ayudan en este trabajo, como en este caso el plano del canónigo Pedro Sucias Aparicio, pero raramente van más allá de mediados del siglo XIX.

En el marco de la observación anterior, se comienza analizando el nombre del municipio. Como se indicó anteriormente lo frecuente era que las fundaciones nuevas mantuvieran el nombre del hisn en cuyo territorio se implantaban. Les pobles de nueva planta se llaman, pues, como los antiguos husûn andalusíes, pero no se ubican en su emplazamiento. La Pobla de Benaguazir (actual Pobla de Vallbona) se sitúa a $2 \mathrm{~km}$ del núcleo del que depende, Benaguzir, pero su denominación hace referencia clara a él puesto que es un nuevo núcleo de población constituido en su territorio.

En diferentes pergaminos datados en el año 1400, se deja constancia al referirse a la nueva pobla con la denominación la Pobla de Vallbona alias de Benaguazir. Con el paso del tiempo, 


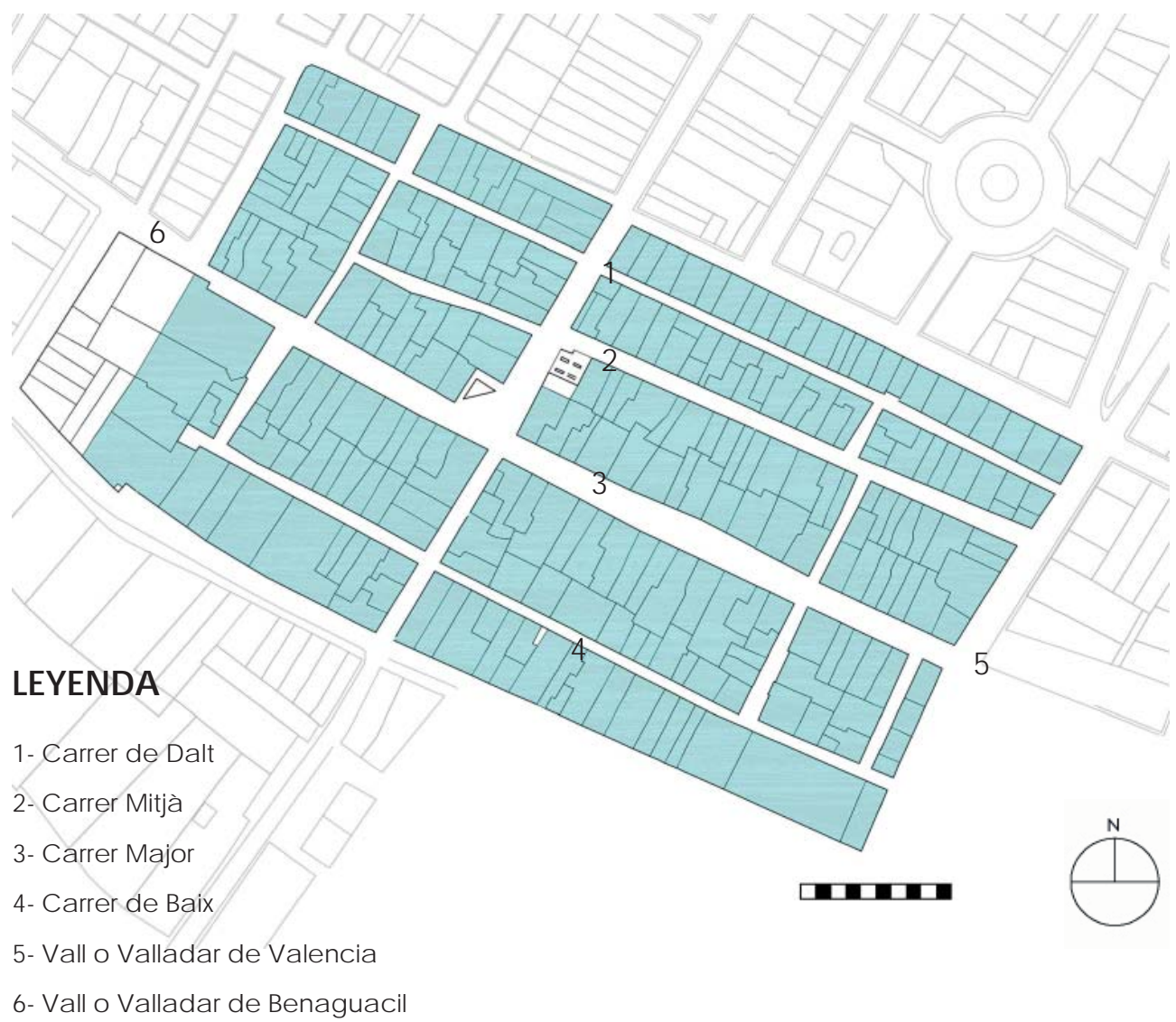

Fig. 178. El centro histórico de la Vila de la Pobla de Vallbona con los topónimos de cada vial y zona. en documentos fechados de 1700, desaparece el apelativo del término Benaguazir. En otras palabras, existe una predisposición desde los primeros moradores a detentar un nombre propio que no haga referencia a otro municipio, aunque en origen esa sea la costumbre. Este topónimo se perdió a lo largo de la historia, la memoria oral no lo recordaba y solo se ha podido recuperar por los escritos históricos.

En lo tocante a la denominación de los viales, como se ha demostrado, la planta de todos los centros históricos queda dividida por dos ejes principales, siendo el eje longitudinal, el que presenta una medida superior, el citado como carrer Major. En lo que se refiere a la calle principal del núcleo medieval de La Pobla se han localizado dos escritos que acreditan su antiguo nombre. En primer lugar, los protocolos notariales de la reforma barroca de la iglesia de Santiago Apóstol fechados en el año 1700, en el apartado XXI indica que se debe de modifica el acceso de 


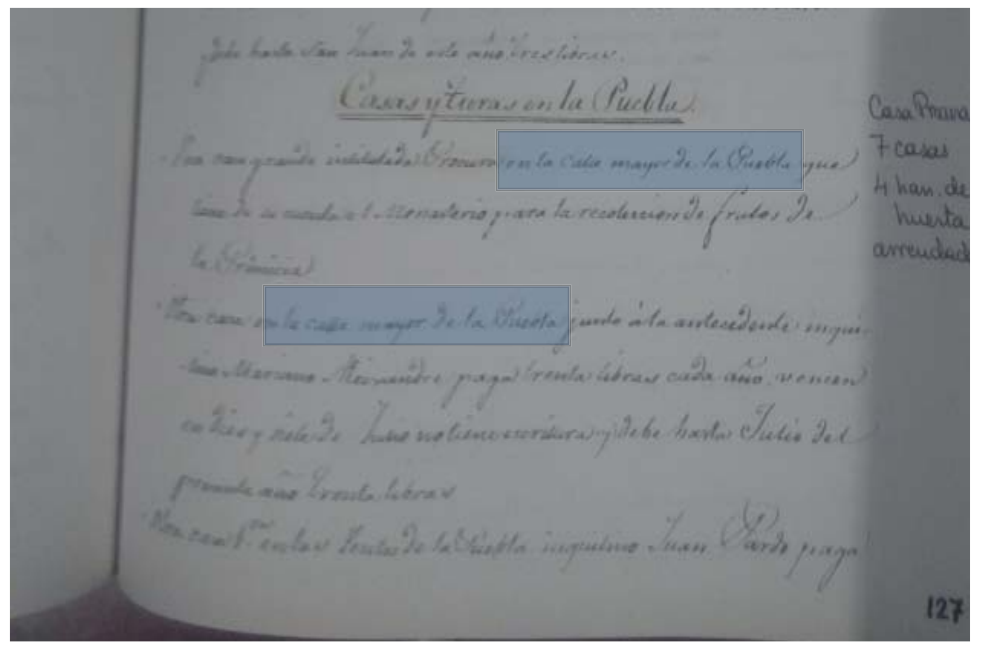

la iglesia gótica sito en la calle mayor a la calle perpendicular a esta, deja documentado claramente la nomenclatura de este vial en la citada época.

Item que el dit mestre tinga obligació de retirar la prota principal de dita iglesia que está al carrer machor de la present Vila, lo qual ha de estar retirada a la part y deves del cor [...).

La siguiente referencia histórica al citado apelativo se encuentra en los documentos que detallan las posesiones de la cartuja de Porta-celi en la vila ${ }^{245}$. Al detallar la ubicación de los inmuebles indica que se emplazan en la calle mayor de la puebla. El texto dice así:

Una casa grande instaurada para casa procura en la calle mayor de la Puebla que tiene de su cuenta el Monasterio para la recolección de frutos de primicia [...).

Otra casa en la calle mayor de Puebla junto a la antecedente inquilino Mariano Aleixandre paga treinta libras al año, vencen el diecisiete de julio no tiene escritura y debe el presente año [...).

En lo que concierne a los viales secundarios -en este caso paralelos al eje longitudinal- son semejantes a los apelativos que se utilizan en las vilas valencianas estudiadas. En la actualidad esas calles llevan otra denominación pero aún se conocen popularmente como antaño. Así se encuentra la calle d'Enimg o carrer Mitja (actual calle Jesús Pitarch), haciendo
Fig. 179. Documento del año 1820 que detaIlan las posesiones de la cartuja de Porta-celi en la Vila de La Pobla y deja constancia de la utilización del topónimo de carrer Major.

${ }^{245}$ Propiedades antiguas del reino de Valencia, Inventarios de la cartuja de Portaceli en el tiempo de las exclaustraciones 1812-40, legajo 470, pág. 127. 
Fig.180. Documento del año 1655 que detalla las posesiones del Convento del Carmen. Se describe la ubicación de un edificio en el carrer Mitjà, y la existencia del carrer de Baix.

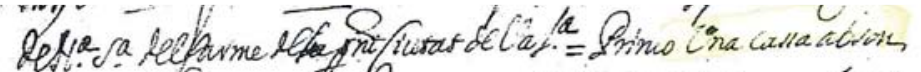

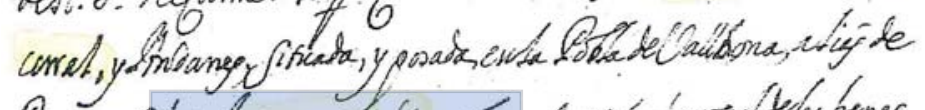

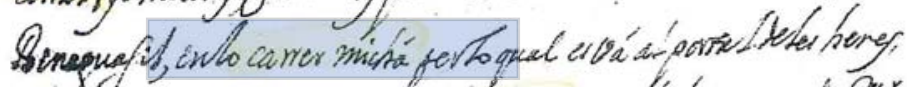

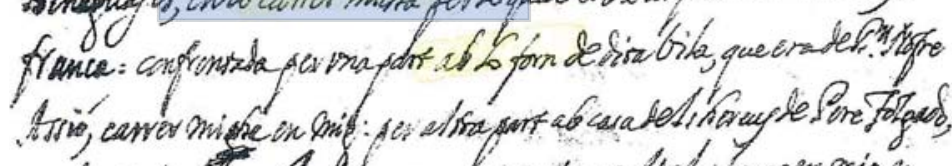

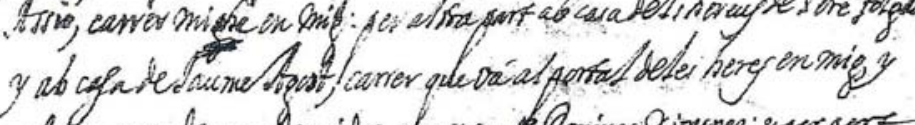

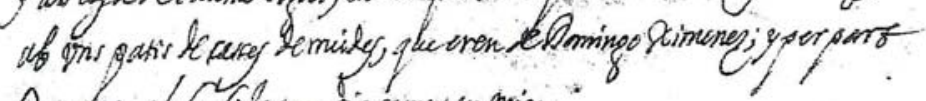

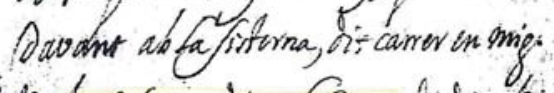

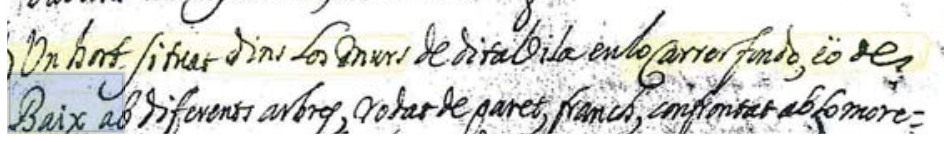

clara referencia a su dimensión. El carrer de dalt o d'amunt (actual calle Maestro Giner), situado al norte, y el carrer de Baix (actual calle Sant Antoni), el vial cuya ubicación es mas al sur.

Para documentar la existencia histórica de los topónimos de estos viales, se retoma el listado de posesiones del Convento del Carmen ${ }^{246}$, fechado en el año 1655, donde explícitamente utilizan los apelativos, el carrer Michá y el denominado carrer de Baix:
Un hort situat dins lo murs de dita vila en lo carrer fondo, o de baix, ab diferents arbres, rodat de paret, francs, conformats aba more...de de $S$. Nicandro Assió, murs de esta Vila, sequia y senda enmig y ab a altra part de dit mur, per la qual es port anar a Ribarroja y a la Casa de San Onofre, que solia ser Monastir [...].

De manera semejante se encuentra similitudes ente los diferentes municipios a la hora de denominar los portales de la cerca muraria. El portal que estaba en el camino que comunica La Pobla con Riba-roja del Turia, era conocido popularmente como el Portalet -apelativo aún es utilizado por el colectivo social para esta zona-. Este mismo topónimo se encuentra en los municipios de Penáguila y Almenara para uno de sus portales.

La segunda nomenclatura que se repite en varias poblaciones para denominar un portal, es el Valencia. En La Pobla de Vallbona se constata este apelativo para uno de sus accesos, puesto que 
aparece en el listado de las posesiones del Monasterio del Convento del Carmen ${ }^{247}$. Así se encuentra:

Sis cafisades y dos fanegues de terra poc mes o mens, franques, situades y posades en la horta de dita vila, en la partida de dos séquies y del Campes, confrontades amb lo portal dit de Valencia, ab lo Camí Real y ab torres de [...].

El siguiente topónimo que popularmente se ha conservado se trata del vall, nombre que se daba al foso que se encontraba alrededor del perímetro amurallado. En el núcleo histórico referenciado este término se utiliza para emplazar dos zonas. La primera en la zona lindante con el Portal de Valencia: a esta superficie extramuros, actualmente se conoce como calle la Eliana y Calle Juan Lázaro Blasco, se la denomina como el vall o valladar de Valencia. La segunda referencia encontrada en un documento escrito aparece en el libro de Vicente Llavata, historia de la villa y Baronía de la Pobla de Vallbona, donde indica que la zona recayente al portal de Benaguacil es identificada como el vall o el valladar de Benaguazir.

Para concluir un topónimo típico de las construcciones de piedra en seco. En el bajo medievo era común crear caminos para el ganado, así se conoce un camino situado entro dos muros, el assagador. Eran amplios corredores que atendían convenientemente el tránsito del ganado de una zona a otra, solían tener acequias o abrevadores para que el ganado pudiera abastecerse y los muros impedían que el ganado entrara a los bancales $^{248}$. La Pobla de Vallbona cuenta popularmente con un camino conocido como el camí del assagador. Se ubica entre parcelas de regadío, cuenta con bastantes acequias donde podría beber el ganado, pero se desconoce si estuvo delimitado con muros de piedra.

\footnotetext{
${ }^{246}$ Posesiones del Convento del Carmen (1655): Archivo del Reino de Valencia. Listado de posesiones desde el año 1600 al 1700 , páginas 19-21.

${ }^{247}$ Ibídem.

${ }^{248}$ Roca Traver, F. (2006): Tierra y propiedad en la Valencia Medieval, Ajuntament de Valencia, Delegación de Cultura, servicio de publicaciones, Valencia, pág. 126.
} 


\section{La Ciudad de Eximenis}

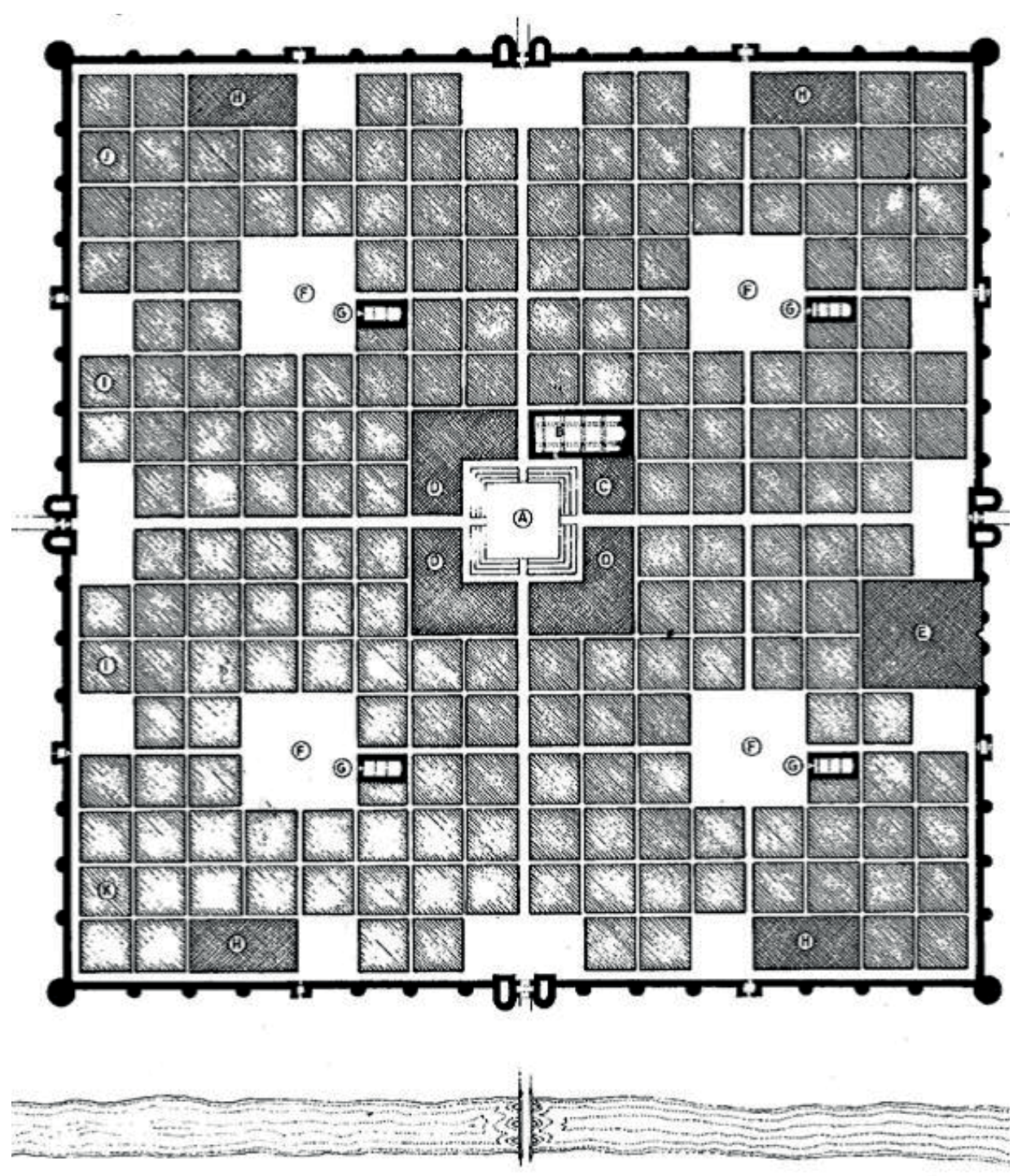

\section{LEYENDA}
A- Plaza Central
B- Catedral
C-Palacio Episcopal
D. Casas sacerdotales
E- Palacio del príncipe
F- Plaza de bamio

G- Parroquia

$\mathrm{H}$ - Convento mendicante

I- Hospital

J-Casa de Juego

k- Burdel

L- Puerta Principal

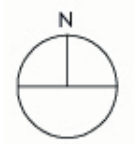


Fig. 181. La ciudad de Eiximenis según Ramón Beltran Abadía.

\section{EL URBANISMO POSTERIOR}

No se puede dar por concluido un estudio sobre las vilas nuevas medievales sin hacer referencia a Les Ordenacions de Jaime II. Fue el año 1300 cuando ordenó que las nuevas fundaciones que centralizaran la colonización del territorio fueran diseñadas por un ordenador o stablidor con arreglo a unas normas en que el espacio se reparte mediante cuadros perfectos $^{249}$.

Petra, San Pablo, Lluchmayory Felanitx son pueblas nacidas de un modelo de planta cuadrada de $450 \mathrm{~m}$ de lado, capacitada para 100 familias, dividida en 16 manzanas cuadradas, cada una de las cuales se subdivide en cuatro parcelas cuadradas iguales ${ }^{250}$.

En esta zona se encontraron ante pobles creadas por la colonización agropecuaria de la llanura mallorquina, por lo que el trazado reticular de las calles se prolongó para ordenar el espacio rural. Al quedar en segundo plano la función mercantil, de una plaza que aprovechan dos submanzanas centrales, y de una cerca sin importancia militar, es por lo que el concepto de jerarquía, que se imponía en las villas turolenses de sociedades más complejas, se rebajó un tanto pero, en cambio, desde el punto de vista de la perfección geométrica del reparto en cuadrados se alcanzó una cota de diseño más fácilmente teorizable, como haría a finales del siglo XIV el monje Eiximenis.
${ }^{249}$ Estamos ante la primera propuesta escrita de una ciudad ordenada por sucesiva partición de un cuadrado perfecto, y también ante un verdadero programa de planificación y colonización territorial partir de esas nuevas ciudades. Mas características en el apartado de anexos pág. 435.

250 Bielza de Ory, V. (2000): La ciudad ortogonal aragonesa del Camino de Santiago y su influencia en el urbanismo regular posterior. Aragón el la Edad Media, XVI, Univ. Zaragoza, Zaragoza, pág. 39. 
Fig.182. Plano de Petra, fundación a principios del Siglo XIV.

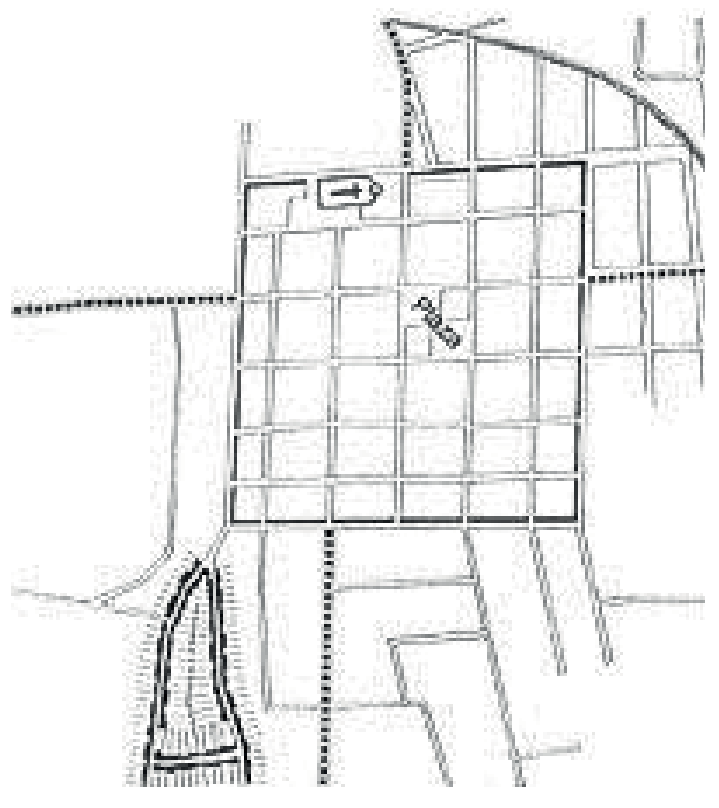

6.1| Francesc Eiximenis

En este ambiente propicio se comprende que alguien teorizase a partir de la nueva realidad urbanística. Ese alguien fue un franciscano valenciano, Eiximenis ${ }^{251}$.

Nacido en Gerona a finales del primer tercio del siglo XIV, recibió formación académica en Oxford, viajó a Colonia, París, Roma y Toulouse. Vivió en Valencia entre 1383 y 1408 y en este último año fue nombrado obispo de Elna. Murió en Perpiñán al año siguiente ${ }^{252}$.

De Francesc Eiximenis se ha dicho que condensaba admirablemente las cualidades y aún los defectos de la época y del ambiente en el que vivió. Su espíritu era plenamente medieval. El orden y la sistematización eran en él, como en la mayoría de sus contemporáneos, una preocupación absorbente; las divisiones y subdivisiones se multiplicaban hasta el infinito y a veces casi perjudicaban la claridad de la exposición.

Ésta y otras características desvelaban su formación escolástica. Su obra más extensa y ambiciosa, que quedó inacabada, fue $L O$ Crestià. Los cuatro libros que han llegado a la actualidad, aunque suman la respetable cantidad de 2.592 capítulos no representan apenas la tercera parte del proyecto global. El citado libro es esencialmente una vasta enciclopedia - una Summa teológica- 


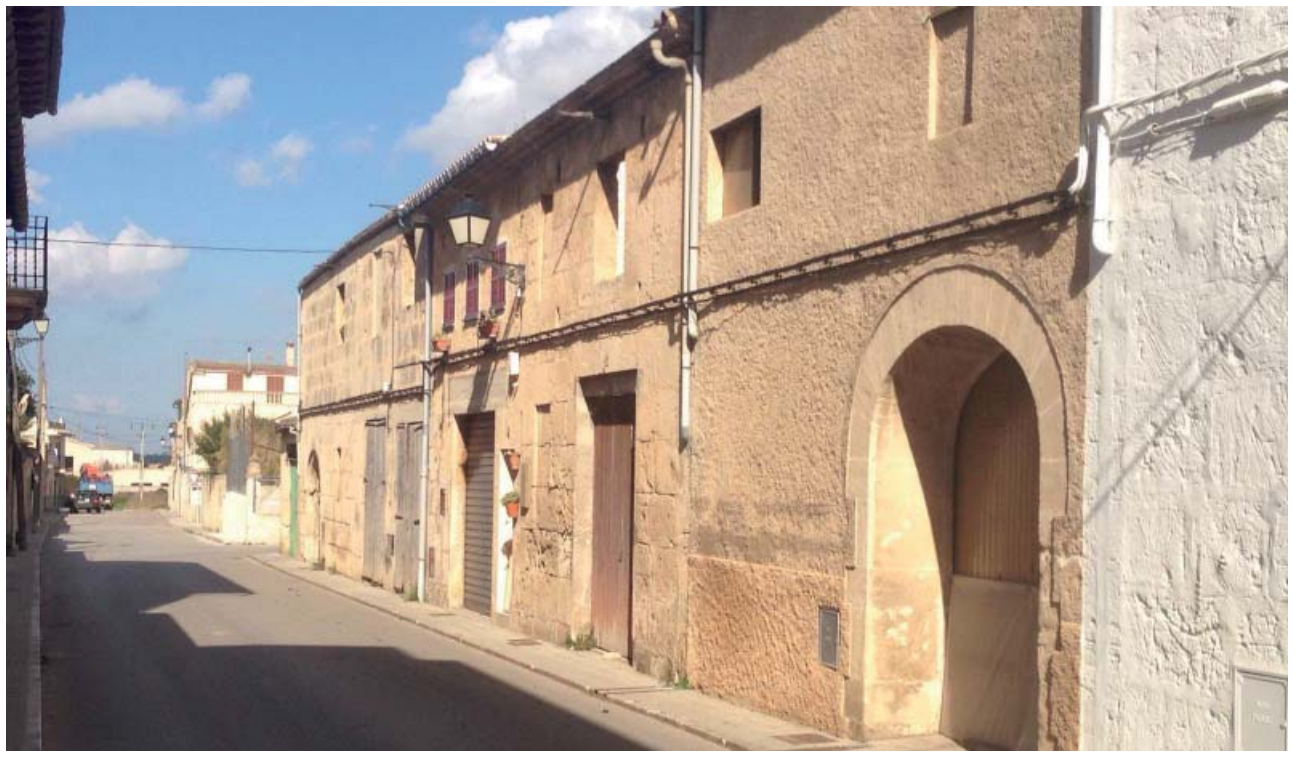

escrita en lengua vernácula. En ella el estilo y la forma de los mensajes subordinaban a la intención didáctica y pastoral253.

Eiximenis era un entusiasta de las formas de vida urbanas, dedicó a los jurados de Valencia en el año 1383, el Regiment de la cosa pública, anticipo del libro Dotzé del Crestià. La carta introductoria del Regiment es un canto fervoroso y espléndido a las excelencias de la ciudad y la tierra de Valencia ${ }^{254}$. Por esta razón el Consell Municipal de Valencia acordó, el año 1384, copiar el libro Primer del Crestiá y tenerlo en la sala de juntas, para que todo el mundo pudiera consultarlo además de encargar que una copia iluminada del Regiment estuviese atada con una cadena a la mesa del escribano de la Sala.

En el libro, describía la ciudad utópica - apoyándose en los filósofos griegos, como por ejemplo Aristóteles, y en los sabios cristianos como S. Agustín y Sto. Tomás - como una ciudad cuadrada para ser bella y ordenada:

de la forma de la ciutat sostades diverses opinions: car dixeren los grechs philosofos jatsia que apres hi hajen ajustat quelcom los savis crestians e han dit summariament en esta materia que tota ciutat devía esser quadrat car ret sen pus bella e pus ordenada ${ }^{255}[. .$.$) .$
Fig. 183. Vista de una de las calles del municipio de Petra en Mallorca.

${ }^{253}$ Zaragozá Catalá, A.(2000): "Arquitectura gótica valenciana", capítulo IV Valencia: un laboratorio urbanístico medieval, pág. 117.

254 Ibídem, pág. 118.

${ }^{255}$ Bielza de Ory, V. (2000) : La ciudad ortogonal aragonesa del Camino de Santiago y su influencia en el urbanismo regular posterior. Aragón el la Edad Media, XVI, Univ. Zaragoza,Zaragoza, pág. 42. 
256 Bielza de Ory, V. (2000): La ciudad ortogonal aragonesa del Camino de Santiago y su influencia en el urbanismo regular posterior. Aragón el la Edad Media, XVI, Univ. Zaragoza, Zaragoza, pág. 42.

257 Beltrán Abadía, R. (2005): "Planeamiento y geometría en la ciudad aragonesa". Colegio de Arquitectos de Zaragoza. Arqueología y Territorio medieval. Revista de Arqueología del Área de Historia Medieval. Universidad de Jaen. Tomo 12.2, pág.117.
Es evidente que Eiximenis tuvo en cuenta no sólo la ciudad hipodámica de los griegos y la Jerusalén celestial del Apocalipsis, sino también las nuevas fundaciones levantinas. La ciudad utópica se articulaba como las nuevas villas y pueblas a partir de los ejes principales ortogonales y orientados hacia los puntos cardinales, que, al cruzarse en una plaza central dividían el recinto cuadrado en cuarteles ${ }^{256}$.

El texto del franciscano, escrito en territorio de la Corona de Aragón a finales del siglo XIV, supuso la primera teoría urbanística expuesta desde la antigüedad, alumbrando ya un modelo renacentista de ciudad, que encontraría después su marchamo con el descubrimiento del Códice de Vitruvio. Él como consejero de Pedro IV (1334-1387), describió una ciudad utópica que representaba bien el ideal urbano bajo medieval:

\section{una ciutat bella e bé edificada concebida como conjunto armónico y, por tanto, lógico e inteligible[...).}

La ciudad eximeniana es la culminación de una nueva idea de la creación artificial enunciada por la escolástica tomista, sustancialmente distinta de la agustiniana que había dominado hasta el siglo XIII. La obra artificial ya no se agota en un valor simbólico, ni puede aplicarse el principio de la concordancia de opuestos para afirmar que la belleza del conjunto requiera la fealdad de sus partes inferiores ${ }^{257}$.

Revolucionariamente, se concibe entonces la posibilidad de una obra de arte específicamente bella, por su cualidad material y no por lo que representa, formada por partes análogamente bellas:

No basta con la belleza de unos cuantos edificios privilegiados inmersos en un caserío cochambroso; la perfección del conjunto exige la belleza homóloga de todas sus partes. La ciudad de Eximenis es la propuesta teórica medieval más acabada de una ciudad orgánicamente bella, concebida ya, como lo hará el Renacimiento, como un cuerpo entero y bien acabado -perfectode partes bellas, dispuestas de tal modo que ninguna pueda cambiarse, quitarse ni añadirse, de acuerdo con la máxima aristotélica que retomará León Battista Alberti.

Para ser perfecta, la ciudad deberá asentarse en llano y lograr el perfecto acuerdo entre la forma social y la material: "La ciudad -escribe Eiximenis en el capítulo XCVIII- debe estar bien 
331 de 536

Fig. 184. Cruz de térmi-

no o peirón del muni-

cipio de Petra en Ma-

llorca.

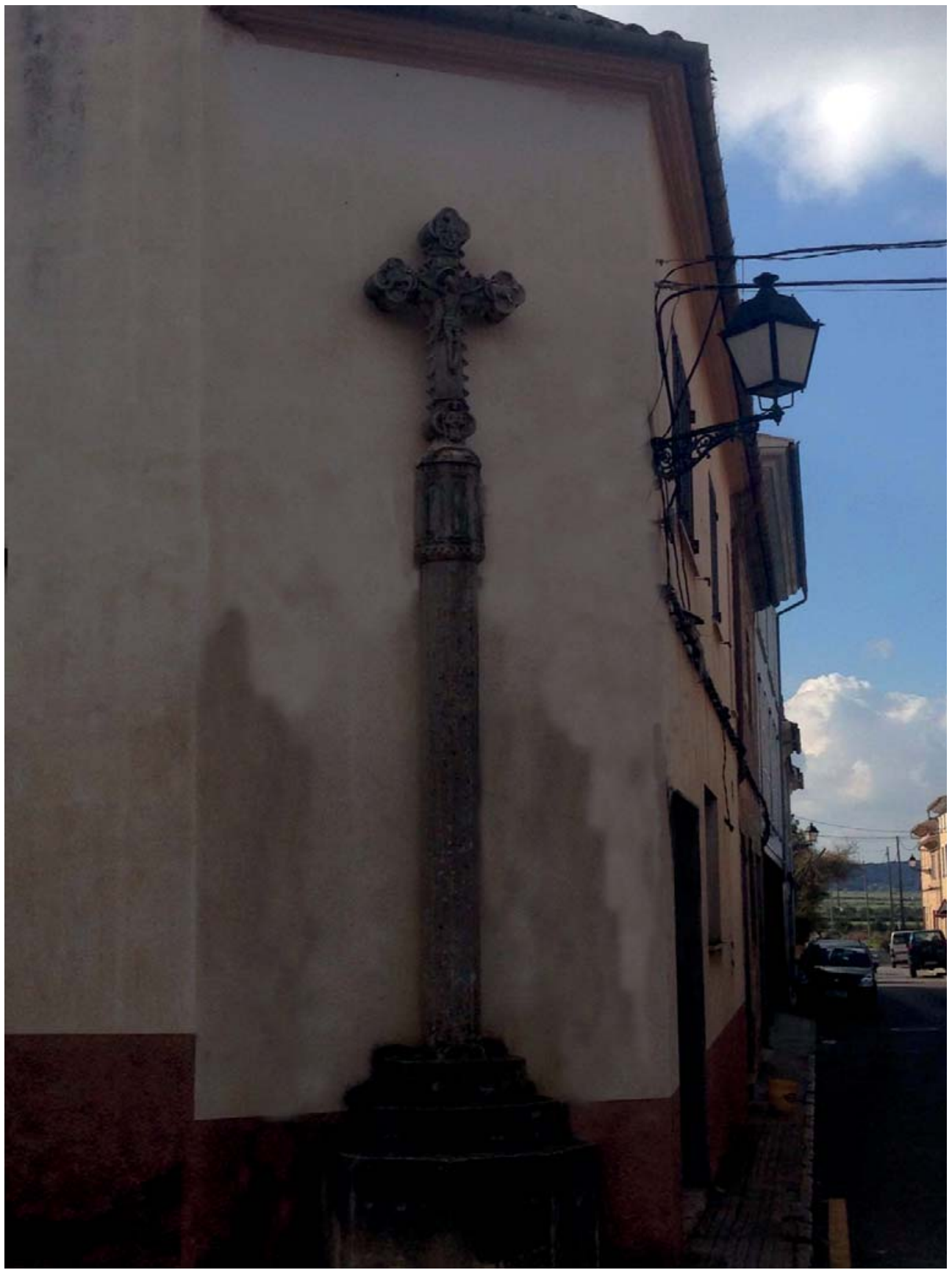


compuesta, esto es, bien ordenada en tres aspectos: el primero es que esté bien arreglada en lo espiritual; el segundo, que esté gobernada por una buena ley temporal, y el tercero que esté bien edificada en su forma material.»

Como en la Jerusalén Celeste, en la muralla cuadrada de la ciudad ideal de Eiximenis hay doce puertas, tres en cada lado. El conjunto se configura a partir de dos ejes principales ortogonales y orientados hacia los puntos cardinales, que al cruzarse en una plaza central dividen el recinto cuadrado en cuatro cuarteles, cada uno con una plaza secundaria propia y destinado a un tipo diferente de habitantes; paralelas a esos ejes, corren cuatro calles secundarias en cada dirección, que dividen cada cuartel en dieciséis manzanas de 82 metros de lado, divididas en cuatro solares de 41 por 41 metros $^{258}$.

Cada uno de los cuatro barrios en que queda dividido el recinto urbano constituye algo parecido a una pequeña ciudad dotada de todo lo preciso para que sea posible en él una vida autosuficiente: un almudí, un convento mendicante, una parroquia y una plaza que le sirve de centro particular, además de todos los oficios necesarios para su funcionamiento autónomo: carniceros, pescaderos, labradores, comerciantes...

De este modo, la nueva ciudad no se reparte en barrios diferenciados, como la contemporánea ciudad gremial, sino que materializa el principio tomista del cuerpo perfecto compuesto por partes perfectas.

El esquema eximeniano comprende al mismo tiempo la experiencia del campamento y la ciudad de fundación romana, la ciudad ideal apocalíptica y lo visto en las ciudades aragonesas de Levante y en Mallorca, cuyas pueblas tienen dimensiones de solares y manzanas casi iguales ${ }^{259}$.

\footnotetext{
${ }^{258}$ Beltran Abadía, $\mathrm{R}$ (2005): "Planeamiento y geometría en la ciudad aragonesa". Colegio de Arquitectos de Zaragoza. Arqueología y Territorio medieval. Revista de Arqueología del Área de Historia Medieval. Universidad de Jaen. 2005, tomo 12.2 , pág. 117.

${ }^{259}$ Íbidem.
}

Las propuestas de Eiximenis supusieron la culminación del camino iniciado en Mosqueruela y proseguido en Levante y en Mallorca durante los siglos XIII y XIV. Con todo lo expuesto se observa como el urbanismo medieval ortogonal iniciado en Jaca (1076) en función de unos fueros "parcelas iguales para hombres iguales" se transmite, junto con los mismos, por el Camino de Santiago y hacia el resto de la Corona de Aragón en su avance colonizador, influyendo tanto en la bastida, por el norte, como en las Ordenaciones de las pueblas mallorquinas de Jaime II o en las Teorías de Eiximenis, por el sur, a partir de los siglos XIII y XIV, 
dando lugar, en estos últimos casos, a estructuras cuadriculares en torno a plazas centrales, que se prolongarán ortogonalmente por el territorio circundante

Eiximenis habría visto la modesta aplicación de su plan, realizado en épocas anteriores, en las ciudades de nueva planta y trazado regular de la Plana de Castellón antes descritas. La ciudad eiximeniana habría servido de texto básico en la concepción del hecho urbano durante el reinado de los Reyes Católicos (El Dotzé se imprimió en Valencia en 1494). Su influencia habría llegado a la política urbana desarrollada durante la conquista de América.

\subsection{Semejanzas y diferencias entre el urbanismo valenciano y mallorquín medieval}

Antes de nada señalar que a Francesc Eiximenis no sólo le importaba la belleza de unos cuantos edificios privilegiados, sino que buscaba la perfección del cúmulo de circunstancias que allí se daba y por esta razón no sólo decretó normas para los edificios sino también para el urbanismo del recinto amurallado, por este motivo el presente apartado procede a comparar sus soluciones urbanísticas con las realizadas en el Reino de Aragón y de Valencia.

Es probable que el monje conociera tanto las pueblas aragonesas como las valencianas, por lo que resulta evidente pensar que lo que intentó fue mejorar aquello que había visto funcionar, es decir, que recogió y utilizó lo que a su parecer estaba correctamente planteado e intentó crear un modelo de ciudad que correspondiera a su ideal de perfección y belleza.

En el orden de las ideas anteriores conviene empezar por la ubicación de las nuevas poblaciones. En sus escritos hacía referencia a la situación ideal . El monje elegía los emplazamientos en llanuras que configuraba con un trazado reticular, porque para ser perfecta, la ciudad debía asentarse en llano y lograr el perfecto acuerdo entre la forma social y la material. En esta primera referencia el criterio utilizado es el mismo que el demostrado a la hora de situar les pobles valencianes.

Continuando con el análisis de sus palabras, el trazado reticular que propone, resulta corresponderse con el mayor rasgo que caracteriza las pueblas valencianas: calles formando retículas paralelas y ortogonales entre sí. 
Asimismo Francesc Eiximenis deja por escrito que la ciudad era organizada por un ordenador o stablidor de acuerdo a unas normas marcadas e incidiendo sobre la condición de que el espacio se repartía mediante cuadros perfectos. Después de haber comprobado que los catorce municipios analizados siguen las mismas pautas a la hora de dimensionar sus viales, sus solares, y sobre todo, a la hora de elegir su ubicación, queda demostrado que en el Reino de Valencia disponía de unas personas, quiñoneros, ordenadors o soguejadors (Ilamados así dependiendo del contexto), responsables de marcar una serie de normas a la hora de construir una nueva vila, de elegir la ubicación del lugar y de realizar el replanteo de sus calles y solares.

Conviene subrayar que aunque las pueblas valencianas cumplen con las pautas de ortogonalidad de sus viales y con la ubicación de la plaza en el cruce de sus calles principales no es así en cuanto a su planta, ya que no encarnan cuadrados perfectos, sino que tienden a ser rectangulares y algunos casos, como el municipio de Cullera, poligonales. Eximenis determina la dimensión de planta cuadrada en sus estudios con 450,00 m de lado, esta dimensión sólo se encuentra en las villas valencianas en el que presenta mayor lado, en el municipio de Castellón. La perfección geométrica del reparto en cuadrados se alcanzó en Mallorca no en los Reinos de Aragón y Valencia.

Concretamente el autor proponía una ciudad jerarquizada, como la sociedad medieval, donde el poder eclesiástico se ubicaría en el centro. Les pobles valencianes también se encuentran jerarquizadas en cuanto a la dimensión de sus viales y fachadas pero no se cumple la jerarquización del poder eclesiástico sobre el civil que sí aparece en las pueblas mallorquinas. Asimismo las citadas presentan una plaza en el centro del cruce de sus dos viales principales denominada la plaza mayor, donde se ubica el poder civil, quedando el poder eclesiástico, representado por la parroquia desplazado a un lateral que normalmente lindaba con la muralla.

Es evidente que el franciscano valenciano, dejó en segundo plano la función mercantil de la plaza y se decanta por crear varias submanzanas, en las que crea otras plazas centrales, donde desvía el mercado y el poder civil.

Asimismo ambos conjuntos de villas, tanto las valencianas como las diseñadas por Eiximenis presentan en común la 
ortogonalidad de sus viales principales, además de la plaza central. Queda patente que el proyecto de Francesc Eiximenis es más ambicioso porque a partir de esta plaza principal, crea varias otras plazas secundarias en cada uno de sus cuarteles.

Por el contrario difieren en la función de las calles secundarias y de les travesseres, puesto que estas dejan de tener sentido en las villas mallorquinas al tratarse de villas de planta cuadrada.

En lo que concierne a la organización municipal así como las pueblas valencianas se organizan en quartes, para la elección de los jurados y se disponen gremialmente en cambio en las pueblas mallorquinas el monje plantea cuatro zonas con sus correspondientes plazas y todos los edificios necesarios para poder funcionar correctamente y los denomina cuarteles.

Por otro lado en lo referente a la muralla y en particular a la cantidad de número de puertas en la muralla, la solución dada por Francesc, presenta un número muy superior con respecto al $\mathrm{n}$ o de puertas existentes en las diferentes vilas estudiadas, que siempre partían de 4, a excepción de Mascarell que únicamente cuenta con dos puertas.

Por último cabe destacar un apunte respecto a la situación de las manzanas, que se sitúan más cerca del recinto defensivo. El monje valenciano también establece una distancia mínima que se debe de cumplir desde la última manzana a la muralla. Esta solución, la separación del recinto defensivo de las manzanas destinadas a viviendas parece obvia, pero a veces pasa desapercibida puesto que en los núcleos históricos tal y como han llegado hasta la actualidad, las edificaciones alcanzan hasta la propia muralla o han sido embebidas en el interior de éstas. Seguramente esta distancia de seguridad también se cumplía en las villas valencianas originalmente, pero con el paso de los siglos, al perder importancia defensiva o por la necesidad de ocupar superficie fue ocupada por las distintas edificaciones. 


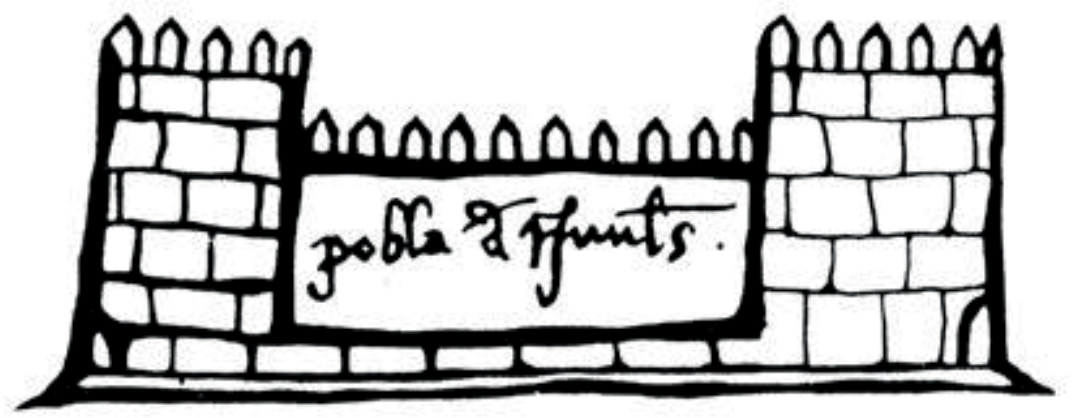


Fig. 185. Grabado de Nules medieval con su muralla. Representación caligráfica realizada en el manuscrito de la visita pastoral a la diócesis de Tortosa del obispo Paholach en 1314.

\section{APITLLO VII|}

\section{DISC USIÓN GENERAL DE LOS RESULTADOS}

Una vez finalizado el trabajo de investigación y después de comparar cada uno de los datos obtenidos en este estudio, se puede afirmar que el resultado final ha sido el que se pretendía. Queda demostrado el origen medieval de la Pobla de Vallbona y documentado todo el patrimonio material e inmaterial de la misma época que ha llegado a la actualidad o del que se tenía noticias.

Como se indicó en el primer capítulo de esta tesis, el procedimiento utilizado ha constado de dos fases claramente diferenciadas, una primera centrada en la labor de búsqueda de documentación histórica y la toma de datos, y una segunda basada en un trabajo de análisis gráfico.

Para comenzar se prestó especial atención a trece municipios valencianos de la misma fecha fundacional y se revisó los archivos históricos de cada una de estas villas solicitando la delimitación de los núcleos históricos en las oficinas técnicas municipales. En los casos en los que ya existían estudios previos sobre estas zonas se tomaron éstos como referencia.

Seguidamente se procedió a analizar la trama urbana de cada uno de estos municipios. A partir de los planos catastrales, y ya con la delimitación clara, se procedió a la medición de cada uno de los núcleos históricos. Una vez concluida esta tarea se 
llevó a cabo el análisis de los bienes inmuebles comprendidos en el mismo periodo histórico. Para ello se identificó la situación de cada edificio, sus características y su tipología constructiva.

Conviene subrayar que fue una ardua tarea de recopilación, puesto que hubo que indagar en fuentes documentales y en algunos casos incluso buscar testimonios personales que nos ayudaran a identificar los núcleos históricos o las edificaciones medievales que se buscaba registrar.

Como resultado esta fase se obtuvo la delimitación de las tramas urbanas de las villas analizadas, con indicación de los límites del espacio intramuros, el trazado de los viales y la distribución aproximada de las manzanas, además de la identificación de los elementos arquitectónicos de valor patrimonial destacado.

A continuación se procedió a realizar los mismos pasos en el municipio objeto de este estudio, La Pobla de Vallbona. Para ello lo primero que se llevó a término fue indagar en su historia. Esta fue la mayor dificultad de todo el presente plan de investigación. El archivo histórico del consistorio desapareció durante la Guerra Civil Española, siendo el plano más antiguo existente en el municipio del año 1928, con el problema añadido que este plano no era de suelo urbano sino del suelo no urbanizable por esta razón no venían grafiados los viales, sino solo la envolvente del núcleo fundacional.

A falta de planimetría histórica en el municipio, se procedió a realizar un profundo escrutinio en los diferentes archivos históricos valencianos y aragoneses con el fin de poder encontrar algún grabado, plano o documentación que diera indicios de cómo había sido su centro histórico.

Como hemos podido constatar en muchos casos, a partir de la planimetría se puede deducir aproximadamente la ocupación fundacional, sin embargo para poder delimitarla exactamente era necesario ampliar las fuentes de información, rastreando la documentación escrita y la cartografía.

Con la documentación encontrada, lo primero fue identificar la existencia de recinto amurallado, confirmando su existencia a través de un grabado y de documentación escrita. A partir de este punto se procedió a identificar la zona intramuros. El trazado del cinturón amurallado resulta estratégico a la hora de delimitar el espacio fundacional, por lo que la muralla puede considerarse el 
indicador principal para conocer la línea que marcaba el espacio urbano de las villas medievales. Las puertas, además, marcan el trazado de los viales de acceso y salida de la villa.

Asimismo resultó imprescindible el análisis de los elementos urbanos que componían la trama de la parcelación de la villa: manzanas y solares, por un lado, viales y espacios públicos, por otro, para determinar su implicación en el tejido urbanístico. En cuanto a los demás elementos, al comparar la trama urbana de la vila objeto de este plan de investigación con las del resto de pueblas de colonización, se observó que el casco histórico de la Pobla aún se podía identificar perfectamente, tanto sus viales como sus manzanas habían perdurado al paso del tiempo. Posiblemente lo más difícil dentro de este análisis fuera delimitar la profundidad de las parcelas de las manzanas lindantes con la muralla.

En lo que concierne a la arquitectura se ha documentado los diferentes edificios medievales llegados a nuestros días. Se consiguió identificar y poner en valor diversos bienes inmuebles de la Pobla de Vallbona, esperando que, como resultado de su registro, se tuviera una mayor consideración sobre ellos y esto conlleve un mayor reconocimiento histórico.

A partir del análisis de los diferentes cascos históricos, se ha podido comprobar que, con el paso del tiempo, ha sido relativamente corriente la apertura de espacios públicos con motivo de operaciones urbanísticas. Igualmente atestiguada resulta la apertura de nuevos viales, la desaparición de cantones, la reestructuración de manzanas completas o la amortización de viales públicos. Si bien es cierto que la mayoría de estos núcleos históricos ha llegado a nuestros días en gran medida con sus alineaciones modificadas, al igual que se ha permitido introducir variaciones en sus tipologías constructivas, pasando de viviendas entre medianeras a edificios en bloque.

Es necesario señalar que en la mayoría de nuestros municipios aún existe este patrimonio medieval, sus trazas, sus bienes inmuebles, su toponimia y todavía se está a tiempo de salvaguardarlos. Realizando un correcto estudio de cada uno de ellos es posible identificar, proteger y llevar a cabo procesos urbanísticos que no mermen sus trazados y características originales. 


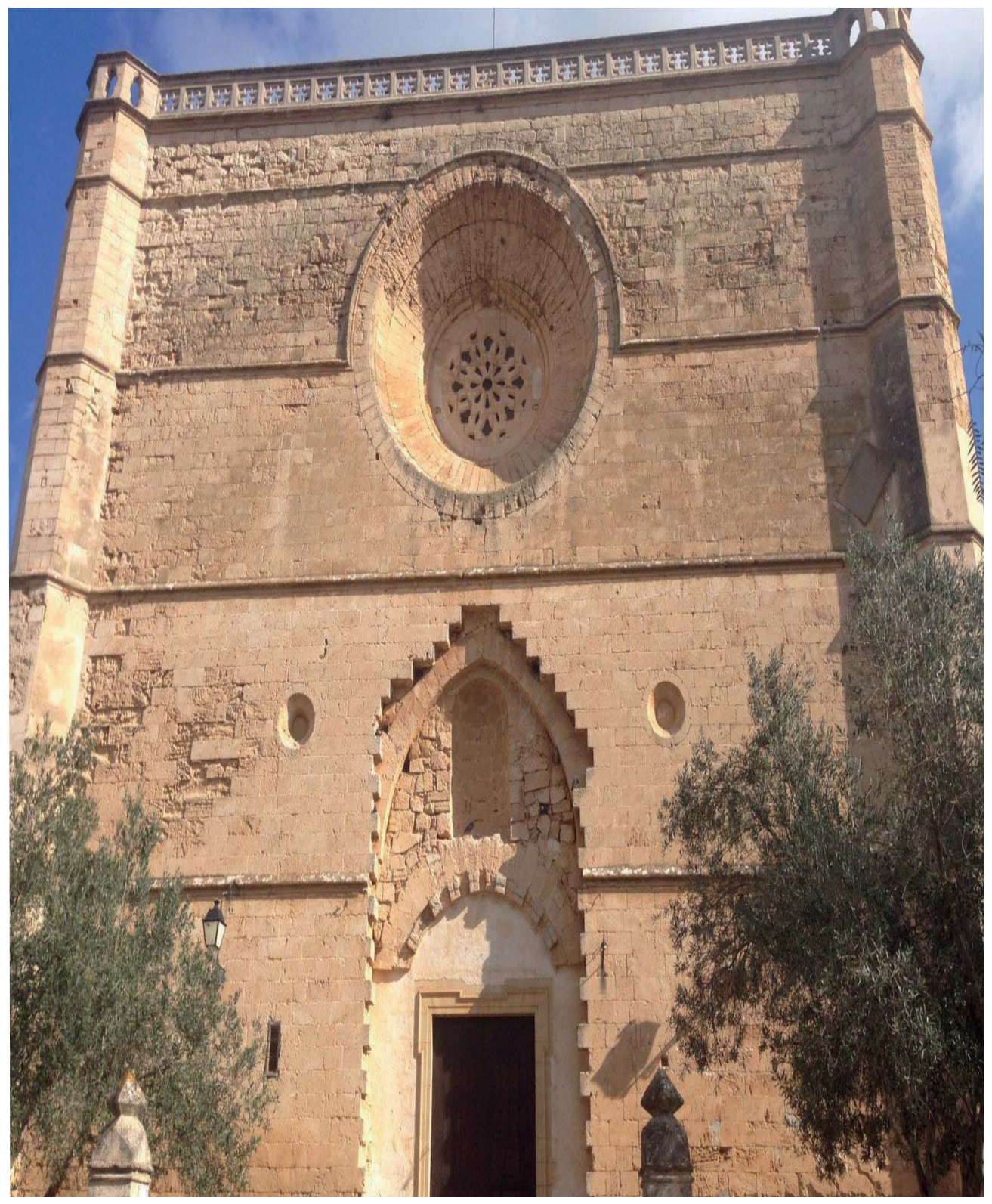

Fig.186. Fachada de la actual de la Iglesia del Municipio de Petra en Mallorca. 
Es por ello que lo importante es su correcta señalización y puesta en valor, puesto que se trata de espacios de nuestra historia que están al alcance de cualquier ciudadano interesado por conocer y comprender mejor nuestro pasado. En sus viales, en sus edificios, en todo su patrimonio, se recogen siglos y siglos de nuestra historia común.

Para finalizar querríamos concluir con las siguientes palabras del Rey Felipe VI en el discurso de Navidad del año 2015:

Esa historia, sin duda, debemos conocerla y recordarla, porque nos ayuda a entender nuestro presente y orientar nuestro futuro y nos permite también apreciar mejor nuestros aciertos y nuestros errores; porque la historia, además, define y explica nuestra identidad a lo largo del tiempo. 


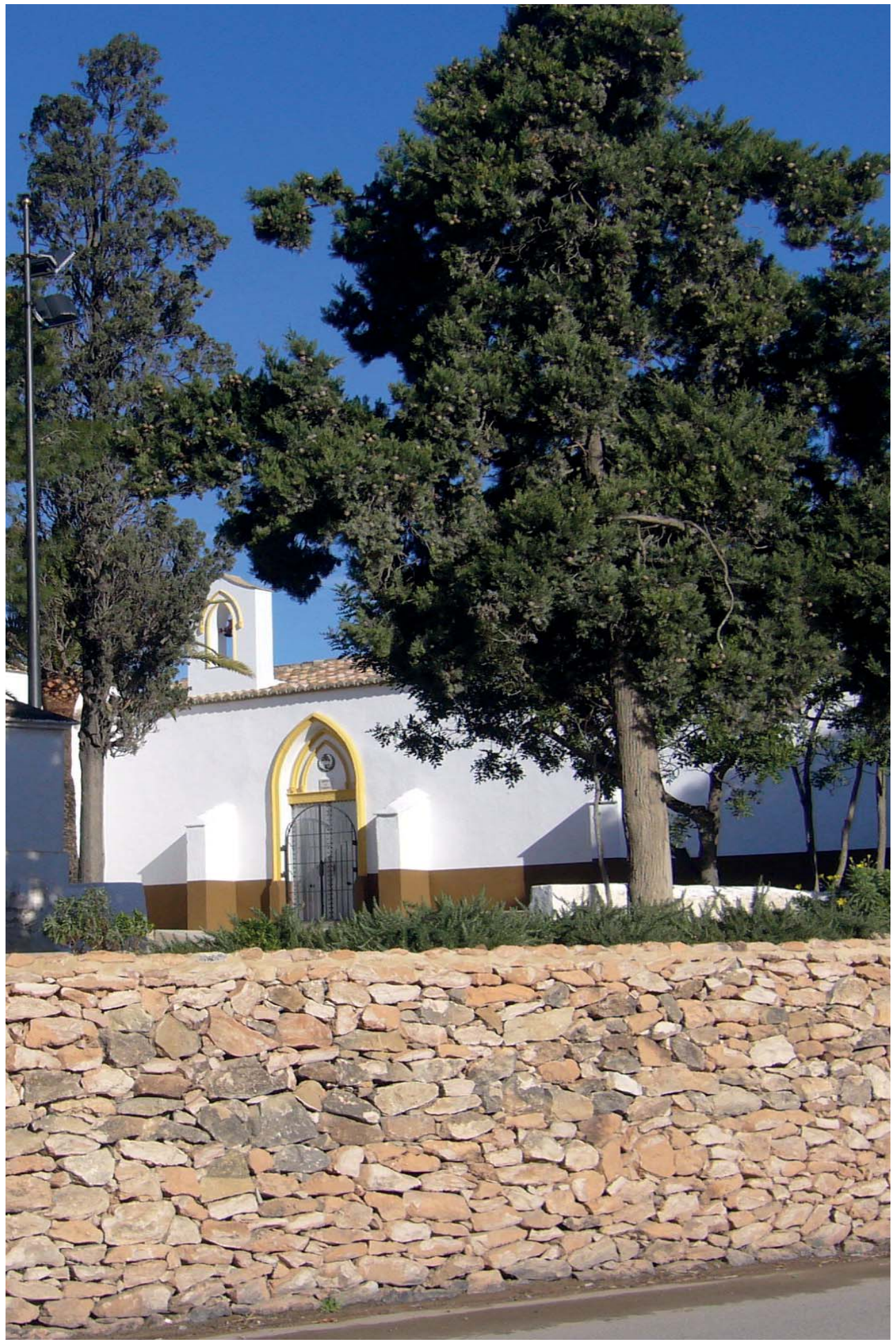


Fig. 187. Vista actual de la ermita de San Sebastián junto con el muro de piedra recuperado.

\section{Concusiones}

El siguiente trabajo partió con un propósito fundamental: el análisis del origen y urbanismo medieval concerniente a la vila de La Pobla de Vallbona, alias de Benaguazir, mediante la documentación y descripción de cómo se formaron y originaron las poblaciones de nueva planta durante la conquista de Valencia a partir del s. XIII. Con este fin se prestó especial atención a las trazas, las dimensiones y los elementos arquitectónicos que han llegado a nuestros días de municipios similares y misma fecha fundacional, para posteriormente, realizar un análisis gráfico y comparativo entre ellos que nos ayudara a enmarcar, documentar y analizar el origen y creación del municipio que nos atañe.

La primera conclusión a la que hemos llegado es que La Pobla de Vallbona corresponde a la creación de poblaciones de nueva planta. En efecto, el proceso urbanizador durante la reconquista tuvo varias modalidades tales como la reforma de ciudades existentes, su ampliación o la creación de nuevas poblaciones. En el Reino de Valencia se fundaron casi doscientas nuevas pueblas, unas veces sobre zonas despobladas y otras eliminando de forma paralela el poblamiento disperso en alquerías andalusíes, las cuales, en todo caso, eran desbordadas inmediatamente por las dimensiones y planta de la nueva villa cristiana. La Pobla de Vallbona surge como un emplazamiento de cristianos viejos ubicados en un valle bajo la protección del castillo de Benaguazir según las fuentes e indicios analizados. 
Siguiendo con las conclusiones, debemos señalar que nuestro municipio cumple una serie de pautas observadas tras el análisis de trece villas de nueva planta que, aunque fueron creadas con sus propias características de adaptación al territorio, se ceñían a una serie de patrones similares como la regularidad de sus parcelas, la ortogonalidad o la distribución de sus calles. Estas pautas responden claramente a la voluntad de organizar de un determinado modo un municipio, y este es el caso del modelo de ciudad regular que, según las fuentes y la documentación consultadas, a finales del $\mathrm{s}$. XI surgió en Jaca, y que posteriormente se transmitió a lo largo de la ruta jacobea y al resto de Aragón gracias a los fueros.

Encontramos, pues, que las villas de nueva creación se denominaban pueblas de colonización y correspondían a municipios perfectamente planificados, normalmente delimitados por murallas o cercas, respondiendo a las iniciativas de ordenación y dominio espacial de los poderes regionales y de las monarquías, cuyos documentos fundacionales establecían el régimen jurídico de su vecindario, los fueros y las cartas pobla. Tenemos constancia de que Jaime I, tras la conquista de Valencia, necesitaba controlar el territorio repoblándolo con cristianos para asegurarse su dominio. Para ello, como muestran los documentos de la época, se creó una red de municipios dotados de unas cartas de población o fueros con el fin de atraer nuevos colonos que se emplazaron en villas uniformemente espaciadas y sujetas a una jerarquía. En el orden interno, la geometría permitía controlar el asentamiento de la población al imponer un orden en la partición del suelo y posibilitar su incorporación al proceso productivo y fiscal. La Pobla de Vallbona, alias de Benaguazir, se enmarca perfectamente en este contexto y cumple la mayor parte de las características analizadas. Los resultados del estudio comparativo entre la evolución y reforma urbanísticas de este grupo de poblaciones de nueva planta durante la conquista de Valencia y nuestro municipio han dado como resultado unas conclusiones que se exponen a continuación. 


\section{SITUACIÓN}

- La ubicación de estas villas no era casualidad. Todas ellas se ubicaban en territorios donde había campos parcelables de regadío y de secano. En un valle, a unos pocos kilómetros del castrum del que dependían, al lado de una acequia, de modo que se garantizaba el suministro de agua, y en la cota inmediatamente regable.

- La orientación de los distintos municipios estudiados es indistinta, dependía de la climatología del lugar, incluso en el caso de Cocentaina y de Alcoy se podría aventurar que sería por adaptarse al medio.

\section{PLANTA}

- La forma geométrica de los núcleos de población es diversa, aunque la mayoría cuenta con forma cuadrangular. No se ha hallado relación entre el tamaño de los municipios, sino que éste parece depender sólo de la importancia de la villa: cuando más importante es el núcleo de nueva creación, mayor superficie abarca y mayor número de nuevos pobladores pretende atraer.

- Por otra parte la organización urbanística de las villas analizadas no fue aleatoria, durante la investigación se han demostrado dos relaciones:

1- Las trece villas estudiadas guardan aproximadamente una relación del perímetro con sus lados de 3:5, lo cual demuestra la intención de buscar un orden a la hora de organizar el espacio.

2- La relación entre sus lados comprende el intervalo 1:1 o $1: 2$.

- Los 3 centros históricos con mayor superficie serían Castellón, Gandía y Vila-real, llegando el primero a contar con 500 × 450 m. Esta dimensión coincide con la que Francesc Eiximenis indica, en su libro Lo Crestià, que deben de tener las nuevas villas. 
- La planta del municipio de la Pobla de Vallbona presenta forma rectangular. Su trazado tiene gran similitud con las tramas medievales de Puzol y Vila-real.

\section{LOS VIALES}

- La planta queda dividida por dos ejes principales, ambos perpendiculares entre sí. El eje longitudinal siempre será identificado como carrer Major. Paralelos a estos viales aparece la segunda categoría de calles, los viales secundarios. Se ha demostrado que pueden ser indistintamente paralelos al carrer Major o a su transversal. En los municipios de Castellón, Cullera, Puzol, Vila-real, Cocentiana, La Pobla de Vallbona y Teulada estas rúas son paralelas al eje principal longitudinal.

El número de viales secundarios solían ser tres. El primero es el denominado el carrer del Mig o Mitja, presenta un ancho intermedio con referencia a todos los demás. Seguido por el carrer de Dalt situado más al norte de la población, y al sur el conocido como carrer de Baix.

Perpendiculares a las calles anteriormente citadas aparecen otras más estrechas, simplemente funcionales y sin accesos a inmuebles, denominadas Travesseres. Se pueden observar en Nules, Almenara, Vila-real o La Pobla de Vallbona. Para finalizar se documentan els carrerons, callejones que no tienen salida y que solían dar servicio a una única casa.

- En el cruce de los dos ejes principales aparece la plaza que se ubicaba en el centro del municipio y era el eje de referencia de la vida civil. En los municipios aragoneses no se incorporó la plaza central hasta el siglo XII, pero en todas las pueblas de colonización valencianas analizadas, la plaza se encuentra incorporada a la trama urbana desde su origen.

\section{DIMENSIONES}

- Se ha identificado dos clases de espacios delimitados por sus viales existentes en su centro histórico: manzanas que lindan con la muralla, y las que no lindan con muralla tipo islas. 
En el caso de las primeras quedan definidos una serie de cánones: son rectangulares, sólo cuentan con una única edificación entre medianeras y su anchura no suele sobrepasar los $25 \mathrm{~m}$. En lo referente a su longitud no hay una constante hay testimonios desde 4 hasta 11 veces su ancho.

La segunda clase de manzanas se encuentra en el interior de las villas y están rodeadas por cuatro viales a modo de isla. Estas manzanas cuentan con dos inmuebles orientados perpendicularmente uno hacia la calle de mayor importancia y el otro hacia la calle paralela. Suelen ser cuadradas o rectangulares, cumpliéndose el doble del ancho en muchos de los casos.

- Después de analizar las dimensiones de las trazas, viales y espacios urbanísticos queda demostrado que a la hora de formar un nuevo núcleo fundacional se seguían unas pautas o cánones, con diversos criterios jerarquizados:

1- Los anchos de los viales; calle más importante cuenta con mayor anchura. Se ha hallado las medias aritméticas de la anchura de los viales en la actualidad y convertidas a varas valencianas con su correspondiente factor de tolerancia, siendo el resultado es el siguiente: carrer Major, 7 varas, eje perpendicular y carrer Mitjà 6 varas, carrer de Dalt 5 varas, carrer de Baix 4 varas y las denominadas travesseres $i$ carrerons 3 varas.

2- La longitud de las fachadas; vial secundario fachada más estrecha o de menor dimensión. Los frentes de los inmuebles situados en los dos viales principales oscilan entre 4,00 y $8,00 \mathrm{~m}$, los frentes en las calles secundarias cuentan con un intervalo de 4,00-5,00 m.

3- La orientación de los inmuebles, siempre el acceso principal hacia el vial de mayor relevancia.

4- La profundidad de las parcela es mayor en las parcelas del carrer Major, en detrimento de sus opuestas. En los catorce municipios valencianos analizados se observa que hay una manzana tipo isla donde las parcelas recayentes al carrer Major cuentan con mayor profundidad en contraposición de sus parcelas opuestas. 
Los parámetros descritos de las 13 villas valencianas junto con los de la Pobla de Vallbona son semejantes a los de las villas aragonesas en sus centros históricos.

\section{LA MURALLA}

- La mayor parte de los municipios del Reino de Valencia siguió el mismo criterio que en Aragón, con la villa consolidada se cerraba el perímetro con la cerca muraria. Los portales de acceso se ubicaban en los ejes principales que dividían la planta del municipio.

- Al igual que Francesc Eiximenis presentaba su ciudad ideal cercada por un muro pero con un espacio de separación entre las edificaciones y los paramentos verticales del recinto amurallado, queda demostrado que en las villas medievales valencianas de nueva planta también fue así, aunque con el paso del tiempo se ocupara este espacio por diversos inmuebles.

- En la actualidad, en la mayoría de los municipios, resulta obvio que la muralla ha sido embebida en el parcelario como resultado de la invasión de las viviendas particulares: primero desaparecía el camino de ronda que circunda la muralla por el interior, luego se adosaban a ella los patios y los espacios privativos que acaban siendo parte de la vivienda, y posteriormente se edificaba pasando a convertirse la cerca defensiva en parte de la estructura del inmueble.

- Tras el estudio de la documentación histórica, el trazado urbano y los parámetros urbanísticos de la trama medieval de la Pobla de Vallbona, el resultado obtenido es el siguiente:

A) La Pobla de Benaguazir se fundó como un Iloc dependiente del municipio de Benaguacil. Este primer recinto fundacional no se encontraba amurallado y estaba formado por ocho manzanas simétricas respecto a los viales principales.

B) Una centuria después al concederle carta pobla, 1382, tuvo derecho a tener termino propio, pasó tener la consideración de vila y se cerró años después perimetralmente por un recinto amurallado, puesto que según els furs solo las vilas tenían derecho a estar amuralladas.

La cerca muraria contaba con cuatro portales. Existía un espacio desde el último bloque edificado hasta el lienzo defensivo. 
C) Hasta el año 1700 existen documentos que acreditan que no se podía construir adosados a la muralla, pero pasado un tiempo (1811) esta superficie fue ocupada, construyendo adosado al camino de ronda. Se formaron nuevos bloques de manzana o se alargaron las edificaciones existentes.

D) Una vez perdida la función defensiva del muro fue derruido, parte de la muralla fue derrumbada entre los años 1860-1866, parte pasó a ser la trasera de las viviendas y en otros casos un muro interior. No solo se eliminaron los portales sino que carrerons se convirtieron en viales abiertos en toda su longitud.

- La única imagen de la Pobla de Vallbona amurallada se obtiene en un documento sobre el proceso de los arroces en la Comarca del Camp de Turia fechado en el año 1582. Los últimos testimonios, existentes en nuestros días, de los elementos que formaron parte del cerco defensivo: parte del foso denominado como valladar de Benaguacily el escudo del portal de Riba-roja esculpido en una pieza de sillar en el año 1701.

\section{ARQUITECTURA}

- Desde el punto de vista arquitectónico todas las villas analizadas al igual que la Pobla de Vallbona contaron con numerosos edificios de carácter noble y de órdenes religiosas, dada su naturaleza como pobla de cristianos viejos, así como con otras construcciones de menor entidad donde habitaría la población de menores recursos: labradores y artesanos. Los primeros se situaban en los dos ejes principales y los segundos en los viales secundarios

- La mayoría de los edificios medievales del municipio objeto de este estudio no ha llegado hasta nuestros días pero, a partir de esta investigación, se ha podido documentar la ubicación de los siguientes inmuebles intramuros:

A-En la plaça Major: la sala del Consell. Queda documentado que en el año 1402 los vecinos ya se reunían en esta plaza donde se situaba el ayuntamiento y el sindicato de Riegos, las galerías subterráneas y el pozo central, en el mismo lugar que se ubican según los grabados de Viciana en las vilas de Nules y Vila-real. 
B- En el carrer Major: la casa abadía, el convento de San Onofre, la casa procura y un segundo Inmueble del Convento de Porta-celi y comercios de primera necesidad: el horno y la carnicería situados en la misma quarta administrativa.

C- En el vial transversal principal: La cisterna y un edificio propiedad del Convento del Carmen.

D- En otros viales: El fossar. Su ubicación queda demostrada documentalmente y con el hallazgo de dos estelas discoidales descubiertas en la parcela. El hallazgo de estas dos piezas es algo inédito.

- El inmueble ubicado a la derecha del cementerio medieval es el destinado a parroquia de Santiago Apóstol. Edificio construido con bóvedas de crucería, se sitúa en la esquina del parcelario, al igual que en el resto de villas valencianas, al lado del portal de Benaguacil. Queda de manifiesto por escritos inéditos la existencia de la iglesia de San Jaime el año 1390 y se argumenta la ubicación de la torre gótica del inmueble original en la esquina izquierda de la iglesia gótica: a partir del dibujo de los arrozales de 1584 y al descubrir los sillares de esquina de uno de los paramentos verticales de la torre.

- Extramuros, de carácter religioso se identifica el mismo patrimonio inmueble que en las demás pueblas valencianas. En un pequeño montículo la ermita de San Sebastián, construida con arcos de diafragma, y una monumental cruz donde seguramente estaría situado un peiró hasta su destrucción durante la guerra de la independencia.

- Otro tipo de patrimonio inmueble inventariado en la citada población sería la masía de la Casa Blanca, propiedad del convento de San Onofre, la existencia del desaparecido convento del Carmen y como arquitectura popular de piedra en seco, en la zona norte del término municipal, los catxirulos, aljubs y muros de piedra en seco. 
- Siguiendo el orden expuesto se ha probado que las pueblas se construyen a una distancia del hisn del que dependen y su nombre es heredado casi siempre por la nueva vila. Un ejemplo claro lo constituye La Pobla de Vallbona alias de Benaguazir.

- En cuanto a los viales, en la mayoría de las pueblas analizadas se encuentra la misma toponimia. El carrer Major es el eje longitudinal. Las vías secundarias, calle Mitjana o Mitja, la calle de Dalt, y la calle de Baix. Las calles perpendiculares a estas, de menor importancia, cuentan en su gran mayoría con nombres de santos cristianos. Por lo que se refiere a La Pobla de Vallbona en la actualidad, en la memoria de las generaciones de mayor edad aún perduran estas denominaciones.

- El siguiente topónimo hace referencia a una parte de la muralla, el foso. Aquellos municipios donde alrededor de la muralla se encontraba el foso, lo solían denominar el vall o valladar. En el municipio centro de este estudio perdura, el valladar de Valencia y de Benaguacil, y en la zona de regadío histórico se deja constancia del camídel assegador.

Después de todas las conclusiones citadas, a manera de resumen final conviene precisar que resulta evidente que todas las poblaciones analizadas cuentan con características semejantes, desde la elección del lugar, seguido por los trazados paralelos y ortogonales de los viales, la tipología de las manzanas o los parámetros urbanísticos de los inmuebles, los inmuebles situados intramuros o extramuros, y hasta la toponimia. Todo este conjunto es la prueba de que se buscaba un patrón coherente. Por lo tanto queda demostrado que se seguían unas normas, que se buscaba un diseño, un modo de distribuir el espacio y que había personal cualificado encargado de replantear y organizar estas poblaciones, los urbanistas de la época, todos con la misma función pero con distintos nombres, sogejadors, quiñoneros, batles o agente assentisa. Nada se dejaba al azar. 


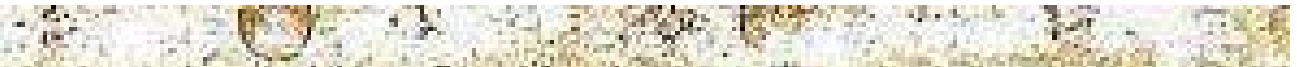

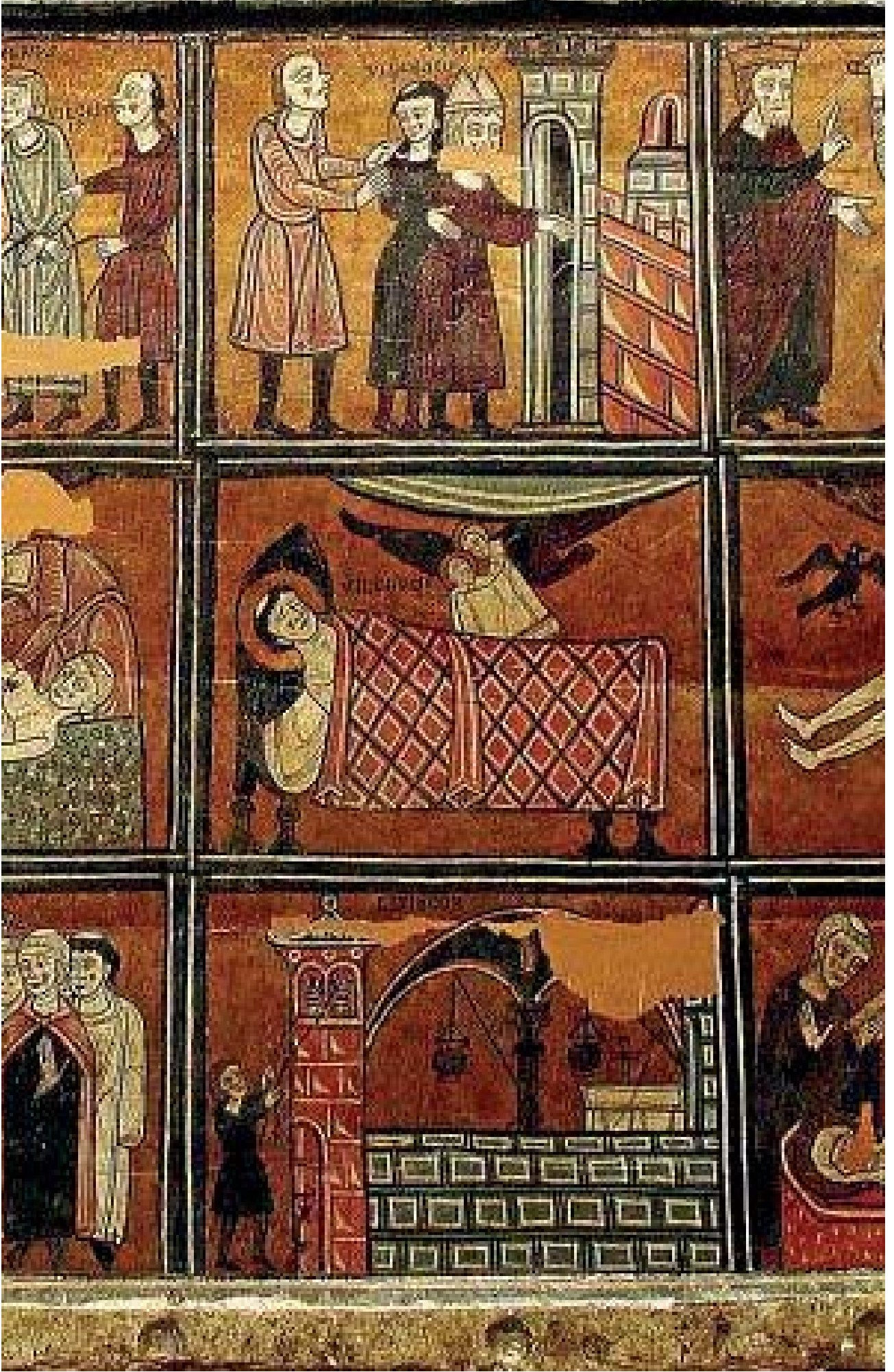




\section{CONCLUSIÓN FINAL}

El presente plan de investigación nos ha llevado a identificar el origen y modelación de estos municipios ordenados en plena Baja Edad Media, sus pautas y organización espacial. Este conocimiento nos servirá para recuperar un patrimonio urbanístico de los centros históricos que se ha podido conservar en buena parte.

Estos núcleos origen de nuestra historia se han convertido en un lugar de reunión, de encuentro, de convivencia y un lugar de vida. La vida de las ciudades debe partir de sus centros históricos y cualquier iniciativa de fomentar el debate sobre cómo hacer más humano y habitable el centro es fundamental. Dicho de otro modo debemos de trabajar en su conservación porque su importancia radica en conocer nuestro patrimonio y mantener la memoria del pueblo.

En lo que concierne a las expectativas de este estudio, creemos que estas se han cumplido con creces. Se ha podido demostrar el origen medieval de La Pobla de Vallbona, inventariar todos los bienes muebles e inmuebles que se conocen en la actualidad y, a través de la comparación con otros municipios de la época, poder ubicar su origen y realizar diversas hipótesis de cómo podría haber sido su evolución.

Dar a conocer el patrimonio de La Pobla, ponerlo en valor, era el objetivo buscado al iniciar este trabajo de investigación. Porque si se comprende y se entiende, se podrá apreciar y conservar, como dice una cita muy conocida:

\section{"Solo se valora aquello que se conoce"}

Y ese conocimiento es el que instará a las futuras generaciones a mantenerlo, porque si se conoce cómo y porqué se concibió, podrá ser preservado del modo más idóneo.
Fig. 188. Detalle del retablo de San Vicente Mártir donde se observa en la parte superior la construcción de la muralla de una vila $y$ en la parte inferior la construcción de una iglesia con bóvedas de crucería. 
$\mathbf{3 5 4}$ de 536

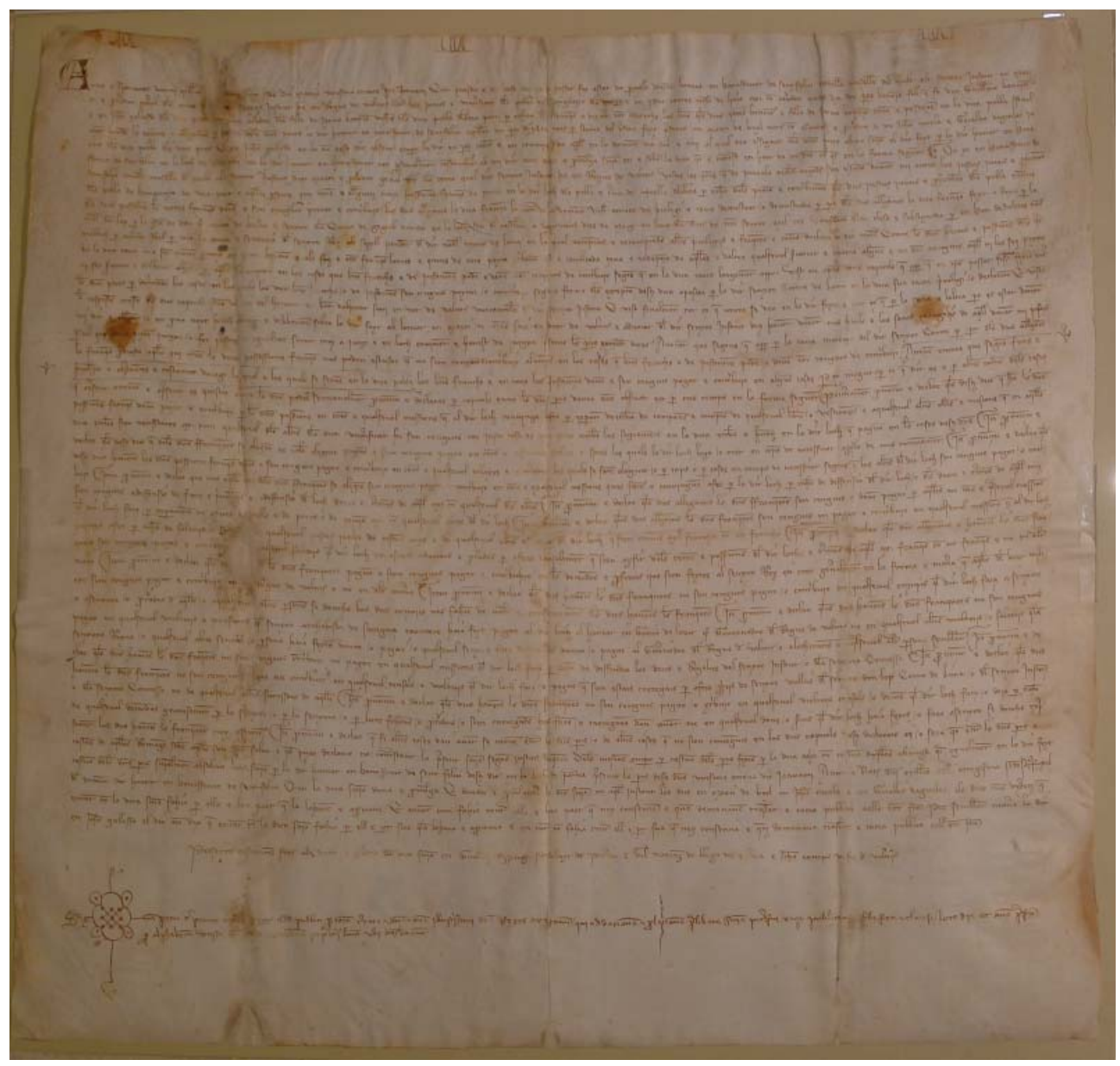


Fig. 189. Imagen del 5 pergamino inédito del Sindicato de Riegos de La Pobla de Vallbona, fechado en el año 1.402 .

\section{ANEXOS| Doc umentación}

\section{A.1|Ampliaciones notas a pie de página}

Documentos inéditos del Sindicato de Riegos

o Pergamino 1

o Pergamino 2

o Pergamino 3

o Pergamino 4

o Pergamino 5

o Pergamino 6

o Pergamino 7

o Pergamino 8

o Pergamino 9

o Pergamino 10

La Carta Pobla

Listado de posesiones del Monasterio de Portacoeli en la Vila de la Pobla de Vallbona a lo largo de la historia.

Protocolos Notariales 1700-1702. Archivo del Seminario del Corpus Christi de Valencia Protocolos, 21.981. Notari Jaume Llorens.

\section{A.2| Restauración de las pinturas murales góticas de la Iglesia Santiago Apóstol}

\section{A.3| Restauración de la ermita de San Sebastián}

A.4| Inventario del año 1873 perteneciente al Ayuntamiento de La Pobla de Vallbona señalando los documentos existentes en el archivo del municipio Documento del año 1945 que deja constancia la quema del archivo municipal durante la Guerra Civil Española

A.5 I Fichas de los municipios con los resultados

o Ficha de datos históricos, mediciones y bienes inmuebles

o Tablas comparativas 


\section{A.1|Ampliaciones notas a pie de página}

Nota al pie de página no 140 (pág. 148)

106. Ferran Diaz, castillo y villa de Benaguacil. 8 de diciembre.

121. Domingue Lupi de Ricla, alquería del Felx que se encuentra en el interior de la Villa. 2 de Enero.

1227. Aceyt aboceyt, alquería de la Aladaya, junto a Benaguacil, con sus hornos y molinos.

2206. Ferradus Diego,villa de Benaguacil y alquería del Felx junto a la aldea del Beniaro.

\section{Nota al pie de página no148 (pág. 156)}

Texto integro

Si ea que a principio sunt rationabiliter ordinata, tempore procedente ex iustis super venientibus causis mutari posunt in melius mutentur, non est absonum nec debet reprehensibile judicari.

Hinc est quod cum parrochialis ecclesia de Benaguazir, sita fuerit a principio et fundata in loco predicto de Benaguazir, eo quod ipsius fundationis tempore infra eiusdem parrochie limites non erat locus aliqui populatus; nec locus de Benaguazir predictus nunc autem per Dei gratiam infra eosdem limites sit quadam nova populatio vocata Vallbona, in qua ducenti et ultra christiani habitant; in dicto autem loco de Benaguazir licet bene quingenti habitent sarraceni, christiani tamen non, nec quinque vel sex sint habitatores preter dominum dicti loci, qui quandoque cum cum familia sua moratur ibidem.

Idcirco nos, Raymundus, miseratione divina valentinus episcopus, attendentes petitionem nobilis domini Jacobi Petri, dictorum locorum domini, et domine Sancie Ferrandis, eiusdem uxoris; attendentes etiam instantem supplicationem Guillermi de Ginebredo, rectoris eiusdem ecclesie, necnon christianorum in dictis locis habitantium, quia hoc solicitant nos instanter; considerantes insuper quod longe melius longeque utilius esse parrochialem ecclesiam ibi est ubi mayor christianorum habitat multitudo [pro] presenti, cum dificile est rectoriad locum de Vallbona predictum et homines de Vallbona ad dictum locum de Benaguazir propter ipsorum locorum distantiam venire pro ecclesiasticis sacramentis; de consensu capituli valentini transferimus et mutamus parrochialem ecclesiam seu ius ipsius parrochialis ecclesie a dicto loco de Benaguazir ad locum predictum de Vallbona, cum modis et moderationibus infrascriptis, videlicet: 
Quod de cetero in dicto loco de Vallbona sit parrochialis ecclesie et simenteriis eiusdem; in loco autem de Benaguazir non sit parrochialis ecclesia, sed ecclesia qui ibidem est et fuit actenus parrochialis a modo sit capella.

Posint tamen in cimenterio de Benaguazir defunctorum corpora dictis locis si hoc elegerint sepeliri.

Rector autem qui nunc est et pro tempore fuerit, teneatur personalem facere residentiam in dicto loco de Vallbona, nec in loco de Benaguazir teneatur celebrare divina offitia, seu facere celebrari nisi ter in septimana, in diebus tamen pro festis; et ipsa die qua in dicta cappella de Benaguazir misam celebraverit seu fecit celebrari, non teneat ad celebrandum in ipsa parrochiali ecclesia de Vallbona, nec teneatur idem rector ac tenendum alium presbiterum, quod día ipse personaliter sumum offitium exequi sit paratus.

Predicti autem nobiles, scilicet dominus Jacobus Petri et domina Sancia Ferrandis, consors eius, teneantur dare domos et hortum sufficientes in dicto loco de Vallbona rectori qui nunc est et pro tempore erit ibi.

In cuius rei testimonium presentem literam fecimus sigillari, nostri pendentis minimine roborari.

Acta [fuit] data Valentie decimo septimo calendas aprilis, anno Domini millesimo tercentesimo quarto.

\section{Traducción}

Si es razonable, y fue ordenada desde el principio las cosas que, a su debido tiempo, cuando las causas de los justos, de lo que se pueden cambiar para mejor, ser cambiados no es simplemente absurdo y no debe ser juzgado reprobable

De ahí que, con la iglesia parroquial de Benaguacil, se encuentra en el lugar que era desde el principio y el fundamento de lo anterior de Benaguacil, porque él y la fundación de la parroquia del mismo tiempo, dentro de los límites de algunos de los países, no había lugar; ahora, sin embargo, por la gracia de Dios, ni dentro de un mismo pasaje del Benaguacil los límites de lo anterior pueden ser convocadas por una nueva población de Vallbona, en el que doscientos, y habite en el cristiano; quinientos habitantes de los sarracenos en dicho lugar vamos a discutir a Benaguacil aunque bien, que los cristianos, sin embargo, no lo hicieron, y no hacer, aparte de los habitantes de los cinco o seis que están llamados por el Señor del lugar, que a veces tanto tiempo en el mismo lugar cuando él, con su familia. 
Por esta razón, nosotros, Raymond, San Valentín, el obispo de la misericordia divina, escuchando a petición de éste, un noble señor James de Pedro, de estos lugares, y el Señor Sancie Ferrandis, de su esposa; asistir, también hizo ferviente oración a Guillermi de Ginebreda, del rector de la misma iglesia, así como en los pasajes anteriores de los habitantes de la cristiana, porque esto nos Solicitante con urgencia; Teniendo en cuenta también que hay una mucho mejor y mucho más beneficioso a la iglesia parroquial, donde la población cristiana alcalde vive [para] el presente, cuando es difícil colocar el director de Vallbona dijo que los hombres se les dijo que solicitar estos puestos Benaguazir distancia para venir a los sacramentos; con el consentimiento de su derecho, la parroquia o la iglesia parroquial del capítulo de la iglesia, y para cambiar transferimos el lugar del Benaguazir al lugar de los mencionados por dicho de Vallbona, junto con los métodos y dirección en los siguientes, a saber:

Eso es para el futuro de la iglesia parroquial y el cementerio de Vallbona en dicho lugar de la misma; no está en el lugar de la parroquia de la Benaguazir la iglesia, pero la iglesia que están en el mismo lugar es y fue hasta ahora ha sido que en la forma en que se encuentra la capilla de la iglesia parroquial.

Proponen, sin embargo, dijo que los cuerpos de los muertos de Benaguazir cementerio si deciden ser enterrado.

Rector, sin embargo, que es ahora y por el momento, está obligado a hacer una residencia personal en dicho lugar de Vallbona, se une a, o en el lugar de la Benaguazir para celebrar el oficio divino, o para hacer que se celebrará sino tres veces en la semana, los días, sin embargo, para todas las fiestas; será también el día en que debía celebrar, o hecho que se celebrará en la capilla de la misam Benaguazir, no puede mantener la celebración de la iglesia parroquial de Vallbona en la misma, o de otro sacerdote está obligado y del ejercicio de que el rector de la misma, que es llevar a cabo la oficina del día él, personalmente, nosotros debemos estar preparados.

Lo anterior, sin embargo, de noble cuna, es decir, el señor del señor de San Pedro y Jacobo Ferrandis, el socio suyo, están obligados a pagar por el rector de las casas y el jardín, y con la suficiente de Vallbona en dicho lugar estará allí, por el tiempo que es ahora.

En testimonio de lo que hemos hecho, y sellado con la presente carta, y nuestros hombres colgando sello minimine.

Acta [fue] el séptimo mes se dio en Valencia, el diez de abril, el cuarto año del Señor de su canonización. 
Transcripción de los textos originales de los diez pergaminos originales y la regesta de cada uno de ellos en el apartado de anexos. Archivo del Sindicato de Riegos de La Pobla de Vallbona. Documentos transcritos y traducidos por Tomas Hurtado y Josep Borde en abril de 2015. Traducidos y restaurados mediante un convenio firmado con el Ayuntamiento de La Pobla de Vallbona en febrero de 2014.

Pergamino 1

\section{Transcripción}

[...] dei mensis januarii anno a Nativitate Domini M CCCo septuagesimo scriptam aduabus [...] sigille nomini illustrissimem domini Regis Aragonem pa[...] tenetum qui [...]. Nos Petrus

dei gratia [---] in favorem dono quod remeter vobis[...] florenos per [-- ]

[--] et valorem cuius generalis [--] olim meum absolimus, difinimus, remitimus [--] graciose universis et singulis vasallis ipsius vostra et aliis [..] ipsius quem die et anno.

(4) quos etiam [--] omnia et singula [--] excesus et deliteram [...] condiciones [--] existant de quipus fuit vel esse posit decreto [--] delalte seu qualibe [--]

(5) garente que [--] et regem Petrum castelle tamque rebelionibus et castrorum ac fortaliciorum tradictorum alias gravis causa que poterit usque in hinc presentem diem vel posit inpositionem ocasionem dictem guerrem vasallis (6) [--] universitatibus te cumunitatibus dicti brachii ad termine excesum quomodolibet seu delictum autculpa singularitem [---] generalter imputari. Ita quam modo nunque posit por inde per nos aut nominem primogenitum nec oficiales nostros vel suos [---] (7) alias quasius personas quantantumque potestare [--] adversas pisos vasallos aut aliquem [---] vellbona sua pius minus precedit nec eis fueri quesito petitio seu desmanda in judicio [---] extra judicium quiuliter aut criminaliter nec al quius modo (8) Qum (sic) petius inde sunt cum ómnibus certum bonis habitis et habendis quitii, fatica liberi et in nominis ad perpertuo absoluti varitate presentis et solucionis et grave firmiter et [---] temporibus

Sig + num honorabilis Garcie de Loris militis serenissimi domini Regis Aragonem consiliarii gerentis vices gubernatoris in regno Valencie quod inclito domino infante Johane predicti domini regis primogénito eiusque regnorum et terrarum gubernatore generali duce gerunde et commite Cervarie quid visis prefatis originalibus cartis hunc tarslatio autoritatem suam prestitit e decretum 
Sig + num mei Arnaldí Ferrarii de la Palma Regia Autoritate notario publici Valencie qui loco discreti Andree Vitalis, notario publici eadem autoritatem regentis scribania curie gubernacionis regni Valencie quod Benarabili Dalmacio de Jaffero milite in hoc traslato auctoritatem dicti honorabilis gerentes vices gubernatoris, eius jussu appocam et scripsi.

Sig + num Guillermo Sserra notario publici Valentie, qui hoc ad suis originalibus trasllatari et scribi fecit et comprobata clausit, loco die et anno in prima línea contentis et cum literis rasis --- in presenti linea clausure in ----- clausis.

\section{Traducción o regesta:}

1370, enero 12. El rey Pedro, por la gracia de Dios, rey de Aragón, de valencia, de Mallorca, de Cerdeña y Corcega y conde de Barcelona, Roselló y Cerdeña, señala delante del brazo militar del reino de Valencia y a su termino general, presente en la ciudad de Valencia, que determinados lugares y castillos del reino pueden tener penas determinadas si actúan a favor del rey en la guerra que se está produciendo con Pedro de Castilla.

Firmado. Honorable garcia de Loris, caballero, consejero de la casa real y gerente del gobernador general del Reino de Valencia, en nombre del infante Juan, primogénito del rey. Este vió la carta original real y su traslado por autorización real.

Firmando ante el notario real Arna Ferrer de la Plama, regente de la escribanía de la curia del Gobernador del Reino de Valencia, por Dalmau de Jafer, caballero.

Pergamino 2

\section{Transcripción}

Sapien tuyt com nós, Johan Galiffa, y na Paschuala muller sua, et na Matheua, muller de Domingo Pellayo, et Ramon Bonet, e na María, muller sua, vehins de la Pobla de Beneguazir, tots ensemps e cascun de nós per si e per lo tot, ab testimoni de la present públicha terra per tots temps valedera e en res no revocadora, venem e atorgam, liuram, o (quaix) liuram a vós, en Pere Gilabert, laurador de la ciutat de València, present e reebent, e als vostres propriis en per tots temps, doents sous reals de València censals, rendals, annuals, perpetuals, ab fadigua e loysme, e ab tot altre plen dret emphitèotich e dret de reebre aquells per cascuns anys segons fur de València, los quals dits doents sous censals a vós assignam havedors e reebedors per cascuns annys (sic) en la festa de Sent Miquell del mes de setembre primervinent, e d'aquí avant per cascun any en lo dit termini e festa. E assignam e carreguam aquells a vós e als vostres, havedors e reebedors cascun any en lo dit termini, en e sobre les posessions nostres inffrasegüents: primerament, sobre hun troç de 
terra que nós, dits Johan Galiffa e na Paschuala, avem e poseim en la orta de la dita Pobla, franch e liure, segons que affronta ab camí públich, e ab terra de hereus de Matheu Adam, e ab terra de Martín Segorb, que por estar tro a setze fanequadas de terra poch més o menys; ítem, hun troz de vinya situat en la orta de la dita Pobla, ffranqua, que affronta ab camí de Líria, escorredor enmig, e ab vynya de Pedro de (Inssa), e ab vinya de hereus de Matheu Adam; item, hun altre troz de terra situat en la orta de la dita Pobla, ffranch, que affronta ab vinya de Gil de Linyán, e ab terra d'en Guillem Felemir, e ab céquia Bona, e ab céquia Primera; ítem, hun altre troz de vinya al Campés, orta de la dita Pobla, ffranqua, que affronta ab camí de Líria, escorredor enmig, e ab vinya de Bonanat (Caglerm), e ab vinya de Michel Banyó, e ab terra dels moros, escorredor enmig; ítem, un altre bancal de terra situat en la dita orta, franch e liure, que affronta ab terra d'en Guillem Rausell, e ab terra de Gil de Linyán, e ab terra de Pere Oltrera. Les quals damunt dites possesions són ffranques e liures, segons damunt és dit, de sens, mazmodines e morabatí, salvant peyta de senyor.

Item, nós, dits Ramon Bonet e na María, muller sua, obligam a vós, dit en Pere Gillabert, e als vostres, per los dits doents sous censals, les possesions nostres inffrasegüents: primerament, una sort de vinya o terra a la foya d'Alginet, orta de la dita Pobla, ffranqua e liure, que affronta ab terra e vinya de Pere Ortiz, e ab céquia d'Alginet, e ab céquia Bona, senda enmig; ítem, unes cases situades en la dita Pobla, ffranques e liures, segons que affronten ab cases de Andreu Felemir, e ab cases de Matheu Adam, e ab carera (sic) públiqua; ítem, hun altre troç de vinya situat en la dita orta, ffranch, que affronta ab vynya d'en Guillem Galiffa, e ab céquia Bona, e ab vinya de Guillamó Galiffa; ítem, hun bancal de terra situat en la dita orta, franch, que affronta ab terra de Guillem Galiffa de dos parts, e ab carrera pública. Les quals dites possesions són ffranques, segons dit és, de cens, morabatí e maçmodines.

Ítem, yo, dita na Matheua, muller del dit en Domingo Pellayo, oblich a vós, dit en Pere Gilabert, e als vostres, per los dits doens sous censals e preu de aquells, les posessions mies inffrasegüents: primerament, unes cases situades en la dita Pobla, franques, que affrontan ab cases... Banyón, e ab cases de Pere de (Hiesa), e ab carrera pública; ítem, les kafficades de terra camí de Beneguazir, ffranques, que affrontan ab céquia Bona, e ab la céquia Primera, e ab terra de Lorenç Vicent, e ab terra de Pero Martínez; ítem, tres fanequades de terra situades en la orta de la dita Pobla, franques, segons que affrontan ab la céquia Primera, e ab terra de Bernat de Sent Martín, senda enmig; item, altres fanecades de terra situades en la dita orta, ffranques, que affrontan ab terra de hereus de Jacme Benajam, e ab terra de Jacme Monreal, e ab terra de Michel Lopp (sic) de la Torre. Les quals dites possesions, segons dit és, són franques de sens, morabatí, mazmodines, salvant ... de senyor e messions de la villa. 
Et generalment sobre tots altres béns e drets nostres, e de cascun de, per lo tot, mobles, seents e semovents, haüts e per haver, axí que la general obligació no derogue a la special nec (contra), mas l'altra sia corroboració de l'altra e de qualsevol d'aquelles puxats usar a e per aver lo dit vostre censal ab tots ses clàusul[les] ... any en lo dit termini, los quals dits doens sous censals, annuals, perpetuals, prometem donar, liurar e pagar a vós e als vostres, en la sobre dita festa de Sent Michel, dins la ciutat de València, 0 dins les cases 0 ... on és la vostra habitació o en altre alberch o loch on a vós plaurà dins la dita ciutat, ab nostra pròpria messió, risch, ... sens tota empara o secrestació e impediment alcú, ecclesiàstich o seglar, en açò cesants, ans aquells prometem liurar e pagar a vós e als vostres per cascuns anys, en la dita festa, franchs e liures e exi ... de totes e cascunes peytes, subsidiis (sic), censos, qüestes, talayas, hosts e cavalcades, morabatí, e redempció de aquells, custòdia ... conffecció e reparaçió de obres de murs e de vayls, d'altra qualsevol sisa, almoyna, imposició ... comissions, remissions, e de totes altres e qualsevol servituts reals, dominals o vehinals, ordinaries o extraordinaries, que dir o nomenar se poguesen. Et açò sots pena de cent sous reals de València per cascuna pagua e solució donadora, paguadora, per nós e els nostres a vós e als vostres, per pena e en nom de pena, dan e interés vostre en ... tantost pasat lo dit termini o festa siam encorreguts sens alcuna requisició o protestació, la qual fer no siats tengut; la qual pena, si comesa serà, a pagar aquella obligats siam nós e cascun de nós per si e per lo tot. Et açò per pacte special açí expressament opposat, e tantes vegades sia comesa, quantes serà contra feyt, e aquella dita pena una vegada o moltes, si comesa serà, pagada o no pagada o graciosament remesa, no resmeyns siam tenguts nós e cascun de nós, per si e per lo tot, de attendre e complir a vós e als vostres totes e sengles coses dessús espacifficades e recomptades. Et si en lo dit termini o festa en lo qual nós som tenguts pagar a vós los dits doents sous censals, vós e els vostres del dit cens complidament no serets pagats o satisfets segons damunt és contengut, ara com lavors e lavors com ara, per pacte special entre nós e vós convengut e açi opposat, donam a vós e als vostres licència, auctoritat e potestat que puxats convenir nós e qualsevol de nós d'avant l'onrat portantveus de governador en lo regne de València, o d'avant lo honrat lo justícia de la dita ciutat o en lo loch de la Pobla d'on som vehins e habitadors, o d'avant qualsevol altre jutge o justícia ordinari delegat o o (sic) subdelegat, e en qualsevulla loch, villa o ciutat dins lo regne de València, una vegada o moltes, vós e els vostres elegerets laychs, emperó e si e segons que a vós e als vostres serà ben vist fahedor, jatsesia lo dit jutge no sia nostre ne a nós no sia idóneo ne competent jutge.

Emperò nós, pernós e els nostres, a la juredicció, discrecció, coherció e potestat al dit jutge o jutges per vós e els vostres elegidor o elegidors, segons dit és, prerogam e en aquell cosentim, e d'avant aquell per nós o legítim procurador nostre e de cascun de nós per si e per lo tot, prometem comparer e dret fermar a la juredició e fur, del qual nós e tots los béns nostres e de cascun per 
lo tot sotsmetem. E estar e obeyr al seu arbitri e sentència, no contrastant a vós e als vostres lo fur de València posat en "rúbriqua de jurediccions o depondre de tot jutge", en lo qual és contegut que, onsevulla que hom sia domiciliat, allí deïa ésser convengut, o als clamants de aquell, que allí sia tengut de fer compliment de justícia, si donchs en altre loch no serà obligat, o haja promés de pagar, o el contracte ffet hi fos, segons que•n lo dit fur pus larguament és contengut. E... sia que hu o dos de nós o més, convendrets en alcun loch, ciutat o villa, puxats altre e altres de nós en aquell mateix loch $o$ en altre, emperò dins lo regne de València, e davant aquell jutge $o$ altres per les dites co[ses conv]enir, e el primer o els primers convenguts, convenir e reconvenir e mudar puxats tantes vegades com a vós o als vostres ben vist serà fahedor, no contrastant a vós e als vostres lo fur de València posat sots "rúbriqua de fiançes", lo qual és reguardar que, si॰l actor o 1 creedor volrrà convenre o convenrà, lo hu d'aquells que per los béns de aquell sia tengut a pasar abans, que per los béns dels altres ab aquell ensemps obligats, segons que $\bullet$ lo dit fur pus larguament és recomptat. Los quals dits furs e tots altres ffurs, privillegis e drets contra les dits coses vinents, e totes exepcions e malicies e ape/•/acions justes e (frenoles), axí de dret com de feyt per nós e els nostres, ara com lavors e lavors com ara, espressament de tot en tot renunciam per special pacte e exprés ací oppossat, renunciant encara sobre açò al for, jurdiccó (sic) e descret nostres e de qualsevol de nós.

Et encara prometem per nós e els nostres, e en bona fe convenym per ferma e solempnial estipulació açí epposada que nós o qualsevol de nós, ne altre en loch nostre e per nós, no empetrerem ne empetrar farem del molt alt senyor rey d'Aragó, ni de la senyora regina e eius consorte, ni de l'alt senyor inffant don Johan, primogènit del dit senyor rey, ne de l'alt senyor inffant don Marti, senyor nostre, ne de alcun altre fill o filla, ne de alcuna altra persona eclesiàstica o seglar, alcuna carta de gràcia o privillegi, alonguament, letra o sobresehiment, manament, (iterguaries), inducció, remessió, absolució, per los quales o qualssevulla de aquelles nós poguesem el dit sens o alcuna part de aquell ultra lo dit termini prolongar, o contra los sobre dites coses o davall scriptes, o alcuna de aquelles venir, trenquar o en alcuna cosa revocar, jacsia per propri moviment real d'aquell o dels seus, o de alcú de nostra libertat $o$ pròpria volentat sien fetes $O$ atorguades. E si seran, prometem per nós e els nostres que de aquelles o alcuna de aquelles no usarem, ne usar farem ne•y consentrem per alcuna causa, manera o rahó, e siøu fem, o fer fem o consentrem, volem per nós e els nostres siam encorreguts en pena de doents sous de la dita moneda per cascuna vegada que la al•legarem o mostrarem a vós e als vostres, per pena e en nom de pena donadors e paguadors, la qual pena pagadora, si comesa serà, volem ésser tenguts e obligats per pacte special e exprés açí opposat. La qual pena, pagada o no pagada, noresmenys si la dita carta de largua gràcia, privillegi, alongament, letra, manament, sobresehiment, pregàries, indució (sic), remessió o absoluçió en cort o fora cort, en juhí o fora juhí, mostrarem per nul•les, incongrués, vanes e per no 
fetes de tot en tot sien haüdes. Et de les sues forçes o desinyments de tot en tot sien freturans, en axí que a nós ne als nostres no puxen aprofitar, ne a vós ne als vostres en alc[un]a ... noure, com nós de present a aquelles e a cascuna de aquelles les impetrades o impetradores, en general o en special, per se dan, invicció o qualsevulla dilació de trenta o deu dies, més o menys, a verifficar les coses impotrades de fur, privillegi e de dret atorgat e atorgader e de tot altre prefferment de dret, de tot en tot renunciam, attenents e considerants que a cascun sia leguda ... proprii dret renunciar, del qual seus penes si comeses seran, e e (sic) altres totes e sengles coses dessús e davayll escriptes, ensemps o departidament, volem per nós e els nostres. $E$ de present atorguam per special pacte que, pasat lo dit termini, que sia feyta e puxa ésser feyta execució contra nós e béns nostres, e de qualsevol de nós per lo tot, lícits o prohibits, privillegiats o no privillegiats ... com fora casa. $E$ primerament los béns mobles e semovents, e en apprés en los béns sients e damunt a vós obligats e en lo present con[tracte] espacifiquats, sola hostensió de aquesta present públicha carta, sens ninguna scriptura, o figura judiciaria, o condepnacions de (penar) de grat, o alcuna altra cosa acostumada segons que • fa e és acostumat de fer de sentència o manam[ent] ... que en cosa jutgada legitimament és traspassat, perquè per lo dit special pacte volem per nós e els nostres que la present públiqua carta en totes les sue[s] clàusules e condicions forca o fortalea obtinguen, e efficàcia de sentència donada en cosa jutgada legítimament traspasat de tot en tot. Et de present renunciam a qualssevol furs o privilegis, lo qual condepnacions [de] (penar) de grat (serà) feyts contra ... ació e de apellació, e qualsevulla dret, ffur o solempnitat, e totes e sengles coses desús dites per special pacte ací opposat prometem attenir e ... complir sens tota dilació e execució e de tot dan vostre, greuges, messions, intereses e clam de cort.

En axí, los damunt dits dohents sous sensals, annuals, perpetuals, ab fadigua e loysme e tot altre plen dret emphitèotich segons ffur de València en la forma dessús dita, tots ensemps e cascun de nós per si e per lo tot, venem e atorgam, liuram o quaix liuram a vós, dit en Pere G[ilabert] e als vostres, ço és, per preu de dos millia sous reals de València, los quals tots en comptant de vós havem haüts e reebuts a tota nostra volentat e d'aquells per ben pagats nós tenym, per què renunciam a tota exepció de la peccúnia damunt dita no comptada e de vós no aguda o reebuda, segons damunt és dit, e a engany e a benefici de menor preu, e a engany de doble, e aquella ley que ajuda als enganats (sic) ultra la mitat del just preu, e a tot altre dret contra açò vinent, donam e atorgam a vós e als vostres la venda damunt dita, amplament d'açí avant valrrà o ça enrere a valgut, per lo preu damunt dit, en axí que si la dita venda més val, o d'ací avant més valrrà, tot allò quantque sia de mayor valor en donació pura e irrevocable que s dita entre vius, a vós e als vostres sia entesa e haüda. En axí, vós e els vostres successors ajats la venda damunt dita ab tot son millorament feyt e per ffer, tingats e posseexquats e en pau per tots temps, expletets a donar, vendre, alienar, obligar, excambiar, empenyorar, 
trasportar e ffer de aquella a tota vostra pròpia volentat, axí com de cosa vostra pròpia, exceptant a cavallers e a sants. E prometem e en bona fe convenim, a vós e als vostres, de la venda damunt dita res serà sentència per les rahons o causes qualsevol donada sobre la evicció damunt dita, puxgue a nós e als nostres serà denunciat. E encara no esperada denunciació vostra, la qual a vós e als vostres remetem de present per pacte special segons que dessús és dit, tot allò quantque, quant e qualque cosa sia o serà a vós e als vostres intregrament (sic), jacsesia que obtingats o subcumbats restituhir, tornar e esmenar, vos o prometem tots ensemps, e cascun de nós per lo tot, a tota vostra volentat ab tots danys, greuges, messions e despenses d'aquí avant sotstengudes (sic) per vós e els vostres sagrament e propriament averades, lo qual ara e lavors e lavors com ara, a vós defferim, e aquell per delat aver volem ningun altre linatge de prova en nenguna manera request, al qual de certa sciència e expressament e per pacte special renunciam de present.

Volens encara que per aquest pacte special, que si alcuna cosa deffayl en aquesta present públiqua carta de venda, que per cavil•lació de alguna savia persona o de dret alcuna subtilitat pot ésser atrobada que a vós o als vostres pogués aproffitar, que per posades sien aüdes. E si algunes hi són ací opposades que a vós o als vostres poguesen (noure) per no posades, de tot en tot sien enteses la (olfura) emperò ambigües si algunes ne són o seran açí o s'atrobaran que per correccò (sic), interpetració (sic) e esmena se merexqua de vós e dels vostres a interpetració (sic) d'àrbitre, líberamen6t sien comanades o encara declarades. Adonchs aquestes coses, totes e sengles, e a qualsevol d'aquelles damunt dites, a vós e als vostres en poder e mà del notari deiús scrit, axí com a públiqua persona, a nós e a cascun de nós per lo tot en loch e nom de vós e dels vostres, et encara de tots altres dels quals se pertany e pertanyer pot d'aquí avant, legítimament stipulant e reebent (duhim) expressament prometedora, suffiridora e encara atorgadora, per les quals coses totes e sengles damunt dites attenedores, observadores, e attenents e complents a tots ensemps e cascun de nosaltres, per lo tot obligam a vós e als vostres nós e tots béns nostres e de cascun de nós, mobles o no mobles, aüts e per haver, on que sien en tot loch. E de nostra certa sciència renunciam quant açò a beneffici de partida, e a la nova e veyla constitució, acció, e a la epístola de diví Adrià, e a tot altre qualsevol ffur, ley o dret contra açò vinent. E a mayor cautella e seguretat de totes les damunt dites coses nós damunt dites, na Paschuala, muller de Johan Galiffa, e na Matheua, muller de Domingo Pelayo, e na María, muller de Ramon Bonet, juram per Déu e los Sants Quatre Evangelis pròpriament de les nostres mans corporalment toquats, les sobre dites coses, totes e sengles, per nós e els nostres, per tots temps, bones e fermes aurem e tendrem e encara complirem, e en alcuna cosa no contrafarem o vernem per alguna rahó sots (vincel). Del qual sagrament som certifficades de tot lo dret nostre e plenament instruydes per lo notari deiús scrit, renunciam quant a acò a benefficii (sic) de senatconsult Veleya, e als dots e esposalicis nostres, e al dret de la ypotheca e obligacions nostras e 
de cascun de nós, e a tot altre dret e beneficii (sic) contra açò vinent. Ffeyt fon açò en la Pobla de Beneguazir, septima die octobris, anno a Nativitate Domini millessimo CCCo septuagesimo sexto. S(señales)nes de Johan Galiffa e de na Pascuala; s(señal)ne de na Matheua; s(señales)nes de Ramon Bonet e de na María, damunt dits, que açò loam, atorgam e ffermam.

Testimonis foren açò presents en Jacme Julià, vehí de la Pobla de Beneguazir, e Garcia Gómez, vehí de València.

Sig(señal)no de Gil de Linyán, notari públich de la Pobla de Beneguazir e de Beneguazir, que present a les dites coses fui e açò scriví, ab sobreposat en la XXIIa línea on diu "en", et ab ras e esmenat en la XLVIa línea on diu "de la venda damunt", e ab ras e esmenat en la LIIIIa línea on se lig "tots", e ab sobreposat en la $\mathrm{LV}$ a línea on se conté "e a la nova e veyla constitució", et ab ras e esmenat en lo títol o clausura de aquest meu signe on diu sobreposat "e açò cloy loch, día e any dessús dits".

Sapien tuyt com nós, Johan Galliffa, e na Pascuala, muller sua, e na Matheua, muller de Domingo Pellayo, e Ramon Bonet, e na María, muller sua, vehins de la Pobla de Beneguazir, scientment e de certa sciència tots ensemps, e cascun de nós per si e per lo tot, ab testimoni de la present públiqua carta per tots temps valedora e en res revocadora, atorguam e regonexem nós aver haüts e en comptant reebuts de vós, en Pere Gilabert, laurador e vehí de la ciutat de València, present e reebent, e dels vostres, dos millia sous de moneda reals de València, los quals vós a nós liuràs e pagàs per rahó de doents sous reals de València censals, rendals, perpetuals e annuals ab fadigua e loïsme e tot altre dret emphitèotich, que nós a vós venem e asignam, avedors e reebedors per cascuns anys en la festa de Sent Michel del mes de setembre, sobre certes possesions nostres, ço és, cases, vinyes e terres situades en la Pobla de Beneguazir e terme de aquella, açò segons que $\bullet$ la carta de la venda dels dits doents sous censals, la qual és ffeyta en lo present día, closa e subsignada per mà del notari deiús scrit larguament se conté. Perquè•ns atorguam per ben pagats dels dits dos millia sous de la dita moneda, renunciam a tota exepció a tota exepció (sic) de la peccúnia dessús dita no comprada e de vós no aguda o reebuda, segons damunt és dit, e a engany. $E$ com açò axí és lo feyt de la veritat, volem que us sia feyta la present carta de àppocha e de absolució per lo notari deiús scrit a conservació de vostre dret e a (perpditrable) memòria. Ffeyt fon açò en la Pobla de Beneguazir, septima die octobris, anno a Nativitate Domini millessimo CCCo LXXo sexto. S(señales) nes de Johan Galiffa e de na Pascuala; s(señal)ne de na Matheua; s(señales) nes de Ramon Bonet e de na María, damunt dits, que açò loam, atorgam e fermam.

Testimonis foren açò presents en Jacme Julià, vehí de la Pobla de Beneguazir, e Garcia Gómez, vehí de València. 
S(señal)no de Gil de Linyán, notari públich de la Pobla de Beneguazir e de Beneguazir, que present a les dites coses fui, e acò scriví e cloy en lo dit loch de la Pobla, día e any dessús dits.

\section{Pergamino 3}

\section{Transcripción}

Sapien tuyt com nós, Johan Galiffa, y na Paschuala muller sua, et na Matheua, muller de Domingo Pellayo, et Ramon Bonet, e na María, muller sua, vehins de la Pobla de Beneguazir, tots ensemps e cascun de nós per si e per lo tot, ab testimoni de la present públicha terra per tots temps valedera e en res no revocadora, venem e atorgam, liuram, o (quaix) liuram a vós, en Pere Gilabert, laurador de la ciutat de València, present e reebent, e als vostres propriis en per tots temps, doents sous reals de València censals, rendals, annuals, perpetuals, ab fadigua e loysme, e ab tot altre plen dret emphitèotich e dret de reebre aquells per cascuns anys segons fur de València, los quals dits doents sous censals a vós assignam havedors e reebedors per cascuns annys (sic) en la festa de Sent Miquell del mes de setembre primervinent, e d'aquí avant per cascun any en lo dit termini e festa. E assignam e carreguam aquells a vós e als vostres, havedors e reebedors cascun any en lo dit termini, en e sobre les posessions nostres inffrasegüents: primerament, sobre hun troç de terra que nós, dits Johan Galiffa e na Paschuala, avem e poseim en la orta de la dita Pobla, franch e liure, segons que affronta ab camí públich, e ab terra de hereus de Matheu Adam, e ab terra de Martín Segorb, que por estar tro a setze fanequadas de terra poch més o menys; ítem, hun troz de vinya situat en la orta de la dita Pobla, ffranqua, que affronta ab camí de Líria, escorredor enmig, e ab vynya de Pedro de (Inssa), e ab vinya de hereus de Matheu Adam; item, hun altre troz de terra situat en la orta de la dita Pobla, ffranch, que affronta ab vinya de Gil de Linyán, e ab terra d'en Guillem Felemir, e ab céquia Bona, e ab céquia Primera; ítem, hun altre troz de vinya al Campés, orta de la dita Pobla, ffranqua, que affronta ab camí de Líria, escorredor enmig, e ab vinya de Bonanat (Caglerm), e ab vinya de Michel Banyó, e ab terra dels moros, escorredor enmig; ítem, un altre bancal de terra situat en la dita orta, franch e liure, que affronta ab terra d'en Guillem Rausell, e ab terra de Gil de Linyán, e ab terra de Pere Oltrera. Les quals damunt dites possesions són ffranques e liures, segons damunt és dit, de sens, mazmodines e morabatí, salvant peyta de senyor.

Ítem, nós, dits Ramon Bonet e na María, muller sua, obligam a vós, dit en Pere Gillabert, e als vostres, per los dits doents sous censals, les possesions nostres inffrasegüents: primerament, una sort de vinya o terra a la foya d'Alginet, orta de la dita Pobla, ffranqua e liure, que affronta ab terra e vinya de Pere Ortiz, e ab céquia d'Alginet, e ab céquia Bona, senda enmig; ítem, unes cases situades en la dita Pobla, ffranques e liures, segons que affronten ab cases de Andreu 
Felemir, e ab cases de Matheu Adam, e ab carera (sic) públiqua; ítem, hun altre troç de vinya situat en la dita orta, ffranch, que affronta ab vynya d'en Guillem Galiffa, e ab céquia Bona, e ab vinya de Guillamó Galiffa; item, hun bancal de terra situat en la dita orta, franch, que affronta ab terra de Guillem Galiffa de dos parts, e ab carrera pública. Les quals dites possesions són ffranques, segons dit és, de cens, morabatí e maçmodines.

Item, yo, dita na Matheua, muller del dit en Domingo Pellayo, oblich a vós, dit en Pere Gilabert, e als vostres, per los dits doens sous censals e preu de aquells, les posessions mies inffrasegüents: primerament, unes cases situades en la dita Pobla, franques, que affrontan ab cases ... Banyón, e ab cases de Pere de (Hiesa), e ab carrera pública; ítem, les kafficades de terra camí de Beneguazir, ffranques, que affrontan ab céquia Bona, e ab la céquia Primera, e ab terra de Lorenç Vicent, e ab terra de Pero Martínez; ítem, tres fanequades de terra situades en la orta de la dita Pobla, franques, segons que affrontan ab la céquia Primera, e ab terra de Bernat de Sent Martín, senda enmig; ítem, altres fanecades de terra situades en la dita orta, ffranques, que affrontan ab terra de hereus de Jacme Benajam, e ab terra de Jacme Monreal, e ab terra de Michel Lopp (sic) de la Torre. Les quals dites possesions, segons dit és, són franques de sens, morabatí, mazmodines, salvant ... de senyor e messions de la villa.

Et generalment sobre tots altres béns e drets nostres, e de cascun de, per lo tot, mobles, seents e semovents, haüts e per haver, axí que la general obligació no derogue a la special nec (contra), mas l'altra sia corroboració de l'altra e de qualsevol d'aquelles puxats usar a e per aver lo dit vostre censal ab tots ses clàusul[les] ... any en lo dit termini, los quals dits doens sous censals, annuals, perpetuals, prometem donar, liurar e pagar a vós e als vostres, en la sobre dita festa de Sent Michel, dins la ciutat de València, o dins les cases 0 ... on és la vostra habitació o en altre alberch o loch on a vós plaurà dins la dita ciutat, ab nostra pròpria messió, risch, ... sens tota empara o secrestació e impediment alcú, ecclesiàstich o seglar, en açò cesants, ans aquells prometem liurar e pagar a vós e als vostres per cascuns anys, en la dita festa, franchs e liures e exi ... de totes e cascunes peytes, subsidiis (sic), censos, qüestes, talayas, hosts e cavalcades, morabatí, e redempció de aquells, custòdia ... conffecció e reparaçió de obres de murs e de vayls, d'altra qualsevol sisa, almoyna, imposició ... comissions, remissions, e de totes altres e qualsevol servituts reals, dominals o vehinals, ordinaries o extraordinaries, que dir o nomenar se poguesen. Et açò sots pena de cent sous reals de València per cascuna pagua e solució donadora, paguadora, per nós e els nostres a vós e als vostres, per pena e en nom de pena, dan e interés vostre en ... tantost pasat lo dit termini o festa siam encorreguts sens alcuna requisició o protestació, la qual fer no siats tengut; la qual pena, si comesa serà, a pagar aquella obligats siam nós e cascun de nós per si e per lo tot. Et açò per pacte special açí expressament opposat, e tantes vegades sia 
comesa, quantes serà contra feyt, e aquella dita pena una vegada o moltes, si comesa serà, pagada o no pagada o graciosament remesa, no resmeyns siam tenguts nós e cascun de nós, per si e per lo tot, de attendre e complir a vós e als vostres totes e sengles coses dessús espacifficades e recomptades. Et si en lo dit termini o festa en lo qual nós som tenguts pagar a vós los dits doents sous censals, vós e els vostres del dit cens complidament no serets pagats o satisfets segons damunt és contengut, ara com lavors e lavors com ara, per pacte special entre nós e vós convengut e açi opposat, donam a vós e als vostres licència, auctoritat e potestat que puxats convenir nós e qualsevol de nós d'avant l'onrat portantveus de governador en lo regne de València, o d'avant lo honrat lo justícia de la dita ciutat o en lo loch de la Pobla d'on som vehins e habitadors, o d'avant qualsevol altre jutge o justícia ordinari delegat o o (sic) subdelegat, e en qualsevulla loch, villa o ciutat dins lo regne de València, una vegada o moltes, vós e els vostres elegerets laychs, emperó e si e segons que a vós e als vostres serà ben vist fahedor, jatsesia lo dit jutge no sia nostre ne a nós no sia idóneo ne competent jutge.

Emperò nós, pernós e els nostres, a la juredicció, discrecció, coherció e potestat al dit jutge o jutges per vós e els vostres elegidor o elegidors, segons dit és, prerogam e en aquell cosentim, e d'avant aquell per nós o legítim procurador nostre e de cascun de nós per si e per lo tot, prometem comparer e dret fermar a la juredició e fur, del qual nós e tots los béns nostres e de cascun per lo tot sotsmetem. E estar e obeyr al seu arbitri e sentència, no contrastant a vós e als vostres lo fur de València posat en "rúbriqua de jurediccions o depondre de tot jutge", en lo qual és contegut que, onsevulla que hom sia domiciliat, allí deïa ésser convengut, o als clamants de aquell, que allí sia tengut de fer compliment de justícia, si donchs en altre loch no serà obligat, o haja promés de pagar, o el contracte ffet hi fos, segons que•n lo dit fur pus larguament és contengut. $E$... sia que hu o dos de nós o més, convendrets en alcun loch, ciutat o villa, puxats altre e altres de nós en aquell mateix loch $o$ en altre, emperò dins lo regne de València, e davant aquell jutge o altres per les dites co[ses conv]enir, e el primer o els primers convenguts, convenir e reconvenir e mudar puxats tantes vegades com a vós o als vostres ben vist serà fahedor, no contrastant a vós e als vostres lo fur de València posat sots "rúbriqua de fiançes", lo qual és reguardar que, si॰l actor $0 \bullet /$ creedor volrrà convenre o convenrà, lo hu d'aquells que per los béns de aquell sia tengut a pasar abans, que per los béns dels altres ab aquell ensemps obligats, segons que $\bullet$ lo dit fur pus larguament és recomptat. Los quals dits furs e tots altres ffurs, privillegis e drets contra les dits coses vinents, e totes exepcions e malicies e apel•lacions justes e (frenoles), axí de dret com de feyt per nós e els nostres, ara com lavors e lavors com ara, espressament de tot en tot renunciam per special pacte e exprés ací oppossat, renunciant encara sobre açò al for, jurdiccó (sic) e descret nostres e de qualsevol de nós. 
Et encara prometem per nós e els nostres, e en bona fe convenym per ferma e solempnial estipulació açí epposada que nós o qualsevol de nós, ne altre en loch nostre e per nós, no empetrerem ne empetrar farem del molt alt senyor rey d'Aragó, ni de la senyora regina e eius consorte, ni de l'alt senyor inffant don Johan, primogènit del dit senyor rey, ne de l'alt senyor inffant don Marti, senyor nostre, ne de alcun altre fill o filla, ne de alcuna altra persona eclesiàstica o seglar, alcuna carta de gràcia o privillegi, alonguament, letra o sobresehiment, manament, (iterguaries), inducció, remessió, absolució, per los quales o qualssevulla de aquelles nós poguesem el dit sens o alcuna part de aquell ultra lo dit termini prolongar, o contra los sobre dites coses o davall scriptes, o alcuna de aquelles venir, trenquar o en alcuna cosa revocar, jacsia per propri moviment real d'aquell o dels seus, o de alcú de nostra libertat o pròpria volentat sien fetes o atorguades. E si seran, prometem per nós e els nostres que de aquelles o alcuna de aquelles no usarem, ne usar farem ne•y consentrem per alcuna causa, manera o rahó, e si•u fem, o fer fem o consentrem, volem per nós e els nostres siam encorreguts en pena de doents sous de la dita moneda per cascuna vegada que la al •legarem o mostrarem a vós e als vostres, per pena e en nom de pena donadors e paguadors, la qual pena pagadora, si comesa serà, volem ésser tenguts e obligats per pacte special e exprés açí opposat. La qual pena, pagada o no pagada, noresmenys si la dita carta de largua gràcia, privillegi, alongament, letra, manament, sobresehiment, pregàries, indució (sic), remessió o absoluçió en cort o fora cort, en juhí o fora juhi, mostrarem per nul•les, incongrués, vanes e per no fetes de tot en tot sien haüdes. Et de les sues forçes o desinyments de tot en tot sien freturans, en axí que a nós ne als nostres no puxen aprofitar, ne a vós ne als vostres en alc[un]a ... noure, com nós de present a aquelles e a cascuna de aquelles les impetrades o impetradores, en general o en special, per se dan, invicció o qualsevulla dilació de trenta o deu dies, més o menys, a verifficar les coses impotrades de fur, privillegi e de dret atorgat e atorgader e de tot altre prefferment de dret, de tot en tot renunciam, attenents $e$ considerants que a cascun sia leguda ... proprii dret renunciar, del qual seus penes si comeses seran, e e (sic) altres totes e sengles coses dessús e davayll escriptes, ensemps o departidament, volem per nós e els nostres. $E$ de present atorguam per special pacte que, pasat lo dit termini, que sia feyta e puxa ésser feyta execució contra nós e béns nostres, e de qualsevol de nós per lo tot, lícits o prohibits, privillegiats o no privillegiats ... com fora casa. $E$ primerament los béns mobles e semovents, e en apprés en los béns sients e damunt a vós obligats e en lo present con[tracte] espacifiquats, sola hostensió de aquesta present públicha carta, sens ninguna scriptura, o figura judiciaria, o condepnacions de (penar) de grat, o alcuna altra cosa acostumada segons que •s fa e és acostumat de fer de sentència o manam[ent] ... que en cosa jutgada legitimament és traspassat, perquè per lo dit special pacte volem per nós e els nostres que la present públiqua carta en totes les sue[s] clàusules e condicions forca o fortalea obtinguen, e efficàcia de sentència donada en cosa jutgada legítimament traspasat de tot en tot. Et de present renunciam a 
qualssevol furs o privilegis, lo qual condepnacions [de] (penar) de grat (serà) feyts contra ... ació e de apellació, e qualsevulla dret, ffur o solempnitat, e totes e sengles coses desús dites per special pacte ací opposat prometem attenir e ... complir sens tota dilació e execució e de tot dan vostre, greuges, messions, intereses e clam de cort.

En axí, los damunt dits dohents sous sensals, annuals, perpetuals, ab fadigua e loysme e tot altre plen dret emphitèotich segons ffur de València en la forma dessús dita, tots ensemps e cascun de nós per si e per lo tot, venem e atorgam, liuram o quaix liuram a vós, dit en Pere G[ilabert] e als vostres, ço és, per preu de dos millia sous reals de València, los quals tots en comptant de vós havem haüts e reebuts a tota nostra volentat e d'aquells per ben pagats nós tenym, per què renunciam a tota exepció de la peccúnia damunt dita no comptada e de vós no aguda o reebuda, segons damunt és dit, e a engany e a benefici de menor preu, e a engany de doble, e aquella ley que ajuda als enganats (sic) ultra la mitat del just preu, e a tot altre dret contra açò vinent, donam e atorgam a vós e als vostres la venda damunt dita, amplament d'açí avant valrrà o ça enrere a valgut, per lo preu damunt dit, en axí que si la dita venda més val, o d'acíavant més valrrà, tot allò quantque sia de mayor valor en donació pura e irrevocable que•s dita entre vius, a vós e als vostres sia entesa e haüda. En axí, vós e els vostres successors ajats la venda damunt dita ab tot son millorament feyt e per ffer, tingats e posseexquats e en pau per tots temps, expletets a donar, vendre, alienar, obligar, excambiar, empenyorar, trasportar e ffer de aquella a tota vostra pròpia volentat, axí com de cosa vostra pròpia, exceptant a cavallers e a sants. E prometem e en bona fe convenim, a vós e als vostres, de la venda damunt dita ab tot son millorament per tots temps deffendre, e salvar, e ffer aver e tener contra a tots persones contravinents o en alguna cosa perturbants a ffur de València, e siam tenguts en d'aquí a vós a vós (sic) e als vostres de fferm e leal evicció e de tot altre dan o interés. Axí que si per ventura d'aquí avant, en tot o en partida, d'aquesta venda per alcun temps o per alcú o per alcuns de qualsevol ley, condició o estament sien, a vós e als vostres serà feyta, moguda o inceptada qüestió alguna, o demanda, o controversia, força o tolta, de dret o de feyt, en juhí o fora juhí, axí per obligació de libell com per altra qualsevulla manera, e en continent feyta a nós o als nostres denunciació o no feyta, et encara no esperada denunciació de vós, la qual a vós e als vostres remetem de present per pacte special en aquest contracte opposat, lo fur e dret dient que si la venda serà tolta, ans que sia tolta dega ésser denunciada als venedors, als quals fur e dret renunciam expressament e de certa sciència de present, ans de dan donat e en vós e els vostres aüt e reebut. E apprés encara aquelles qüestions e demandes e a tota deffensió vostra, tots ensemps e cascun de nosaltres per lo tot, prometem nós offerir, e per vós e els vostres respondre e dret fer e satisfer ab nostres pròpries messions e despenses a vós emperò e als vostres e tots los béns vostres e dels vostres d'aquí avant a tot dan, greuge, messions, intereses, de tot en tot guardar. E encara aquelles qüestions, pleyts, 
causes en nós reebre, dur e tractar en juhí e fora juhí o en qualsevula (sic) loch, e a la defensió d'aquells en nós offerir e encara preseguir, e en aquells axí principals com appellacions continuament tant e tan longuament ésser tro per diffinitiva sentència, de la qual alcú appellar o suplicar nós convengua serà per fi deguda determenar, o vós o els vostres si velrets e elegerets puxats aquella causa o causes per vós, o per altre en loch de vós, demanar o deffendre, dur e tractar, a vós e als vostres sobre acò electo servada, axí en lo comencament, mig anyà, com en la fi e en qualsevol encara part del pleyt, tantes quantes o en qual a vós serà ben vist o direts elegidor, relexam a vós e als vostres per pacte special, dret e necessitat de denunciar, appellar, provocar, suplicar, hoch encara de proseguir. E si vós, dit comprador, e els vostres, la dita causa o causes demanar e deffendre, dur e tractar, elegerets e sobre la evicció contra vós o els vostres pronunciar convendrà, e d'aquí avant dan alcú, greuge o interés per vós sostengut serà, o messiós e despenses ffer convendrà, e de la venda damunt dita o part d'aquella, e a nós alcuna cosa serà tolt o diminuyt, tolt o forcat, per qualsevol manera tot allò quantque sia e serà a vós e als vostres restituhir e esmenar vos o prometem tots ensemps, e cascun de nós per si e per lo tot, en continent a tota la vostra volentat, volens resnomenys nós. E a vós atorgans que, per aquesta special, que nós ne els nostres no puxam dir a vós, o per alcuna manera allegar per vós e els vostres, feyta serà o sia feyta injuria o injustícia si tota la dita venda o alcuna part de aquella a vós o als vostres serà eventuda, diminuyda, tolta o forçada per força o poder de alcú, ne que de vós o dels vostres culpa o negligència serà de aquella, e en alcuna cosa serà eventuda, tolta o deminuyda, tolta, admisa, o encara forcada, ne per jutge, advocat, notari e procurador de vós, (impertia) no saber culpa o ffrau, engany, desidia o contumàcia, o per altra qualsevol manera a totes e sengles altres adversitats qualsevol de tot en tot renunciam de present ... si contra vós e els vostres serà sentència per les rahons o causes qualsevol donada sobre la evicció damunt dita, puxgue a nós e als nostres serà denunciat. E encara no esperada denunciació vostra, la qual a vós e als vostres remetem de present per pacte special segons que dessús és dit, tot allò quantque, quant e qualque cosa sia o serà a vós e als vostres intregrament (sic), jacsesia que obtingats o subcumbats restituhir, tornar e esmenar, vos o prometem tots ensemps, e cascun de nós per lo tot, a tota vostra volentat ab tots danys, greuges, messions e despenses d'aquí avant sotstengudes (sic) per vós e els vostres sagrament e propriament averades, lo qual ara e lavors e lavors com ara, a vós defferim, e aquell per delat aver volem ningun altre linatge de prova en nenguna manera request, al qual de certa sciència e expressament e per pacte special renunciam de present.

Volens encara que per aquest pacte special, que si alcuna cosa deffayl en aquesta present públiqua carta de venda, que per cavil•lació de alguna savia persona o de dret alcuna subtilitat pot ésser atrobada que a vós o als vostres pogués aproffitar, que per posades sien aüdes. E si algunes hi són ací opposades que a vós o als vostres poguesen (noure) per no posades, de tot en tot sien enteses la (olfura) emperò ambigües si algunes ne són o 
seran açí o s'atrobaran que per correccò (sic), interpetració (sic) e esmena se merexqua de vós e dels vostres a interpetració (sic) d'àrbitre, líberamen6t sien comanades o encara declarades. Adonchs aquestes coses, totes e sengles, e a qualsevol d'aquelles damunt dites, a vós e als vostres en poder e mà del notari deiús scrit, axí com a públiqua persona, a nós e a cascun de nós per lo tot en loch e nom de vós e dels vostres, et encara de tots altres dels quals se pertany e pertanyer pot d'aquí avant, legítimament stipulant e reebent (duhim) expressament prometedora, suffiridora e encara atorgadora, per les quals coses totes e sengles damunt dites attenedores, observadores, e attenents e complents a tots ensemps e cascun de nosaltres, per lo tot obligam a vós e als vostres nós e tots béns nostres e de cascun de nós, mobles o no mobles, aüts e per haver, on que sien en tot loch. E de nostra certa sciència renunciam quant açò a beneffici de partida, e a la nova e veyla constitució, acció, e a la epistola de diví Adrià, e a tot altre qualsevol ffur, ley o dret contra açò vinent. E a mayor cautella e seguretat de totes les damunt dites coses nós damunt dites, na Paschuala, muller de Johan Galiffa, e na Matheua, muller de Domingo Pelayo, e na María, muller de Ramon Bonet, juram per Déu e los Sants Quatre Evangelis pròpriament de les nostres mans corporalment toquats, les sobre dites coses, totes e sengles, per nós e els nostres, per tots temps, bones e fermes aurem e tendrem e encara complirem, e en alcuna cosa no contrafarem o vernem per alguna rahó sots (vincel). Del qual sagrament som certifficades de tot lo dret nostre e plenament instruydes per lo notari deiús scrit, renunciam quant a acò a benefficii (sic) de senatconsult Veleya, e als dots e esposalicis nostres, e al dret de la ypotheca e obligacions nostras e de cascun de nós, e a tot altre dret e beneficii (sic) contra açò vinent. Ffeyt fon açò en la Pobla de Beneguazir, septima die octobris, anno a Nativitate Domini millessimo CCCo septuagesimo sexto. S(señales)nes de Johan Galiffa e de na Pascuala; s(señal)ne de na Matheua; s(señales)nes de Ramon Bonet e de na María, damunt dits, que açò loam, atorgam e ffermam.

Testimonis foren açò presents en Jacme Julià, vehí de la Pobla de Beneguazir, e Garcia Gómez, vehí de València.

Sig(señal)no de Gil de Linyán, notari públich de la Pobla de Beneguazir e de Beneguazir, que present a les dites coses fui e açò scriví, ab sobreposat en la XXIIa línea on diu "en", et ab ras e esmenat en la XLVIa línea on diu "de la venda damunt", e ab ras e esmenat en la LIIII- línea on se lig "tots", e ab sobreposat en la LVa línea on se conté "e a la nova e veyla constitució", et ab ras e esmenat en lo títol o clausura de aquest meu signe on diu sobreposat "e açò cloy loch, día e any dessús dits".

Sapien tuyt com nós, Johan Galliffa, e na Pascuala, muller sua, e na Matheua, muller de Domingo Pellayo, e Ramon Bonet, e na María, muller sua, vehins de la Pobla de Beneguazir, scientment e de certa sciència tots ensemps, e cascun de nós per si e per lo tot, ab testimoni de la present públiqua carta per tots 
temps valedora e en res revocadora, atorguam e regonexem nós aver haüts e en comptant reebuts de vós, en Pere Gilabert, laurador e vehí de la ciutat de València, present e reebent, e dels vostres, dos millia sous de moneda reals de València, los quals vós a nós liuràs e pagàs per rahó de doents sous reals de València censals, rendals, perpetuals e annuals ab fadigua e loïsme e tot altre dret emphitèotich, que nós a vós venem e asignam, avedors e reebedors per cascuns anys en la festa de Sent Michel del mes de setembre, sobre certes possesions nostres, ço és, cases, vinyes e terres situades en la Pobla de Beneguazir e terme de aquella, açò segons que $\bullet$ la carta de la venda dels dits doents sous censals, la qual és ffeyta en lo present día, closa e subsignada per mà del notari deiús scrit larguament se conté. Perquè•ns atorguam per ben pagats dels dits dos millia sous de la dita moneda, renunciam a tota exepció a tota exepció (sic) de la peccúnia dessús dita no comprada e de vós no aguda o reebuda, segons damunt és dit, e a engany. $E$ com açò axí és lo feyt de la veritat, volem que us sia feyta la present carta de àppocha e de absolució per lo notari deiús scrit a conservació de vostre dret e a (perpditrable) memòria. Ffeyt fon açò en la Pobla de Beneguazir, septima die octobris, anno a Nativitate Domini millessimo CCCo LXXo sexto. S(señales) nes de Johan Galiffa e de na Pascuala; s(señal)ne de na Matheua; s(señales) nes de Ramon Bonet e de na María, damunt dits, que açò loam, atorgam e fermam.

Testimonis foren açò presents Johan ---------, vehíns de la Pobla de Beneguazir, e ----------- juheu de València.

S(señal)no de Gil de Linyán, notari públich e ----- de la Pobla de Beneguazir e de Beneguazir, que present a les dites coses fui, e acò scriví e cloy en lo dit loch de la Pobla, día e any dessús dits.

\section{Pergamino 4}

\section{Transcripción}

Anno a Nativitate Domini millessimo tescentesimo (sic) nonagesimo, die veneris, vicesima tercia novembris. En lo loch de Beneguazir, constituhits davant los honrats en Bereguer Marti, de la dispensseria del senyor duch, en Gil de Linyán, notari, e Abdallà Abenamir, sarrahí e alamí de Beneguazir, los honrats en Guillem Ferrando, justícia, en Domingo Portogalés e en Domingo Enyego, jurats de la Pobla de Beneguazir, de una part, e Mahomat Alorquí, sarrahí, tinentloch del dit Abdallà Abenamir, alamí, Alí Almaurellí, Hacem Abeayet e Mahomat Anadir, vells o jurats del dit loch de Beneguazir. E presentaren a aquells, e per mi Miquell de Camayes, notari públich per auctoritat real per tot lo regne de València, legir e publicar feren una carta de compromés ffet per les universitat e aljama dels lochs dessús dits en los dessús dits en Berenguer Martí, en Gil de Linyán e Abdallà Abenamir, de la tenor següent: 
In Dei nomine e eius gratia. Com segons ffur, dret e bona rahó, permís e lícit sia a cascú sobre les coses duptoses, litigioses e suptuoses, comprometre majorment en les coses que són en plet e qüestió, em, per amor d'açò, nós, en Guillem Ferrando, justícia del loch de la Pobla de Beneguazir, en Domingo Portogalés, Domingo Eneguo, vehins e jurats del dit loch en l'any present, Bonanat (Caglerm), Pere Lop, Vicent Lop, Miquell Lop, Bernat de Sant Martí, consellers, Pere Julià, Pasqual Sanxo, Domingo Navarro, Miquell de Camayes, Johan Stheve, Pere Oltrera, Jacme Tatay, Berenguer Baldós, Jacme de Vilanova, Pere Senceloni, Domingo Beneyto, Gil (Cahuenga), Pere Godín, Barthomeu Loba, Lorenç d'Escó, Miquell Galiffa, Goncalvo d'Aguillar, e Domingo Belido, Andreu Dezgraus, Johan Montagut, Martín de la Foz, Miquell Lop de la Torre, menor de dies, Lop Dassió, Martín Beneyto e Matheu Galiffa, vehins del dit loch de la Pobla, e molts altres ajustats en la ecclésia de Sant Jacme del dit loch, tots concordants e alcú de nós no discrepant, fahens consell e universitat concordadament, de una part. E nós, Mahomat Alorquí, sarrahí, tinentloch de alamí per Abdalà Abenamir, alamí del loch de Beneguazir, Alí Almaurellí, Mahomat Nadir e Hacem Abenayet, vells o jurats del dit loch, Abdallà Xoaïp, Mahomat Galip, Mahomat Alífraqui, Caat Almaureli, Hamet Almodrí, Hamet Almaurelí, Yahia Alharqí (sic), Alí Alifraquí, Hamet Halit, Abdallà Xarrellí, Mahomat Acabà, Juceff Alorquí, Mahomat Abramir, Fat Alponti, Mahomat Ayup, Mahomat Abinçalemé, Mahomat Faraig, Hiaya Alfaquí, Alí Alazllà, Mhomat (sic) Abçuni, Mahomat Alfferriol, Abdallà Abinçalemé, Abdallà Algercí, Caat Ablimén, Caat Almuzeny, Hamet Almoxalení, Alí Borruz, Hamet Axalobén, Hacen Abiaffià, Maymó Abeamir, Abdallà Xach, Lopo Algercí, Alí Arrami, Abdallà Azanoní, fill de Hacem, Mahomat Ayet, Abadallà Xabech e Alí Alffaquí, sarahins e habitadors del dit loch, congregats e ajustats en lo porche de la mizquita del dit loch de Beniguazir, on en lo dit loch és acostumat tenir e ajustar consell general per talls o semblants coses, per veu de Johan Castellano, públich corredor del dit loch, tots concordans e de bons coratges e espontàneas volentats e algú de nós no discrepant, fahens consell, universitat e aljama, de la part altra.

Scientment e de nostres certes sciències, attenents e regonexents que pleyt e qüestió és entre nós, parts dessús dites, per rahó del compartement del feyt de les cavalleries, e de les messions que •s deuen pagar per rahó de corts e qites (sic) reals, e altres messions que convenen a pagar al braz militar, de les quals convé o pertany als dits lochs pagar sa part. E encara per rahó del contrast que és entre les dites universitat e aljama per rahó del compartiment de la aygua dels royls de Alfeig e de Belestar e del Galspont, e per [o]casió de molts altres contrasts e qüestions que són e speren ésser enffre enfre (sic) los dits lochs per rahó de la dita céquia e altres, havem esguart a les dites coses, volents perdonar e obviar atreballs e messions e grans despeses e altres escàndels e perills que•s porían esdevenir entre nós, parts dessús dites, per les rahons dessús scrites. Per tal, per les causes e rahons dessús e deiús 
scrites, nós, parts dessús dites, axí cristians com sarrahins, concordantment comprometem e verdader compromés fem en vós, honrat en Berenguer Martí, ciutadà de la ciutat de Sogorb de la dispensseria del molt alt senyor duch, senyor de les dites universitats, absent, e en Gil de Linyán, notari dels dits lochs de la Pobla e de Beneguazir, e Abdallà Abenamir, alamí del dit loch de Beniguazir, presents, en tots vosaltres ensemps e no departidament, axí com en arbitris arbitradors e amigables composadors per nós, parts damunt dites, comunament elegits sobre totes e qualssevol qüestions, accions, peticions e demandes o contrasts civils, ordinaris o extraordinaris, e altres qualssevol que sien entre nós, dites parts e universitat e aljama, $0 \bullet / s$ uns contra els altres sien stats, són de present o•s speren ésser d'aquí avant, convenim o reconvenim de tot lo tepms (sic) passat tro a present día de l'any, e axí per les damunt dites rahons e qüestions, com per altres qualssevol qüestions de contribucions vehinals e de demandes fahedors d'ací avant per senyor o senyora als dits lochs o procuradors de aquells o altres en nom de aquells, e de obres de murs e de valls, e per rahó de las tandas de la céquia d'el Campés, e del prediment de la aygua que de aquellas fa qitar (sic) aquella per los escorredors en altres céquies, e generalment sobre totes altres qüestions que són entre los dits lochs de la Pobla e de Beneguazir per qualsevol causa, manera o rahó.

En axíque vistes e hoydes les dites qüestions, contrasts, peticions, demandes e accions que són entre nós, parts dessús dites, axí de paraulla (sic) com per scrit, e encara no vistes, donam e atorguam a vós, dits arbitris arbitradors e amigables composadors, ab lo present compromés, auctoritat, licència e ple poder les dites qüestions jutgar, sentenciar, pronunciar e declarar. $E$ prometen haver agradable e ferm tot co que per vós serà jutgat, sentenciat, arbitrat e declarat sios vol sia pronunciat per rigor de fur o de dret, com per amigable composició, com en altra qualsevulla manera, e (com iure) ... de o per amigable composició tota solepnitat de fur e de dret foragitades e no observades a sola volentat e discreció vostra, car nós, per ... renunciam a tota exepció, deffensió e contradició (sic) que contra la vostra sentència, arbitració e amigable composició porían fer o mover, quacumque casii super ad arbitrium boni viri recurrere, non valeanus ullo modo ... al dit recors de certa sciència renunciam de present. En axíque vós, dits [ar]bitris arbitradors e amigables composadors, sobre les dites qüestions, demandes e altres qualssevol incidents, dependents, emergents, coherents e annexes, puxats dir, diffinir, declarar, jutgar, sentenciar e pronunciar nós, parts dessús dites, presents o absents, o la [una] present e l'altra absent, en día feriat com no feriat, seents $o$ en peus estants, $o$ anants en loch convinent de jutgar o no convinent, orde de ffur e de dret observades o no observades, e de tot en tot foragitades sios vol en una pronunciació o en moltes, promete $[\mathrm{m}]$ ad in vicem que estarem e obeyrem la sentència dita, pronunciació o amigable composició o declaració vostres. E a aquelles o alcuna de aquelles no contradirem o contravendren, ne contravenir farem per nós o per los nostres 
o per altres interposades persones amagadament o (a palles) per alcun cars, manera o rahó, e açó sots pena de cinch-cents florins d'or d'Aragó comuns, pagadors per la part inobedient e no asistent e contravinent a la sentència dit (sic), pronunciació e declaració vostra, la mitat als coffres del senyor duch, senyor nostre, e l'altra mitat a la part obedient e asistent a la dita sentència, pronunciació, arbitració o declaració vostres, si per aquella serà acusada per pena, interés e dan de aquella, de la qual pena comprometen axí com dels feyts principals, la qual pena paguada o no paguada, resnomenys la sentència dit (sic), pronunciació, declaració o amigable composició vostra romangua en sa força e valor, de la qual pena si comesa serà ensemps ab la cosa jutgada o sens aquella, (vel) e conversso puxa ésser feta execució en los béns de la part contravinent. E si per les dites coses attendre e complir per la una part a l'altra ad in vicem convendrà fer o sostenir danys, greuges, messions o interesos, tot allò quacumque sia o serà la una part a l'altra ad in vicem prometen satisfer, esmenar e restituhir a la sua volentat, sobre les quals cascuna part de nosaltres sia creguda per sa plana e simple paraula sens testimonis e altra prova obligans, scientment quant a açò l'altra part de nós a l'altra, e l'altra a l'altra ad in vicem, nós e tots béns nostres e de les dites universitat e aljama e dels singulars e aquelles, mobles e no mobles, haüts e per haver, on que sien, renunciants quant a açò a benefici de partida, acció, e a la novella o vella constitució, e a la epistola de diví Adrià, e a tot altre qualsevol fur, ley o dret, constitució, ordinació, beneffici, privillegi e ajuda, e a çuna e xara de sarrahins, atorgats o atorguadors en favor de nós, parts dessús dites, o de qualsevol de aquelles, contra les dites coses vinents o en tot o en part a les coses sobre dites contrastants.

Volem emperò e declaram que $/$ present compromés dur tro a la festa de Tots Sants primera vinent inclusive, salvo iure prorogandi, la qual prorogació vós, dits arbitris arbitradors e amigables composadors, puxats fer per vós matexos ab consentiment o sens consentiment de nós, parts dessús dites, $e$ aquelles absents o presents, e en qualsevol loch tantes vegades com a vós serà ben vist fahedor. E encara volem que $\bullet /$ present compromés puxa ésser dictat si mester serà e en alcuna cosa, ara o en l'esdevenidor, serà vist duptós o no bastant a les coses sobre dites per los notaris del present feyt a consell de savis o de notaris aptes e entesos ... una e moltes veguades, tantes com mester serà, ab totes aquelles clàusulles, punts, fermetats que (millors) ordenar se puxa a profit de les parts, e a corroboració e a corroboració (sic) e fermetat de les coses supra espacifficades (sic), e a decisió e diffinició dels contrasts e qüestions dessús dites.

Ffeyt fon açò quant a la ferma de la universitat e singulars del dit loch de la Pobla, en lo dit loch de la Pobla, vicesima die septembris; e quant a la ferma de la aljama e singulars del dit loch de Beneguazir, en lo dit loch de Beneguazir, vicesima tercia die dicti mensis septembris, anno a Nativitate Domini Mo CCCo nonagesimo. Sen(señal)yal d'en Guillem Ferrando, justícia; 
sen(señales)yals d'en Domingo Portogalés e Domingo Enyego, jurats del dit loch de la Pobla; sen(señales)yals d'en Bonanat (Caglerm), Pere Lop, Vicent Lop, Bernat de Sant Martí, consellers; sen(señales)yals d'en Pere Julià, Pasqual Sanxo, Domingo Navarro, Miquell de Camayes, Johan Steve, Pere Oltrera; sen(señales)yals de Jacme Tatay, Berenguer Baldós, Jacme de Vilanova, Pere Senceloni, Domingo Beneyto, Gil (Cahuengua); sen(señales) yals de Pere Godín, Bartomeu Lobat, Lorenc d'Escó, Miquell Galiffa, Goncalbo d'Aguillar, Domingo Belido; sen(señales)yals de Andreu Dezgraus, Pasaber de Rodiella, Johan Navarro, mayor de dies, Guillem Galiffa, Pere Ferrando, menor de dies, Guillamó Amat; sen(señales)yals de Johan Enyéguez, Pere Thomás, Jordi Albert, Stheven Alcanyiz, Martín Navarro, Domingo Dezgraus; s(señales) nyals de Johan de Montagut, Martín de la Foz, Miquell Lop de la Torre, menor de dies, Lop Dassió, Marti Beneyto, Matheu Galiffa, vehins e habitadors del dit loch de la Pobla. Sen(señal)yal de Mahomat Alorquí, sarrahí, tinentloch de Abdallà Abenamir, alamí del dit loch de Beneguazir; sen(señales)yals de Alí Almaurelli, Mahomat Nadir e Hacem Abeayet, jurats o vells del dit loch; sen(señales)yals de Abdallà Xuaip, Mahomat Galip, Mahomat Alifraquí, Cat Almaurelí, Hamet Almudrí, Hamet Almaurelli; sen(señales)yals de Hiaya Alhaig, Alí Alifraquí, Hamet Halit, Abdallà Xarrellí, Mahomat Acabà, Jucef Alorquí; sen(señales)yals de Mahomat Abeamir, fat Alponti, Mahomat Ayup, Mahomat Abincalemé, Mahomat Faraig, Yahia Alfaquí; sen(señales)yes de Alí Alazllà, Mahomat Abcunní, Mahomat Alfferriol, Abdallà Abinçalemé, Abdallà Algercí, Cat Ablimén; sen(señales)yals de Caat Almuzeny, Hamet Abnoxalení, Alí Borruz, Hamet Axaloben, Hacem Abeahià, Maymó Abeamir; sen(señales) yals de Abdallà Xach, Lopo Algercí, Alí Arramí, Abdallà Axeno[n]í, fill de Hacem, Mahomat Ayet, Abdallà Xabech e Alí Alffaquí, sarrahins dessús dits. Los quals tots damunt dits, axí cristians com sarrahins, totes e singulars coses dessús dites loam, atorguam e ffermam.

Testimonis foren presents, quant a la fferma e atorgament de la universitat e singulars del dit loch de la Pobla, en Pere Sanc, Vicent d'Escoriolla e Johan Garcia, fu ... vehins de la dita Pobla, e en Johan Català, vehí de València. E testimonis foren, quant a la ferma e atorgament de la dita aljama e singulars del dit loch de Beneguazir, presents, Jacme Ferrando, vehí del dit loch de la Pobla, Domingo Calatayú, vehí de Líria, e Johan de Alballat, vehí de Beneguazir, Muça Abincalemé, sarrahí del dit loch, e Mahomat Alcorraybí, sarrahí de Xestalguar.

Sig(señal)no de Anthón de Linyán, notari públich dels dits lochs de la Pobla e de Benaguazir, en poder e mà (del) qual la dita universitat e singulars de la Pobla de Beneguazir loaren, atorgaren e ffermaren totes e sengulars coses desús dites e altres dites coses. Quant a la fferma de la dita universitat e singulars present ffuy, e aquelles scriure fiu e cloy en lo loch, día e any desús dits, ab sobreposat en la IIIIa línea que diu "en", e ab ras e corregit en la XXXVIa línea on diu "abtes e enteses". 
Pergamino 5

\section{Transcripción}

Anno a Nativitate Domini millessimo [oc]togesimo secundo, die martis vicesimo octava die januarii. Com qüestió e contrast (teniis la) passat, fos estat de paraula davant l'onrat en Bonaffonat de Sent Feliu, cavaller, conseller del molt alt senyor infant en Marti, e procurador general de la terra que $\bullet$ dit alt senyor infant ha en regne de València, entre los jurats e universitat de la Pobla de Benaguazir de la una part, e en Pere Cortés, vehí de Liria, axí com a curador que s diu de Pere Benania, fill que fo d'en Guillamó Benania, e en Johan Galliffa, de la dita Pobla, axí com a curador de la filla de Jacme Benania, vehins de la dita Pobla de l'altra part, per rahon ... ffranquea o dient ésser ffranchs los béns que $/ s$ dits Pere Benania e filla de Jacme Benania tenen e posseexen en la dita Pobla, ffinalment, hoydes les rahons e al•legacions per cascuna de les dites parts, lo dit honrat en Bonaffonat de Sant Feliu, appellant mi, Pere Dezprat, notari, per scrivà del present feyt, presents en Martí de Boyl, notari, com a síndich e procurador, e en Johan Català e Gocalbo d'Aguilar, jurats de la dita Pobla, de la una part, e en Johan Galliffa en lo nom desús dit, absent, emperò lo dit en Pere Cortés, e en contuma[cia] de aquell, en lo damunt dit día e any, al qual era assignat a les dites parts a hoyr sentència el dit feyt per lo dit honrat en Bonaffonat de Sent Feliu en lo loch de Paterna, on lo dit honrat en Bonaffonat era personalment constituhit ab mi, dit notari, donà e promulgà sentència en e sobre la dita qüestió e contrast en hora de vespres (ultra qui), en la forma següent:

On yo, en Bonaffonat de Sent Feliu, cavaller, conseller del molt alt senyor infant don Martí e procurador general de la terra que•l dit senyor infant ha en regne de València, vistes les qüestions que de paraula moltes vegades són estades davant mi entre los justícies, jurats e prohòmens de la Pobla de Benaguazir de una part, e aquelles persones que tenen o al•leguen tenir possessions franques de peyta en lo dit loch de la Pobla e terme de aquella de l'altra, per rahon de les peytes e contribucions que•ls dits justícia, jurats e prohòmens de la Pobla entenen que $/ s$ dits possehins les terres franques deuen e són tenguts peytar e contribuir, los dits al•legants la dita franquea lo contrari affermants. Vist encara un privilegi o carta demostrat o demostrada per part del dits al•legants la dita franquea feyt o feyta per lo noble don Lop, per la gràcia de Déu quondam comte de Luna e senyor de la ciutat de Segorb, donada en lo loch seu d'el Castellar, a vint-cinch dies de maig en l'any de la Nativitat de Nostre Senyor mil CCC cinquanta-nou, closa e subsignada per en Bru d'Escahues, notari públich per auctoritat real per tota la terra e senyoria del senyor rey, ab sagell pendent del dit noble comte de Luna, en la qual, recomptats e recomptades altres privilegis e franquees o cartes, declara lo dit noble comte les dites heretats e possessions de les quals en la dita carta era feta menció pertanyer an Pere Bonania e als seus, e ésser franques, 
liures e quites de tota peyta, contribució, ost e cavalcada, çena e redempçió de aquelles e d'altra qualsevol servitut e exacció alguna, e no ésser tenguts aquell ni los seus peytar ni fer servitut e contribució alguna per aquella, exceptat en los cases (sic) que béns franchs e de infançons poden e deven ésser tenguts de contribuir, segons que en la dita carta largament appar. Vist en aprés uns capítols que appar que en temps passat fossen feyts entre les dites parts per determenar los casos en los quals los dits béns franchs o de infançons són tenguts peytar o contribuir segons forma de la excepció desús dita, aposada per lo dit senyor comte de Luna en la dita sua carta, privilegi o declaració. E vistes les respostes a cascun dels dits capítols fetes de mà de I'honrat en Bernat d'Alpicat, savi en dret de València, vicecanceller del dit senyor infant. E vist finalment tot ço que veure se deu en lo dit feyt, e tot ço que per la una e l'altra part és estat davant mi dit e al•legat o en prova treyt, haüd acort e deliberació sobre lo dit feyt ab l'onrat en Martí de Torres, savi en dret de València e advocat del dit senyor infant, Déus havent davant mos hulls e los Sants Evangelis de aquell davant mi posats per tal que (mills) puxen jutgar o fer justicia e egualtat feent com a jutge, e en loch covinent e honest de jutgar, presents les parts damunt dites.

Attenent que segons que appar per la carta mateixa del dit senyor comte per part dels dits al•legants, la franquea produïda aquells qui tenen les dites possessions franques no s poden escusar que no sien tenguts de contribuir, almenys en los cases (sic) que béns franchs e de infançons poden o deuen ésser tenguts de contribuir. Attenent encara que segons furs e privilegis e observançes e costumes d'Aragó, lo qual e les quals se serven en la dita Pobla, los béns franchs, e encara los infançons, deuen e són tenguts pagar e contribuir en alguns cases (sic). Per ço, mogut per ço que dit és, e per altres rahons dels cases (sic) que a present occorren e a present és qüestió entre les dites parts, sentencialment pronunciu e declarar per capítols entre les dites parts deure ésser observat (en e) per tots temps en la forma següent:

Primerament, pronunciu e declar que $\bullet$ s desús dits que han les dites possessions franques, deuen pagar e contribuir per les dites possessions en totes e qualsevol messions que al dit loch convinga a fer per reparació de ecclésia, de campanes, e compres de qualsevol libres o vestiments, e a qualsevol altres obres e mesions que en aquella dita ecclésia sien necessàries, axí com qualsevol dels altres de la dita universitat hi són tenguts, car justa cosa és que, pus reeben los sagraments en la dita ecclésia e habiten en lo dit loch, que paguen en les coses desús dites.

Ítem, pronunçiu e declar que $\bullet$ desús dits que de les dites franquees se alegren, es (noler) alegrar, paguen e sien tenguts pagar en totes e cascunes scoltes e spies, les quals lo dit loch loga o met en temps de necessitat a profit de tots comunament. 
Ítem, pronunçiu e declar que $/ s$ desús dits, havents les dites possessions franques, deuen e són tenguts pagar e contribuir en totes e qualsevol talayes e atalladós, los quals se facen a loguer o per caps o per cases en temps de necessitat, segons que los altres del dit loch són tenguts pagar e contribuir. Item, pronunçiu e declar que tots aquells qui de les dites franquees se alegren, són tenguts pagar e contribuir en totes e qualsevol messions que $\bullet$ facen $o$ convinguen a fer per lo dit loch per rahó de deffensió del dit loch o dels drets e térmens de aquell, com sien tenguts a deffensió de furs e privilegis, e a deffensió del loch, drets e térmens de aquell, axí com qualsevol de les altres. Item, pronunciu e declar que $\bullet /$ dits al•legants les dites franquees són tenguts e deuen pagar per aquelles en totes e qualsevol messions que $/$ dit loch faça per reparaments de murs e valls, e de ponts e de camins, axí com qualsevol altre del dit loch.

Ítem, pronunciu e declar que los dits al•legants les dites franquees són tenguts en pagar e contribució en qualsevol messions que al dit loch convinga a fer per rahó de salaris o solda[des] ... qualsevol justícia, jurats de cascuns anys, e de qualsevol altres officials del dit loch qui sien comuns, axí franchs com no franchs.

Ítem, pronunçiu [e] declar que $\bullet / s$ dits al•legants e havents les dites franquees són tenguts pagar e contribuir ... qualsevol salaris que $/$ dit loch do a savis, advocats e procuradós per afers tansolament que sien a profit de les terres e possessions del dit loch e térmens de aquell, axí franques com no franques, e no en altra manera.

Item, pronunciu e declar que $/ s$ dit [s hav]ents les dites franquees paguen e sien tenguts pagar e contribuhir en les demandes e prefectes que sien feytes al senyor rey en cort generalment en la forma e manera que aquells del braç militar sien tenguts pagar e contribuir en [lo] regne de València, e no en altra manera.

Item, pronunciu e declar que $\bullet$ s dits havents les dites franquees no són tenguts pagar o contribuir en qualsevol convits que $\bullet /$ dit loch faça a senyor o a senyora o procuradós de aquells o qualsevol altres persones, si donchs los dits convits nos fahien de (noler) e consentiment dels dits havents les franquees.

Item, pronunciu e declar que los dits havents les dites franquees no són tenguts pagar en qualsevol violaris o pensions que $\bullet /$ senyor archabisbe de Saragoça ça enrere haia feyt pagar al dit loch a l'honrat en Garcia de Loriç, quondam governador del regne de València, ne en qualsevol altres violaris o salaris que la senyora reyna o qualsevol altre senyor o persona haia feyts donar o pagar, o qualsevol senyor faça d'açíavant donar o pagar al governador del regne de València o a lochtinents o a qualsevol altra persona semblant. 
Item, pronunçiu e declar que•/s dits havents les dites franquees no són tenguts contribuir ne pagar en qualsevol messions que•/ dit loch faça per rahó de deffendre los drets e regalies del senyor infant o de la senyora comtessa.

Ítem, pronunçiu e declar que•/s dits havents les dites franquees no són tengut[s] [pa]gar ne contribuir en qualsevol censals o violaris que $/$ dit loch façe o pague que sien estats carregats per afers propris de senyor, vullàs del senyor don Lop, comte de Luna, o del senyor infant, o de la senyora comtessa, ne de qualsevol altres successors de aquells.

Ítem, pronunçiu e declar que $\bullet / s$ dits havents les dites franquees no són tenguts pagar o contribuir en qualsevol violariis (sic), censals o deutes que $\bullet$ dit loch faça o deia per rahon de qualsevol demandes graciosament per lo senyor, o per la senyora, o per lurs fahedós o procuradós, o sien carregades hos faran o carregaran d'açí avant ne en qualsevol dons o servicis que $\bullet /$ dit loch haia feyts o farà a senyor, si donchs expresament los dits havents les franquees no y consentien.

Ítem, pronunciu e declar que si altres cases (sic) d'acíavant se mouen entre les dites parts, o de altres cases (sic) que no sien contenguts en los dits capitols desús declarats és o serà questió entre les dites parts, cascuna de aquelles romanga sobre aquells son dret salvu; e que $\bullet$ s puxa declarar, no contrastant la present sentència, segons justícia (requerà) de les mesions, emperò per cascuna de les parts feytes per la dita rahó, com cascuna d'aquelles obtinga (qui) egualment en lo dit feyt, cascuna de les dites parts sentencialment absolvu l'atra (sic).

Sentència per lo dit honrat en Bonaffonat de Sent Feliu desús dit, en lo loch de Paterna, presents les parts desús dites, vicesima octava die januarii, anno a Nativitate Domini millessimo CCC octogesimo secundo. S(señal)yal del damunt dit honrat en Bonaffonat de Sent Feliu, qui la dita sentència dóna e promulga.

E donada e promulgada la dita sentència en aquell instant, los dits en Martí de Boyl, en Johan Català e en Gocalbo d'Aguilar els dits noms dixeren, que en tant com la dita sentència fahia per ells e lur part, que la lohaven e aprovaven, e en tant com fahia contra ells e lur part, que no•y consentien, e que•n demanaven translat e carta pública a ells ésser feta. Per semblant manera, lo dit en Johan Galliffa el dit nom dix, que en tant com la dita sentència fahia per ell e part sua, que la lohava e aprovava, e en tant com fahia contra ell e part sua, que no•y consentia, e que $n$ demanava translat e carta pública a ell ésser feta.

Presents testimonis foren a la dació e prelació de la dita sentència en Guillem Dezpuig, sotsalcayt de Paterna, e Gil Martínez de Blega, de Paterna, e Johan 
Camps, vehí de València.

Sig(señal)num Petri de Pratis, auctoritate regis notarii publici per tota terram e dominacionem illustrissimi domini regis Aragonum, qui ad dacionem e prelacionem prelibate sentencia inter fui, e (aque) publicam ... feci i clausi loco, die et anno (prefixem) per alphabetum divissa cum ... e mandato. In XVIIa linea ubi dicem "damunt".

\section{Pergamino 6}

\section{Transcripción}

(Sapien tuyt com nós, en) Johan Portogalés, justícia en el present any del loch de la Pobla de Benaguazir, en non (sic) del dit justiciat auctorizant, e en nom nostre propri, e en cascun dels dits noms per si e per lo tot; en Pere Philip e en Pere Lop, jurats en lo present any (del) dit loch, en nom (de la) ... juraderia auctorizant ... nostres propris e en cascun dels dits noms per si e per lo tot; Alamay de Montagut, Pere Oltrera, Guillem Sent Martí, Estheve Alcanyiz e Domingo Senta Pau, consellers ordinaris; Miquel Gallifa, Pere Ferrando, (Falliez), Jacme Ferrando, ... Martíneç, castellà, Berthomeu ... Jacme Vicent, mayor de dies, Anthoni Oliver, Jacme Vicent, menor de dies, Martí Queralt, Martí de la Foç, Pere de la Foç, Domingo Godí, Vicent Dassió, Jacme Senceloni, Bernat Bono, Vicent Vinou, Pere Bono, Domingo Portogalés, menor de dies, Guillem ... Bernat Avella, Jacme Carinyena, Johan Lop, Domingo Lop, Francesch Çolivell, menor de dies, Domingo Gorgori, Berthomeu Tonya, Guillem Amat, Pere Gorgori, Domingo Beneyto, Anthoni de Moya, Johan Felemir, Domingo Enyego, Pere Enyégueç, Jacme d'Aytona, Jacme Péreç, Blasquo Bernabé, Johan Gascó, Miquel Sancho, Johan Salze, menor de dies, Pere Julià, Simón Marí, Domingo Beneyto, Jacme Riquer, Martí Fortunyo, Domingo Buenya, Johan Montagut, Johan Gali, Jacme Bono, Johan Dassió, Johan ... nyo, Johan Adam, Domingo Sancho, Jacme Sancho, Anthoni Johan, Berthomeu Sent Çaloni, Pere d'Escó, Garcia Bono, Guillem Felemir, Domingo Rodela, Matheu de Calatayú, e molt altres consellers e pròmens, vehins e habitadors del dit loch de la Pobla, a consell general appellats, specialment per fer les coses deiús scrites.

E convocats ab crida pública per veu d'en Rodrigo Peralta, satg e públich corredor del dit loch, ... ajustats en la plaça del dit loch, en lo qual loch e segons és acostumat consell general tenir e ajustar e celebrar en lo loch dessús dit, confessants e regonexents per virtut de sagrament per nós deiús prestador, que som en lo present general consell, les dites parts dels hòmens del dit loch doneus suficients a fer e celebrar consell e representants tota la universitat del dit loch et son terme, de vehins e habitadors d'aquella, haüd col•loqui e deliberació concordantment sobre les coses deiús scrites, ordena ... aquelles de present per bé e vitilitat e squivament de dampnatges de la 
dita universitat ésser fetes, attenents, segons dixeren, que la universitat del dit loch de la Pobla solia ésser carregada de molts censals e violaris, los quals fahia a diverses persones, axí de la ciutat de València com de altres parts, e ... universitat no pogués bonament bastar e fer les pagues dels dits censals e violaris en los térmens que •s deuen pagar, per la qual rahó se fahien a la dita universitat moltes desmoderades messions. Perquè la dita universitat, volent-se afranquir ... dits censals e violaris, (encorcorense) ab lo discret en Johan d'Aguilar, notari, ciutadà de la ciutat de València, sots aquesta forma e condició que $/$ consell e universitat de la dita Pobla són tenguts donar al dit en Johan d'Aguilar per espay de tretze anys ladonchs contínuament comptadors, e los quals se començaren a comptar lo primer día del mes de jener en l'any de mil quatre-cents set, mill sous reals de València pagadors en tres terminis o pagues, sots certes penes e obligacions ... de anar tenir hostatges deu persones de la dita Pobla per lo dit en Johan d'Aguilar elegidors sots pena de mil cinch-cents sous, açò cascun any durant los dits tretze anys, et que lo dit en Johan d'Aguilar dins lo dit termini sia tengut de ... per cascuns anys los dits censals e violaris, e sia tengut ... e reebre tots los dits censals e violaris e donar al dit consell e universitat les cartes de les revendes dels primers contractes dels carregamets (sic) dels dits censals e violaris. $E$ com al dit Johan d'Aguilar resten a present per pagà per la dita universitat tres mill doents cinch sous e quatre diners reals de València, ço és, dos mill treents trenta tres sous e quatre diners de la paga que li devia ésser feyta en lo primer día del present mes de maig, e huyt-cents setanta dos sous de l'any prop passat de mil quatre-cents e quatre, volent-se ell pagar de les dites quantitats, requerí ab carta pública que $\bullet /$ justicia e jurats ab d'altres anassen a tenir los dits hostatges sots les penes contengudes en lo dessús dit contracte. E com no vulla en res relexar ne fluxar lo dit en Johan d'Aguilar que no vajen tenir los dits deu hòmens los dits hostatges, e nós, havents esguard que si los hostatges (avaem) a tenir aquelles persones que per lo dit en Johan d'Aguilar elegidós, són que seria (vuy) gran dapnatge (sic), car farien tots dies de messió trenta sous, e més avat (sic).

Per ço, havents sguard que la dita universitat de la Pobla no ha diners a present ab que puxa paguar les dites quantitats, e sia a present pus profitós de vendre e carregar ... censal com la universitat haurà mester, axíque•l preu de aquell bast a fer paga al dit en Johan d'Aguilar que no anar a tenir los dits hostatges e sostenir totes messions e dapnatges (sic) com se farien en aquell cars (sic), per tal, per haver la dita moneda e carregar lo censal com en altra manera haver nos puxa de grat e de certa sciència e ab deliberada pensa, nós, damunt dits e nomenats, tots ensemps, concordants e alcun de nós no descrepant, en loch, nom e veu de tota la dita universitat del dit loch de la Pobla e dels singulars de aquella de qualssevol ley, condició o estament, sien majors, menors, presents, absents e esdevenidors, e de cascun de aquells, e encara en noms nostres propris e de cascun de nós per si e per lo tot, e per tots singulars del dit loch, ab testimoni de la present carta pública per 
tots temps valedora, constituïm, fem, elegim, cream e ordenam cert e special e altres coses deiús scrites general procurador, síndich, actor e missatger nostre e de tota la universitat e singulars de aquella ab ... e liura e general administració axí com en cosa vostra pròpria saber aquests afers, ço és, dos ... Dassió, vehí del dit loch de la Pobla, present. E aquesta procuració e sindicat, acceptant e reebent, ço és, a vendre, alienar e atorgar en e sobre tots e sengles béns e drets nostres e de la dita universitat e de tots los singulars de aquella de qual[se]vol ley, condició o estament ... presents e esdevenidors, e de qualssevol de nós, e d'aquella e d'aquelles per si e per lo tot a la honorable madona Sibilia de Pròxida, muller que fon de l'honorable mossén Andreu Guillem Escrivà, quondam habitador de la ciutat de València, e als seus, per tots temps, per preu de tres mill sous de moneda de reals de València, doents cinquanta sous de la dita moneda ensals (sic) rendals annuals e perpetuals, sens fadiga e loïsme, empero ab tot altre plen dret emphitèotich e dret de reebre aquells cascuns anys segons fur de València pagadors, portats e posats en casa sua e de sos successors en la ciutat de València, en aquells térmens que plaurà a la compradora a risch, perill e fortuna e messions nostres e de la dita universitat e singulars de aquella, no contrastants qualssevol secrestació e represàlies, empares e altres impediments de dret e de fet just e injust, franchs, liures e exemps de totes exaccions e servituts e despeses que dir e nomenar se puxen, o en altra manera, segons que la dita compradora pus fermament e pus segura volrà e a vós serà vist faedor.

E de e sobre les coses damunt dites e diús (sic) scrites e cascuna de aquelles, e per fermetat e corroboració de aquelles, puxats a la dita compradora e als seus fer, atorgar e fermar carta de venda e carregament del dit censal ben corroborada e fermada, ab totes aquelles clàusules e sots aquelles provisions, pactes, penes, juraments, homenatges, hostatges, execucions, renunciacions, obligacions, submissions de for, variació de juhí, axí en persones com en béns e altres qualssevol cuacions o clàusules e seguretats, les quals les segons que la dita compradora voldrà e demanarà e a vós serà ben vist, faedor salaris de procurador o missatger, et constituir a voluntat de la dita compradora salari diürnal a procurador o altre per part d'aquells trametedor a justar o silicitar ésser fetes annualment les dites pagues. E en la dita carta de venda, axí per evicció expressa e executòria com en altra manera, perattendre e complir totes e sengles coses que en aquella seran contengudes, e a vós seran demanades, e a la dita compradora seran per vós atorgades, promesses e fermades, nós e la universitat e singulars de aquella, e tots los béns, drets nostres e d'aquella e d'aquelles ensemps e cascun, e de cascun de nós e d'aquella e d'aquelles per si e per lo tot, obligar e transportar en la dita compradora tots los drets, lochs, veus e accions nostres e de la universitat e singulars dessús dits. $E$ sotmetre nós e la dita universitat e singulars de aquella al for, juridicció (sic), coherció e juhí de qualssevol jutge, jutge o jutges seglars, e en aquell loch o lochs dins lo regne de València on la dita compradora volrà e elegirà, e al propri for nostre e de les dites universitats e singulars renunciar en favor de 
la dita compradora. E lo preu dels damunt dits doents cinquanta sous censals confessar haver reebuts e reebre, e d'aquell fer àpocha e absolució e a jurar en (aïnes) nostres e de cascun de nós e dels altres de la dita universitat, e donar e prestar sagrament e homenatge de attendre e complir tot ço e qualsevol cosa que per vós serà promés, atorgat e fermat en e sobre les dites coses e cascuna de aquelles. Et a qualsevol drets, furs, privilegis e encara allongaments, sobresehments, gràcies e altres qualsevol provesions, axí reals com altres qualsevol, ajudants a nós, a la dita universitat e si[ngu]lars de aquella, universalment e singularment renunciar, e sots certes e grans penes prometre de no usar de aquellas (sic) o alcuna d'aquelles per alguna causa, manera o rahó quant que sia o fos necessària o vigent. E prometre e jurar encara en nom nostre [e] dels dits universitat e singulars, de no posar rahons contra manament executori fahedor contra la dita universitat e singulars de aquella, ne pendre trasllat del dit manament executori, ne pledejar ab la dita compradora, ve ab los seus, o fer pledejar, sots certas penas a voluntat de la dita compradora.

E com nós a present no hajam ne haver puxam prestament la ferma e consentiment de la molt alta senyora reyna, senyora nostra e senyora de la dita Pobla, que fermàs en lo present contracte, perço donam e atorgam a vós, dita compradora e síndich nostre, plen poder que en loch e nom e veu nostre e de la dita universitat e de tots e sengles los singulars de aquella, puxats ensemps ab altre e per lo tot prometre e obligar vós a la dita compradora e als seus, sots aquella pena que volrets, que d'ací a la prop vinent festa de Sent Miquell del mes de setembre o abans, segons que la dita compradora volà (sic), nós e la dita universitat e singulars haurem hauda de la dita senyora reyna, e liurarem realment a la dita compradora o a qui ella volrà, carta o letra de la dita senyora reyna, ab la qual aquella dita senyora reyna loarà, aprovarà, ratificarà e confermarà la carta fahedora atorgadora per vós, de la venda e carregament per vós fahedora dels dits doents cinquanta sous censals, e (limrà) aquella ferma e valedora e agradable segons se pertany, axí si proceïts licència de la dita senyora en la dita venda. E d'açò puxats fer e fermar carta pública sots aquells pactes, penes, obligacions, renunciacions, clàusules e cauteles que demanades vos seran e a vós serà vist faedor, e que sobre totes les dites coses e cascuna d'aquelles puxats en nom nostres e dels dits universitat e singulars renunciar al benefici de departida, acció e a la nova e vella constitució, e al dret e al fur dehuits del principal primer convenidor, e a jurar en (aïnes) nostres e nom nostre e per nós, e senyaladament en nom de les fembres havents marits e de les menors e sots virtut del dit sagrament e renunciar en nom de totes les fembres al dot e sposalici de aquelles e al benefici d'en Velleya, e als dots, esposalicis e ypotheques e al benefici de menor edat e de restitució en entegre en esguard dels menors, e per tots a tot altre qualsevol dret, fur, privilegi, constitució, beneficis e ordinacions contra les dites coses vinents, e generalment totes e sengles altres qualssevol coses fer que a les damunt dites coses e ferma de aquelles e de qualsevol 
de aquelles necessàries e expedients seran dir, fer e fermar a vostra bona coneguda. Les quals, (e segent) nós e tota la dita universitat e tots los singulars de aquella fer e fermar poriem si personalment presents hi fossem e fossen, encara si seran coses majors o pus greus de les sobre dites, e les quals de dret o de fur manament special requerint o exigissen, comanats e atorgants a vós tot nostre loch ab liura e general administració, axí com en cosa propria vostra ... nostres veus e de la dita universitat e singulars de aquella, e de cascun de nós e de aquella o aquelles sobre les dites coses e cascuna d'aquelles per si e per lo tot, prometents en bona fe a vós e al notari deiús scrit axí com a pública persona aquestes coses nós stipulant e rebent en nom e loch vostre e de tots los altres dels quals és o pot o poria ésser interese. E encara jurats per Déu e per los Sants Quatre Evangelis de les nostres mans dretes per cascun de nós corporalment tocats, nós ésser en lo dit general consell les dues parts, e més dels consellers, vehins e habitadors del dit loch, aptes, idoneus a consell fer e tenir representants tota la universitat del dit loch e de son terme e dels habitadors en aquella, e nós, haver per ... agradable e valedor per tots temps tot ço que vos serà fet, atorgat e fermat ... sobre les dites coses, e jamés no ho revocarem ne revocar farem, sots ypotheca e obligació de tots los drets e béns e de la dita universitat (e singulars de) aquella e de qualssevol ley, condició o estament, sien majors, menors, presents, absents e esdevenidors, e de cascun de nós e de aquells per si e per lo tot mobles e no mobles, axí privilegiats com altres haüds e per haver, hon que sien o seran, et de present certificats, plenerament instruhits, de tots los drets per nós e per la dita universitat fahents per lo notari dejús escrit, de nostra certa sciència renunciam sobre açò al benefici de departida, acció o a la nova e vella constitució, e a la epístola de diví Adrià, e a benefici de senatconsult Velleya, e als dots e esposalicis e ypotheques de les dones, e dret de menor edat e de restitució íntegren, e a tot altre fur, ley, privilegi e ajuda, consuetut e constitució contra açò vinents per qualsevol causa, manera o rahó.

Açò fon feyt, jurat, loat, atorgat e fermat en la plaça de la Pobla de Benaguazir en ple e general consell segons damunt és dit, a vint e dos dies del mes de matg en l'any de la Nativitat de Nostre Senyor mil quatre-cents e cinch. $S(s e n ̃ a l) y a l ~ d ' e n$ Johan Portogalés, justícia; s(señales)yals d'en Pere Felip e d'en Pere Lop, jurats; s(señal)yals d'en Alamany Montagut, d'en Pere Oltrera, d'en Guillem Sent Marti, d'en Etheve (sic) Alcanyiz, e de Domingo Santa Pau, consellers; s(señales)yals d'en Miquel Gallifa, d'en Pere Ferrando, d'en Jacme Ferrando, d'en Johan Martíneç, castellà, d'en Berthomeu (Quarç), d'en Jacme Vicent, de n'Anthoni Oliver, d'en Jacme Vicent, d'en Martí Queralt, d'en Martí de la Foç, d'en Pere la Foç, d'en Domingo Godí, d'en Vicent Dassió, d'en Jacme Senceloni, d'en Bonanat Bono, d'en Vicent Vinou, d'en Pere Bono, d'en Domingo Portogalés, d'en Guillem Ferrando, d'en Bonanat Avella, d'en Jacme Carinyena, d'en Johan Lop, d'en Domingo Lop, d'en Francesch Çolivell, d'en Domingo Gorgori, d'en Berthomeu Tonya, d'en Guillem Amat, d'en Pere Gorgori, d'en Domingo Beneyto, de n'Anthoni de Moya, d'en Johan Felomir, 
d'en Domingo Enyego, d'en Pere Enyégueç, d'en Jacme d'Aytona, d'en Jacme Péreç, d'en Blasquo Bernabé, d'en Johan Gascón, d'en Miquel Sancho, d'en Johan Salze, d'en Pere Julià, d'en Simón Marí, d'en Domingo Beneyto, d'en Jacme Riquer, d'en Martí Fortunyo, d'en Domingo Buenya, d'en Johan Montagut, d'en Johan Gali, d'en Jacme Bono, d'en Johan Dassió, d'en Johan (Franyo), d'en Johan Adam, d'en Domingo Sancho, d'en Jacme Sancho, de n'Anthoni Johan, de Berthomeu Senceloni, d'en Pere d'Escó, d'en Garcia Bono, d'en Guillem Felomir, d'en Domingo Rodela e d'en Matheu de Calatayú damunt dits, que en noms nostres propris e en nom de tota la dita universitat e de tots los singulars de aquelles, totes les damunt dites coses e cascuna de aquelles loam, atorgam e fermam.

Testimonis foren açò presents Diago Romer e Gonçalbo de Vera, de casa del noble mossén Vidal de Vilanova, e Miquell Marti, spardenyer, vehí de la dita Pobla.

Sig(señal)no de Gil de Linyán, notari públich de Benaguazir e de la Pobla e sa tinença, que present a les dites coses fui e açò scriure fiu e cloy, loch, día e any dessús dits, ab ras e esmenat en la VIa línea on diu "d'Escó", e en la XVa línea on diu "sia tengut de affranquir", et en la XXIIIIa línea on diu "en", et en aquesta matexa línea que diu "Dassió", et en la XXVa línea "dita universitat", et en aquesta matexa line (sic) on se conté "sien majors menors", et en la XXXVIII línea "coses", et en la XLVIa línea que diu "e haurà", et en LIa línea "segons", et en la LIIIIa línea on se conté "e loch vostre e".

\section{Pergamino 7}

\section{Transcripción}

Omnipotentis Dei nostri euisque purissima ac inmaculata semperque viginis matris Mariae nominibus humiliter imploratis. Cunctis pateat evidenter et sic notum quod Nos Philippus Dei Gratia Rex Castella Aragonum Legionis utrusque Sicilia, Hierusalem, Portugalia, Navarra, Granata, Toleti, Valentia etc.. et prosua Majestate.

Nos don Joannes Alfonsus Pimentel et de Herrera comes de Benavent locuntentus et capitaneus generalis in presenti valentía Regno. Vista in primis suplicationen, coram praedecesorenm nostro oblata per Nicolaum Dezllor notarim, syndicum et procuratorem baronia de Vilamarchant, die vigésimo sexto mensis augusti anni millessimi quingentesimi nona .

In et cum qua rationibus et causis ibi deductis et allegatis ad Regiam Audientaiam evocari et ali qui ex magnificis regii conclii doctoribus juxta fórum comitto, causam nullitatum allegatarum et appellationis per eum interposita a qudam sententia per geretem vices generalis gubernatoris 
presentiss civitatis et regni publicate in favorem villarum de Benaguazir et la Pobla, in quadam causa requisitionis qua intre partes ducta fuit, rationibus et causis de quibus in processu.

Qua quidem cuas tunc non evocata, sed tantum Magnifico dilecto regio consiliario Vicent San Joan de Aguirre ad recognoscendum fuit comissa et suplicata cum ea in regio concilio referret et verbum faceret. Visa dicata comissionem et provisionem ad eius caloens manu propia dicti magnifici auditoris facta el continuata injunctioneque earundem ac dicata supplicationis una cum appelationis scriptura Jacobo cherta, notario, syndico et procuratoi dicata villa de la Pobla subsequnta et viso mandato deponedis actis super tota causa proviso, die decimo nono mensis januarii anni millesimi quingentesimi nonagésimi sexti.

Et visis respontionibus factis per juratos et alios oficiales dexpositionibus proparte dicti Dezllor notario dicto nomine ----. Et visa alia scriptura asimilis distincta posita per Michaelem Hieronymun San Joan et Jacobum Martinum vaciero notarium síndicos et procuratores respective dicarum villarum de la Pobla et.

\section{Traducción o regesta}

Delante de todos yo Beatriz Peris, mujer del honorables Juan Peris, carpentador de Valencia. De forma consciente confeso y en verdad reconozco que vosotros honorables Justicias, Jurados del lugar de la vila da La Pobla de Vallbona o Benaguacil, tanto presentes como ausentes, me disteis y yo recibí sesenta monedas reales de Valencia del precio acordado en instrumento público que puso Luis spinot, notario bajo firmado y escrito, de aquellas 80 monedas cénsales de renta y anuales, $Y$ por especial pacto se dieron y recibí. Testimonios fueron el honorable Vicent Fontant, mercader y Ausias Colomer, habitantes de Valencia.

Pergamino 8

\section{Transcripción}

Hoc est translatum factum Valentia, quintadecima septembris anno a Nativitate Domini, millesimo quadringentesimo vicésimo, supra cum equodam apoca contenta in libris notularum discreti Bartholomei Almenar, notario publici Valentie. Jam in publicam formen redacta tenor cuius sequitur, quod hec verba. Noverint universi quod Ego Bernardus Medina, civis Valencie, receptor generalis pecci egregi veri domini Frederici de Aragoni, comité de Luna, ac domini civitatis Sugurbi, scienter et gratis confiteor et in veritate reconosco vobis Guillermo Amat, sindico, actori et procuratori universitatis loci Popule de Vallbona allias de Benaguazir, presenti et vestris per per manus 
Vitalis de Riusech, civis dicta civitate, dedistis et soluistis michi numerando me omnimodo voluntate duos mille sexcentos (...) quingentis florenis, quos universitas civitatorum Sugurbi, et dicti loci Popule de Benaguazir et aliquorum aliorum (...) domini comitis graciose pronunciato, egregio viro domino Frederico dederun ac solvere promiserun in (...) matrimonium (...) et firmati intra dominam Yolante, predicti domini comitis sororem Egregium virum Comitem de Nievla, Regni Castelle (...) quidem dictis mille quingenti vigintiocto solidi sunt ex illes rebus mille solidis per quibus sive quorum precio vos ut sindicis et procuratori predictus dicto Vitali de Riusech, vendidistis et alienastis ducentos quatordecim solidos, septem dineros, censuales, cum instrumento die presenti confecto in posse et manu notario sucontinenti. Et quia hec est rei veritas renuncio scienter omnia excepcione dicte (...) octavo die madii anno a Nativitate Domini millesimo quadringentesimo vicesimo tercio. Sig + um. Bernardi Medina predicti. Qui hec dicto nomine concedo et firmo. Testes huius rei sunt Dominicus de Forte, pelliparius, et Jacobus Vilave, apuntator, vicini Valencie.

Sig + num honorabils Johannis Valleriola, Justicie civitatis Valencie in civilibus, qui visis dictis libris in quibus dicta apoca continetur hinc traslatum (...)

Sig + num mei Petri Navarro, notario publici Valencie, qui loco venerabili Anthonii Johanni, mei (...) et scribe Curie civilis dicte civitate in hoc traslato auctoritate Domini honorabile Justicie, eius jussu apposen et scripsi, etc.

Sig + num mei Guillermi de Castellbell, civite Valentie, notari publici, qui predictum transuntum a sua originali nota abstrai et scribi feci clausuque, loco die et anno in prima mea contentur.

\section{Regesta}

1420 , septiembre 15 . Se trata de un texto que recoge un traslado de un documento anterior que se encontraba en los registros notariales del notario de la ciudad de Valencia Bernat Almenar. En el texto se explica que Bernat Medina, ciudadano de Valencia, receptor general en nombre de Frederic de Aragón, conde de Luna y señor de Segorbe reconoce que Guillem Amat, representante y procurador de La Pobla de Vallbona, a través de Vidal de Riusech, ciudadano de Valencia, le entregó 2650 florines de oro. Se trata del pago que la Pobla y otros lugares del condado como Benaguacil y Segorbe le habían prometido a Frederic de Aragón con motivo de su matrimonio. 
Pergamino 9

\section{Transcripción}

Nos Petrus Sanç laborator ville Popule Vallisbone, et Vicenta, coniuges, Aisuasius Morell, operarius ville, habitator dicte ville Popule, et Ysabel, coniuges. Et certa sciencia simil omnes et quilibet nostrum insoludum damus, vendimus et titulo puro per feste tradimus seu quasi tradimus vobis honorabile Jacobo Danyo, habitator dice ville, licet absenti notum, infrascripto pro vobis et ómnibus illis quorum interest, intereris, aut interesse potest aut poterit quomodolibet in futurum stipulante, legitime et vestris, viginti quinque solidos monete regalis (2) sive laudimio et fática set cum toto alio pleno jure enphiteotico et jure percipiendi ipsos secundoum fórum Valentie franquos, quitios, inmunes et exemptos ab omni peyta, questia, sisa, cena, monedatico, mutuo, dono, servicio hoste, exercitu, armata et cavalcata et arredemcione ligeo o imposito vel imponendo que dici nominar vel excogitar possiut, quos positos et aportatos per nos et nostros in hospicio o habitacionis vestriet vestro in dicto censuali suncte forma nostris propris expensis periculo et fortuna et sine dampno, periculo et expensis vestri et vestros et sive (4) exemptos ut predicitur vobis por vobis et vestris stipulanti aut uni vel quibus volteritis solvere et realiter et cum efectu tradere promitimus causis singulis vicessima prima die mensis decembris in visa slutione incipiendo nobis primatu facere, solutionem suo termino prestatuto (...) in dicto termino continuabimus dicte pensionis, solutionis nin obstante quanta empare nec quonis impediemento (...) facti quontam omnia (...) in orta dicte ville in partita del Real confrontatias cum terra mei Petri Sanç,cum terra Petri, uvisque habitis et habendis. Itaque speciales obligatio generali non deroget nec e contra setque (...) quod de in et super pensionibus et aliis hic contentis nomine lictigabimus aut causa sabimur vobiscum (...) qua vendite constet cum vera apoca vel albarà de soluto nec in pecia quinque nec inpeciabimus (...) nec quique aliud in generali vel speciali dimini nostri regis Aragonum eius consortis primogenitus (...) seu mou modo aliqua revocare. Et si motu proprio concedentia alia facta vel mandata (...) de facto quod si contra predicta vel aliquod predictorum et vel contentorum in hoc instrumentum (...) monete de vobis nostes et utriusque nomine insolidum et meorum deudorum et solvendorum (...) in hoc instrumento contenta rata maneant valida atque firma (...) semper hoc pacto (...) index (...) per vos vel vestros digendos (...) presentes publico (...)

Habitatores ville Popule Vallisbone et firmo (...) Vincente et Ysabelis factis Popule vicesima prima dictorum mensus et anni. Fuerunt testes Petrus Ferrando et Petrus Dassió, habitatores dicte ville.

(...) Bernardus Dassiñi, notario publici Valentie, qui predictre interfii causa per olim scribi feci clausioque locis, diebus et anno predictis. 


\section{Regesta}

Pere Sans, labrador de la Pobla de Vallbona, y su esposa Vicenta, Ausiàs Morell, obrero de la Pobla, y su esposa Isabel, venden a Jaume Danyó, vecino de la Pobla de Vallbona un censal por valor de 20 sueldos, cargados sobre una casa en dicha población.

Traducción

Jo Pere Sans, Ilaurador de la vil•la de la Pobla de Vallbona, i la seua dona Vicenta; Ausiàs Morell, obrer, habitant de la dita Pobla, i la seua dona Isabel. De forma consciente i solidària, nosaltres donem, venem i lloguem a tú, honorable Jaume d'Anyó, habitante del dite poble, tant present como ausent, de forma legítima, vint i cinc sous moneda real, sense lleuda i fadiga, i amb tots els drets enfitéutics, segons el fur de València, franc, quitis, inmunes i exempts de cualsevol peita, questia, sisa, cena, monedatge, prèstec, donació, servici d'hostatge, exèrcit i cavalgada i arrendament, impost o imposició, situats i posat per nosaltres i els nostres en la casa o habitacions vostres en el dit censal baixa la nostra pròpia forma, a expenses de cualsevol perill i fortuna e sense dany, perill i expenses vostres i als vostres y exemps a tú i als vostres, en cualsevol ca prometem pagar el vint-i-un del mes de decembre.

(...) en l'horta de la vil•la, en la partida del Real, davant amb la meua propia terra de Pere Sans, amb la terra de Pere, i amb altres possesions. A més, no són derogades altres obligacions generals.

Habitants de la vil•la de la Pobla de Vallbona. Vicent e Isabel. Fet en la Pobla, vint-i-u del dit mes e any. Fóren testimonis Pere Ferrando i Pere Dassió, habitants de la dita vil•la.

Bernat

Pergamino 10

\section{Transcripción}

Testius(...) rei sunt discretus Sthhefanus Julia, notario, el Petrus Pahoni, scutifer, cives dicte civitatis

Sig+num mei Francisci de Milla, notario publici auctoritatem regiam per totam terram et dominacionem domini regis Aragonum. Qui eidem auctoritate potevit (..) eadem línea ubi videtur enfiteotico et in decim et séptima línea ubi dicitur nomine et in línea penúltima ubi habetur ratione.

\section{Regesta}

1389, noviembre 18 . Venta de un censal entre vecinos de la Pobla y un vecino de Valencia. 
Pergamino 11

\section{Transcripción}

Omnipotentis Dei nostri euisque purissima ac immaculata semperque virginis matris Mariae nominibus humiliter imploratis. Cunctis pateat evidenter et sic notum quod Nos Philippus Dei Gratia Rex Castella Aragonum Legionis utrusque Sicilia, Hierusalem, Portugalia, Navarra, Granata, Toleti, Valentia etc et prosua Majestate.

Nos don Joannes Alfonsus Pimentel et de Herrera comes de Benavent locuntentus et capitaneus generalis in presenti valentia Regno. Visa in primis suplicationen, coram praedecesoronem nostro oblata per Nicolaum Dezllor notarium, syndicum et procuratorem baronia de Vilamarchant, die vigesimo sexto mensis augusti anni millessimi quingentesimi nonagesimi quinti. In et cum qua rationibus et causis ibi deductis et allegatis ad Regiam Audientiam evocari et aliqui ex magnificis regii concilii doctoribus juxta forum comitto, causam nullitatum allegatarum et appellationis per eum interposita a quadam sententia per gerentem vices generalis gubernatoris presentiss civitatis et regni publicata in favorem villarum de Benaguazir et la Pobla, in quadam causa requisitionis qua intre partes ducta fuit, rationibus et causis de quibus in processu. Qua quidem cuas tunc non evocata, sed tantum Magnifico dilecto regio consiliario Vincentio San Joan de Aguirre ad recognoscendum fuit comissa et suplicata cum ea in regio concilio referret et verbum faceret. Visa dicta comissionem et provisionem ad eius caloens manu propria dicti magnifici auditoris facta et continuata injunctioneque earundem ac dicta supplicationis una cum appellationis scriptura Jacobo cherta, notario, syndico et procuratori dicta villa de la Pobla subsequnta et viso mandato deponedis actis super tota causa proviso, die decimo nono mensis januarii anni millesimi quingentesimi nonagesimi sexti. Et visa scriptura posita per dictum Nicolaum Dezllor, notario, dicto nomine, die vigesimo septimo mernsis januarii dicti anni in justificationem dictarum nullitatum et appellationis, et suplicat super capitulis dicta scriptura, responderi et super negatis testes sibi recipi, provisionem et relationem intima subsecutis. Et visa provisione facta die decimoquinto mensis februarii dicti anni Millesimmi quingentesimi nonagesimi sexti, partibus presentibus et auditis. Et visa regia comissionem ad perducendos testes scriba presentis causa facta et expedita die vigesimo quarto praedictorum mensis et anni. Et visis respontionibus factis per juratos et alios officiales dicta villa de la Pobla super Capitulis antedicta scriptura. Et visis etiam testium dexpositionibus proparte dicti Dezllor notario dicto nomine -------. Et visa alia scriptura asimilis distincta posita per Michaelem Hieronymum San Joan et Jacobum Martinum vaciero notarium syndicos et procuratores respective dictarum villarum de la Pobla et Benaguazil diebus vigesimonono et trigesimo maii dicti anni millessimi quimgentesimi nonagesimi sexti, suplicando testes sibi recipi cum in junctione partis adversa 
provisione et relatione intima. Et visa provisionem publicationis testium facta die decimo mensis octobris anni Millessimi quingentesimi nonagesimi septimi et illius intimatione. Et visa provisione facta die vigesimo primo dictorum mensis et anni et intimatione facta die vigesimo primo dictorum mensis et anni et intimactionem subsequnta Et visa revisionem petita per dictum Dezllor notario dicto nomine et deductis et allegatis in justificationem illius cum actum comparendo facto die decimoseptimo dictorum mensis et anni et relationem intima- Et visa provisionem facta die vigesimo quinto mensis januarii dicti anni millessimi quingentessimi nonagesimi septimi et relationem intima. Et visis testium depositionibus pro parte syndicorum dictarum villarum de Benaguazir et la Pobla de Vallbona productorum. Et visa alia capitulorum scriptura posita per dictum Michaelem Hieronymum Sen joan notario dicto nominem die vigesimo nono mensis augusti dicti anni millessimi quingentessimi nonagesimi septimi, suplicando etiam testes sibi recipi, quod fuit ita provisionum. Et visa dicta provisionem et relationem intima. Et visa provisione facta die decimo sexto mensis octobris sepedicti anni et relatione intima. Et visis depositionibus testimonium ad instantiam dicti Sen Joan productorum et viso mandato de ponendis actis super tota causa proviso die duodecimo mensis augusti anni millesimi quingentesimi nonagesimi noni, et illius intimatonem sequita. Et visa comissionem ad referendum dictum procesum facta doctori Simoni Rodríguez relatori provisa die decimoseptimo mensis augusti dicti anni et relationem intima. Et visa provisionem assignationis ad relationem in Regio Palacio cum dierum et sorarum continuationem provisa, die vigesimo sexto mensis martii proxime preteriti dicti et presentis anni millesimi sexcentesimi primi. Et visa relationem intima dicta provisionis et viso toto procesu coram dicto gubernatore actitado interdictas partes et omnibus singulis in eo deductis a allegatis et probatis, et presertim visa sentencia in eo data die decimo quarto mensis augusti dicti anni millesimi quingentesimi nonagesimi quinti a qua extitit appellatum et de nulitatibus dictum et omnibus et singulis in ea provisis et declaratis et visis tandem omnibus aliis videndis et attentis attendendis nihil de contingentibus et ad uius modi causam conferentibus omittendo, auditis ad plenum partibus antedictis seu earum procuratoribus et advocatis in omnibus iis quae dicere ostendere et allegare voluerunt tam verbo quam scriptis factaque relationem per dictum doctorem Simonem Rodríguez relatorem super statu et meritis presentis causa, conclusionemque et deliberationem in dicto regio concilii factam insequendo Deum omnipotentem proeculis nostris sabentes et eius sacrosantis evangeliis coram nobis propositis et eis multum reverenter inspectis et de vultu dei nostri rectum prodeat inditium nostrum, et oculi mentis nostrae iustitiam et aequitatem cernere valeant quod est justum hocque dicta sententiae prolationi constituto quem iterum ad majorem caut cauthelam, ad id cum presenti repetimus et assignamus ad illius prolationem procendimus in hunc qui sequiter modum. Christus attento quod meritis utrius quod processus discussis et examinatis constat sententiam latam per gerentemvices generalis gubernatoris presentis civitatis et regni, die decimo 
quarto augusti millesimi quingentesimi nonagesimi quinti in favorem oppidorum de la Pobla de Vallbona et Benaguazir et contra locum de Vilamarchant esse justam et rationi consonam; et quod per syndicum de Vilamarchant appellantem, non fuit aliqud probatum nec estensum in justificationem dictarum nulitatum et appellationis propoterque sententia jam dicta revocari debeat semsu aliquo comittari. Ideo et alis conclusionem et deliberationem in regio concilio factam insequenta pronuntiamus et declaramus, bene fuisse judicatum per dictum iudicem a quo et minus bene ab ea appellatum, ilamque quatemus opus est confirmamos nonobstantibus in contrarium praetensis et allegatis et partem subcunbentem in expensas condemnantis taxacionem inposterum re ... Banyatos, $R$ Vicent San Juan, Vicent Pellicer, Vicent Monterde. Lata fuit iuis modi regia sententia per nos seum in personam nostri per magnificum et dilectum regium consiliarum Joseph Sumperez de Banyatos militem juris utriusque doctorem ad regiam cancelariam in presenti in civitate et regno Valentia, regentem dequi nostris illisquem mandato lecta et publicata perdilectum regnum escribam mandati Franciscum Paulum Alreus militem in quadam aula domus dicti magnifici regentis cancellariam quam favores in procesu presenti civitate in plate campanari sive Micalet sedis dicta civiatis parochia Santi Petri ubi tunc palaci demore regia celebrabatur audiencia. Die sententia prolatione constituto inclito vigesimo secundo mensis augusti anni millesimi sexgentesimi primi regnorum autem praefacte regia magestatis omnium cuarto: instantem et dictam sententiam ferri et publicati suplicante Jacobo Paulo Cherta notario nomine quo in causa altera parte absente citata de non comparente. Et presentibus protestibus Ludovicis de Berbegal regio scriba mandati. Onuffrio Messeguer juniore notario Francisco Joffre notario regio civitatis Alicantes nunc Valentiae reperto, Petro Villegas Domicello, Bartholomeo Andreu famulo dicti regentis et aliis quod plurimis ibi assistentibus in multitudine copiosa. Banyatos $R$.

Signum Philippi Dei Gratia Regis Castella Aragonum Legionis utrusque Siciliae Hierusalem Portugaliae, Navarrae, Granatae, Toleti Valentiae etc et prosua Majestate

Joannis Alfonsi Pimentel et de Herrera Comitis de Benavent locutenentis et capitanis generalis in presente vivitate et regno qui hanc sententiam tulimus eidemque sigillum regiam appresenti justisimo appenditum.

Signum Ludovicus de Berbegal S C regia majastis mandati scribe qui superiore sententia per Francisco Paolo Alrreus magíster scriban lectam et publicatam in hanc publica forma redactam

Ludovicus deberbeegal sententia in hac regia valentia audiencia latam per banato [--] carta visa per Sant Joan, Pellicer et Monterde Regiir consili doctores [--] autem subscripta perditos [--] et Sant Juan [--] et facet cum eisu schede 


\section{Regesta:}

1601, agosto 22. Documento que aparece encabezado con el nombre y todos sus titulos y posesiones del monarca de la casa de Austria, Felipe III. A continuación se indica que Juan Alfonso de Pimentel, conde de Benavente, Capitán General del Reino de Valencia, ha visto una serie de protestas ante la Real Audiencia realizadas por parte de Nicolau Dezllor, notario y procurador de la Vila de Vilamarxant, que datan del año 1595, se señala que ya se dio una sentencia favorable a las poblaciones de la Pobla de Vallbona y Benaguacil. Se copian las distintas alegaciones y protestas de las poblaciones pero sin indicar nunca la causa real del conflicto que seguramente es por el aprovechamiento de las aguas del río Turia.

\section{Nota al pie de página no 151 (pág 160)}

Carta de Poblament de la Pobla de Vallbona atorgada per l'Indfant Martí i na María de Luna l'any 1382

Arxiu del Regne de València, Justicia Civil, Manaments i empares, any 1626, llibre 4, ma 38, fol. 38rㅇ. a 48vo., ma 40, fol. 39ro. a 44vo.

fol. 38r‥] In Dei nomine Domini amen // [fol. 38v‥] nostri Jesuchristi et eius genitricis ac omnium civium superiorum, amen. Pateat universis quod nos, infans Martinus, illustrissimi domini Petri Regis Aragonum filii et Dei gratia Comes de Exericha et de Luna, ac dominus civitatis Sugurbi, et nos, María, ipsius domini Infantis coniux et Dei gratia comitisa comitatuum et domina civitatis predictorum. Quoniam pro parte vestri universitatis loci Popule Vallisbone fuerunt coram noobis per viam suplicationis certa oblata capitula quibus et eorum quilibet pro parte nostra fuerunt facte responsiones et provisiones prout in fine cuiuslibet ipsorum capitulorum plenius continetur, quorum quidem capitulorum et responsium ac provisionum predictarum ipsis capitulis thenor sequitur in hunch modum:

Primerament, que per l'alt senyor Infant don Martí, e per la egrègia la senyora Comtessa de Luna, sia reconegut al lloch de la dita Pobla com no era privilegiada e volen que d'así en avant hajen tots los vehins y habitants de la dita Pobla totes les seues posessions franques et lliures, e puixen aquelles vendre, alienar e transportar // [fol. 39r-o.] e fer de aquelles a totes les seues pròpies voluntats en vida o en mort, a fur de Aragó. Respon lo senyor Infant que'ls de la dita vila de la Pobla han acostumat e són tenguts pagar per peyta ordinària per cascun any quatre milia sous, que aquells sien pagats segons que és acostumat, e ters delme e morabati; e si altres censals et drets hi ha del senyor Infant, vol lo senyor que en aquells hi romanga tot son dret salvo sobre totes ses regalies e sobre tots sos drets als dits senyor Infant i Comtesa pertanyents. E retengudes les dites coses y altres regalies drets al dit senyor Infant en lo dit lloch prtanyents, plau als dits senyors Infant e senyora Comtesa 
que la dita Pobla sia privilegiada e que tots los privilegis a aquella otorgats e acostumats servar, sien tenguts observar segons que és acostumat. E que'ls habitants de la dita vila per peyta ordinària per cascun any, paguen quatre milia sous sens que no'ls sia crescuda ni augmentada, e que tinguen, poseheixquen // [fol. 39vo.] Ilurs posessions e puguen aquelles transportar, vendre et alienar e de aquelles fer a llurs pròpies voluntats, en vida o en mort, segons fur de Aragó als quals són poblats. Remanent a senyors los censals e drets de recobrar aquells, segons fur de València; emperò, si per alguna carta dels establiments se mostra que lo censal sia establit a fur de Aragó, que el establiment sia observat, e s'ens mostra que sia a fur de València, que sia observat segons les cartes. Item, que'ls senyors Infant e Comtesa e los seus succesors, presents et avenidors, sien tenguts de donar a la universitat de la dita Pobla e habitants de aquella bastament de molins, bons e aparellats de moldre, e fer bastament farina; e si ve per cas que al dit lloch de la Pobla los molins que ara són no obstaven de fer farina a la dita universitat, que el senyor sia tengut fer altre molí o molins, e aquell molí o molins se dejen fer en la dita Pobla e terme de aquella. Plau al senyor In [fol. 40ro] fant que compliment de molins sia donat als habitants de la dita Pobla. Item, que no contrastant que lo lloch de la Pobla de Vallbona és a de fur de Aragó, la dita universitat e habitants de aquella puixen usar de totes mesures e de totes peses que usen en la ciutat e Regne de València, com tota vegada an usat de aquelles; açò per tal com lo dit lloch és en lo dit Regne de València, ne de açò no'ls puixa ésser feta qüestió ne demanda ne treta conseqüència en perjudiçi del fur de Aragó, usos e observàncies del Regne aquell. Plau al senyor Infant que les mesures del Regne de València e les peces se tinguen e usen en la dita Pobla segons que's tenen, e perquè per lo ús de les mesures e de les peces no'ls sia algun perjudici engendrat quan és a la observaància dels furs de Aragó. Item, que tots aquells que són senyors // [fol. 40vo.] del forn de la dita Pobla, sien tenguts de fer forn e forns, tants com seran menester per obs de coure pà, estants als vehins e habitants de la dita Pobla així que per culpa o falta de forn no puixen perdre alguns pans. E si u fan, que sien encorreguts en çerta pena. Respon lo senyor Infant que a requesta dels Jurats e sindichs de la dita Pobla, e apellat de constrènyer e forçar los senyors dels forns de la dita Pobla que tingueren en son dret los forns, en manera que'ls junts puixen bé coure sos pans e hajen compliment de forns, e sobre açò metrà totes aquelles penes que sien necesàries. Item, que los vehins e habitants de la dita Pobla o altres qualsevol que en lo dit forn couran, no sien tenguts donar de puja o salari per lo dit coure, sinó en aquella forma e manera que's paga la puja en los forns de València, e no pús. E si lo contrari // [fol.41ro.] faran, per cascuna vegada encorreguen en pena de sis sous. Plau al senyor Infant, segons que's possat. Item, que la universitat de la dita Pobla puixa per cascun any, elegir los seus oficials, Justícia, Jurat et Mostasaf en la festa de la Nativitat de nostre Senyor en lo mes de desembre; que aquells juren en lo seu comensament del any, de bé e lealment usar de son ofici, açò segons que fur de Aragó, usos e observàncies de les Corts de aquell mana et requirr ésser feyt, com així o 
hajen tota vegada acostumat de fer. Plau al senyor Infant que's faça segons que's acostumat. Item; que tots los vehins e habitadors de la dita Pobla hajen de assí avat tots los termes e montanyes de la dita Pobla, a obs dels dits vehins e habitadors de la dita Pobla, a fer servituts de llenya, de herba, de pastures e de tantes coses que los dits termes seran, açò a totes les seus pròpies voluntats e sens que no sien tenguts //[fol. 41vo.] de donar e pagar per aquel servi, do o rehemso en qualque manera sia apellat o nomenat. Plau al senyor Infant segons que és acostumat. Item, que tots los vehins e habitants de la dita Pobla de assí avant com per tots temps puixen tenir en la dita Pobla taverna o tavernes, tenda o tendes de totes e qualsevols coses o mercés que volrran tenir o vendre en les seus cases o en altres parts, sens que no sien tenguts de donar al damunt dit senyor o als seus servici, do, cens o altres rehemçó en qualque manera sia nomenat o apellat. Palu al senyor Infant que's fasa segons que's acostumat. Item, que'ls dits vehins e habitants de la dita Pobla o altres qualsevol persones puixen tenir, fer, construir et edificar en lo dit lloch de la Pobla obradors de lances, obradors de draperies, així de llana com de Ili, espacieries e altres qualsevol mercés o borfoneries, //.[fol. 42ro.] e açò francament e lliures de totes e qualsevols cosses que'ls pogués ésser feta qüestió o demanda segons fur de Aragó. Plau al senyor Infant que obradors de draperies, així de lli com de llana, de especieries y altres coses profitoses et honorables als de la dita Pobla, qui volrrà en aquella habitar, puixen ésser fetes en la dita Pobla sens alguna rehemçó de senyor, segons per fur de Aragó és degut, com entena lo senyor Infant que per la dita rahó si's fa, se millorarà la dita vila. Item, que la dita universitat e singulars de aquella puixen fer e ordenar boalar de redona en montanya e terme de la dita Pobla, a obs e servitud de la dita Pobla, per bestiars de llaurada e altres necessitats et emprius que dehuen haver en lo dit boalar de redonda, segons fur de Aragó, sens alcun do o servey, així com damunt dit és contengut. Plau al senyor Infant que sens perjudici de les seues regalies, los de la dita Pobla, per a obs de llurs besties // [fol. 42vo..] de llaurada, segons la granea del lloch, puix fer boalar et redonda, segons per fur fer se pot et dit és. Item, que'l notari de la Cort qui ara és o per temps serà, no puixa prevendre mayor salari de algunes escriptures sinó aytant com prenen en les Corts de les viles, ciutats y llochs del Regne de Aragó. Plau al senyor Infant que l'escrivà de dit lloch prena segons que's acostumat en Aragó. Item, que el Consell e Universitat de la dita Pobla, ço és, Justícia e Jurats e altres vehins y habitants en aquella, puixen ordenar per cascun any tots aquells establiments e ordinacions que a élls seran vist fahedor, et en aquells establiments et ordinacions posar aquelles pena o penes que a ells serà vist fahedor, així per fet de la horta de la dita Pobla com de la montanya, et de aygües et de totes aquelles coses que a ells serà vist fahedor, et crèixer e aminvar açò sens llisènçia de senyor, procurador o altres oficials d'aquell. Et les dites ordinacions et establiments per la dita universitat feyts o de así avat // [fol. 43ro.] fahedors, lo Alcayt de Benaguazil que ara és o per temps serà, o llochtinent seu, sia tengut de confermar aquells e haver per bones. E per la dita confirmació de establiments 
et ordinacions, aquel no deman o puixe haver salari algú, com així ho hajen tostemps acostumat. Plau al senyor Infant que puixen fer establiments en que no haja pena corporal ne civil que sobrepuig cantitant de seixanta sous, e que per la confirmació dels establiments lo alcayt de Benaguazil ne altre oficial del dit senyor que ara són o per temps seran, no puguen e o gosen pendre alguna pecúnia. Item, que de assí en avant lo lloch de la damunt dita Pobla no puixa ser poblat de sarraïns, sinó de christians; e tota vegada de así en avant, al damunt dit fur de Aragó et no a altre fur o costum o usatje. Plau al senyor //.[fol. 43vo.] Infant que havent-hi compliment de pobladors christians, moros no y puixen ser poblats dins lo dit lloch de la Pobla. Item, que tots los vehins y habitadors de la dita Pobla puixen cassar en tots los termes de la damunt dita Pobla, qualsevol cassa de llebres, conills, perdius e totes altres qualsevols casses que ha trobar poran, aixi ab caus, ballesta, paranses, com sens aquells, açò sens pena alguna o sens do de rehemsó. Plau al senyor Infant segons que és acostumat. Item, que si ve per cars el lloch de la Pobla o los habitants d'aquell, per voluntat dels senyors que hara són o per temps seran, per fet de guerra o de altres necessitats se havien de recollir en lo lloch de Benaguazil, que en lo dit lloch de Benaguazil los christians de la dita Pobla puixen tenir tenda // [fol. 44ro.] o tendes de qualsevol mersés o coses que tenir ne volrran, e taverna o tavernes, així de sos propis vins com de altres, si menester serà, açò sen rehemsó alcuna o contrast alcú que no és puixa ésser feyt, com com així ho hajen acostumat en tots los temps passats. Plau al senyor Infant segons que és acostumat. Item, que lo dit lloch, ço és, Justícia e Jurats e prohomens de aquell, puixen posar de açí avant en e per tots temps en per cascun anys, cequiers, guardians, corredors, així de orella com altre qualsevol en totes aquelles maneres et condicions que a ells serà vist fahedor. E açò sens llicència et authoritat de senyor o altres oficials de aquell, et lo senyor ne altres en lloch seu, en açò no s'en puixen en res enremetre. Plau al senyor Infant que's faça segons que han acostumat. Item, //.[fol.44vo.] que dits vehins e habitadors en la dita Pobla puixen en les montanyes e terme de la dita Pobla bastir et fer cases, corrals, colmenars, mallades, a obs dels bestiars e altres qualsevols edificis que fer-ne volran, et en qualsevulla lloch o llochs del damunt dit terme, açò sens que no sien tenguts de demanar llicència a senyor o altres persones, e açò francament e lliure, sens alguna inquietació o impediment. Emperò, que per aquelles cases, massos, corrals, colmenars que edificaran e obraran sien tenguts de peytar per aquells ab los altres vehins de la dita Pobla, segons que els altres pagaran. Plau al senyor Infant, sens perjudici seu e de les sues regalies. Item, que si ve per cas que'ls christians de la diat Pobla haguesen a recollir en lo dit lloch de Benaguazir, que'ls sarrahins de Benaguazir que ara són o altres qualsevol persones christianes o sarrahines que en dit lloch de Benaguazir habitaran, sien tenguts de donar la mitat del lloch de Benaguazir, ço és, la metat dels I/.[fol. 45.ro.] alberchs de Benaguazir a una part dels christians de la diata Pobla, perquè cascuns estiguen a una part de ella, axí que no estiguen mesclats moro et christià en casa, com no sia sinó ocasió de molts mals e 
perill de mort e violament de la fé cathòlica. Lo senyor Infant ordenarà e ordena et proveheix de present que'ls christians sien collocats en Banaguazir per bona manera que no s'en segueixca ocasió, e que'ls dits christians de la Pobla sien recollits dins Benaguazir en temps de necessitat e de guerra, així com és acostumat, e si res en fa a millorar o farà millorar segons dit és. Item, que no contrastant que'ls christians de la dita Pobla en temps de guerra e de necessitat se haguesen a recollir en lo dit lloch de Benaguazir, emperò que puixen portar ses mullers et alguna partida de sos béns a la ciutat de Sogorb $o$ a atres parts ahon a ells serà vist fahedor, ab que los homens defents se recullen e estguen en lo dit lloch de Benaguazir. Emperò, si era //.[fol. 45ํo.] guerra de moros, ço que Déu no vulla, que en aquell cars los christians de la Pobla no sien tenguts de recollir-se en Benaguazir, ans puixen anar on se volrran, açò per tal com estarien ab los seus propis enemichs, e que se haurien així de guardar de aquells com dels altres enemichs de fora, salves als dits christians e als seus, em per tots temps, lurs possessions. Plau al senyor Infant que en cars que moros enemichs poderosament entrasen o fesen dins 10 Regne en loch que versemblant fos perill que'ls habitadors de la Pobla, que'ls habitadors de la Pobla no sien tenguts per força recollir-se dins Benaguazir, e si esdevenia que fos altra guerra et los de la Pobla o alcuns d'ells acordaven que menasen ses mullers en altres llochs, que feyta abans notificació al senyor Infant o a son procurador general, que puguen ses mullers et sos béns mobles e partida de aquells portar a Sogorb o a altres llochs deffenents del dit senyor Infant dins Regne de València; emperò, que'ls //.[fol.46ro.] homens que sien per armes ab son forniment, se hajen a recollir dins Benaguazir per deffendre la força de Benaguazir, segons que's acostumat. Item, que'l dit lloch de la Pobla no sia tengut així mateix donar al senyor e senyora que ara són o per temps seran, atzembles alcunes per en lo Regne o fora del Regne, sinó per sos diners et lloguers; et si per ventura alcunes atzembles fòra pendre lo sou sobre atzembles o altra qualsevulla persona, que aquelles façen pagar lo seu sou e lloguer, e si per ventura pagar no voldrà, que'l lloch de la dita Pobla que la pagara, pach, e aquelles atzembles de la peyta que'l dit lloch farà als dits senyors, com ja may no hajen acostumat de donar atzembles algunes forçadament, mas per llur sou e lloguer. Plau al senyor Infant que en lo fet de les atzembles lo dit lloch de la Pobla haja aytal privilegi, com ha y los altres lochs de christians que'l senyor Infant ha en lo Regne de València, et que ninguna // [fol. 46vo.] altra força no'ls sia feyta ultra forma acostumada. Item, que'l dit lloch de la Pobla haja determinació de terme e ab sos mollons, entre la Pobla e Paterna. Dispon lo dit senyor que com sia qüestió entre lo dit senyor Infant e la ciutat de València, dels termes de Paterna, tro que la dita qüestió sia deffinida no poria determinar los dits termes, però determinada la dita qüestió, plau al senyor que'ls dits mollons hi sien mesos. Item, que alguna pesquisa e inquisició, no sia feta contra alguna persona en la dita Pobla, açò segons fur de Aragó, exceptant en aquells casos que són en lo dit fur de Aragó especificades. E que tots e qualsevol qüestions, peticions et demandes civils et criminals que de ací avant en lo dit lloch de la Pobla sien 
jutjades, sabudes e determinades sogons lo dit fur. E que el senyor ne altra persona en lloch e nom de aquell, no puixen traure del dit lloch de la Pobla algun pres $0 / /$ [fol. 47ro.] presos per jutjar o fer alguns enantaments contra aquell o aquells, car si lo contrari era feyt seria contra fur e bona rahó, e les usances et observançes del Regne de Aragó Plau al senyor Infant que sia observat segons que és estat acostumat en lo temps passat en la dita Pobla, et plau al senyor Infant que'ls delictes o contrasts feyts o fahedors en lo terme de la Pobla, sien determinats per fur de Aragó. Item que dit llohc de la Pobla no sia tengut donar al senyor o altra persona cosa alguna o redempció de aquella, o donar present o donació alguna a aquell forçadament, si donchs lo dit lloch he habitants de aquell no lo y volrran donar graciosament en aquella manera que al dit lloch serà vist fahedor, en altra mnera que no y sien tenguts ni forçats per alcuna rahó, ni altra manera obligats. Plau al senyor Infant que no paguen cisa ni altres coses, que jamés no són tenguts ne acostumats de pagar, però atés lo senyor Infant, que'ls puixa demanar // [fol. 47vo.] graciosa demanda en cars de necessitat. Item, que la universitat de la dita Pobla e los vehins e habitants en aquella, presents et sdevenidors, per les possessions que hauran, així com és cases, casals, terres, vinyes, orts, ortals, los quals hauran e possehiran en la dita Pobla e terme de aquella per cascun any de la peyta ordinària, meytat en la festa de la Nativitat de nostre Senyor en lo mes de dehembre, e l'altra meytat en la festa de Sant Joan Batista del mes de juny, quatre milia sous reals de València, lo dit lloch de la Pobla, estant poblat en et per forma que ara és o aquell estant millor poblat en mayor poble que ara no és, e que lo dit lloch de la dita Pobla no estant poblat tan bé com és ara en lo temps que el present privilegi se fa, e que lo dit lloch de la dita Pobla ne los vehins o habitadors en la dita Pobla no sien tenguts de açí avat donar et respondre als dits senyor e senyora que ara són o per temps seran, sinó tan solament dels damunt dits quatre milia sous de la dita peyta // [fol. 48ro.] ordinària, e sa part del delme sogons que li pertany, et no altres coses algunes sinó, emperò, si lo dit lloch volrrà fer alguns dons al dit senyor, als que no sien tenguts de respondre de altres coses ni forçats ni obligats per alguna altra manera. Respon lo senyor Infant que la peyta dels dits quatre milia sous li sien pagats així, et plau-li que les provisions damunt feytes en los altres capitols e principalment en lo present, sien tengudes et observades com per la present resposta del present capítol. Item, per tal que'l dret que's pertany a la damunt dita peyta no sia en alcuna manera deffraudat, per a que de açí avant tots aquells qui han o hauran possessions en la damunt dita Pobla e terme de aquella no puixen vendre, donar o en alguna manera alienar $o$ transportar alguna possessió o possessions que ara fan o paguen peyta ordinària et vehinal a cavallers ne a sants o a persones religioses, ne a moros ne a jueus, sinó ab càrrech de la dita peyta. E si's fa, que no hi vala en la dita venda lo fur de Aragó en lo present cas, en alguna cosa no contrastant com en altra manera sia gran // [fol. 48vo.] dany e perjudici de totes les altres possessions. Plau al senyor Infant que les alienacions que's faran de les dites possessions dels homens de la Pobla, sia feyta ab càrrec de la peyta segons 
que és lo capítol contengut. Item, que tots los christinas que ara són o per temps seran, estant lo lloch de Benaguazir poblat de sarrahïns, segons que ara és, aquells christians d'açíavant perpetuament sien tenguts de contribuhir ab los dits christians de la dita Pobla en totes peytes e altres qualsevols càrrechs, tot així e present a present com fan los christians de la dita Pobla, com així ho hajen tots temps acostumat de fer. Plau al senyor Infant que tots temps sia observada la costum que huy se observe sobre la contribució dels christians que estan en Benaguazir ab los habitadors de la Pobla. Item, que lo Justicia, Jurats e Consell de la damunt dita Pobla puixen acollir en son vehinatge e rebre per vehins a qualsevols persones ab bestiars e sens aquells, sens llicència o manament de senyor e procurador, // [fol.39ro.] sent açò a profit del dit senyor e del lloch e habitants de aquell. Plau al senyor Infant que les coses en lo dit capítol contengudes se facen segons que és estat acostumat per totstemps. Item, que'ls christians de Benaguazir sien tenguts de venir a la damunt dita Pobla a juhí per determinar totes e qualsevols qüestions, pleyts e contrasts que entre aquells seran o hauran ab altres persones. E lo Justicia de la Pobla que ara és o per temps serà, sie Justicia e jutge ordinari de aquells dits christians de Benaguazir et no altre algú, com així u sia estat tota vegada, et així ho han acostumat de fer tota vegada, et ést just e consonant a rahó. Plau al senyor Infant que'l Justicia de la Pobla ús de són offici en los christians de Benaguazir, segons que és estat acostumat en lo temps passat. Item, que si ve per cars que fos voluntat del senyor que lo lloch de Benaguazir se poblàs de christians e s'en despoblàs de sarrahins, e lo senyor volgués privilegiar los pobladors novells que hi vendrien a Benaguazir e volien que en lo dit privilegi et novella població fossen entesos los christians que ara són // [fol. 39vo.] en Benaguazir o seran, en aquell cars que el dit lloch se despoblàs de moros, que en aquell cars lo senyor que ra és o per temps serà, volent fer la dita població novella, sia tengut de abatre al lloch de la Pobla e habitadors de aquella, tanta peyta com los dits christians de Benagazir fan o faran, en aquells cars que's despoblàs lo, dit lloch de Benaguazir de sarrahins e se poblàs de christians, contant les possessions de aquella als de la dita Pobla, e contant per sou e per lliura et disminuhir aquelles dels dits quatre milia sous de la dita peyta aytant com muntaven. Respon lo senyor Infant que si novella població serà feyta de christians en Benaguazir, que li plau que per aquella ningun pejudici no sien generat als habitants de la Pobla, e que la costum antiga sia servada. Item, que si ve per cas que al senyor Infant et senyora Comtesa que ara són o altres qualsevol senyors que per avant seran, volrran fer gràcia especial a algú o alguns havents possessions en la dita Pobla e terme de aquella, que'ls fes franchs o franchs de peyt, que'ls // [fol. 40ro.] dits senyor o senyora que aytal donació o gràcia volran fer, que tant com muntarà la peyta o peytes de aquells que afranquir volran, sia franquit de pendre-u-ho en son conte et diminuhir-hi dels dits quatre milia sous de la dita peyta a la damunt dita Pobla, per tal que açò que a uns és o serà goig, a altres no serà plany et desolació. Plau al senyor Infant. Item, que si ve per cas que algú no volrrà pagar la peyta que tachada li serà per la possessió o possessions que 
haurà e cull e sia en lloch de la Pobla o en altra part, puxs que sia certificat per lo cullitor de la venda, que'l pagant com li vendrà o tachada li serà, que pagar no volrrà, que los Jurats de la dita Pobla, per son propi ofici puixen fer venda o logació de aquelles possessió o possessions de que no volrran pagar la dita peyta, sens frau algú del senyor de la poseçió. Et si trobara a qui logar, que no venen, en altra manera que u venen, et pagada la dita peyta et ço que serà degut per aquella // [fol.40vo.] poseçió, que so que sobrarà del preu que s'atrobarà de aquella possessió sien tenguts de tornar e lliurar al senyor de la dita posesió venuda. E aquel qui comprarà sia tengut per aquella cosa a peytar, segons que li serà tachat. Plau al senyor Infant. Item, que lo honarable Jordi Joan, així com a dispenser dels damunts dits senyors Infant i Comtessa, sia tengut de fermar lo dit privilegi et jurar segons lo seu ofici, y contra les dites coses per los dits senyors fermades no vendrà per alcuna causa, manera o rahó, ans aquelles tendrà e servarà et servar farà a la letra. Plau al senyor Infant. Item, que tots e qualsevol senyors o procuradors que seran dels damunt dits senyors que ara són o per avant seran, e altres qualsevol substituits o delegats de aquells que hauran a conèixer algunes qüestions en la dita Pobla, // [fol. 41ro.] ans aquell ús de algun juy o coneiximent de qüestió alguna, sia tengut de jurar de bé et de legalment tenir furs et privilegis, usos et costums de Aragó, privilegis e bones costumes, e utilitat e profit del senyor e habitants del dit lloch de la Pobla et o en altra manera. Plau al senyor Infant, segons que és acostumat en lo llochs poblats a fur de Aragó. E pro parte vestre universitatis loci predicti Vallisbone fuit nobis humiliter suplicatum ut dicta capitula et contenta in his dignaremur vobis eidem universitati concedere de gratia speciali. Ideo, nos suplicatione vestra predicta benigne suscepta, attendentes quod vos, dicta universitas per viam domini et alias cum pro pacto nostre curie // [fol. 41vo.] nobis petita in nostris subvenitis necessitatibus prompta corde. Atendentes etiam quod huiusmodi ratione pro nuvilio dare nobis quadrigentos florenos auri de Aragonum abstulistis, thenore presentis carte nostre sirve publici instrumenti perpetuo valituri, concedimus vobis universitati predicte et singularibus ipsius et successoribus vestris in dicto loco ac pro vobis facimus privilrgium quod dictis capitulis et contentis in eisdem et eorum singulis uti libere valeatis iuxta formam responsionum et provisionum eisdem capitulis et eorum quilibet per nos facturum ut in fine cuiuslibet ipsorum capitolorum continetur. Promittimus vobis, dicte universitatiet singularibus ipsius et vestris perpetuo successoribus, ac etiam nos, dictum Infans, iuramus per dominum Deum et eius Sancta Quatuor Evangelia, , manibus nostris corporaliter tacta, // [fol. 42ro.] quod non impediemus seu impedire faciemus aut promittimus vos, dictam universitatem nec seccessores vestros aut ipsius singulares, eunde contentis indictis capitulis et eorum quolibet iuxta tamen formam responsionum et provissionumeisdem capitulis et eorum singulis factarum ut superius expresatur, uti libere valeatis quinimo predicta omnis et singula ut in dictis nostris responsionibus uti sunt concessa tenebimus perpetuo, ac teneri et observari inviolabiliter faciemus et non contraveniemus seu aliquem 
contravenire permitemus aliqua ratione et causa. Et pro maiori predictorum validatate, nos, dicta comitissa, ea quod ex causa iuxta personaliter iurarunt predicta facere et et fixamus ad ipsum prestandum iuramentum nostro nomine et pro nobis constituimus et ordinamus procuratorem nostrum Petrum Raymundi de Canporells, militem, qui in predicta iuramenti religioni pro nobis promitat vobis // [fol. 42vo.] predicta tenere et observare ut superius est contemtum. Et ego, Petrum Raymundi de Canporells, procurator iamdicto domine comitise, iuro per Deum et Sancta Quatuor Evangelia, meis manibus corporaliter tacta, quod dicta domina comitissa et sui perpetuo successores tenebunt et ebservabunt. Et ego, eius nomine tenebo et observabo omnia et singula tam per dictum dominum Infantem quam per ipsam dominam comitisam superius concessa et promissa ut superius continetur. Et predicta omnia et singula ut superius sunt dicta facimus, concedimus et pascimus nos, dicto Infans et Comitissa, vobis dicte universitatis et singularibus ipsius et vestris perpetuo successoribus sicut melius dici potest inteligi ad vestri vestrorumque omnium successorum commodum et salvamentum ac bonum et sanum intellectum in pose, // [fol.43ro.] videlicet notarii subescripti, tanquam publice persone, hec a nobis pro vobis et pro aliis etiam personis quorum interest vel potest interesse legitime stipulantis et recipientis. Mandantes cum eodem instrumento vicem epistole gerente, procuratoribus, bayulis, iusticiis ac aliis oficialibus et subditis nostris, presentibus et futuris, quod contra predicta non faciant vel veniant seu aliquemcontravenire permitant aliqua ratione. Quinimo ea omnia et singula vobis dicte universitati et singularibus eiusdem et vestris perpetuo succesoribus teneant et observent et faciant et inviolabiliter observare ut superius est narratum. Et pro predictis confitemur et recognoscimus quod nos, dictus exponens a vobis, dicta universitate habuisse et recepisse quadrigentos florenos auri de Aragonum quod nobis respectu predictorum unde promitio concessistis quosque pro nobis et de mandato nostro numerando tradidistis dilecto consiliario et expensori nostro // [fol. 43vo..] Georgio lohannis, in quorum testimonium presentem fieri iussimos nostris sigillis appenditiis comunita.

Datum et actum est hoc Valentie, vigessima die madii, anno Naivitate Domini millessimo trecentessimo octuagessimo secundo. Vidit pro vicecancellario.

Sig+num Infantis Martini, Illustrissimi domini Petris Regis Aragonum filii et Dei gratia Comitis de Exerica et de Luna, ac dominus civitati Sugurbi, que hec concedimus, firmamus et iuramus. Infans Martini.

Sig+num Marie, Comitise de Exerica et de Luna, ac domine civitatis Sugurbi, que hec concedimus et firmamus. María Comitisa.

Sig+num Petri Raymundi de Camporells, procuratoris predicti, qui predicta concedo et iuro nomine supradicto. 
Testes huius rei sunt nobiles Eximeneus Petri de Arenoso, miles, et Geraldus de Queralto, camarlengi, Petrus Sancii de Calatayubio, mayordomus, miles, conciliarii, e Franciscus de Aranda, de domo dicti domini Infantis. // [fol.44ro] Sig+num Raymundi de Cumbis, auctoritate regia notari publici per totam terram et dominationem illustrissimi domini Regis Aragonum, qui predictis interfui eaque escribi fecit et clausit.

\section{Nota al pie de página no 208 (pág. 266)}

Listado de posesiones del Monasterio de Porta-celi en la Vila de la Pobla de Vallbona a lo largo de la historia

Existe una relación de todos los bienes que poseía la Cartuja a finales del Siglo XV hasta la desamortización agrupados con el tipo de dominio y disfrute de rentas. Con el objetivo de poder identificar los bienes muebles e inmuebles que tenían en el municipio se realizó un estudio de todos ellos. En los documentos no se describe la dirección exacta de los bienes tal y como lo conocemos en la actualidad puesto que no existía en aquel momento ninguna organización como el catastro actual que delimitara las parcelas, los polígonos o los números de las calles. Los bienes van referenciados por los nombres de las partidas de rústica, existiendo muchas de ellas en la actualidad. El nombre de la calle hace referencia a como se denominaban antiguamente. Se procede a detallarlos cronológicamente.

a) Recepta el Expensa de Porta-celi. Años 1375-1388

Describe los gastos pero no indica en que municipio ni en que terreno se ha realizado el gasto o el ingreso

b) Memoria escrita por el prior D. Francesc Maresme, prior de esta casa de Porta-celi en el año 1417 de todas sus posesiones, bienes y rentas

De Benaguazir e de la Pobla

Item reeb tota la primicia del loch de Benaguazir e de la Pobla sesua sesus alguna excepcio e cosa reservada per al rector daqui sino la sua pensio tatxada per suma de totes coses acostumades pagar e pendre primicia, la qual primica se acostuma de arendar a cent anya al menys de tres en tres anys, lo qual arrendamente un any ab altre val seus deduies messions e pensió

En este documento también se refleja el pago al cura de la iglesia de la pobla, siempre en el mes de noviembre. También indica que el rector debía de dar 3 caffiços de forment a la cartuja.

c) Manifest dels bens de realench de Porta-celi. 1448 
Rendes de la Pobla e Benaguzir 136.5 lliures

c) Pensiones de censos y arriendos de Porta-celi año 1553

En estos documentos se describe los recibos y gastos del año 1553 de la Cartuja. Fue realizado por Jaon Castro prior de Porta-celi e indica siempre en el recibo la parte del arrendador o aquello que explotan directamente, dejando constancia de la clase de bien de que se trata ya sean tierras o frutos como paja. En este censo no aparece ningún inmueble referenciado en La Pobla de Vallbona

d) Proceso contra los conventos del Carmen y el convento de san Onofre de Museros sobre la primicia de la Eliana y la casa blanca. Años 1600-1669

Antecedentes año 1583.

La cartuja de Porta-celi lleva causa por el tribunal de la Real Audiencia desde los primeros años de 1600 contra los conventos de Nta Señora del Carmen y San Onofre para cobrar de estos la primicia que se le debe a Porta-celi de las heredades de la Eliana del Término de la Pobla de Vallbona y de la Casa Blanca, en el término de la pobla, de los cuales son señores los citados conventos.

Este pleito se incluyó en los procesos civiles de los años 1707-1835, dejando constancia por escrito en los años 1754-65. Parece entenderse que nuestra señora del Carmen tiene el convento en la Eliana y el de la casa Blanca, pertenece al convento de San Onofre.

d) Pensiones de censos y arriendos del Monasterio año 1624

El siguiente documento trata de los recibos de enero del año 1624, los cobros de los arriendos de bienes muebles como mulas, y corderos y bienes inmuebles como tierras de cebollino o bodegas en general y nombra al municipio de La Pobla de Vallbona.

e) Soldadas de los criados de la cartuja de Porta-celi

Datados de los años 1709-1740 se encuentran las soldadas de los criados que dependían del monasterio de Porta-celi y que se encargaban de mantenerlos correctamente. Se cuentan mas de 1100 personas a su servicio identificados por nombre, procedencia y salarios. No aparece ninguna persona destinada al municipio de la Pobla de Vallbona lo que hace pensar que o no tenían ya bienes inmuebles en esta zona o que los tenían todos arrendados. Se encuentra una persona destinada al municipio de Benaguacil, pero no en La Pobla. 
f) Bienes de realengo de la Cartuja de Porta-celi Años 1741

"Que la otra pieza de la puebla de Benaguacil son 18 hanegadas de un total de 30 de la partida del Alguacil, antoadas en fol.68 b bajo el no1, que pretenden permutarse con otras tierras del Convento del Carmen.

h)Pleito del Monasterio de Ntra señora de Porta-celi con el convento de san Onofre de Musseros sobre amparo de posesión de exigir los derechos rectorales de las primicias de frutos de las villas de liria y Benaguacil y La Pobla de Vallbona

El pleito indica por parte de la real Cartuja de Porta-celi en justificación de estar en la posesión inmemorial de cobrar la primicia de frutos y carruaje de las vilas de liria, benaguacil y la puebla de Vallbona y especialmente de las dos heredades de Eliana, propia del Convento del Carmen y de la casa blanca propia del convento de San Onofre de religiosos dominicos.

i)Manifiesto de Rentas y Gastos del año 1776-165

Cabe destacar que en estos documentos la descripción de las propiedades se muestran separados en cuatro grupos y se presentan mas detallados que en los documentos anteriores. Las cuatro agrupaciones son:

- Bienes arrendados

- Bienes que cultiva por su cuenta

- Cargos reales de bienes impuestos por testadores y donantes

- Gastos de conservación de masías

De los primeros, bienes arrendados, se encuentran en total casas y tierras en la Pobla, además de los derechos de primicias, se describe del siguiente modo

Casas y tierras en las villas de Liria y la Puebla de Benaguazil y la masía del collado.885 libras con 14 sueldos.

Derecho de primicia de carruaje de Liria, Benaguacil, La Pobla, Olocau y su valle 70 libras.

Derecho de primicia de Benaguacil y la Puebal excepto de carruaje. 1460 libras.

Señala el cultivo de varias tierras directamente por el Monasterio, no hace referencia a la situación de las tierras, pero debieron ser bastantes por la cantidad de libras que se obtienen, dice así:

Tierras de la puebla de Benaguacil , 2618 libras, 13 sueldos, 5 dineros Y por último se observan los gastos y conservación de las masías, graneros, lagares, bodegas cubas y tinajas bienes que no se encontraban arrendados y 
que mantenía el monasterio por los frutos obtenidos para autoabastecerse. Lo mas destacable de este punto es que no nombra ninguna masía en el término de la pobla, cuando en los otros municipios en el caso de existir si que lo hace.

j) Bienes de realengo de la Cartuja de Porta-celi Años 1789

Termino La puebla de Vallbona

Partidas diversas 381 hang de huerta, 191 cahizadsa y 3 hangedass de secano, junto con 2 evas y 2 pajares

1 casa-hospicio en la puebla de Vallbona.

Bienes en arriendo 8 casa en la puebla de Vallbona y 152,5 hanegadas de huerta.

La pobla no aparece ni en las masías, ni en el apartado de alquerías.

k) Manifiesto de Rentas y Gastos del año 1804

Los datos mas destacables en el apartado de bienes arrendados donde se deja constancia de tierras arrendadas en la puebla vendidas. A partir de este momento la cartuja tendrá tierras en el municipio que explotará directamente pero ya no en alquiler. No deja constancia de la parcela ni la finca registral ni catastral.

En cambio indica que sigue teniendo 6 casas en la pueblas que están arrendadas y que de ellas obtiene 536 libras.

I) Inventario de Porta-celi de la comisión de Liria.1820

Destacar en primer lugar que este documento al tratarse de un inventario, es de donde se pueden obtener mayores referencias de los bienes inmuebles propiedad de Porta-celi en la vila de la Puebla de Vallbona. Se detallan en primer lugar tanto los bienes muebles como los frutos que se tienen en este municipio a fecha 22 de diciembre del citado año, de este modo se encuentra una casa primicia que cuenta con:

- Muebles: Una mesa grande de nogal, una mesa de pino mediana, dos sillas de nogal, dos prensas de vino etc.

- Frutos: dos hanegadas de cebada, dos hanegadas y media de cebollas,, Imagen de este papel.

Otro de los inventarios del Monasterio de Porta-celi es el de las fincas rústicas y urbanas de ese mismo año. En este inventario se marcan todos los bienes estén en arrendamiento o no. En este caso se deja constancia de la propiedad de una viña y un garroferal de la Torre en el Término de la Puebla, al igual que casas y tierras. La viña se sitúa en el llano de los alginers y son cincuenta y seis cahizadas junto con catorce cahizadas en los hornillos. 
El garroferal, se refiere sobre todo a tierra campa, y nombra una gran cantidad de posesiones en los hornillo, alginers, la tabla larga, el garrofera/ clar, la archila, Mallaeta Y Camino de Valencia. Las últimas partidas existen en la actualidad.

En cuanto a los bienes inuembles que tiene en la puebla, se refiere tanto a bienes inmuebles y tierras. Los bienes referenciados son 7 casas y 4 hanegadas de huerta que se encuentran arrendadas. En la zona de la vila en el centro histórico identifica dos bienes en la calla mayor, el resto de bienes inmuebles los sitúa ya en extramuros El texto dice así:

"Una casa grande instaurada para casa procura en la calle mayor de la Puebla que tiene de su cuenta el Monasterio para la recolección de frutos de primicia. Otra casa en la calle mayor de Puebla junto a la antecedente inquilino Mariano alexiandre paga trenta libras al año, vencen el diecisiete de julio no tiene escritura y debe el presente año.

Otra casa en las ventas de puebla de Vallbona inquilino Juan Pardo paga veinte libras.

Otra casa 2 en las ventas de puebla inquilino Marimon, paga veinte libras

Otra casa 3 en las ventas...

Otra casa 4 en las ventas....

Otra casa 4 en las ventas inquilino pedro Puchades

Otra casa 6 en las ventas......

Quatro hanegadas de tierra y huerta partidad de la Aldaya arrendada por Pedro Real y su hermano de Benaguacil...

Nota al pie de página no 229 (pág. 297)

Archivo del Seminario del Corpus Christi de Valencia. Protocols, 21.981. Notari Jaume Llorens.

\subsubsection{0}

Escritura de nombramiento de electos para la obra de la iglesia

"Mosen Pedro Villarte, Mosen Joseph Rumbau y Mosen Vicent Cariñena preberes, Matheu Segura, Batiste Desco, Juan Mir, Juan López, Dotor Vicent Meseguer, Joseph Herrero, Vicent Jorda, Christofol Marti, Pere Juan López, Vicent Orti, Vicent Rius, Luys Jorda Rada, Joseph Pu.., Maximiano Gomis, Ypolit March, Batiste Julibert, Francisco Bono, Pere Camps, Joseph Monfort, Bastiste Vesis?, Marco Zamora, Berthomeu Soriano, Luys estarlich, Luys Gomis, Domingo Polo, Esteve Rillo, Juan Martínez, Miguel Rabadán, Juan Romero, Thomas Grau, Vicent Sirera, Juan Torres, Ildefonso Aragones, Vicent Girines, Romualdo Samnia, PascualCarsi, Juan de la Raga, Gerona Bondia, Nicolau Silvestre, sirujia, y Jaume Llorens notari y asi (...) del reveren Vicent Sebastián prebere Dotor en Sagrada Teología Retor de la Parroquial Iglesia de 
la present Vila de la Pobla de Ballbona (sic) dits vehins y habitadors de dita y present vila y parroquians de dita parroquia convocats y congregats en la Iglesia de dita Vila hon esta el Glorios Sent Jaume per cap de altar y titular hon per a semblants y altres afers negocis es solen y acostumen convocar $y$ congregar presehint convocacio feta per Juan Jordan ministre de la present Vila en la forma acostumada per a el present día y hora segons aquell feu Relacio medio Juramento a nostre Señor Deu Jesuchrist en ma y poder del notari davall escrit y en presencia dels infraiscrits testimony prestat el haver convocat a tots los parroquians de dita parroquia presehint aixa mateix llicencia permis y facultat donada per lo Justicia de la present Vila en lo día primero del corrent feta per a la primera Junta registrada en la primera ma de dita Cort del dit Justicia. Attes y considerat que havent estat propossat per dit Retor que la present Iglesia necesitava de obrarse y lluirse y que per a effecte veure quina obra era menester se havien de formar uns capitols y havense llegit aquells per lo Notari Infraiscrit... dixeren que es corregues y subastas dita obra ab los dits Capitols y que determinasen et nomenassen sis elets y que daquells sel fos donada facultat y poder per a añadir y llimar dits capitols en tot allo que paregues convenient a dita obra y determinasen $y$ nominasen que pera elet elegit per dita Junta el dit Retor y el Jurat mayor que ara es o pertanyes sera y es posa els restants quatre elets foren proposats Mosen Vicent Cariñena, Mosen Pere Villarte, Mosen Joseph Rumbau y el pare Joseph Montalt prebere per eleccio de dos elets eclesiastics y per a la eleccio de dos elets seculars faltaven a dos numero de sis foren proposats Hypolit March, Lluys Gomis, Juan Lopez, el Dr Vicent Messeguer y Jaume Llorens Notari infraiscrit y haventlos postha casen enson albaret $y$ en son sombrero foren extrets per son infant en elets eclesiastichs a Mosen Pere Villarte prebere, al pare Joseph Montalt etiam prebere $y$ en los dos restants seculars sortecharen Lluys Gomis y Juan López (...)"

\subsection{0}

Festes:

"Batiste Desco jurat mayor. fer les festes que se acostumen fer eren molt modiques y que els jurats expedien moltes mes que sels prenia en conte en grave detriment de les pobres cases per quant los frares que venien (...) pareixia mal que sen anassen al convent después de haverse cantat y acabarse (...) en particular la de lo día del Corpus y (...) havien pasta molts entredits vehins que sel y done al Jurat la facultat per a que en Zinc lliures fassa la festa del Corpus y la festa de Sent Jaume la cantitat de quatre lliures, St Sebastián, Mare de Deu de Agost a dos lliures cascuna y que los Jurats Vicent Orti y Romulado Sarriá conten dites festes en la conformitat expresada la qual delliberacio feren los dits (...)"

8.06.1700 (al marge: assi entren los antes de la obra de la lglesia) "Matheu Segura Justicia de la present Vila, Batiste Desco Jurat mayor Juan 
Alis jurat menor Ypolit March Sindich Vicent Desco Vicent Sirera, Domingo Polo, Vicent Urbi, Pere Juan López, Domingo Desco, Batiste Perez, Vicent Girines, Remualdo Sunnia conseller del Consell particular junts y congregts en la sala de dita Vila certificant que tots juramenses (...) pareixia nomenar quatre lets del present consell per a trastechar... en dit Plen y ohida dita proposissio manimes y concordes determinares que es seguisdipler per Justicia y que lo Sindich Ypolit March que busque el diners que sia menester per a subministrar los gastos que se offeriran en dit plen y que en lo día de Jesus Juan primer vinent es fassa una tacha proporcionada (...)

Item los dits consellers determinaren y nomenaren en Advocat de aquella al Doctor Joseph Gilabert en la futura del Dotor Nicolau Bas tambe advocat de dita Vila per a que sempre y quan lo dit Dr Nicolau Bas estiga in disposito ausent de la ciutat de Valencia asistixca a la pnt Vila en tot allo que se offeira y aço sia sens salari algun.

Vehins y habitadors en dita Vila havent presedit prego publich fes per Juan Jordan ministre de dita Vila lo qual mijansant jurament apostre señor Deu JesuCrist y en presencia del notari y Testimonys davall escrits feu prego haver preconisat per los puestos acostumats de dita Vila que aun dissen los dits vehins a cellebrar consell general per al present día de juny hora y puesto fonch proposat per dit Jurat mayor: el motiu que ha tengut per a haverlos juntat al present puesto era per ferlos noticiosos (...)"

\subsection{0}

"Joseph Piñó y Juan Viñes obrers de Vila de la Ciutat de Valencia y al present atrobats en la Vila de Paterna. Attes y considerat que ab gete rebut per lo notari infraiscrit en lo día de huy (...) y elets de la Parroquia de la Parroquial Iglesia de la Vila de la Pobla de Vallbona alias de Benaguacil com son lo Rector Vicent Sebastián preveré Rector actual de dita Iglesia de dita Vila, el Pare Joseph Montalt prebere Religios del Patriarca Sent Domingo, resident en la casa y heretat propia del convent Sent Onofre dita la Cassa Blanca situada en el terme de dita Vila, Batiste Desco Jurat mayor de la Vila y Juan López y Luys Gomis vehins de dita Vila los quals en dits noms de elets de la dita parroquia de dita Vila nos han lliurat la obra de la Iglesia de dita Vila ab los Capitols mencionats y espesificats de dita obra per lo notari rebedor de la present obligació y lliurament y Addiccio de aquells y añadits de aquells que después de determinada la obra principal capitularen el haver de fer la Porta hon estava lo altar mayor de dita Iglesia que les dos capitulacions foren determinades per dita parroquia y parroquians de aquella y trobantse presents onze mestres de obrers de Vila de la Ciutat de Valencia fonch correguda y subastada dita obra per Juan Jordan corredor publich de la Vila en presencia dels onze mestres que huy havia en dita Vila de la Ciutat de Valencia y havent mirat y regonegut la primera y segona 
capitulació y donada be y degudament a entendre als dits mestres foren subastades les dos (...)

y per sia pagant y pro es troba qui mayor dita donas que la que donaren Joseph Piñó y Juan Viñes mestres de obrers de Vila de dita ciutat de Valencia la qual obra de la primera y segona capitulació ab les obligacions alli mencionades fonch lliurada als dits Juan Viñes y Joseph Piñó en cantitat de mil trescentes quaranta nou lliures per les dos capitulacions ab la obligacio de donar fianses a contento dels damunt dits elets y ab los partes y condicions y obligacions en dits capitols mencionades y expresades, los quals trobantse presents aceptaren (...) dit lliurament de les dos capitulacions; y per a cumpliment juicio $y$ seguritat de dites coses donen en fianses y principals obligats juntament ab ells, sens ells e a soles a Jasintho Vilar, Ignacio Llopis, Vicent Garcia, Faustino Sancho y Jaume Carreres obrers de Vila y Joseph Piñó llaurador mayor en diez tots de la Ciutat de Valencia vehins y habitadors y atrobats en la Vila de Paterna (...) Testes Petrus Blanch agrícola Villa de Paterna et Joseph Brisa etiam agrícola Horta de Campanar respectivament habitadres."

Capítols para "Redificar" la iglesia de la Pobla de Ballbona titular del Glorios Sent Jaume

"Primo que el mestre o mestres que entraran a fer dita obra tinguen la obligació de fer fonaments en tots los puestos que carreguen los Archs de la Esglessia que al present son columnes de pedra redones y afondar aquells lo que sera menester y de la amplaria y llargaria que es trobara en lo carregant de dits archs en un pam de rabasa, o escarpa tota la alrededor ademes de la dita amplaria y llargaria de forma que la perpinticular del buelo que tenen tots los archs de pedra vinga a plom de les pilatres, ó pilastrons com en avant (...) ademes de la dita escarpa a rebost que se ha de fer en tots aquells omplintlos de morter blanch y pedra ben castigats y abeurats en aigua y dits fonaments han de quedar tots molt ben anibellats de una tirada.

II Item que sobre els fonaments del capitol antecedent se hagen de puchar les pilastres ó pilastrons en tota forma com es del payment de la Esglessia en amunt desta la alsada de quatre o sinch pams de rachola y morter blanch per raho de les humetats y lo restant de alli en amunt de algep y rachola ben trabat fent moles en les dites colunes o tamborinos de pedra pera que quede ben trabada la pedra en la rachola y algeps.

III Item que tots los dits pilastrons o pilastres hachen de puchar hasta la alsada (...) es fara en totes les parets per a fer y asegurar la Arquitrau, Fris y cornisa forrantlo tot molt be de algeps y rachola donantli els buelos y resalts de demostra el perfil cada cosa en son puesto no escusant el rompre tot lo que sera menester en los Archs de pedra de dita Iglesia per asegurar y 
fortificar dita cornisa y tot lo demes que sera menester en la dita Iglesia y Capelles de aquella y Sacristía.

IV Item que el dit mestre tinga obligació de fer un arch abocinat puchant la planta de aquell desde els fonaments que se han dit se han de fer nous y el dit Arch abocinat se ha de fer y executar en lo Arch toral que esta mes proxim al Altar Machor pera fer divisió del Presbyteri, travant el Arch de Rachola y algeps que se ha de fer abocinat en lo arch de pedra que al present $y$ ha del millor modo y forma que se estila pera machor seguritat y permanencia de aquell advertint que el dit arch abocinat ha de anar pararelo en la oblisquetat Montea de la bolta de la Iglesia (...) y tancar la Capella que esta dins del Presbyteri del millor modo y gruixa de paret que sia menester.

$V$ Item que el dit mestre tinga obligació en tots los demes archs de la Nau de la Iglesia y forners de aquella el quadrarlos de algeps y rachola del millor modo, y forma que es... fent traves en los archs de pedra y de la amplaria que el planteig de gruixa de ells requirira y el quadrar dits archs ha de ser reduhintlos a punt redo en lo mig de aquells... y la mateixa diligencia se fara en demes voltres suavisant aquelles com ya esta dit en les dos primeres.

VI Item que el dit mestre tinga obligació de quadrar los Diagonals y archs de pedra que ha en dites voltes conforme els altres principals que carreguen de una pilastra de arch del mateix modo y forma.(...)

VII Item que el dit mestre tinga obligacio de desfer la volta de la Sacristía y la paret que sustenta aquella que es la que esta entrant en dita Sacristía a ma dreta y puchar les tres parets tot lo que dara la teulada y bolta de la Capella de Sent Lluys y teulada de la Sacristía.

VIII Item que damunt de dita Sacristía se posaran les bigues que seran menester, que estiguen de dos en dos pams, una de altra y que entren en les parets lo menys pam y mig de cada part,que sien de fusta Castellana y de galga de a vint y quatre de bon mellis encabironant aquella de cabirons de tres y zinc del pam clavant dits cabirons en claus de encabironar en totes les dites bigues y aixi mateix encabironar de rachola prima de bona calitat cuberta de teulada aumentant la futa a aquella largaria que sera menester per a que tinga la teulada el ters de la rostaria fentla la dita teulada paymentada de morter blanch ben bruñida y perfilada que entren les canals y cubertes quatre dits dins les parets pera que per ningun temps es puixa ploure en sos cavallons alrededor de morter blanch.

IX Item que el dit mestre tinga obligació davall de la cubierta de la Sacristía de fer bolta de cañes (...) clavant contra les mateixes vigues de la dita primera cuberta (...) ben clavada en Claus de empaliar y trenelles llafardantla y reparantla de algeps que quede ben igual (....) y tirar una c..reta a la arrededor de bona moldura apegada a la mateixa bolta y después (...) de alabastre que 
quede ben bruñit y fer faixes dobles en tots los puestos que sera menester $y$ lo mateix se fara en totes les quatre parets, reparantles de algeps y después de alabastre (...) y fer y asentar la finestra y reixa que sera menester en dita Sacristía a conte de dit mestre allisant lo sol de dita Sacristía a nivell del pla del Presbiteri rompent $y$ allsant el arch lo que sera menester en la porta pera entrar en dita Sacristía mudant aquella ahon sera menester asegurant y fent el arch de algeps y rachola pera seguritat y permanencia de dita paret, y la amplaria y alsada de dita porta hacha de ser y sia de bona proporció paymentant lo sol de dita Sacristía de taulells grans en cortapisa ala rededor y acartabo advertint que la Sacristía ha de ser de llarg tot lo que y ha des de la paret del Presbitery hasta el estrep del arch abocinat, ha de tenir de amplaria lo que es troba al present, rompent pera dita execució tot lo que sera menester y deixar forats per a que ventilen los ayres en (...) les voltes de cañes no excusant fer en dita Sacristía en lo mig de la bolta de aquella un floro de bona talla. y quatre tarchetes en los rincons també de bona talla.

$X$ Item se advertís que totes les portes finestres y reixes que seran menester les haja de pagar y fer a ses costes lo dit Mestre o mestres de davant que les reixes han de ser cinch o quatre pera la Iglesia de zinc pams de amplaria y set de alsada (...) y lo mateix han de tenir les finestres en dos cloendes que tinguen uns alquitraus de fusta (...) y la mateixa moldura per lo mig en sa travesera per a poder tancar dites finestres... y fer y asentar la porta de la Sacristía. Advertint que la dita porta ha de tenir de amplaria zinc pams y alsada nou y haja de estar guarnida de moldures dobles (...) que es us costum posar ben clavades en claus machats ben pulits y llimats.

Arquitectua y talla que ha de la Sacristía principal con se veu en lo perfil y fer les portes de la lglesia les que cahuen al carrer de dos cloendes ab son portich apeinasa des la part de dins y en llandades per la part de fora picades les dites Ilandes en les armes o insignes que voldran los elets y clavades dos ferradures que es troben en les portes velles, guarnintles dites ferradures en dos tarchetes picondes sobre la mateixa llanda per ser tradició del rey Don Jaume y quatre travesseres cada porta per la part de dins (...)

XI Item que el dit mestre tinga obligació de fer y eixecutar la capella de Sent Lluys Beltrán en lo mig (...) de forma que el mig de la bolta de la capella vinga en lo mig o a plom de la mitat del former de dalt de la bolta de la nau de la Iglesia y de la amplaria y alsada, que sera menester pera que quede en tota perfeccio, que es veu en lo perfil rompent les parets, archs y boltes (...) y puchar los estreps hasta la alsada que sera menester y no escusant el obrir el fonament de la amplaria y fondaria dels demes de les altres parets de dita Capella y omplir aquelles de morter blanch y pedra y puchar I adita paret o parets de la mateixa gruixa de les antecedents dites de dita Capella ara sia de pedra o de rachola y morter blanch; fent sobre dites parets una bolta per igual de rachola y algeps (...) y después doblada de miches y algeps 
(...) encarreronada com se acostuma en semblants fabriques y dits carrerons han de tenir el ters de la notaria (...) se ha de fer sobre dits carrerons trent dos bardes al recibidor y la teula que bole el ters de ella y dita teulada ha de quedar acabada y perficcionada en los mateixos pactes y condicions que la de la Sacristía y alsada de volta de bona proporció.

XII Item que dins en la dita Capella se taja de perficionar reparant la bolta (...) de algeps y después de alabastre corrent una cornisa de bona moldura y proporció resaltant aquella y retornant aquella en tots los puestos que sera menester y reparar les parets de algeps y después de alabastre en faixes dobles en los puestos que sera menester, advertint que totes les racholetes de Manises les hacha de guardar y conservar y posar les que faltavan pera tornar a chapar tota la dita Capella y el sol de aquella la hatja de paymentar de taulells grans a cartabó en la cortapisa alrededor.

XIII Item que el dit mestre tinga obligació de fer y eixecutar en la altra part y colateral a dita capella un sentit de capelles en les chambes (...) y archs del mateix modo y forma que la Capella de Sent Luys Beltrán y es veu en la planta y perfil; advertint que si paregues a la present vila la tapia fos de bona calitat e la fondar tres pams pera el nicho del retaule pera la profunditat de tota la capella tenga obligació de afondar, o per machor hermosura de sita Iglesia y capella fent un arch de la gruixa de una rachola la micha y de la fondaria de uns tres pams carregant lo dit arch sobre (...) branques que se han de fer della mateixa gruixa del arch trabantho molt be (...) tot en algeps y rachola ben paredat y masisar en les motees que demostra el perfil, posant en lo dit arch tres florons de bon relieve y talla en cascú de aquells llevant lo pulpit y acomodarlo en lo puesto que ben vist sera a la oida dels elets nomenats per aquella.

XIV Item que el dit mestre tinga obligació de retirar la finestra que esta en lo former del cor tan arrimada al Campanari com se puga y obrir aquella dela amplaria y alsada que esta dit en lo capitol advertint que la dita finestra ha de obrir biaix contra biaix pera que el mig de ella vinga a estar en lo mig del former del dit Cor pera millor adorno y hermosura perque de otro modo quedara molt imperfet, y el ferla de viaix contra viaix com se ha dit, es per raho del campanar y (...) donar lloch aquell a posar la dita finestra paralela $o$ esquadra de dites parets y deste modo bes dona llum y se acudís al art, fent arch de algeps y rachola de dos pams de gruixa y de tota la amplaria de dita paret, forticant y davant tot lo desusdit molt be de algeps y rachola.

XV Item que aixi en la dita finestra com en tots los dits forners y finestres que y haura ubertes que son tres sens la desusdita se ha de correr uns alquitraus tota la rededor de bona moldura y fer los adornatos com se veu en lo perfil advertint que en la dita finestra del former de cor seria de aumentar a proporció del diámetro de aquell donant y fent el mateix adorno en dita 
finestra que en las demes (...) rachola de dos pams de duella y de tota la gruixa de la paret en les finestres que quedaran hubertes no es (...) en la capella de Sent Andreu la paret y archs que sera menester y que afonta la dita.. pera acomodar el retaule de Sent Andreu co es la tapia que quedara a la part de fora del carrer si quedas rebentada al temps de rompre la dita tapia.

XVI Item que el dit mestre tinga la obligació de fer y executar en tots los archs de la nau de lavlglesia, co es en cascu de aquells set florons de bona talla y proporció y en los diagonals de ditesvboltes nou, fortificant y asegurant molt be tots aquells ben apulits y perficionats en los dosvformers, com es lo del cap de altar y el del cor aquella part y porcio que el tocara fent faixes devalgeps prim y delluits de alabastre dobles que queden ben netes y tallades y si acas pareguesvpera que sia convenient el examplar els pilastrons o muros a la meitat de la amplaria de lavpilastra y pasaro enjasenar resalts en aquells restituintlo en damunt de la cornisa paralelo en losvformers en florons (...)

XVII Item que el dit mestre tinga obligació de picar totes les boltes y parets de la Iglesia ben picades y aixi mateix llevar totes les corfes de algeps que haura quebrantades y cascarrades aixi de les boltes y parets y en tot lo demes que sera menester y después de (...) ben picat se agranara pera que salte be la pols y se arruixara molt en aigua y es llafardara de algeps lo que será menester y lo restant reparat de paleta que quede ben igual posant (...) les insignies de les armes (...) en la forma per ben ser la introducció del rey don Jaume de Aragó.

XVIII Item que dit mestre tinga obligació (...) dos de bolta consentida y de mateixa calitat de formarla, restituir y fortificar del millor modo y forma que sera menester deixantho tot ben reparat com esta dit después ben pasat de ganivet de raure que quede ben igual, trent mestres en tots los puestos que seran menester, com son en los formers paret de la Iglesia y donar de alabastre a tota la dita nau de la lglesia parets, formers y capelles que quede ben bruñit y llavat y ben igual tallant faixes en tots los puestos com ya esta dit que seran menester y les dites faixes han de ser belles com també fer bon los peus y (... ) aixi per dins com per fora de la dita Iglesia Campanar y final (...) asta cantitat de 150 lliures y en cas de que excedisca de dita cantitat la hacha dese fer la dita Vila valuador la dita obra (...) per lo expert que nomenara la dita Vila.

XIX Item que le mestre tinga obligació de fer y perficionar la cornisa, alquitrau, fris, pilastres, bases, ósculos, chambes achasenats capelles y finalment tot quant sera menester així en la dita Iglesia com en tot lo restant de aquella de bona estampa y del modo y forma que es veu en lo perfil que quede tot a bon gust y costum de bon oficial no escusant el fer davall del Cor una bolta de cañes en los mateixos partes y condicions circunstancies y ordinacions que esta dispot en lo capitol que parla de la Sacristía paimentant lo dit Cor 
de taulells grans y bon morter que quede ben net y junt con su cortapisa alrededor y mudar les teules (...)

XX Item que en lo arch (...) del dit Cor als arrancaments de aquell se hacha de paredar uns tres o quatre partes per a machor fortalea y hermosura de aquell $y$ el dit paredat ha de ser en les mateixes circunstancies y ordinacions que esta dit en les pilastres y pilastrons de la Nau de la Iglesia fent ósculos y bases, capelles, imposta, segons en aquell se requirira suavisant la montea per raho dels sis o set pams que estreny en arch de punt de arch de cerdell, posant en aquell set florons de relieve de bona proporció, y apañar y perficionar tot lo que sera menester en lo caragol de dit Cor com també el perficionarles dos capelletes que están davall lo Cor, que estiguen uniformes les dos rompent $y$ fortificant $y$ asegurant tot lo que en aquelles sera menester y correr unes capitelades alrededor en ses impostes per la part de fora, reparant aquelles de algeps primerament y después de alabastre que quede ben bruñit y llavat en les faixes del modo que está dit en los capitols antecedents y els crehuers de dites capelles, co es del Santo Christ y les Animes es picaran y es donaran de algeps y pincell de bon color y (...) faixes de alabastre tallat y paymentar dites capelletes de tauells grans y aixi mateix acomodar el Sent Jaume y la pila dels batismes en lo puesto a hon les pareixera als vehins de dita Vila, $o$ ellets de aquella que pera effecte de dita obra, y hermosura de dita Iglesia sean menester $y$ davant les grades que y ha posades en dita pila $o$ al peu de aquella, y acomodarles del modo y forma que el dits ellets ordenayran y asentar la varana del Cor en forma de sisavo com se veu en la planta y fer aquella de costes de dit mestre en unes pilastres de fusta en sos capitallets $y$ vases y una corniseta per damunt tot de fusta, y si volgueren (...) de ferro tajen de correr a conte de la Vila y aixi mateix tinga obligació de nichar o abaixar les sepultures y sols de les capelles que seran menester al nivell del sol de la Iglesia menys el sol de la Sacristía que ha de quedar a nivell de les dos grades del Presbyteri y paymentar la Iglesia de taulells grans y acartabó.

XXI Item que el dit mestre tinga obligació de retirar la porta principal de dita Iglesia que esta al carrer machor de la present Vila, lo qual ha de estar retirada a la part y deves lo Cor de aquella aixi que retorantla a la part de sus dita selle dona mes hermosura a la demostració de la Capella y retaule del Glorios Sent Andreu, com també per lo que ocupen los branchs y angustien lo Presbyteri, y ser puesto mes propi pera el pulpit y dar mes desaogo y amplitut a les grades que puchen al Altar Machor, y la dita porta se ha de obrir dela mateixa amplaria y alsada que hui es troba aprofitant les pedres de la Portalada que alli y ha y posantles que faltaran o rompran al temps de desferla en son llindar de pedra (...)

XXII Item (....) se ha de fortificar y asegurar del millor modo y forma y materials que mes al intent sera pera fortalea y permanencia de dita porta y arch de la gruixa de tota la dita paret fent les branques de algeps y racholes que seran 
menester pera carregar y asegurar lo dit arch sobre dites branques y aixi el de pedra en lo restant que se ha de fer de rachola ben travat lo hu en lo altre donant biaxos y cap y alsat que se estilen en semblats portes y el puesto donara lloch asentant aixi dita porta com totes les demes portes y finestres que seran menester aixi en la dita Iglesia Sacristía, archiu y finalment en tots los demes puestos de la Iglesia que se offerian (...) fent la dita porta quadrada per la part de fora de pedra que de alli eixira.

XXIII Item que en la capella de la Mare de Deu del Roser tinga obligació el dit Mestre de posar la boquilla a aquella enquant a la amplaria y la alsada colateral y correspondent a les demes y en cas que el arch que está a la part de dins de dita capella que te set pams de gruixa no donas lloch a (...) que dempostra en lo perfil haga de fer y tindra obligació el dit mestre de fer de son arch abosinat, advertint que si es fa el arch abosinat en esta dita Capella se ha de fer lo mateix en totes les restants buscant y guardant el ordre del nivell del Alquitrau y perficionar y executar la dita Capella per la part de dins com está en la planta y perfil afondant los fonaments tot lo que sera menester, y omplir aquells de pedra y morter blanch en lo cuydado que tanque mig pam de rabasa tot alrededor ademes de lo que es veu en la planta pera machor fortalea de aquelles, no escusant el eixecutar tot quant se veu en dit perfil, planta de bona arquitectura y talla, adornatos alquitrau, fris y cornisa y finalment quant sia menester en dita Capella que quede segons bones regles de alquitectura no escusant el fer la teulada paimentada (...) posar la cornisa Al quadro y del arch boquilles en quatre (...) de bona proporció en portes $y$ adornos de talla, con los puestos que seran menester y en cada boquilla una repisa de bona moldura y talla fent los quatre arcs carcahols y tot lo demes en la fortalea que sera menester de algeps y rachola. Y fer una micha taroncha obrada de rachola y algeps doble corent un serquillo alrededor de bona moldura. Y vestir aquell de talla y aixi mateix se faran quatre adornatos en los quatre forners y els huit creuers de la micha taroncha tot de bona alquitectura y talla advertint que la dita micha taroncha a de tindre tres pams de rebanch, ab una finestra en lo former pera donar llum a dita capella ab la reixa de ferro.

XXIV Item que el dit mestre tinga obligació de fer un adornato en dos pilatretes y un frontispici en una tarcheta en lo mig de bona talla en lo nicho de la Gloriosa Senta Barbara en la imposta ala part de fora bases daticurbes, y que el dit adornato sia de ordre composta en son alquitrau, fris y cornisa $y$ tot lo demes que es requereix segons bones regles de architectura posant uns relampaguets de talla en los puestos que mes convinga (...) y moldures ben llavades y florons donats de alabastre.

XXV Item que el dit mestre tenga obligacio de fer un adornato en los mateixos pactes condicios, circunstancies y ordenanses que el de Senta Barbera en la capella que esta davall lo Cor colateral al caragol que puchen al Cor so 
advocació de Senta María Magdalena.

XXVI Item que el dit mestre tinga la obligació de donar primer de algeps y después de alabastre en tot lo Sagrari fent un tarcho en lo mig ab les insignies del Santissim Sacrament de bon relieve guardant $y$ conservant totes les moldures que en dit Sagrari y ha que quede el dit alabastre ben bruñit y llavat en faixes dobles en los puestos que sia menester.

XXVII Item que dit mestre tinga obligació aprofitantse de tota la (...) que y ha en lo Presbiteryde fer les grades de pedra y posar la que faltava en la forma com es cada grada huits dits de alsada y en cas de ducten menys que mes, pam y mig de amplaria en un filet y bosell de bona planta (...) per a puchar donde el nivell del pulpit de la Iglesia hasta puchar al del Altar de forma que la última grada y regla de dalt ha de servir de tarima y ha de ser tot de pedra $y$ que tenga de ample sis pams $y$ vint de llarch tot lo sobredit ha de estar ben treballat com ya esta dit y la forma o planta que han de fer dites grades ha de ser a modo de sisavo aixi per la machor hermosura com també pera guañar amplaria y ensanchar el primer reglo que está puchant sobre les dos primeres grades que també han de ser de pedra conforme suon capitulades, ben treballades y juntades com totes les demes que esta dit asentant $y$ fortificant tot lo sobredit ben anivell junt y en morter blanch y paymentant lo primer rego de sembradillo y taulells grans.

XXVIII Item que el dit mestre tinga obligació en tot lo restant de la lglesia, capelles, Sacristía, Cor y demes cosses si foren menester dins la dita Iglesia y capelles paymentar de taulells grans com ya está dit en cortapises alrededor y a cartavo ben anivellat y juntats el taulells uns en altres y de morter blanch (...) per bon oficial y fer guardapolvos que quedaran entre la cortapisa y parets pera machor hermosura y fortificació de aquells y els dits guardapolvos los hacha de fer hasta la altura o nivell del Limo escapo (imoscapo) de la basa se ha de fer de algeps que quede de ben bruñit y llavat lo dit guardapolvo hacha de quedar ben retundit y igualat en la linea o nivell del alabastre que es tallara pera machor fortificació y hermosura de aquell, no escusant fer totes les meses de altars que seran menester com es us y costum el ferles, com també tarimes de taulells y manperlans de fusta en un bocell y filet com se acostumen y grades (...) en sos manperlans també de fusta com está dit en la demes (...)

XXIX Item que si per descuyt, o omissió sia el que vullga se hagués deixat alguna cosa sens capitular y fos menester alguns trosos de paret o peus en tota la dita obra que esta capitulada tinga lo dit mestre de ferho pera machor fortalea y hermosura en tot y per tot com si estigues capitulat ningún capitol, y en cas de interpretarlo se hatja de entendre a favor della obra, com també se adverteix que no puga fer millota ninguna perque en cas de ferla no la y pagaran menys que no sia comunicada en los vehins de dita Vila o ellets de 
aquella, y que primer sia consertada de entrambos parts y per la persona 0 persones que dita Vila nomenara per sa part y el mestre per la sehua y en cas de no concordar hatja de nominar Aixa pera lo desusdit com per a totes les demes visures que es faran un terser de sa part la Vila, y que hatjen de estar tenguts a lo que el terser dira sens que en aso Puga intervenir termens de Justicia y que les visures hatjen de ser tantes guantes ben vistes li serant a la Vila o elets pera la dita obra (...).

XXX Item si per causa del mestre, officials y manobres y aprenents de aquell rompesen qualsevull cosa del retaule o retaules y les demes coses que y a dins de dita Iglesia, expeto lo orge, tinga obligació de apañarles o pagarles (...).

XXXI Item que el dit mestre tinga obligació de posar tota la fusta que sera menester pera andamis, cordes, cabazos grans y chiquets, venelles, cordes de talla, corrioles, pasteres, barrils, claus de encabironar y empaliar pera les boltes de cañes y cañes, bigues pera les cubertes de la Sacristía y arxiu, quartons pera les boltes de cañes, portes, finestres y reixes com ya está dit, alabastre, pastar y amerar la cals, garbellar y amenar la terra que sera menester, teula, la que faltara pera tot lo desus dit, arena pera pastar la cals, (...) y portarse el aigua al peu de la obra y pucharsela ell mateix ahon lo haura menester, posar draps pera llabar el alabastre y ferse totes les (...) per que seran menester pera eixecutar en bona la arquitectura y moldures de aquella (...) com també tota la ferramenta que haura menester (...) y pagar actes y concordies de offici.

(...).

XXXII Item que dit mestre tinga obligació de pagar a ses costes el algeps, rachola, pedra picada y mampostería pera lo demes que sera menester y fonaments; cals, arena, racholetes de Manises, teula com ya está dit tot lo sobredit ho hacha de arrancar y pagar a ses costes y portecharlo tot a ses costes com també quatre filats de ferro que se han de fer pera les quatre finestres de la lglesia.

(...)

XXXIV Item que tinga la obligació el mestre de donar la obra acabada dins de un any contant desde el día que se li dona la primera paga y el modo de les pagues sia de fer en tres yguals parts la una habilitades les fiances, la segona a la mitad y la tercera acabada y visurada y donada per bona la dita obra, y en cas de no acabarla puga la dita Vila y ellets posar gent a ses costes y de ses fianses que les ha de donar el dit mestre a contento de la Vila y sos ellets y renovar eo millorar aquelles sempre que ne vistes lo sera y la dita obra se ha de comensar dins quinse diez contant del día que es lliurara.

XXXV Item que tinga obligació el dit mestre de apañar hasta el piso de dites campanes y aixi mateix ha de reparar y fortificar (...) los archs de les (...) y on no y ha campanes restituir aquelles a son primer fer aixi hon sera menester 
pedra hatja de posar pedra y les domes dintes escarcatarles y mamantonarles de algeps y morter en bones falques que queden ben apretades y asegurats, no escusant fer la mateixa diligencia en les boltes del dit campanar y parets escarcatant y fortificant tot lo que sera menester en aquell aixi per dins del sambori com per fora y posar la campaneta chiqueta hon dira la Vila eo els ellets, y del modo que voldran aquells y apañar tot lo que sera menester en la teulada o teulades y carrerons de dita Iglesia. Y aixi mateix tinga la obligació el dit mestre de tapar tots los forats que y haura per fora de la Iglesia y Campanar, reparant lo dit campanar y Iglesia per fora de morter ben bruñit...que quede tot a us y costum de bon oficial no excusant lo mateix en lo Sagrari per la part de fora y posar una vidriera y filat de ferro en la finestra de dit Sagrari advertint que tota la part que correspon a la part de fora de la dita Iglesia aixi com diu lo XXXVI capitol que hi ha de esta es fasa de algeps y cals (...)

XXXVI Item que la dita Vila tinga obligació de donar al mestre que fara la obra tot lo ferro que yha dins dita Yglesia (...) com també tot lo genero de pedra que estrobara en la dita Iglesia y pagar cantitat en que es lliurara la dita obra en tres igual pagues: la primera después de donades les fianses, la segona a la mitad de la obra; y la tercera acabada, visurada y donada per bona la dita obra.

XXXVII Item que el dit mestre que fara dita obra se hacha de aprofitar de tot lo pertret que eixirá de dita obra com es pedra, rachola, reble, miches, fusta, portes, finestres, tot lo ferro que eixira, menys la reixa de la capella de la Mare de Deu del Roser que aquella ha de servir en la capella de la Comunió, ni els demes ferros com son creus, candeleros y els demes que será portátil, ni els basos de dita iglesia ni el ferro que está a les espatlles de les cadires del presbiterio o altar machor ni la porta que al present se troba en la Sacristía.

XXXVIII Item que lo mestre que fara dita obra tinga obligació de pendre tot lo algeps que haura de menester per a dita obra del algepsar de Antoni Vidal situat en lo terme de Benaguasil segons los pactes expresats en lo acte de obligació fermat per dit Vidal rebut per lo notari infraiscrit en - dels corrent pagant per cascun cafis cavaller quatre sous y dos dines portechantlo lo dit mestre a ses costes des de el algepsar fins lo peu de la obra (...) en la segona paga que li abonara el dit mestre sa hatja de retirar de aquella tot lo que haura important lo algeps gastat fins a entonces y lo mateix se obrera en la tercera paga, y pera que no y hatja duote en lo numero dels cafisos se hajen de observar les talles que en dit acte se expresen pagant la Parroquia al dit Mestre les apoques del Algepser.

Que lo dit Antonio Vidal se obliga a la Parroquia de la Pobla a donar tot lo algeps que será menester pera la fabrica de la Iglesia Parroquial de dita Vila ben molt garbellat y rebedor a contento del Mestre que fara la dita obra 
posat dins lo algepsar y que de alli lo hatja de traure lo Mestre de la obra a ses costes, sent lo Cafis Cavaller, so es dotze cabasos, segons costum en les Viles de Liria y Benaguasil (...) donant lo dit Vidat a tota hora y quant lo Mestre el demane(...).

XXXIX Item que dita Parroquia puga juntar totes les visures (...) per la relació dels experts que los materials san bons y que la obra es treballa be en tal cas lo gasto de la dita visura vinga en carrech de la dita Parroquia (...)

$X L$ Item per quant les fiances se contracte pera pagar lo jutgat deuen ser convengudes y que (...) qualsevol condemnacio que obtenga la dita parroquia contradit Mestre (...) es puga ejecutar contra ses fians (...)

$X L I$ Item que lo dit mestre que fara dita obra tinga obligació de prendre tota la cals que haura de menester pera dita obra del forn que fara Lorens Cercos Ilaurador de la Vila de Betera, lo qual está obligat lo dit Cercos a fabricar en lo term de la pnt Vila (...) y que la dita parroquia es tinga obligada a pagar dita cals al dit Lorena Cercos de fornada que sempre seran vint (...) y quatre cafisos (...) sia de la primera paga y lo mateix se observa en totes les dites pagues que se le hy han de donar al dit mestre cobrant les apoques (...)"

\section{Segundos Capítols}

"La Vila de la Pobla de Vallbona haventse determinar fer la Iglesia Parroquial de dita Vila con reparo com es renovarla y per a daso haver fer matraca y capitulacions y Subasta la obra segons aquella trasa y capitols (...) determina el nomenar experts per a que veren regonegueren aquells ductes que se offerien per a daço fonch nomenats per part de dita Vila y elets de aquella a Gil Torralba mestre de obres y per part dels mestres arrendadors de la dita obra a Juan Perez tambe mestre de obres y haventse (...) reparar la dita Iglesia (...) quedava en consideracio dels dits experts eleixir (...) reparos que se encontrava en la dita obra ...se passa a Capitular lo que es seguéis sens derogacio de les primeres capitulacions enquesta lliurada la dita obra sols anses millorar (...) la obra mes considerant en alguns dubtes y dificultats (...)

Prim. Ha estat determinat que la porta que se havia de deixar a la part de (...) carrer principal de dita Vila esta se hacha de tapar y condenar aquella de tota la gruixa de la paret ab advertencia que se ha de deixar al temps de condenar aquella lloch y fer lo caragol y escala per a muntar al Pulpit. (...)

Item que el Altar machor se ha de lliurar del puesto hon esta desfer lo cor y desfer lo hu y lo altre lo que huy es capo de altar y sagrari y fer en les parets de aquell tres portes co es sita zona de aquelles tinga noranta? pams de amplaria (...) Arch de Rachola y nich de Duella reparant les branques abaixantse el sol de aquell tot allo que sia menester deixant tot ben acabat $y$ 
deixant en cada una porta un escalo de un pam de alsada en una Rachola de Rassell si hagues de Pedra.

Item que en la Pared de la testera de la Iglesia se ha de romper y obrir una Portada tota la amplaria y alsada que manen los antecedents capitols del lliurament de la obra en tot y per tot fera son arch segons dibuixen los antecedents capitols (...) Les portes que en aquells tenen obligacio y ferse son Rassell de Pedra y aumentant el Portich de fora dels mateixos taulells y materials que la lglesia (...) deixantlo tot en la deguda perfecció.

Item que hon huy son els peus de la Iglesia se ha de acomodar y fer lo cap de altar en esta forma: Desfer les dos Capelles que huy estroban en lo dit cap de altar que es present fer y se advertís que derrocades aquelles se han de macizar les dos Boques de aquelles de tota la gruixa de aquella ab advertencia que al temps de paredarles se ha de deixar una Porta ...per dar entrada al Sagrari que es present fer branques, Arch y tot lo que en aquella se oferisca per a seguritat de dita Paret y entrada del Sagrari falcant aquelles de algeps y deixantles ben aseguradse y en lo mig rompre y obrir una finestra per hon se ha de acomodar hon adecentar el Sagrari del Sacramento que del Altar machor al Sagrari es dona la ma deixant branques Arch y dita Paret tot asegurat y del ample y alt que sia menester y fer esta diligencia se han de formar les grades y presbiteri (...) en lo modo y forma que estroba capitulat en los Capitols y a fer de pino y lliurament asentant el Retaule machor y els Retaules que es troben huy al costat del Retaule machor hon determinasen los elets aixi lo hu con lo altre tinguen obligació els mestres que fan dita obra de acomodarlos y asentarlos y fer les Peanes que pera daquells se offereixen asegurant aquells en fer parets y se advertís que si en aquells al temps de lliurarlos de son puesto o al temps de asentarlos estos rebesen qualsevol dany tinguen los mestres la obligació de pagarlos a fer despeses y de deixarlos ab tota perfecció.

Item que se ha de fer lo Sagrari en esta forma hon es la paret de la trada de la Iglesia y en la part del Carrer ha de cerrar sens encontrar la muralla de aquella amplaria que sia menester aixi en fer fonament que sia menester $y$ pera esta diligencia se ha de proseguir la pared de la Muralla a la alsada que sia menester y a la tirada y plom de aquella amplaria que mes convinga per a fer lo dit Sagrari.

Item que pera esta diligencia se ha de formar la bolta del Sagrari es esta forma com es fer una bolta de algep y en lo mig lo quadro se ha de fer una bolta igual ferse son dibuixos y pilatras segons bona Regla de Arquitectura en carrero naus y dalt aixi la bolta per Igual com la de algep donantly la Regla del terc fent los carrerons travantlos (...) y deixantsos forats per a que correga el ayre (...) y dos fileres y la Barda encabirotanse de Rachola fent la teulada paimentada ben bruinida y pera filada enbargant be les teules fent ben los cavellons y entrants (...) y le advertís que la pared del cap de altar que huy 
está per la part que mira a Benaguasil (...) se ha de socavar y fer un peu y fer de tot lo ample y alt y fondo que sia menester del mateix material que lo restant de dita obra tapantse la finestra que ya en dita pared de tota la gruixa de aquella; Aixi mateix se adverteix que al dit Sagrari se ly ha de dar llum y en lo puesto que mes convinga fent Arch asentar Reixes y Vidrieres conforme está en los Capitols (...)

Item que per la part de dins se ha de perfeccionar el dit Sagrari en esta forma com es tirar al aderredor una cornisa y perficionar tots los archs y sensit de aquells en floronantlos en (...) florons en cada hu de aquells de bona talla y en la Bolta per lgual al igual de los formers tirar un serquillo de moldura separant huit creuers (...) que vinguen a encontrarse en hu que se ha de fer en lo mig que tinga de diámetro sis pams y en los dits creuers? Se han de sembrar diferents florons (...) asentat la clau quedara la dita Vila y en los quatre triangulos a carcañols contancho de bona talla en les insignies del Sacrament en lo mig, tirant les quatre impostes arrededors de dits Archs y en los quatre formers fer quatre sentits de finestres en cada hu de aquells tirar son Alquitrau en son parament (...)

En lo Arch com es lo frontó baixantse les pilastres fent friso, alquitrau, capitells y basas del orde composta separant dit lo restant de aquell de Algeps y después de Alabastre y se advertís que dita Vila volgueria chaparlo de Rachotetes ho hacha de pagar la dita Vila (...) y se advertís que el Payment se ha de fer de sembradillo y este tinguen obligació de fer els mestres a ses costes deixantlo tot ben acabat.

Item que el Piso del cap de altar se ha de pavimentar de taulelles grans tot a nivell del sol del Sagrari y se advertís que la terra que yxira de tota la obra aixi de llevar com de posar hacha de correr per conte dels mestres que fan la obra.

Item se advertíx que la Sacristía se ha de fer al costat del cap de Altar y fer en esta forma com es dons la mateixa tirada de la Capilla de la Comunió y laltra de la paret del cap de Altar que al present se ha de fer que estiguen atirada ambas a dos fent lo fonament que sia menester segons está en lo restant de dises parets de la Iglesia (...) fent les parets de racholes y de tres pams y mig de amplaria cada una de aquelles muntantles esta la alzada de dihuit a vint pams formant y fent una Bolta de pastera closa y doblada de algeps y racholar encarreronant aquella a la Regla del terç travant los carrerons de uns a altres deixant los forats per a que correguen los ayres a la part de fora dels parets trahent les aristes als carrerons encabironantse racholas y (...) de algeps fent la teulada paimentada trahens dos bandes fent con los cavallons que sien menester enbagant be les teules y deixantla ben perfilada rebosant tota la paret per fora y (...) tirant la cornisa al arrededor separant dita la dita Sacristía de Algeps y Alabastre posant son floró en lo mig de bona talla paimentant 
aquella de taulells grans deixant una reixa, finestra y porta de arquillo com esta capitulada y sia la Vila en volgues altra el hacha de pagar aquella de tot cost.

Item que en la paret del Cap de altar en la porta que correspon al Sagrari esta se ha de obrir pera dar entrada al campanar fent a la part del fosar una paret de rachola y micha de amplaria a la alçada que sia menester co es a cartabó obrint una porta en la paret del Campanar asegurant ambes dos parets en dos Archs de Rachola y micha de Huella y de tota la amplaria de la pared cobrint el dit pasadis en una bolteta del modo que es puga acomodar doblant aquella y encarreronantla be en ses bandes en la teulada paymentada com les restants de dita obra.

Item que des de el nivell del cor que hay es troba asta el sol de la Iglesia se ha de rrocar el caragol y (...) fer y acomodar altre en lo buit del campanar de rachola y algeps del millor modo que es puga per a que comodament es puga muntar y vaixar de la escala y campanar que hui ia en dita Iglesia separant aquell y deixantlo tot ben acabat y aixi mateix pimentar tot lo sol de terra.

Item que el dit mestre (...) en obligació de llevar lo orgue y asentar (...) la caixa -y flautes- de aquell en lo puesto que mes convinga (...)

Item que en la Nau (...) de la Iglesia aixi com es la trasa pasa la cornisa desta ha de resaltar y correr en la endererera de les pilastres, pilastrons y morir contra les parets y la moldura, modillones de damunt la corona han de cortar tot a nivell minorant el buelo del albolada de la corona y que los mestres tinguen obligació de acomodar y fer hornat que dispondra Gil Torralba y Juan Perez co es per a la definició del former y frontó en tot y part sens eixir de la voluntat de aquells ab advertenia que la Capella se han de expirar y muntar aesta la alsada de lo que dona lloch el Alquitrau y fris y per a la imposta se hacha de aprofitar y servir de la gruixada de davall la forma y no de altra manera.

Item que les boquilles de totes les capelles hagen de quedar de onze pams de diámetro conforme la que esta plantechada quis la de la Capella de la Comunió en ses pilastres y conforme es veu en lo perfil.

Item que els dos mestres tinguen obligació de eixamplar la Paret de la Capella de la Comunió y la Sacristía vella a la tirada de la testera de la Capella de la Comunió, co es per la part de fora de la mateixa amplaria que aquella (...)

Item que en lo puesto hon mes convinga se hachen de deixar y colocar dos o tres Almaris pera colocar la plata o allo de que necesitara dita Iglesia afensant les portes y almaris que ya es la Sacristía vella y bien es vulguera mes els 
hacha de fer de fusta la dita Vila a ses costes.

Item que totes les Capelles y estreps de aquelles se han de obrir unes portetes fent dos Archs a daquelles de algeps y racholles y de dos pams de huella que quede tot ben (...) segur separant totes les branques y paymentant lo sol de aquelles del mateix modo que les capelles.

Item que en los peus de la Iglesia en la paret de aquella ha de formar la cornisa y fer un ornato en lo frontó de bona Arquitectura obrint una finestra en lo mig de aquella y (...) en son Arch (...) baixant una micha Pilastra per lo Raco fently baix son anbasament con lo restant de dita obra en capitell llano y resaltant aquesta en la cornisa enmodillonant la distancia que y a de una paret a la altra.

Item que se ha de fer son cor co es posant y fent un Arch hon esta en lo altar part o posant una casería falsa se haura per baix en un Arch de Cor del de cloenda deixantlo tot ben asegurat fent una bolta posant les bigues quo y als lo altre Cor encabironant de cabirons y racholes paimentant aquell y posar la barana com esta capitulat en los altres capitols repasant per lo baix de algeps y alabastre (...)

Al dit cor se ha de fer una escala en lo puesto que millor se ponga acomodar deixantla acabada en tota perfecció.

Item que el sol de la Iglesia en lo puesto se ha de lluir el Presbiteri se ha de paimentar com en lo restant de dita Iglesia (...)

Item la Sepultura que huy es troba en lo presbiteri esta de hy ha de acomodar la boca en la endresera que huy cau aquella (...)

Item que se hauhen de tapar los forats que huy haura en la paret de hon estava el Retaule machor y els demes ansigaments y en los demes entremigs dels Archs se hachen de fer correspondencia de capelles en tot aquells conforme está capitulat en los capitols que ya formats apart.

Item que tota la dita obra (...) segons hus y costum de bons Artífices y en los Pilastrons que havia de baixar a Plom esta se ha de disimular co es fer un carteló en lo fris de la cornisa al capitel y en esta forma queda desimulada y corregít (...)

Item que la present obra se ha de pagar en quatre iguals pagos que corresponen cascuna a 112 Il.10s. en lo temps de 18 mesos que son aquells que estan designats a fer $y$ acabar dita obra segon los primers y segons capitols de la concordia.

Rubricado: Juan Perez y Gil Torralba obrers de Vila de Valencia" 
(---) julio 1700

"Matheu Segura Justicia, Batiste Desco, Jurat mayor, Juan Aler jurat menor, Hypolit March Sindich, Romualdo Sannia, Batiste Prez, Vicent Ort, Domingo Desco, Juan Torres, Lluys Estarlich, Vicent Sirera, Pere Juan López, Domingo Polo, Sebastia Ruix, Josph Vilarroja, Joseph Monfort, Juan Perez, Marco Hernández, Christofol Marti, Francisco Bono, Miguel Rabadán, Marco Samora, Esteve Galves, Estevan Rillo, Joseph Herrero, Pere Camps, Ildefonso Aragonés, Roche Lozano, Joseph de la Raga, Juan Casi, Jaume Llomet, Gerony Bondia, Francisco Rabadán, Batiste Vedes, Lluys Gomis, Batiste Julibert, Juan López menor, Pere Gómez, Bernardo Galves, Vicent Rius, Joseph Xeres, Juan Galves, Joseph Roda, Juan Romero junts y congregats per a la pnt hora y día de huy en lo porche de la present Vila hon se solen y acostumen juntar presehint connocacio feta per Pere Soriano ministre ab Jurament prestat per aquell en may poder del Notari a Nostre Señor Deu, Sinc proposat per lo Jurat mayor quel Llibre del Cequiaje estava curt y que determinase: si se havia de añadir y aixi mateix que se havia empeñat lo Prior de Portazeli per a que el Doctor Thomas Lleonart es tornase a anomenar Advocat de la present Villa y assi mateix que els obrers de la vila demanen al forn del Racholar de la present vila per a fer dos o tres fornades de Rachola y taulell pera la Iglesia de la present.

Vila y obra que escomensa en aquella y ohides dites proposicions mencionades per lo dit Jurat mayor determinen unánimes y concordes que del mateix modo y manera que en lo any pasat se determina el preu del cequiaje que hauria estar ara de Deu sous y sis diners pague en lo any corrent per Cafisada per rahodel cequiaje per quans en lo corrent any se havien freix cuts los gastos en los ompiments de les Cequies (...)

Item determinar que sel y torne la resposta al obrer de vila que es fassa fer les tres fornades de rachola y taulell ab tal que aquells o als tres se obliguen proseguir en dit forn el fer la obra que ben vist los fera donant la obra que eixira de dit forn la hachent de donar als mateixos preus que aquells la han feta per a la Yglesia de la pnt Vila y aço hacha de ser per lo temps de quatre anys y ab la obligació de conservar dit forn en dit temps acostes dels Racholers (...)".

30.10 .1700

"Ines Meseguer doncella de la Pobla" en lo llit de greu malaltia corporal (...) executor Vicent Sebastián prevere Dotor en Sagrada Teología Retor actual de la Parroquial Iglesia de la Vila (...) deixch sepultura al mes cos fahedora en la Yglesia Parroquial de la pnt Vila de la Pobla de Vallbona en la Capella de Nuestra Señora del Roser construida dins dita Iglesia (...)" 


\section{ARCHIVO DEL REINO DE VALENCIA}

Protocols, 1.333, Jaime Llorens

\subsubsection{0, s/f}

Obra de l'església en aquests anys

Vicent Meseguer, doctor en Medicina, veí de la Pobla, com a procurador de Josep Munyós, Vicent Garcia, Jacint Vilar i Ignasi Llopis, obrers de vila de València, "Sia a tots cossa manifesta com yo Vicent Meseguer Dotor en Medicina y Habitador en la pnt Vila de la Pobla de Vallbona en mon de Prior de Juseph Muños, Vicent Gacía, Jasinto Vilar, Ignacio Llopis obrers de Vila della ciutat de Valencia es (...) dels poders ab actes rebuts per Franco Causes nott en trenta hu de novembre del corrent any en dits noms de mon bon grat y certa sciencia per thenor de la present pública carta, en dits noms, me obligue $y$ em constituixch principal obligat, juntament ab los dits mos principals, per sempre y quant Juseph Pinyó, obrer de villa, no cumplirà la obra de la yglésia de la present villa, que ha oferit fer segons los capítols y planta rebuts per lo notari infrascrit en cert chalendari, per a el qual efecte, en dits noms respectivament, me obligue a que, sempre y quant lo dit Pinyó no concluix la obra de dita yglésia, la faré yo en dits noms y pagaré les bestretes que haurà rebut lo dit Pinyó, danys y menyscaptes que manifestaran los elets de dita parròquia, y pagarà així mateix tot lo gasto que se haurà contragut, així en visures y altre género de treballs y actes que se hauran rebut, y per ço obligue mea persona y béns en ànima de mos principals".

\subsubsection{1, s/f}

Es degueren fer obres importants en l'església de la Pobla, ja que Joan Vinyes i Josep Pinyó, obrers de vila de València, confessen haver rebut del pàrroc, Vicent Sebastià, 64 L a compte d'un deute mayor de 299 L, 13 \& i 4 d, "ço es catorze lliures tretze sous a cumpliment de la primera paga de la obra que fabricam en dita yglésia, segons capítols, i los restants quaranta-nou lliures, sis sous y huit diners a conte de la segona paga que nosaltres havem de persebre".

\subsubsection{1, s/f}

Joan Vines i Josep Pino, "villae operarii civitatis Valencie", confessen haver rebut del rector de la parròquia de la Pobla, Vicent Sebastià, 61 lliures i 15 sous, "sexaginta unam Ilibras y quindecim solidos pecunia Valentiae y són a conte y en part de paga de la obra que nosaltres estam fabricant en la iglésia de la dita y present villa, la qual cantitat hem rebut en diners com en forment $(\ldots)^{\prime \prime}$ 
Josep Pino, obrer de vila, etc., dóna notícia que l'obra de l'església es va contractar l'any 1700, per preu de 899 lliures, a ell i a Joan Vinyes, segons sembla davant del mateix notari, però que en 16 de novembre d'aquell any els elets els van afegir noves obres "per a sa maior perfecció", amb una altra escriptura amb pactes i condicions, per preu de 450 lliures, i en aquesta escriptura Pino i Vinyes diuen que van acordar sortejar a qui li tocava aquesta nova obra, acordant que aquell que se la quedara pagaria a l'altre 50 lliures, i en el sorteig va eixir Piñó.

"Ego Joseph Piñó Villae operarii Valentiae habitator en la pnti Villa Popula Vallisbona (...)

Attenent y considerant que ab acte rebut per lo notari infraiscrit en primer de juny del any propassat mil setcents, los elets de la parroquia de la present Villa lliurar la obra fahedora en la Iglesia de dita Villa ab los capitols y pactes en dit acte expresat a mi dit Piñó y Joan Viñes també obrer de Vila de dita Ciutat de Valencia per preu de huycents noranta nou lliures pera securitat del tal contracte donaren diferents fiances. Attes etiam, que ab altre acte per lo notari infaiscrit en setze de novembre dit any lo elets resolgueren y lliurarent altres obres fahedores en dita Iglesia que conduixen pera sa mayor perfecció a nosaltres dit Piñó y Joan Viñes també ab diferents capitols y pactes per preu de quatresentes y sinquanta lliures y donaren aixi mateix fianses pera son cumpliment en seguida de lo qual habent tengut diferents debats yo dit Piñó y el referit Juan Viñes per obrar, los quals resolgueren de paraula traure a sort qual de nosaltres dos se ha de quedar en la execusió de dites obres prometentnos... que aquel per qui quedaran dites obres hages de donar al altre la cantitat de sinquanta lliures en esta forma, vint y cinch a cumplimt $y$ les altres vint $y$ cinch lliures per tot lo mes de agost primer vinent $y$ havent presenthit redolints ab concurs dels dos segons lo referit concerniente nosaltres es fer la extrasió per un Infant y quedaren les obres de dita Iglesia per mi dit Piñó, per lo que novament ab acte per lo dit y infaiscrit notari en dotze dels corrents dony fiador idoneos habilitat per dits elets.

Attes ultimament que per mayor satisfacció de dit Viñes y es excluirlo de qualsevol perill y contingencia aixi este com a ses fianses (...)"

28.04.1701, s/f

Josep Pino confessa haver rebut de la parròquia de la Pobla 156 Iliures.

“(...) ego Joseph Piñó Villa operarii ciutatis Villa Habitator et in pnt Villa Popula 
Vallibona (...) et recepisse ex vobis parroquia y parroquians de la lglesia (...) per mans de Vicent Sebastià, (...) la cantitat de quaranta y sis lliures moneda reals de Valencia y son a conte de la obra de dita Iglesia y a conte de la segona paga del primer lliurament".

30.05.1701, s/f

Josep Pino confessa haver rebut de la parròquia, per mà del rector Vicent Sebastià, 116 lliures i 12 sous de l'obra de l'església " co es seixanta uma lliuras que ab apoca rebuda per lo notari infrainscrit en dos de Abril propossat confesse haver rebut y cinquanta quatre lliures y deset sous que regonech aixi mateix de pnt haver rebut que dites partides fon suma de dita cantitat de cent y setze lliures y dotze sous los quals son co es cent dotze lliures y deu sous per la primera paga del segon lliurament de la obra de la dita Iglesia y los restants quatre lliures, dos sous a conte de la segona paga de dit segon lliurament de dita obra (...)"

\subsubsection{1}

“(...) ego Joanes Ribera mercater Villa Liria Habitator scienter y gratis confitior habuisse et recepisse realiter numerando Joseph García oficial de obrer de Vila absent y als seus y per mans y de dines propis de Joseph Piñó mestre de obrer de Vila de la ciutat de Valencia la cantitat de tres lliures dotze sous, moneda reals de Valencia: y son per altres tantes lin confessa deure lo dit Piñó per conte de dit García ab obligació rebuda per lo notari infraiscrit en dotze dies del mes de mars del present y corrent any cancellant aquella desde la present linea fins la última inclusive".

29.08.1701, $s / f$

Josep Pino confessa haver rebut de la parròquia de la Pobla 212 lliures, 14 sous $i 8$ diners.

“(...) Yo Joseph Piñó, obrer de Vila de la ciutat de Valencia hab. atrobat en la pnt Vila de la Pobla de Vallbona de mon bon grat y certa ciencia confesse y en veritat (...) haver agut y rebut realment y de contents de la Parroquia y Parroquians de la pnt Vila de la Pobla de Vallbona y dels vehins. Y per mans del Dr Vicent Sebastián prebere rector actual de dita Vila altre dels elets de la Obra que se está fabricant en la present Iglesia la cantitat de Docentes dotze lliures catorze sous y huit dines moneda reals de Valencia ó es les cent y quatre lliures, sis sous y huit dines a cumpliment de les docentes noranta nou lliures tretze sous y quatre dines que importa la segona paga del primer lliurament que es celebrà de dita obra de dita Iglesia la qual segona paga fan los dits parroquians per mans del dit Dr Vicent Sebastián avant fet relació la visura que vingué de la ciutat de Valencia, ço es Gil Torralba mestre de 
obres per part de la dita parroquia y parroquians, Juan Pérez també mestre de obres per part de mi dit Joseph Piñó, la qual relassio feren en poder del notari infrainscrit asesor y escrivà del Justicia de dita Vila ya feta la mitat de la obra de dita Iglesia encara mes de la mitad y les restants cent huit lliures y huit sous son a cumpliment de les cent y dotze lliures y deu sous que importa la segona paga del segon lliurament. Testes Pere Martínez Alfaro de Manises y Joseph García de obrer de Vila de la present Vila reset habitadors".

\section{Nota pie de página 247 (pág. 327)}

Estamos ante la primera propuesta escrita de una ciudad ordenada por sucesiva partición de un cuadrado perfecto, y también ante un verdadero programa de planificación y colonización territorial a partir de esas nuevas ciudades. Cada puebla se destinaba a una población formada por cien familias de agricultores, cada una de los cuales se le adjudicaban dos parcelas, una intramuros, de un cuartón de superficie $-1.775 \mathrm{~m} 2-$-, y otra agrícola, de cinco cuarteradas -3’55 hectáreas-, además de otras diez cuarteradas -7'10 hectáreas- de pastos para el ganado. Consecuentemente, el campo periurbano se parcelaba con criterios geométricos que prolongaban los utilizados en el recinto urbano.

La ciudad de las Ordenaciones tiene una estructura elemental, que puede reproducirse en llano cuantas veces sea necesario. Su perímetro es un cuadrado de unos 450 metros de lado, en el que se contienen 16 (4 por 4) manzanas cuadradas de unos 84 metros de lado. 


\section{A.2| Restauración de las pinturas murales góticas de la Iglesia de Santiago Apóstol}

\section{Estado de conservación inicial}

En relación al estado en que se encontraron las pinturas, en realidad, el problema se presentaba en los paramentos verticales más que en zona de la representación. Los muros de tapial que servían de soporte a las pinturas tenían un grave problema de humedad agravado por la existencia de un zócalo en la fachada, un zócalo cerámico interior y el pavimento de la calles. Esta humedad procedente del subsuelo ascendía por capilaridad hacia la parte superior del muro, haciendo peligrar la estabilidad de las pinturas.

Los perjuicios provocados por la humedad eran:

1- Destrucción de las pinturas.

2- Aumento del contenido de vapor de agua en el interior de la Iglesia.

3- Formación de eflorescencias.

4- Ataque químico al material que constituye el muro.

El grueso del mortero que recubría las pinturas era diferente en las dos partes. En la parte superior del lado de la epístola, era aproximadamente medio centímetro, mientras que en la parte inferior se reducía a 3 capas de película fina de pintura plástica sin mortero. El paramento vertical izquierdo estaba recubierto con pintura plástica y hacia los laterales aparecía una fina capa de yeso, que en algunas zonas puntuales se convertía en un mortero de dos centímetros de espesor.

Estructuralmente el muro situado a la diestra del acceso presentaba fisuras, lagunas y faltas de muchos fragmentos. El paramento vertical de la izquierda presentaba numerosas faltas debidos a fallos mecánicos. La preparación del mortero era de cal $y$ arena ${ }^{260}$.

\section{Proceso de ejecución}

En el mes de junio de 1994, llegó el primer equipo de restauración de la Conselleria de Cultura, recogieron muestras y se guardaron los escombros hallados el primer día. A finales de septiembre empezaron a realizar catas, siendo la empresa encargada Rest Art, pero no fue hasta el mes siguiente cuando se procedió con la compañía de tratamientos anti humedad Estrx Color a comprobar el estado del muro, siendo en noviembre del mismo año, cuando el Departamento de Restauración de la Conselleria dio la orden de comenzar las obras ${ }^{261}$.

\footnotetext{
${ }^{260}$ Blanco Gomez, P. y otros (1997):" Restauración. La Pobla de Vallbona, Pinturas murales góticas. Església Sant Jaume. Conservació i Resturació del Patrimoni Históric Valencià" en el Tríptico de la Conselleria de Cultura, Educació i Ciencia, Direccio General de Patrimoni Artístic. Valencia.
} 
La primera fase comprendió el siguiente proceso:

1- Descubrir las pinturas que permanecían escondidas detrás del enlucido de yeso, parte derecha.

2-Actuar sobre el muro de tapial, eliminado la humedad por capilaridad existente en este muro.

Tenía prioridad frenar el deterioro que estaban sufriendo las pinturas, atendiendo a esto lo primero que se realizó fue el tratamiento anti humedad, insertando un mineralizador, que en contacto con el agua crecía y se solidificaba, cortando el paso al relente en el sentido ascendente.

En cuanto a los frescos, la restauración consistió en limpiar su base de todo elemento extraño: yeso, pinturas sobre el muro y polvo adosado. Fijar los lienzos originales y repasarlos con resinas para que sacaran los colores propios. En las zonas que se había perdido el color se añadirían con colores naturales sin pigmentaciones químicas y con colores neutros para que no destacaran sobre las pinturas originales ${ }^{262}$.

El resultado fue que en esta zona izquierda se halló:

- Un Nacimiento, con las figuras del Niño Jesús, la Virgen María, San José, un ángel, el buey y la mula, el pesebre y el establo.

- La Adoración de los Reyes Magos, con dos magos y un paje.

- La Anunciación, de la que queda la imagen orante de la Virgen María, ésta se encuentra en la parte inferior de las otras; además quedan trozos de la cenefa, floreada que sirve como contorno de los diversos lóbulos o cuadros que componen el retablo original.

Las pinturas descubiertas en esta pared están compuestas por 4 escenas. Miden $1,50 \mathrm{~m}$ de ancho por 2,72 $\mathrm{m}$ de largo y cada una está separa por otra por una cenefa ornamental con motivos vegetales, de fondo rojo con flores blancas y azules. La zona superior se compone de: el Nacimiento y la adoración de los reyes. En la zona inferior, aparece la Madre de Dios de la Anunciación y a la derecha un fragmento pequeño de pintura ${ }^{263}$.

A la izquierda de las estampas no se ha conservado ningún resto y a la derecha de las mismas se perdieron totalmente con la apertura de la puerta con la reforma barroca en el año 1700. En la parte superior del paramento, en la zona del coro, en uno de los laterales, y por tal de saber si había alguna capa pictórica, se realizaron

\footnotetext{
${ }^{261}$ Aguilar Claramunt, J.(1997): “Crónica del Hallazgo de las Pinturas murales góticas en el atrio del templo parroquial de Santiago Apóstol”.

${ }^{262}$ Ibídem.

${ }^{263}$ Blanco Gómez P. y otros (1997):" Restauración. La Pobla de Vallbona, Pinturas murales góticas. Església Sant Jaume. Conservació i Resturació del Patrimoni Históric Valencià" en el Tríptico de la Conselleria de Cultura, Educació i Ciencia, Direccio General de Patrimoni Artístic. Valencia.
} 
unas catas. Apareció solo un estuco rallado con apariencia de mármol pero de la parte inferior de esta pintura no se había conservado nada, por lo que se inventario para posteriormente ser revestido.

Los trabajos se reanudaron en el mes de junio de 1996; en este caso la empresa que fue a seguir con la restauración era una cooperativa, siendo a principios de julio cuando empezaron sus quehaceres. Su zona de actuación fue en el paramento situado a la derecha del acceso. El primer cometido, investidación, seguir descubriendo las pinturas ocultas, y el descubrimiento no se hizo esperar: aparecieron pinturas más grandes, con mayor y más perfecta elaboración, individuales, representando Santos. Los materiales pictóricos empleados eran mejores, incluso oro en polvo de 24 quilates, el estilo parecía gótico al estilo italiano, los vestidos, los detalles eran más ricos que en las otras pinturas, incluso las ojivas de los lóbulos divisorios estaban más trabajados y adornados ${ }^{264}$.

Las pinturas del lado derecho, están compuestas por 4 escenas:

- San Gil: Esta escena, de la que solo se ha conservado el 30\% de la pintura original, representa la figura de un abad a medida natural con báculo de obispo y nimbo de santidad. Mide $58 \mathrm{~cm}$ de ancho por $75 \mathrm{~cm}$ de alto.

No se ha conservado ningún detalle por el cual se pueda identificar, pero por las características del personaje y la ubicación es posible que pueda tratarse de San Gil Abad.

- San Senént: Lleva un vestido azul, corona dorada de virrey y un nimbo de santidad. En la mano derecha sostiene una copa con un racimo de uvas, a la izquierda una espada, instrumento de su decapitación. Mide $1,7 \mathrm{~cm}$ de ancho por $1,63 \mathrm{~cm}$ de alto. Es la escena más completa que se ha conservado un $80 \%$ de la original.

- San Abdón: Viste como un príncipe, con túnica roja, corona de príncipe, gorguera azul y aureola de santo. Mide $74,5 \mathrm{~cm}$ de ancho por $1,10 \mathrm{~m}$ de alto. A la mano derecha lleva un manojo de espigas, ya que este santo y sant Senén, con quien siembre va representado, son los patrones de los labradores en algunas regiones del mediterráneo. Se conserva aproximadamente el $50 \%$ de la pintura original.

- La Crucifixión: se encuentra dividida en dos partes. A la zona superior aparece la escena de la crucifixión. Cristo crucificado ocupa el centro de la escena. Al fondo se encuentran representadas las murallas de Jerusalén y en primer lugar la Madre de Dios y San Juan, sentados sobre un fondo de piedras y flores. Mide

\footnotetext{
${ }^{264}$ Aguilar Claramunt, J.(1997) “Crónica del Hallazgo de las Pinturas murales góticas en el atrio del templo parroquial de Santiago Apóstol".

${ }^{265}$ Blanco Gómez, P. y otros(1997):" Restauración. La Pobla de Vallbona, Pinturas murales góticas. Església Sant Jaume. Conservació i Resturació del Patrimoni Históric Valencià" en el Tríptico de la Conselleria de Cultura, Educació i Ciencia, Direccio General de Patrimoni Artístic. Valencia.
} 
$78 \mathrm{~cm}$ de alto por $52 \mathrm{~cm}$ de ancho. Debajo de esta escena hay un fondo neutro de las mismas dimensiones ${ }^{265}$.

Pasado el verano se siguió con la labor de recuperación, fijación, limpieza y restauración, pero surgieron los primeros problemas; a pesar de ser un año seco, la humedad invadió la zona donde se encontraban las pinturas, incluso en las zonas ya restauradas, la sal y las eflorescencias hicieron desprenderse parte de los frescos. El mineralizador no había sido todo lo eficaz que se esperaba, por lo que hubo que replantearse el tratamiento de nuevo para paralizar, cortar y hacer remitir la ascensión del agua por capilaridad.

La solución adoptada sería la realización de una ventilación interior de los muros, se perforaron todas las paredes del atrio, a unos pocos centímetros del suelo, a las paredes de las pinturas se le añadiría otra hilera de perforaciones a unos centímetros y se insertaron unas canaletas de terracota cocida, la que se cubrió con unas rejillas para que dejara penetrar el aire, todo ello desmontado, el resto del zócalo de azulejos que quedaba y picando el enlucido de yeso y cemento que cubría las paredes, para dejar al descubierto un excelente muro de tapial.

El tratamiento de choque que se realizó permitía el control de la humedad presente en los muros y en el suelo del atrio, su ventilación permanente a base de higroconvectores cerámicos embutidos en los muros y en el suelo (exteriormente es hacen evidentes en las rejas circulares del perímetro), como también con la eliminación de los revestimientos modernos: el mármol de la fachada, el cerámico en el interior y el saneamiento de los paramentos ${ }^{266}$.

Primero, con medios mecánicos se eliminó el mortero y la pintura que recubría las paredes. Se realizó una consolidación impregnante y polvorizante en las zonas pequeñas donde la pintura aparecía pulverulenta con una solución de resinas acrílicas. Se ejecutó una primera limpieza superficial para eliminar el polvo y, después de la consolidación, se realizó una segunda limpieza para eliminar la suciedad incrustada y los restos de pintura plástica.

Para asegurar su ventilación, se decidió levantar el pavimento para hacer una conducción de aire que reforzara el efecto anti-humedad y al desescombrar aparecieron varios pavimentos a distintos niveles.

Una vez inventariado el descubrimiento, se procedió a remodelar la zona de la entrada, se colocó una canalización en todo el suelo del atrio, bidireccional, terminando con cuatro salidas al exterior, protegidas por unas rejillas, una tras la puerta que da acceso al campanario, otra tras la puerta que da acceso a la escalera 
de subir al Coro, y las otra dos tras la puerta de entrada al templo parroquial.

En aquel momento la solución fue válida y la humedad remitió, por lo que se realizó un estucado como acabado en el muro de tapial. Esta obra fue dirigida por los Arquitectos de la Consellería de Cultura: D. José Manuel Despiau y D. Pedro Blanco.

Terminadas las obras de albañilería dirigidas a eliminar la humedad por capilaridad, se reemprendieron las tareas de restauración de las pinturas, donde habían sido interrumpidas, para terminarlas definitivamente. Retocando las ya restauradas en la parte en que había sido agredidas por el agua.

El criterio de la intervención seguido en la restauración de las pinturas fue configurar la totalidad de las pinturas aparecidas, respetando los principios básicos de toda restauración, reversibilidad, respeto y reconocimiento de la obra artística.

En la parte derecha, mediante cales se reprodujo el dibujo original con la técnica del regatino, técnica que permite diferenciar la pintura original del resto del dibujo nuevo.

En el paramento izquierdo, a causa de las grandes lagunas que presentaba, la continuidad del dibujo fue realizado mediante puntos. En el caso de lagunas más pequeñas se optó por la técnica del puntillismo. En las técnicas utilizadas para la intervención los materiales utilizados son totalmente reversibles.

Para el estucado de las lagunas, la solución adoptada, un estuco de características similares al del soporte. En la reintegración estaban presentes los principios fundamentales para su respeto:

- Reconocimiento de las zonas reintegradas a una determinada distancia.

- Reversibilidad.

- Homogeneidad en las distintas partes de la obra.

- Recomposición de la unidad potencial de la obra partiendo de los fragmentos supervivientes.

- Después de la reintegración, se van a proteger las pinturas con una solución de la resina acrílica.

Solucionado el único problema que podía dañar el revestimiento pictórico, se procedió a restaurar la fachada y el atrio. El zócalo fue limpiado y recompuesta la fábrica y el rebosadero. En el interior, se procedió a recuperar el zócalo a base de un mortero monocapa en las medidas y proporciones barrocas, material que permite la transpiración del muro y que es resistente a los golpes y a la limpieza, en la pared inferior, la solución adoptada, realizar un estucado y por último las puertas de madera se trataron. Por último el cambio del pavimento y de la iluminación de esta zona, para adecuarla y realzar el valor del arte medieval. 


\section{Cronología de los últimos años}

En el año 2012 se observó que el sistema de ventilación del muro estaba fallando puesto que la humedad por capilaridad había ascendido y en algunos puntos, había llegado hasta los restos pictóricos y en otros se encontraba desconchando el estucado.

El anterior cura párroco, D. Joaquín Aguilar, comunicó, que cuando se restauraron las pinturas le indicaron que la Conselleria de Cultura cada año mandaría personal para realizar la limpieza del sistema de sifones que hacen que el muro de tapial, transpire, seque y no llegué la humedad a las pinturas murales. Este mantenimiento nunca se hizo puesto que nadie acudió a realizarlo.

Desde este momento se inició una serie de contactos y visitas con los técnicos de Conselleria de Cultura, la dirección facultativa original, los responsables del Ivacor (Instituto Valenciano de Conservación) y el Ayuntamiento de La Pobla de Vallbona, las cuales se detallan a continuación:

1a. Visita: viernes 30 de marzo de 2012

Carmen Pérez, Directora del Instituto Valenciano de conservación llegó a la iglesia y señaló que el problema tal y como habíamos advertido, era de humedad por capilaridad. En tres zonas había afectado ya a las pinturas.

\section{2a. Visita: viernes 27 de abril de 2012}

El responsable de la intervención en el año 1996, D. Pedro R. Blanco Gómez, Arquitecto Técnico y Jefe de Sección de Gestión de Proyectos de la Conselleria de Educación, Cultura y Deporte, señaló que el problema era que nunca se había realizado el mantenimiento. A su entender, si se limpiaba el sistema, con agua caliente a presión, tendría que seguir funcionando correctamente.

\section{3a Visita Noviembre de 2012}

Personados en el emplazamiento indicado los técnicos responsables, el constructor que hizo la obra y una empresa experta en el sistema de sifones (resultó imposible localizar a la subcontrata pretérita). Indican que al no realizar el mantenimiento los sifones no están en condiciones y han de ser sustituidos. También se considera que el acabado en estuco muy bruñido no permite la porosidad del revestimiento, por lo que en caso de fallo del procedimiento instalado no transpira el muro.

Al mismo tiempo, puesto que se observa que además de aguas blancas puede haber aguas fecales, el Ayuntamiento se compromete a pasar un robot por el sistema de saneamiento y de este modo descartar posibles fugas. Se solicitaron diversos presupuestos para acontecer las obras de restauración. 
El ayuntamiento de La Pobla de Vallbona, via correo electrónico le facilitó al cura párroco de la Iglesia Santiago Apóstol, el informe realizado por el jefe de sección de Proyectos de la Consellería de educación, cultura y deporte, D. Pedro Blanco y por la Arquitecta Técnica Municipal Dạ Ana Isabel Contelles Llopis, donde se le daba a conocer el estado de las obras, presupuestos para realizar las obras necesarias para quitar la humedad del paramento vertical, dejando constancia de su urgencia y señalando lo siguiente:

\begin{abstract}
El Ayuntamiento de La Pobla de Vallbona, en enero 2013, a través de su encargado de la Brigada de Obras, Paco Romero, llevó a cabo, el introducir un robot con cámara en la tubería de saneamiento, para observar si había perdidas de aguas. El resultado que se nos comunicó a este Gabinete Técnico Municipal, es que no existe perdidas en ninguno de los tramos. (Este consistorio tiene la grabación, si se desea observar se puede solicitar).
\end{abstract}

Los presupuestos eran únicamente para paliar la humedad por capilaridad del muro y reponer los revestimientos.

\title{
5ㅇ- 22 de enero de 2014
}

La Técnico Municipal, realizó una visita al inmueble y corroboró que las obras no se habían ejecutado, ni siquiera se había empezado y la humedad, había seguido ascendiendo con el peligro que eso conlleva para las pinturas murales. Por lo que se volvió a reiterar con carácter de urgencia las mismas obras que se decretó en el anterior informe.

Visto que el cura párroco no instaba el inicio de las obras, el ayuntamiento de la Pobla de Vallbona en el mes de mayo de 2014, solicitó una ayuda a la Conselleria de Cultura para abordar de manera inmediata las obras del paramento vertical. La subvención fue denegada.

\section{Situación actual}

Como conclusión final indicar que el estado actual se debe a dos causas en primer lugar a que el sistema colocado inicialmente falló después de 17 años, porque no se realizó ningún tipo de mantenimiento y la segunda causa debida a la inactividad de la propiedad, puesto que en los últimos años no ha ejecutado las soluciones dadas.

Todo ello hace peligrar este tesoro medieval único en la provincia de Valencia, a fecha de la redacción final de esta tesis doctoral, todavía no se ha actuado en el muro, a mi juicio se debe intervenir cuanto antes, espero que así sea. 


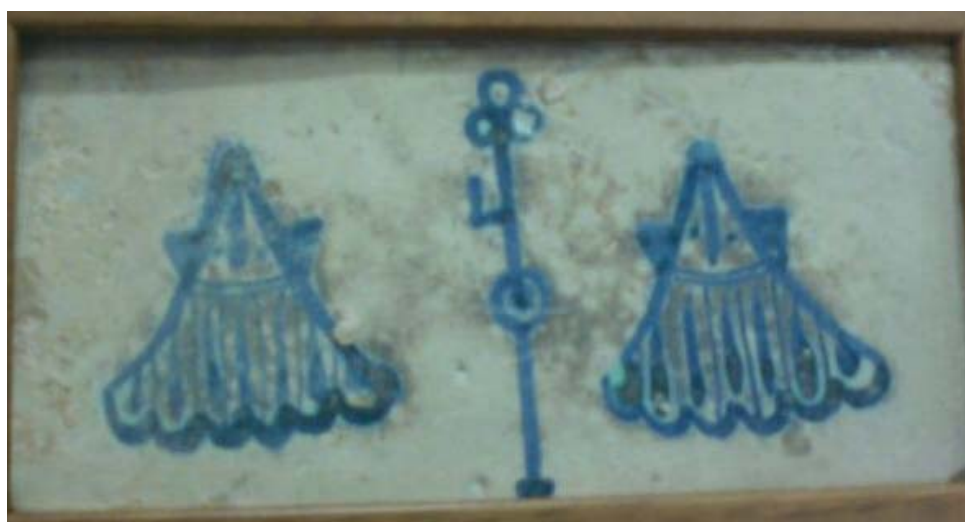

Fig. 190. Loseta cerámica encontrada durante la ejecución de los conductos de ventilación en el pavimento. Representa dos conchas de Santiago y su bastón de peregrino.

\section{La loseta Blasonada}

El 24 de octubre de 1996 en el curso de unos trabajos en el atrio del templo parroquial se encontraba a $45 \mathrm{~cm}$ de profundidad un conjunto de losetas de cerámicas dibujadas, junto con otras que habían perdido la capa esmaltada, probablemente, por desgaste. Las piezas con dibujo bien conservado son pocas, en total 4 unidades ${ }^{267}$.

\section{Descripción}

Se trata de un cuadrilátero irregular, barnizado de cerámica cocida, con dibujos hechos a mano que representan dos conchas de peregrino divididas entre sí por un cayado, que pretende ser blasón de la titularidad de la parroquia; concha y bastón que simboliza la imagen del Apóstol Santiago el Mayor.

La mayoría de las piezas, aunque irregulares, cuenta con las siguientes medidas: límite de la parte superior $22,4 \mathrm{~cm}$; límite de la parte inferior $22,7 \mathrm{~cm}$, límite de la parte vertical derecha $10 \mathrm{~cm}$, límite de la parte vertical de la izquierda $10,8 \mathrm{~cm}$. Las representaciones gráficas tienen las siguientes dimensiones: concha de la parte derecha: $6,5 \mathrm{~cm}$ de alto por $6,8 \mathrm{~cm}$ de ancho, Concha de la parte izquierda $6,6 \mathrm{~cm}$ de alto por $6,5 \mathrm{~cm}$ de ancho, y el bastón $9,8 \mathrm{~cm}$.

\section{Antigüedad aproximada}

Por las características y peculiaridades de la loseta puede ser del siglo XVII o siglo XVIII aproximadamente. El descubrimiento tiene una gran importancia debido a que este modelo de decoración fue hecho exclusivamente para el templo de La Pobla; puesto que hasta ahora, no se han localizado restos de cerámica similar. Podrían ser perfectamente de la reforma barroca, coincidiendo con la de 1701 cuando se

\footnotetext{
${ }^{267}$ Aguilar Claramunt, J.(1997): “Loseta de Cerámica Blasonada de la Parroquia de Santiago Apóstol” en Libro de fiestas patronales en honor del Mártir San Sebastián, Clavaría 1997, La Pobla de Vallbona 1997, pág. 12.
} 
cambió la orientación de la iglesia, aunque no aparece mencionado este tipo de pavimento en los protocolos notariales de la obra.

\section{A.3| Restauración de la ermita de San Sebastián}

En el año 2009 la ermita de San Sebastián se encontraba en un lamentable estado, debido en gran parte, a la cantidad de filtraciones existentes a través de su cubierta principal. El agua penetraba y corría por los paramentos verticales, deteriorando sus revestimientos y aspecto interior. Por esta razón el cura párroco de la iglesia Santiago Apóstol, D. Joaquín Aguilar Claramunt y la Alcaldesa de La Pobla de Vallbona, Dạ. M Carmen Contelles Llopis acordaron, a través de la firma de un convenio, realizar las medidas urgentes para salvar la ermita y su entorno.

En primer lugar se decidió por parte de la dirección facultativa de las obras, D. Francisco Silla Sevilla y Dạ. Ana Isabel Contelles, comenzar las obras de restauración por los elementos constructivos más dañados, las cubiertas de ambas edificaciones, tanto en la zona perteneciente a la ermita, como a la casa del ermitaño ${ }^{268}$.

Señalar que era más urgente intervenir en la zona de la ermita puesto que la cantidad de filtraciones estaban acabando con los revestimientos de los paramentos verticales, por lo que se actuó en esta zona en primer lugar. Para ello se procedió a desmontar parte del falso techo de cañizo con el fin de observar el estado de la cubierta. La situación real era peor de lo que se creía. Los desperfectos allí encontrados fueron los siguientes:

1- El falso techo de escayola estaba repleto de elementos vegetales que habían ido depositando distintos agentes vivos, roedores o aves. El sobre esfuerzo al que se vio sometido este revestimiento había provocado junto con las innumerables goteras parte de su desprendimiento

2- En la primera crujía diez pares de madera habían perdido la unión con los muros de carga. La cubierta en este tramo se sostenía en el aire y por el falso techo de cañizo.

3- Las goteras eran innumerables.

4- Las pares y las dos vigas centrales, situadas en el primer y segundo tramo, estaban todas totalmente atacadas por diferentes agentes xilófagos y por pudrición.

Cabe destacar que estructuralmente se hallaron dos hechos remarcables:

- Se observó que en las dos primeras crujías, el sistema constructivo no era el

\footnotetext{
${ }^{268}$ Contelles Llopis, A. (2011): La ermita de San Sebastián, patologías y diagnosis, Trabajo final de Grado. La Pobla de Vallbona. 138-192p.
} 
primitivo, sino a par e hilera, es decir las vigas apoyan en el muro y en una viga central, en cambio, en el tercero y cuarto tramo, apoyan los pares en los arcos de diagrama. Por lo tanto, claramente la cubierta se había reformado.

- La segunda, que evidenciaba el cambio de cubierta, era que el entramado ya no era todo de madera, sino que se había sustituido por ladrillos cerámicos sobre rastreles, y al tercer tramo se le había aumentado la pendiente, a diferencia de las otras tres crujías.

Una vez desmontada toda la cubierta fue evidente que no iban a ser reutilizables los pares existentes en la ermita, por esta razón se colocaron nuevos todos elementos de madera. En las dos primeras crujías, se dejó las dos vigas entradoras, para dejar constancia de la reforma hecha en su día. Los ladrillos cerámicos macizos, se pudieron reutilizar en su mayor parte al igual que la teja moruna utilizada como elemento de cobertura.

El siguiente paso fue analizar los paramentos verticales puesto que se evidenciaba la existencia de policromía. Los restos de las capas inferiores constataron que en sus inicios los paramentos verticales estaban recubiertos con una tonalidad blanco mate. En la zona inferior de los encuentros de los pares de madera con el arco de diafragma apareció una cenefa muy simple, realizada con una franja amarilla y otra verde, remarcada con dos líneas de color almagra. Está sencilla decoración también fue hallada en la parte superior de los paramentos verticales, marcando el perímetro de la cubierta.

En el paramento opuesto al altar, donde existía una pequeña ventana cuadrada, apareció, al eliminar el revestimiento, un pequeño óculo, que también llevaba a su alrededor la misma policromía anteriormente descrita. Los revestimientos de los paramentos verticales fueron picados, enlucidos y posteriormente reproducida la policromía. Se utilizó mortero de cal para enlucir los paramentos y pintura al silicato.

Para finalizar se intervino en el pavimento. En esa época se encontraba colocado un pavimento de terrazo que, aunque no se encontraba en muy mal estado, desmerecía totalmente la intervención allí realizada. Los vecinos de mayor edad recordaban que el pavimento inicial era de barro de $40 \times 40 \mathrm{~cm}$, por lo que se colocó encima un revestimiento como el indicado. A consecuencia de esta intervención, las puertas de entrada de la ermita se tuvieron que cortar unos centímetros y adaptarlas a la nueva cota.

En el perímetro exterior del inmueble, para facilitar la evacuación del agua que caía procedente de la cubierta, se construyó una acera de hormigón impreso color gris.

La casa del ermitaño

Una vez finalizada la intervención en la zona de la ermita se actuó en la casa del ermitaño. Esta zona del edificio contaba con innumerables problemas de 
mantenimiento, humedad y falta de ventilación causada en gran parte por el cierre de su acceso unos años antes para evitar que fuera ocupada.

Por lo tanto, en primer lugar, se abrió el acceso y comenzó la restauración de la cubierta. Era una cubierta de una única pendiente, construida con rastreles, ladrillo cerámico y vigas de madera. Fueron sustituidos, con los mismos criterios que en la ermita, los pares de las vigas, los listones de madera y se volvieron aprovechar los ladrillos cerámicos y la teja moruna.

Seguidamente procedía picar todos los paramentos verticales. En este caso en las capas inferiores había resto de hollín que evidenciaba que el inmueble en algún momento de sus historia se había incendiado (los datos históricos explicados en el apartado de la ermita señala que fue en una batalla durante la guerra de la Independencia). Tras proceder a su eliminación fue revestido y posteriormente pintado con pintura al silicato blanca. En este inmueble no fueron hallados restos de policromía.

El citado inmueble consta de dos plantas, debido a sus escasa superficie, ambas con una única estancia. El forjado construido con pares de madera y revoltones cerámicos presentaba un gran deterioro debido en parte a la pudrición y el ataque de agentes xilófagos a los pares de madera, por estas razones, fueron sustituidas las vigas, tratadas y reforzado todo el elemento constructivo mediante una capa de hormigón sujeta por la parte superior a las vigas creando una estructura mixta que trabaja conjuntamente.

Cabe señalar que en la planta primera se recuperó el pavimento original, formado por ladrillo cerámico macizo colocado a espiga. La planta baja, tenia baldosas de barro 40 x $40 \mathrm{~cm}$, en este caso fueron sustituidas las piezas que se encontraban deterioradas por otras de similares características.

La siguiente intervención llevada a cabo fue en la carpintería de ambas edificaciones, recuperando en los paramentos verticales las distintas oquedades que habían sido cegadas en distintas épocas. Es importante destacar que este edificio cuenta con dos elementos constructivos muy significativos:

1- Se observa claramente que los muros son de tapial (tierra y paja). Las claves se encuentran a la vista.

2- La primera planta cuenta con un festejador, se trata de un asiento situado en la parte interior de una ventana, para sentar y conversar, propio de las masías valencianas en siglos XIV al XVII

Se puso en valor ambos elementos, el primero mediante unas ventanas arqueológicas en dos zonas, una por planta, con el fin de poder observar cómo se encuentra construido el muro. Esta zona se consolidó con una resina, dejando transpirar el paramento pero cohesionándolo para evitar los desprendimientos. 
El festejador fue restaurado y colocado en un lateral un directorio que explica su función primitiva.

Para finalizar dejar constancia de la intervención realizada en la parte trasera de la ermita, si bien esta zona carece de importancia histórica puesto que se trata de un patio trasero realizado seguramente en el siglo XIX. Este zona se derribó totalmente y se volvió a construir, esta vez retranqueada unos centímetros, para que se observara claramente que se trata de una edificación añadida. Este edificio destinado a servicio higiénico conservó su uso, puesto que era necesario, pero adaptado a minusválidos, y se habilitó una zona para almacén de productos de limpieza y cuadro de luces. En la parcela inferior, perteneciente al Ayuntamiento de la Población, se ubicó una fosa séptica prefabricada, para garantizar el servicio del cuarto de baño.

\section{EL ENTORNO}

Tanto la ermita como la casa del ermitaño están emplazadas sobre una parcela que cuenta con una ligera pendiente ascendente, quedando en el sitio más elevado respecto a toda la población.

Este pequeño montículo, según indicaban sus restos, perimetrálmente estaba rodeado por muros de piedra en seco que contenían las tierras. La parcela cuenta al sur con cota 0,00 llegando a alcanzar un desnivel de 4,00 aproximadamente en la zona norte. Este elemento de arquitectura popular en el año 2008 había desaparecido prácticamente en su totalidad, quedando únicamente restos en diferentes tramos. En el citado año la Conselleria de Cultura comienza a conceder diferentes subvenciones con el fin recuperar este tipo de construcciones. Es este preciso momento cuando el ayuntamiento, con el concejal de obras D. Hector Llorens, plantean su recuperación con el fin de poner en valor la ermita y su entorno. En la actualidad se encuentra totalmente recuperado.

La solución adoptada fue la más obvia: volver a realizar este elemento arquitectónico de piedra en seco como se ejecutó en origen. La cimentación fue realizada con bolos, el material, la piedra, fue llegando a la parcela, de todos los rincones del Término municipal, para posteriormente ser elegida y colocada en seco. El remate perimetral fue realizado con piedra y mortero de cal.

Los tramos realizados abarcaron todo el perímetro de la ermita: el muro longitudinal que lindaba con el vial de la C/San Sebastián y el muro trasero. También se construyó una rampa para poder acceder desde una parcela municipal y facilitar el acceso de los viandantes en esta zona.

Para concluir un breve apunte, después de lo anteriormente descrito cabe precisar que, para poner en valor todo el entorno únicamente falta intervenir en una zona: la zona del calvario. 
A.4| Inventario del año 1873 perteneciente al Ayuntamiento de La Pobla de Vallbona señalando los documentos existentes en el archivo del municipio. Archivo documental de la Diputación de Valencia.

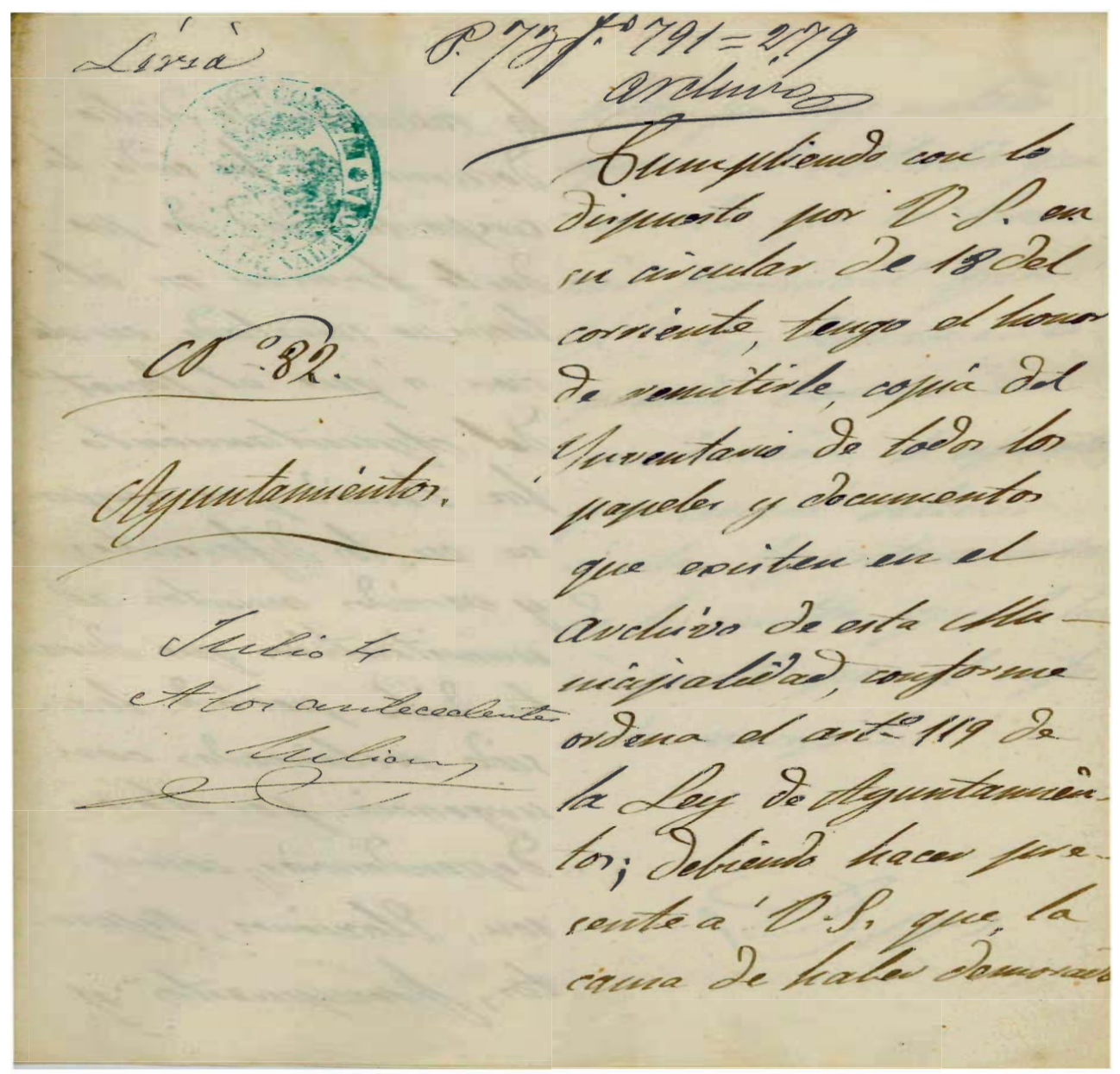


la pourinion te diclis Socumento ha site, la infenibitidad de

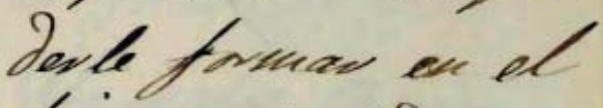
terinfes serialato, en ale crou a quee el Panodto Idel checentamenouts tra terido

se en los 2 iferentes y variados aresctor ad uninitsatsion que denama te didio nevióds han sido seelanceados con urgenera for otsas Seprendasracis; cones sou, Plarcienes, lefear. tor, fresugencertos 
446 de 536

dros, fror cuego nuateino afreva el cticrlole qua sureside, que ta bourerreon fovouical geer

U1. Tau digmamerete picnide touraua see conidesacion lo esfucents, y se revivia' celovas $\rightarrow$ 'ite Ayventaruvinto de la suntta que ble infuverto fior el uefte rito conceleto.

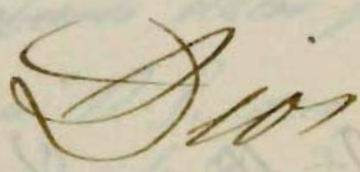




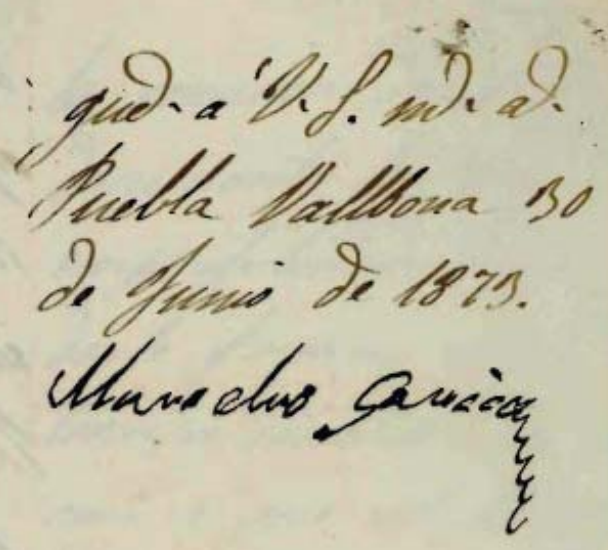




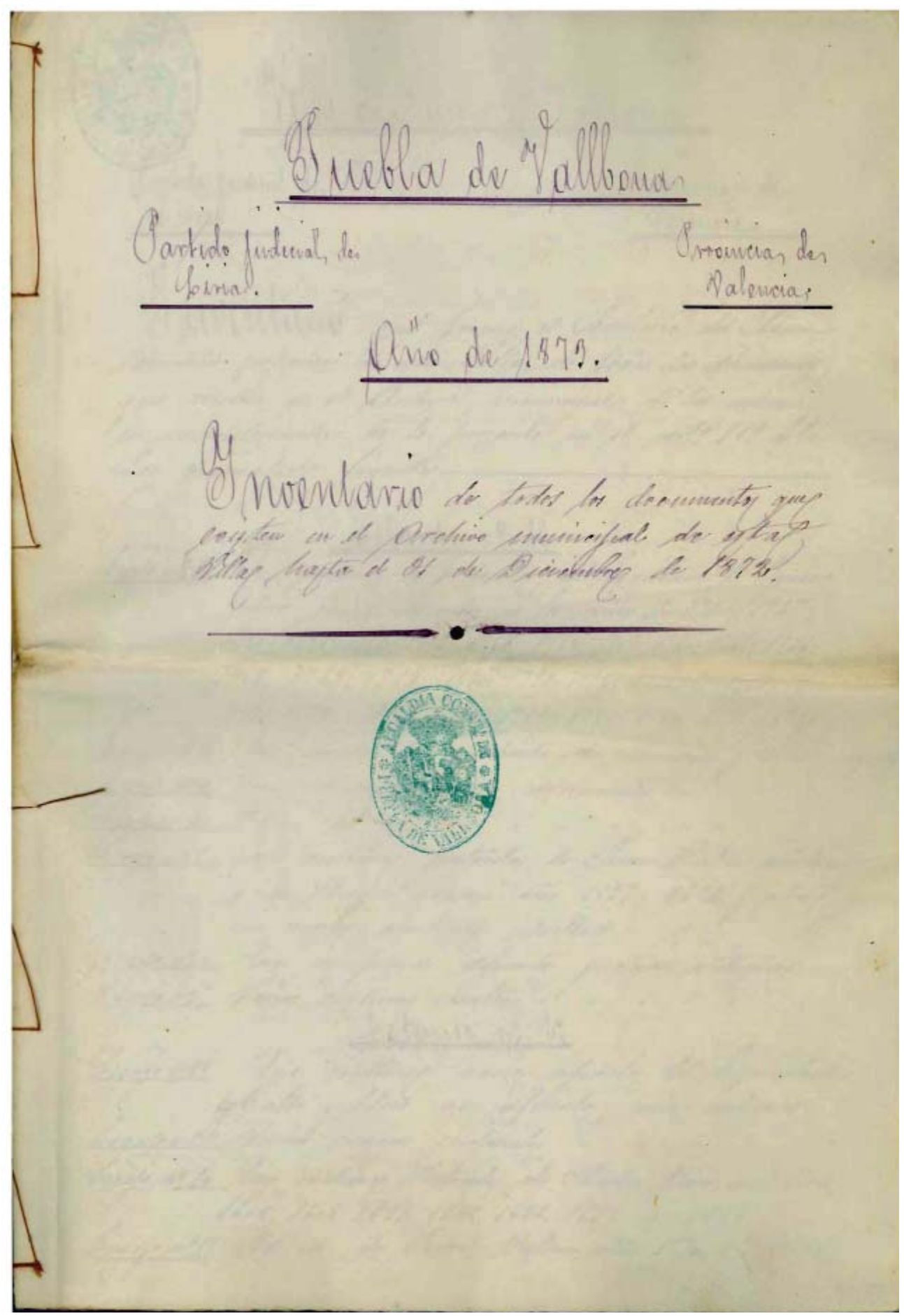




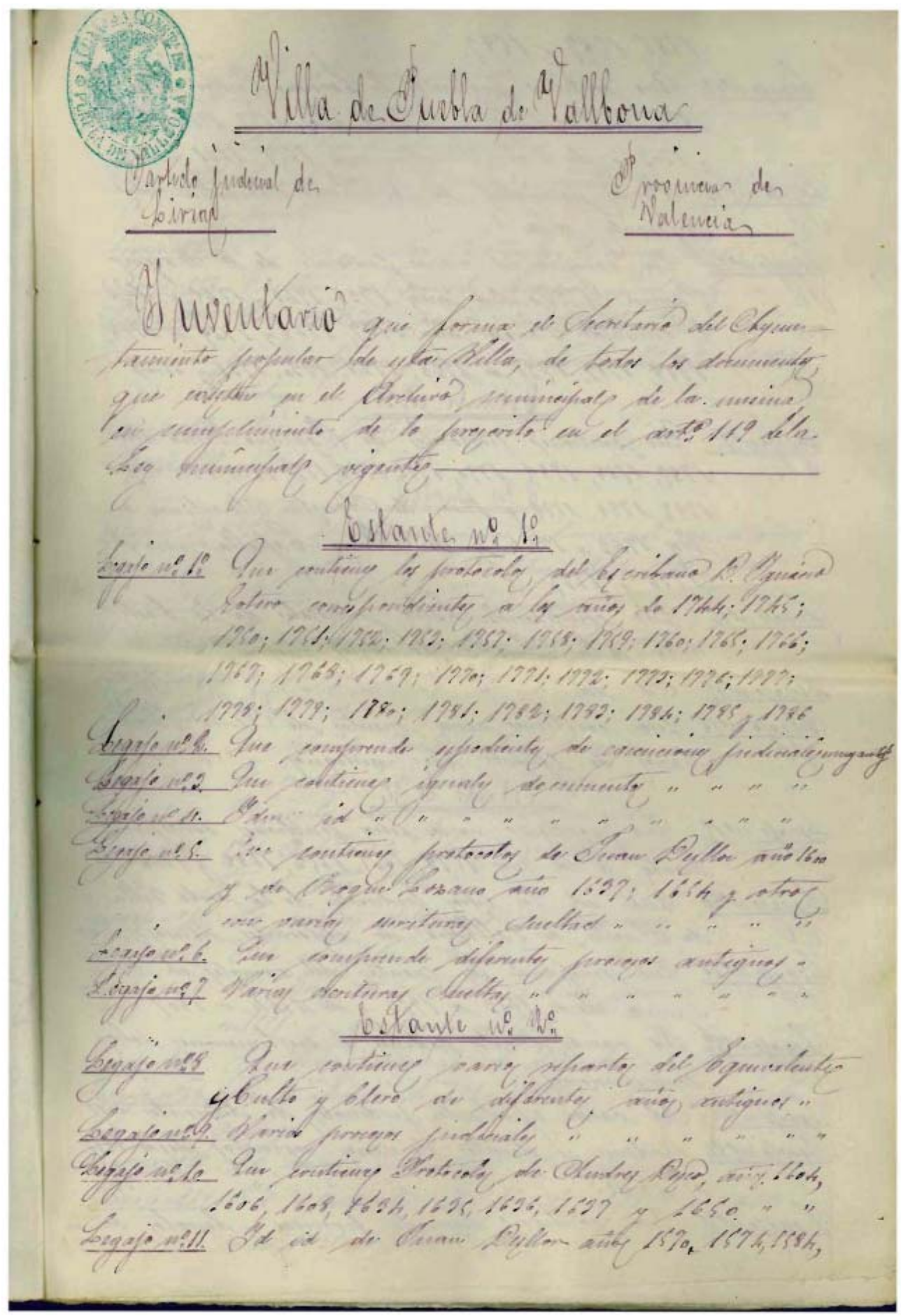




\section{0 de 536}

$$
156,1599,1597 .
$$

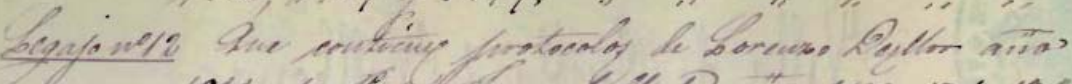

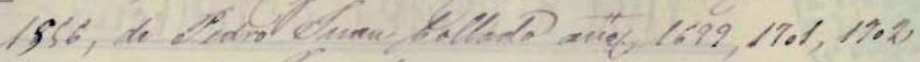

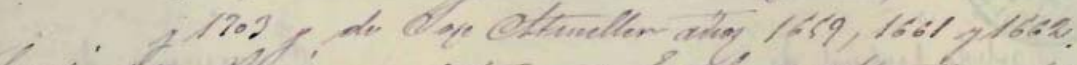

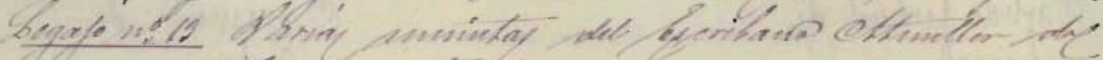

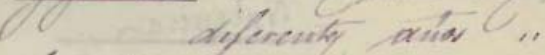

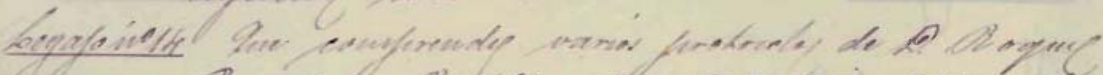

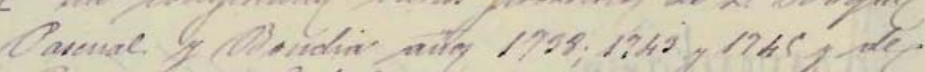

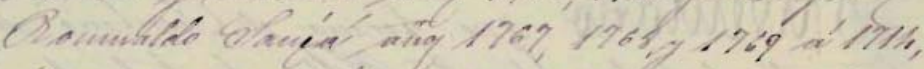
$1918,1919,1221$ - $1226,1728,1920,1129$ y otwer boxaute wis?

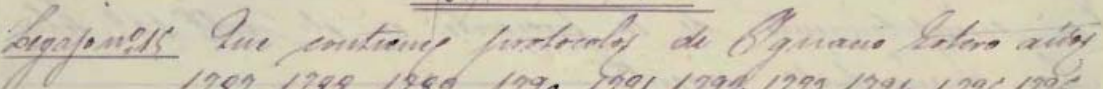

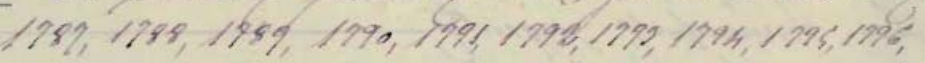

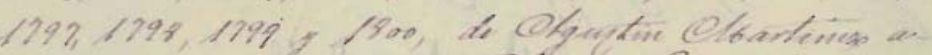

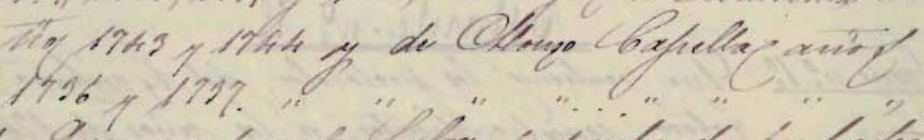

Sogexte w16! coegenent Cit. and

colgere wets and

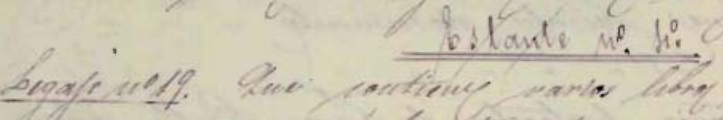

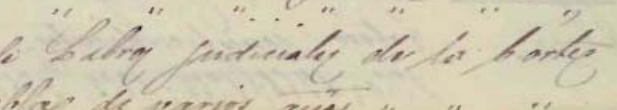

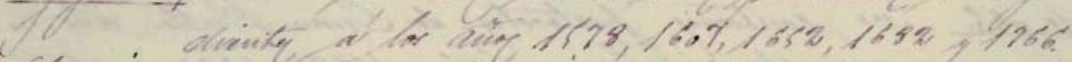

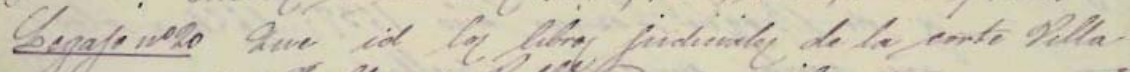

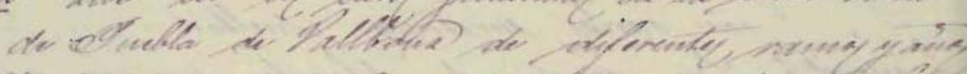

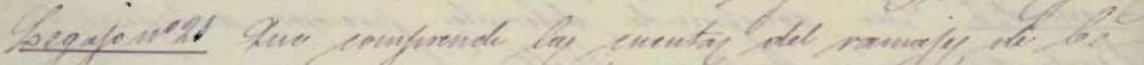

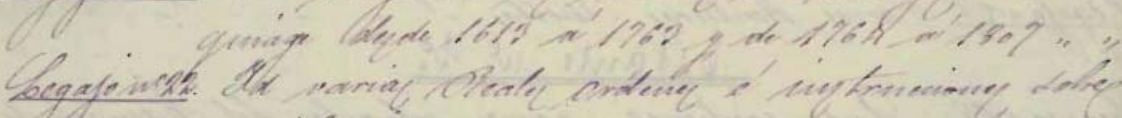

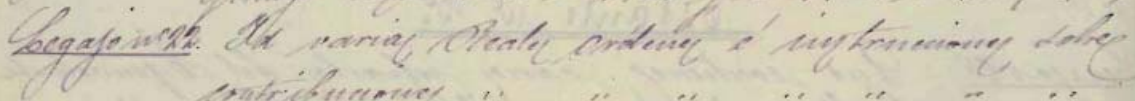

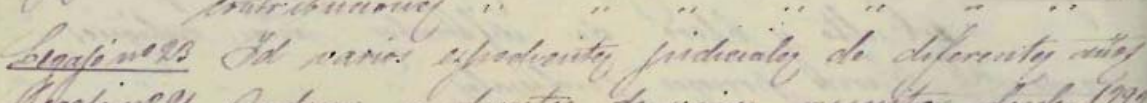

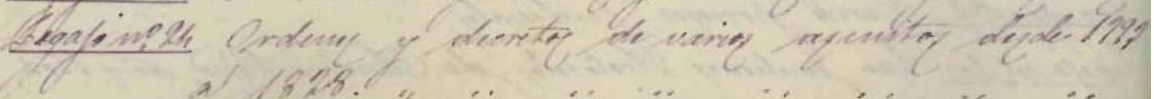

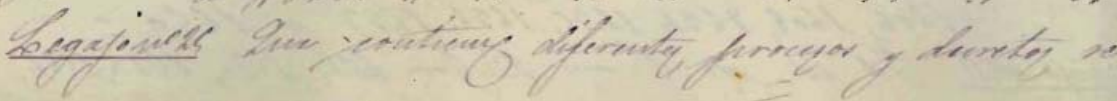




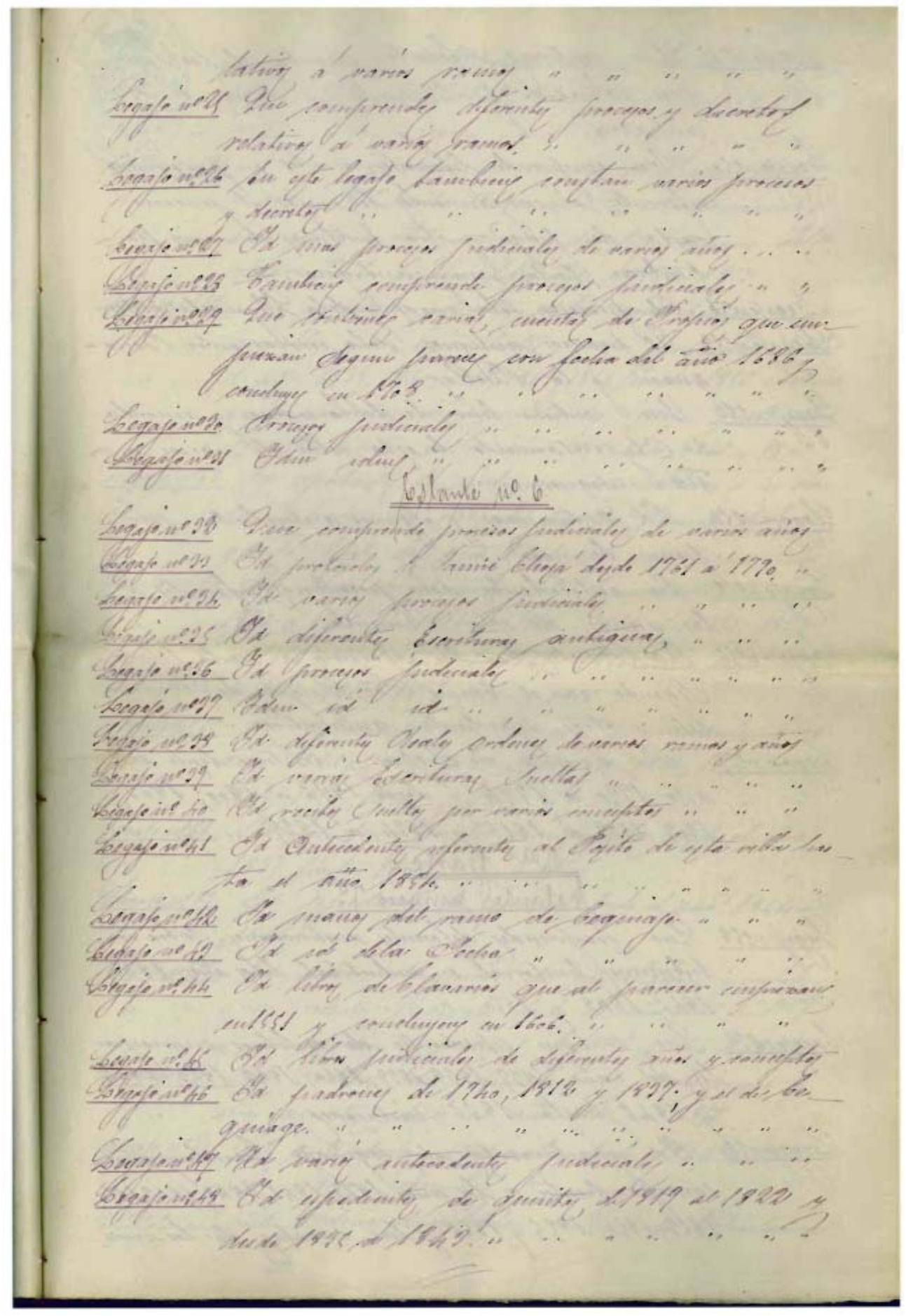




\section{2 de 536}

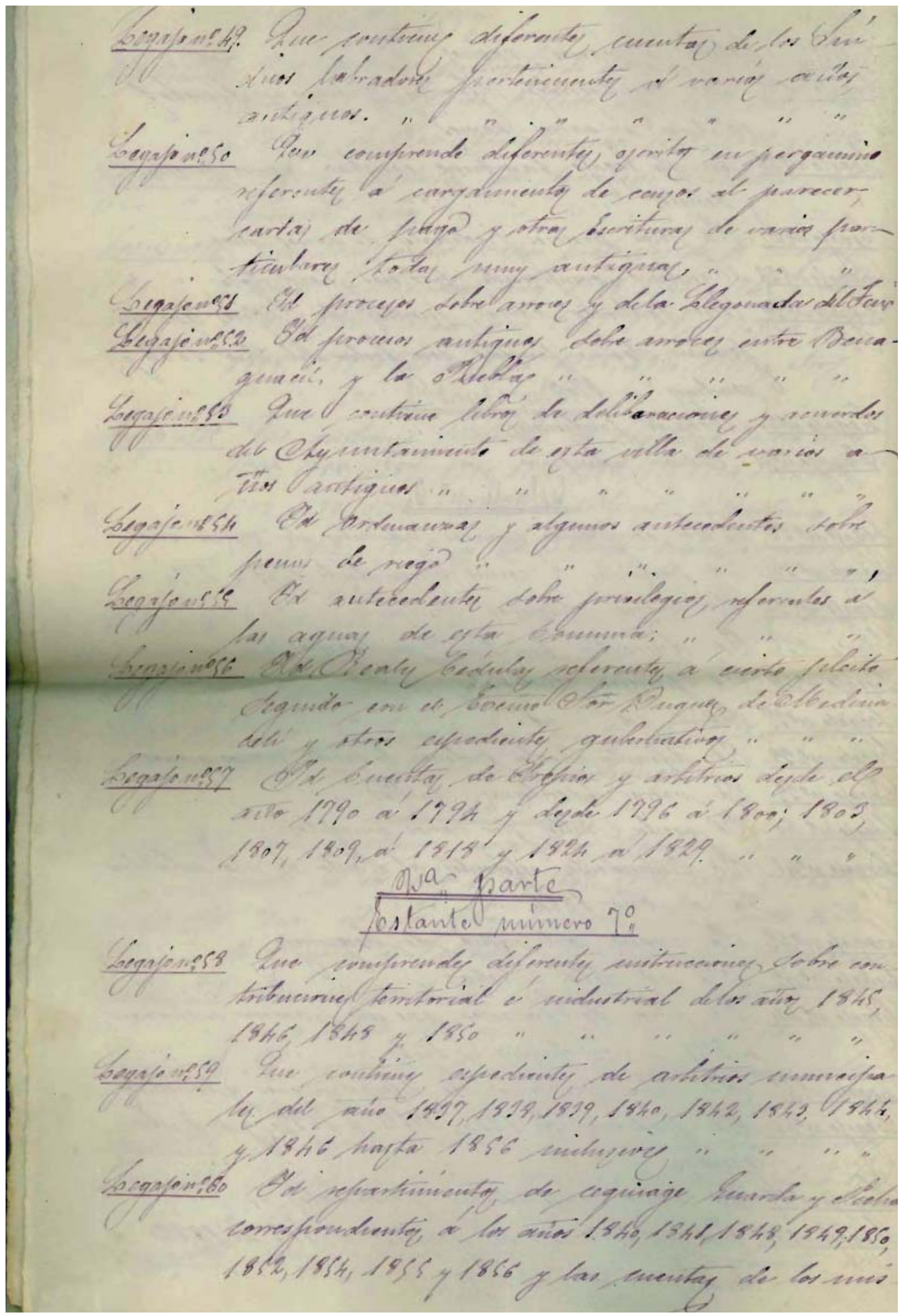




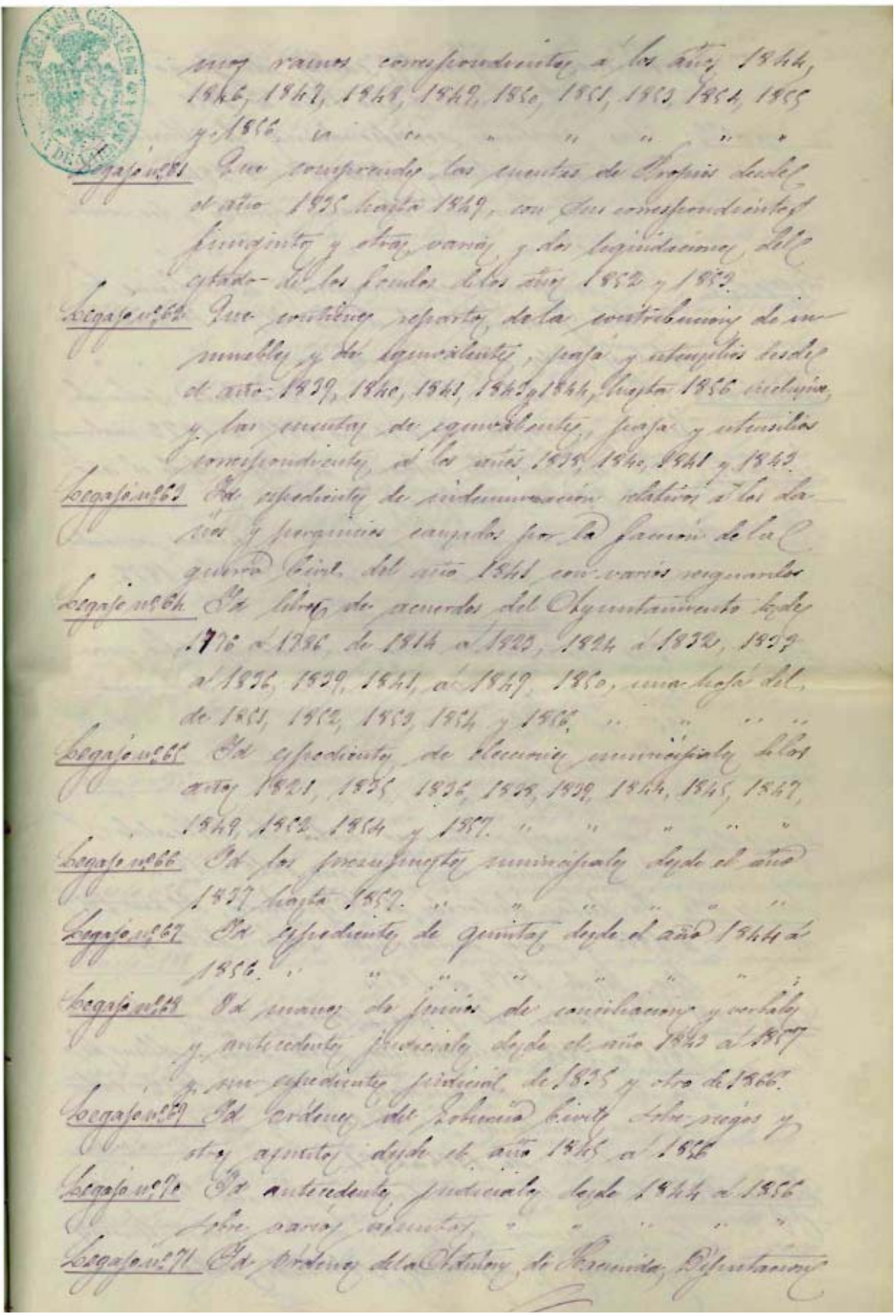




\section{4 de 536}

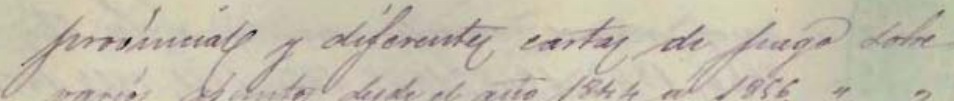

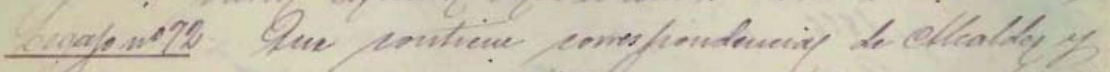

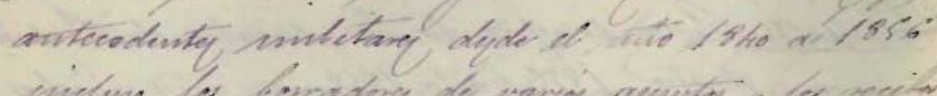

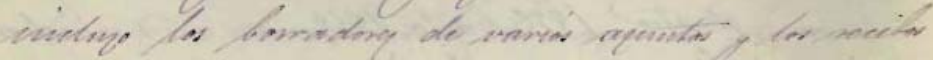
dele bine?

tremeis:? She

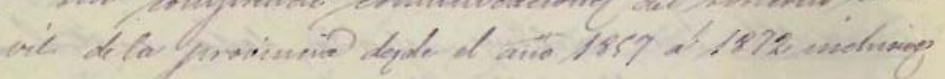

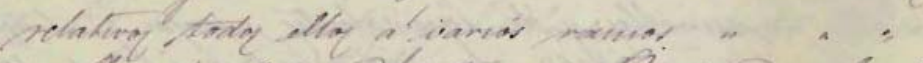

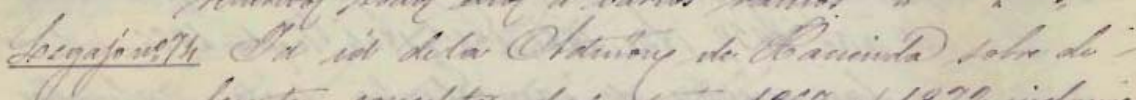

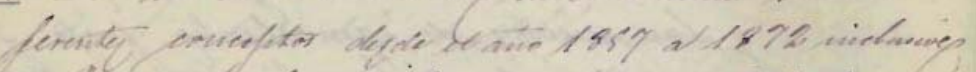

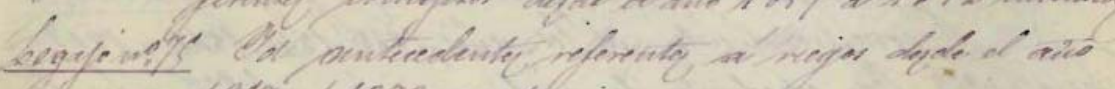

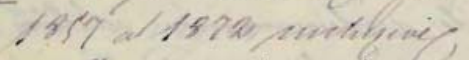

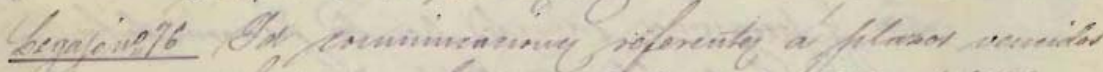

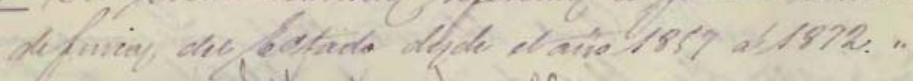

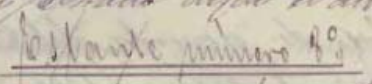

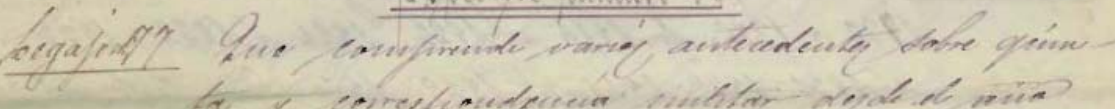

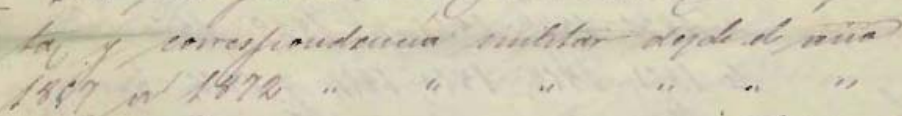

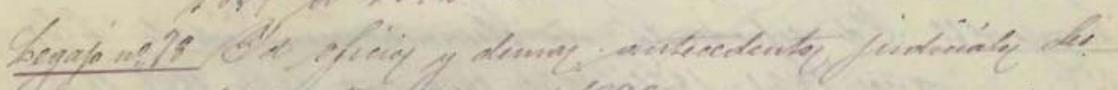

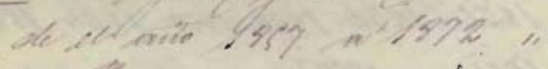

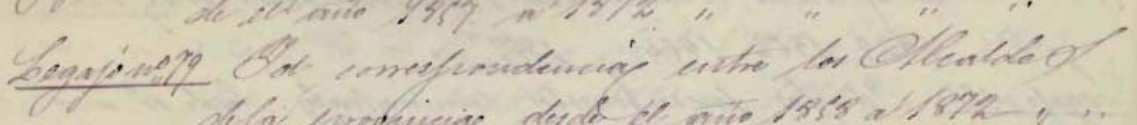

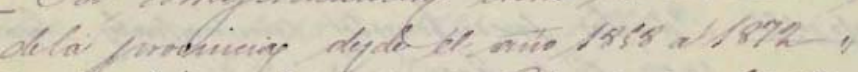

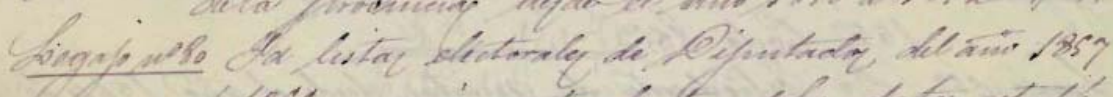

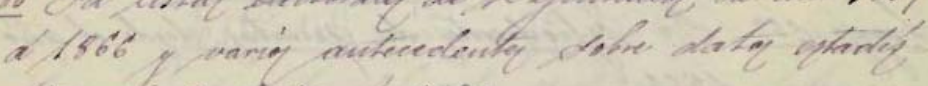
Aing deve lore a 1892

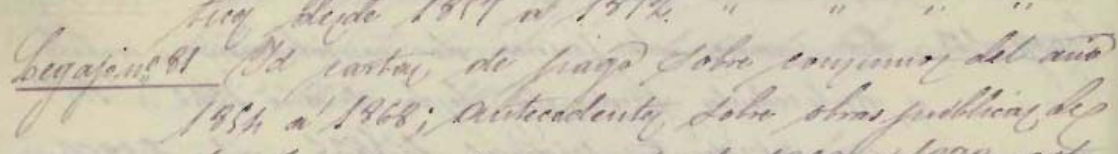

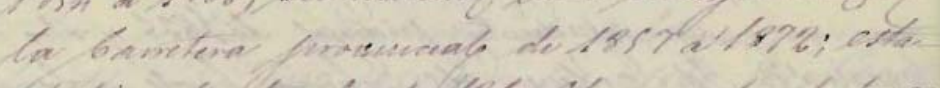

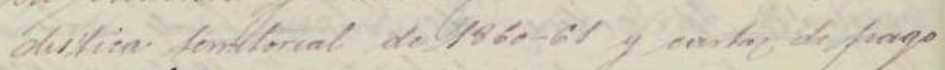

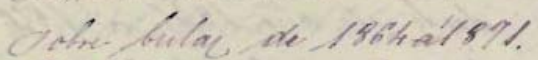

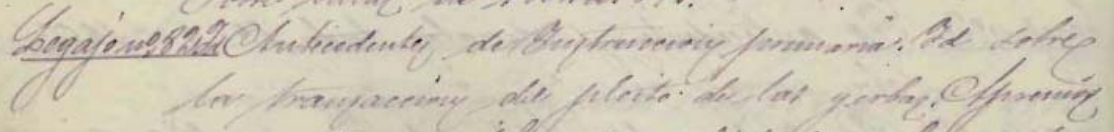

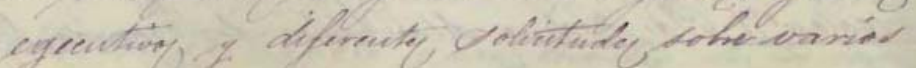




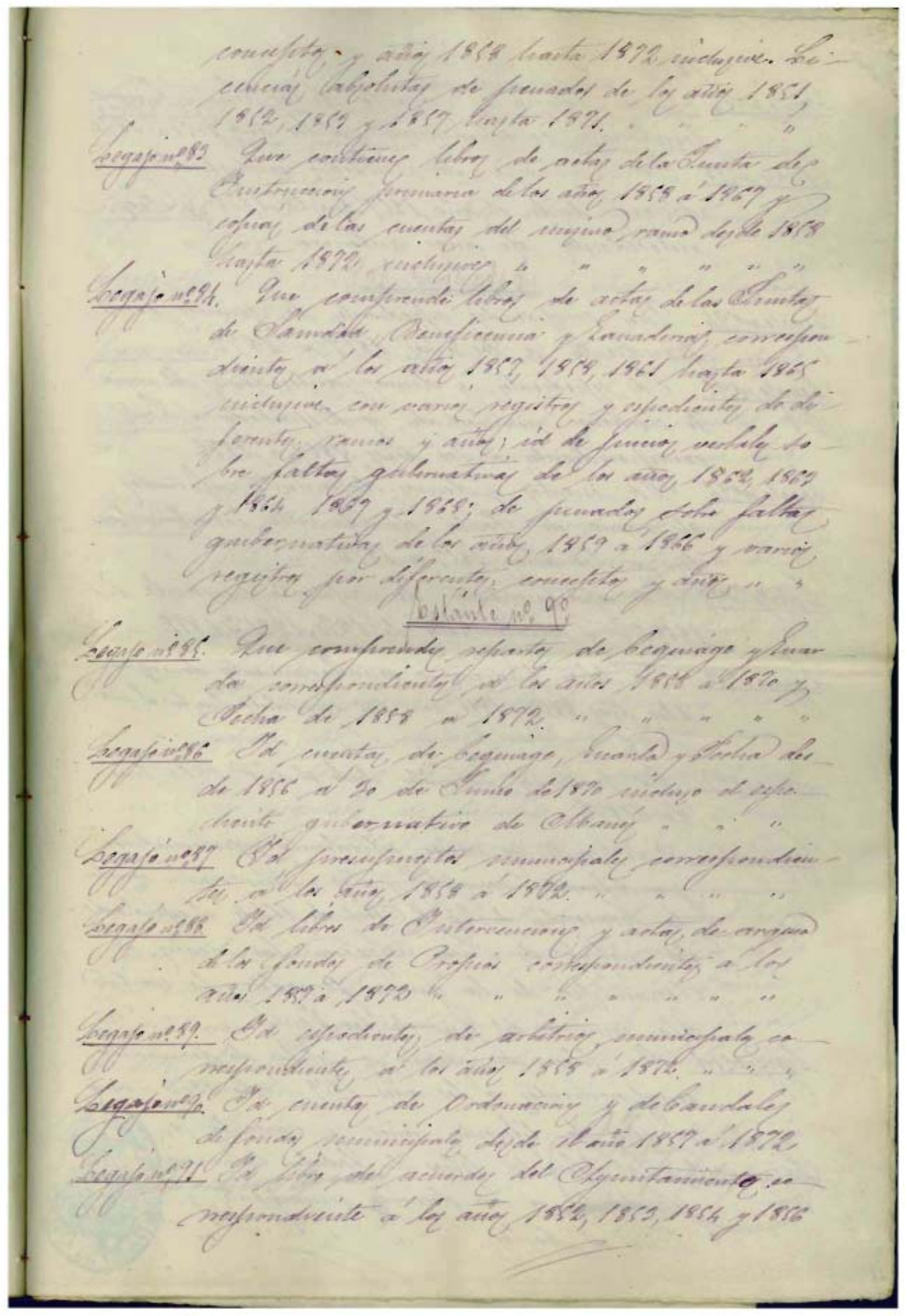




\section{6 de 536}

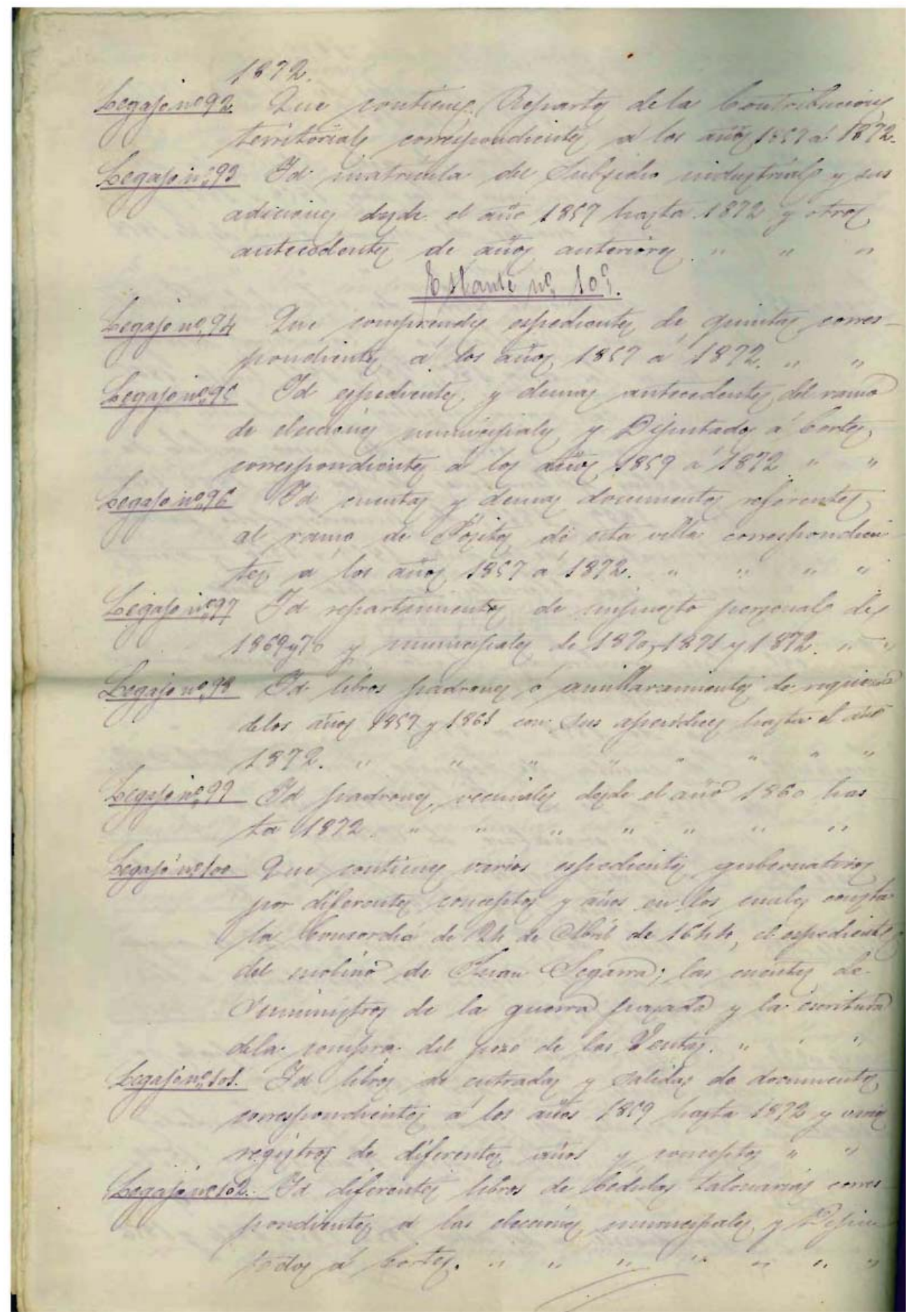




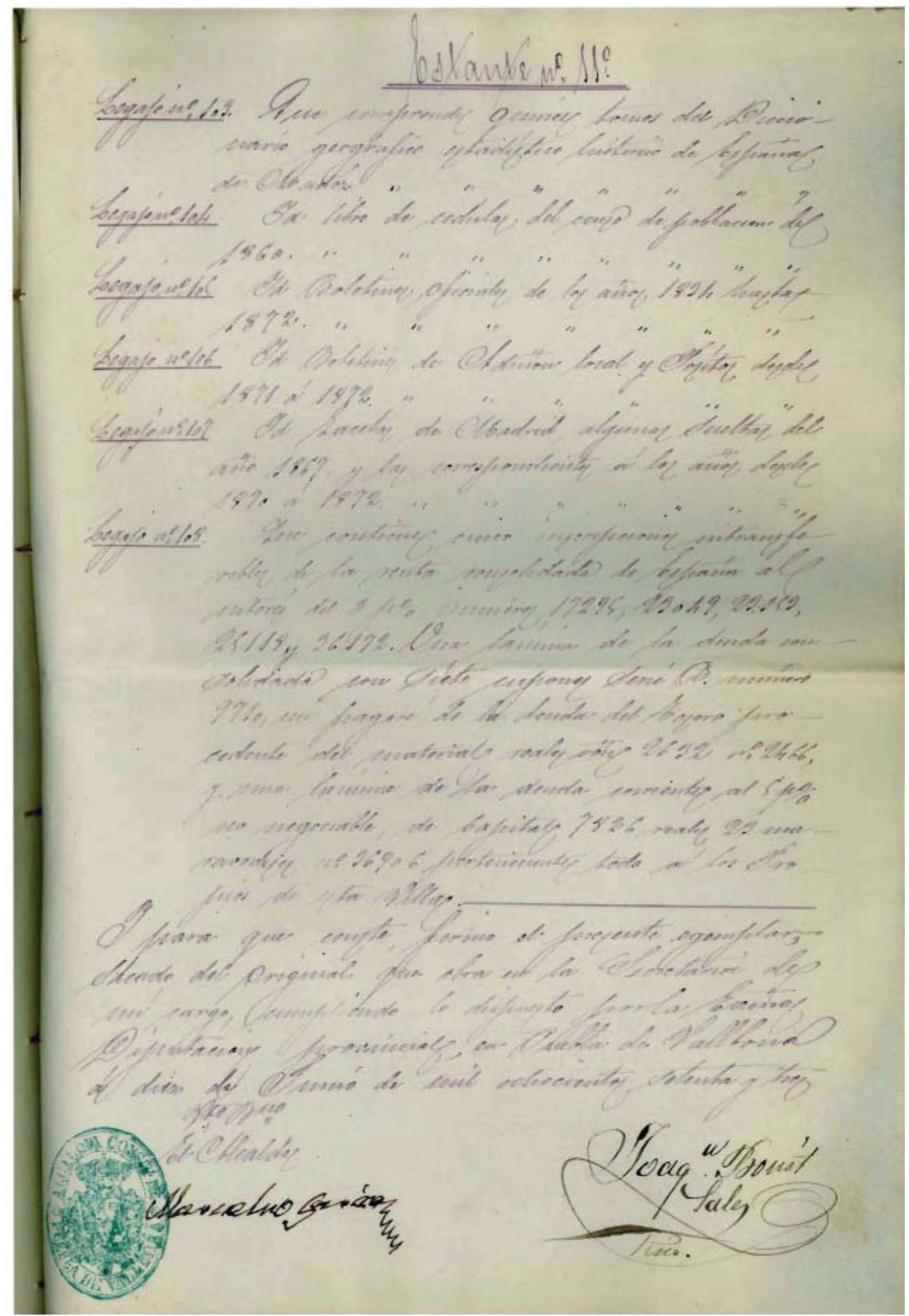


458 de 536

Documento del año 1945 que deja constancia la quema del archivo municipal durante la Guerra Civil Española I. Archivo Diputación de Valencia

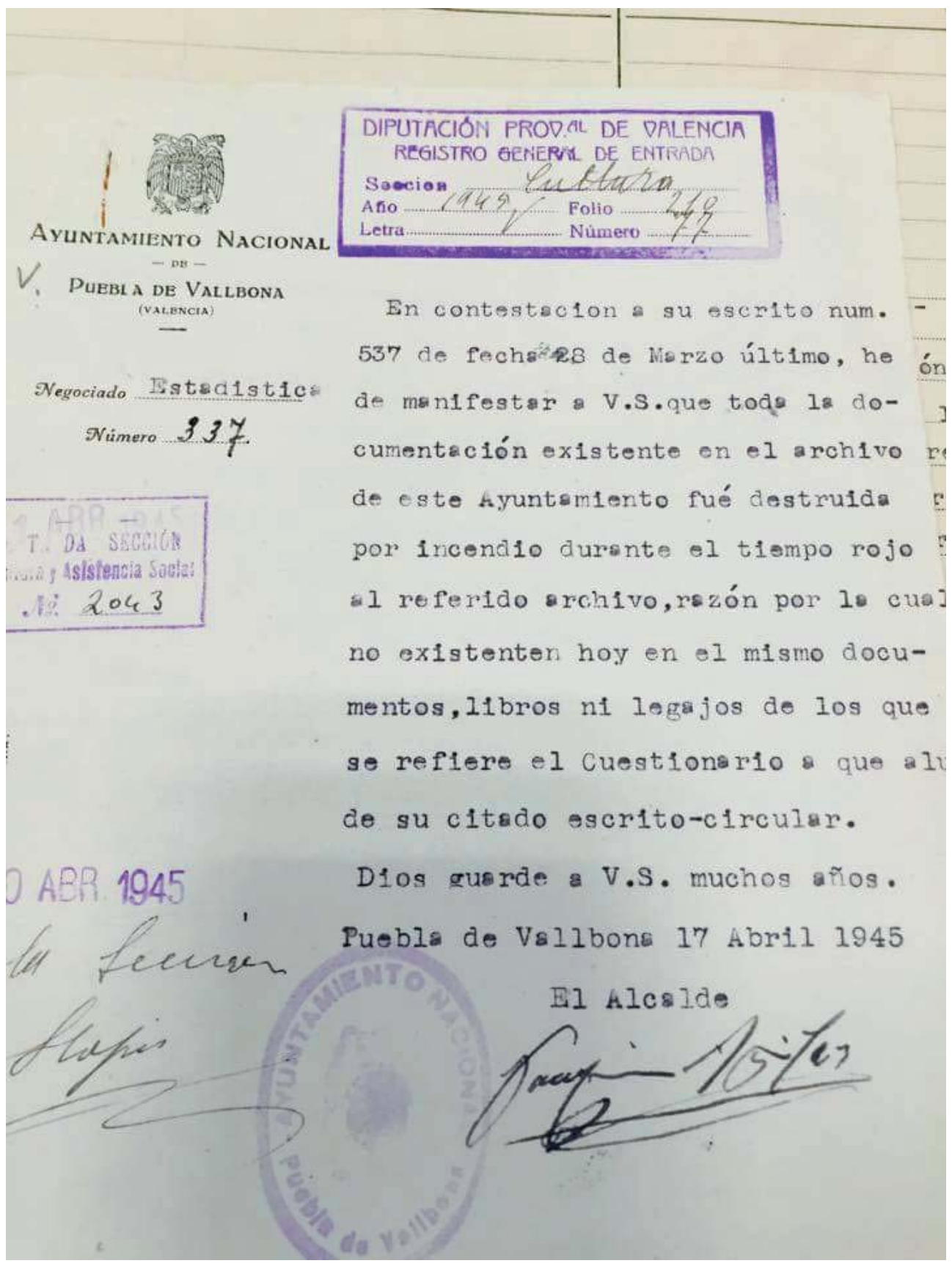




\section{A.5I Fichas de los municipios con los resultados}

\section{Datos de los catorce munic ipios valencianos estudiados:}

Ficha de datos históric os y bienes inmuebles

001 Vinaroz

\begin{tabular}{|c|c|c|c|}
\hline \multicolumn{4}{|c|}{ DATOS DE LA POBLACIÓN } \\
\hline Nombre actual & Vinaroz & Nombre original & Bynalaroç \\
\hline \multicolumn{2}{|c|}{ Hisn cerca del cual se construye } & \multicolumn{2}{|c|}{ Castillo de Peñiscola } \\
\hline Fundación & \multicolumn{3}{|l|}{1.241} \\
\hline Año Carta Puebla & 1.241 & Otorgante & Rey Jaime I \\
\hline Fuero & Zaragoza & Privilegios & \\
\hline Villa o Lloc & Villa & & \\
\hline Casas en 1490 & 152 & Casas en 1560 & 328 \\
\hline Notas & & & \\
\hline
\end{tabular}

\begin{tabular}{|c|c|c|c|c|c|}
\hline \multicolumn{6}{|l|}{ URBANISMO } \\
\hline \begin{tabular}{ll|} 
RAZÓN: & PERIMEIRO \\
CON LOS LADOS
\end{tabular} & \multicolumn{5}{|l|}{ 3:5 } \\
\hline LONGITUD & \multicolumn{2}{|l|}{$170,00 \mathrm{ml}$} & \multicolumn{2}{|l|}{ AMPபTUD } & $150 \mathrm{ml}$ \\
\hline \multicolumn{6}{|l|}{$\begin{array}{l}\text { SITUACIÓN DE LA } \\
\text { POBLA }\end{array}$} \\
\hline \multicolumn{6}{|l|}{ ANCHO DE CAШE } \\
\hline & \multicolumn{2}{|c|}{ Decamanus (Este- Oeste ml) } & \multicolumn{3}{|c|}{ Cardus ( Norte-Sur ml) } \\
\hline EJES & C/Mayor & 5,97 & \multicolumn{2}{|c|}{$\begin{array}{l}\text { C/ Purisima y C/ del } \\
\text { Rosario }\end{array}$} & 4,83 \\
\hline \multirow{3}{*}{ 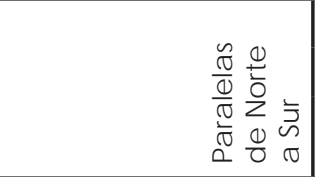 } & \multirow{3}{*}{\begin{tabular}{|ll} 
Travesía & San \\
Vic ente &
\end{tabular}} & \multirow[t]{3}{*}{$3,50 \mathrm{~m}$} & \multirow{3}{*}{ 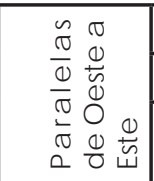 } & C/ San Roque & 2,93 \\
\hline & & & & C/ San Isidro & 3,82 \\
\hline & & & & $\begin{array}{l}\text { C/ Sanjuan y } \\
\text { C/ Santos }\end{array}$ & 4,95 \\
\hline
\end{tabular}




\begin{tabular}{|l|l|l|}
\hline COMPARATIVA & Aragón S.XI. J aca & Urbanismo en C.V. S. XIII \\
\hline MANZANAS & Iguales & \\
\hline LONGITUD MANZANAS & Doble o triple a ncho calle & De 15 a $20 \mathrm{~m}$ \\
\hline PARCELAS & Iguales & desigua les \\
\hline Frente de fachada & $4-5$ o 6 & 4,5 o $6 \mathrm{~m}$ \\
\hline Profundidad & Hasta $25 \mathrm{~m}$ & \\
\hline TIP. VIVIENDAS & Viv. Entre medianeras & \\
\hline MURAШA & No & si \\
\hline PLAZA CENTRAL & No, situada a la entrada & No, situada en la entrada \\
\hline NOTAS: & \\
\hline La población escuadrangular. & \\
\hline
\end{tabular}

\begin{tabular}{|c|c|c|c|}
\hline \multicolumn{4}{|l|}{ ARQUTIECTURA } \\
\hline $\begin{array}{l}\text { MURAШA O CERCA } \\
\text { Muraria }\end{array}$ & \multicolumn{3}{|l|}{$\mathrm{SI}$} \\
\hline Materiales & \multicolumn{3}{|l|}{ Tapial mixto } \\
\hline Altura & & Espesor & \\
\hline № de puertas & 2 & № de torres & 4, torres a ngulares \\
\hline $\begin{array}{l}\text { Construida al mismo } \\
\text { tiempo o posterior a } \\
\text { la fundación de la } \\
\text { puebla }\end{array}$ & \multicolumn{3}{|c|}{$\begin{array}{l}\text { Hugo de Folcalquer, maestre del Hospital levantaría "los muros y valls } \\
\text { cavats a la penya" en } 1.312 \text {. Se construyó después }\end{array}$} \\
\hline $\begin{array}{l}\text { CISTERNA } \\
\text { CENTRAL }\end{array}$ & & $\begin{array}{|ll|}\text { ERMITA } & \text { ARCOS } \\
\text { DIAFRAGMA } & \end{array}$ & \\
\hline $\begin{array}{l}\text { IGLESIA BÓVEDAS DE } \\
\text { CRUCERÍA }\end{array}$ & 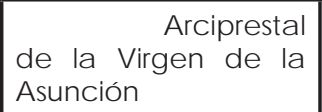 & \begin{tabular}{|l|} 
CASTIШO \\
INTRAMUROS
\end{tabular} & \\
\hline \multicolumn{4}{|l|}{ CRUCES DE TERMINO } \\
\hline \multicolumn{4}{|l|}{ NOTAS } \\
\hline \multicolumn{4}{|c|}{$\begin{array}{l}\text { En las afueras de la población destaca la Montaña del Puig, a unos seis kilómetros del casco } \\
\text { urbano, en la que aparte de poder disfrutar de su hemoso entomo natural, podemos visitar } \\
\text { varios edific ios religiosos como la Ermita de los Patronos de Vinaroz, o los vestigios históric os } \\
\text { del poblado ibérico. }\end{array}$} \\
\hline
\end{tabular}




\section{DIMENSIONES DE MANZANAS}

\begin{tabular}{|c|c|c|c|c|}
\hline Manzanas & Largo & Ancho & Profundidad & $\begin{array}{c}\text { Relación/ } \\
\text { largo-ancho }\end{array}$ \\
\hline 1 & 45,03 & 44,82 & 23,44 & 1,00 \\
\hline 2 & 29,27 & 42,00 & 12,47 & 1,43 \\
\hline 3 & 59,40 & 26,26 & 12,59 & 2,26 \\
\hline 4 & 90,20 & 18,27 & 18,27 & 4,94 \\
\hline 5 & 55,50 & 29,88 & 15,26 & 1,86 \\
\hline 6 & 91,96 & 30,69 & 16,09 & 3,00 \\
\hline 7 & 51,59 & 28,04 & 14,01 & 1,84 \\
\hline 8 & 95,14 & 28,89 & 14,21 & 3,29 \\
\hline 9 & 39,35 & 31,68 & 13,80 & 1,24 \\
\hline 10 & 62,74 & 29,70 & 15,34 & 2,11 \\
\hline 11 & 31,78 & 33,04 & 16,34 & 1,04 \\
\hline
\end{tabular}




\begin{tabular}{|l|l|l|l|}
\hline DATOS DE LA POBLACIÓN & Nombre original & $\begin{array}{l}\text { Alqueria de } \\
\text { Benimahomet }\end{array}$ \\
\hline Nombre actual & Castellón & Castillo de la Magdalena \\
\hline Hisn cerca del cual se construye & \multicolumn{3}{l|}{} \\
\hline Fundación & S.XIII & Otorgante & Rey Jaime I \\
\hline Año Carta Puebla & 1.259 & Privilegios & \\
\hline Fuero & Valencia & & \\
\hline Villa o Lloc & Villa real & & \\
\hline & & &
\end{tabular}

\section{URBANISMO}

\begin{tabular}{|c|c|c|c|}
\hline $\begin{array}{l}\text { RAZÓ N:PERIM ETRO } \\
\text { CON LOSLADOS }\end{array}$ & $3: 5$ & & \\
\hline LONGITUD & $\begin{array}{l}\text { 1‥ Recinto: } 300 \mathrm{~m} \\
\text { 2‥ Rec into(año 1.272): } 500 \mathrm{~m}\end{array}$ & AMPLTUD & $\begin{array}{l}\text { 1‥ Rec into:390 } \\
\text { 2o. Rec into: } 450 \mathrm{~m}\end{array}$ \\
\hline $\begin{array}{l}\text { SITUACIÓN DE LA } \\
\text { POBLA }\end{array}$ & \multicolumn{3}{|c|}{ J unto a la acequia mayor, en la parte no regable } \\
\hline
\end{tabular}

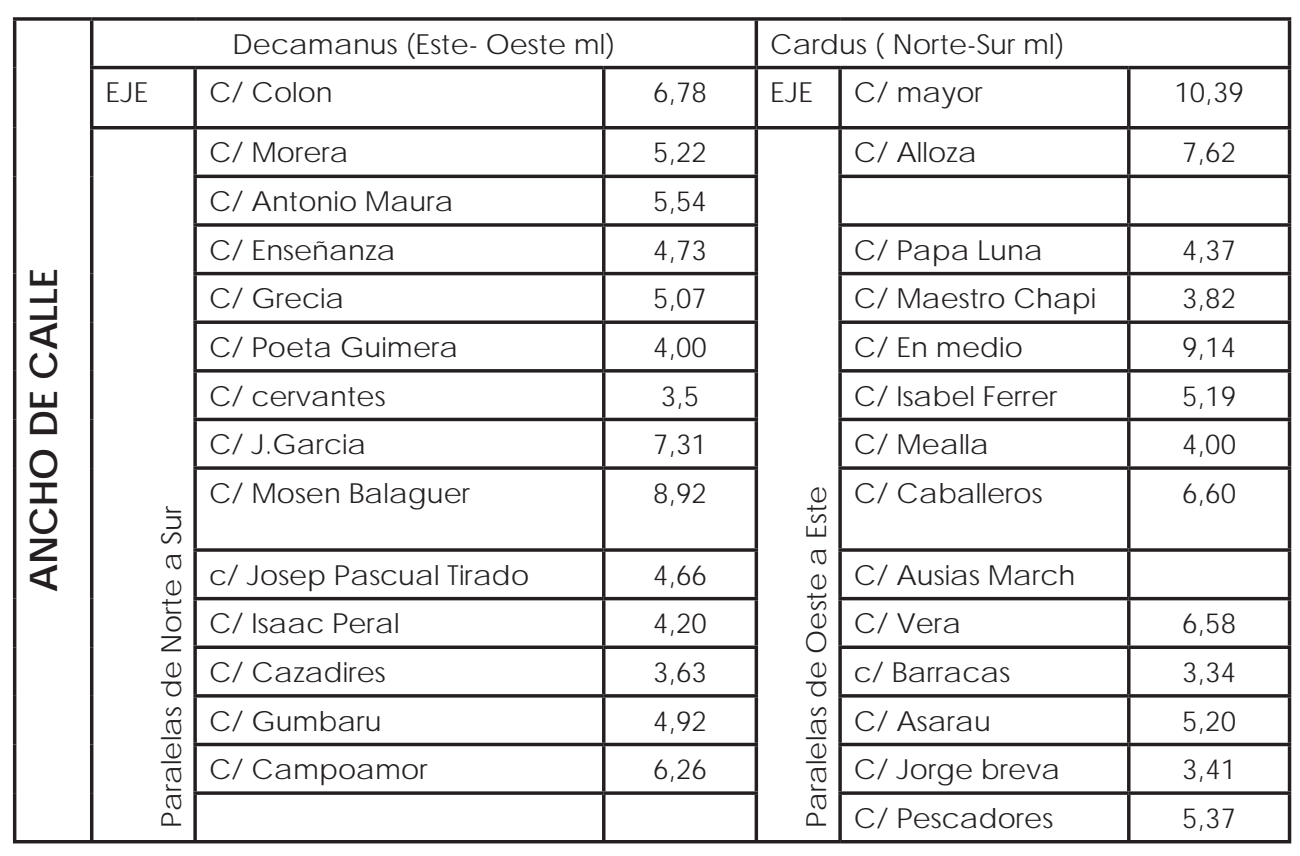




\begin{tabular}{|c|c|c|}
\hline COMPARATIVA & Aragón S.X.Jaca & Urbanismo en C.V. S. XIII \\
\hline MANZANAS & Iguales & Iguales \\
\hline LONGITUD MANZANAS & Doble o triple ancho calle & $\begin{array}{l}\text { Cuadradas, doble, triple, } \\
\text { incluso } 5 \text { veces mas es la } \\
\text { longitud respecto al ancho }\end{array}$ \\
\hline PARCELAS & Iguales & Desiguales \\
\hline Frente de fachada & $4-5 \circ 6$ & De 3,00 a $6,00 \mathrm{~m}$ \\
\hline Profundidad & Hasta $25 \mathrm{~m}$ & $\begin{array}{l}\text { Hasta } 25 \mathrm{~m} \text {. Pero hay varias } \\
\text { manzanas que llegan a } 30,00\end{array}$ \\
\hline TIP. VIVIENDAS & Viv. Entre medianeras & Viv. Entre medianeras \\
\hline MURAШA & No & $\mathrm{Si}$ \\
\hline PLAZA CENTRAL & No, situada a la entrada & \\
\hline NOTAS: & & \\
\hline \multicolumn{3}{|c|}{$\begin{array}{l}\text { La calle Mayor } 10 \mathrm{~m} \text {. El resto de paralelas desde } 5 \text { a } 9 \mathrm{~m} \text {. Lasperpendicula res desde } 3,5 \text { hasta } \\
7 \mathrm{~m} \text {. Parece como si se hubiera modificado la alineación original para ensancharen algunas } \\
\text { de lascalles. } \\
\text { Los nombres de las calles fueron cambiadas a principios de siglo, solo se quedaron, la calle } \\
\text { mayory la de en medio. }\end{array}$} \\
\hline \multicolumn{3}{|c|}{$\begin{array}{l}\text { Cuenta con calle Mayor, del Mig y calle de dalt ( d'amunt). En el } 1 \text { recinto la iglesia y el } \\
\text { cementerio se encuentran junto a una puerta de la muralla. En la a mpliación del } 20 \text { recinto, } \\
\text { quedan bastante centrados. } \\
\text { Cuenta con plaza central, donde estuvo la primitiva casa de la Vila }\end{array}$} \\
\hline
\end{tabular}

\begin{tabular}{|c|c|c|c|}
\hline \multicolumn{4}{|l|}{ ARQUITECTURA } \\
\hline $\begin{array}{l}\text { MURAШA O CERCA } \\
\text { Muraria }\end{array}$ & \multicolumn{3}{|l|}{$\mathrm{Si}$} \\
\hline Materiales & \multicolumn{3}{|l|}{ Tapial } \\
\hline Altura & & Espesor & \\
\hline № de puertas & $\begin{array}{l}4 \text { en origen, } \\
\text { posteriomente se } \\
\text { añadieron } 2\end{array}$ & № de torres & \\
\hline \multicolumn{2}{|c|}{$\begin{array}{l}\text { Construida al mismo tiempo o posterior a la } \\
\text { fundación de la puebla }\end{array}$} & \multicolumn{2}{|l|}{ Después en 1.390} \\
\hline $\begin{array}{l}\text { CISTERNA } \\
\text { CENTRAL }\end{array}$ & & $\begin{array}{ll}\text { ERMITA ARCOS } \\
\text { DIAFRAGMA }\end{array}$ & $\begin{array}{l}\text { Basílica del Ledo en } \\
\text { origen }\end{array}$ \\
\hline $\begin{array}{l}\text { IGLESIA BÓVEDAS DE } \\
\text { CRUCERIA }\end{array}$ & $\begin{array}{l}\text { Catedral de } \\
\text { Santa María }\end{array}$ & $\begin{array}{ll}\text { CASTLO } & \text { EN } \\
\text { INTRAMUROS }\end{array}$ & No \\
\hline \multicolumn{4}{|l|}{ CRUCESDE TERMINO } \\
\hline \multicolumn{4}{|c|}{ Se encuentra situada delante de la Emita del Ledo } \\
\hline \multicolumn{4}{|l|}{ NOTAS } \\
\hline \multicolumn{4}{|c|}{$\begin{array}{l}\text { Porta les en el siglo XIV. Portal de Valencia, portal de I'aigua, portal de I'Hospital, portal d'en } \\
\text { Ruvio i porital de la Fira. }\end{array}$} \\
\hline \multicolumn{4}{|c|}{ Contaba con foso que era denominado "el vall" } \\
\hline
\end{tabular}


DIMENSIONES DE MANZANAS

\begin{tabular}{|c|c|c|c|c|}
\hline Manzanas & Largo & Ancho & Profundidad & $\begin{array}{l}\text { Relación/ } \\
\text { largo-ancho }\end{array}$ \\
\hline 1 & 149,73 & 27,22 & 27,72 & 6 \\
\hline 2 & 72,87 & 31,24 & 31,24 & 2 \\
\hline 3 & 228,45 & 29,76 & 29,76 & 8 \\
\hline 4 & 26,30 & 66,70 & 12,70 & 3 \\
\hline 5 & 124,75 & 30,26 & 30,26 & 4 \\
\hline 6 & 73,58 & 27,65 & 27,65 & 3 \\
\hline 7 & 163,80 & 30,20 & 30,20 & 5 \\
\hline 8 & 126,80 & 29,62 & 29,62 & 4 \\
\hline 9 & 71,29 & 29,42 & 29,42 & 2 \\
\hline 10 & 161,59 & 30,54 & 30,54 & 5 \\
\hline 11 & 65,47 & 67,53 & 33,11 & 1 \\
\hline 12 & 50,41 & 62,83 & 30,99 & 1 \\
\hline 13 & 114,12 & 46,04 & 31,73 & 2 \\
\hline 14 & 62,45 & 78,28 & 32,00 & 1 \\
\hline 15 & 65,50 & 32,25 & 32,25 & 2 \\
\hline 16 & 87,73 & 60,20 & 30,37 & 1 \\
\hline 17 & 74,68 & 60,14 & 32,46 & 1 \\
\hline 18 & 70,96 & 54,26 & 20,93 & 1 \\
\hline 19 & 114,40 & 38,12 & 20,94 & 3 \\
\hline 20 & 50,17 & 30,02 & 15,57 & 2 \\
\hline 21 & 55,85 & 39,33 & 24,18 & 1 \\
\hline 22 & 48,80 & 36,00 & 26,85 & 1 \\
\hline 23 & 42,30 & 28,03 & 28,02 & 2 \\
\hline 24 & 42,68 & 43,66 & 30,50 & 1 \\
\hline 25 & 42,55 & 67,14 & 21,92 & 2 \\
\hline 26 & 33,60 & 70,10 & 17,77 & 2 \\
\hline 27 & 49,84 & 65,91 & 33,56 & 1 \\
\hline 28 & 48,70 & 65,57 & 28,53 & 1 \\
\hline 29 & 49,17 & 62,50 & 20,16 & 1 \\
\hline 30 & 77,38 & 27,74 & 27,44 & 3 \\
\hline 31 & 64,31 & 97,63 & 22,35 & 2 \\
\hline 32 & 51,64 & 83,70 & 19,13 & 2 \\
\hline 33 & 31,66 & 60,58 & 31,66 & 2 \\
\hline 34 & 57,58 & 40,60 & 27,31 & 1 \\
\hline 35 & 18,06 & 61,04 & 18,06 & 3 \\
\hline 36 & 27,83 & 105,40 & 18,00 & 4 \\
\hline 37 & 37,10 & 128,97 & 37,00 & 3 \\
\hline 38 & 142,69 & 22,62 & 22,62 & 6 \\
\hline
\end{tabular}




\begin{tabular}{|c|c|c|c|}
\hline \multicolumn{4}{|c|}{ DATOS DE LA POBLACIÓN } \\
\hline NOMBRE ACTUAL & Villa-real & NOMBRE ORIG INAL & Villa-real \\
\hline \multicolumn{2}{|c|}{ Hisn o castillo cerca del cual se construye } & \multicolumn{2}{|l|}{ Medina de Bomiana } \\
\hline FUNDACIÓN & \multicolumn{3}{|l|}{20 de febrero de 1.274} \\
\hline $\begin{array}{l}\text { AÑO CARTA } \text { PUEBLA } \\
\text { O PRIVILEGIO } \\
\text { FUNDACIÓN }\end{array}$ & \multicolumn{3}{|l|}{1274} \\
\hline FUERO & \begin{tabular}{|l|} 
Zaragoza ( en el año \\
1.330 adopta los de \\
Valencia)
\end{tabular} & OTORGANTE & Rey J a ime I \\
\hline VIШA O ШOC & Villa real & & \\
\hline Casasen 1490 & 350 & Casas en 1560 & 327 \\
\hline \multicolumn{4}{|l|}{ NOTAS } \\
\hline \multicolumn{4}{|c|}{$\begin{array}{l}\text { La novedad viene subrayada por el propio topónimo, acuñado para la ocasión, aunque } \\
\text { no se trata, en absoluto, de una práctica frecuente. Lo nomal es que las fundaciones } \\
\text { nuevas mantengan el nombre del hisn en cuyo temitorio se implantan. Las villas, en efecto, } \\
\text { no se conciben únicamente en su calidad de núcleos urbanos («pueblas»), sino también } \\
\text { como unidades temitoriales delimitadas con precisión, al igual que los castra (castillos con } \\
\text { término). Si Vila-real adopta un nombre inédito es porque su témino se constituye como } \\
\text { una segregación del distrito original de Bomiana, no tanto para resaltar lo novedoso de su } \\
\text { planificación urbana; }\end{array}$} \\
\hline
\end{tabular}

\begin{tabular}{|l|l|l|l|}
\hline \multicolumn{4}{|l|}{ URBANISMO } \\
\hline $\begin{array}{l}\text { RAZÓN DEL } \\
\text { PERÍMEIRO CON LOS } \\
\text { LADOS }\end{array}$ & $3: 5$ & $190 \mathrm{ml}$ \\
\hline LONGITUD & $380 \mathrm{ml}$ & AMPUTUD & $\begin{array}{l}\text { Se fundó en el valle junto a un acequia nueva, en la cota } \\
\text { inmediatamente superiorno regable }\end{array}$ \\
\hline $\begin{array}{l}\text { SITUACIÓN DE } \\
\text { POBLA }\end{array}$
\end{tabular}

\begin{tabular}{|l|l|l|}
\hline COMPARATIVA & Aragón S.XI. J aca & Urba nismo en C.V. S. XIII \\
\hline MANZANAS & Iguales & Iguales a proximadamente \\
\hline LONGITUD MANZANAS & Doble o triple ancho calle & $\begin{array}{l}\text { Cuadradas, el doble o el triple del } \\
\text { ancho de la manzana. }\end{array}$ \\
\hline PARCELAS & Iguales & Desiguales \\
\hline Frente de fachada & $4-5$ o 6 & De 3 a $6,00 \mathrm{~m}$ \\
\hline Profundidad & Hasta $25 \mathrm{~m}$ & Hasta $25 \mathrm{~m}$. \\
\hline TIP. VIVIENDAS & Viv. Entre medianeras & Viv. Entre medianeras \\
\hline MURAШA & No & Si \\
\hline PLAZA CENTRAL & No, situada a la entrada & Si, a porticada \\
\hline NOTAS: & \\
\hline $\begin{array}{l}\text { Las calles principales se disponen para lelasa la calle mayor. } \\
\text { La mayoría de las viviendas solo tiene acceso por una de las calles }\end{array}$ \\
\hline
\end{tabular}




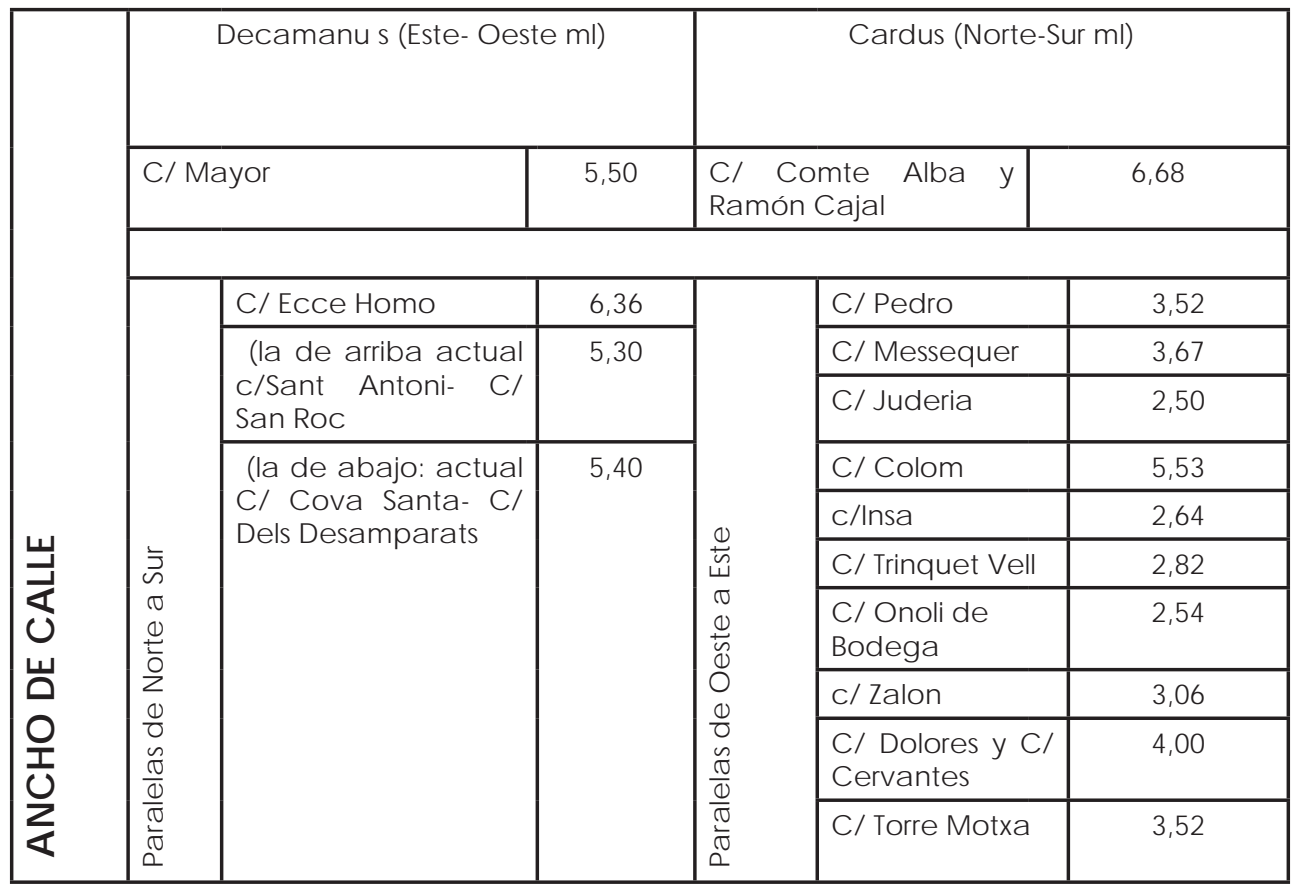

\begin{tabular}{|c|c|c|c|}
\hline \multicolumn{4}{|l|}{ ARQUITECTURA } \\
\hline $\begin{array}{l}\text { MURAШA O CERCA } \\
\text { Muraria }\end{array}$ & \multicolumn{3}{|l|}{$\mathrm{Si}$} \\
\hline Materiales & \multicolumn{3}{|c|}{$\begin{array}{l}\text { Fueron construidas con mampostería de piedra de la comarca } \\
\text { unida por argamasa y en el tramo conservado de la Casa de I'Oli } \\
\text { está levantado en sillenía }\end{array}$} \\
\hline Altura & & Espesor & $0,75 \mathrm{~m}$ \\
\hline № de puertas & 4 & № de torres & 4 \\
\hline \multicolumn{3}{|c|}{ Construida al mismo tiempo o posteriora la fundación de la puebla } & Desde el siglo XIII \\
\hline $\begin{array}{lll}\text { CISTERNA } & \text { O POZO } \\
\text { CENTRAL } & & \end{array}$ & $\mathrm{Si}$ & $\begin{array}{|ll|}\text { ERMITA } & \text { ARCOS } \\
\text { DIAFRAGMA } & \end{array}$ & $\begin{array}{l}\text { Situada a dos Km. de } \\
\text { la población, y en un } \\
\text { promontorio a orillas } \\
\text { del nío Mijares, el } \\
\text { Emitorio de Nuestra } \\
\text { Señora de Gracia es } \\
\text { del s-XVI }\end{array}$ \\
\hline $\begin{array}{l}\text { IGLESIA BÓVEDAS DE } \\
\text { CRUCERIAA }\end{array}$ & ---- & \begin{tabular}{|l|} 
CASTILO \\
INTRAMUROS \\
\end{tabular} & No \\
\hline CRUCESDE TERMINO & & & \\
\hline
\end{tabular}




\section{NOTAS}

La muralla contaba porsu lado exterior con un foso (el vall), que en condicionesnomalesera tan solo una depresión sin agua.

Las 4 puertas básicas (portal de Castelló, d 'Onda, de Valencia i del Mig), opuestos dosa dos como extremos de las dos calles principales que se cruzaban en la Plaza mayor. En el siglo $X V$, se construyeron 4 portales mas.

Dos principales arterías, perpendiculares entre sí, dividen la población en cuatro cuarteles iguales. Doscalles (la de a miba y abajo) se disponen paralelasa la calle mayor (que coincidió con el nuevo trazado del camino real Valencia-Tortosa).

Este cruce via rio daba lugara cua tro "quarters" exactosque tenían funciones de organización vecinal en "deenes" y de representación de los consejeros municipales, pero no religiosas, ya que tan solo existe una parroquia.

En la confluencia de las dos principales calles perpendiculares se sitúa la plaza. Esta es de planta cuadrada y en sus frentes lleva porches fomados por arcos apuntados de piedra. En la plaza se ubicaba la casa de la villa, los hostales, el almudín y en ella se celebraba la feria. De la población medieval queda actualmente el trazado urbano, parte de la plaza porticada, fragmentos de la muralla y una de lastorresangulares (la torre Motxa)

La iglesia se encuentra en un lateral junto a la muralla, aunque dando a una de las calles principales.

La planta se completaba con otras cuatro calles que partían los "quarters" y de las que destacaban las dos mas largas: el ca rer d 'Amunt i el d'avall.

La plaza Jaime I El Conquistador, es uno de los escasos ejemplos de plazas porticadas que se conservan, junto con Onda. Está declarada BIC 


\section{DIMENSIONES DE MANZANAS}

\begin{tabular}{|c|c|c|c|c|}
\hline Manzanas & Largo & Ancho & Profundidad & $\begin{array}{c}\text { Relación/ } \\
\text { largo-ancho }\end{array}$ \\
\hline 1 & 70,78 & 22,92 & 22,92 & 3 \\
\hline 2 & 96,98 & 22,92 & 22,92 & 4 \\
\hline 3 & 88,69 & 26,39 & 26,39 & 3 \\
\hline 4 & 65,69 & 24,27 & 24,77 & 3 \\
\hline 5 & 17,62 & 48,07 & 27,64 & 3 \\
\hline 6 & 54,47 & 47,19 & 20,74 & 1 \\
\hline 7 & 40,80 & 47,29 & 20,00 & 1 \\
\hline 8 & 47,17 & 49,48 & 21,93 & 1 \\
\hline 9 & 40,94 & 48,04 & 17,64 & 1 \\
\hline 10 & 44,00 & 47,71 & 17,31 & 1 \\
\hline 11 & 54,15 & 46,90 & 20,61 & 1 \\
\hline 12 & 15,64 & 48,68 & 15,64 & 3 \\
\hline 13 & 36,31 & 49,28 & 26,57 & 1 \\
\hline 14 & 42,37 & 50,51 & 26,90 & 1 \\
\hline 15 & 54,13 & 49,04 & 26,35 & 1 \\
\hline 16 & 32,33 & 49,04 & 19,26 & 2 \\
\hline 17 & 40,89 & 49,16 & 19,94 & 1 \\
\hline 18 & 16,96 & 30,01 & 13,62 & 2 \\
\hline 19 & 22,94 & 45,07 & 11,63 & 2 \\
\hline 20 & 29,58 & 20,96 & 17,94 & 1 \\
\hline 21 & 33,21 & 30,94 & 18,60 & 1 \\
\hline 22 & 46,82 & 11,64 & 11,63 & 4 \\
\hline 23 & 32,93 & 47,00 & 24,62 & 1 \\
\hline 24 & 45,88 & 20,67 & 20,92 & 2 \\
\hline 25 & 44,95 & 30,22 & 21,62 & 1 \\
\hline 26 & 94,32 & 46,94 & 21,77 & 2 \\
\hline 27 & 47,05 & 39,21 & 18,60 & 1 \\
\hline 28 & 42,42 & 19,93 & 19,93 & 2 \\
\hline
\end{tabular}




\section{DATOS DE LA POBLACIÓN}

\begin{tabular}{|c|c|c|c|}
\hline NOMBRE ACTUAL & Mascarell & NOMBRE ORIG INAL & $\begin{array}{l}\text { Campamento en } \\
\text { árabe }\end{array}$ \\
\hline \multicolumn{3}{|c|}{ Hisn o castillo cerca del cual se construye } & Buriana \\
\hline FUNDACIÓN & \multicolumn{3}{|l|}{ S.XIV (1.233) } \\
\hline $\begin{array}{l}\text { AÑO CARTA PUEBLA } \\
\text { O PRIVILEGIO DE } \\
\text { FUNDACIÓN }\end{array}$ & \multicolumn{3}{|l|}{1276} \\
\hline \multicolumn{4}{|l|}{ NOTAS } \\
\hline \multicolumn{4}{|c|}{ 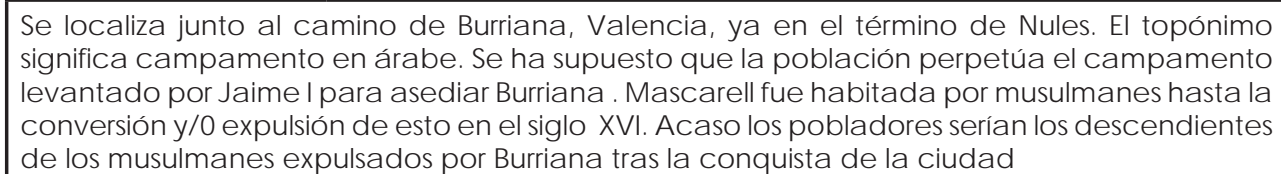 } \\
\hline
\end{tabular}

\section{URBANISMO}

\begin{tabular}{l|l|l|l|}
\hline $\begin{array}{l}\text { RAZÓ N DEL PERÍMEIRO } \\
\text { CON LOSLADOS }\end{array}$ & $5: 3$ \\
\hline LONG ITUD & $179,6 \mathrm{ml}$ & AMPLTUD & $121,52 \mathrm{ml}$ \\
\hline SITUACIÓN DE LA POBLA & $\begin{array}{l}\text { J unto a la acequia de Mascarell, marcha paralela a } \\
\text { la muralla }\end{array}$ \\
\hline
\end{tabular}

\begin{tabular}{|l|l|l|}
\hline COMPARATIVA & Aragón S.XI. J aca & Urbanismo en C.V. S. XIII \\
\hline MANZANAS & Iguales & Desiguales \\
\hline LONGITUD MANZANAS & Doble o triple ancho calle & $\begin{array}{l}\text { Doble y triple el ancho de la } \\
\text { manzana. Hay un caso de 8 } \\
\text { veces mas }\end{array}$ \\
\hline PARCELAS & No iguales \\
\hline Frente de fachada & Iguales & $\begin{array}{l}3,65 \text { a } 4,00 ~ m \text { las mas } \\
\text { numerosas }\end{array}$ \\
\hline Profundidad & $4-5$ o 6 & Hasta 25 m \\
\hline TIP. VIVIENDAS & Hasta 25 m & Viv. Entre medianeras \\
\hline MURAШA & Viv. Entre medianeras & Si \\
\hline PLAZA CENTRAL & No & Si, en el centro \\
\hline NOTAS: & No, situada a la entrada \\
\hline $\begin{array}{l}\text { La población escuadrangular. } \\
\text { Se desa molló alrededor de una desaparecida tore central que es citada en antiguos } \\
\text { documentos }\end{array}$ & \\
\hline
\end{tabular}




\begin{tabular}{|c|c|c|c|c|c|c|}
\hline \multirow{6}{*}{ 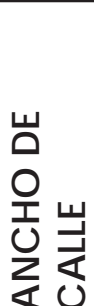 } & \multicolumn{3}{|c|}{ Decamanus (Este- Oeste ml) } & \multicolumn{3}{|c|}{ Cardus (Norte-Sur ml) } \\
\hline & \multirow[t]{2}{*}{ EJE } & \multirow[t]{2}{*}{ C/ Mayor } & \multirow[t]{2}{*}{3,53} & \multirow[t]{2}{*}{ EHE } & C/ Cueva Santa & 4,30 \\
\hline & & & & & C/ San Roque & 3,19 \\
\hline & \multirow{3}{*}{ 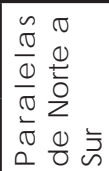 } & C/ San Roque & 4,20 & \multirow{3}{*}{ 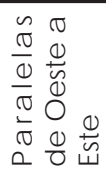 } & \multirow{2}{*}{$\begin{array}{l}\text { Calle lindante a la } \\
\text { muralla }\end{array}$} & 3,95 \\
\hline & & C/ San Miguel & 4,19 & & & \\
\hline & & C/ Cueva & 4,70 & & $\begin{array}{l}\text { Travesía C/ Cueva y } \\
\text { Virgen del Camen }\end{array}$ & 4,03 \\
\hline
\end{tabular}

\begin{tabular}{|c|c|c|c|}
\hline \multicolumn{4}{|l|}{ ARQUITECTURA } \\
\hline $\begin{array}{l}\text { MURAШA O CERCA } \\
\text { Muraria }\end{array}$ & \multicolumn{3}{|l|}{$\mathrm{SI}$} \\
\hline Materiales & \multicolumn{3}{|l|}{ Tapial mixto } \\
\hline Altura & ----- & Espesor & $125 \mathrm{~cm}$ \\
\hline № de puertas & $\begin{array}{l}2(\text { anchura } 2,50 \mathrm{~m} \mathrm{y} \\
\text { la otra } 2,25 \mathrm{~m})\end{array}$ & № de torres & 4 \\
\hline \multicolumn{2}{|c|}{$\begin{array}{l}\text { Construida al mismo tiempo o posterior a la } \\
\text { fundación de la puebla }\end{array}$} & $\begin{array}{l}\text { No. A mediados del } \\
\text { siglo XVI. }\end{array}$ & \\
\hline $\begin{array}{l}\text { CISTERNA } \\
\text { C O POZO } \\
\text { CENTRAL }\end{array}$ & - & \begin{tabular}{ll|} 
ERMITA & ARCOS \\
DIAFRAGMA
\end{tabular} & \begin{tabular}{|l} 
Emita de la Font \\
Santa
\end{tabular} \\
\hline $\begin{array}{l}\text { IGLESIA BÓVEDAS DE } \\
\text { CRUCERÍA }\end{array}$ & \begin{tabular}{|l|} 
Iglesia de Santa \\
Catanina
\end{tabular} & \begin{tabular}{ll|} 
CASTILO & EN \\
INTRAMUROS
\end{tabular} & No \\
\hline \multicolumn{4}{|l|}{ CRUCES DE TERMINO } \\
\hline \multicolumn{4}{|l|}{$\begin{array}{c}--- \\
---\end{array}$} \\
\hline \multicolumn{4}{|l|}{ NOTAS } \\
\hline \multicolumn{4}{|c|}{ Lavadero en el exterior de las murallas. } \\
\hline \multicolumn{4}{|c|}{ La iglesia se encuentra en la plaza, en el centro del municipio } \\
\hline
\end{tabular}

\section{DIMENSIONES DE MANZANAS}

\begin{tabular}{|c|c|c|c|c|}
\hline Manzanas & Largo & Ancho & Profundidad & $\begin{array}{l}\text { Relación/ } \\
\text { largo-ancho }\end{array}$ \\
\hline 1 & 103,91 & 30,02 & 15,40 & 3 \\
\hline 2 & 60,41 & 31,51 & 16,39 & 2 \\
\hline 3 & 93,16 & 33,58 & 19,00 & 3 \\
\hline 4 & 64,65 & 20,48 & 13,73 & 3 \\
\hline 5 & 45,14 & 26,30 & 11,45 & 2 \\
\hline 6 & 119,8 & 15,01 & 15,01 & 8 \\
\hline 7 & 95,51 & 21,51 & 21,51 & 4 \\
\hline 8 & 72,01 & 13,56 & 13,56 & 5 \\
\hline 9 & 38,34 & 18,78 & 18,78 & 2 \\
\hline 10 & 60,00 & 24,25 & 24,25 & 2 \\
\hline
\end{tabular}




\section{DATOS DE LA POBLACIÓN}

\begin{tabular}{|c|c|c|c|}
\hline NOMBRE ACTUAL & Nules & NOMBRE ORIG INAL & La Pobla de Nules \\
\hline \multicolumn{2}{|c|}{ Hisn o castillo cerca del cual se construye } & \multicolumn{2}{|c|}{$\begin{array}{l}\text { Cerca del castillo musulmán de Villavieja de } \\
\text { Nules. Actual Vila Vella }\end{array}$} \\
\hline FUNDACIÓN & \multicolumn{3}{|l|}{ S.XIV } \\
\hline $\begin{array}{l}\text { AÑO CARTA PUEBLA } \\
\text { O PRIVILEGIO DE } \\
\text { FUNDACIÓN }\end{array}$ & \multicolumn{3}{|l|}{1.254} \\
\hline FUERO & Valencia & OTORGANTE & Guillem de Montc ada \\
\hline VIШA O ШOC & Villa-Real & & \\
\hline Casasen 1490 & 248 & Casasen 1560 & 220 \\
\hline
\end{tabular}

\section{URBANISMO}

\begin{tabular}{l|l|l|l|}
\hline RAZÓN DEL PERÍMEIRO CON LOS LADOS & $3: 5$ & \\
\hline LONGITUD & $298,00 \mathrm{ml}$ & AMPUTUD & $279,20 \mathrm{ml}$ \\
\hline $\begin{array}{l}\text { SITUACIÓN DE LA } \\
\text { POBLA }\end{array}$ & $\begin{array}{l}\text { Se fundó junto a un acequia nueva, en la cota inmediatamente } \\
\text { superior no regable. }\end{array}$ \\
\hline
\end{tabular}

\begin{tabular}{|l|l|l|}
\hline COMPARATIVA & Aragón S.X. J aca & Urbanismo en C.V. S. XIII \\
\hline MANZANAS & Iguales & lguales \\
\hline LONG ITUD MANZANAS & Doble o triple a nc ho calle & Cuadradadas \\
\hline PARCELAS & Iguales & Desiguales \\
\hline Frente de fachada & $4-5$ o 6 & De 5 a $6 \mathrm{~m}$ \\
\hline Profundidad & Hasta $25 \mathrm{~m}$ & Hasta $21 \mathrm{~m}$ \\
\hline TIP. VIVIENDAS & Viv. Entre medianeras & Viv. Entre medianeras \\
\hline MURAШA & No & $\mathrm{Si}$ \\
\hline PLAZA CENTRAL & No, situada a la entrada & $\mathrm{Si}$ \\
\hline NOTAS: & & \\
\hline La calle principal es la calle Mayor. & \\
\hline $\begin{array}{l}\text { A diferencia de Villa-Real lascalles principales se disponen perpendiculares a la calle mayor- } \\
\text { camino ral. Lascalles en paralelo a la calle mayor-tra vesseres-ca reen de puertas de acceso } \\
\text { a las viviendas. }\end{array}$ \\
\hline
\end{tabular}




\begin{tabular}{|c|c|c|c|c|c|c|}
\hline \multirow{7}{*}{ 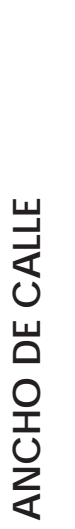 } & \multicolumn{3}{|c|}{ Decamanus (Este- Oeste ml) } & \multicolumn{3}{|c|}{ Cardus ( Norte-Sur ml) } \\
\hline & EJE & $\begin{array}{l}\text { C/ Matias Torrejon y } \\
\text { C/ San Francisco }\end{array}$ & 5,73 & EJE & C/ Mayor & 6,50 \\
\hline & \multirow{5}{*}{ 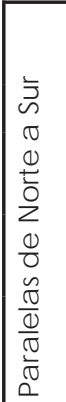 } & $\begin{array}{l}\text { C/ San Antonio y C/ } \\
\text { del Rosario }\end{array}$ & 4,25 & \multirow{5}{*}{ 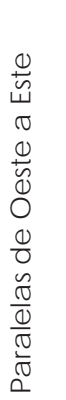 } & \multirow[t]{2}{*}{ C/ San J osé } & \multirow[t]{2}{*}{4,55} \\
\hline & & C/ Pedro Alcazar & 4,60 & & & \\
\hline & & $\begin{array}{l}\text { C/ J ose Beltran y C/ } \\
\text { San Blas }\end{array}$ & 4,82 & & C/ San Felix & 5,50 \\
\hline & & $\begin{array}{l}\text { C/ San Roque y C/ } \\
\text { San Miguel }\end{array}$ & 4,60 & & \multirow[t]{2}{*}{$\begin{array}{l}\text { C/ Virgen de la } \\
\text { Soledad }\end{array}$} & \multirow[t]{2}{*}{4,66} \\
\hline & & $\begin{array}{l}\text { C/ Gilverto Centelles } \\
\text { y C/ Virgen de los } \\
\text { angeles }\end{array}$ & 4,50 & & & \\
\hline
\end{tabular}

\begin{tabular}{|c|c|c|c|}
\hline \multicolumn{4}{|l|}{ ARQUITECTURA } \\
\hline \multicolumn{2}{|c|}{ MURAШA O CERCA Muraria } & \multicolumn{2}{|l|}{$\mathrm{Sl}$} \\
\hline \multirow{2}{*}{$\begin{array}{l}\text { Materiales } \\
\text { Altura }\end{array}$} & \multicolumn{3}{|l|}{ Tapia } \\
\hline & & Espesor & \\
\hline № de puertas & $\begin{array}{l}\text { 4, dos de ellas } \\
\text { p rinc i p a l e s, } \\
\text { defendida por dos } \\
\text { torreones que por } \\
\text { circunstancias tienen } \\
\text { másdiámetro }\end{array}$ & № de torres & 26 de cal y canto \\
\hline \multicolumn{4}{|c|}{$\begin{array}{l}\text { Construida al mismo tiempo o posterior a la } \\
\text { fundación de la puebla }\end{array}$} \\
\hline $\begin{array}{l}\text { CISTERNA O POZO } \\
\text { CENTRAL }\end{array}$ & ---- & \begin{tabular}{|ll} 
ERMITA & ARCOS \\
DIAFRAGMA &
\end{tabular} & $\begin{array}{l}\text { Actual museo de } \\
\text { historia. Iglesia de la } \\
\text { Sang }\end{array}$ \\
\hline $\begin{array}{l}\text { IGLESIA BÓVEDAS DE } \\
\text { CRUCERÍA }\end{array}$ & $\begin{array}{l}\text { Iglesia arciprestal } \\
\text { de san Bartolomé y } \\
\text { san Jaime. S.XIII }\end{array}$ & \begin{tabular}{|l|} 
CASTILO \\
INTRAMUROS
\end{tabular} & No \\
\hline \multicolumn{4}{|l|}{ CRUCES DE TERMINO } \\
\hline \multicolumn{4}{|l|}{---} \\
\hline \multicolumn{4}{|l|}{ NOTAS } \\
\hline \multicolumn{4}{|c|}{ La iglesia se encuentra en la en la plaza. } \\
\hline \multicolumn{4}{|c|}{ En el año 1887 se produjo el demibo de sus murallas } \\
\hline \multicolumn{4}{|c|}{$\begin{array}{l}\text { No contaban las murallascon foso, como queda documenta do que durante la guema de las } \\
\text { Gemanías, Nules fue cuartel general de las tropas realistas, pero a pesar de ser una de las } \\
\text { poblaciones más fortific adas de la zona, las tropas tuvieron que trasladarse a Bomana, dado } \\
\text { que, al no tener fosos, la villa de Nules no ofrecía seguridad. }\end{array}$} \\
\hline \multicolumn{4}{|c|}{$\begin{array}{l}\text { El Archivo Histórico de Nules guarda un importante fondo documental sobre la vida del } \\
\text { municipio desde mediadosdel siglo XVI hasta iniciosdel siglo XX; son de destacarlassecciones } \\
\text { de "Manuals de Consell", "Aigües" y los expedientes de reconstrucción y demibo de murallas. }\end{array}$} \\
\hline
\end{tabular}


DIMENSIONES DE MANZANAS

\begin{tabular}{|c|c|c|c|c|}
\hline Manzanas & Largo & Ancho & Profundidad & $\begin{array}{c}\text { Relación/ } \\
\text { largo-ancho }\end{array}$ \\
\hline 1 & 124,34 & 43,35 & 30,98 & 3 \\
\hline 2 & 54,93 & 38,91 & 17,41 & 1 \\
\hline 3 & 56,94 & 41,22 & 21,00 & 1 \\
\hline 4 & 56,94 & 41,22 & 21,00 & 1 \\
\hline 5 & 57,24 & 40,76 & 20,77 & 1 \\
\hline 6 & 57,82 & 40,08 & 19,11 & 1 \\
\hline 7 & 123,44 & 20,67 & 20,67 & 6 \\
\hline 8 & 62,03 & 40,45 & 19,82 & 2 \\
\hline 9 & 61,41 & 40,20 & 19,56 & 2 \\
\hline 10 & 62,03 & 40,26 & 19,43 & 2 \\
\hline 11 & 61,14 & 41,26 & 20,97 & 1 \\
\hline 12 & 60,26 & 41,33 & 24,97 & 1 \\
\hline 13 & 43,52 & 41,19 & 26,97 & 1 \\
\hline 14 & 43,93 & 41,55 & 23,38 & 1 \\
\hline 15 & 44,85 & 41,29 & 21,06 & 1 \\
\hline 16 & 44,94 & 40,73 & 19,70 & 1 \\
\hline 17 & 44,13 & 40,69 & 15,00 & 1 \\
\hline 18 & 43,12 & 41,86 & 21,00 & 1 \\
\hline 19 & 44,00 & 40,71 & 28,88 & 1 \\
\hline 20 & 43,85 & 41,41 & 28,67 & 1 \\
\hline 21 & 44,46 & 40,58 & 31,53 & 1 \\
\hline 22 & 43,87 & 40,05 & 27,65 & 1 \\
\hline 23 & 44,82 & 40,46 & & 1 \\
\hline 24 & 45,89 & 38,00 & 19,36 & 1 \\
\hline 25 & 50,86 & 40,32 & 20,11 & 1 \\
\hline 26 & 51,03 & 41,54 & 20,23 & 1 \\
\hline 27 & 49,57 & 39,69 & 20,50 & 1 \\
\hline 28 & 20,23 & 40,59 & 20,47 & 2 \\
\hline 29 & 50,00 & 87,69 & 16,36 & 2 \\
\hline 30 & 49,75 & 35,91 & 19,22 & 1 \\
\hline 31 & 43,87 & 37,00 & 18,41 & 1 \\
\hline 9 & 29,4 & 35,41 & Nuevo & 1 \\
\hline 10 & 61,13 & 20,57 & 20,57 & 3 \\
\hline 11 & 39,25 & 20,6 & 20,6 & 2 \\
\hline 12 & 80,18 & 19,36 & 19,36 & 4 \\
\hline 13 & 76,63 & 40,68 & 27,27 & 2 \\
\hline
\end{tabular}




\begin{tabular}{|c|c|c|c|c|}
\hline 14 & 67,00 & 37,24 & 24,16 & 2 \\
\hline 15 & 30,63 & 30,82 & 16,72 & 1 \\
\hline 16 & 96,06 & 36,82 & 19,62 & 3 \\
\hline 17 & 74,96 & 45,12 & 24,85 & 2 \\
\hline 18 & 55,93 & 45,12 & 24,85 & 1 \\
\hline 19 & 59,90 & 47,08 & Nuevas & 1 \\
\hline 20 & 49,80 & 44,05 & 24,07 & 1 \\
\hline 21 & 92,01 & 39,58 & 19,85 & 2 \\
\hline
\end{tabular}




\section{DATOS DE LA POBLACIÓN}

\begin{tabular}{|c|c|c|c|}
\hline Nombre actual & Almenara & Nombre original & \\
\hline \multicolumn{2}{|c|}{ Hisn cerca del cual se construye } & \multicolumn{2}{|c|}{ A los pies del castillo musulmán } \\
\hline Fundación & S.XIII. & & \\
\hline \multicolumn{2}{|l|}{ Año Carta Puebla } & 1238 & \\
\hline Casasen 1490 & 108 & Casasen 1560 & 134 \\
\hline
\end{tabular}

\section{URBANISMO}

\begin{tabular}{|c|c|c|c|}
\hline \multicolumn{3}{|c|}{ RAZÓN DEL PERÍMEIRO CON LOS LADOS } & 3:5 \\
\hline LONGITUD & $264,00 \mathrm{ml}$ & AMPUTUD & $147,00 \mathrm{ml}$ \\
\hline $\begin{array}{l}\text { SITUACIÓN DE LA } \\
\text { POBLA }\end{array}$ & Te & $\mathrm{r}$ & \\
\hline
\end{tabular}

\begin{tabular}{|c|c|c|c|c|c|c|}
\hline \multirow{3}{*}{ 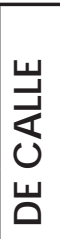 } & \multicolumn{3}{|c|}{ Decamanus (Este- Oeste ml) } & \multicolumn{3}{|c|}{ Cardus (Norte- Sur ml) } \\
\hline & EJE & C/ Dels SantsJ oan & 5,00 & EJE & c/ Dr. Berenguer & 4,70 \\
\hline & \multirow{4}{*}{ 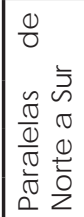 } & C/ D’enmig & 4,00 & \multirow{4}{*}{ 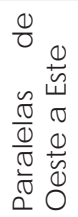 } & C/ De les Roques & 4,26 \\
\hline 오 & & \multirow[t]{3}{*}{ c/ de Dalt } & \multirow{3}{*}{$\begin{array}{c}3,50 \mathrm{a} \\
4,00\end{array}$} & & C/ sant pere & 4,08 \\
\hline$\underline{z}$ & & & & & C/ del Fom & 3,60 \\
\hline 4 & & & & & c/ de l'esglesia & 4,09 \\
\hline
\end{tabular}

\begin{tabular}{|c|c|c|c|}
\hline \multicolumn{4}{|c|}{ ARQUIECTURA } \\
\hline $\begin{array}{l}\text { MURAШA O } \\
\text { CERCA Muraria }\end{array}$ & \multicolumn{3}{|l|}{ Si, construida en el s.XIV } \\
\hline Materiales & Mampostería y cal & & \\
\hline Altura & $5,00 \mathrm{~m}=25 \mathrm{palmos}$ & Espesor & $\begin{array}{l}1,5 \mathrm{~m}=5 \text { palmos de espesor } \\
\text { Hubo varios gruesos }\end{array}$ \\
\hline № de puertas & $\begin{array}{l}3 \text { puertas, Valencia, } \\
\text { Nulesy la de la Vall. }\end{array}$ & № de torres & $\begin{array}{l}4,1 \text { por cada esquina y en } \\
\text { medio de los dos lados mayores } \\
\text { del mismo } 2 \text {. En total } 6\end{array}$ \\
\hline \multicolumn{2}{|c|}{$\begin{array}{l}\text { Construida al mismo tiempo o posterior } \\
\text { a la fundación de la puebla }\end{array}$} & \multicolumn{2}{|c|}{$\begin{array}{l}\text { Posterior a la fundación, s.XVI entre } 1543 \text { y } 1553 \\
\text { por el arquitecto Mosén Miquel de Santande }\end{array}$} \\
\hline $\begin{array}{l}\text { CISTERNA O POZO } \\
\text { CENTRAL }\end{array}$ & $\begin{array}{l}\text { Pozo público en la } \\
\text { plaza vieja. Existe la } \\
\text { c/ la cistema }\end{array}$ & $\begin{array}{l}\text { ERMITA ARCOS } \\
\text { DIAFRAGMA }\end{array}$ & $\begin{array}{l}\text { Los santos Juanes en origen, } \\
\text { reconstruida } 1738\end{array}$ \\
\hline
\end{tabular}




\begin{tabular}{|c|c|c|}
\hline COMPARATIVA & Aragón S.XI. Jaca & Urba nismo en C.V. S. XIII \\
\hline MANZANAS & Iguales & Iguales \\
\hline LONGITUD MANZANAS & Doble o triple ancho calle & $\begin{array}{l}\text { La mayoría cuadradas o el doble } \\
\text { del ancho de la manzana. Hay } \\
\text { una sola que es } 4 \text { vecesmasque el } \\
\text { ancho y otra } 6 \text { vecesmas. }\end{array}$ \\
\hline PARCELAS & Iguales & Desiguales \\
\hline Frente de fachada & $4-5 \circ 6,00 \mathrm{~m}$ & Desde $3,5 \mathrm{~m}$ a $6,00 \mathrm{~m}$ \\
\hline Profundidad & Hasta $25 \mathrm{~m}$ & $\begin{array}{l}\text { Hasta } 25 \text { m de ancho, a excepción } \\
\text { de una manzana, lindante con la } \\
\text { zona de la muralla que cuenta con } \\
29,08 \mathrm{ml}\end{array}$ \\
\hline TIP. VIVIENDAS & Viv. Entre medianeras & Viv. Entre medianeras \\
\hline MURAШA & No & $\mathrm{Si}$ \\
\hline PLAZA CENTRAL & No, situa da a la entrada & $\begin{array}{l}\text { No, situada a la entrada y en la } \\
\text { zona de la iglesia }\end{array}$ \\
\hline \multicolumn{3}{|l|}{ NOTAS: } \\
\hline \multicolumn{3}{|c|}{ 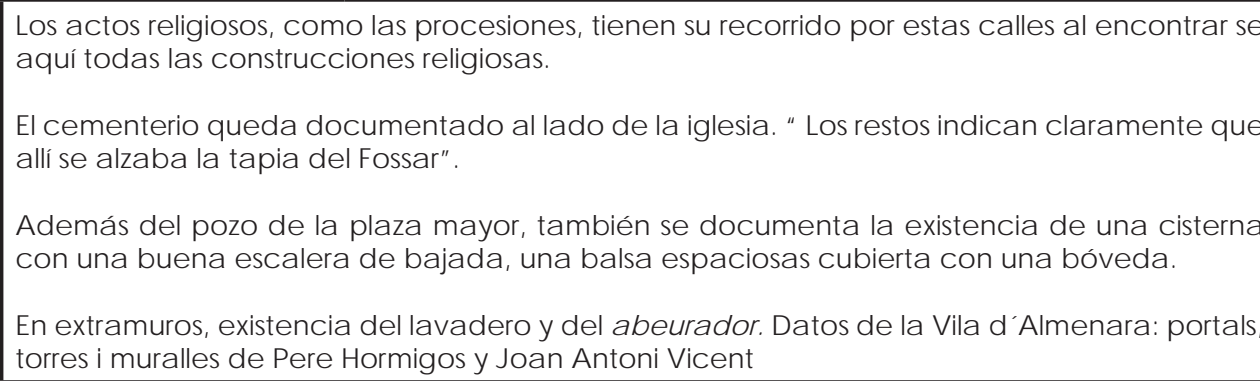 } \\
\hline
\end{tabular}

\section{CRUCES DE TERMINO}

La cruz gótica de Almenara se encuentra en la entrada Norte de la población, en la plaza de la Constitución.

Las cruces góticas son monumentales cruces de piedra de la Edad Media. Son realizadas en piedra calcańa.

La base está compuesta porcuatro hileras de piedras. Sobre tres gradas circulares se sienta la voluminosa base también circular de la que aranca la octogonal caña. La primera grada está formada por 17 piezas, la segunda por 11 y la tercera por 8, todas ellas de piedras calcańa y algunas de rojo. La columna octogonal compuesta de tres tramos. La cruz seria de $75 \mathrm{~cm}$ de alto por $60 \mathrm{dm}$ de ancho. El capitel es de forma poliedro hexagonal.

Destruida en 1936, fue levantada y reconstruida al 1939, sin la cruz original i la falta de un tramo a proxima da mente de $35 \mathrm{~cm}$. Sustituyendo la cruz original se insertó una cruz de hierro forjada.

La reconstrucción de la cruz en gres artístico de alta cocción, ha sido realizada a mano y decorada con colores naturales.

NOTAS

El edificio de la iglesia de excelente aspecto, espacioso y aislado de construcciones particulares; ofrece la particularidad histórica de que dentro de su perímetro estaban empleados el antiguo templo, construido en 1528, La plaza Vieja, El Pozo público, El Homo de la Villa, la Casa Consistorial, La Camicería i la Prisión.

Cuenta con un lavadero extramuros 


\section{DIMENSIONES DE MANZANAS}

\begin{tabular}{|c|c|c|c|c|}
\hline Manzanas & Largo & Ancho & Profundidad & $\begin{array}{c}\text { Relación/ } \\
\text { largo-ancho }\end{array}$ \\
\hline 1 & 164,80 & 29,08 & 29,08 & 6 \\
\hline 2 & 96,14 & 25,13 & 25,13 & 4 \\
\hline 3 & 39,11 & 36,1 & 17,00 & 1 \\
\hline 4 & 36,61 & 37,21 & 18,5 & 1 \\
\hline 5 & 35,94 & 37,63 & 14,26 & 1 \\
\hline 6 & 39,05 & 37,82 & 19,22 & 1 \\
\hline 7 & 46,63 & 41,43 & 24,85 & 1 \\
\hline 8 & 46,28 & 38,66 & 22,12 & 1 \\
\hline 9 & 40,00 & 35,54 & 21,03 & 1 \\
\hline 10 & 35,8 & 12,36 & 18,82 & 3 \\
\hline 11 & 36,58 & 35,82 & 17,38 & 1 \\
\hline 12 & 38,45 & 39,94 & 18,00 & 1 \\
\hline 13 & 45,75 & 77,00 & 21,11 & 2 \\
\hline 14 & 47,00 & 75,00 & 22,63 & 2 \\
\hline
\end{tabular}




\begin{tabular}{|l|l|l|l|}
\hline \multicolumn{2}{|l|}{ DATOS DE LA POBLACIÓN } & Pussol o Puebla de Pussol \\
\hline NOMBRE ACTUAL & Puzol & $\begin{array}{l}\text { NOMBRE } \\
\text { ORIG INAL }\end{array}$ & \\
\hline Hisn o castillo cerca del cual se construye & Castillo del Puig & a 3,4 Km. \\
\hline $\begin{array}{l}\text { AÑO CARTA PUEBLA O PRIVILEG IO DE } \\
\text { FUNDACIÓN }\end{array}$ & 1.242 & \\
\hline FUERO & Valencia & OTORG ANTE & Assa lit de Gúdal \\
\hline VILA O LOC & Loc & & \\
\hline Casas en 1490 & 106 & Casasen 1560 & 157 \\
\hline
\end{tabular}

\begin{tabular}{|l|l|l|l|}
\hline \multicolumn{4}{|l|}{ URBANISMO } \\
\hline RAZÓ N DEL PERIMMEIRO CON LOS LADOS & $3: 5$ & $154,35 \mathrm{ml}$ \\
\hline LONG ITUD & $315,58 \mathrm{ml}$ & AMPUTUD & \\
\hline
\end{tabular}

\begin{tabular}{|c|c|c|c|c|c|c|}
\hline \multirow{5}{*}{ 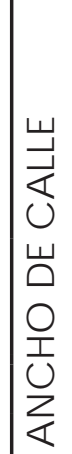 } & \multicolumn{3}{|c|}{ Decamanus (Este- Oeste ml) } & \multicolumn{3}{|c|}{ Cardus ( Norte-Sur ml) } \\
\hline & EJ E & $\begin{array}{l}\text { C/ San Joan, } \\
\text { antigua c/ } \\
\text { Mayor }\end{array}$ & 6,71 & EJ E & $\begin{array}{l}\mathrm{C} / \text { Pere de Morvedre, } \\
\text { anteriomente } \mathrm{C} / \text { Cavallers }\end{array}$ & 3,52 \\
\hline & \multirow{3}{*}{ 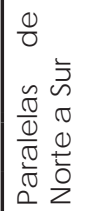 } & $\begin{array}{l}\text { C/ de L'Hort, } \\
\text { antigua C/ } \\
\text { Saragossa }\end{array}$ & 4,19 & \multirow{3}{*}{ 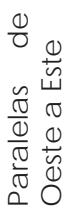 } & C/ Coladors & 3,52 \\
\hline & & C/ San Pere & 4,95 & & C/ de la Font & 3,83 \\
\hline & & & & & c/ de la Torreta & 4,04 \\
\hline
\end{tabular}

\begin{tabular}{|l|l|l|}
\hline COMPARATIVA & Aragón S.XI. J aca & Urbanismo en C.V. S. XIII \\
\hline MANZANAS & Iguales & Desiguales \\
\hline LONGITUD MANZANAS & Doble o triple ancho calle & $\begin{array}{l}\text { Cuadradas, doble o triple del } \\
\text { ancho de la manzana }\end{array}$ \\
\hline PARCELAS & Iguales & desiguales \\
\hline Frente de fachada & $4-5$ o 6 & De 4 a $5 \mathrm{~m}$ \\
\hline Profundidad & Hasta $25 \mathrm{~m}$ & No sobrepasan los $25 \mathrm{~m}$ \\
\hline TIP. VIVIENDAS & Viv. Entre medianeras & Viv. Entre medianeras \\
\hline MURAШA & No & Si \\
\hline PLAZA CENTRAL & No, situada a la entrada & $\begin{array}{l}\text { Si, aunque actualmente ha } \\
\text { desaparecido }\end{array}$ \\
\hline
\end{tabular}




\begin{tabular}{|c|c|c|c|}
\hline \multicolumn{4}{|l|}{ ARQUITECTURA } \\
\hline \multicolumn{2}{|c|}{ MURAШA O CERCA Muraria } & \multicolumn{2}{|l|}{$\mathrm{SI}$} \\
\hline Materiales & \multicolumn{3}{|c|}{ Piedra, teja y ladrillo de barro } \\
\hline Altura & ---- & Espesor & --- \\
\hline № de puertas & ---- & № de torres & 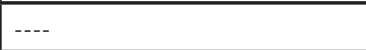 \\
\hline $\begin{array}{l}\text { Construida al mismo } \\
\text { tiempo o posterior a } \\
\text { la fundación de la } \\
\text { puebla }\end{array}$ & S. XIV & & \\
\hline $\begin{array}{lll}\text { CISTERNA } & \text { O POZO } \\
\text { CENTRAL } & & \\
\end{array}$ & ---- & $\begin{array}{|ll|}\text { ERMITA } & \text { ARCOS } \\
\text { DIAFRAGMA } & \\
\end{array}$ & $-{ }_{---}$ \\
\hline $\begin{array}{l}\text { IGLESIA BÓVEDAS DE } \\
\text { CRUCERIIA }\end{array}$ & --- & \begin{tabular}{|ll} 
CASTILO & EN \\
INTRAMUROS
\end{tabular} & \begin{tabular}{|l|} 
Palacio-castillo arzobispal \\
( S.XVI), pero se encuentra \\
fuera de la trama históric a
\end{tabular} \\
\hline \multicolumn{4}{|l|}{ CRUCESDE TERMINO } \\
\hline \multicolumn{4}{|c|}{$\begin{array}{l}\text { Esta simbólica cruz se erigió en un primer momento a las afueras de la población, más } \\
\text { concretamente en la parte norte del ba mio "Hostalets", emplazada a la entrada de un } \\
\text { camino que conducía al convento de "La Vall de Chesus", sitio al pie del Monte Picaio. Se la } \\
\text { reconocía con el nombre de "La Cruz de Piedra" y parece serque data de los siglos XV/XVI. } \\
\text { Era muy venerada y se sabe que existía la costumbre de visitarla en vísperas del } 6 \text { de enero, } \\
\text { llevando cascabeleńas, con la intención de pedira losreyes; hasta que finalmente en época } \\
\text { de adversidad fue destrozada. Una persona de quien solo se conoce la inicial de su nombre, } \\
\text { grabó un escrito que fue difundido por Radio Nacional. Este escrito fue impreso en } 1941 \text { y } \\
\text { posteriomente repartido en la cabalgata de losfesteros de ese mismo año; lo que instó a las } \\
\text { autoridadesa iniciarla reconstrucción de la Cruz en 1947, pero con una diferencia, a hora se } \\
\text { emplazańa en el camino del cementerio. }\end{array}$} \\
\hline \multicolumn{4}{|l|}{ NOTAS } \\
\hline \multicolumn{4}{|c|}{ De la muralla solo queda "la torreta" o Torre Talaia } \\
\hline
\end{tabular}

\section{DIMENSIONES DE MANZANAS}

\begin{tabular}{|c|c|c|c|c|}
\hline Manzanas & Largo & Ancho & Profundidad & $\begin{array}{c}\text { Relación/ } \\
\text { largo-ancho }\end{array}$ \\
\hline 1 & 22,30 & 23,98 & 22,30 & 1 \\
\hline 2 & 41,04 & 24,20 & 19,80 & 1 \\
\hline 3 & 45,70 & 20,83 & 20,83 & 2 \\
\hline 4 & 40,26 & 103,85 & 18,33 & 3 \\
\hline 5 & 40,46 & 82,41 & 21,02 & 2 \\
\hline 6 & 38,28 & 85,37 & 21,72 & 2 \\
\hline 7 & 40,00 & 132,08 & 16,95 & 3 \\
\hline 8 & 65,16 & 38,48 & 20,76 & 2 \\
\hline 9 & 41,25 & 77,34 & 20,17 & 2 \\
\hline 10 & 44,90 & 73,05 & 22,90 & 2 \\
\hline 11 & 40,15 & 80,53 & 20,30 & 2 \\
\hline 12 & 77,76 & 71,64 & 20,63 & 1 \\
\hline 13 & 40,20 & 58,80 & 20,12 & 1 \\
\hline 14 & 39,96 & 49,53 & 16,95 & 1 \\
\hline
\end{tabular}


Fic ha de datos históricos y bienes inmuebles

008 La Pobla de Vallbona

\section{DATOS DE LA POBLACIÓN}

\begin{tabular}{|c|c|c|c|}
\hline NOMBRE ACTUAL & La Pobla de Vallbona & NOMBRE ORIG INAL & La Pobla de Benaguzir \\
\hline \multicolumn{2}{|c|}{ Hisn o castillo cerca del cual se construye } & \multicolumn{2}{|c|}{ Castillo de Benaguacil. a Km. } \\
\hline FUNDACIÓN & 1280 & & \\
\hline $\begin{array}{l}\text { AÑO CARTA PUEBL } \\
\text { FUNDACIÓN }\end{array}$ & A PRIVILEGIO DE & \multicolumn{2}{|l|}{1.382} \\
\hline FUERO & Valencia & \multirow[t]{2}{*}{ OTORGANTE } & \multirow{2}{*}{$\begin{array}{l}\text { Martí I’huma y María } \\
\text { de Luna }\end{array}$} \\
\hline VIША O ШОC & Loc & & \\
\hline Casasen 1490 & 168 & Casasen 1560 & 106 \\
\hline
\end{tabular}

\section{URBANISMO}

\begin{tabular}{|c|c|c|c|}
\hline \multicolumn{2}{|c|}{ RAZÓN DEL PERÍMEIRO CON LOS LADOS } & $3: 5$ & \\
\hline LONGITUD & $281,00 \mathrm{ml}$ & AMPUTUD & $160,70 \mathrm{ml}$ \\
\hline $\begin{array}{l}\text { SITUACIÓN DE LA } \\
\text { POBLA }\end{array}$ & Allado & rimera, e & gable, zona sur. \\
\hline
\end{tabular}

\begin{tabular}{|c|c|c|c|c|c|c|}
\hline \multirow{4}{*}{ 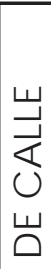 } & \multicolumn{3}{|c|}{ Decamanus (Este- Oeste ml) } & \multicolumn{3}{|c|}{ Cardus ( Norte-Sur ml) } \\
\hline & EJE & $\begin{array}{l}\text { C/ Mayor actual C/ } \\
\text { Obispo Cervera }\end{array}$ & 8,16 & EJE & $\begin{array}{l}\text { ( Avda. colon- } \\
\text { maestro Barona) }\end{array}$ & 5,7 \\
\hline & \multirow{4}{*}{ 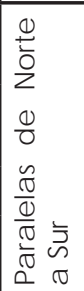 } & $\begin{array}{l}\text { C/ Maestro Giner } \\
\text { (carre de dalt }\end{array}$ & 3,00 & \multirow{4}{*}{ 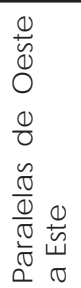 } & C/ Miguel Tarin & 6,00 \\
\hline & & $\begin{array}{l}\text { c/ J esús Pitarch } \\
\text { (carrer del mig }\end{array}$ & 5,00 & & C/ Padre J ose Ma & 3,26 \\
\hline 누 & & C/ Sant Antoni & 3,00 & & C/Angel del Alcazar & 3,85 \\
\hline$\sum$ & & & & & c/ Francisco Barella & 3,28 \\
\hline
\end{tabular}

\begin{tabular}{|l|l|l|}
\hline COMPARATIVA & Aragón S.XI. J aca & Urbanismo en CV S. XIII \\
\hline MANZANAS & Iguales & $\begin{array}{l}\text { Iguales en forma geométrica, } \\
\text { desigua les en dimensiones. }\end{array}$ \\
\hline LONGITUD MANZANAS & Doble o triple ancho calle & $\begin{array}{l}\text { Doble y triple del ancho de la } \\
\text { manza na }\end{array}$ \\
\hline PARCELAS & Iguales & Desiguales \\
\hline Frente de fachada & $4-5$ o 6,00 & De 3,50 m a 6,00 \\
\hline Profundidad & Hasta $25 \mathrm{~m}$ & No pasan de $25 \mathrm{~m}$ \\
\hline TIP. VIVIENDAS & Viv. Entre medianeras & Viv. Entre medianeras \\
\hline MURAШA & No & Si \\
\hline PLAZA CENTRAL & No, situada a la entrada & Si, la plaza mayor \\
\hline NOTAS: & \multicolumn{2}{|l}{} \\
\hline $\begin{array}{l}\text { La mayońa de las viviendas solo tiene acceso por una de las calles. Solo las manzanas más } \\
\text { pequeñas dan a las doscalles, con una profundidad de 20,37 m la mayor }\end{array}$ \\
\hline
\end{tabular}




\begin{tabular}{|c|c|c|c|}
\hline \multicolumn{4}{|l|}{ ARQUITECTURA } \\
\hline \multirow{2}{*}{\begin{tabular}{|l|}
$\begin{array}{l}\text { MURAШA O CERCA } \\
\text { Muraria }\end{array}$ \\
Materiales \\
\end{tabular}} & \multicolumn{3}{|c|}{$\begin{array}{l}\text { No queda nada, solo el escudo que estaba situado en el portal de } \\
\text { Riba-roja }\end{array}$} \\
\hline & Mamposteńa y cal & & \\
\hline Altura & --- & Espesor & --- \\
\hline № de puertas & 4 & № de torres & 2 \\
\hline $\begin{array}{l}\text { Construida al mismo } \\
\text { tiempo o posterior a } \\
\text { la fundación de la } \\
\text { puebla }\end{array}$ & $\begin{array}{l}\text { Posterior, primeros } \\
\text { años del s. XIV }\end{array}$ & & \\
\hline $\begin{array}{l}\text { CISTERNA O POZO } \\
\text { CENTRAL }\end{array}$ & $\begin{array}{l}\text { Si, elíptico, en medio } \\
\text { de la plaza mayor }\end{array}$ & \begin{tabular}{|ll} 
ERMITA & ARCOS \\
DIAFRAGMA &
\end{tabular} & $\begin{array}{l}\text { Emita de San } \\
\text { Sebastián, situada } \\
\text { en un montíc ulo a las } \\
\text { afueras }\end{array}$ \\
\hline $\begin{array}{l}\text { IGLESIA BÓVEDAS DE } \\
\text { CRUCERÍA }\end{array}$ & $\begin{array}{l}\text { Parroquia Santiago } \\
\text { Apóstol) }\end{array}$ & $\begin{array}{l}\text { CASTILO } \\
\text { INTRAMUROS }\end{array}$ & No \\
\hline \multicolumn{4}{|l|}{ CRUCES DE TERMINO } \\
\hline $\begin{array}{l}\text { Se supone que tendría } \\
\text { San Sebastián, por su } \\
\text { ni notic ia hasta nuestrc }\end{array}$ & $\begin{array}{l}\text { que haberuna donde } \\
\text { orma y ubicación, poc } \\
\text { sdías. }\end{array}$ & $\begin{array}{l}\text { encuentra la actua } \\
\text { serposible, pero no }\end{array}$ & $\begin{array}{l}\text { ntrada de la emita de } \\
\text { la llegado ningún resto }\end{array}$ \\
\hline
\end{tabular}

\section{DIMENSIONES DE MANZANAS}

\begin{tabular}{|c|c|c|c|c|}
\hline Manzanas & Largo & Ancho & Profundidad & $\begin{array}{c}\text { Relación/ } \\
\text { largo-ancho }\end{array}$ \\
\hline 1 & 105,88 & 18,57 & 20,04 & 6 \\
\hline 2 & 53,35 & 38,67 & 14,83 & 1 \\
\hline 3 & 71,45 & 32,11 & 10,00 & 2 \\
\hline 4 & 65,34 & 30,00 & 12,56 & 2 \\
\hline 5 & 63,38 & 27,65 & 15,29 & 2 \\
\hline 6 & 73,36 & 38,87 & 19,04 & 2 \\
\hline 7 & 78,87 & 27,09 & 28,37 & 3 \\
\hline 8 & 167,39 & 14,64 & 14,64 & 11 \\
\hline 9 & 99,73 & 19,81 & 20,37 & 5 \\
\hline 10 & 110,33 & 39,75 & 17,89 & 3 \\
\hline 11 & 108,23 & 35,02 & 24,11 & 3 \\
\hline 12 & 170,67 & 22,86 & 21,50 & 7 \\
\hline
\end{tabular}


Fic ha de datos históricos y bienes inmuebles

009 Cullera

\begin{tabular}{|l|l|l|l|}
\hline \multicolumn{4}{|l|}{ DATOS DE LA POBLACIÓN } \\
\hline NOMBRE ACTUAL & Cullera & NOMBRE ORIG INAL & \\
\hline Hisn o castillo cerca del cual se construye & \multicolumn{1}{l|}{ Castillo de Cullera } \\
\hline FUNDACIÓN & 1.253 & & \\
\hline $\begin{array}{l}\text { AÑO CARTA PUEBLA } \\
\text { O PRIVILEG IO DE } \\
\text { FUNDACIÓN }\end{array}$ & 1.244 & & \\
\hline FUERO & Valencia & OTORGANTE & Rey J aime I \\
\hline VILA O एOC & & & \\
\hline Casasen 1490 & 189 & Casasen 1560 & 201 \\
\hline
\end{tabular}

\begin{tabular}{|l|l|l|}
\hline COMPARATIVA & Aragón S.XI. J aca & Urbanismo en C.V. S. XIII \\
\hline MANZANAS & Iguales & Desiguaales \\
\hline LONGITUD MANZANAS & Doble o triple ancho calle & $\begin{array}{l}\text { Doble o triple ancho de la } \\
\text { manzana }\end{array}$ \\
\hline PARCELAS & Iguales & desiguales \\
\hline Frente de fachada & $4-5$ o 6,00 & 3,50 a $4,50 \mathrm{~m}$ \\
\hline Profundidad & Hasta $25 \mathrm{~m}$ & No so brepa san los $21 \mathrm{~m}$ \\
\hline TIP. VIVIENDAS & Viv. Entre medianeras & Viv. Entre medianeras \\
\hline MURAШA & No & Si \\
\hline PLAZA CENTRAL & No, situada a la entrada & $\begin{array}{l}\text { No, un posible ensanche en } \\
\text { la entrada }\end{array}$ \\
\hline & & \\
\hline
\end{tabular}

\section{URBANISMO}

\begin{tabular}{|l|l|l|l|}
\hline \multicolumn{2}{|l|}{ RAZÓN DEL PERÍMEIRO CON LOS LADOS } & \multicolumn{3}{l|}{$3: 5$} \\
\hline LONGITUD & 302,74 & AMPLTUD & 279,14 \\
\hline
\end{tabular}

\section{ARQUITECTURA}

\begin{tabular}{|c|c|}
\hline MURAШA O CERCA Muraria & $\mathrm{SI}$ \\
\hline $\begin{array}{l}\text { Construida al mismo tiempo o posterior a la } \\
\text { fundación de la puebla }\end{array}$ & Posterior.1553-56 \\
\hline NOTAS & \\
\hline Cerca pentagonal con siete torreones. & \\
\hline
\end{tabular}




\begin{tabular}{|c|c|c|c|}
\hline \multicolumn{4}{|l|}{ ARQUITECTURA } \\
\hline \multirow{2}{*}{\begin{tabular}{|l|}
$\begin{array}{l}\text { MURAШA O CERCA } \\
\text { Muraria }\end{array}$ \\
Materiales
\end{tabular}} & \multicolumn{3}{|c|}{$\begin{array}{l}\text { No queda nada, solo el escudo que estaba situado en el portal de } \\
\text { ribaroja }\end{array}$} \\
\hline & Mampostería y cal & & \\
\hline Altura & --- & Espesor & --- \\
\hline № de puertas & 4 & № de torres & 2 \\
\hline $\begin{array}{l}\text { Construida al mismo } \\
\text { tiempo o posterior a } \\
\text { la fundación de la } \\
\text { puebla }\end{array}$ & $\begin{array}{l}\text { Posterior, primeros } \\
\text { años del s. XIV }\end{array}$ & & \\
\hline $\begin{array}{l}\text { CISTERNA } \\
\text { C } \\
\text { CENTRAL }\end{array}$ & $\begin{array}{l}\text { Si, elíptico, en medio } \\
\text { de la plaza mayor }\end{array}$ & \begin{tabular}{|l|} 
ERMITA \\
DIAFRAGMA
\end{tabular} & $\begin{array}{l}\text { Ermita de San } \\
\text { Sebastián, situada } \\
\text { en un montículo a las } \\
\text { afueras }\end{array}$ \\
\hline $\begin{array}{l}\text { IGLESIA BÓVEDAS DE } \\
\text { CRUCERÍA }\end{array}$ & $\begin{array}{l}\text { Parroquia Santiago } \\
\text { Apóstol) }\end{array}$ & $\begin{array}{l}\text { CASTILO } \\
\text { INTRAMUROS }\end{array}$ & No \\
\hline \multicolumn{4}{|l|}{ CRUCES DE TERMINO } \\
\hline $\begin{array}{l}\text { Se supone que tendría } \\
\text { San Sebastián, por su } \\
\text { ni notic ia hasta nuestrc }\end{array}$ & $\begin{array}{l}\text { que haberuna donde } \\
\text { orma y ubicación, podn } \\
\text { s días. }\end{array}$ & $\begin{array}{l}\text { se encuentra la actuale } \\
\text { ía ser posible, pero no h }\end{array}$ & $\begin{array}{l}\text { ntrada de la emita de } \\
\text { la llegado ningún resto }\end{array}$ \\
\hline
\end{tabular}

\section{DIMENSIONES DE MANZANAS}

\begin{tabular}{|c|c|c|c|c|}
\hline Manzanas & Largo & Ancho & Profundidad & $\begin{array}{c}\text { Relación/ } \\
\text { largo-ancho }\end{array}$ \\
\hline 1 & 105,88 & 18,57 & 20,04 & 6 \\
\hline 2 & 53,35 & 38,67 & 14,83 & 1 \\
\hline 3 & 71,45 & 32,11 & 10,00 & 2 \\
\hline 4 & 65,34 & 30,00 & 12,56 & 2 \\
\hline 5 & 63,38 & 27,65 & 15,29 & 2 \\
\hline 6 & 73,36 & 38,87 & 19,04 & 2 \\
\hline 7 & 78,87 & 27,09 & 28,37 & 3 \\
\hline 8 & 167,39 & 14,64 & 14,64 & 11 \\
\hline 9 & 99,73 & 19,81 & 20,37 & 5 \\
\hline 10 & 110,33 & 39,75 & 17,89 & 3 \\
\hline 11 & 108,23 & 35,02 & 24,11 & 3 \\
\hline 12 & 170,67 & 22,86 & 21,50 & 7 \\
\hline
\end{tabular}


Fic ha de datos históric os y bienes inmuebles

010 Gandia

\begin{tabular}{|c|c|c|c|}
\hline \multicolumn{4}{|c|}{ DATOS DE LA POBLACIÓN } \\
\hline NOMBRE ACTUAL & Gandia & NOMBRE ORIG INAL & Ducado de Gandía \\
\hline \multicolumn{2}{|c|}{ Hisn o castillo cerca del cual se construye } & \multicolumn{2}{|l|}{ Castell de Bayren } \\
\hline FUNDACIÓN & 1.240 & $\begin{array}{l}\text { AÑO CARTA PUEBLA } \\
\text { O PRIVILEGIO DE } \\
\text { FUNDACIÓN }\end{array}$ & 1.253 \\
\hline FUERO & Valencia & OTORGANTE & Rey J a ime I \\
\hline VIШA O ШOC & Villa & & \\
\hline Inmuebles en 1490 & 363 & Inmuebles en 1560 & $450+56$ \\
\hline \multicolumn{4}{|l|}{ NOTAS } \\
\hline \multicolumn{4}{|c|}{$\begin{array}{l}\text { Habitaban cristianos y musulmanes según el estudio de las casas de 1.560. Era el " Raval” } \\
\text { habitaron allí hasta su expulsión en el año } 1.609\end{array}$} \\
\hline
\end{tabular}

\section{URBANISMO}

\begin{tabular}{|c|c|c|c|}
\hline \multicolumn{2}{|c|}{ RAZÓN DEL PERÍMEIRO CON LOS LADOS } & \multicolumn{2}{|l|}{$3: 5$} \\
\hline LONGITUD & $477 \mathrm{ml}$ & AMPபTUD & $366 \mathrm{ml}$ \\
\hline $\begin{array}{l}\text { SITUACIÓN DE LA } \\
\text { POBLA }\end{array}$ & Se fundó junto & quia reald & y junto al nó Serpis \\
\hline
\end{tabular}

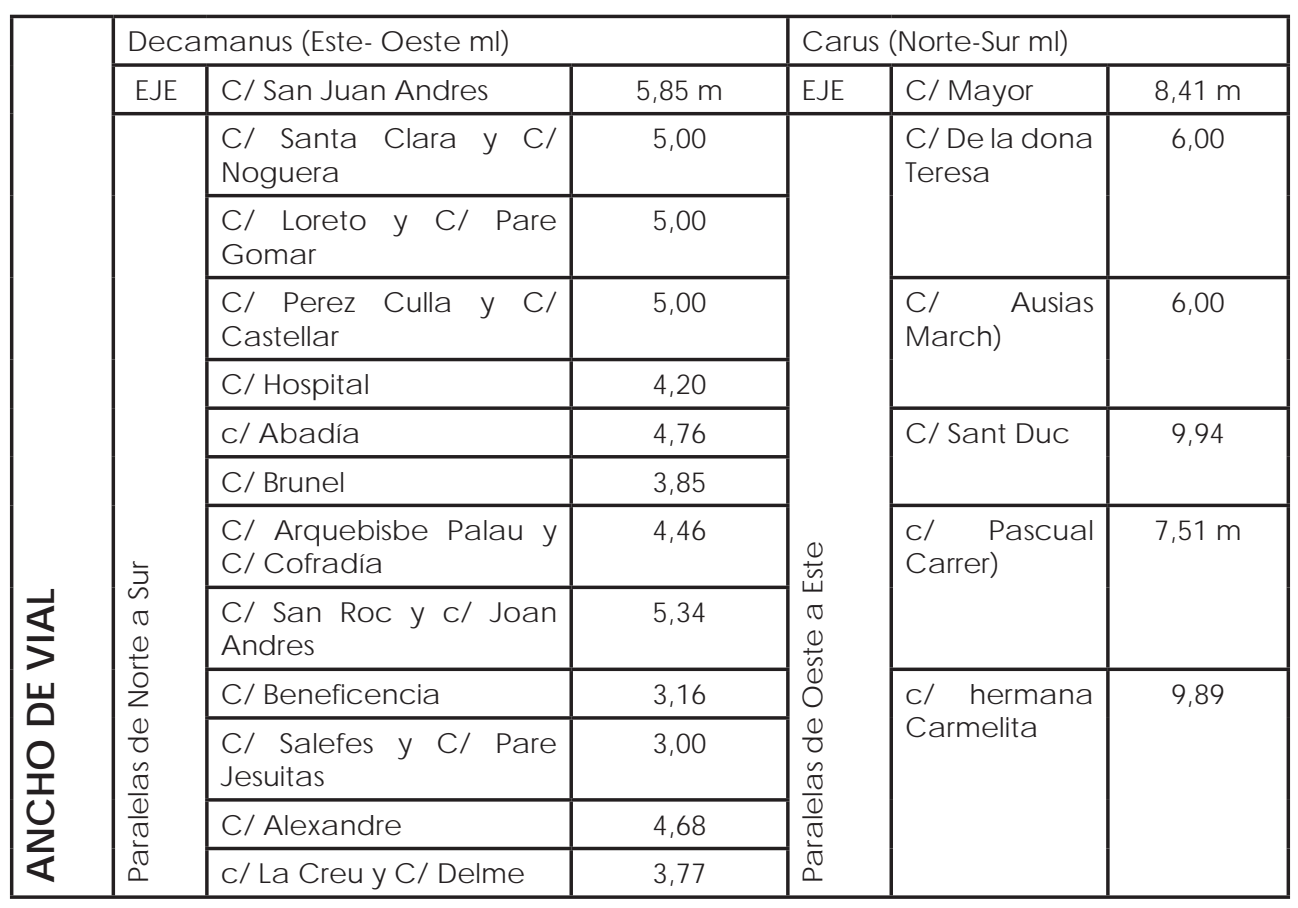




\begin{tabular}{|c|c|c|}
\hline COMPARATIVA & Aragón S.XI. Jaca & Urbanismo en C.V. S. XIII \\
\hline MANZANAS & Iguales & Desiguales \\
\hline LONGITUD MANZANAS & Doble o triple ancho calle & $\begin{array}{l}\text { Doble y triple del ancho de la } \\
\text { manzana }\end{array}$ \\
\hline PARCELAS & Iguales & Desiguales \\
\hline Frente de fachada & $4-5 \circ 6$ & De $3,50 \mathrm{~m}$ a $5,50 \mathrm{~m}$ \\
\hline Profundidad & Hasta $25 \mathrm{~m}$ & Hasta $25 \mathrm{~m}$ \\
\hline TIP. VIVIENDAS & Viv. Entre medianeras & Viv. Entre medianeras \\
\hline MURAШA & No & si \\
\hline PLAZA CENTRAL & No, situa da a la entrada & Si, la plaza mayor \\
\hline \multicolumn{3}{|l|}{ NOTAS: } \\
\hline \multicolumn{3}{|c|}{ Las calles principales se disponen paralelas a la calle mayor. } \\
\hline \multicolumn{3}{|c|}{$\begin{array}{l}\text { La mayoría de las viviendas solo tiene acceso por una de las calles. Solo las manzanas más } \\
\text { pequeñas dan a las doscalles, con una profundidad de } 24,45 \mathrm{~m} \text {. }\end{array}$} \\
\hline
\end{tabular}

\section{DIMENSIONES DE MANZANAS}

\begin{tabular}{|c|c|c|c|c|}
\hline Manzanas & Largo & Ancho & Profundidad & $\begin{array}{l}\text { Relación/ } \\
\text { largo-ancho }\end{array}$ \\
\hline 1 & 66,23 & 40,47 & 40,47 & 2 \\
\hline 2 & 62,00 & 48,75 & 22,01 & 1 \\
\hline 3 & 58,00 & 20,00 & 20,00 & 3 \\
\hline 4 & 25,19 & 62,77 & 25,19 & 2 \\
\hline 5 & 110,94 & 26,45 & 26,45 & 4 \\
\hline 6 & 32,39 & 55,64 & 17,12 & 2 \\
\hline 7 & 78,41 & 41,34 & 17,84 & 2 \\
\hline 8 & 29,23 & 47,99 & 17,13 & 2 \\
\hline 9 & 28,06 & 58,33 & 17,22 & 2 \\
\hline 10 & 18,14 & 146,07 & 18,14 & 8 \\
\hline 11 & 16,07 & 59,82 & 16,07 & 4 \\
\hline 12 & 36,18 & 136,05 & 16,07 & 4 \\
\hline 13 & 37,87 & 118,22 & 18,00 & 3 \\
\hline 14 & 39,34 & 30,11 & 16,71 & 1 \\
\hline 15 & 36,20 & 52,13 & 19,22 & 1 \\
\hline 16 & 36,60 & 67,84 & 17,12 & 2 \\
\hline 17 & 33,56 & 52,51 & 19,74 & 2 \\
\hline 18 & 32,86 & 46,62 & 17,31 & 1 \\
\hline 19 & 25,49 & 41,47 & 11,12 & 2 \\
\hline 20 & 20,61 & 111,78 & 20,61 & 5 \\
\hline 21 & 17,06 & 108,11 & 17,00 & 6 \\
\hline 22 & 41,11 & 99,94 & 16,91 & 2 \\
\hline 23 & 35,64 & 88,94 & 17,78 & 2 \\
\hline 24 & 28,61 & 64,25 & 17,89 & 2 \\
\hline
\end{tabular}




\begin{tabular}{|c|c|c|c|}
\hline \multicolumn{4}{|l|}{ ARQUITECTURA } \\
\hline \multicolumn{2}{|c|}{ MURAШA O CERCA Muraria } & \multicolumn{2}{|c|}{$\begin{array}{l}\mathrm{Sl} \text {, aún queda un trozo de su paramento } \\
\text { vertical }\end{array}$} \\
\hline Materiales & Mampostería y cal & & \\
\hline № de puertas & 4 & № de torres & + de 10 torres \\
\hline \multicolumn{2}{|c|}{$\begin{array}{l}\text { Construida al mismo tiempo o posterior a la } \\
\text { fundación de la puebla }\end{array}$} & \multicolumn{2}{|c|}{ Posterior, primeros años del s. XIV. 1305} \\
\hline $\begin{array}{l}\text { CISTERNA } \mathrm{O} \quad \mathrm{POZO} \\
\text { CENTRAL }\end{array}$ & ----- & \begin{tabular}{|ll} 
ERMITA & ARCOS \\
DIAFRAGMA &
\end{tabular} & $\begin{array}{l}\text { Hospital de san } \\
\text { marcos } \\
\text { Ermita de Santa Ana } \\
\text { a las afueras de la } \\
\text { ciudad, es la patrona } \\
\text { inicial y se baja en } \\
\text { procesión a la iglesia } \\
\text { principal. Cuenta } \\
\text { con calvario. Situada } \\
\text { sobre un montículo( } \\
\text { S. XIV) restaurada en } \\
\text { el S. XVIII }\end{array}$ \\
\hline $\begin{array}{l}\text { IGLESIA BÓVEDAS DE } \\
\text { CRUCERIA }\end{array}$ & $\begin{array}{l}\text { Colegiata de Santa } \\
\text { Mańa ( S.XV-XVI) }\end{array}$ & $\begin{array}{l}\text { CASTILLO } \\
\text { INTRAMUROS }\end{array}$ & Palacio Ducal ( S.XIV) \\
\hline \multicolumn{4}{|l|}{ CRUCES DE TERMINO } \\
\hline \multicolumn{4}{|c|}{$\begin{array}{l}\text { Si que exisita, pero hoy está desa parecida. Queda la imagen Capitel de una cruz de término } \\
\text { gótica, hoy desaparecido, que tenía losescudos del Consejo de la ciudad y de Juan II, antes } \\
\text { de seréste rey de Aragón, siendo príncipe de Viana y duque de Gandía } \\
\text { Escuniosa la presencia de la cruz de témino. Se trata de una pieza gótica, hoy desaparecida, } \\
\text { que tenía en su capitel losescudosdel Consejo de la ciudad y de Juan ll, antes de seréste rey } \\
\text { de Aragón, cuando era príncipe de Viana y duque de Gandía. Habiendo desaparecido la } \\
\text { cruz, esta pieza fue recogida del suelo a trozos el año } 1912 \text { y se conservó durante un tiempo } \\
\text { en el Museo del Palacio Ducal. Conservamos una reproducción en la Guía del P. León, } \\
\text { quien anota también la existencia de cierta tradición, según la cual el duque Carlos selló } \\
\text { con gruesos silla res la puerta por donde salió el duque, y que el canto del salmo In exitu tuvo } \\
\text { lugaral pasar el santo por esta cruz. }\end{array}$} \\
\hline \multicolumn{4}{|l|}{ NOTAS } \\
\hline \multicolumn{4}{|c|}{$\begin{array}{l}\text { El torreón es uno de los últimos testigos de la antigua muralla medieval de Gandía. El torreón } \\
\text { del pino es uno de los últimos restos de la segunda muralla de Gandía del siglo XVII. Fue e } \\
\text { duque Francisco de Borja quien mandó su construcción en el año 1543. Se trata de una torre } \\
\text { con forma circular cuya función era principalmente defensiva. El toreón se encuentra en la } \\
\text { calle San Rafaél, desde dónde es posible apreciar el enome monumento fortificado. En la } \\
\text { parte trasera del torreón se encuentra el patio de las Escuelas Pías. }\end{array}$} \\
\hline $\begin{array}{l}\text { Además del Palaco du } \\
\text { de Santa Clara ( } 1.429\end{array}$ & cal, también se enco & ba en su interior la uni & versidad, y el convento \\
\hline
\end{tabular}




\section{DATOS DE LA POBLACIÓN}

\begin{tabular}{|l|l|l|l|}
\hline NOMBRE ACTUAL & Concentaina & $\begin{array}{l}\text { Hisn o castillo cerca } \\
\text { del cual se construye }\end{array}$ & $\begin{array}{l}\text { Castillo de Qusantaniya } \\
\text { (s. X). Situado a } 300 \mathrm{~m} \\
\text { de la vila }\end{array}$ \\
\hline $\begin{array}{l}\text { AÑO CARTA PUEBLA O PRIVILEGIO DE } \\
\text { FUNDACIÓN }\end{array}$ & 1256 \\
\hline FUERO & Valencia & OTORGANTE & \\
\hline VIШA O ШOC & Villa & & \\
\hline Casas en 1490 & 544 & Casasen 1560 & $650+131$ \\
\hline NOTAS & & & \\
\hline
\end{tabular}

La implantación de la villa de Concentina puede establecerse en el 1.251, debiendo destacarse en primer lugar, que no se da una superposición de la villa sobre la preexistente aglomeración de época islámica, sino que la ubicación tiene lugar sobre los huertos periurbanos de Qusantaniya.

\begin{tabular}{|c|c|c|c|c|c|c|}
\hline \multirow{7}{*}{$\sum_{u}^{\frac{1}{4}}$} & \multicolumn{3}{|c|}{ Decamanus (Este- Oeste ml) } & \multicolumn{3}{|c|}{ Cardus (Norte-Sur ml) } \\
\hline & \multirow{8}{*}{ 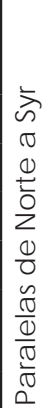 } & C/ Ángeles Custodios & 4,00 & EJE & C/ Mayor & 5,00 \\
\hline & & C/ Pedro Sequina & $4,00 \mathrm{~m}$ & \multirow{7}{*}{ 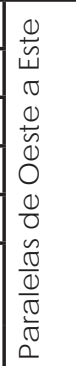 } & C/ Maestro & 3,5 \\
\hline & & C/ De los apóstoles & 4,32 & & \multirow[t]{2}{*}{ C/ Mosen Jeronimo } & \multirow[t]{2}{*}{3,10} \\
\hline & & C/ San Lorenzo & $2,74 \mathrm{~m}$ & & & \\
\hline & & C/ San Cristobal & $4,00 \mathrm{~m}$ & & $\mathrm{C} /$ Dels Crexens & $3,11 \mathrm{~m}$ \\
\hline & & C/ Luis de Fullana & $3,55 \mathrm{~m}$ & & C/ Sagrada Familia & $3,00 \mathrm{M}$ \\
\hline \multirow{2}{*}{$\frac{1}{2}$} & & \multirow[t]{2}{*}{ C/ Guadalet } & \multirow[t]{2}{*}{$2,76 \mathrm{~m}$} & & $\begin{array}{l}\text { C/ Mares de Deu del } \\
\text { Miracle }\end{array}$ & 4,50 \\
\hline & & & & & C/ Caballeros & $3,80 \mathrm{~m}$ \\
\hline
\end{tabular}

\begin{tabular}{|l|l|l|}
\hline COMPARATIVA & Aragón S.XI. J aca & \\
\hline MANZANAS & Iguales & $\begin{array}{l}\text { Iguales en forma geométrica. } \\
\text { Se adaptan a las calles } \\
\text { principales. }\end{array}$ \\
\hline LONGITUD MANZANAS & Doble o triple ancho calle & $\begin{array}{l}\text { Cuadradas, doblesy triples al } \\
\text { ancho de la manzana }\end{array}$ \\
\hline PARCELAS & Iguales & Desiguales \\
\hline Frente de fachada & $4-5$ o 6 & 3,5 a 4,5. Las mas numerosas \\
\hline Profundidad & Hasta $25 \mathrm{~m}$ & No sobrepasan los 24 m \\
\hline TIP. VIVIENDAS & Viv. Entre medianeras & Viv. Entre medianeras \\
\hline MURAШA & No & Si \\
\hline PLAZA CENTRAL & No, situada a la entrada & Si \\
\hline
\end{tabular}




\section{URBANISMO}

\begin{tabular}{|c|c|c|c|}
\hline \multicolumn{2}{|c|}{ RAZÓN DEL PERÍMEIRO CON LOS LADOS } & \multicolumn{2}{|l|}{ 3:5 } \\
\hline LONGITUD & $250 \mathrm{ml}$ & AMPUTUD & $125 \mathrm{ml}$ \\
\hline SITUACIÓN & & & \\
\hline
\end{tabular}

\section{ARQUITECTURA}

\begin{tabular}{|c|c|c|c|}
\hline \multicolumn{2}{|c|}{ MURAШA O CERCA Muraria } & \multicolumn{2}{|l|}{ si } \\
\hline Materiales & \multicolumn{3}{|c|}{ Tapial + base de mampostería para regular la pendiente del terreno } \\
\hline Altura & $10 \mathrm{~m}$ de media & Espesor & $1,50 \mathrm{~m}$ \\
\hline № de puertas & $\begin{array}{l}3 \text { importantes }+3 \\
\text { secundarias }\end{array}$ & № de torres & $9+4$ de esquina \\
\hline \multicolumn{2}{|c|}{$\begin{array}{l}\text { Construida al mismo tiempo o posterior a la } \\
\text { fundación de la puebla }\end{array}$} & $\begin{array}{l}\text { Inmediantamente a } \\
\text { la fundación }\end{array}$ & \\
\hline $\begin{array}{l}\text { CISTERNA O POZO } \\
\text { CENTRAL }\end{array}$ & & $\begin{array}{l}\text { ERMITA ARCOS } \\
\text { DIAFRAGMA }\end{array}$ & $\begin{array}{l}\text { Ermita de Santa } \\
\text { Barbara }\end{array}$ \\
\hline $\begin{array}{l}\text { IGLESIA BÓVEDAS DE } \\
\text { CRUCERÍA }\end{array}$ & $\begin{array}{l}\text { Iglesia Parroquial de } \\
\text { Santa María }\end{array}$ & $\begin{array}{l}\text { CASTILLO } \\
\text { INTRAMUROS }\end{array}$ & $\begin{array}{l}\text { No, en extramuros el } \\
\text { castillo de Penella. } \\
\text { Intramuros Palacio } \\
\text { Condal. }\end{array}$ \\
\hline
\end{tabular}

\section{CRUCES DE TERMINO}

La actual iglesia y convento de los Franciscanos de Cocentaina ocupa el espacio de una antigua ermita del siglo XIV dedicada a San Sebastián Mártir.

Posiblemente, como único testimonio de la antigua emita, se expone en la capilla la cruz gótica tallada en piedra del siglo XV, con una réplica en la plaza del convento. La original se encuentra ubicada en la actualidad en el cementerio municipal.

\section{NOTAS}

La distribución de las torres tenía el siguiente orden: al este, norte y oeste había seis torres; al sur tan sólo había tres y se repartían cuatro en cada esquina. Las puertas principales de entrada a la villa se situaban al norte, la puerta de 'I'Àngel', al este, la puerta de 'Travadell', $y$, al sur, el Portal Fosc (Portal Oscuro)

Desde el punto de vista arquitectónico se ha clasificado a la emita de Santa Bàrbara como una iglesia de 'conquista', caracterizada por una cubierta leñosa de doble vertiente apoyada sobre arcos apuntados. Su construcción debió rea lizarse entre finales del siglo XIII y principios del XIV, coincidiendo con el momento de pleno asentamiento y dominio de los cristianos.

La planta consta de una sola nave rectangular de $14,60 \times 6$ metros y una entrada principal abierta bajo un pórtico igualmente con cubierta a dosaguas, de menoraltura que la nave. Tras cuatro crujías separadas por los arcos aparece la cabecera plana en la que se sitúa el presbiterio.

La entrada presenta un vano frontal con jambas a base de sillares y un arco de medio punto, y, en el lateral izquierdo se abre otro hueco con arco de medio punto rebajado. La espadaña se apoya en la parte superior de la pared, formada por dos pilares y dintel de obra.

En el exterior, los muros son apoyados por contrafuertes. Esta estructura es sustituida en el interior por una bancada de obra a lo largo de todo el perímetro. 


\section{DIMENSIONES DE MANZANAS}

\begin{tabular}{|c|c|c|c|c|}
\hline Manzana & Longitud & Ancho & Profundidad & $\begin{array}{c}\text { Relación/ } \\
\text { largo-ancho }\end{array}$ \\
\hline 1 & 27,44 & 67,95 & 15,32 & 2 \\
\hline 2 & 32,43 & 35,77 & 16,72 & 1 \\
\hline 3 & 91,00 & 61,00 & 13,00 & 1 \\
\hline 4 & 21,74 & 35,22 & 11,67 & 2 \\
\hline 5 & 72,71 & 46,86 & 18,46 & 2 \\
\hline 6 & 55,78 & 33,39 & 14,90 & 2 \\
\hline 7 & 55,95 & 31,70 & 16,34 & 2 \\
\hline 8 & 53,85 & 42,82 & 14,70 & 1 \\
\hline 9 & 30,16 & 36,29 & 17,59 & 1 \\
\hline 10 & 41,32 & 48,92 & 23,15 & 1 \\
\hline 11 & 28,53 & 57,72 & 16,64 & 2 \\
\hline 12 & 61,58 & 36,60 & 15,57 & 2 \\
\hline 13 & 47,36 & 23,09 & 12,57 & 2 \\
\hline 14 & 62,59 & 22,68 & 11,28 & 3 \\
\hline 15 & 25,84 & 72,53 & 15,56 & 3 \\
\hline 16 & 31,78 & 39,62 & 18,78 & 1 \\
\hline 17 & 35,60 & 23,70 & 10,00 & 2 \\
\hline 18 & 35,87 & 76,38 & 19,63 & 2 \\
\hline 19 & 63,29 & 32,64 & 15,96 & 2 \\
\hline
\end{tabular}


Fic ha de datos históric os y bienes inmuebles

\section{Penáguila}

\section{DATOS DE LA POBLACIÓN}

\begin{tabular}{|l|l|l|l|}
\hline NOMBRE ACTUAL & Penáguila & $\begin{array}{l}\text { Hisn o castillo cerca } \\
\text { del cual se construye }\end{array}$ & $\begin{array}{l}\text { Castillo } \\
\text { Penáguila. A 1 Km. } \\
\text { aproximadamente e } \\
\text { la vila }\end{array}$ \\
\hline FUNDACIÓN & 1.276 & Año carta Puebla & 1.278 \\
\hline FUERO & & OTORGANTE & Rey Pedro III \\
\hline VIШA O $\amalg O C$ & Villa & & \\
\hline Casas en 1490 & 142 & Casasen 1560 & 174 \\
\hline NOTAS & \multicolumn{3}{l}{} \\
\hline
\end{tabular}

La fundación de la villa de Penáguila empezó de modo similar, ,con laspromesas efectuadas, en 1276, a los peones de la guamic ión castra. La carta puebla (1278) estipuló, fina Imente, la distribución de heredades muy extensas, de 6y'ovs,(casi 18 ha) y la construcción de casas en las inmediaciones del enriscado castillo (930 ms.n.m. Rodeado por escarpes), y aquellos beneficiarios quedaban obligados al mantenimiento y custodia de la fortaleza: construatis domos et hedific ia vestra quibus habitetis circ iter ipsum castrum.

Sin embargo, este asentamiento castral o sub-castral no llegó a prosperar. Hacia 1286, los habitantes de Penáguila Se redimieron del deber de guardar el castillo mediante el compromiso de Pagar 1.000s anuales y en 1311, incluso, pidieron al rey que les liberase De esta obligación pecuniaria. Por todo ello la villa se construyó en terreno llano, bajo el abrupto peñasco del castillo.

\begin{tabular}{|l|l|l|}
\hline COMPARATIVA & Aragón S.XI. Jaca & Urbanismo en C.V. S. XIII \\
\hline MANZANAS & Iguales & $\begin{array}{l}\text { Desiguales, se adaptan a las } \\
\text { calles principales. }\end{array}$ \\
\hline LONGITUD MANZANAS & Doble o triple ancho calle & $\begin{array}{l}\text { Doble del ancho de la } \\
\text { manzana o iguales. }\end{array}$ \\
\hline PARCELAS & Iguales & Desiguales \\
\hline Frente de fachada & $4-5$ o 6 & 2,65 a $4,52 \mathrm{~m}$ \\
\hline Profundidad & Hasta $25 \mathrm{~m}$ & No sobrepasan los $20 \mathrm{~m}$ \\
\hline TIP. VIVIENDAS & Viv. Entre medianeras & Viv. Entre medianeras \\
\hline MURAШA & No & Si \\
\hline PLAZA CENTRAL & No, situada a la entrada & Si \\
\hline NOTAS: & \multicolumn{2}{|l}{} \\
\hline $\begin{array}{l}\text { En esta población la iglesia si que se encuentra situada en la plaza que se forma en la } \\
\text { intersección del carduscon el decamanus. }\end{array}$ \\
\hline
\end{tabular}




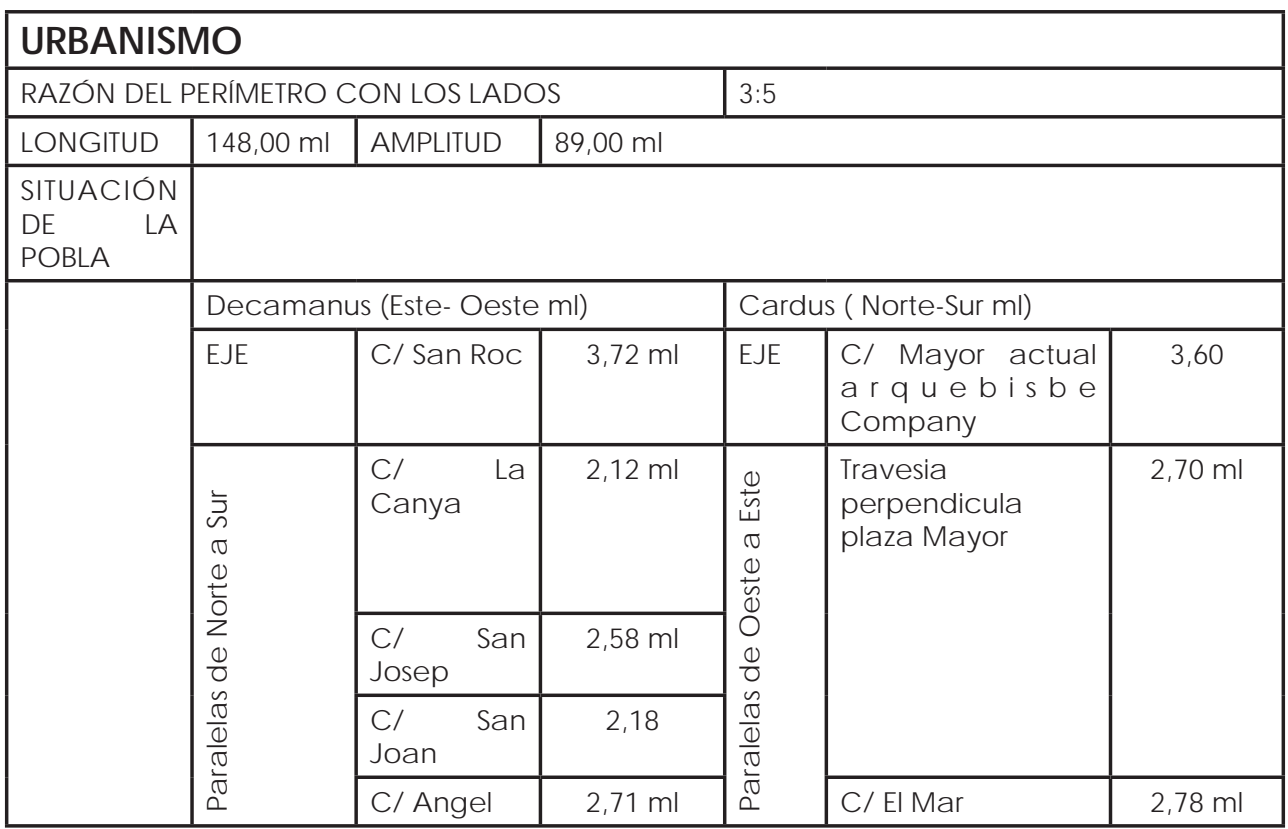

\begin{tabular}{|c|c|c|c|}
\hline \multicolumn{4}{|l|}{ ARQUITECTURA } \\
\hline $\begin{array}{l}\text { MURAШA O CERCA } \\
\text { Muraria }\end{array}$ & \multicolumn{3}{|c|}{ Si. Posterior a la fundación de la Vila.Fina les del XIII, principios del XIV } \\
\hline Materiales & \multicolumn{3}{|c|}{$\begin{array}{l}\text { Tapial con un núcleo intemo mejorado con cal, grava y algunos } \\
\text { mampuestos }\end{array}$} \\
\hline Altura & & Espesor & 7 palmos $(150-160 \mathrm{~cm}$ \\
\hline № de puertas & 2 to rres de ingreso & № de torres & 7 torres de flanqueo \\
\hline $\begin{array}{l}\text { CISTERNA } \\
\text { C ENTRAL }\end{array}$ & & $\begin{array}{ll}\text { ERMITA } & \text { ARCOS } \\
\text { DIAFRAGMA } & \end{array}$ & $\begin{array}{l}\text { Emita de San Roque } \\
\text { y La emita del } \\
\text { Calvaro }\end{array}$ \\
\hline $\begin{array}{l}\text { IGLESIA BÓVEDAS DE } \\
\text { CRUCERIA }\end{array}$ & $\begin{array}{l}\text { La iglesia del siglo XIV } \\
\text { fue destruida para } \\
\text { construir la nueva en } \\
\text { el siglo XVIII }\end{array}$ & $\begin{array}{l}\text { CASTLLO } \\
\text { INTRAMUROS }\end{array}$ & No, solo casasnobles \\
\hline \multicolumn{4}{|l|}{ NOTAS } \\
\hline \multicolumn{4}{|c|}{$\begin{array}{l}\text { Se enciema con la cerca una nueva villa de } 1,3 \text { ha. } \\
\text { La muralla presenta similitudes con las de Alcoy y Cocentaina. El conjunto fortificado es de } \\
\text { planta rectangulary orienta el eje principal de norte a sur. El interior se organiza en calles, el } \\
\text { principal -o calle Mayor- sigue esta orientación y de él salen cinco más estrechos de oeste } \\
\text { a este. La muralla no era igual en la vertiente de levante que en la de poniente. En la de } \\
\text { levante (calle del Mar) aprovecharon el corte del barranco del Anadrac y solo levantaron } \\
\text { lienzo de muro y al nordeste la tore renombrada Vemet. En la vertiente de poniente (calle } \\
\text { de la Virgen del Patrocinio) la mura lla era imponente: altemaban lienzos y torres de planta } \\
\text { cuadrada, aunque todo ha quedado desdibujado y absorbido por las casas, por dentro } \\
\text { las cuales se encuentran los restos (visibles desde la calle). Una de estas cubría el principal } \\
\text { acceso al pueblo, el Portalet, por donde sigue accediéndose al corralón medieval. El } \\
\text { Portalet es un curioso acceso al pueblo medieval que impide entrar en el pueblo en línea } \\
\text { recta, y obliga a hacerun doble ángulo de } 90 \text { grados quien entra, el que evidentemente } \\
\text { aumentaba la seguridad y el control sobre los que accedían. De la torre Vemet, situada al NE } \\
\text { de la muralla solos queda un fragmento, si el visitante marcha desde ella hacia el mercado, } \\
\text { verá un imponente lienzo de muralla medieval engastado en lascasas de la calle. }\end{array}$} \\
\hline
\end{tabular}




\section{DIMENSIONES DE MANZANAS}

\begin{tabular}{|c|c|c|c|c|}
\hline Manzana & Longitud & Anchura & Profundidad & $\begin{array}{c}\text { Relación/ } \\
\text { largo-ancho }\end{array}$ \\
\hline 1 & & 16,24 & 16,24 & 0 \\
\hline 2 & 34,33 & 19,25 & 17,74 & 2 \\
\hline 3 & 55,20 & 24,09 & 17,32 & 2 \\
\hline 4 & 48,48 & 32,3 & 17,06 & 2 \\
\hline 5 & 63,36 & 28,47 & 16,46 & 2 \\
\hline 6 & 57,21 & 40,00 & 14,33 & 1 \\
\hline 7 & 84,59 & 19,43 & 19,43 & 4 \\
\hline 8 & 61,05 & 9,19 & 9,19 & 7 \\
\hline 9 & 11,95 & 11,41 & 11,41 & 1 \\
\hline 10 & 36,29 & 12,13 & 12,13 & 3 \\
\hline 11 & 22,77 & 5,24 & 5,24 & 4 \\
\hline
\end{tabular}




\section{DATOS DE LA POBLACIÓN}

\begin{tabular}{|l|l|l|l|}
\hline NOMBRE ACTUAL & Alcoy & NOMBRE ORIG INAL & --- \\
\hline $\begin{array}{l}\text { Hisn o castillo cerca } \\
\text { del cual se construye }\end{array}$ & $\begin{array}{l}\text { Hisn Alquy. Centro fortificado de Castellasr sito en su montaña. A 3 } \\
\text { Km. de la nueva población }\end{array}$ \\
\hline $\begin{array}{l}\text { AÑO CARTA PUEBLA O PRIVILEGIO DE } \\
\text { FUNDACIÓN }\end{array}$ & 1256 & \\
\hline FUERO & Valencia & OTORGANTE & Rey J aime I \\
\hline Casas en 1490 & 413 & Casasen 1560 & 793 \\
\hline
\end{tabular}

\begin{tabular}{|c|c|c|c|c|c|c|}
\hline \multirow{5}{*}{$\begin{array}{l}\frac{1}{4} \\
\frac{1}{2} \\
\frac{1}{2} \\
\frac{1}{2}\end{array}$} & \multicolumn{3}{|c|}{ Deca ma nus (Este- Oeste ml) } & \multicolumn{3}{|c|}{ Cardus ( Norte-Sur ml) } \\
\hline & EJ E & c/ San Miguel & 4,5 & EJ E & $\begin{array}{l}\mathrm{C} / \text { Pintor } \\
\mathrm{C} \text { a s a n o } v \text { a } \\
\text { (Calle mayor) }\end{array}$ & 5,00 \\
\hline & \multirow{3}{*}{ 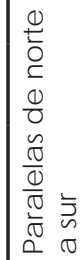 } & C/ Verge Mańa & 7,40 & \multirow{3}{*}{ 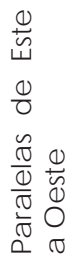 } & & \multirow[t]{2}{*}{4,62} \\
\hline & & C/ Sant Antoni & 3,10 & & & \\
\hline & & C/ Caracol & 3,18 & & & 3,14 \\
\hline
\end{tabular}

\begin{tabular}{|c|c|c|}
\hline COMPARATIVA & Aragón S.XI. Jaca & Urba nismo en C.V. S. XIII \\
\hline MANZANAS & Iguales & $\begin{array}{l}\text { lguales en forma geométrica, } \\
\text { pero no en dimensiones. } \\
\text { Se adaptan a las calles } \\
\text { principales. }\end{array}$ \\
\hline LONGITUD MANZANAS & Doble o triple ancho calle & $\begin{array}{l}\text { Cuadradas o el doble del } \\
\text { ancho de la manzana } \\
\end{array}$ \\
\hline PARCELAS & Iguales & Desiguales \\
\hline Frente de fachada & $4-5 \circ 6$ & De 4,00 a $5,50 \mathrm{~m}$ \\
\hline Profundidad & Hasta $25 \mathrm{~m}$ & No pasan de $24 \mathrm{~m}$ \\
\hline TIP. VIVIENDAS & Viv. Entre medianeras & Viv. Entre medianeras \\
\hline MURAША & No & $\mathrm{Si}$ \\
\hline PLAZA CENTRAL & No, situa da a la entrada & Si,la plaza mayor \\
\hline NOTAS: & & \\
\hline \multicolumn{3}{|c|}{$\begin{array}{l}\text { J osep Tomo ha hecho un a nálisis minucioso del parcelario partiendo de la documentación y } \\
\text { de la lectura de las trazas catastrales actuales, legando a la conclusión de que las parcelas } \\
\text { originales debían tener una superficie de entre } 48 \text { y } 72 \mathrm{~ms} \text { con un ancho de fachada entre } 4 \\
\text { y } 6 \mathrm{~m} \text { y una profundidad de } 12 \mathrm{~m} 2\end{array}$} \\
\hline
\end{tabular}




\begin{tabular}{|l|l|l|l|}
\hline \multicolumn{3}{|l|}{ URBANISMO } \\
\hline \multicolumn{2}{|l|}{ RAZÓN DEL PERÍMEIRO CON LOS LADOS } & $3: 5$ & \\
\hline LONG ITUD & $294,87 \mathrm{ml}$ & AMPUTUD & $187 \mathrm{~m} 25 \mathrm{ml}$ \\
\hline $\begin{array}{l}\text { SITUACIÓN DE LA } \\
\text { POBLA }\end{array}$ & Entre el ńo Xúquery el Río Molinar \\
\hline
\end{tabular}

\begin{tabular}{|c|c|c|c|}
\hline \multicolumn{4}{|l|}{ ARQUITECTURA } \\
\hline $\begin{array}{l}\text { MURAШA O CERCA } \\
\text { Muraria }\end{array}$ & \multicolumn{3}{|c|}{ Queda todavía la Torre Na valora } \\
\hline Materiales & \multicolumn{3}{|c|}{ Tapial en los para mentos vertic a les y en las esquinas silla rejos } \\
\hline Altura & $4,00 \mathrm{~m}$ & Espesor & $0,92-1,12 \mathrm{~m}$ \\
\hline № de puertas & 5 portales & № de torres & $\begin{array}{l}14 \text { torres, incluidas las } \\
\text { de los portales }\end{array}$ \\
\hline $\begin{array}{l}\text { Construida al mismo } \\
\text { tiempo o posterior a } \\
\text { la fundación de la } \\
\text { puebla }\end{array}$ & \multicolumn{3}{|c|}{$\begin{array}{l}\text { Posteriora la concesión de la carta pobla, en el año } 1.264 \text { a un estaba } \\
\text { inacabada. Fin } 1.290 \text {. }\end{array}$} \\
\hline \begin{tabular}{lll|} 
CISTERNA & O & POZO \\
CENTRAL & & \\
\end{tabular} & & $\begin{array}{ll}\text { ERMITA } & \text { ARCOS } \\
\text { DIAFRAGMA } & \\
\end{array}$ & $\begin{array}{lll}\text { Emita de San } \\
\text { Antonio Abad }\end{array}$ \\
\hline $\begin{array}{l}\text { IGLESIA BÓVEDAS DE } \\
\text { CRUCERIA }\end{array}$ & $\begin{array}{l}\text { Iglesia parroquial de } \\
\text { Santa María }\end{array}$ & $\begin{array}{l}\text { CASTILO } \\
\text { INTRAMUROS }\end{array}$ & $\begin{array}{l}\text { No, pero si en } \\
\text { extramuros } \\
\text { de Barxell }\end{array}$ \\
\hline \multicolumn{4}{|l|}{ CRUCESDE TERMINO } \\
\hline \multicolumn{4}{|c|}{$\begin{array}{l}\text { Delante de la emita de San Roc. La primera Emita fue destruida tota Imente en la Guerra } \\
\text { de Suc esión 1705-1714. Se encontraba situada en lo que hoy es el interior de la Calle Onofre } \\
\text { Jordá, en el Paseo de Cervantes, y que luego se convirtió en la Plaça de Bous Vella. } \\
\text { Se procedió a construir una segunda Ermita en otro emplazamiento más cercano a la } \\
\text { población. Fue bendecida la primera piedra el } 15 \text { de marzo de } 1715 \text { por el Doctor Don Felipe } \\
\text { Margarit, Cura Ecónomo de la Parroquia de Santa Mańa. Fue teminada la obra merced al } \\
\text { esfuerzo de losalcoyanosy solemnemente bendecida el } 10 \text { de agosto de } 1731 \text { por el Doctor } \\
\text { Don Nic olás Colomer, Vicario de la Parroquia. Se inauguró con solemne Misa y semón por el } \\
\text { camelita hijo de esta Villa Padre Marcelino Sempere. }\end{array}$} \\
\hline El recinto fortific ado oc & upaba 5 ha. & & \\
\hline
\end{tabular}




\section{DIMENSIONES DE MANZANAS}

\begin{tabular}{|c|c|c|c|c|}
\hline Situación & Largo & Ancho & Profundidad & $\begin{array}{c}\text { Relación/ } \\
\text { largo-ancho }\end{array}$ \\
\hline 1 & 56,95 & 49,28 & 21,13 & 1 \\
\hline 2 & 30,05 & 24,95 & & 1 \\
\hline 3 & 29,31 & 29,31 & & 1 \\
\hline 4 & 89,76 & 41,58 & 16,28 & 2 \\
\hline 5 & 59,77 & 34,8 & 24,24 & 2 \\
\hline 6 & 25,35 & 28,92 & --- & 1 \\
\hline 7 & 35,9 & 25,08 & 13,73 & 1 \\
\hline 8 & 52,66 & 30,00 & 21,00 & 2 \\
\hline 9 & 51,41 & 27,22 & 12,50 & 2 \\
\hline 10 & 53,86 & 23,76 & & 2 \\
\hline 11 & 43,81 & 24,36 & 14,00 & 2 \\
\hline 12 & 53,13 & 24,89 & & 16,43 \\
\hline 13 & 51,26 & 27,72 & 14,74 & \\
\hline 14 & 64,72 & 32,12 & 16,44 & \\
\hline 15 & 57,6 & 14,10 & 14,10 & \\
\hline 16 & 53,45 & 26,28 & 10,73 & \\
\hline 17 & 72,15 & 30,00 & 16,43 & 2 \\
\hline
\end{tabular}


Fic ha de datos históric os y bienes inmuebles

014 Teulada

\begin{tabular}{|l|l|l|l|}
\hline \multicolumn{4}{|l|}{ DATOS DE LA POBLACIÓN } \\
\hline NOMBRE ACTUAL & Teulada & NOMBRE ORIG INAL & Tablada \\
\hline Hisn o castillo cerca del cual se construye & \multicolumn{1}{|l|}{ Castillo de Calpe. a 14 Km. } \\
\hline FUNDACIÓN y carta pobla & 1276 & \\
\hline FUERO & Va lencia & OTORG ANTE & Rey Pedro III \\
\hline Casas en 1490 & 46 & Casasen 1560 & 106 \\
\hline
\end{tabular}

\begin{tabular}{|c|c|c|c|c|c|c|}
\hline \multicolumn{7}{|l|}{ URBANISMO } \\
\hline \multicolumn{3}{|c|}{ RAZÓN DEL PERÍMEIRO CON LOS LADOS } & \multicolumn{4}{|l|}{$3: 5$} \\
\hline LONGITUD & 130 & & & AMPUTUD & $115 \mathrm{ml}$ & \\
\hline \multirow{6}{*}{ 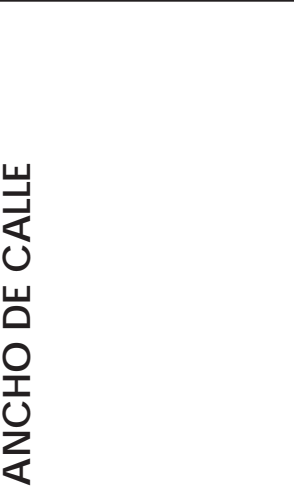 } & \multicolumn{3}{|c|}{ Decama nus (Este- Oeste ml) } & \multicolumn{3}{|c|}{ Cardus ( Norte-Sur ml) } \\
\hline & EJE & $\begin{array}{l}\text { C/ De Costanza y } \\
\text { C/ Cervantes }\end{array}$ & 3,26 & EJE & $\begin{array}{l}\text { C/ San } \\
\text { Josep }\end{array}$ & 3,07 \\
\hline & \multirow{4}{*}{ 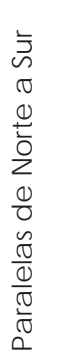 } & $\begin{array}{l}\text { C/ Dr. Moll (antes } \\
\text { carre fondo) }\end{array}$ & 3,34 & \multirow{4}{*}{ 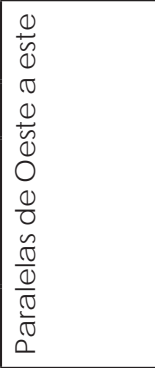 } & \multirow{4}{*}{$\begin{array}{l}\text { C/ de la } \\
\text { divina } \\
\text { Pastora }\end{array}$} & \multirow[t]{4}{*}{3,29} \\
\hline & & C/ De dalt & 3,34 & & & \\
\hline & & $\begin{array}{l}\text { Callejón perpen- } \\
\text { dicular plaza de } \\
\text { losporches }\end{array}$ & 3,18 & & & \\
\hline & & $\begin{array}{l}\text { C/ Colon (antes } \\
\text { callerd'avall) }\end{array}$ & 4,5 & & & \\
\hline COMPARATIVA & \multicolumn{2}{|c|}{ Aragón S.XI. Jaca } & \multicolumn{4}{|c|}{ Urba nismo en C.V. S.XIII } \\
\hline MANZANAS & \multicolumn{2}{|c|}{ Iguales } & \multicolumn{4}{|c|}{$\begin{array}{l}\text { Desiguales se adaptan a las calles } \\
\text { principales }\end{array}$} \\
\hline $\begin{array}{l}\mathrm{L} O \mathrm{O} \quad \mathrm{G} I \mathrm{~T} \\
\text { MANZANAS }\end{array}$ & \multicolumn{2}{|c|}{ Doble o triple ancho calle } & \multicolumn{4}{|c|}{ Varias } \\
\hline PARCELAS & \multicolumn{2}{|c|}{ Iguales } & \multicolumn{4}{|c|}{ Desiguales } \\
\hline Frente de fachada & \multicolumn{2}{|c|}{$4-5 \circ 6$} & \multicolumn{4}{|c|}{3,06 a 11,666} \\
\hline Profundidad & \multicolumn{2}{|c|}{ Hasta $25 \mathrm{~m}$} & \multicolumn{4}{|c|}{ Hasta 20,58} \\
\hline TIP. VIVIENDAS & \multicolumn{2}{|c|}{ Viv. Entre medianeras } & \multicolumn{4}{|c|}{ Vivi. entre medianeras } \\
\hline MURAШA & \multicolumn{2}{|l|}{ No } & \multicolumn{4}{|l|}{$\mathrm{Si}$} \\
\hline PLAZA CENTRAL & \multicolumn{2}{|c|}{ No, situa da a la entrada } & \multicolumn{4}{|l|}{$\mathrm{Si}$} \\
\hline
\end{tabular}




\begin{tabular}{|c|c|c|c|}
\hline \multicolumn{4}{|l|}{ ARQUITECTURA } \\
\hline \multicolumn{2}{|c|}{ MURAШA O CERCA Muraria } & $\mathrm{SI}$ & \\
\hline \multicolumn{2}{|c|}{$\begin{array}{l}\text { Construida al mismo tiempo o posterior a la } \\
\text { fundación de la puebla }\end{array}$} & S.XIV & \\
\hline \begin{tabular}{lll|} 
CISTERNA & O & POZO \\
CENTRAL & & \\
\end{tabular} & & $\begin{array}{|ll|}\text { ERMITA } & \text { ARCOS } \\
\text { DIAFRAGMA } & \\
\end{array}$ & $\begin{array}{l}\text { Emita de la } \\
\text { Santa }\end{array}$ \\
\hline $\begin{array}{l}\text { IGLESIA BÓVEDAS DE } \\
\text { CRUCERÍA }\end{array}$ & \begin{tabular}{|l|} 
Iglesia de \\
Santa Catarina \\
\end{tabular} & $\begin{array}{l}\text { CASTILO } \\
\text { INTRAMUROS } \\
\end{array}$ & \\
\hline \multicolumn{4}{|l|}{ NOTAS } \\
\hline $\begin{array}{l}\text { Iglesia de Santa C } \\
\text { Se puede datar el inic } \\
\text { una primitiva iglesia gó } \\
\text { XV, . Se encuentra situa } \\
\text { Emita de Font santa } \\
\text { Se sitúa a unos tres kiló } \\
\text { En un mismo edificio } \\
\text { pequeña sa la a la izqu } \\
\text { El origen de esta emita } \\
\text { S. XV, fecha en la que, } \\
\text { agua sobre la piedra. }\end{array}$ & $\begin{array}{l}\text { aterina } \\
\text { io de su construcción a } \\
\text { tica que había sido con } \\
\text { ada en una esquina de } \\
\text { metros de Teulada y cie } \\
\text { stá la emita propiame } \\
\text { ierda, donde está la fue } \\
\text { puede remontarse a ti } \\
\text { según tradición San Vic } \\
\text { El edific io actual fue rem }\end{array}$ & $\begin{array}{l}\text { principios del último ter } \\
\text { struida entre fina les del si } \\
\text { I parc ela rio. } \\
\text { n metros de la ca rretera } \\
\text { nte dic ha, que forma e } \\
\text { nte, y la casa del emita } \\
\text { empos muy a ntiguos, co } \\
\text { cente Ferrer rea lizó el mi } \\
\text { lodelado en el siglo XIX }\end{array}$ & $\begin{array}{l}\text { cio del siglo XVI, sobre } \\
\text { iglo XIV y principios del } \\
\text { que va a Moraira. } \\
\text { l cuerpo central, una } \\
\text { ño a la derecha. } \\
\text { ncretamente hacia el } \\
\text { ilagro de hacer brotar }\end{array}$ \\
\hline \multicolumn{4}{|l|}{ MURAШA } \\
\hline \multicolumn{4}{|c|}{$\begin{array}{l}\text { Otra de lasrazones que avaló su BIC es que un considerable número de casas de tradición } \\
\text { gótica, la mayoría de ellas, fueron construidas como casas muralla en las que estaba } \\
\text { integrada la iglesia pamoquial. }\end{array}$} \\
\hline
\end{tabular}

\section{DIMENSIONES DE MANZANAS}

\begin{tabular}{|c|c|c|c|c|}
\hline Manzana & Longitud & Ancho & Profundidad & $\begin{array}{c}\text { Relación, } \\
\text { largo- } \\
\text { ancho }\end{array}$ \\
\hline 1 & 70,21 & 20,48 & 20,48 & 3 \\
\hline 2 & 67,81 & 31,09 & 16,17 & 2 \\
\hline 3 & 59,04 & 31,90 & 12,79 & 2 \\
\hline 4 & 123,65 & 19,69 & 19,69 & 6 \\
\hline 5 & 60,68 & 17,95 & 17,95 & 3 \\
\hline 6 & 36,63 & 25,83 & 13,38 & 1 \\
\hline 7 & 51,79 & 25,88 & 13,53 & 2 \\
\hline 8 & 67,66 & 24,12 & 12,93 & 3 \\
\hline
\end{tabular}


Comparativas entre las villas

\section{Relac ión penímetro con los lados}

\begin{tabular}{|l|c|c|c|c|}
\hline & 1 LADO & 2 LADO & Redondeo & Redondeo \\
\hline CUШERA & 2,60 & 4,95 & 3 & 5 \\
\hline PUZOL & 3,36 & 4,89 & 3 & 5 \\
\hline VINAROZ & 2,66 & 4,91 & 3 & 5 \\
\hline GANDIA & 2,83 & 4,96 & 3 & 5 \\
\hline LA POBLA & 3,18 & 4,90 & 3 & 5 \\
\hline VIШA REAL & 3,33 & 4,91 & 3 & 5 \\
\hline CASTELÍN & 2,63 & 4,97 & 3 & 5 \\
\hline ALMENARA & 3,21 & 4,89 & 3 & 5 \\
\hline MASCAREL & 2,98 & 4,88 & 3 & 5 \\
\hline NULES & 2,58 & 4,95 & 3 & 5 \\
\hline ALCOY & 3,06 & 4,92 & 3 & 5 \\
\hline COCENTAINA & 3,33 & 4,87 & 3 & 5 \\
\hline PENAGUILA & 3,12 & 4,83 & 3 & 5 \\
\hline TEULADA & 2,65 & 4,89 & 3 & 5 \\
\hline
\end{tabular}

\section{Relac ión entre sus lados}

\begin{tabular}{|l|c|c|}
\hline & 1 LADO & 2 LADO \\
\hline NULES & 1,00 & 1,10 \\
\hline CULERA & 1,00 & 1,10 \\
\hline CASTELÓN & 1,00 & 1,10 \\
\hline TEULADA & 1,00 & 1,30 \\
\hline VINAROZ & 1,00 & 1,30 \\
\hline GANDIA & 1,00 & 1,30 \\
\hline MASCAREL & 1,00 & 1,50 \\
\hline PENAGUILA & 1,00 & 1,70 \\
\hline LA POBLA & 1,00 & 1,70 \\
\hline ALMENARA & 1,00 & 1,80 \\
\hline ALCOY & 1,00 & 1,80 \\
\hline COCENTAINA & 1,00 & 2,00 \\
\hline VILA REAL & 1,00 & 2,00 \\
\hline PUZOL & 1,00 & 2,00 \\
\hline
\end{tabular}


Tamaño planta medieval

\begin{tabular}{|l|c|c|c|c|l|}
\hline & 1 LADO & 2 LADO & Redondeo & Redondeo & \multicolumn{1}{|c|}{ Planta } \\
\hline TEULADA & 130,00 & 115,00 & 130 & 115 & Pentagonal \\
\hline PENAGUILA & 148,00 & 89,00 & 148 & 89 & Rectangular \\
\hline VINAROZ & 170,00 & 150,00 & 170 & 150 & Cuadrada \\
\hline MASCAREL & 179,60 & 121,60 & 180 & 122 & Cuadrada \\
\hline COCENTAINA & 250,00 & 125,00 & 250 & 125 & Cuadrada \\
\hline ALMENARA & 264,00 & 147,00 & 264 & 147 & Rectangular \\
\hline LA POBLA & 281,00 & 160,70 & 281 & 161 & Rectangular \\
\hline ALCOY & 294,87 & 187,21 & 295 & 187 & f.iregular \\
\hline NULES & 298,00 & 279,20 & 298 & 279 & Cuadrada \\
\hline CUШERA & 302,74 & 279,14, & 303 & 279 & Pentagonal \\
\hline PUZOL & 315,58 & 154,35 & 316 & 154 & Rectangular \\
\hline VIШA REAL & 380,00 & 190,00 & 380 & 190 & Rectangular \\
\hline GANDIA & 477,00 & 366,00 & 477 & 366 & Cuadrangular \\
\hline CASTELÓN & 500,00 & 450,00 & 500 & 450 & Cuadrangular \\
\hline
\end{tabular}

* Puesto que la plaza mayordel municipio de Puzol ha desaparecido se toma para la medición conforme a la documentación históric a de V. Roselló. El Plano se grafía conforme a la hipótesis de plaza realizada por A. Contelles

\section{Tamaño plazas mayores o centrales}

\begin{tabular}{|l|c|c|c|c|}
\hline & 1 LADO & 2 LADO & Redondeo & Redondeo \\
\hline CULERA & 0,00 & & 0,00 & 0,00 \\
\hline VINAROZ & 0,00 & & 0,00 & 0,00 \\
\hline NULES & 0,00 & & 0,00 & 0,00 \\
\hline LA POBLA & 14,00 & 13,30 & 14,00 & 13,30 \\
\hline PUZO L* & 14,70 & 13,50 & 14,70 & 13,50 \\
\hline PENAGUILA & 20,70 & 13,40 & 20,70 & 13,40 \\
\hline ALMENARA & 21,20 & 15,80 & 21,20 & 15,80 \\
\hline TEULADA & 21,50 & 16,50 & 21,50 & 16,50 \\
\hline COCENTAINA & 22,80 & 12,80 & 22,80 & 12,80 \\
\hline ALCOY & 22,90 & 12,70 & 22,90 & 12,70 \\
\hline MASCAREL & 27,10 & 19,50 & 27,10 & 19,50 \\
\hline VILA REAL & 31,10 & 25,90 & 31,10 & 25,90 \\
\hline GANDIA & 39,90 & 34,10 & 39,90 & 34,10 \\
\hline CASTELÓN & 57,60 & 31,40 & 57,60 & 31,40 \\
\hline
\end{tabular}




\section{Orientación parcelas y hacia que eje se dingen los inmuebles penpendic ulamente}

\begin{tabular}{|l|c|c|c|}
\hline & ORIENTACIÓN & PERP. CARDUS & PERP. DECUMANUS \\
\hline CULERA & Noroeste & $X$ & \\
\hline PUZOL & Noreste & & $X$ \\
\hline VINAROZ & Noroeste & $X$ & $X$ \\
\hline GANDIA & Noreste & & $X$ \\
\hline LA POBLA & Noroeste & & $X$ \\
\hline VILA REAL & Noroeste & & $X$ \\
\hline CASTELLÓN & Noroeste & $X$ & $X$ \\
\hline ALMENARA & Noroeste & & $X$ \\
\hline MASCAREL & Noroeste & & $X$ \\
\hline NULES & Noroeste & $X$ & $X$ \\
\hline ALCOY & Noroeste & & $X$ \\
\hline COCENTAINA & & & $X$ \\
\hline PENAGUILA & Noroeste & & $X$ \\
\hline TEULADA & Noroeste & & \\
\hline
\end{tabular}

\section{Ancho de la calle mayor y no de calles paralelas a este vial}

\begin{tabular}{|c|c|c|c|}
\hline & DECUMANUS & CARDUS & № de calles paralelas a la calle mayor \\
\hline TEULADA & 3,30 & 3,10 & 2, 1 a miba y la otra abajo \\
\hline MASCAREL & 3,50 & 3,20 & 4,2 a miba y 2 abajo \\
\hline PUZOL & 6,70 & 4,50 & s, 1 a miba y otra abajo \\
\hline PENAGUILA & 3,70 & 3,60 & \\
\hline ALMENARA & 5,00 & 4,70 & 3 , paralelasa la calle mayor \\
\hline VINAROZ & 6,00 & 4,80 & 1 paralela a la calle mayor \\
\hline COCENTAINA & 4,50 & 5,00 & \\
\hline ALCOY & 4,20 & 5,00 & \\
\hline LA POBLA & 8,20 & 5,10 & 3, 2 a miba y 1 abajo \\
\hline NULES & 5,70 & 7,20 & \\
\hline GANDIA & 4,50 & 6,80 & \\
\hline VILA REAL & 5,90 & 8,60 & 2, 1 a miba y la otra abajo \\
\hline CUШERA & 5,00 & 9,00 & 3,1 a riba y 2 abajo \\
\hline CASTELÓN & 7,00 & 10,00 & \\
\hline
\end{tabular}




\section{Ancho de viales por su ubicación en los municipios}

\begin{tabular}{|l|c|c|c|c|}
\hline VIALES & c/ de dalt & c/ mayor & c/mitja & c/ de baix \\
\hline VINAROZ & 4,00 & 6,00 & 4,00 & \\
\hline CASTELÓN & & 6,00 & 9,14 & \\
\hline VILA-REAL & 5,30 & 5,85 & & 5,40 \\
\hline MASCAREL & 4,20 & 3,53 & 4,19 & \\
\hline NULES & 4,55 & 7,20 & 5,50 & 4,66 \\
\hline ALMENARA & 3,50 & 5,00 & 4,00 & \\
\hline PUZOL & 4,19 & 6,71 & 4,95 & \\
\hline LA POBLA & 3,50 & 9,00 & 5,50 & 3,50 \\
\hline CUШERA & 4,17 & 5,03 & 4,79 & \\
\hline GANDIA & 6,00 & 6,78 & 6,00 & \\
\hline TEULADA & 3,34 & 3,26 & 3,34 & 3,34 \\
\hline COCENTAINA & 3,50 & 5,00 & 3,10 & 3,04 \\
\hline PENÁG UILA & 2,70 & 3,60 & & 2,78 \\
\hline ALCOY & 4,62 & 5,00 & & 3,14 \\
\hline MEDIA & 3,77 & 5,21 & 4,96 & 3,25 \\
\hline
\end{tabular}

\section{Anc ho de fac hadas por viales}

\begin{tabular}{|l|c|c|c|c|c|c|}
\hline FACHADAS & c/ de dalt & c/ mayor & c/mitja & c/ de baix & Transversales & Paralelas \\
\hline VINAROZ & & 4,00 & & & 4,04 & 3,71 \\
\hline CASTELÓN & 3,83 & 6,00 & 3,50 & 3,50 & 3,78 & 3,00 \\
\hline VILA-REAL & 3,76 & 6,00 & 3,50 & 3,50 & 4,11 & 4,52 \\
\hline MASCAREL & 4,28 & 4,81 & 6,18 & & 3,00 & \\
\hline NULES & 3,50 & 5,75 & 3,25 & & & \\
\hline ALMENARA & 4,20 & 6,02 & 5,56 & & 5,00 & 3,50 \\
\hline PUZOL & 4,40 & 4,47 & 4,75 & & 5,00 & 3,52 \\
\hline LA POBLA & 3,43 & 6,62 & 4,37 & 5,46 & 6,01 & 3,50 \\
\hline CUШERA & 6,10 & 4,32 & & 4,32 & 6,09 & 3,50 \\
\hline GANDIA & 4,00 & 7,88 & 4,64 & & 3,75 & 3,50 \\
\hline TEULADA & 3,86 & 4,06 & 4,12 & & 3,61 & 3,18 \\
\hline COCENTAINA & 4,00 & 5,00 & 4,50 & 4,62 & 4,64 & 3,50 \\
\hline PENÁGUILA & 3,20 & 4,10 & 4,52 & & 2,50 & \\
\hline ALCOY & 4,23 & 5,50 & 5,62 & & 5,27 & \\
\hline MEDIA & 3,74 & 4,93 & 4,07 & 4,28 & 3,96 & 3,54 \\
\hline
\end{tabular}


502 de 536

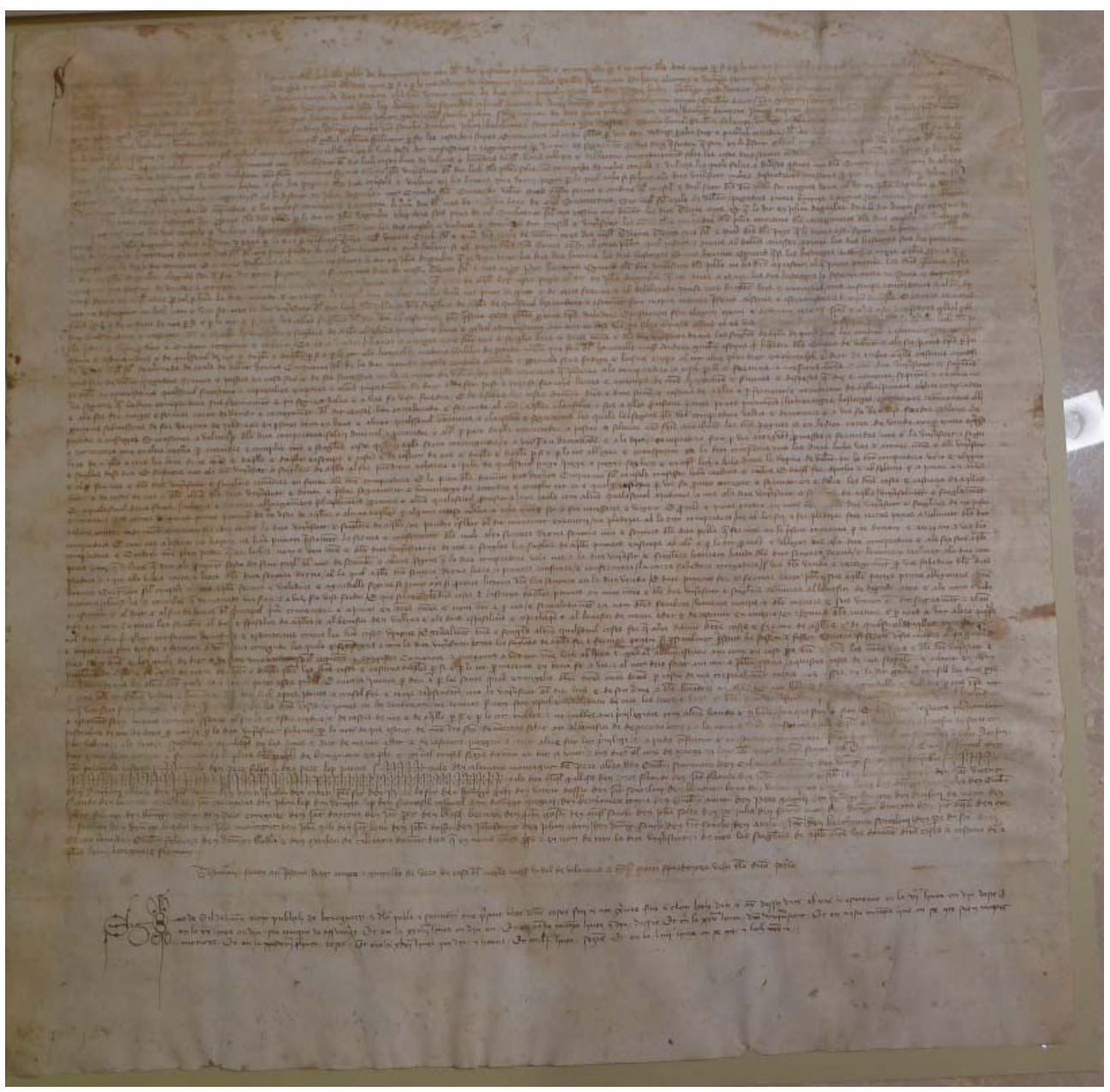


Fig.191. Pergamino 6 del Sindicato de Riegos fechado en el año 1405.

\section{Créditos fotográfcos}

Portada: Dibujo recreando La Pobla de Vallbona durante el periodo medieval. Autor José Luis Navarro. Historia de la Villa y Baronía de La Pobla de Vallbona. 1981. Archivo fotográfico José Luis Navarro.

Fig. 001. El carrer Major de la vila de La Pobla de Vallbona durante los años 50 antes de que se procediera a su asfaltado. Archivo fotográfico de José Llopis Esteve.

Fig. 002. Imagen nocturna de la fachada trasera de la ermita gótica de San Sebastián del municipio de La Pobla de Vallbona. Archivo fotográfico de Ximo Tortajada Salavert.

Fig. 003. Grabado en cerámica de Valencia amurallada. Zócalo del Cambril de la Mare de Deu de la Consolació. Parroquia de San Bernabé de Corcolilla. Alpuente. Archivo fotográfico Joan Alepúz Chelet.

Fig. 004. Vila-real. Grabado de la Tercera Parte de la crónica de la ínclita y coronada Ciudad de Valencia y su reino. Martín de Viciana. 1566. Archivo fotográfico Biblioteca Valenciana Nicolau Primitiu.

Fig. 005. Penáguila. Imagen de una de las puertas de la muralla del municipio de Penáguila en la actualidad, denominada el Portalet. Archivo fotográfico del Ayuntamiento de Penáguila.

Fig. 006. Vista de la ciudad de Jerusalén recreando de forma ideal la ciudad de Segorbe y su alcázar llegando desde el camino de Valencia, en la tabla Llanto por Cristo muerto de Vicente Macip (c. 1525-1531) .Arquitectura año zero. Archivo fotográfico Arturo Zaragozá. 
Fig. 007. La Población de Cafranc en el siglo XII. Se observa su planta en formación de línea. Archivo fotográfico R. Beltran Abadía.

Fig. 008. Planos de diversos municipios de la comunidad de Aragón donde se observa en su planta la tipología de espina de pez. Archivo fotográfico R. Beltran Abadía.

Fig. 009. La Población de Jaca fundada con arreglo a su fuero en el año 1.706, queda reflejado el trazado ortogonal en su urbanismo y su evolución. Archivo fotográfico R. Beltran Abadía.

Fig. 010. Plano de la vila de Mosqueruela, fundada en 1.263. La plaza central está situada en el cruce de los dos viales principales. Archivo fotográfico R. Beltran Abadía.

Fig. 011. Plaza mayor de Cantavieja. Se observan los soportales en la planta baja de la casa consistorial donde se realizaba el mercado y las diferentes reuniones. Archivo fotográfico Ana Isabel Contelles.

Fig. 012. Plaza mayor del municipio aragonés de Aínsa. Imagen que detalla los restos patrimoniales de los soportales y la torre gótica a principios de siglo XX. Archivo fotográfico Lucian Briet.

Fig. 013. Puente gótico en Aragón cerca del municipio de Cantavieja. Imagen en la actualidad. Archivo fotográfico Inma Aleixandre.

Fig. 014. Pinturas murales del castillo de Alcañiz (Teruel). Siglo XIII. Representa la entrada de Jaime I en Valencia durante la reconquista. Archivo fotográfico José Luis García Corbin.

Fig. 015. Expansión del modelo social de las pueblas de colonización desde la corona de Aragón hacia Valencia, Murcia y Baleares. Archivo fotográfico Vicente de Olrzy.

Fig. 016. Imagen de Llibre del Repartiment. En este libro Jaime I anotó como se iban repartiendo las tierras entre aquellos que le habían ayudado en la Reconquista de Valencia. Archivo fotográfico Vicent García Editores.

Fig. 017. Planos del centro histórico de Almenara y Vila-real. Se observa el trazado ortogonal de sus viales. Archivo fotográfico Ana Isabel Contelles.

Fig. 018. Traslado del centro colonizador del Castillo de Bairén a una zona más llana, la ubicación actual de la vila de Gandía (1249). Archivo fotográfico Joan Torro.

Fig. 019. Perímetros urbanos de Castellón (1251, 1272). Basado en Enric Guinot y Joan Martí (2006).

Fig. 020. Almenara en el siglo XIX. Perfectamente reconocible su muralla y trazado medieval. Archivo fotográfico Ayuntamiento de Almenara. 
Fig. 021. Listado general de las poblas valencianas nacidas después de la Reconquista de Valencia según E. Guinot y J. Martí. Se sitúan en el plano las catorce pueblas analizadas en el presente plan de investigación. Archivo fotográfico Ana Isabel Contelles.

Fig. 022. Imagen medieval de albañiles trabajando en la construcción de la torre de Babel. Pertenece a la Biblia de Maciejowski. llustrada en el año 1250. Lámina no3.

Fig. 023. Castillo de Concentaina. Al abrigo de este castillo en el valle, se planificó y construyó la vila de Cocentaina. Archivo fotográfico del Ayuntamiento de Cocentaina.

Fig. 024. Ámbitos de los centros históricos analizados, basados en diferentes historiadores. De izquierda a derecha y de arriba abajo. Página izquierda: Vinaroz y Castellón por E. Guinot y J. Martí, Mascarell, Nules y Puzol. Página derecha: Cullera y Gandía según V. Rossello Verguer, Cocentaina, según Torro - Ivars, Penáguila por J. Ivars, J. Torró y E. Cortell, Alcoy medieval, por J. Torro y Teulada por J. Ivars. Archivo fotográfico Ana Isabel Contelles.

Fig. 025. Centro histórico de Almenara, según Vicenc Rossello Verguer. Detalla sus trazas ortogonales y la plaza central. Archivo fotográfico Ana Isabel Contelles.

Fig. 026. Plaza mayor de Vila-real. Las fachadas aún conservan los arcos apuntados formando un porche típico de la época medieval. Archivo fotográfico Ayuntamiento de Vila-real.

Fig. 027. Plano del centro histórico de Alcoy. Identificadas sus trazas ortogonales y la plaza central. Archivo fotográfico Ana Isabel Contelles.

Fig. 028. Plano del centro histórico de Vila-real donde son detalladas las calles, principales, secundarias, travesseres i carrerons. Archivo fotográfico Ana Isabel Contelles.

Fig. 029. El carrer Major de Castellón en la actualidad. Archivo fotográfico Maribel García Corbin.

Fig. 030. Carrer Major de Cullera actual calle del Riu. En las fachadas no se observa ningún resto que recuerde a las antiguas edificaciones medievales. Archivo fotográfico Ana Isabel Contelles.

Fig. 031. Carrer Mitjà situado en el centro histórico de la vila de Castellón. Archivo fotográfico Maribel García Corbin.

Fig. 032. Una de las calles conocidas como travessera en el núcleo medieval de CuIlera. Archivo fotográfico Ana Isabel Contelles. 
Fig. 033. Plano del centro histórico de Vila-real donde se observan la división administrativa en quarters. Archivo fotográfico Ana Isabel Contelles.

Fig. 034. Situación de la vila medieval de La Pobla de Vallbona detallando la organización administrativa en quarters Archivo fotográfico Ana Isabel Contelles.

Fig. 035. Plano de la vila de Mascarell, único municipio que queda amurallado en Castellón. Se detalla los dos tipos de manzanas, las perimetrales pegadas al muro y la tipo isla, rodeadas de viales, en la zona central. Archivo fotográfico Ana Isabel Contelles.

Fig. 036. Plano de Cullera. Las manzanas situadas en el carrer Major, cuentan con más profundidad que sus parcelas opuestas. Archivo fotográfico Ana Isabel Contelles.

Fig. 037. Planos donde se identifican las manzanas con menos profundidad de lo habitual. Municipios de Vila-real, $m-22$ y de Penáguila, $m-8, m-9, m-10$ y m-11. Archivo fotográfico Ana Isabel Contelles.

Fig. 038. Las manzanas de Castellón como se han tenido en cuenta para analizar el centro histórico de dicho municipio. Archivo fotográfico Ana Isabel Contelles.

Fig. 039. Orientación de las parcelas del municipio de Cullera. Los inmuebles se sitúan perpendiculares a los ejes principales. Archivo fotográfico Ana Isabel Contelles.

Fig. 040. Ámbitos de los centros históricos analizados, marcando la orientación de sus parcelas. Se encuentra en todos casos las viviendas perpendiculares al carrer Major y su eje transversal. El resto ortogonales a los viales secundarios. De izquierda a derecha y de arriba abajo. Página Izquierda, Vinaroz, Castellón, Vila-real, Mascarell y Nules. Página derecha: Almenara, Gandía, Cocentaina, Penáguila, Alcoy y Teulada. Archivo fotográfico Ana Isabel Contelles.

Fig. 041. Plano de la orientación de las parcelas de Puzol. En la mayoría de las manzanas las parcelas se sitúan en la misma dirección, perpendiculares al carrer Major. Archivo fotográfico Ana Isabel Contelles.

Fig. 042. Escena de agrimensura representada en la Siençia de destrar y la Siençia d'atermenar de Bertrand Boysset. Carpentras. Biblioteca Ingibertina. ms. 327r. Pag 9. Arquiany 0. Archivo fotográfico Arturo Zaragozá.

Fig. 043. Uno de los portales y parte del paramento vertical de la cerca de Mascarell en la actualidad. Archivo fotográfico Ana Isabel Contelles.

Fig. 044. Plano de situación de la Vila-real medieval, con su recinto y sus cuatro puertas. Archivo fotográfico del Ayuntamiento de Vila-real. 
Fig. 045. La Torre Na Valora de Alcoy posteriormente a su restauración. Archivo fotográfico Ana Isabel Contelles.

Fig. 046. Resto de la torre Motxa de Villa Real, uno de sus pocos restos que existen en la actualidad. Archivo fotográfico Ana Isabel Contelles.

Fig. 047. Grabado de la ciudad de Gandía en el año 1786, donde se observa la villa con su muralla y puertas. De Atlante Español, Bernardo Espinalt y García. Viajeros Británicos por la Valencia de la llustración.

Fig. 048. Arquitectura civil gótica, sala de los Jurados Teulada. Archivo fotográfico Javier Ruiz.

Fig. 049. Detalle de los arcos de diafragma de Hospital de San Marcos en Gandía. Archivo fotográfico Margarita Sendra.

Fig. 050. Ermita de San Antonio situado extramuros del municipio de Alcoy. Archivo fotográfico Ayuntamiento de Alcoy.

Fig. 051. Ermita de Santa Bárbara situada en un pequeño montículo del término municipal de la vila de Cocentaina. Archivo fotográfico del Ayuntamiento de Cocentaina.

Fig. 052. La Seu de Gandía, Colegiata de Santa María. Se observa el sistema de cubrición construida con bóvedas de crucería. Archivo fotográfico Javier Ruiz.

Fig. 053. Resto de los nervios de las bóvedas de crucería de la iglesia parroquial de Almenara. Archivo fotográfico Francisco Cervera Arias.

Fig. 054. Peiró de Almenara. Quedan detallados sus 3 elementos, la zona escalonada, la cruz y el capitel. Archivo fotográfico Francisco Cervera Arias.

Fig. 055. Peiró de Cocentaina en la actualidad. Archivo fotográfico del Ayuntamiento de Cocentaina.

Fig. 056. Peiró del Lledó situado en la vila de Castellón delante de la ermita del mismo nombre. Archivo fotográfico Maribel García Corbin.

Fig. 057. Ermita de San Roc en Alcoy en el año 1.916. La imagen deja constancia de la existencia de un peiró delante del inmueble. Archivo fotográfico del Ayuntamiento de Alcoy.

Fig. 058. Detalle de la cruz del Peiró de Almenara. Zona del capitel. Archivo Francisco Cervera Arias. 
Fig. 059. Calle denominada $d^{\prime} A v a l /$ del municipio de Teulada que se mantiene en la actualidad. Archivo fotográfico José Luis García Corbin.

Fig. 060. La rúa de Baix del municipio de Cullera. El topónimo se mantiene en el presente. Archivo fotográfico José Luis García Corbin.

Fig. 061. Calle de Dalt del municipio de Teulada. En este vial aún se conserva el topónimo medieval. Archivo fotográfico Joan Llovell.

Fig. 062. Fotografía aérea de los términos de La Pobla de Vallbona y de Benaguacil. Se ubica el castillo de Benaguazir y la distancia a la que se formó el nuevo de población cristiano, en un valle a apenas dos $\mathrm{km}$ de distancia del castillo del que dependía. Archivo fotográfico Ana Isabel Contelles.

Fig. 063. Huellas de las carriladas del camino ibero existente en el término municipal de La Pobla de Vallbona. Archivo fotográfico Ana Isabel Contelles.

Fig. 064. Acueducto islámico de la Cova Tella. Aunque inicialmente se creía romano los arqueólogos no encontraron restos que lo acreditaran. Archivo fotográfico Ana Isabel Contelles.

Fig. 065. Fachada posible villa romana Más de Tous. Pérez Mínguez, Rafael: "Aspectos del Mundo Rural Romano en el territorio comprendido entre los ríos Turia y Júcar", Servicios de Investigación de Prehistoria, no 106, Diputación Provincial de Valencia.

Fig. 066. Fotografía aérea del municipio de La Pobla de Vallbona en la actualidad y la zona donde se ubicaban las villas romanas. Archivo fotográfico Ana Isabel Contelles.

Fig. 067. Lápida romana encontrado en La Pobla por Escolano. Década primera de la Historia de la Insigne Coronada Ciudad y Reyno de Valencia.

Fig. 068. Inscripción de una piedra romana existente en el término municipal de la Pobla de Benaguazir, según Carlos Sarthou y no reproducido por Escolano. Archivo fotográfico Carlos Sarthou.

Fig. 069. Imagen en la actualidad de detrás del altar de la iglesia de San Jaime donde Pedro Sucías Aparicio indica que estaba ubicada la lápida romana en el año 1911. Archivo fotográfico Ana Isabel Contelles.

Fig. 070. Fachada del castillo islámico de Benaguacil antes de su derribo. Archivo fotográfico Josep Nicolau i Baunt. 
Fig. 071. Plano de la comarca del Camp de Turia, donde se encuentra delimitado el territorio que estaba bajo el castillo de Benaguacil, en época medieval. Archivo fotográfico Ana Isabel Contelles.

Fig. 072. Imagen del interior del castillo de Benaguacil antes de su derribo. Archivo fotográfico Josep Nicolau i Baunt.

Fig. 073. La acequia primera a su salida del centro histórico de La Pobla de Vallbona. Junto a ella se fundó el lloc La Pobla de Benaguazir . Archivo fotográfico Ana Isabel Contelles

Fig. 074. El presente croquis refleja el sistema de riego (acequias) existentes desde Benaguacil hasta La Eliana, parte del Término Municipal de La Pobla hasta que se segregó en el año 1958. Como curiosidad indicar que la villa de La Pobla que debería aparecer en el centro, no se encuentra indicada, pero si el Castillo de Benaguacil y la ubicación del molino de L'Eliana. Documento existente en el pleito del Convento del Carmen por el agua de Riego contra D. Juan Baba. Año 1743. Archivo fotográfico de Vicente Rubio miembro del Centro de Estudios Locales de I'Eliana.

Fig. 075. En el presente documento se habla de llocs o castells, en ningún momento se nombra al municipio o indica que sea una Vila. 12 de enero de 1.370. Pergamino 1. Archivo fotográfico del Sindicato de Riegos de La Pobla de Vallbona.

Fig. 076. En el presente pergamino fechado el 12 de enero de 1376 se detallan los mismos topónimos de partidas de rústica que aún existen en la actualidad y se menciona la acequia primera, al lado de la cual se fundó el municipio. Pergamino 2. Archivo fotográfico del Sindicato de Riegos de La Pobla de Vallbona.

Fig. 077. Carta de Población de La Pobla de Vallbona sita en el Archivo del Reino, transcrita en el año 1626. Archivo fotográfico de Ana Isabel Contelles.

Fig. 078. En el documento de la imagen superior aparece denominado el municipio como La Pobla de Vallbona, alias de Benaguazir con fecha 15 de septiembre de 1420. Pergamino 8. Archivo fotográfico del Sindicato de Riegos de La Pobla de Vallbona.

Fig. 079. En pergamino de la imagen superior ya no aparece nombrado el municipio como un lloc sino referenciado como una vila. Años posiblemente 1449-1488. Pergamino 9. Archivo fotográfico del Sindicato de Riegos de La Pobla de Vallbona.

Fig. 080. Imagen de la fachada de la cartuja de Porta-celi. Archivo fotográfico Valencia terra y mar.

Fig. 081. Plano de las posesiones del monasterio de Porta-celi en la comarca del Camp de Turia en la edad media Archivo fotográfico Francisco Fuster Serra. 
Fig. 082. Plano del término municipal de La Pobla de Vallbona en la actualidad donde se observa las zonas de regadío y de secano. Archivo Ana Isabel Contelles.

Fig. 083. Imagen del Azud de La Pobla de Vallbona y Benaguacil sobre el río Turia. También se observa la compuerta la Real. En el paramento vertical se observan sillares de la compuerta original. Archivo fotográfico Ana Isabel Contelles.

Fig. 084. La acequia mare a su entrada en La Pobla de Vallbona desde el Término de Benaguacil. Archivo fotográfico Ana Isabel Contelles.

Fig. 085. Uno de los cequiers del Sindicato de Riegos de La Pobla de Vallbona haciendo tareas de mantenimiento y limpieza en una de las compuertas. Archivo fotográfico Ana Isabel Contelles.

Fig. 086. Algunas de construcciones de Piedra en seco existentes en la zona de secano del Término Municipal de La Pobla: 1- Catxirulo dels Rincons, 2- Catxirulo del Garroferal Clar, 3- Aljub delante de la Taula de Miralles y 4- Muro de contención ermita de San Sebastián. Archivo fotográfico Ana Isabel Contelles.

Fig. 087. Extracto del plano posterior donde se observa el grabado de la Pobla, sus murallas, un portal y el foso. Mapas y cartografía Archivo del reino de Valencia.

Fig. 088. Plano del pleito de los arroces entre Benaguacil, Riba-roja de Turia y La Pobla de Vallbona 1584. Mapas y cartografía Archivo del reino de Valencia.

Fig. 089. Cartografía Valentica Regni Olim. Año 1585. Autor Abraham Ortelius. Archivo fotográfico "Valencia" de Luis Giménez Lorente.

Fig. 090. Cartografía Valentia. Año 1606. Autor Petrus Bertius y Barent Langenes. Archivo fotográfico de José Huguet.

Fig. 091. Mapa cartográfico. Regni Valentia Typus. Año 1609. Autor Gerard Mercator o Kremer. Archivo fotográfico colección de Luis Giménez Lorente.

Fig. 092. Carte du Royaume de Valencia. Año 1760. Autor Jean Beaurain. Archivo fotográfico de la colección "Valencia” de Luis Giménez Lorente.

Fig.093. Mapa del arzobispado de Valencia dispuesto por orden del arzobispo y Cabildo a su iglesia en el año 1761. Marca la Pobla como Vila. Mapas y cartografía. Archivo del Reino de Valencia.

Fig. 094. Mapa geográfico del Reyno de Valencia conforme a sus trece partidos por Tomás López de Vargas, 1.788. Archivo Biblioteca digital de Patrimonio.

Fig. 095. Mapa de la huerta de Valencia y de los principales riegos de los ríos Guadalaviar y Júcar. Año 1820. Archivo fotográfico Diputación de Valencia. 
Fig. 096. Croquis de las trazas medievales realizado en 1860 por el canónigo Pedro Sucías Aparicio. Llavata, Vicente: Historia de la Villa y Baronía de La Puebla de Vallbona, La Puebla de Vallbona 1981.

Fig. 097. Croquis de la provincia de Valencia en el que se representan las carreteras que comprende el plan provincial aprobado el 14 de mayo de 1881 y las del plan general del estado de 1880.

Fig. 098. Plano antiguo de de los lindes entre los términos municipales de La Pobla de Vallbona y Riba-roja, propiedad de conde de Revillajijedo Año 1891. Archivo fotográfico de Vicent Rubio.

Fig. 099. Plano topográfico de los lindes entre los términos municipales de La Pobla de Vallbona y Riba-roja realizado por el perito Rafael Badia por Año 1891. Archivo fotográfico de Vicent Rubio.

Fig. 100. Croquis de las trazas medievales y del ensanche realizado en 1911 por el canónigo Pedro Sucías Aparicio para sus Notas útiles del Reino de Valencia distritos de Onteniente y Llíria.

Fig. 101. Plano del Instituto Geográfico y catastral realizado por Ingeniero Víctor Gesalvez, año 1928. Se observa el centro la delimitación del centro histórico.

Fig. 102. Vista aérea del vuelo americano del año 1950 donde aún se puede observar el centro histórico de la vila perfectamente.

Fig. 103. Plano de la vila del Instituto Geográfico y catastral, año 1980. Archivo Ayuntamiento de La Pobla de Vallbona.

Fig. 104. Delimitación del núcleo medieval en las normas subsidiarias año 1986. Archivo Ayuntamiento de La Pobla de Vallbona.

Fig. 105. Ordenación pormenorizada Plan General del año 2004. Archivo Ayuntamiento de La Pobla de Vallbona.

Fig. 106. Delimitación del centro histórico de La Pobla de Vallbona, denominado la Vila, según el Plan General de Ordenación urbana en la actualidad. Archivo fotográfico Ana Isabel Contelles.

Fig. 107. La plaza mayor de la Vila de La Pobla de Vallbona, alias de Benaguazir en la actualidad. El edificio situado en el centro ocupa el inmueble donde se ubicaba la Sala del Consell en el bajo medievo. Archivo fotográfico José Luis García Corbin.

Fig. 108. Plano de viales. El carrer Major, su eje transversal, la calles secundarias paralelas, y les travesseres i carrerons. Archivo fotográfico Ana Isabel Contelles. 
Fig. 109. Vial principal que corta perpendicularmente al carrer Major. En la actualidad calle maestro Barona y Avda. Colón. El primer tramo cuenta con la antigua alineación. Archivo fotográfico Ana Isabel Contelles.

Fig. 110. El carrer Major en la actualidad, denominada calle Obispo Cervera. No mantiene la antigua alineación, se ensanchó a lo largo de la historia. Archivo fotográfico José Luis García.

Fig. 111. El carrer Mitjà en la actualidad, conocido por calle Jesús Pitarch. Cuenta con el mismo ancho que la calle Maestro Barona. Archivo fotográfico José Luis García.

Fig. 112. Imagen del carrer de Dalt, en el presente con el apelativo calle Maestro Giner. Archivo fotográfico José Luis García.

Fig. 113. Organización administrativa de La Pobla de Vallbona en quarters. Archivo fotográfico Ana Isabel Contelles.

Fig. 114. Designación de las manzanas conforme al estudio realizado. Archivo fotográfico Ana Isabel Contelles.

Fig. 115. Plano donde se grafía la orientación de las viviendas en las diferentes manzanas de La Pobla de Vallbona.

Fig. 116. Imagen de una de las traveseras, actualmente calle ángel del Alcázar. Se observa que no hay fachadas principales. Archivo fotográfico José Luis García.

Fig. 117. Sección de los Trullos de la casa gran, lindante con la muralla o tal vez amplió sobre el foso aprovechando la oquedad del este para construir los trullos. Se observa la diferencia de cotas de la calle al interior de la vivienda. Cuando llueve se llenan de agua pero no sobrepasan el nivel de pavimento. Autora Ana Isabel Contelles.

Fig. 118. Hipótesis sobre la evolución de la villa. Primero cuando fue lloc sin amurallar, en la presente página en la zona superior, cuando se amuralla. La tercera imagen muestra como la necesidad de solares va cogiendo el camino de ronda hasta hacerlo desaparecer. La última imagen en centro histórico de la Pobla en la actualidad, sin restos de muralla a la parte inferior de este texto. Autora Ana Isabel Contelles.

Fig. 119. Protocolo notarial del 24 de marzo de 1384, reconociendo de una deuda de 290 florines que prestó Samuel Xixá judío de Valencia a La Pobla de Benaguazir. Archivo Sindicato de Riegos de La Pobla de Vallbona.

Fig. 120. En azul claro el núcleo medieval original con las posibles ampliaciones hasta la muralla que se han ido realizando con el paso del tiempo. Archivo fotográfico Ana Isabel Contelles. 
Fig. 121. El Valladar de Valencia. En la fachada de las casas antiguas se puede intuir una hipotética altura de la muralla medieval Archivo fotográfico Ana Isabel Contelles.

Fig. 122. Vista actual del valladar de Benaguacil. Se observa el desnivel existente entre la zona trasera de la muralla y la nueva zona de expansión. Archivo fotográfico Ana Isabel Contelles.

Fig. 123. Acequia realizada con sillares a menos de $100 \mathrm{~m}$ de donde si situaba la muralla medieval junto al portal de Riba-roja. Archivo Isaac Sania Contelles.

Fig. 124. Único resto de la muralla del casco antiguo de La Pobla, el escudo del portal de Riba-roja de Turia. Archivo fotográfico Ana Isabel Contelles.

Fig. 125. Imagen actual del las ubicaciones donde hipotéticamente se encontraban el portal de Benaguacil y el Portal de Riba-roja. Se puede observar en uno el rebaje del pilar y en el otro un remate de final de muro. Archivo fotográfico Ana Isabel Contelles.

Fig. 126. Croquis de las estelas discoidales del municipio de Fuentespalda (Aragón) con diferentes grabados. Archivo fotográfico del Ayuntamiento de Fuentespalda.

Fig. 127. Cementerio medieval situado en el municipio de Fuentespalda (Aragón). Archivo fotográfico del Ayuntamiento de Fuentespalda.

Fig. 128. Las dos estelas discoidales encontrada en el antiguo fossar de la iglesia, en la actualidad sitas en el patio del museo etnológico de la población. Archivo fotográfico Ana Isabel Contelles.

Fig. 129. Esquina de fachada de una edificación pasando de una calle travessera al carrer de Baix. Se observa la esquina realizada con sillares curvos. Archivo fotográfico José Luis García.

Fig. 130. Resto de un pilar construido con sillares encontrados recientemente en el carrer Mitja. Posiblemente perteneció a un inmueble propiedad del Convento del Carmen. Archivo fotográfico Ana Isabel Contelles.

Fig. 131. Situación de los edificios más importantes del bajo medievo en el núcleo de la vila. Archivo fotográfico Ana Isabel Contelles.

Fig. 132. Pergamino 4 del Sindicato de Riegos fechado en el año 1402 donde indica que los prohombres del municipio se encuentran en esta plaza reunidos. Archivo fotográfico Ana Isabel Contelles.

Fig. 133. Arco apuntado en el interior de una casa a $4 \mathrm{~m}$ de la alineación actual del carrer Major. Archivo fotográfico Ana Isabel Contelles. 
Fig. 134. Brocal del pozo descubierto en el año 2002 en el centro de la plaza mayor. La planta es elíptica, actualmente cegado. Archivo fotográfico Ana Isabel Contelles.

Fig. 135. Dibujos realizados por Martín de Viciana de Nules y Villa Real medieval, en ambas se observa un pozo en la plaza mayor. Archivo fotográfico Nicolau Primitiu. Grabado de la Tercera parte de la crónica de la ínclita y coronada Ciudad de Valencia y su reino de Martín de Viciana, 1563.

Fig. 136. Jardín situado sobre la antigua cisterna. Popularmente se cuenta que cuando se derribo se construyó en su parte superior este jardín, actual plaza de los mártires. Archivo fotográfico Ana Isabel Contelles.

Fig. 137. Plano situación del trazado de las galerías subterráneas por debajo de los inmuebles. Archivo fotográfico Ana Isabel Contelles.

Fig. 138. Interior de las galerías que discurren por el subsuelo de la vila, se aprecia un acceso desde los túneles a un inmueble través de una escalera. Archivo fotográfico Ana Isabel Contelles.

Fig. 139. Vista de los escombros arrojados a las galerías a lo largo de la historia. Archivo fotográfico Ana Isabel Contelles.

Fig. 140. Acceso desde las galerías a un inmueble. En la actualidad se encuentra cegado. Archivo fotográfico Ana Isabel Contelles.

Fig. 141. Memoria escrita por el Prior D. Francesc Maresme, prior de esta casa de Porta-celi en el año 1417 de todas sus posesiones, bienes y rentas. Archivo del Reino de Valencia.

Fig. 142. Documento del año 1553 que describe las posesiones de Porta-celi en la vila de La Pobla. Archivo del Reino de Valencia.

Fig. 143. Pleito del Monasterio de Porta-celi contra el convento de San Onofre, donde indica que la propiedad de la Casa Blanca es de los dominicos de San Onofre Archivo del Reino de Valencia.

Fig. 144. Azulejos de San Onofre situados en la fachada de la C/ Salvador Giner, no 1 de Valencia. Idéntica a la que se situaba en la fachada de la casa blanca. Archivo fotográfico Ana Isabel Contelles.

Fig. 145. Fachada de la Masía denominada de la Casa Blanca, en los años 80, antes de su derribo. Archivo de José Ma Llopis Esteve.

Fig. 146. Imagen del interior de la casa blanca donde se observan sus muros de carga. Archivo fotográfico José Mestre. 
Fig. 147. Imagen de la escalera imperial que existía en el interior de la masía de la casa blanca. Imagen antes de su derribo. Archivo fotográfico José Mestre.

Fig. 148. Plano catastral del polígono donde se situaba la casa blanca del año 1928. Se observa en planta la extensión de la masía. Archivo fotográfico Ana Isabel Contelles.

Fig. 149: Recorte de noticia del Diario provincial: Las Provincias, página 4, sábado 1 o de mayo de 1928, Biblioteca virtual, prensa histórica. Edicto de pública subasta de la masía de la Casa Blanca en el citado año. Archivo fotográfico Biblioteca virtual prensa histórica.

Fig. 150. Interior de la ermita de San Sebastián después de su restauración en el año 2009. Archivo fotográfico Ana Isabel Contelles.

Fig. 151. Sección A-A' de la ermita de San Sebastián de La Pobla de Vallbona donde se observan los arcos de diafragma. Al fondo la casa del ermitaño. Archivo fotográfico Ana Isabel Contelles.

Fig. 152. Púlpito gótico existente en la ermita de San Sebastián antes de la Guerra Civil Española. Archivo fotográfico Carlos Sarthou.

Fig. 153. Retablo medieval desaparecido de la ermita de San Sebastián durante el conflicto bélico de 1936. Archivo fotográfico Carlos Sarthou.

Fig. 154. Cápsula del tiempo fechada en 1929, encontrada en el interior de un paramento vertical de la fachada principal. Detalla las obras realizadas en el citado año. Archivo fotográfico Ana Isabel Contelles.

Fig. 155. Fachada de la ermita de arcos de diafragma. Se observa el arco original de la puerta de medio punto. La ermita de San Sebastián 1928. Archivo fotográfico Rosario Serra

Fig. 156. Vista desde el calvario, al fondo, la plaza, la ermita, lateral izquierdo la casa del ermitaño y en el perímetro del calvario izquierda, los casilícios de los dolores. 1930. Archivo fotográfico Rosario Serra.

Fig. 157. Festejador existente en la planta primera de la casa del Ermitaño. Típico de las masías Valencianas en el s. XV. Archivo fotográfico Ana Isabel Contelles.

Fig. 158. Ventanas arqueológicas dejadas en el muro de tapial, el paramento vertical del inmueble de uso no religioso. Archivo fotográfico Ana Isabel Contelles.

Fig. 159. Fachada actual de la ermita de arcos de diafragma, la ermita de San Sebastián. Archivo fotográfico Ana Isabel Contelles. 
Fig. 160. Vista actual de la parte trasera ermita. Muro de contención de piedra en seco. Archivo fotográfico Ana Isabel Contelles.

Fig. 161. Interior de la ermita donde se observan los arcos de diafragma y el cambio de dirección de los pares de madera. Archivo fotográfico Ana Isabel Contelles.

Fig. 162. Fachada actual de la Iglesia Santiago Apóstol de La Pobla de Vallbona. En la baja edad media en este paramento no se situaba el acceso principal sino el altar mayor. Archivo fotográfico Ana Isabel Contelles.

Fig. 163. Sección A-A' de la iglesia de Santiago Apóstol. En sombreado la nave gótica. El acceso se situaba el segundo altar por la izquierda y el altar se situaba en la actual entrada, a la derecha. Archivo fotográfico Ana Isabel Contelles.

Fig. 164. Pergamino del Sindicato de Riegos fechado en el año 1390 donde indica que los hombres se encuentran reunidos en la iglesia de San Jaime. Archivo fotográfico Sindicato de Riegos de La Pobla de Vallbona.

Fig. 165. Plano de planta de la iglesia s de Santiago Apóstol. En sombreado la nave gótica. La entrada era el segundo altar por la izquierda y el altar se situaba en la actual entrada, a la derecha. El fossar se situaba en lo que actualmente es un jardín municipal. Archivo fotográfico Ana Isabel Contelles.

Fig. 166. Conforme lo descrito en los protocolos notariales de la reforma barroca, los pilares de la iglesia gótica eran de piedra redondos. Similares a los existentes en el Castillo de Calatrava la Nueva (Ciudad Real) Archivo fotográfico Ana Isabel Contelles.

Fig. 167. Pilares actuales conforme al gusto del barroco en la Iglesia Santiago Apóstol. Archivo fotográfico Ana Isabel Contelles.

Fig. 168. Arcos apuntados góticos similares a los que habría en la Iglesia de Santiago Apóstol en el gótico, conforme a la descripción que se da en los Protocolos Notariales de la reforma. Imagen del Castillo de Calatrava la Nueva (Ciudad Real) Archivo fotográfico Ana Isabel Contelles.

Fig. 169. Arcos de medio punto tapando los apuntados conforme al gusto barroco del a reforma efectuada. Archivo fotográfico Ana Isabel Contelles.

Fig. 170. Imagen del 4 pergamino inédito del Sindicato de Riegos de La Pobla de Vallbona, fechado el 23 de septiembre de 1.390. Archivo fotográfico Ana Isabel Contelles.

Fig. 171. Posibles restos de los paramentos verticales de la torre gótica. Archivo fotográfico Ana Isabel Contelles. 
Fig. 172. Sección transversal de la iglesia donde se observa la ubicación de las pinturas, altar mayor de la iglesia medieval. Archivo fotográfico Ana Isabel Contelles.

Fig. 173. Pinturas murales góticas del altar situado a la izquierda del acceso actual. Archivo fotográfico Ana Isabel Contelles.

Fig. 174. Restos pictóricos medievales situados a la derecha de la entrada en la página siguiente. Archivo fotográfico Ana Isabel Contelles.

Fig. 175. Inauguración de la cruz del calvario en el año 1930 en sustitución de la destruida durante la Guerra de la Independencia. Archivo fotográfico Ana Isabel Contelles.

Fig. 176. Cruz actual, colocada en sustitución de la destruida durante la Guerra Civil Española. Archivo fotográfico Ana Isabel Contelles.

Fig. 177. Mapa de la batalla acontecida cerca de la ermita de San Sebastián durante la guerra de la Independencia el 2 de octubre de 1811. Archivo fotográfico José Luis Alarcón.

Fig. 178. El centro histórico de la Vila de La Pobla de Vallbona con los topónimos de cada vial y zona. Archivo fotográfico Ana Isabel Contelles.

Fig. 179. Documento del año 1820 que detallan las posesiones de la cartuja de Porta-celi en la Vila de La Pobla y deja constancia de la utilización del topónimo de carrer Major. Archivo fotográfico Ana Isabel Contelles.

Fig. 180. Documento del año 1655 que detallan las posesiones del Convento del Carmen. Se detalla la ubicación de un edificio en el carrer Mitjà, y la existencia del carrer de Baix. Archivo del Reino. Listado de bienes del Monasterio del Carmen.

Fig. 181. La ciudad de Eiximenis según R. Beltran Abadía. Archivo fotográfico Arturo Zaragozá.

Fig. 182. Plano de Petra, fundación a principios del Siglo XIV. Archivo fotográfico R. Beltran Abadía.

Fig. 183. Vista de una de las calles del municipio de Petra en Mallorca. Archivo fotográfico David García Martínez.

Fig. 184. Cruz de término del municipio de Petra en Mallorca. Archivo fotográfico David García Martínez.

Fig. 185. Grabado de Nules medieval con su muralla. Representación caligráfica realizada en el manuscrito de la visita pastoral a la diócesis de Tortosa del obispo Paholach en 1314 (Archivo Capitular de Tortosa). Archivo fotográfico Arturo Zaragozá. 
Fig. 186. Fachada actual de la Iglesia del Municipio de Petra en Mallorca. Archivo fotográfico David García Martínez.

Fig. 187. Vista actual de la ermita de San Sebastián junto con el muro de piedra recuperado Archivo fotográfico Ana Isabel Contelles.

Fig. 188. Detalle del retablo de San Vicente Mártir donde se observa en la parte superior la construcción de la muralla de una vila y en la parte inferior la construcción de una iglesia con bóvedas de crucería.

Fig. 189. Imagen del 5 pergamino inédito del Sindicato de Riegos de La Pobla de Vallbona, fechado el 1.402. Archivo fotográfico Sindicato de Riegos de La Pobla de Vallbona.

Fig. 190. Loseta cerámica encontrada durante la ejecución de los conductos de ventilación en el pavimento. Representa dos conchas de Santiago y su bastón de peregrino. Archivo fotográfico Ana Isabel Contelles.

Fig. 191. Pergamino 6 del Sindicato de Riegos fechado en el año 1405. Archivo fotográfico Ana Isabel Contelles. 


\section{FuENTES Y biBUografí}

\section{F.1| Fondos de archivos consultados}

- Archivo Histórico Nacional.

o Códice 529 B. Recepta et expenda de Porta-celi 1375-1417.

- Archivo del Reino de Valencia.

o Manifiesto y puntual relación de los individuos, rentas y obtenciones de la Real Cartuja de Porta-celi, deducciones de gastos de fabrica, comunicado al arzobispado. Año 1776. Legajo 417, caja 1135.

o Manifeste dels bens de realench de Porta-celi. Año 1448. Secciones real Cancellería nㅇ493.

o Manifiesto de rentas y gastos. Año 1804, caja 1135.

o Procesos civiles de Porta-celi. Escribanías de Cámara. Años 1707-1835 .

- Propiedades antiguas del reino de Valencia, Inventarios de la cartuja de Portacoeli en el tiempo de las exclaustaciones 1812-40.legajos 228-283-318390-470,551.

o Papeles varios sobre censos, bienes, cuentas, testamentos y beneficios de Porta-celi, siglos XIV al XIX. Clero, legajo 417, cajas 1136,1137.

o Bienes de Realengo de la Cartuja de Porta-celi. 1789. Expediente de la Real Cartuja de Porta-celi años 1741 y 1787-92. Balía, letra a, expediente de amortización 2624.

o Relación de libros de recibos y gastos de Porta-celi.

'Libro de recibos y gastos con sus definiciones desde 1553 hasta 1561.

Sección clero. Libro 329.

${ }^{\circ}$ Recibos con sus definiciones y salidas de dinero del arca hechos por los padres arqueros del Convento de Porta-celi, desde el año 1651 hasta el 1671. Sección clero libro 1874. 
${ }^{\circ}$ Recibos (años 1737-8) y gastos de la procura de Valencia. Sección clero libro 1848.

${ }^{\circ}$ Recibos y gastos de la cartuja de Porta-celi (1797-1802). Sección clero libro 675.

`Gastos de la corredería de Porta-celi desde el año 1823 hasta el 1834. Sección clero libro 2161.

'Soldadas de los criados de Porta-celi. Años 1709-40. Sección clero libro 4015.

-Pensiones de Censos y arriendos de la Cartuja de Porta-celi. Sección clero. •Pensiones cénsales 1588-1632. Cargos y obligaciones. Libro no 347.

'Pensiones cénsales 1630-1659. Libro no 247.

'Procura de Valencia y relación de pagas hasta el año 1680. Letra o. Libro no 1817.

${ }^{\circ}$ Recibos de censos y arriendos. 1683-1733.

${ }^{\circ}$ Rentas anuales de cenos. 1712-79. Libro n 1.

'Libro de rentas 1733-1793. Libro no 279.

'Entradas y salidas del dinero del depósito de propiedades con las definiciones de las cuentas. 1793-1825. Libro no 1857.

'Libro de rentas de tierras, casas, censos, debitorios y otras reposiciones. Años 1793-1825. Libro no 1670.

`Libro de censos de la procura de valencia. Letra Q. Años 1796-1825. Libro no 1694.

'Libro colecta de censos enfitéuticos. 1832-1835. Libro no 486.

${ }^{\circ}$ Rentas de casas y pensiones de censos. Colecta corriente. 1834-35. Libro $\mathrm{n}$ ㅇ 1312 .

o Subastas de bienes de Porta-celi, valoración de fincas, obras artísticas, enseres y frutos de la ex cartuja para su arriendo y venta en pública subasta en el periodo de las exclaustraciones. 1812-74. Propiedades antiguas. Legajos $143,210,313,324,362,499,510,523,530,613,621,731,722$.

o Manaments i Empares. 1626, libro 4, mà 39, fol.38v-48v, mà 40-fol. 39-44. o Manaments i Empares. 1702.libro 2, mà 26.

o Real Cancillería (1416-1458). Consejo Supremo de Aragón, Oficiales 14161620.

o Posesiones del Convento del Carmen (1655). Listado de posesiones desde el año 1600 al 1700, páginas 19-21

-Archivo de la Diputación provincial de Valencia.

o Presupuestos municipales de La Pobla de Vallbona. Años 1842-1889.

o Archivo general y fotográfico. Mapas y cartografía.

-Archivo Municipal de Valencia.

- Archivo de Protocolos del Colegio del Patriarca de Valencia.

o Protocolos Notariales 21.981. Notari Jaume Llorenç.

o Protocolos Notariales, 21.983. Notari Jaume Llorenç. 
- Archivo Parroquial de la Iglesia de Santiago Apóstol.

o Libros de fábrica 1.700.

o Libros de fabrica 1.800.

o Libros de fabrica 1.900.

o Libro de visita pastoral de 1920.

o Libro de cuentas 1911.

o Libro de cuentas 1960.

- Archivo de la archidiócesis de Valencia, digital.

- Archivo Biblioteca Valenciana, Nicolau Primitiu.

- Archivo del Sindicato de Riegos de La Pobla de Vallbona.

o Pergamino no 1.1370.

o Pergamino no 2. 1376.

o Pergamino no 3. 1384.

o Pergamino no 4.1390.

o Pergamino № 5.1402

o Pergamino no 6. 1405.

o Pergamino no 7. 1591.

o Pergamino no 8. 1420.

o Pergamino no 9.

o Pergamino no 10. 1389.

- Archivo del COACV.

- Archivo del CAATV.

- Archivo histórico de la Diputación de Valencia.

- Biblioteca digital del Patrimonio.

- Biblioteca digital de la Universidad Jaume I.

- Biblioteca central de la Universidad Politécnica de Valencia

- Hemeroteca Municipal de Valencia.

- Oficinas técnicas municipales.

- Oficina virtual del catastro.

\section{DELIMITACIONES CENTROS HISTÓRICOS}

- Cocentaina, según J. Torro y J. Ivars.

- Gandía Medieval, según A. Zaragozá.

- Vila-real según R. Beltrán Abadía.

- Teulada medieval, según J. Ivars.

- Alcoy medieval, por J. Torró.

- Castellón de la plana por E. Guinot y J. Martí.

- Vinaroz por E. Guinot y J. Martí.

- Gandía, según V. Rossello Verguer.

- Almenara, según V. Rossello Verguer.

- Nules, según V. Rossello Verguer.

- Puzol, según V. Rossello Verguer. Plaza Mayor A. Contelles

- Cullera, según V. Rossello Verguer.

- Penáguila por J. Ivars, J. Torro y E. Cortell. 


\section{F.2| Páginas web consultadas}

- Beniganim. Patrimonio. www.caixaontinyent.es/patrimonio/ v_a/beniganim/ benig_p08.htm

- Las vías Romanas en el mediterráneo.http://www.viadomitia.org

- Románico en Barcelona y Tarragona. http://www. Arteguias.com/romanico Barcelona.htm

- Gremi de campaners de la Comunidad Valenciana. www.campanerz.com

- Ermitas y Santuarios de la Comunidad Valenciana. ww.ermitasdelacomunida dValenciana.com

- Relojes de Torre SANTIAGO MARFAGÓN. Indicación de los cuidados que necesita un reloj de torre. Internet. Gremi de Campaners. Relojes: bibliografía general

- Biblioteca digital de la Unicersidad Jaime I. http://www.uji.es/CA/cd/digital/

-Biblioteca Valenciana difital.http://www.bv2.gva.es/es/cms/elemento. cmd?id=estaticos/paginas/inicio.html

- Archivo digital del Real Colegio Seminario del Corpus Cristi. http://www. seminariocorpuschristi.org/\#!archivo-digital/c1p55

- Fondos documentales del Archivo de la Corona de Aragón. http://www. mecd.gob.es/cultura-mecd/areas-cultura/archivos/mc/archivos/aca/fondosdocumentales.html

- Las cuevas y galerías de Requena. http://www.requena.es/content/cuevas-dela-villa

- Grup harca. Medievalistas valencianos.

- Ministerio de cultura. Portal de archivos españoles. http://www.mecd.gob.es/ cultura-mecd/ 


\section{F.3| Bibliografía}

-AGUILAR CLARAMUNT, Joaquín (1997): "Loseta de Cerámica Blasonada de la Parroquia de Santiago Apóstol", Libro de fiestas patronales en honor del Mártir San Sebastián, La Pobla de Vallbona, Clavaría San Sebastián, pp: 22-24.

-AGUILAR CLARAMUNT, Joaquín (1997): “Crónica del Hallazgo de las Pinturas murales (frescos) góticas en el atrio del templo parroquial de Santiago Apóstol" en Libro de fiestas patronales en honor del Mártir San Sebastián, La Pobla de Vallbona, Clavaría San Sebastián, pp. 10-20.

-ALBA PAGAB, ÉSTER Y otros (2011): La Pobla de Vallbona, Historia, Geografía y Arte, Universidad de Valencia, Facultad de Geografía i Historia, Edición Ayuntamiento de La Pobla de Vallbona. 497p.

-ALBAIGUES OLIBART, Jose Maria (1998): Enciclopedia de los topónimos españoles, Barcelona, Planeta, $678 \mathrm{p}$.

-ALIAGA, Isidoro (1631): Advertencias para los edificios y fabricas de los Templos: y para diversas cosas de las que en ellos figuren al culto divino y a otros ministerio", Sínodo de Valencia.

-ALONSO DURA, Aurelio (2002): La Muralla Musulmana de Benaguacil, Benaguacil, autoedición, Ayuntamiento de Benaguacil, 460p.

-AQUINO DE, Santo Tomás (1266): Del Gobierno de los principes, opúsculo, libro prim., Buenos Aires, Losada, 1964.

-ARAGÓ, José (1995): Plan General de Ordenación Urbana, La Pobla de Vallbona. Ayuntamiento de La Pobla de Vallbona.

-ARAGÓ, José (2004,): Plan General de Ordenación Urbana, La Pobla de Vallbona, Ayuntamiento de La Pobla de Vallbona.

-ARGENTE DAROQUI, Enrique y otros (2004): Patrimonio Monumental Intervenciones Recientes, Valencia, Ícaro, COACV, pp. 161-211.

-ARNOU AMO, Joaquín (1988): La Teoría de la arquitectura en los tratados, Tomo II. Universidad Politécnica de Valencia, Madrid, Artes Graficas Flores.

-AZUAR, Rafael y otros (1993). Urbanismo medieval del País Valenciano, Madrid, Ediciones Polifemo. 413p.

-BELTRÁN ABADÍA, Ramón (1992): La forma de la ciudad, Las ciudades de Aragón en la Edad Media, Col. Of. de Arquitectos, Zaragoza, 510p.

-BELTRAN ABADÍA, Ramón (1999): El Camino de Santiago y la ciudad ordenada en Aragón, Gobierno de Aragón, Zaragoza. Prólogo de V. Bielza.

-BELTRAN ABADÍA, Ramón (2005): "Planeamiento y geometría en la ciudad aragonesa". Colegio de Arquitectos de Zaragoza, Arqueología y Territorio medieval, Revista de Arqueología del Área de Historia Medieval, Universidad de Jaén, pp: 75-140. 
-BENAVENTE, José Antonio (2003): “Proyecto de recuperación y puesta en valor del cementerio viejo de Fuentespalda (Teruel)", Fuenteespalda, inédito.

-BENITO DOMÉNECH, Fernando y otros (2006): La Memoria recuperada, Pintura Valenciana recuperada de los siglos XIV y XV, Valencia.

-BENITO DOMENECH, Fernando y GÓMEZ FRECHINA, José (2009): La Edad de Oro del Arte Valenciano, Rememoración de un centenario. Valencia. Edición Museo de Bellas Artes de Valencia.

-BERNARD, Guilles (1993): “L'Advenutre des bastides, ”Ed.Privat, Tolouse, ed. 2003, $160 p$.

-BIELZA DE ORY, Vicente (2000): "La ciudad ortogonal aragonesa del camino de Santiago y su influencia en el urbanismo regular posterior", Universidad de La Rioja, fundación Dialnet, núm. 16, pp: 25-43.

-BIELZA DE ORY, Vicente (2002): “De la ciudad ortogonal aragonesa a la ciudad cuadricular hispanoamericana como proceso de innovación-difusión, condicionado por la utopía", Scripta Nova, Revista electrónica de geografía y ciencias sociales, Universidad de Barcelona, vol. VI, núm. 106.

-BLANCO GÓMEZ, Pedro y otros (1997): "Restauración. La Pobla de Vallbona, Pinturas murales góticas, Església Sant Jaume. Conservació i Resturació del Patrimoni Históric Valencià" en el Tríptico de la Conselleria de Cultura, Educació i Ciencia, Direccio General de Patrimoni Artístic, Valencia.

-BRIZ DAUDER, Joaquín (2001): “Informe sobre la restauración del reloj de la torre Santiago Apóstol", Concejalía de Patrimonio del Ayuntamiento de La Pobla de Vallbona.

-CALVE, Oscar (2015): "Un siglo y medio del derribo de la muralla medieval", Las Provincias, Valencia.

-CAMPS, C., TORRÓ, Josep (2002): “Baños, hornos y pueblas. La pobla de Vila-rasa y la reordenación urbana de Valencia en el siglo XIV", en Historia de la ciudad, II. Territorio, sociedad y patrimonio, Valencia, Ajuntament - ICARO - PUV, pp. 126146.

-CANDEJA Y MÉNDEZ, José (1889): El código civil español, Ministerio de Gracia y Justicia, BOE n206 de 25/07/1889.

-CANIGGIA, Gianfranco (1973): "La casa-corte: Definizione, diffusione, origine ed accezione comense", en AA.VV. XVIII Congreso Internazionale di Storia dell Architetturam Studi e note, Firenze, Alinea, 1985, pp. 13-62.

-CAPARROS BENAVENT, Juan A. (1963): Geografía del Reino de Valencia, Valencia. Suc. viver Mora, pág. 158.

-CARCELLER, José y otros (2010): Guía didáctica La Pobla de Vallbona, Diputació de Valencia, Sarc. Ayuntamiento de La Pobla de Vallbona.

-Cartografía Valenciana, (siglos XVI-XIX). Centre cultural La Beneficencia, sin autor Diputación de Valencia. 1997, colección Imagen, pp. 136-188. 
-CASTAÑEDA ALCOVER, V. (1921): Relaciones geográficas, topográficas e Históricas del Reino de Valencia hechas en el siglo XVIII a ruego de Don Tomás López, Madrid, revista de Archivos, Bibliotecas y Museos.

-CAVANILLES, Antonio José, (1795-1797): Observaciones sobre la historia natural, geografía, agricultura, población y frutos del Reyno de Valencia, Madrid.

-CERVERA ARIAS, Francisco (2002): "Restauración de la torre Campanario de la Iglesia Santiago Apóstol de La Pobla de Vallbona", Edificios y Monumentos, Noticias CaatValencia, Noviembre.

-CERVERA ARIAS, Francisco (2000): Memoria de la restauración de la torre Campanario de la Iglesia Santiago Apóstol de La Pobla de Vallbona, proyecto de ejecución, Valencia.

-COLON I DOMENECH, Germà y GARCIA, Arcadi (1974): Furs de València, 4v, Barcino, colección Els Nostres clàssics, Barcelona.

-CONEJO MARTIN, Miguel Ángel (2014): Propuesta metodológica para el sistema de estudios gráficos topográficos aplicados a la representación gráfica de bodegas subterráneas tradicionales, Tesis doctoral, Universidad Politécnica de Madrid, Escuela de Ingenieros agrónomos, Madrid.

-CONTELLES LLOPIS, Ana Isabel (2002): La Torre Barroca de Santiago Apóstol y sus coetáneas, Trabajo final de Master, título propio UPV.

-CONTELLES LLOPIS, Ana Isabel y otros (2008): El sistema de riego a La Pobla de Vallbona: Pozos y acequias, Ayuntamiento de La Pobla de Vallbona, Concejalía de Patrimonio, autoedición, La Pobla de Vallbona.

-CONTELLES LLOPIS, Ana Isabel (2010): La Ermita de San Sebastián, Trabajo final de grado, Titulo oficial UPV.

-CONTELLES LLOPIS, Ana Isabel (2012): La Iglesia de Santiago Apóstol. Trabajo final de Master. Titulo Oficial.

-CHUECA GOITIA y TORRES BALBÁS, Leopoldo (1951): Planos de las ciudades iberoamericanas y filipinas, leal, Madrid.

-DELGADO ECHEVERRÍA, Jesús y LEDESMA RUBIO, M.(1990): Cartas de población, fueros y ordenaciones municipales de Aragón, Marzo, 1600, Centro de Documentación Bibliográfica Aragonesa, DGA, Zaragoza, 101 p.

-DESPONT, Raimon (1695): Manaments i Empares, Valencia, Archivo del Reino de Valencia.

-ESCOLANO, Gaspar (1610).: Década primera de la Historia de la Insigne Coronada Ciudad y Reyno de Valencia, Valencia.

-ESCRIBANO SAN CLEMENTE, Roberto (2015): Estudio histórico-gráfico y reconstrucción virtual del despoblado de Benicalaf en el término de Benavites Valencia, Trabajo final de Master, Valencia. 200p. 
-ESQUILACHE, Ferran (2011): “L'evolució del paisatge agraria andalusí i feudal de les grans hortes fluvials, Les séquies de Quart i del Comuner d'Aldaia a I'horta de València", Recerques, 62, pp: 5-36.

-FELIP, Vicent (2008): “La Vila de Nules com a expemple d'urbanisme de nova planta en l'epoca de Jaume I", Arquitectura any zero (1.208-2008). Generalitat Valenciana, Valencia, pág 88.

-FERRER ORTS, Alberto (2003): L'esplendor de la decoració esgrafiada Valenciana (1642-1720), Ajuntament de Xirivella, Xirivella.

-FURIÓ, Antoni (2001): “La domesticación del medio natural. Agricultura, ecología y economía en el País Valenciano en la baja Edad Media", en J. Clemente (ed.), El medio natural en la España medieval, Actas del I Congreso sobre eco-historia e historia medieval, Cáceres, Universidad de Extremadura.

-FUSTER SERRA, Francisco (2003): Cartuja de Porta-celi. Historia, vida, arquitectura y arte. Valencia, Ayuntamiento de Valencia. 561p.

-GARÍN ORTIZ DE TARANCO, Felipe Mạ . (1986): Catálogo monumental de la provincia de Valencia, Buñol en Garín, Valencia, pp. 213-215.

-GARCIA MAIQUES, Rafael: "El concepto icónico de san Francisco de Borja elaborado por los jesuitas a partir de la adquisición del palacio ducal de Gandía", Universidad de Valencia.

-GIL VICENT, Vicent (2008): "El Paisatge de Vila-Real al temps de Jaume I", Arquitectura any zero, Museu de Belles Arts de Castelló, Generalitat Valenciana, pp: 97-113.

-GLICK, Thomas y otros (2007): Paisajes de conquista, Cambio cultural y geográfico en la España medieval, Valencia, Institució Alfons el Magnànim.

-GÓMEZ I SAHUQUILO, M.(2010): “ La Torre i Ermita de Sant Miquel de Corbera”. Generalitat Valenciana. Castillos de España.

-GONZÁLEZ GUDINO, Mạ Ángeles (2003): “Campanas de siempre, Recuerdos de siempre Recuerdos de todos", Valencia.

-GONZÁLEZ VILLAESCUSA, Ricardo (2002): Las formas de los paisajes mediterráneos, Jaén, Universidad de Jaén.

-GUICHARD, Pierre (2001): Al-Andalús frente a la conquista cristiana, Madrid: Biblioteca Nueva, Universidad de Valencia.

-GUINOT RODRIGUEZ, Enric (1991): Cartes de Poblament medievals Valencianes. Generalitat Valenciana, Valencia, Servei de publicacions de la presidencia, Direcció general de relacions Institucionals i Informatica.

-GUINOT RODRIGUEZ, Enric (2005): “'L'Horta de València a la baixa Edat Mitjana. De sistema hidràulic andalusí a feudal”, Afers, 51, pp. 271-300.

-GUINOT RODRIGUEZ, Enric (2007): “La construcció d'un paisatge medieval irrigat: I'horta de la ciutat de València", en F. Sabaté (Ed.), Natura i desenvolupament, El medi ambient a l'Edat Mitjana, Lleida, Pagès Editor. 
-GUINOT, Enric y ESQUILACHE, Ferran (2010): “Moncada i l'Orde del Temple en el segle XIII. Una comunitat rural de l'Horta de València en temps de Jaume I", Valencia, Institució Alfons el Magnànim.

-GUINOT RODRIGUEZ, Enric y MARTÍ, Javier (2006): “Las villas nuevas medievales Valencianas (siglos XIII-XIV)”, Boletín Arkeolan, 14, pp. 183-2016.

-GUINOT, Enric y TORRO, Javier (2006): "Repartimens medievals a la Corona d'Arago", Universidad de Valencia.

-HERMOSILLA PLA, Jorge (2007): Pla Estratègic de La Pobla de Vallbona, Ajuntament de La Pobla de Vallbona, 168p.

-HORMIGOS SÁNCHEZ, Pere y VICENT CAVALLER, Joan Antoni: La vila d'Almenara: Portals, Torres i Muralles, trabajo de adaptación y reelaboración de la transcripción de Alemanara de Luis Cebrián.

-HOYOS, Manuel María P. (1962): Registro Hispano Dominical, Editorial Sever Cuesta, Valladolid.

-HURTADO MULLOR, Tomas y BORDES, Joseph (2015): “Transcripción y traducción de 10 pergaminos del archivo Sindicato de Riegos de La Pobla de Vallbona, Archivo Sindicato de Riegos de La Pobla de Vallbona", documentos del 1 al 10, Concejalía de Patrimonio, Ayuntamiento de La Pobla de Vallbona.

-HURTADO MULLOR, Tomas y otros (2014): Benaguasil: Un segle d'identitat, Benaguacil, Ayuntamiento de Benaguacil, 237p.

-IBAÑEZ CATALÁ, J. (2002): Memoria del proyecto de intervención de la Iglesia de La Pobla del Duc, La Pobla de Duc.

-JARQUE, Francesc y BERCHEZ, Joaquin (1993): Arquitectura Barroca Valenciana, Bancaixa, Valencia.

-JARQUE, Francesc y otros (1995): Las observaciones de Cavanilles doscientos años después libro primero, Obra Social, Bancaja, Valencia.

-JORDÁ MARIN, Carmen y MARTINEZ GARCIA, Remedios: "Textos tríptico conjunto arqueológico la Cova Tella", en Investigación del Yacimiento la Cova Tella, La Pobla de Vallbona 2011.

-LACARRA, José Ma.(1950): “El desarrollo urbano de las ciudades de Navarra y Aragón en la Edad Media", Pirineos, no 15-16, Zaragoza, pp: 5-21.

-La Santa Biblia (1994), San Juan, Apocalipsis, Centro Bíblico Católico, Editorial Alfesa Ortells, Valencia.

-LLAVATA, VICENTE (1981) : Historia de la Villa y Baronía de La Puebla de Vallbona, La Puebla de Vallbona. 592p.

-LLISO RUIZ, Jose Luis (2009): Libro de ponencias y comunicaciones. III foro Ibérico España-Portugal sobre rehabilitación de Centros históricos, Generalitat Valenciana, Archival, Valencia. 
-LLOP I BAYO, Francesc (2005): "Fitxa de les Campanes de La Pobla de Vallbona", Inventari General de Campanes de la Comunitat Valenciana, Gremi de Campaners.

-LLOP I BAYO, Francesc (2006): "Rito simple de la bendición de una campana" en Gremi de Campaners de la Comunitat Valenciana.

-LLOP I BAYO, Francesc (2006): "Recomendaciones para la Conservación y restauración de campanas y relojes Monumentales" en Gremi de Campaners de la Comunitata Valenciana 2006.

-LÓPEZ GOMEZ, Antonio (1997): "Los croquis y mapas del Reino de Valencia de López y Cavanilles: dos geógrafos y dos métodos opuestos”, Cuadernos de Geografía, Valencia.

-LÓPEZ, R. (1998): “Gremi de Campaners de la Comunitat Valenciana”, en Asociación cultural Amigos de Tordesillos. Las campanas una voz olvidada. Tordesillos.

-LOPEZ, T. (ca.1770-1780): Relaciones geográficas, topográficas e históricas del Reino de Valencia, recopiladas por Castañeda y Alcover, Revista de Archivos, Bibliotecas y Museos, 1916 y siguientes.

-LLORENÇ, Jaime (1700): Protocolos Notariales 21.981. La Puebla de Vallbona. Archivo de Protocolos del Colegio del Patriarca de Valencia.

-LLORENÇ, Jaime (1700): Protocolos Notariales 21.983. La Puebla de Vallbona. Archivo de Protocolos del Colegio del Patriarca de Valencia.

-LLORENÇ, Jaime (1700): Protocolos Notariales 1.333. La Puebla de Vallbona. Archivo de Protocolos del Archivo del Reino de Valencia.

-LLORENÇ, Jaime (1702): Protocolos notariales. La Puebla de Vallbona, Archivo de Protocolos del Archivo del Reino de Valencia.

-LLORENTE Y OLIVARES, Teodoro (1887): Valencia, tomo 1, Ed. Nabu Press, 2010, pág. 894.

-LLORENTE Y OLIVARES, Teodoro (1887): Valencia. Sus monumentos y artes. Su naturaleza e historia, tomo 2, Albatros Ediciones, Valencia, 1980

-LLORENTE Y OLIVARES, Teodoro (1910): Epistolari Llorente. Cartes de Llevantins. Correspondencia recibida de 1861 a 1911, Volumen I, Barcelona, Editorial Balmes.

-LLORENTE Y OLIVARES, Teodoro (1910): Epistolari Llorente, Cartes de Llevantins. Correspondencia recibida de 1861 a 1911, Volumen II, Barcelona, Editorial Balmes.

-LLORENTE Y OLIVARES, Teodoro (1910): Epistolari Llorente. Cartes de Llevantins. Correspondencia recibida de 1861 a 1911, Volumen III, Barcelona. Editorial Balmes

-MADOZ, Pascual (1826-1829): Diccionario geográfico-Estadístico de España y Portugal, Sebastián de Miñano y Bedoya, 11 Tomos, Madrid.

-MAGRO MORO, Julián Vicente (1993): Textos para una historia de la Construcción, Universidad Politécnica de Valencia. 
-MARIN, F. y ORTIZ DE TARACO (1986): Catálogo Monumental de la Provincia de Valencia, pág. 322 y 323, Caja de Ahorros y Monte del piedad de Valencia.

-MARTI FERRANDO, Luis (1990): Benisano y su historia, Ayuntamiento de Benisano, 431p.

-MARTÍ, INFANT (1382): La Carta de Poblament de La Pobla de Vallbona, Archivo del Reino de Valencia.

-MAS I FORNES, Antoni (2003): “L'antiga vila de Manacor i les ordenacions de Jaume II", III Jornades d'Estudis Locals de Manacor, pp. 18-20.

-MATEU BELLÉS, Joan (2001): L'empenta del poblament cristiá, Temes d'Etnografía Valenciana, Institució Alfons el Magnanim, Valencia, 1983, pp. 68-86.

-MENÉNDEZ PIDAL, Ramón (1968): Historia de España, Madrid, Espasa, Calpe.

-MONTOLIU SOLER, Violeta (1987): La personalidad del Barroco en la Vall d'Albaida, Ayuntamiento y Cooperativa de Quatretonda.

-MONTOLIU SOLER, Violeta (1994): L’Esglesia de Quatretonda, Ayuntamiento y Cooperativa de Quatretonda.

-MONTOLIU SOLER, Violeta (1999): Estudio Analítico de los Campanarios, Universidad Politécnica de Valencia.

-NAVARRO FAJARDO, Juan Carlos (2006): Bóvedas de la Arquitectura gótica Valenciana, Valencia.

-NAVARRO GARCIA, Vicent (2002): Monografías históricas de la Villa de Cheste, Cheste.

-NAVARRO SEGURA, Monserrat (2006): "Las fundaciones de ciudades y el pensamiento urbanístico", Revista electrónica de Geografía y ciencias sociales, Universidad de Barcelona, vol. X, 218p.

-NICOLAU BAUZA, Josep (1990): Páginas de la Historia de Benaguacil, Benaguacil, Autoedición Ayuntamiento de Benaguacil, 331p.

-PASCUAL Y BONDÍA, R. (1741): Registros Notariales del Archivo del Reino de Valencia, no373, sig. 10.659, La Pobla de Vallbona.

-PASCUAL GIMENO, Salvador (1979): Torres y Campanarios, Valencia.I

-PEREZ MINGUEZ, Rafael (2006): “Aspectos del Mundo Rural Romano en el territorio comprendido entre los ríos Turia y Júcar", Servicios de Investigación de Prehistoria, Serie de trabajos varios, no106, Diputación Provincial de Valencia.

-PIQUERAS, Juan y SANCHIS, Carmen (1992): La organización histórica del territorio valenciano, Generalitat Valenciana, Departamento de Geografía, Universidad de Valencia, Conselleria d’obres públiques, urbanisme i transport, Valencia.

-PINGARRÓN ESAIN, Fernando (2003): El campanario barroco de la iglesia de Santa Catalina Mártir de Valencia, Valencia. 
-PEREZ, Santiago (2012): "Almenara módulo 2 patrimonio artístico" , Antropología Castellón de la Plana y su entorno, Blog para el curso de Antropología Cultural de nuestro entorno, Universidad Jaime I de Castellón.

-PLAZA DE LA ESCUDERO, Lorenzo y otros (2010): Diccionario Visual de Términos Arquitectónicos, grandes temas cátedra, 5ạ edición, Anaya, Madrid.

-PUCH FONCUBERTA, Enrique (1990): “Estelas discoideas de Fuentespalda”, Gaceta del Matarraña no 19, noviembre, Fuentespalda, pp. 4-5.

-ROCA TRAVER, Francisco A. (2006): Tierra y propiedad en la Valencia Medieval, Ajuntament de Valencia, Delegación de Cultura, servicio de publicaciones, Valencia.

-RODRIGUEZ MOLINA, Ma José y otros: Mapas, planos y dibujos existentes en la diputación de valencia (1678-1884), Diputación de Valencia, Archivo general de fotografía, pp. 61 y 621.

-ROSSELLO VERGER, Vicenc (1987): "Villas planificadas medievales del País Valenciano", Anales de Geografía de la Universidad Complutense de Madrid, 7.

-ROSSELLO VERGER, Vicenc (1989): "El Camp de Llíria: Poblament, viabilitat, recursos", I Congrés d'Estudis Comarcals del Camp de Túria. I.E.C.T, pp. 15-33.

-RUBIO, Vicent (2009): “ La Masía del Pilar", Centre d'Estudis Locals de I'Eliana, Eliana, pág. 370.

-SÁNCHEZ VEDUICH, Mā del Mar (2002): Cheste y su historia, Diputación de Valencia.

-SANCHIS GUARNER, Manuel (1972): La ciutat de Valencia, Sintesi d'Història i de geografía urbana, Quarta edició, Publicacions de L’Ajuntament de Valencia. Grafiques Siler, Valencia.

-SANCHIS SAMPEDRO, Francisco Javier (2013): La Geometría De Las Superficies Arquitectónicas Análisis Formal Geométrico De La Ciutat De Les Arts I Les Ciències De Valencia, Valencia, $391 \mathrm{p}$.

-SANCHIS MORENO, Francisco Jose y otros (2010): Mapas y Planos (1678-1884), arxiu general i fotogràfic, Diputació de València, Ed. Gráficas Varona, Salamanca, $516 \mathrm{p}$.

-SARASA SÁNCHEZ, Esteban (1991): “El Reino de Aragón en la época de Jaime II ( 1.291-1.327)", Universidad de Zaragoza.

-SARTOHU, Carlos (1922) : Geografía General del Reino de Valencia, Tomo II, Casa Editorial Alberto Martín, Barcelona.

-SEBASTIÀ, Vicent (1686): Dels drets de fábrica, Archivo Parroquial Santiago Apóstol, La Pobla de Vallbona.

-SOLER MOLINA, Abel (1999): De Vilanova de Rugat a La Pobla del Duc: persones i fets d'un poble de llauradors de la Vall d'Albaida, Ontinyent.

-SUCÍAS APARICIO, Pedro (1911): Notas útiles del Reino de Valencia, Distritos de Onteniente y Llíria, Tomo 7, Valencia, pp.154-159. 
-SUCÍAS APARICIO, Pedro (1911): Templos de la Santísima Virgen, Parte 1, Valencia, 250.

-SUCÍAS APARICIO, Pedro (1911): Historia de los conventos del Reino de Valencia, Tomo IV. 2 parte, Valencia.

-TAMBORERO, Manuel (1969): Geografía agraria de Benisanó y Pobla de Vallbona, Valencia, Departament de Geografia e Institució Alfons el Magnànim, 51p.

-TORRES BALBÁS, Leopoldo y otros (1954): Resumen Histórico del Urbanismo en España, Madrid Instituto de Estudios de Administración Local.

-TORRES BALBÁS, Leopoldo (1952): La Arquitectura gótica: Tomo III Valencia y Murcia.Madrid .

-TORRES BALBÁS, Leopoldo y otros (1971): Ciudades Hispano-Musulmanas, Madrid Instituto de Estudios de Administración Local.

-TORRES BALBÁS, Leopoldo (1987): “la Edad Media”, En: GARCIA BELLIDO, A. Et allii: Resumen histórico del urbanismo en España, Madrid.

-TORRÓ, Josep (1998): “La colonización del valle de Pego (c. 1280 - c. 1300). Prospección y estudio morfológico: primeros resultados", Arqueología Espacial.

-TORRÓ, Josep (1999): “El naixement d'una colónia. Dominació i resistència a la frontera Valenciana (1236-1276)", Univesitat de Valencia.

-TORRÓ, Josep (2003): “Arqueologia de la conquesta. Registre material, substitució de poblacions i transformació de l'espai rural valencià (s. XIII-XIV)", en M. Barceló et al. (eds.), El feudalisme comptat i debatut, Formació i expansió del feudalisme català", Valencia, PUV - Museu d'Història de Catalunya.

-TORRÓ, Josep (2007): “Terrasses irrigades a les muntanyes Valencianes. Les transforma-cions de la colonització cristiana", en J. Bolós, Territori i societat a l'Edat Mitjana, IV, Estudiar i gestionar el paisatge històric medieval, Lleida, Universidad de Lleida.

-TORRÓ, Josep (2007): “Field and canal-building after the Conquest: modifications to the cultivated ecosystem in the kingdom of Valencia, ca. 1250-ca. 1350", en B. A. Catlos (Ed.), A World of Economics and History: Essays in Honor of Prof. Andrew M. Watson, Valencia, PUV, pp. 77-108.

-TORRÓ, Josep (2010): “Tierras ganadas. Aterrazamiento de pendientes y desecación de marjales en la colonización cristiana del territorio Valenciano", en H. Kirchner (Ed.), Por una arqueología agraria. Perspectivas de investigación sobre espacios de cultivo en las sociedades medievales hispánicas (BAR International Series 2062), Oxford, Archaeopress.

-TORRÓ, Josep y GUINOT, Enric (2001): “De la madîna a la ciutat. Les pobles del sud i la urbanització dels extramurs de València", Saitabi.

-TORRÓ, Josep e IVARS, J. (1992): "Villas fortificadas y repoblación en el sur del País Valenciano. Los casos de Cocentaina, Alcoy y Penáguila", en III Congreso de Arqueología Medieval Española, Oviedo, Universidad de Oviedo, vol. 2. 
-TORRÓ, Josep y SEGURA, J. (2008) : Arqueología urbana en Alcoy: Los datos del subsuelo, Recercas del Museo de Alcoy.

-TORRÓ, Josep (1989): “El problema del hábitat fortificado en el sur del Reino de Valencia después de la segunda revuelta mudéjar ( 1276-1304).

-TORRÓ, Josep (2001) : La conquista del reino de Valencia. Un proceso de colonización medieval desde la arqueología del territorio.

-TOSCA, Tomas (1774): Tratado de la gnomónica de la Teórica práctica de los reloxes de Sol, De los principios fundamentales de la Gnomónica, Valencia.

-URTEAGA, Mertxe (2014): “Trama urbana en villas medievales del Pais Vasco. Las Villas nuevas medievales de Castilla, León, Junta de Castilla León, E.T.S. de Arquitectura de Valladolid, Valladolid, Universidad de Valladolid, pp. 77-95.

-VICIANA, Martín de (1564): Crónica de la ínclita y coronada ciudad de Valencia, Libro tercero, Burriana.

-VIDAL, Juan Francisco (2000): Los Campanarios de José Minguez, Valencia. 176p.

-ZARAGOZÁ CATALÁN, Arturo (1996): “Naves de arcos diafragma y techumbre de madera en la arquitectura civil Valenciana", en A. de las Casas, S. Huerta, E. Rabasa (eds.), Actas del Primer Congreso Nacional de Historia de la Construcción, Madrid, CEHOPU.

-ZARAGOZÁ CATALÁN, Arturo (2000): Arquitectura gótica Valenciana, Valencia, Generalitat, Valencia, Direcció General de Promoció Cultural i Patrimoni Artístic. $243 p$.

-ZARAGOZÁ CATALÁN, Arturo y otros (2008): Arquitectura any zero (1.208-2008). Generalitat Valenciana, Valencia, 276p. 


\section{Agradecimientos}

El presente plan de investigación comenzó a gestarse, sin saberlo, en el año 2.008, cuando la entonces alcaldesa de La Pobla de Vallbona Da Ma Carmen Contelles Llopis y la Concejala de Patrimonio, Dạ. Sara Montañana Bolea, confiaron en mí para iniciar un proyecto que hasta entonces no se había llevado a cabo: gestionar el patrimonio local del municipio a través de su recién inaugurado museo etnológico, la Casa Gran. Comenzaba así una experiencia que me ha enriquecido a nivel personal y laboral, pero sobre todo me ha dado a conocer muchos aspectos desconocidos de mi pueblo hasta ese momento.

El objetivo era poner el valor el patrimonio local y darlo a conocer. Se iniciaba todo desde cero, cada investigación, cada divulgación, la declaración de colección museográfica permanente de la Comunidad Valenciana, la implantación de las jornadas de historia, el descubrimiento de la cápsula del tiempo en la ermita de San Sebastián junto a su restauración, el archivo inédito del Sindicato de Riegos de La Pobla, la puesta en valor del acueducto de la Cova Tella, el descubrimiento de las estelas discoidales y la Biblioteca de patrimonio local entre otros. Cada hito hacía que fuera creciendo en mí la necesidad de plasmar cada uno de los detalles descubiertos en un escrito, que al final se ha concretado en esta tesis doctoral.

El primer agradecimiento va dirigido a ellas, por depositar en mi esa responsabilidad, puesto que para hacer un buen trabajo de recuperación y puesta en valor del patrimonio es necesario unir tanto la voluntad técnica como la política y en este caso, durante estos 8 años de trabajo, así fue. Desde aquí os mando este mensaje, "lo que habéis restaurado, lo que se ha documentado, ya queda para la historia". Gracias por el trabajo realizado. 
En segundo lugar para mi director de tesis, D. Vicente García Ros por su implicación en este y otros trabajos, dirigiendo el plan de investigación siempre por buen camino y fijándose hasta en el detalle más insignificante. El ir pidiéndome cada vez un poquito más ha hecho que este trabajo fuera lo que iba persiguiendo desde el principio, la recopilación más completa posible sobre el origen del municipio estudiado. Gracias

A mis antiguas compañeras del colegio de la Sagrada Familia, Dạ Margarita Sendra y Da. Isabel Sacristán, por facilitarme fotografías, datos o los nombres de las personas que podían ayudar en el municipio donde cada una reside, Gandía y Almenara. Después de tantos años da gusto comprobar que aún existe amistad y compañerismo.

A D. Joan Alepúz, secretario del Gremi de Campaners de Valencia, a D. José Mestre, a D. Ximo Tortajada, y a la familia de José Marimóm por sus fotografías antiguas del municipio. También a todos los vecinos del municipio que desinteresadamente, al preguntarles si podía utilizar sus fotografías para mi estudio, no pusieron ninguna objeción. No he utilizado todas las que he solicitado pero han sido de una gran ayuda.

A D. Javier Ruiz por sus fotografías de Teulada, por el gran apoyo informático y sobre todo por las correcciones. A Dā. Inma Aleixandre por sus fotografías de Aragón. A D. David García Martínez por facilitarme las fotografías del municipio de Petra en Mallorca.

A Dạ. Amparo Desco, por poner a mi disposición la historia del pueblo vecino de Benisano.

A los dos curas párrocos de La Pobla de Vallbona, mientras realizaba mi investigación. A D. Joaquín Aguilar, cura párroco de la Iglesia Santiago Apóstol por dejar hacer, sin poner ningún tipo de impedimento y estar siempre dispuesto a responder a mis preguntas. Y a D. Javier, ex cura párroco de la Iglesia Santísima Trinidad y San José, en la actualidad cura del municipio de Chiva, por encauzarme, siempre en cualquier duda significativa. Gracias por enriquecerme tanto a nivel histórico y personal, nuestro municipio tuvo una gran suerte al tenerte como párroco, gracias allí donde te encuentres.

A Dạ. Amparo Martí, por responder a mis preguntas con todo lo que atañe al escudo de piedra de sillar de su fachada, el único resto de la muralla medieval de La Pobla de Vallbona en la actualidad.

A Dá. Isabel Blay Llorens, amiga y bibliotecaria del ayuntamiento de La Pobla de Vallbona, por facilitarme o indicarme siempre la ubicación más cercana del documento o libro necesario. 
A D. Tomas Hurtado, por aportar sus conocimientos, enriquecer los míos y facilitarme parte de la documentación de su archivo personal.

A D. Francisco Cervera Arias, arquitecto, por su ayuda incondicional. Me enseñó no solo a intervenir correctamente en el patrimonio sino a saberlo escuchar. En el presente estudio me facilitó los datos arquitectónicos de un municipio que conoce perfectamente, Almenara.

A mi cuñada, Maribel García Corbin, por todos los documentos y fotografías del Municipio de Castellón, población de la cual ha gestionado durante años todos sus actos culturales. Sus libros me han facilitado mucho el trabajo.

A D. Daniel García Badía, presidente del Sindicato de Riegos de La Pobla de Vallbona, por poner a mi disposición el archivo del Sindicato y autorizarme a utilizar para este trabajo de investigación los 10 pergaminos traducidos y digitalizados por el Ayuntamiento de La Pobla de Vallbona mediante convenio firmado en febrero de 2014.

A D. Sebastian Roca, amante del patrimonio de nuestro municipio, por presentarme a D. Francisco Fuster, estudioso del monasterio de Porta-celi, no solo me ilustró con sus conocimientos sino que me abrió las puertas de su archivo personal. Gracias por todo, no es habitual encontrar personas que te dejen acceder, consultar y poder llevarte a tu domicilio tanto resúmenes de trabajo como parte de documentación original, notas o traducciones sin ningún impedimento. Nunca podré agradecerte suficientemente tu ayuda.

A D. Evelio Valladolid, por tener una gran amplitud de miras y darse cuenta que para que tuviera todos los datos precisos en esta investigación debía conocer a D. Vicent Rubio, miembro del Centro de Estudios Locales de I'Eliana. Gracias por facilitarme los escritos referentes a esta zona del municipio y sobre todo por las conversaciones que hicieron casar nuestra historia y la suya que es la misma.

A D. Ramón Mañez Llavata, amigo y compañero de despacho durante estos últimos años. He tenido la suerte de poder ir comentando cada detalle que surgía con la persona que más conocimientos tiene sobre el Término municipal de La Pobla. Gracias por ayudarme a que este trabajo fuera lo más exacto posible.

A. Dạ. Olga Bondarevscaia por sus conocimientos en la lengua inglesa y a Dạ. Lidia Julio Camps por su buen saber de nuestra lengua valenciana. Ambas han enriquecido el presente plan de investigación con sus traducciones.

A Dạ. Jenny García Devis, amiga desde tiempos universitarios, su formación en Bellas Artes y en el conocimiento de la lengua castellana la hacían la persona ideal para ayudarme a que las ideas de este plan de investigación fueran lo más coherentes posibles. 
A mi hermano, D. Gerardo Contelles Llopis, por los comentarios, por estar disponible a leer y dar sus opiniones sobre aquello investigado y descubierto.

A D. Jesús García Navarro, el Rullo, por ayudarme y aconsejarme en todo lo que conllevaba la maquetación y la impresión del presente plan de investigación.

A mis padres, Gerardo y $\mathrm{M}$ a Carmen, que siempre nos han animado a todos a buscar algo mas, a no parary a seguir formándonos. Ellos me han dado desinteresadamente el bien más preciado, parte de su tiempo, facilitando de este modo mi concentración, sabiendo que lo más quiero se encuentra en las mejores manos. Este doctorado es una realidad gracias a ellos.

Y no me puedo olvidar de mis compañeros de ruta, aquellos que hicieron las visitas a los municipios más amenas y seguras, puesto que al quedarme embarazada visitar los municipios sola era una ardua tarea. Así que debo recordar a los que me acompañaron por tierras turolenses, Inma, Javi, José Carlos y Sonia. Los que vinieron con el calor del mes de julio por la provincia de Castellón, mi padre Gerardo y mi sobrino, Isaac, siempre presente.

Y por último a mi marido, José Luis y mi hija Noa, ellos me acompañaron por tierras valencianas y alicantinas. Gracias por cederme parte de vuestro tiempo. Nunca olvidaré aquella tarde en Cullera. 